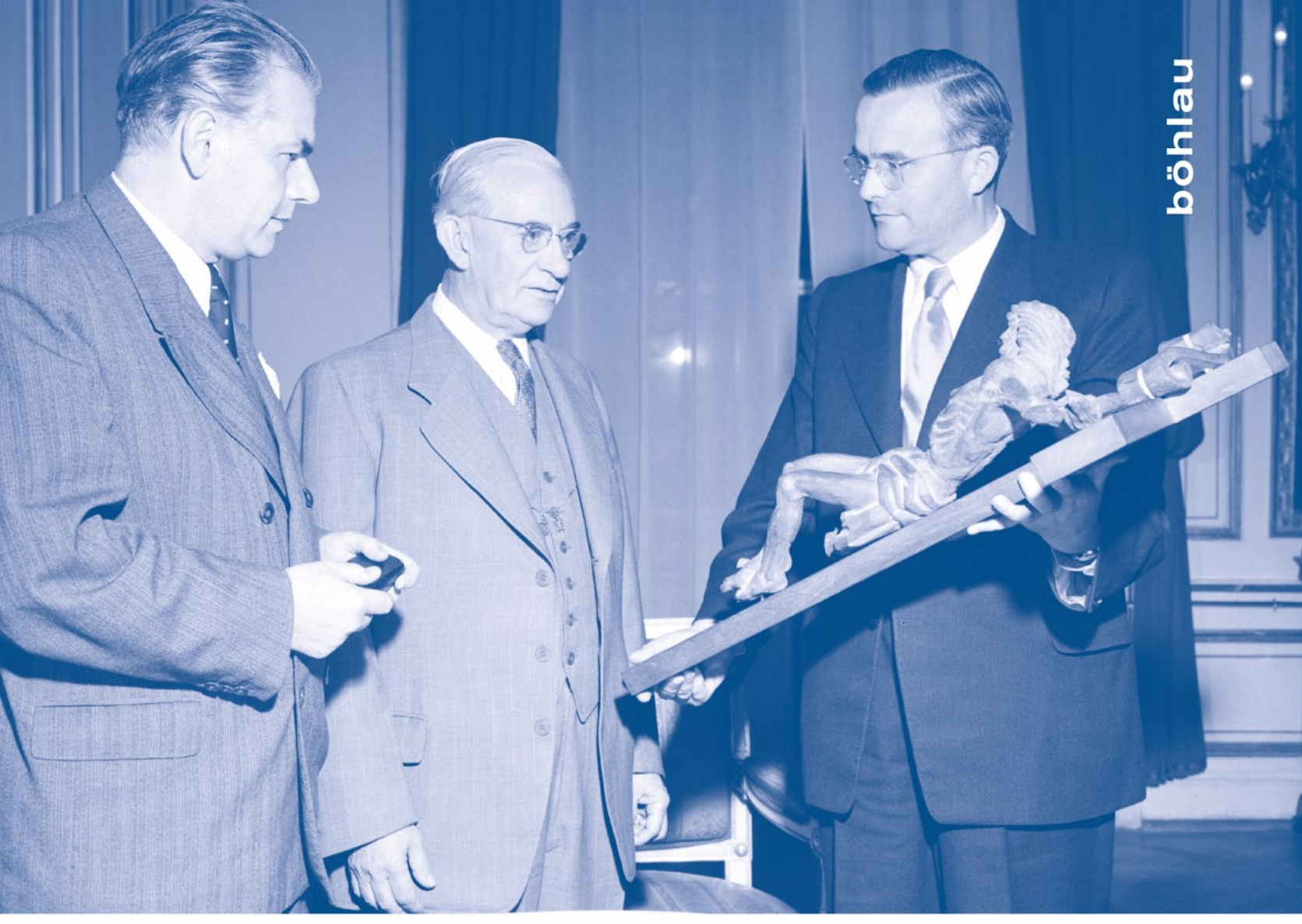

\title{
Zwischen geistiger Erneuerung und Restauration
}

US-amerikanische Planungen zur Entnazifizierung und demokratischen Neuorientierung österreichischer Wissenschaft 1941-1955

Christian H. Stifter 
böhlau 

Christian H. Stifter

\section{Zwischen geistiger Erneuerung und Restauration}

US-amerikanische Planungen zur Entnazifizierung und demokratischen Reorientierung und die Nachkriegsrealität österreichischer Wissenschaft 1941š1955

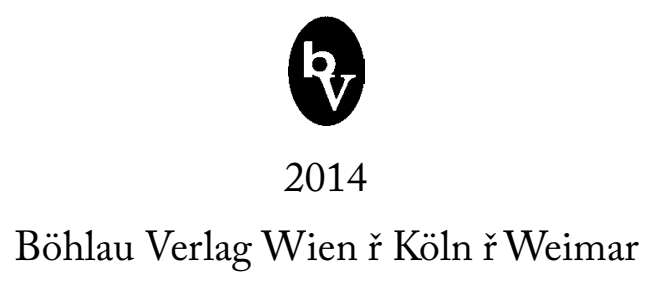


Gedruckt mit Unterstützung durch

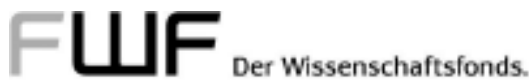 \\ The research was funded by the \\ Austrian Science Fund (FWF): PUB 82-V16
}

Bibliografische Information der Deutschen Nationalbibliothek:

Die Deutsche Nationalbibliothek verzeichnet diese Publikation in der

Deutschen Nationalbibliografie; detaillierte bibliografische Daten sind im Internet über http://dnb.d-nb.de abrufbar.

\author{
Umschlagabbildung: \\ Samuel Howard Williams, zusammen mit Felix Hurdes (li) und Ernst Kolb (re)
}

(ÖNB Inv. Nr. US 10.374/3)

(C) 2014 by Böhlau Verlag Ges.m.b.H \& Co. KG, Wien Köln Weimar

Wiesingerstraße 1, A-1010 Wien, www.boehlau-verlag.com

Alle Rechte vorbehalten. Dieses Werk ist urheberrechtlich geschützt.

Jede Verwertung außerhalb der engen Grenzen des Urheberrechtsgesetzes ist unzulässig.

Umschlaggestaltung: Michael Haderer, Wien

Lektorat: Nadine Hauer und Kornelia Trinkaus

Druck und Bindung: UAB BALTO print

Gedruckt auf chlor- und säurefrei gebleichtem Papier

Printed in the Lithuania

ISBN 978-3-205-79500-1 
"The damage done by the Nazis to the Austrian educational system was a most serious threat to the country's future, because the damage was spiritual as well as material. A systematic attempt has been made to pervert the minds of teachers and pupils [...] drastic measures were necessary to ensure that post-war Austrian education would develop on healthy lines."

Richard Hiscocks "The Rebirth of Austria" [1953, I64f.]

"Europeans have never stopped laughing at America, yet their collective imagination has filled with a repertoire of Americana. They may have reacted vehemently to it, producing a litany of anti-Americanism that has been one long attempt at exorcism, driving out the devil of a pernicious American culture. Nevertheless, the devil was not simply to be wished away. If cultural guardians were watching the front door, American culture slipped in through the rear entrance. It found a loving welcome among those, mostly of the younger generations, who aimed to wrest cultural control out of parental hands. What to older generations may have seemed to be the mindless conformity of American culture became the stuff of cultural revolt for younger generations." Roв Kroes

"If you've seen one, you've seen the mall. Europeans and American Mass Culture" [1996, ixf.]

„Demokratie ist die einzige politisch verfasste Gesellschaftsordnung, die gelernt werden muss - immer wieder, tagtäglich und bis ins hohe Alter hinein.“

Oskar Negt „Der politische Mensch. Demokratie als Lebensform“ [2010, I3] 
Für I. W. 


\section{Inhalt}

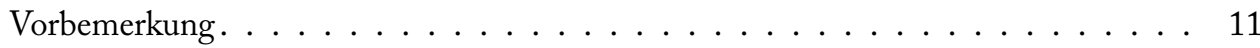

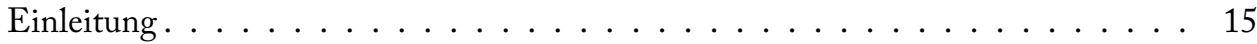

1. Images, Stereotype und Vorurteile - Herkunft und Veränderung der kulturellen Geringschätzung der USA in Europa seit dem 18. Jahrhundert. . . . . . . . . . . 31

Das Bild Amerikas aus europäischer Sicht bis Anfang der 1930er-Jahre . . . . . 33

Spiegelung: Anmerkungen zum Bild Deutschlands

und Österreichs aus US-amerikanischer Sicht . . . . . . . . . . . . . . . 66

NS-Feindbild Amerika: Antiamerikanismus als Kampf gegen

"Niggerkultur“, „Judenstaat" und ,westliche Demokratie“. . . . . . . . . . . . . . 82

2. „Education for Victory“ - US-Demokratisierungs-Konzepte und die zivilen

Reeducation-Planungen für ein post-totalitäres Europa, 1941-1945 . . . . . . . . 97

„Education in Wartime“ - Nationalsozialismus als

Fundamentalbedrohung der US-amerikanischen Zivilgesellschaft . . . . . . . . . 99

„Our Country’s Call to Service“ - konkrete

Auswirkungen des Verteidigungs- und Abwehr-Diskurses . . . . . . . . . . . . 107

Binnenamerikanische Reeducation: Stärkung nationaler

Moral, Militarisierung des Bildungswesens und Bildungsreform . . . . . . . . . 108

Educational Reconstruction - Überlegungen und Konzepte

1942-1943/44 zur Demokratisierung nach Kriegsende . . . . . . . . . . . . . 138

"What to do with the mentally ill Germans?" Ursprünge, Entwicklung

und Veränderungen der zivilen Reeducation-Konzepte, 1940-1944 . . . . . . . 157

Exkurs: die österreichische Emigration in den USA - ein kultur- und

bildungspolitisch folgenloses Kapitel für die Nachkriegsplanungen . . . . . . . 175

Spätphase der zivilgesellschaftlichen Überlegungen und

Konzepte zur Reeducation und Reorientation 1943/44-1945 -

langfristige Reorientierung als Paradigma . . . . . . . . . . . . . . . . 201

Missing Link: Fehlende Umsetzung der Reorientierungs-Konzepte

in die militärischen Planungen, 1943-1945 . . . . . . . . . . . . . . . . . . 210 
"Takeover" durch die U.S. Army: Wirrwarr und Kompetenzgerangel-

Ausdünnung der Reorientation auf,unpolitische'Säuberungsmaßnahmen . . . . . 210

Randnotiz zu einem fehlgeschlagenen Experiment

der US-Armee - POW-Camps zur Reeducation . . . . . . . . . . . . . . . 228

Zur Rolle Österreichs in der Reeducation-Planung

der US-Militärstäbe 1943 /44-1945 . . . . . . . . . . . . . . . . . . . . . . . 239

Österreich - ein unklarer Planungsfaktor alliierter Politik bis 1944/45 . . . . . . 239

Militärisch-gremiale Detailplanung für Österreich-

Administrationsunterlagen ohne Reorientation als Ergebnis . . . . . . . . . . . 248

3. Beginn der US-Reorientierung nach 1945 -

die Education Division als zentrale US-Militärbehörde . . . . . . . . . . . . . 265

4. „The democratic way of life in Austria“ - erste Umsetzungsphase bis zum

Nationalsozialistengesetz 1947: Zwischen Laissez Faire, strenger Observation und milder Beurteilung . . . . . . . . . . . . . . . . . . . . . 277

Kooperation statt Intervention und die Folgen für die Entnazifizierung im Bildungsbereich: das Fallbeispiel Universität . . . . . . . . . . . . . . 277

Ausgangslage: Perspektive nötiger, Säuberungsmaßnahmen' . . . . . . . . . . . 277

Bestimmungen zur Entnazifizierung in US-Planungsdirektiven . . . . . . . . . 288

Die Ausgangssituation an den Universitäten im Frühjahr 1945 . . . . . . . . . . 292

Personalsäuberungen durch „Sonderkommissionen“ und deren Senate . . . . . . . 318

Entnazifizierung am Beispiel der Universität Wien . . . . . . . . . . . . . . . 346

Rückkehr unerwünscht? - Maßnahmen zur Rückholung

österreichischer WissenschafterInnen aus der Emigration . . . . . . . . . . . . . 365

Fallbeispiel: Ernst Karl Winter (1895-1959) . . . . . . . . . . . . . . . . . 373

Fallbeispiel: Hans Kelsen (1881-1973) . . . . . . . . . . . . . . . . . 393

Fallbeispiel: Felix Ehrenhaft (1879-1952) . . . . . . . . . . . . . . . . . 404

Wissenschaftspolitische Restauration und amerikanisch-

österreichische Beziehungen. Ein Zwischenresümee . . . . . . . . . . . . . . . . 410

Rahmenrichtlinien und Entnazifizierung der

Studentenschaft an Österreichs Universitäten . . . . . . . . . . . . . . . . . . . 427

ÖH-Wablen November 1946: erste Großdemonstration gegen

"nazistische Umtriebe" in der Zweiten Republik und die Folgen . . . . . . . . . . . 448

Auswirkungen der Hochschulkrawalle: Turbulenzen im Alliierten Rat,

Re-Screening der Studierenden und Lehrkräfte . . . . . . . . . . . . . . . . . . 477 
Turnaround in der Entnazifizierungspolitik - Kontroversen zwischen State Department und War Department . . . . . . . . . . . . . 502

5. US-Reorientierungs-Planungen im Frühen Kalten Krieg:

Zwischen Popularisierung des „American Way of Life“ und Psychologischer

Kriegsführung, 1947-1950 . . . . . . . . . . . . . . . . . . . 517

Longe Range Policy 1946/47 - Paradigmenwechsel: langfristige zivile

Reorientierungs-Konzepte anstelle militärischer Kontrolle . . . . . . . . . 517

Elitenbildung über „Austauschprogramme“: zentrales Element der besatzungspolitisch aufgewerteten US-Reorientierung ab 1947/48 . . . . . . 548

Die ideologische Überformung der US-Reorientierung durch Propagandakampagnen des Kalten Krieges . . . . . . . . . . . . . 562

Cultural Exchange-Rahmenbedingungen der US-Kulturoffensive . . . . . . . 562 Reorientierung und psychologische Kriegsfübrung: "War of ideas""Campaign of Trutb"- „Struggle for Minds". . . . . . . . . . . . . . . 573

6. Endphase der Besatzung: Akademische Austauschprogramme und ihre Umsetzung in Österreich, 1950-1955 . . . . . . . . . . . . . . . . . 595

Beginn der „U.S. Exchange“-Programme - Seltsamkeiten und Pannen . . . . . 595

Kurzer Exkurs: das Salzburg-Seminarakademische Freiheit mit Hindernissen. . . . . . . . . . . . . . . . . . . . 609

Umstrukturierung und Expansion: neuer Anlauf unter Supervision des U.S. Department of State . . . . . . . . . . . . . . 616

Übernahme durch das State Department -

Instrumentalisierung des „Exchange-Program“ als Teil der psychologischen Kriegsführung gegen die Sowjetunion . . . . . . . . . 625

,Phasing out ${ }^{\prime}$ - zivile Verwaltung und Beginn der Normalisierung . . . . . . . 638

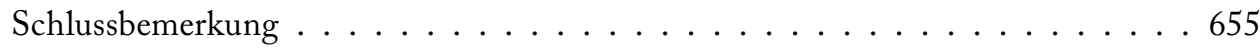

Quellenverzeichnis . . . . . . . . . . . . . . . . . . . . 665

Literaturverzeichnis . . . . . . . . . . . . . . . . . . . . . 673

Verzeichnis der Abkürzungen . . . . . . . . . . . . . . . . . . 735

Personenverzeichnis. . . . . . . . . . . . . . . . . . . . . . 741 



\section{Vorbemerkung}

Vor manchen Studien würde man vermutlich zurückschrecken, stünde einem von Beginn an klar vor Augen, wie viel Zeit, Energie und Nervenanspannung zu ihrer Fertigstellung schließlich nötig sein werden. Umso erfreulicher ist es allerdings, auf ein solches Projekt mit Erleichterung zurückblicken zu können, da es nun endlich und unverrückbar abgeschlossen ist.

Die ersten Überlegungen und Quellenrecherchen für diese Arbeit reichen bis weit vor „9/II“ zurück. Nach Erstellung eines konzeptuellen Grundrisses für das Vorhaben der freilich im Laufe der Jahre mehrfach überarbeitet, abgeändert und erweitert wurde - zeigte sich bald, dass die Dokumentenlage in Österreich wohl zu schmal sein würde, um die US-amerikanischen Planungen einigermaßen konzise darstellen zu können. Erst ein Forschungsaufenthalt in Washington D.C. im Jahr 2000 und die dabei durchgeführten Recherchen im Records Center der „National Archives“ in College Park/Maryland (NARA II) sowie in der Library of Congress schufen die erforderliche und solide Quellengrundlage für diese Studie; die Gliederung, Auswertung und kritische Lektüre dieses großen Fundus an kopierten Dokumenten nahm in der Folge allerdings viel Zeit in Anspruch.

Zahlreiche berufliche Herausforderungen - darunter eine Reihe bildungshistorischer Forschungsarbeiten - haben dann dazu beigetragen, dass die Ausarbeitung der ersten Rohkapitel der vorliegenden Arbeit wiederholt unterbrochen werden musste und daher eine vergleichsweise lange Zeit in Anspruch nahm. Retrospektiv betrachtet hatten die wiederkehrenden Unterbrechungen sowie die lange währende Auseinandersetzung mit dem Recherchegegenstand - neben der sukzessiven Erweiterung der Quellenbasis und der Einarbeitung einer Vielzahl an neueren Forschungspublikationen - vielleicht auch den Vorteil, dass sich durch den wiederholt neu zu erarbeitenden Forschungsfokus zwangsläufig zusätzliche Aspekte und Fragestellungen eröffneten, wodurch retrospektiv betrachtet wohl auch eine differenziertere Betrachtung von Ereignissen und Zusammenhängen möglich war. Das Ergebnis dieser Forschungsarbeit wurde 20II schließlich als zeithistorische Dissertation an der Universität Wien eingereicht und 20I2 approbiert.

Wie bei den meisten länger währenden Forschungsarbeiten, die man als Einzelperson in Angriff nimmt, ist für deren erfolgreichen Abschluss zumeist eine Reihe von Personen mitverantwortlich, denen nachfolgend gedankt werden soll.

Ohne den motivierenden Zuspruch, die nie abreißende Unterstützung, wertvolle Hinweise und die Überlassung von Dokumenten seitens meines Dissertationsbetreuers, Herrn Univ.-Prof. Mag. DDr. Oliver Rathkolb, wäre diese Studie in der vorliegenden Form wohl kaum fertigzustellen gewesen. Ihm gebührt an dieser Stelle somit mein größter, aufrichtiger Dank. 
Für die freundliche Unterstützung der Recherche in den National Archives in Maryland danke ich ganz besonders der Forschungsarchivarin Dr. Amy Schmidt (NARA II), die mir durch ihre fachkundigen Hinweise und ihre unkomplizierte Unterstützung bei der Suche nach Aktenmaterial - als Archivar wusste ich die einmalige Gelegenheit, direkt in den Archivmagazinen gemeinsam nach scheinbar unauffindbaren Dokumenten zu recherchieren, in mehrfacher Weise zu schätzen - in überaus zuvorkommender Weise weitergeholfen hat; einen großen Fundus des in dieser Studie verwendeten Quellenmaterials verdanke ich ihrem ,Support'. Des Weiteren danke ich auch ihren Fachkollegen Dr. Bill Walsh (NARA II) sowie Dr. Milt Gustavson (NARA II) für die Hilfe bei der zum Teil schwierigen Suche nach zivilen beziehungsweise militärischen Dokumenten.

Für Hilfe bei der Informationsbeschaffung bezüglich früherer Offiziere der US-Armee danke ich Joe Webb (Historical Support Branch, Department of the Army, Center of Military History, Washington D.C.).

Für die freundliche und unkomplizierte Unterstützung bei der Suche nach weiteren Archivalia und publizierten Quellen danke ich folgenden KollegInnen: Deborah Kelley-Milburn (Research Librarian, Harvard College Library), Jennifer Govan (Research \&Informations Services, Gottesman Libraries, Teachers College/Columbia University), Jocelyn K.Wilk (Public Services Archivist, Columbia University Archives / Butler Library), David R. Grinnell (Bibliothek der University of Pittsburgh), Mag. Susanne Fröhlich (Österreichisches Staatsarchiv, Wien), Michael Winter (Archiv der Bundespolizeidirektion Wien).

Eine Reihe von Personen hat mir durch fachliche Hinweise sowie durch Überlassung von Materialien in unterschiedlicher Weise weitergeholfen. Ich danke an dieser Stelle: Herrn emer. Univ.-Prof. Dr. Kurt Tweraser (University of Arkansas), Herrn Dr. KarlHeinz Füssl (Technische Universität Berlin), Herrn Univ.-Prof. Dr. Mitchell G. Ash (Universität Wien), Herrn Dr. Lonnie Johnson (Fulbright Commission Austria); weiters den Kollegen Heimo Gruber (Wien), Ass. Prof. Dr. George Holt Blaustein (Harvard University/University of Amsterdam), Dr. Maria Wirth (Wien), Dr. Kurt Bauer (Wien), Dr. Klaus Taschwer (Wien), Univ.-Doz. Dr. Siegfried Mattl sowie Ass. Prof. Dr. Sonja Wentling (Concordia College Minnesota).

Meinem ,väterlichen' Freund und zugleich zeithistorisch-bibliothekarischen ,Lehrer Dr. Peter Malina (Wien) danke ich insbesondere für seine technische Unterstützung und Hilfestellung bei der Auswertung umfangreicher Mikrofiche-Dokumente.

Für die freundliche Unterstützung bei der Planung meines nunmehr lange zurückliegenden und - trotz der überaus intensiven und zeitaufwendigen Recherchen - in überaus angenehmer Erinnerung gebliebenen Forschungsaufenthaltes in Washington D.C. möchte ich meinen beiden Kollegen Mag. Stefan August Lütgenau und Mag. Alexander Schröck ebenso danken wie Mrs. Joane Worden (Washington D.C.), dass sie mir für die Dauer meines Aufenthaltes eine wunderbare Gastgeberin und abendliche Gesprächspartnerin war.

Meinem Freund und Fachkollegen, Herrn Fachbibliothekar AR Mag. Robert Stumpf (Fachbibliothek für Geschichtswissenschaften, Universität Wien) schulde ich in besonde- 
rer Weise Dank für seine Unterstützung bei Literaturrecherchen und für wertvolle fachliche Hinweise und kritische Anregungen.

Für das Lektorat der Arbeit beziehungsweise einzelner Kapitel danke ich Frau Edith Hahn, Herrn Prof. Dr. Anton Szanya, Herrn Siegfried Sorz sowie meinem Kollegen Dr. Stephan Ganglbauer.

Zuletzt danke ich Frau Nadine Hauer für ihre genaue und mit großem inhaltlichen Interesse vorgenommene Durchsicht des Textes, die überaus hilfreich war und der Lesbarkeit sehr zugutegekommen ist. 



\section{Einleitung}

„Der Begriff vom Zivilisationsbruch will den nachgerade singulären Umstand der Vernichtung von Menschen durch Menschen als Durchbrechung aller bisher als gewiss erachteten ethischen und instrumentellen Schranken von Handeln kennzeichnen. Eine solche Überschreitung markiert einen an der Menschheit verübten Zivilisationsbruch. ${ }^{\text {1 }}$

DAn Diner

Der wirtschaftliche, gesellschaftliche und sicherheitspolitische Wiederaufbau Westeuropas nach I945 verdankt sich unzweifelhaft ganz maßgeblich der Expansion US-amerikanischer Interessen und der weltmachtpolitischen Führungsrolle, welche die Vereinigten Staaten nach Kriegsende als neues Imperium einnahmen. Sowohl in militärischer als auch in wirtschaftlich-technologischer Hinsicht waren die USA nun das bei weitem stärkste und überlegenste Land, dessen neuer Internationalismus angesichts der großen materiellen Hilfestellungen und Unterstützungsleistungen in Europa gerne angenommen und zum Teil wohl auch geradezu eingeladen wurde. ${ }^{2}$

Das Ende des Zweiten Weltkrieges bedeutete aber nicht nur das von den Alliierten militärisch erzwungene Ende des nationalsozialistischen Vernichtungskrieges, der halb Europa in Schutt und Asche legte und Millionen zivile und militärische Opfer forderte, sondern darüber hinaus auch das Ende eines Terrorregimes, das für monströsen Massenmord und unfassbare Gräuel verantwortlich war, in deren Kern der Holocaust steht.

Angesichts der ungeheuren geistigen und materiellen Verwüstungen, die dieser bestialische „Zivilisationsbruch“ zur Folge hatte, befanden sich die Vereinigten Staaten von Amerika nach Kriegsende in einer historisch besonderen, ja geradezu exzeptionellen $\mathrm{Si}$ tuation.

Nachdem die politischen und gesellschaftlichen Eliten Europas über Dekaden hinweg - quer durch alle Lager - eindringlich vor den wirtschaftlichen und gesellschaftlich-kulturellen Folgen einer ,Amerikanisierung، der europäischen Länder gewarnt hatten und sich in hochkulturellen Überlegenheitsgefühlen gegenüber der ,flachen“ US-amerikanischen Lebenskultur und deren massenkulturellen Hervorbringungen ergangen waren, standen die USA 1945 nun nicht nur in ökonomischer, wirtschaftlicher, militärischer und machtpolitischer Hinsicht als die neue Supermacht des Westens auf

1 Dan Diner, Gegenläufige Gedächtnisse. Über Geltung und Wirkung des Holocaust, Göttingen 2007, 14.

2 Geir Lundestad, Empire by Invitation? The United States and Western Europe, 1945-1952. In: Journal of Peace Research, Vol. 23, 1986, No. 3, 264 f. Mit lediglich 6\% Anteil an der Weltbevölkerung verfügten die USA 1945 über 46\% der gesamten Weltenergie, über 48\% aller Radios, über 54\% aller Telefone und ihre Wirtschaft kontrollierte 59\% aller weltweiten Erdölreserven. Die US-Automobilindustrie war achtmal so groß wie die von Frankreich, Großbritannien und Deutschland zusammengenommen und die US-Navy die größte und effizienteste der Welt. Vgl. ebd. 
dem Boden des Alten Kontinents - sie waren zudem auch ethisch-moralischer Sieger dieses „totalen“ Krieges.

Der Zweite Weltkrieg war für die USA keinesfalls nur eine Angelegenheit, bei der es gemeinsam mit den Alliierten um die militärische Niederschlagung der Achsenmächte ging. Das zivilgesellschaftliche Amerika - hier vor allem die Bildungselite des Landes und in der unmittelbaren Folge auch Regierungsstellen, werteten die nationalsozialistische Aggression als Existenzbedrohung westlicher Zivilisation schlechthin und damit auch als Generalangriff auf die demokratischen Grundlagen des „American way of life“; dieser Bedrohung war nicht nur mit militärischen Waffen, sondern - ganz im Sinne eines globalen „Wissenschafts- und Bildungskrieges“ - auch weltanschaulich-propagandistisch entschieden entgegenzutreten, zumal ja auch die NS-Propaganda Zerrbilder eines zwar wirtschaftlich mächtigen, aber sonst kulturell inferioren und vollständig korrumpierten Landes zeichnete. In diesem Sinne hatte der Zweite Weltkrieg eine profunde weltanschauliche Dimension, da es keineswegs nur darum ging, die Motivationsbereitschaft der Bevölkerung und der Armee durch Rückbezug auf die Freiheitsideale der amerikanischen Demokratie zu stärken, sondern eben auch darum, zu beweisen, dass sich in diesem Krieg letztlich das überlegenere System einer auf humanistischen Prinzipien beruhenden Bildung und Wissenschaft durchsetzen wird.

Der Kriegseintritt der Regierung Roosevelt gegen die Achsenmächte hatte eine landesweite intellektuelle und weltanschauliche Generalmobilmachung zur Folge, die im Kampf gegen aggressiven Militarismus und totalitäre Unterdrückung nichts weniger als den Fortbestand von Freiheit, Demokratie und Selbstbestimmung - letztlich der menschlichen Zivilisation - bedroht sah.

Gewissermaßen als letzte große Zufluchts- und Hoffnungsbastion des freien Westens traten die USA an, die Wertgrundlagen der eigenen Nation und somit der (europäischen) Aufklärung - sozusagen als erweiterte „Manifest Destiny“"3 mit der in der Art des „An-

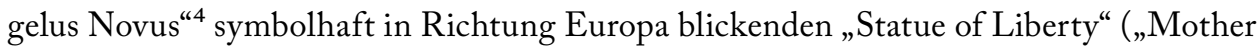

3 Die umgangssprachliche Redewendung der „Manifest Destiny“ der US-amerikanischen Politik, also die „offenkundige Bestimmung “ Amerikas zur geopolitischen Expansion der ,US-Freiheit' geht auf den New Yorker Journalisten John O'Sullivan zurück, der $1845 \mathrm{im}$ Zusammenhang mit der Annexion von Texas vom „fulfillment [sic] of our manifest destiny to overspread the continent“ sprach. Vgl. Shane Mountjoy, Manifest Destiny. Westward Expansion, New York 2009, 9 f. Zur Vorgeschichte und ideologischen Prägekraft der „Manifest Destiny“ sowie zur Ausweitung ihrer räumlichen Anwendungsbereiche siehe auch: Anders Stephanson, Manifest Destiny. American Expansion and the Empire of Right, New York 1995.

4 In seiner IX. „Geschichtsphilosophischen These“ entwarf Walter Benjamin, in Anlehnung an ein Bild von Paul Klee mit dem Titel „Angelus Novus“ und geprägt unter anderem durch die mörderischen Erfahrungen des 20. Jahrhunderts, eine geradezu apokalyptische Metapher des „Engels der Geschichte“: „Es gibt ein Bild von Klee, das Angelus Novus heißt. Ein Engel ist darauf dargestellt, der aussieht, als wäre er im Begriff, sich von etwas zu entfernen, worauf er starrt. Seine Augen sind aufgerissen, sein Mund steht offen und seine Flügel sind ausgespannt. Der Engel der Geschichte muß so aussehen. Er hat das Antlitz der Vergangenheit zugewendet. Wo eine Kette von Begebenheiten vor uns erscheint, da sieht er eine einzige Kata- 
of Exiles“) $)^{5}$ - gegen das in tiefste Barbarei und Inhumanität zurückgefallene Europa zu verteidigen.

Tatsächlich waren die während der Kriegsjahre in den Vereinigten Staaten entwickelten Umerziehungs-Konzepte für die Nachkriegszeit unmittelbarer Ausdruck einer tiefgehenden inneramerikanische Verunsicherung angesichts der Bedrohung durch das nationalsozialistische Deutschland und seine Verbündeten. Die zivilgesellschaftliche Auseinandersetzung mit den Ursachen und Folgen totalitärer Herrschaft sowie mit den diametral entgegengesetzten Grundlagen der eigenen demokratischen Gesellschaftsordnung hatte eine breitangelegte nationale Bildungsdiskussion zur Folge, die sowohl hinsichtlich ihres Umfangs als auch hinsichtlich ihrer inhaltlichen Substanz eine historische Besonderheit darstellt.

Obwohl es bereits im I9. Jahrhundert zu nationalen Bildungsdebatten mit nachfolgenden Reformen gekommen war - allerdings hauptsächlich im Gefolge verlorener Kriege ${ }^{6}$-, und nach dem Ersten Weltkrieg mitunter staatliche Rekonsktruktionsmaßnahmen auf bildungspolitischer Ebene gesetzt wurden, ${ }^{7}$ stellt die US-amerikanische „Education for Victory“-Bewegung ein Novum dar. Nie zuvor - und wohl auch nicht danach - hat sich

strophe, die unablässig Trümmer auf Trümmer häuft und sie ihm vor die Füße schleudert. Er möchte wohl verweilen, die Toten wecken und das Zerschlagene zusammenfügen. Aber ein Sturm weht vom Paradiese her, der sich in seinen Flügeln verfangen hat und so stark ist, daß der Engel sie nicht mehr schließen kann. Dieser Sturm treibt ihn unaufhaltsam in die Zukunft, der er den Rücken kehrt, während der Trümmerhaufen vor ihm zum Himmel wächst. Das, was wir den Fortschritt nennen, ist dieser Sturm. "Walter Benjamin, Zur Kritik der Gewalt und andere Aufsätze, Frankfurt a. Main 1981, 82.

5 Rob Kroes verweist in seiner Interpretation der „national destiny“ Amerikas auf die (in Wandlung begriffene) symbolische Verheißung einer Zukunft auf Basis der Werte von Demokratie und republikanischem System: „The Statue of Liberty, a French gift to the United States, was meant to express such underlying affinities. The statue represented the American goddess Columbia, facing Europe and holding up her torch in a symbolic gesture of ,liberté éclairant le monde' (freedom illuminating the world). It was only later, in a characteristic act of recontextualization, that Americans came to conceive of the statue as the ,Mother of Exiles'. It changed the reading of the message that Columbia carried. No longer did her forward stride express the rolling frontier of freedom washing across the globe; she was now seen as standing beside the ,Golden Door', a keeper of the gate to freedom found only inside it. She is reminiscent of a sentry at a border hedging off America as a refuge from a world beyond redemption." Rob Kroes, Rob: Them and us. Questions of citizenship in a globalizing world, Urbana 2000, 15.

6 So war etwa die Bildungsreform Preußens ab 1810 Folge der Kriegsniederlage gegen das napoleonische Frankreich, die Intensivierung der dänischen Heimvolkshochschulbewegung nach 1864 u.a. stimuliert durch die Niederlage im Deutsch-Dänischen Krieg und den Verlust Schleswig-Holsteins, das österreichische Reichsvolksschulgesetz 1869 späte Reaktion auf die Niederlage gegen Preußen in Königgrätz und der Ausbau der spanischen University Extension unmittelbare Folge der Niederlage im Spanisch-Amerikanischen Krieg 1898. Vgl. Barry J. Hake/Tom Steele/Alejandro Tiana (Eds.), Masters, Missionaries and Militants. Studies of Social Movements and Popular Adult Education 1890-1939, Leeds 1996.

$7 \mathrm{Zu}$ den auf den Ersten Weltkrieg folgenden Reformen im Erziehungs- und Bildungswesen der Siegermächte Frankreich, Großbritannien, Russland und USA siehe: Walter M. Kotschnig, Slaves Need No Leaders. An Answer to the Facist Challenge to Education, New York 1943, $3 \mathrm{ff}$. 
eine ganze Nation - mit Einschränkungen auch Großbritannien ${ }^{8}$-, noch dazu in direkter Involvierung in Kriegsgeschehnisse, derart intensiv in eine erziehungs- und bildungspolitische Debatte vertieft, die sich auf alle gesellschaftlichen, militärischen, geheimdienstlichen Bereiche und Einrichtungen und auf alle Bildungs-, Wissenschafts- und Forschungsinstitutionen erstreckte; in dieser Debatte wurden nicht nur Erziehung und Bildung als zentrale demokratiepolitische Säulen des amerikanischen Gemeinwesens fixiert, sondern darüber hinaus als direkte Folge noch während der Kriegsjahre bildungspolitische Reformen durchgeführt.

Der parallel zu dieser öffentlichen Bildungsdebatte geführte Experten-Diskurs beschäftigte sich auf Basis unterschiedlicher disziplinärer Zugänge mit der Frage, inwiefern beziehungsweise in welcher Form die durch die NS-Rassenideologie indoktrinierten, kulturell „pervertierten“ Menschen nach dem Krieg geistig-mental „rekulturalisiert“werden könnten. Motiviert war diese Überlegungen unter anderem auch dadurch, im Unterschied zur fehlgeschlagenen Friedenssicherung nach dem Ende des Ersten Weltkrieges, diesmal nicht nur den Krieg, sondern auch den Frieden nachhaltig zu gewinnen.

Die von den Siegermächten - je unterschiedlich - durchgeführten Reeducation-Aktivitäten ${ }^{9}$ stellen ein historisch einzigartiges Experiment dar, da erstmals in der Geschichte eine militärische Kapitulation mit einem großangelegten erzieherischen und sozialpsychologischen Programm zur mentalen Abrüstung („mental disarmament“) junktimiert wurde. Mit der alliierten Niederwerfung von Nationalsozialismus und Faschismus sahen sich die Vereinigten Staaten somit auch in moralischer und ethischer Hinsicht als siegreiche Kulturnation mit zentraler Verantwortung für die zukünftige demokratische Entwicklung ein Prozess, der durch Frieden, politische Zusammenarbeit und wirtschaftliche Kooperation geprägt sein sollte.

8 Immerhin wurde auch in England eine, wenn auch keineswegs vergleichbar breite, Reeducation-Diskussion geführt, gab es Kontakte zu amerikanischen Bildungsinstitutionen und wurde 1944 mit dem „Education Act" ein eigenes Reformgesetz für Sekundarschulen beschlossen, das insbesondere die Mobilisierung der Arbeiterschicht zum Ziel hatte. Vgl. Harold Collet Dent, The Education Act, 1944. Provisions, regulations, circulars, later acts, London 1960, $11 \mathrm{ff}$.

9 Die Fachliteratur zu den alliierten Reeducation-Maßnahmen ist im Verlauf der letzten zwei Jahrzehnte durch quellenbasierte Monografien, Detailstudien und zunehmend auch akademische Abschlussarbeiten erheblich angewachsen. Durch die Erweiterung der Forschungsperspektive auf Prozesse des Kultur- und Wissenschaftstransfers bzw. der Kulturdiplomatie hat sich dieser Bereich der „Cold War Studies“ zudem sowohl in methodischer als auch in disziplinärer Hinsicht zu einem weitverzweigten Forschungsbereich entwickelt, was einen Literaturbericht unter anderem auch deshalb schwierig macht, da es nach wie vor keine einschlägigen Monografien gibt, die eine Bilanz des bisherigen Forschungsstandes erlauben. Eine, wenn auch keineswegs mehr rezente Ausnahme bildet das Standardwerk von Manfred Heinemann, das Auskunft zu den unterschiedlichen Reeducation-Ansätzen der Alliierten in Deutschland und Österreich gibt: Manfred Heinemann (Hrsg.), Umerziehung und Wiederaufbau. Mit einem Vorwort von Manfred Heinemann und einer Einleitung von Wilhelm Roeßler (= Veröffentlichung der Historischen Kommission der Deutschen Gesellschaft für Erziehungswissenschaft, Bd. 5), Stuttgart 1981. 
Durch umfassende Entnazifizierung und Demilitarisierung sowie durch eine adäquate "Erziehung" zu Toleranz, Freiheit und demokratischer Selbstbestimmung quer durch alle Generationen sollte der weltweiten Bedrohung durch die menschenverachtende nationalsozialistische Rassen- und Herrenmenschenideologie ein für alle Mal die Grundlage entzogen werden. Weit über den Bedeutungsumfang des deutschen Begriffs „Erziehung“ hinausgehend, sollte Deutschland respektive die kriegsverursachenden Achsenmächte durch „Reorientation“ beziehungsweise „Reeducation“ in „die Kulturgemeinschaft zivilisierter Nationen, die es unter der nationalsozialistischen Herrschaft verlassen hatte[n] “, ${ }^{10}$ zurückgeführt werden.

\section{FORSCHUNGSANSATZ - METHODISCH-THEORETISCHE ASPEKTE}

Die Beschäftigung mit dem Fragenkomplex der sogenannten „Reorientierung“ beziehungsweise mit der „Reeducation“ stellt in der österreichischen zeitgeschichtlichen Forschung zum Schwerpunkt „Kalter Krieg“ - trotz der für den deutschen Sprachraum konstatierten „kulturalistischen Wende“ ${ }^{11}$ und des regelrechten Booms der angloamerikanischen „Cultural Cold War Studies“ - nach wie vor eine Art zweit- oder auch drittrangige Thematik dar. Zumindest ergibt sich dieses Bild mit Blick auf den bisher quantitativ eher dürftigen Forschungsoutput. ${ }^{12}$ Zuweilen wurde diese forschungsthematische Mar-

10 Karl-Ernst Bungenstab, Umerziehung zur Demokratie? Re-education-Politik im Bildungswesen der USZone 1945-1949, Düsseldorf 1970, 19.

11 Vgl. Volker Berghahn, Industriegesellschaft und Kulturtransfer. Die deutsch-amerikanischen Beziehungen im 20. Jahrhundert (=Kritische Studien zur Geschichtswissenschaft, Bd. 182), Göttingen 2010, 15.

12 Für Österreich existieren, abgesehen von den bahnbrechenden Arbeiten von Alfred Hiller, Josef Leidenfrost, Michael Schönberg, Reinhold Wagnleitner und Oliver Rathkolb zur US-Medien- und ReorientierungsPolitik (sowie den akademischen Abschlussarbeiten von Gerda Theuermann, Johann Schoiswohl, Thomas Liebl, Doris Graf, Michaela Anderle und Simone Krienzer) kaum Studien zur „Umerziehungspolitik“ der anderen Besatzungsmächte. Zur engagiert betriebenen französischen Kulturpolitik gibt es die beiden Arbeiten: Elisabeth Starlinger, Aspekte französischer Kulturpolitik in Österreich nach dem Zweiten Weltkrieg (1945-1948), Dipl.-Arb., Univ. Wien 1993 sowie Michaela Feuerstein-Prasser, Von der Besatzungspolitik zur Kulturmission. Französische Schul- und Bildungspolitik in Österreich 1945-1955, Diss., Univ. Wien 2002. Zur britischen Kulturpolitik allgemein siehe: Johannes Feichtinger, Eduard G. Staudinger, Aspekte des kulturellen Wiederaufbaus in der Steiermark zwischen Kooperation und Kontrolle. In: Siegfried Beer (Hrsg.), Die „britische“ Steiermark 1945-1955 (=Forschungen zur geschichtlichen Landeskunde der Steiermark, 38). Unter wiss. Mitarbeit v. Felix Schneider u. Johannes Feichtinger, Graz 1995, 499-527. Die Entnazifizierung im steirischen Pflichtschulbereich beleuchtet, jedoch ohne Einbettung in die britische Reeducation-Politik: Gudrun Fessler, 1945-46 - das erste Schuljahr. Schulalltag, Entnazifizierung, Umerziehung und Wiederaufbau des steirischen Pflichtschulwesens im ersten Schuljahr nach Kriegsende, Dipl.Arb., Univ. Graz 1995; mit der britischen Reeducation, allerdings primär im Zusammenhang britischer Kriegsgefangenenlager, beschäftig sich bisher lediglich: Brigitte Weiß, Re-education. Der Umerziehungsversuch von Kriegsgefangenen in Großbritannien während und nach dem Zweiten Weltkrieg, Dipl.-Arb., 
ginalisierung durch Aussagen einschlägiger Studien selbst verstärkt: In ihnen wurde beispielsweise darauf verwiesen, dass die „Reorientierung“ im Kontext der Gesamtaufgaben der Militärregierung lediglich eine Nebensächlichkeit darstellte und ohnedies nie richtig gegriffen beziehungsweise infolge des Kalten Krieges bald über Bord geworfen worden wäre. ${ }^{13}$ Wie Karl-Heinz Füssl konstatierte, ging die einschlägige Forschung auch für Deutschland, analog zur Entnazifizierung, von einem weitgehend pessimistischen Bild der Reeducation aus ${ }^{14}$ und interessierte sich daher - dies gilt freilich insbesondere für Österreich - über längere Zeit nicht weiter für vertiefte Forschung. Die einfache, jedoch durchaus erkenntnisfördernde Gegenfrage, wie die Nachkriegsentwicklung wohl obne jegliche Reorientierungs-Maßnahmen und unter völligem Ausbleiben der konkret durchgeführten Entnazifizierung ausgesehen hätte, wurde unter dieser paradigmatischen Herangehensweise bezeichnenderweise erst gar nicht gestellt.

Methodisch und theoretisch verfeinerte sowie quellenmäßig breitere Zugänge präsentieren hier ein etwas anderes Bild, wie etwa in Reinhold Wagnleitners grundlegender Studie zur „Coca-Colonisation“, aber auch schon viel früher in einer ersten lokalen Fallstudie von John Gimbel ${ }^{15}$ sowie ansatzweise in den Studien von James F. Tent, ${ }^{16}$ Henry J. Kellermann ${ }^{17}$ oder auch bei Karl-Ernst Bungenstab, ${ }^{18}$ die vor allem die Entstehungs- und unterschiedlichen Implementierungskontexte der US-Reorientierung stärker berücksichtigen und die Frage nach den intentionalen und konterintentionalen Wirkungen neu fassen. ${ }^{19}$

Univ. Graz 2002, sowie: Florentine Kastner, 373 Camp Wolfsberg. Britische Besatzungslager in Österreich von 1945 bis 1948, Dipl.-Arb., Univ. Wien 2001. Die sowjetische „Umerziehung“, ebenfalls von Kriegsgefangenen, behandelt: Michael Pucher, Umerziehung im sowjetischen Kriegsgefangenenlager Talicy, Dipl.Arb., Univ. Graz 1997; den Kontext von Entnazifizierung und russischer Besatzungsmacht Alexander Knes, Entnazifizierung in der sowjetischen Zone Österreichs von 1945 bis 1948, Dipl.-Arb., Univ. Graz 2005.

13 So z.B. Helmut Engelbrecht, Die Eingriffe der Alliierten in das österreichische Schul- und Erziehungswesen nach 1945. In: Manfred Heinemann (Hrsg.), Umerziehung und Wiederaufbau. Mit einem Vorwort von Manfred Heinemann und einer Einleitung von Wilhelm Roeßler (=Veröffentlichung der Historischen Kommission der Deutschen Gesellschaft für Erziehungswissenschaft, Bd. 5), Stuttgart 1981, $278 \mathrm{ff}$.

14 Karl-Heinz Füssl, Zwischen NS-Traumatisierung und Demokratie: Die Erziehungspolitik der USA in der deutschen Nachkriegsgeschichte (1945-1952). In: Paedagogocica Historica. International Journal of the History of Education, XXXIII, 1997, Heft 1, $221 \mathrm{ff}$.

15 John Gimbel, A German community under American occupation: Marburg, 1945-1952, Stanford 1961; weiters: Ders., Amerikanische Besatzungspolitik in Deutschland 1945-1949, Frankfurt a. Main 1971.

16 James F. Tent, Mission on the Rhine. Reeducation and Denazification in American-Occupied Germany, Chicago - London 1982.

17 Henry J. Kellermann, Cultural relations as an Instrument of U.S. Foreign Policy. The Educational Exchange Program between the United States and Germany 1945-1954 (= Department of State Publication 8931), Washington D.C. 1978.

18 Bungenstab, Umerziehung zur Demokratie?, a.a.O., 1970.

19 Exemplarisch lassen sich an dieser Stelle folgende Arbeiten nennen: Karl-Heinz Füssl, Deutsch-Amerikanischer Kulturaustausch im 20. Jahrhundert. Bildung - Wissenschaft - Politik, Frankfurt a. Main 2004; Ellen Latzin, Lernen von Amerika? Das Kulturaustauschprogramm für Bayern und seine Absolventen 
Hierbei zeigt sich, dass es sinnvoll ist, die Reeducation beziehungsweise Reorientation auf die terminologischen Unterschiede wird später noch einzugehen sein - verstärkt im Sinne einer „reculturalization“ zu begreifen: eine begriffliche Erweiterung beziehungsweise inhaltliche Präzisierung, die obendrein auf die tatsächlich zugrundeliegenden Planungen vor 1945 rückführbar ist und die US-amerikanischen Konzepte einer Nachkriegsdemokratisierung um einiges genauer kennzeichnet.

Im Folgenden soll dargestellt werden, dass es sich bei der Frage der gesamten Reeducation, Reorientation, Rehabilitation oder wohl besser „Rekulturalisierung“ um einen zentralen Aspekt der US-amerikanischen Konfrontation mit dem Nationalsozialismus handelt, der nach Kriegsende auch die sicherheits- und machtpolitische Position der USA und ihrer Außenpolitik mitbestimmte. Für die Geschichte der Nachkriegszeit und des beginnenden Kalten Krieges haben die US-Reorientierungs-Konzepte zumindest dreifache Bedeutung: zunächst als identitätsstiftende ideologische Legitimationsformel für den nationalen Kriegseinsatz sowie als kultur- und bildungspolitische Planungsperspektive einer Frieden sichernden Nachkriegsentwicklung; sodann als konkretes außenpolitisches Strategem einer nachhaltigen Demokratisierung; und mit Ausbruch des Kalten Krieges schließlich als kulturpolitisches Instrument der antikommunistischen Westintegration und Blockbildung, das bald Aktivitäten zur propagandistischen Beeinflussung von aktuellen oder künftigen Exponenten der politischen, kulturellen und wissenschaftlichen Elite miteinbezog. Als ideologisches „backbone“ der US-Außenpolitik unterstützte der US-Reorientierungs-Diskurs das nachhaltige Ende der bisherigen isolationistischen Kulturdiplomatie der Vereinigten Staaten und mündete - freilich mit sinkender Reflexionsbereitschaft hinsichtlich des damit einhergehenden demokratiepolitischen Erklärungsbedarfes - schließlich direkt in die offensive und expansive Mission der „Pax Americana“. ${ }^{20}$

(=Transatlantische Historische Studien, Bd. 23), Stuttgart 2005; eine breit angelegte Untersuchung zu einem speziellen Implementierungsbereich der US-Reorientation findet sich zuvor bereits bei: Maritta Hein-Kremer, Die amerikanische Kulturoffensive. Die Gründung und Entwicklung der amerikanischen Information Centers in Westdeutschland und West-Berlin, 1945-1955, Köln 1996; zum Konnex der USReorientierungs-Politik mit geheimdienstlichen Aktivitäten siehe: Volker Berghahn, Transatlantische Kulturkriege. Shepard Stone, Die Ford-Stiftung und der europäische Antiamerikanismus (=Transatlantische Historische Studien, Bd. 21), Stuttgart 2004. Zum Bereich der Reorientierung der Universitäten in Deutschland siehe jüngst die materialreiche und historisch weit ausgreifende Studie von: Stefan Paulus, Amerikanisierung von Universität und Wissenschaft in Westdeutschland 1945-1976 (= Studien zur Zeitgeschichte. Hrsg. v. Institut für Zeitgeschichte, Bd. 81), München 2011.

20 Vgl. Eric P. Louw, Roots of the Pax Americana. Decolonisation, Development, Democratisation and Trade, Manchester 2010; Ronald Steel, Pax Americana. Weltreich des Kalten Krieges, Darmstadt 1968; Ursula Lehmkuhl, Pax Anglo-Americana. Machtstrukturelle Grundlagen angloamerikanischer Asien- und Fernostpolitik in den 1950er-Jahren, München 1999. Zur Thematisierung der „Pax Americana“ im Kontext aktueller weltpolitischer Entwicklungen siehe: Ronald Bauermeister, Pax Americana versus „Krieg der Kulturen“. Studie über die Chancen einer von den USA dominierten Weltordnung für das 21. Jahrhundert im Kontext historischer Ereignisse und gegenwärtiger Entwicklungen im politischen Europa, Diss., Freie Uni- 
Eine explizite Zuordnung der grundlegenden theoretischen Annahmen dieser Studie zu einer der älteren oder der rezenten Theoriebildungen wie beispielsweise der Kritischen Theorie ${ }^{21}$ oder dem Struktur- oder Sozialkonstruktivismus ${ }^{22}$ wurde - trotz mancher Nähe unterlassen; dies nicht zuletzt deshalb, weil großtheoretische Erklärungsansätze in der Regel starr sind und durch einzeltheoretische Grundlegungen im Kontext historiografischer Arbeiten aufgrund der Komplexität des Gegenstandsbereiches ebenso wenig gewonnen ist wie durch die bloße Auflistung prägender Lektüren.

In methodischer Hinsicht ergab sich die spezifische Mischung aus traditioneller historisch-kritischer Verfahrensweise ${ }^{23}$ sozialwissenschaftlichen und strukturgeschichtlichen Ansätzen, ${ }^{24}$ historisch-kulturwissenschaftlichen Anleihen ${ }^{25}$ oder soziologischer ${ }^{26}$ und ethnologischer Kulturtheorien ${ }^{27}$ erst im Fortgang und Verlauf der Arbeit durch die jeweiligen Perspektiven und Fragestellungen, durch die Art des verwendeten Quellenmaterials sowie letztlich durch die Orientierung am Methodeninventar rezenter Zeitgeschichteforschung.

versität Berlin 2004. Eine erste antiamerikanische Polemik unter diesem Titel publizierte bereits 1920 der Göttinger Althistoriker Ulrich Kahrstedt (1888-1962): Ulrich Kahrstedt, Pax Americana. Eine historische Betrachtung am Wendepunkte europäischer Geschichte, München 1920. Vgl. dazu: Joachim Riecker, „Das Geheimnis ist Mut". Antike Vorbilder in der amerikanischen Außenpolitik von Theodore Roosevelt bis Bill Clinton, Paderborn 2006, $71 \mathrm{ff}$.

21 Vgl. Max Horhkeimer, Traditionelle und Kritische Theorie. Vier Aufsätze, Frankfurt a. Main 1984, 12-64; vgl. dazu weiters: Jürgen Habermas, Erkenntnis und Interesse. Mit einem neuen Nachwort. 6. Aufl., Frankfurt a. Main 1981, $59 \mathrm{ff}$.

22 Vgl. John Gerad Ruggie, Constructing the World Polity. Essays on International Instiutionalization, London 1998; weiters: Daniel M. Green, Constructivism and Comparative Politics, Armonk N.Y. 2002.

23 Mit dem Vorzug analytischer gegenüber hermeneutischer Rekonstruktion bzw. Argument versus Erzählung/Narration. Vgl. Stefan Jordan, Theorien und Methoden der Geschichtswissenschaft. Orientierung Geschichte, Paderborn 2009, $45 \mathrm{ff}$.

24 D.h. der Auswertung empirischer Daten (Quantitifizierung), der Berücksichtigung überindividueller Prozesse, und der Analyse situationsübergreifender Ordnungen der Sinnproduktion (Typisierung, Generalisierung, Diskursanalyse). Vgl. Hans-Ulrich Wehler, Historische Sozialwissenschaft und Geschichtsschreibung. Studien zu Aufgaben und Traditionen deutscher Geschichtswissenschaft, Göttingen 1980.

25 Vgl. Achim Landwehr, Kulturwissenschaft und Geschichtswissenschaft. In: Klaus Stiersdorfer/Laurenz Volksmann (Hrsg.), Kulturwissenschaft interdisziplinär, Tübingen 2005, 39-57; weiters: Jan Kusber/Mechthild Dreyer/Jörg Rogge /Andreas Hütig (Hrsg.), Historische Kulturwissenschaften. Positionen, Praktiken und Perspektiven, Bielefeld 2010.

26 Vgl. Pierre Bourdieu, Sozialer Sinn. Kritik der theoretischen Vernunft, Frankfurt a. Main 1993: „Die Theorie der Praxis als Praxis erinnert gegen den positivistischen Materialismus daran, daß Objekte der Erkenntnis konstruiert und nicht passiv registriert werden [...]“. Ebd., 97.

27 Siehe: Clifford Geertz, Dichte Beschreibung. Beiträge zum Verstehen kultureller Systeme, Frankfurt a. Main 1987: „Kultur, dieses Dokument, ist also öffentlich [...]. Obwohl sie aus Ideen besteht, existiert sie nicht in den Köpfen; obwohl sie unkörperlich ist, ist sie keine okkulte Größe. [...] Sobald menschliches Verhalten als symbolisches Handeln gesehen wird [...] verliert das Problem, ob Kultur vorgestanztes Verhalten, ein beschränkter intellektueller Horizont oder sogar von beiden etwas ist, seinen Sinn." Ebd., 16 
Im Zusammenhang der historischen Rekonstruktion der US-Reorientierungs-Konzepte und deren Implementierung im Bereich des akademisch-universitären Wiederaufbaus in Österreich ging es vor allem um eine möglichst konzise Argumentation, um eine verlässliche Analyse und Interpretation der Quellen, um ein konsistentes Begriffs- und Ordnungssystem sowie um die kohärente Verbindung von Makro- und Mikroanalysen, durch die sich Institutionen-Logiken ebenso wie die spezifischen Handlungsdispositionen einzelner Akteure und Akteursgruppen nachzeichnen lassen.

Obwohl die hier behandelte Themenstellung somit auch Schnittflächen zu den historischen beziehungsweise kulturanthropologischen Untersuchungsfeldern der sogenannten „Amerikanisierung“"28 beziehungsweise „Westernisierung“29 aufweist, die im Übrigen keineswegs immer klar und nachvollziehbar definiert werden ${ }^{30}$ und zuweilen auch zu diffusen Explanationen führen, ${ }^{31}$ bilden die damit verknüpften methodischen und theoretischen

28 Zum Begriff der „Amerikanisierung“, der sich in der Regel auf den US-Kulturtransfer im weitesten Sinne bezieht, wie bspw. Werthaltungen, gesellschaftliche Normen, Verhaltensweisen, Institutionen oder Symbole, siehe u. a.: Alf Lüdtke/Inge Marßolek/Adelheid von Saldern (Hrsg.), Amerikanisierung. Traum und Alptraum im Deutschland des 20. Jahrhunderts (=Transatlantische Historische Studien, Bd. 6), Stuttgart 1996; Konrad Jarausch/Hannes Siegrist (Hrsg.), Amerikanisierung und Sowjetisierung in Deutschland 1945-1970, Frankfurt a. Main 1997; Egbert Klautke, Unbegrenzte Möglichkeiten. „Amerikanisierung“ in Deutschland und Frankreich (1900-1933) (=Transatlantische Historische Studien, Bd. 14), Stuttgart 2003; zuletzt: Reiner Marcowitz (Hrsg.), Nationale Identität und transnationale Einflüsse. Amerikanisierung, Europäisierung und Globalisierung in Frankreich nach dem Zweiten Weltkrieg, München 2007.

29 Der Begriff Westernisierung, der „Westintegration“ mitumfasst, referenziert auf die bi- oder multilaterale ordnungspolitische Erweiterung der Amerikanisierung sowie auf die Ausbildung einer, wie Anselm Doering-Manteuffel formuliert, „gemeinsamen Wertordnung in den Gesellschaften diesseits und jensseits des Nordatlantik“. Anselm Doering-Manteuffel, Wie westlich sind die Deutschen? Amerikanisierung und Westernisierung im 20. Jahrhundert, Göttingen 1999, 13. Siehe weiters: Theodore H. Laue, The World Revolution of Westernization. The 20th Century in Global Perspective, New York 1987; Eckart Conze, Wege in die Atlantische Gemeinschaft. Amerikanisierung und Westernisierung in Westeuropa nach 1945. In: Reiner Marcowitz (Hrsg.), Nationale Identität und transnationale Einflüsse. Amerikanisierung, Europäisierung und Globalisierung in Frankreich nach dem Zweiten Weltkrieg, München 2007, 72 ff.; sowie: Vanessa Conze, Das Europa der Deutschen. Ideen von Europa in Deutschland zwischen Reichstradition und Westorientierung (1920-1970), München 2005. Für Österreich gaben Günter Bischof und Anton Pelinka einen ersten Band zum Themenkomplex heraus, der jedoch inhaltlich und methodisch überaus heterogen ist und bedauerlicherweise auf theoretische Erklärungsansätze und semantische Auslotung der verwendeten Titelbegriffe weitgehend verzichtet. Günter Bischof/Anton Pelinka (Eds.), The Americanization/Westernization of Austria, New Brunswick 2004.

30 So verwendet bspw. Michael Hochgeschwender explizit den Begriff „Westernisierung“, da es nicht um Formierung einer politisch-militärisch-ökonomischen Hegemonie geht, sondern „um die ideologische Flankierung dieser eng miteinander verschränkten Prozesse auf der Ebene der Hochkultur“. Michael Hochgeschwender, Freiheit in der Offensive? Der Kongress für kulturelle Freiheit und die Deutschen, Tübingen 1996, 36.

31 So meint etwa Günter Bischof, dass erst die US-Militärpräsenz nach Ende des Zweiten Weltkriegs die Grundlage für die Ankunft der amerikanischen Populärkultur bereitet hätte: „The American global military presence during the Cold War - in postwar occupation regimes and through a global ring of military bases 
Forschungsansätze im Zusammenhang mit der vorliegenden Arbeit, ähnlich wie die Akkulturations- beziehungsweise Kulturtransfer-Forschung, ${ }^{32}$ nur einen allgemeinen Bezugsrahmen ohne spezifischen methodologisch-inhaltlichen Bezug im engen Sinne, da der jeweilige Fokus dieser Forschungsfelder zumeist auf einzelne Segmente gerichtet ist: Dieser konzentriert sich entweder auf Prozesse des bilateralen Kulturaustausches, auf US-Propaganda-Strategien, auf die Wirkungen der amerikanischen Populärkultur, auf ordnungspolitische Integrations- und Bündnispolitik oder auf fachwissenschaftlich-disziplinäre Diskurse und deren spezifischen Veränderungen im Rahmen wissenschaftlicher Institutionen.

Rob Kroes hat zudem nachdrücklich darauf aufmerksam gemacht, dass der hegemoniale Begriff „Americanization“, im Unterschied zu „Americanism“, eine eindeutig negative Konnotation besitzt, indem er immer auf eine Form der De-Europäisierung verweist; damit würde, so Kroes, ein komplexes Phänomen sehr oft auf eine vergleichsweise simple Erklärungsformel reduziert, was der Analysekraft des Begriffes kaum zugutekäme. Immerhin könnten veränderte theoretische Parameter durchaus zu inversen Interpretationen führen: „America's colonization of Europe then turns into Europe's Coca-colonization“..33 Als methodisch und theoretisch avancierter Kulturanthropologe schlägt Kroes daher - in humorvoller Anleihe an ein populäres Hollywood-Icon der Gegenwart - vor, zunächst einmal den transformativen „Black-Box-Charakter" der „Amerikanisierung“ anzuerkennen, um so nicht vorschnell die Mehrdimensionalität, die diesen Prozess unzweifelhaft kennzeichnet, aus dem Blick zu verlieren:

"If in this process there are obviously senders and receivers as well as modes and means of transmission, the black box is the semiotic dark room where messages undergo a process of translation, where they are decoded and reencrypted, decontextualized and recontextualized, and made to fit the receivers' frames of reference. The black box in this sense is not unlike the

encircling the Soviet Union - laid the groundwork for the advent of American popular culture. In other words, cultural exports followed on the heels of a preponderance of American military power." Bischof, Introduction. Austria in McWorld. In: Bischof/Pelinka (Eds.), The Americanization/Westernization of Austria, a.a.O., 2.

32 Zum diesem überaus spannenden Forschungsfeld, das mitunter auch lernzentrierte Theorieansätze adpatiert hat, siehe u.a.: Martin Aust/Daniel Schönpflug (Hrsg.), Vom Gegner lernen. Feindschaften und Kulturtransfers im Europa des 19. und 20. Jahrhunderts, Frankfurt a. Main 2007; Volker R. Berghahn, Industriegesellschaft und Kulturtransfer. Die deutsch-amerikanischen Beziehungen im 20. Jahrhundert (= Kritische Studien zur Geschichtswissenschaft, Bd. 182), Göttingen 2010; Oliver Agard/Christian Helmreich/Hélène Vinckel-Roisin (Hrsg.), Das Populäre. Untersuchungen zu Interaktionen und Differenzierungsstragien in Literatur, Kultur und Sprache, Frankfurt a. Main 2011.

33 Rob Kroes, If you've seen one, you've seen the mall. Europeans and American mass culture, Amsterdam 1996, xii. Auch Wagnleitner hat diesbezüglich angemerkt, dass hinter der „Amerikanisierung“ der Welt eigentlich deren „Europäisierung“ liegt. Reinhold Wagnleitner, Coca-Colonisation und Kalter Krieg. Die Kulturmission der USA in Österreich nach dem Zweiten Weltkrieg (= Österreichische Texte zur Gesellschaftskritik, Bd. 52), Wien 1991, 7. 
children's toys that we know as Transformers, whose changing configurations of constituent elements produce widely divergent meanings from essentially empty signifiers. Of course, the elements of an American mass culture transmitted to Europe are never so purely devoid of meaning (although a long tradition of European anti-American rhetoric has tended to make that claim), yet when they pass through the black box of the semantic transformer, they do come out in different configurations." 34

Ähnlich wie mit dem Bereich der Kulturtransfer-Forschung verhält es sich auch mit den Forschungsbereichen der „Cultural Diplomacy“, des „Cultural Cold War“ oder der „Intellectual History“, deren jeweiliger Untersuchungsschwerpunkt entweder auf Prozessen des bilateralen Kulturaustausches beziehungsweise der politischen Kulturentwicklung und deren Begleitdebatten liegt $t^{35}$ oder stärker fachwissenschaftliche Diskurse und deren spezifische Veränderungen im Rahmen wissenschaftlicher Institutionen oder Gremien berücksichtigt. ${ }^{36}$ Auch hier existieren im Zusammenhang mit dem akademisch-universitären

34 Ebd., xi.

35 Zum Bereich der „Cultural Diplomacy“ siehe exemplarisch: Naima Prevots, Dance for Export. Cultural Diplomacy and the Cold War, Hanover 1998; Oliver Matthias Arnold Schmidt, Civil Empire by Co-optation. German-American Exchange Programs as Cultural Diplomacy, 1945-1961, Diss., Univ. Harvard 1999; J. Michael Waller, Fighting the War of Ideas like a Real War, Washington D.C. 2007. Zum mittlerweile kaum mehr überblickbaren Forschungsbereich des „Cultural Cold War“ siehe u.a.: David Ellwood (Eds.), Hollywood in Europe. Experiences of a Cultural Hegemony, Amsterdam 1994; Scott Lukas, Freedom‘s War. The US Crusade against the Soviet Union, 1945-1956, Manchester 1999; Frances Stonor Saunders, Who Paid the Piper? The CIA and the Cultural Cold War, London 1999; Uta Poiger, Jazz, Rock, and Rebels. Cold War Politics and American Culture in a Divided Germany, Berkeley 2000; David Caute, The Dancer Defects. The Struggle for Cultural Diplomacy during Cold War, Oxford - New York 2003; Bradley Abrahams, The Struggle for the Soul of the Nation. Czech Culture and the Rise of Communism, Lanham 2004; Giles Scott-Smith/Hans Krabbendam (Eds.), The Cultural Cold War in Western Europe, 1945-1960, London 2004; Arnd Bauernkämper/Konrad H. Jarausch/Marcus M. Payk (Hrsg.), Demokratiewunder. Transatlantische Mittler und die kulturelle Öffnung Westdeutschlands 1945-1970, Göttingen 2005. Zuletzt zwei rezente Arbeiten, welche die Problematik fehlender Einbeziehung des politischen ,Decision-Makings' verdeutlichen: Brian M. Puaca, Learning Democracy. Education Reform in West Germany, 1945-1965 (= Monographs in German History, Vol. 27), New York 2009, sowie: Jens Christian König, Politische Kultur in den USA und Deutschland: Nationale Identität am Anfang des 21. Jahrhunderts, Berlin 2010. Eine avancierte Arbeit mit breitem Bezug auf Primärquellenmaterial legte in diesem Bereich jüngst Georg Holt Blaustein Jr. vor: Ders., To the Heart of Europe: Americanism, the Salzburg Seminar, and Cultural Diplomacy, Diss., Harvard University, 2010.

36 Beispiele für Arbeiten in diesem Segment sind u. a.: Christopher Simpson, Science of Coercion. Communication Research and Psychological Warfare 1945-1960, New York - Oxford 1994; Noam Chomsky/Laura Nader/Immanuel Maurice Wallerstein, The Cold War \& the University. Toward an intellectual history of the postwar years, New York 1997; Martin J. Medhurst, Cold War rhetoric. Strategy, Metaphor, and Ideo$\operatorname{logy}$ (=Contributions to the study of mass media and communications, Vol. 19), New York 1990; Rebecca S. Lowen, Creating the Cold War University. The Transformation of Stanford, Berkeley 1997; Ron Robin, The Making of the Cold War Enemy. Culture and Politics in the Military-Intellectual Complex, Princeton 
Wiederaufbau in Österreich nach 1945 vielfache inhaltliche und methodische Überschneidungen zur der in dieser Arbeit vorgenommenen Auseinandersetzung mit der US-Reorientierung und deren Implementierung.

Ohne jede Notwendigkeit einer Abgrenzung - schließlich führen theoretische und methodische Anleihen mitunter zu interessanten neuen Forschungsfragen - zeigt sich hinsichtlich des gewählten Ansatzes aber doch eine wichtige Differenz. Den hauptsächlichen Unterschied zu den genannten Forschungsbereichen bildet der hier gewählte Bezugsrahmen der Politik-, Diplomatie- und Gesellschaftsgeschichte sowie die durchgängige Orientierung der Analyse auf themenrelevante Aspekte realpolitischer Entwicklungs- und Entscheidungsverläufe im zivilen und militärischen Bereich, was auch durch das vergleichsweise breite Primär- und Sekundärquellenmaterial deutlich wird. So gilt das Hauptaugenmerk dieser Arbeit weniger den „Reorientation“-Diskursen und deren Interpretation, sondern vielmehr deren Konnex zu den politischen und militärischen Planungsund Entscheidungsprozessen und deren konkreten Manifestationen, was im vorliegenden Fall unter anderem anhand des Fallbeispiels des akademisch-universitären Wiederaufbaues nachgezeichnet werden soll.

In diesem Sinne versteht sich die vorliegende Publikation sowohl hinsichtlich der theoretischen Grundannahmen als auch hinsichtlich der methodisch-analytischen Herangehensweise als zeithistorische Studie im Bereich der „Cold War Studies“, die nach ihrer Neuausrichtung Ende der I99oer-Jahre vermehrt multidisziplinäre sowie multiarchivalische Ansätze integrierten und den Bezugsrahmen zunehmend auf die kulturelle ${ }^{37}$ „Ordnung der Dinge“ (M. Foucault), also auf die kulturelle Dimension des Kalten Krieges und dessen spezifischer Relevanz erweitert haben. ${ }^{38}$ Der inhaltliche Schwerpunkt ist daher auf demokratie-, kultur- und wissenschaftspolitische Zusammenhänge gerichtet, wobei sich die zeitliche Einschränkung der Arbeit durch den Beginn der Reorientierungs-Planungen und dem Ende ihrer besatzungspolitischen Umsetzung spätestens im Jahr I955 ergibt.

Unter Einbeziehung der weit zurückreichenden wechselseitigen amerikanisch-europäischen Zuschreibungen und Perzeptionen wird versucht, die Provenienz und die historische Genese der US-amerikanischen Reeducation-Konzepte, ihre unterschiedlichen Bestimmungsmerkmale, Interessenslagen und Ergebnisse ebenso nachzuzeichnen, wie ihre spezifischen Veränderungen und konkreten Implementierungen im Kontext der militärischen

2001; Uta Gerhardt, Talcott Parsons. An intellectual Biography, Cambridge 2002; Nils Gilman, Mandarins of the Future. Modernization Theory in Cold War America, 2003; George A. Reisch, How the Cold war Transformed Philosophy of Science. To the Icy Slopes of Logic, New York 2005.

37 „Kultur“ verstanden als ein gültiges Sinnsystem oder die Gesamtheit der miteinander geteilten verhaltensprägender Bedeutungen für eine größere Gruppe von Menschen.

38 Odd Arne Westad meinte diesbezüglich: „New Cold War history is in its essence multiarchival in research and multipolar in in anlysis, and, in the cases of some of its best practitioners, multicultural in its ability to understand different and sometimes opposing mindsets." Odd Arne Westad, Reviewing the Cold War. Approaches, Interpretations, Theory, London 2000, 5. 
Besatzungsplanungen bis Kriegsende sowie im Zusammenhang der darauffolgenden USPropagandastrategien zu Ausbruch des Kalten Krieges.

Besonderes Interesse gilt dabei freilich der spezifischen Rolle Österreichs in all diesen Untersuchungsbereichen. Obwohl die politische Sprachregelung - wenn auch primär aus Gründen psychologischer Kriegsführung - nach der „Moskauer Erklärung über Österreich“ im Jahr I943 die künftige „Befreiung“ des Landes propagierte und einen von Deutschland unterschiedenen, quasi „freundlicheren“ Besatzungsstatus vorsah, machten die konkreten Reorientierungs-Planungen hinsichtlich der tatsächlichen NS-Indoktrinierung der Bevölkerung und der de facto vollständigen Durchdringung des gesamten Erziehungs- und Bildungssystems durch den Nationalsozialismus jedoch weder zu Kriegsende noch danach signifikante Unterschiede zwischen Deutschland und Österreich.

Vor diesem Hintergrund zielt die allgemeine forschungsleitende Ausgangsfrage der Arbeit auf den impliziten Zusammenhang zwischen den von der amerikanischen Besatzungsmacht in den Nachkriegsjahren gesetzten Demokratisierungsmaßnahmen und der Ausbildung einer post-nationalsozialistischen, demokratischen Wissenschaftskultur, im weitesten und allgemeinsten Sinne: der Ausbildung einer weltoffenen, international orientierten akademischen österreichischen Identität. Oder anders gefragt: Inwiefern hat die Präsenz der alliierten Besatzungsmächte, die, wie Oliver Rathkolb im Zusammenhang mit der hochgradig restaurativen Kunst- und Kulturentwicklung zu Beginn der Zweiten Republik angemerkt hat, „,vor allem in den ersten Jahren mit großer realpolitischer Macht ausgestattet war“, ${ }^{39}$ tatsächlich Einfluss auf den universitär-akademischen Wiederaufbau genommen? Welche Rolle spielten dabei insbesondere die verantwortlichen US-Militärstellen vis à vis der sich rasch reetablierenden konservativ-restaurativen Professorenschaft und der Ministerialbürokratie, und lässt sich deren Aktivität, wie Reinhold Wagnleitner meint, tatsächlich als Erfolg sehen $?^{40}$ Und wenn ja, in welcher Hinsicht? Noch einmal anders formuliert: Wenn heute, unter heuristischer Ausblendung der immensen strukturellen und finanziellen Probleme an Österreichs Universitäten und außeruniversitären Wissenschaftseinrichtungen und so mancher hartnäckiger Provinzialismen und Selbstmarginalisierungstendenzen, davon ausgegangen werden kann, dass sich Österreichs Wissenschaftssystem nach über 65 Jahren, grosso modo, von allen vormodern-autoritären, reaktionären oder antisemitischen Prägungen befreit hat - ist das eine Entwicklung, an der die Supervision durch die Alliierten Truppen beziehungsweise die Reorientierungs-Maßnahmen der US-amerikanischen Besatzungsmacht einen rekonstruierbaren Anteil hatten?

39 Oliver Rathkolb, Die paradoxe Republik. Österreich 1945 bis 2005, Wien 2005, 309.

40 Wagnleitner schreibt dazu in diesem Zusammenhang: „Die US-Behörden, die die restaurativen Tendenzen im österreichischen Geistesleben mit Mißtrauen verfolgten, entwickelten daher verschiedene Austauschprogramme, mit deren Hilfe sie die langjährige intellektuelle Isolation durchbrechen und den Rückzug auf traditionelle wissenschaftstheoretische Positionen verhindern wollten. “ Und an anderer Stelle: „Die Bemühungen der US-Education Division waren also, trotz mancher Schwierigkeiten, als Resultat institutioneller und mentaler Trägheitsmomente, langfristig nicht ohne Auswirkungen."Wagnleitner, Coca-Colonisation, a.a.O., 194 bzw. 204. 
Es ist klar, dass sich derart zugespitzte Fragestellungen auf Grund der Vielschichtigkeit und Komplexität des historischen Realgeschehens nicht ohne Weiteres beantworten lassen und hauptsächlich den Zweck erfüllen, den Problemhorizont abzustecken und nach operationalisierbaren Thesen Ausschau zu halten. Im Folgenden sollen daher zwei forschungsleitende Hypothesen sowie eine paradoxale Vermutung vorangestellt werden, die im weiteren Durchgang der Arbeit durch entsprechendes Quellenmaterial und dessen Analyse belegt beziehungsweise zumindest in Ansätzen beantwortet werden sollen.

\section{FORSCHUNGSLEITENDE HYPOTHESEN}

Erste These: Obwohl die Vereinigten Staaten von Amerika sowohl vor als auch nach Kriegsende viel Energie und Ressourcen darauf verwendet haben, elaborierte ReorientierungsKonzepte für die geistige, kulturelle, politische und ökonomisch-wirtschaftliche Demokratisierung der früheren Achsenmächte auszuarbeiten und durch ein ganzes Bündel an konkreten Maßnahmen zu implementieren, die selbstredend auch den Wiederaufbau des universitären und akademischen Lebens miteinschlossen, gingen diese Maßnahmen in Österreich selbst in ihrem eigentlichen Kernbereich, der die conditio sine qua non aller USReorientierungs-Konzepte bildete, nämlich der politischen „Säuberung“ der universitären Behörden sowie des akademischen Lehrpersonals, im Wesentlichen an ihrem Ziel vorbei: die Entnazifizierung vollzog sich letztlich weitgehend ohne direkten Einfluss und intervenierende Kontrolle der amerikanischen Besatzungsmacht. Ja mehr noch: Die konkreten Formen der Kommunikation und Interaktion zwischen den verantwortlichen Offizieren der US-Militärregierung mit ministeriellen und akademischen Behördenvertretern auf österreichischer Seite sowie die praktizierte US-Politik der freundlichen Nichteinmischung („non-interference“) unter anderem auch im Bereich des Elitenaustausches haben die traditionell restaurativen Tendenzen im akademisch-universitären Wiederaufbau tendenziell eher verstärkt denn gehindert.

Zweite These: Anders als dies sowohl im Fachdiskurs zur „Reeducation“ als auch zur „Amerikanisierung“ beziehungsweise „Westernisierung“ nach 1945 oftmals angeführt wird, waren die US-Reorientierungs-Konzepte von Anfang an der Popularisierung des „American way of life" orientiert, aber eben nicht im Sinne einer propagandistischen, durch Mittel der psychologischen Kriegsführung forcierten Penetrierung, wie das zur Zeit des Kalten Krieges im Gefolge der antikommunistischen Kampagnen versucht wurde. Im Gegenteil: Die ursprünglich zivilen Reorientierungs-Konzepte orientierten sich zwar am „Modell“ Amerikas beziehungsweise am amerikanischen „way of life“, aber die pragmatische Orientierung daran war keineswegs normativ gedacht: Sie zielte auf das edukative und demokratiepolitische Prinzip, das allen künftigen Maßnahmen zur Reorientierung, Zivilisierung, Rehabilitierung oder Rekulturalisierung - Synonyma für die intendierte Demokratisierung nach Kriegsende - zugrunde liegen sollte. 
Den beiden aufeinander bezogenen Thesen sei an dieser Stelle, in loser Anlehnung an die von Oliver Rathkolb präsentierten Längsschnitte zur „paradoxen Republik“, ${ }^{41}$ noch eine paradoxale Vermutung hinzugefügt: Dass nach der machtpolitisch-militärischen Überformung der avancierten Reorientierungs-Konzepte in Richtung antikommunistischer Propaganda im Zusammenhang mit der Politik des „Containment“ und „Roll-Back“ letztlich - neben der Marshallplan-Wirtschaftshilfe - die Verbreitung US-amerikanischer Populärkultur langfristig betrachtet womöglich den nachhaltigsten Demokratisierungseffekt hatte, scheint auf den ersten Blick eine paradoxe Pointe zu sein. Das Arsenal der populärkulturellen Hervorbringungen des „Amerikanismus“ schuf insbesondere für jugendliche Identitätsfindungsprozesse nach 1945 Möglichkeiten einer demonstrativen Abkehr von konservativ-autoritären Lebensentwürfen - immerhin bildete der Antiamerikanismus ein konstitutives Element der autoritär-antidemokratischen Kräfte vor 1945. Über diesen Umweg mag es zu einer allmählichen, katalytischen Ablöse der nachfolgenden Generationen von provinziellen, konservativ-traditionalistischen Diskurs- und Reflexionsmustern gekommen sein. Faktum ist jedenfalls, dass diese ziemlich lange Bestand hatten und, gleichsam phasenverschoben, erst vergleichsweise spät zu erodieren begannen:

„Eine in den ersten Nachkriegsjahrzehnten höchst gehorsame, konfliktscheue Gesellschaft mit extrem autoritären Einstellungen in wichtigen gesellschaftlichen Fragen verzeichnete seit den I97oer-Jahren hier einen langsamen Wandel.“42

De facto spräche die hier vermutete Wirksamkeit und Funktion einer gewissen gesellschaftlichen Modernisierung und Öffnung bereits durch bloße Prozesse der „Amerikanisierung“ und „Westernisierung“ jedenfalls für die demokratiepolitisch hochgradig motivierten Konstrukteure der US-Reorientierung. Unbeantwortet bleibt aber insbesondere im Kontext des universitären Wiederaufbaues die Frage, um wie viel effizienter und nachhaltiger die geistige Öffnung und Demokratisierung in Österreich nach 1945 womöglich verlaufen wäre, hätten die amerikanischen Reorientierungs-Maßnahmen während der Besatzungszeit einer „autochthonen Provinzialisierung “43 oder "geistigen Stagnation “44 erst gar keine Chance gegeben.

41 Rathkolb präsentiert insgesamt 10 Längschnitte zu zentralen Bereichen der „politischen Kultur und Demokratieentwicklung“ in Österreich, wobei die akademisch-universitäre beziehungsweise wissenschaftliche Nachkriegsentwicklung allerdings nur kurz gestreift wird. Vgl. Rathkolb, Die paradoxe Republik, a.a. O., $415 \mathrm{ff}$.

42 Ebd., 416.

43 Vgl. Christian Fleck, Autochthone Provinzialisierung. Universität und Wissenschaftspolitik nach dem Ende der nationalsozialistischen Herrschaft in Österreich. In: Österreichische Zeitschrift für Geschichtswissenschaften, 7. Jg., 1996, Heft 1, $67 \mathrm{ff}$.

44 Fritz Fellner, Restauration oder Fortschritt. Hochschulprobleme aus der Sicht des Historikers. In: Heinz Fischer (Hrsg.), Versäumnisse und Chancen. Beiträge zur Hochschulfrage in Österreich, Wien - Hannover 1967, 12. Für den Literaturhinweis danke ich Kollegen Dr. Stephan Ganglbauer. 



\title{
1. Images, Stereotype und Vorurteile - Herkunft und Veränderung der kulturellen Geringschätzung der USA in Europa seit dem 18. Jahrhundert
}

\begin{abstract}
„Zwei Österreicher und ein Amerikaner sitzen in der Eisenbahn. Die Österreicher unterhalten sich übers Essen, Gewand und so weiter. Dabei jammern sie viel. Worauf der Amerikaner sagt: ,Ich verstehe nicht, wieso sich die Österreicher nur über solche banalen und materiellen Dinge unterhalten‘. Worauf die Österreicher fragten: ,Und worüber unterhalten Sie sich?’ Der Amerikaner antwortetet:,Wir reden über Kultur und Kunst.' Darauf bemerkte der Österreicher: , $\mathrm{Na}$ ja, jeder redet halt über das, was ihm abgeht. “45 (Kolportierter Witz aus dem Nachkriegsösterreich)

“[...] the public mind [is] not as a uniform and persistent force such as the alleged national character, or the public opinion much invoked by politicians. A nation shows a multitude of characters; there are forces striving to integrate them in unity, and others working for disintegration. As a rule there is not a single public opinion, but a variety of divergent trends.” 46

Frederick Hertz
\end{abstract}

Über den Antiamerikanismus als spezifisch gehässige „Reaktion auf die Moderne“ ${ }^{47}$ entstand in den letzten Jahren, insbesondere nach den katastrophalen Terroranschlägen des 9. September 20oI, vermehrt neue Forschungsliteratur. ${ }^{48}$ Neben traditionellen Arbeiten zu

45 Ingrid Bauer, Welcome Ami Go Home. Die amerikanische Besatzung in Salzburg 1945-1955. Erinnerungslandschaften aus einem Oral-History-Projekt, Salzburg - München 1998, $140 \mathrm{f}$.

46 Frederick Hertz, The Development of the German Mind. A Social History of German Political Sentiments, Aspirations and Ideas. The Middle Ages. The Reformation, London 1957, 3.

47 Dan Diner, Feindbild Amerika. Über die Beständigkeit eines Ressentiments, München 2002, 9 f.; weiters: Emil-Peter Müller, Antiamerikanismus in Deutschland. Zwischen Care-Paket und Cruise Missile, Köln 1986; Gesine Schwan, Antikommunismus und Antiamerikanismus in Deutschland. Kontinuität und Wandel nach 1945, Baden-Baden 1999; David W. Ellwood, Comparative Anti-Americanism in Western Europe. In: Heide Fehrenbach/Uta G. Poiger (Eds.), Transaction, Transgressions, Transformations, New York 2000, 26-44; einen konzisen Überblick über die Literatur gibt: Philipp Gassert, Amerikanismus, Antiamerikanismus, Amerikanisierung. Neue Literatur zur Sozial-, Wirtschafts-, und Kulturgeschichte des amerikanischen Einflusses in Deutschland und Europa. In: Archiv für Sozialgeschichte, Bd. 39, 1999, 531-661.

48 Thomas von der Osten-Sacken/Andrea Woeldike (Hrsg.), Amerika. Der „War on Terror“ und der Aufstand der Alten Welt, Freiburg 2003; weiters: Benjamin Barber, Fear's Empire. War Terrorism and Democracy, New York 2003; Richard Crockatt, America embattled. September 11, anti-Americanism, and the global order, London 2003; Ders., After 9/11: cultural dimension of American global power, London 2007; Michael Draxlbauer/Astrid M. Fellner/Thomas Fröschl (Eds.), (Anti-)Americanisms (=American 
Feindbildkonstruktionen erweiterte sich der Fokus dabei nicht nur methodisch, sondern auch thematisch. Neben historisch weit zurückgreifenden synoptischen Darstellungen zur europäischen Lingua franca ${ }^{49}$ entstanden Analysen, die sich auf die Zusammenhänge zwischen Antiamerikanismus und Antisemitismus konzentrieren, ${ }^{50}$ Studien zum linken Antiamerikanismus, ${ }^{51}$ sowie Beiträge, die sich mit dem Antiamerikanismus im Mittleren Osten, in Russland, Indien oder in China beschäftigen. ${ }^{52}$

Studies in Austria. Hrsg. v. Astrid M. Fellner/Klaus Rieser/Hanna Wallinger, Vol. 2), Wien 2004; Mary Nolan, „Anti-Americanism and Anti-Europeanism“. In: Lloyd Gardner/Marilyn Young (Eds.), The New American Empire: A 21st-Century Teach-In on U.S. Foreign Policy, New York 2004, 113-132; Alexander Stephan (Ed.), The Americanization of Europe. Culture, Diplomacy, and Anti-Americanism after 1945, New York - Oxford 2006; David Farber (Ed.), What they think of us. International perceptions of the United States since 9/11, Princeton 2007; zuletzt: Margit Reiter/Helga Embacher (Hrsg.), Europa und der 11. September 2001, Wien - Köln - Weimar 2011.

49 Christian Schwaabe, Antiamerikanismus. Wandlungen eines Feindbildes, München 2003; Barry Rubin/Judith C. Rubin, Hating America. A History, Oxford 2004; Rudolf von Thadden/Alexandre Escudier (Hrsg.), Amerika und Europa - Mars und Venus? Das Bild Amerikas in Europa, Göttingen 2004; Konrad Jarausch, Missverständnis Amerika. Antiamerikanismus als Projektion. In: Jan C. Behrends/Árpàd von Klimó/Patrice G. Poutrus, Antiamerikanismus im 20. Jahrhundert. Studien zur Ost- und Westeuropa, Bonn 2005, 34-49; Timo Nitz, Deutscher Antiamerikanismus. Grundlagen, Entwicklung und Beständigkeit einer Ideologie, Saarbrücken 2006; Josef Joffe, Überpower. The imperial temptation of America, New York - London 2006; Andrei S. Markovits, Uncouth Nation. Why Europe dislikes America, Princeton 2007, 11 ff.; weiters: Georg Kreis (Hrsg.), Antiamerikanismus. Zum europäisch-amerikanischen Verhältnis zwischen Ablehnung und Faszination, Basel 2007; Brendon O’Connor (Ed.), Anti-Americanism. History, Causes, Themes. Volume 3: Comparative Perspectives, Oxford 2007.

50 Tobis Jaecker, Antisemitische Verschwörungstheorien nach dem 11. September. Neue Varianten eines alten Deutungsmusters. 2. Aufl., Münster 2005; weiters: Andrei S. Markovits, Amerika, dich hasst sich's besser. Antiamerikanismus und Antisemitismus in Europa, Hamburg 2004; Jasmin Waibl-Stockner, „Die Juden sind unser Unglück“. Antisemitische Verschwörungstheorien und ihre Verankerung in Politik und Gesellschaft, Wien $2009,87 \mathrm{ff}$.

51 Vgl. Elisabeth Wohofsky, „Mickey Mouse trübt den Blick“. Antiamerikanismus in der österreichischen Linken im Übergang der 1980er- zu den 90er-Jahren am Beispiel der Volksstimme und Salto, Dipl.-Arb., Univ. Wien 1996; Michael Hahn (Hrsg.), Nichts gegen Amerika. Linker Antisemitismus und seine lange Geschichte, Hamburg 2003; weiters: Tami Ensinger, Linke Projektionen. Zum pädagogischen Umgang mit Antisemitismus unter besonderer Berücksichtigung des Antisemitismus von links, Dipl.-Arb., Techn. Univ. Darmstadt 2006, 13 ff.; Florian Hartleb, Rechts- und Linkspopulismus. Eine Fallstudie anhand von Schill-Partei und PDS, Wiesbaden 2004, $273 \mathrm{ff}$.

52 Vgl. Jim Sciutto, Against us. The new face of America's enemies in the Muslim world, New York 2008; Iyanatul Islam, Anti-Americanism in the Muslim world. A sceptic's guide. In: Brendon O'Connor/Martin Griffiths (Eds.), The Rise of Anti-Americanism, London 2006, 68-90; weiters: Vladimir Shlapentokh/Joshua Woods/Eric Shiraev (Eds.), America. Sovereign Defender or Cowboy Nation?, Aldershot 2005. 
Die tief verankerten europäischen Negativ-Stereotype und verklärenden $\mathrm{Mythen}^{53}$ gegenüber der „Neuen Welt“ haben als nachhaltige imagologische Feindbildkonstruktion allerdings historisch weit zurück reichende Wurzeln, deren ambivalenten Ausprägungen im Folgenden kurz nachgegangen werden soll.

\section{DAS BILD AMERIKAS AUS EUROPÄISCHER SICHT BIS ANFANG DER I93OER-JAHRE}

Die negativen Vorurteile, Feindbilder und Klischees hinsichtlich einer kulturellen Inferiorität Amerikas als Land einer vulgären, degenerierten Massenkultur, mit denen sich die US-amerikanischen Besatzungstruppen in Europa wie auch in Österreich nach 1945 immer wieder konfrontiert sahen, bildeten insbesondere im Kontext des beabsichtigten geistigkulturellen Wiederaufbaues demokratischer, westlicher Werte eine nicht zu vernachlässigende Mentalreserve in den Köpfen der Nachkriegsbevölkerung. Nicht zuletzt handelte es sich bei diesen Klischees und Feindbildern, gegen die die US-amerikanische Politik nicht nur im Zusammenhang der Reeducation anzukämpfen hatte, um Negativ-Stereotype, die nicht nur in der gezielt rassistisch angelegten NS-Propaganda mit „Demokratie“ allgemein zusammenfielen, sondern auch in der über Dekaden durch einschlägige Stereotype geprägten Bevölkerung.

Freilich stellt die Kritik am „Amerikanismus“, ${ }^{54}$ womit das Gefahrenszenario einer drohenden ökonomisch-wirtschaftlichen Hegemonie einerseits sowie die aus dem Gefühl einer proklamierten kulturellen Überlegenheit resultierende Geringschätzung gegenüber allen diesbezüglichen Leistungen Amerikas andererseits bezeichnet wurde, keineswegs eine Erfindung des Nationalsozialismus dar. Der Boden hierfür wurde lange vorher bereitet, was im Folgenden anhand einiger Beispiele illustriert werden soll, wenn auch der historische Tiefpunkt zweifellos erst mit dem spezifisch antisemitisch-rassistischen Antiamerikanismus des Nationalsozialismus zu verzeichnen ist.

53 Vgl. Rainer Götz, Der Wandel des Amerikabildes in der deutschsprachigen Literatur seit 1945. Mythos Amerika und Realität USA, phil. Diss., Univ. Graz 1979; zur Entstehung, Entwicklung und Verfestigung nationaler Images und Stereotype siehe in diesem Zusammenhang allgemein u.a.: Robert B. Downs, Images of America. Travelers from abroad in the New World, Urbana/Ill., 1987; Jack P. Greene, The intellectual construction of America. Exceptionalism and identity from 1492 to 1800, Chapel Hill, NC 1993; Philip R. DeVita (Ed.), Distant mirrors. America as a foreign culture, Belmont/Calif. 1993; Stephen Fender (Ed.), American and European national identities. Faces in the mirror, Keele 1996; David E. Barclay (Ed.), Transatlantic images and perceptions. Germany and America since 1776, Washington D.C. 1997.

54 Vgl. John Russell Bartlett, Dictionary of Americanism. A Glossary of Words and Phrases Usually Regarded as Peculiar to the United States of America, 2. erw. Aufl., Boston 1859. Zur Begriffsgeschichte des Terminus „Amerikanismus“ siehe weiters: Otto Basler, Amerikanismus: Geschichte eines Schlagwortes. In: Deutsche Rundschau, 224, August 1930, 142-146; weiters: Theodor Lüddecke, Amerikanismus als Schlagwort und Tatsache, ebd., 221, März 1930, 214-221; Richard Freienfels-Müller, „Amerikanismus“ und europäische Kultur. In: Der deutsche Gedanke, 1927, Heft 4, 30-35. 
Bis Anfang des 20. Jahrhunderts waren die in Europa zirkulierenden Vorstellungen von der „Neuen Welt“ grosso modo von exotischer Distanz zum Gegenstand geprägt: hier trafen sich die Faszination an „Art und Sitten der Wilden“, 55 die Bewunderung der offenkundig enormen Reichtümer dieses weit entfernt liegenden Kontinents, Projektionen einer apostrophierten grenzenlosen Freiheit des Schmelztiegels Amerika ${ }^{56}$ - das in den folgenden Jahren und Jahrzehnten für viele Millionen sozial deklassierter europäischer Emigranten dann zum Land der Hoffnung auf unbegrenzte Möglichkeiten wurde - sowie die Angst feudal-reaktionärer Gesellschaftskreise vor einer plebejischen Massendemokratie auf Grundlage eines materiellen Individualismus; letztere verdichtete sich ab der zweiten Hälfte des 19. Jahrhunderts allerdings zu einem Schreckensszenario, das das „alte Knochengerüst Europas“ (Antonio Gramsci) ${ }^{57}$ bereits nachhaltig erschütterte. Die lange Zeit überwiegenden ahistorischen ${ }^{58}$ Vorstellungen eines weit entfernt liegenden, buchstäblich

55 Die ersten Schilderungen und exotischen Bildansichten auf die „Wilden“ der Neuen Welt publizierte Theodor de Bry in seinem 1590 erschienen Buch „Erstaunliche, aber wahrheitsgetreue Beschreibung der Art und Sitten der Wilden in Virginia“. Siehe: Gerhard E. Sollbach, Amerika 1590. Europas erste Bilder von der Neuen Welt, Kettwig 1992, X. Siehe dazu auch: Ray Allen Billington, Land of Savagery, Land of Promise. The European Image of the American Frontier, New York - London 1981. Wie Rob Kroes verdeutlicht, finden sich auch bereits bei William Shakespeare bspw. in der Figur des „schwarzen“ Caliban (vis à vis Prospero) in „Der Sturm“ die tiefsitzenden europäischen Ängste vor dem diabolisch Fremden, Unzivilisierten und Wilden im Hinblick auf Amerika klar thematisiert. So meint Kroes: „The Tempest is an early example of European fantasies about America after its discovery. It displays a rejection of America and Americans as diametrically opposed to civilization and culture - a rejection that would continue for centuries, even long after ,the American' was no longer an Indian savage but a transplanted European." Kroes, If you've seen one, you've seen the mall, a.a.O., 6.

56 Ein literarisches Zeugnis der Faszinationskraft Amerikas als „Land der Freiheit und Erlösung“ zu Beginn des 20. Jahrhunderts findet sich unter anderen in Hermann Brochs „Esch oder die Anarchie“, dem zweiten Teil seines Romans „Die Schlafwandler“, worin der Hauptprotagonist davon träumt, endlich der „Alten Welt ein Valet zu[zu]rufen, auf Nimmerwiedersehen.“ „Esch sah die Freiheitsstatue vor sich, deren Fackel all das verbrennt und erlöst, was herüben zurückgelassen wird, alles Gewesene und alles Tote dem Feuer überantwortet, - und wenn dies Mord ist, so ist es einer, über den die Polizei nicht mehr richten darf." Zit. nach: Hermann Broch, Die Schlafwandler. Eine Romantrilogie (= Kommentierte Werkausgabe. Hrsg. v. Paul Michael Lützeler, Bd. 1), Frankfurt a. Main 1994, 291.

57 Antonio Gramsci, Amerikanismus und Fordismus [§§1-16]. In: Antonio Gramsci, Gefängnishefte. Hefte 22 bis 29. Bd. 9. Hrsg. v. Peter Jehle, Klaus Bochmann, Wolfgang Fritz Haug, Berlin 1999, 2070; weiters: Reinhold Wagnleitner, Coca-Colonisation und Kalter Krieg. Die Kulturmission der USA in Österreich nach dem Zweiten Weltkrieg (=Österreichische Texte zur Gesellschaftskritik, Bd. 52), Wien 1991, a.a.O., 22.

58 Auf den dominierenden „unhistorischen Dilettantismus“ der deutschen Literatur über Amerika verweist interessanterweise der Hauptprotagonist in Ferdinand Kürnbergers Roman „Der Amerikamüde“; bezeichnenderweise hat Kürnberger selbst Amerika nie bereist. „Bücher, von einem liebenswürdigen, aber unhistorischen Dilettantismus geschrieben, sprachen von Amerika so, wie man ungefähr am winterlichen Kamin von Nizza, Meran und vom Comersee spricht; gleichsam als wäre das soziale Leiden Europas mädchenhafte Schwindsuchtpoesie. So schrieben Racknitz und Scherpf über Texas, Bromme über Florida, Duden über Missouri, Gerke über Illinois [...]. Noch mehr aber als durch die belletristische Ornamentik 
irdischen Paradieses, wie es Columbus für das christliche Europa zu entdecken vermeinte, ${ }^{59}$ begannen sich spätestens mit dem weltweiten Siegeszug der kapitalistischen Produktionsweise und der damit einhergehenden tiefgreifenden industriellen Veränderung der Arbeitsund Lebenswelt, deren kommerzielle Auswirkungen auch Europa bald zu spüren bekam, grundlegend in Richtung einer scharfen bildungsbürgerlichen Kritik beziehungsweise Ablehnung amerikanischer Massenkultur zu wandeln ${ }^{60}$ - wobei der ökonomisch-wirtschaftlichen Stärke Amerikas weiterhin mit Respekt oder auch Bewunderung begegnet wurde.

Die Ambivalenz zwischen enthusiastischer Bewunderung einerseits und enttäuschter Ablehnung des „American way of life“ andererseits kennzeichnete freilich bereits - ob real oder fiktiv - die frühen europäischen Studien ${ }^{61}$ und Reiseberichte $^{62}$ des 19. Jahrhunderts, wobei die anfänglich überwiegende Amerikabegeisterung bereits gegen Ende des Jahrhunderts allmählich der prognostizierten Gefahr einer „Überfremdung“ durch die Verbreitung amerikanischer Lebensart wich.

Lange bevor die europäische literarische Moderne die inhumanen Arbeits- und Existenzbedingungen des amerikanischen Systems, den gewalttätigen Kapitalismus und den drohenden Wertezerfall anprangerte ${ }^{63}$ - unter partieller Ausblendung der realen sozialen

litt die Wahrheit des Gegenstandes durch die politische. Der Liberalismus der Restaurationsperiode fand in Wort und Schrift über Amerika eines seiner wenigen erlaubten Ausdrucksmittel. Er benutzte es eifrig. Er feierte die Sternenbannerrepublik als die praktische Verwirklichung seines geächteten Ideals. Aus dieser Tendenz ging zwar die Wahrheit auf, aber nicht die volle Wahrheit. Er hätte es für politische Unklugheit, ja für Verrat gehalten, die Flecken seiner Sonne zu gestehen. In dieser filtrierten Sonnenbeleuchtung nun übernahmen die Gebildeten der vorigen Generation Amerikas Bild. [...] In der Tat erkannte Moorfeld seine europäische Lektüre über Amerika jetzt bloß als Unterhaltungslektüre und sah die Notwendigkeit ein, die Belehrungslektüre von vorn anzufangen." Ferdinand Kürnberger, Der Amerikamüde, Wien - Köln - Graz 1985, 81 f. Tatsächlich sah sich bspw. Gottfried Duden angesichts der immer zahlreicher werdenden Warnungen und Negativ-Berichte über Amerika, die von Rückkehrern formuliert wurden, 1837 genötigt, seinen teilweise euphorisch gehaltenen Bericht über Amerika in einer „Selbstanklage“ zumindest leicht zu revidieren. Vgl. Lerg, Amerika als Argument. Die deutsche AmerikaForschung im Vormärz, a.a.O., 42.

59 Tzvetan Todorov, Die Eroberung Amerikas. Das Problem des Anderen, Frankfurt a. Main 1985, 25 ff.

60 Insbesondere im Zusammenhang romantischer Vorstellungen von einem „Neu-Deutschland“ in den amerikanischen Kolonien - die mitunter soweit gingen, den Erwerb ganz Kaliforniens anzuregen, um dort eine deutsche Kolonie zu gründen - und siedlungspolitischen Überlegungen im deutschen Mutterland gewann der „Kulturbegriff“ bzw. der „Vorwurf mangelnder Kultur in der jungen Republik eine zentrale Facette.“ Charlotte A. Lerg, Amerika als Argument. Die deutsche Amerika-Forschung im Vormärz und ihre politische Deutung in der Revolution von 1848/49, Bielefeld 2011, 32 bzw. 36.

61 Conrad Friedrich Schmidt-Phiseldeck, Europa und Amerika, oder die künftigen Verhältnisse der civilisirten Welt, Copenhagen 1820.

62 Vgl. Gottfried Berger, Das Bild der Vereinigten Staaten von Nordamerika in der deutschen Reiseliteratur des 19. Jahrhunderts. Unter besonderer Berücksichtigung von Werk und Persönlichkeit des Österreichers Karl Postl (Charles Sealsfield), phil. Diss., Univ. Wien 1945.

63 So beispielsweise bei Gerhart Hauptmann, Rainer Maria Rilke, Franz Kafka, Frank Wedekind, Lion Feuchtwanger oder Bertolt Brecht. Vgl. Wagnleitner, Coca-Colonisation, a.a.O., 26. 
Missstände im europäischen Mutterland -, geriet Amerika bereits ins Visier europäischer Kultur- und Gesellschaftskritik.

Die ersten naturwissenschaftlichen Reiseberichte eines Alexander von Humboldt ${ }^{64}$ enthielten zunächst noch kein greifbares Bild des gesellschaftlichen (Nord-)Amerika. Nachdem aber bereits Goethe „Amerika als Zukunftsland, als Land einer neuen Kultur“65 bezeichnet und Grillparzer geäußert hatte, man müsse nach „Nordamerika emigrieren, um Gedankenfreiheit zu haben", ${ }^{66}$ folgten bis Mitte des 19. Jahrhunderts eine Vielzahl an zunächst begeisterten Berichten, Studien, Reiseschilderungen und Romanen. ${ }^{67}$ Und auch Friedrich Schlegel erklärte noch 1828 in einer Vorlesung an der Wiener Universität, dass die Vereinigten Staaten für Frankreich und den Rest Europas "the real school and nursery of all these revolutionary principles"68 wären.

Dessen ungeachtet grassierten in Europa seit dem i8. Jahrhundert Vorstellungen von der degenerierten Fauna und Flora der Neuen Welt. ${ }^{69}$ Insbesondere waren es französische Aufklärer und Naturwissenschafter wie Voltaire, Raynal oder Comte de Buffon, die mit ihren verächtlichen, stereotypen Ansichten gegenüber der Neuen Welt gewissermaßen die Urform eines philosophischen beziehungsweise naturwissenschaftlich geprägten Antiamerikanismus schufen. ${ }^{70}$ So konstatierte etwa der französische Naturforscher de Buffon, dass Amerika, „viel zu spät aus der Sintflut aufgetaucht [...] und damit noch feucht ${ }^{\text {“71 }}$ sei. Die publizierten Vorurteile der europäischen Aufklärer gegenüber Amerika wurden dabei

64 Hierbei konzentrierte sich Humboldt allerdings primär auf das „äquatoriale Amerika“, wobei er schließlich in den 1850er Jahren auch die Ostküste der Vereinigten Staaten bereiste. Vgl. Herbert Christ, „Aber schauen ist nicht beobachten". Alexander von Humboldt und Alexis de Tocqueville als Beobachter in Amerika. In: Fremde Texte verstehen. Festschrift für Lothar Bredella. Hrsg. v. Herbert Christ/Michael K. Legutke, Tübingen 1996, $291 \mathrm{ff}$. bzw. 293.

65 Zit. nach: Gottfried Berger, Amerika im XIX. Jahrhundert. Die Vereinigten Staaten im Spiegel zeitgenössischer deutschsprachiger Reiseliteratur, Wien 1999, 48.

66 Franz Grillparzer in einem Brief an seinen Freund Beethoven in den 1820er Jahren. Zit. nach: Wilder E. Spaulding, The Quiet Invaders. The Story of the Austrian Impact upon America, Vienna 1968, 55.

67 So z.B. Gottfried Duden in einem „Bericht über eine Reise nach den westlichen Staaten Nordamerikas“ und einen mehrjährigen Aufenthalt am Missouri, 1829. Dieses Buch wurde dann von Auswanderungsagenturen in zahlreichen billigen Nachdrucken massenhaft verbreitet. Siehe: Manfred Durzak, Perspektiven des Amerikabildes, historisch, gegenwärtig. Reisen in der Zeitmaschine. In: Sprache im technischen Zeitalter, 56, 1975, 298.

68 Friedrich von Schlegel, The Philosophy of History, New York 1841, 2, 272.

69 Vgl. Rubin/Rubin, Hating America, a.a.O., 7 ff.

70 Philipp Roger, Aufklärer gegen Amerika. Zur Vorgeschichte des amerikanischen Antiamerikanismus. In: Thadden/Escudier (Hrsg.), Amerika und Europa - Mars und Venus?, a.a.O., $18 \mathrm{ff}$.

71 Zit. nach: Thomas Fröschl, Antiamerikanismus in Europa und Lateinamerika. Sieben historische Dimensionen. In: Thomas Fröschl (Hrsg.), Atlantische Geschichte (= Wiener Zeitschrift zur Geschichte der Neuzeit, 3. Jg., 2003, Heft 2, 84; siehe dazu weiters: Thomas Fröschl, Historical Roots of the European Anti-Americanism in the 18th and 19th Centuries. In: Draxlbauer/Fellner/Fröschl (Eds.), (Anti-)Americanisms, a.a. O., $60 \mathrm{f}$. 
zumeist, wie auch im Fall der Charakterisierung Amerikas bei Hegel, ohne viel Sachkenntnis und jede eigene Erfahrung formuliert. ${ }^{72}$ Gegen diese Stigmatisierung Amerikas als eines degenerierten Kontinents, die die kulturelle Inferiorität seiner (indigenen) Einwohner miteinschloss, hatten die amerikanischen Eliten von Anbeginn anzukämpfen. Dieses kulturpolitische Ringen um Anerkennung und Gleichberechtigung gegenüber dem europäischen Mutterland, das schließlich in die US-amerikanische Unabhängigkeitserklärung von I776 mündete, führte zwischenzeitlich zu höchst kuriosen Versuchen, wie beispielsweise dazu, die Maya-Tempelstädte auf der Halbinsel Yukatan zu europäisieren, indem diese kurzerhand zu römisch-karthagischen Gründungen erklärt wurden. ${ }^{73}$

Eine erste - ebenso prägnante wie nachhaltig wirksame - Kritik nordamerikanischer Lebenskultur verfasste der aus Mähren stammende politische Emigrant Charles Sealsfield (alias Karl Anton Postl), der, anders als viele der nachfolgenden Autoren, von keiner Sentimentalität für europäische Werte getrieben war und in seiner Amerika-Kritik durchaus Realist blieb; nicht zuletzt hatte Sealsfield in einer 1827 publizierten Schrift mit den Idealen der "deutschen Gelehrsamkeit" gebrochen und das lebensorientiert-praktische republikanische Bildungssystem, in dessen öffentlicher Förderung der „humane Bürgersinn des Amerikaners“ zum Ausdruck komme, gelobt und obendrein festgestellt, „dass in keinem Lande für die Bildung des weiblichen Geschlechts so viel Sorge getragen wird“ ${ }^{74}$

In dem zwischen I834 und I837 erschienenen Romanfragment „Lebensbilder aus beiden Hemisphären" übte Postl, trotz der positiv dargestellten Freiheit des Individuums in der Neuen Welt, ${ }^{75}$ scharfe Kritik an der dortigen Allmacht des Geldes und den dadurch verur-

72 In seinen ab 1822/23 abgehaltenen „Vorlesungen über die Philosophie der Geschichte“ sprach Hegel von der "geographischen Unreife Neuhollands“ und beschrieb die indigene Kultur Amerikas als inferior, wild und roh. Des Weiteren konstatierte er, dass „die Schwäche des amerikanischen Naturells [...] ein Hauptgrund dazu [gewesen sei, d. Verf.], die Neger nach Amerika zu bringen, um durch deren Kräfte die Arbeit verrichten zu lassen; denn die Neger sind weit empfänglicher für europäische Kultur als die Indianer [...].“ Dennoch stand auch für Hegel, der die Neue Welt strikt nach dem (entwicklungsfähigen) Nord- und dem (unreif-ohnmächtigen) Südamerika schied, fest, dass von hier aus künftig globale Veränderungen ihren Ausgang nehmen werden: „Amerika ist somit das Land der Zukunft, in welchem sich in vor uns liegenden Zeiten, etwa im Streite von Nord- und Südamerika, die weltgeschichtliche Wichtigkeit offenbaren soll; es ist ein Land der Sehnsucht für alle die, welche die historische Rüstkammer des alten Europa langweilt. Napoleon soll gesagt haben: Cette vieille Europe miennuie. Amerika hat von dem Boden auszuscheiden, auf welchem sich bis heute die Weltgeschichte begab. Was bis jetzt sich hier ereignete, ist nur der Widerhall der Alten Welt und der Ausdruck fremder Lebendigkeit, und als ein Land der Zukunft geht es uns überhaupt hier nichts an [...]“. [Kursiv im Orig.] Georg Wilhelm Friedrich Hegel, Vorlesungen über die Philosophie der Geschichte. Werke 12, Frankfurt a. Main 1970, 108 f. bzw. 114.

73 Fröschl, Antiamerikanismus in Europa und Lateinamerika, a.a. O., 84.

74 Zit. nach: Primus-Heinz Kucher, Polyphone Spiegelungen und Kulturkritik in Charles Sealsfields Amerika-Bericht. Die Vereinigten Staaten von Nordamerika nach ihren politischen, religiösen und gesellschaftlichen Verhältnissen betrachtet (1827). In: Austriaca, Sommaire No. 62, Juni 2006, 37.

75 Vgl. Wynfried Kriegleder, Amerika-Idyllik und Europa-Skepsis. Zum Verhältnis Amerika-Europa im Werk Charles Sealsfields. In: Alexander Ritter (Hrsg.), Sealsfield-Studien 1 (= Schriftenreihe der Charles- 
sachten sozialen Zuständen. ${ }^{76}$ Anders als in seiner frühen Schrift „Austria as it is “ $[1827 / 28]$, wo Sealsfield in quasi erzieherischer Gegenüberstellung von Alter und Neuer Welt in den „schlanken amerikanischen Handelsschiffen“ den beweglichen Unternehmungsgeist der freien Welt - gegenüber einer „plump gebauten[n] französischen Brigg“ - repräsentiert sah, rechnete er hier entschieden mit der amerikanischen „Geldplutokratie“ ab.

Umgekehrt übte die überaus scharfe Kritik, die Postl in „Austria as it is“ hinsichtlich des vormärzlichen Österreich äußerte und dabei insbesondere die Wiener als gedankenloses, vergnügungssüchtiges und von einer antiintellektuell-repressiven Obrigkeit kontrolliertes Volk charakterisierte nachhaltigen - so Erich Zöllner - Einfluss auf das englische und amerikanische Österreichbild einer phäakenhaft-derben Genuss- und Weinseligkeitskultur aus, der freilich auch, in der Musik und einzelnen Wissenschaftsbereichen, besondere Leistungen zugesprochen wurden. ${ }^{77}$ Der Einfluss der durch fiktionale literarische Darstellungen medial verbreiteten Amerika- und Europabilder kann durchaus als erheblich angesehen werden, ${ }^{78}$ da die Schriftsteller und Journalisten mit ihren Schilderungen eine erste Grundlage für die Ausbildung von negativen und positiven Stereotypen, Mythenbildungen und Projektionen schufen. ${ }^{79}$

Geraume Zeit nach Postl zeichnete der österreichische Schriftsteller Ferdinand Kürnberger, inspiriert von den Eindrücken des zutiefst enttäuschten Amerikafahrers Nikolaus

Sealsfield-Gesellschaft XI), München 1998, 19 ff. Die Literatur und der Wissensstand zu Sealsfields ambivalentem Amerika-Bild ist mittlerweile stark angewachsen. Aus der schier kaum zu überblickenden Fülle an Fachpublikationen siehe zuletzt insbesondere: Alexander Ritter, Die USA als Utopie liberaler Staatlichkeit und ethnokulturellen Selbsterhalts. Zum Paradigmenwechsel des Amerikabildes in den Auswandererromanen „Die deutsch-amerikanischen Wahlverwandtschaften“ (1839/40) von Charles Sealsfield und „Ein Deutscher“ (1862) von Otto Rupius. In: Alexander Ritter (Hrsg.), Amerika im europäischen Roman um 1850. Varianten transatlantischer Erfahrung (=SealsfieldBibliothek 8), Wien 2011, 89-118, sowie: Wynfried Kriegleder/Gustav-Adolf Pogatschnigg (Hrsg.), Die Geschichten des Charles Sealsfield. Zeitschriftenveröffentlichungen und Vorlagen (= SealsfieldBibliothek 7), Wien 2009.

76 Zit. nach Günter Schnitzler, Nachwort. In: Charles Sealsfield, In der Neuen Welt. Aus: Morton oder die große Tour, München 1997, 150. Der Hauptprotagonist erfährt: „,In a free country?’ lachte der Alte fort. ,In a free country? Free to starve I say.“ Z Zit. nach: Ebd., 92; weiters: Berger, Das Bild der Vereinigten Staaten von Nordamerika in der deutschen Reiseliteratur des 19. Jahrhunderts, a.a.O., 33.

77 Vgl. Erich Zöllner, Zur Geschichte des Klischees von Wien und den Wienern. In: Michael John/Albert Lichtblau, Schmelztiegel Wien - einst und jetzt. Zur Geschichte und Gegenwart von Zuwanderung und Minderheiten, 2. verb. Aufl., Wien - Köln - Weimar 1993, 7.

78 Vgl. dazu im Besonderen den rezenten Sammelband: Ritter (Hrsg.), Amerika im europäischen Roman um 1850. Varianten transatlantischer Erfahrungen, a.a. O.; weiters: Wynfried Kriegleder, Vorwärts in die Vergangenheit. Das Bild der USA im deutschsprachigen Roman 1776 bis 1855, Tübingen 1999 [Habilitation an der Univ. Wien 1986].

79 Vgl. Alexander Schmidt, Reisen in die Moderne. Der Amerika-Diskurs des deutschen Bürgertums vor dem Ersten Weltkrieg im europäischen Vergleich, Berlin 1997, 82 f.; vgl. weiters: Viktor Otto, Deutsche Amerika-Bilder. Zu den Intellektuellen-Diskursen um die Moderne 1900-1950, München 2006, 66 ff. 
Lenau, ${ }^{80}$ mit seinem 1855 erschienenen Roman „Der Amerikamüde“ ${ }^{\text {81 }}$ ein drastisch verzerrtes, wenn auch vielschichtiges Bild, obwohl er Amerika nie betreten hat. Neben aller Bewunderung für die „Freiheitsideale“, den prosperierenden Pragmatismus und die „ungeheuren Energien Amerikas" lieferte diese ressentimentgeladene Schrift ${ }^{82}$ in hoher Auflage eine breite Palette eindeutig negativer Vorurteile und Stereotype gegenüber den dortigen Sitten und Gebräuchen, die in den späteren Fundus der europäischen Amerika-Kritik eingingen. Darin häuften sich Punzierungen wie „unfeine Esskultur“, luxurierende, „kindhaftverstandlose Geschmacklosigkeit“, ,routinierte Flachheit", „Gedankenarmut“, Kulturlosigkeit, Bildungslosigkeit selbst der gesellschaftlichen Elite, ${ }^{83}$ fabrikmäßige Uniformität, nationaler Hass auf alles Deutsche ${ }^{84}$ sowie Gewalttätigkeit und eine alles durchdringende „Geldgier“. Ähnlich drastisch „enttäuscht“ hatte sich zuvor bereits Charles Dickens geäußert, der in den USA „eine monströse Vorspiegelung des erhofften Garten Eden“, eine „barbarische Wildnis“85 sah. Kritik an der Maschinenkultur sowie an der inhumanen Kälte des US-Kapitalismus äußerten auch viele deutschsprachige Autoren der Moderne, angefangen von Gerhart Hauptmann, über Rainer Maria Rilke, Franz Kafka, Franz Wedekind bis hin zu Bertolt Brecht. ${ }^{86}$ Hinzukommt das große Befremden, das die Sklaverei und die Sklavengesetze der USA ${ }^{87}$ bis zu deren Abschaffung I86r bei differenzierten europäischen

80 Lenau benötigte genau acht Tage, um zum Schluss zu kommen, dass die Amerikaner „himmelanstinkende Krämerseelen“ seien. Zit. nach: Manfred Thaller, Studien zum europäischen Amerikabild. Darstellung und Beurteilung der Politik und inneren Entwicklung der Vereinigten Staaten von Amerika in Großbritannien, Deutschland und Österreich im Vergleich zwischen 1840 und 1941, Diss., Univ. Graz, 1975, Bd. I, 46.

81 Vgl. dazu: Clemens Ruthner, „Amerikamüde“ ,Deutsche“ und ihre „Neger“. Skizze zur Theorie der literarischen Stereotypenforschung (mit einem Seitenblick auf F. Kürnberger). In: Germanistische Mitteilungen. Zeitschrift für deutsche Sprache, Literatur und Kultur, 67, 2008, Heft 67, 82-100.

82 Der Roman ist einerseits als Gegenprogramm zu Ernst Willkomms Amerika-Utopie „Die Europamüden“ aus dem Jahr 1838 angelegt sowie andererseits als politischer Kommentar zur Emigration im Gefolge der 1848er-Revolution - die ersehnte Freiheit findet sich für den Wiener 1848er-Revolutionär Kürnberger auch im Land des aufstrebenden Kapitalismus nicht. Der Held des Erfolgsromans resümiert seine Eindrücke folgendermaßen: „Oh, Herr, schick uns alle Jahre eine Pest und nimm dafür eins unsrer Vorurteile von uns. - Amerika ist ein Vorurteil." Kürnberger, Der Amerikamüde, a.a.O., 337.

83 „Ihr Wohlstand ist gewachsen, ihre Bildung nicht. [...] Ich habe Häuser von Reichtum und gesellschaftlichem Rang betreten, aber ihre Bibliotheken waren nicht hinaus über den hundertjährigen Kalender." Ebd., 317

84 Ebd., 157

85 So z. B. in seinen American Notes (1842). Zit. nach: Wagnleitner, Coca-Colonisation, a.a.O., 24.

86 Vgl. Wagnleitner, Coca-Colonisation, a.a.O., 26.

87 Für die Gegner der amerikanischen Republik bot der „Schandfleck der Sklaverei“, das „Brandmal der Nation“, wie Charlotte A. Lerg mit Hinweis auf zeitgenössische Aussagen deutscher Staatsrechtler und Politiker hervorhebt, ,ein willkommenes Gegenargument, das keinen Widerspruch erlaubte, und durch das jegliche Bezugnahme auf vorbildliche Aspekte der USA abgewertet werden sollte. „Amerika lassen wir nicht gelten, es hat noch Sclaven", fasste Carl Mathy in der Paulskirche diese Argumentationsweise zusammen.“ Lerg, Amerika als Argument. Die deutsche Amerika-Forschung im Vormärz, a.a.O., 306 f. 
Beobachter/Innen wie zum Beispiel der österreichischen Weltreisenden Ida Pfeiffer ${ }^{88}$ oder Alexander von Humboldt auslösten. ${ }^{89}$

Dessen ungeachtet präsentierten insbesondere liberale Autoren wie Alexander Mackay die USA und ihre Verfassung, die amerikanischen Schwurgerichte, das demokratische Parteienwesen, das Erziehungssystem und das politische Leben im Allgemeinen als vorbildhaft. $^{90}$

Drei Jahrzehnte später übten sich europäische - hier vor allem deutsche ${ }^{91}$ - Autoren nicht mehr bloß in distanzierter Kulturkritik, sondern warnten angesichts der zunehmenden Macht Amerikas bereits vor ernsten Gefahren für das Geistesleben Europas. So sprach der Physiologe Emil Du Bois-Reymond 1877 offen Ängste gegenüber der „Maschinenzivilisation“ aus, indem er „die gefürchtete Überwucherung und Durchdringung der europäischen Kultur mit Realismus und das reißend wachsende Übergewicht der Technik als Amerikanisierung ${ }^{\text {(92 }}$ thematisierte.

88 Die weithin bekannte österreichische Reiseschriftstellerin Ida Pfeiffer (1797-1858) hatte Amerika in den Jahren 1853-1854 von San Franscisco ausgehend besucht, und dabei - neben so manchen sozialen Missständen - insbesondere die Sklaverei als „größten Schandfleck der Menschheit“ bezeichnet. Vgl. PrimusHeinz Kucher, ,... dass die Vereinigten Staaten bisher einzig in der Welt dastehen. Ida Pfeiffers Reisebericht über Amerika. In: Ritter (Hrsg.), Amerika im europäischen Roman um 1850. Varianten transatlantischer Erfahrungen, a.a.O., 257.

89 Der Humanist und Aufklärer Alexander von Humboldt hatte sich bereits im Zusammenhang seiner Expedition 1799-1804 in die „Neue Welt“ ausdrücklich gegen jede Form von Sklaverei ausgesprochen. Als der amerikanische Verleger John Sidney Thrasher 1854 Humboldts Schrift „The Island of Cuba“ veröffentlichte, protestierte dieser lautstark dagegen, dass in der englischen Übersetzung seine kritischen Aussagen zur dortigen Sklaverei einfach weggelassen worden waren. In einem Interview mit der New York Evening Post übte der 85-jährige Humboldt harsche Kritik am amerikanischen Festhalten an der Sklaverei: „You have gone backward, very far backward in every respect. [...] In Europe you will also find bad things. But I tell you, you will not find anything half as bad as your system of slavery, and I know what slavery is like in your country.“ Zit. nach: Mischa Honeck, We are the Revolutionists. German-speaking Immigrants and American Abolitionists after 1848, Athens/Georgia 2011, 26.

90 Alexander Mackay, Western World, London 1849.

91 Ähnlich wie in Italien waren - aufgrund der großen Zahl familiärer Kontakte zu Auswandererfamilien die antiamerikanischen Stereotype und Vorurteile ursprünglich wohl auch in Frankreich etwas weniger scharf ausgeprägt; insbesondere in der künstlerisch-literarischen Intelligenz, die die amerikanische Kunst („le style américain“) europäisierten. Vgl. Philippe Soupalt, The American Influence in France, Seattle 1930, 30 ff. Dessen ungeachtet existierte auch in Frankreich unter Kommunisten, aber besonders unter der politischen Rechten spätestens in den 1920er-Jahren ein ausgeprägter Antiamerikanismus, da man Amerika als Gefahr für die grande nation ansah. Vgl. Richard F. Kuisel, Seducing the French: The Dilemma of Americanization, Berkeley 1993, 11 ff.; David Strauss, The Rise of Anti-Americanism in France. French Intellectuals and the American Film Industry, 1927-1932. In: Journal of Popular Culture, 10, 1977, 4, $752 \mathrm{ff}$.

92 Emil Du Bois-Reymond, Kulturgeschichte und Naturwissenschaft. Rede, 1877. Zit. nach: Basler, a.a.O., 144; Vgl. Wagnleitner, Coca-Colonisation, a.a.O., 34. Vgl. Estelle Du Bois-Reymond (Hrsg.), Reden von Emil Bois-Reymond, Leipzig 1912, 541-566. 
Abgesehen von der auch in der Habsburger-Monarchie konsumierten „Americana“Literatur entwickelten sich kontinuierliche diplomatische Kontakte zu Amerika, ähnlich wie in anderen europäischen Staaten, auch am Wiener Hof erst vergleichsweise spät und beschränkten sich zunächst vor allem auf Handelsbeziehungen. ${ }^{93}$

Wie zuvor bereits die Französische Revolution und die innere ,Bedrohung durch die reformorientierten Jakobiner ${ }^{94}$ bedeutete spätestens seit dem Wiener Kongress I814/15 auch die republikanisch-demokratische Verfassung Amerikas eine implizite politische Bedrohung für die restaurative Herrschaftsordnung des alten Europa, gegen dessen imperiale „aristokratisch-monarchische Weltbilder" sich die I823 proklamierte „Monroe-Doktrin“ als panamerikanische Schutzklausel gegenüber Südamerika richtete. ${ }^{95}$

Die Haltung der Habsburgermonarchie zum republikanischen Amerika war grundsätzlich überaus distanziert und reserviert, zumal US-Politiker 1848/49 revolutionäre Aktivitäten der Ungarn offiziell zumindest moralisch unterstützten. ${ }^{96}$ So berichtete Reverend Philip Schaff anlässlich einer Europareise 1854, dass speziell in Österreich „many respectable men of high culture [...] spoke only with contempt of America, which they regard as a grand bedlam, a rendezvous of European scamps and vagabonds. ${ }^{“ 97}$ Nach den ersten großen Auswanderungswellen des I9. Jahrhunderts ${ }^{98}$ und dem sich langsam inten-

93 Abgesehen von der Scheu vor der Verbreitung republikanisch-demokratischen Gedankenguts spielten hier wie auch im Fall anderer europäischer Staaten - auch die unterschiedlichen politischen Kulturen und der Informationsstand eine Rolle. So meinte etwa Thomas Jefferson in Bezug auf Österreich: „Sie schienen in der Tat nur das von uns zu wissen, dass wir Rebellen sind, welche Glück gehabt, als sie das Joch des Mutterlandes von sich geworfen; ohne irgend ein Verständnis sowohl für unseren Handel, welcher stets ein Monopol Englands war, als auch über den beiderseits gleich vorteilhaften Warenaustausche zu besitzen, wollten sie sich so lange reserviert verhalten, bis sie klarer sehen könnten, was für Beziehungen nutzbar mit uns angeknüpft werden konnten. “ Zit. nach: Hanns Schlitter, Die Beziehungen Österreichs zu Amerika 1778 bis 1885 , Innsbruck $1885,114 \mathrm{ff}$.

94 Vgl. Matthias Rettenwander, Nachwirkung des Josephinimus. In: Helmut Reinalter (Hrsg.), Josephinismus als aufgeklärter Absolutismus, Wien - Köln - Weimar 2008, 336 ff.; weiters: Karl Ucakar, Demokratie und Wahlrecht in Österreich. Zur Entwicklung von politischer Partizipation und staatlicher Legitimationspolitik, Wien 1985, $40 \mathrm{f}$.

95 Vgl. Fröschl, Antiamerikanismus in Europa und Lateinamerika, a.a. O., $86 f$.

96 Vgl. Spaulding, The Quiet Invaders, a.a. O., 45.

97 Philip Schaff, America. A Sketch of the Political, Social, and Religious Character of the United States, New York 1855, VII. Zit. nach: Merle Curti, The Reputation of America Overseas (1776-1860). In: American Quarterly, No. 1, 1949, 61.

98 In der Zeit des Vormärz war die Auswanderung nach Übersee quantitativ vergleichsweise gering. Auch nach der erfolglosen bürgerlichen Revolution von 1848 waren es hauptsächlich liberale demokratische Exponenten, die das Land in Richtung Neue Welt verließen. Erst in den letzten beiden Dekaden des 19. Jahrhunderts stieg die Zahl der österreichischen Einwanderer in Nordamerika merklich an (1876: 6173; 1890: 32.848; 1901: 59.581). Zwischen 1870 und 1910 kamen rund 3 Millionen Einwanderer aus ÖsterreichUngarn in die USA, wovon zwei Drittel Männer im Alter zwischen 14 und 40 Jahren waren; über $50 \%$ der Auswanderer kamen aus der Landwirtschaft, rund 30\% waren ArbeiterInnen. Vgl. Heinz Faßmann, Aus- 
sivierenden Handelsverkehr tauchten auch hierzulande vereinzelt Studien auf, welche die wirtschaftliche Übermacht Amerikas, die sich I85I auf der Londoner Weltausstellung im "Crystal Palace“ erstmals imposant gezeigt hatte, ${ }^{99}$ sorgenvoll thematisierten. So umriss zum Beispiel Alexander Peez - Nationalökonom, Industrieller, Volksbildner und liberales Reichsratsmitglied - im Jahr I88I detailliert die Gefahr der „Amerikanischen Concurrenz“ für Europa, wobei er als „Abwehrmaßnahme“ unter anderem die Schaffung eines „centraleuropäischen Bundes“ vorschlug. Peez resümierte in seiner Schrift sachlich-nüchtern und hellsichtig zugleich:

„Man mag es gut finden oder nicht: die Staaten nehmen immer mehr den Charakter grosser Genossenschaften an (um nicht zu sagen, Geschäfte'), mit dem Endzwecke der Sicherung eines grossen Antheils an den irdischen Gütern für alle Classen der Gesellschaft. [...] Wer nicht zurückbleiben und zertreten sein will, muss mitlaufen, Ruhe und Romantik verschwinden aus der Welt. Einen Tropfen amerikanischen Bluts müssen sich die alten Staaten des Continents aneignen. Liebgewordene Träume, tausendjährige Vorurtheile sind nicht länger haltbar. Wie wird in dieser grausamen Rennbahn der Ueberbelastete bestehen? Und wird noch für den Sport des Nationalitätenhaders Raum sein? "100

In Reaktion auf die zunehmende Rohgüterüberschwemmung aus Amerika sowie auf die allgemeinen politischen Gefahren einer „Amerikanisierung“ griffen sowohl der deutsche Kaiser $^{101}$ als auch das österreichische Außenamt die Idee einer Gründung von „Vereinigten

wanderung aus der österreichisch-ungarischen Monarchie 1869-1910. In: Traude Horvath/Gerda Neyer (Hrsg.), Auswanderung aus Österreich: Von der Mitte des 19. Jahrhundert bis zur Gegenwart. Mit einer umfassenden Bibliographie zur österreichischen Migrationsgeschichte, Wien - Köln - Weimar 1996, $34 \mathrm{ff}$. Bis zum Beginn des Ersten Weltkriegs war Österreich-Ungarn mit $20 \%$ aller US-EinwanderInnen eine Hauptquelle für die amerikanische Immigration. In der Zeitspanne zwischen 1901 und 1910 waren 18\% der US-EinwandererInnen aus Österreich-Ungarn galizische Polen, 7\% waren Juden, 16\% Kroaten, Serben oder Slowenen und $15 \%$ Slowaken. Wie u.a. anhand der Passagierlisten rekonstruiert werden konnte, bildeten zwischen 1876 und 1885 zunächst die Tschechen die Hauptgruppe der US-AuswandererInnen aus Österreich-Ungarn. Die neue Immigrationswelle der letzten beiden Dekaden des 19. Jahrhunderts bis 1910 dominierte jedoch klar die Gruppe der Auswanderer aus Galizien, die rund $70 \%$ aller US-Immigranten ausmachte. Vgl. dazu den Projektbericht: Josef Ehmer/Annemarie Steidl/Hermann Zeitlhofer, Migration Patterns in Late Imperial Vienna (= KMI Working Paper Series: Working Paper Nr. 3), Kommission für Migrations- und Integrationsforschung, Österreichische Akademie der Wissenschaften, Wien 2004, 7 bzw. 17. Ich danke an dieser Stelle Herrn Univ.-Prof. DDr. Oliver Rathkolb für den Literaturhinweis.

99 Vgl. Curti, The Reputation of America Overseas, a.a.O., 78.

100 Alexander Peez, Amerikanische Concurrenz, Wien 1881, 118. Vorangestellt ist dem Buch folgendes amerikanisches Sprichwort: „Es genügt nicht grosse Scheunen zu bauen, und zu warten, bis Gott sie füllt.“

101 Auf amerikanischer Seite prägten die martialischen Reden des antisemitischen „war lord“ Wilhelm II. das öffentliche Bild der Deutschen; für Präsident Roosevelt war er gar „a perfect fool“. Zit. nach: Raimund Lammersdorf, Zur Perzeption Wilhelm II. in den Vereinigten Staaten, 1888-1909. In: Amerikastudien/American Studies, 31. Jg., 1986, Heft 3, 301. 
Staaten von Europa ${ }^{\text {“102 }}$ auf - eine Idee, die im krisenhaften, politisch inhomogenen Europa freilich erst sehr viel später Realität werden sollte.

Neben allmählich aufkeimenden Ängsten gegenüber der wirtschaftlich-ökonomischen Stärke der Neuen Welt - um die Jahrhundertwende traten die USA zunehmend als Macht nach außen auf, die sich keineswegs mehr allein auf den amerikanischen Kontinent beschränkte ${ }^{103}$ - trug insbesondere auch die Presseberichterstattung zur Verfestigung von Negativ-Stereotypen über die kulturelle Inferiorität Amerikas bei. So etwa die ab 1857 dem Innenministerium unterstehende Wiener Zeitung, das offizielle Organ des österreichischen Staats. In einer Auflage von 4.00o Exemplaren publizierte Die Wiener Zeitung ab I860 neben Warnungen vor der Auswanderung nach Amerika vermehrt klischeehafte Zerrbilder vom amerikanischen „Pöbel“, dem jedwede Kultur und Sitten abgingen, ${ }^{104}$ von den „naiven“, „kindischen“ und „feigen“ Einwohnern, ${ }^{105}$ die zur rücksichtslosen „Geschäftstüchtigkeit" neigen würden. ${ }^{106}$

Zusätzlich und mit nachhaltiger Wirkung unterfüttert wurde dieses ambivalent-gedoppelte Amerikabild - einerseits der faszinierende, exotische und wilde Kontinent, anderseits das inhumane und hyper-moderne jedoch „kulturlose“ Amerika - zur Jahrhundertwende durch die massenhaft erfolgreichen Romane Karl Mays, der selbst nie in Amerika war, mit seinen Amerika-Stereotypen aber ganze Generationen vorwiegend deutschsprachiger

102 Am 20. November 1897 proklamierte der österreichisch-ungarische Staatssekretär des Auswärtigen Amts, Graf Goluchowsky, den Schulterschluss gegen die transatlantische Konkurrenz: „Das 20. Jahrhundert sagt sich für Europa als ein Jahrhundert des Ringens ums Dasein auf handelspolitischem Gebiete an, und die Völker Europas müssen sich vereinigen, um mit Erfolg die Voraussetzungen zu verteidigen, auf denen ihre Lebenskraft beruht.“ Zit. nach: Paul Rache, Vorwort. In: Amerikanismus. Schriften und Reden von Theodore Roosevelt. Ins Deutsche übertragen und mit einem Vorwort versehen von Paul Rache. 2. Aufl., Leipzig 1903, 4. Der Aufruf Goluchowskys wurde in ganz Europa heftig diskutiert. Vgl. Thomas Lenschau, Die Amerikanische Gefahr, Berlin 1902, 1.

103 Nach der Samoa-Krise 1889, bei der es vornehmlich um Rohstoffkonkurrenz (Kohle) zwischen den USA, Deutschland und England gegangen war, und im Vorfeld des spanisch-amerikanischen Krieges 1898 u.a. um die Philippinen hatte der US-Außenminister Richard Olney mit Berufung auf die Monroe-Doktrin am 20. Juli 1895 explizit Mittel- und Südamerika unter Schutz der Vereinigten Staaten gestellt und erklärt, die „USA hätten das Recht, dort zu intervenieren.“ Den vorläufigen Höhepunkt erreichte das politische Spannungsverhältnis zwischen den USA und Deutschland im Zuge der Venezuela-Krise Dezember 1902, als Deutschland und England wegen ausständiger Zinsrückzahlungen an deutsche Gläubiger mit Kriegsschiffen eine Blockade der venezolanischen Küste durchführte und damit gegen die Monroedoktrin der US-Regierung verstieß. Johannes Reiling, Deutschland: Safe for Democracy? Deutsch-amerikanische Beziehungen aus dem Tätigkeitsbereich Heinrich F. Alberts, kaiserlicher Geheimrat in Amerika, erster Staatssekretär der Reichskanzlei der Weimarer Republik, Reichsminister, Betreuer der Ford-Gesellschaften im Herrschaftsgebiet des Dritten Reiches, 1914 bis 1945, Stuttgart 1997, 35 bzw. 42 ff.

104 Markus Gatschnegg, „Amerikabilder“ in der Berichterstattung der „Wiener Zeitung“ 1860 bis 1867, Dipl.-Arb., Univ. Wien 2004, 78.

105 Ebd., $82 \mathrm{f}$.

106 Vgl. ebd., 85 ff. 
Europäer prägte ${ }^{107}$ und durchgängig provinziell angesammelte Imaginationen vom, rauen und wilden Leben ${ }^{108}$ produzierte, die obendrein unterschwellig , autoritär-antidemokratische Standards" festschrieben. ${ }^{109}$

Einer der wenigen, hochprominenten österreichischen Amerikabesucher des 19. Jahrhunderts war Erzherzog Franz Ferdinand, dessen Reiseeindrücke Aufschluss über das Amerikabild des Kaiserhauses respektive des Hofadels geben. Anlässlich einer Weltreise besichtigte er neben Kanada auch die Vereinigten Staaten und besuchte hier 1893 unter anderem die Weltausstellung in Chicago. Der Trophäensammler und spätere Thronfolger zeigte sich von der Weite des Landes sowie den Naturschönheiten des Yellowstone Parks beeindruckt, von der hektischen Urbanität, den schmutzigen Straßen und von der rauen Lebensweise Amerikas, die ihn jede „Gemütlichkeit und jeden Geschmack“ missen ließ, jedoch abgestoßen. ${ }^{110}$ Der technische Fortschritt machte nur wenig Eindruck auf den österreichischen Erzherzog, der sich im abschließenden Resümee seiner in Summe negativen Eindrücke von der amerikanischen Gesellschaft zu einem völlig abwegigen Vergleich verstieg, indem er deren Zivilisationsgrad mit dem Papua Neuguineas verglich, das er auf seiner Weltreise ebenfalls besucht hatte. ${ }^{111}$

Angewidert vom Niedergang europäischer Kultur sah auch Friedrich Nietzsche, der den Leistungen der ,Neuen Welt' nicht ganz ohne (dionysische) Sympathie gegenüberstand und der Erstausgabe seiner Schrift „Die fröhliche Wissenschaft“ (I882) noch ein Zitat

107 Neben vielen jugendlichen Lesern freilich auch - ob indirekt oder direkt, ,negativ' oder ,positiv' - zahlreiche, spätere Schriftsteller wie u.a. Bertolt Brecht (so das „Chicago-Stereotyp“ in „Die heilige Johanna der Schlachthöfe“ oder „Der Aufstieg des Arturo Ui“, oder - nach 1940 - Carl Zuckmayer („Pioneer“Mythologie im „Vermonter Roman“, 1942/43). Siehe: Otto, Deutsche Amerika-Bilder, a.a.O., $109 \mathrm{ff}$. bzw. $269 \mathrm{ff}$.

108 Interessanterweise konnten, wie Valerie Popp mit Bezug auf Jeffrey L. Sammons hervorhebt, die USAmerikaner mit diesen auf Basis von Sekundärliteratur frei assoziierten „deutschen Heterotypen“ wenig anfangen, sodass Karl May in den Vereinigten Staaten „so gut wie gar nicht rezipiert wurde.“ Valerie Popp, „Aber hier war alles anders ...“. Amerikabilder der deutschsprachigen Exilliteratur nach 1939 in den USA, Würzburg 2008, 32, Anm. 56; siehe dazu weiters: Jeffrey L. Sammons, Ideology, Mimesis, Fantasy: Charles Sealsfield, Friedrich Gerstäcker, Karl May, and Other German Novelists of America, Chapel Hill 1998. Zit. nach: Popp. „Aber hier war alles anders ...“. Amerikabilder, a.a. O., ebd.

109 Wie Viktor Otto konstatiert, zählten Karl May und Richard Wagner „zu den wenigen Exponenten deutscher Kultur, mit denen sich auch ein Anti-Intellektueller wie Adolf Hitler aus offenkundig persönlichem Interesse befaßte." Otto, Deutsche Amerika-Bilder, a.a.O., 89.

110 Obwohl er dem technischen Fortschritt an sich nicht uninteressiert gegenüber stand, zeigte Franz Ferdinand in Amerika kein Interesse am modernen Massenverkehr oder der industriellen Massenproduktion. Vgl. Günter Bischof, Two Sides of the Coin: The Americanization of Austria and Austrian Anti-Americanism. In: Alexander Stephan (Ed.), The Americanization of Europe. Culture, Diplomacy, and AntiAmericanism after 1945, New York - Oxford 2006, 149; siehe insbesondere auch: Robert Hoffmann, Erzherzog Franz Ferdinand und der Fortschritt. Altstadterhaltung und bürgerlicher Modernisierungswille in Salzburg, Wien - Köln - Weimar 1994.

111 Bischof, Two Sides of the Coin, a.a. O., 150. 
Ralph Waldo Emersons als Motto vorangestellt hatte, die Dynamik des neuen Zeitalters durch ein signifikantes West-Ost-Gefälle - ,nach dem Westen zu wird die moderne Bewegtheit immer grösser “112 - gekennzeichnet, eine Dynamik, die für ihn allerdings klar auf Kulturverfall hinauslief:

„Es ist eine indianerhafte, dem Indianer-Bluthe eigenthümliche Wildheit in der Art, wie die Amerikaner nach Gold trachten: und ihre athemlose Hast der Arbeit - das eigentliche Laster der Neuen Welt - beginnt bereits durch Ansteckung das alte Europa wild zu machen und eine ganz wunderliche Geistlosigkeit darüber zu breiten. Man schämt sich jetzt schon der Ruhe; das lange Nachsinnen macht beinahe Gewissensbisse. Man denkt mit der Uhr in der Hand, wie man zu Mittag isst, das Auge auf das Börsenblatt gerichtet, - man lebt wie Einer, der fortwährend Etwas ,versäumen könnte'.,Lieber irgend Etwas thun, als Nichts' - auch dieser Grundsatz ist eine Schnur, um aller Bildung und allem höheren Geschmack den Garaus zu machen. " ${ }^{113}$

Interessanterweise war es, wie Günter Bischof hervorhebt, just der Gründervater der modernen Psychoanalyse, der den kulturellen Hautgout und die Arroganz der europäischen Bildungselite in seltsam unkritisch-undifferenzierter Weise übernahm; zwar nicht in seinen wissenschaftlichen Arbeiten, ${ }^{114}$ jedoch in brieflichen Äußerungen. So bezeichnete Sigmund Freud das dollar-materialistische Amerika als konformistisches „Gegen-Paradies“ und wetterte anlässlich seiner Amerikareise 1909 über das schlechte Essen. ${ }^{115}$ Gegenüber Ernest Jones meinte er gar: „America is a mistake, admittedly a gigantic mistake, but a mistake nevertheless. ${ }^{\text {"116 }}$

112 Friedrich Nietzsche, Menschliches, Allzumenschliches I (5. Anzeichen höherer und niederer Cultur). In: Friedrich Nietzsche. Kritische Studienausgabe. Bd. 2. Hrsg. v. Giorgio Colli/Mazzino Montinari, München 1999, §285, 232.

113 Friedrich Nietzsche, Die fröhliche Wissenschaft. Viertes Buch. In: Friedrich Nietzsche. Kritische Studienausgabe. Bd. 3, a.a.O., $\$ 329,556$.

114 Der einzige Hinweis findet sich in seiner 1929 publizierten Schrift „Das Unbehagen in der Kultur“. Hier machte Freud das „psychologische Elend der Masse“ - interessanterweise mit einem Untergriff gegen egalitäre Organisationsformen - am Fallbeispiel Amerikas fest, wo „gesellschaftliche Bindung hauptsächlich durch Identifizierung der Teilnehmer untereinander hergestellt wird, während Führerindividualitäten nicht zu jener Bedeutung kommen, die ihnen bei der Massenbildung zufallen sollte. Der gegenwärtige Kulturzustand Amerikas gäbe gute Gelegenheit, diesen befürchteten Kulturschaden zu studieren. Aber ich vermeide die Versuchung, in die Kritik der Kultur Amerikas einzugehen; ich will nicht den Eindruck hervorrufen, als wollte ich mich selbst amerikanischer Methoden bedienen." Sigmund Freud, Das Unbehagen in der Kultur. In: Sigmund Freud. Studienausgabe. Bd. IX. Fragen der Gesellschaft - Ursprünge der Religion, Frankfurt a. Main 2000, 244.

115 Bischof, Two Sides of the Coin, a.a.O., 150.

116 Zit. nach: Ernest Jones, The Life and Work of Sigmund Freud. Vol. 2: Years of Maturity, 1901-1919, New York 1955, 60. 
Angesichts der anwachsenden antiamerikanischen Tendenzen in Europa ${ }^{117}$ insbesondere in Deutschland, ging US-Präsident Theodore Roosevelt, der im Übrigen über Österreich-Ungarn wohlinformiert war, ${ }^{118}$ I894 mit einer flammenden Rede zum „wahren Amerikanismus“ in die Offensive, in der er offen den „parochialen Geist“, die „Kirchturmpolitik und eng begrenzten Lokalpatriotismus“, die „Überkultur, Reizbarkeit und Nervosität“ europäischer Politiker und Intellektueller anprangerte und stolz dagegen hielt, dass „von allen Völkern der Erde [...] das unsere die Zukunft für sich“119 hat.

Brachte der gelehrte Diskurs in ökonomischer Hinsicht größtenteils mahnende Ratlosigkeit zum Ausdruck, ${ }^{120}$ etablierte sich gegenüber Amerika seitens der herrschenden bildungsbürgerlichen Eliten mit dem steigenden Export von US-Magazinen und Hollywood-Filmen zu Beginn des 20. Jahrhunderts ein ideologischer Abwehr-Diskurs auf breiter Front ${ }^{121}$ - dieser vermochte die Popularität Amerikas in der Bevölkerung allerdings nicht zu unterminieren. ${ }^{122}$

117 So widersetzten sich Kaiser Wilhelm I. und Kaiser Franz-Josef I. gegen die Einrichtung von Lehrstühlen zur Amerikanischen Geschichte an den Universitäten Berlin, Prag und Wien; dem französischen Historiker Jules Michelet wurde seine Pariser Professur u.a. wegen seiner allzu deutlich ausgesprochenen Sympathie gegenüber der Amerikanischen Revolution entzogen und die Sorbonne schloss ihre Türen für Eduard Laboulaye, als dieser eine Vorlesung über die amerikanische Verfassung ankündigte. Vgl. Curti, The Reputation of America Overseas, a.a.O., 62.

118 So hielt bspw. ein diplomatischer Bericht der österreichischen Gesandten in den USA am 19. August 1905 erstaunt fest, dass der US-Präsident „merkwürdig gut unterrichtet“ sei. Und weiter: „Er ist ein warmer Freund meines engeren Vaterlandes, dessen Geschichte er kennt und dessen nationale Aspirationen er vollkommen begreift. Er findet aber, daß dieselben mit der Großmachtstellung der Monarchie in Einklang gebracht werden müssen und daß Ungarn selbst hieran das allergrößte Interesse habe." Zit. nach: Erwin Matsch, Wien - Washington. Ein Journal diplomatischer Beziehungen 1838-1917, Wien Köln 1990, 539.

119 Theodore Roosevelt, Der wahre Amerikanismus. In: Amerikanismus. Schriften und Reden von Theodore Roosevelt, a.a.O., 11-16. Hier heißt es weiter: „Trotz aller Fehler und Gebrechen gibt es kein Land auf der ganzen Welt, das so sehr einem jeden, der davon Gebrauch zu machen versteht, Gelegenheit zum Vorwärtskommen bietet, wie das unsere. Keiner von uns kann aber etwas Ordentliches zu stande bringen, wenn er es nicht auf echt amerikanische Weise anpackt." Ebd., 16.

120 Siehe: George W. Steevens, The Land of the Dollar, London 1898; Brooks Adams, America's Economic Supremacy, London 1900.

121 Vgl. Christian Stifter, Die Erziehung des Kino und die „Mission des Kulturfilms“. Zur sozialen Organisation des "Guten Geschmacks" in der frühen Volksbildung und Kinoreform in Wien 1898-1930. In: Spurensuche, 8. Jg., 1997, Heft 3-4, 54-79.

122 So erschien beispielsweise 1909 in Brünn eine eigene pro-amerikanische Schriftenreihe - „Cěský Amerikanism“ - in der, neben Gedanken amerikanischer Millionäre wie Carnegie, über Individualismus, Technik, Fotografie, Architektur, Reklamewesen, autogenes Training etc. berichtet wurde. William T. Stead meinte diesbezüglich bereits 1901: „Der Mittelpunkt des Widerstandes gegen amerikanische Prinzipien in Europa ist Berlin und der Führer gegen alle Amerikanisierung der Kaiser von Deutschland. [...] Es gibt keine mehr amerikanisierten Städte als Hamburg oder Berlin. Sie sind amerikanisch in der Schnelligkeit ihres Wachstums, amerikanisch in ihrer nervigen Thatkraft, amerikanisch in der weitgehenden 
Im Versuch einer Antwort auf die Frage nach dem „Geheimnis des amerikanischen Erfolgs" attestierte selbst ein kritischer Autor wie William T. Stead den USA - neben der hier erstmals rassentheoretisch explizierten Fähigkeit der Amerikaner zu puritanischer Selbstbeschränkung und Leistung ${ }^{123}$ - im Bereich von Kunst, Wissenschaft und Musik schöpferische Leistungen, die in Europa oft unterschätzt würden. ${ }^{124}$

Dessen ungeachtet grassierten im deutschen Bildungsbürgertum angesichts der zunehmenden,Amerikanisierung ' deutscher Städte bald tiefsitzende Ängste vor Traditions- und Identitätsverlust, die teilweise kuriose Blüten trieben. So bezeichnete Werner Sombart im Jahr 1907 Berlin - im Unterschied zur nach wie vor andersartigen, nämlich traditionellen Lebenskultur in Wien - abschätzig als „Vorort von New York“; ${ }^{125}$ und der deutsche Schriftsteller Franz Serveas betrachtete 1908 das konservative Wien „als „Damm und Bollwerk wider den eindringenden Amerikanismus“ im „Gesamtbereich der deutschen Kultur." ${ }^{126}$

In politischer Hinsicht hingegen schien, wie Silvia Daniel konzise darzustellen vermochte, die Habsburgermonarchie für die amerikanische Politik so gut wie nicht zu existieren. Und obwohl das Kaiserreich durchaus nicht unmaßgeblichen Anteil am Ausbruch des Ersten Weltkriegs hatte und zunächst „für wenige Wochen Deutschland und Österreich in einem Atemzug genannt“127 wurden, rückte Österreich - selbst nach der „Ancona“-Krise September 1915, bei der ein k.k. U-Boot ein italienisches Schiff mit US-Bürgern an Bord versenkt hatte - im Zuge des weiteren Kriegsverlaufes völlig in den Hintergrund. Aus USPerspektive verfestigte sich bald das Bild eines militärisch und politisch schwachen Machtgebildes, dessen „weakness“ bereits dem verbündeten Deutschen Reich zur Last fiele. ${ }^{128}$ Nicht zuletzt auch aufgrund der wiederholt kritisierten ethnischen Unterdrückungspolitik

Einführung schneller Transportgelegenheiten."William T. Stead, Die Amerikanisierung der Welt, Berlin 1902, 11 f.; siehe weiters: Gertrud Deicke, Das Amerikabild der deutschen öffentlichen Meinung von 1898-1914, Diss., Univ. Hamburg 1956.

123 „Der Aufschwung Amerikas lässt sich in verschiedener Weise erklären. Eine junge und lebenskräftige Rasse geriet über die unermesslichen Schätze eines jungfräulichen Kontinents. [...] Diese grosse Mischung heterogener Kräfte stellt eine neue zusammengesetzte Rasse dar, die sich nunmehr allen Forderungen dieser Erde unbeschränkt gegenüber sah, befreit von allen Fesseln der Vorurtheile, Ueberlieferungen und alteingebürgerter Einrichtungen, die die Völker der alten Welt einschränken. Die Amerikaner hatten keine unbequemen Gewänder abzuwerfen." Stead, Die Amerikanisierung der Welt, a.a.O., 1.

124 Ebd., $135 \mathrm{ff}$.

125 Werner Sombart, Wien. In: Morgen. Wochenzeitschrift für Deutschen Kultur, 1, 1907, Heft 6, 173. Zit. nach: Otto, Deutsche Amerika-Bilder, a.a.O., 115.

126 Franz Serveas, Wien. Briefe an eine Freundin in Berlin, Leipzig [1908], 129 ff. Zit. nach: Otto, Deutsche Amerika-Bilder, a.a.O., 115.

127 Silvia Daniel, A Brief Time to Discuss America. Der Ausbruch des Ersten Weltkriegs im Urteil amerikanischer Politiker und Intellektueller (= Internationale Beziehungen. Theorie und Geschichte, Bd. 3), Göttingen 2008, 424.

128 Ebd., $426 f$. 
des habsburgischen Vielvölkerstaates und des von Woodrow Wilson klar proklamierten Selbstbestimmungsrechts ging die US-Politik von der Auflösung der Habsburgermonarchie nach Kriegsende aus. In einem Interview mit der New York Times äußerte sich Präsident Wilson, der sich selbst mit dem Staatsgefüge Österreich-Ungarns beschäftigte hatte, in Bezug auf Österreich im Dezember I9I4 unmissverständlich: „It seems to me that the Government of Germany must be profoundly changed, and that Austria-Hungary will go to pieces altogether - ought to go to pieces for the welfare of Europe. " ${ }^{129}$

Wie Daniel überzeugend rekonstriert hat, unterschied sich der Blick der USA auf Österreich-Ungarn deutlich von dem auf andere Mächte wie Großbritannien, Deutschland, Russland oder Japan, indem die Habsburgermonarchie nicht nur das „alte Europa des langen neunzehnten Jahrhunderts" verkörperte, sondern darüber hinaus als keine ernstzunehmende Gefahr oder Konkurrenz angesehen wurde:

„Die Ziele der Habsburgermonarchie lagen in einem begrenzten Gebiet, das für amerikanische Interessen entfernt und ohne Belang war. [...] Allein, die Entwicklung der Minoritätenpolitik und das Verhältnis Ungarns sowohl zu Österreich als auch zu seinen serbischen und rumänischen Minderheiten zogen amerikanisches Interesse auf sich und zeigten den Reformbedarf dieser Region nach amerikanischen Prinzipien auf. Für die amerikanische Elite war die Donaumonarchie in der Tat schon eine , second class power ${ }^{\star}[\ldots]^{\text {“ }} .{ }^{130}$

Nachdem im Kontext des Ersten Weltkriegs kurzfristig die nachgerade exotische Frage nach den militärisch-politischen Auswirkungen einer deutsch-österreichischen Suprematie im Fall eines Kriegsgewinnes aufgeworfen worden war, ${ }^{131}$ gingen die USA nach Kriegsende schließlich als definitive Sieger hervor, indem sie nun „sowohl Kriegsschulden als auch Reparationen "132 finanzierten. Gegen Mitte der I920er-Jahre erfolgten massive Investitionen in die deutsche Ökonomie und Wirtschaft und noch bis 194I betrugen die Investitionen US-amerikanischer Firmen (ITT, General Motors, American IG Chemical Corporation et cetera) rund 475 Millionen Dollar. ${ }^{133}$

129 Woodrow Wilson am 14. Dezember 1914. Hier zit. nach: Silvia Daniel, A Brief Time to Discuss America. Der Ausbruch des Ersten Weltkriegs im Urteil amerikanischer Politiker und Intellektueller, a. a. O., 428.

130 Ebd., 433.

131 So sprach der US-Historiker Roland G. Usher für den Fall einer siegbedingten „reorganization of Germany and Austria“ nach Kriegsende von der bisher möglicherweise größten Krise für die USA, denn: „We shall be blind to the most obvious of facts if we fail to see that a European army can be maintained in the United States as easily as the present European armies can be maintained from the United States. [...] Invasion oft the United States is no longer forbidden by the practical difficulty of maintaining at such a distance a force sufficiently large to make an invasion decisive." Roland G. Usher, Pan-Americanism. A Forecast of the Inevitable Clash between the United States and Europe's Victor, London 1915, 102, 135.

132 Wagnleitner, Coca-Colonisation, a.a.O., 28.

133 Siehe: Ralph Willet, The Americanization of Germany, 1945-1949, London - New York, 1992.2.Aufl., 9. 
In der Folge stiegen in Europa amerikanische Investitionen und Exporte bis in die Dreißigerjahre sprunghaft an, und neben Massenartikeln der Konsumgüterindustrie und deren tayloristisch-fordistischen Produktionsmethoden waren auch die Segnungen moderner Unterhaltungsindustrie wie Jazz-Schallplatten, illustrierte Magazine oder HollywoodFilme bald allgegenwärtig. Luigi Pirandello meinte 1929 diesbezüglich:
„Der Amerikanismus überflutet uns. Ich glaube, dass man [...] einen neuen Leuchtturm der Zivilisation entzündet hat. [...] Das Geld, das die Welt durchläuft, ist amerikanisch, und hinter dem Geld läuft die Lebensweise und die Kultur. Hat Amerika eine Kultur? Es hat Bücher und Gewohnheiten. Die Gewohnheiten sind seine neue Literatur, jene, die durch die am stärksten befestigten und verteidigten Tore dringt. In Berlin spüren sie nicht den Abstand zwischen altem und neuem Europa, weil die Struktur dieser Stadt keine Widerstände bietet. In Paris, wo es eine geschichtliche und künstlerische Struktur gibt, wo die Zeugnisse einer autochthonen Zivilisation zugegen sind, sticht der Amerikanismus ab wie die Schminke auf dem alten Gesicht einer Lebedame.“134

Ebenso wie in Italien ${ }^{135}$ waren auch Frankreichs Intellektuelle, deren antiamerikanische Ressentiments trotz der differenzierten frühen Studie Alexis de Tocquevilles zur amerikanischen Massendemokratie ${ }^{136}$ traditionell besonders ausgeprägt waren, ${ }^{137}$ spätestens

134 Luigi Pirandello in einem Interview mit Corrado Alvaro. In: L'Italia Letteraria, 14. April 1929. Zit. nach.: Gramsci, Amerikanismus und Fordismus, a.a.O., 2098.

135 Vgl. Gamal Morsi, „Amerika ist immer woanders“. Die Rezeption des American Dream in Italien, Marburg 2001, 105 ff.; für die Nachkriegszeit siehe die elaborierte Studie: Alessandro Brogi, Confronting America. The Cold War between the United States and Communists in France and Italy, Chapel Hill 2011; weiters: Ekkehart Krippendorf (Ed.), The Role of the United States in the Reconstruction of Italy and West Germany 1943-1949. Papers presented at a German-Italian Colloquium held at the John F. Kennedy-Institut für Nordamerikastudien, Berlin 1981.

136 Auf Basis von Reiseeindrücken, die Alexis de Tocqueville (1805-1859) in den Jahren 1831/32 in den Vereinigten Staaten gemeinsam mit seinem Begleiter Gustave de Baumont gemacht hatte, publizierte dieser 1835 bzw. 1840 zwei Bände seine umfangreichen demokratietheoretischen Studie „Über die Demokratie in Amerika“. In diesem Klassiker der modernen Demokratietheorie analysierte der spätere Abgeordnete Tocqueville sowohl Stärken als auch Schwächen des amerikanischen politischen Systems. Obwohl das Buch respektive sein Autor, trotz der darin enthaltenen deutlichen Kritik der Ungleichstellung von Afroamerikanern und Indianern, insbesondere in den USA bald einen regelrechten Kultstatus erreichte, blieb dessen Wirkungsgeschichte außerhalb Frankreichs allerdings äußerst gering. Vgl. dazu: Karlfriedrich Herb/Oliver Hidalgo, Alexis de Tocqueville, Frankfurt a. Main 2005, 146; weiters: Alexis de Tocqueville, Über die Demokratie in Amerika, Stuttgart 1985; zur Amerikareise Tocquevilles im Detail siehe die ausführliche Darstellung bei George Wilson Pierson, Tocqueville in America, Baltimore London 1996 [zuvor veröffentlicht unter dem Titel: Tocqueville and Baumont in America, New York 1938].

137 Vgl. Richard J. Golsan, From French Anti-Americanisms and Americanization to the „American Enemy“? In: Alexander Stephan (Ed.), The Americanization of Europe. Culture, Diplomacy, and Anti-America- 
seit dem US-amerikanischen Kriegseintritt I9I7 - die militärische Einmischung der USA wurde ebenso wie „Wilsons Nachkriegspolitik als unstatthafte Einmischung in europäische Angelegenheiten " ${ }^{138}$ verurteilt - voll auf den grassierenden Antiamerikanismus eingeschwenkt: sie machten den amerikanischen „Utilitarismus“ für die „geistige Krise, die Europas Niedergang in die Wege geleitet habe", ${ }^{139}$ verantwortlich. Auch hier wurde Amerika "als mahnendes Schreckbild“ für den alten Kontinent betrachtet, drohte der „Taylorismus, Vermassung und Verlust der sozialen Bindungen [...] auch Europa zu zersetzen, wenn der Siegeszug des Amerikanismus nicht aufgehalten werden konnte. "“140

Angesichts der „ökonomischen Demoralisierung ${ }^{\prime \prime 141}$ und der Überschwemmung mit standardisierter Massenware verschärfte sich die Kritik an Amerika, da nun zunehmend auch Zweifel und Skepsis gegenüber dem gesellschaftlich-politischen System insgesamt laut wurden: „[...] democracy has become a synonym for machine politics. ${ }^{\text {"142 }}$ Die Schattenseiten wie Korruption, hohe Kriminalität, Sklaverei beziehungsweise "Rassenunterschiede “143 und die Rechtlosigkeit der Arbeiterklasse traten in den Vordergrund und warfen die Frage auf, wie es um die proklamierte Freiheit des „Land of freedom" eigentlich bestellt ist. Anders als linke Theoretiker wie Karl Marx, Siegfried Kracauer, Walter Benjamin oder Antonio Gramsci, die in der amerikanischen Produktions- und Reproduktionsweise die transatlantische Front der europäischen Entwicklung sahen, ${ }^{144}$

nism after 1945, New York - Oxford 2006, 44 ff.; sowie weiters: Philippe Roger, L’Ennemi américain. Généalogie de l'antiaméricanisme français, Paris 2002.

138 Urs Bitterli, God's own country? Einige Überlegungen zum Antiamerikanismus. In:Thomas Beck/Marília dos Santos Lopes/Christian Rödel (Hrsg.), Barrieren und Zugänge. Die Geschichte der europäischen Expansion, Wiesbaden 2004, 232-247.

139 Hans-Wilhelm Eckert, Konservative Revolution in Frankreich? Die Nonkonformisten der Jeune Droîte und des Ordre Nouveau in der Krise der 30er Jahre (= Studien zur Zeitgeschichte, Bd. 58), München 2000, 98.

140 Ebd., 99; zum Entwicklungsverlauf des französischen Antiamerikanismus nach dem „Schwarzen Freitag“ 1929 siehe im Detail: Seth D. Armus, French anti-Americanism, 1930-1948. Critical moments in a complex history, Lanham 2007, $20 \mathrm{ff}$.

141 Tom Mann, Preface. In: W.T. Colyer, Americanism. A World Menace, London 1922, 1.

142 Ebd., 159.

143 Obwohl der Vorwurf der Ungleichbehandlung bezeichnenderweise kaum breiten Raum einnahm, eignete sich der Hinweis auf die Diskriminierung der „Neger“ doch gut, um auf die Bigotterie der amerikanischen Demokratie insgesamt zu verweisen. Zum Verlauf der europäischen Diskussion rund um die Fragen der amerikanischen Rassendiskriminierung beziehungsweise der Sklaverei siehe die materialreiche Presseauswertung bei Thaller, Studien zum europäischen Amerikabild, a.a. O., Bd. II, $442 \mathrm{ff}$.

144 „Dass es sich im Falle des Amerikanismus, nicht nur im Sinne von Kaffeehausleben, sondern auch als Ideologie des Rotary Clubs, nicht um einen neuen Zivilisationstyp handelt, ist daran ablesbar, dass nichts sich geändert hat am Charakter und an den Beziehungen der fundamentalen Gruppen: es handelt sich um eine organische Verlängerung und Intensivierung der europäischen Zivilisation, die im amerikanischen Klima lediglich eine neue Haut angenommen hat." Gramsci, Amerikanismus und Fordismus, a.a.O., 2099 f.; siehe weiters: Siegfried Kracauer, Die Angestellten. Aus dem neuesten Deutschland, Frankfurt a. 
schwenkte auch die europäische Arbeiterbewegung, wenn auch in gemäßigter Form, auf den Antiamerikanismus ein. ${ }^{145}$

Gramsci analysierte die Situation 1934 präzise: „Was heute ,Amerikanismus“ genannt wird, ist großenteils die vorbeugende Kritik der alten Schichten, welche die mögliche neue Ordnung geradezu erdrücken wird und die bereits jetzt von einer Welle gesellschaftlicher Panik der Auflösung und Verzweiflung gepackt sind, es ist ein Versuch unbewusster Reaktion von jemand, der unfähig zur Rekonstruktion ist und sich auf die negativen Aspekte der Umwälzung beruft."

Noch vor dem Börsenkrach erreichten die bildungsbürgerlichen, oft auch technophoben Überfremdungsängste hinsichtlich des Verhältnisses von (deutscher) Hochkultur einerseits und amerikanischer Kommerzkultur beziehungsweise der „zivilisatorischen Barbarei “147 andererseits einen ersten vorläufigen Höhepunkt. In dem Buch des deutschen Erfolgsautors Adolf Halfeld verdichteten sich gleichsam alle bisherigen NegativVorurteile und Stereotype, die in der Provinzpresse bereits seit Beginn der Zwanzigerjahre verbreitet waren, zu einer einzigen Ablehnungstirade gegen das „Imperium“ der „Dollardiktatur“:

„Zwei Welten, zwei Kulturen. Aber kaum wohl geistige Brücken, die über den Atlantischen Ozean führen. Und vollends Verquickung oder gegenseitige Befruchtung würde Herabwürdigung des europäischen Niveaus bedeuten, ohne daß doch der noch unentwickelten Eigenart Amerikas gedient wäre. Jazz, Hollywood und Yankeeland-Rhapsodien beweisen es uns täglich." ${ }^{148}$

Main 1971 [1930]; Walter Benjamin, Politisierung der Intelligenz. Zu S. Kracauers „Die Angestellten“. In: Kracauer, Die Angestellten, a.a. O., $118 \mathrm{ff}$.

145 In Ambivalenz zwischen Abwehr und Faszination der amerikanischen Massenkultur verwendete die Sozialdemokratie, in deren Konzept des „Neuen Menschen“ sich Hochkultur mit eigenständiger Arbeiterkultur verschränken sollte, Anfang der 1920er-Jahre auch Begriffe wie „Entartung“ und „Niggerkultur“. Siehe: Adelheid von Saldern, Überfremdungsängste. Gegen die Amerikanisierung der deutschen Kultur in den zwanziger Jahren. In: Amerikanisierung. Traum und Alptraum im Deutschland des 20. Jahrhunderts (=Transatlantische Historische Studien, Bd. 6). Hrsg. v. Alf Lüdtke/Inge Marßolek/Adelheid von Saldern, Stuttgart, 1996, 215. Vgl. Colyer, Americanism, a.a.O., 161; zur Ambivalenz gegenüber der USamerikanischen Kultur in der Weimarer Zeit siehe insbesondere auch: Frank Peter Biess, Zwischen Ford und Hollywood. Amerika und der Amerikanismus in der Weimarer Republik, 1924-1930, MA Thesis, Washington University 1992.

146 Gramsci, Amerikanismus und Fordismus, a.a.O., 2099.

147 Ernst Jünger, Das Sibirische Tagebuch. In: Ja und Nein, 1. 1929, Heft 7/8, 27. Zit. nach: Otto, Deutsche Amerika-Bilder, a.a.O., 168.

148 Adolf Halfeld, Amerika und der Amerikanismus. Kritische Betrachtungen eines Deutschen und Europäers, Jena 1927, 145. 
Als Belege für die mechanisierte, maschinenhafte, „,verkümmerte Zivilisation“ der USA ${ }^{149}$ führte Halfeld unter anderem an: die „Simplizität aller Lebensgrundsätze“, „,rassefremde Einwanderung aus dem Osten“, „,seelische Sterilität“, „Taylorisierung der Arbeiterhirne“, „übermütige Lustigkeit des Parvenülandes“, „salonfähiger Barbarismus und stimulierte Stimmungsmache“, ${ }^{150}$ „Anmaßung und Geschmacklosigkeit“ der Literatur und Publizistik, ${ }^{151}$ die „Unzulänglichkeit des Bildungswesens“, „schablonenhaftes Denktraining“, hoher Analphabetismus ${ }^{152}$ sowie „Kulturfeminismus“, ${ }^{153}$ der diese konservativ-reaktionäre Kapitalismuskritik um das Schreckensszenario einer ins Berufsleben vordringenden Masse geschminkter Amazonen abrundete. Dieser Einfluss von Frauen im öffentlichen Leben der USA veranlasste Geistliche dazu, im amerikanischen Feminismus geradezu die Umkehrung des göttlichen Schöpferwillens zu sehen. ${ }^{154}$

Tatsächlich war es insbesondere die moderne, emanzipierte Stellung der Frau in der US-amerikanischen Gesellschaft, die die zumeist männlichen europäischen Reiseschriftsteller mit allergrößter Verblüffung registrierten und wohl nicht wenige ihrer Leser verunsichert haben mag. Die Amerikanerinnen wurden als „rational und umfassend gebildet“, als „selbstbewußt und emanzipiert [...] bisweilen extrem verwöhnt" wahrgenommen und hatten damit Eigenschaften, die „dem europäischen Frauenbild um die Jahrhundertwende zumal im konservativ-liberalen Bürgertum fast diametral entgegenliefen und daher Irritation auslösten. “155 Ähnliches galt auch für die sich in Amerika abzeichnende Veränderung der Geschlechterbeziehungen sowie der Umkehr der traditionellen familiären Hierarchien, die ebenfalls ambivalente Reaktionen und Typisierungen auslösten. ${ }^{156}$

149 „Eine Zivilisation, die sechzigtausend [sic] Menschen zumutet, in einem einzigen, um die Grand Central Station in Neuyork gelagerten Häuserblock zusammenzuhausen, nicht weil das Gebot des Raumes dazu zwang, sondern weil sinnlose Spekulation die Preise in die Höhe trieb - eine Zivilisation, die darin nicht nur unleugbare technische Leistung, sondern eine ethische Tat erblickt: Sie muß schließlich auch die Geister nummerieren, damit der Betrieb, ihr großer Zweck, ungehindert funktionieren kann. " Halfeld, Amerika und der Amerikanismus, a.a.O., 76 f.; vgl. weiters: Schmidt, Reisen in die Moderne. Der Amerika-Diskurs des deutschen Bürgertums, a.a.O., $127 \mathrm{f}$.

150 Ebd., 239.

151 Ebd., 223.

152 Ebd., 184.

153 Die gestärkte soziale Position der Frau in der amerikanischen Gesellschaft wurde mit ebenso großem Argwohn betrachtet wie der „Bluff“ ihres hübschen äußeren Erscheinungsbildes: „Sie [die Amerikanerin, d. Verf.] verwandelt ihr Gesicht in eine Maske, die dem allgemeinen Geschmack entspricht. Sie verunstaltet die Lippen mit dem Lippenstift zu einem ovalen Etwas; zupft sich Augenbrauen aus, um Zügen, die es nicht selten nötig haben, den Anschein der Delikatesse zu geben [...].“ Halfeld, Amerika und der Amerikanismus, a.a.O., 212.

154 So bspw. im Fall des Münchner Kaplans Joseph Roth 1927. Siehe: Adelheid von Saldern, Überfremdungsängste. Gegen die Amerikanisierung der deutschen Kultur in den zwanziger Jahren, a.a.O., 223.

155 Schmidt, Reisen in die Moderne. Der Amerika-Diskurs des deutschen Bürgertums, a.a. O., 191.

156 Vgl. ebd., $202 \mathrm{ff}$. 
Besonders verabscheuungswürdig schienen aus europäischer Sicht auch so manche „typisch“ amerikanische Umgangsformen, die zwar „egalisierend“, aber dennoch minderwertig wären, wie insbesondere der Gebrauch von Zahnstochern oder Kaugummi:

„Nur eine Nation, die ästhetisch gesehen in der Barbarei lebt, kann sich dem Kaugummi ergeben. [...] Es gibt Leute die Gummi kauen und den Zahnstocher im Munde halten - doppelt hohe Seligkeit! ${ }^{[157}$

Ähnliche wertkonservative Argumente wie Halfeld publizierte auch der spätere Berater des Vizekanzlers Franz von Papen, Edgar Julius Jung, in seinem Buch „Die Herrschaft der Minderwertigen“, worin er die kulturelle Amerikanisierung als „seelische Selbstaufgabe alter Kulturvölker“158 bezeichnete und einer bloß technischen „Zivilisation“ (nämlich der Amerikas) die (europäische) „Kultur“ gegenüberstellte.

Als Gegenbild zu einer statischen, agrarisch strukturierten, traditionell hierarchisch verfassten Gesellschaft wurde das expandierende, inter- und polynationale Amerika mit all seinen negativ angesehenen Attributen zur „Chiffre für vorbehaltslose und bindungslose Modernität", ${ }^{159}$ zum Angsttraum und Feindbild für die Vertreter national-völkischer Ideale.

Dessen ungeachtet gab es korrespondierend zum großen Publikumserfolg amerikanischer Massenkultur ${ }^{160}$ insbesondere im Bereich der Kinofilme, ${ }^{161}$ auch - quer durch die Lager - Gegenstimmen, die sich um die Propagierung des „American way of life“162

157 Weltbühne 17, 1921, 102. Zit. nach: Adelheid von Saldern, Überfremdungsängste. Gegen die Amerikanisierung der deutschen Kultur in den zwanziger Jahren, a.a.O., 231.

158 Edgar Julius Jung, Die Herrschaft der Minderwertigen. Ihr Zerfall und ihr Ablösung, Berlin 1927, 207 f.

159 Detlev J.K. Peukert, Die Weimarer Republik. Krisenjahre der klassischen Moderne, Frankfurt a. Main, $1987,179$.

160 So wurde 1929 in Essen die erste Produktionsstätte für Coca Cola eingerichtet, das nach Auffassung des Unternehmenspräsidenten Robert Woodruff „the essence of American capitalism“ darstellte. Siehe: Ralph Willet, The Americanization of Germany, 1945-1949.2.Aufl., London - New York, 1992, 12.

161 Die insbesondere von jüdischen Emigranten sehr stark geprägte Entwicklung des Hollywood-Kinos schuf die attraktive Imago eines auf individueller Leistung des Einzelnen beruhenden Amerikas, wo „nationale Herkunft oder andere Identitätsmerkmale “ für die Entwicklungsmöglichkeiten des Einzelnen keine Rolle spielen würden: „Der in Hollywood erfundene amerikanische Westen war ein Ort, an dem Neuankömmlinge die Vergangenheit abstreifen und sich einen Ruf schaffen konnten, der nur auf ihren Leistungen beruhte." Leon Bostein, Hollywood und die Geburt des audiovisuellen Amerika. In: Werner Hanak (Hrsg.), Bigger than Life. 100 Jahre Hollywood. Eine jüdische Erfahrung. Anlässlich der Ausstellung „Bigger than Life“. 100 Jahre Hollywood. Eine jüdische Erfahrung. Jüdisches Museum Wien, 19. Oktober 2011-1. April 2012, Berlin 2011, 26.

162 So meinte der SPD-Bildungsbeauftragte Hans Siemsen, Bruder der Pädagogin Anna Siemsen, 1921 in der Weltbühne (in Bezug auf den Weltkrieg) ironisch: „[...] Hätte der Kaiser Jazz getanzt - niemals wäre das alles passiert! Aber ach! Er hätte es nie gelernt. Deutscher Kaiser zu sein ist leichter, als Jazz zu tanzen." Und der Jesuitenpater Overmanns sah in der Amerikanisierung des Geistes ein probates Gegenmittel gegen deutsche Schwerfälligkeit und Weltfremdheit. Siehe: Jakob Overmanns, Amerikanisierung 
beziehungsweise um die Akzentuierung der positiven Seiten des fordistischen Produktionssystems bemühten. ${ }^{163}$

Trotz oder gerade wegen des großen Erfolges Amerikas nahm der Überfremdungsdiskurs Anfang der Dreißigerjahre aber immer schrillere Töne an. Vor der respektlosen Verflachung des (deutschen) Kulturlebens durch „minderwertige Niggerkultur“ warnten nun nicht nur konservative bildungsbürgerliche „Gralshüter“, auch innerhalb der Sozialdemokratie sah man - nicht zuletzt auch hinsichtlich des Erfolges der Hollywood-Filme - ein wahres „Niagara von Unkultur“ hereinbrechen.

Auch die österreichische Sozialdemokratie war in ihrem Verhältnis zu Amerika durch die Ambivalenz von Technikeuphorie und exotischer Bewunderung gegenüber der ungeheuren Urbanität amerikanischer Großstädte einerseits und der Verurteilung aller „Fäulniserscheinungen der hochkapitalistischen Welt“ sowie deren apostrophierter Kulturlosigkeit andererseits bestimmt. In den Arbeiterschulen, in der Parteischule, der Arbeiterhochschule und in den Arbeiterbüchereien wurden unter anderem auch amerikanische Schriftsteller besprochen beziehungsweise vermittelt, deren Werke Bezüge zur sozialen Realität aufwiesen (z.B. John Dos Passos, Upton Sinclair), ${ }^{164}$ oder Vorträge über die „Weltmacht Amerikas“ gehalten. ${ }^{165}$ Hinsichtlich der Beurteilung der US-amerikanischen Lebenswelt und Alltagskultur schloss sich aber der sozialdemokratische Kuckuck-in Anknüpfung an auflagenstarke, sozialkritische Amerika-Bücher wie Egon Erwin Kischs „Paradies Amerika“ (I930) oder „Hotel Amerika“ (1903) der sozialistischen Schriftstellerin Maria Leitner - dem kulturellen Denunzierungs-Diskurs gegenüber dem „American way of life" nahtlos an:

des Geistes. In: Stimmen der Zeit, 60. Jg., 1929/1930, Heft 118, 161-173. Beides zit. nach: Adelheid von Saldern, Überfremdungsängste. Gegen die Amerikanisierung der deutschen Kultur in den zwanziger Jahren, a.a.O., 232 bzw. 243.

163 Vor allem auf gewerkschaftlicher Seite. Vgl. Mary Nolan, The Infatuation with Fordism: Social Democracy and Economic Rationalization in Weimar Germany. In: Wolfgang Maderthaner/Helmut Gruber, Chance and Illusion. Labor in Retreat, Wien 1988, $165 \mathrm{f}$.

164 Upton Sinclairs Bücher wurden in den sozialdemokratischen Arbeiterbüchereien favorisiert. Siehe: Alfred Pfoser, Literatur und Austromarxismus, Wien - Kleinenzerdorf 1980, 81 f. bzw. 156. Daneben erfreuten sich aber auch sozialistische Zukunftsvisionen, wie die des amerikanischen Schriftstellers Edward Bellamy in seinem Buch „Rückblick aus dem Jahre 2000 auf das Jahr 1887“, das mit einer Einleitung von Clara Zetkin versehen war, großen Zuspruchs. Vgl. ebd. 134.

165 Josef Weidenholzer, Austromarxismus und Massenkultur. Bildungs- und Kulturarbeit der SDAP in der Ersten Republik. In: Gerhard Botz/Hans Hautmann/Helmut Konrad/Josef Weidenholzer (Hrsg.), Bewegung und Klasse. Studien zur österreichischen Arbeitergeschichte. Mit einem Vorw. v. BM Hertha Firnberg, Wien - München - Zürich, 1978, 492; weiters: Josef Weidenholzer, Auf dem Weg zum „Neuen Menschen“. Bildungs- und Kulturarbeit der österreichischen Sozialdemokratie in der Ersten Republik (=Schriftenreihe des Ludwig Boltzmann Instituts für Geschichte der Arbeiterbewegung). Mit einem Vorw. v. Karl R. Stadler, Wien - München - Zürich 1981, 116 f. 


\begin{abstract}
„Amerika, das Land der unbegrenzten Möglichkeiten, das Land der reichsten Männer und der schnellsten Eisenbahnen, der höchsten Häuser und der meisten Automobile, der größten Korruption und der banalsten Spießer [...]. Sie haben alles: Dollars und Technik, die mächtigsten Banken und gewaltigsten Fabriken, das Alkoholverbot und alle Weltrekorde, die besten Stiefel und die rücksichtslosesten Ausbeuter. Nur eines haben sie nicht: Geschmack und Kultur. “166
\end{abstract}

Obwohl die Sozialdemokratie in Übereinstimmung mit der konservativen Elite sowie den bestehenden Gesetzen und den obrigkeitlichen Organen grundsätzlich danach trachtete, die Jugend vor „Schmutz und Schund“ zu bewahren, sah sie sich anlässlich eines Auftrittes von Josephine Baker 1928 in Wien, der eine Sittlichkeitsdebatte im Bundesrat auslöste, zu einem kulturpolitischen Spagat veranlasst: Einerseits wurde die „Kopulierung von nackter Frau und nacktem Geld ${ }^{“ 167}$ verurteilt, andererseits versuchte man, den Auftritt gegen die rigiden Verbotsforderungen klerikaler und deutsch-völkischer Kreise zu verteidigen, indem man „die bornierte Verbissenheit des antimarxistischen Lagers“"168 anprangerte.

Die Auseinandersetzung der österreichischen Sozialdemokratie mit Amerika erfolgte bis in die Spätphase der Ersten Republik primär auf zwei Ebenen. Zum einen pflegte man den politischen Kontakt zur „American Federation of Labor“ und zu den US-Gewerkschaften; ebenso wie die deutsche Sozialdemokratie ${ }^{169}$ hegte sie Hoffnungen auf einen Erfolg der amerikanischen Sozialdemokraten, die sich, wie eigens angemerkt wurde, I907 jedoch nur mehr zu 50 Prozent aus deutschen beziehungsweise deutschstämmigen Genossen zusammensetzten. ${ }^{170}$ Zum anderen studierte die österreichische Sozialdemokra-

166 Der Kuckuck, 14, 1929. Zit. nach: Stefan Riesenfellner/Josef Seiter, Der Kuckuck. Die moderne BildIllustrierte des Roten Wien, Wien 1995, 279.

167 Pfoser, Literatur und Austromarxismus, a.a.O., 196.

168 So wetterte die Arbeiter-Zeitung: „Nur in Österreich ist es möglich, daß ein Regierungschef diejenigen, die die polizeiliche Reglementierung in solchen Dingen ablehnen, als Förderer der Unsittlichkeit hinzustellen wagt. Das ist nur möglich in einem Lande, in dem dumpfe, provinzielle Borniertheit, die in jeder Großstadt ein Sodom, ein Gomorrha sieht, den Staat regiert und die Großstadt reglementieren möchte, nur in einem Lande, in dem der anmaßlichste Klerikalismus, von keinerlei Kritik des liberalen Bürgertums belästigt, modernes Leben in seine alten Fesseln schlägt." Zit. nach: ebd., 196.

169 Zum Entwicklungsverlauf des hochgradig ambivalenten Amerikabildes innerhalb der Deutschen Sozialdemokratie sowie zum Amerikabild bei Karl Marx, Wilhelm Liebknecht, August Bebel, Karl Kautsky, Eduard Bernstein oder Rudolf Hilferding siehe im Detail die elaborierte Studie von: Werner Kremp, In Deutschland liegt unser Amerika. Das sozialdemokratische Amerikabild von den Anfängen der SPD bis zur Weimarer Republik (= Politikwissenschaftliche Perspektiven, Bd. 6. Hrsg. v. Manfred Mohs), Hamburg 1993.

170 Noch 1895 war der Prozentsatz deutscher Parteigenossen in den USA bei $95 \%$ gelegen. Siehe: Der Kampf. Sozialdemokratische Monatsschrift, 3. Jg., 1. Oktober 1909, Heft 1, 35; zu den Aktivitäten der nach Amerika ausgewanderten deutschen Sozialdemokraten - nach dem Verbot sozialdemokratischer Aktivitäten und Organisationen 1878 unter Wilhelm I. („Sozialistengesetz“) waren etwa rund 120 deutsche Sozialdemokraten nach Amerika geflohen - sowie zu deren Kontakten zur alten Heimat siehe: Marek Czaja, Die 
tie Amerika, dessen „Unternehmertüchtigkeit“ ebenso faszinierte wie abschreckte - und als Kampf- und Experimentierfeld des modernen Ausbeutungskapitalismus, dessen wirtschaftlich-ökonomische Verwerfungen im Verein mit den sozialen Problemen die Zukunft der europäischen Verhältnisse vorwegzunehmen schien - auch wenn vorerst, wie bei Karl Kautsky, noch Hoffnungen in Richtung einer erfolgreichen Auflehnung gegen die „kapitalistische Tyrannei“ gehegt wurden. ${ }^{171}$ Eine ernüchternde Analyse eines (deutschen) Genossen im theoretischen Organ der österreichischen Sozialdemokratie fasste die Situation I909 allerdings folgendermaßen zusammen:

\begin{abstract}
„Amerika ist also ein Land von stark ausgeprägten kapitalistischen Wirtschaftstendenzen. Es ist das Eldorado der Europamüden geworden. Alle diejenigen, denen in der Heimat die Verhältnisse zu enge wurden, gingen hinüber, um dort ihr Glück zu versuchen. [...] Auf jungfräulichem Boden wurde dort eine kapitalistische Kultur aufgebaut. Es entstand der Typ des amerikanischen Arbeiters, der in seinem Erwerbsinn nur von heute auf morgen rechnet, dessen krasser Einzelegoismus kein Gemeinschaftsgefühl und keinen Klassenegoismus aufkommen lässt. Aus dem gleichen Holz ist auch der amerikanischen Unternehmer geschnitzt. [...] Amerika zeigt eine kapitalistische Kultur in ihrem höchsten Reifestadium, der Amerikanismus ist für den Unternehmer des alten Festlandes eine vorbildliche Arbeitsorganisation, eine Wirtschaftsweise, die sich sieghaft durchgesetzt hat und der er nachzustreben sucht. So zeigt denn auch der europäische Unternehmer das Bestreben, sich zu ,amerikanisieren‘. Das Studium der einschlägigen Unternehmerfachpresse belehrt uns darüber, dass hier für den Arbeiter die ,Amerikanische Gefahr' darin besteht, mit Arbeitsmethoden beglückt zu werden, die drüben mit Erfolg erprobt worden sind. Da heisst es auf der Hut zu sein [...].“172
\end{abstract}

Nachdem bereits Mitte der Zwanzigerjahre der „parlamentarische Kretinismus“ angeprangert worden war, findet sich das Verdikt gegenüber dem amerikanischen System I928 in überdeutlicher Weise ausgesprochen, indem der Chance auf positive Veränderungen in den USA eine völlige Absage erteilt wurde:

USA und ihr Aufstieg zur Weltmacht um die Jahrhundertwende. Die Amerikaperzeption der Parteien im Kaiserreich, Berlin 2006, $74 \mathrm{ff}$.

171 So meinte Karl Kautsky 1902: „Die Zukunft, die uns Amerika weist, wäre freilich eine schlimme, wenn sie nicht auch ein Erstarken der sozialistischen Bewegung zeigte. Nirgends sind alle Mittel der politischen Macht, Regierung, Volksvertretung, Gerichte und Polizei, so sehr und so direkt von den großen Kapitalisten abhängig, wie in Amerika. Nirgends liegt es klarer zutage wie dort, daß ein sozialistisch denkendes Proletariat das einzige Mittel ist, die Nation zu retten, die noch rascher in vollständiger Knechtung durch eine handvoll Riesenkapitalisten versinkt, als die es vermögen, dem Ausland ihr Joch aufzuerlegen." Vg1. Czaja, Die USA und ihr Aufstieg zur Weltmacht um die Jahrhundertwende, a.a.O., $81 \mathrm{f}$.

172 Richard Woldt (Berlin): Ausbeutungsmethoden im modernen Großbetrieb. In: Der Kampf. Sozialdemokratische Monatsschrift, 3. Jg., 1. Oktober 1909, Heft 1, $28 \mathrm{f}$. 
„Die Vereinigten Staaten von Amerika sind nach dem Wortlaut ihrer Verfassung ein parlamentarisch-demokratisches Gemeinwesen. Aber es kann kein Zweifel darüber bestehen, daß die Konzentration des Kapitals und die fabrikmäßige Produktion der öffentlichen Meinung die ,freieste Verfassung' der Welt aufgehoben und die Vereinigten Staaten zu einer oligarchischen Diktatur der Kapitalsmagnaten umgewandelt haben, in der kleinbürgerliche oder gar proletarische Kräfte, so stark sie sozial auch sein mögen, ebenso wenig Aussicht haben, sich politisch durchzusetzen, wie etwa in der Diktatur der feindlichen Kräfte in Italien Mussolinis oder in Sowjetrußland. [...] Für sie sind die Wahlen nur ein durch die amerikanische Tradition geheiligter Umweg zur Diktatur der Kapitalsmagnaten, die vielleicht noch fester angewurzelt ist als die faschistische oder bolschewistische Diktatur. “173

Zusätzlich zeichnete sich für die Sozialdemokratie aufgrund des enormen wirtschaftlichökonomischen Aufschwungs Amerikas Mitte der Zwanzigerjahre zunehmend die Gefahr einer „Weltherrschaft“ des amerikanischen Imperiums ab, das „Rücksichten“ sowie die „Nichteinmischung in europäische Verhältnisse“ längst nicht mehr so streng nähme, wie noch zur Zeit der Monroe-Doktrin. ${ }^{174}$

Aufseiten der katholischen Kirche sowie seitens konservativer Parteien, wie zum Beispiel der Deutschen Zentrumspartei, geriet, neben der Abscheu vor dem rücksichtslosen Materialismus, insbesondere das politische Parteienwesen sowie der „politische Schwindel“ und die „Entartung“ des allgemeinen Wahlrechts ins Zentrum der Kritik. Dieses würde die „Bestechlichkeit von Richtern, finanzielle Unredlichkeit und die Käuflichkeit von Ämtern und Presse auf die Spitze treiben“175 und auf diese Weise ein „korruptes“ System von „Gönnern, Günstlingen, Bestechungen und Abhängigkeiten“ schaffen, in dem „Sonderinteressen vor diejenigen der Gesamtheit des Landes gestellt" ${ }^{\text {"176 }}$ würden; eine Kritik, die auch von Repräsentanten des linksliberalen Spektrums geteilt wurde, wenn auch hier die „Ausartungen“ der „amerikanischen Maschinenpolitik“ als temporäre und somit korrigierbare Erscheinungen aufgefasst wurden. ${ }^{177}$

Von deutschnationaler völkischer Seite (DNVP) wurde Amerika im Preußischen Landtag ab I930 dann bereits immer wieder als „Judenstaat“ bezeichnet, dessen „kranke“, „artfremde Niggerkultur“ von der deutschen Volksgemeinschaft fernzuhalten wäre. Aggressive Kulturarroganz und rassistischer Überlegenheitsdünkel „deutscher“ Hoch- und Volkskultur als Kultur schlechthin wurden zunehmend lauter artikuliert:

173 Siegmund Kunst, Die Weltlage des demokratischen Sozialismus. In: Der Kampf. Sozialdemokratische Monatsschrift, 21. Jg., April 1928, Nr. 4, 138.

174 Richard Kleineibst, Mexiko. Ein Kapitel des amerikanischen Imperialismus. In: Der Kampf. Sozialdemokratische Monatsschrift, 19. Jg., Februar 1926, Nr. 2, 111.

175 Czaja, Die USA und ihr Aufstieg zur Weltmacht um die Jahrhundertwende, a.a. O., 44.

176 Ebd., 45.

177 Ebd., 47. 
„Wagner, Goethe, Beethoven, Schiller und all die anderen Großen der deutschen Kultur - sie sind geboren aus der deutschen Rasse, aus dem deutschen Blut und aus dem Empfinden des deutschen Volkes und sind nicht anders denkbar.“178

Hinsichtlich der Perzeption Amerikas in der wissenschaftlich-akademischen Auseinandersetzung zeigt eine erste systematische Auswertung von Lehre und Forschung über Amerika an österreichischen Universitäten von I80o bis I955, dass sich das akademische Interesse an der Neuen Welt vorwiegend auf die Geografie Nordamerikas beziehungsweise auf den Bereich der Wirtschaftsgeografie reduzierte; dabei rief zwar der wirtschaftliche Erfolg der Vereinigten Staaten Bewunderung hervor, gleichzeitig stand aber „die Verachtung hinsichtlich einer angeblich fehlenden kulturellen Entwicklung ${ }^{\text {“179 }}$ im Vordergrund. In allen anderen akademischen Disziplinen kam Amerika, wenn überhaupt, nur als Randthema vor.

Interessant ist in diesem Zusammenhang, dass Amerika zu Beginn des 20. Jahrhunderts unter deutschen Pädagogen und Bildungsreformern vermehrt - wenn auch ambivalent Beachtung fand. Anders als in Deutschland, wo die Ideen Friedrich Fröbels zu einer grundlegenden Erziehungsreform des Kindergartenwesens unter dem Verdacht revolutionärer, sozialistisch-atheistischer Umtriebe standen und daher nicht umgesetzt wurden, wurde dieses pädagogische Modell in den USA von der Mitte des 19. Jahrhunderts an zur Grundlage einer emanzipatorischen Kindererziehung gemacht. ${ }^{180}$ Ebenso wie im Bereich der frühen Kindererziehung war auch das Ende des I9. Jahrhunderts, Anfang des 20. Jahrhunderts entstehende öffentliche Schulwesen in den Vereinigten Staaten darauf ausgerichtet, die in Europa dominierende „Segregation nach sozialer Schichtung grundsätzlich zu vermeiden“. ${ }^{181}$ Die edukativen Entwicklungen im Bereich der „secondary education“ sowie im Bereich der High Schools, Colleges und ,vocational training institutes“ wurden von europäischen Fachleuten sowohl vor Ort als auch aus der Distanz studiert und kommentiert. ${ }^{182}$

Bis I90o hatten sich auch die amerikanischen Universitäten nach einer Phase zahlreicher Neugründungen vom Vorbild des deutschen Universitätsmodells emanzipiert und selbst ein

178 Der Abgeordnete Dr. Freiherr von Gregore im Preußischen Landtag, 12./13. Sitzung, 24.6.1932, 1008. Zit. nach: Adelheid von Saldern, Überfremdungsängste. Gegen die Amerikanisierung der deutschen Kultur in den zwanziger Jahren, a.a.O., 219.

179 Margarete Grandner/Brigitta Bader-Zaar, Lehre und Forschung über Nordamerika an österreichischen Universitäten vom Beginn des 19. Jahrhunderts bis 1955. In: Thomas Fröschl/Margarete Grandner/Birgitta Bader-Zaar (Hrsg.), Nordamerikastudien. Historische und literaturwissenschaftliche Forschungen aus den österreichischen Universitäten zu den Vereinigten Staaten und Kanada (=Wiener Beiträge zur Geschichte der Neuzeit, Bd. 24), Wien - München 2000, 171.

180 Karl-Heinz Füssl, Deutsch-Amerikanischer Kulturaustausch im 20. Jahrhundert. Bildung - Wissenschaft - Politik, Frankfurt a. Main 2004, $24 \mathrm{f}$.

181 Die Entwicklung des US-amerikanischen Bildungssystems wurde im Gefolge der Chicagoer Weltausstellung von 1893 in zahlreichen Publikationen deutscher Autoren beschrieben. Füssl, Deutsch-Amerikanischer Kulturaustausch im 20. Jahrhundert, a.a.O., 27.

182 Vgl. Schmidt, Reisen in die Moderne. Der Amerika-Diskurs des deutschen Bürgertums, a.a. O., 232 ff. 
avanciertes wissenschaftliches Niveau erreicht, das insbesondere im Bereich technischer Studien und Labors die europäischen Einrichtungen weit überragte $;^{183}$ im Bereich der Sozialwissenschaften spielten durch die führende Rolle der „Chicago School“ in der Grundlegung dieser neuen akademischen Disziplin ab 1892 bereits einzelne Frauen wie Jane Addams eine bedeutende Rolle. ${ }^{184} \mathrm{Zu}$ einem verstärkten Interesse an Amerika seitens deutscher Universitäten kam es aber erst - nach dem unabweisbaren Erfolg der US-amerikanischen Universitäten - in den Zwanzigerjahren durch den Beginn von Studentenaustauschprogrammen. ${ }^{185}$

Entgegen dem allgemeinen Trend zum Antiamerikanismus innerhalb der kontinentalen Bildungselite wurden einzelne Facetten des amerikanischen Bildungssystems unter europäischen Bildungsexperten und Bildungsreformern bis Ende der Zwanzigerjahre geradezu in den höchsten Tönen gelobt und in vielerlei Hinsicht als vorbildlich angesehen. Besonders hervorgehoben wurde dabei, dass das US-Bildungssystem vom Kindergarten bis zur Universität vergleichsweise barrierefrei ${ }^{186}$ und somit für jedermann zu jeder Zeit zugänglich wäre ${ }^{187}$ auch dessen dezentrale Organisation und der vergleichsweise geringe Grad an Bürokratie ${ }^{188}$ sowie - im Unterschied zu den europäischen Bildungssystemen - die zentrale Rolle, die der sozialen Bildung („,itizenship“) beigemessen würde ${ }^{189}$ fand Anerkennung.

183 Stefan Paulus, Amerikanisierung von Universität und Wissenschaft in Westdeutschland 1945-1976 (= Studien zur Zeitgeschichte. Hrsg. v. Institut für Zeitgeschichte, Bd. 81), München 2011, 62 ff. Die gleichrangige bzw. ebenbürtige Rolle von Frauen an amerikanischen Universitäten jener Zeit unterstrich auch der österreichische Physiker Ludwig Boltzmann, der anlässlich seiner Reise nach Kalifornien im Jahr 1905, wo er u.a. an Universitäten Berkeley und Stanford Vorträge hielt, feststellte: „Daß an solchen Universitäten das männliche und weibliche Element unter den Studenten und im Lehrkörper gleichberechtigt ist, versteht sich von selbst [...] Alle Räume der Universität wimmeln von Damen, die an der Zahl den männlichen Studenten nicht viel nachstehen dürften." Ludwig Boltzmann, Reise eines deutschen Professors ins Eldorado. Nach der Ausgabe der Populären Schriften, 1905. Herausgegeben und mit einem Personenregister versehen von Gabriele Dörflinger (= Heidelberger Texte zur Mathematikgeschichte), Heidelberg 2005, 15.

184 Vgl. Martin Bulmer, The Chicago School of Sociology. Institutionalization, diversity, and the rise of sociological research, Chicago et al. 1984; Mary Joe Deegan, Jane Addams and the Men of the Chicago School 1982-1918, New Brunswick 1988.

185 So z.B. durch die Gründung des „Deutschen Akademischen Austauschdienstes“(DAAD). Siehe: Paulus, Amerikanisierung von Universität und Wissenschaft in Westdeutschland, a.a.O., $87 \mathrm{f}$.

186 So wurde bspw. Frauen seit 1885 sukzessive der Zugang zu amerikanischen Universitäten ermöglicht. Siehe: Barbara Salomon, In the Company of Educated Women. A History of Women and Higher Education in America, New Haven 1985. Zit. nach: Füssl, Deutsch-Amerikanischer Kulturaustausch im 20. Jahrhundert, a.a.O., 41.

187 Siehe: Georg Kartzke, Das Amerikanische Schulwesen, Leipzig 1928, 191 ff.; Walter Lietzmann, Unterschiede zwischen amerikanischem und deutschem Schulwesen. In: Die Erziehung, Bd. VI, Leipzig 1930-31, 17-18.

188 Vgl. Maurice M. Caullery, Universities and Scientific Life in the United States, Cambridge 1922, 237 f.; Reinhold Löwenthal, Das Schulwesen in den Vereinigten Staaten Amerikas. In: Die Quelle, LXXXIII, Wien 1933, $629 \mathrm{ff}$.

189 Vgl. H. Loiseau, L’Education Sociale en Amérique. In: Revue Universitaire, XXXIV, Paris 1925, 228; weiters: Peter A. Silbermann, Aus New Yorks höheren Schulen, Berlin 1927; Sebald Schwarz, Amerika 
Neben bekannten Pädagogen wie Georg Kerschensteiner ${ }^{190}$ unternahmen auch österreichische Volksbildner wie Eduard Reyer Studienreisen in die Vereinigten Staaten ${ }^{191}$ und adaptierten danach als innovativ angesehene Modelle wie zum Beispiel die Fernleih-Versorgung („Delivery System“) im Bereiche des öffentlichen Büchereiwesens. ${ }^{192}$ Wie eine Auswertung aller zwischen I887 bis 1938 gehaltenen Kurse und Vorträge zu Amerika an den wissenschaftsorientierten Wiener Volksbildungseinrichtungen zeigt, erfolgte die thematische Bezugnahme auf und die Auseinandersetzung mit Amerika überwiegend in positiver Weise. Der von 1926 an über mehrere Jahre laufende Urania-Kulturfilm „Amerika. Das Land der unbegrenzten Möglichkeiten (Landschaft, Städte, Menschen)“ resümierte gewissermaßen, was bis dahin über I2o Kurse, Vorträge und Kinematogramme der Wiener Bevölkerung vermittelt hatten: Einblicke in Leben und Alltag, Geschichte, Wirtschaft, politisches System, soziale Spannungen, Architektur, Bildungswesen und Literatur eines facettenreichen Landes, ${ }^{193}$ über dessen

und Wir. In: Die Erziehung, Bd. VI, Leipzig 1930-31, 481; Erich Hylla, Das Bildungswesen in den Vereinigten Staaten. In: Handbuch der Amerikakunde, Frankfurt a. Main 1931, 277; August Wilhelm Fehling, Die Vereinigten Staaten von Amerika. Land und Menschen unter dem Sternenbanner, Berlin 1933, $302 \mathrm{ff}$. Noch Jänner 1944 meinte Sir Ernest David Simon in einem englischen Bericht mit dem Titel „The Development of British Universities": „We have nothing at all to learn from the Americans in the matter of instruction: our schools are better than theirs, but there is perhaps something that we can obtain from their efforts to introduce and develop social education in their schools." Zit. nach: I.L. Kandel, United States Activities in International Cultural Relations (= American Council on Education Studies Studies. Reports of Committees and Conferences, No. 23). Vol. IX, Washington D.C., September 1945, 23.

190 Der deutsche Pädagoge Georg Kerschensteiner (1854-1932) besuchte im Jahr 1910 amerikanische Schulen und verglich die dortigen Praktiken und Gepflogenheiten mit dem deutschen Erziehungssystem. Siehe: Füssl, Deutsch-Amerikanischer Kulturaustausch im 20. Jahrhundert, a.a.O., 30.

191 Reyer publizierte 1893 eine detaillierte Darstellung u.a. des US-amerikanischen Systems der Volksbibliotheken mit genauem Bestandsüberblick, Benützungs- bzw. Entlehnziffern, einer Bewertung der „relativen Leistung" in Bezug auf die Einwohnerzahl der jeweiligen Städte sowie einen Überblick über Kosten und Personal. Die Bostoner Public Library zählte für Reyer „zu den bestverwalteten Bibliotheken der Welt.“ Siehe: Eduard Reyer, Entwicklung und Organisation der Volksbibliotheken, Leipzig 1893, 43.

192 Eduard Reyer (1849-1914), Geologe und Volksbildner, Gründungsmitglied des Wiener Volksbildungsvereines und Gründer des „Vereins Zentralbibliothek“, der europaweit größten öffentlichen Bücherei in Wien. Reyer besuchte auf zahlreichen Studienreisen u.a. Amerika, dessen öffentliches Büchereiwesen ihn nachhaltig beeindruckte. Vgl. Peter Vodosek, Eduard Reyer 1849-1914. Biobibliographie, Berlin 1976, 11f.; weiters: Christian Stifter, „Library work is not philanthropy“. Zur historischen Rolle der Volksbüchereien im Kontext der Volksbildung des 19. und 20. Jahrhunderts. In: Alfred Pfoser/Peter Vodosek (Hrsg.), Zur Geschichte der öffentlichen Bibliotheken in Österreich, Wien 1995, $79 \mathrm{f}$.

193 Unter den 474 Kursen, Vorträgen, Kinematogrammen und Kulturfilmen, die sich bis 1938 in irgendeiner Form mit „Amerika“ befassten, finden sich, neben zahlreichen Reiseberichten, u. a. folgende Themen bzw. Titel: „Amerikanische Städte“ [Albrecht Penck, 1903], „Lektüre und Besprechung amerikanischer Literatur (Zyklus)“ [1907], „Die hervorragendsten touristischen Attraktionen Amerikas (Naturdenkmäler; mit Lichtbildern)“ [1908], „Amerikanische Eindrücke“ [Michael Hainisch, 1915], „Deutschamerikanische Hoffnungen und Enttäuschungen“ [Eduard Castle, 1915], „Aus dem Wirtschaftsleben der amerikanischen Union (mit Lichtbildern)“ [1912], „Die amerikanische Sphynx (Das Leben der 
„Kulturproblem“ (Hans Tietze, 1932) nur einmal an der Urania referiert wurde. Ein spannendes Dokument stellt in diesem Zusammenhang der 1930 im Urania-Verlag veröffentlichte Amerika-Reisebericht des deutschen Reformpädagogen, Volkshochschulgründers und späteren Widerstandskämpfers Adolf Reichwein ${ }^{194}$ dar, der sich mit seiner differenzierten und keineswegs unkritischen Analyse des amerikanischen Systems gegen die in Europa grassierenden antiamerikanischen Vorurteile, die oft genug jeder persönlichen Erfahrung entbehrten, wandte. Bereits in der Vorbemerkung seiner populären Schrift gab er unumwunden seine Begeisterung für die Dimension und Dynamik des Landes zu erkennen, ${ }^{195}$

Frauen in USA)“ [1913], „Englisch-Amerikanische Geschichte“ [Robert Endres, 1919], „Über Amerikanismus (Deutschamerikaner; Politik und Wirtschaft)“ [1918], „Verkehrswesen und Ingenieurbauten amerikanischer Großstädte (Aufgrund der im Auftrag der Stadtgemeinde Wien 1924 unternommenen Studienreise; mit Lichtbildern)“ [1924], „Das Alkoholverbot in Amerika“ [1926], „Arbeit und Leben in Amerika (Fordismus und Taylorismus; mit Lichtbildern)“ [1927], „Taylorismus und Fordismus. Bilder aus dem amerikanischen Arbeitsleben (Mit Lichtbildern)“ [1928], „17.000 Kilometer im Auto durch Amerika. Anschließend: Der neue Ford-Betrieb im Film“ [1929], „Der schwarze Bruder. Musik und Dichtung in Afrika und Amerika“ [1930/31], „Die Vereinigten Staaten von Amerika und der Völkerbund“ [Alfred Verdross, 1930/31], „Der Behaviorismus - eine amerikanische Menschenkunde“ [Paul Lazarsfeld, 1931/32], „Naturkundliche Museen in Amerika (Mit Lichtbildern)“ [Wilhelm Marinelli, 1931/32], „Die Idee eines sozialen Rechtes in Amerika“ [Erich Voegelin, 1928], „Das Schulwesen in Amerika (Besonders Blindenerziehung)“ [1931/32], „Bildung und Frau in Amerika (Mit Lichtbildern)“ [Erna Patzelt, 1931/3]. Berufsbezogene Angebote wie bspw. Sprachkurse (Amerikanisches Englisch) oder „Amerikanische Buchführung“ hielten sich über die Zeit des „Anschlusses“ hinaus im Programm der ab April 1938 der nationalsozialistischen „Deutschen Arbeitsfront/KdF“ unterstellten Volkshochschulen. Vgl. Datenbank „Theseus“ des Österreichischen Volkshochschularchivs, Wien.

194 Adolf Reichwein (1898-1944), deutscher Reformpädagoge, Professor an der Pädagogischen Akademie in Halle a. d. Saale, Mitbegründer und Leiter der Volkshochschule Jena sowie Widerstandskämpfer. Als Mitglied des „Kreisauer-Kreises“ wurde Reichwein nach Verurteilung im Volksgerichtshofprozess durch den NS-Blutrichter Roland Freisler am 20. Oktober 1944 im Strafgefängnis Berlin-Plötzensee hingerichtet. Vgl. Ulrich Amlung, Reichwein, Adolf. In: Neue Deutsche Biographie. Bd. 21, Berlin 2003, 322 f.; siehe weiters: Ullrich Amlung, Adolf Reichwein 1898-1944. Ein Lebensbild des politischen Pädagogen, Volkskundlers und Widerstandskämpfers. 2 Bde., Diss., Univ. Marburg 1991; Jörg Wollenberg (Hrsg.), „Völkerversöhnung“ oder „Volksversöhnung“. Volksbildung und politische Bildung in Thüringen 19181933. Eine kommentierte Dokumentation, Bremen 1998; Martha Friedenthal-Haase (Hrsg.), Adolf Reichwein - Widerstandskämpfer und Pädagoge. Gedenkveranstaltung an der Friedrich-Schiller-Universität Jena 15. Oktober 1998, Erlangen - Jena 1999.

195 „Ich kann und will auf diesen wenigen Blättern nicht mehr geben als eine Resonanz des Atems, den ich in Amerika gespürt habe: des Landes und des Volkes, das dort wohnt. Ich glaube, daß etwas von dem echten Geist dieses Kontinents jenem begegnet, der frei von den üblichen Fesseln des Reisenden, der zwischen Expreß und Hotel seine Erfahrungen sammelt, gereist ist - dem Bankhäuser und Farmen, Riesenfarmen und ärmliche Shops der Einwandererquartiere, dem der Rhythmus der City-Straße, wie die geheimnisvolle Stille der menschenleeren Prärie, die strahlende Wärme Kaliforniens und der Eishauch der Rockies gleich vertraute Dinge sind. Ich kann nicht erschöpfend sein, dafür ist der Gegenstand zu gewaltig [...].“ Adolf Reichwein, Blitzlicht über Amerika (=Vierte Beigabe zu den „Urania“-Kulturpolitischen Monatsheften über Natur und Gesellschaft, Jg. 29/30), Jena 1930, 3. 
für die „Kühnheit“ und „Entschlußkraft“, die europäischen „Eiertänzen“ entgegen stehe. ${ }^{196}$ Reichwein bot mit seinem ein vergleichsweise großes Publikum erreichenden Reisebericht einen kontrastreichen Einblick in die multiethnisch zusammengesetzte amerikanische Gesellschaft, in die drückende soziale Not, aber auch in die faszinierende Dynamik der Weltmetropole New York und den dort anzutreffenden, schier unglaublichen Luxus:

\begin{abstract}
„Abends fand ich mich wieder in dem phantastisch-luxuriösen Central-Station-Hotel, einem Traum von praktischem Genie und materieller Fülle. Dies war zwar nicht das eigentliche, aber das andere Amerika, das euch die illustrierten Zeitungen zeigen. Das Amerika der sorgenlosen Bequemlichkeit, der lautlosen Teppiche und Lifts, das Amerika der, efficiency', der höchst zweckmäßigen Gestaltung, kurz, dort fand ich mich plötzlich wieder, wo Glück und Mehrwert sich begegnen, wo alles nur in Riesenzahlen gesagt werden kann, die Masse der Zimmer, der Telephone und Bäder, des elektrischen Lichtverbrauchs und nicht zuletzt die Zahl der Stein gewordenen Dollars, die sich rentieren müssen. “197
\end{abstract}

Auffällig ist, dass sich Vertreter der volksbildnerischen Wissenschaftspopularisierung, die zum Großteil Akademiker und oftmals auch Universitätsdozenten oder Professoren waren, in den Volksbildungseinrichtungen und deren publizistischen Organen - im Unterschied zu den disziplinären Fachbereichen an den Universitäten - in geradezu euphorischem Ton die von großzügigen Mäzenen finanzierten Bildungs- und Forschungseinrichtungen Amerikas priesen und diese kritisch mit der ärmlichen Situation und den limitierten Möglichkeiten in Österreich beziehungsweise Europa verglichen. So stand bereits I9or im offiziellen Organ der 1895 an der Universität Wien eingerichteten österreichischen University Extension-Bewegung, ${ }^{198}$ dem Wissen für alle, ${ }^{199}$ in genauer Auflistung der Namen der USMäzenaten und deren gespendeten Summen, ${ }^{200}$ folgender optimistischer Aufruf zu lesen:

196 Reichwein bezog sich hier auf eine Äußerung Henry Fords I., der gesagt hätte: „Wenn ich vor die Wahl gestellt würde, entweder die Löhne zu drücken oder die Dividenden abzuschaffen, ich würde ohne Zögern die Dividenden beseitigen." Zit. nach: ebd., 15.

197 Reichwein, Blitzlicht über Amerika, a.a.O., 15.

198 Vgl. dazu Hans Altenhuber, Universitäre Volksbildung in Österreich 1895-1937 (=Zur Geschichte der Erwachsenenbildung, Bd. I), Wien 1995, 34 ff.; weiters: Christian H. Stifter, Geistige Stadterweiterung. Eine kurze Geschichte der Wiener Volkshochschulen, 1887-2005 (= Enzyklopädie des Wiener Wissens, Bd. III: Volksbildung). Hrsg. v. Wiener Vorlesungen - Dialogforum der Stadt Wien, Weitra [2006], $40 \mathrm{ff}$.

199 Klaus Taschwer, Das Wissen für Alle. Annäherungen an das populärwissenschaftliche Zeitschriftenwesen um 1900. In: Relation. Medien - Gesellschaft - Geschichte. Sonderdruck. Hrsg. v. Österreichische Akademie der Wissenschaften, Wien 1997, 33 S.

200 Namentlich genannt wurden: John D. Rockefeller (University of Chicago und Vermont Academy), Stephen Gerard (Gerard College), Charles Pratt (Pratt Institute), Johns Hopkins (Johns Hopkins University), A.J. Drexel (Drexel Institute), Leland Stanford jun. (L. Stanford University), Ezra Cornell (Cornell University), The Vanderbilts (Vanderbilt University), Seth Low (Columbia University). Vgl. Amerika, du hast es besser! In: Das Wissen für Alle, 1. Jg. 1901, Bd. 7, $147 \mathrm{f}$. 
„Amerika, Du hast es besser! - So könnten bedauernd die Universitäten der alten Welt seufzen. Sparend und knausernd müssen diese meistentheils trachten, mit den ihnen vom Staat zur Verfügung gestellten Mitteln das Auskommen zu finden. Wie anders doch ihre amerikanischen Schwestern! Kaum eine der Universitäten in Amerika ist auf Staatshilfe angewiesen; denn beinahe eine jede hat ihr eigenes Vermögen, das von Schenkungen wissenschafts- und bildungsfreundlicher Millionäre und Milliardäre herrührt. [...] Millionäre gibt es überall; aber wie man sieht, gleichen auch Millionäre sich nicht überall. Vielleicht ermuntert die Veröffentlichung dieser Liste die europäischen Millionäre zu gleichem Thun und Spenden [...] und vielleicht wird man daher in nicht allzu ferner Zeit sprichwörtlich sagen können: Gute Beispiele bessern schlechte Sitten. ${ }^{\text {201 }}$

Aber nicht nur das Universitätssystem Amerikas fand Beachtung unter österreichischen Volksbildnern, sondern auch spezifisch amerikanische Einrichtungen wie die philanthropischen Kurse und Vorträge, die eine Ausbildung für die Arbeit in der Armen- und Wohlfahrtspflege offerierten, ${ }^{202}$ wie zum Beispiel an der 1904 gegründeten „New York School of Philanthropy. “203 Darüber hinaus wurde auch die Praxis der „amerikanischen Volkserziehung“, die insbesondere in Form der universitär angebundenen „Settlements“ auch in verarmten Gegenden und Stadtvierteln Nachbarschaftshilfe und Bildungsarbeit organisierten, überaus positiv rezipiert. ${ }^{204}$ Für die nachhaltige Würdigung US-amerikanischer Volksbildungsaktivitäten sorgten vereinzelt auch Fachbeiträge amerikanischer Bildungsexperten, die die nationalen edukativen Anstrengungen in diesem Bereich freilich ebenso detailliert wie glorreich darstellten und Amerika - vis à vis der europäischen Länder - geradezu als die Volksbildungsnation schlechthin präsentierten. So in einem Beitrag des deutschamerikanischen Schriftstellers Karl Knortz, ${ }^{205}$ der 1907 in dem von Ernst Schultze und Gustav Hamdorff herausgegebenen Archiv für das Volksbildungswesen aller Kulturvölker ei-

201 Ebd.

202 Zur frühen Ausbildung der Sozialberufe in Amerika siehe: Marcus Gräser, Wohlfahrtsgesellschaft und Wohlfahrtsstaat. Bürgerliche Sozialreform und Welfare State Building in den USA und in Deutschland 1880-1940, (=Bürgertum. Neue Folge. Studien zur Zivilgesellschaft, Bd. 6. Hrsg. v. Manfred Hettling/Paul Nolte), Göttingen 2009, $244 \mathrm{ff}$.

203 Schools of Philanthropy in Amerika. In: Das Wissen für Alle, 7. Jg. 1907, Bd. 30, $476 \mathrm{f}$.

204 Ueber amerikanische Volkserziehung. In: Das Wissen für Alle, 9. Jg. 1909, Bd. 2, 27 f. Der Beitrag bezog sich auf einen zuvor in der Frankfurter Zeitung abgedruckten Artikel. Vgl. ebd., 27.

205 Karl Knortz (1841-1918), geb. in Garbenheim bei Wetzlar, studierte u.a. Philosophie an der Universität Heidelberg. Nach einem Aufenthalt in London wanderte Knortz 1863 in die USA aus. Von 1864-1871 lehrte er als Professor der deutschen und lateinischen Sprache an der Universität Wisconsin. Nach Übersiedlung nach Cincinnati übernahm er die deutsche Abteilung des dortigen städtischen Lehrerseminars. Von 1875 an arbeitete er zudem als Redakteur der Indiana-Deutschen-Zeitung in Indianapolis. Ab 1886 zog sich Knortz, der mit Walt Whitmann befreundet war, nach New York zurück, und widmete sich dort v.a. seinen umfangreichen Studien bzw. seinem schriftstellerischen Werk. Siehe: Lexikon der deutschen Dichter und Prosaisten des neunzehnten Jahrhunderts. Bearb. v. Franz Brümmer, 5. ergänzte u. vermehrte Aufl., 2. Bd.: Gi-L, Leipzig [1895], 308. 
nen enthusiastischen Befund aussprach, wie Jahrzehnte zuvor schon Alexis de Tocqueville, der - im Unterschied zu Europa - den Bildungsstand (der weißen Bevölkerung) in den Vereinigten Staaten als „überall gleichermaßen hoch“206 eingeschätzt hatte:

\begin{abstract}
„Wenn irgend ein Volk auf der ganzen Erde von der Wichtigkeit allgemeiner Volksbildung durchdrungen ist, so ist es sicherlich das amerikanische. [...] Der Amerikaner läßt sich selten eine Gelegenheit entgehen, seine Bildung zu bereichern. Einen Arbeiter, der nicht regelmäßig seine Tageszeitung liest, habe ich während meines vierzigjährigen Aufenthaltes in den Vereinigten Staaten noch nicht gesehen. Selbst der am Ende der Zivilisation wohnende Urwaldfarmer ist Abonnent eines der vielen Wochenblätter, die an Reichhaltigkeit und Mannigfaltigkeit des Lesestoffes die europäischen Zeitungen weit übertreffen. [...] Das Sprichwort ,Schuster bleib' bei deinen Leisten', das fossile Professoren und aufgeblasene Würdemeier in Deutschland höher strebenden, aus der unteren Volksschicht stammenden Jünglingen verächtlich zuzurufen pflegen, hält der Amerikaner für den Ausdruck gemeiner Gesinnung. [...] Der Yankee ist kein Kleinkrämer, noch viel weniger aber ein Neidhammel; dadurch unterscheidet er sich vorteilhaft von dem eingewanderten Deutschen. Schule, Kirche und Presse machen ihn beständig auf die Tatsache aufmerksam, daß dem Mutigen und Strebsamen die Welt gehört und daß der Amerikaner berufen ist, alle sozialen Fragen im Sinne der Demokratie zu lösen und so der übrigen Menschheit als nachahmungswürdiges Muster zu dienen. “207 [Hervorhebung d. Verf.]
\end{abstract}

Im Unterschied zu den positiven Berichten deutschsprachiger Volksbildner und Bildungsreformer über die edukativen Leistungen Nordamerikas betrachtete man auf amerikanischer Seite das kontinentaleuropäische Bildungssystem, vor allem das autoritäre und bürokratische deutsche Schulsystem, zunehmend unter kritischen Gesichtspunkten. ${ }^{208}$ Die 1902 publizierte Vergleichsstudie eines englischen Autors kritisierte an der deutschen Schule die „vollständig ausbleibende Eigeninitiative der Schüler, die vorauseilende Mentalität der staatlichen Pflichterfüllung, die Diskriminierung der weiblichen Schülerschaft und die strikte Separation zwischen Elternhaus und Schule. “209

206 Herbert Christ fasst die positive Beobachtung Tocquevilles folgendermaßen zusammen: „Man findet daher in der einfachsten und einsamsten Blockhütte von weißen Siedlern ebenso wie in städtischen Wohnungen Zeitungen und Bücher; man findet überall nicht nicht nur einen vergleichbaren Informationsstand, sondern auch eine vergleichbares Warenangebot." Zit. nach: Christ, „Aber schauen ist nicht beobachten“. Alexander von Humboldt und Alexis de Tocqueville als Beobachter in Amerika, a.a.O., 302.

207 Prof. Karl Knortz (Evansville, Indiana), Wie in Amerika die allgemeine Volksbildung gefördert wird. In: Ernst Schultze/G. Hamdorff (Hrsg.), Archiv für Volksbildungswesen aller Kulturvölker. Bd. 1, Hamburg 1907, 303-312.

208 Gerhard Th. Mollin, Amerikanische Spiegelungen - das Deutschlandbild in den USA 1870-1918. In: Dan Diner (Hrsg.), Deutschlandbilder (=Tel Aviver Jahrbuch für deutsche Geschichte. Bd. XXVI), Tel Aviv 1997, 107.

209 Füssl, Deutsch-Amerikanischer Kulturaustausch im 20. Jahrhundert, a.a.O., 34. 
Wie Karl-Heinz Füssl herausstreicht, resultierte der enorme gesellschaftliche Wandel Amerikas von einem ehemals wilden Agrarland zu einem zunehmend durch urbane GroßMetropolen charakterisierten Hochindustrieland in einem „Paradigmenwechsel [...], der ein von europäischen Traditionen abgesetztes Verständnis von Bildung und Wirtschaft erzeugte“ und als Reformstrategie ein „eigenständiges Wissenschafts- und Gesellschaftsverständnis kultivierte“, das dem erneuerten „Geist der kommunitaristischen Tradition Amerikas“210 entsprach und neben Reformen im Hochschulwesen auch zur Gründung der großen philanthropischen Bildungseinrichtungen Amerikas im Übergang vom I9.zum 20. Jahrhundert führte. ${ }^{211}$

Das neue edukative Selbstverständnis und Selbstbewusstsein amerikanischer Kulturund Bildungspolitik im 20. Jahrhundert dokumentierte sich unter anderem auch darin, dass die US-Vertreter in den Zwanzigerjahren im Genfer Völkerbundkomitee teilweise massive Kritik an der Praxis europäischer Bildungspolitik übten und die Kooperation aufgrund der elitären Wissenschafts- und Bildungskonzepte sowie wegen zunehmender „nationalistisch-chauvinistischer Strömungen in Europa " beeinträchtigt sahen. ${ }^{212}$

An den stereotypisierten Bildern amerikanischer Lebenskultur sowie deren alltäglichen massenhaften Hervorbringungen vermochten positive Aussagen einzelner Bildungsfachleute und Gelehrter freilich ebenso wenig zu ändern wie am Unbehagen und den Ressentiments gegenüber einer in wirtschaftlicher und militärischer Hinsicht längst zur Großmacht aufgestiegenen Nation.

So sehr die breite Masse in den europäischen Ländern dem „Land der unbegrenzten Möglichkeiten“ fasziniertes Interesse entgegenbrachte und die Segnungen der modernen Unterhaltungsindustrie gerne konsumierte, blieben die konservativen, antidemokratischen europäischen Eliten in ihrem Bildungsdünkel weiterhin der generell ablehnenden Haltung gegenüber Amerika verhaftet. Der Siegeszug amerikanischer Automobile, „billiger“ Hollywoodfilme, populärer Unterhaltungsmusik sowie des Massenkommunikationsmittels Radio wurden als Indikatoren eines europäischen Niedergangs betrachtet, der neben dem ökonomischen und politischen Bedeutungsverlust nunmehr auch den sensiblen Bereich bisheriger kultureller Hegemonievorstellungen betraf. Infolge der anwachsenden Attraktivität amerikanischer Unterhaltungskultur auf europäischem Boden - in der sich obendrein ab den I92oer-Jahren verstärkt afro-amerikanische Einflüsse bemerkbar machten -, zeichnete sich für Europa eine schmerzliche Niederlage gegenüber den USA just „im Kernbereich seiner traditionell beanspruchten Überlegenheit, nämlich der Kultur “213 ab.

210 Ebd., 40.

211 Beispiel sind hier das Carnegie-Institute (gegr. 1896) bzw. das Carnegie Endowment (gegr. 1913) oder die Rockefeller Foundation (gegr. 1910). Vgl. ebd., 41.

212 Ebd., $69 f$.

213 Fröschl, Antiamerikanismus in Europa und Lateinamerika, a.a.O., 92. 
SPIEGELUNG: ANMERKUNGEN ZUM BILD DEUTSCHLANDS

UND ÖSTERREICHS AUS US-AMERIKANISCHER SICHT

Abgesehen von persönlichen Kontakten der Auswanderer zu ihrer Heimat, hielt sich das Interesse der vereinigten „Amerikaner“ an Deutschland, nicht zuletzt wohl auch aufgrund der kaum existierenden politischen Reibeflächen, nicht nur politisch in engen Grenzen. Die mit dem Wiener Kongress I8I4 zementierte neoabsolutistische Reaktion in Europa sowie die folgenden ersten interventionistischen Expansionsansätze der „Heiligen Allianz“ bestätigten den Vereinigten Staaten das Bild einer auf sozialer und politischer Unfreiheit und Unterdrückung gegründeten Gesellschaftsordnung auf dem alten Kontinent - wie umgekehrt die USA mit ihrer auf revolutionärem Wege erlangten Souveränität aus europäischer Sicht ein Faktotum mit andauernder politischer Brisanz darstellten. ${ }^{214}$ Dies auch deshalb, weil die wirtschaftlichen Handelsbeziehungen zwischen Amerika und den europäischen Ländern sukzessive ausgebaut wurden.

Nach der aus der Distanz mit Interesse verfolgten, aus amerikanischer Sicht jedoch letztlich enttäuschend verlaufenen I848er-Revolution, änderte sich das entspannt-ungetrübte Verhältnis zu den im Sezessionskrieg neutral gebliebenen protestantischen Hohenzollern erst mit der Niederlage des ehemals verbündeten freiheitlich-republikanischen Frankreich durch das autokratische Preußen I870/7I, aber auch die nachfolgende Reichseinigung I87I, wodurch Deutschland formal erstmals als eigenständiger Nationalstaat auf der politischen Großwetterkarte auftauchte. Dabei wurde die Einigung von amerikanischer Seite zunächst durchaus begrüßt. ${ }^{215}$

Innerhalb der Vereinigten Staaten hatte sich als quasi erste Imago der „Deutschen“ zunächst das Bild der als arbeitseifrig, integrationsfähig und sparsam charakterisierten deutschen Einwanderer aus der Pfalz verfestigt - der „Pennsylvania Dutch“, auf deren Land vor

214 So schrieb Kanzler Metternich 1824 an den russischen Außenminister Karl Robert v. Nesselrode: „These United States of America, which we have seen arise and grow, and which during their short youth already meditated projects which they dared not then avow, have suddenly left a sphere too narrow for their ambition, and have astonished Europe by a new act of revolt, more unprovoked, fully as audacious, and no less dangerous than the former. They have distinctly and clearly announced their intentions to set not only power against power, but to express it more exactly, altar against altar [...]. In permitting themselves to these unprovoked attacks, in fostering revolutions wherever they show themselves [...] they lend new strength to the apostles of sedition, and reanimate the courage of every conspirator. “ Zit. nach: Spaulding, Quiet Invaders, a.a.O., $42 \mathrm{f}$.

215 Immerhin hatte US-Präsident Ulysses S. Grant in einer Rede am 7. Februar 1871 noch Hoffnungen auf eine friedvolle Adaption der amerikanische Verfassung im Deutschen Reich geäußert, indem er meinte: „The adoption, in Europe of the American system of Union, under the control and direction of a free people, educated to self restraint, cannot fail to extend popular institutions, and to enlarge the peaceful influence of American ideas." Zit. nach: Daniel, A Brief Time to Discuss America. Der Ausbruch des Ersten Weltkriegs im Urteil amerikanischer Politiker und Intellektueller, a.a.O., 161. 
allem Kraut und Kohl gezogen wurden. ${ }^{216}$ Das Bild der grobknochig-bodenständigen, Bier trinkenden und Sauerkraut und Speck verzehrenden Deutsch-Amerikaner ${ }^{217}$ modifizierte sich gegen Mitte des i9. Jahrhunderts allmählich durch Eindrücke, die „Graduierte aus Neuengland aus den deutschen Reformuniversitäten heimbrachten“, ${ }^{218}$ wobei auch hier noch das Klischee verzopft-schwerfälliger deutscher Gelehrtheit dominierte. Als aber im Gefolge des amerikanischen Bildungsbooms im letzten Drittel des i9. Jahrhunderts eine Reihe neuer Colleges und Universitäten gegründet wurden, studierten bis I9oo schließlich rund 9.000 Amerikaner an deutschen Universitäten - so etwa der gesamte Lehrkörper der Johns Hopkins Universität in Baltimore ${ }^{219}$-, wodurch sich, auf der Basis einer Vielzahl individueller Bildungserlebnisse und germanophiler Erfahrungsberichte, das Ansehen Deutschlands als „Land der Denker“ und die Reputation des deutschen Kaiserreichs als „Heimat der Wissenschaft“ zu verfestigen begann. ${ }^{220}$ So meinte etwa der amerikanische Schriftsteller Ralph Waldo Emerson, „daß die Deutschen eine geistige Integrität besitzen, welche ihre Wissenschaft über die aller anderen erhebt.“221

Hinzu kommt, dass die deutschen Einwanderer in den USA am rapiden Aufstieg Amerikas zu einer gigantischen Industrienation als fleißig-sparsame und erfolgreiche Handwerker, verlässliche Ingenieure und fallweise auch als Erfinder durchaus Anteil hatten, ${ }^{222}$ wenn auch nur wenige deutschstämmige Amerikaner, wie Johann Jacob Astor, John D. Rockefeller oder George Westinghouse zu großem Vermögen und Einfluss gelangten. ${ }^{223}$ Vereinzelt erfolgreiche österreich-stämmige US-Amerikaner wie etwa John Daniel Hertz, der Gründer von Hertz-Rent-A-Car, der obendrein das „Yellow Cab“-Taxi-System begründete, sind wohl selbst in Österreich heute nicht als Ex-Landsmänner bekannt. ${ }^{224}$ Trotz so manch puritanischer Erregung über die laute Trink- und Geselligkeitskultur der Deutschen just auch an Sonntagen, ihrer argwöhnisch beäugten Neigung zur Vereinsmeierei sowie ihrer Vorliebe für uniformierte Paraden, zum Beispiel in Form von Schützenver-

216 Zacharasiewicz, Das Deutschlandbild in der amerikanischen Literatur, a.a.O., 19 f.

217 Vgl. Christine M. Totten, Deutschland - Soll und Haben. Amerikas Deutschlandbild, München 1964, $26 \mathrm{ff}$.

218 Ebd., 22.

219 Mollin, Amerikanische Spiegelungen - das Deutschlandbild in den USA, a.a.O., 87; vgl. auch: Stefan Paulus, Amerikanisierung von Universität und Wissenschaft in Westdeutschland 1945-1976 (= Studien zur Zeitgeschichte. Hrsg. v. Institut für Zeitgeschichte, Bd. 81), München 2011, 36.

220 Mollin, Amerikanische Spiegelungen - das Deutschlandbild in den USA, a.a.O., 87.

221 Ebd.

222 So z.B. der aus Braunschweig stammende Klavier- und Orgelbauer Heinrich Steinweg, der 1850 nach New York ausgewandert war und hier die höchst erfolgreiche Firma „Steinway and Sons“ gründete. Vgl. Totten, Deutschland - Soll und Haben. Amerikas Deutschlandbild, a.a. O., 34.

223 Mollin, Amerikanische Spiegelungen - das Deutschlandbild in den USA, a.a. O., 87.

224 Zudem wurde John Daniel Hertz (1879-1961) im ungarischen Ruttka, heute Vrútky, auf dem Gebiet der heutigen Slowakei geboren. Siehe: Spaulding, Quiet Invaders, a.a.O., 166. 
einen, ${ }^{225}$ überwog innerhalb der amerikanischen Gesellschaft bis Anfang des 20. Jahrhunderts eine freundlich-wohlgesonnene Einstellung gegenüber Deutschen sowie ein hohes Ansehen deutscher Kultur und Wissenschaft.

Nach dem Sturz Napoleons III. unterlag das Stimmungsbarometer der öffentlichen Meinung Amerikas gegen Ende des I9. Jahrhunderts, auch wegen des aggressiven Militarismus und der imperialen Machtpolitik des Wilhelminischen Reiches, aber einem tiefgreifenden Wandel, der im Verlauf des Ersten Weltkrieges schließlich seinen vorläufigen Tiefpunkt erreichen sollte.

Anders als die meisten europäischen Länder, so wie selbst Großbritannien, hatte sich die Habsburgermonarchie nicht zu einer offiziellen Anerkennung der neu geschaffenen amerikanischen Staatsunion durchringen können und betrieb auch die wirtschaftlichen Handelsbeziehungen bis zu den ersten offiziellen Handelsverträgen auf verschämt inoffizieller Basis; erst am I. Juni I837 holte Staatskanzler Fürst Metternich bei Kaiser Ferdinand I. die Genehmigung zur Aufnahme diplomatischer Beziehungen mit den Vereinigten Staaten von Amerika ein. ${ }^{226}$ Die katholische Habsburgermonarchie, geführt von einem „idiot“ als Kaiser (Thomas Jefferson) und dem reaktionären Metternichschen System, das die Freiheitsbestrebungen in Griechenland, Italien und Spanien niederschlagen half, wurden aus amerikanischer Perspektive geradezu zum Inbegriff eines despotisch-reaktionären Herrschaftssystems, das auf polizeilicher Bespitzelung, Pressezensur und Ausbeutung der werktätigen Bevölkerung beruhte. Den Hauptrepräsentanten dieses Systems sowie der „Holy Alliance“, nämlich Metternich, ${ }^{227}$ belegte der berühmte amerikanische Erfinder des Telegrafen, Samuel F. B. Morse, kurzerhand mit folgenden Worten: „the greatest enemy of the human race who lived for ages “228

225 Totten, Deutschland - Soll und Haben. Amerikas Deutschlandbild, a.a.O., 36.

226 Als Grund hierfür wie für die nachfolgende kaiserliche Ernennung eines österreichischen Gesandten in New York am 3. April 1838 führte Metternich aus: „Bei dem stets zunehmenden Gewichte, welches die rasch in ihrer Entwicklung fortschreitenden Nordamerikanischen Freistaaten in der politischen Wagschale [sic] gewinnen, war es wirklich auffallend, daß Österreich, im Gegensatz mit fast allen anderen grösseren Staaten, bisher gar keine diplomatischen Verbindungen mit besagten Freistaaten angeknüpft hatte, obwohl der Handelsverkehr zwischen den beiderseitigen Unterthanen bereits eine solche Wichtigkeit erlangt, daß einige Handelsverträge nothwendig geworden waren [...]“. Zit. nach: Matsch, Wien Washington. Ein Journal diplomatischer Beziehungen 1838-1917, a.a.O., 1. Vgl. dazu auch: Renate Goger, Die Beziehungen der Habsburgermonarchie zu den Vereinigten Staaten von Amerika von 1838 bis 1967, phil. Diss., Univ. Wien 2010, $21 \mathrm{f}$.

227 Klemens Wenzel Lothar Fürst von Metternich-Winneburg zu Beilstein (1773-1859), führender österreichischer Politiker der Restaurationszeit; 1809 wurde Metternich Außenminister und 1821 österreichischer Staatskanzler, der mit polizeistaatlichen, antiliberalen Mitteln die absolutistische Staatsmacht zu bewahren bemüht war. Vgl. Wolfram Siemann, Metternich. Staatsmann zwischen Restauration und Moderne, München 2010.

228 Zit. nach: Spaulding, Quiet Invaders, a.a.O., 43. 
Auch der US-Reiseschriftsteller Henry Edwin Dwight, der 1829 seine Eindrücke von der deutschen Universitätskultur veröffentlichte, hatte für die geistige Unterdrückung im vormärzlichen Österreich Metternichs nur Spott und Verachtung übrig: „Stumpfsinnigkeit und Faulheit" würden alles dominieren und die repressiv niedergehaltene Bevölkerung würde durch „Unwissenheit und Aberglauben“ beherrscht. ${ }^{229}$ Ein Negativ-Eindruck, der sich in einem privaten Brief des US-Historikers John Lothrop Motley in Bezug auf den kulturellen Status quo des Vielvölkerstaates noch deutlicher niederschlug: er beschrieb das österreichische Staatsgefüge als Land, ,which contains eight millions of civilised Germans and nearly thirty millions of Asiatics in sheep-skins and in tight pantaloons inside their boots“. 230

Tatsächlich war aber der Terminus „Österreich“ in den Vereinigten Staaten, auch nach Gründung des Kaisertums Österreich als Erbmonarchie durch Kaiser Franz I., nahezu vollständig unbekannt. ${ }^{231}$ Die zahlenmäßig vergleichsweise sehr kleine Gruppe der österreichischen US-Einwanderer ${ }^{232}$ - allesamt keine „supermen“, wie Spaulding trocken anmerkt ${ }^{233}$-, die im Gegensatz zu den als leutselig „laut" auftretend beschriebenen deutsch-stämmigen Immigranten ${ }^{234}$ zudem „leise“ und unbemerkt agierten, wurde daher in Ermangelung genauerer Kenntnisse schlichtweg unter (andere) „Germans“ rubriziert.

So wie Wien von US-Journalisten als das „German Paris“235 beschrieben wurde, galten auch die deutschsprachigen Einwohner Cisleithaniens, ob nun Tiroler oder Wiener, als "Germans", für die sich jedoch, nicht zuletzt durch publizierte Reiseschilderungen, allmählich diffuse Stereotype einer gänzlich unpreußischen Lebenskultur auszubilden begannen. So finden sich, wie schon in der nationalen Charakterisierung bei Sealsfield, Bilder einer pittoresk-unbedarften Gemütlichkeit, exotisch-operettenhafter Kulissen - „heavy German postillions with their cocked hats and yellow coats ${ }^{{ }^{2236}}$-, weinselig-walzertanzender

229 Zit. nach: Waldemar Zacharasiewicz, Das Deutschlandbild in der amerikanischen Literatur, Darmstadt 1998, 34.

230 Zit. nach: ebd., 39.

231 Vgl. Spaulding, Quiet Invaders, a.a. O., 20.

232 ,The German Austrians were, indeed such a minority of the whole that it is not difficult to understand why they were so often forgotten." Ebd., 70.

233 Spaulding, Quiet Invaders, a.a. O., 75. Die österreichischen US-Immigranten hatten unter den Neuamerikanern den am deutlichsten ausgeprägten ruralen Herkunftshintergrund. In der ersten Ausgabe der „Who is Who in America“ von 1899/1900 finden sich lediglich 32 „Österreicher“ - zum großen Teil Musiker -, deren Provenienz, wie auch bei den meisten statistischen Erhebungen jener Jahre, zudem der gesamten Monarchie als Staatsgebilde zugeordnet wurde. Vgl. ebd.

234 Vgl. Christine M. Totten, Deutschland - Soll und Haben. Amerikas Deutschlandbild, München 1964, $50 \mathrm{f}$.

235 So bspw. 1838 durch den amerikanischen Journalisten und Reiseautor Nathaniel Parker Willis in seinen für den New York Mirror verfassten „First Impressions on Europe“. Siehe: Zacharasiewicz, Das Deutschlandbild in der amerikanischen Literatur, a.a.O., 49.

236 Ebd. 
Ausgelassenheit ${ }^{237}$ sowie phäakenhafter Unterhaltungslust, untermalt durch die „thrilling music of one of the finest bands in Germany" $[\mathrm{sic}]$. $^{238}$

Bezeichnenderweise war es dann insbesondere die Musik als „leichte Muse“, über die sich im I9. Jahrhundert positiv besetzte „Österreich“-Assoziationen verfestigten - mit dem zentralen „Topos ,Musikstadt Wien““239 - und dann auch in Amerika verbreiteten, die in ihrer nationalen Zuschreibung jedoch, aufgrund der oftmaligen Subsumierung unter deutsche Kultur, keineswegs klar ausfielen. Die klassische, frühromantische Musik verhalf Wien jedenfalls dazu, sich als Welthauptstadt genialer Komponisten zu etablieren, und die Werke Haydns, Händels, Beethovens, Schuberts, später auch Mozarts, Bruckners oder Mahlers wurden in der Neuen Welt ebenso enthusiastisch gefeiert wie die leichten Operetten des Walzerkönigs Johann Strauß (Sohn) oder die Auftritte einer Fanny Elßler anlässlich ihrer Amerika-Tournee i84I. ${ }^{240}$

Bereits im April 1748 hatte der schottische Philosoph David Hume anlässlich eines Wien-Besuches und einer anschließenden Reise durch die Steiermark und Kärnten - trotz Bewunderung für das österreichische Kaiserpaar - teils wenig schmeichelhafte Worte über die Reichsmetropole sowie über Land und Leute gefunden, die ihm insbesondere in der Steiermark als schockierend „unzivilisiert, deformiert und grässlich in ihrem Aussehen“241 erschienen.

Eine einprägsame und besonders pointierte, wohl auch regelrecht zornig-polemische Abrechnung mit der dumpf-derben Genuss-Sucht, der Gehorsamskultur, der despotischen Knebelung von Bildung und Wissenschaft, der Verdrossenheit und Verschwendungssucht der Einwohner jenes Landes, dessen Wappentier - der Doppeladler - „das ganze Reich in verderblicher und tödlicher Umklammerung “ ${ }^{\text {242 }}$ gefangen halte, verfasste dann der bereits

237 So bspw. die englische Schriftstellerin Francis Trollope 1838 in ihrer Charakterisierung der österreichischen „terra incognita“, wo die Bevölkerung Walzer oder Heurigengesänge der Politik vorziehen würde. Vgl. Spaulding, Quiet Invaders, a.a.O., 44.

238 Nathaniel Parker Willis, „First Impressions on Europe“. Zit. nach: Zacharasiewicz, Das Deutschlandbild in der amerikanischen Literatur, a.a.O., 49.

239 Martina Nußbaumer, Bauen an der „Musikstadt“. Materialisierungen eines Stadtimages im öffentlichen Raum Wiens. In: Margit Franz et al. (Hrsg.), Mapping contemporary history. Zeitgeschichten im Diskurs. Bd. 1, Wien - Köln - Weimar 2008, 107. Vgl. dazu im Detail die publizierte Dissertation: Martina Nußbaumer, Musikstadt Wien. Die Konstruktion eines Images, Freiburg i. Breisgau - Wien 2007.

$240 \mathrm{Vgl}$. Spaulding, Quiet Invaders, a.a.O., $106 \mathrm{ff}$.

241 Zit. nach: Gerhard Streminger, David Hume. Der Philosoph und seine Zeit, München 2011, 261. Hume, der sich angesichts der der landschaftlichen Reize der Steiermark beeindruckt zeigte, merkte in Bezug auf die dortige Landbevölkerung des Weiteren an: „Sehr viele von ihnen haben hässlich geschwollene Kehlen. Debile und Taube tummeln sich in jedem Dorf, und das allgemeine Erscheinungsbild der Leute ist das schockierendste, das ich je gesehen habe." Ebd.

242 Charles Sealsfield [Karl Postl], Österreich, wie es ist. Oder: Skizzen von Fürstenhöfen des Kontinents. Von einem Augenzeugen [London 1828]. Hrsg. u. bearb. v. Primus-Heinz Kucher, Wien - Köln - Wei$\operatorname{mar} 1997,139$. 
erwähnte Charles Sealsfield ${ }^{243}$ in seinem I828 erschienenen Buch „Austria as it is“. Darin charakterisierte Sealsfield die von der k.k. Studienhofkommission ausgearbeiteten Studienunterlagen, an die sich alle Professoren - allesamt von „Amts wegen Spione ${ }^{\text {“244 }}$ - penibel zu halten hätten, als die „kläglichsten und dümmsten, welche jemals die Druckerpresse verlassen haben“. 245

Des Weiteren würden die „klägliche Unwissenheit, Kriecherei und Beschränktheit der österreichischen Staatsbeamten und Offiziere“ im Verein mit den "schwerfällig arbeitenden Zivilbeamten" in ihrer Unfähigkeit für eine Finanzverwaltung den Staatshaushalt in den Bankrott treiben. ${ }^{246}$ In jedem Amt säßen ,unter den Räten und Kanzlisten meistens zwei Spione, welche mit dem Präsidenten der k.k. Obersten Polizei- und Zensurhofstelle in Wien oder mit dem Kaiser selbst in Verbindung stehen. ${ }^{\text {247 }}$ Der Nachrichtendienst würde gleichsam das gesamte Kaiserreich umspannen - dieser reiche ,in die Hütte des Bauern, in die Wohnung des Bürgers, in die Gaststube des Wirts und in das Schloß des Adeligen. Kein Ort ist vor den Horchern des Kaisers sicher. ${ }^{2248}$ Die Volksbildung würde durch die österreichische Regierung vollständig unterbunden und bezüglich des Umgangs mit Kunst- und Kulturgütern in der Reichsmetropole merkte Sealsfield in solider Kenntnis gängiger Praktiken an:

„Vergeblich aber würde man in Wien einen richtigen Sinn für die dort aufgehäuften Schätze, eine Liebe zu Kunst und Wissenschaft, oder Achtung vor hervorragenden Talenten suchen. Die Kunstschätze und Bibliotheken werden als Prunkstücke und nichts anderes behandelt. Selbst hervorragende Schriftsteller, wie Gentz und Schlegel, werden hier besoldet, - weniger um zu schreiben, als um nicht zu schreiben. Sie gelten sozusagen als geistige oder literarische Handelsleute. "249

Ähnliche Aussagen in Bezug auf den Zustand von Wissenschaft und Bildung im Metternichschen Österreich traf der irische Augenarzt und Sozialreformer William Robert Willis Wilde im Jahr 1842 in seinem detaillierten Studienbericht, der der US-amerikanischen Öffentlichkeit wohl ebenfalls kaum verborgen geblieben sein dürfte. ${ }^{250}$ Darin fasste der Vater Oscar Wildes seine anlässlich einer Studienreise I840 angestellten Beobachtungen

243 Zu Leben und Werk von Karl Postl (1793-1864) siehe: Eduard Castle, Der große Unbekannte. Das Leben von Ch. Sealsfield - C. Postl. Briefe und Aktenstücke, Wien 1955.

244 Sealsfield, Österreich, wie es ist, a.a.O., 58.

245 Ebd., 57.

246 Ebd., 60.

247 Ebd., 59 .

248 Ebd., 91.

249 Ebd., 139.

250 William R. Wilde, Austria: Its Literary, Scientific and Medical Institutions with Notes upon the Present State of Science and a Guide to the Hospitals and Sanatory Establishments of Vienna, Dublin 1843. In: Irene Montjoye (Hrsg.), Oscar Wildes Vater über Metternichs Österreich, Frankfurt a. Main 1989. 
kritisch zusammen und äußerte mit dem nüchternen Blick des externen Beobachters ein geradezu vernichtendes Urteil über die geistig-kulturelle Stagnationspolitik der Habsburgermonarchie:

„Während keine andere europäische Hauptstadt sich schönerer und größerer kunst- und naturhistorischer Sammlungen und Museen rühmen kann als die österreichische, ist es gleichermaßen erwiesen, daß nirgends weniger getan wird, um die Wissenschaft ganz allgemein zu fördern oder den einzelnen echten Philosophen zu unterstützen, wie dies in jeder anderen Stadt vergleichbarer Größe, die über ähnliche Möglichkeiten verfügt, heute üblich ist. “251

Zudem würde, so Wilde, die österreichische Regierung jede Art der Veränderung, insbesondere auch im Bereich von Wissenschaft und Kultur, ebenso scheuen, ,wie das Schreckgespenst politischer Emanzipation oder Reformen. “252 Neuerung im Bereich des wissenschaftlichen Fortschritts - die universitäre Medizin klammerte Wilde aus und attestierte ihr höchste Qualität - sowie technologische Innovationen wären angesichts der antiaufklärerischen Haltung des Kaiserhauses ebenso wenig zu erwarten, wie eine gesellschaftliche Umwälzung angesichts der auf billiges Vergnügen abonnierten Studenten, die die „Annehmlichkeiten des Lebens wann und wo immer“ genießen, wie die Holländer rauchen würden und „beinahe soviel Bier wie die Bayern“253 tränken. Wildes Resümee fiel daher wenig hoffnungsfroh aus:

„Während die umliegenden Königreiche ihren Handel ausgeweitet und ihr Ansehen verbessert haben, in dem sie durch die Förderung, die sie den Wissenschaften und Künsten zukommen ließen, der Menschheit nützlich werden konnten, kann Österreich sich noch immer rühmen, daß seine Herrscher es in den letzten vierzig Jahren erfolgreich gegen den revolutionären Fortschritt der Wissenschaft abgeschirmt haben. Vielleicht nützt es Österreich politisch, wenn das doppelköpfige Wappentier der Nation Neuerungen im Ausland und Veränderungen im Inland wachsam im Auge behält. Aber wir befürchten sehr, daß diese übergroße Vorsicht bewirkt hat, daß die ausgestreckten Flügel des schwarzen Adlers große Teile des Landes, vor allem die Kaiserstadt, überschattet haben. So wurde verhindert, daß das Licht des Wissens eindringt, während jener helle Eifer, ohne den es keine Erfindungen und keinen Fortschritt gibt, im Dunklen blieb.“254

Noch fünf Jahrzehnte später prangerte Mark Twain das Verbot des Straßenverkaufs von Zeitungen sowie die oftmals skurrile, im Regelfall „launenhaft und unausgewogene“ ös-

251 Wilde, Austria: Its Literary, Scientific and Medical Institutions, a.a. O., 93.

252 Ebd., 95.

253 Ebd., 91.

254 Ebd., 96. 
terreichische Pressezensur an, mit der die Regierung die „Verbreitung von Informationen“ behindere, ${ }^{255}$ „alles Blut aus der Zeitung“ sauge und diese „farb- und saftlos“ hinterlasse. ${ }^{256}$

Zu Spannungen im politischen Verhältnis zwischen den USA und dem österreichischen Kaiserreich kam es erstmals im Gefolge der unter Alfred Fürst zu Windisch-Graetz gewaltsam niedergeschlagenen I848er-Revolution. Abraham Lincoln hatte insbesondere den Befreiungskampf der ungarischen Aufständischen unterstützt und diesen als „their present glorious struggle for liberty" bezeichnet. ${ }^{257}$ Als publik wurde, dass der Pariser US-Attaché Ambrose Dudly Mann im Auftrag des US-Außenministers John M. Clayton wirtschaftliche Geheimverhandlungen mit Ungarn aufgenommen hatte, brachte Österreich bei der US-Regierung im Mai r85o lediglich eine formale Protestnote ein, um die handelspolitischen Beziehungen nicht zu beeinträchtigen. ${ }^{258}$ Als dann aber dem in die Türkei entflohenen ungarischen Revolutionär Lajos Kossuth - der sich in den USA allerdings jedes kritischen Kommentars enthielt ${ }^{259}$ - im Dezember I85 auch noch ein tosender Empfang in New York bereitet wurde ${ }^{260}$ und der US-Secretary of State dem akkreditierten österreichischen US-Attaché Johann Georg Hülsemann ${ }^{261}$ versicherte, dessen Empfang wäre „strictly

255 Mark Twain, Turbulente Tage in Österreich. Aus dem Amerikanischen übertragen und kommentiert von Rudolf Pikal, o.O. (Wien) 2012, 19.

256 „Es gibt einen Pressezensor, der anscheinend immer in Dienst ist und schwer arbeitet. Um fünf Uhr früh wird ihm ein Exemplar jeder Morgenzeitung gebracht. Seine Dienstkarossen warten an den Eingängen der Redaktionen und eilen mit den ersten Abzügen aus der Druckerpresse zu ihm. Eine Gruppe von Gehilfen liest jede Zeile in diesen Zeitungen und markiert jene Passagen, die gefährlich scheinen. Dann fällt der Zensor das abschließende Urteil über diese markierten Stellen. [...] Die Assistenten haben nicht alle denselben Begriff davon, was gefährlich ist und was nicht; der Zensor hat nicht die Zeit, ihre Kritikpunkte im Einzelnen zu überprüfen; und so kommt es manchmal vor, dass ein und dieselbe Sache, die in der einen Zeitung gestrichen wird, in der anderen nicht beanstandet und in vollem Wortlaut unverändert veröffentlicht wird." Zit. nach: Twain, Turbulente Tage in Österreich, a.a.O., $16 \mathrm{f}$.

257 Goger, Die Beziehungen der Habsburgermonarchie zu den Vereinigten Staaten, a.a.O., 276.

258 Vgl. ebd., $266 \mathrm{f}$.

259 So zeigten sich US-amerikanische Anti-Slaverei-Aktivisten enttäuscht über Kossuth, der erklärte hatte, sich in nationale Belange der USA - einschließlich der Sklaverei - nicht einmischen zu wollen. Edmund Quincy, der Herausgeber des National Anti-Slavery Standard meinte gar, Kossuth hätte sich verkauft und würde sich nun erniedrigen ,to kiss the feet of American women-whippers [...] and slave-catchers“. Vgl. Honeck, We are the Revolutionists, a.a. O., 27.

260 Mit einer gewissen Erleichterung und wohl auch Genugtuung hielt der diplomatische Bericht der österreichischen Gesandtschaft in den USA fest, dass der anschließende Empfang von Kossuth ,in Philadelphia viel kühler als in New York" war und die Stadtverwaltung von Richmond es sogar abgelehnt hätte, „Kossuth zu einem Besuch der Hauptstadt von Virginia einzuladen.“ Zit. nach: Matsch, Wien - Washington. Ein Journal diplomatischer Beziehungen 1837-1917, a.a. O., 125.

261 Hülsemann stand als Diplomat bereits zuvor in Metternichs Diensten und hatte 1823 in Göttingen seine Dissertation in Buchform veröffentlicht, worin er, wenig diplomatisch, eindringlich vor der politischen Gefahr der USA für die monarchische Ordnung Europas warnte, was prompt Verstimmungen hervorrief. [Johann Georg Hülsemann, Geschichte der Democratie in den Vereinigten Staaten von Nord-Amerika, Göttingen 1823]; vgl. auch: Fröschl, Historical Roots of the European Anti-Americanism in the 18th and 19th 
non-political and unofficial“ ${ }^{262}$ war offensichtlich, dass sich das amerikanisch-österreichische Verhältnis nachhaltig eingetrübt hatte. In einem diplomatischen Bericht vom ir. Februar 1898 hielt der österreichische Gesandte in New York mit kritischem Unterton fest, dass die Habsburgermonarchie nunmehr „die einzige europäische Großmacht“ sei, „welche ihre Vertretung hier in der früheren Weise als Gesandschaft belassen hat.“ Und weiter: „Daß die Fortdauer dieses Zustandes unserem Ansehen und der Wirksamkeit unserer Vertretung bei den Vereinigten Staaten nicht förderlich ist, drängt sich vom hierortigen Standpunkte von selbst auf. Die natürliche Entwickelung der Dinge ist aber zugleich eine solche, daß während die Rangerhöhung unserer Vertretung heute noch als ein Compliment an die Vereinigten Staaten erschiene, sie in absehbarer Zeit diesen Charakter verlieren und als aufgedrungene Anerkennung der hiesigen Machtstellung aufgefaßt werden könnte. “263

Es verwundert kaum, dass parallel zum anwachsenden europäischen Antiamerikanismus und angesichts des zunehmenden Selbstbewusstseins amerikanischer Wirtschaft und Politik, die kulturellen Vorurteile der Alten Welt gegenüber Amerika - so Günter Bischof nunmehr vermehrt auch zurückgespiegelt wurden. So zeigte sich anlässlich der Wiener Weltausstellung I873 der Leiter der amerikanische Delegation, Charles Francis Adams, nur wenig beeindruckt und war von der amerikanischen Überlegenheit gegenüber der sozial und ökonomisch rückständigen Donaumonarchie und ihrer verabscheuungswürdigen Reichsmetropole überzeugt. ${ }^{264}$

Im Unterschied zu Österreich, wo sich trotz des keineswegs ungespannten Verhältnisses der USA zur österreichischen Monarchie, weder im Verlauf des I9. noch zu Beginn des 20. Jahrhunderts ein spezifisch negatives amerikanisches Österreich-Stereotyp herauskristallisierte ${ }^{265}$ kippte das ehemals positive amerikanische Bild von Deutschland und den

Centuries, a.a.O., 66 f. Bezeichnenderweise nahm Heinrich Drimmel einen von Hülsemann verwendeten Begriff, der die vollständige politisch-weltanschauliche Unvereinbarkeit der USA und der Habsburgermonarchie bezeichnete - ,antipodär“ - als Titelbegriff für sein Buch, dessen wertkonservativen Ausführungen er zudem die Einleitung aus Hülsemanns Dissertation voranstellte. Vgl. Heinrich Drimmel, Die Antipoden. Die Neue Welt in den USA und das Österreich vor 1918, Wien - München 1984, 9 f.

262 Spaulding, Quiet Invaders, a.a.O., 46.

263 Zit. nach: Matsch, Wien - Washington. Ein Journal diplomatischer Beziehungen 1837-1917, a.a. O., 433.

264 Vgl. Bischof, Two sides of the Coin, a.a.O., 151.

265 So hatte Samuel Langhorne Clemens alias Mark Twain (1835-1910) zwar anlässlich seiner Besuche im österreichischen Parlament gehässige Schimpftiraden und Schreiduelle zwischen Lueger und Schönerer mitverfolgt und den Nationalitätenkonflikt als ernstes Problem registriert, aber sonst nahm er mit allergrößtem Interesse an den gesellschaftlichen Ereignissen der Wiener Salonkultur teil und zeigte sich hocherfreut über eine ihm zuteil gewordene Privataudienz bei Kaiser Franz Joseph I.. Siehe: Albert Locher, Mit Mark Twain durch Europa. Samuel Langhorne Clemens in der Alten Welt (1891-1899 und 1903/1904). Bd. 2, o. O. 2007, 182 ff. bzw. 209. Vgl. dazu neuerdings auch den in deutscher Fassung publizierten Bericht Mark Twains zu den schier unglaublich turbulenten Geschehnissen im österreichischen Reichsrat anlässlich der Badenischen Sprachenverordnung im Oktober/November 1897, wo es zu wüsten antisemitischen Schreiduellen und vulgären Verbalinjurien („Krieg der Beleidigungen“) und 
Deutschen ins Gegenteil. In den Negativzuschreibungen wurden jedoch - insbesondere nach dem Ersten Weltkrieg - kaum explizit Unterschiede zu den „deutschen“ Österreichern gemacht und diese unter dem Begriff „Germans“ zunächst quasi subsumiert. ${ }^{266}$

Untersuchungen zum Österreich-Image in den Vereinigten Staaten verdeutlichen, trotz der stark negativen Auswirkungen der „Waldheim-Affäre“ ${ }^{267}$ dass Österreich aus Sicht gebildeter US-Amerikaner nach wie vor als „traditionelles Kulturland“ gilt - ein Bild, das allerdings weitgehend von der „,musikalischen “Tradition Österreichs determiniert ist. “268

$\mathrm{Zu}$ ersten, offen deutsch-feindlichen Protesten war es im Zusammenhang des Gewerkschaftstreiks in Chicago 1886 gekommen, an dem radikal-anarchistische deutsche Immigranten führend beteiligt gewesen waren. Die ein Jahr danach gegründete „American Protective Association“verdammte bereits den „Germanism als eine der für die amerikanische Gesellschaftsordnung bedrohlichsten Ideologien“.269

Es war aber die auf aggressive Expansion zielende imperiale Machtpolitik des deutschen Kaiserreichs, die schließlich zu einem tiefgreifenden und fundamentalen Wandel in der Wahrnehmung Deutschlands führte - ein Wandel, der sich in der amerikanischen Öffentlichkeit zunehmend in Form antideutscher, germanophober Affekte niederschlug. Die Flotten-Aufrüstungspolitik unter dem I898 zum preußischen Marineminister berufenen Admiral Tirpitz („Tirpitzplan“) sowie die brüskierenden, konfrontativ-militaristischen Äußerungen und Aktivitäten des deutschen Kaisers Wilhelm II., unter anderem im Zusammenhang des amerikanisch-spanischen Krieges $1898,{ }^{270}$ mündeten in einen regelrechten „Kalten Krieg“" zwischen den USA und Deutschland vor dem Ersten Weltkrieg. ${ }^{271}$

Prügelszenen mit nachfolgendem Aufmarsch von Polizeibattalionen kam. Nicht zuletzt aufgrund dieser Beobachtungen formulierte der zutiefst irritierte Twain: „[...] diese Monarchie [...] sie widerspricht unserer Vorstellung darüber, wie ein Staat beschaffen sein sollte, um eine Existenzberechtigung zu haben [...]. Zit. nach: Twain, Turbulente Tage in Österreich, a.a.O., 14.

266 Eine frühe und vergleichsweise seltene positive Gleichsetzung, die auch über die Erfahrungen des Ersten Weltkriegs hinweg anhielt, findet sich in den Romanen sowie Notizen von Thomas Wolfe (1900-1938), für den Deutschland mit Österreich das „Gegenbild und Kontrastfolie zur kapitalistischen Gesellschaft mit ihren [...] künstlerischen Defiziten“ darstellte. Zacharasiewicz, Das Deutschlandbild in der amerikanischen Literatur, a.a. O., 184. In seinen Eindrücken von der Donaumetropole 1928 sprach Wolfe hier von einer im Vergleich zu Deutschland sogar größeren „urbanity and fine delicacy, charm and gaiety“. Elizabeth Nowell (Ed.), The Letters of Thomas Wolfe, New York 1956, 127 f. Zit. nach: Zacharasiewicz, Das Deutschlandbild in der amerikanischen Literatur, a.a.O., 188.

$267 \mathrm{Vgl}$.John Bunzl, American attitudes toward Austria and Austrian-German relations since 1945. In: David F. Good/Ruth Wodak (Eds.), From World War to Waldheim. Culture and Politics in Austria and the United States, New York - Oxford 1999, 25 f.

268 Winfried Kerschhaggl, Das Image Österreichs in den Vereinigten Staaten von Amerika. Eine explorative Studie über das Österreich Image (USA, Jänner 1992), Dipl.-Arb., Univ. Wien 1992, 139.

269 Mollin, Amerikanische Spiegelungen - das Deutschlandbild in den USA, a.a.O., 83.

270 Im Juli 1898 löste das Aufeinandertreffen amerikanischer und deutscher Geschwader in der Bucht von Manila kurzfristig sogar panikartige Kriegsbedrohungszenarien in der US-Presse aus. Vgl. ebd., 96.

271 Ebd., $89 \mathrm{ff}$. 
Nicht zuletzt vor diesem Hintergrund und den enormen Einwanderungswellen aus Südund Osteuropa starteten private Bildungsorganisationen und US-Regierungsstellen ein großangelegtes Programm zur kulturellen Assimilierung der Immigranten, die zu ,guten Amerikanern“ gemacht werden sollten. In sogenannten „Americanization-Schools“ hatten Kinder, Jugendliche und erwachsene Einwanderer Englisch-Sprachkurse zu belegen, amerikanische Geschichte zu lernen und sich mit den Grundsätzen der amerikanischen Demokratie vertraut zu machen. Neben dem Ziel einer Integration in die plurale amerikanische Zivilgesellschaft beabsichtigten diese edukativen Maßnahmen einer politischen Bildung - die auch führende amerikanische Intellektuelle wie Horace Mann begrüßten freilich auch, dass die Immigranten im Zuge dieses Amerikanisierungsprozesses ihre Herkunftskultur im Sinne eines multiethnischen „Melting Pots“ allmählich aufgeben sollten. ${ }^{272}$ Angefangen vom Kindergarten, über Public Schools, Public Libraries bis hin zu Erwachsenenbildungsangeboten der „National Education Association of the United States“ (NEA) sollten alle Bildungsagenturen des Landes dieser kulturellen Assimilierung zuarbeiten, was offenkundig so durchschlagend gelang, dass die NEA bereits I908 davor warnte, dass die rapide Amerikanisierung der Einwandererfamilien die traditionellen Eltern-Kind-Beziehungen untergraben würde. ${ }^{273}$ Nach dem Ersten Weltkrieg wurde das System der „Americanization Schools“ mit Unterstützung des U.S. Bureau of Education weiter ausgebaut und nun auch vom War Department im Rahmen einer Offensive zur „Good Citizenship“ begleitet, die auf die Sicherstellung national-patriotischer Loyalität und Respekt gegenüber sozialem Fortschritt zielte und leistungsfähige Bürger und unerschrockene Soldaten („intrepid soldiers“), ,,equipped for industry, commerce and business“ schaffen sollte. ${ }^{274}$

Angesichts der bellizistisch-martialischen Weltmachtpolitik des Deutschen Reiches verwandelte sich Deutschland jedenfalls zu einem Feindbild - zum „evil empire“275 -, dem sukzessive auch die an sich germanophilen amerikanischen Intellektuellen zunehmend kritisch gegenüberstanden. Neben dem amerikanischen Philosophen George Santayana, der, nach Studien in Göttingen und Dresden, den „deutschen Volkscharakter“ als Mischung aus „the uniforms, the music and the beer “276 zusammenfasste, sah dann etwa auch John Dewey, Lehrstuhlinhaber für Philosophie an der Columbia University und zentraler Repräsentant amerikanischer Bildungstheorie, einen tiefergehenden ideologischen Konflikt zwischen der deutschen „Kultur“ und der anglo-amerikanischen „Zivilisation“ ausgebrochen, der - aller-

272 Jeffrey E. Mirel, Patriotic pluralism. Americanization education and European immigrants, Cambridge 2010, 48.

273 Ebd., $57 \mathrm{f}$.

274 John C. Hennen, The Americanization of West Virginia. Creating a Modern Industrial State, 1916-1925, Lexington 1996, 121.

275 Detlef Junker, Politics, Security, Economics, Culture, and Society. Dimensions of the Transatlantic Relations. In: Detlef Junker (Ed.), The United States and Germany in the Era of the Cold War. A Handbook. Vol. 12, Cambridge 2004, 2.

276 Zit. nach: Zacharasiewicz, Das Deutschlandbild in der amerikanischen Literatur, a.a. O., 117. 
dings bereits vor dem Hintergrund des Ersten Weltkrieges - entscheidende Gegensätze ans Tageslicht bringen würde: so den Gegensatz zwischen der demokratischen, auf empirische Verbesserungen hin orientierten amerikanischen Gedankenwelt, und der idealistischen Innerlichkeit deutscher Kultur, die zwar, kurioserweise durch Immanuel Kant, die Idee der Freiheit ausformuliert hätte, während aber „gleichzeitig die Masse des deutschen Volkes sich zur Selbstregulierung unfähig erweise. “277 Die Aggressionsbereitschaft der Deutschen schien Dewey Ergebnis der primär durch kriegerische Akte erzielten nationalen Einigung, die mit Rückgriff auf die Vorstellungen des Mittelalters romantisch verklärt würde, und ebenso wie die „halbpathologische“ Sehnsucht des deutschen Kaisers nach „Rampenlicht“nur ein Eingeständnis ihres „Mangels an politischer Vernunft und Reife“278 wäre. Ähnlich wie Dewey sah dies auch Nicholas Murray Butler, Präsident der Columbia University und Vorstandsmitglied des „Carnegie Endowments for Peace“, der zwar Österreich und Deutschland für den Kriegsausbruch verantwortlich machte, aber klar zwischen dem brutalen Militarismus der politischen Führungselite und der Bevölkerung unterschied. ${ }^{279}$

Trotz aller bereits existierenden Feindbilder gegenüber dem aggressiven deutschen Militarismus, die insbesondere durch das marottenhafte Agieren des Deutschen Kaisers Wilhelm II. weiter genährt wurden, ${ }^{280}$ gab es innerhalb der amerikanischen Bildungselite am Vorabend des Ersten Weltkrieges vereinzelt noch positive Deutschlandbezüge ${ }^{281}$ und - wie im Fall Andrew Carnegies - sogar noch Hoffnungen auf den Deutschen Kaiser als „Friedensgaranten“. ${ }^{282}$ Unter dem Eindruck des öffentlich zunehmend diskreditierten Deutschland als Gefahr für den Weltfrieden kippten schließlich auch innerhalb der intellektuellen und politischen Elite Amerikas die ambivalenten Deutschlandbilder, die noch immer Achtung vor den geistigen Leistungen Deutschlands miteinschlossen, in Ablehnung der antidemokratisch-autoritären Strukturen der preußischen Militärmacht und deren Politik.

277 Jürgen Möckelmann, Das Deutschlandbild in den USA 1914-1918 und die Kriegszielpolitik Wilsons, phil. Diss., Univ. Hamburg 1965, 49.

278 Ebd., 50.

279 Ebd., 50. Interessanterweise sprach sich Butler, wie Möckelmann anführt, ähnlich wie dann später Wilson, bereits zu Beginn des Ersten Weltkriegs für die Schaffung einer neuen Weltordnung nach Kriegsende aus. Vgl. ebd.

280 Ein in der Literatur zitiertes Beispiel hierfür ist die in martialischem Ton gehaltene sogenannte „Hunnenrede" Wilhelms II. anlässlich der Entsendung eines deutschen Militärkorps als Unterstützung der alliierten Truppen zur Niederschlagung des chinesischen Boxeraufstandes im Jahr 1900. Daniel, A Brief Time to Discuss America. Der Ausbruch des Ersten Weltkriegs im Urteil amerikanischer Politiker und Intellektueller, a.a.O., 166.

281 So nennt Silvia Daniel in diesem Zusammenhang als Beispiel die positive öffentliche Berichterstattung z.B. in der New York Times - zum 25-jährigen „Thronjubliäum des Hohenzollern“. Daniel, A Brief Time to Discuss America. Der Ausbruch des Ersten Weltkriegs im Urteil amerikanischer Politiker und Intellektueller, a.a.O.

282 Ebd., $166 f$. 
Mit Ausbruch des Ersten Weltkrieges - und nicht erst mit Kriegseintritt der USA I9I7, wie Alexander Sedlmaier meint ${ }^{283}$ - kulminierte die bisherige Ablehnung und Aversion gegenüber deutscher Großmannssucht und pangermanisch-militärischem Säbelrasseln aber schließlich in einer offenen und geradezu exzessiven Kampagne der US-Presse gegen die mörderischen Deutschen, die nun nicht mehr nur als Inbegriff von Militarismus und Imperialismus galten, sondern mit propagandistischem Aufwand als „outlaws“, als mörderische „Hunnen“, als „barbarische Kindermörder und Hochseepiraten“284 dämonisiert wurden, geführt von einem hinterlistigen und brutalen Tyrannen, den man sogar zum Sa$\tan$ („Satanic Kaiser“) stilisierte. ${ }^{285}$ Zudem trug Präsident Woodrow Wilson, der offiziell zunächst noch weiter auf Neutralitätspolitik und friedliche Beziehungen zu Deutschland setzte, ${ }^{286}$ zur inneramerikanischen Hetze gegen die Deutschamerikaner bei, indem er diese I9I - „born under other flags but welcomed under our generous naturalization laws to the full freedom and opportunity of America“ - in einer Rede als Störenfriede der nationalen Friedens bezeichnete. ${ }^{287}$

Die hysterische Stimmung führte zu Schmähungen und gewaltsamen Übergriffen gegenüber Deutschamerikanern ${ }^{288}$ sowie zur Ächtung deutscher Kultur und Sprache an der „Heimatfront“. ${ }^{289}$ Unterstützt wurde diese Stimmung gegen alles Deutsche - zusätzlich aufgeheizt durch die Versenkung des englischen Passagierschiffes „Lusitania“ im Mai I9I5, auf dem sich 128 Amerikaner befanden, und dem fortgesetzten deutschen U-Bootkrieg ${ }^{290}$

283 Vgl. Alexander Sedlmaier, Deutschlandbilder und Deutschlandpolitik. Studien zur Wilson-Administration (1913-1921) (= Historische Mitteilungen im Auftrag der Ranke-Gesellschaft. Hrsg. v. Jürgen Elvert/Michael Salewski, Bd. 51), Stuttgart 2003, 76.

284 Vgl. Totten, Deutschland - Soll und Haben. Amerikas Deutschlandbild, a.a. O., 86.

285 Mollin, Amerikanische Spiegelungen - das Deutschlandbild in den USA, a.a.O., 77.

286 In einem veröffentlichten Appell an die US-Bevölkerung vom 18. August 1914 hatte Wilson noch davon gesprochen, das sich die Vereinigten Staaten unparteiisch - ,impartial in thought as well as in action“ - zu verhalten beabsichtigten. Daniel, A Brief Time to Discuss America. Der Ausbruch des Ersten Weltkriegs im Urteil amerikanischer Politiker und Intellektueller, a.a.O., 77.

287 Zit. nach: Sedlmaier, Deutschlandbilder und Deutschlandpolitik. Studien zur Wilson-Administration, a.a.O., 59 .

288 Tatsächlich gab es auch ein Opfer, einen jungen deutschstämmigen Minenarbeiter in Illinois. Vgl. Don H. Tolzmann (Ed.), German-Americans in the World Wars. Bd. 1: The Anti-German Hysteria of World War One, München - New Providence 1995, 237 ff. Zit. nach: Mollin, Amerikanische Spiegelungen - das Deutschlandbild in den USA, a.a.O., 77.

289 So wurde in den Bildungseinrichtungen der US-Bundesstaaten die deutsche Sprache regelrecht eliminiert, was, wie Mollin ausführt, zu einem „Kahlschlag“ führte: zwischen 1915-1922 „verringerte sich der Anteil von deutschlernenden High-School-Schülern von $25 \%$ auf weniger als $1 \%$ “. Mollin, Amerikanische Spiegelungen - das Deutschlandbild in den USA, a.a.O., 78; vgl. dazu insbesondere auch: Paul Finkelman, War on German Language and Culture, 1917-1925. In: Hans-Jürgen Schröder (Ed.), Confrontation and Cooperation. Germany and the United States in the Era of World War I, 1900-1924, Oxford 1993, $189 \mathrm{ff}$.

290 Vgl. Sedlmaier, Deutschlandbilder und Deutschlandpolitik. Studien zur Wilson-Administration, a.a.O., $183 \mathrm{f}$. 
dann von der am i3. April I9I7 von Wilson eigens eingerichteten US-Propaganda-Abteilung, dem „Creel Committee“, das in der Folge regelrechte Gräuelpropaganda betrieb. Eine Woche nachdem der US-Kongress die Kriegserklärung abgegeben hatte, erließ USPräsident Woodrow Wilson die „Executive Order No. 2594“, wonach ein „Committee on Public Information“ einzurichten war, um im Inland Unterstützungsbereitschaft für die militärische Intervention zu gewinnen und die Kriegsziele der Vereinigten Staaten publik zu machen. Das unter Leitung des US-Journalisten George Creel stehende Gremium existierte bis Kriegsende und produzierte mit seinem rund 150.000 [sic] umfassenden Mitarbeiterstab Tonnen von Büchern, Plakaten, Fotos und Flugzetteln, die hinter den feindlichen Linien abgeworfen wurden und die Moral schwächen sollten. ${ }^{291}$

Interessanterweise maß Creel, der die ideologischen Grundlagen der Kriegspropagandaaktivitäten 1920 in einem Buch mit dem Titel „How we advertised America“ zusammenfasste, der Herausforderung des neugeschaffenen Propaganda-Komitees die nahezu gleiche Bedeutung bei wie Siegen oder Niederlagen an der Westfront. Innerhalb Amerikas zielte der propagandistische "fight for the mind of men“292 vor allem darauf, die Meinung der Bevölkerung zu gewinnen ${ }^{293}$ - „the battle-line ran through every home in every country ${ }^{\prime 294}$. Im Unterschied zu allen bisherigen Kriegen sei dieser Waffengang jedoch, wie Creel ausführte, neben allen militärischen und politischen Aspekten, auch und vor allem ein tiefgehender Kampf um die kulturellen und moralischen Grundlagen der zivilisierten Welt:

291 Siehe: Rober E. Elder, The Information Machine. The United States Information Agency and American Foreign Policy, Syracuse /New York 1968, a. a.O., 34; zum „Creel Committee“ siehe insbesondere: Holger Ohmstedt, Von der Propaganda zur Public Diplomacy. Die Selbstdarstellung der Vereinigten Staaten von Amerika im Ausland vom Ersten Weltkrieg bis zum Ende des Kalten Krieges, Diss., Ludwig-Maximilians-Universität München 1993, 35 ff.; weiters: Schuhmacher, Kalter Krieg und Propaganda, a.a. O., 41 ff.; ein konzise Darstellung dieser ersten US-Informations- bzw. -Propagandaeinrichtung findet sich bei: Gregg Wolper, The Origins of Public Diplomacy: Woodrow Wilson, George Creel, and the Committee on Public Information, Diss., University of Chicago 1991.

292 George Creel, How we advertised America. The first telling of the amazing story of the Committing on Public Information that carried the Gospel of Americanism to every corner of the Globe, New York 1920, 3. Der Text ist online abrufbar unter [Zugriff am 29.7.2011]:

http://www.archive.org/stream/howweadvertameri00creerich/howweadvertameri00creerich_djvu.txt1991.

293 In diesem Zusammenhang schrieb Creel: „A wave of national feeling might carry us into the war and national passions and hatred might whip us on, but froth and dregs would be the only ultimate result. Such methods might carry a mob a city block to tear something down, but they would not bear a self-determining democracy along the road of travail and uttermost sacrifice for great ideals. Could we count on a national understanding of such ideals? Could we be sure that a hundred million the fathers, the mothers, the children of America, alien born and native alike understood well enough so that they would support one loan after another, would bear new burdens of taxation and send wave after wave of America's young manhood to die in Flanders fields?" Creel, How we advertised America, a.a.O., 99.

294 Creel, How we advertised America, a.a. O., 3. 
"Other wars went no deeper than the physical aspects, but German Kultur raised issues that had to be fought out in the hearts and minds of people as well as on the actual firing-line. The approval of the world meant the steady flow of inspiration into the trenches; it meant the strengthened resolve and the renewed determination of the civilian population that is a nation's second line. The condemnation of the world meant the destruction of morale and the surrender of that conviction of justice which is the very heart of courage." [Hervorhebung d. Verf.]

Und Präsident Wilson, der im historischen Rückblick dem Erfolg Deutschlands auf wirtschaftlichem und wissenschaftlichem Gebiet durchaus Wertschätzung und Bewunderung entgegenbrachte, sah nun gerade in der deutschen Gründlichkeit und Effizienz, die sich mit weltherrschaftlichem Anspruch gegen die demokratischen Freiheiten richte, die allergrößte Gefahr:

"Germany is determined that the political power of the world shall belong to her. There have been such ambitions before. They have been in part realized, but never before have those ambitions been based upon so exact and precise and scientific a plan of domination." 295

Obwohl sich die tiefen anti-deutschen Ressentiments nach Ende des Ersten Weltkriegs wieder legen sollten, und es, nicht zuletzt auch unterstützt durch anti-englische Stimmungslagen, kurzfristig sogar zum Wiederaufleben freundlicher Klischees des alten Deutschlandbildes kam, ${ }^{296}$ blieb mit der martialischen, vormodernen, nicht-zivilen kulturellen Andersartigkeit der Deutschen (Dewey) und ihrer Bedrohung gegenüber demokratisch organisierten Gesellschaften doch ein Thema angesprochen, das sich insbesondere mit dem aggressiv-rassistischen Antiamerikanismus des Nationalsozialismus sowie dessen präzise geplanter Vernichtungspolitik grausam zu bewahrheiten schien und bis heute als Thema amerikanischer Gegenwartsliteratur virulent geblieben ist. ${ }^{297}$

295 Rede Wilsons in Buffalo am 19. November 1917 bei einer von der „American Federation of Labor“ organisierten Veranstaltung. Zit. nach: Sedlmaier, Deutschlandbilder und Deutschlandpolitik. Studien zur Wilson-Administration, a.a.O., 85.

296 So bemühten sich bspw. amerikanische Schriftsteller (Sinclair Lewis oder Joseph Hergesheimer) oder auch Historiker darum, die entstellten Darstellungen des Deutschlandbildes zu entkräften. Vgl. Totten, Deutschland - Soll und Haben. Amerikas Deutschlandbild, a.a.O., 89; weiters: Zacharasiewicz, Das Deutschlandbild in der amerikanischen Literatur, a.a.O., $166 \mathrm{ff}$.

297 So bspw. in der differenzierten Bearbeitung eigener, biografischer Traumata bei Kurt Vonnegut („Mother Night“; „Slaughterhouse-Five“) oder in den komplexen, mit einer Fülle zeithistorischer Details durchsetzten Romanen von Thomas Pynchon („V“; „The Crying of Lot 49“; „Gravity’s Rainbow“). Vgl. Zacharasiewicz, Das Deutschlandbild in der amerikanischen Literatur, a.a. O., $241 \mathrm{ff}$. 
Amerikanische Journalisten wie zum Beispiel Edgar Ansel Mowrer, ${ }^{298}$ der als Auslandskorrespondent der Chicago Daily News in Berlin die zunehmend krisenhafte politische Entwicklung der Weimarer Republik verfolgte, sahen Deutschland spätestens Ende der Zwanzigerjahre, nicht zuletzt auch durch das drückende Konfliktpotenzial des Versailler Vertrags und die wirtschaftliche Depression, bald in einem fürchterlichen Rückfall begriffen. In seinem 1932 fertiggestellten, noch heute spannend zu lesenden Buch „Germany puts the clock back" analysierte Mowrer detailliert den Entwicklungsverlauf der Weimarer Republik, angefangen von dem durch die Alliierten mitverursachten „bad start“, die Rückkehr des preußischen Militarismus, über den reaktionären Einfluss des Finanzkapitals bis hin zum Aufstieg der Nationalsozialisten, und diagnostizierte die gesellschaftlichen Auswirkungen des deutschen Führerkults in seiner bisher extremsten Ausformung:

\footnotetext{
"The individual cease to exist: the hive counts more than the bees - not the physical hive, the metaphysical hive - the nation considered as a lasting reality rather than a historical accident. This is nationalism in its ultimate spasm. Everyone, from top to bottom, even the Leader, must serve the idea, serve not as a volunteer freely assenting, but as part and parcel of it. Dissent becomes 'impossible', heresy a destructive disease, obedience the greatest virtue. Therefore the insistence of discipline. Therefore the process of Gleichschaltung or turning all feet in the same direction. The aim is the greatness of the nation conceived as crude expansion. The Fascist does not think: he feels. And he feels that nothing is worth while, but to win is an endless (perhaps ultimately aimless) striving of national groups to devour each other."299
}

Die Bemühungen Wilsons'um eine stabile und friedliche Nachkriegsordnung, dem es, wie er in seiner I4-Punkte Rede ausführte, keineswegs darum ging, Deutschland „with arms or with hostile arrangements of trade“ zu unterdrücken, sofern es bereit wäre, sich mit Amerika und den friedliebenden Nationen der Welt zu verbünden - ,willing to associate herself with us and the other peace-loving nations of the world in convenants of justice and law and fair dealing ${ }^{\text {“300 }}$ - blieben, nicht zuletzt auch auf Grund der machtlosen Politik

298 Edgar Ansel Mowrer (1892-1977), Absolvent der University of Michigan, Presse-Journalist, u.a. Deutschlandkorrespondent und Büroleiter der Chicago Daily News in Berlin, der 1933 für seine Berichterstattung über die Machtergreifung Hitlers den Pulitzer Prize erhielt und nach dem erzwungenen Abzug aus Deutschland kurzfristig als Korrespondent der Neuen Freien Presse in Wien arbeitete. Von 1942 bis 1943 arbeitete Mowrer als Deputy Director des US-Kriegsgeheimdienstes „Office of Facts and Figures“(OFF). Vgl. Heinz-Dietrich Fischer (Ed.), The Pulitzer Prize Archive. Vol. 1. International Reporting 1928-1985, München - London - New York - Oxford - Paris 1987,31; weiters auch: Edgar Ansel Mowrer, Triumph and Turmoil. A Personal History of Our Times, London 1970, 225 f.; vgl. auch: Zacharasiewicz, Das Deutschlandbild in der amerikanischen Literatur, a.a.O., 198.

299 Edgar Ansel Mowrer, Germany puts the clock back, revised edition, London 1938 [1933], 244.

300 Rede Wilsons vor dem Kongress, 8. Jänner 1918. Zit. nach: Sedlmaier, Deutschlandbilder und Deutschlandpolitik. Studien zur Wilson-Administration, a.a.O., 90. 
des Völkerbundes und der Nichtteilnahme der Vereinigten Staaten, weitgehend erfolglos und so war der Weg in die bisher größte Barbarei der Menschheitsgeschichte zwar nicht vorgezeichnet, aber eben doch möglich.

Dass sich Amerika als die Siegermacht des Zweiten Weltkriegs fünfundzwanzig Jahre später ganz konkret zur geistig-kulturellen Umerziehung der Deutschen beziehungsweise der Achsenmächte aufmachen sollte, war zu diesem Zeitpunkt wohl selbst für germanophobe Hardcore-Pessimisten keinesfalls absehbar.

NS-FEINDBILD AMERIKA: ANTIAMERIKANISMUS ALS KAMPF GEGEN
„NIGGERKULTUR“, „JUDENSTAAT“ UND „WESTLICHE DEMOKRATIE“

„Ein Sieg über die militärischen Kräfte der USA wäre nur ein halber Sieg, wenn dem Amerikanismus weiter Gelegenheit gegeben würde, das Mark der Völker auszuhöhlen. Der Amerikanismus kann aber nur überwunden werden, indem die europäischen Völker endgültig die Lehren des Liberalismus vernichten und aus eigenen völkischen Werten ihr kulturelles Leben neu aufbauen. “" ${ }^{\text {301 }}$

(SS-Propagandaschrift, 1943)

Das spiegelbildliche Negativ zur positiven Selbstvergewisserung der kulturellen und wissenschaftlichen Leistungen des demokratischen Amerika, das auch nach 1945 in den Köpfen der Bevölkerung als anti-demokratisches Ideologem eingehämmert blieb, bildete während der Kriegsjahre die nationalsozialistische Antiamerika-Propaganda.

Der Nationalsozialismus konnte in seinem propagandistischen Antiamerikanismus nahtlos an einschlägige Negativ-Stereotype anknüpfen, die bereits die kontinentale Publizistik der vorangegangenen Jahrzehnte geliefert hatte ${ }^{302}$ - mit zwei gravierenden Unterschieden: zum einen wurde der Antiamerikanismus in Deutschland nun zum Bestandteil rassenpolitischer Propaganda, die sich letztlich mit dem ideologischen Vernichtungsfeldzug gegen Liberalismus und Demokratie vereinigte; zum anderen trat mit der NS-Herrschaft eine kulturelle DeAmerikanisierung im alltäglichen Leben ein. Überall, wo - wie im Fall moderner Rationalisierung - fordistisch-tayloristisch organisierte Produktionstechniken ${ }^{303}$ nach amerikanischem

301 Amerikanismus eine Weltgefahr. Reichsführer SS - SS-Hauptamt, Berlin-Grunewald, 1944, 23.

302 Vgl. Inge Marszolek, Das Amerikabild im Dritten Reich. In: Daniela Münkel/Jutta Schwarzkopf (Hrsg.), Geschichte als Experiment. Studien zu Politik, Kultur und Alltag im 19. und 20. Jahrhundert. Festschrift für Adelheid von Saldern, Frankfurt - New York 2004, 25-34.

303 Tatsächlich existierten bis in die Kriegsjahre hinein Geschäftsbeziehungen zu US-amerikanischen Großunternehmen wie Standard Oil, General Motors oder Ford. Im Fall Fords ging die Kooperation sogar weit über wirtschaftlich-technische Geschäftsbeziehungen hinaus. Henry Ford I.I., der 1921 die Zeitung The Dearborn Independent gekauft hatte, begann in dieser selbst unter krauser Bezugnahme auf die fingierten „Protokolle der Weisen von Zion“ unter dem Titel „The International Jew“ eine Hetzkampagne gegen die 
Muster zum Einsatz kamen, wurden diese umgehend ideologisch „germanisiert“. Allerdings verlief die kulturelle De-Amerikanisierung im Bereich von Film und Musik langsam beziehungsweise nur mäßig erfolgreich. Obwohl die Zahl amerikanischer Filme nach 1933 rasch abnahm, bis I940 schließlich nur mehr fünf zur Aufführung kamen, ${ }^{304}$ fanden US-Filme mit Clark Gable, Joan Crawford, Gary Cooper ebenso ihr Publikum wie Mickey Mouse, Goofy und andere Produktionen von Walt Disney. ${ }^{305}$ Und trotz des generellen Verbots von US-Filmen ab 1940 wurden in Dänemark zur deutschen Truppenbetreuung noch bis Mitte des Jahres 1944 Mickey Mouse- und Donald Duck-Filme gezeigt. ${ }^{306}$ Ähnlich verhielt es sich beim Jazz - in der Hand der Juden eine ,außerordentlich gefährliche weltanschauliche Waffe, die arischen Völker zu unterhöhlen “307 -, der zwar vollständig und gründlich diffamiert, aber dennoch nicht gänzlich ,ausgemerzt" werden konnte. ${ }^{308}$

Der Nationalsozialismus verstand sich dezidiert als „,ölkische Revolution“ gegen die Ideen der Französischen Revolution, gegen Demokratie und Liberalismus. Wie Philipp Gassert herausstreicht, spiegelt das NS-Amerikabild dabei zentrale Inhalte der NS-Ideologie wieder. Der „reaktionäre Modernismus“309 der Zwischenkriegszeit, also die Bewunderung der ökonomisch-technischen Effizienz Amerikas bei gleichzeitiger Ablehnung von Demokratie und massenkulturellem Konsum-Individualismus, sollte nun in Verbindung von hocheffizienter „Technik und (deutscher) Kultur“310 zum erfolgreichen autoritären Gegenprogramm zur Moderne werden. ${ }^{31}$

Trotz allen Hasses auf die Siegermacht USA, auf den „Verrat“ Woodrow Wilsons am deutschen Volk im Zusammenhang mit den uneingelösten „I4-Punkten“von I9I8 und auf den Versailler Friedensvertrag war Hitler regelrecht fasziniert vom technologischen Vor-

,jüdische Weltverschwörung` zu publizieren. Übersetzungen dieser antisemitischen Hetzschrift wurden auch ins Deutsche übersetzt und kursierten Anfang der 1920er-Jahre auch in Europa. Wie Leonard Dinnerstein darlegt, hatte dieses Pamphlet auch einen gewissen Einfluss auf Hitlers „Mein Kampf“. Nicht zuletzt hielt Hitler ein Foto von Henry Ford I. in Ehren und zeichnete diesen 1938 zu dessen 75. Geburtstag mit dem „Verdienstorden vom Deutschen Adler“ aus. Vgl. Leonard Dinnerstein, Antisemitism in America, New York 1994, 82f.; siehe weiters: James E. Pool, Who financed Hitler. The secret funding of Hitler's rise to power, 1919-1933, New York et al. 1997, 45 ff.

304 Gassert, Amerika im Dritten Reich, a.a.O., 165.

305 Vgl. Carsten Laqua, Wie Mickey unter die Nazis fiel. Walt Disney und Deutschland, Reinbek 1992, $44 \mathrm{f}$.

306 Laqua, Wie Mickey unter die Nazis fiel, a.a.O., 100; Gassert, Amerika im Dritten Reich, a.a. O., 172.

307 Amerikanismus eine Weltgefahr, Reichsführer SS, a.a.O., 36.

308 Vgl. dazu: Mike Zwerin, La tristesse de Saint Louis: Jazz Under the Nazis, New York 1987; Heiko Hasebein, Unerwünscht - toleriert - instrumentalisiert. Jazz und Swing im Nationalsozialismus. In: 1999, 10. Jg., 1995, 38-52; Uta G. Poiger, Jazz, Rock, and Rebels: Cold War Politics and American Culture in a Divided Germany, Berkeley 2000.

309 Vgl. Jeffrey Herf, Reactionary Modernism. Technology, Culture and Politics in Weimar and Third Reich, Cambridge 1984.

310 Gassert, Amerika im Dritten Reich, a.a.O., 16.

311 Vgl. Peter Schwerber, Nationalsozialismus und Technik. Die Geistigkeit der nationalsozialistischen Bewegung, München 1932 [1930], 40 ff. 
sprung der Vereinigten Staaten, begeisterte sich für moderne Waffentechnik ebenso wie für Automobile $^{312}$ und zeigte sich von der wirtschaftlich-technischen Stärke der Vereinigten Staaten beeindruckt. ${ }^{313}$

Doch trotz aller Faszination gegenüber technischer Produktion und Rationalisierung, die auch eine kompetitive Facette aufwies, ${ }^{314}$ war Hitlers Amerikabild letztlich fundamental negativ geprägt, und zwar nicht zuletzt deshalb, weil für ihn „westliche Demokratie einerseits und russischer Bolschewismus andererseits [...] die Form [bilden], innerhalb derer die heutige jüdische Weltanschauung ihren Ausdruck findet. “315 Die Überlegenheit der USA - die sich „zu einem hohen Prozentsatz den deutschen Beitragsleistungen“316 verdanke - interpretierte Hitler in kruder Weise rassenpolitisch, indem er den Vereinigten Staaten infolge der europäischen Auswanderung ${ }^{317}$ und der selektiven Einwanderungspolitik ein „eugenisch“ hohes Potenzial attestierte. ${ }^{318}$ Angesichts des „minderen Wertes der europäischen Völker“ könne dem gegenüber nur eine „bewusst völkische Rassenpolitik [...] die europäischen Nationen davor retten, das Gesetz des Handelns an Amerika zu verlieren“; ${ }^{319}$ nach dem Vorbild der ungeheuren räumlich-geografischen Entfaltungsmöglichkeiten der USA sollte sich dieses ,Gesetz des Handelns‘, gemäß der rassistisch ausge-

312 Ebd., 26.

313 So meinte Hitler bei seinen Tischgesprächen, dass Deutschland auf wirtschaftlichem Gebiet viel von den Vereinigten Staaten lernen müsse. Vgl. James V. Compton, Hitler und die USA. Die Amerikapolitik des Dritten Reiches und die Ursprünge des Zweiten Weltkrieges, Oldenbourg 1968, 23. Umgekehrt orientierte sich Roosevelt interessanterweise beim Aufbau des Arbeitsdienstes des „New Deal“, dem „Civilian Conservation Corps“ (CCC), an organisationalen Elementen des nationalsozialistischen „Reichsarbeitsdienstes“ (RAD). Siehe: Kiran Klaus Patel, „All of this helps us in planning“. Der New Deal und die NSSozialpolitik. In: Aust/Schönpflug (Hrsg.), Vom Gegner lernen. Feindschaften und Kulturtransfers im Europa des 19. und 20. Jahrhunderts, a.a.O., $237 \mathrm{f}$.

314 Vgl. Inge Marszolek, Das Amerikabild im „Dritten Reich“. Ambivalenzen und Widersprüche. In: Thadden /Escudier (Hrsg.), Amerika und Europa - Mars und Venus?, a.a.O., 51.

315 Adolf Hitler, Reden, Schriften, Anordnungen. Februar 1925 bis Januar 1933. 5 Bde. Hrsg. v. Institut für Zeitgeschichte München, München 1992 ff., Bd. I, Dok. 65, 17. September 1925, 153. Zit. nach: Gassert, Amerika im Dritten Reich, a.a.O., 97.

316 In den ausgewanderten Deutschen sah Hitler den (unterschätzten) „Kulturdünger für andere Völker“. Zit. nach: Hitlers Zweites Buch. Ein Dokument aus dem Jahr 1928. Eingeleitet und kommentiert von Gerhard L. Weinberg. Mit einem Geleitwort von Hans Rothfels, Stuttgart 1961, 117.

317 Nur die „Mutigsten, die Tapferen, entschlossensten, widerstandsbereitesten Menschen“ wären - in die USA - ausgewandert, wohingegen die „Feiglinge und Schwächlinge“ zu Hause geblieben wären [sic]. Zit. nach: Hitlers Zweites Buch, a.a.O., 50.

318 Zur Beschäftigung Hitlers mit amerikanischen Arbeiten zur Rassenhygiene und Eugenik siehe Gassert, Amerika im Dritten Reich, a.a.O., 96.

319 Hitlers Zweites Buch, a.a. O., 125. „So wenig man nun die Leistung von 1.000 verkommenen Levantinern in Europa, sagen wir auf Kreta [sic], gleichsetzen kann der Leistung von 1.000 rassisch noch viel wertvolleren Deutschen oder Engländern, so wenig kann man aber auch die Leistung von 1000 rassisch bedenklichen Europäern gleichsetzen der Leistungsfähigkeit von 1000 rassisch hochwertigen Amerikanern." $Z$ it. nach: Hitlers Zweites Buch, a.a.O., 125. 
legten europäischen Monroe-Doktrin, ${ }^{320}$ für das deutsche Volk im neuen „Lebensraum im Osten" entfalten.

Flankierend dazu sah Hitler, wie sein vertrauter Amerika-Berater Colin Ross ${ }^{321}$ I936 in seinem Buch „Unser Amerika“322 darlegte, in den ausgewanderten Deutschen - insbesondere in den rund sieben Millionen Deutsch-Amerikanern der ersten und zweiten Generation $^{323}$ - ein unterschätztes politisches Potenzial, an dem sich arische Missionierungs- und Befreiungsphantasien entzündeten. Nicht zuletzt wegen der Vorstellung von der „Bestimmung des deutschen Bluts in Amerika“- deutsche Schulbücher sprachen von „Amerika, ein ausgewandertes Europa“"324 - erhofften die Auslandsabteilungen der NSPropaganda in den USA, ihre in Amerika geborenen Volksgenossen zum „Glauben an Volk und Führer ${ }^{\text {“325 }}$ zurückzuführen - allerdings völlig vergeblich.

Mit dem wirtschaftlichen Einbruch der USA nach dem Börsenkrach, der darauf folgenden Finanzkrise, der zunehmenden Arbeitslosigkeit, den Streikunruhen, der vermehrten Aktivität kommunistisch-gewerkschaftlicher Organisationen, wie das in drastisch-ironischer Weise bereits 1929 Egon Erwin Kisch ${ }^{326}$ und dann 1932 A. E. Johann [alias Alfred Wollschlaeger] in seinem Buch „Amerika. Untergang am Überfluss“327 zur

320 So verkündete Hitler in seiner Reichstagsrede vom 28. April 1939 die „europäische Monroe-Doktrin“ als „Interventionsverbot für raumfremde Mächte“. Siehe: Gassert, Amerika im Dritten Reich, a.a. O., 296.

321 Colin Ross (1885-1945) war in der Zwischenkriegszeit neben Egon Erwin Kisch einer der bekanntesten deutschen Reisejournalisten. Er veröffentlichte über zwanzig, teilweise in zahlreichen Auflagen publizierte Reisebücher, die sich mit der kolonialen Welt von der Kongomündung bis Shanghai beschäftigten. Ross war Nachrichtendienst-Offizier im Ersten Weltkrieg, , kurzfristig Hauptakteur in der Novemberrevolution von 1918, Propagandist der deutschen Republik in Südamerika und schließlich des „Dritten Reiches“ in den USA“. Wie Bodo-Michael Baumunk hervorstreicht, blieb Ross auch als Weltreisender im Grunde „Offizier in Aufklärungsmission, der für seine Erkundungsfahrten meist den Segen staatlicher Mächte suchte.“ Die Erfahrungen und Erlebnisse seiner Weltreise 1923/24 brachte er in dem Film „Mit dem Kurbelkasten um die Erde“ zur Ansicht, worin er sich überzeugt gab vom baldigen Aufstieg des „pazifischen Raumes“ und dem nahenden Ende der europäischen Kolonialherrschaft in Asien. Vgl. Bodo-Michael Baumunk, Ein Pfadfinder der „Geopolitik“ - Colin Ross und seine Reisefilme. In: Jörg Schöning (Red.), Triviale Tropen. Exotische Reise- und Abenteuerfilme aus Deutschland 1919-1939, München 1997, 85-94.

322 Colin Ross, Unser Amerika. Der Deutsche Anteil an den Vereinigten Staaten, Leipzig 1936. Das Buch wurde mit Unterstützung des NS-Propagandaministeriums anschließend ins Englische übersetzt. Vgl. Gassert, Amerika im Dritten Reich, a.a.O., 110.

323 In Summe existierten im Amerika der Dreißigerjahre rund 20 Millionen Amerikaner deutscher Abstammung. Vgl. Klaus Klipphahn, Deutsche Propaganda in den Vereinigten Staaten 1933-1941 (= Beiheft zum Jahrbuch für Amerikastudien, 31. Heft), Heidelberg 1971, 22, 52.

324 Gassert, Amerika im Dritten Reich, a.a.O., 135.

325 Klipphahn, Deutsche Propaganda in den Vereinigten Staaten 1933-1941, a.a. O., 23, $54 \mathrm{ff}$. Von den rund sieben Millionen Deutsch-Amerikanern lasen noch ein Viertel eine der 178 deutschsprachigen Blätter in den USA. Von diesen waren ca. 12 unverhüllt pro-nationalsozialistisch, drei Dutzend lehnten Hitler und den Nationalsozialismus ab. Ebd., 52.

326 Egon Erwin Kisch, Paradies Amerika, Berlin 1929, $248 \mathrm{ff}$.

327 A.E. Johann [Alfred Wollschlaeger], Amerika. Untergang am Überfluss, Berlin 1932. 
Darstellung brachten, schien sich das NS-Amerikabild Mitte der Dreißigerjahre kurzfristig etwas zu modifizieren. Das Gefühl der Unterlegenheit gegenüber den leicht angeschlagenen USA nahm ab, es machte sich nun im Gegenteil ein systemischer Überlegenheitsdünkel breit. ${ }^{328}$ Anders als der „New Deal“ Roosevelts wäre der Nationalsozialismus tatsächlich erfolgreich im Kampf gegen die Schattenseiten der Moderne, in der Lösung der sozialen Frage, in der Bekämpfung der „kommunistischen Gefahr“ und darüber hinaus in der Lage, die Monumentalität Amerikas zu übertreffen, letztlich sogar selbst Weltmacht zur werden. ${ }^{329}$

Dem Kultur-Kampf gegen Amerika verschrieben sich - neben dem im März 1933 geschaffenen „Reichsministerium für Volksaufklärung und Propaganda“ unter Joseph Goebbels - insbesondere auch der NS-Chefideologe Alfred Rosenberg als Leiter des von ihm geschaffenen „Kampfbunds für deutsche Kultur “330 und als „Hauptschriftleiter“ des Völkischen Beobachters. Das NSDAP-Parteiorgan mobilisierte dazu bereits 1930 alle NegativKlischees und Feindbilder gegen die „Unkultur Amerikas“. ${ }^{331}$ Der Antisemitismus bildete ab 1933 ebenso wie bald darauf die „Bolschewismusfurcht“ - der Kampf gegen den Liberalismus als „Brutstätte bolschewistischer Agitation“- den festen Bestandteil der AntiAmerika-Propaganda. ${ }^{332}$

Worauf die NS-Propaganda gegenüber den USA besonderes Augenmerk richten sollte, vermeinte Hitler im Rekurs auf die quasi vorbildhafte Kriegspropaganda Amerikas während des Ersten Weltkriegs auszumachen:

„Es war zum Beispiel grundfalsch, den Gegner lächerlich zu machen, wie dies die österreichische und deutsche Witzblattpropaganda vor allem besorgte. Grundfalsch deshalb, weil das Zusammentreffen in der Wirklichkeit dem Manne vom Gegner sofort einen ganz andere Überzeugung beibringen mußte, etwas, was sich dann auf das fürchterlichste rächte [...]. Demgegenüber war die Kriegspropaganda der Engländer und Amerikaner psychologisch richtig. Indem sie dem eigenen Volke den Deutschen als Barbaren und Hunnen vorstellte, bereitete sie den einzelnen Soldaten schon auf die Schrecken des Krieges vor und half so mit, ihn vor Enttäuschungen

328 So fokussierte ab 1934 insbesondere auch der Volkische Beobachter auf Obdachlosigkeit, Not, Hungerelend, Arbeitslosigkeit und Kriminalität in US-Amerika. Vgl. dazu Gassert, Amerika im Dritten Reich, a.a.O., 225.

329 So plante Hitler - einmal abgesehen von der Schaffung des „Großraum[s] Europa“ - in Hamburg Wolkenkratzer „von der gleichen Gewalt der amerikanischen“; Goebbels wollte zudem in Babelsberg Hollywood übertreffen. Zit. nach: Gassert, Amerika im Dritten Reich, a.a.O., 180.

330 In seinem „Kampf gegen die Zerstörung der Grundlagen unserer Kultur“ richtete sich der Kampfbund, zu dessen Mitgliedern u.a. auch Winifred Wagner gehörte, insbesondere gegen Jazz. Siehe dazu: Gassert, Amerika im Dritten Reich, a.a.O., 67.

331 Vgl. Gassert, Amerika im Dritten Reich, a.a.O., 101; weiters: Wagnleitner, Coca-Colonisation, a.a.O., 35.

332 Gassert, Amerika im Dritten Reich, a.a.O.,199, 231. 
zu bewahren, wie sie andererseits Wut und Haß gegen den verruchten Feind steigerte. “" ${ }^{333}$ [Hervorhebung d. Verf.]

Solange das isolationistische Amerika Roosevelts vornehmlich mit inneren Problemen kämpfte und die offiziellen diplomatischen Kontakte zu Deutschland in routinemäßiger Höflichkeit stattfanden, vollzog sich die verordnete Anti-Amerika-Propaganda tendenziell in politisch abgebremster Form - schließlich war die nationalsozialistische Führung angesichts der Erfahrungen des Ersten Weltkrieges an einer neutralen Europapolitik Amerikas interessiert. Gleichzeitig wuchs die Befürchtung, dass die liberale Ideologie Amerikas mit seiner „Demokratie-Propagand “ ${ }^{\text {“334 }}$ und seiner zunehmend „alarmistischen Politik“ diese Neutralität früher oder später aufgeben könnte. ${ }^{335}$ Immerhin hatte Morgenthau bereits 1933 in einer Rede erklärt: „Ich fühle, dass Deutschland heute eine große internationale Schande ist, die nicht geduldet werden sollte. Das deutsche Streben geht nicht nur gegen die Juden, sondern auch gegen die intellektuelle Freiheit des deutschen Volkes, und nicht nur innerhalb der deutschen Grenzen, sondern über die ganze Welt hinaus, und gegen jede geistige Freiheit und gegen jeden Individualismus. “336

Aber trotz der Rooseveltschen „Quarantänerede“ vom Oktober 1937, ${ }^{337}$ der empörten Reaktionen der amerikanischen Regierung auf die Ereignisse der sogenannten „Reichskristallnacht" vom 9. November 1938 und der sich sukzessive anbahnenden demokratischen anglo-amerikanischen Allianz ${ }^{338}$ gegenüber der europäischen Diktaturen agierte die NSPropaganda zunächst mit zähneknirschender politischer Zurückhaltung. ${ }^{339}$

Doch noch vor dem amerikanischen Kriegseintritt veranlasste Goebbels aufgrund der zunehmenden Parteinahme und militärischen Unterstützung Amerikas für England und für die Sowjetunion, dem bereits existierenden „Feindbild schärfere Konturen zu

333 Adolf Hitler, Mein Kampf. Zwei Bände in einem Band, München 1938, 198 f.

334 So der Begründer der „deutschen Amerikanistik“, Friedrich Schönemann, im Kontext der pan-amerikanischen Konferenz von Lima 1938; Ders., Die aggressive Wirtschaftspolitik der Vereinigten Staaten in Südamerika und die Stellung Deutschland, Stuttgart 1939, 57.

335 „Was Präsident Roosevelt heute noch so gefährlich macht, ist nicht so sehr Wall Street oder das Rüstungskapital, wenngleich sie wichtig genug sind, sondern die Ideologie des amerikanischen Volks. Sie ist die treibende Kraft hinter der Außenpolitik; denn sie ist der entscheidende Inhalt der öffentlichen Meinung.“ Friedrich Schönemann, Demokratie und Außenpolitik der USA, Berlin 1939, 63.

336 Zit. nach: Friedrich Schönemann, Amerika und der Nationalsozialismus, Berlin 1934, 11.

337 Am 5. Oktober 1937 hatte Roosevelt in einer Rede in Chicago die „Feinde des Friedens“ verurteilt und die Forderung erhoben, diese aus der Staatengemeinschaft auszustoßen und unter „Quarantän“" zu stellen. Vgl. Gassert, Amerika im Dritten Reich, a.a.O., 248.

338 So stellte Friedrich Schönemann 1940 die bange Frage, inwieweit „die Großmacht USA ihre Rechte und Pflichten eines Neutralen wirklich ernst nimmt." Vgl. Friedrich Schönemann, England gegen Amerika. Eine geschichtlich-kritische Betrachtung, Berlin 1940, 70.

339 Gassert, Amerika im Dritten Reich, a.a.O., 273 f. 
geben. “340 So vermeldete der Volkische Beobachter im Februar I94I: „Heute plant das Land der ,Freiheit' die totale Englandhilfe, um Europa neu zu versklaven und seiner wirtschaftlichen und politischen Unabhängigkeit zu berauben. “341

Mit der Verkündigung der „Atlantik-Charta“ am I4. August i94I durch Präsident Roosevelt und Premierminister Churchill ${ }^{342}$ - in der NS-Sprachregelung einerseits ein „Verrat an Europa“ und andererseits ein „plumper Agitationsbluff mit alten abgestandenen Phrasen“" ${ }^{\text {343 }}$ - und der nachfolgenden Kriegserklärung Deutschlands an die USA am Ir. Dezember 194I ging die Anti-Amerikapropaganda vollends in die rassistische Offensive. ${ }^{344}$

Im Krieg mit dem Land, dessen „drohende Überwältigung der Welt“ ihm bereits 1927 Sorge bereitet hatte, fand Hitler 1942 für Amerika „klare“ Worte: „Es ist ein innerlich faules Land mit Rassenproblemen und sozialer Ungleichheit, ein Land ohne Ideen. [... ] Meine Gefühle für Amerika sind voll Haß und Widerwillen; halb verjudet, halb vernegert und alles auf dem Dollar beruhend [...]. Die Amerikaner haben ein Hühnergehirn. Das Land ist ein Kartenhaus mit ungleichem materiellen Niveau. Die Amerikaner leben wie die Schweine, wenn auch in einem höchst luxuriösen Schweinestall. “345 Und anlässlich eines seiner Monologe im Führerhauptquartier präzisierte Hitler: „Was wir gegen diese Nation anführen, ist in erster Linie der völlige Kulturmangel““ ${ }^{346}$

In Anknüpfung an das „traditionell negativ gefärbte deutsche Wilson-Bild“347 wurden, bar jeder Logik, Präsident Roosevelt und die „Washingtoner Judenclique“ als „kranke Kriegshetzer“348 diffamiert. Zusätzlich bemühte sich die deutsche Propaganda im Nachweis der negativen Seiten Amerikas den Mythos vom Land der „unbegrenzten Möglichkeiten“ zu unterminieren. Darüber hinaus konzentrierte sich die NS-Propaganda in

340 Günter Moltmann, Amerikaklischees der deutschen Kriegspropaganda 1941-1945. In: Amerikastudien/ American Studies, 31. Jg., 1986, Heft 3, 305.

341 Volkischer Beobachter, Nr. 44, 13. Februar 1941. Zit. nach: Gassert, Amerika im Dritten Reich, a.a. O., 309.

342 Vgl. Keesings Archiv der Gegenwart, XV. Jg., 1945, 1. Jänner, $10 \mathrm{f}$.

343 Erklärung auf einer eigens einberufenen Sonderpressekonferenz im NS-Propagandaministerium. Zit. nach: Gassert, Amerika im Dritten Reich, a.a.O., $312 \mathrm{f}$.

344 Interessant ist in diesem Zusammenhang, dass anscheinend selbst in der britischen Bevölkerung antiamerikanische Gefühle deutlich ausgeprägt waren. So ergab eine Meinungsumfrage vom Oktober 1940, dass lediglich $24 \%$ der Befragten gegenüber den USA positiv eingestellt waren. Wie Wagnleitner anführt, lagen die „Sympathiewerte für die US-Amerikaner hinter jenen für Griechen, Polen und Juden.“ Zit. nach: Wagnleitner, Coca-Colonisation, a.a.O., 33. Leider ist bei Wagnleitner die diesbezügliche Referenz unklar, da die Fußnote 68 fehlt.

345 Zit. nach: Compton, Hitler und die USA, a.a.O., 21.

346 Henry Picker, Hitlers Tischgespräche im Führerhauptquartier 1941-42. Hrsg. v. Gerhard Ritter, Bonn 1951, 58. Zit. nach: Gert Raethel, Wiederkehrende Elemente im deutschen Antiamerikanismus der Nachkriegszeit. In: Amerikastudien/American Studies, 31. Jg. 1986, Heft 4, 336.

347 Moltmann, Amerikaklischees der deutschen Kriegspropaganda, a.a. O., 305.

348 Amerika als Zerrbild europäischer Lebensordnung. Schulungsunterlage Nr. 19. Hrsg. v. Reichsorganisationsleiter der NSDAP, Hauptschulungsamt, o. O., o. J [1942/43], 7. 
bewusster Anlehnung an negative Kulturstereotypen nun wieder verstärkt auf die apostrophierte ,amerikanische Kulturlosigkeit“ gegenüber der großen Tradition Deutschlands, wobei, wie Gassert meint, Goebbels Kalkül, den ,völligen Mangel an Kultur“ zum Thema der antiamerikanischen Propaganda zu machen, ,jedenfalls teilweise auf[ging].“349

In Tornisterschriften ${ }^{350}$ sowie zahlreichen ideologischen Propagandapamphleten zog man nun alle Register. So wurde etwa der „USA-Zivilisation“ in der vom „Reichsführer SS“ herausgegebenen Schrift mit dem Titel „Amerikanismus - eine Weltgefahr“ jegliche Kultur abgesprochen, und „alles, was in den USA an sogenannter Kultur geschaffen wurde“, europäischem Einfluss zugeschrieben; ${ }^{351}$ denn: „Die Leistung ganzer Generationen europäisch-nordischer Menschen würden ihren Sinn verlieren, wollte man die technische Barbarei der USA-Zivilisation überhaupt als Kulturfaktor ansprechen.“352

Mit Goethe-Zitaten im Mund wurde gegen ,jüdische Schmutzfinken“ wie Heinrich Heine oder Franz Werfel gehetzt, gegen den ,jüdischen Sendungsanspruch einer angemaßten demokratischen Mission“, gegen die „Heuchelei amerikanischer Kultur“, gegen „blutleeren Liberalismus“ respektive „blutleere Allerweltsmenschen“, gegen „Nigger kreischenden Jazz“, sowie - amüsanterweise - auch gegen die „völlige Uniformität der [amerikanischen] Kleidung ${ }^{\text {“353 }}$ polemisiert.

Anhand der von „Juden“ und „Freimaurern“ proklamierten universalen Gültigkeit von Freiheit, Fortschritt und Vernunft, der bis auf den „Friedensapostel“ Jefferson zurückgehenden „missionarischen Überzeugung, dass diese „politischen Ideale [...] richtig für alle Völker und Länder“ ${ }^{\text {“354 }}$ wären, zeige sich die „demokratische [...] Fassade“ des „krassesten Imperialismus “ ${ }^{\text {"35 }}$ der USA, wie auch „die sogenannte westliche Demokratie weiter nichts [...] als die ungeheuerlichste Diktatur der jüdisch-amerikanischen Weltmacht. ${ }^{\text {"356 }}$

Die „Enthüllung“ des „Doppelgesichts“ des „seelenlosen Dollarimperialismus“, eines von „dunklen Hintermännern“ - „Bankhyänen“, „korrupten Politikern“, „Juden“ und „Negern“ mit „psychologischen Kniffen und Raffinessen“357 gelenkten Systems spielte dabei im Vergleich zur Rettung versprechenden ,germanischen Welt“ des Nationalsozialismus eine zentrale Rolle. Als Kern des demokratischen Systems galt es, Freiheit und Parlamentarismus als „Heuchelei“, als Trugbilder zu denunzieren:

349 Gassert, Amerika im Dritten Reich, a.a. O., 357.

350 Vgl. Colin Ross, USA. Tornisterschrift des Oberkommandos der Wehrmacht. Abt. Inland. Bd. 47, o. O. 1941.

351 Amerikanismus eine Weltgefahr. Reichsführer SS, a.a.O., 24.

352 Ebd., 38.

353 Ebd., 30.

354 Ebd., 16.

355 Ebd., 21.

356 Ebd., 32.

357 Ebd., 26 
„Angeblich sind die US-Amerikaner als Hüter der Demokratie frei, sie bestimmen mit ihrem Wahlzettel scheinbar den Kurs des Landes für die nächste Regierungsperiode, nur sieht der einzelne Amerikaner nicht oder nur sehr selten etwas von den politischen Verkaufspsychologen, die es vorher verstanden haben, die Massenteilchen mit einem Magnet, der Presse, Filme, Rundfunk $[\ldots]$ von vorneherein so auszurichten, daß die freie demokratische Volksmeinung genau die Wünsche der regierenden Plutokraten erfüllt. “358

In einer regelrechten Flut an Büchern, Broschüren, Zeitungsartikeln, Radiosendungen oder Wochenschauberichten wurden diese Negativ-Stereotype in ständig neuen Variationen wiederholt. Angesichts der „Entartung“ Amerikas infolge der hohen Zahl jüdischer Emigranten („Rassejuden“), der bedenklichen öffentlichen Rolle der „Farbigen“359 sowie der Auswanderung von jetzt „religiös und sozial Anomale[n], Übereiferer[n], Querulanten und Hysteriker[n] ${ }^{\text {360 }}$ beantwortete Edmund Fürholzer die von ihm aufgeworfene Frage „Menschen wie wir?" rassepolitisch bereits eindeutig negativ. ${ }^{361}$

Andere Autoren jener Jahre bemühten sich darum, durch die Auflistung von Beispielen für „Geschmacklosigkeit“ und „geistigen Urwaldzauber“, die amerikanische Gesellschaft in psychiatrischen Termini wie „geisteskrank“, „wahnsinnig“ oder „verrückt“362 lächerlich zu machen beziehungsweise - in Anknüpfung an bereits existierende Negativ-Stereotype - darum, nachzuweisen, dass beim Kriegsfeind Amerika, dem „Land ohne Herz “ ${ }^{363}$ „mangelhafte Erziehung, unzulängliche Bildung und primitiver Geschmack“364 dominierten und dementsprechend - wenn überhaupt - nur „Tarzan-Bände“ und billige „Bahnhofsliteratur“365 gelesen würden.

Den vorläufigen Kulminationspunkt des NS-Antiamerikanismus bildete schließlich dessen Zusammenfallen mit dem nationalsozialistischen Antibolschewismus. Vor dem Hintergrund des alliierten Kriegsbündnisses mit der Sowjetunion strich man den „Materialismus“ als „tiefe weltanschauliche Gemeinsamkeit“ Amerikas mit dem „Bolschewismus“ heraus. In der bereits zitierten SS-Broschüre heißt es dazu:

358 Ebd.

359 „Mit fünfzehn Millionen Negern und weiteren Millionen mexikanischer Mischlinge sind die USA heute schon kein weißer Staat mehr." Edmund Fürholzer, Menschen wie wir? Ein Amerika-Buch für Europäer, Berlin 1943, 329.

360 Ebd., 361.

361 „Dass das amerikanische Volk in seiner jetzigen Form nicht in Zukunft bestehen kann, liegt auf der Hand. Der Sieg des europäischen Geistes [sic] über jüdischen Vernichtungswillen wird sich in Amerika nicht minder entscheidend auswirken, wie in der Alten Welt." Fürholzer, Menschen wie wir?, a.a.O., 362.

362 Ernst Machek, Verrückte Neue Welt. Ein Panoptikum von Tollheiten, Berlin-Friedenau 1943.

363 So Titel eines mit 40.000 Exemplaren aufgelegten Hetz-Buches von A.E. Johann [Johan Wollschlaeger]; Ders., Land ohne Herz. Eine Reise ins unbekannte Amerika, Berlin 1942.

364 K.F. Herrmann, Schrifttum. In: Friedrich Schönemann/Adolf Halfeld/Friedrich Kegel et al., Kultur in USA. Die Wirklichkeit eines Massenwahns, Berlin 1943, 261.

365 Ebd., 250. 


\begin{abstract}
„Den Magazinmenschen Nordamerikas entspricht der seelenlose, doktrinäre, keine Kultur anerkennende Bolschewist. Abstufungen ergeben sich höchstens daraus, daß der Bürger der USA mitunter ein paar Anzüge und Konservendosen mehr haben könnte als der Genosse Stalins, dass die rassischen Produkte, die beide Systeme in ihre Schmelztiegel taten, bisweilen an Zahl und Wesen verschieden waren. [...] Entscheidend ist vor allen Dingen, dass in beiden Staaten das Judentum an führender Stelle und Nutznießer ist. [... Sie bilden eine Klammer, die alles zusammenhält. “366
\end{abstract}

Und weiter: „Gegen die Weltherrschaftsansprüche des Amerikanismus und Bolschewismus kämpft heute Deutschland für das Lebensrecht Europas und damit für eine den Völkern arteigene Kultur. Dieser Kampf wird entschieden durch eine klare weltanschauliche Haltung. “367

Die angeführten Elemente des NS-Antiamerikanismus verschärften sich sukzessive analog zu den Rückschlägen im Kriegsverlauf und den ersten westlichen Bombenangriffen, bis die Anti-Amerikapropaganda Mitte I944- wohl auch im Kontext mit den bekannt gewordenen Morgenthau-Plänen - geradezu hysterische Züge annahm.

Als Oktober 1944 amerikanische Truppen einen ersten Streifen Westdeutschlands besetzt hatten, kolportierten deutsche Nachrichten-Dienststellen im Versuch, gegen die sich in der Bevölkerung breit machenden Distanzierungs- und Ermüdungstendenzen anzukämpfen, regelrechte Horrormeldungen. In einer Mischung aus Rassismus und Gräuelpropaganda versuchten groß angelegte Kampagnen gezielt, den selbst verursachten ,amerikanisch-britischen Mordkrieg gegen Frauen und Kinder“" auszuschlachten. Es ging darum, wie ein Bericht des Sicherheitsdienstes der SS bereits 1943 feststellte, die Gefühle des „Abscheus, der Verachtung und der Verbitterung“ zu stimulieren, sowie den Amerikanern gegenüber ein „seelisches und kulturelles Überlegenheitsgefühl“368 zu mobilisieren, denn schließlich wären „Mordbrenner und Banditentum“ der alliierten Luftangriffe der Beweis dafür, dass die USA „bewusst und absichtlich Kulturstätten, Krankenhäuser [... ] und sonstige zivile Objekte angreifen, um die Zivilbevölkerung zu terrorisieren.“369

Gemäß dieser Propagandavorgaben berichteten der Rheinische Merkur oder der Völkische Beobachter von haarsträubenden Ausschreitungen „sowjetischer Mordbestien“ und „anglo-amerikanischer Kriegsverbrecher“, ${ }^{370}$ die auf die „völlige Ausrottung des deutschen Volkes“ abzielen würden. ${ }^{371}$ Die Meldungen des NS-Propagandastabes überschlugen sich

366 Amerikanismus eine Weltgefahr. Reichsführer SS, a.a.O., 42.

367 Ebd., 43.

368 SD-Bericht zu Inlandsfragen, 2. Dezember 1943, Meldungen aus dem Reich. Zit. nach: Gassert, Amerika im Dritten Reich, a.a.O., 363.

369 Ebd.

370 Volkischer Beobachter, Nr. 305, 31. Oktober 1944.

371 Johannes Kleinschmidt, Amerikaner und Deutsche in der Besatzungszeit. Vom Fraternisierungsverbot zur deutsch-amerikanischen Freundschaft. Die Regulierung sozialer Beziehungen durch die amerikanische 
bis zuletzt mit ständig neuen erfundenen Horrormeldungen wie: „Zivilbevölkerung unter Negerbewachung zu Aufräumarbeiten im deutschen Artilleriefeuer gezwungen“, „Betrunkene Nigger morden deutsche Kinder“ oder „Verschleppung deutscher Kinder, Schokolade als Lockmittel“. ${ }^{372}$

Wie viel von diesen bizarren Gräuelmeldungen der NS-Propaganda seitens der ausgehungerten und erschöpften Bevölkerung gegen Kriegsende tatsächlich geglaubt wurde, bleibt offen; eine positive Einstellung zu den späteren US-Besatzern wird die NS-Propaganda, die - wie dargestellt - zu großen Teilen an bereits lange zuvor existierende Feindbilder und Negativ-Stereotype anknüpfen konnte, aber wohl kaum bewirkt haben.

Es ist daher nicht weiter erstaunlich, dass nach Kriegsende vor allem die unmittelbar durch die NS-Propaganda und -Ideologie geprägte ältere Generation den Segnungen der amerikanischen Besatzungsmacht, trotz aller unwiderlegbaren Hilfeleistungen bei der Nahrungsmittelversorgung und dem materiellen Wiederaufbau, mit einer gewissen Mentalreserve begegnete, die jüngere Generation die US-Besatzungssoldaten hingegen in Form von Schokolade und Kaugummi verteilenden GI's eher positiv erlebte und im Rückblick mit positiven Erinnerungen verknüpfte. ${ }^{373} \mathrm{~W}$ ie aus zahlreichen Interviews mit der Salzburger Nachkriegsbevölkerung hervorgeht, spukten in den Köpfen der durch zwei autoritäre Regime geprägten Generation unmittelbar nach Kriegsende durchaus noch Voreingenommenheit und handfeste ideologische Feindbilder vom „verjudeten, vernegerten“ und primitiven Amerika, ${ }^{374}$ die erst allmählich, nicht zuletzt auch durch die konkreten Begegnungen im Alltag, verblassten: „Und ich muß auch nach wie vor sagen: Wir sahen in

Armee in den Jahren 1944 bis 1949, Diss., Univ. Tübingen 1995, 86; zit. nach: Gassert, Amerika im Dritten Reich, a.a.O., 366.

372 Moltmann, Amerikaklischees der deutschen Kriegspropaganda, a.a.O., 307; Gassert streicht hingegen heraus, dass die NS-Propaganda weitgehend darauf verzichtet hätte, in dieser letzten Kriegsphase „rassistische Vorurteile der deutschen Bevölkerung gegenüber afroamerikanischen Soldaten zu mobilisieren." Zit. nach: Gassert, Amerika im Dritten Reich, a.a.O., 366. De facto hatte sich die nationalsozialistische Propaganda allerdings spätestens mit der Besetzung des Rheingebietes 1923, wo durch die Franzosen angeblich "nicht-weiße Regimenter" eingesetzt worden seien, einer aggressiv-rassistischen Rhetorik bedient und selbst den Kontakt zur „schwarzen Rasse“ als „Kultur- und Rasseschande“ gebrandmarkt: Die Franzosen, die „Schwarze und Gelbe als ihre Hüter in die Wiege der europäischen Kultur gesetzt haben“, hätten damit - als „weiße Neger“ - ,aufgehört, ein europäisches Volk zu sein.“ [Völkischer Beobachter, Nr. 23, 22. Februar 1923, 3 f.]. Zit. nach: Christian Koller, ,Von Wilden aller Rassen niedergemetzelt. Die Diskussion um die Verwendung von Kolonialtruppen in Europa zwischen Rassismus, Kolonial- und Militärpolitik (1919-1930), Stuttgart 2001,318. Noch am 22. März 1945 erinnerte der Volkische Beobacbter angesichts der vorrückenden „farbigen“ französischen und amerikanischen Soldaten auf der Titelseite an die einstige „schwarze Schmach“. Vgl. Christian Koller, Die „Schwarze Schmach“ - afrikanische Besatzungssoldaten und Rassismus in den zwanziger Jahren. In: Marianne Bechhaus-Gerst/Reinhard KleinArendt (Hrsg.), AfrikanerInnen in Deutschland und schwarze Deutsche - Geschichte und Gegenwart, Münster 2004, 166.

373 Gassert, Amerika im Dritten Reich, a.a.O., 367.

374 Bauer, Welcome Ami Go Home, a.a. O., 19 f. bzw. 46. 
den Amerikanern unsere größten Feinde. [...] Bis zu dem Zeitpunkt, als ich das erste Mal mit Amerikanern gesprochen habe, dann war plötzlich dieser Bann gebrochen. ${ }^{“ 375}$

An anderer Stelle erinnert sich eine damals I5-jährige Schülerin aus Radstadt an die ersten Begegnungen mit den amerikanischen Besatzern:

„Wir haben ja von den Nazis nie etwas Positives gehört über die Amerikaner - also eigentlich nur furchtbare Sachen, daß das die bösartigsten Menschen sind. Jetzt waren wir schon erleichtert, daß die wenigstens ganz normal gekocht haben $[\ldots]]^{“ 3} .{ }^{376}$

Einen positiven Effekt auf den Abbau von Vorurteilen und antiamerikanischen Einstellungen hatten sicherlich die trotz anfänglichen Fraternisierungsverbotes unmittelbar nach Kriegsende stattfindenden Kontakte zwischen den US-Besatzungssoldaten und der Bevölkerung in Deutschland und Österreich, wodurch es zur einer allmählichen „Normalisierung“ der Beziehungen kam, wie eine US-Studie bereits zwei Jahre nach Kriegsende darlegte. ${ }^{377}$

Eindrucksvoll liest sich der durch das konkrete Auftreten und die materiellen Hilfestellungen der GI's induzierte Meinungsumschwung in der Erinnerungsperspektive eines zu Kriegsende I3-jährigen Mädchens aus Bischofshofen:

„Ja, wir haben Angst gehabt, wir haben uns gefürchtet vor den Amis. Es hat ja bei den Nationalsozialisten immer geheißen, daß das ein grausames Volk ist, die Schwarzen, die Menschenfresser. Und dann kommen da lauter, Nikoläuse auf Jeeps ${ }^{`}$ - mit Schokolade und Kaugummi für die Kinder. ${ }^{\text {“378 }}$

Die tiefsitzende Gespaltenheit und die Ressentiments insbesondere der Soldatengeneration und der durch die NS-Indoktrinierung maßgeblich geprägten Jugendgeneration gegenüber den US-Besatzern - „das waren ganz normale Leute, nur halt doch primitiv“"379 - vermochten das Auftreten und die besatzungspolitischen Maßnahmen der, saloppen Sieger nur allmählich zu verändern.

375 Interview mit Herrn S., Jg. 1929. Ebd., 77. In etwas abgemilderter Form: „Für mich sind klarerweise die Amerikaner in der ersten Folge als Besatzer dagewesen, da gibt es keine Zweifel. Aber mit längerem Nachdenken, muss ich heute sagen, haben die Amerikaner für mich auch den Status von Befreiern gehabt." Interview mit Herrn H., Jg. 1928. Zit. nach: Bauer, Welcome Ami Go Home, a.a. O., 78. Unter den Parteigängern und Angehörigen der Waffen-SS hat die Prägung durch die NS-Ideologie zuweilen in ambivalenten Einstellungen überdauert: „Ich habe nie Haßgefühle gehabt. Die habe ich auch jetzt nicht. Aber mögen tue ich sie heute noch nicht, die Amerikaner." Interview mit einem ehemaligen Angehörigen der Waffen-SS, der im US-Entnazifizierungslager „Camp Marcus W. Orr“ (Glasenbach) interniert war, Jg. 1913, Ebd., 95.

376 Zit. nach: Bauer, Welcome Ami Go Home, a.a.O., 24.

377 Joseph R. Starr, Fraternization with the Germans in World War II. Occupation Forces in Europe Series, Frankfurt 1947, 23. Zit. nach: Oliver Matthias Arnold Schmidt, Civil Empire by Co-optation. GermanAmerican Exchange Programs as Cultural Diplomacy, 1945-1961, Diss., Univ. Harvard 1999, 96.

378 Zit. nach: Bauer, Welcome Ami Go Home, a.a.O., 24.

379 Ebd., 46. 
Wie Ingrid Bauer dargelegt hat, identifizierten sich Teile der Soldatengeneration ausgerechnet mit jenen Teilen der neuen Machthaber, die in der NS-Propaganda besonders negativ dargestellt worden waren. Gespräche mit Kriegsheimkehrern dokumentieren den „emotionalen Schulterschluß mit den schwarzen US-Soldaten“, deren Diskriminierung in pointierter Weise auf das eigene Lebensgefühl verwies: „Es hat damals so einen Spruch gegeben: Ich Mensch zweiter Klasse. Du Mensch zweiter Klasse‘, erzählt ein Interviewpartner. - Was das bedeute habe, fragte die Interviewerin. - Ja, daß die Neger in Amerika an zweiter Stelle waren, und wir in Österreich, weil wir den Krieg verloren haben. ““380

Grundsätzlich positiv standen den Amerikanern als „Platzhalter für jenes bessere Leben jenseits autoritärer Strukturen, geistiger Enge und Krieg, das Österreich erst zu realisieren galt $^{\text {“381 }}$, nur jene Menschen gegenüber, die das Ende der NS-Herrschaft in Österreich als Befreiung erlebt hatten.

Nach Kriegsende hatte es die US-Reeducation somit ohne Zweifel zunächst mit einer geballten Ladung an kultureller Ignoranz, politisch-rassistischen Vorurteilen und allgemeinem Bildungsdünkel gegenüber den USA zu tun. Hinzu kamen, wie Carl Zuckmayer in seinen geheimen Nachkriegsreports für die „Civil Affairs Division“ (CAD) des amerikanischen War Departments festhielt, so manche, realitätsfremde“ Unterlegenheitsgefühle vieler Deutscher, die angesichts der deprimierenden sozialen und wirtschaftlichen und ökonomischen Verhältnisse zuweilen in dumpfe emotionale Ressentiments umschlugen:

„Man hört natürlich eine ganze Menge anderer anti-alliierter oder anti-amerikanischer Slogans und Worte, wenn man sich - als Zivilist unter Zivilisten - umhört, in Eisenbahnen, Straßenbahnen, auf Ämtern, in Brot- und Kartoffelschlangen, wie z.B.: Ja, Hitler war schlecht, unser Krieg war falsch, aber jetzt tun sie dasselbe Falsche, sie sind alle gleich, es gibt keinen Unterschied, sie wollen Deutschland jetzt genauso versklaven, wie Hitler die Polen versklaven wollte, jetzt sind wir die Juden, die ,minderwertige Rasse', sie lassen uns mit Absicht aushungern, können Sie nicht sehen, daß dies ein Plan ist, sie nehmen uns alle unsere Erwerbsquellen, sie lassen uns langsam sterben, die Gaskammern arbeiteten schneller [...]. Es gibt eine weitere - eine primitivere Art von Haß, die von Ursachen und Ereignissen geschürt wird, wie es sie in jedem besetzten Land gibt [...] wie die Wut der Jungen und jungen Männer, deren Mädchen mit den ,Herren“ (denjenigen, die Zigaretten und Süßigkeiten besitzen) schlafen, oder der Groll von Menschen, die auf brutale Weise und mit unnötiger Härte aus ihren beschlagnahmten Häusern geworfen wurden - wie es manchmal gemacht wurde, unabhängig davon, ob diese Leute Nazis waren oder unter den Nazis gelitten haben. “382

380 Ebd., 72 .

381 Ebd., 74.

382 Carl Zuckmayer, Zusammenfassender Bericht über einen Auftrag in Deutschland und Österreich, November 1946 bis 31. März 1947. In: Carl Zuckmayer, Deutschlandbericht für das Kriegsministerium der Vereinigten Staaten von Amerika. Hrsg. v. Gunther Nickel et al., Frankfurt a. Main 2007, 72 f. 
Ressentiments dieser Art, die durch die schwierigen Lebensumstände der Nachkriegszeit gestärkt wurden - wobei die amerikanische Zone hinsichtlich der Versorgungslage und der individuellen Freiheiten noch immer als „beste“ galt ${ }^{383}$-, verflüchtigten sich allerdings mit zunehmender Stabilisierung der wirtschaftlichen und ökonomischen Situation.

Die Vorbehalte gegenüber Amerika, das sich nun nicht nur als militärische Besatzungsmacht, sondern darüber hinaus gegenüber der in tiefste Inhumanität und Barbarei abgedrifteten Deutschen auch als Kultur- und Bildungsnation gerierte, saßen jedoch tiefer und schliffen sich wohl insbesondere in den gebildeten Mittel- und Oberschichten erst allmählich und phasenverschoben zur wirtschaftlich-ökonomischen Wiederaufbau ab; Vorurteile und Vorbehalte, die sich unter anderem auch in der kulturellen Abwehrhaltung gegenüber der fremdländischen englischen Sprache dokumentierten, die vor allem die Lehrerschaft gegenüber dem als besonders inferior angesehenen amerikanischen Englisch einnahm. ${ }^{384}$

Erst infolge der vielfältigen aufklärerisch-propagandistischen Bemühungen der einschlägigen Abteilungen der US-amerikanischen Besatzungsmacht wie der „Education Division“ oder der „Information Service Branch“(ISB), die nach Kriegsende durch ein breites Angebot an Sprachkursen, durch Literatur- und Zeitschriftenspenden, Radiosendungen sowie durch Musik- und Filmproduktionen neben den vermittelten Inhalten auch die Sprachkompetenz zu heben bemüht waren, kam es nach 1945 zu einem allmählichen Anstieg der Englischkenntnisse in der österreichischen Bevölkerung. ${ }^{385}$

383 Ebd., 73.

384 Vor der „orkanartige[n] Verbreitung“ der „fremdvölkischen Denkungsart“ und der damit einhergehenden geistigen Verflachung selbst im britischen Englisch hatte bezeichnenderweise einer der ersten Vorstände des Instituts für Übersetzer- und Dolmetscherausbildung an der Universität Wien nach Kriegsende, Louis Heinrich Paulovsky, bereits in seiner 1943 approbierten Dissertation gewarnt. Siehe dazu: Wagnleitner, Coca-Colonisation, a.a.O., 199.

385 Freilich hatten daran auch die kulturpolitischen Aktivitäten der britischen Besatzungsmacht in Österreich einen Anteil, aber ohne Zweifel verfügte das amerikanische Besatzungselement über die weitaus größeren finanziellen, materiellen und organisatorischen Möglichkeiten. Hatten in Österreich 1948 lediglich knapp 20\% Englischkenntnisse, so stieg der Prozentsatz bis 1955 auf immerhin 50 an. Washington National Records Center (WNRC) 260/35/Surveys. Headquarters USF in Austria. ISB Survey Section. Report 44, 17. Mai 1948. Zit. nach: Wagnleitner, Coca-Colonisation, a.a.O., 200. 



\title{
2. „Education for Victory“ - US-Demokratisierungs- Konzepte und die zivilen Reeducation-Planungen für ein post-totalitäres Europa, 1941-1945
}

\begin{abstract}
"The importance of the military in today's struggle is clear to us all. My concern tonight is with an even more powerful weapon than the gun, and that is, the idea. [...]

What we must win now, during the war, are the principles"386
\end{abstract}

(Wendell L. Willkie, i6. November I942)

Bezüglich der während der Kriegsjahre entstandenen Reeducation-Konzepte ist zunächst interessant, wie das zuvor in Europa als weitgehend "kulturlos" angesehene Amerika angesichts der Bedrohung der gesamten „zivilisierten Welt“ durch Faschismus und Nationalsozialismus nicht nur mit einer tiefgehenden inneramerikanischen Bildungsreformdiskussion reagierte, sondern sich darüber hinaus - sozusagen vis à vis der NS-Barbarei - erstmals als führende „Kulturnation“ des Westens definierte, deren eigene politische, bildungspolitische und kulturelle Vorgaben für die projektierte Reeducation nach Kriegsende das zentrale Modell für die gesellschaftliche Demokratisierung bildeten.

Die fundamentale, weltweite Bedrohung von Freiheit, Frieden und Demokratie durch den Nationalsozialismus hatte gravierende Auswirkungen auf die Einschätzung Deutschlands als „Kulturnation“ in der amerikanischen Öffentlichkeit.

Der aggressive Antiamerikanismus der NS-Propaganda, die nationalsozialistische Verhöhnung von Pazifismus, Liberalismus, Demokratie und Parteienwesen, amerikanische Berichte über die Pervertierung des deutschen Erziehungswesens, über die Militarisierung der Gesellschaft, über brutalen Rassismus sowie über Konzentrationslager ${ }^{387}$ ersetzte bereits lange vor Kriegsausbruch das Bild Deutschlands als Land der „Dichter und Denker“ durch das eines in vollständige Barbarei ${ }^{388}$ zurückgefallenen Staates, dessen europäische

386 Wendell L. Willkie, Economic Freedom for the world. Address on Monday evening, November 16, 1942, before the Eleventh Forum on Current Problems, under the auspices of the New York Herald Tribune. Zit. nach: Representative American Speeches: 1942-1943. Selected by A. Craig Baird, New York 1943, 103 bzw. 108.

387 So wuchs sich ein Vortrag von Friedrich Schönemann am 26. November 1933 vor dem Ford Hall Forum in Boston in der amerikanischen Presse zu einem regelrechten Skandal aus, da er, angesprochen auf die Zustände in deutschen Konzentrationslagern, beschwichtigend erklärt hatte, dass die Insassen „[were] living in cleanliness and order, almost as though they were in college." Zit. nach: Gassert, Amerika im Dritten Reich, a.a.O., $121 \mathrm{f}$.

388 Vgl. Erika Mann, School for Barbarians. Education under the Nazis, New York 1938 [in Deutsch: Die Erziehung der Jugend im Dritten Reich, München 1986]. Über die Entwicklungen im totalitären Europa berichtete ein Fülle einschlägiger Literatur bzw. Fachliteratur, die z.T. in der Karl Stadler-Studienbi- 
Hegemonialpolitik zunehmend als politische und ideologische Bedrohung auch für die USA gesehen wurde.

Noch bevor die Auseinandersetzung mit dem Nationalsozialismus zu einem Waffengang unter Einsatz aller verfügbaren militärischen Mittel wurde, sah sich das zivilgesellschaftliche Amerika mit Ausbruch des Weltkrieges in einen fundamentalen Krieg der Weltanschauungen, in ein Armageddon zwischen Freiheit und Sklaverei ${ }^{389}$ hineingezogen, dessen unmittelbare Folge eine intensive nationale Selbstvergewisserung des Realzustands des US-Bildungssystems sowie der zugrundeliegenden moralisch-ideellen Werte bildete. In einer nach Kriegende publizierten Analyse verwies der US-Bildungswissenschafter Isaac L. Kandel ${ }^{390}$ darauf, dass die US-Regierung spätestens ab I940 intensiviert Fragen nach dem Zusammenhang von Wehruntauglichkeit bei jungen Rekruten, Illiterarität und sozialer Ungleichheit aufgegriffen wurden:

"World War II brought the country to a clear realization that education is a national concern and that, if the faith of the American people in education and in the ideal of giving every potential citizen a chance for his fullest development is to continue, the resources of the nation

bliothek des Österreichischen Volkshochschularchivs in Originalausgaben erhalten ist. So z.B.: Winfred Ernest Garrison, Intolerance, New York, 1934; Franz Neumann, The Decay of German Democracy. In: The Political Quarterly, 1933, Heft 4, 525-543; Fredrick L. Schumann, Nazi Dictatorship. A Study in Social Pathology and the Politics of Fascism, New York 1936; Howard R. Marraro, The New Education in Italy, New York 1936; Margaret M. Ball, Post-War German-Austrian Relations: The Anschluss Movement, 1918-1936, Stanford 1937; Richard Keane (Ed.), Germany what next? London 1939; Konrad Heiden, One man against Europe, London 1939; Jan Peterson, Germany beneath the Surface. Stories of the Underground Movement, London - Melbourne 1940; Franz Neumann, Behemoth. The Structure and Practice of National Socialism, London 1942; Oscar Paul, Underground Europe, London 1942; H.R. Knoickerbocker, Is tomorrow Hitler's? 115 Questions on the battle of mankind, London 1941; Walter M. Kotschnig, Slaves Need No Leaders. An Answer to the Facist Challenge to Education, New York 1943.

389 „Democracy is freedom“ schrieb die New York Times August 1939 und fügte an: „The contest to-day is not between democracy and something newer and therefore presumably better called totalitarism. It is a choice between the familiar thing called freedom and the very old thing called slavery." New York Times, August 1939. Zit. nach: School and Society, Vol. 50, No. 1286, August 19, 1939, 250.

390 Isaac Leon Kandel (1881-1965), gebürtiger Rumäne und aufgewachsen in Großbritannien, studierte an der University in Manchester Erziehungswissenschaften, wo er bei Michael Sadler über die Lehrerausbildung in deutschen Grundschulen promovierte. Kandel, der viel reiste und auch beim Herbartianer Wilhelm Rein an der Universität Jena studierte, entwickelte sich bald zu einem der führenden vergleichenden Erziehungswissenschafter. Nach Fertigstellung einer Studie über Woodrow Wilson gemeinsam mit Paul Monroe 1918 nahm er 1920 die amerikanische Staatsbürgerschaft an; 1923 wurde Kandel ordentlicher Professor am Teachers College der Columbia University. In der Folge hatte Kandel u.a. Gastprofessuren an den Universitäten Yale und Johns Hopkins inne. Siehe: Erwin Pollack, Isaac Leon Kandel (18811965). In: PROSPECTS. The Quarterly Review of Comparative Education, Vol. 23, No. 3/4, 1993, $775 \mathrm{ff}$. Kandel war u.a. auch Autor des Buches „The Making of the Nazis“, New York 1935, in dem er sich u.a. eingehend mit der NS-Erziehung beschäftigte. 
must be pooled. [...] During the war realization of the existing inequalities was sharpened by the reports of the Selective Service on the number of young men who had to be rejected on account of mental and physical deficiencies. The figures on illiteracy only helped to confirm the reports of the census of 1940 on the subject." 391

Erst im Kontext der breit geführten inneramerikanischen Auseinandersetzung zu den Werten und Grundlagen der Demokratie tauchten erste Überlegungen hinsichtlich der Frage auf, was in der historischen Entwicklung des „deutschen Charakters“ schief gelaufen sein könnte und wie nach Kriegsende durch geeignete Rekonstruktions-Maßnahmen eine nachhaltige, friedensichernde Demokratisierung der Achsenmächte zu erreichen wäre.

\author{
„EDUCATION IN WARTIME“- NATIONALSOZIALISMUS ALS \\ FUNDAMENTALBEDROHUNG DER US-AMERIKANISCHEN ZIVILGESELLSCHAFT
}

„Tarzan: Jetzt ist Sandra vor ihnen sicher. Was sind das für Männer? Sandra: Deutsche Soldaten. Sie haben unser Volk zu Sklaven gemacht. Tarzan: Du meinst, diese Männer sind Nazis?“392 TARzan Triumphs (Tarzan and the Nazis), I943

Die Ausbreitung des Faschismus beziehungsweise des Nationalsozialismus in Europa, die schnellen Erfolge des deutschen „Blitzkriegs“ im Frühjahr und Sommer 1940, der ideologische Kreuzzug gegen Amerika und seine Werte und Ideale der „free world“, aber auch die Parteinahme und Unterstützung Großbritanniens bei gleichzeitiger Intensivierung der eigenen Verteidigungsbereitschaft hatten zur Folge, dass in der amerikanischen Öffentlichkeit eine breite Diskussion über demokratische Grundwerte und die notwendige Stärkung der geistigen Abwehrkräfte der Nation einsetzte.

391 I.L. Kandel. The Impact of the War upon American Education, Chapel Hill, N.C. 1948, 7.

392 Im Kampf gegen den Nationalsozialismus wurden auch populäre Filmstoffe des US-Unterhaltungskinos in allegorisch-parodistischer Weise ideologisiert. In der vom U.S. State Department finanzierten Filmproduktion „Tarzan Triumphs“ (Tarzan und die Nazis) 1943 unter der Regie des emigrierten österreichischen UFA-Regisseurs William [Wilhelm] Thiele (1890-1875) kämpft Johnny Weismüller auf Basis der Romanvorlage des Tarzan-Erfinders Edgard Rice Burroughs gegen im Dschungel abgestürzte Nazis und schreckt dabei selbst nicht vor grausamen Bestrafungsmaßnahmen zurückt. In einer Szene telephoniert Tarzans Schimpanse Cheeta mit Grunz- und Kreischlauten mit NS-Offizieren in Deutschland und wird dabei akkurat für den „Führer“ gehalten. Vgl. Rudolf Ulrich, Österreicher in Hollywood, Wien 2004, $523 \mathrm{f}$; w weiters: Caroline Joan Picquard, The Holocaust Film Source book. Documentary and Propaganda, Westport 2004, 472 f.; zu Wilhelm Thiele siehe: Klaus Kreimeier, The Ufa-story. A history of Germany's greatest film company, 1918-1945, New York 1996, 325 f. 
Bevor Fragen zu konkreten Maßnahmen im Zusammenhang des „postwar planning“ erhoben wurden und die Debatte um die Reeducation des totalitären Europa zu den Werten von Demokratie und Freiheit begann, etablierte sich, angeführt vom Diskurs an Colleges, Universitäten und in akademischen Fachzeitschriften ein mit großem Aufwand geführter nationaler Abwehrkampf; darin ging es um Aufklärung über die Grundlagen der Demokratie, um die Stärkung der nationalen Moral und um eine vorbeugende „Impfung“ gegen indoktrinär-dogmatische Beeinflussung.

$\mathrm{Ab}$ dem Ende der Dreißigerjahre erschien in den USA eine regelrechte Flut von $\mathrm{Pu}-$ blikationen auch überaus prominenter Autoren wie unter anderen vom Kultursoziologen Lewis Mumford ${ }^{393}$ oder vom Politikwissenschafter Harold J. Laski, ${ }^{394}$ die sich mit Fragen der Erziehung zur Demokratie, der Bedrohung westlicher Zivilisation oder der Erziehung im Faschismus und Nationalsozialismus beschäftigten. ${ }^{395}$

Die Eindringlichkeit und Intensität, mit der in diesem Zusammenhang gerade Erziehungsfragen gestellt wurden, erklärt sich aus der zentralen Rolle und Bedeutung, die „Education“ innerhalb der amerikanischen Demokratie seit jeher inne hat.

Von Thomas Jefferson, über Horace Mann bis hin zu John Dewey, ${ }^{396} \mathrm{dem}$ wohl bedeutendsten amerikanischen Erziehungstheoretiker und Pädagogen, beruht der Glaube - der „Pedagogic Creed“397 - an ein stabiles Funktionieren der pluralistischen, individuell-egalitär organisierten demokratischen Gesellschaft der Vereinigten Staaten traditionell auf der Vorstellung einer durch praktische demokratische Erfahrung („learning by doing“) und Wissen gebildeten Öffentlichkeit. Nicht Lernen als Selbstzweck, sondern Lernen verstanden als "problem solving“, ${ }^{398}$ eine auf aktive Partizipation gerichtete soziale Erziehung, ${ }^{399}$

393 Lewis Mumford, Faith for Living, New York 1940.

394 Harold J. Laski, The Rights of Man, London 1940.

395 Vgl. Alina M. Lindgren, Education in Germany (U.S. Department of the Interior, Office of Education Bulletin, No. 15), Washington D.C. 1939; Hermann Rauschnig, The Voice of Destruction, New York 1940; Lyman Bryson, Which Way America? Communism - Fascism - Democracy, New York 1939; Hans Kohn, Not by Arms Alone. Essays on our Time, Cambridge 1940; Edward Charles Merriam, The New Democracy and the New Despotism, New York 1939; Ralph Barton Perry, Shall Not Perish From the Earth, New York 1940; Douglas Miller, You Can’t Do Business With Hitler, Boston 1941. Darüber hinaus lag auch die kurzgefasste Darstellung des NS-Reichsministers für Wissenschaft, Erziehung und Volksbildung, Bernhard Rust, in Englischer Übersetzung auf: Bernhard Rust, Education and the Third Reich, London 1939.

396 John Dewey (1859-1952), US-amerikanischer Philosoph und bedeutender Erziehungsreformer, der über Immanuel Kant dissertiert hatte und das europäische Bildungssystem gut kannte. In seiner 1915 veröffentlichten Schrift „Imperial Germany and the Industrial revolution“ kritisierte Dewey die militaristischautokratischen Aspekte der deutschen Kulturtradition, die er insbesondere durch den deutschen Idealismus geprägt sah. Siehe: Deutsch-Amerikanischer Kulturaustausch im 20. Jahrhundert, a. a. O., 49.

397 So der Titel der berühmten und nachhaltig prägenden Erklärung Deweys zu Fragen der Erziehung. Vg1. John Dewey, My Pedagogic Creed. In: The School Journal, Vol. LIV, No. 3, January 16, 1897, 77-80.

398 John Dewey, Progressive Education and the Science of Education. In: Progressive Education, 5, 1928, 197.

399 An dieser Stelle ist zu erwähnen, dass die antiautoritär ausgerichtete deutsche Reformpädagogik von der Jahrhundertwende bis in die Zwanzigerjahre („Jena-Plan“) starke Anleihen an Deweys Theorie be- 
die Idee der Verantwortlichkeit des Einzelnen, die Ausbildung eines gemeinsamen Wertesystems auf Basis des puritanischen Glaubens an individuelle Leistungsfähigkeit sowie die Leitidee ,that all man are created equal“ ${ }^{\text {“400 }}$ bilden die Elemente, aus denen sich nach Auffassung der pragmatischen Erziehungsphilosophie der Fortschritt und die Integration der Gesellschaft - trotz aller ethnisch-kulturellen Unterschiede der gesellschaftlichen Gruppen - zusammensetzen. ${ }^{401}$ Die Realität des „Pedagogic Creed“ bestätigte auch der in die USA emigrierte Carl Zuckmayer in seinem nach Kriegsende erschienenen Amerikabericht, worin er der traditionell autoritären Bildungsauffassung Europas unter anderem die amerikanische gegenüberstellte:

\begin{abstract}
"Amerika glaubt an Erziehung, das ist einer seiner fundamentalen Glaubensartikel, an Erziehung als Mittel zur Welt- und Lebensgestaltung und an die Erlernbarkeit alles Wesentlichen, und darin liegt auch ein Teil seiner Schwäche und seiner Stärke. Europa glaubt aus seiner humanistischen Tradition heraus an Bildung, die in ihrer höchsten Bedeutung an ein Privileg gebunden ist, ein Privileg der Berufung oder der Standesvorzüge. Amerika kennt kein Privileg, darin liegt seine wunderbare menschliche Freiheitlichkeit und Generosität. ${ }^{“ 402}$
\end{abstract}

Im direkten Gegensatz zur „etatistisch-autoritären deutschen und japanischen Erziehungsphilosophie“, ${ }^{403}$ die Bildungs- und Erziehungsprozesse weitgehend abgekoppelt vom öffentlichen politischen Leben betrachtet, ist die pragmatische Auffassung von

ziehungsweise am amerikanischen Bildungs- und Erziehungssystem (Stichwort: koedukative Einheitsschule) nahm. Vgl. dazu: Val D. Rust, The German Image of American Education through the Weimar Period. In: Paedagocica Historica. International Journal of History of Education, XXXIII, 1997, 1, $31 \mathrm{ff}$; weiters: Hermann Röhrs, Progressive Education in the United States and ist Influence on Related Educational Developments in Germany. In: Ebd., $55 \mathrm{ff}$.

400 So der Wortlaut der amerikanischen Unabhängigkeitserklärung vom 4. Juli 1776. Vgl. Henry Steele Comager (Ed.), Documents of American History, New York 1942, 100.

401 In einer Rede vor dem „National University Extension Association meeting“ meinte der Präsident der University of California, Robert Gordon Sproul, diesbezüglich: „Americans have made almost a fetish of public education because it was obvious that, without the tools of intelligence and without facts to serve intelligence as guideposts, the people of this country would be unable to function efficiently as citizens of a democracy, and the Constitution would become only a scrap of paper recording a dream that could not be realized. [...] If democratic individuals are to hold their own against the increasing pressure of totalitarian sycophants, education must be a lifetime process." Robert Gordon Sproul, Adult Education and the State. In: School and Society, Vol. 50, August 12, 1939, No. 1285, 192-193.

402 Carl Zuckmayer, Amerika ist anders. In: Alfred Gong (Hrsg.), Interview mit Amerika. 50 deutschsprachige Autoren in der neuen Welt, München 1962, 396.

403 Beate Rosenzweig, Erziehung zur Demokratie? Amerikanische Besatzungs- und Schulreformpolitik in Deutschland und Japan, Stuttgart 1995, 69; siehe dazu weiters: Felicitas Hentschke, Demokratisierung als Ziel der amerikanischen Besatzungspolitik in Deutschland und Japan 1943-1947 (= Studien zu Geschichte, Politik und Gesellschaft Nordamerikas, Bd. 16), Hamburg 2001; vgl. dazu auch: James F. Tent, Mission on the Rhine. Reeducation and Denazification in American-Occupied Germany, Chicago - London 1982, $5 \mathrm{ff}$. 
„education“ in der amerikanischen Demokratie synonym gesetzt mit Demokratie selbst gewissermaßen Demokratie in actu. ${ }^{404}$ So gesehen ist Demokratie freilich eng mit zivilgesellschaftlicher Aktivität verknüpft: „Democracy is not merely a form of government but a way of life, a set of social habits, a code of ethics. “ ${ }^{\text {"405 }}$

Diese leitmotivische Auffassung eines direkten politischen Konnexes zwischen Demokratie und „Education“ brachte Präsident Franklin D. Roosevelt auf den Punkt, indem er 1932 anlässlich einer Rede konstatiert hatte: „the greatest duty of a statesman is to educate. ${ }^{406}$ Und sieben Jahre später präzisierte er - angesichts des soeben ausgebrochenen Zweiten Weltkrieges - in einem offenen Brief an alle „Patrons, Students, and Teachers of American Schools“ die humanitäre Mission amerikanischer Erziehung und Bildung:

"From kindergarten through college our schools train us to use the machinery of reason; parliamentary practice; the techniques of cooperation; how to accept with good grace the will of a majority; how to defend by logic and facts our deep convictions. This is education for the American way of life $[\ldots]$. To the resolution of conflicts and struggles of life, democracy supplies no easy answer. The easy answer, the quick but incomplete answer, is force: tanks and torpedoes, guns and bombs. [...] In our schools our coming generations must learn the most difficult art in the world - the successful management of democracy. [...] And let us hope that out of our schools may come a generation which can persuade a bleeding world to supplant force with reason." ${ }^{407}$ [Hervorhebung d. Verf.]

Vor dem Hintergrund dieses spezifisch politischen Verständnisses von demokratischer „Education“ innerhalb der amerikanischen Gesellschaft erklären sich die intensiven Aktivitäten, die ab 1939 im Kontext der „Education in Wartime“ zu verzeichnen sind.

Den Auftakt bildete ein dreitägiger, groß angelegter „Congress on Education for Democracy“ unter Begleitschutz von Präsident Franklin D. Roosevelt, der am 15. August I939 am Teachers College der Columbia University in New York eröffnet wurde, und an dem -

404 Nach Deweys Vorstellung sollte jede Schule in nuce ein demokratisches Labor darstellen. „To do this means to make each one of our schools an embryonic community life, active with types of occupations that reflect the life of the larger society and permeated throughout with the spirit of art, history, and science." John Dewey, The School and Society, Chicago 1942 [1900], 27.

405 Edwin G. Conklin, Education for Democracy [Eröffnungsansprache vor der vierten Generalversammlung der National Education Association in San Francisco am 5. Juli 1939]. Abgedruckt in: School and Society, Vol. 50, Saturday, August 5, 1939, No. 1284, 161.

406 Franklin D. Roosevelt anlässlich einer Rede vor dem Commonwealth Club in San Francisco 1932. In: Samuel I. Rosenman (Ed.), The Public Papers and Addresses of Franklin Roosevelt. Vol. I: The Genesis of the New Deal, 1928-1932, New York 1938, 742-756.

407 Offener Brief von Franklin D. Roosevelt anlässlich der „American Education Week“: „To the Patrons, Students, and Teachers of American Schools“, The White House, Washington D.C., October 2, 1939. Abgedruckt in: School and Society, Vol. 50, Saturday, October 28, 1939, No. 1296, 1. 
neben zahlreichen amerikanischen und britischen Wissenschaftern - unter anderen der frühere britische Premierminister, Stanley Baldwin (Earl Baldwin of Bewdley), der Präsident des französischen Abgeordnetenhauses, Edouard Herriot, der frühere polnische Minister John M. Ciechanowski sowie Ernest Bevin, späterer britischer Arbeits- und Außenminister und zum damaligen Zeitpunkt Generalsekretär der britischen Transportarbeitergewerkschaft, teilnahmen. ${ }^{408}$

In der Vorankündigung der Konferenz verwies der Präsident der Columbia University, Nicholas Murray Butler, ${ }^{409}$ auf die Zielsetzung der Zusammenkunft, nämlich auf die Verteidigung der Demokratie , as a form of government and as a way of life" durch Erziehung: "If we would protect democracy we must learn to defend it. We must also learn to advance it, and this defense and advance must come in the democratic way, the democratic spirit. That is why it is a problem of education. " ${ }^{410}$

In seiner Eröffnungsrede verstand es der Dekan des Teachers College an der University of Columbia, William F. Russel, die Frage nach der spezifischen Verantwortung der „Education" hinsichtlich der Verteidigung der Demokratie in eine prägnante Formel zu gießen:

"The 'first line of defense' of democracy is education. You cannot shoot an idea. The defense against a bad idea is a better idea; the defense against a half truth is a truth; the defense against propaganda is education; and it is in education that democracies must place their trust." ${ }^{\text {411 }}$ [Hervorhebung d. Verf.]

Den elementaren Zusammenhang von Bildung und Erziehung mit dem Funktionieren einer gelebten Demokratie strich auch US-Präsident Roosevelt in einem offenen Geleit-

408 Unter den teilnehmenden amerikanischen Institutionen befanden sich unter anderen: die American Association of University Women, die American Bankers Association, die American Federation of Labor, die National Association of Manufacturers, der National Negro Congress, die Chamber of Commerce of the United States of America, der Congress of Industrial Organization, die Farmers' Educational and Cooperative Union of America, die American Association of Advertising Agencies, Kiwanis International, Lions International oder der National Congress of Parents and Teachers. In Summe verzeichnet das Educational Directory des U.S. Office for Education 1941 über 450 bundesweit (!) agierende Bildungseinrichtungen.

409 Der Pädagoge und Friedensnobelpreisträger [1931] Nicholas Murray Butler (1862-1947), der Mitte der 1880er Jahre bei Johann G. Droysen und Friedrich Paulsen in Berlin studiert hatte, war bereits Jahrzehnte zuvor einer jenen zentralen US-amerikanischen Gelehrten, die sich aktiv für einen amerikanisch-deutschen Kulturaustausch einsetzten: so hatte er 1906 die „Roosevelt-Bibliothek“ in Berlin begründet, aus der dann das „Amerikanische Institut“ hervorging, und organisierte bereits ab 1905 einen Professorenaustausch zwischen der Columbia University und der Universität Berlin. Vgl. Schmidt, Civil Empire by Co-optation, a.a.O., 56; weiters: Füssl, Deutsch-Amerikanischer Kulturaustausch im 20. Jahrhundert, a.a.O., 53 f.

410 Zit. nach: The Congress on Education for Democracy. In: School and Society, Vol. 50, Saturday, October 28, 1939, No. 1281, 80.

411 Zit. nach: Raymond Walters, The Congress on Education for Democracy. In: School and Society, Vol. 50, Saturday, August 26, 1939, No. 1287, 260. 
Brief zur Konferenz an Dekan Russel hervor, dessen Wortlaut im Anschluss an die „keynote“ verlesen wurde. Darin formulierte Roosevelt:

"Everyone knows that democracy can not long stand unless its foundation is kept constantly reinforced through the process of education. [...] Education or democracy cannot merely be taken for granted. What goes on in the classroom must be checked against the fact that the children are growing up to live in a democracy." ${ }^{412}$

Als früherer Politiker strich Ciechanowski in seinem Statement die zentrale Rolle der USA heraus, indem er darauf verwies, dass es angesichts der derzeitigen „Sünden gegen die Demokratie“ in der „Alten Welt“ wohl keinem Europäer anstünde, in Amerika Demokratie zu predigen, denn schließlich wäre das amerikanische Volk „certainly the most truly democratic people in the world. “413 Ein Jahr später fasste H[erbert] G[eorge] Wells anlässlich einer Rede in New York die Führungsrolle Amerikas im Kampf für Demokratie und Freiheit dann bereits in noch deutlichere Worte: „Mankind may expect America to be the intellectual synthesis of the world in the next few years. " ${ }^{414}$

Der britische Beitrag zur Konferenzdebatte von Stanley Baldwin, der „Freiheit“ und „Unabhängigkeit“ als gemeinsame Wurzeln der beiden Staaten hervorhob, fokussierte angesichts Europas „challenge to the death“ bereits klar auf das kriegsbedingte Erfordernis einer intensiven Selbstvergewisserung demokratischer Ideale sowie einer Stärkung der nationalen Moral. Freiheit und Demokratie, so Baldwin, seien nicht wie „Manna vom Himmel gefallen“, sondern wurden von Generationen unter größten Mühen erkämpft. Die Mehrheit der Bevölkerung hätte allerdings vergessen, „that this freedom was bought with a great price“. Anders als in einem totalitären Staat käme es in einer Demokratie in Zeiten einer äußeren Bedrohung auf die Verantwortung des Einzelnen an, sich seiner Pflicht zu besinnen. „That calls for education and character“, wie Baldwin weiter ausführte, denn schließlich ginge es ums Ganze: „A democrat should work for and be prepared to die for his democratic ideals, as the Nazis and Communists are for theirs. " 415

Auf amerikanischer Seite sah man das Problem ähnlich, jedoch bereits mit kritischem Anmerkung gegenüber den Schwächen der englischen „Education, ${ }^{416}$ die es zu vermeiden gälte:

412 Zit. Nach: Kandel. The Impact of the War upon American Education, a.a.O., $13 \mathrm{f}$.

413 Ebd., 261.

414 Zit. nach: H.G. Wells et al., Present Views on the Post-War World. In: School and Society, Vol. 52, December 21, 1940, No. 1356, 652 .

415 Earl Baldwin of Bewdley, The Ideals of Democracy. In: In: School and Society, Vol. 50, Saturday, August 26, 1939, No. 1287, 267.

416 Die britische „Gerontocracy“ hätte sich traditioneller Weise auf akademische Elitenkultur beschränkt und es dabei verabsäumt „, [to] learn, as we have not learned, that the ideals of a nation must be continually clarified $[\ldots]$ and $[\ldots]$ to translate them into practical procedures under new conditions.“ Thomas H. Brigs, The Ramparts we defend. In: School and Society, Vol. 52, Saturday, September 7, 1940, No. 1341, 147. 
"To defend the ramparts of the civilization that we hold dear, we must avoid the weaknesses that we recognize in England, our moral ally, and we must be wise enough to learn from the strengths of Germany, the menacing threat to democracy. We are not willing to use all its means; but we are challenged to invent and to use better ones that are consistent with the life that we wish to protect and to promote." ${ }^{417}$

Die Columbia-Konferenz war kaum zu Ende gegangen, als Hitler-Truppen in Polen einfielen, Frankreich und Großbritannien am 3. September 1939 Deutschland den Krieg erklärten und die Verteidigung der Demokratie somit zur harten Realität wurde. Am 8. September des Jahres erklärte Präsident Roosevelt, dass eingeschränkte „nationale Gefahr“ bestehe. ${ }^{418}$ Einen Monat später gab die „Educational Policies Commission“ eine Broschüre mit dem Titel "American Education and the War in Europe" heraus, in deren Vorwort die human-demokratische Dimension eines nationalen Abwehrkampfes („Education for a Day of Peace") umrissen wurde und worin ansatzweise erstmals auch ein bildungspolitisches Aufgabenspektrum nach Kriegsende auftaucht:

\footnotetext{
"Those who are commissioned by society in the service of education should be the last to capitulate to the forces of hatred, greed, and fear. With the darkness of war falling upon the world, the United Sates becomes more than ever a reservoir of hope for a humane and democratic order among men. When peace comes again, as come it must, the people of the United States ought to be prepared to play their part - sanely, bravely, and generously, in the process of rebuilding a world order from which the threat of war and violence may be removed. Those who are to fulfill that mission can approach the task best if their hands are unstained by blood, their spirits uncorroded by hatred, and their minds uncrippled by months or years of wartime regimentation." ${ }^{19}$
}

Nach Kriegsausbruch und im Gefolge der Columbia-Konferenz entwickelte sich die Auseinandersetzung mit Fragen der öffentlichen Moral, der Festigung demokratischer Loyalität sowie der Stärkung der geistigen Verteidigungsbereitschaft zu einem landesweit heiß diskutierten Thema. Radiosendungen des „Wake Up America Programs“ “20 strahlten Vorträge, öffentliche politische Debatten und „round-table“-Diskussionen aus, Aufnahmen

417 Ebd.

418 Zit nach: Kandel. The Impact of the War upon American Education, a.a.O., 14.

419 Zit nach: ebd.

420 So z.B. „How can we defend Democracy in America now?“ (5. Oktober 1939) oder „Our Liberties and Civil Rights and Public Dangers" (1941). Education in Wartime and After. Hrsg. v. Stanford University/School of Education Faculty, New York - London 1943, 57. 
von NBC Radiosendungen ${ }^{421}$ wurden in Schulklassen vorgeführt und diskutiert, ${ }^{422} \mathrm{Ra}-$ dio-Hörspielfolgen wie „Let Freedom Ring“ ${ }^{423}$ beschäftigten sich in eindringlicher Form mit der amerikanischen Verfassung und den US-Bürgerrechten, Filme thematisierten Geschichte und Gegenwart des American way of life, ${ }^{424}$ Zeitschriften, Bücher und Handbücher setzten sich mit dem Thema „Civilian Education and Morale“425 auseinander, und die unter gemeinsamer Leitung des „National Council for the Social Studies“ und der „National Association of Secondary School Principals“ stehende „Ressource unit“ gab eine eigene Schwerpunktschriftenreihe mit dem Titel „Democracy versus Dictatorship“426 heraus.

Auf den universalen Konflikt zwischen nationalsozialistischer Tyrannei und der Bedrohung der demokratischen Freiheit sowie auf das damit verbundene ,awakening of America“ verwies auch das von einem Autorenkollektiv I940 herausgegebene demokratische Manifest „The City of Man“, ${ }^{427}$ worin der weltgeschichtliche Siegeszug des demokratischen Systems als unaufhaltbar beschworen und bezüglich einer künftigen Weltordnung mit geradezu emphatischem Ton prognostiziert wurde:

421 So z.B. das am 15. Dezember ausgestrahlte Programm „We Hold These Truths“. Vgl. Education in Wartime, a.a.O., 204.

$422 \mathrm{Zu}$ diesem Zweck wurde vom National Council on Education - neben dem American Council on Education (ACE) eine der bundesweit größten Dachverbandsorganisationen der US-Bildungseinrichtungen, in Zusammenarbeit mit der National Broadcasting Company eine eigene Recordings Division eingerichtet, die Radioaufzeichnungen Schulen und andere Bildungseinrichtungen zur Verfügung stellte. Vgl. Education in Wartime, a.a.O., 57.

423 Ebd. $57 \mathrm{f}$.

424 So z. B. „Declaration of Independence“, „The story that couldn't be printed“, „Son of Liberty“, „Servant of the People“ [Geschichte der US-Verfassung], „Mr. Smith Goes to Washington“ [R: Frank Capra, 1939; mit James Steward], ,The Howards of Virginia“ [R: Willard Huyck, 1940; mit Cary Grant], „Abe Lincoln in Illinois“ [R: John Cromwell, 1940], ,Sergeant York“ [R: Howard Hawks, 1941; mit Gary Cooper] Siehe: American Council on Education. Films for America at War. Supplement, Number 1 to Selected Educational Motion Pictures. Prepared for the Committee on Motion Pictures in Education, Washington D.C. 1942; Mary Losey, Films for the Community in Wartime (National Board of Review of Motion Pictures), New York 1943; weiters: Education in Wartime, a.a.O., $56 \mathrm{f}$.

425 Education and the Defense of American Democracy. Educational Policies Commission/National Education Association of the United States, Washington D.C. 1940; Paul V. McNutt, Civilian Morale and the Colleges. In: Education Digest, 6, March 1941, 52-55; Ralph Barton Perry, The Meaning of Morale. In: Educational Record, 22, July 1941, 446-460; Benjamin Sprock et al., The Contribution of Development to Morale. In: Progressive Education, 18, May 1941, 240-264; Lawrence A. Averill, Civilian Moral and Mental Health. In: School and Society, Vol. 57, February 13, 1943, No. 1469, $169 \mathrm{ff}$.

426 Siehe: T.V. Smith/Glenn Negley/Robert Bush, Democracy versus Dictatorship (Problems in American Life: Unit No. 10), Washington D.C. 1942.

427 The City of Man. A Declaration on World Democracy, New York 1940. Unterzeichnet wurde das Manifest u.a. auch von prominenten europäischen Emigranten: Herbert Agar, Christian Gauss, Frank Aydelotte, Oscar Jaszi, G. A. Borgese, Alvin Johnson, Hermann Broch, Hans Kohn, Van Wyck Brooks, Thomas Mann, Ada L. Comstock, Lewis Mumford, William Yandell Elliott, William Allan Neilson, Dorothy Canfield Fisher, Reinhold Niebuhr und Gaetano Salvemini. 
"Universal and total democracy is the principle of liberty and life which the dignity of man opposes to the principle of slavery and spiritual death represented by totalitarian autocracy. No other system can be proposed to the dignity of man, since democracy alone combines the fundamental characteristics of law, equality, and justice. [...] Democracy, therefore, is an ancient hope of man calling for fulfillment in the coming age of man. Its unity rests upon three principles. The first is universal participation in government, through the direct expression of referendum or town meeting, or through electoral mandate, or even - when the stress of time so commands - through the delegation of all authority to a responsible chief executive freely chosen by the people by the people, the foundation of law. [...] The second principle emphasizes that the state is the agent of collective human purposes, the servant of the common good $[\ldots]$. The third principle, fundamental to the other two, establishes that a democratic community is a community of persons. Democracy, therefore, cannot be run by robots and automatons, by serfs and slaves." ${ }^{428}$

\section{„OUR COUNTRY'S CALL TO SERVICE“ - KONKRETE \\ AUSWIRKUNGEN DES VERTEIDIGUNGS- UND ABWEHR-DISKURSES}

Neben der großen Zahl ziviler amerikanischer (Bildungs-)Organisationen, ${ }^{429}$ die ihre Ressourcen in die „Education in Wartime“ einbrachten, gingen - neben US-Regierungsstellen, die diese Aktivitäten unterstützten - insbesondere auch neugeschaffene Behörden in die Offensive, mit dem Ziel, die Öffentlichkeit auf einen Krieg gegen NS-Deutschland beziehungsweise gegen die Achsenmächte vorzubereiten. ${ }^{430}$

428 The City of Man. A Declaration on World Democracy. 3. Aufl., New York 1941 [1940]. Ebd., 28 f.

429 Darunter, unter vielen anderen: American Association for Social Security, American Council on Education, American Council on Public Affairs, American Economic Foundation, American Education Press, American Federation of Labor, American Jewish Committee, American Civil Liberties Union, American Library Association, American Public Welfare Association, Carnegie Endowment for International Peace, Catholic Association for International Peace, Civil Service Commission, Commission on Interracial Cooperation, Council for Democracy, Czechoslovak National Council America, Institute for Adult Education, Inter-Allied Information Center/Center for Information on Studies in Postwar Reconstruction, Investment Bankers Association America, National Association for Advancement of Colored People, National Association of Manufactures, National Bureau of Economic Research, Office of Civilian Defense, National Opinion Research Center, Office of War Information/Bureau of Public Inquiry, The Post-War World Council, Transport Association of America, U.S. Department of Agricu1ture, U.S. Department of Labor, U.S. Department of State, U.S. Information Service, U.S. Office of Education, World Peace Foundation.

430 Vgl. Richard W. Steele, Preparing the Public für War: Efforts to Establish a National Propaganda Agency, 1940-41. In: The American Historical Review, Vol. LXXV, October 1969 to December 1970, 1640-1653. 


\section{Binnenamerikanische Reeducation: Stärkung nationaler Moral, Militarisierung des Bildungswesens und Bildungsreform}

Die ersten Anfänge einer Institutionalisierung der amerikanischen „Missionsidee“431 von der „Auserwähltheit Amerikas als Hort eines geglückten demokratischen Experiments “432 beziehungsweise der programmatischen Gleichsetzung von individueller Freiheit und ökonomischer Prosperität $t^{433}$ datieren zwar ins 19. Jahrhundert zurück und eine erste sowohl binnenamerikanisch orientierte als auch auf das Ausland gerichtete US-Propagandaeinrichtung wurde bereits während des Ersten Weltkrieges (Stichwort „Creel Committee“) eingerichtet, aber erst die massive Bedrohung durch die Goebbelsche NS-Propaganda bewirkte, dass aktive Öffentlichkeitsarbeit nun zu einem wichtigen Thema der Nationalen Sicherheit Amerikas wurde. ${ }^{434}$

431 Die sukzesssive Erweiterung der „horizontalen Raumdimension“ der zivilisatorischen Missionsidee Ende des 19. Jahrhunderts um die „vertikale[n] Dimension der Erhebung und Erhöhung“, die Theodor Roosevelts bereits 1899 als Aufgabe - „uplifting mankind“ - bezeichnet hatte, wird mittlerweile auch unter dem kulturwissenschaftlichen Begriff der „Zivilisierungsmission“ analysiert. Vgl. Jürgen Osterhammel. „The Great Work of Uplifting Mankind“. Zivilisierungsmission und Moderne. In: Boris Barth/Jürgen Osterhammel (Hrsg.), Zivilisierungsmissionen. Imperiale Weltverbesserung seit dem 18. Jahrhundert, Konstanz 2005, 364; vgl. dazu weiters: Frank Ninkovich, Kontinentale Expansion, Empire und die Zivilisierungsmission im Amerika des 19. Jahrhunderts. In: Barth/Osterhammel (Hrsg.), Zivilisierungsmissionen, a.a. O., 285-309.

432 Frank Schuhmacher, Kalter Krieg und Propaganda. Die USA, der Kampf um die Weltmeinung und die ideelle Westbindung der Bundesrepublik Deutschland, 1945-1955, Trier 2000, 38. In Konkurrenz zu den alten europäischen Kolonialmächten entwickelte sich mit dem allmählichen Aufstieg der USA zu einer Weltmacht Mitte des 19. Jahrhundert die „Manifest Destiny“ als spezifisches Missionsbewusstsein der jungen transatlantischen Demokratie, das allerdings primär von privater Seite getragen wurde. Befördert wurde die Außenwerbung u.a. auch durch Ansätze eines Kulturaustausches über Forschungsinstitute und Bibliotheken (Austausch von Hochschullehrern sowie von Büchern). Siehe: ebd., $38 \mathrm{f}$.

433 Die Ende des 19. Jahrhundert auftauchenden Gedanken eines „amerikanischen Exzeptionalismus“ gewannen Einfluss auf die US-Außenpolitik und vermischten sich nachfolgend mit Elementen einer „ideology of liberal-developmentalism“, die nach Emily Rosenberg durch folgende Elemente gekennzeichnet war: „1) Belief that other nations could and should replicate America's own developmental experience; 2) faith in private free enterprise; 3) support for free or open access for trade and and investment; 4) promotion of free flow of information and culture; and 5) growing acceptance of government activity to protect private enterprise and to stimulate and regulate American participation in international economic and cultural exchange." Emily S. Rosenberg, Spreading the American Dream: American Economic and Cultural Expansion, New York 1982, 7. Zit. nach: Nicolas J. Cull, The Cold War and the United States Information Agency. American Propaganda and Public Diplomacy, 1945-1989, Cambridge 2008, 4.

434 Nach ersten wissenschaftlichen Studien zur Propaganda in den 1920er-Jahren (so z.B. Walter Lippmann, Public Opinion [1922]; Harold Lasswell, Propaganda technique in World War [1927]) kam es in den 1930er-Jahren, finanziert durch die Rockefeller-Stiftung, zu ersten systematischen sozial- und kommunikationswissenschaftlichen Analysen der Auslandspropaganda an der Princeton University und an der Columbia University. Siehe: Schuhmacher, Kalter Krieg und Propaganda, a.a.O., 51.1937 wurde in New 
In direkter Gegenreaktion auf die aggressive NS-Propaganda insbesondere in Lateinamerika, hatte die Regierung Roosevelt schon im Mai 1938 im State Department ein „Interdepartmental Committee for Scientific and Cultural Cooperation with the American Republics" eingerichtet. ${ }^{435}$ Ziel dieses Komitees war es, die Zusammenarbeit mit den lateinamerikanischen Nachbarstaaten im Bereich der „Landwirtschaft, Kommunikation, Verwaltung, Gesundheitsfürsorge und Erziehung“ zu verstärken und „Informationsaustausch und organisierte Personenaustauschprogramme ${ }^{\star 436} \mathrm{zu}$ initiieren. Darüber hinaus wurde im Juli 1938 die „Division of Cultural Relations“ geschaffen, die ebenfalls innerhalb des State Department angesiedelt war und ihre Aktivitäten zunächst auch primär auf Lateinamerika ausrichtete. ${ }^{437}$ Im August 1940 wurde dann der junge Nelson D. Rockefeller als „Coordinator of Commercial and Cultural Affairs“von Präsident Roosevelt eingesetzt. Diese erste, dezidiert geheimdienstliche Auslandsagentur wurde schließlich am 30. Juli I94I in das „Office of the Coordinator of Inter-American Affairs“ (CIAA) umgewandelt und die Leitung an William J. Donovan übergeben. ${ }^{438}$ Dem CIAA wurde zudem ein eigenes „Foreign Informations Service“ unter Führung von Robert E. Sherwood (dem Redenschreiber Roosevelts) unterstellt, das sich nach dem Angriff auf Pearl Harbour (7. Dezember 194I) im Februar 1942 mit ersten Rundfunksendungen der „Voice of America“ (VOA) - einem Zusammenschluss aus ir US-Kurzwellenstationen - der Nazi-Propaganda entgegenstellte. ${ }^{439}$

Doch bereits I 940 hatte sich - neben der anlaufenden US-Auslandskulturoffensive - die Aufmerksamkeit von US-Regierungsstellen angesichts der immer wahrscheinlicher werdenden Kriegsbeteiligung Amerikas auch auf die öffentliche Meinung im eigenen Land gerichtet. ${ }^{440}$

York als politisch unabhängige Einrichtung das vom Bostoner Kaufmann Edward Filene finanzierte „Institute for Propaganda Analysis“ gegründet. Ziel des Instituts, das von C.D. Jackson, dem späteren Berater Eisenhowers in Propagandafragen, geleitet wurde, und das ein eigenes Monatsmagazin herausgab, war es, „Propaganda zu entlarven und der amerikanischen Bevölkerung zu zeigen, wie man Propaganda erkennen konnte“. Ohmstedt, Von der Propaganda zur Public Diplomacy, a.a.O., 40.

435 Thomas Klöckner, Public Diplomacy - Auswärtige Informations- und Kulturpolitik der USA. Strukturanalyse der Organisation und Strategien der United States Information Agency und des United States Information Service in Deutschland (= Nomos Universitätsschriften. Politik, Bd. 41), Baden-Baden 1993, 39.

436 Schuhmacher, Kalter Krieg und Propaganda, a.a.O., 53.

437 Elder, The Information Machine, a.a.O., 34.

438 Klöckner, Public Diplomacy - Auswärtige Informations- und Kulturpolitik der USA, a.a.O., 41.

439 Ohmstedt, Von der Propaganda zur Public Diplomacy, a.a. O., 40 f.; weiters: Elder, The Information Machine, a.a.O., 35.

440 Zum Zweck einer engeren Kooperation der Staaten auf dem amerikanischen Kontinent zwecks Abwehr der NS-Propaganda entstand bereits unmittelbar nach Kriegsausbruch anlässlich der Außenministerkonferenz der amerikanischen Republiken in Panama (vom 23.9 bis 3.10.1939) der Plan, ein „Emergency Advisory Committee for Political Defense" einzurichten, das jedoch erst nach dem Überfall auf Pearl Harbor bei einem Treffen der „Pan Amerikanischen Union“ eingerichtet wurde; gemäß dem „Memo- 
Ein erster „Basic Plan for Public Relations“ war bereits unmittelbar nach Kriegsausbruch vom "Joint Army-Navy Board“ vorgelegt worden. Im Juni 1940 wurde dem Weißen Haus ein weiterer Plan präsentiert, ,to maintain nationale morale by the adequate presentation of the aims, views and progress of the nation “ ${ }^{441}$ Beide Pläne fanden zunächst keine unmittelbare Unterstützung von Präsident Roosevelt, der in dieser Angelegenheit vorsichtig agierte, um sich nicht dem öffentlichen Vorwurf Wilsonscher „Kriegspropaganda“ auszusetzen. ${ }^{442}$

Nachdem die amerikanische Außenpolitik im März 194I mit der Genehmigung des „Lend-Lease Act“ durch den US-Kongress durch Finanz- und Waffenhilfe an Großbritannien jedoch von der bisherigen isolationistischen Neutralität deutlich abgerückt war, verwies Vizepräsident Henry Wallace gegenüber Roosevelt auf die dringende Notwendigkeit ,[of doing] everything possible to create a national morale which will make $99 \%$ of our people work to the limit for the cause of increased production. “443

Nachdem auch Kriegsminister Henry L. Stimson in einer Kabinettsitzung die Einrichtung einer "morale agency" moniert hatte, kam es, nach einigen Differenzen hinsichtlich der Frage, inwieweit eine harte oder eine weiche Propaganda bevorzugt werden solle ${ }^{444}$ im Mai 194I unter Leitung des New Yorker Bürgermeisters Fiorello La Guardia schließlich zur Einrichtung des „Office of Civilian Defense“ (OCD). ${ }^{445}$ Die Arbeit dieser Einrichtung, deren Aufgaben nur unklar formuliert waren, verlief aber in hohem Maße unbefriedigend, zumal La Guardia Propagandaagenden kaum wahrnahm und sich weitgehend auf den Zivilschutz beschränkte. Daher schlug er Roosevelt die Einrichtung einer eigenen Propagandaabteilung innerhalb des OCD vor, die, gegliedert in drei Einheiten, als „Bureau of Facts and Figures“ arbeiten solle. Das Ergebnis dieser Gespräche war, dass Roosevelt dem OCD die Propagandafunktion entzog und im Oktober 194I unter dem Titel „Office of Facts and Figures“ $(\mathrm{OFF})^{446}$ eine direkt dem Präsidenten unterstellte Organisation des Pentagons unter Leitung des ehemaligen Bibliothekars der Library of Congress in Washington D.C. und herausragenden amerikanischen Intellektuellen, Ar-

randum on the Regulation of Subversive Activities" sollte ein siebenköpfiges Komitee, bestehend aus Vertretern der amerikanischen Staaten, Maßnahmen gegen anti-demokratische Aktivitäten in Amerika und Lateinamerika koordinieren. Vgl. Ruth D. Master, Handbook of International Organizations in the Americas [Carnegie Endowment for International Peace], Washington D.C. 1945, 67 ff.

441 Steele, Preparing the Public für War, a.a.O., $1641 \mathrm{f}$.

442 Ebd., 1642.

443 Ebd., 1644.

444 In den Diskussionen innerhalb der präsidentialen Planungsgruppe vertrat insbesondere Henry Wallace eine harte Position, indem er für eine Informationspolitik analog zur NS-Propaganda eintrat, dabei aber auf den Widerstand seitens Harold Smith und John J. McCloy stieß; letzterer hatte die Goebbelsche Propaganda in Deutschland selbst erlebt. Vgl. Steele, Preparing the Public für War, a.a. O., 1646.

445 Ebd., 1648.

446 Allan M. Winkler, The Politics of Propaganda. The Office of War Information, 1942-1945.2.Aufl., New Haven - London 1979, 22 f.; siehe weiters: Philip S. Broughton, Government Agencies and the Civilian Morale. In: The Annals of the American Society of Political and Social Science, CCXX, 1942, 168-177. 
chibald MacLeish, ${ }^{447}$ schuf. La Guardia selbst wurde im Jänner 1942 von James M. Landis in der Leitung des OCD abgelöst, dessen Arbeit nun primär dem „civilian defense service“ galt. Aufgabe des OFF sollte es nun sein, quasi nach innen gerichtet die US-Bevölkerung über die laufenden Verteidigungsanstrengungen zu informieren und für Unterstützung zu werben: ,[...] giving the public the presumably ungarnished facts about the war and the American response to it - facts that would ideally speak for themselves and permit enlightend decision by an informed citizenry. “448

MacLeish, einer der - wie Richard T. Arndt schreibt - engsten Freunde des späteren US-Außenministers Dean Achesons,${ }^{449}$ war von der Sinnhaftigkeit von Propagandamaßnahmen jedoch wenig überzeugt und hatte zudem differenzierte kulturdiplomatische Ansichten darüber, wie eine angemessene aufklärerische, kulturpropagandistische Antwort der USA auf die Bedrohung seitens der Achsenmächte aussehen sollte, nämlich durch Ausweitung der „cultural relations“:

\footnotetext{
"It [cultural relations, d. Verf.] stands for the realization of informed persons that the present struggle of propagandas $[\ldots]$ is a struggle for something more than markets [...].” The Axis "flank attack on the culture of the North American democracies in Latin America was perhaps not a flank attack at all but the principal engagement [....${ }^{450}$
}

Dementsprechend ging es - als entschiedene und nachhaltige Gegenmaßnahme zur NSPropaganda in Lateinamerika - darum, den kulturellen Austausch zu fördern, „to persuade the artists and intellectuals [...] that a North American culture exists, that it is a culture worthy admiration, and that the substitution of a different cultural influence in the Americas might be the substitution of a worse. “451

Entgegen dem eigentlichen Auftrag versuchte der differenziert kapitalismuskritische Intellektuelle MacLeish ${ }^{452}$ daher das OFF - nach heftigen Angriffen seitens der USamerikanischen Presse - weniger als Propagandaabteilung zu führen und die Agenden in Richtung einer breit angelegten Informationsvermittlung auszudehnen, die jedoch als hochemotionaler Kulturkampf zwischen, Gut' und ,Böse' angelegt war. ${ }^{453}$

447 Archibald MacLeish (1892-1982), amerikanischer Schriftsteller, Intellektueller und Politiker. Von 1930 bis 1938 Herausgeber des US-Magazins Fortune. Von 1939-1944 hatte MacLeish die Leitung der Library of Congress inne. Siehe: Scott Donaldson (in collaboration with R.H. Winnick), Archibald MacLeish. An American Life, Boston - London 1992.

448 Winkler, The Politics of Propaganda. The Office of War Information, 1942-1945, a.a. O., 22.

449 Richard T. Arndt, The First Resort of Kings. American Cultural Diplomacy in the Twentieth Century, Dulles 2005, 99.

450 Archibald MacLeish. In: The Nation, February 1940. Zit. nach: Arndt, The First Resort of Kings, a.a. O., 105.

451 Ebd.

452 Siehe: Donaldson, Archibald MacLeish. An American Life, a.a. O., $231 \mathrm{f}$.

453 Winkler, The Politics of Propaganda. The Office of War Information, 1942-1945, a.a.O., $18 \mathrm{f}$. 
De facto erwies sich das „Office of Facts and Figures“ aus Sicht der übergeordneten politischen Stellen letztlich ineffektiv, die "morale-building needs of wartime America “454 entsprechend zu kanalisieren. Die Agenden des OFF und des CIAA wurden daher bereits am I3. Juni 1942 der direkt dem US-Präsidenten unterstellten Propagandaabteilung „Office of War Information (OWI ${ }^{455}$ übertragen, zu dessen stellvertretendem Direktor MacLeish ernannt wurde. ${ }^{456}$ Die Gesamtleitung des OWI wurde Elmer Davis, ${ }^{457}$ dem angesehenen Redakteur der New York Times und CBS Radioreporter, übertragen. Dieser gewichtete als erfolgreicher Reporter die Agenden des OWI künftig pragmatischer (,to see that the American people are truthfully informed“) ${ }^{458}$ und agierte nunmehr auch im Bereich der Overseas-Propaganda („strategy of truth“) einigermaßen erfolgreich. ${ }^{459}$ Neben der "Heimpropaganda“ bestand die Aufgabe der primär zivil strukturierten OWI-Overseas Branch unter Leitung von Russell Barnes darin, in Zusammenarbeit mit dem State Department und den „psychological warfare units" der US-Streitkräfte (PWD/SHAEF) $)^{460}$ selbst über Außenposten des „United States Information Service“ (USIS) via Rundfunk, Film oder Literatur Auslandspropaganda gegen Hitler-Deutschland zu betreiben, aber auch Propagandadirektiven zu erstellen, wobei, Österreich' dabei konkret miteinbezogen wurde. ${ }^{461}$ Insbesondere in der Radioprogrammabteilung der OWI-Overseas Branch, die nach „Language Desks“ eingeteilt war und ab Februar 1942 unter Verwendung privater USKurzwellensender wie der „National Broadcasting Company“ (NBC) oder des „Columbia

454 Steele, Preparing the Public für War, a.a.O., 1652.

455 Das OWI wurde unter Leitung des ehemaligen Journalisten und Radiokommentators Elmer Davis [Executive Order No. 9182, 13. Juni 1942] zu einem großen Propagandaapparat ausgebaut, der sich in eine Domestic und in eine Overseas Branch gliederte. Zum Zweck der Propagierung der „One World“ setzte das OWI bald auf den Einsatz des Mediums Film und engagierte Hollywood-Regisseure wie John Ford, John Huston oder Frank Capra für groß angelegte Filmproduktionen, in denen sowohl Soldaten als auch ArbeiterInnen in den Rüstungsfabriken auftraten, „to influence thinking, change opinion and effect conduct.“ Karl-Heinz Pütz, Business or Propaganda? American Films and Germany, 1942-1946. In: Ekkehard Krippendorf (Ed.), The Role of the United States in the Reconstruction of Italy and West Germany, 1943-1949. Papers presented at a German-Italian Colloquium held at the John F. Kennedy-Institut für Nordamerikastudien, Berlin, June 1980 (= Materialien 16), Berlin 1981,190; weiters: Winkler, Politics of Propaganda: The Office of War Information, 1942-1945, a.a.O., $31 \mathrm{f}$.

456 Donaldson, Archibald MacLeish. An American Life, a.a.O., 362.

457 Winkler, Politics of Propaganda: The Office of War Information, 1942-1945, a.a. O., 31 ff.; weiters: Ohmstedt, Von der Propaganda zur Public Diplomacy, a.a.O., 41.

458 Vgl. Winkler, Politics of Propaganda: The Office of War Information, 1942-1945, a.a. O., 47.

459 Ebd., 76 ff.; weiters: Richard W. Steele, Roosevelt, Marshall, and the First Offensive. The Politics of Strategy Making, 1941-1942, Diss., Johns Hopkins University 1969, 152-165 bzw. 234-251; zit. nach: Steele, Preparing the Public für War, a.a.O., 1653.

460 Vgl. Winkler, Politics of Propaganda: The Office of War Information, 1942-1945, a.a. O., $118 \mathrm{ff}$.

461 Oliver Rathkolb, Politische Propaganda der amerikanischen Besatzungsmacht in Österreich 1945 bis 1950. Ein Beitrag zur Geschichte des Kalten Krieges in der Presse-, Kultur- und Rundfunkpolitik. Bd. I, Diss., Univ. Wien 1981, $37 \mathrm{f}$. 
Broadcasting System“ (CBS) als „Voice of America“ (VOA) auszustrahlen begann, ${ }^{462}$ arbeiteten eine Reihe emigrierter Österreicher, die zum Teil bereits vorher als Mitarbeiter bei den Kurzwellendiensten der großen US-Rundfunkanstalten tätig waren, ${ }^{463}$ als Sprecher, Übersetzer oder Redakteure im Rahmen der US-Auslandspropaganda mit. Ab April I942 wurde in der VOA auch eine feste Österreich-Sendeleiste installiert, die täglich in der

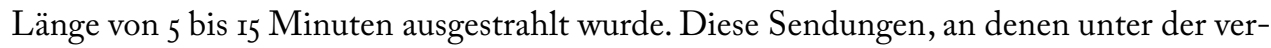
antwortlichen Redaktion von Martin Fuchs ${ }^{464}$ unter anderen Robert Bauer, ${ }^{465}$ Friedrich

462 Die US-Regierung hatte 1942 kurzerhand die Sendezeit aller 14 Kurzwellensender der Vereinigten Staaten gekauft und plante darüber hinaus die Errichtung von weiteren 22 Sendern. Die Mitarbeiter für die Propagandasendungen waren jedoch Angestellte des OWI. Siehe: FLIS Press Release, Index-Nr. 5266-German, 24.12.1942 [DÖW E 19.861]. Zit. nach: Peter Eppel, Österreichische Exilpolitik in den USA. In: Österreicher im Exil USA, 1938-1945. Eine Dokumentation. Bd. 2. Hrsg. v. Dokumentationsarchiv des österreichischen Widerstands. Einleitung, Auswahl und Bearbeitung: Peter Eppel, Wien 1995, 172.

463 So arbeiteten bspw. Ferdinand Bruckner und Ernst Waldinger beim deutschen Kurzwellensender der NBC mit, John Albert, William S. Schlamm, Ernst Landau oder Werner Thormann bei der CBS, und Robert Bauer leitete die Deutschland-Redaktion beim Kurzwellensender WLWO, Radio Cincinnati/Ohio. Siehe: Eppel, Österreichische Exilpolitik in den USA. In: Österreicher im Exil USA, 1938-1945. Eine Dokumentation. Bd. 2, a.a.O., $36 \mathrm{f}$.

464 Dr. Martin Fuchs (1903-1969), früherer Pressechef des österreichischen Außenministeriums sowie der österreichischen Botschaft in Paris. Im Pariser Exil arbeitete er zunächst eng mit Otto Habsburg zusammen, bevor er sich schließlich gegen diesen stellte. Nach dem Fall Frankreichs emigrierte Fuchs in die USA und gründete dort eine "Jung-Konservative“ Gruppe, die im „Austrian National Committee“ vertreten war. In dem von Otto Habsburg verfassten Dossier wurden Fuchs tiefe Kenntnisse der französischen Situation attestiert und sein Buch „Showdown in Vienna“ [The death of Austria, New York 1939] als „probably the best publication of the inside story of the collapse in Austria“ eingeschätzt. Siehe: Otto Habsburg, Brief survey of the history of the Austrian organisations in the United States. OSS Foreign Nationalities Branch, 14. April 1942, 6. U.S. Office of Strategic Services. Foreign Nationalities Branch Files 1942-1945. Indexes, Bethesda 1998 [Mikrofiche-Bestand, Institut für Zeitgeschichte der Universität Wien, Bibliothek], INT-4AU-36. Der Nachlassbestand von Martin Fuchs, der 1947 nach Österreich zurückkehrte und dann österreichischer Botschafter in Brüssel und Paris war, befindet sich am Institut für Zeitgeschichte der Universität Wien.

465 Robert [Albert] Bauer (1910-2003), österreichischer Ökonom und Jurist; ab 1934 war Bauer Mitglied und Propaganda-Redner der „Vaterländischen Front“ (VF). Von 1933 bis 1937 arbeitete er als Rechtsanwaltskonzipient, und von 1937 bis 1938 als Anwalt für die Österreichische Handels- und Gewerbekammer. 1938 emigrierte er zunächst nach Prag. Über Zwischenstationen in Polen, Ungarn, Jugoslawien, Italien und der Schweiz gelangte er im April 1939 schließlich nach Frankreich, wo er sich als Mitglied der „Ligue Autrichienne“ anschloss. Nach seiner Tätigkeit als Sendechef für den österreichischen Freiheitssender „Fécamp/Normandie“ floh er nach dem Fall Frankreichs 1940 schließlich über Portugal und Kanada in die USA, wo er für eine private Radiosendeanstalt in Cincinnati zu arbeiten begann. 1942 begann Bauers Mitarbeit bei der „Voice of America“. 1944 übernahm er die „German Radio Section“ der „American Broadcasting Station Europe“ (ABSiE) des OWI. Ab 1953 arbeitete er für die neugegründete Propagandaabteilung „United States Information Agency“ (USIA) als Radiomanager. Seine anschließende diplomatische Karriere als erster Sekretär für „Cultural Affairs“ brachte ihn nach Teheran, Paris, New Delhi und Kairo. Bauer lehrte zudem an verschiedenen amerikanischen Universitäten, so u.a. an der 
Bock-Bordy, Maria Deutsch, Hans Fischl, Julius Deutsch, ${ }^{466}$ Carl Furtmüller und Franz Höllering mitarbeiteten, ${ }^{467}$ bestanden für gewöhnlich aus der „Verlesung von Namenslisten der Gefangenen, der Beschreibung des Lageralltags, teilweise mit Interviews oder Aufrufen der Gefangenen an ihre Kameraden, sich zu ergeben. ${ }^{\text {“468 }}$ Außerdem sendeten Kurzwellenstationen in einzelnen US-Bundesstaaten Programme in deutscher Sprache, an denen auch österreichische Flüchtlinge mitwirkten, so zum Beispiel Eduard März bei der Kurzwellenstation WRUL in Boston/Massachusetts, wo er jeden Samstag die österreichischen Bevölkerung jeden Samstag von den USA aus mit fünfzehnminütigen Informationen über den Stand von Verfolgung und Widerstand versorgte - allerdings konnten die Kurzwellensendungen nur von wenigen empfangen werden. So hieß es in einer Sendung vom 1o. Oktober 1942:

„Wir Österreicher - so wurde die Nazipropaganda nicht müde zu wiederholen - hätten weder den Wunsch noch das Recht auf ein unabhängiges Staatswesen. [...] Aber Nazipropaganda und Wirklichkeit sind zwei grundverschiedene Dinge. [...] Nirgends haben die Nazis auf so brutale und rücksichtlose Weise jung und alt in den Kriegsdienst gepreßt wie in den österreichischen Ländern. [...] Die Ansiedelung von Reichsdeutschen an Stelle der eingekerkerten, verschickten und in den Kriegsdienst gepreßten Österreicher ist ein weiterer Schritt in der Richtung einer totalen Nazifizierung und Kolonisierung unseres österreichischen Heimatlandes. “469

John Hopkins University. Siehe: http://www.austrianinformation.org/jan-feb-2004/2007/2/15/917081. html [Zugriff 9.7.2011]. Biographisches Handbuch der deutschsprachigen Emigration nach 1933. Bd. I: Politik, Wirtschaft, Öffentliches Leben. Bearb. V.: Werner Röder/Herbert A. Strauss, München - New York - London - Paris 1980, 40. Vgl. dazu auch Rathkolb, Überlegungen zum Exodus der „Jurisprudenz“, a.a.O., 288.

466 Julius Deutsch war eigenen Angaben zufolge 1942 vom Chef des OSS, William J. Donovan, persönlich eingeladen worden, Propaganda-Aufgaben innerhalb des OWI zu übernehmen: „Ich hatte täglich eine aufklärende Rede auszuarbeiten, die, von einem Berufsschauspieler gesprochen, auf Kurzwellen nach Österreich ging. Außerdem verfasste ich von Fall zu Fall militärische Erläuterungen zur Kriegslage“. Julius Deutsch, Ein weiter Weg. Lebenserinnerungen, Zürich - Leipzig - Wien 1960, 368f. Zit. nach: Eppel, Österreichische Exilpolitik in den USA. In: Österreicher im Exil USA, 1938-1945. Eine Dokumentation. Bd. 2, a.a.O., 168.

467 Siehe: Eppel, Österreichische Exilpolitik in den USA. In: Österreicher im Exil USA, 1938-1945. Eine Dokumentation. Bd. 2, a.a.O., 36.

468 Conrad Pütter, Rundfunk gegen das „Dritte Reich“. Deutschsprachige Rundfunkaktivitäten im Exil 1933-1945. Ein Handbuch (= Rundfunkstudien, Bd. 3), München 1986, 133 ff. Zit. nach: Eppel, Österreichische Exilpolitik in den USA. In: Österreicher im Exil USA, 1938-1945. Eine Dokumentation. Bd. 2, a.a.O., 36.

469 Zit. nach: Eppel, Österreichische Exilpolitik in den USA. In: Österreicher im Exil USA, 1938-1945. Eine Dokumentation. Bd. 2, a.a.O., 37. Einzelne dieser Sendemanuskripte sind erhalten geblieben. Siehe DÖW E 17.843. 
Des Weiteren produzierten eine Reihe kommerzieller US-Radiosender mit Unterstützung des OWI in New York deutschsprachige Sendungsprogramme, um gegen die ,auch in den USA verbreiteten Sympathien für das Dritte Reich“ anzukämpfen. ${ }^{470}$

Ein interessantes Detail in diesem Zusammenhang stellt auch der Umstand dar, dass die im März 1944 gegründete „American Broadcasting Station in Europe“, die der Psychological Warfare Division des alliierten Hauptquartiers (PWD/SHAEF) unterstellt war, zunächst über die BBC und ab Oktober 1944 über Radio Luxemburg ausstrahlte ${ }^{471}-$ die Leitung der deutschsprachigen Abteilung hatte der österreichische Exil-Schriftstellers Hans Habe inne, der dafür eigens „zum Captain befördert wurde“. 472

In Kontakt mit österreichischen Widerstandsgruppen insbesondere in Wien, versuchte das OWI für die Gestaltung eines eigenen „Austrian radio programs“ möglichst genau herauszufiltern, welche Informationen gezielt verbreitet werden sollten - ,positive mention of Austrians who are fighting Nazis in Allied Austrian programs would be worthwile“473 und in welcher Form dies am besten geschehen sollte: „Austrians are unreceptive at this time to Heurigensketchs, Leopold Lieder and other similar propaganda programs from London, and it would be too much to expect an opposite attitude, caught as they are between daily Anglo-American air attacks and Nazi terror. ${ }^{4474}$ Wie aus einem bereits im

470 Ebd., 40. So wies das deutschsprachige Programm des New Yorker Radiosenders WBNX bis Mitte 1942 „deutschnationale Töne auf. Lieder wie ,Wir fahren nach Engelland” oder das ,Horst-Wessel-Lied“ tauchten noch bis einen Tag vor der deutschen Kriegserklärung an die USA [...] in den Sendungen auf [...]“. Pütter, Rundfunk gegen das „Dritte Reich“, a.a.O., 177. Zit. nach: Eppel, Österreichische Exilpolitik in den USA. In: Österreicher im Exil USA, 1938-1945. Eine Dokumentation. Bd. 2, a.a.O., 40 f. Zwischen September 1942 und Februar 1943 produzierte WBNX dann im Auftrag des OWI die Sendereihe „We Fight Back. German American Loyalty Hour“, die unter Leitung von Ernst J. Aufricht von acht Radiosendern in vier Sprachen ausgestrahlt wurde und in bunter Form gegen „Nazismus, Rassenhetze, Fifth-Column-Aktivität jeder Art - für den totalen Sieg der Prinzipien der amerikanischen Demokratie“ kämpfte. An österreichischen Exilanten wirkten u.a. mit: Karl Farkas, Dietrich Hildebrand, Lotte Lehman, Lotte Lenya, oder Alexander Roda Roda. Ebd. 41. Der New Yorker Mittelwellensender WCNW produzierte seit 1940 eine Radiostunde der „German American Writers Association“, an der u.a. neben Kurt Hellmer oder Carl Zuckmayer auch die österreichischen Schriftsteller Franziska Ascher-Nash, Adrienne Gessner, Ferdinand Bruckner, Raoul Auernheimer und Oskar Jellinek mitwirkten. Weitere österreichische Schriftsteller, Journalisten, Intellektuelle bzw. Musiker, die an US-Radiosendungen mitwirkten waren u.a. Anton Kuh (WLTH in New York), Robert Breuer, Ralph Benatzky, Oskar Klarweis (WHOM in New Jersey), Maria Prihuda, Rudolf Jakob (WLTH in Cincinnati) sowie Wilhelm Börner und Hans Leo Reich. Siehe: ebd., $42 \mathrm{f}$.

471 Winkler, The Politics of Propaganda. The Office of War Information, 1942-1945, a.a. O., 127.

472 Pütter, Rundfunk gegen das „Dritte Reich“, a.a.O., 237 f. Zit. nach: Eppel, Österreichische Exilpolitik in den USA. In: Österreicher im Exil USA, 1938-1945. Eine Dokumentation. Bd. 2, a.a. O., 39.

473 National Archives, Washington D.C., College Park, Maryland (künftig: NARA II). NARA II, RG 208, Office of War Information, Box 106. American Legation Bern, to Secretary of State, Washington D.C., „Paraphrase of Program Received“, 26. Dezember 1944, 2.

474 Ebd., 1. 
September 1943 vorliegenden „Working-Plan of Austrian Broadcasts“ des OWI hervorgeht, bildeten dabei „stories of resistance“ sowie eingestreute Hinweise, dass Österreichs Unabhängigkeit (mit Bezug auf die Moskauer Deklaration) diesmal - anders als nach dem Ersten Weltkrieg - keineswegs ökonomische Isolation bedeuten würde, zentrale Propagandathemen. Ohne direkte Aufrufe zu Streik und Gegenwehr - „the hour has not yet come to this“ - bestand das generelle Ziel der über Kurzwellen ausgestrahlten USPropaganda freilich darin, Widerstand gegen den Nationalsozialismus anzuregen, unter anderem dadurch, dass auf die Unterschiede zwischen Österreichern und Deutschen gesetzt wurde: „Our propaganda to Austria has one main object, the stimulation of resistance to the Germans. “475

Aus einem geheimen Memorandum von James W. Riddleberger, dem Leiter der Division of Central European Affairs im State Department, geht allerdings hervor, dass bis Jänner 1945 für alle Österreich-Sendungen des OWI die Direktive galt, davor zu warnen, dass die Zeit für den in der Moskauer Deklaration geforderten Beitrag Österreichs zu seiner eigenen Befreiung auslaufe („the time for this is running out“). Künftig hätte, so Riddleberger, diese Warnung allerdings nicht nur zu unterbleiben, sondern es solle der Beitrag Österreichs zu seiner eigenen Befreiung möglichst herunter gespielt werden: „The reference to ,contribution' in the Moscow Declaration should be played down rather than up. When used at all, it should be handled not as a threat for failure to contribute, but as a promise of reward for contribution the Austrians to make. "476 Tatsächlich begann das OWI bereits am Tag der Veröffentlichung der Moskauer Deklaration am I. November 1943, zwei integrierte österreichische Kurzwellensendungen („Austrian shortwave shows“) auszustrahlen, die ab Mai 1944 um eine dritte und ab Oktober I944 um eine vierte Sendung erweitert wurden und offenkundig psychologische Kriegsführung mit Humor verbanden:

"The Austrian show relayed to the BBC features American foreign policy, America at War, news from Germany that is being withheld by the Nazis, reports on the reconstruction of liberated countries and a humorous talk by two Viennese on problems of the day. The Austrian show relayed by Radio Algiers is addressed mainly to Austrian patriots. It deals with resistance movements in Austria and other oppressed countries. The Austrian show relayed by ABSiE [ "American Broadcasting Station in Europe", d. Verf.] is aimed twice a week at Austrian soldiers in the Wehrmacht, once a week at Austrian workers and once a week it brings a commentary of American and neutral thoughts and ideas on Austria's present and future problems.

475 P.W.E. General Working-Plan of Austrian Broadcasting, 2. Dezember 1943. NARA II, RG 208, Office of War Information, Box 106, 1.

476 Geheimes Office Memorandum von James W. Riddleberger, Chief, Division of Central European Affairs, State Department, betref. Direktiven für Österreich-Sendungen des Office of War Information, 3.1.1945. NARA II, RG 59, Records of the State Department, 740.00119 Control (Austria)/1-345 [DÖW E 20220]. Zit. nach: Eppel, Österreichische Exilpolitik in den USA. In: Österreicher im Exil USA, 19381945. Eine Dokumentation. Bd. 2, a.a. O., 174. 
Still dealing with the consequences of Nazi mismanagement and corruption in Austria. Two of our Austrian shows are carrying messages by Austrian prisoners of war to their families in Austria." 477

Eine vertrauliche Auswertung der von Robert Bauer gestalteten Österreich-Sendungen des OWI, denen unter anderem auch die Aufgabe zukam, der Bevölkerung Österreichs die Notwendigkeit alliierter Bombardements für die Befreiung zu „erklären“, ergab, dass dessen „brillanter Stil“ und „stark emotionaler Zugang“ („talking from the heart“) zumindest bei den Zuhörer-Panels in Bern, Stockholm und New York gut ankam: „He used ,language that ,every Austrian would readily recognize as familiar', and his accent, though unmistakably Austrian, never interfered with intelligibility." ${ }^{478}$

Das im US-State Department angesiedelte OWI arbeitete mit britischen Stellen zusammen und produzierte, neben der bereits angesprochenen Rundfunkpropaganda und einer in mehrere Sprachen übersetzten Zeitschrift, ${ }^{479}$ unter anderem Millionen von Flugblättern, die über Nordafrika, Italien und Deutschland abgeworfen wurden, um die Moral der Achsenmächte zu untergraben und zur Kapitulation aufzurufen. ${ }^{480}$

Das OWI, das bei Kriegsende immerhin I3.00o Mitarbeiter hatte und über ein Budget von 70 Millionen US-Dollar verfügte, wurde, unter anderem nach anhaltender Kritik von republikanischer Seite an dessen angeblich unamerikanischen Propagandaaktivitäten, nach Kriegsende im August 1945 von Präsident Harry S. Truman aufgelöst und das Personal auf andere Dienststellen aufgeteilt. ${ }^{481}$

477 Ebd., 176.

478 Vertraulicher Bericht der Evaluation Division der Overseas Operations Branch des Office of War Information über Reaktionen auf Österreich-Sendungen des OWI aus Bern, Stockholm, und New York, Februar 1945 [DÖW 6756/2a]. Zit. nach: Eppel, Österreichische Exilpolitik in den USA. In: Österreicher im Exil USA, 1938-1945. Eine Dokumentation. Bd. 2, a.a.O., 177.

479 So z.B. die für Frankreich herausgegebenen L'Amerique en Guerre, die in einer Auflage von bis zu 7 Millionen [sic] wöchentlich erschien, oder die russischsprachige Zeitschrift America, die in über 50.000 Exemplaren gedruckt und als einzige Zeitschrift nach Auflösung des OWI 1945 weitergeführt wurde. Vgl. Elder, The Information Machine, a.a.O., 36 bzw. Ohmstedt, Von der Propaganda zur Public Diplomacy, a.a.O., 44 bzw. 47.

480 Wie Robert Sherwood aus der Eisenhowerschen militärischen Propagandaabteilung berichtete, hatte die Psychologische Kriegsführung in der Endphase überall Einzug gehalten: „From that time on there was no major Allied landing from Normandy to the Philippines that did not have a Psychological Warfare Division as a part of the force." Zit. nach: Ohmstedt, Von der Propaganda zur Public Diplomacy, a.a.O., 43 bzw. 44.

481 Charles A. Thompson, Overseas Information Service of the United States Government, New York 1948 [1972]; vgl. auch: David F. Kugler, The Voice of America and the Domestic Propaganda Battles, 19451953, Missouri 2000, 185 f.; siehe weiters dazu: Klöckner, Public Diplomacy - Auswärtige Informationsund Kulturpolitik der USA, a.a.O., 42. Vgl. auch: Ohmstedt, Von der Propaganda zur Public Diplomacy, a.a.O., 47; weiters: Elder, The Information Machine, a.a.O., 35. 
Die „Education“ als „higher form of propaganda“482 verlegte sich seitens der US-Regierung zunehmend auf Unterstützung und Kooperation für auf diesem Feld bereits erfolgreich aktive zivile Agenturen auf bundesstaatlicher Ebene sowie auf deren Koordination. $\mathrm{Zu}$ diesem Zweck gab das U.S. Office for Education eine eigene Zeitschrift heraus - „Education for Victory“483 - und richtete Ende des Jahres I94I die „Wartime Commission“ ein, deren Hauptaufgabenbereich vier Punkte enthielt:

“г. To improve educational services for the government.

2. To aid in caring for civilian educational needs associated with the war and to determine to what extent federal financial assistance may be necessary.

3. To advise the government and educational institutions with respect to special problems involving the effects of wartime measures on schools, colleges and libraries.

4. To facilitate formulations of plans for study of post-war readjustments." ${ }^{484}$

Neben der Publikation beziehungsweise Herausgabe von Broschüren und Schriften sowie der Produktion von einschlägigen Filmen und Radiosendungen sollte die Aufgabe der „Wartime Commission" vor allem darin bestehen, als Informationsschnittstelle zu allen Fragen von „education and defense“ sowie als zentrale Koordinierungsstelle „for many voluntary organizations and government agencies ${ }^{\text {“485 }}$ zu dienen. Darüber hinaus sollte die Wartime Commission, in Kooperation mit anderen Abteilungen wie der "Federal Security Agency“ des U.S. Office for Education, dem „National Resources Planning Board“ sowie der „Public Works Administration“, ein Programm zum „long-time planning for education in the states “486 ausarbeiten. Daneben wurden aber auch konkrete Maßnahmen gesetzt: Um die Schulen außerhalb der Schulstunden und während der Sommermonate für militärische Schulungskurse zu nützen, wies die Wartime Commission in Absprache mit dem „Office of Civilian Defense“ am 24. April I942 alle Schulleitungen landesweit an, die Schulgebäude für kriegsbezogene Trainings- und Schulungskurse offen zu halten, darunter unter anderem für: „mathematics, science, English, social studies adapted to the specific needs of the armed forces and war production; aviation education; courses to train girls and women in business, trade and clerical occupations to replace men drawn into the armed forces; courses in home nursing, nutrition, first aid, and other fields related to civilian defense and other war needs; courses in physical fitness; training in cooperation with the Office of Civilian Defense for air raid wardens, auxiliary fire and police officers, and such other personnels as might needed. “487

482 Richard S. Lambert, Propaganda, Toronto - New York 1938, 105.

483 Education in Wartime, a.a.O., 233.

484 Zit. nach: Carter V. Good, Educational Progress During the Year, 1941. In: School and Society, Vol. 55, Saturday, March 7, 1942, No. 1419, 256.

485 Ebd.

486 Ebd.

487 Kandel, The Impact of the War upon American Education, a.a. O., 29. 
Der Zentralisierung der Agenden im U.S. Office for Education vorausgegangen war indes die Gründung des „National Committee on Education and Defense“ am 7. September 1940 in Washington, das von der "National Education Association of the United States“ (NEA) ${ }^{488}$ und von dem „American Council on Education“ (ACE), das eng mit dem Wartime Office kooperierte, ${ }^{489}$ unterstützt wurde und in dem insgesamt ${ }_{49}$ Organisationen vertreten waren. ${ }^{490}$ Eine weitere führende Einrichtung innerhalb des „Committees on Educational Recommendations“ der NEA bildete die bereits länger existierende „Educational Policies Commission“, der neben John W. Studebaker, seines Zeichens Leiter des U.S. Office of Education, auch George F. Zook, ${ }^{491}$ der Präsident des ACE, als beratende Mitglieder angehörten.

Wie sich anhand der „Educational Policies Commission“, die vorrangig mit der Ausarbeitung konkreter Schulungsmaterialien befasst war, zeigt, verlief die Arbeit von staatlichen Gremien und zivilen Privateinrichtungen im Kontext der „Education in Wartime“ in enger personeller und institutioneller Verflechtung.

Der Output der neugeschaffenen Institutionen schlug sich vor allem in einer Reihe elaborierter Broschüren und Bücher nieder, die von der Educational Policies Commission der NEA beziehungsweise vom U.S. Office of Education herausgegeben wurden.

So wurde zum Beispiel für den Unterricht an Schulen und Colleges 1940 von der Educational Policies Commission - neben einer allgemeinen Darstellung der kriegsbedingten Herausforderungen für die Erziehung ${ }^{492}$ - eine eigene Materialsammlung zum Thema "Learning the Ways of Democracy" publiziert, um die Entwicklung von „good citizenship“

488 Wartime Handbook for Education [National Education Association of the United States], Washington D.C. 1943.

489 Das „National Committee on Education and Defense“ agierte in der Folge gewissermaßen als übergeordnetes Koordinationsgremium, in dem Vertreter ziviler und militärischer Einrichtungen in regelmäßigen Abständen Bericht erstatteten. Mitglieder des Komitees waren u. a. Alonzo G. Grace als Vorsitzender des industriellen Trainingsprogramms, Williard E. Givens als Sekretär der NEA, J.W. Studebaker als Leiter des U.S. Office for Education sowie Brigadier General Lewis B. Hershey und Francis J. Brown vom War Department. Vgl. The National Committee on Education and National Defense. In: School and Society, Vol. 53, February 22, 1941, 237.

490 School and Society, Vol. 52, September 28, 1940, No. 1347, 257.

491 George F. Zook (1885-1951), Leiter der „Division of Higher Education at the U.S. Bureau of Education“ von 1920-1925; Präsident der University of Akron; ab 1933 „U.S. Commissioner for Education“ sowie Präsident des „American Council on Education“, der einflussreichsten US-Organisation für „Higher Education" in den Vereinigten Staaten. Zook, der Präsident Roosevelt persönlich kannte, war einer der bedeutendsten amerikanischen Pädagogen seiner Zeit. Bereits 1933 widmete ihm Time eine Titelseite (Vgl. Time. The Weekly Magazine, 18. September 1933). Siehe: Steven Brint/Jerome Karabel, The Diverted Dream: Community Colleges on the Promise of the Educational Opportunity in America, 1900-1985, New York 1989, 68.

492 American education and the war in Europe [Educational Policies Commission/National Education Association of the United States and the American Association of School administrators], Washington D.C. 1940; dabei handelte es sich bereits um die Zweitauflage der 1939 erstmals erschienenen Broschüre. 
speziell unter Jugendlichen zu fördern. ${ }^{493}$ Zur Stärkung der „moral resources of democracy“ folgten ein Jahr darauf zwei weitere Publikationen, nämlich „The Education of Free Men“ und „Education and the Morale of a Free People“, die weite Verbreitung fanden und die Argumente und programmatischen Ziele der „Education in Wartime“ prägnant zusammenfassten. Darin wurde klar herausgestellt, worum es in dem soeben erst begonnenen universalen „Kampf zwischen Tyrannei und Freiheit“vordringlich ging, nämlich um ein klares Verständnis des eigenen Erbes („heritage of freedom“), um ein Verständnis der eigenen Stärken und Schwächen, sowie um den „sozialen Glauben“" ${ }^{494}$ an die Ideale der amerikanischen Demokratie:

"Democracy is more than institutions and ways of life. It is a great social faith [...]. It is the finest of all social faiths that mankind has fashioned and followed during the thousands of years of human history. [...] And it will conquer, not by force of arms and the use of terror, but by the power of its ideas and its hopes. It will conquer because it is the only social faith that can bring justice and mercy to all men." ${ }^{495}$ [Hervorhebung d. Verf.]

Im direkten Gegensatz zur autoritären Struktur der totalitären Regime in Europa wurde die Demokratie als ein unermesslich kompliziertes Unterfangen charakterisiert, dessen manifeste Umsetzung davon abhinge, inwiefern es in den konkreten Lebensformen, dem Verhalten, den Gefühlen und im Denken der Menschen seinen Niederschlag findet: „Let these patterns be destroyed and democracy itself is destroyed. " ${ }^{496}$ Herausgefordert durch die militärische und weltanschauliche Bedrohung durch Faschismus und Nationalsozialismus, sich auch ideologisch klar von diesen Systemen und deren „Education to Death“497

493 Educational Policies Commission, Learning the Ways of Democracy: A Case Book in Civic Education, Washington D.C. 1941, $486 \mathrm{f}$.

494 Die Notwendigkeit eines geradezu „militärischen Glaubens“ in den „democratic way of life“ - „democracy as a fighting faith [...] a faith in freedom“ - hob auch Archibald MacLeish in seiner demokratiepolitischen Auseinandersetzung mit der Bedrohung durch Nationalsozialismus und Faschismus hervor. Archibald MacLeish, The American Cause, New York 1941, 42.

495 The Education of Free Men in American Democracy. Educational Policies Commission, National Association of the United States, Washington D.C. 1941, 33.

496 Ebd., 48.

497 Vgl. Gregor Ziemer, Education for Death. The Making of a Nazi, New York 1941. Ziemer, früherer Direktor der Amerikanischen Schule in Berlin, war es durch Bestechung gelungen, für sein Buch den Unterricht in deutschen Schulklassen an Ort und Stelle zu beobachten. Interessant ist in Bezug auf Österreich, dass in der New York Times im Zusammenhang einer kolportierten Erklärung des NS-Reichsministers für Wissenschaft, Erziehung und Volksbildung, Bernhard Rust, zunächst in den eroberten Westgebieten und später dann auch im „Altreich“ das „,bewährte österreichische Schulsystem“ einführen zu wollen (,the cornerstone of Austria's pre-World War culture“) „Austrifizierungstendenzen“, vermerkt wurde: „This is not the first time the Nazis have recognized the cultural leadership of Austria. [...] Austria, at least as represented by the Viennese, thus in a sense leads captive her captors, as the incredible Greeks once did 
abzugrenzen - bis 194r auch, wenn auch keineswegs in ebenso großer Schärfe und Deutlichkeit, gegenüber dem Kommunismus -, ging es letztlich um die Mobilisierung puritanischer Werte, um die Verbindung von Glauben, Moral und Ökonomie:

"The guarding of American democracy may require powerful armies, navies, and air fleets, but armies, navies, and air fleets are not enough. If democracy is to save itself, it must do far more than appropriate billions of dollars for military defense, build tanks, airplanes, and battleships [...]. The defense of democracy is far more than an economic question. In the last analysis it is a moral and spiritual question - a question of the values and ideas to be defended and applied to life. It is a question of the education of free men, broadly and fundamentally considered." ${ }^{998}$

Die konkreten Inhalte beziehungsweise die Loyalität zu jenen Werten, von denen das Überleben der Demokratie gegenüber der Bedrohung durch die totalitären Achsenmächte maßgeblich abhängen würde, umriss diese Schrift, wie zahlreiche andere auch - in freier Auslegung der Grundrechte der amerikanischen Verfassung sowie der „vier Freiheiten“ Roosevelts ${ }^{49}$ - folgendermaßen: es ging um die Würde und den Wert des einzelnen Menschenlebens, das Prinzip der Gleichheit und Brüderlichkeit, um intellektuelle Redlichkeit, Kritik- und Meinungsfreiheit, um Fairness, Vertrauen in die Wissenschaft, soziale Verantwortungsbereitschaft, gegenseitigen Respekt, Recht auf Arbeit, individuelle Verpflichtung zur ,intelligenten“ Information über das Gemeinwesen, um den Kampf gegen Ignoranz, um Weiterbildungsbereitschaft sowie - letztlich - um den Glauben an die Herrschaft eines gemeinsamen Gottes. ${ }^{500}$

Die genannten Werte und Vorstellungen, die freilich ausführlich beschrieben und exemplifiziert wurden, sollten unter Einsatz aller Mittel mobilisiert werden, um der nunmehr

their Roman conquerors." Zit. nach: The Nazis and their Subjugated Neighbors. In: School and Society, Vol. 52, 14. Dezember, 1940, No. 1356, 625. Auch nach Kriegsende findet sich ein Hinweis auf diese angebliche „Austrifizierung“, indem auf den „Sieg' des österreichischen Hauptschulgedankens im Dritten Reich“ verwiesen wurde: „Daß das österreichische Schulwesen in Organisation und bildender Wirksamkeit turmhoch über jenem des sogenannten Altreiches stand, mußten sogar die eingefleischstesten Nazilehrer zugeben, als bald nach dem März 1938 Kinder von draußen [sic] in unsere Schulen - der Zuzug war ja äußerst rege - aufzunehmen waren [...]. Der innere Wert unseres österreichischen Schulwesens konnte nicht einmal von den maßgeblichen Nazibehörden in Abrede gestellt werden. Ja, sie mußten sich schließlich sogar bequemen, die Überlegenheit unserer Hauptschule gegenüber den mittleren Schultypen von draußen [sic] insofern anzuerkennen, als durch das Hauptschulgesetz diese Hauptschule für das gesamte Reichsgebiet eingeführt wurde." Zit. nach: Neues Österreich. Organ der demokratischen Einigung, 1. Jg., 15. Juli 1945, 2. [Hervorhebung im Original]

498 The Education of Free Men, a.a. O., $49 \mathrm{f}$.

499 „Freedom of speech“, ,freedom of every person to worship god“, „freedom from want“, „freedom from fear“. Zit. nach: Our Country's Call to Service. Education and National Defense Series Pamphlet No. 1. Hrsg. v. Federal Security Agency/U.S. Office of Education, Washington D.C. 1942, 23.

500 Ebd., $55 \mathrm{ff}$. 
globalen Verantwortung Amerikas für die Verteidigung von Demokratie und menschlicher Freiheit nicht nur gerecht zu werden, sondern vermittels der „Education in Wartime“501 auch jene Energien und Ressourcen freizusetzen, die angesichts der ungeheuren militärisch-ideologischen Bedrohung durch den Nationalsozialismus für einen Sieg nötig wären: "The first necessity in the development of such a program is the achievement of a clear understanding of the nature of democracy and a clear perception of the values at stake. Only when this has been done can free men be expected to throw their energies without reserve into the struggle. “502

Im Zusammenhang mit den Maßnahmen zur Vorbereitung der amerikanischen Öffentlichkeit auf einen möglicherweise bevorstehenden Krieg ging es also keineswegs nur um die politische Unterstützung einer interventionistischen Außenpolitik gegenüber den Achsenmächten, oder darum, mit den Verbündeten der „Anti-Hitler-Koalition“503 einen Krieg zu führen und auch zu gewinnen, sondern zwecks totaler Kräftemobilisierung - anders als im Fall des faschistischen „credere-obbedire-combattere“-Prinzips - auch darum, genau zu wissen, weshalb man diesen führt. Die Nation müsse geeint und das Prinzip der „free men“, so der generelle Tenor, in jedem amerikanischen Staatsbürger, insbesondere in jedem Soldaten, verkörpert und präsent sein.

Dass die massiven, kriegsbedingten Veränderungen des gesamten amerikanischen Bildungswesens, insbesondere die sukzessive Militarisierung - „total training program for a total war" ${ }^{\text {“504 }}$ - nach dem Überfall auf Pearl Harbour, wie das der US-Schulhistoriker Gerard Giordano darlegte, primär im zunehmenden Einfluss und politischen Erfolg konservativer, republikanischer Erzieher („educators“) ihre Ursache hätten, ${ }^{505}$ greift meines Erachtens zu kurz, und zwar schon allein deshalb, weil die pluralen, in sich zum Teil heterogenen Begründungselemente der „Wartime Education“ auf basalen Grundannahmen amerikanischer Bildungsphilosophie beruhten. Darüber hinaus wurden, sozusagen quer durch die politischen Lager - die allerdings, wie auch Giordano konstatiert, bald allesamt auf einen „total defense“-Kurs einschwenkten ${ }^{506}$ - Maßnahmen wie etwa die Umwandlung

$501 \mathrm{Vgl}$. The Support of Education in Wartime (Educational Policies Commission, National Education Association of the United States and the American Association of School Administrators), Washington D.C. 1942.

502 Ebd., 30.

503 Vgl. Rudolf Riemer, Die Anti-Hitler-Koalition (Ost-Kurier. Informationen - Analysen - Berichte. Hrsg. v. Studienzentrum für Ost-West-Probleme), München o.J. [1985].

504 Vgl. W.W. Carpenter/A.G. Capps, A total training program for a total war. In: School and Society, Vol. 56, 1942, 197-200.

505 Gerard Giordano, Wartime Schools. How World War II Changed American Education (= History of Schools \& Schooling, Vol. 34), New York - Washington D.C. 2004, xxii ff.

506 Selbst das „New York City's Teacher College“, eine Einrichtung, deren Leitung eine prononciert liberale Position vertrat, sponserte bereits 1941 unter dem Titel „Schools and the Defense“ ein "prewar symposium on teacher-centered defense activities“. Siehe Giordano, Wartime Schools, a.a.O., 5. 
der US-Klassenzimmer in „battlefronts“ als durchwegs temporäre Maßnahmen für die Erfordernisse eins totalen Kriegseinsatzes angesehen.

In den von der Federal Security Agency des U.S. Office of Education ab I94I in der Schriftenreihe „Education and National Defense Series“" ${ }^{\text {507 }}$ herausgegebenen Büchern und Broschüren wurde die vorgezeichnete Argumentationslinie vollinhaltlich übernommen und, vor allem für Lehrpersonal an amerikanischen Schulen und Ausbildungsstellen, darin nochmals die Unterschiede zwischen Diktaturen und der westlichen Demokratie herausgearbeitet und verdeutlicht. ${ }^{508}$

Wie der U.S. Commissioner of Education John W. Studebaker im Vorwort zum „Pamphlet No. I“ mit dem Titel „Our Country’s Call to Service“ im November I94I schrieb, ginge es im Rahmen des „National Defense Programs“ nunmehr verstärkt um den Ausbau konkreter, wohlüberlegter Maßnahmen, denn - „patriotic enthusiasm will produce disastrous results“. 509

Vor dem Hintergrund der Niederlage der französisch-britischen Armee in Dünkirchen und dem Fall Frankreichs im Juni I940 hatte unter Führung des U.S. Office of Education im Juli dieses Jahres ein groß angelegtes Trainings- und Schulungsprogramm für die Rüstungsindustrie begonnen, das von hunderten Schulen und technischen Colleges im ganzen Land administriert wurde, und an denen bis I94I bereits mehr als eine Million Frauen und Männer spezifische berufliche Schulung erhalten hatten. ${ }^{510}$

Mit der im Zusammenhang des „Lend-Lease-Abkommens“ gewaltig angekurbelten Aufrüstung wurden ab I94I zahlreiche neue Fabrikationsstätten für die Rüstungsindustrie errichtet. Angesichts des enormen Arbeitskräftebedarfs für die Waffenproduktion - I50o Büros des U.S. Employment Service bemühten sich um eine landesweite Registrierung des Arbeitskräftepotenzials -, wurde nun die „Education for Work“ in zweifacher Hinsicht weiter ausgebaut, um schnell und effizient auf hinreichend geschultes Personal zurückgreifen zu können: einerseits in Form des „training-within-industry-programs“ und andererseits durch die Fortführung des „school-training-programs“ “ ${ }^{511}$ Ein kurzer Auszug aus der zitierten Broschüre verdeutlicht den Aktivitätsrahmen dieser beruflichen Weiter-,

507 How to Read the News. Education and National Defense Series Pamphlet No. 16. Hrsg. v. Federal Security Agency/U.S. Office of Education, Washington D.C. 1942; Guidance Problems in Wartime. Education and National Defense Series Pamphlet No. 18. Hrsg. v. Federal Security Agency/U.S. Office of Education, Washington D.C. 1942.

508 Education under Dictatorships and in Democracies. Education and National Defense Series Pamphlet No. 15. Hrsg. v. Federal Security Agency/U.S. Office of Education, Washington D.C. 1941; weiters: What the Schools Can Do. Education and National Defense Series Pamphlet No. 4. Hrsg. v. Federal Security Agency/U.S. Office of Education, Washington D.C. 1941.

509 Our Country's Call to Service. Education and National Defense Series Pamphlet No. 1. Hrsg. v. Federal Security Agency/U.S. Office of Education, Washington D.C. 1942.

510 Ebd., 11.

511 „You cannot take an unemployed shoe salesman and overnight put him in charge of an engine lathe.“ Ebd., 9. 
Um- und Einschulungsmaßnahmen zu Rüstungszwecken, die, eingebettet in Kurse zur Stärkung der nationalen Moral und zur Festigung demokratischer Loyalität, in hohem Tempo angelaufen waren:

"Engineers are being given short courses in some 150 technical colleges and universities; these and other colleges are providing special short courses of training in physics, chemistry, and production supervision for fields essential to the national defense. Additional thousands of unemployed men and women, drawn from registers of public employment offices, are being given preemployment courses in many of the 55 o defense industrial occupations - in machine shop work, in aircraft work, in riveting, and in ship building." ${ }^{, 12}$

Der deutsche Angriff auf die Sowjetunion im Juni 194I sowie insbesondere der japanische Überfall auf Pearl Harbour am 7. Dezember 194I mit dem darauffolgenden Kriegseintritt Amerikas an der Seite von Großbritannien und der Sowjetunion ${ }^{513}$ hatten eine weitere Intensivierung der angelaufenen Programme, der medialen Propaganda und der psychologisch-sozialwissenschaftlichen Auseinandersetzung mit den spezifischen Erfordernissen des nationalen Abwehrkampfes ${ }^{514}$ sowie des öffentlichen „Education in Wartime“-Diskurses zur Folge. ${ }^{515}$

Auf einer bundesweiten Konferenz zu „Higher Education and the War“ in Baltimore Anfang Jänner 1942, die vom kurz zuvor geschaffenen „Committee on Military Affairs“ des staatlichen „National Committee of Education and Defense“ durchgeführt wurde und an der mehr als I. 000 offizielle Vertreter aus den Bereichen College, Universität, War Department, Navy Department und Militär allgemein teilnahmen, wurde angekündigt, nun

512 Ebd., 11.

513 Vgl. Viktor Issraelian, Die Antihitlerkoalition. Die diplomatische Zusammenarbeit zwischen der UdSSR, den USA und England während des Zweiten Weltkrieges 1941-1945, Moskau 1975, 67.

514 Siehe dazu: George Creel, Propaganda and Moral; James Rowland Angell, Radio and National Morale; Robert E. Park, Morale and the News sowie Walter Wanger, The Role of Movies in Moral; alle in: The American Journal of Sociology, Vol. XLVII, November 1941, No. 3, 340-351; 352-359 bzw. 360-377 bzw. 378-383.

515 So wurde 1942 neben The School and Society auch der Klassiker der amerikanischen Bildungsphilosophie schlechthin, nämlich „Democracy and Education“ von John Dewey, ergänzt um einen Bezug zum Faschismus, aus Gründen nationaler Verteidigung und ideeller Selbstvergewisserung neu aufgelegt. 1942 hatte Dewey einen Vortrag über die Situation in Deutschland - „The One-World of Hitler's National Socialism“- gehalten, in dem er ausführte, dass der Nationalsozialismus die konsequente Fortsetzung beziehungsweise die pervertierte Vollendung der dualistischen, abstrakten Philosophie des deutschen Idealismus sei. Vgl. Otto Schlander, Der Einfluß von John Dewey und Hans Morgenthau auf die Formulierung der Re-educationpolitik. In: Manfred Heinemann (Hrsg.), Umerziehung und Wiederaufbau. Die Bildungspolitik der Besatzungsmächte in Deutschland und Österreich (=Veröffentlichungen der Historischen Kommission der Deutschen Gesellschaft für Erziehungswissenschaft, Bd. 5), Stuttgart 1981, 47. 
auch alle Ressourcen und geistigen Kapazitäten der Colleges und Universitäten zu mobilisieren, ${ }^{516}$ um so sowohl den Krieg, als auch den Frieden zu gewinnen: „[... to win the war and win the peace that follows “. ${ }^{517}$ In einer Grußnote an die Konferenz ging auch Präsident Roosevelt vage auf die angesprochene Herausforderung ein:

"We have one great task before us. That is to win the war. At the same time it is perfectly clear that it will be futile to win the war unless during its winning we lay the foundation for the kind of peace and readjustment that will guarantee the preservation of those aspects of American life for which the war is fought." 518

Ähnlich sah dies auch Frederick L. Schuhmann, Autor der 1935 erschienenen Studie „The Nazi Dictatorship“, ${ }^{519}$ der 1942 in geradezu dialektischer Form die Kernfrage des gesamtes „Education for victory“-Diskurses, nämlich, ob die USA tatsächlich bereit wären, „[...] to pay the price of victory now", auf den Punkt brachte. Wie Schuhman ausführte, wäre ein demokratisch geführter (und somit aufwendiger) Krieg - also eine tiefgehende demokratische Selbstvergewisserung, voller Kräfteeinsatz in präziser Kenntnis der zu verteidigenden Ideale und Ziele ebenso wie Überlegungen („post-war-planning“) einer nachhaltigen globalen Friedenssicherung nach Kriegsende bereits zur Kriegszeiten - die unabdingbare Vorleistung für einen demokratischen Sieg: „For it is almost as certain as death and taxes [...] that the winning of the war will not precede, but will follow, the formulation of our plan for winning the peace. That will be the principal weapon of our victory. “520

516 Seit 1940 liefen an der Columbia University und am Carnegie Endowment for International Peace spezielle Technik-Kurse, die auf militärische Anwendungsgebiete ausgerichtet waren, sowie Kurse, die sich mit den sozialen Aspekten des Krieges beschäftigten; an der Universität Chicago wurden für Mathematikstudenten u.a. Kurse in Ballistik angesetzt und an der Universität Harvard beschäftigte sich eine eigene „American Defense, Harvard Group“ mit der Ausarbeitung von landesweiten Plänen für eine vollständige Mobilisierung der Universitätsangehörigen zu Verteidigungszwecken, und zwar in den Bereichen medizinische Versorgung, Flüchtlingsaufnahme und -betreuung etc. Siehe: War and Defense Courses in Some of the Universities. In: School and Society, Vol. 52, 7. September, 1940, No. 1341, 158; weiters: Education for war and peace [Sponsored by the School of Education of Stanford University with the co-operation of the Division of Intercourse and Education of the Carnegie Endowment for International Peace] Stanford 1942.

517 Raymond Walters, The Baltimore Conference on Higher Education and the War. In: School and Society, Vol. 55, 17. January, 1942, No. 1412, 57-62.

518 Ebd., 57.

519 Frederick L. Schuman, The Nazi Dictatorship. A Study in Social Pathology and the Politics of Fascism, New York [2. Aufl.] 1936. Auf über 500 Seiten lieferte der Chicagoer Universitätsprofessor Schuhman hier eine elaborierte und quellengesättigte Analyse der Nationalsozialismus bzw. der nationalsozialistischen Ideologie.

520 Frederick L. Schuman, Design for People's Peace. Address before the Institute of Public Affairs, University of Virginia, Charlottesville, 11. Juli 1942. In: Representative American Speeches: 1942-1943, a.a. O., 148. 
Vorerst ging es aber, wie Paul McNutt von der Federal Security Agency des U.S. Office for Education herausstrich, primär um die vollständige Mobilisierung der „Education for Victory", wobei McNutt den Unterschied zwischen zivilen und militärischen Anstrengungen im nationalen Abwehrkampf zumindest "moralisch“ bereits aufgehoben sah. So meinte er gegenüber den Konferenzteilnehmern: „You are in the army now - that or a Nazi straightjacket later! Every resource of the nation must be geared to victory. “521

Neben der Bereitstellung von zusätzlichen Lehrkräften für sogenannte militärische „Pre-Instruction“-Kurse an Colleges und Universitäten ${ }^{522}$ zur Unterstützung der völlig überlasteten Offiziersausbildung an den Militärakademien - pro Jahr wurden nun Io.00o Offiziere ausgebildet - sowie der umfassenden Weiterbildung militärischen und zivilen Personals ging es auch um Vorkehrungsmaßnahmen zur Verbesserung der landesweiten Ernährung, ${ }^{523}$ Gesundheitserziehung und um entsprechende Hygiene-maßnahmen. Immerhin hatte eine empirische Erhebung ergeben, dass nur 50 Prozent der Army-Rekruten die erforderlichen körperlich-gesundheitlichen Voraussetzungen für den allgemeinen Wehrdienst erfüllten. ${ }^{524}$

Aufgrund des Arbeitskräftemangels ${ }^{525}$ in der Agrarwirtschaft infolge der Einziehung der Landjugend für die Kriegsindustrie beziehungsweise zum Militärdienst ${ }^{526}$ wurden

521 Ebd., 58.

522 Robert M. Hutchinson [Präsident of the University of Chicago], Education and the War. The University in War and Peace. In: Representative American Speeches: 1942-1943, a.a.O., 236-247.

523 So stellten Expertenberichte fest, dass zwischen 30 und $40 \%$ der amerikanischen Bevölkerung, also rund rund 45 Millionen, armutsbedingt unterernährt wären. Vgl. Our Country's Call to Service, a.a.O., 7.

524 Ein Report vom November 1941 stellte fest, dass von zwei Millionen untersuchen Rekruten nur eine Million unmittelbar wehrtauglich war. Von der anderen Million wäre lediglich die Hälfte für eingeschränkten Militärdienst verwendbar, die andere gar nicht. 20,9\% der Rekruten hätten darüber hinaus gravierende Zahnprobleme, 13,7\% ernst zunehmende Augenprobleme, $13 \%$ Herzprobleme, und immerhin 10,6\% Geschlechtskrankheiten. Siehe: Analysis of Reports of Physical Examination: Summary of Data from 19.923 Reports of Physical Examination (Medical Statistics Bulletin No. 1, National Headquarters Selective Service System), Washington D.C., 10. November 1941, $31 \mathrm{f}$.

525 Das zu lösende generelle Problem hinsichtlich der Menge des erforderlichen, adäquat geschulten Personals für Verteidigungszwecke wurde in einem Satz umrissen: „The problem seemed elementary: several million men out of work, several million needed - match men and jobs." Our Country's Call to Service, a.a.O., 9.

526 Anfang 1942 waren bereits 17 Millionen Männer - auf freiwilliger Basis - bei der Army registriert; 10 Millionen weitere Rekruten wurden schätzungsweise noch benötigt [laut Aussage General Hershey auf der Baltimore-Konferenz im Jänner 1942]. Dabei wurde von den Militärs auch bereits deutlich ausgesprochen, dass eine planmäßige und systematische Rekrutierung auf ,freiwilliger“ Basis möglich sei. Vgl. Walters, The Baltimore Conference, a.a.O., 60. Im Jänner 1944 schlug schließlich auch Präsident Roosevelt einen „national service act" vor: „Although I believe that we and our Allies can win the war without such a measure, I am certain that nothing less than total mobilization of all our resources of manpower and capital will guarantee an earlier victory, and reduce the toll of suffering and sorrow and blood." Franklin D. Roosevelt, Message to Congress, January 11, 1944. In: Representative American Speeches: 1943-1944. Selected by A. Craig Baird, New York 1944, 22. 
Programme zur Effektuierung der Versorgungsgüter-Produktion erstellt, Fragen eines „Reemployments“ in der Landwirtschaft nach Kriegsende thematisiert ${ }^{527}$ sowie spezielle Rehabilitationsprogramme für körperlich Behinderte zwecks Einsatzes in der Rüstungsindustrie entworfen. ${ }^{528}$

Angesichts der militärisch nunmehr real gewordenen Bedrohung der amerikanischen Zivilgesellschaft („democracy is on the defensive everywhere“) ${ }^{529}$ durch Nationalsozialismus beziehungsweise Faschismus - die letzten Isolationisten waren ab Pearl Harbour in die amerikanische Kriegsfront eingeschwenkt ${ }^{530}$ - wurde das gesamte Schul- und Bildungswesen der USA in kurzer Zeit auf die Zwecke und Erfordernisse nationaler Verteidigung umgestellt, wobei neben dezidiert kriegsbezogenen Aktivitäten auch Basisprogramme zur Erhöhung des kritischen Lesepotenzials anliefen. ${ }^{531}$

Als lokale Zentren mit entsprechendem Raumangebot wurden insbesondere Schulen, öffentliche Bibliotheken ${ }^{532}$ und Universitäten neben ihrer Aufgabe zur Bürger-Information und zur patriotisch-moralischen Stärkung („Civilian defense“) ${ }^{533}$ vor allem auch damit beauftragt, vermittels interkultureller Veranstaltungen zur kriegsnotwendigen Einigung und Zusammenarbeit aller nationalen Minderheiten beizutragen.

527 Rural Youth Program: A Suggested Plan of Action. Recommendations of the Institute for Rural Youth Guidance, Washington D.C. 1941; Wartime Guideposts for Rural Youth. Abbreviated proceedings of the Institute of Rural Youth Guidance and 27th Annual Meeting of the Alliance for Guidance of April 23-25, Richmond - Washington D.C. 1942.

528 Vgl. Vocational Rehabilitation and National Defense. Education and National Defense Series Pamphlet No. 19. Hrsg. v. Federal Security Agency/U.S. Office of Education, Washington D.C. 1942; Guidance Problems in Wartime. Education and National Defense Series Pamphlet No. 18. Hrsg. v. Federal Security Agency/U.S. Office of Education, Washington D.C. 1942.

529 The Education of Free Men in American Democracy, a.a. O., 115

530 Vgl. Education in Wartime and After, a.a.O., 53; Steele, Preparing the Public für War, a.a.O., 1652.

531 Vgl. How to Read the News. Education and National Defense Series Pamphlet No. 16. Hrsg. v. Federal Security Agency/U.S. Office of Education, Washington D.C. 1942;

532 Als Noch-Direktor der Library of Congress sprach Archibald MacLeish insbesondere den Bibliotheken eine besondere Rolle und Bedeutung als demokratische „Erziehungsagenturen“ $\mathrm{zu}$ : „The libraries alone are capable of acting directly upon the present adult generation." Archibald Mac Leish, Library Journal, 64, 1941, 879-882. Zit. nach: William P. Tucker, How Can Libraries Aid Democracy? In: School and Society, Vol. 53, 10. Mai 1941, 23.

533 Die spezifisch homogenisierende Dimension von „Moral“ im Kontext der nationalen Verteidigung wurde auch von Seite der psychologischen Forschung hervorgehoben: „All of these organizations, federal, state, and local, require their own morale. They call for physical strength and alertness. They must be infused with a spirit of combativeness and of emulation [...]. But the organization of Civilian Defense has a deeper meaning. It is symbolic of the fact that readiness for defense, like war itself, is total. [...] Civilian Defense gives every man and woman a place in the ranks, along with the armed forces, the leaders in industry, and the workers in industrial plants." James M. Landis [Office of Civilian Defense], Moral and Civilian Defense. In: The Journal of the Abnormal and Social Psychology, 38. Jg., 1943, 337. 
Von Anbeginn war der öffentliche „Education for Victory“-Diskurs, der zum Zweck der moralisch-geistigen Einigung der USA die eigenen zu verteidigenden demokratischen Werte in den Vordergrund stellte und dabei wiederholt auf die demokratische Pflicht verwies, auch die eigenen Schwächen klar zu erkennen, ein Diskurs, in dessen Windschatten das Problem der „Rassen“-Diskriminierung im eigenen Land sozusagen mitlief. ${ }^{534}$

Im Hinblick auf die Erfordernisse einer vollständigen Mobilisierung des nationalen Arbeitskräftepotenzials besann sich die US-Regierung daher der prinzipiellen Gleichheit aller amerikanischen Bürger. In der oben bereits zitierten nationalen Verteidigungsbroschüre „Our Country's call to Service" wurde diesbezüglich in pragmatisch-nüchternem Ton festgehalten:

"Another source of manpower which must increasingly be used is the Negro worker. Every ef-
fort has been made by the schools to extend defense training opportunities to Negroes. Several
thousand Negroes are now receiving training; many others have already been employed in muni-
tions factories, in aircraft manufacturing, and in shipbuilding. And as the urgency of the need for
employing our full resources of trained manpower becomes every day more pressing, we shall see
Negroes, by increasing thousands, finding their way into employment in many defense industries.
[...] It would be both dangerous and stupid to deny I3, ooo. ooo Negro citizens, who love freedom as
much as any of us do, the fullest opportunity to give of their strength, their courage, and their devotion to
our defense effort, whether in the Army, the Navy, or the labor force of the Nation. Unless we can devel-
op a tolerance based upon justice and mutual understanding we bid fair to become an easy prey for
the softening-up tactics so successfully used by the Nazis in Europe."

Und mit Blick auf die wiederkehrenden Versuche der NS-Propaganda, soziale, ethnische und religiöse Gruppen in den USA gegeneinander aufzuhetzen ${ }^{536}$ - tatsächlich kam es zwischen 1942 und 1943 in den Südstaaten zu heftigen Auseinandersetzungen zwischen Weißen und Afroamerikanern ${ }^{537}$-, wurde durchaus realistisch konstatiert: „Few Americans understand the true menace of these tactics which by exploiting racial and religious prejudice, by rousing class suspicion, by capitalizing on economic controversy, short-circuit united action and weaken resistance to military conquest. "

Auch die Propagandaabteilungen der Achsenmächte nutzten die Angriffsfläche, die die amerikanische Minderheitenpolitik bot. So meldete der japanische Rundfunk am I5. März I942 von Mandschuko aus in englischer Sprache: „Democracy, as preached by the Anglo-

534 In den zitierten Schriften des „National Defense“-Programms wurde auf die Frage der nationaler Minderheiten bzw. der existierenden Rassendiskriminierung lediglich in allgemeiner Form eingegangen, indem man jegliche Ungleichbehandlung als unvereinbar mit demokratisch-humanitären Werten und Idealen erklärte.

535 Our Country's Call to Service, a.a. O., 12 bzw. 19.

536 Vgl. Jerome S. Bruner, The Dimension of Propaganda: German Short-Wave Broadcasts to America. In: The Journal of the Abnormal and Social Psychology, 38. Jg., 1943, 311-337.

537 Vgl. Howard W. Odum, Race and Rumors of Race, University of North Carolina 1943.

538 Our Country's Call to Service, a.a.O., 19. 
Americans, may be an ideal and noble system of life, but democracy as practiced by AngloAmericans is stained with the bloody guilt of racial persecution and exploitation. " ${ }^{539}$

Das vielschichtige Problem der Diskriminierung von Minderheiten im eigenen Land, ${ }^{540}$ an vorderster Stelle die Diskriminierung der „Negroes“, ${ }^{541}$ bedeutete angesichts der auf demokratische Selbstvergewisserung angelegten „Education at War“ eben nicht nur ein politisches und motivationales Problem im Hinblick auf die angestrebte nationale Einigung im Kampf gegen Nationalsozialismus und Faschismus, sondern stellte darüber hinaus auch die Glaubwürdigkeit ${ }^{542}$ der zu verteidigenden demokratischen Werte der „free world“ in Frage, denn schließlich: "The American Dream is the dream of the Negro. The dream of the Negro is the dream of an America which guarantees [...] all rights for all. " ${ }^{433}$ [Hervorhebung d. Verf.]

Es überrascht daher nicht, dass sich in jenen Jahren vermehrt Studien und Berichte kritisch mit der Gleichstellung der Afroamerikaner in den USA, deren unzureichenden Bildungsmöglichkeiten, ${ }^{544}$ mit allgemeinen Fragen interkultureller Erziehung sowie mit „Rasse“-Vorurteilen befassten, ${ }^{545}$ und - angesichts des NS-„Rassen-Mythos“vom „,superi-

539 The Negro's War. In: Fortune, XXV, June, 1942, 77. Zit. nach: Education in Wartime and After, a.a. O., 65. 540 Siehe dazu: Matthew Pratt Guterl, The Color of Race in America, 1900-1940, Cambridge/Mass. 2001.

541 Die ungleiche Ausgangssituation zwischen „Weißen“ und „Farbigen“ verdeutlicht u.a. auch die Statistik der Zurückstellung von Rekruten aufgrund von Wehruntauglichkeit, die am 1. Dezember 1944 veröffentlicht wurde: von insgesamt 4.458.000 Registrierten (3.588.000 „white“ und 870.000 „Negroes“) im Alter zwischen 18-37 Jahren wurden nur in der Kategorie "geistig-intellektuelle Schwächen“ („Mental deficiency“) prozentuell signifikant mehr Afro-Amerikaner abgewiesen (32,1\% gegenüber 9,5\% bei den „Weißen“), in allen anderen Kategorien wie bswp. „Manifestly disqualifying defects“ (7,3\% zu 11,3\%), „mental diseases“ (10,2\% zu 18,7\%), „Physical defects“ (48,9\% zu 59,\%) sowie „Nonmedical“ (1,5\% zu $1,5 \%)$ schnitten die Afro-Amerikaner besser ab bzw. lagen gleich auf. Vgl. Kandel, The Impact of the War upon American Education, a.a.O., 43.

542 „The fact that America denies tolerance, freedom, and equality of opportunity to large numbers of American citizens in our minority groups has, of course, made us vulnerable to charges from our enemies that we do not practice the democratic ideal which we preach." Education in Wartime and After, a.a.O., 65.

543 L.D. Reddick, The Negro in the Building of America. In: School and Society, Vol. 53, February 8, 1941, No. $1363,164$.

544 So hatte bereits 1934 eine Studie des State Department of Education in Mississippi ergeben, dass 1.428 von insgesamt 3.737 Schulen für Afroamerikaner in privaten Unterkünften wie z.B. in Zelten, Kirchengebäuden untergebracht wären und von den insgesamt 5.930 Lehrkräften lediglich 600 über eine Bildung knapp über dem High School Niveau verfügten. Vgl. Leon Eubanks, Negro Education in the South. In: School and Society, Vol. 53, February 1, 1941, No. 1362, 152 f.; weiters siehe folgende vom „National Council of Education" herausgegebene Studien: Charles S. Johnson, Growing Up in the Black Belt. Negro Youth in the Rural South, Washington D.C. 1941; W. Lloyd Warner/Buford Helmholz Junker/Walter A. Adams, Color and Human Nature. Negro Personality Development in a Northern City, Washington D.C. 1941; Edward Franklin Frazier, Negro Youth at the Crossways. Their Personality Development in the Middle States, Washington D.C. 1940.

545 So z.B. Robert E. Park, The Bases of Race Prejudice. In: Annals of the American Academy of Political and Social Science, CXXXX, November 1928, 11-20; Elaine Ogden McNeil/Horace R. Cayton, Research on the Urban Negro. In: American Journal of Sociology, Vol. XLVII, September 1941, No. 2, 176-183; 
or "white man“ - wissenschaftliche Argumente gegen einen derartigen „kulturellen Chauvinismus" darlegten. ${ }^{546}$ So hätten neuere Untersuchungen zu den Ergebnissen bisheriger Intelligenz-Tests zur Untermauerung der Unterschiede zwischen Weißen und „Farbigen“ gezeigt, dass „[the] racial approach is all too simple in its methodology. "547

Gezielte Fördermaßnahmen gegen den hohen Analphabetismus (I94I: rund I7 Prozent), ${ }^{548}$ der Ausbau des primären und sekundären Bildungswesens für Afroamerikaner ${ }^{549}$ sowie Literarisierungsmaßnahmen innerhalb des Militärs speziell für „Farbige“550 sollten Abhilfe schaffen. Die Kritik der real existierenden Diskriminierung im Alltagsleben, die Erhöhung der staatlichen Ausgaben für öffentliche Schulen für Afroamerikaner, wiederkehrende Verweise auf den wichtigen Beitrag der „Negroes“ als Arbeitskräfte in der Kriegsindustrie sowie die proklamierte Notwendigkeit einer Einheit der sozial und ethnisch heterogenen USA führten während des Krieges zu tatsächlichen Verbesserungen im Bereich der Arbeitssituation von Afroamerikanern sowie im Bereich des Bildungswesens. ${ }^{551}$ Diese Erfolge konnten freilich selbst grundsätzlich optimistische Autoren nicht darüber hinwegtäuschen, dass hier weiterhin fundamentaler demokratiepolitischer Entwicklungsbedarf gegeben war.

Selbst eine von Präsident Roosevelt am 25. Juni i94I erteilte Weisung [Executive Order 8802], insbesondere im Bereich der Verteidigungsindustrie künftig Afroamerikaner nicht zu diskriminieren - „[...] warning [...] government, employers, and labor that discrimination in defense industries is contrary to the country's fundamental interests and must not be

Leon Eubanks/Edgar T. Thompson (Eds.), Race Relations and the Race Problem, Durham 1939; Ruth Benedict/Mildred Ellis, Race and Cultural Relations. Problems in American Life (National Education Association, Unit No. 5), Washington D.C. 1942; M.F. Ashley Montagu, Man’s Most Dangerous Myth. The Fallacy of Race, New York 1943; William E. Vickery/Steward G. Cole, Intercultural Education in American Schools, New York 1943.

546 So z.B. die Beiträge von Margaret Mead, Franz Boas oder Hans Kohn in: Alain Locke/Bernhard J. Stern (Eds.), When People Meet. A Study in Race and Cultur Contacts, New York 1942.

547 Herman G. Canady, The Methodology and Interpretation of Negro-White Mental Testing. In: School and Society, Vol. 55, May 23, 1942, No. 1430, 570.

548 Reddick, The Negro in the Building of America, a.a.O., 163.

$549 \mathrm{Im}$ Jahr $1940 \mathrm{gab}$ es in 17 Bundesstaaten im Süden der USA keine einzige staatlich unterstützte Universität, an der „farbige“ College StudentInnen weiter studieren konnten. Siehe: Charles H. Wesley, Graduates for Negroes in Southern Universities. In: Harvard Educational Review, Vol. X, 1940, No. 1, 82; weiters: Alice I. Bryan, Equalizing Public Education for Negroes in Tennesse. In: School and Society, Vol. 58, July 3, 1943, No. 1488, 11 .

550 So stellte die NEA Research Division 1940 in einer Untersuchung in einem Militär-Camp in Washington D.C. fest, dass $76 \%$ der afroamerikanischen Rekruten - gegenüber $11 \%$ der weißen - funktionelle Analphabeten wären. Vgl. Education in Wartime and After, a.a.O., 185.

551 So bspw. in Montgomery/Alabama: 1936 hatten nur wenige afroamerikanische Lehrer Universitätsabschlüsse; 1944 waren es dann immerhin bereits 53,6\% und damit mehr, als 1936 für weiße Lehrer zutraf. Vgl. School and Society, Vol. 61, June 30, 1945, No. 1592, 430. 
tolerated“552 - hatte nur wenig Wirkung. So berichtete das „Bureau of Employment Security“ Ende 194I, dass 5I Prozent von 282.245 ausgeschriebenen Stellen „were barred to Negroes“.553 Auch die Armee betrieb aktive Diskriminierung durch Separierung und dadurch, dass bestimmte Militärdienste für „farbige“ Rekruten gesperrt wurden; selbst 200 Gewerkschaften verweigerten „Farbigen“ per Statut die Mitgliedschaft. ${ }^{554}$ Im liberalen akademischen Klima setzte es angesichts dieser Tatsachen deutliche Kritik an der Diskriminierung der Afroamerikaner im demokratischen Amerika: „People all over the world have been horrified at the treatment which Jewish scholars, scientists, and artists have received at the hand of the Nazis, and they have been shocked that any civilized people could be so destructive of talent and skill. In many ways America's practice is just as short-sighted though not sadistic or inhuman." ${ }^{\text {"555 }}$

Im Bereich der Kindererziehung wurde, zum Zweck der Stärkung der nationalen Kampfbereitschaft auch unter den Kleinsten, im Schulunterricht verstärkt Informationen über die vernichtenden Folgen eines Sieges der Achsenmächte für Amerika gebracht. Für Schul- und Klassenbüchereien empfahl man besonders rezente Darstellungen des nationalsozialistischen Systems wie Douglas Millers „You can't do business with Hitler“, Wallace Deuels „People Under Hitler“, Williams Shirers „Berlin Diary“, Anna Seghers „The Seventh Cross“, Paul Palmers „Denmark in Nazi Chains“, Arthur Koestlers „All Night Long“" oder Bücher zur amerikanischen Demokratie, wie zum Beispiel Archibald MacLeishs „Land of the Free“ anzukaufen und im Unterricht zu diskutieren. ${ }^{556}$ Darüber hinaus wurden die Lehrpläne der Colleges dezidiert an die Erfordernisse praktisch-technischer Fertigkeiten für die Kriegswirtschaft abgestimmt und das Lehrpersonal von Schulen und Universitäten zusätzlich zur Ausbildung von Arbeitern und technischen Spezialisten („Navy V-I2 Program“) ${ }^{557}$ für die seit Juli I940 rapide anwachsende Kriegsindustrie herangezogen. Neben den Industrie-Trainingsprogrammen liefen auch die genannten SchulTrainingsprogramme weiter, die sogenannte „Preemployment"-Kurse für Arbeitskräfte in Munitions-, Schiffs- und Flugzeugfabriken durchführten. Um die enorme Zahh ${ }^{558}$ der für

552 Zit. nach: Education in Wartime and After, a.a.O., 73.

553 Ebd.

554 Angesichts dieser Situation befasste sich sogar die „War Manpower Commission“ mit der Problematik. Manpower. One Tenth of the Nation. By Paul V. McNutt, Chairman of the War Manpower Commission, Washington D.C. 1942. Zit. nach: Education in Wartime and After, a.a.O., 73.

555 Ebd., 72.

556 Vgl. Ebd., 59 f.

557 Zur Ausbildung hochqualifizierter Spezialisten für die Navy wurden an 1941 spezielle Eignungstests landesweit an allen Schulen, Colleges und Universität durchgeführt; die Ausbildung der Kandidaten erfolgte dann ebenfalls an Colleges und Universitäten. Vgl. The Second Nation-Wide Test for the ASTP and the Navy V-12 Program. In: School and Society, Vol. 58, October 2, 1943, 252.

558 Bis Anfang 1942 wurden - von insgesamt 18 Millionen ArbeiterInnen in der Rüstungsindustrie - in öffentlichen Schulen immerhin 2,5 Millionen Arbeitskräfte mit für die Kriegsindustrie erforderlichen Skills ausgestattet. Vgl. William H. Johnson, Industrial Education in the War Program. In: School and Society, Vol. 55, May 30, 1942, No. 1431, 597. 
die Rüstungsindustrie benötigen FacharbeiterInnen in kürzester Zeit auszubilden, wurden - neben Schulungsmaßnahmen in den Rüstungsbetrieben selbst - an Schulen, Berufsschulen und Erwachsenenbildungs-Einrichtungen nach dem beziehungsweise parallel zum regulären Unterricht Millionen an „skilled workers who are now employed making or servicing commodities like refrigerators, kitchen appliances, radios, washing machines“ in speziellen Trainings- und „Auffrischungskursen“ unterrichtet.

Der enorme Arbeitskräftebedarf der Kriegsindustrie ${ }^{559}$ führte dazu, dass Firmen wie Lockheed oder Vega Aircraft Corporations in Los Angeles ab 1943 kombinierte „workschool-programs " für Schüler im Alter zwischen i6 und I8 Jahren durchführten, wobei diese alternierend einen Monat in der Fabrik - bei regulärer Bezahlung - oder einen Monat in der Schule verbrachten. ${ }^{560}$

I943 wurden an über 400 amerikanischen Universitäten und Colleges pro Semester rund 300.000 Militärs in hochspezialisierten Kursen für ihren Kriegseinsatz ausgebildet. ${ }^{561}$ Mit dem im Juli 1943 begonnenen „Civil Affairs Training Schools“562-Programm wurde den Universitäten aufgrund der Nachfrage an gut geschultem Personal für die Militärstäbe in Europa - Anfang I943 waren in Nordafrika erste Militärbehörden installiert worden ${ }^{563}$ die Ausbildung entsprechenden Militärpersonals übertragen. Nach der Einrichtung der ersten „Military-Government School“ an der University of Virginia in Charlottesville bereits im April $1942^{564}$ wurden an den Universitäten Yale, Harvard, Michigan, Chicago, Stanford und Pittsburgh - jede Universität war einer definierten Auslandszone zugeordnet - spezielle Ausbildungs- und Trainingsprogramme für Offiziere unter Leitung der Militärschule Charlottesville angesetzt. Die 2905 teils hochrangigen Offiziere („non combatants“) der späteren Militärbehörden in den zu besetzenden Gebieten erhielten hier a) spezielle Schulung in Fremdsprachen, insbesondere Deutsch und Ostsprachen, aber auch in Geografie, Wirtschaftskunde, Recht, Ökonomie und Gesundheitswesen sowie b) in „Personnel Psychology“; diese Gruppe bildeten rund I50 vorwiegend zivile Akademiker, die nach einem 24-Wochenkurs US-Militärcamps zugeteilt wurden, um dort als „educa-

559 Allein 1942 wurden 48.000 Militärflugzeuge produziert; für 1943 wurden als Ziel 125.000 angegeben. Education in Wartime and After, a.a.O., 232.

560 Ebd., 379.

561 Raymond Walters, Statistics of Attendance in American Universities and Colleges, 1943. In: School and Society, Vol. 58, December 25, 1943, No. 1153, 484.

562 Zur selben Zeit wurde vom War Department auch eine eigene Civil Affairs Division (CAD) eingerichtet, welche die US-Militärregierung weltweit planen und koordinieren sollte. Vgl. James F. Tent, Mission on the Rhine. Reeducation and Denazification in American-Occupied Germany, Chicago - London 1982, 15.

563 Josef Leidenfrost, Die Amerikanische Besatzungsmacht und der Wiederbeginn des politischen Lebens in Österreich 1944-1947. Bd. 1, Diss., Univ. Wien 1986, 2.

564 Karl Bungenstab, Die Ausbildung der amerikanischen Offiziere für die Militärregierung nach 1945. In: Jabrbuch für Amerikastudien, 18, 1973, 199 f. 
tional administrators “ ${ }^{\circ 65}$ einen möglichst effizienten Einsatz von Militärpersonal zu garantieren. ${ }^{566}$ Interessant ist das vor allem auch deshalb, weil sich die Offiziere der späteren Militärregierungen, wie Josef Leidenfrost darlegt, im Rahmen dieser „area lectures“ auch erstmals mit Österreich auseinanderzusetzen begannen und der zentraleuropäische Raum dabei sogar einen Schwerpunkt darstellte. ${ }^{567}$

Interessant ist auch, dass die auf vollen Touren laufende „Education for Victory“ offenkundig zu einer zunehmenden Militarisierung der Lehrpläne an Schulen, Colleges und Universitäten ${ }^{568}$ führte, weshalb sich immer öfter Pädagogen und Bildungsreformer kritisch zu Wort meldeten und angesichts der kriegsbedingten Zurückdrängung humanistischer Fächer beziehungsweise der Überbetonung naturwissenschaftlich-technischmilitärischer Studien Sorgen um die längerfristigen Auswirkungen auf das amerikanische Bildungswesen, insbesondere auf die Universitäten, zum Ausdruck brachten: ${ }^{569}$

"The war has put a premium on applied mathematics and applied science and on technical courses at the expense of history, social science, literature, fine arts, and philosophy. Many people fear that liberal education will never be restored; that the current emphasis on technical training will give it such a dominant position that the liberal arts will never regain their place at the center of higher education." ${ }^{570}$

Angesichts der konstatierten disziplinären Überspezialisierung, wo Wissen mehr zählen würde als Verstehen, wäre es, wie es hieß, „ein tragisches Paradox, wenn als Folge des Krieges das Höhere Bildungswesen Amerikas genau in jenen Typ verwandelt würde, der es Verbrechern wie Hitler so leicht gemacht hätte, ein ganzes Volk zu kommandieren. “571

565 Tent, Mission on the Rhine. Reeducation and Denazification in American-Occupied Germany, a.a.O., 15.

566 Training for Military Government in the Conquered Countries. In: School and Society, Vol. 58, July 3, 1943, No. 1488,5 f.

567 Leidenfrost, Die Amerikanische Besatzungsmacht und der Wiederbeginn. Bd. 1, a.a. O., 3 f.

568 Vgl. dazu: John Dale Russell (Ed.), Higher education under war conditions, University of Chicago 1943; Understanding the war. Suggestions for summer school courses, for extra-curricular programs, and for discussions relating to war information, Washington D.C. 1943; Ernest O. Melby (Ed.), Mobilizing educational resources for winning the war and the peace, New York - London 1943; Wartime redirection in secondary education; suggested emphases in the secondary school program to meet wartime demands, prepared by members of the staff of the College of education of the State University of Iowa, Iowa City 1942; Schools at war. A program for action. Handbook of suggestions. Sponsored by the War savings staff of the U.S. Treasury Department, the U.S. Office of Education and its War-time Commission, Washington D.C. 1942.

569 Vgl. Alexander Meiklejohn, The Future of Liberal Education. In: New Republic, 108, January 25, 1943, 113-115; Guy E. Snavely, The Outlook for Liberal Education. School and Society, Vol. 60, July 1, 1944, No. 1540, 2. Carter Davidson, Has the War doomed Coeducation? In: Ebd., Vol. 59, 1944, No. 1518, $93 \mathrm{ff}$.

570 T.R. McConnell, Liberal Education After the War. In: The Annals of the American Academy of Political and Social Science, Vol. 223, January 1944, 821.

571 Ebd., 82. 
Die kriegsbedingte Militarisierung des gesamten US-Bildungs- und Erziehungswesen fasste Präsident Roosevelt in einer Kongress-Rede 1944 anschaulich zusammen:

"I understand that nearly the whole energies of the university have been drawn into the preparation of American youth for the battlefield. For this purpose, all classes, courses have been transformed and even the most sacred vacations have been swept away in a round-the-year and almost round-the-clock drive to make warriors and technicians for the fighting fronts." ${ }^{572}$

Unter der Herausforderung des „totalen Krieges“, ${ }^{573}$ wo es aus Sicht amerikanischer Bildungsfachleute, Wissenschafter und Politiker nicht nur um Sieg oder Niederlage, sondern um ,either we or they “ ${ }^{574}$ um Demokratie oder Diktatur und damit um Freiheit oder Vernichtung ging, sollten die Schulen und sonstigen Bildungsagenturen des Landes - ganz im Sinne der Deweyschen Vorstellungen - in der gemeinsamen Anstrengung gegen den Feind zu Lern- und Werkstätten praktizierter Demokratie werden.

Die bildungspolitische Herausforderung an das gesamte amerikanische Bildungswesen und deren Subordinierung unter militärische Imperative - deren Folgewirkung man in gewissem Sinne als kriegsbedingte, binnenamerikanische „Reeducation“, 575 als binnenamerikanische Demokratisierung ${ }^{576}$ interpretieren könnte, die der Reeducation der Achsen-

572 Franklin D. Roosevelt, Message to Congress, January 11, 1944. In: Representative American Speeches: 1943-1944, a.a.O., 29.

573 Der 1938 in die USA emigrierte österreichische Historiker und spätere Professor am Cornell College, Eric C. Kollmann, analysierte den Zweiten Weltkrieg als ersten globalen, industriellen und zugleich „totalen“ Krieg, der alle Bereiche der Gesellschaft umfasse und als globale Krise die Reevaluation westlicher Fundamente und Werte dringend erforderlich mache. „Consequently, no single individual can escape the war, whether physically, or psychologically, or spiritually. [...] What does that mean to American Education [...]. It means first, of course, that the schools are drafted, too, that education as usual is out. And, I think, not just for the duration. "Eric C. Kollmann, The Nature of this War and American Education. In: School and Society, Vol. 57, Saturday, February 20, 1943, No. 1469, 203.

574 Our Country's Call to Service, a.a.O., 2.

575 So verwies beispielsweise Ross Stagner in einem psychologischen Fachbeitrag zur Reeducation der durch Chauvinismus, Militarismus und Rassismus indoktrinierten Deutschen dezidiert darauf, dass Umerziehungsmaßnahmen dieser Art u.a. auch der amerikanischen Bevölkerung gut täten: „Our attention should not be drawn too much away from home while thinking along this line. Many inhabitants of the United Nations need a similar education toward replacing many established emotional patterns. Latent hostility against our Russian, British, and Chinese allies is still high, even if under cover.“ Ross Stagner, PeacePlanning as a Problem in the Psychology of Learning. In: The Journal of Abnormal and Social Psychology, 38, $1943,189$.

576 So wurde im Bereich des Militärs für die Stärkung der Moral der Rekruten und deren „Education“- 1940 waren immerhin 55\% der Army-Rekruten „splendid isolationists“ - 1942 mit dem „Why We Fight“Filmprogramm der Army Moral Branch begonnen, das der Regisseur Frank Capra als Leiter der „Film Production Section of Special Services Division“ (SSD) koordinierte. Jeder US-Soldat, der nach Europa einschiffte, musste diese Dokumentarfilme wie z.B. „The Nazi Strike“ [1943] obligatorisch ansehen, die, 
mächte nach Kriegsende sozusagen vorausging - wies dabei zwei miteinander verschränkte Perspektiven auf:

I. Die völlige Mobilisierung des gesamten nationalen Bildungswesens im Rahmen des „National Defense Programs“ angesichts der bücherverbrennenden und massenmordenden Bedrohung westlicher Zivilisation ${ }^{577}$ durch Nationalsozialismus und Faschismus wurde als elementare Herausforderung angesehen, neben allen Kriegsmaßnahmen im engeren militärischen Sinne auch die überlegenen geistig-moralischen Kapazitäten einer freiheitsmotivierten, demokratischen Zivilgesellschaft zu demonstrieren.

In der Perspektive einer geeinten humanistisch-demokratischen Front aller religiösen und ethnischen Gruppen in diesem „world-wide civil war“578 tauchte, sozusagen als Gegenstück zur isolationistischen Position der früheren Jahre, die Vorstellung eines aktiv zu betreibenden amerikanischen Universalismus auf, denn - „Victory when it comes, will not be ours alone. It will be victory for all oppressed peoples, and they will be looking for leadership and guidance. ${ }^{\text {" } 579}$

Im Modell der „One World“, wie dies der republikanische Gegenkandidat zu Roosevelt, Wendel Willkie, in seinem überaus populären Buch formulierte, ${ }^{580} \mathrm{sah}$ man in Amerika

neben den brutalen Zielen und der menschenverachtenden Vorgehensweisen der Feinde, v.a. die Prinzipien der Demokratie und die Bedrohung der Freiheit in den Vordergrund stellten. Diese Filme wurden, nach anfänglichen Bedenken des Office of War Information, da sie nicht den Hollywood-Standards und der hier gängigen Personifizierung des „Bösen“ genügten, dann ab 1943 auch in tausenden US-Kinos unentgeltlich zur Aufführung gebracht. Österreich kam in den teilweise von den Walt Disney Studios animierten Filmen, im Gegensatz zur pestschwarzen Landkarte Deutschlands, als untergegangenes, ertrunkenes Land vor. Siehe: Klaus Kämpfe, Educating the Re-educators: Films in the Morale-Program of the U.S. Army. In: Krippendorf (Ed.), The Role of the United States, a.a.O., 158-182.

577 „Fires make short order of books which represent the cumulative wisdom of the race in its age-long search for truth. Concentration camps isolate critical intelligence and, by harsh example, silence the expression of dissident opinions. [...] If the power of the few control and exploit the many is unchecked and unlimited, we can expect nothing but a repetition of the unbridled arrogance of tyranny. The history of despotism provides a reliable prophecy of the social catastrophe which may be expected if totalitarianism triumphs." Our Country's Call to Service, a.a.O., 1.

578 Education in Wartime and After, a.a. O., 37. Vgl. auch: Herbert Agar/Lewis Mumford/Frank Kingdon, World-wide civil war. Report of Lincoln day meeting, New York 1942.

579 Education in Wartime and After, a.a.O., 37.

580 Wendell L. Willkie, One World, New York 1943. In scharfer Kritik des US-Isolationismus früherer Jahre sah Willkie, freilich rhetorisch zugespitzt, für die USA nunmehr drei Optionen gegeben: „America must choose one of three courses after this war: narrow nationalism, which inevitably means the ultimate loss of our own liberty; international imperialism, which means the sacrifice of some other nation's liberty; or creation of a world in which there shall be an equality of opportunity for every race and every nation. I am convinced, the American people will choose, by overwhelming majority, the last of these courses. [...] To win this peace three things seem to me necessary - first, we must plan now for peace on a world basis; second, the world must be free, politically and economically, for nations and for men, that peace may exist in it; third, America must play an active, constructive part in freeing and keeping its peace." Zit. nach: ebd., 166. 
jenes hohe Zivilisationsniveau erreicht, das künftig den Maßstab für die weitere demokratische Entwicklung aller Länder abgeben sollte; in den Worten von Willkie: „One America could become one world. “581 Wobei Präsident Roosevelt in einer Rede vor Studenten I942 noch durchaus offen ließ, inwieweit die kommende Weltzivilisation tatsächlich eine primär von Amerika geprägte sein solle: „It means that the old term ,Western civilization no longer applies. World events and the needs of all humanity have joined the culture of Asia with the culture of Europe and the Americas to form for the first time a real world civilization." ${ }^{582}$

2. Daneben begriff man die externe Bedrohung durch einen totalitären Aggressor als Herausforderung, die nationalen Anstrengungen für den Sieg des demokratischen „way of life" für innere Reformen sowie zum grundlegenden Nachdenken über bildungspolitischfriedenssichernde Maßnahmen für die „postwar-reconstruction“ zu nützen.

Noch im Oktober 1944 wurde die Postwar-Education als andauernde Aufgabe für die amerikanische Gesellschaft im Sinne einer nachhaltigen Reeducation begriffen. So heißt es in einer Publikation, die sich mit den Möglichkeiten des Films als niederschwelligem Bildungsmedium beschäftigte - der Film wurde ja bereits seit 1942 im Rahmen der USNavy, der US-Army und in zivilen Rüstungsbereichen Amerikas intensiv genützt -, in Bezug auf den Zweiten Weltkrieg als gewissermaßen erstem „Bildungskrieg“:

"Never has a war required so much learning as this one. Civilians have learned to produce modern weapons and soldiers have been trained to use them effectively. Both civilians and men in military service have been forced to learn new habits of living and to acquire new knowledge and attitudes. This vast program of re-education of whole populations has been greatly facilitated by the motion picture. [...] Thousands of miles of films have been used for training soldiers, sailors, aviators, and war workers." ${ }^{583}$ [Hervorhebung d. Verf.]

Die in direkter Weise kriegsbezogenen Informations- und Bildungsmaßnahmen wurden dabei jedoch mit allgemeinbildenden Maßnahmen für „democratic citizenship“ eng verknüpft gesehen:

"If education for democratic citizenship is taken as a goal, existing barriers must be removed.

[...] The first barrier to democracy which it behoves education to remove is that of illiteracy,

581 Ebd., 157.

582 Franklin D. Roosevelt, Address to students from 29 United Nations assembled in conference at Washington D.C., September 3, 1942. Zit. nach: Education and the United Nations. The Report of A Joint Commission of the London International Assembly and Council for Education in World Citizenship, London, March 1943, 49.

583 Motion Pictures for Postwar Education. Prepared by the Commission on Motion Pictures in Education. American Council on Education Studies (= Reports of Committees and Conferences No. 21), Vol. VIII, Washington D.C., October 1944, 2 f. 
ignorance, and a general low level of mass education. Democracy requires a higher level of education than any other way of life $[\ldots]$. The democratic citizen must be well informed on social issues, particularly those that affect the welfare of his community and nation. [...] An illiterate may very well be an upright, honest, and useful citizen [...] but his usefulness as a citizen of the wider community is seriously handicapped." ${ }^{584}$ [Hervorhebung d. Verf.]

Die „Education in Wartime“ führte also ganz zweifellos zu methodischen und curricularen Verbesserungen, ${ }^{585}$ zu verstärkter finanzieller Unterstützung und letztlich zu nachhaltigen Demokratisierungsprozessen in der amerikanischen Bildungslandschaft, ${ }^{586}$ was im Übrigen auch durch empirische Langzeituntersuchungen wie etwa von Kurt Lewin und Harold Anderson verifiziert wurde. ${ }^{587}$

In Fortsetzung der bisherigen Konferenzen zur „Education for Victory - Education in War“, den Diskussionen laufender National-Defense-Programme sowie erster Überlegungen zur Nachkriegsordnung fand vom I3. bis I7. September 1943 in West-Virginia unter Vorsitz des Dekans der Stanford University die Harpers-Ferry Bildungskonferenz statt, an der Vertreter aus 29 Nationen teilnahmen. ${ }^{588}$ Gemäß der Devise „Uneducated People are unable to meet their obligation of citizenship in a democratic society" wurde dabei unter anderem auch die baldige Einrichtung einer internationalen Erziehungsinstitution thematisiert. In dem kurz darauf im Herbst 1943 publizierten Handbuch „Education in Wartime“ der Stanford University heißt es dazu kurz und unmissverständlich: „The educational needs of reconstruction period should be recognized now; after peace is declared it is late to educate for peace. ${ }^{\text {5 }} 89$

584 Ebd., 6 f.

585 So zum Beispiel die Aufwertung der „Social Studies“ innerhalb der Lehrpläne an amerikanischen Schulen und Colleges, die Intensivierung mathematisch-technischer Fächer, die Verbesserung der physischen Erziehung. Vgl. Kollmann, The Nature of this War and American Education, a.a. O., 203; vgl. dazu weiters: Willis Rudy, Total war and twentieth-century higher learning. Universities of the Western world in the First and Second World Wars, London - New York 1991; V.R. Cardozier, Colleges and Universities in World War II, Westport 1993; Roy Lowe (Ed.), Education and the Second World War. Studies in schooling and social change, London - Washington D.C. 1992.

586 Vgl. Ambrose Caliver, Postwar education of Negroes. Educational implications of army data and experiences of Negro veterans and war workers. Report of a conference sponsored by the U.S. Office of Education, Washington D.C. 1945; Education. Why the Federal Government must Help [Division of Research/National Education Association of the United States], Washington D.C. 1945.

$587 \mathrm{Vgl}$. Education in Wartime and After, a.a.O., 133.

588 Vgl. School and Society, Vol. 58, November 1943, No. 1506, 363; 379; weiters: Karl-Heinz Füssl, Restauration und Neubeginn. Gesellschaftliche, kulturelle und reformpädagogische Ziele der amerikanischen „Reeducation“-Politik nach 1945. In: Aus Politik und Zeitgeschichte, B 6, 1997, 6.

589 Education in Wartime and After, a.a.O., VII. 


\section{Educational Reconstruction - Überlegungen und Konzepte 1942-1943/44 zur Demokratisierung nach Kriegsende}

"It is idle to plan a free world and, at the same time, to plan that we shall be masters of it. [...]
All men, all nations must be educated." 590

Wie sich zeigt, entwickelten sich die bildungspolitischen Überlegungen hinsichtlich eines demokratischen Nachkriegsaufbaus von Anfang an in enger Verschränkung mit der Bedrohung durch Nationalsozialismus und Faschismus beziehungsweise den folgenden inneramerikanischen Bildungs- und Erziehungsanstrengungen. ${ }^{591}$

Das gilt in ähnlicher Weise auch für Großbritannien, das mit seinen bereits seit 194I/42 laufenden bildungspolitischen Initiativen auf der Ebene eigens geschaffener internationaler Gremien - zum Beispiel der „London International Assembly“ und dem „Council for Education“- zumindest im halbstaatlichen beziehungsweise zivilen Planungsbereich der „Educational Reconstruction" bald mit amerikanischen Institutionen kooperierte. Überhaupt lief die diesbezügliche Diskussion in Großbritannien, ähnlich wie in den USA, zunächst hauptsächlich über inoffizielle zivile Stellen sowie in der Öffentlichkeit. Auch hier schalteten sich von Anfang an einzelne Politiker in die Debatte ein, auch die politischen Parteien und das britische Parlament, doch mit einem Unterschied: Trotz aller Präferenz für indirekte Kontrollmaßnahmen lag die Gewichtung von Beginn an stärker auf der politischen Reeducation, also auf einer Veränderung des aggressiv-kriegerischen „deutschen Volkscharakters“, wie das Lord Vansittart in einem Memorandum („The Nature of the Beast“) für das britische Foreign Office bereits 1940 formuliert hatte. ${ }^{52}$ Insbesondere nach dem Ausbleiben eines antifaschistischen Volksaufstandes des ,anderen Deutschlands“, wie es von links-liberaler Seite antizipiert worden war, gewannen die Thesen Vansittarts großen Einfluss in der bri-

590 Alexander Meiklejohn, Education as a Factor in Post-war Reconstruction. In: Free World, January 1943. Zit. nach: O.H. Mowrer, Educational Considerations in Making and Keeping the Peace. In: The Journal of the Abnormal and Social Psychology, 38. Jg., 1943, 177.

591 Bezüglich der nationalen Kraftanstregung im Bereich von Bildung und Erziehung hieß es 1942 in einem Bericht des „National Institute on Education and the War“: „Education must make ist special and particular contribution to the struggle. Fighting with learning is the slogan of victory [...]. Never was there a time when educational workers faced heavier responsibilities for adjusting the school program to a great national need." Zit. nach: Kandel. The Impact of the War upon American Education, a.a.O., 35.

592 Günter Pakschies, Re-education und die Vorbereitung der britischen Bildungspolitik in Deutschland während des Zweiten Weltkriegs. In: Heinemann, Umerziehung und Wiederaufbau, a.a.O., 104; siehe weiters: Kurt Koszyk, „Umerziehung“ der Deutschen aus britischer Sicht. In: Aus Politik und Zeitgeschichte. Beilage zur Wochenzeitung das Parlament, 1978, Heft 29, 3-12; Heinz-Dittrich Fischer, Reeducation und Pressepolitik unter britischem Besatzungsstatus. Die Zonenzeitung „Die Welt“ 1946-1950. Konzeption, Artikulation und Rezeption, Düsseldorf 1978; Michael Balfour, In retrospect: Britain's Policy of ,Reeducation'. In: Nicholas Pronay/Keith Wilson (Eds.), The Political Re-Education of Germany and Her Allies After World War II, Kent 1985, 139-150. 
tischen Öffentlichkeit. ${ }^{593}$ Deren Verbreitung führte den britisch-jüdischen Verleger Victor Gollanz dazu, eine Gegenschrift zu publizieren, in der er, nach einer kurzen Analyse der jüngeren deutschen Geschichte, pointiert gegen jede Form von Revanchismus und hasserfüllter Moralisierung Stellung bezog und für eine „Versachlichung“ des Diskurses rund um den angeblich grundsätzlich aggressiven „German Character“ eintrat. ${ }^{594}$

Eine weitere Ähnlichkeit zur Situation in den USA liegt darin, dass die totale Mobilisierung der britischen Gesellschaft angesichts des nationalsozialistischen Vernichtungskrieges ebenfalls zu einer edukativen Selbstvergewisserung führte, die mit dem „Education Act 1944 “595 bereits während des Krieges in eine Reform des traditionell elitären und stark klassenspezifischen Bildungssystems mündete und besonderes Augenmerk auf die Garantie demokratischer Chancengleichheit legte. ${ }^{596}$

Im Gegensatz zu den Vereinigten Staaten und Großbritannien hatte Frankreich kaum Zeit und Gelegenheit, vor Kriegsende über die Ziele oder die konkrete Form einer französischen Besatzungspolitik nachzudenken. ${ }^{597}$ Das betrifft auch Fragen des bildungs- und kulturbezogenen Wiederaufbaues, obwohl erste Überlegungen einer „Reeducation“ vereinzelt bereits $1943 \mathrm{im}$ algerischen Exil angestellt wurden. ${ }^{598}$ Was die Kriegsplanungen

593 Pakschies, Re-education und die Vorbereitung der britischen Bildungspolitik in Deutschland während des Zweiten Weltkriegs, a.a.O., 107.

594 In Anerkennung der Notwendigkeit einer strikten internationalen Kontrolle der militärischen Abrüstung nach Kriegsende, sah Gollanz (1893-1967) - im entschiedenen Gegensatz zu der in der Atlantik-Charta angepeilten „restaurativen Liberalisierung“ - einzig in einer fundamentalen gesellschaftlichen Neuordnung Deutschlands auf Basis einer von innen kommenden, sozialistischen Revolution die Garantie für eine dauerhafte Friedenslösung gegeben: „Unless the German people themselves overthrow their militarists, junkers and industrialists by means of a democratic (which in the twentieth century must be a socialist) revolution, the terrible lessons of the past will be repeated. The whole of the German history proves that the German people will win freedom only if they win it FOR THEMSELVES by the conquest of power. It cannot be won for them or ,granted" to them. And their winning of it is the condition for a genuine, solidly based, liberalizing of Germany. "Victor Gollanz, Shall our Children Live or Die? A Reply to Lord Vansittart in The German Problem, London 1942, 33.

595 Darin heißt es: „In the 1944 Education Act we have a more comprehensive and systematised program of education than in any previous Act. At last we have the idea being developed that there is a public duty to provide and finance a comprehensive system of education'“" The Education Act 1944. With explanatory notes by Alfred E. Ikin, London 1944, XIV.

596 Der „Education Act“ war beeinflusst von einem Reformpapier, das der Historiker Arnold Toynbee im Auftrag des August 1940 eingerichteten War Aims Committee 1941 verfasst hatte, worin er hinsichtlich einer zu schaffenden „Neuen Ordnung“ für das Nachkriegseuropa insbesondere auch die Demokratisierung des rückständigen britischen Erziehungssystems forderte. Vgl. Koszyk, „Umerziehung“ der Deutschen aus britischer Sicht, a.a.O., 4.

597 Vgl. Rene Cheval, Die Bildungspolitik in der Französischen Besatzungszone. In: Heinemann, Umerziehung und Wiederaufbau, a.a.O., $190 \mathrm{ff}$. ; sowie Jerome Vaillant, Was tun mit Deutschland? Die französische Kulturpolitik im besetzten Deutschland von 1945 bis 1949. In: Ebd., $205 \mathrm{ff}$.

598 Helen Liddell, Education in Occupied Germany: A Field Study. In: International Affairs, 1948, 40. 
der Sowjetunion betrifft, waren diese, neben Entmilitarisierung und Entnazifizierung, freilich nicht an einen Demokratisierungsdiskurs geknüpft, sodass „Überbau“-Fragen der längerfristigen Etablierung einer autonomen, demokratischen Erziehung-, Bildungs- und Kulturlandschaft gegenüber politischer Propaganda sowie dem Vertrauen in die prägende Wirkung von Politik, Regierung und Behördenapparaten eine völlig untergeordnete Rolle spielten; ${ }^{599}$ folgerichtig bestand das antifaschistisch-volkspädagogische Konzept leninistisch-stalinistischer Prägung in der Hauptsache darin, die besetzten Oststaaten zu „Lizenznehmern der Sowjets“600 zu machen.

Obwohl sich also die zivilen und militärischen Agenden eigentlich von Anfang an kreuzten, blieben der amerikanische „Reeducation-Diskurs“ im engeren Sinne wie auch die Überlegungen zur allgemeinen „Educational Reconstruction“ zunächst weitgehend von zivilen Personen und zivilen Gremien - hier vor allem auch privaten, halb-staatlichen Organisationen - dominiert.

Das von der US-Regierung beauftragte „National Resources Planning Board“ arbeitete zwar bereits I94I dezidiert an Plänen zur Post-War-Reconstruction, aber mit ausschließlichem Bezug auf die Vereinigten Staaten. ${ }^{601}$ Überlegungen, wie nach einem gewonnenen Krieg das durch die Nationalsozialisten pervertierte Erziehungswesen Deutschlands beziehungsweise die Bevölkerungen der faschistischen Achsenmächte erfolgreich demokratisiert werden könnten, tauchten darin nicht auf.

Mitte des Jahres 1942 wurde vom „Bureau of Educational and Cultural Affairs“ des U.S. State Department ${ }^{602}$ damit begonnen, ein „General Advisory Committee on Post-War Program“ einzurichten, in dem neben Mitgliedern des State Departments - gelegentlich auch des War Departments - bis Juni 1943 auch ein Stab externer Experten vertreten war, die die zivilen „Education in Wartime“-Debatten maßgeblich prägten. Unter ihnen befan-

599 Vgl. dazu: Jan Kuhnert, Die Berufsschule im Rahmen der Einheitsschule. Ein Kernproblem der Bildungspolitik in der SBZ. In: Heinemann, Umerziehung und Wiederaufbau, a. a. O., 245-263; Christoph Kleßmann, Politische Rahmenbedingungen der Bildungspolitik in der SBZ/DDR 1945 bis 1952. In: Ebd., 229-244; weiters: Liddell, Education in Occupied Germany, a.a.O., $37 \mathrm{ff}$.

600 Jürgen Danyel, Politische Rituale als Sowjetimporte. In: Konrad Jarausch/Hannes Siegrist (Hrsg.), Amerikanisierung und Sowjetisierung in Deutschland 1945-1970, Frankfurt a. Main 1997, 68 f.

601 Vgl. After Defense - what? Edited by National Resources Planning Board, Washington D.C. 1941; Reports of National Planning Association on Post-War Reconstruction, Washington D.C. 1942; George Galloway, Post-War Planning in the United States, New York 1942.

602 Bereits 1938 war im US-State Department die „Division for Cultural Relations“ eingerichtet worden, deren hauptsächlicher Aktivitätsradius anfänglich auf Lateinamerika gerichtet war und sich erst mit Kriegseintritt der USA allmählich auch auf bildungspolitische und kulturelle Nachkriegsplanungen u.a. für Europa zu beschäftigen begann. Vgl. I.L. Kandel, United States Activities in International Cultural Relations (=American Council on Education Studies. Reports of Committees and Conferences, No. 23). Vol. IX, Washington D.C., September 1945, iv bzw. 85; weiters: Henry. J. Kellermann, Cultural relations as an Instrument of U.S. Foreign Policy. The Educational Exchange Program between the United States and Germany 1945-1954 (= Department of State Publication 8931), Washington D.C. 1978, 5 f. 
den sich der Pädagoge Walter M. Kotschnig, ${ }^{603}$ James B. Conant, Präsident der Harvard University, Edmund Day, Präsident der Cornell University, Laurence Duggan, Direktor des „Institutes of International Education“, Archibald MacLeish, Direktor der Library of Congress und späterer Assistant Secretary of State, John W. Studebaker vom U.S. Office for Education, Grayson N. Kefauver, Dekan der School of Education an der Stanford University, George F. Zook, Präsident des „American Council on Education“ und William G. Carr, Präsident der „National Education Association“. ${ }^{604}$ Dieses Komitee, an dessen Sitzungen fallweise auch Vizepräsident Henry Wallace teilnahm, fungierte primär als eine Art Gedankenwerkstatt, in der Fragen eines kulturellen Nachkriegsaufbaues („best education minds available" $)^{605}$ thematisiert wurden, die über nur „negative“ Entnazifizierungsmaßnahmen, wie sie von Militärs und Beamten der „Cultural Affairs Division“ (CAD) des War Departments für die Militärregierungen projektiert wurden, weit hinaus gingen.

603 Walter M[aria] Kotschnig, geboren 1901 in Judenburg/Steiermark, studierte in den Jahren 1920 bis 1921 zunächst an der Universität Graz und legte dann 1924 an der Universität Kiel sein Doktorat ab. Nachdem er 1924 bis 1925 als Assistent des Instituts für Weltökonomie und daran anschließend für das Internationale Studenten Service in Genf gearbeitet hatte, übernahm der deklarierte NS-Gegner zwischen 1934 und 1936 als zuständiger Hochkommissar im Rahmen des Völkerbundes die Flüchtlingshilfe. Bereits zuvor hatte er sich - neben seiner Frau Elined Prys Kotschnig (1895-1983) - als Mitherausgeber eines Symposion-Bandes zum Thema "The University in a Changing World“, der 1932 bei Oxford University Press erschien, einen Namen als Wissenschafter gemacht. Mitte der Dreißigerjahre emigrierte Kotschnig in die USA, wo er 1942 „naturalisiert" wurde. In den Jahren zwischen 1937 und 1944 unterrichtete er als Professor für vergleichende Erziehungswissenschaft am Smith College und Mt. Holyoke College in Massachusetts, wo er sich intensiv mit dem NS-Erziehungssystem zu beschäftigen begann. Parallel dazu arbeitete Kotschnig in jenen Jahren als Abteilungsassistent (divisional assistent) des U.S. State Department, wo er mit 1. Februar 1945 zum Leiter der „Division of International Organisational Affairs“ bestellt wurde und in dieser Funktion maßgeblich an den Vorarbeiten zur Gründung der Vereinten Nationen beteiligt war. Ab 1946 schlug Kotschnig die Diplomatenlaufbahn ein. Er begann zunächst in London als Sekretär für die UNESCO zu arbeiten, bevor er mit 9. Juni 1948 zum Leiter der United Nations Economic and Social Affairs Division aufstieg. In den folgenden Jahren nahm Kotschnig als delegierter US-Repräsentant an zahlreichen UN-Großkonferenzen teil, wie beispielsweise an der „UN Slavery Conference“ in Genf 1956. 1971 beendete Kotschnig seiner Karriere als Deputy Assistant Secretary of State. Kotschnigs Nachlass befindet sich im Archiv der University of Albany/State University of New York. Vgl. Biographic Register of the Department of State, April 1, 1949. Office of Public Affairs (Department of State. Publication 3471), Washington D.C. 1949, 223; The Biographic Register 1957 (Revised as of May 1,1957). Office of Special Services (Department of State 6503), Washington D.C. 1957, 360. Für den Hinweis auf die biografischen Angaben zur Person von Walter M. Kotschnig danke ich Herrn Univ.-Prof. DDr. Oliver Rathkolb. Siehe auch: http://library.albany.edu/speccoll/emigre.htm [University Albany/State University of New York]; weiters: Johannes Feichtinger, Wissenschaft zwischen den Kulturen. Österreichische Hochschullehrer in der Emigration 1933-1945, Frankfurt a. Main - New York 2001, 96.

604 Füssl, Restauration und Neubeginn, a.a. O., 6.

605 U.S. Department of State, Bureau of Educational and Cultural Affairs, History Files, (CU/H). Minutes. Meeting of the General Advisory Committee on Post-War Programs (GAC), February 23, 1942, $24-25$. Zit. nach: Tent, Mission on the Rhine, a.a.O., 19. 
Gerade weil sich sowohl die CAD als auch die militärischen Geheimdienste wie das „Office for Strategic Studies“ (OSS) ${ }^{606}$ oder das „Office of War Information“ (OWI) nicht mit Konzepten eines längerfristigen, edukativ-kulturellen Rehabilitations-Programmes beschäftigen konnten oder wollten, vertraten die Mitglieder des „Advisory Committees“ einhellig die Auffassung, dass diese Agenden weiterhin vom State Department betreut werden sollten. ${ }^{607}$

Inhaltlich bildete die Reorientierungs-Diskussion innerhalb des „Advisory Committees“ ab, was innerhalb der öffentlichen Auseinandersetzung mit der „Education or Victory“ bereits (ebenso vage) thematisiert wurde: in einer ersten Phase Entnazifizierungs- und Kontrollmaßnahmen der Militärregierung unmittelbar nach Kriegsende und daran anschließend kulturelle Rekonstruktion („cultural reconstruction“) in Form ziviler Kooperation im Bereich von Bildung und Kultur. Es fehlte aber ein klares Konzept und ebenso eine Antwort auf die Frage, welche US-Einrichtung für die Rekonstruktion schließlich verantwortlich zeichnen würde. Dem Komitee, das im Sommer 1943 bereits wieder aufgelöst wurde, folgte das unmittelbar darauf geschaffene „Interdivisional Committee for Germany“ des State Department, das unter Leitung von David Harris im September einen allgemeinen Plan zur „Political reorganization of Germany“ vorlegte. Wie James F. Tent ausführt, sah dieser Plan eine reduzierte alliierte Kontrolle vor und sollte auf Seite der Deutschen möglichst ein „minimum of bitterness“608 bewirken; von „Educational Reconstruction“ war darin allerdings kaum die Rede. Erst im Frühjahr 1944 beschäftigte sich das „Interdivisional Committee for Germany“ neuerlich mit Fragen der „Reeducation“, diesmal auf Anfrage der CAD und bereits im Kontext der Planungen für die Militärregierungen der Supreme Headquarter Allied Expeditionary Forces (SHAEF) unter General Eisenhower. Das ausgearbeitete Papier, das unter dem Einfluss der zuvor geführten Diskussion des Advisory Committees stand, blieb im Zusammenhang der angelaufenen militärischen Planungen zunächst aber ohne jede praktische Auswirkung. ${ }^{609}$

Vielfältiger, differenzierter und mitunter auch kontroversieller verlief der Diskurs zur Educational Reconstruction allerdings in der öffentlichen Diskussion; er setzte auch früher $e^{2}{ }^{610}$ und auf ihn soll im Folgenden etwas näher eingegangen werden.

606 Vgl. Richard Harris Smith, OSS. The Secret History of America’s First Intelligence Agency, Berkeley 2005 [1972].

607 U.S. Department of State, Bureau of Educational and Cultural Affairs, History Files, (CU/H). Minutes. Meeting of the General Advisory Committee on Post-War Programs (GAC), February 23, 1942, 24-25. Zit. nach: Tent, Mission on the Rhine, a.a.O., 19.

608 Ebd., 21.

609 Ebd., $21 \mathrm{f}$.

610 Vgl. dazu Walter M. Kotschnig, Problems of Education after War. In: International Conciliation, No. 379, April 1942 [Carnegie Endowment for International Peace]. Darin beschäftigte sich der österreichische Emigré Kotschnig zwar primär mit den Erfordernissen einer international ausgerichteten Erziehung nach dem Krieg in Amerika, schuf aber durch die Abgrenzung zu NS-Erziehung und kommunistischer Indok- 
Am Rande des „moral awakening“611 vis à vis der NS-Diktatur, der demokratischen Selbstvergewisserung im Kontext der „Education for Victory“, die, wie dargestellt, unter anderem in einen binnenamerikanischen Bildungsreformdiskurs mündete, entstanden ab 1942 - teilweise mit expliziter Bezugnahme auf die vagen Friedensperspektiven der Atlantik-Charta vom I4. August I94I - auch erste, freilich größtenteils ebenso vage bildungspolitische Überlegungen hinsichtlich der „Post-war Reconstruction“ - für die Vereinigten Staaten selbst, und, daraus entspringend, für die Demokratisierung des posttotalitären Europa.

Anders als die im sozialpsychologischen und psychiatrischen Bereich entwickelten Reeducation-Konzepte, auf die noch gesondert einzugehen sein wird, waren die im pädagogisch-erziehungswissenschaftlichen und philosophischen Bereich entfalteten Vorstellungen von einer gesellschaftlichen Deindoktrinierung ihrer Tendenz nach einer strikt pazifistisch-moralischen Argumentationslinie verpflichtet, ${ }^{612}$ kaum interdisziplinär orientiert und wenig empirisch untermauert. Die edukativen Rekonstruktions-Überlegungen lesen sich außerdem eher unsystematisch-pragmatisch (es gibt vor 1945 vergleichsweise wenig gesonderte Literatur zu diesem Thema); sie zielten neben der Demokratisierung des deutschen Schulwesens vor allem auch auf kooperative, langfristige Veränderungen der gesellschaftlich-politisch Rahmenbedingungen nach dem Vorbild des „American way of life" sowie auf die Schaffung internationaler, überstaatlicher Gremien zur nachhaltigen Friedenssicherung. ${ }^{613}$ Wie im schon skizzierten „Education in Wartime“-Diskurs bildete auch hier die Formel Demokratie $=$ Freiheit $=$ Education den inhaltlichen Kern der Debatte, nun allerdings erweitert um die Elemente „American way of life“ und Friedensicherung durch internationale Zusammenarbeit.

Geistige „Umerziehung“ durch die Siegermächte im Sinne einer strengen und harten, womöglich auf Bestrafungsmaßnahmen basierenden Rezivilisierung der Völker oder einer

trinierung eine Diskussionsgrundlage für eine „Welterziehung“, in der sozialwissenschaftliche Methoden und Inhalt zum Einsatz kommen sollten.

611 The Education of Free Men, a.a. O., 114.

612 Die moralischen Motive in der ursprünglichen Reeducation - oder besser: Educational Reconstruction sieht auch Henry Kellermann, wenn er vom „Kreuzzug des Guten gegen das Böse“ spricht; allerdings vertritt Kellermann die Auffassung, dass sich der „pragmatische Charakter“ der „Reeducation“ nach 1945 neben der wiederholten Anpassung und Veränderung des Programms insbesondere „in der Abwesenheit eines ideologischen und bis in alle Einzelheiten festgelegten Planes“ zeige. Diese Analyse lässt allerdings außer Acht, dass die universalistische Gleichsetzung von Demokratie und „American way of life“ zutiefst ideologische Wurzeln aufweist. Henry Kellermann, Von Re-education zu Re-orientation. Das amerikanische Re-orientierungsprogramm im Nachkriegsdeutschland. In: Heinemann, Umerziehung und Wiederaufbau, a.a.O., $87 \mathrm{f}$.

613 So meinte beispielsweise der Präsident der Harvard University, James Bryant Conant: „We must be prepared at the outset to have the process of reconstruction proceed slowly, very slowly. There can be no magical restoration of freedom, peace and happiness for all." Zit. nach: School and Society, Vol. 55, January 3, 1942, No. 1410,10 . 
direkt-invasiven Veränderung des Mind-Sets der Menschen in Deutschland, Österreich oder Japan enthält der Reform-Diskurs zumindest der humanwissenschaftlichen Pädagogen, Historiker und Philosophen - also der „weichen“, traditionellen Gesellschaftswissenschafter - kaum. Es verwundert daher auch kaum, dass im Kontext edukativer Post-War-Überlegungen, die sich - anders als im Fall der psychiatrisch-psychologischen Konzepte - zum Teil mit sozialpsychologischen Überlegungen mischten, der Begriff „Reeducation“ als Terminus technicus nur selten vorkommt und weitaus häufiger von „Rehabilitation“, „Reconstruction“, „Democratization“ und später auch „Re-orientation“ gesprochen wurde. ${ }^{614}$

Ein wesentliches politisches Element der Überlegungen zur „Educational Reconstruction“, das sich im „Education for Victory“-Diskurs analog zur Selbstvergewisserung der demokratischen Werte entfaltete, stellt der amerikanische Universalismus dar. So wie der Kampf gegen Nationalsozialismus und Faschismus als universaler Kampf zweier diametral entgegengesetzter, feindlicher weltanschaulicher Systeme angesehen wurde, in dem es im fundamentalen Sinne um „either we or they“ ging, sollte dieses Mal auch der Sieg - anders als nach Ende des Ersten Weltkrieges - ein universaler Sieg von demokratischer Freiheit, Frieden und Sicherheit für die ganze Menschheit sein. ${ }^{615}$

\begin{abstract}
"We ought not to hate the Germans, Italians and Japanese. Hatred against men may help to win a war, but it surely helps to lose the peace. Our students must learn that this is a war not between nations but between fundamentally different concepts of man and life. [...] We do want a world order in which free men can develope themselves and their society, follow their interest, and worship their God in their own way." ${ }^{\prime 16}$
\end{abstract}

Und da die Vereinigten Staaten in diesem „Kreuzzug des Guten gegen das Böse“617 das liberale, demokratische Erbe nicht nur der eigenen Nation, sondern - stellvertretend für die „freie Welt“ - der Menschheit insgesamt zu verteidigen hatten ${ }^{618}$ und die amerikani-

614 Ähnliches gilt auch für die britische Bildungsreformdebatte, die ab 1943 über institutionelle Kooperationsplattformen in teils engem Austausch mit amerikanischen zivilen Einrichtungen geführt wurde. So z.B. in der britischen „Joint Commission of the London International Assembly and the Council for Education in World Citizenship“, in der unter den Vertretern von 12 Mitgliedsländern u.a. auch China, die USA und „fighting France“ vertreten waren. Vgl. Educational Reconstruction in Europe. In: Nature, Vol. 152, August 14, 1943, No. 3850, 169.

615 „It is a mistake to assume that an enduring peace will come from winning the war. Only the opportunity to shape a lasting peace naturally follows the winning of the war." Harold F. Harding, Can the Liberal Arts Tradition Survive? [Rede von Colonel Harding vor der Phi Beta Kappa Association of Hawaii, May 28, 1943]. In: Representative American Speeches: 1943-1944, a.a.O., 313.

616 Kurt Bergel, Education for Reconstruction. In: School and Society, Vol. 55, April 11, 1942, No. $1424,417$.

617 Kellermann, Von Re-education zu Re-orientation, a.a.O., 87.

618 „The glory of American foreign policy has certainly not been the effectiveness with which it stopped the spread of tyranny but the insistence with which it proclaimed the necessity for standards of international conduct. [...] No other government raised its voice as clearly because [...] no other enjoyed the same 
sche Gesellschaft die demokratischen Werte selbst klar verdeutlichen würde, konnte der „amerikanische Weg“" gelebter Demokratie im Sinne der „One-World“Willkies als Vorbild für eine Neuorientierung nach Kriegsende auftauchen, ohne dabei als arrogante Demonstration der Macht gemeint zu sein. Der Universalismus begründete sich dieser Auffassung nach klar durch die in der amerikanischen Demokratie grundgelegten Prinzipien: „It is not the uniqueness of American ideals but their universality that constitutes their significance." Wobei der hier zitierte US-Historiker Henry Murray Dater die kritische Frage anfügte, inwieweit das derzeitige nationalistische Amerika angesichts des alle Ideale unterminierenden Materialismus für eine weltweite, ideelle Führungsaufgabe überhaupt geeignet sei: "Even more difficult will be the task of making American idealism fit the world pattern. If the leadership of the United States is to benefit all human society, it must appeal in terms wich other peoples can understand.“619

Und Archibald MacLeish, I94I und 1942 Leiter der US-Propagandaabteilung „Office for Facts and Figures“, meinte bezüglich der künftigen Führungsrolle Amerikas („the future is America's to make“): „It is not our future, as a few Americans have asked us to believe, to master or exploit [...]. It is ours to shape, not because we have many planes or great numbers of ships or rich industrial resources but for a different reason; because we have the power as a people to conceive so great a future as mankind must now conceive - because we have behind us a tradition of imagination in the people. “620

Die traditionell enge Verknüpfung von „Education“ mit Demokratie, das politische Verständnis von amerikanischer „Education“ als spezifisch demokratischer, also amerikanischer Lebenspraxis im Sinne einer aktiven „Citizenship“, der Glaube an den „American way of life “, die intensive demokratiepolitische Selbstvergewisserung sowie die wiederkehrenden Verweise auf die Fehler der Wilsonschen Politik nach dem Ersten Weltkrieg bilden die moralische Hintergrundfolie für die „Educational Reconstruction“, später auch für die „Reeducation“ beziehungsweise die „Reorientation“ als Instrument der politischen Neuordnung und des demokratischen Wiederaufbaues - ein Wiederaufbau, dessen inhaltliche Zielsetzung von gänzlich anderen, nämlich friedliebend-demokratischen Idealen und Wertvorstellungen geprägt sein müsse: „[...] if we are to have peace in the world, we must have teaching with exactly opposite ideals." ${ }^{\text {221 }}$

Die politische Ausgangslage für die Post-War-Reconstruction wurde wiederholt mit direktem, kritischem Bezug auf die historischen Versäumnisse nach I9I8 formuliert. So

sense of security." Henry Murray Dater, The Mission of American Liberal Scholarship in the New World Order. In: School and Society, Vol. 58, October 2, 1943, No. 1501, 251.

619 Letztlich wäre es - und hier berief sich der US-Historiker der Kent-State University auf eine Aussage eines (ungenannten) „bedeutenden österreichischen Historikers“ - ja auch weitaus einfacher, eine Revolution auszulösen, als eine Institution oder eine Gesellschaft auf Abwegen zurück auf den rechten Weg zu bringen. Dater, The Mission of American Liberal Scholarship, a.a.O, $251 \mathrm{f}$.

620 Zit. nach: Harding, Can the Liberal Arts Tradition Survive?, a. a.O., 312.

621 Henry S. Curtis, Education for Permanent Peace. In: School and Society, Vol. 58, July 17, 1943, No. 1490, 34. 
stand etwa für das U.S. Office for Education außer Frage, dass nach Kriegsende eine Rekonstruktion nötig sein würde, „which permits the spirit of freedom and democracy to flourish.“622 Die Frage nach dem „Wie“ beziehungsweise „Warum“ - „Why have we failed? Why is it again necessary to defeat Germany as the precondition for the possible restoration of some tolerable order in international relations?" 623 - wurde auch hier mit Bezug auf die strukturell ähnliche Ausgangssituation nach dem Ende des Ersten Weltkrieges gestellt, wo Präsident Wilson mit der Anregung zu Schaffung des Völkerbundes eine dauerhafte Friedensicherung intendiert hatte. Eine Frage, die sogleich mit einem Katalog möglicher Gründe („Ifs“) beantwortet wurde:

\begin{abstract}
"Many answers have been advanced to these questions. If we had joined the League of Nations; if we had more actively contributed to the support of democratic elements in Germany, thus preventing Hitler's rise to power; if we had settled the reparations and war debts questions unselfishly and realistically; if we had helped to build an international system of political economy, etc. - this grim price we must now pay for a second chance at the building of a civilized world might never been required of us." ${ }^{624}$
\end{abstract}

Und es war klar, dass die zweite Chance einer dauerhaften „Zivilisierung“, also eine nachhaltige Veränderung in Richtung einer (globalen) gesellschaftlichen Demokratisierung, neben Entmilitarisierung, Entnazifizierung ${ }^{625}$ und sozialer und wirtschaftlicher Stabilisierung, aus amerikanischer - aber auch aus britischer ${ }^{626}$ - Sicht vor allem beim Bildungsund Erziehungswesen anzusetzen hatte:

"This systematic and intensive indoctrination of German youth has been called the most effective bit of teaching ever carried on anywhere. It leaves no doubt as to the intent of those who organized it. Those who have had ten years of it in the German schools will be a tremendous problem in the years to come. The young men who have just surrendered to the American forces in Tunisia have been saying: 'We may lose this war, but we will win the next one.," ${ }^{27}$

622 Our Country's Call to Service, a.a.O., 21.

623 Ebd.

624 Ebd.

625 Ziele, die in der Atlantik-Charta 1941 bereits angesprochen und dann erst auf der Jalta-Kriegskonferenz im Februar 1945 als gemeinsamer „Wille“ der alliierten Nachkriegspolitik proklamiert wurden. Vgl. Keesings Archiv der Gegenwart, Jg. 1945, 1. Jänner, 10 ff. bzw. ebd., Jg. 1945, 11. Februar, 87.

626 Vgl. Educational Reconstruction. In: Nature, Vol. 152, July 31, 1943, No. 3948, 120-121 sowie: Education after War. In: Nature, Vol. 152, August 21, 1943, No. 3851, 221-222.

627 Ähnlich wurde die Situation übrigens auch in Japan eingeschätzt: „Much the same spirit pervades the schools of Japan." Curtis, Education for Permanent Peace, a.a.O., 33. Im Unterschied zu Deutschland und Österreich wurde nach 1945 das japanische Erziehungswesen strukturell tief greifend verändert und zumindest äußerlich amerikanisiert - die zentrale Befehlsgewalt der US-Militärbehörden mag hier zusam- 
Bezüglich der notwendigen materiellen Unterstützung für den Aufbau der durch Krieg oder NS-Terror zerstörten Bildungs-Infrastruktur, also von Schulen, Universitäten oder Bibliotheken, ${ }^{628}$ herrschte weitgehend Konsens. Und obwohl in der gesamten Diskussion primär von „Nazi-Germany“ die Rede war und Österreich im Zusammenhang der „Educational Reconstruction“ kaum je explizit genannt wurde, wusste man über die konkreten Veränderungen des Erziehungs- und Bildungswesen in den von Hitler-Deutschland okkupierten Ländern durchaus gut Bescheid. ${ }^{629}$ So - neben der politischen Geschichte ${ }^{630}$ auch über die Entwicklung, ${ }^{631}$ die strukturellen Veränderungen ${ }^{632}$ und über den Effekt der nationalsozialistischen Indoktrinierung des österreichischen Bildungswesens, wobei gegen Ende des Krieges auch auf vereinzelten Widerstand innerhalb der akademischen Jugend hingewiesen wurde. ${ }^{633}$

men mit der traditionell zentral-hierarchischen Tradition des japanischen Bildungswesens eine Umsetzung erleichtert haben; wobei der Strukturwandel ,nicht notwendig auch ein Bruch mit den traditionellen Idealen der vertikal strukturierten Gesellschaft" folgte. Rosenzweig, Erziehung zur Demokratie?, a.a.O., 210.

628 American Aid in Foreign-Library Rehabilitation urged by the ALA [American Library Association]. In: School and Society, Vol. 58, August 7, 1943, No. 1493, 85.

629 Die Exponenten des „Education in Wartime“-Diskurses waren zumindest generell über die Veränderungen des Erziehungs- und Bildungswesens in Hitlerdeutschland, in der „Ostmark“, in der Slowakei, in Italien und im Vichy-Frankreich gut informiert. Vgl. The Eclipse of Education under Nazi Rule. In: School and Society, Vol. 53, March 8, 1941, No. 1367, 304f.; I.L. Kandel, The Vichy Government and Education in France. In: School and Society, Vol. 52, December 14, 1940, No. 1355, 619-625. Joseph S. Roucek, Educational Changes in Slovakia. In: School and Society, Vol. 50, August 19, 1939, No. 1286, 249-250.

630 Vgl. George E.R. Gedye, Betrayal in Central Europe. Austria and Czecho-Slovakia: the fallen bastions, New York - London 1939; Martin Fuchs, Showdown in Vienna. The death of Austria, New York 1939.

631 So publizierte die „Federal Security Agency“ des U.S. Office of Education beispielsweise die Darstellung des emigrierten österreichischen Mittelschullehrers und Hofrats im Unterrichtsministerium (1920-1938) sowie langjährigen Volkshochschul-Fachgruppenleiters, Max Lederer, Secondary Education in Austria, 1918-38 (=United States Government Printing Office, Bulletin No. 9), Washington D.C. 1941. Darin gab Lederer einen detaillierten Aufriss des österreichischen Schulwesens mit Schwerpunkt Mittelschule, und strich dabei den „revolutionären Elan“ und die zukunftsweisenden Leistungen der österreichischen Schulreform der Zwanzigerjahre heraus. Lederer schloss seine Darstellung, die mit einer umfangreichen Bibliographie zum österreichischen Schul- und Bildungswesen versehen war, mit einem resignativen Hinweis auf die Realsituation: „The Austrian school has disappeared. Today - at least outwardly - it is submerged in the German school system. [...] Thus we may hope that ideas of this educational movement, though overthrown in the country of its origin, may still live on and bear fruit in other lands." Ebd., 38.

632 So beispielsweise, dass im Jahr 1938 die Zahl der jüdischen Schülerinnen und Schüler in den insgesamt 4.721 österreichischen Volksschulen - bei einer Gesamtschülerzahl von rund 657.000 SchülerInnen im Jahr 1938 - bereits um $80 \%$ gesunken war. Die Gesamtzahl der jüdischen SchülerInnen in öffentlichen und privaten Schulen fiel von $19.913 \mathrm{im}$ Jahr 1937 auf $8.962 \mathrm{im}$ Herbst 1938. The Status of Elementary Education in Germany, 1939. In: School and Society, Vol. 52, September 14, 1940, No. 1342, 192.

633 „Every organ of the German state, from the Hitler Youth to the Gestapo, is working in close collaboration to maintain an iron grip on Austrian Youth. [...] Austrian students are beginning to take part in the fight of the whole Austrian nation for a free and independent Austria. Resistance among youth in general is as 
Lediglich hinsichtlich der Frage, wie diese Aufgabe einer „Educational Reconstruction“ nach Kriegsende konkret umgesetzt werden sollte, liefen die Meinungen mitunter auseinander, wenn auch zu konstatieren ist, dass die amerikanischen „Erzieher“ - ähnlich wie die sozialpsychologischen Experimentatoren und Theoretiker - grosso modo eine nichtpunitive, weiche Linie vertraten, wonach der Demokratisierungseffekt durch begleitende Überzeugungsarbeit „from within“, in letzter Konsequenz also im Wesentlichen durch „Selbsterziehung“ ${ }^{“ 34}$ eintreten sollte.

Interessant an dieser Stelle ist, dass die Präferenz für einen weichen, primär unterstützenden Ansatz der „Educational Reconstruction“ auch auf Ebene des U.S. Office for Education fortgesetzt wurde. Dessen „Educational Policies Commission“ beabsichtigte im Unterschied zur britischen „Joint Commission of the London International Assembly and Council for Education in World Citizenship“, 635 die die „Re-education in the Enemy Countries“ unter die strenge Kontrolle eines eigenen „High Commissioner for Education“636 im Auftrag der „United Nations“ stellen wollte -, die Verantwortung für den

yet on a small scale. But groups of resistance exist in the youth service camps and at the universities, as was mentioned in a broadcast of the Station ,Oesterreich', the illegal broadcasting station of the Austrian Freedom Front. Austrian youth has also had a number of its best representatives, such as the student Christoph Probst, the Catholic Margarete Jost, and the young communists Hedi Urach and Rosa Hoffmann, executed by the Germans." Youth in Austria. Six Years of Occupation. In: The Times Educational Supplement, No. 1506, 1944, 124.

634 „Re-education must be self-education“ heißt es diesbezüglich auch in dem unter britischer Führung herausgegebenen Report: Education and the United Nations. The Report of A Joint Commission of the London International Assembly and Council for Education in World Citizenship, London, March 1943, 33. Und Grayson N. Kefauver, Dekan der Stanford University, meinte anlässlich einer Sitzung des General Advisory Committees for Post-War Foreign Policy im U.S. State Department, dass „the readjustment of education in those countries is [to be] worked out by the peoples themselves with the assistance of a group we and the other United Nations might select to formulate the operating policy." Zit. nach: Tent, Mission on the Rhine, a.a.O., 19.

635 Ende 1941 hatte die „London International Assembly“ und das „Council for Education in World Citizenship“ eine „Joint Commission“ eingerichtet [insgesamt 65 Personen plus zusätzliche Beobachter], die damit beauftragt wurde, ,to consider and report upon the Place of Education, Science and Learning in PostWar Reconstruction“. Präsident der Joint Commission war der Graezist Gilbert Murray (1866-1955), von 1923-1938 Vorsitzender des Völkerbundes und nach 1946 erster Präsident des „general council of the United Nations Association“; Murray war zudem Präsident des „International Committee on Intellectual Co-operation“. Die Mitglieder der Joint Commission wurden von der September 1941 gegründeten „London International Assembly“ - Vize-Präsident war u. a. Jan Masaryk (1886-1948), der Sohn von Tomáš Garrigue Masaryk - als inoffizieller Versammlung nominiert und setzten sich aus Repräsentanten „from all the United Nations“ zusammen, nämlich: Belgien, China, Tschechoslovakei, „Fighting France“, Großbritannien, Griechenland, Niederlande, Indien, Norwegen, Polen, USA und Jugoslawien; darunter mehrere Mitglieder alliierter Regierungen, Unterrichtsminister, sowie als Beobachter, Repräsentanten der UdSSR. Siehe: Education and the United Nations, a.a.O., 3 f.; Jean Smith/Arnold Toynbee (Eds.), Gilbert Murray. An Unfinished Autobiography. With Contributions by his Friends, London 1960.

636 Education and the United Nations, a.a. O., 25. 
edukativen, geistig-kulturellen Wiederaufbau nicht über die Überprüfung, die Diskussion und öffentliche Berichterstattung hinaus auszudehnen - allerdings ebenfalls unter der „permanenten“ Autorität eines internationalen Gremiums. ${ }^{637}$

Abgelehnt wurde von den US-Pädagogen jede Form aktiver Gegen-Indoktrinierung, direkter Kontrolle und Propaganda, sowie das Überstülpen eines externen Bildungssystems Maßnahmen, die, wie man überzeugt war, einen gegenteiligen Effekt zeitigen würden.

Die durch ein Statement von US-Vizepräsident Henry A. Wallace in den Raum gestellte Frage „Should we take over their schools?“638 beantwortete zum Beispiel Stephen M. Corey vom Department of Education der Universität Chicago mit einem klaren Nein und einer Reihe überzeugender Argumente. Wie Corey darlegte, wäre die Sozialisationsagentur „Schule“ grundsätzlich immer durch eine gewisse Tendenz zum Konservatismus gekennzeichnet und vielmehr dazu angetan, ,apt to solidify and rationalize what a people already stand for than they are to tear down the old idols and erect new ones. In all probability the verdict of history will be that we have greatly exaggerated the role of formal education in ,remaking' Germany, ,Education for Death ' to the contrary notwithstanding." "639 Die Etablierung eines neuen „way of life“ wäre weder durch strikte Kontrolle ${ }^{640}$ noch durch die Publikation von Millionen neuer Textbücher beziehungsweise den darin enthaltenen neuen Ideen oder ,Dogmen“ alleine zu erreichen. Großangelegte Austauschprogramme („educational trips“) für Personen quer durch die Berufsstände wären weitaus zielführender und auch ökonomisch leichter zu finanzieren; ${ }^{641}$ eine Überlegung, die im Übrigen auch vom U.S. Committee on Education angestellt wurde. ${ }^{642}$ Ein wirklich überzeugendes Argument aber, so meinte der Pädagoge, würde erst die für jeden Einzelnen spürbare materielle Überlegenheit des demokratischen Systems darstellen, nämlich, wenn

637 Vgl. George D. Strayer, Education in a Time of Crisis. In: School and Society, Vol. 58, August 14, 1943, No. 1494, 98.

638 Stephen M. Corey, Should we take over their schools? In: School and Society, Vol. 58, October 23, 1943, No. 1504,34 .

639 Ebd., $321 \mathrm{f}$.

640 „We would face some baffling problems in using German schools to make little democrats out of the little Nazis as the Germans have faced in trying to do the opposite in some of the conquered countries. That nice boy from Indiana, wearing an American uniform, who was made to stand in the corridor of a Stuttgart elementary school to see to it that the German children learned the truth about Hitler and Hess (OWI copyright) would not be a nice boy to the Herren and Frauen and Kindern [sic] of Stuttgart, or Munich, or Leipzig, or Düsseldorf. He would be, instead, the symbol of an outside tyranny“. Ebd., 322.

641 Ebd.

642 Diese Überlegungen bezogen sich allerdings nur auf Studenten. Siehe: An Educational „Lend-Lease“ Program Proposed. In: School and Society, Vol. 58, November 20, 1943, No. 1508, 403 f. Das Programm sollte speziell auf „scholarship exchange“ basieren und tausenden Studenten und Studentinnen aus den Besatzungsgebieten die Möglichkeit geben, ein Jahr lang an amerikanischen Universitäten, Colleges, technischen Schulen zu verbringen, um danach fallweise im Rahmen der Educational Reconstruction eingesetzt werden zu können. Ebd. 
selbst dem „Trübsten“ („dim-witted“) klar würde, „that freedom and democracy will bring more of this world's happiness to everyone, including the Germans, than will any other political or economic scheme known“. ${ }^{643}$

Insbesondere die von Grayson N. Kefauver, dem Dekan der School of Education an der Stanford University veröffentlichten Ergebnisse der bereits genannten Harper-Ferry Konferenz zur Educational Reconstruction hatten eine Reihe kritischer Kommentare zur Folge. Aufgrund der darin aufgelisteten Vorschläge für konkrete Maßnahmen nach dem Kriegsende sahen einzelne Autoren eine „Educational Invasion“ bevorstehen und warnten vor einem „Messianic Complex“644 gegenüber den Achsenmächten.

Wie bereits ein Jahr zuvor, anlässlich einer Konferenz des „American National Committees on Intellectual Co-operation" 1942 in Havanna, wo europäische intellektuelle Emigrés nach Meinung der beiden bekannten Pädagogen I.L. Kandel und Walter Maria Kotschnig den kulturellen Wiederaufbau mit großen Worten, aber deutlich realitätsfremd diskutiert hatten, sahen die beiden Autoren auch in der intensiven amerikanischen Debatte Missverständnisse über die Ziele und Erfordernisse einer Demokratisierung des totalitären Europa nach Kriegsende vorliegen. Die Erziehung zu demokratischen Werten und Idealen, der nötige Glaube („faith“) an die Demokratie, könne weder durch „Export“ von Büchern, Curricula und Lehrpersonal allein noch durch die „Transplantation“ amerikanischer Methoden oder spezifisch amerikanischer „cultural environments“ gelingen, sondern nur durch den langsamen Prozess einer gesellschaftlichen Neuorientierung entsprechend der Erfordernisse und Bedürfnisse an Ort und Stelle. Angesichts des Umstandes, dass es keinen Sinn machen würde, Erziehungs- und Bildungsmaßnahmen ohne Rücksicht auf die spezifischen Gegebenheiten zu diskutierten, entwarfen Kandel und Kotschnig für den demokratischen Wiederaufbau ein globales Szenario dreier Einsatzgebiete: zum einen die von Hitler-Deutschland besetzten Länder Europas, zum anderen die sogenannten „backward countries“ und letztlich die Achsenmächte selbst. In den besetzten Ländern sollten vor allem intellektuelle Exilanten die Führung des Wiederaufbaues übernehmen, wobei sich die Vereinigten Staaten auf finanzielle Hilfe beschränkten sollten - „providing the means of education rather than education itself.“645 [Kursivsetzung im Original] In den „backwardcountries" wäre ein langwieriger Aufbauprozess nötig, allerdings unterstützt durch externe Berater und adäquate Führungskräfte. Und in den europäischen Terrorregimen selbst: Obwohl beide Pädagogen die Auffassung vertraten, dass die Hauptaufgabe in diesem Fall in der „Re-education“ bestünde, also in der Auslöschung der jahrelangen totalitären Konditionierung, monierten sie: „re-education must come from within; it cannot be imposed from without, for as the story of education in the German Republic illustrates, the evils of mili-

\section{Ebd.}

644 I.L. Kandel/Walter M. Kotschnig, The Messianic Complex. In: School and Society, Vol. 57, February 6, 1943, No. 1467, 156-158.

645 Kandel/Kotschnig, The Messianic Complex, a.a.O., 157. 
tarism and hate may continue to lurk under a veneer of professed democratic ideals. ${ }^{\text {"646 }}$ Ein von beiden vorgeschlagener Weg wäre dabei die Finanzierung eines Austauschprogramms speziell für die Jugend, die in ausgewählten Gruppen in Amerika mit dessen demokratischen Zielen und der dortigen Lebensrealität vertraut gemacht werden sollte, um die darin verkörperten Ideale in der kulturellen Umgebung ihrer Heimat einbringen zu können.

Interessanterweise vertrat Kotschnig hier eine etwas weichere Position als in seiner Rolle als Experte innerhalb des oben genannten „General Advisory Committee“ des U.S. State Department, wo er sich für eine dezidiert „ideologische Reorientierung“ des deutschen Lehrpersonals durch spezielle langfristige Trainingskurse für ältere Lehrer und längere Amerikaaufenthalte für die unter Dreißigjährigen aussprach, ,to understand life in a democracy and free country“. ${ }^{647}$ Außerdem schlug Kotschnig - durchaus ähnlich dem von ihm kritisierten „export of education“ - vor, bereits jetzt mit der Produktion von Unterrichtsbüchern (,textbooks“) zu beginnen, die unmittelbar nach Kriegsende die NS-Bücher ersetzen sollten. Dies stieß prompt auf massive Kritik von John W. Studebaker vom „U.S. Office for Education“, der die Auffassung vertrat, derartige Maßnahmen wären erst mit einer klaren Einschätzung der tatsächlichen Bedürfnisse sinnvoll durchzuführen. ${ }^{648}$

Die Vorschläge der Harper-Ferry-Konferenz, die vom „Liaison Committee for International Education “649 übernommen wurden, waren also de facto weit von einem harten Reeducation-Konzept entfernt und beinhalteten lediglich eine Reihe von konkreten Punkten, die über den Bereich bloß theoretischer Reflexion hinausgingen. ${ }^{650}$

Nach der vollständigen Beseitigung („eradication“) aller nationalsozialistischen Spuren auch im Bildungswesen war für die Übergangsphase bis zur Einsetzung nationaler Regierungen eindeutig von der notwendigen Kontrolle der Achsenmächte durch zivile und militärische Besatzungsorgane der siegreichen „United Nations“ die Rede, die jedoch „naturally, attempt to secure the co-operation of local people who are in sympathy with their general objectives and to have as many of steps in educational reconstruction as possible taken by local administrators. “651

Vorgeschlagen wurde für den „early stage of United Nations administration“ unter anderem

- eine gezielte Informations- und Medienpolitik über Film, Presse und Rundfunk,

- die Unterstützung der Militärbehörden durch lokale Komitees, zusammengesetzt aus deklarierten Gegnern von Faschismus, Nazismus und japanischem Militarismus, zur Elimi-

646 Ebd.

647 Zit. nach: Tent, Mission on the Rhine, a.a.O., 18.

648 Tent, Mission on the Rhine, a.a.O., 18.

649 Bei diesem Verbindungskomitee dürfte es sich um ein unter den Auspizien des U.S. Office of Education stehendes Gremium gehandelt haben, das u.a. auch Kontakt zum genannten britischen Joint Committee hielt.

650 Proposal for the Reconstruction of Education in the Axis Countries [Grayson N. Kefauver]. In: School and Society, Vol. 58, November 6, 1943, No. 1506, 379-381.

651 Ebd., 379. 
nierung aller anti-demokratischen Kräfte im Lehr- und Verwaltungsapparat von Schulen und deren Ersetzung durch vertrauenswürdiges Personal,

- die Auflösung aller faschistischen und nationalsozialistischen Jugendorganisationen und Schaffung adäquater Jugendeinrichtungen auf demokratischer Grundlage,

- die Erstellung eines Programms zur Lehrerfortbildung auf Basis von „international fellowship and exchange, in-service training, short courses, foreign lecturers“ und Bildungskonferenzen,

- der Ersatz von NS-Unterrichtsmaterialien durch geeignete neue Lehrmittel,

- die Etablierung eines Systems der Jugenderziehung und Erwachsenenbildung mit dem Ziel, zu einer aktiven Bürgerbeteiligung durch Diskussion nationaler und internationaler Probleme in Schulen, Universitäten, öffentlichen Bibliotheken, öffentlichen Diskussionsforen sowie durch Bücher und audiovisuelle Medien beizutragen. ${ }^{652}$

Kernstück des hier vorgeschlagenen Maßnahmenkataloges war die Schaffung einer permanenten internationalen „Organization for Education and Cultural developement“, einer Erziehungsorganisation im Rahmen des neu zu belebenden Bundes der internationalen Staatengemeinschaft, die die vorgeschlagenen Maßnahmen permanent supervidieren sollte.

Nach der Unterzeichnung der "Joint Declaration“ der nun mit 33 Ländern im Kampf gegen Nationalsozialismus, Faschismus und Militarismus vereinten „United Nations“ am I. Jänner I942, ${ }^{653}$ die sich den in der Atlantik-Charta und in der „Declaration by United Nations“ I94I proklamierten Zielen einer friedlichen Nachkriegsordnung sowie der auf der Kriegskonferenz in Casablanca erhobenen „Unconditional Surrender“-Forderung ${ }^{654}$ anschlossen, tauchte verstärkt die Vorstellung eines „Weltparlaments“655 - einer exekutiven Agentur der internationalen Staatengemeinschaft mit Aufgabe der Sicherung des demokratischen Wiederaufbaues, auch und besonders im Kontext der „Educational Reconstruction“.

652 Ebd., 380.

653 Darunter die Sowjetunion, China, die Niederlande, Norwegen, Polen, Belgien, Griechenland und Jugoslawien. Vgl. Herbert Wright, Attitude of the United States towards Austria, New York [1943] 1944, 106. Bei dieser Publikation des Rechtsexperten Herbert Wright, der dabei von Willibald Plöchl unterstützt wurde, handelte es sich um eine vom US-Kongress im März 1943 beauftragte Studie in Bezug auf den „Anschluss“ und die Zukunft Österreichs nach Kriegsende. Siehe: Robert H. Keyserlingk, Austria in World War II. An Anglo-American Dilemma, Kingston - Montreal 1988, 142 f.

654 Die „Unconditional Surrender“-Formel der Alliierten auf der Casablanca-Konferenz beinhaltete immerhin eine vage Zielvorstellung hinsichtlich einer „Reeducation“ nach Kriegsende. Die Eliminierung der deutschen Kriegsmacht auf Basis bedingungsloser Kapitulation bedeute, wie es im Wortlaut heißt, keineswegs die Vernichtung des deutschen Volkes, sondern ,it does mean the destruction of the philosophies in those countries which are based on conquest and subjugation of other people“. Zit. nach: Siegfried Koß, Vorstellungen der Alliierten von Nachkriegsdeutschland. In: Aus Politik und Zeitgeschichte, B 42-43, 1972, 25 f. Vgl. weiter: Riemer, Die Anti-Hitler-Koalition, a.a.O., 12.

655 Schuman, Design for a People’s Peace, a.a.O., 155. 
Insbesondere waren es hier die unter britischer Führung gesetzten Aktivitäten der „Conference of Allied Ministers of Education“ (CAME) ${ }^{656}$ - sie tagte seit I6. November I942 unter dem Vorsitz von Richard A. Butler (dem späteren konservativen britischen Erziehungsminister) -, einer der direkten Vorläufereinrichtungen der 1945 gegründeten UNESCO ${ }^{657}$ die den neuzuformierenden „United Nations“ eine besonders prominente Rolle zuwiesen. Die alliierten Erziehungsminister - I8 Vertreter von (Exil-)Regierungen, darunter von Polen, den Niederlanden, Norwegen, Griechenland, Jugoslawien und der Tschechoslowakei - zeigten sich besonders besorgt über die intellektuelle Devastierung Europas durch das NS-Regime, die Verschleppung von Kulturschätzen und bemühten sich um ein konstruktives Gegenprogramm, speziell um die Ausarbeitung von Plänen für den Wiederaufbau des Schul- und Bildungswesens in den von den Nationalsozialisten okkupierten Ländern. ${ }^{658}$ Ergebnis dieser CAME-Beratungen, an denen seit April I944 auch offizielle Delegierte der Vereinigten Staaten teilnahmen, ${ }^{659}$ war ein Vorschlag zur Abhaltung einer „United Nations Conference“ zwecks Gründung einer „Educational and Cultural Organisation“ (ECO/CONF), die dann, unter der treibenden Kraft Großbritanniens ${ }^{660}$ und Frankreichs, vom I. bis I6. November 1945 in London tagte: hier wurde die UNESCO gegründet - eine Organisation, die künftig die „intellectual and moral solidity of mankind“"661 garantieren sollte. In der Präambel der UNESCO-Verfassung findet sich

656 Vgl. Allied plan for education. The story of the Conference of Allied Ministers of Education, London 1945. 657 Direkte Vorläufer der UNESCO waren das „International Committee of Intellectual Co-operation“ [gegr. in Genf 1926 unter Vorsitz von Gilbert Murray], das „International Institute of Intellectual Co-operation“ [gegr. in Paris 1924 unter Vorsitz von Henri Bonnet] und das „International Bureau of Education“ [gegr. in Genf 1925; 1969 ging es im UNESCO-Sekretariat auf]. Die UNESCO-Konstitution wurde auf der CAME-Tagung in London am 16. November 1945, an der 44 Staaten teilnahmen, von insgesamt 37 Staaten unterschrieben und trat am 4. November 1946, nach Ratifizierung durch 20 Signatarstaaten, im Rahmen der UNO in Kraft. Siehe dazu allgemein: http://www.un.org.

658 Insbesondere ging es um den Aufbau von Schul- und Bibliotheksinfrastruktur, um die Ausbildung von Pädagogen in den Vereinigten Staaten, um Lehr- und Unterrichtsmaterialien sowie um die Ausstattung mit wissenschaftlichen Geräten.

659 Am 25. März 1944 erklärte der U.S. Secretary of State, Cordell Hull, dass die Vereinigten Staaten von nun auch eine Delegation unter Vorsitz von Archibald MacLeish zu den Konferenzen der „Allied Ministers of Education“ nach London entsenden. Die weiteren Mitglieder der Delegation waren: Senator J. William Fulbright, John W. Studebaker, Ralph E. Turner, Dekan C. Mildred Thompson und den mittlerweile für das State Department arbeitenden Grayson N. Kefauver. Siehe: Events Leading Up To World War II. Chronological History, 1931-1944 (78th Congress, 2d Session, House Document No. 541), Washington D.C. [U.S. Government Printing Service] 1944, 414; weiters: Ralph E. Turner/Hope Sewell French, Conference of allied ministers of education, Washington D.C. 1944.

660 Auf Drängen der UdSSR, die den Plänen zur Ausarbeitung nationaler Curricula für Schulen ebenso ablehnend gegenüberstand wie der Führungsrolle der Briten, entschloss sich das U.S. State Department dann, künftig zwei ständige Beobachter für London abzustellen. Siehe dazu: Füssl, Restauration und Neubeginn, a.a.O., 6.

661 Siehe dazu: www.un.org. 
das zentrale Leitmotiv einer auf offenen Kulturaustausch und Bildung basierenden, friedvollen Demokratisierung angesprochen:

"The Governments of the States Parties to this Constitution on behalf of their peoples declare: That since wars begin in the minds of men, it is in the minds of men that the defences of peace must be constructed [...]. That ignorance of each other's ways and lives has been a common cause, throughout the history of mankind, of that suspicion and mistrust between the peoples of the world through which their differences have all too often broken into war [...]". ${ }^{662}$ [Hervorhebung d. Verf.]

Auch auf amerikanischer Seite wurde, wenn auch vielleicht weniger emphatisch, wiederholt auf die „United Nations“ und ihre mögliche Rolle im Hinblick auf einen Nachkriegsaufbau hingewiesen. Ähnlich wie bereits zuvor im Rahmen der General Advisory Commission des State Department, wo neben Walter Kotschnig auch Archibald MacLeish die „reeducation of public opinion“663 unter Ägide der „United Nations“ präferierte, strichen sowohl das Vorschlagspapier der Harper-Ferry-Konferenz als auch das nachfolgend publizierte Konferenz-Handbuch die zentrale Rolle der „United Nations“664 beziehungsweise eine zu schaffende „International Organization for Education and Cultural Development“ heraus. So heißt es diesbezüglich in dem Kefauver-Proposal-Report:

"It is further recommended that, as soon as feasible, the United Nations representatives cause to be created an educational commission, composed of nationals qualified to develop and to direct the long-time policies and procedures for educational reconstruction, with such advisory assistance and approval from United Nations authorities as may be required." ${ }^{665}$

Gemeinsam mit Sir Ernest Simon, dem Präsidenten der britischen „Association for Education for Citizenship“, bemühte sich Kefauver dann um die umgehende Einrichtung einer "Joint Commission on Education for Democratic Societies“, welche die edukative Vorarbeit bis zur Übernahme der Agenden durch die United Nations nach Kriegsende übernehmen sollte. ${ }^{666}$

Aber auch in diesem Zusammenhang wurde Kritik laut, indem - mit deutlichem Seitenhieb auf Großbritannien - angezweifelt wurde, ob das Programm einer längerfristigen

662 Zum Wortlaut des UNESCO-Gründungsdokuments siehe weiters: http://portal.unesco.org/en/ev.phpURL_ID=15244\&URL_DO=DO_TOPIC\&URL_SECTION=201.html [Zugriff 10.11.2010]; siehe auch: Arndt, The First Resort of Kings. American Cultural Diplomacy, a.a.O., 107.

663 Tent, Mission on the Rhine, a.a. O., 18.; vgl. weiters: Arndt, The First Resort of Kings. American Cultural Diplomacy, a.a.O., $107 \mathrm{f}$.

664 Education in Wartime and After, a.a.O., $437 \mathrm{f}$.

665 [Kefauver], Proposal for the Reconstruction of Education in the Axis Countries, a.a.O., 380.

666 Mowrer, Educational Considerations, a.a.O., 177. 
„Educational Reconstruction“ „be undertaken by the United Nations as a group when one of the most powerful of these nations is not as yet a democracy even in form; when several others, while democracies in form, are very far from democracies in fact; and when still others, while good democracies at home, have not as yet granted democratic autonomy to many of their colonial possession." ${ }^{667}$

Trotz dieser und anderer Einwände sowie konstruktiver Kritik ${ }^{668}$ gegenüber einer womöglich schwachen Führungsrolle der „United Nations“ blieb die Einrichtung eines zentralen Exekutivorgans, das unter Observanz der internationalen Staatengemeinschaft die kulturellen und bildungspolitischen Demokratisierungsprozesse begleiten sollte, zumindest im Bereich der zahlreichen zivilen Konzepte ein - wenn auch unterschiedlich gewichteter - Bestandteil der Planungsperspektiven.

Insbesondere Einrichtungen im Umfeld der „World Peace Foundation“, des „Carnegie Endowment for International Peace ${ }^{“ 669}$ oder der genannten „Joint Commission of the London International Assembly and the Council for Education in World Citizenship“waren in ihren Post-War-Konzepten stark auf internationale Planungsperspektiven hin orientiert und favorisierten eine demokratische Erziehung in Richtung einer „World Citizenship“, ${ }^{670}$ die

667 When is an „Educational Invasion“ of Conquered Countries „Messianic“? In: School and Society, Vol. 58, November 6, 1943, No. 1506, 364.

668 Vgl. Hans Kelsen, International Peace - By Court or by Government? In: American Journal of Sociology, Vol. XLVI, January 1941, No. 4, 571-581. In seiner Analyse stellte Kelsen klar, dass das historische Versagen des Völkerbunds mit der vom Völkerrat nicht zu erfüllenden Aufgabe eines Exekutivorgans ohne klaren juristischen Auftrag - wie beispielsweise im Fall des Den Haager Friedensgerichtshofs - zusammen hänge. „Nothing can demonstrate this more clearly than the fact that the violation of the territorial integrity of member states, when it came from outside and led actually to the complete annihilation of these states, as in the case of Austria [...] in open opposition to the provisions of Articles 10 and 11, did not even reach the stage of discussions in the league“. Ebd., 580. [Hervorhebung d. Verf.]

669 Unter Führung des vormaligen Präsidenten der Columbia University, Nicholas Murray Butler, der 1931 den Friedens-Nobelpreis erhalten hatte, beschäftigte sich die Carnegie Friedensstiftung seit Anfang der Dreißigerjahre in enger Kooperation mit einer Vielzahl internationaler Einrichtungen mit Fragen einer künftigen Friedensordnung. Darüber hinaus gab die Carnegie Stiftung aber auch ausgesprochen elaborierte Studien in Auftrag, die sich als detaillierte Handbücher für die Verwendung durch die künftigen Militärregierungen in den besetzten Ländern verstanden. So z.B. die umfangreiche Arbeit des polnischen Juristen Raphael Lemkin von der Duke University in Durham in North Carolina, in der unter anderem auch materialreich auf die Annexion Österreichs, die administrativen und gesetzlichen Veränderung danach sowie auf die Haltung der USA eingegangen wurde, wobei sich der Österreich betreffende Passus der Moskauer Deklaration bereits eingearbeitet findet. Raphael Lemkin, Axis Rule in Occupied Europe. Laws of Occupation, Analysis of Government, Proposals for Redress, Washington D.C. 1944, 108-117; 283-299.

670 Dieses Ziel legte z.B. die „International Conference on Teachers“ anlässlich einer Konferenz im August 1942, die unter Schirmherrschaft des „Council for Education in World Citizenship“ stattfand, in einer eigenen Deklaration fest. Vgl. Education and the United Nations, a.a.O., 38; auch das „Universities Committee on Post-war International Problems“, das aus einem Zusammenschluss von rund fünfzig Zirkeln und Gruppen bestand und sich vor allem mit Problemen der „Psychological reorientation“ beschäftigte, 
mit Hilfe eines erst einzurichtenden „World Bureau of Education“" ${ }^{\text {"61 }}$ im Rahmen der United Nations gewährleistet werden sollte.

Neben den bereits genannten Institutionen ${ }^{672}$ existierte eine Fülle weiterer ziviler Einrichtungen, die in der edukativen und kulturellen „Rehabilitierung“ (unter Einschluss der sozialen und ökonomischen Stabilisierung) das zentrale politische Problem für eine dauerhafte demokratische Friedenssicherung nach dem Krieg sahen. 1944 befassten sich allein in den Vereinigten Staaten rund 60 verschiedene zivile Gruppierungen ${ }^{673}$ beziehungsweise Institutionen mit Fragen der „Educational Reconstruction“ beziehungsweise mit der „Reeducation“; - ein Begriff der sich unter dem Einfluss psychiatrischer und psychologischer Studien ab 1943/44 in der zivilen Diskussion mehr und mehr durchzusetzen begann, bis er schließlich als Terminus technicus in den Planungsszenarien für die militärische Besatzung Einzug hielt.

In die zivilen Planungen innerhalb des genannten „General Advisory Committee“ des U.S. Department of State, das von Beginn an die Zusammenarbeit mit zivilen beziehungsweise privaten Institutionen und Organisationen suchte, wurden Anfang 1944 wichtige Kooperationspartner einbezogen, indem das „American Council on Education“ unter Vorsitz von Präsident George F. Zook das „Committee on International Education and Cultural Relations“ gründete. Die Leitung dieser Studienabteilung, ${ }^{674}$ die als eine Art zusätzlicher „Think tank“ des U.S. State Departments unter anderem auch eine Reihe an $\mathrm{Pu}$ -

verlautete diesbezüglich: „[...] the schools must teach world citizenship and peace instead of petty nationalism and hatred“. Henry S. Curtis, Wanted: An International Conference on Postwar Education. In: School and Society, Vol. 59, February 19, 1944, No. 1521, 140.

671 Education and the United Nations, a.a.O., $38 \mathrm{f}$.

672 Hier noch einmal zum besseren Überblick: American Council on Education (ACE), CAME - Conference of Allied Ministers of Education, Educational Policies Commission, General Advisory Committee on Post-War Programs, International Committee of Intellectual Co-operation, Joint Commission of the London International Assembly and the Council for Education in World Citizenship, Liaison Committee for International Education, National Council on Education (NCE), National Committee on Education and Defense, Universities Committee on Post-war International Problems.

673 So zum Beispiel: die Association of University Professors and Lecturers of the Allied Countries, umfasste 249 Mitglieder aus 17 Ländern und beschäftigte sich primär mit der Ausarbeitung praktischer Methoden für die Aufgaben der Post-War-Education; das private Institute on Reeducation of the Axis Countries, das 1944 als Sonderabteilung des U.S. Committee on Educational Reconstruction, mit Sitz in New York gegründet wurde, und das sich aus Emigranten, Wissenschaftern und vereinzelten Mitarbeitern des Propaganda-Geheimdienstes (Office of War Information) zusammensetzte [siehe dazu die Ausführungen am Ende von Kapitel 2]; weiters das 1944 wiedergründete Institute of Intellectual Cooperation unter Leitung von Henri Bonnet [Henri Bonnet emigrierte 1942 in die USA und wurde nach dem Krieg Botschafter Frankreichs in Washington D.C.], das ursprünglich 1924 gegründet worden war und zuvor im Rahmen des Völkerbunds gearbeitet hatte; oder das im Frühjahr 1944 gegründete Council for Democratic Germany unter Leitung von Paul Tillich.

674 Weitere Angehörige des Studienkomitees waren Ben M. Cherrington, Stephen P. Duggan, Virginia C. Gildersleeve, Waldo G. Leland, Carl H. Milam, Roscoe L. Wets und Howard E. Wilson. Siehe dazu: Kandel, United States Activities in International Cultural Relation, a.a.O., 1. 
blikationen zur bildungspolitischen und kulturellen Nachkriegsplanung herausgab, hatte der Präsident der Indiana University, Hermann B. Wells, ${ }^{675}$ inne - jener Mann, der dann im November 1947 John Taylor als Chef der OMGUS-Educations and Religious Affairs Branch ablösen sollte. ${ }^{676}$

Der inhaltliche Kern der in den Kriegsjahren angestellten Gedanken zu einer friedensichernden Nachkriegsordnung findet sich im Vorwort zu einer 1945 erschienenen Schrift des „Council on Education Studies“, das von einem der einflussreichsten US-Pädagogen verfasst wurde. Darin skizzierte George F. Zook, mit Verweis auf die als notwendig erachtete Unterstützung durch die Vereinten Nationen, ein globales edukatives Projekt, das gleichsam das gesamte Leben - angefangen von der Schule, über die Öffentlichkeit bis hin zum Esstisch - erfassen sollte und das durch die Verschränkung der Bezugspunkte Erfolg, Profit und Komfort bereits klar auf die Popularisierung des „American way of life" verwies:

"On education lies a major responsibility for preventing future wars. [...] The regular channels of education - schools, the press, radio, motion pictures, the pulpit, and discussion at all levels from the public forum, even the soapbox, to the family dinner table - must be utilized to disseminate the knowledge that peace is the most successful, the most profitable, as well as the most pleasant way of life. The glorification of war in the Axis countries was the deliberate result of planned educational process. [...] To insure that it will not happen again, every effort should be made to put before the public and the planners of the United Nations organization facts and ideas that can be used as tools and texts in educating the peoples of the world for peace." ${ }^{677}$ [Hervorhebung d. Verf.]

„What to do with the mentally ill Germans?" Ursprünge, Entwicklung und Veränderungen der zivilen Reeducation-Konzepte, 1940-1944

"Observers say that the mass of the German people today are mentally ill. Why should they not be ill? There will be memories to stalk the Reich, ghosts that cannot be appeased; memories of slaughtered women and children, of soldiers dead by hundred thousand, of word of honor broken, of cruelty unspeakable, memories to sicken the toughest mind." (New York Times, Editorial, 27.Juli 194I)

Die prägnanteren Formulierungen und die zumindest terminologisch griffigeren Überlegungen und Konzepte für eine geistig-mentale Rekulturalisierung des totalitären Europa nach Kriegsende - die sich zu Kriegszeiten im Sinne einer offensiven Propaganda

675 Hermann B. Wells (1902-2000), Ökonom, seit 1938 Präsident der Indiana University.

676 Allerdings nur kurzfristig, da er bereits im Dezember 1948 von Alonzo Grace abgelöst wurde.

677 George F. Zook. In: United States Activities in International Cultural Relations, Vol. IX, a.a.O. 
auch politisch besser verwenden ließen - enthalten die psychiatrisch-psychologischen „Reeducation“-Ansätze. ${ }^{678}$

Sowohl für die Proponenten einer „Educational Reconstruction“ als auch für die Vertreter einer psychiatrisch-psychologisch inspirierten Variante einer mentalen Neuorientierung nach Kriegsende bildete die als unumgänglich angesehene Notwendigkeit einer tiefgreifenden und nachhaltigen Rehabilitierung der „outlaw nation“ Deutschland - tatsächlich stellte der Rekurs auf das deutsche Volk den primären theoretisch-anwendungsbezogenen Bezugsrahmen dar - den gemeinsamen Ausgangspunkt. ${ }^{679}$ Hier wie dort sah man in der strikten Entnazifizierung und Entmilitarisierung, in der sozio-ökonomischen Stabilisierung, in der Re-Demokratisierung des pervertierten Schul- und Bildungswesens sowie der gesamten Bildungs-, Kultur- und Medienlandschaft die Vorbedingungen für eine längerfristige Veränderung des „way of life“ in Richtung einer post-totalitären Gesellschaft.

Im Unterschied zum weichen, nicht Kollektivschuld-bezogenen Diskurs der „Pädagogen“, deren liberal-aufklärerischer Ansatz vom autonomen Subjekt und nicht vom devianten Patienten ausging, und dabei - neben curricularer Schulung - das konkrete öffentliche Handeln und Verhalten in einer demokratischen Lebenspraxis in den Mittelpunkt stellte, zielte das kollektiv-psychiatrische „Reeducation“-Konzept - unter Verwendung klinischer Kategorien - direkt auf die Köpfe beziehungsweise Einstellungen („minds“) der „mentally sick German people“ ${ }^{680}$ Angesichts der aggressiven NS-Hetzpropaganda gegen „Freiheit“ und „Demokratie“, des mörderischen Wahnsinns von Holocaust und Vernichtungskrieg und der dabei verübten unvorstellbaren Gräueltaten, drängte sich auch in der Öffentlichkeit die Vorstellung von einem durch „maniacal perverts“681 verrückt gewordenen Volk auf.

Die ersten (sozial-)psychologisch angelegten Analysen des Nationalsozialismus - zum Teil handelte es sich dabei um journalistischen Arbeiten - waren bereits im Jahr der Machtergreifung Hitlers erschienen. ${ }^{682}$ Hier und insbesondere bald darauf in der materialreichen Studie des Politikwissenschafters Frederick L. Schuman zur „Sozialpathologie und Politik

678 Siehe: Uta Gerhardt. A Hidden Agenda of Recovery: The Psychiatric Conceptualization of Re-education for Germany in the United States during World War II. In: German History, Vol. 14, 1996, No 3, 297-324.

679 Ernst Bungenstab, Umerziehung zur Demokratie? Re-education-Politik im Bildungswesen der US-Zone 1945-49, Gütersloh 1970, 28; einen Überblick über den allgemeinen Forschungsstand für Deutschland bietet: Ellen Latzin, „Reeducation“ - „Reorientation“: Theorie und Praxis zentraler Leitbegriffe der amerikanischen Besatzungspolitik nach 1945. In: Elisabeth Kraus (Hrsg.), Die Universität München im Dritten Reich. Aufsätze. Teil I, München 2006, 609-635.

680 Karl Loewenstein, Political Reconstruction, New York 1946, 337. Zit. nach: Bungenstab, Umerziehung zur Demokratie?, a.a.O., 22.

681 Denna Frank Fleming, What is it that we fight? [Radioansprache am 3. März 1943, Nashville/Tennesse]. In: Representative American Speeches: 1942-1943, a.a.O., 71.

682 So z.B. Edgar A[nsel]. Mowrer, Germany Puts the Clock Back, London 1933 oder Harold D. Lasswell, The Psychology of Hitlerism. In: The Political Quarterly, Vol. IV, July-September 1933, No. 3, 373-384. In derselben Ausgabe des Political Quarterly erschien übrigens ein Beitrag von Mussolini: Benito Mussolini, The Political and Social Doctrine of Fascism. In: Ebd., 341-356. 
des Faschismus“ wurden spannende Analysen zur „Neurose“ des deutschen Kleinbürgertums, zum „Führerprinzip“, zur „Rassenmythologie“, zur Sündenbockfunktion des Antisemitismus (,persecution of scapegoats“), ${ }^{683} \mathrm{zu}$ imperialistischen Allmachtsphantasien, zur Indoktrinierung der Jugend und zur politischen Funktion von NS-Terror und Gewalt vorgelegt. Trotz vereinzelter Verweise auf Elemente eines spezifisch martialischen und zu simpler Unifizierung ${ }^{684}$ neigenden deutschen Nationalcharakters beschränkten sich diese Darstellungen jedoch auf die Analyse des politischen Systems.

Nachdem sich das emigrierte Frankfurter Institut für Sozialforschung unter Federführung von Erich Fromm bereits 1936 mit Studien zum autoritären Charakter beschäftigt hatte, ${ }^{685}$ befassten sich Ende der Dreißigerjahre auch Medizin und Psychiatrie verstärkt mit diesem Themenfeld. Psychiater wie Edward Strecker begannen sich mit Fragen der Massenparanoia und Massenbeeinflussung im Kontext einer politischen Reorientierung zu beschäftigen und sahen dabei in der durch „Re-education“ vermittelten „Mentalhygiene“ ein Gegenmittel zu destruktiver Indoktrinierung. ${ }^{686}$ Ende 1940 wurde auch ein eigenes „Committee for National Morale" - unter Vorsitz von Harold Ickes und der Mitarbeit des späteren Hochkommissars für Deutschland John McCloy ${ }^{687}$ - gegründet, in dem sich neben Pädagogen, Historikern, Sozialwissenschaftern, Medizinern und Neurologen insbesondere auch Psychiater und Psychologen befanden. ${ }^{688}$ Des Weiteren wurde im November 1940 vom „National Research Council“(NRC) in Washington ein Team von 25 Sozialpsychologen zusammengezogen, das sich künftig mit Fragen der Stärkung nationaler Moral befassen und über ein eigenes Subkomitee des NRC landesweite „Defense Seminars“ an Universitäten organisieren sollte. ${ }^{689}$

$\mathrm{Ab}$ 1943/44 wurde schließlich unter der Leitung von Theodor W. Adorno und dem US-Sozialpsychologen R. Nevitt Sanford in Berkeley ein Forschungs-Großprojekt zur "Authoritarian Personality“ begonnen. Ziel dieses vom „American Jewish Congress“ finanzierten Antisemitismus-Forschungsprojektes, das an die Vorarbeiten von Erich Fromm aus

683 Schuman, Design for a People's Peace, a.a.O., $312 \mathrm{ff}$.

684 „Unity has been partially attained by the superficial co-ordination of external motions; , the German national dance Step' is the goose step. Beneath the facade of external harmony survive the legacies of disunion." Lasswell, The Psychology of Hitlerism, a.a.O., 381.

685 Erich Fromm/Max Horkheimer et al., Studien über Autorität und Familie: Forschungsberichte aus dem Institut für Sozialforschung, Paris 1936.

686 Uta Gerhardt, The Medical Meaning of Reeducation for Germany: Contemporary Interpretation of Cultural and Institutional Change. In: Paedagogica Historia, XXXIII, 1997, 1, $136 \mathrm{f}$.

687 Schuhmacher, Kalter Krieg und Propaganda, a.a.O., 53.

688 In diesem Komitee saßen unter anderen die Psychologen Gardner Murphy, Henry Murray, Goodwin Watson und Robert Yerkes. In dem „Psychologischen Subkomitee“ befanden sich des Weiteren u. a. Gordon Allport, Walter Bingham, Geoffrey Gorer, Ernst Kris und Kurt Lewin. NA, OSS, Entry 146, Box 150, Folder 2278. Zit. nach: Louise E. Hoffman, American Psychologists and Wartime Research on Germany, 1941-1945. In: American Psychologist, Vol. 47, February 1992, 267; Vgl. auch Gerhardt, The Medical Meaning of Reeducation for Germany, a.a.O., 136.

689 Hoffman, American Psychologists and Wartime Research on Germany, a.a.O., 266. 
den Dreißigerjahren anknüpfte, war es, in theoriegeleiteter Form auf empirischer Basis die spezifischen charakterlichen Persönlichkeitsstrukturen und Wertvorstellungen zu analysieren, die antisemitischen Verhaltensweisen zugrunde liegen. ${ }^{60}$ Mittels „Fragebögen, mehrstündigen Interviews und projektiven Tests“ sowie der Entwicklung einer ausgeklügelten typologischen „F(aschismus)-Skala“ konnten die Autoren der schließlich I.০oo-seitigen Studie - die allerdings erst 1950 publiziert wurde ${ }^{691}$ - verifizieren, dass es einen nachweisbaren Zusammenhang zwischen Charakterstruktur und anti-demokratischen beziehungsweise faschistischen Denkmustern gibt. ${ }^{692}$ Mit diesem damals unpublizierten Befund unterstützte die Berkeley-Studie zur autoritären Persönlichkeit tendenziell sozialpsychologische Ansätze in der Auseinandersetzung mit Fragen der Nachkriegs-Reorientierung.

War die empirische Psychologie in den USA ab I9I8 als Profession relativ einflusslos gewesen, befand sie sich spätestens mit dem Kriegseintritt der USA in starkem Aufwind. ${ }^{63}$ Klinische Diagnosen des aggressiven deutschen Nationalcharakters sahen dessen „Eliminierung“ nun weniger als Problem der „Education“, als vielmehr eines der „Psychotherapie“, ${ }^{694}$ wobei mitunter auch hier die Idee einer internationalen Kontrolle durch die internationale Staatengemeinschaft auftauchte. ${ }^{695}$

Immer öfter taucht nun der Begriff „Reeducation“"696 in der Diskussion auf, ein Terminus, der dem zeitgenössischen Theorienarsenal der klinischen Psychologie, Psychiatrie und

690 Rolf Wiggershaus, Theodor W. Adorno, 3. überab. u. erweiterte Aufl., München 2006, 83.

691 Theodor W. Adorno/Else Frenkel-Brunswik/Daniel J. Levinson/R. Nevitt Sanford, The Authoritarian Personality, New York 1950.

692 Wiggershaus, Theodor W. Adorno, a.a.O., $84 \mathrm{f}$.

693 George W. Hartmann. Toward a Reasonable Peace. A Little Psychology of the Psychologist. In: The Journal of the Abnormal and Social Psychology, 38. Jg., 1943, 199.

694 „In many respects the problem is not so clearly one of education as it is of psychotherapy." Stagner, PeacePlanning as a Problem, a.a.O., 189.

695 So sprach sich der Psychoanalytiker Franz Alexander, Emigrant und Direktor des Chicagoer Instituts für Psychoanalyse, in Anlehnung an die historische „Pax Romana“ und die „Pax Britannica“ für eine neue, sozial organisierte Form einer dauerhaften Friedensicherung im Zusammenhang der Vereinten Nationen aus. Franz Alexander, The Psychiatric Aspects of War and Peace. In: The American Journal of Sociology, Vol. XLVI, January 1941, No. 4, 519 f.; dem schloss sich, unter Kritik der Versäumnisse des Völkerbundes, auch der britisch-polnische Anthropologe Bronislaw Malinowski an: „I believe that the future peace of mankind is possible only on a principle of a commonwealth of nations. [...] The great enemy of today is the sovereign state, even as we find it in democratic commonwealths - certainly as it has developed into the malignant growth of totalitarianism." Bronislaw Malinowski, An Anthropological Analysis of War. In: Ebd., 549.

696 Karl-Ernst Bungenstab erwähnt, dass die erstmalige Verwendung des Begriffs „Re-education“ der USJournalist Leopold Schwarzschild für sich reklamierte, der diesen in einem Zeitschriftenartikel 1939 verwendet habe, worauf er sogleich von der Politik aufgenommen worden sei. Vgl. Bungenstab, Umerziehung zur Demokratie?, a.a.O., 9 f. Hellen Liddell wiederum verweist in diesem Zusammenhang auf eine Schrift Wickham Steed's, The Fifth Arm, London 1940, 152. Darin heißt es: „Germany cannot again be a part of Europe till she has gone through a process of deep moral re-education." Zit. nach: Liddell, Education in Occupied Germany, a.a.O., 35. 
Ethnologie entstammt und sich ursprünglich auf ein mentales oder emotionales Handicap bezieht; dabei bezeichnet der Begriff „Reeducation“ hier einen Vorgang, bei dem ein Patient etwas noch einmal beziehungsweise neu lernt, oder - anders ausgedrückt - „learning material that has been forgotten". 697

Der aus der therapeutischen Anwendungspraxis gegenüber einzelnen Individuen übernommene Begriff wurde jetzt auf die Gesamtheit der „mentally ill Germans“ bezogen, deren komplettes ,Mind-Set' einer profunden demokratischen Umorientierung unterzogen werden sollte. Dabei nahm man fallweise auch explizit auf Äußerungen Lord Vansittarts und Anthony Edens Bezug:

\footnotetext{
"'Germans have made five wars in the last 75 years besides four near misses', as Lord Vansittart said and Mr. Eden repeated several times. Vansittart concludes that 'a complete change of mind, heart and soul (of Germany), of taste and temperament and habit [...] a new, a brand new way of looking at life ${ }^{698}$ is necessary. But it would probably be impossible to change all German habits. Social psychology must find out which of them are relevant for aggression. ${ }^{1099}$
}

Die freilich keineswegs unproblematische ${ }^{700}$ Diagnose eines "German character" - ein höchst fragwürdiges, problematisches Konstrukt - wird, zwar in abgeschwächter Form, aber auch bei der emigrierten österreichischen Sozialpsychologin Charlotte Bühler ausgesprochen: „The Nazis represent only a particulary distorted form of the potentialities of thought and action which are general German qualities. The special Nazi mentality is only a distorted outgrowth of quite general trends in German reasoning and feeling “; 701 so existiere nach Bühler zum Beispiel ein neurotischer Perfektionismus (im Gegensatz

697 Bungenstab, Umerziehung zur Demokratie?, a.a.O., 1

698 Lord R. G. Vansittart, Black Record, London 1941, 15.

699 Fritz Schreier, German Aggressiveness - its Reasons and Types. In: The Journal of the Abnormal and Social Psychology, 38. Jg., 1943, 213.

$700 \mathrm{Zu}$ wissenschaftlicher Vorsicht und nötiger Selbstkritik in der Analyse kollektiver Vorurteile und sozialpsychologischer Formen eines ,unconscious nationalism“ mahnte in diesem Zusammenhang der ebenfalls aus Österreich emigrierte Kollege Bühlers, der bedeutende Sozialpsychologe Gustav Ichheiser (18971969): „The writer is himself a Jew. It is his scientific conviction that if one wishes to analyze certain group-prejudices, he must first of all rid himself and see through the prejudices of the group to which he himself, by origin, belongs. It makes no sense, as often happens, to ,unmask the ideologies and mythologies of the ,others' and at the same time to remain blind to the ideology and mythology of one's own group." Gustav Ichheiser, Some Psychological Obstacles to an Understanding Between the Nations. In: The Journal of the Abnormal and Social Psychology, 36. Jg., 1941, No. 3, 429.

701 Charlotte Bühler, Why do Germans so Easily Forfeit their Freedom? In: The Journal of the Abnormal and Social Psychology, 38. Jg., 1943, 153. 
zur spezifisch österreichischen Ignoranz ${ }^{702}$ und „Schlamperei“), ${ }^{703}$ die Bereitschaft, sich bedingungslos „höheren Idealen“704 zu verschreiben („the idea of dying for the country, not living for it“), eine Überschätzung abstrakter, „objektiver Werte“, „Nibelungen Treue“ sowie eine fundamentale Skepsis gegenüber Kritik überhaupt. Abgesehen von den Auswüchsen nationalsozialistischer Indoktrinierung sah Bühler das grundlegende Problem im - historisch bedingten - „deutschen Charakter“ angelegt:

„They have no discriminative understanding of tolerance born out of strength, humor, and an ultimate belief in all human beings' potential goodness, and they consider all tolerance a weakness. The democratic idea to allow for free development so long as possible and not to interfere with anybody so long as not absolutely necessary is completely foreign to all German thinking in education as well as in all affairs of civilian or public life." ${ }^{\text {"705 }}$

Ebenso wie Bühler beschäftigte sich auch der im englischen Exil weilende Otto Neurath $^{706}$ mit der Frage, inwiefern der Nationalsozialismus als deutsches Phänomen zu begreifen sei und strich dabei die Rolle und Bedeutung der spezifischen Traditionen im deutschen Kultur- und Geisteswesen hervor („German climate“), die gesellschaftliche Verhaltensweisen wie Gehorsamkeit, Autoritätsgläubigkeit, „Geniekult“ (Edgar Zilsel) oder inhumane Metaphysik befördert hätten. Im völligen Unterschied dazu würde das englische Gesellschaftsklima - so Neurath - auf Freundlichkeit, Toleranz, gegenseitiger

702 Bühler zitiert hier ein vor dem „Anschluss“ gebräuchliches Sprichwort: „There was a saying in Austria before it became Nazified. It ran as follows: ,In England everything is allowed that is not expressly forbidden. In Germany everything is forbidden that is not expressly allowed. In Austria everything is allowed that is expressly forbidden.' Ebd., 149.

703 „The best slogan for a leniency born out of weakness is the Austrian formula: ,Da kann man nix machen (,There one can't do anything'). The Prussian calls this scornfully the Austrian ,Schlamperei' (slovenliness).“ Ebd, 150.

704 Hier bewegte sich Charlotte Bühler entlang der Deweyschen Kritik am Deutschen Idealismus und dessen ,monströsen Folgen“.

705 Ebd., 157.

706 Otto Neurath (1882-1945), österreichischer Nationalökonom, Sozialreformer, Wissenschaftsvermittler und im Zusammenhang der Münchner Räteregierung - Kurzzeit-Politiker. Neurath gilt als führender Vertreter des linken Flügels des neopositivistischen Wiener Kreises, dessen Manifest „Wissenschaftliche Weltauffassung“ (1929) er gemeinsam mit Hans Hahn und Rudolf Carnap entwarf. Darüber hinaus ist Neurath Schöpfer der „Wiener Methode der Bildstatistik“, die ab 1934 als ISOTYPE (International System of Typographic Picture Education) internationale Verbreitung fand. Siehe: Elisabeth Nemeth/Friedrich Stadler (Eds.), Encyclopedia and Utopia. The Life and Work of Otto Neurath (1882-1945). With the first publication of Otto Neurath's full manuscript of „Visual Education“ and the documentation of the Otto Neurath Nachlass (Haarlem, The Netherlands) (=Vienna Circle Institute Yearbook 1996), Dordrecht - Boston - London 1996; weiters: Johann Dvořák, Otto Neurath und die Volksbildung. Einheit der Wissenschaft, Materialismus und umfassende Aufklärung. In: Friedrich Stadler (Hrsg.), Ausstellung Arbeiterbildung in der Zwischenkriegszeit. Otto Neurath und sein Gesellschafts- und Wirtschaftsmuseum, Politische Grafik von Gerd Arntz und den Konstruktivisten, Wien - München 1982, 149-156. 
Unterstützung und Hilfestellung, Zivilcourage und Gemeinschaftssinn beruhen. ${ }^{707}$ Oder wie Neurath 1944 im Vergleich der unterschiedlichen Lebenskulturen ausführte: „It will perhaps be useful to distinguish between ways of life, in which 'self-sacrifice' has no limits, as far as the 'State' or some 'Deity' is concerned, and those in which the 'personal conscience' plays an important role, and no order from the outside forces a person to think it a duty' to persecute and torment his neighbour " ${ }^{708}$ [Hervorhebung d. Verf.]

Seine „erzieherischen“ Überlegungen führten Neurath - der, obwohl enttäuscht über den Erfolgs des Nationalsozialismus in Österreich, wie Günther Sandner darlegt, Unterschiede zwischen dem gesellschaftlichen Klima in Deutschland und Österreich ${ }^{709}$ sah interessanterweise auch zu praktischer Mitwirkung im Rahmen der britischen „Re-education“. So brachte Neurath seine Ideen einer auf ISOTYPE („International Standard of Typografic Pictorial Education“) beruhenden „visuellen“ Umerziehung als Experte in Gremien der unter anderem auch mit Entnazifizierungsfragen beschäftigten „Conference of Allied Ministers of Education“ (CAME) ein ${ }^{710}$ und arbeitete gemeinsam mit dem Dokumentarfilmer Paul Rotha im Auftrag des britischen Informationsministeriums (MoI) an mehreren Filmen für die vom Nationalsozialismus okkupierten Gebiete, für die er Trickfilmsequenzen einbaute, die auf der Technik von ISOTYPE basierten. ${ }^{711}$

Außer Frage steht jedenfalls, dass der Begriff der „Reeducation“ ab 194I zunehmend Einfluss auf politische Konzepte eines nicht-pädagogischen, interventionistischen und zum Teil auf Bestrafung abzielenden Nachkriegsaufbaues gewann, wie sie dann am deutlichsten in den germanophoben Überlegungen Henry Morgenthaus, in abgeschwächter Form aber auch im US-War Department, artikuliert wurden.

In der öffentlichen politischen Diskussion wurde der Reeducation-Begriff zwar meistens im Zusammenhang mit einer politisch „härteren“, interventionistischen Friedensicherung für die Zeit nach dem Krieg verwendet, aber ebenso unscharf und ohne genauere inhaltliche Definition wie in der Fachliteratur. So findet sich der Begriff „Reeducation“ in

707 Günther Sandner, The German Human Climate and Its Opposite: Otto Neurath in England, 1940-45. In: Anthony Grenville/Andrea Reiter (Eds.), Political Exile and Exile Politics in Britain after 1933, New York - Amsterdam 2011, 76 ff. Ich danke an dieser Stelle Dr. Günther Sandner für den Hinweis auf seine Publikation und die Überlassung einer Kopie.

708 Zit. nach ebd. 78.

709 Dies führte Neurath unter anderem just darauf zurück, dass die idealistischen Lehren Immanuel Kants in Österreich nur geringen Einfluss entfaltet hätten. Sandner, The German Human Climate and Its Opposite, a.a.O., 78 .

710 „Neurath $[\ldots]$ was convinced that literature that reflected the Nazi standpoint should not necessarily be banned; however, nor should it be used in schools. Denazification in his view meant examining a long intellectual and cultural tradition." Sandner, The German Human Climate and Its Opposite, a.a.O., 80.

711 Günther Sandner, „Demokratisierung des Wissens. Politische und ökonomische Bildung in Otto Neuraths intellektueller Biographie“. Vortrag bei der internationalen Konferenz „Mit Bildung ist zu rechnen. Erwachsenenbildung im Spannungsfeld von ökonomischen Zwängen und Wissensvermittlung“, Wiener Urania, 9.11.2012. 
der fortlaufenden Diskussion wiederholt synonym verwendet mit „Reconstruction“, „Rehabilitation“, „Reculturalization“ oder auch „Reorientation“; darin dokumentieren sich terminologisch-inhaltliche Unschärfen, die sich sogar, wie noch zu zeigen sein wird, bis ins „Handbook for Military Government Austria“ hinein fortsetzten.

Deutlicher als in der Debatte um die „Educational Reconstruction“ unter den Pädagogen - ihnen ging es neben dem formalen Aufbau eines demokratischen Bildungs- und Erziehungswesens primär um die Initiierung kooperativ zu gestaltender, langfristiger informeller (Selbst-)Lernprozesse und um sozial verantwortliches Handeln in einer offenen Gesellschaft - zielte die psychiatrisch-psychologische Reeducation auf De-Konditionierungsprozesse beziehungsweise auf gezieltes Ver-Lernen spezifischer Verhaltensmuster:

"The German people must learn to un-learn all that they have been taught, not only by Hitler, but his predecessors in the last hundred years, by so many of their philosophers and teachers, the disciples of blood and iron." 712

Eine Diktion, die, nicht zuletzt durch die darin enthaltene Personifizierung des ,Bösen“ in Form eines Kollektiv-Subjekts, für die Stärkung nationaler Moral geeignet war - in der Öffentlichkeit ebenso wie in der US-Army. So meinte 1942 ein Militär in einem Interview gegenüber der New York Times: „We must de-educate and re-educate [the German and Japanese, d. Verf.] people for Democracy. [...] The one hope for Europe remains as a change of mentality on the part of the German. He must be taught to give up the century-old conception that his is the master race. "713

Tatsächlich kam es, wenn auch nur kurzfristig, bereits zu einem frühen Zeitpunkt zur Zusammenarbeit von Psychologie und militärischem US-Geheimdienst. Aber obwohl die „American Psychiatric Association“ 194I/42 ein eigenes „Military Mobilization Committee“ ins Leben rief, das sich speziell mit Fragen der „Morale and its control“714 beschäftigte, waren es dann eben nicht Psychiater, die hier einbezogen wurden, sondern primär Sozialpsychologen, die zu einem nicht unerheblichen Prozentsatz Emigrés waren. Obwohl die ersten Anregungen zu einer mentalen „Reeducation“ von Seite der klinischen Psychiatrie gesetzt wurden, schien sowohl für die Stärkung nationaler Moral und psychologischer Gegenpropaganda als auch für Konzepte einer gesellschaftlichen Mental-Therapie die interdisziplinär ausgerichtete Sozial- beziehungsweise Gruppenpsychologie das geeignetere Instrument zu sein. Zudem bot sich für Verhaltenswissenschaft und Sozialpsychologie - wie

712 Peter Matthews, The German people must learn to un-learn. In: Free Europe (Fortnightly Reviev on international Affairs), 1941, No. 46, 125. Zit. nach: Mowrer, Educational Considerations, a.a.O., 174.

713 Capt. L.D. Gammas, M.P. Interview in: New York Times, December 2, 1942. Zit. nach: Ebd.

714 Military Mobilization Committee of the American Psychiatric Association, Psychiatric Aspects of Civilian Moral, New York 1942. Vgl. Gerhardt, The Medical Meaning of Reeducation for Germany, a.a.O., 144. 
für die Psychiatrie und die Psychologie allgemein - hier, wie auch Louise Hofmann meint, eine Möglichkeit, die eigene fachlich-wissenschaftliche Autorität durch Indienstnahme im Rahmen des nationalen Abwehrkampfes öffentlich aufzuwerten. ${ }^{715}$

In direkter Antwort auf den nationalsozialistischen „Weltanschauungskrieg“ gegen die USA und die dabei angewandten Methoden einer psychologischen Kriegsführung berief Präsident Roosevelt am 25. Juni I94I seinen Freund und prominenten Wallstreet-Anwalt, William Joseph Donovan, zum „Coordinator of Information“ (COI), der ersten zentralen, halb-zivilen amerikanischen Geheimdienstabteilung. Bereits im August wurde innerhalb dieser Abteilung eine eigene „Research \& Analysis Branch“ (R \& B) unter Leitung von William L. Langer eingerichtet, in der eine große Zahl hochrangiger, teils emigrierter Sozialwissenschafter, Historiker, Ökonomen und Psychologen Basismaterial für „Intelligence Reports" sammelten und evaluierten. ${ }^{716}$ Parallel dazu entstanden unter dem mit Donovan befreundeten Assistant Secretary of War, John McCloy, dem späteren Oberbefehlshaber der amerikanischen Besatzungsmacht in Deutschland, kleine militärische Geheimdiensteinrichtungen ${ }^{717}$ wie die „Psychological Warfare Branch“, die 1943 nach mehreren Umbenennungen schließlich als „Psychological Warfare Division“ unter Leitung von Brigadier General Robert McClure gemeinsam mit dem OWI und dem britischen „Political Warfare Executive“ (PWE) in der „Psychological Warfare Division“ des „Supreme Headquarters Allied Expeditionary Forces“ (PWD/SHAEF) aufging. ${ }^{718}$

Nach der infolge der militärischen „Order“ Präsident Roosevelts erfolgten Umbenennung des COI in „Office of Strategic Studies“ (OSS) vom I3. Juni 1942 stand die Ge-

715 Hoffman, American Psychologists and Wartime Research on Germany, a. a.O., 264.

716 Arthur B. Darling, The Central Intelligence Agency. An Instrument of Government, to 1950, Pennsylvania State University - London 1990, 8 f. Darunter befanden sich eine Reihe hochrangiger (deutscher) Geistes- und Sozialwissenschafter, die als Linksintellektuelle noch rechtzeitig in die USA flüchten konnten und hofften, innerhalb der "Central European Section“ der R\&B mit ihrem historischen, politischen und soziologischen Wissen für einen demokratischen Neubeginn in Europa beitragen zu können. So u.a. Herbert Marcuse, der Verwaltungsjurist Franz L. Neumann, Otto Kirchheimer, Carl Schorske, Arthur Schlesinger oder Paul Sweezy. Vgl. Rainer Erd (Hrsg.), Reform und Resignation. Gespräche über Franz L. Neumann, Frankfurt a. Main 1985, 153 ff. Innerhalb des OSS / R \& B für Österreich zuständig waren Henry Mayer, Robert G. Neumann, Lorenz Eitner und Paul R. Sweet. Vgl. Oliver Rathkolb, Professorenpläne für Österreichs Zukunft. Nachkriegsfragen im Diskurs der Forschungsabteilung Research and Analysis. In: Jürgen Heideking/Christoph Mauch (Hrsg.), Geheimdienstkrieg gegen Deutschland. Subversion, Propaganda und politische Planungen des amerikanischen Geheimdienstes im Zweiten Weltkrieg, Göttingen 1993, $168 \mathrm{ff}$.

717 So z.B. die Research Branch der U.S. Army Division of Morale unter Leitung von Samuel Stoffer. Vgl. Christopher Simpson, Science of Coercion. Communication Research and Psychological Warfare 19451960, New York - Oxford 1994, 26.

718 Vgl. dazu: Simpson, Science of Coercion, a.a. O., 23 ff.; weiters: Siegfried Beer, Alliierte Planung, Propaganda und Penetration 1943-1945. Die künftigen Besatzungsmächte und das wiederzuerrichtende Österreich, von der Moskauer Deklaration bis zur Befreiung. In: Das Burgenland im Jahr 1945. Beiträge zur Landes-Sonderausstellung 1985. Hrsg. v. Stefan Karner, Eisenstadt 1985, 75. 
heimdienstabteilung nun unter der Direktive der Joint Chiefs of Staff (JCS), des amerikanischen Generalstabs. Die geheimdienstliche Funktion des OSS beschränkte sich jetzt auf jene Aufgaben, „necessary for the planning and execution of the military program for psychological warfare“, darunter auch Sabotage, Spionage und Gegenspionage in „enemyoccupied or controlled territory, guerilla warfare, underground groups, and contacts with foreign nationals in the United States. “719

Innerhalb des von Donovan geführten OSS wurde im Sommer 1942 unter Leitung von Robert C. Tryon von der University of California eine eigene „Psychology Division“ (OSS PD) geschaffen, in der insgesamt I6 Psychologen, in erster Linie Sozialpsychologen, damit befasst waren, psychologisch relevantes Material für andere Abteilungen der psychologischen Kriegsführung aufzubereiten. ${ }^{720}$ Tatsächlich aber verfassten diese Psychologen gemeinsam mit Geografen und anderen Spezialisten in der Hauptsache lediglich „pocketsized Soldier Guides“; zu Beginn des Jahres wurde die OSS-Abteilung bereits wieder aufgelöst und ihre Mitarbeiter wurden der interdisziplinär arbeitenden Research \&Analysis Branch (R \& B) beziehungsweise dem OWI zugeteilt. ${ }^{721}$

Die Research \&Analysis Branch arbeitete seit I942/ 43 neben „Target Exploitations“ für Bombenziele oder „Interrogation Reports of Prisoners of War“ für einen späteren Elitenaustausch $^{722}$ auch an Materialsammlungen für die Erstellung von Handbüchern für die US-Militärbehörden in den künftigen Besatzungsgebieten in Europa; dafür verfassten sie Analysen zu historischen, politischen, wirtschaftlichen oder aktuellen Entwicklungen in den jeweiligen Gebieten. So war zum Beispiel der aus Brünn gebürtige Lorenz Eitner, der I935 mit seiner Familie in die USA emigriert war und an der Duke University studierte hatte, ab 1943 in der „Central European Section“ der Research \& Analysis Branch tätig und arbeitete nach seiner Versetzung nach London im Juni I944 an den Vorarbeiten für die Militärhandbücher in Österreich und Deutschland mit, wobei Österreich „unter dem damaligen Sach-Referenten für Österreich-Angelegenheiten“, dem amerikanischen Historiker Paul R. Sweet, in den ersten Monaten „nur als Appendix zur Deutschlandfrage behandelt" wurde. ${ }^{723}$

Obwohl einige der frühen OSS-Berichte „soweit sie die Situation in Österreich betrafen, aussageschwach und teilweise sogar inkorrekt waren“, ${ }^{724}$ gibt es neben den faktenori-

719 Zit. nach: Darling, The Central Intelligence Agency, a.a.O., 12.

720 Hoffman, American Psychologists and Wartime Research on Germany, a.a.O., 265.

721 Ebd., 266.

722 Oliver Rathkolb (Hrsg.), Gesellschaft und Politik am Beginn der Zweiten Republik. Vertrauliche Berichte der US-Militäradministration aus Österreich 1945, Wien - Köln - Graz 1985, 13.

723 Ebd., 414 bzw. 13.

724 Im Unterschied zur Deutschland-Planung des OSS, an der zahlreiche, teils herausragende Intellektuelle wie Franz Neumann oder Herbert Marcuse mitarbeiteten, „beschränkte sich das Interesse für österreichische Emigrantengruppen auf reine Observationen, für die in London Robert Neumann, ein österreichischer Emigrant bürgerlich-katholischer Prägung, verantwortlich zeichnete. Ebd., 12 f. bzw. 14. Siehe 
entierten Darstellungen der OSS-Abteilungen nach Kriegsende vereinzelt auch spannende Berichte aus den Kriegsjahren. So ein im August 1942 verfasstes, 54-seitiges Dossier mit dem Titel „The Austrians“, das eine sehr informative Analyse der Situation der österreichischen politischen Emigration in den Vereinigten Staaten sowie der US-Politik gegenüber Österreich enthält und bereits zum damaligen Zeitpunkt davon ausging, dass Österreichs geographische Situation nach dem Krieg „highly strategic“ sein würde. ${ }^{725}$ Oder eine im April 1944 verfasste, 64-seitige OSS-Studie mit dem Titel „The Attitude of the Austrian People Towards the Moscow Declaration on Austria“, ${ }^{726}$ die überaus spannende Innenansichten der öffentlichen Auswirkung der alliierten Österreich-Erklärung bietet, auf deren Wortlaut später im Zusammenhang mit den militärischen Österreich-Planungen ab 1943/44 noch einzugehen sein wird.

Eine weitere, konkretere Aktivität im Hinblick auf die Nachkriegsplanung entfaltete die Research \&Analysis Branch des OSS durch ein Projekt, das unter anderem auch einen Überblick über in Österreich vorhandene Personalreserven und deren politische Verwendbarkeit im Bereich von Schule, Universität, Kirche und Politik geben sollte. 1943/44 wurde damit begonnen, aus qualitativ bewerteten Zeugenaussagen sowie schriftlichen Quellen „Biographische Reports“ zusammenzustellen, deren teils unsystematisch-voluntaristischer Charakter allerdings auf ein zunächst nur wenig koordiniertes beziehungsweise koordinierbares Vorgehen schließen lässt. ${ }^{727}$ So trat das OSS über die US-Botschaft in London an Vertreter ausländischer österreichischer Exil-Gruppen heran, um nähere Informationen zu einzelnen Personen einzuholen. ${ }^{728}$ Des Weiteren wurden breitflächig

insbesondere auch: Tim B. Müller, Krieger und Gelehrte. Herbert Marcuse und die Denksysteme im Kalten Krieg, Hamburg 2010.

725 The Austrians. Foreign Politics in the United States. Foreign Nationalities Branch. Office of the Coordinator of Information, August 1942, 1. U.S. Office of Strategic Services. Foreign Nationalities Branch Files 1942-1945. Indexes, Bethesda 1998 [Mikrofiche-Bestand, Institut für Zeitgeschichte der Universität Wien, Bibliothek], INT-4AU-303.

726 The Attitude of the Austrian People Towards the Moscow „Declaration on Austria“. Office of Strategic Services. Research and Analysis Branch, R\&B No. 1704. Secret. 14. April 1944. A Guide to O. S. S./State Department Intelligence and Research Reports. Germany and its Occupied Territories during World War II. Part 4 [A Microfilm Project of University Publications of America, Inc.], Washington D.C. 1977. Bestand Institut für Zeitgeschichte, Universität Wien (Bibliothek), Rolle 1 [14-15].

727 Report of Investigation of Land Government officials (Upper Austria), Col. R.A. Snook to Col. Norcross, Chief, Internal Affairs Division, 16. Oktober 1945. Hoover Institution Archives, Stanford University, John Doane Hartigan Papers, 1909-1958, Box 7: Military reports and career of John Doane Hartigan. Für die Überlassung von Kopien aus diesem Quellenbestand bin ich Herrn Univ.-Prof. DDr. Oliver Rathkolb zu Dank verpflichtet. Die Erstellung von biografischen Files wurde nach Kriegsende vom neugeschaffenen militärischen US-Geheimdienst „Counter Intelligence Corps“ (CIC) in der amerikanischen Besatzungszone fortgeführt.

728 I.S. Dorfmann, Office of Strategic Services, American Embassy London, to O. Pollak, 17. Dezember 1943. DÖW-Akt 17859/157, London-Büro Material, Dez. 1943-März 1944. Darin erbat das OSS Auskunft über: den österreichischen Chemiker Prof. Wassicky, den Wirtschaftsverhandler Richard Schuller, 
Dossiers angelegt, die neben Pflichtschul- und Gymnasiallehrern, Schuldirektoren und Universitätsprofessoren auch Minister umfassten, wie zum Beispiel den Ex-Unterrichtsminister Hans Pernter - zum damaligen Zeitpunkt Häftling im Konzentrationslager Dachau -, sowie den kurzzeitigen Direktor der Wiener Urania, Ludwig Riedl, Lokal- und Regionalpolitiker wie den ehemaligen Stadtrat von Steyr, Franz Roithner, geistliche Würdenträger wie den Abt vom Benediktiner Stift Seitenstetten, Bruno Rauchegger oder Erzbischof Andreas Rohracher. ${ }^{729}$ Die Erstellung dieser Personen-Dossiers dürfte im Umfeld der OSS-Sondereinrichtung „Foreign Nationalities Branch“ (FNB) durchgeführt worden sein, die 1942 auf Initiative des State Departments eingerichtet wurde, um einen besser informierenden Überblick über die „verschiedenen Aktivitäten und Haltungen ausländischer Gruppierungen in den USA“730 zu erhalten. Das FNB baute unter Leitung des früheren US-Gesandten in Wien, John C. Wiley, ein großes Netz freiwilliger Mitarbeiter auf, die vor allem die deutschsprachige Presse nach sicherheitspolitischen Informationen durchkämmten, und beschattete darüber hinaus auch Gruppierungen und Einzelpersonen des österreichischen Exils in den USA. ${ }^{731}$ Unter dem Projektnamen „Name File Project" wurden vom OSS ab Anfang 1943 über 5.00o biografische Daten erhoben, darunter über 2003 Deutsche und 706 Österreicher im „Dritten Reich“ sowie über 90 deutsche und österreichische Emigranten. ${ }^{732}$

den früheren österreichischen Gesandten in Washington, [Edgar L.G.] Prochnik, [Kurt] Schusschnig [sic!] und [Theodor] Hornbostel. Oscar Pollak antwortete Dorfmann mit einem detaillierten Bericht zur österreichischen Exil-Sozialdemokratie in London und schloss daran einen Bericht über die aktuelle Situation des österreichischen Widerstands an. Diesem Infomationsaustausch folgte im Oktober 1944 ein erster geheimer Bericht der OSS R\&B zur „Austrian Intelligence“, der einen gerafften Überblick über die Auswirkungen des Stauffenbergattentates vom 20. Juli 1944 auf Österreich, über den aktuellen Stand der österreichischen Widerstandsaktivitäten, die allgemeine Personalsituation „in den Alpen- und Donaugauen“, über Veränderungen der NS-Stadtregierung in Wien sowie über die Situation der österreichischen Emigration in London gab. Vgl. „Austrian Intelligence. Office of Strategic Services, Research and Analysis Branch, APO 413. By authority of CO, OSS, ETOUSA, 5. Oktober 1944, 1-44 [DÖW-Akt 17859/157, London-Büro Material, Dez. 1943-März 1944].

729 NARA II, RG 260, OMGUS ECR, Box 50. Office of Strategic Services, Research \&Analysis Branch, Biographical Reports. [Secret].

730 Siegfried Beer, Exil und Emigration als Information. Zur Tätigkeit der Foreign Nationalities Branch (FNB) innerhalb des amerikanischen Kriegsgeheimdienstes COI bzw. OSS, 1941-1945. In: Jahrbuch 1989. Dokumentationsarchiv des österreichischen Widerstandes. Redaktion: Siegwald Ganglmair, Wien 1989, 133.

731 Neben Journalisten mit Zentraleuropaerfahrung zählten auch politische Emigranten zu informellen Gesprächspartnern der „Foreign Nationalities Branch“ wie bspw. Julius Deutsch, Ferdinand Czernin oder Otto Habsburg. Vgl. Beer, Exil und Emigration als Information. Zur Tätigkeit der Foreign Nationalities Branch (FNB), $135 \mathrm{ff}$.

732 NARA II, Military Records, RG 226 (OSS); Entry 159, Box 1, Folder 4. Vgl. Gunther Nickel/Johanna Schrön, Carl Zuckmayers Geheimreport für das „Office of Strategic Services“. In: Carl Zuckmayer, Geheimreport. Hrsg. v. Gunther Nickel/Johanna Schrön. 2. Aufl., München 2007, 413 f. 
Die meisten der psychologischen Forschungsarbeiten innerhalb der Geheimdienstabteilungen waren eng auf pragmatisch-behavioristische Konzepte zugeschnitten und wiederholten - so Louise Hoffman - zumeist Standard-Stereotypen hinsichtlich des deutschen Nationalcharakters. Der Einfluss dieser Arbeiten, die so gut wie nie von höheren Dienststellen wahrgenommen wurden, auf reale Entscheidungsprozesse war denkbar gering. ${ }^{733}$

Psychologische Studien zur Evaluierung der „Nazi Mentality“ wurden im Auftrag des OSS hauptsächlich von externen Konsulenten wie Erik Erikson, Walter C. Langer (dem Bruder des Leiters des R \& B, William L. Langer) oder Henry Murray verfasst. Die hier präsentierten diagnostischen Ansätze zur psychologischen Erklärung des Nationalsozialismus beziehungsweise zu Hitlers Persönlichkeit führten - trotz fallweiser rhetorisch überzogener und wenig tiefschürfender Pointen ${ }^{734}$-, wie im Fall der psychologischen HitlerStudie von Walter C. Langer, an der unter anderem auch Ernst Kris ${ }^{735}$ mitgearbeitet hatte, zu differenzierten charakterologischen Analysen, in die auch historisch-diskursive Bezüge einflossen. ${ }^{736}$ Vorschläge hinsichtlich der schwierigen Frage nach der „Reeducation“ nach Kriegsende finden sich darin allerdings kaum. Nur Murray gab in seiner umfangreichen Studie auch einige überaus interessante Hinweise bezüglich der zu bewerkstelligenden "profound conversion of Germany's attitude“:

"We must realize that we are dealing with a nation suffering from paranoid trends; delusions of grandeur; delusions of persecution; profound hatred of strong opponents and contempt of weak opponents; arrogance, suspiciousness and envy - all of which has been built up as a reaction to an age-old inferiority complex and a desire to be appreciated." ${ }^{\prime 37}$ [Kursivsetzung i. Orig., d. Verf.]

733 Hoffman, American Psychologists and Wartime Research on Germany, a.a.O., 271.

734 So formulierte etwa Langer: „It was not only Hitler, the madman, who created German madness, but German madness that created Hitler." Ebd., 267.

735 Ernst Walter Kris (1900-1957), Sohn eines Wiener Rechtsanwalts, Kunsthistoriker und Psychoanalytiker sowie Kustos am Kunsthistorischen Museum in Wien, war nach dem „Anschluss“ über London schließlich 1940 in die USA emigriert, wo er zunächst an der „University in Exile“, d.i an der „New School of Social Research“ lehrte, später u.a. an den Universitäten Harvard und Yale. Siehe: International Biographical Dictionary of Central European Emigrés 1933-1945. Vol. II/Part 1: A-K, a.a.O., 665 f.; siehe auch Feichtinger, Wissenschaft zwischen den Kulturen. Österreichische Hochschullehrer in der Emigration 1933-1945, a.a.O., $368 \mathrm{ff}$.

736 Walter C. Langer, A psychological Analysis of Adolph [sic] Hitler. His Life and Legend. With collaboration of Prof. Henry A. Murr (Harvard Psychological Clinic), Dr. Ernst Kris (New School of Social Research), Dr. Bertram D. Lawin (New York Psychoanalytic Institute), Office of Strategic Services, Washington D.C. 1943. Zit. nach: http://www.nizkor.org/hweb/people/h/hitler-adolf/oss-papers/ text/profile-index.html. Für den Hinweis auf die online verfügbare Studie danke ich Herrn Univ.Prof. DDr. Oliver Rathkolb.

737 Henry Murray, Analysis of the Personality of Adolph [sic] Hitler, October 1943, 277 ff. Zit. nach: Hoffman, American Psychologists and Wartime Research on Germany, a.a.O., 269. 
Darüber hinaus konstatierte Murray, dass sich die Modalitäten der Einzeltherapie einer paranoiden Persönlichkeit nicht auf die Behandlung einer ganzen Nation umlegen lassen, denn „[the] Germans would resist reeducation by the victors.“" einer zielführenden „Reeducation“ insbesondere der Jugend in Richtung „fair play“ sah er vor allem im Bereich von Sport- und Freizeitaktivitäten, wobei seiner Meinung auch hier gelte, dass ausschließlich deutsche Pädagogen „could carry out the reorientation of German youth." ${ }^{739}$

Diesen Ansatz einer von außen kooperativ zu unterstützenden „Self-education“ vertrat auch der Deutsch-Amerikaner Kurt Lewin in seinen differenzierten sozialpsychologischen Arbeiten. ${ }^{740}$ Lewin - den James F. Tent irrtümlicherweise dem Lager der Psychiater rund um Richard Brickner zuzählt ${ }^{741}$ - ging es darum, deutlich zu machen, dass die Auswirkungen des pervertierten NS-Erziehungssystems nur durch einen demokratischen Elitentausch sowie durch langfristige Veränderungsmaßnahmen des gesamten „Kulturellen Klimas“ („education for independence“) wirksam verändert werden können. Mit ihrem Konzept einer langfristigen „Rekulturalisierung“ zu demokratischen Werten und symmetrischen Verhaltensmustern („fair play“), das neben formalen Erziehungsabläufen auch informelle Formen des Lernen umfasst, fokussierten Sozialpsychologen - wie unter anderen auch Gregory Bateson und Margaret Mead ${ }^{742}$-, ähnlich wie die „Educational Reconstruction“-Pädagogen, auf verantwortliches Handeln in einer demokratischen Lebenspraxis. Das sollte durch in „democratic leadership“ entsprechend geschultes Personal unter Supervision der (west-)alliierten Besatzungsmächte erreicht werden:

"This training does not need to bear the stigma of 'education', because a job is to be done, a job of cooperation in the interest of Germany. It could be demonstrated there and experienced first hand that 'democracy works better'. If strategically managed, such training on the job of

\section{Ebd.}

739 Ebd.

740 Kurt [Zadek] Lewin (1890-1947) entstammte einer jüdischen Familie in der preußischen Provinz Posen. Lewin studierte an der Universität Berlin und befand sich mit seinen Forschungen im Umfeld des Frankfurter Instituts für Sozialforschung. 1933 emigrierte Lewin in die USA, wo er u.a an der Cornell University und am Massachusetts Institute of Technology (MIT) Lehraufträge inne hatte. Lewin gilt als einer der bedeutendsten Psychologen des 20. Jahrhunderts. Er war Mitbegründer der Experimentellen Sozialpsychologie und führender Vertreter der Gestaltpsychologie. Nachdem er sich während der Kriegsjahre mit Fragen der Reeducation befasst hatte, arbeitet er nach 1945 im Kontext von ReorientierungsMaßnahmen in POW-Camps mit. Vgl. Alfred J. Marrow, The Practical Theorist. The Life and Work of Kurt Lewin, Univ. of Michigan 1969, 3 f.; Marvin R. Weisbord, Productive Workplaces Revisited. Dignity, Meaning and Community in the 21st Century, San Francisco 2004, $230 \mathrm{ff}$.

741 Tent, Mission on the Rhine. Reeducation and Denazification in American-Occupied Germany, a.a.O., 22.

742 Vgl. Gregory Bateson/Margaret Mead, Principles of Moral Building. In: Journal of Educational Sociology, 15, 1941, 206-220. 
leaders and trainers of leaders might well reach into every aspect of community leadership. It might help to set in motion a process of self-reeducation." ${ }^{743}$

Selbst am Höhepunkt der öffentlich ausgetragenen psychiatrischen Reeducation-Debatte, als der Neuropsychiater Richard M. Brickner die medizinische Frage „Is Germany Incurable?"744 in den Raum stellte, zeichnete sich schließlich doch eine gewisse Trendumkehr ab, indem nun - zumindest ansatzweise - auch sozialwissenschaftliche beziehungsweise sozialpsychologische Überlegungen Eingang in die psychiatrischen Therapievorschläge fanden; wohl auch deshalb, weil sich die fachliche Auseinandersetzung zunehmend interdisziplinär gestaltete. ${ }^{745}$ Nicht zuletzt verwies auch Margaret Mead in ihrem Vorwort eigens auf die Bedeutung der Sozialwissenschaften in der Lösung des "German Enigmas“ (so der Titel eines der Buchkapitel) und strich heraus, dass Brickner seinen Therapievorschlag für den „paranoiden Patienten Deutschland“ um den Blick auf das Verhalten von dessen nationaler „Familie“, nämlich der United Nations, erweitert hätte. Und auch Edward A. Strecker, gewissermaßen der Erfinder der psychiatrischen „Reeducation“, zog in seinem Vorwort zum Buch den von Brickner angesprochenen Aspekt der, Rekulturalisierung' heran:

"The paranoia of a group, such as Germany, is a new concept. [...] Its cure might well stem from a better use of the human brain by all of us, through a well-thought-out, thorough plan of reeducation, of reculturing". ${ }^{746}$ [Hervorhebung d. Verf.]

In Beantwortung der Frage, wie sich im Zusammenhang der als paranoid diagnostizierten deutschen Nation psychiatrische Methoden anwenden ließen, blieb Brickner, nach umfangreichen Explanationen zur deutschen „Megalomania“, dem Unterdrückungs- und Verfolgungskomplex, dem „War Cult“ sowie dem „German Race Cult“ aber überaus vage und zitierte lediglich einen Journalisten mit Deutschlanderfahrung, nämlich den späteren Pulitzerpreisträger Edgar Ansel Mowrer, ${ }^{747}$ der in Bezug auf die vermeidbaren alliierten Fehler zu Beginn der Weimarer Republik [sic] - zitiert in den Lebenserinnerungen seiner Frau - gemeint habe:

"Occupy the key positions within the State, of course. Place its own people in all positions of responsibility or control, eliminate, bribe, fetter or even gag its political opponents at least until it has definitely solidified its own position. Wipe out dangerous traces of the past. Destroy

743 Kurt Lewin, The Special Case of Germany. In: Public Opinion Quarterly, 7, 1943, 566.

744 Richard M. Brickner, Is Germany Incurable? Philadelphia - New York 1943.

745 Nicht zuletzt zeigt sich dies anhand der Danksagungen im Vorwort, wo Brickner u.a. auf die Leistungen von Erik H. Erikson, Erich Fromm, Gregory Bateson, Geoffrey Gorer, Harold D. Laswell sowie Margaret Mead verwies.

746 Edward A. Strecker, Preface. In: Brickner, Is Germany Incurable?, a.a. O., 18.

747 Siehe Kapitel 1, S. 81, Anm. 298. 
former symbols and substitute new ones for them. Embark upon a vast campaign of education to make clear to the people the evils of the old and the benefits of the new. A revolution must be a break with tradition." ${ }^{748}$

Mit prognostischem Blick auf die Situation unmittelbar nach dem Ende des Zweiten Weltkrieges, wo es nach Brickner um die strategische Aufgabe ginge, eine „,clear area“ of non-paranoid Germans within the German group “749 $\mathrm{zu}$ schaffen, fügte er hinzu: „The best time to start would be the day after the collapse of the Nazi regime, for then German minds and institutions, thrown into confusion by the discrediting of what had sustained them, would be easily reoriented. At any rate, plans for the psychiatric campaign should be prepared as far in advance as those for military occupation."

Trotz der letztendlich abgemilderten, durchaus auch auf innerdeutsche Kooperation setzenden Überlegungen Brickners - immerhin ging der Psychiater davon aus, „that a great many of Germans have little or nothing to do with the national paranoid trend“"751 scheute er aber nicht davor zurück, die, freilich monströs-indiskutable, Exterminierung der Deutschen tatsächlich auszusprechen:

"The bare idea of deliberate massacre of all Germans is, of course, intolerable, even in talk. [...] The paranoid SS-trooper can sleep nights after planning and carrying out mass-slaugther of defenseless - not we." ${ }^{752}$ [Hervorhebung d. Verf.]

Angesichts dieser, im Vergleich zu den pädagogisch-sozialwissenschaftlichen Rekulturalisierungs-Konzepten doch eher harschen Äußerungen, die politisch durch die von Präsident Roosevelt und seinen engen Beratern wie Henry Morgenthau lange Zeit vertretene Kollektivschuldthese und die geplante harte Behandlung Deutschlands nach Kriegsende verstärkt wurden, überrascht es nicht, dass vereinzelt auch innerhalb des „Educational Reconstruction“-Diskurses Stimmen laut wurden, die einen „Erziehungskrieg“, einen „educational battle“, befürchteten. So ging der emigrierte deutsche Rechtswissenschafter Werner Peiser ${ }^{753} 1944$ bezüglich der künftigen „Reeducation“ der deutschen Jugend von

748 Brickner, Is Germany Incurable?, a.a. O., $301 \mathrm{f}$.

749 Ebd., 308.

750 Ebd., 303.

751 Ebd.

752 Ebd., 298 f.

753 Werner Peiser (geb. 1895 in Berlin) studierte Rechts- und Wirtschaftswissenschaften und romanische Philologie an der Universität Berlin. Er war bis 1931 im Preußischen Staatsministerium tätig, zuletzt als Oberregierungsrat und stellvertretender Pressechef. Von 1931-1933 arbeitete er in besonderem Auftrag am Preußischen historischen Institut in Rom. 1933 erfolgte seine Entlassung aus dem Staatsdienst. Peiser ging ins Ausland, hielt zunächst von 1933-1938 Gastvorlesungen in Rom und Florenz und emigrierte dann in die USA. 1939-1944 wirkte er als Ordinarius für romanische Sprachen an der Loyola Universität 
einem geradezu klinisch-pathologischen Setting aus und meinte, mit Bezug auf den psychiatrischen Therapieansatz, dass nach den Jahren totalitärer mentaler Indoktrinierung der deutschen Schuljugend ausschließlich zu behandelnde „Patienten“ übrig geblieben wären:

„We do not like the word totalitarian. Yet we must apply it, at least, for a moment to clarify the task we are facing. The future education of German youth must be ,totalitarian ' in so far as it has to embrace the whole personality of the child. "Und weiter: „The teacher who enters the classroom will find himself in the situation of a physician who enters a hospital where all the patients show the same or similar signs of being poisoned. “754

Derart starre beziehungsweise technokratische Positionen im Bereich der wissenschaftlich-edukativen Auseinandersetzung mit ideologisch-kulturellen Reorientierungs-Fragen waren nach Kriegsende aber eher Randerscheinungen. Abgesehen davon, dass es unterschiedliche Auffassungen darüber gab, wie Reeducation-Maßnahmen tatsächlich umzusetzen wären, zeichnete sich in der generellen Debatte immer deutlicher eine Wende gegen eine prinzipiell harte Gangart ab. Hinsichtlich der Option „Bestrafungskonzept versus Westintegrationskonzept ${ }^{\text {“755 }}$ setzte sich bis etwa I943/44 unter den Entscheidungsträgern des State Department und auch im Bereich staatlicher, mit „Reeducation“ beziehungsweise „Reorientation“ befasster Behördenstellen, sukzessive die (wie auch immer umzusetzende) friedliche Demokratisierung nach amerikanischem Vorbild als vage Planungsperspektive durch - eine Perspektive, die den zivilgesellschaftlichen edukativ-philanthropischen Diskurs von Anfang an klar geprägt hatte.

Der starke Einfluss psychiatrischer Reeducation-Konzepte, den James F. Tent zu Recht für die Kriegsmitte konstatiert, ${ }^{756}$ hielt sich nur für eine kurze Phase und war gegenüber dem privaten, zivilgesellschaftlichen Diskurs keineswegs bestimmendes Element - im Gegenteil. In den primär auf Formalsäuberungen ausgerichteten militärischen Planungen blieben die Kernelemente beider Konzepte ohnedies Makulatur; als besatzungspolitisches Paradigma durchgesetzt haben sich nach Kriegsende schließlich vorerst, wenn auch mit enormer zeitlicher Verzögerung, wie noch zu zeigen sein wird, die zivilen Demokratisierungskonzepte.

Dass sich die auf Friedensicherung hin orientierten Überlegungen einer demokratiepolitischen Reeducation beziehungsweise Reorientation tendenziell durchsetzten, und schließlich auch ,von den Vertretern der antikommunistischen Realpolitik [...] übernom-

von New Orleans und später an der Universität von Maryland. Von 1946-1948 war er bei amerikanischen Dienststellen in Europa tätig. Danach beschäftigte er sich mit wissenschaftlichen Arbeiten, bis er 1951 in den Auswärtigen Dienst der deutschen Bundesrepublik berufen wurde. Vgl. Internationales Biographisches Archiv, 27/1959 vom 22. Juni 1959.

754 Werner Peiser, Re-education of the German Youth. In: School and Society, Vol. 59, March 11, 1944, No. $1524,178$.

755 Jutta-B. Lange-Quassowski, Amerikanische Westintegrationspolitik, Re-education und deutsche Schulpolitik. In: Heinemann, Umerziehung und Wiederaufbau, a.a.O., 54.

756 Tent, Mission on the Rhine. Reeducation and Denazification in American-Occupied Germany, a.a. O., 22. 
men“ wurden, ist, wie Bungenstab in Anlehnung an Hans-Peter Schwarz meint, keineswegs „der messianischen Grundtendenz der Linken“757 zuzuschreiben.

Der nationalsozialistische Generalangriff auf die freie Weltgemeinschaft war zugleich auch ein Angriff auf die weltanschaulichen Grundlagen des freien Westens, der an die Wurzeln der amerikanischen kulturellen Identität und seines demokratischen Selbstverständnisses ging. Die dadurch erzwungene Selbstvergewisserung der eigenen moralischethischen Werte und politischen Grundlagen in den Bereichen Bildung, Öffentlichkeit, Wirtschaft und Gesellschaft führte schließlich dazu, dass der - wenn auch vage - Konsens der Pädagogen, Sozialwissenschafter und Psychologen letztlich keineswegs quer zur USPolitik oder zur öffentlichen Diskussion stand. Trotz der von Präsident Roosevelt und seinen engen Beratern wie Henry Morgenthau vertretenen Kollektivschuld-These und der von ihnen vorgeschlagenen harten Behandlung Deutschlands, hatte der sozialpsychologische und gesellschaftstheoretische Ansatz innerhalb des Reeducation-Diskurses und damit - wie der US-Diplomatiehistoriker Henry J. Kellermann meint - ein weniger ideologischer, als vielmehr pragmatischer Ansatz den deutlich größeren Einfluss auf politische Überlegungen und schließlich auch auf das politische Decision making ${ }^{758}$ - wenn auch nicht, oder nur in bescheidenem Maß, auf die ab 1944 anlaufenden militärischen Planungen für die Besatzungsagenden der US-Militärstäbe.

Dass die konkrete Planung der Reeducation beziehungsweise der konkreten Umsetzungsszenarien nach Kriegsende im Zusammenhang mit den Vorarbeiten für die Agenden der militärischen Besatzungsapparate nicht in der gewünschten Weise vorankam beziehungsweise ins Stocken geriet, spiegelte sich auch in der öffentlichen Berichterstattung, die von Regierungsstellen aufmerksam verfolgt wurden, wider. So hieß es zum Beispiel in einem Report über die Presseberichterstattung zur „education control in conquered Axis countries“ Ende I943:

"Many persons in Washington, educators as well as political observers, are asking more and more what is to happen to the schools in the conquered Axis countries. The impression up until now has been widespread that the question whether the United States should interest itself at all in the post-war schools of occupied countries was in the academic stage. Stories printed in the secular press of late would seem to indicate that it has all gone well beyond the discussion period. And gone, with the Allied Nations, in committing itself to the reorganization of schools in conquered Axis countries. What type of person is to be entrusted with executing whatever plans are decided upon?“759

757 Bungenstab, Umerziehung zur Demokratie?, a.a.O., 25.

758 Kellermann, Von Re-education zu Re-orientation. Das amerikanische Re-orientierungsprogramm im Nachkriegsdeutschland, a.a.O., 87.

759 NARA II, RG 165, Box 174. J.J. Gilbert, Washington Letter. Education Control in Conquered Axis Countries. Stories in secular press cause observers to wonder what types of persons will be entrusted with programs, 20. Dezember 1943, 1. 
Tatsächlich verliefen die vertiefte inhaltliche Auseinandersetzung mit der Problematik der „Reeducation“ beziehungsweise „Reorientation“ und die Ausarbeitung militärischer Besatzungsszenarien, wie noch zu zeigen sein wird, gewissermaßen in getrennten Regelkreisen eine Transmission der elaborierten Sach- und Fachdiskussion auf ziviler Expertenebene in die militärischen Planungsstäbe fand weder auf personeller noch auf inhaltlich-konzeptioneller Ebene statt. Es waren daher primär akademische Zirkel und Vereinigungen im Dunstkreis amerikanischer Universitäten oder Colleges wie das New Yorker Hunter College, Zusammenschlüsse von Schriftstellern wie zum Beispiel das „Writers' War Board“ ${ }^{460}$ die bereits erwähnten großen, privaten philanthropischen US-Bildungsvereinigungen sowie zivilgesellschaftlich-pazifistische Initiativen wie die von Friedrich Wilhelm Foerster und Isidore Lipschutz gegründete „Society for Prevention of World War III“, ${ }^{761}$ die sich intensiv mit Fragen einer demokratischen Nachkriegsordnung Europas auseinandersetzten.

\section{EXKURS: DIE ÖSTERREICHISCHE EMIGRATION IN DEN USA - EIN KULTUR- UND} BILDUNGSPOLITISCH FOLGENLOSES KAPITEL FÜR DIE NACHKRIEGSPLANUNGEN

Den Daten der US-Volkszählung aus dem Jahr I940 zufolge lebten rund I,2 Millionen Personen in den USA, die entweder selbst in Österreich-Ungarn geboren waren, oder zumindest einen dort geborenen Elternteil hatten; von diesen gaben 479.000 Personen Österreich als ihr Geburtsland an - zwei Drittel dieser Gruppe waren bereits US-Staatsbürger. ${ }^{72}$ Davon waren geschätzte 40.000 Österreicherinnen und Österreicher nach dem "Anschluss" 1938 in die Vereinigten Staaten von Amerika emigriert. ${ }^{763}$

760 Siehe: Astrid M. Eckert, Feindbilder im Wandel: Ein Vergleich des Deutschland- und Japanbildes (Studien zur Geschichte, Politik und Gesellschaft Nordamerikas, Bd. 13), Münster 1999, 45.

761 Mitglieder dieser prononciert antinazistischen Gesellschaft, die ein eigenes Monatsblatt (Prevent World War III) herausgab, waren unter anderen der ehemalige Deutschland-Korrespondent Edgar A. Mowrer, William L. Shirer oder George Creel. Siehe: Astrid M. Eckert, Feindbilder im Wandel: Ein Vergleich des Deutschland- und Japanbildes (Studien zur Geschichte, Politik und Gesellschaft Nordamerikas, Bd. 13), Münster 1999, 45. In der Präambel plädierte die Gesellschaft für eine kompromisslose Vorgehensweise bei nachfolgenden ,Säuberungsmaßnahmen': „The widespread habit of setting the Nazis apart from the German people results from an inadequate knowledge of German history. [...] The forces in Germany that raised Hitler to power and have maintained him, are identical forces that stood behind Bismarck and Kaiser Wilhelm. Any treatment of the enemy, after military victory, which does not destroy those forces will leave Germany as strong and dangerous as ever." Zit. nach: ebd., 47.

762 Foreign Nationality Groups in the United States. A Handbook (revised edition), April 1945, $18 \mathrm{ff}$. Zit. nach: Siegfried Beer, Exil und Emigration als Information. Zur Tätigkeit der Foreign Nationalities Branch (FNB) innerhalb des amerikanischen Kriegsgeheimdienstes COI bzw. OSS, 1941-1945. In: Jahrbuch 1989. Dokumentationsarchiv des österreichischen Widerstandes. Redaktion: Siegwald Ganglmair, Wien 1989, 137.

763 Siehe: The Austrians. Foreign Politics in the United States. Foreign Nationalities Branch. Office of the Coordinator of Information, August 1942, a.a. O., 8. 
In Bezug auf die Rolle österreichischer Emigrantenzirkel beziehungsweise einzelner Émigrés, auf die später unter anderem im Zusammenhang mit dem Fallbeispiel Ernst Karl Winter noch ein wenig eingegangen werden wird, ist anzumerken, dass diese stark zersplittert waren, unterschiedlich schwer an den Lebens- und Arbeitsbedingungen in der Emigration litten ${ }^{764}$ und von Seite der USA politisch keine Anerkennung erhielten. Bis Kriegsende wurde von der amerikanischen Regierung, die sich, mit Rücksichtnahme auf die britische Regierung „nicht vorzeitig auf eine bestimmte Nachkriegsordnung festlegen lassen wollte“ ${ }^{765}$ keine politische Exilregierung Österreichs anerkannt. Hinzu kommt, dass die amerikanische Politik hinsichtlich der rechtlichen Stellung Österreichs nach dem „Anschluss“ bis zur Moskauer Deklaration 1943, die die Wiederherstellung eines „freien und unabhängigen Österreichs" proklamierte, keine klare Linie vertrat. ${ }^{766}$

Tatsächlich hatten die Vereinigten Staaten, anders als Chile und Mexiko, ${ }^{767}$ den „Anschluss“ Österreichs an Hitler-Deutschland völkerrechtlich nicht als ungültig erklärt, und die gewaltsame territoriale Annexion, die nach dem Friedensvertrag von St. Germain als Option strikt verboten war, auch öffentlich nicht verurteilt - anders als etwa Großbritannien, wo immerhin Lord Halifax im House of Lords und Clement R. Attlee als Oppositionsführer im Unterhaus gegen den „Anschluss“ als brutalen Akt der Aggression aufgetreten waren. ${ }^{768}$ Nach einigen Tagen des Schweigens unmittelbar nach dem I3. März I938 gab US-Staatssekretär Cordell Hull auf einer Pressekonferenz gegenüber Reportern ein schwammiges Statement ab: zwar sei der Frieden gefährdet, die USA jedoch nicht bereit, den „Anschluss“ gesondert von der allgemeinen weltpolitischen Lage zu erörtern. Dabei hielt sich Hull - wenn auch überaus vage - alle Optionen offen: „The extent to which the Austrian incident, or any other similar incident, is calculated to endanger the maintenance

$764 \mathrm{Zu}$ den Schwierigkeiten der in die USA emigrierten österreichischen Schriftstellerinnen und Schriftsteller siehe die kurze, aber einprägsame Schilderung bei: Mimi Grossberg, Österreichs literarische Emigration in den Vereinigten Staaten 1938, Wien - Frankfurt a. Main - Zürich 1970, 33 ff.; zur Emigration österreichischer Individualpsychologen in die USA siehe: Clara Kenner, Der zerrissene Himmel. Emigration und Exil der Wiener Individualpsychologie, Göttingen 2007, $17 \mathrm{ff}$.

765 Peter Eppel, Österreichische Exilpolitik in den USA. In: Österreicher im Exil USA, 1938-1945. Eine Dokumentation. Bd. 2. Hrsg. v. Dokumentationsarchiv des österreichischen Widerstands. Einleitung, Auswahl und Bearbeitung: Peter Eppel, Wien 1995, 233.

766 Auch nach der Veröffentlichung der Deklaration wurde jede politische Mithilfe österreichischer Emigranten abgelehnt; das Dokument war primär auf die Stärkung des Widerstands auf Heimatboden orientiert. Siehe: Franz Goldner, Die österreichische Emigration 1938 bis 1945, Wien - München 1972, 70.

767 Vgl. Christian Kloyber, Mexicos Protest vor dem Völkerbund. In: Informationen des Österreichischen Lateinamerikainstituts, 1988, 8 ff.; sie dazu im Detail: Christian Kloyber/Marcus G. Patka, Österreicher im Exil: Mexiko 1938-1947. Eine Dokumentation. Hrsg. v. Dokumentationsarchiv des österreichischen Widerstandes. Mit einem Geleitwort von Friedrich Katz, Wien 2002.

768 Vgl. Robert H. Keyserlingk, Austria in World War II. An Anglo-American Dilemma, Kingston - Montreal 1988, 18. 
of peace and the preservation of the principles in which this Government believes is of course a matter of serious concern to the Government of the United States. " 769 In einer öffentlichen Stellungnahme am 19. März 1938 gegenüber dem letzten akkreditierten österreichischen Gesandten in Washington, Edgar L. G. Prochnik, hatte das State Department allerdings lapidar mitgeteilt, dass ,appropriate consideration was being given to the ,technical steps' on the part of the Government of the United States necessitated by the changed status of the Austrian Republic. “770 Obwohl damit nicht die Rechtmäßigkeit der Annexion anerkannt wurde, kam dies doch einer de facto Anerkennung des Status quo gleich. Da es offenkundig auch unter den Beamten des State Department anhaltende Unklarheit bezüglich der offiziellen Sprachregelung zur Eingliederung Österreichs in das Deutsche Reich gab, ${ }^{771}$ bemühte sich der stellvertretende Unterstaatssekretär Adolf A. Berle in einer öffentlichen Stellungnahme im Juni 1939 um Klärung, wobei seine Worte kaum hilfreich gewesen sein dürften: „The Government of the United States has accepted that Austria has ceased to exist as an independent sovereign state and that Germany is administering the territory of the former Republic Austria."

Die indifferente Haltung der USA gegenüber der Annexion Österreichs begann sich erst im Gefolge der unmittelbar auf den Einmarsch der Wehrmacht in die Tschechoslowakei und in Polen erfolgten Kriegserklärung Großbritanniens und Frankreichs am 3. September 1939 allmählich zu ändern. Spätestens die prononcierte Aussage des britischen Premiers Winston Churchill in einer Rede am 9. November I940 im Mansion House, in der er betont hatte, Großbritannien habe auch für Österreich sein Schwert gezogen, ${ }^{773}$ machte nun eine Revision der bisherigen pragmatisch-abstinenten Haltung der US-Politik in Europa - schon allein aus moralisch-weltanschaulichen Gründen - geradezu notwendig. Immerhin hatte Churchill in seiner Rede klargestellt, dass die Souveränität aller „overrun countries“ wiederhergestellt würde, schließlich: „The people of Britain [...] will never desert the cause of the freedom of Austria from the Prussian joke“ ${ }^{774}$ Vor dem Hintergrund der Aussagen Churchills entschied das britische Kriegsministerium, die „Unabhängigkeit Österreichs“, nicht zuletzt auch aus Gründen psychologischer Kriegsführung, künftig als Einigungsvokabel zu propagieren: „[...] the British War Office, in the prosecution of psy-

769 Zit. nach: ebd., 20.

770 Wright, Attitude of the United States towards Austria, New York, a.a. O., 97.

771 Vgl. The Austrians. Foreign Politics in the United States. Foreign Nationalities Branch. Office of the Coordinator of Information, August 1942, a.a.O., 2.

772 Assistant Under-Secretary of State Adolf A. Berle to Burleigh and Beckworth, 7. Juni 1939. NARA II, RG 59, Numerical Files 863.01/628. Zit. nach: Keyserlingk, Austria in World War II, a.a.O., 21.

773 „All the countries with whome or for whome we draw the sword - Austria, Czecho-Slovakia, Poland, Norway, Holland, Belgium, France, Greece [...] our victory will supply the liberation of them all."Winston Churchill, Mansion House, London, 9. November 1941. Zit. nach: Wright, Attitude of the United States towards Austria, New York, a.a.O., 106.

774 Zit. nach: Keyserlingk, Austria in World War II, a.a.O., 19. 
chological warfare, has found that the independence of Austria is the one platform in which all groups can be united."775

Um die USA von der isolationistisch-,,neutralen“ Haltung abzubringen und zu einem raschen Kriegseintritt auf Basis einer „,equal partnership“ zu bewegen, begann der britische Geheimdienst ab I940 eine breitangelegte „Propaganda“-Kampagne, die seitens der „British Security Coordination“ (BSC) und der „American Division“ des „British Information Service“ (BIS) in New York betrieben wurde. In Zusammenarbeit mit den Kurzwellenstationen der BBC sowie einer Vielzahl zusätzlich geschaffener britischer Konsulatsstellen in mehreren US-Bundesstaaten bemühten sich die Briten darum, die öffentliche Meinung in Amerika in ihrem Sinne zu beeinflussen. ${ }^{776}$ Die Absicht der gezielten Informationskampagne, die das „British Ministry of Information“ (MOI) unter dem Namen „strategy of truth " koordinierte - ab 1942 verstärkt in Kooperation mit dem Office of War Information $(\mathrm{OWI})^{777}$-, war es, wie Harold Butler, der Chef des BIS formulierte, „to create the right emotional attitude in the United States towards Great Britain “. ${ }^{778}$ Insbesondere zielten die Aktivitäten darauf, anti-britische Ressentiments in der amerikanischen Bevölkerung abzubauen und die bevorstehende Suprematie der USA nach Kriegsende auf Basis einer gleichrangigen Kriegsallianz zumindest einzudämmen:

"When the Second World War broke out, the British government adopted discreet methods of persuading the United States to abandon neutrality, chiefly using reports of Britains's brave defense against Nazi Germany's triumphal aggression to rally Americans to the Allied cause. [...] Britain's service of information was the product of an intricate process. Propaganda policy makers evaluated U.S. foreign policy goals, analyzed American domestic politics, identified audiences, and studied opinion in order to offer interpretations of events that resonated with the American public." 779

775 The Austrians. Foreign Politics in the United States. Foreign Nationalities Branch. Office of the Coordinator of Information, August 1942, a. a. O., 2.

776 „Propagandists studied American opinion, set up discreet organizations, identified target audiences, defined themes, considered language, and chose methods of dissemination. American political culture, therefore, played a role in shaping the development of Britain's propaganda campaign, a campaign dedicated to influence American opinion." Susan A. Brewer, To Win the Peace. British Propaganda in the United States during World War II, Ithaca - London 1997, 4.

777 Zu diesem Zweck wurde im August 1942 vom OWI und der Britischen Botschaft ein „Joint Committee on Information Policy“ geschaffen, dessen Aufgabe eine „,propaganda offensive“ on postwar cooperation directed at the American and British people" sein sollte. Wie ein Assistent von Archibald MacLeish im Office of Facts and Figures (OFF) verlautete: „The American public does need a good selling job on the English." Zit. nach: Brewer, To Win the Peace. British Propaganda in the United States, a.a.O., 96 bzw. 94.

778 Brewer, To Win the Peace. British Propaganda in the United States, a.a.O., 94.

779 Ebd., 236 f. 
Jedenfalls signalisierte Präsident Roosevelt in einer nationalen Radioansprache am 27. Mai 1941 einen Kurswechsel in der Österreichpolitik, indem er feststellte: „The attack on Czechoslovakia began with the seizure of Austria." Des Weiteren ließ Roosevelt vage Bereitschaft erkennen, sich gegen die nationalsozialistische Aggressionspolitik zu wenden, allerdings mit einer Einschränkungsklausel: „We do not forget the silenced peoples [...]. But those people, spiritually unconquered: Austrian, Czechs, Poles, Norwegians, Dutchs, Belgians, Frenchmen, Greeks, Southern Slavs - yes, even those Italians and Germans who themselves have been enslaved - will prove to be a powerful force in disrupting the Nazi system. ${ }^{\text {“780 }}$

Mit dem definitiven Einschwenken der Regierung Roosevelt in eine gemeinsame „AntiHitler-Koalition“ mit Großbritannien im August I94I und der Verlautbarung der „Atlantik-Charta“, die als erste westalliierte Richtlinie für eine spätere Nachkriegsordnung - die Sowjetunion trat der Front erst im Dezember 194I bei - die „endgültige Vernichtung der nationalsozialistischen Tyrannei ${ }^{\text {“781 }}$ als Ziel festlegte, veränderte sich, wenn auch mit erheblicher Verzögerung, schließlich auch die Haltung gegenüber dem okkupierten Österreich. Die politische Auseinandersetzung mit der Zukunft Österreichs blieb im weiteren Kriegsverlauf aber im Wesentlichen auf die „Schwächung Deutschlands, und nicht [auf] die Unterstützung einer österreichischen Nationalidee "782 ausgerichtet, sodass die alliierte Österreichplanung bis knapp vor Kriegsende lediglich ein „Nebenprodukt der Aufteilung Deutschlands ${ }^{\text {“783 }}$ darstellte.

Nach einer weiteren nationalen Radioansprache am 9. Dezember 194I, zwei Tage nach dem japanischen Angriff auf Pearl Harbour, in der Präsident Roosevelt die Gründe für den Kriegseintritt der USA erklärte, ordnete er Österreich jenen Ländern zu, die gewaltsam „without warning“ - von Hitler-Deutschland okkupiert worden waren. ${ }^{784}$

Ein weitere Klärung über den Status der künftigen US-Politik gegenüber Österreich ergab sich dann anlässlich einer Pressekonferenz, bei der der Secretary of State, Cordell Hull, hinsichtlich der bisherigen konfusen Position der US-Regierung in defensiv-verteidigender Haltung mitteilte:

"This Government very clearly made known its opinions as to the manner which the seizure of Austria took place and the relation of that seizure to this Government's well-known policy toward the taking of territory by force. This Government has never taken the position that Austria was legally absorbed into the German Reich." ${ }^{785}$ [Hervorhebung d. Verf.]

780 Wright, Attitude of the United States towards Austria, New York, a.a.O., 99.

781 Keesings Archiv der Gegenwart, 1945, 1. Jänner, 11.

782 Fritz Fellner, Die außenpolitische und völkerrechtliche Situation Österreichs 1938. Österreichs Wiederherstellung als Kriegsziel der Alliierten. In: Österreich - Die Zweite Republik. Bd. 1. Hrsg. v. Erika Weinzierl/Kurt Skalnik, Graz 1972, 64.

783 Ebd.

784 Wright, Attitude of the United States towards Austria, New York, a.a.O., 103. Vgl. auch: Keyserlingk, Austria in World War II, a.a.O., 22.

785 Wright, Attitude of the United States towards Austria, New York, a.a.O., 104. 
Wie Franz Goldner in diesem Zusammenhang anmerkt, war für die „offenkundige Apathie der öffentlichen Meinung Amerikas zur Frage des Verlustes und der möglichen Wiederherstellung der Unabhängigkeit Österreichs [...] unter anderem die Überzeugung“ maßgebend, dass hinsichtlich der dauerhaften politischen und wirtschaftlichen Krise der jungen Republik „die Wiederherstellung eines neuen unabhängigen Österreich kein unbedingt politisch erstrebenswertes Ziel“786 für die USA war. Österreichische Exilanten mussten daher mitunter viel Energie darauf verwenden, nicht als Deutsche zu gelten. ${ }^{787}$ Nach Kriegseintritt der USA I94I fielen kurzfristig auch als Deutsche registrierte Österreicher, die noch keine US-Staatsbürgerschaft besaßen, in die Kategorie der „enemy aliens“ und hatten mit Einschränkungen zu kämpfen. Dagegen trat die zahlenmäßig stärkste Gruppierung an Exil-Österreichern, die sich unter Ferdinand Czernin in der anti-habsburgischen „Austrian Action“ versammelten, mit einer am 22. Dezember 194I in New York abgehaltenen Loyalitätsversammlung - nebst Telegrammen an Präsident Roosevelt und Premierminister Churchill - auf. ${ }^{788}$

Wie Peter Eppl dargestellt hat, waren rund zehn Prozent der in die Vereinigten Staaten emigrierten Österreicherinnen und Österreicher politisch aktiv. Von einer Vielzahl zumeist kurzlebiger Exilorganisationen und Gruppen wurden bis 1945 auch über 20 Exilzeitungen publiziert, wovon sechs in deutscher Sprache erschienen. ${ }^{789}$

Neben dem bereits 1938 von Ernst Karl Winter ${ }^{790}$ in New York gegründeten „AustroAmerican Center“, das allerdings primär kulturelle Ziele verfolgte und nicht auf die Schaffung einer österreichischen Exilregierung ausgerichtet war, sind unter den größeren Gruppierungen der österreichischen politischen Emigration vor allem zu nennen: die bereits am I. Mai 1939 von Robert Heine Geldern gegründete und I940 von Otto Kallir übernommene katholisch-konservative „Austrian-American League“,791 die allerdings nach Gründung

786 Goldner, Die österreichische Emigration 1938 bis 1945, a.a.O., 70.

787 Siehe: Österreichische Rundschau. Austrian Review. Mitteilungsblatt der Austrian Action, September 1942, 14. Zit. in: Peter Eppel, Österreichische Exilpolitik in den USA. In: Österreicher im Exil USA, 19381945. Eine Dokumentation. Bd. 1. Hrsg. v. Dokumentationsarchiv des österreichischen Widerstands. Einleitung, Auswahl und Bearbeitung: Peter Eppel, Wien 1995, 221 sowie 174.

788 Goldner, Die österreichische Emigration 1938 bis 1945, a.a.O., 108. Am 9. Februar 1942 wurde durch die US-Justizverwaltung ein erster Schritt in Richtung einer Trennung der Österreicher von den Deutschen gemacht - eine Trennung, die dann am 4. Juni 1942 in einem Memorandum der „Foreign Nationalities Branch“, die gegen ,jede Rückklassifizierung der Österreicher als feindliche Ausländer Stellung“ bezog, zementiert wurde. Ebd., 116.

789 Eppel, Österreichische Exilpolitik in den USA. In: Österreicher im Exil USA, 1938-1945. Eine Dokumentation. Bd. 2, a.a.O., 231; vgl. dazu weiters: Benjamin Link, Die österreichische Emigrantenpresse in den Subkulturen von New York City 1942 bis 1948, Diss., Univ. Salzburg 1972.

790 Siehe dazu Kapitel 4, Seite $380 \mathrm{f}$.

791 Ab März 1940 war der Dekan des Hunter College in New York, George N. Shuster, Präsident der „Austrian-American League“. Vgl. Eppel, Österreichische Exilpolitik in den USA. In: Österreicher im Exil USA, 1938-1945. Eine Dokumentation. Bd. 2, a.a.O., 278: siehe auch: http://www.doew.at/publikationen/exil/ploechl/kallir.pdf; siehe insbesondere auch: Helga Erhart, Die politische Arbeit der kon- 
des „Free Austrian Movement“ in Selbstauflösung begriffen war; ${ }^{792}$ das von Hans Rott ${ }^{793}$ am I6. Oktober 1940 in Toronto gegründete (und ab 1942 in New York angesiedelte) legitimistische „Free Austrian Movement“ (FAM) ${ }^{794}$ mit dem deklarierten Ziel der Schaffung einer österreichischen Exilregierung, die spätestens mit den Bemühungen um die Aufstellung eines eigenen „Österreich-Bataillons“ innerhalb der US-Streitkräfte ins exilpolitische Abseits unter den österreichischen Gruppierungen geriet; ${ }^{795}$ die bereits genannte, im Ap-

servativen österreichischen Emigration. Versuch einer Darstellung anhand eines exemplarischen Falles: Hochschulprofessor Dr. Dr. h.c. mult. Willibald M. Plöchl, Diss., Univ. Wien 1985, 252 f.; weiters: Gerhardt Plöchl, Willibald Plöchl und Otto Habsburg in den USA. Hrsg. v. Dokumentationsarchiv des österreichischen Widerstandes. Ringen um Österreichs „Exilregierung“ 1941/42, Wien 2007, 9 ff.

792 Hoor betreffend politische Emigration in den USA (ca. Mitte 1942). Institut für Zeitgeschichte, Wien, Nachlass Martin Fuchs [DÖW E 19.1512]. Zit. nach: Eppel, Österreichische Exilpolitik in den USA. In: Österreicher im Exil USA, 1938-1945. Eine Dokumentation. Bd. 2, a.a.O., 251.

793 Hans Rott (1886-1962), christlicher Gewerkschafter der Post-, Telephon und Telegraphenangestellten, christlichsozialer Bundesrat und Bundesminister ohne Portefeuille der Regierung Schuschnigg IV ab 16. Februar 1938, der es „nicht schaffte, Englisch zu erlernen“, hatte gleich bei acht österreichischen Exilorganisationen eine führende Position inne, und zwar: Free Austrian Movement, Free Austrian National Council, American Friends of Austria, Austrian National Committee, Military Committee for the Liberation of Austria, Christian-Socialist Party of Austria, Associated Austrian Relief und bei der Austrian American Federation. Vgl. auch: Otto Habsburg, Brief survey of the history of the Austrian organisations in the United States. OSS Foreign Nationalities Branch, 14. April 1942, a.a.O., 12. Eppel, Österreichische Exilpolitik in den USA. In: Österreicher im Exil USA, 1938-1945. Eine Dokumentation. Bd. 2, a. a. O., 290. Gertrude Enderle-Burcel (unter Mitarb. v. Johanns Kraus), Christlich - Ständisch - Autoritär. Mandatare im Ständestaat 1934-1938. Biographisches Handbuch der Mitglieder des Staatsrates, Bundeskulturrates, Bundeswirtschaftsrates und Länderrates sowie des Bundestages. Hrsg. v. Dokumentationsarchiv des österreichischen Widerstandes, Wien 1991, $204 \mathrm{f}$.

794 Goldner, Die österreichische Emigration 1938 bis 1945, a.a.O., 87 f.; prominente Mitarbeiter des zahlenmäßig überrepäsentierten monarchistischen Lagers in den USA waren u.a. Otto Habsburg, Willibald M. Plöchl - der sich bald mit Otto Habsburg überwarf -, Otto Kallir sowie Franz Klein. Siehe: Eppel, Österreichische Exilpolitik in den USA. In: Österreicher im Exil USA, 1938-1945. Eine Dokumentation. Bd. 2, a.a.O., 283.

795 Das von der OSS-,„Foreign Nationalities Branch“ mitunterstützte Projekt einer Einbindung eines „Österreich-Bataillons" scheiterte aufgrund der durch die Legitimisten verursachten Unruhe unter den österreichischen Exilorganisationen aufgrund des Versuchs, den sich abzeichnenden Erfolg einer militärischen Einbindung für die Befreiung Österreichs als genuin legitimistische Initiative darzustellen. So hieß es in einem geheimen OSS /FNB-Memorandum vom 20. November 1942: „The consensus appeared to be (a) that emphasis on the separate national existence of Austria was desirable, but (b) that no single Austrian faction, and especially not the legitimist faction of Otto Habsburg, should be allowed to ,hijack' the credit. [...] As you know, precisely the opposite has happened. A headline in the ,Washington Post' of this morning reads ,Archduke Otto to lead battalion recruit drive‘. The ensuing news item begins: ,Close on the heels of Secretary Stimson's announcement the Archduke stated that he will head a Military Committee for the Liberation of Austria, whose chief aim will be in helping to raise a battalion." NARA II, RG 226, records of the OSS, Entry 100, Box 9, Au-230. [DÖW E20.225]. Zit. nach: Eppel, Österreichische Exilpolitik in den USA. In: Österreicher im Exil USA, 1938-1945. Eine Dokumentation. Bd. 2, a.a. O., 88. 
ril I94I in New York gegründete und über I.50o Mitglieder zählende anti-habsburgische „Austrian Action“, die vor allem Repräsentanten zentraleuropäischer Staaten, insbesondere der Tschechoslowakei, umfasste und - vergeblich - um eine Einigung des österreichischen Exils bemüht war ${ }^{796}$ weiters das 1942 in New York gegründete „Austrian Jewish Representative Committee“ die „Assembly for a Democratic Austrian Republic“ unter Vorsitz von Fritz Rager - deren Mitglieder von den Exil-Sozialisten als „Renegaten“ bezeichnet wurden $;{ }^{798}$ das I94I von Joseph Buttinger eingerichtete und nach Ausscheiden der „Revolutionären Sozialisten“799 I942 von Friedrich Adler übernommene (später von Wilhelm Ellenbogen beziehungsweise Julius Deutsch geführte) „Austrian Labor Committee“ (ALC), die gegen die legitimistische FAM gerichtete Auslandsvertretung der österreichischen Sozialisten ${ }^{800}$ sowie die nach Auflösung der Komintern 1943 gegründete, zahlenmäßig kleine prokommunistische „Austrian American Association“ in New York unter Leitung von Wilhelm Gründorfer mit ihrem Organ Austria American Tribune und der angeschlossenen Jugendorganisation „Austro American Youth Council ${ }^{4001}$ unter Führung von Vera und Kurt Ponger (früher: „Free Austrian Group“) ${ }^{802}$ - sie traten politisch nicht deklariert auf und wurden vom USGeheimdienst sowohl im Exil als auch hinsichtlich ihrer kommunistischen Untergrundaktivitäten in der Heimat beobachtet. ${ }^{803}$

796 Beer, Exil und Emigration als Information. Zur Tätigkeit der Foreign Nationalities Branch (FNB), a.a. O., 138.

797 Vgl. Thomas Albrich, Österreichs jüdisch-nationale und zionistische Emigration. Holocaust und Nachkriegsplanung 1942-1945. In: Zeitgeschichte, 18. Jg., 1990/91, Heft 7-8, 183 ff.

798 Hoor betreffend politische Emigration in den USA (ca. Mitte 1942). Institut für Zeitgeschichte, Wien, Nachlass Martin Fuchs [DÖW E 19.1512], a.a.O., 249.

799 Nach wiederholten Querelen und der erfolglosen „geistige[n] Austragung der Gegensätze“ traten am 7. Dezember 1941, am „Pearl-Harbour-Day“, Gustav Richter, Karl Hubeny, Hans Sailer, Otto Leichter und Manfred Ackermann und schließlich auch Joseph Buttinger aus der „Auslandsvertretung der österreichischen Sozialisten“ aus. Siehe: Joseph Buttinger, Das Ende einer Massenpartei. Am Beispiel Österreichs, Frankfurt a. Main 1954, 596.

800 Goldner, Die österreichische Emigration 1938 bis 1945, a.a.O., 87 f.

801 Foreign Nationality Groups in the United States. A Handbook (revised edition), April 1945, $18 \mathrm{ff}$. Zit. nach: Siegfried Beer, Exil und Emigration als Information, a. a. O., 139.

802 Gaby Falböck, Nachrichten aus der Zwischenwelt. Die Austro American Tribune, eine österreichische Exilzeitschrift, erschienen in New York. In: John M. Spalek/Konrad Feilchenfeldt/Sandra H. Hawrylchak (Hrsg.), Deutschsprachige Exilliteratur seit 1933. Bd. 3: USA, Berlin - New York 2010, 425 f.; des Weiteren: Hoor betreffend politische Emigration in den USA (ca. Mitte 1942). Institut für Zeitgeschichte, Wien, Nachlass Martin Fuchs [DÖW E 19.1512], a.a.O., 265.

803 Siehe: The Communist Party in Austria. Office of Strategic Services. Research and Analysis Branch, R\&A No. 2635. Secret, 23. Dezember 1944. A Guide to O.S.S./State Department Intelligence and Research Reports. Germany and its Occupied Territories during World War II. Part 4 [A Microfilm Project of University Publications of America, Inc.], Washington D.C. 1977. Bestand Institut für Zeitgeschichte, Universität Wien (Bibliothek), Rolle 2 [1-9]. 
Die politische Einschätzung der vergleichsweise kleinen österreichischen politischen Emigrantenzirkel in New York und an der amerikanischen Westküste, die mehr gegeneinander als miteinander arbeiteten, fiel aus Sicht der geheimdienstlichen „Foreign Nationalities Branch“ kurz und präzise aus:

\begin{abstract}
"The main concern of the Austrians, and the only one which has united them, has been the re-creation of an independent Austria. There has been a tendency among Social Democrats to pursue the Pan-German traditions of their party, favouring union with a postwar Socialist Germany. [...] The presence in this country until late in 1944 of Otto von Habsburg, pretender to the Austrian throne, complicated the political situation and caused divisions within the Austro-American community. [...] The majority of the refugees, supported by certain representatives of European countries contiguous to Austria, denounced Otto's pretentions and opposed the political organizations associated with the Habsburg cause. [...] The left wing of the Austrian political community in the United States has recently shown a bifurcation. The Austrian Labor Committee, a Social Democratic organization, perpetuates with some modifications the traditions of Austro-Marxism and its dreams of a gesamt-deutsche Revolution. [...] The other branch of the Austrian Left is represented by the Communist-line Austro American Association and Austro American Youth [...]. These organizations have come into sharp conflict with the Social Democrats over the Moscow Declaration on Austria of November I, I943. While the Communist organizations took the Declaration as a signal for Austrians abroad to drop party differences and unite behind the cause of Austrian liberation, the Austrian Labour Committee greeted the pronouncement with reserve and has refused to enter a coalition." 804
\end{abstract}

Bereits 1942 hatte ein OSS-Bericht zur österreichischen Emigration in den Vereinigten Staaten hinsichtlich der Sozialdemokratie lapidar festgestellt, dass diese die Kooperation mit anderen Exil-Gruppierungen strikt ablehne, und eine Einheit unter den politischen Émigrés schon allein deshalb unmöglich sei. ${ }^{805}$ Das Auftreten monarchistischer Zirkel rund um Otto Habsburg wäre aus Perspektive des amerikanischen Demokratieverständnisses schwierig nachzuvollziehen, ${ }^{806}$ mit den „cold realities of the New

804 Foreign Nationality Groups in the United States. A Handbook (revised edition), April 1945, $18 \mathrm{ff.} \mathrm{Zit.}$ nach: Siegfried Beer, Exil und Emigration als Information, a.a.O., 139, $140 \mathrm{f}$.

805 The Austrians. Foreign Politics in the United States. Foreign Nationalities Branch. Office of the Coordinator of Information, August 1942, a.a.O., 18.

806 So schrieb bspw. u.a. Dr. Ernst Hoor Briefe an prominente amerikanische Tageszeitungen, in denen er versuchte, ein Missverständnis auszuräumen: „[...] it is a mistake to think that people are , anti-democratic because they advocate a monarchic form of government.“ Zit. nach: Memorandum. Military Committee for the Liberation of Austria, 23. Februar 1943, 11. U.S. Office of Strategic Services. Foreign Nationalities Branch Files 1942-1945. Indexes, Bethesda 1998 [Mikrofiche-Bestand, Institut für Zeitgeschichte der Universität Wien, Bibliothek], INT-4AU-303. 
World“807 jedenfalls nicht in Übereinstimmung zu bringen. Unter den Mitgliedern der „unabhängig-liberalen“ Gruppierung (Guido Zernatto, Ferdinand Czernin) würden bedauerlicherweise viele unter ihren früheren politischen Beziehungen leiden: „[...] suffer from previous connection with the Dollfuss and Schuschnigg regime. “808 Insgesamt, so das Resümee des OSS-Berichtes, hätte die österreichische politische Emigration in den USA jedoch ein zentrales Problem:

"This lack of a well-organized American group of Austrian descent has an important effect upon the
politics of the Austrian now in this country. Other refugees come into contact with representa-
tives of their own nationality who are used to American ways; the Austrian remain isolated.
[...] Instead of being able to concentrate on national independence, the refugees have had
to face the question of a republican versus a monarchist regime." ${ }^{809}$ [Hervorhebung d. Verf.]

Soweit die Analyse des US-Geheimdienstes zum Realzustand des österreichischen politischen Exils in den USA, dessen politischen Grabenkämpfe Erich Voegelin ${ }^{810}$ in einer ablehnenden Antwort an Willibald M. Plöchl, der diesen I94I zur Mitarbeit im „Free Austrian National Council“ bewegen wollte, in überdeutlichen Worten kommentierte: „Nach meinen Wiener Erfahrungen hängt es mir zum Hals heraus, der passive oder semiaktive ,Mitbeteiligte“ irgendwelcher österreichischer Politik zu sein. [...] Soweit mir die österreichischen Emigrationsverhältnisse durch die zahlreichen Zuschriften und Publikationen der verschiedenen Gruppen bekannt sind, setzt sich die österreichische Misère in der Emigration fort. Wenn es nicht einmal in der Emigration möglich ist, eine gemeinsame österreichische Basis wenigstens im Auftreten nach außen zu erreichen, dann ist eine österreichische Politik heute ebenso unmöglich, wie sie es in Österreich selbst war. " ${ }^{\text {"11 }}$ In einem vertraulichen Dossier des OSS wurde hinsichtlich der zum Teil operettenhaft anmutenden österreichischen Exilpolitik im Mai I943 nüchtern Bilanz gezogen:

807 The Austrians. Foreign Politics in the United States. Foreign Nationalities Branch. Office of the Coordinator of Information, August 1942, a.a.O., 13.

808 Ebd., 24.

809 The Austrians. Foreign Politics in the United States. Foreign Nationalities Branch. Office of the Coordinator of Information, August 1942, a.a.O., $13 \mathrm{f}$.

810 Eric Voegelin (1901-1985), einer der meist rezipierten österreichischen Exil-Staatsrechtler in den USA, war Unterstützer der austrofaschistischen „Ständeverfassung“ gewesen und begriff auch im US-Exil „politische Wissenschaft als autoritäre, Ordnungswissenschaft “. Siehe dazu: Oliver Rathkolb, Überlegungen zum Exodus der „Jurisprudenz“. Rechts- und staatswissenschaftliche Emigration aus dem Österreich der Zwischenkriegszeit. In: Friedrich Stadler (Hrsg.), Vertriebene Vernunft. Bd. 1. Emigration u. Exil österreichischer Wissenschaft, Wien - München 1987, $282 \mathrm{f}$.

811 Antwortschreiben von Erich Voegelin (Dep. of Political Science, Univ. of Alabama) an Willibald M. Plöchl betreffend die an Voegelin gerichtete Aufforderung (30. September 1941), dem Free Austrian Council beizutreten, 2.10.1941 [DÖW 15.188/30]. Zit. nach: Eppel, Österreichische Exilpolitik in den USA. In: Österreicher im Exil USA, 1938-1945. Eine Dokumentation. Bd. 2, a.a.O., 366. 


\begin{abstract}
"Although only a small group within the Austrian emigration may be considered political (perhaps only about 2000 altogether, according to a State Department estimate), the Austrians have received considerable publicity in this country. This in part because their internal quarrels lead them to air in their grievances in open attacks and demonstrations, and partly because the leader of one faction, Otto Habsburg himself, has attracted the attention of the American public by reason of his royal heritage and his personal charm. There is no doubt that a pretender to a throne holds a certain glamor for many Americans whether or not they would actually support the form of government he represents. It is unfortunate for the Austrian emigration that it has to face within its ranks the problem deciding the form of government it would sponsor in a liberated Austria - whether a republic or a monarchy - rather than being able to devote full energies to the defeat of Hitler." ${ }^{812}$ [Hervorhebung d. Verf.]
\end{abstract}

Das „Versagen“ der österreichischen Exilpolitik in den Vereinigten Staaten, das freilich auch durch die unklare Haltung der USA in Bezug aufÖsterreich mitverschuldet war, resümierte Ernst Karl Winter gegenüber Viktor Matejka im Frühjahr I946 - trotz polemischen Untertons - jedenfalls nicht ganz unzutreffend folgendermaßen: „Daß die österr. Emigration versagte, hat mehrere Gründe: a) das Überwiegen jüdischer Intellektueller, die in der Hauptsache kein Interesse an Österreich hatten, b) die Identifizierung der wenigen Katholiken im Exil mit dem Monarchismus, c) der relative Erfolg des Monarchismus in den USA unter Roosevelt (freilich nur aufgepäppelt, um wieder fallengelassen zu werden, darunter aber die österreichische Sache selbst zu begraben), d) die primitive quasi-legitimistische Politik der Sozialdemokratie, der jedes aktive und offensive Konzept mangelte und die sich erst nach der Moskauer Erklärung auf den Boden der neuen Tatsachen stellte. “813

Tatsächlich reagierte Julius Deutsch ebenso wie Friedrich Adler, der es als notwendig erachtete, der ,kindische[n] Farce von der besonderen, österreichischen Nation““814 entgegenzutreten, auf die Moskauer Deklaration geradezu verärgert und sah in der projektierten künftigen „Unabhängigkeit“ Österreichs ein russisches „Diktat“, das „Österreich wieder auf die klägliche Stufe eines kleinen, lebensunfähigen Staatswesens “815 bringen würde.

812 NARA II, RG 226, Records of the OSS, Entry 100, Box 10. Au-347 [DÖW E 20.225], Vertrauliches Memorandum „Austrian Monarchist“ der Special War Policies Unit/War Division/Department of Justice (Washington, D.C.) an Dewitt C. Poole, OSS (Washington, D.C.) 13. Mai 1943. Zit. nach: Eppel, Österreichische Exilpolitik in den USA. In: Österreicher im Exil USA, 1938-1945. Eine Dokumentation. Bd. 2, a.a.O., $449 \mathrm{f}$.

813 Brief von Ernst Karl Winter an Viktor Matejka betreffend das „Versagen“ der österreichischen Emigration, 25. März 19946 [DÖW 15.060/77]. Zit. nach: Eppel, Österreichische Exilpolitik in den USA. In: Österreicher im Exil USA, 1938-1945. Eine Dokumentation. Bd. 2, a.a. O., 267 f.

814 Friedrich Adler, Die Legende vom glücklichen Österreich. In: Austrian Labor Information, N.Y.C., November/Dezember 1943, 12-15. [DÖW Bibliothek 3058 A/1]. Zit. nach: ebd., 607.

815 Julius Deutsch, Echte und falsche Unabhängigkeit. In: Austrian Labor Information, N.Y.C., November/Dezember 1943, 10 f. [DÖW Bibliothek 3058 A/1]. Zit. nach: ebd., 607. 
Einmal abgesehen von den politischen Zerwürfnissen und Unstimmigkeiten und von manchen Kuriositäten ${ }^{816}$ des österreichischen Exils in den USA entstanden innerhalb der Exilorganisationen weder elaborierte Konzepte und Überlegungen eines demokratischen Neubeginns, die über Maßnahmen zur Entnazifizierung hinausgingen, noch finden sich in den fallweise angestellten Überlegungen inhaltliche Bezüge zum breiten Reeducation-Diskurs; wie Joseph Buttinger für die sozialistische Auslandsvertretung feststellte, wurde „eine geistige und theoretische Vorbereitungsarbeit für künftige Aufgaben “817 schlichtweg nicht geleistet. Und obwohl es innerhalb des „Austrian Labor Committees“ ein eigenes Veranstaltungs- und Bildungsgremium gab, das von Manfred Ackermann und Ernst Papanek betreut wurde, und unter den zahlreichen österreichischen Exilorganisationen in den Vereinigten Staaten auch einige existierten, die sich dezidiert mit kulturellen beziehungsweise wissenschaftlichen Aufgaben befassten - wie zum Beispiel das "Committee for the Preservation of Austrian Art and Culture in the USA“ oder das „Austrian Institute for Science, Art and Economy ${ }^{\text {"818 }}$-, gilt dies grosso modo auch für alle Thematisierungen der nationalsozialistischen Zerstörung des Bildungswesens sowie für Fragen eines wissenschafts- und bildungspolitischen Neubeginns nach Kriegsende. Es gab allerdings Ausnahmen, die zum Teil indirekt die inneren Zerwürfnisse des österreichischen politischen Exils in den USA widerspiegeln. Eine solche Ausnahme bildet zum Beispiel ein bereits 1939 erschienener Artikel des emigrierten Psychoanalytikers Rudolf Ekstein ${ }^{819}$ worin dieser kursorisch die primitiven und barbarischen Ziele und Mittel „faschistischer“ Erziehung und Bildung („marching, fighting, killing“) mit denjenigen eines

816 In seinen Lebenserinnerungen gibt Julius Deutsch einen subjektiven Blick auf die österreichische künstlerische Intelligenz im New Yorker Exil: „Roda-Roda stolzierte in seiner berühmten roten Weste über den New Yorker Broadway, als wäre es die Wiener Kärntnerstraße, und er erzählte voll schmunzelnden Behagens seine Schnurren aus der k. k. Militärzeit ganz so wie einst. [...] Unter den Musikern setzten sich [...] die Meister der leichten Muse am erfolgreichsten durch, so Robert Stolz, dessen große Hallenkonzerte stets ausverkauft waren. Die österreichische Literatur führte Franz Werfel [an] [...]. Sensible Poeten wie Alfred Polgar oder Berthold Viertel waren dem amerikanischen Publikum nicht so ohne weiteres verständlich; aber in literaturbeflissenen Kreisen wurden sie bereitwillig anerkannt." Julius Deutsch, Ein weiter Weg. Lebenserinnerungen, Zürich - Leipzig - Wien 1960, 371f. Zit. nach: ebd., 370.

817 Brief Joseph Buttingers an Friedrich Adler (N.Y.C.) betreffend die Stilllegung der Auslandsvertretung, 16.12.1940 [DÖW 7642]. Zit nach: ebd., 556.

818 Eppel, Österreichische Exilpolitik in den USA. In: Österreicher im Exil USA, 1938-1945. Eine Dokumentation. Bd. 2, a.a.O., $280 \mathrm{f}$.

819 Rudolf Ekstein (1912-2005), aus Wien gebürtiger jüdischer Schulpädagoge und Psychoanalytiker. Schüler u.a. von Anna Freud und August Aichhorn. Während der Zeit des Austrofaschismus (1934-1938) Führer der verbotenen sozialdemokratischen Jugendorganisation „Rote Falken“. Ekstein emigrierte über Großbritannien Dezember 1938 in die USA. Sein Nachlass befindet sich an der Universitätsbibliothek Wien. Siehe: International Biographical Dictionary of Central European Emigrés 1933-1945. Vol. II/ Part 1: A-K. The Arts, Sciences, and Literature. Hrsg. v. Hanna Caplan/Belinda Rosenblatt, München New York - London - Paris 1983, 255. 
demokratischen Gemeinwesens verglich. Angesichts der totalitären Barbarei in Europa strich Ekstein demonstrativ die auf Freiheit des Einzelnen gegründete Gesellschaftsordnung Amerikas als vorbildhaften Gegenpol hervor und huldigte dem „pedagogic creed“ des Exillandes:

"Fascist education is [...] using the primitive instincts and wishes of people. [...] We must understand the needs of our children and show them that all they want they can find in our democratic culture, but not in fascist barbarism. [...] They want to have ideals, good models they can love, trust and imitate. [...] It is courageous to defend the liberty of every member of the nation. It is courageous to destroy all remainders of inequality between different groups in our nation. It is courageous and dangerous to work on sky scrapers, on the great bridges and to build great dams. It is courageous to decide independently, to think and act as a free man; but it is not courageous to follow a leader blindly like a small child. [...] We have real ideas for our children. [...] The lives of our great inventors, explorers, writers are much more thrilling than the life of a watchdog in a concentration camp. [...] I prefer that attitude, which Abraham Lincoln expressed in these words: 'As I don't want to be a slave, I also don't want to be a master'." 820

Weitere Überlegungen für eine Nachkriegserziehung in Österreich finden sich in einem kurzen Manuskript Willibald M. Plöchls, der hinsichtlich der Ausarbeitung von „Leitgedanken“ und Vorschlägen für die „künftige Regelung des gesamten Schul- und Erziehungswesens" und die "geistige Umgestaltung der Schuljugend“ insbesondere an die $\mathrm{He}-$ ranziehung von „Mitglieder[n] geistlicher Orden und Kongregationen“ dachte. In dem angesprochenen Text, der freilich kaum an transideologischer Demokratisierung interessiert war, heißt es diesbezüglich wörtlich: „Wir müssen in der Lage sein, für alle unteren und mittleren Schultypen sofort Lehrbücher ausgeben zu können, die der Idee einer Gemeinschaft der Donauvölker dienen und die getragen sind von den Fundamenten unserer christlichen Weltanschauung. [...] Im besonderen muß das Leitmotiv des Unterrichts, sofern er auf das Vaterlandsgefühl Rücksicht nimmt, folgendes sein: Österreich ist Teil des Donauraumes $[\ldots]$ Österreich ist darin $[\ldots]$ nicht die bloße,Brücke‘ eines jede andere Nation unterdrückenden, Gesamtdeutschtums', sondern der Kern einer übernationalen Reichsidee, die ihre tiefste Wurzel im universalen Katholizismus hat. “821

820 Rudolf Ekstein, A refugee teacher looks on democratic and fascist education. In: Education. A monthly magazine. Devoted to science, art, philosophy and literature of education, Vol. 60, 2, Boston/Massachusetts [Oktober] 1939, 101-109. Zit. nach: Eppel, Österreichische Exilpolitik in den USA. In: Österreicher im Exil USA, 1938-1945. Eine Dokumentation. Bd. 1, a.a. O., $481 \mathrm{f}$.

821 Willibald M. Plöchl, Leitgedanken zu Vorarbeiten für das künftige österreichische Schul- und Unterrichtswesen [DÖW 15.188/64]. Zit. nach: Eppel, Österreichische Exilpolitik in den USA. In: Österreicher im Exil USA, 1938-1945. Eine Dokumentation. Bd. 2, a.a. O., 332. 
Im Sommer 1942 richteten Friedrich Engel-Jánosi ${ }^{822}$ und Willibald M. Plöchl ein Schreiben an Präsident Roosevelt, worin sie auf den „allseits bekannten Fakt“ verwiesen, dass Österreich von 1933 bis 1938 der NS-Aggression mit dem ersten Opfer Kanzler Dollfuß Widerstand geleistet hätte, und empfahlen für die politisch-strategische Nachkriegsplanung die Ernennung eines „American Commissioner on Austrian Affairs and of several American and Austrian experts“, um den Wiederaufbau der „silenced nation“ Österreich „in a reorganized Danubian area" vorbereiten zu helfen. Kultur-, bildungs- oder wissenschaftspolitische Überlegungen wurden darin, im Gegensatz zu militärischen oder nachrichtendienstlichen Fragen, allerdings nicht angesprochen. ${ }^{823}$

Die raren Dokumente der österreichischen US-Emigration, die sich zumindest in Ansätzen mit einer geistigen „Umerziehung“ nach dem Krieg befassten, entstanden innerhalb der österreichischen Exil-Sozialdemokratie. Bereits im Februar 1943 hatte Carl Furtmül$1 \mathrm{r}^{824}$ einen kurzen Artikel in der Austrian Labor Information, dem Organ des „Austrian Labor Committees“, veröffentlicht, in dem er sich - bezugnehmend auf die von Vizepräsident Henry A. Wallace geforderte „psychologische Abrüstung“ - mit der Frage der geistigen Umerziehung in „Deutschland und Österreich“ auseinandersetzte und die „Nachbarschaft mit der militärischen Abrüstung“ als nicht „unglücklich“ ansah:

„Dies ist eine Zwangsmaßnahme gegen einen besiegten Friedensstörer, sie bringt ihn naturgemäß und bewusst in eine schlechtere Lage als seine Nachbarn und hat somit eine von außen kommende Kontrolle als notwendiges Korrelat. Die ,psychologische Abrüstung، strebt eine

822 Friedrich Engel-Jánosi (1893-1978), österreichischer Historiker und Jurist. Engel-Jánosi studierte u.a. bei Alfred Francis Pribram und habilitierte sich 1929 unter Heinrich von Srbik an der Universität Wien. Er emigrierte 1938 zunächst nach England, 1940 dann weiter in die USA. Im US-Exil unterstützte Engel-Jánosi die Einrichtung eines „Österreich-Battaillons“. Siehe: International Biographical Dictionary of Central European Emigrés 1933-1945. Vol. II/Part 1, a.a.O., 264.

823 Brief von Friedrich Engel-Jánosi und Willibald M. Plöchl an Präsident Franklin D. Roosevelt (White House, Washington, D.C.) mit Vorschlägen betreffend die amerikanische Österreichpolitik, 20.7.1942 [DÖW 15.188/5]. Zit. nach: Eppel, Österreichische Exilpolitik in den USA. In: Österreicher im Exil USA, 1938-1945. Eine Dokumentation. Bd. 2, a.a.O., 425 f.

824 Carl Furtmüller (1880-1951), österreichischer Pädagoge, sozialistischer Schulreformer und Psychologe, Mitarbeiter Alfred Adlers. Von Otto Glöckel wurde Furtmüller in die Reformabteilung des Unterrichtsministeriums berufen. 1922 folgte er Glöckel in den Wiener Stadtschulrat. Von 1920 bis 1933 war er Herausgeber der Zeitschrift Wiener Schule des Stadtschulrats. 1939 emigrierte Furtmüller mit seiner Frau nach Paris und fiel nach dem Fall Frankreichs auf der Flucht nach Spanien den Franko-Truppen in die Hände. Durch persönliche Unterzeichnung eines Einreisevisums durch Präsident Roosevelt gelangten beide über Lissabon in die USA, wo Furtmüller zunächst als Deutschlehrer in Baltimore, dann als Übersetzer für Deutschsendungen der „Voice of America“ arbeitete. 1947 kehrte er nach Österreich zurück. Von 1948 an leitete er das Pädagogische Institut der Stadt Wien. Siehe: Kenner, Der zerrissene Himmel. Emigration und Exil der Wiener Individualpsychologie, a.a.O., $120 \mathrm{ff}$; weiters: Sabine Zaufarek, Carl Furtmüller - Biografie: http://www.psyalpha.net/biografien/wiener-psychoanalytische-vereinigungbis-1938/carl-furtmueller-1880-1951/carl-furtmueller-biografie-sabine-zaufarek [Zugriff 11.7.2011]. 
geistige Haltung der Jugend an, wie es sie von demokratischen und friedliebenden Faktoren in Deutschland [sic] selbst als eine notwendige Voraussetzung für den Wiederaufbau des eigenen Landes und Europas herbeigesehnt wird. Dieses Ziel hat nichts von Diskriminierung, es will im Gegenteil die deutsche Jugend mit dem besten Teil der Jugend der anderen Völker in eine Linie bringen. “ 825

Aufgrund des Umstandes, dass nichts von dem verwendbar sein wird, „was jetzt an Lehrbüchern und in Schulbibliotheken für die Hände der Lehrer und Schüler bestimmt ist, denn jedes dieser Bücher, bis zu den Lehrbüchern der Botanik oder Darstellenden Geometrie, ist irgendwie mit Nazigift verseucht", sprach sich Furtmüller für die Schaffung einer „Kommission für psychologische Abrüstung ${ }^{\star 826}$ aus, die sowohl die Schulbücher und Lehrpläne als auch personelle,Säuberungsmaßnahmen' überprüfen sollte. Ebenso wie die Jugend durch „schonungslose Aufdeckung des barbarischen Charakters des Faschismus auch in den Formen des Halb- und Kryptofaschismus gegen das Gift unterirdischer Beeinflussung immun gemacht" werden müsse, sollten auch die Universitäten nach dem Krieg durch internationale Unterstützung zu Stätten eines demokratischen geistigen Wiederaufbaues werden:

„Den Universitäten würden amerikanische Gastprofessoren eine wertvolle Hilfe sein, die von den Nazis geistig verwüsteten Stätten der Forschung und Lehre neu aufzubauen. Junge Amerikaner und Amerikanerinnen, die ohne jede politische Nebenabsicht das Leben der deutschen Jugend in den Jugendorganisationen mitleben und ihr helfen würden, demokratische Lebensformen zu finden, würden Erlebnismaterial schaffen, das den theoretischen Lehren über nationale Zusammenarbeit einen tragfähigen Unterbau geben würde. “827

Wie Furtmüller mit Verweis auf die amerikanische Erziehungstradition hervorhob, wäre dies freilich eine Anstrengung, die nicht von außen oktroyiert werden dürfe: „Und in dem Land, in dem das pädagogische Stichwort ,Learning by doing' geprägt worden ist, wird es ohne weiteres verstanden werden, dass all solche Erziehungsarbeit nur wirklich fruchtbar gemacht werden kann, wenn das Leben der Jugend selbst in Schule und Jugendorganisationen im Sinne freier demokratischer Zusammenarbeit gestaltet wird. “828

Anlässlich einer Konferenz des Völkerbundes im Frühsommer 1943 in Hot Springs wurde dem Chef der US-Delegation, John G. Erhardt, vom „Austrian Labor Committee“ ein Memorandum zur politischen und wirtschaftlichen Rekonstruktion Österreichs überreicht und auch Vorschläge für die „österreichische Erziehung nach Hitlers Sturz" ${ }^{\text {“829 }}$ unterbrei-

825 Carl Furtmüller, Erziehung - ein zentrales Nachkriegsproblem. In: Austrian Labor Information, No. 11, 20. Februar 1943, 11.

826 Ebd.

827 Ebd., 12.

828 Ebd.

829 So Julius Deutsch in einem geharnischten Brief an Hans Rott, worin er die von Rott und Plöchl beanspruchte Führung des österreichischen politischen Exils - bezugnehmend auf einen Artikel in der New 
tet, die von einem Ausschuss, dem Hugo Breitner, Maria Deutsch, Hans Fischl, Carl Furtmüller, Ernst Papanek und Josef Luitpold Stern angehörten, ausgearbeitet worden waren. Dieses von Carl Furtmüller in schriftliche Fassung gebrachte „Sofortprogramm für das Schul- und Erziehungswesen“, ${ }^{830}$ dessen Kernargumentation darauf abzielte, den Sozialismus im zerstörten Europa nicht nur als „eine wirtschaftliche, soziale und politische, sondern auch [als] eine pädagogische Notwendigkeit " ${ }^{\text {831 }}$ anzusehen, wurde anschließend in der Austrian Labor Information, dem Organ des „Austrian Labor Committees“, als „Denkschrift" veröffentlicht.

Obwohl in dieser Denkschrift auch Jugendarbeit, Erwachsenenbildung und Universitätswesen angesprochen wurden, konzentrierte sich das Dokument primär auf Leitlinien einer künftigen „Schulpolitik“ - ein „Werk“, das nur von innen, „unbehindert von ausländischer Kontrolle“ unternommen werden sollte -, wobei die „Gedanken und Forderungen der Schulreformbewegung in der österreichischen Republik als vorläufige Arbeitsgrundlage dienen“832 und den Weg zur „Einheitsschule“ bereiten sollten.

Auch hier wurde die „Ausrottung des Nazismus und Faschismus“, und zwar nicht nur in Form von „Zeichen und Gesten“, sondern auch in Form von „Inhalt und Führung des Unterrichts“ sowie „Ton und Haltung des Lehrers“, als notwendige Voraussetzung eines Neubeginns im Sinne einer „Sozialen Demokratie“833 angesehen. Es sollte niemand in Dienst gestellt werden, „der sich für Austrofaschismus oder Nazismus [...] über das durch politischen Druck erzwungene Ausmass hinaus betätigt hat“. Zur Deckung des Lehrerbedarfs wären jedoch im Übergang auch ehemalige Austrofaschisten und Nationalsozialisten zu belassen, wenn diese ihr Verhalten „eidesstattlich darlegen und das Versprechen [...] geben, dem neuen Staatswesen in demokratischen Geiste zu dienen.“" ${ }^{\text {"34 }}$ Als flankierende demokratische Umerziehungsmaßnahme sollte künftig für alle Lehrer „ein Studium der Vorgeschichte und Geschichte des Zweiten Weltkriegs und des Faschismus verbindlich sein“, wobei der Erfolg „durch Ablegung einer Prüfung zu bestätigen“ 835 sein würde.

York Times vom 28. September 1941, worin sich Rott als „Fortsetzer der Regierung Schuschnigg“ betrachtete und sich berechtigt sah, als „Bundespräsident“ zu firmieren - deutlich zurückwies und es ablehnte, „mit ,Republikanern auf Kündigung“ eine Arbeitsgemeinschaft zu bilden.“ Veröffentlichter Briefwechsel von Hans Rott mit Julius Deutsch in: Frei Österreich. Mitteilungen Free Austrian Movement. Frei-Österreich-Bewegung, N.Y.C., April 1945 [DÖW Bibliothek 3017/4]. Zit. nach: Eppel, Österreichische Exilpolitik in den USA. In: Österreicher im Exil USA, 1938-1945. Eine Dokumentation. Bd. 2, a.a. O., $484 \mathrm{f}$.

830 Die oesterreichische Erziehung nach Hitlers Sturz. Entwurf eines Sofortprogrammes fuer das Schul- und Erziehungswesen. In: Austrian Labor Information, No. 19, 20. Oktober 1943, $11 \mathrm{ff}$.

831 Ebd., 15.

832 Ebd., 11.

833 Ebd., 12.

834 Ebd.

835 Ebd. 
Nicht uninteressant sind schließlich noch die Ausführungen zum Hochschulwesen, die, trotz kritischer politischer Analyse der jüngeren schmerzvollen Entwicklungen, einen parteipolitisch besonnen-pragmatischen Weg vorzeichneten. So wurde festgestellt, dass die Hochschulen vom Beginn der Ersten Republik an „Hauptstützpunkte der Reaktion“ gewesen seien, der Lehrkörper ,auf Austrofaschismus und Nazismus mit der gleichen Servilität“ reagiert hätte und der wissenschaftliche Nachwuchs in der NS-Zeit ,rassisch, weltanschaulich und politisch besonders sorgfältig gesiebt worden“ sei, mithin also „ausserordentliche Sorgfalt bei ihrer [der Hochschulen, d. Verf.] Umgestaltung notwendig ${ }^{4836}$ wäre. Im Hinblick auf die Anstellung von Universitätslehrern und die Zulassung von Hörern kamen die Autoren zu folgendem Schluss: „Sobald im Lehrkörper und in der Hörerschaft ein zuverlässiger Kern sichergestellt ist, können auch solche früheren Lehrer und Hörer wieder zugelassen werden, von denen nicht mehr als volle politische Neutralität zu erwarten ist, wenn sachliche Gründe für ihre Zulassung ${ }^{\text {“837 }}$ vorliegen. Die Erwachsenenbildung, der nach Kriegsende weitaus größere Mittel zur Verfügung gestellt werden sollten als in der Vergangenheit, sollte sich nach Kriegsende insbesondere der „Umschulung der heimkehrenden Soldaten“, der „Vermittlung historischer und soziologischer [...] Bildung" sowie der „Förderung des Studiums von Fremdsprachen im Dienst der Völkerverständigung ${ }^{\text {“838 }}$ widmen.

Bezeichnenderweise richtete sich die nachfolgende Diskussion in der „Austrian Labor Information“ primär auf schulische Sachfragen, wie auf die im "Sofortprogramm“ anscheinend zu wenig deutlich hervorgehobene Bedeutung der Koedukation - immerhin wäre diese ja in Amerika „an den meisten Schulen Selbstverständlichkeit“ ${ }^{\text {“839 }}$ - oder auf Unklarheiten bezüglich des geplanten Überganges zur Einheitsschule beziehungsweise auf die Darstellung der Leistungen der Glöckelschen Schulreform. ${ }^{840} \mathrm{~W}$ ie aus einem letzten Artikel hervorgeht, der im kritischen Rekurs auf die „Vaterländische Erziehung“ des Austrofaschismus eine erste Skizze einer „Staatsbürgerlichen Erziehung“ für die neue Republik zeichnete - eine konkordanzpolitische Doktrin, die mit dem 1949 von Unterrichtsminister Hurdes herausgegebenen Ministerialerlass zur „Staatsbürgerlichen Erziehung“ schließlich das gesellschaftliche Konfliktpotenzial der jüngeren Vergangenheit durch eine großkoalitionäre Tabuisierungspolitik entschärfte ${ }^{841}-$, fühlten sich die sozialistischen Lehrer vor

836 Ebd., 14.

837 Ebd.

838 Ebd., 15.

839 Robert Plank/Nuschi Plank, Das oesterreichische Erziehungsprogramm. In: Austrian Labor Information, No. 25, 1. Mai 1944, 8.

840 Carl Furtmüller, Progressive Education in the Austrian Republic. In: Austrian Labor Information, No. 23, 12. November 1943, $11 \mathrm{f}$.

841 Vgl. dazu: Stephan Ganglbauer/Christian H. Stifter/Robert Streibel, Kein Ort des Verdrängens. Die Auseinandersetzung mit Austrofaschismus und Nationalsozialismus an Wiener Volkshochschulen. In: Jahrbuch 2011. Schwerpunkt: Vermittlungsarbeit mit Jugendlichen und Erwachsenen. Hrsg. vom Dokumentationsarchiv des österreichischen Widerstandes. Redaktion: Christine Schindler, Wien 2010, $165 \mathrm{f}$. 
dem Hintergrund der großen Schulreform-Tradition der Ersten Republik den künftigen Aufgaben mehr als gewachsen. ${ }^{842}$

Ein letztes Beispiel findet sich in einem Vortrag von Otto Spranger ${ }^{843}$ über „Erziehung für ein freies Österreich“, den die „Assembly for a Democratic Austrian Republic“ im Oktober 1942 in New York organisiert hatte, den H. Strauss ${ }^{844}$ in einem kurzgefassten Bericht in der zunächst von Fritz Rager und Alois Englander herausgegebenen Zeitschrift Freiheit für Österreich. Anti Nazi Monthly. Austrian Democratic Review ${ }^{845}$ veröffentlichte. Darin fasste Strauss die allgemein gehaltenen, offenkundig nur wenig analytisch fundierten psychologischen Ausführungen Sprangers zusammen, der - wohl in Kenntnis der 1936 im Pariser Exil publizierten Studienergebnisse des Frankfurter Instituts für Sozialforschung für das Nachkriegsösterreich insbesondere die Überwindung des ,autoritären Charakter[s]“ sowie seiner durch den ,jahrhundertelangen Absolutismus“ produzierten „sado-masochistischen“ Charakterzüge als vorrangige Aufgabe hervorstrich: „Diesen ,autoritären“ Charak-

842 Carl Furtmüller, Staatsbürgerliche Erziehung im neuen Österreich. In: Austrian Labor Information, No. 36, 1. April 1945, 8-9.

843 Gemeinsam mit Viktor Matejka und Anton Forcher hatte Otto Spranger 1936 den „Österreichischen Arbeiter-Schriftstellerverband“ gegründet. Vgl. Herbert Exenberger, Adolf Unger. In: Herbert Exenberger (Hrsg.), Als stünd' die Welt in Flammen. Eine Anthologie ermordeter sozialistischer SchriftstellerInnen, Wien 2000, 280.

844 Vermutlich der deutsche Neurologe und Psychiater jüdischer Herkunft, Hans Strauss (1898-1978), der 1937 in die Vereinigten Staaten emigriert war. Vgl. International Biographical Dictionary of Central European Emigrés 1933-1945. Vol. II/Part 2: L-Z, a.a.O., 1138.

845 Die Freiheit für Österreich erschien (gemeinsam mit ihrer Jugendbeilage Jugend und Kampf) von 1942 bis Juli 1943 als gemeinsames Organ der „Austrian Action“, der „Assembly for a Democratic Austrian Republic“, dem „Free Austrian Youth Committee“ und der „Austrian Youth Assembly“- u.a. zur Bekämpfung des habsburgischen Projektes eines „Austrian Battalion“. Ab Juli 1943 ging die Zeitschrift im (prokommunistischen) englisch-deutschsprachigen Nachfolge-Organ Austrian American Tribune auf, die von William Green [alias Wilhelm Gründorfer] und Alfred Hornik bis 1948 herausgegeben wurde. Während die Nachrichten aus der Heimat darin eher spärlich ausfielen, dominierte in der Zeitschrift die Berichterstattung über die Exilpolitik in den USA. Zur inhaltlichen Analyse der Zeitschrift siehe: Alexander Godula, Analyse und Diskussion der österreichischen Exilzeitschrift Freiheit für Österreich und ihrer Beilage Jugend und Kampf. Schriftliche Hausarbeit, SE Institut für Publizistik, Universität Wien, Wintersemester 2003/04, 2 ff.; weiters: Gaby Falböck, Nachrichten aus der Zwischenwelt. Die Austro American Tribune, eine österreichische Exilzeitschrift, erschienen in New York. In: John M. Spalek/Konrad Feilchenfeldt/Sandra H. Hawrylchak (Hrsg.), Deutschsprachige Exilliteratur seit 1933. Bd. 3: USA. Supplement 1, Berlin - New York 2010, 419 f. Den (österreichischen) Kommunisten war es in den USA nicht möglich, sich als solche offen zu bekennen. Sie wurden, wie alle als kommunistische „Tarnorganisationen" verdächtigte Einrichtungen, vom OSS laufend observiert. Zu den Aktivitäten der kommunistischen „Freien Österreichischen Jugend“ zählten Diskussionsabende, Lesungen exilierter Schriftsteller, Jura Soyfer-Abende oder „das Absingen von Arbeiterliedern und Liedern aus dem Spanischen Bürgerkrieg, Blutspendeaktionen und österreichisch-patriotische Aufmärsche ebenso wie Spiel und Sport einschließlich der Teilnahme an Wettkämpfen." Eppel, Österreichische Exilpolitik in den USA. In: Österreicher im Exil USA, 1938-1945. Eine Dokumentation. Bd. 2, a.a. O., 641 bzw. 642 f. 
terzug zu bekämpfen und unschädlich zu machen, werde zu den großen Erziehungsaufgaben einer neuen Republik in Österreich gehören. Hauptsächlich diesen Charakterzug haben die Nazis ausgenützt [sic] in ihren Haßfeldzügen, ihrer unsinnigen Rassenpolitik. [...] Wenn die neue Republik sich Geltung verschaffen wolle, werde sie nicht versuchen dürfen, sich mit den ,autoritären' Sado-Masochisten zu versöhnen [... “. ${ }^{846}$

Soweit einige wenige Beispiele für die Auseinandersetzung mit Fragen einer geistigkulturellen „Reorientierung“ der österreichischen Nachkriegsgesellschaft, an denen - insbesondere im direkten Vergleich zu einer Vielzahl zeitgenössischer angloamerikanischer Publikationen $^{847}$ oder auch einzelner Beiträge des deutschen Exils zur Reeducation - vor allem ihre Vagheit sowie ihr wenig differenzierter und teils apologetischer Charakter auffällt. Auswirkungen auf weiterführende Debatten dürften diese marginalen Erörterungen wohl weder innerhalb des österreichischen US-Exils noch auf den amerikanischen Reeducation-Diskurs gehabt haben.

Diese Einschätzung korrespondiert auch mit der innen- sowie außenpolitischen Position der USA gegenüber der österreichischen Emigration: eine direkte Einbeziehung in die Nachkriegsplanungen war schon allein aufgrund der substanziellen Uneinigkeit unter den Vertretern der österreichischen Exil-Gruppierungen ausgeschlossen; eine mögliche ,Verwendung“ der Exilanten als „lebendige Beispiele“ für den Krieg der Weltanschauungen sah man von amerikanischer Seite jedoch im Kontext der psychologischen Kriegsführung:

"The primary domestic importance of any refugee political group now in the United States relates to the influence members of the group may exercise on their blood kin here in connection with the war effort. In the case of the Austrians, the potentiality of help or danger under this head is not great because there is no large American group of Austrian descent recognizable as such. The importance of the Austrian political refugees relates almost exclusively, therefore, to the play of war and politics in Europe. [...] In view of Austria's strategic position, individual Austrians can conceivably be of help in a number of specific military or quasi-military ways. [...] The Austrian refugees can possibly be used also as a token. They are a living demonstration that this is not merely a war between states but a war of ideals. The strategy of psychological warfare comes into play." ${ }^{848}$ [Hervorhebung d. Verf.]

846 Freibeit für Österreich, N.Y.C., 15.11.1942 [DÖW Bibliothek 3003]. Zit. nach: Eppel, Österreichische Exilpolitik in den USA. In: Österreicher im Exil USA, 1938-1945. Eine Dokumentation. Bd. 2, a.a.O., $585 \mathrm{f}$.

847 So z.B. die 1944 publizierte, überaus konzise Studie eines britischen Journalisten, der u.a. in Berlin studiert hatte und eine spannend zu lesende Analyse sowohl der historischen Wurzeln des Nationalsozialismus als auch der anstehenden Reeducation-Problematik unter massenpsychologischen Gesichtspunkten verfasste: [Henry] Noel Brailsford, Our settlement with Germany, London 1944 [2012], $106 \mathrm{ff}$.

848 The Austrians. Foreign Politics in the United States. Foreign Nationalities Branch. Office of the Coordinator of Information, August 1942, a.a. O., $40 \mathrm{f}$. 
Einen quasi indirekt-verstreuten österreichischen „Einfluss“ auf amerikanische Aktivitäten im Zusammenhang der "Reorientation“ gab es höchstens in Form der Mitwirkung einzelner österreichischer Emigrés im Bereich der laufenden Kriegsaktivitäten. ${ }^{849}$ So initiierte Ernst Haeuserman als Angehöriger der US-Armee Diskussionen in US-Kriegsgefangenenlagern wie Papago Park in Phönix/Arizona und zeigte den Insassen erste Dokumentarfilme zu NS-Konzentrationslagern. ${ }^{850}$ Der emigrierte österreichische Journalist und Schriftsteller Hans Habe führte als Oberstleutnant der US-Army und Mitarbeiter der Psychological Warfare Branch Informationsgespräche unter deutschen Kriegsgefangenen in mehreren US-Kriegsgefangenenlagern. ${ }^{851}$ Und der Jurist und ehemalige Konzipient in der Österreichischen Handelskammer, Robert Bauer, arbeitete für das OWI und führte unter Leitung von US-Major Aiken von November 1944 bis Jänner 1945 in I9 US-Kriegsgefangenenlagern Gespräche und zeichnete Tonbandaufnahmen auf, die zum Zweck der psychologischen Kriegsführung verwendet wurden. ${ }^{852}$

Bis Sommer I943 verfasste der 194I in die USA emigrierte österreichische Ökonom und Banker jüdischer Herkunft, Hans Simon, ${ }^{853}$ für die Foreign Nationalities Branch des OSS zahlreiche Analysen und Berichte, so zum Beispiel ein 38 -seitiges, elaboriertes Manuskript

849 Nach Schätzungen befanden sich etwa zwischen 3.000 bis 4.500 Österreicher als Freiwillige und Eingezogene in der US-Armee. Vgl. Alfred M. Posselt, Österreichische Soldaten in den alliierten Streitkräften des Zweiten Weltkriegs. Teil 1: Bearbeitung des statistischen Materials. Fakten und Zahlen, Wien 1987, 46 ff. Hier zit. nach: Eppel, Österreichische Exilpolitik in den USA. In: Österreicher im Exil USA, 19381945. Eine Dokumentation. Bd. 2, a.a.O., 5.

850 Bericht von Ernst Haeuserman (Wien) betreffend seinen Militärdienst in Kriegsgefangenenlagern im Gespräch mit Tilly Spiegel, 15.5.1974 [DÖW 13.4046]. Zit. nach: Eppel, Österreichische Exilpolitik in den USA. In: Österreicher im Exil USA, 1938-1945. Eine Dokumentation. Bd. 2, a.a.O., 158.

851 Hans Habe, PWB/Psychological Warfare Branch/-5th Army, to PWB/Headquarters, North African Theater of Operations, Commanding Officer, 18.4.1944. NARA II, RG 208, Records of the Office of War Information, Entry 359, Box 116 [DÖW E 20222]. Zit. nach: Eppel, Österreichische Exilpolitik in den USA. In: Österreicher im Exil USA, 1938-1945. Eine Dokumentation. Bd. 2, a.a. O., $151 \mathrm{f}$.

852 Bezüglich der österreichischen Kriegsgefangenen und deren Haltung zur Moskauer Deklaration heißt es in einem bei Eppel dokumentierten Bericht Bauers: „The Austrian prisoners unanimously want to get out of the German Reich and want to have an independent Austria. [...] We have talked to Austrian prisoners who have been home in April, May and June 1944 and they did not know what the Moscow declaration is or what it means [...]." Major Aiken und Robert Bauer an Office of War Information, 22.1.1945. NARA II, RG 208, Entry 360, Box 118, Records of the Office of War Information [DÖW 20.222]. Zit. nach: Eppel, Österreichische Exilpolitik in den USA. In: Österreicher im Exil USA, 1938-1945. Eine Dokumentation. Bd. 2, a.a.O., 156.

853 Hans Simon, geb. 1880 in Wien, Neffe des Walzerkönigs Johann Strauß (Sohn), war u.a. Mitarbeiter des österreichischen Finanzministeriums und für die Konsolidierung der „Anglo-Austrian Bank“ in Wien verantwortlich, die 1926 von der Bodencreditanstalt gekauft wurde. Simon emigrierte 1941 in die USA. Vgl. Hedi Stadlen. Dauntless Austrian émigrée who campaigned on liberal issues and supported music as the wife of the pianist Peter Stadlen. In: The Sunday Times, 31. Jänner 2004. 
$\mathrm{zu}$ „Austria and National Socialism“", 854 worin er sich sowohl mit den geistig-ideologischen Aspekten als auch mit der materiellen Seite des „komplexen Phänomens“ auch im Hinblick auf Reeducation-Fragen auseinandersetzte. Bezüglich der unterschiedlich weitreichenden Indoktrinierung der verschiedenen Altersgruppen ging Simon davon aus, dass es insbesondere die 15- bis 24-Jährigen wären, die vom Nationalsozialismus besonderes beeinflusst seien, was eine Reeducation insofern erleichtern würde, da die junge Generation vergleichsweise leichter umzupolen wäre. Mit Blick auf einen demokratischen Neubeginn sah Simon, der davon ausging, dass die Majorität der Österreicher „Anti-Nazis“ wären - wenngleich der Antisemitismus zweifellos bereits lange vor dem Ersten Weltkrieg weit verbreitet gewesen sei $^{855}$-, in Bezug auf das universitäre Lehrpersonal die größten und zugleich auch wichtigsten Herausforderungen:

"The saddest and in its consequences the most fatal aspect of Nazism in Austria was the relatively high proportion of university professors who either actively belonged or were sympathetic to the movement. [...] in any case, the necessity of purging the Austrian universities of many professors and of finding a sufficient number of well trained teachers to take their places will presumably be one of the greatest difficulties which the future regime in Austria will have to face." 856 [Hervorhebung d. Verf.]

Der zentrale Kern des zitierten Berichtes von Hans Simon, dem es um eine ausgewogene Einschätzung („balanced judgement“) ${ }^{857}$ ging, behandelt jedoch die Frage, inwieweit der Nationalsozialismus als totalitäre Ideologie in Österreich tatsächlich Fuß fassen konnte, und ob Österreich in dieser Hinsicht nach Kriegsende in gleicher Weise wie Deutschland zu behandeln sein würde.

854 Memorandum for the Secretary of State, DeWitt C. Poole, 25. August 1943. Hans Simon, Austria and National Socialism, 4. August 1943. U.S. Office of Strategic Services. Foreign Nationalities Branch Files 1942-1945. Indexes, Bethesda 1998 [Mikrofiche-Bestand, Institut für Zeitgeschichte der Universität Wien, Bibliothek], INT-33AU-120.

855 Wobei Simon in seiner Analyse zugleich - wohl aus politischer Räson und im Hinblick auf die argumentierte Sonderstellung Österreichs gegenüber Deutschland nach Kriegsende - relativierte, indem er in seltsam krauser ,Beweisführung' und Wortwahl hervorhob, dass der Nationalsozialismus in Österreich von der NS-Propaganda gezielt ausgenutzt worden („deliberately exploited“) und das Phänomen europaweit anzutreffen gewesen sei, und die Juden zudem in Österreich immerhin hohe Posten eingenommen hätten: „Prior to the growing dissemination of Nazi propaganda from the early thirties onward, anti-Semitism in Austria was not different from that in most continental Europe with exception of the Scandinavian states, the Netherlands, and Italy, where it was less prominent. Such anti-Semitism as existed in Austria has not prevented [sic] Jews from penetration [sic] to a very large extent the economic and particularly the financial life of the country; similarly, the medical and legal profession and journalism showed a percentage of Jews far in excess of their proportion to the total of the population." Zit. nach: ebd., 21.

856 Ebd., 7.

857 Ebd., 1. 
Ausgehend davon, dass Österreich nie „Germany's arrogant belief in the superiority of German racial stock“ geteilt hätte, verwies Simon auf die womöglich unterschätzte, traditionell eher ironisch bis feindselige Haltung der Österreicher gegenüber den „Preußen“. Angesichts der nach Simon weitverbreiteten Aversion gegen „the overbearing attitude of

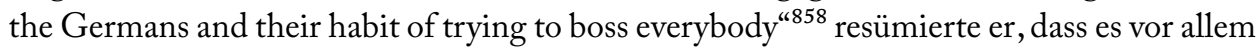
die trügerische Propaganda eines wirtschaftlich-ökonomischen Aufschwunges durch den „Anschluss“ gewesen sei, die bei den „unemployed workers, jobless white-collar men, and industrialists working far below capacity ${ }^{\text {(859 }}$ auf fruchtbaren Boden gefallen sei. ${ }^{860}$

Im Übrigen, so die pointierte und zuweilen zugespitzt-ironische Darstellung Simons, die - wohl nicht ganz ohne Absicht - bestehende Stereotype aufgriff, gebe es in kaum einem anderen Land zu Totalitarismus, Militarismus und Nationalismus eine derart geringe Affinität wie Österreich, dessen Bevölkerung seit jeher ein schwieriges Verhältnis zu Disziplin und Gehorsam habe, sofern dabei nicht unterhaltsame Momente mit ins Spiel kämen:

"The Austrians are definitively individualistic and they never had much disposition to subordinate their private lives to the demands of the state or a party; the kind of discipline dear to the hearts of Germans is certainly not their strong side. Nor could anybody complain of Austria's militarism; her only weakness in this respect was for the military music bands with their popular marching tunes. Similarly all observers will agree that Austria has been remarkably free of nationalism, perhaps with the exception of fraction of the Sudetendeutsche element $[\ldots] " .{ }^{861}$ [Hervorhebung d. Verf.]

Mit dem sicherlich korrekten Hinweis auf das gering ausgeprägte österreichische $\mathrm{Na}-$ tionalbewusstein unterschlug Simon hier aber kurzerhand sowohl den grassierenden Deutschnationalismus, der selbst noch in der Emigration nach Veröffentlichung der Moskauer Deklaration - etwa innerhalb der Sozialdemokratie - keineswegs überwunden war, als auch die adventistische Begeisterung, mit der der Nationalsozialismus an manchen Orten Österreichs nachweislich begrüßt wurde. ${ }^{862}$

858 Ebd., 23.

859 Ebd., 24.

860 „On the whole I believe that none of the ideological tenets of National Socialism was congenial to Austrians of a more mature age whereas its economic doctrine and the resulting hope of ridding themselves of their personal troubles by joining a seemingly prosperous Germany without unemployment was well adapted to the mentality of a country in threes of an almost chronic economic crisis." Ebd.

861 Ebd., 19.

862 Vgl. etwa: Graz die Stadt der Volkserhebung. Hrsg. v. der Nationalsozialistischen Deutschen ArbeiterPartei. Gau Steiermark, Graz 1938; siehe insbesondere auch: Gerhard Botz, Nationalsozialismus in Wien. Machtübernahme und Herrschaftssicherung, Radikalisierung 1938/39, überarb. u. erweiterte Aufl., mit einem Nachwort v. Karl R. Stadler, Wien 2008, 99 f. Obwohl eine Quantifizierung des Anteils jener Ös- 
Inwieweit derartige Berichte nun tatsächlich einen Einfluss auf den Prozess der politischen Entscheidungsfindung hatten, lässt sich freilich schwer feststellen. Fakt ist jedoch, dass einzelne Passagen der von Hans Simon verfassten Analyse zum Teil wörtlich unmittelbar darauf in einem OSS-Bericht der „Foreign Nationalities Branch übernommen“ wurden. ${ }^{863}$ Interessant ist in diesem Zusammenhang außerdem, dass das Stereotyp vom spezifisch österreichischen „biegsamen Charakter“ Einzug in Dokumente der US-Besatzungsmacht hielt. So heißt es 1948 in einem Überblicksreport des amerikanischen Besatzungselements:

"It is not easy to define the Austrian character in a few words. Suffice it to say that the Austrians are a very mixed people, both racially [sic] and culturally. The centuries of Hapsburg [sic] rule over Slavic, Italian, Magyar, Flemish and Germanic people left their imprint on the Austrian character. The most strenuous efforts of the Nazis were unable to cure the Austrians of their most famous trait 'Schlamperei' š an easy going outlook, born of the Austrian inability to take serious view of the material difficulties of existence. The extraordinary resiliency of the Austrian character can readily be seen in Austria today. In spite of the upheavals of the war years, she has easily slipped back into her previous manner of life, combining an invincible optimism, skilled workmanship, artistic brilliance, fertile inventiveness, and a genius for making the best of a bad situation. ${ }^{" 664}$ [Hervorhebung d. Verf.]

Aufgrund des differenzierten und kenntnisreichen Blickes auf politische Befindlichkeiten und mögliche Reaktionsbildungen in der österreichischen Bevölkerung fanden die Berichte Simons nicht nur bei den übergeordneten Geheimdienststellen große Beachtung, sondern wurden auch an das US-Außenministerium weitergeleitet. So schrieb der mit Simon

terreicherinnen und Österreicher, die den „Anschluss“ befürworteten, anhand der vorliegenden Quellen schwer möglich ist, gehen auch neuere Analysen davon aus, dass die „Mehrheit der Österreicher bereit war, in dem Großdeutschen Reich ihre ,Pflicht' zu erfüllen." Jedenfalls findet sich, wie Bukey anmerkt, unter den Millionen Fotos vom „Anschluss“ „,nur ein einziger Schnappschuss mit verstörten und traurigen Gesichtern“. Siehe: Evan Burr Bukey, Hitlers Österreich. „Eine Bewegung und ein Volk“, Hamburg š Wien 2001, 66 bzw. 57 .

863 So z.B. in folgendem Passus: „Austria's situation is highly strategic. Well placed both for sabotage and for eventual revolt, the Austrians may come to be valuable supporters of the United Nations. In the making of peace, as well, Austria's role is likely to be significant, providing either a neucleus [sic] of order or an element of danger in the chaos of post-war Europe. [...] British and American policy toward Austria has not been entirely clear. The legality of the Anschluss was accepted by both England and France; and the United States authorities, though with evident reluctance, were thought to have followed with de jure recognition." [Unterstreichung im Original] Zit. nach: The Austrians. Foreign Politics in the United States. Foreign Nationalities Branch. Office of the Coordinator of Information, August 1942, 1. U.S. Office of Strategic Services. Foreign Nationalities Branch Files 1942š1945. Indexes, Bethesda 1998 [MikroficheBestand, Institut für Zeitgeschichte der Universität Wien, Bibliothek], INTš 4AUš 303.

864 Austria. A Graphic Survey. Prepared by U.S. Element Allied Commission for Austria, December 1948. 
persönlich bekannte DeWitt C. Poole vom OSS / FNB an den Secretary of State bezüglich der psychologischen Kriegsführung gegenüber Österreich:

"Dr. Simon believed they [the Austrians d. Verf.] would dare to stir against the Nazi power this time only when they came to realize that they were not going to be held more responsible for the war than any of the other nations which, like themselves, were unwillingly incorporated into the German war machine. Any propaganda directed toward Austria should, therefore, in Dr. Simon's opinion, start by making clear not only that Austrians would regain her independence under the terms of the Atlantic Charter, but also that Austria was not going to be singled out for treatment as an enemy; that therefore after victory the Austrian position, both politically and economically, would be the reverse of what it was after the last war. Similarly, according to Dr. Simon, the Austrians should be told that while they could not participate in the present discussion of post-war plans, because there was nobody to represent them officially, their interests respecting relief and economic reconstruction were not being forgotten $[\ldots] "{ }^{865}$

Aber trotz der Einbeziehung und Mitwirkung einzelner österreichischer Exilanten im Bereich verschiedener US-Kriegsaktivitäten blieb ihnen dennoch jede direkte Einflussnahme auf politische Entscheidungen verwehrt. Die amerikanischen Behörden und Geheimdienstabteilungen nützten das Engagement und Wissen der deutschsprachigen Emigranten, freilich ohne jedes Zugeständnis zur konkreten Mitwirkung für den Nachkriegsaufbau. ${ }^{866}$

Anders als im Fall des österreichischen politischen Exils wurde im Kontext mit der deutschen Emigration im Frühjahr I944 - gewissermaßen als überparteiliche Gegengründung zum kommunistischen „Nationalkomitee Freies Deutschland“ (NKFD) in Moskau unter Mitinitiative des OSS das „Council for a Democratic Germany “867 eingerichtet, des-

865 Memorandum for the Secretary of State, DeWitt C. Poole, 25. August 1943. U.S. Office of Strategic Services. Foreign Nationalities Branch Files 1942-1945. Indexes, Bethesda 1998 [Mikrofiche-Bestand, Institut für Zeitgeschichte der Universität Wien, Bibliothek], INT-33AU-120, 1.

866 Vgl. Walter F. Peterson, Zwischen Mißtrauen und Interesse. Regierungsstellen in Washington und die deutsche politische Emigration 1939-1945. In: Manfred Briegel/Wolfgang Frühwald (Hrsg.), Die Erfahrung der Fremde. Kolloquium des Schwerpunktprogramms ,Exilforschung der Deutschen Forschungsgemeinschaft. Forschungsbericht, Weinheim 1988, $54 \mathrm{f}$.

867 Vgl. Heike Bunkert, Das Nationalkomitee und der Westen. Die Reaktion der Westalliierten auf das NKFD und die Freien Deutschen Bewegungen 1943-1948 (=Transatlantische historische Studien, Bd. 8), Stuttgart 1997, 102 f. Zum „Council“ siehe Ursula Langkau-Alex/Thomas M. Ruprecht (Hrsg.), Was soll aus Deutschland werden? Der Council for a Democratic Germany in New York 1944-1945, Frankfurt a. Main 1994,18ff. sowie insbesondere die umfangreiche Monografie von: Petra Liebner, Paul Tillich und der Council for a Democratic Germany, 1933-1945 (=Europäische Hochschulschriften, Reihe 3, Bd. 902), Frankfurt a. Main 2001; zur deutschen Emigrationspolitik in den Vereinigten Staaten siehe: Joachim Radkau, Die deutsche Emigration in den USA. Ihr Einfluß auf die amerikanische Europapolitik 1933-1945, Düsseldorf 1971. 
sen Gründungsdokument im Übrigen auch John Dewey mitunterzeichnet hatte. Unter Vorsitz von Paul Tillich ${ }^{868}$ und der stellvertretenden Leitung von Reinhold Niebuhr und der US-Zeitungsreporterin Dorothy Thompson widmeten sich Repräsentanten und nahe stehende Personen des deutschen politischen Exils - darunter auch Carl Zuckmayer, der geheime Dossiers über deutsche und österreichische Kulturschaffende für den OSS verfasste ${ }^{869}$ sowie Klaus und Erika Mann - dem ,aktiven antinazistischen Kampf innerhalb und außerhalb Deutschlands“. ${ }^{870}$ Die Aktivitäten rieben sich aber, trotz breiter medialer Berichterstattung in großen US-Zeitungen, letztlich in parteipolitischem Hick-Hack auf, sodass sich auch das OSS bald zurückzog.

Ebenso wie im Fall der österreichischen Emigration in den USA lag die Wirkungsmacht - so es diese überhaupt gab - des deutschen politischen Exils ,allenfalls im Handlungspotential von Einzelpersonen. “871

Nicht wenige der österreichischen Emigranten, die erst nach dem „Anschluss“ und damit meistens später in die USA kamen als die deutschen Exilanten, hatten jedenfalls große Probleme, Fuß zu fassen. So machten viele der Wissenschafterinnen und Wissenschafter große Anstrengungen, um, wie Lewis Coser es ausdrückte, , auf einen fahrenden Zug aufzuspringen“, um dann feststellen zu müssen, „daß alle Abteile schon voll besetzt sind." ${ }^{\text {"72 }}$ Der Überlebenskampf der Intellektuellen und Kulturschaffenden, für die die „Deterrito-

868 Paul Tillich (1886-1965), deutsch-amerikanischer Religionsphilosoph von Weltruf und enger Freund von Max Horkheimer und Leo Löwenthal. Tillich arbeitete am Frankfurter Institut für Sozialforschung u. a. mit Hugo Sinzheimer, Theodor W. Adorno, Karl Mannheim, Friedrich Pollock und Karl Mennicke zusammen, und lehrte nach seiner Emigration 1933 in die USA an der Harvard University und an der University of Chicago. Siehe: Martin Jay, Dialectical Imagination. A History of the Frankfurt School and the Institute of Social Research 1923-1950, Berkeley - Los Angeles - London 1996, $24 \mathrm{ff}$.

869 Der emigrierte deutsche Dramatiker und Schriftsteller Carl Zuckmayer verfasste 1943 / 44 über 150 „Charakterportraits" deutscher und österreichischer Schriftsteller, Schauspieler, Musiker, Regisseure, Verleger und Publizisten, darunter u. a. über Karl Heinrich Waggerl, Hans und Hermann Thimig, Hans Nüchtern, Erhard Buschwerk, Max Mell, Willy Forst, G.W. Pabst, Mirko Jelusich, Friedrich Schreyvogel, Bruno Brehm oder über die beiden damals bereits verstorbenen - Egon Friedell und Alexander Moissi. Vgl. Carl Zuckmayer, Geheimreport. Hrsg. v. Gunter Nickel/Johanna Schrön. 2. Aufl. München 2007. Der Einfluss bzw. die Wirkung der von Zuckmayer verfassten Dossiers dürfte allerdings gering gewesen sein, wie Gunter Nickel und Johanna Schrön darlegen. Vgl. Gunther Nickel/Johanna Schrön, Carl Zuckmayers Geheimreport für das „Office of Strategic Services“. In: Zuckmayer, Geheimreport, a.a. O., $466 \mathrm{f}$.

870 Eckert, Feindbilder im Wandel: Ein Vergleich des Deutschland- und Japanbildes, a.a.O., 46.

871 Füssl, Deutsch-Amerikanischer Kulturaustausch im 20. Jahrhundert. Bildung - Wissenschaft - Politik, a.a.O., 118.

872 Lewis Coser, Die österreichische Emigration als Kulturtransfer, Europa - Amerika. In: Friedrich Stadler (Hrsg.), Vertriebene Vernunft. Bd. II, Emigration und Exil österreichischer Wissenschaft, Wien - München 1988, 94; siehe auch: Mitchell G. Ash, Forced Migration and Scientific Change. Steps Towards a New Overview. In: Edward Timms/Jon Hughes (Eds.), Intellectual Migration and Cultural Transformation. Refugees from National Socialism in the English-Speaking World. (=Veröffentlichungen des Instituts Wiener Kreis 12), Wien 2003, 241-263. 
rialisierungserfahrung als solche prägender war als das Erlebnis Amerika“, ${ }^{873}$ führte nur in wenigen Fällen zu wirklich großem Erfolg. Neben der Wiener Schriftstellerin Hertha Pauli, die gemeinsam mit ihrem Mann eine erfolgreiche Biografie über Alfred Nobel verfasst hatte, erzielte insbesondere der bereits erwähnte österreichische Schriftsteller Hans Habe mit seinem I94I erschienen autobiografischen Roman zum Fall Frankreichs („A Thousand Shall Fall“), der in einer Auflage von über vier Millionen erschien, den größten Erfolg eines deutschsprachigen Exil-Autors in Amerika. ${ }^{874}$

Aber trotz so mancher sprachlichen Verständigungsprobleme, der zuweilen sicher nicht leicht zu verkraftenden sozialen Isolation ${ }^{875}$ und Negativerfahrungen amerikanischer Lebenskultur ${ }^{876}$ empfanden viele der emigrierten Intellektuellen, Künstler und Schriftsteller das amerikanische Exil als demokratisches Refugium. ${ }^{877}$ So schrieben Erika und Klaus

873 Popp, „Aber hier war alles anders ...“. Amerikabilder der deutschsprachigen Exilliteratur, a.a.O., 290.

874 Ebd., 289

875 Beispiele österreichischer US-Exilanten sind in diesem Zusammenhang Edgar Zilsel (1891-1941), Josef Luitpold Stern (1886-1966) oder Karl (1879-1963) und Charlotte Bühler (1893-1974). Der Wissenschaftshistoriker Edgar Zilsel vermochte in der Erinnerung seines Sohnes Paul Zilsel „mit der ungewohnten Sprache und dem blinden, verständnislosen Rattenlabyrinth, das die Stadt New York den armen Leuten darbietet, mit den Hungersubventionen der gelehrten Gesellschaften, die Refugeewissenschaftler unterstützten“, nicht klarzukommen und verübte in dieser depravierten Isolation, in der er wissenschaftlich keinen Anschluss finden konnte und sich mit den österreichischen Exil-Sozialisten überwarf, schließlich Selbstmord. Siehe: Paul Zilsel, Über Edgar Zilsel. In: Friedrich Stadler (Hrsg.), Vertriebene Vernunft II. Emigration und Exil österreichischer Wissenschaft 1930-1940, Wien - München 1988, $930 \mathrm{ff}$.; zu Zilsels Zeit im US-Exil siehe weiters: In der Emigration gestorben. Edgar Zilsel. In: Austrian Labor Information, No. 24, March-April 1943, 9. Der sozialdemokratische Arbeiterdichter und Volksbildner Josef Luitpold Stern arbeitete als Fürsorger in den Slums in Philadelphia und fühlte sich, wie einzelne Briefe belegen, trotz reger Betätigung in den USA nicht besonders wohl; erst 1948 konnte er, nach Bereitstellung der nötigen materiellen Mittel, nach Österreich zurückkehren. Vgl. Walther Viktor, Dichter und Volksbildner [Josef Luitpold Stern]. In: Austro American Tribune. Anti-Nazi Monthly, Vol. IV, No. 9, April 1946, 11 f. [ÖNB MF 2273]; zu Stern siehe jüngst: Marcus Strohmeier, Lernen um zu kämpfen kämpfen um zu siegen. Josef Luitpold Stern (1886-1966), Wien 2011, 15 f. Obwohl Karl und Charlotte Bühler bereits in den 1920er-Jahren an mehreren amerikanischen Universitäten gelehrt hatten und in Wien außergewöhnlich erfolgreich waren, konnten sie tragischerweise in den USA letztlich nicht Fuß fassen und verstummten, ,als sie kein Echo für ihre Ideen fanden und auch keine Universitätspositionen erhielten." Coser, Die österreichische Emigration als Kulturtransfer, Europa - Amerika, a.a. O., 99.

876 Zum literarischen Niederschlag dieser Negativ-Erfahrungen, die zum Teil an die breite Palette vorgängige Amerika-Bilder anknüpften, siehe insbesondere die Darstellung bei: Popp, „Aber hier war alles anders ..... Amerikabilder, a.a.O., $106 \mathrm{ff}$.

877 Zuweilen entfalteten Emigranten in den USA auch Bildungsaktivitäten mit beträchtlichen Einfluss und Nachhaltigkeit auf inneramerikanischen Entwicklungen. So konstatiert Karl-Heinz Füssl für das am 25. September 1933 in den Bergen von North Carolina gegründete „Black Mountain College“ (BMC), eine alternative Gründung „radikaler Bildungs- und Gemeinschaftskultur“, einen „nachhaltigen Einfluß auf den inneramerikanischen Bildungsdiskurs“. In diesem College waren eine Vielzahl deutscher [sic] Künstler, Gelehrter und Wissenschafter tätig, so z.B. Josef Albers, Ernst Krenek [sic], Peter Bergmann, 
Mann 1939 aus dem Bostoner Exil: „Die Pest unserer Gegenwart, die faschistische Barbarei, nirgendwo auf der Welt ist sie so von Grund auf verhaßt, nirgends wird ihr ein so einmütiger Widerstand entgegengesetzt, als in den Vereinigten Staaten. Gäbe es sonst hier nichts, was uns anzöge, dies allein wäre anziehend genug. Aber es gibt vieles darüber hinaus. “878 Und bezüglich des zu führenden „Kriegs ohne Waffen“ formulierte das Schriftsteller-Geschwisterpaar aus dem US-Exil stellvertretend für alle in die Emigration Gezwungenen:

"Je schwächer und unwissender die Gegenspieler der faschistischen Gewalt in den europäischen Demokratien sich zeigen, je mehr die Hoffnung schwindet, daß mit ihrer Hilfe in Folge jenes, Drucks von außen', von dem in unseren Kreisen viel geträumt worden ist, die deutsche Diktatur eines Tages zu Fall kommen möchte, um so dringlicher erscheint die Sendung der Emigration. Zwischen dem verdunkelten Deutschland und der verschreckten Welt bilden die deutschen Exilierten eine Brücke. Und neben den Aufgaben, die das Leben jedes einzelnen bestimmen, sind es zwei Aufgabenkreise, vor welche die Emigration in ihrer Gesamtheit sich gestellt sieht. Der erste betrifft die Welt, der zweite die verlorene Heimat. ${ }^{4779}$

SPÄTPHASE DER ZIVILGESELLSCHAFTLICHEN ÜBERLEGUNGEN UND
KONZEPTE ZUR REEDUCATION UND REORIENTATION I943/44-I945 LANGFRISTIGE REORIENTIERUNG ALS PARADIGMA

Während der Jahre 1943 bis 1945 fanden zahlreiche größere und kleinere Tagungen und Konferenzen zur Reeducation statt, die zumeist von akademisch-universitärer Seite geplant und organisiert wurden, jedoch in der Regel - so auch die Konferenzen des von Vertretern der klinischen Psychiatrie und Psychologie dominierten „Joint Committee on Postwar-Planning ${ }^{480}$ - in einem Kooperations- und informellen Austauschverhältnis mit staatlichen Behördenstellen wie dem bereits genannten „General Advisory Committee on Post-War Programs“ standen. Das „Joint Committee on Postwar-Planning“ versammelte hochrangige amerikanische Psychiater, Psychotherapeuten, Entwicklungs- und Sozialpsychologen, Psychoanalytiker, Anthropologen und Sozialwissenschafter wie Margaret

Karl Niebyl, Gretel und Edward Lowinsky oder Elizabeth Jennerjahn. Siehe: Füssl, Deutsch-Amerikanischer Kulturaustausch im 20. Jahrhundert. Bildung - Wissenschaft -Politik, a.a. O., $133 \mathrm{ff}$.

878 Erika und Klaus Mann, Escape to Life - Deutsche Kultur im Exil, München 1991 [Boston 1939], 364.

879 Ebd., 382.

880 Diesem Komitee gehörten folgende Einrichtungen an: American Association on Mental Deficiency, American Branch of the International League against Epilepsy, American Neurological Association, American Orthopsychiatric Association, American Psychiatric Association, American Society for Research in Psychotic Problems, National Committee for Mental Hygiene. Siehe: Germany After the War, Round Table - 1945. In: American Journal of Orthopsycbiatry, Vol. XV, No. 3. Juli 1945, 381. Zit. nach: Bungenstab, Umerziehung zur Demokratie?, a.a.O., 216, Anm. 36. 
Mead, Erik Erikson, Kurt Lewin, Erich Fromm, Gregory Bateson, Friedrich (Frederick) Foerster, Talcott Parsons ${ }^{881}$ oder Walter Kotschnig, und stand im direkten Austausch mit US-Regierungsstellen. Ende April bis Anfang Juni 1944 fand an der Columbia University eine von diesem „Committee“ organisierte Konferenz zu „Germany After War“ statt, an der unter anderem auch die österreichischen Exil-Psychoanalytiker Heinz Hartmann, ${ }^{882}$ Ernst Kris, Hans Ernst Fried und Marianne Kris teilnahmen. ${ }^{883}$

Das Protokoll dieser zivilgesellschaftlichen Experten-Konferenz - zu der das Berkeley-Forschungsteam zur „Authoritarian Personality“ offenbar nicht eingeladen war - dokumentiert in seiner hybriden inhaltlichen Form und Sprache den Versuch, die psychiatrischen Ansätze, die nach wie vor von der ,aggressiveness [...] of German character“ ausgingen, mit den differenzierteren und zugleich theoretisch avancierten sozialwissenschaftlich-pädagogischen Theorien zu einem kulturtheoretischen Grundlagenkonzept für eine „Postwar-Education“ zusammenzuführen. Das Resultat fiel ebenso elaboriert wie paradox aus: Zum einen hob man hervor, dass eine friedensichernde Nachkriegsentwicklung nur auf Basis eines inneren Wandels der Deutschen garantiert sein würde, der durch „Selbsterziehung“ und nicht durch Auflagen der „conquerors“ eintreten müsse. Da das au-

881 Talcott Parsons (1902-1979), einer der führenden US-amerikanischen Soziologen, der in den 1920erJahren u.a. an der Universität Heidelberg studiert und dort 1928 promoviert hatte. Im Zusammenhang der Reeducation warnte Parsons davor, die geistig-weltanschauliche,Konversion“ der Deutschen, d.h. ihre demokratische Reorientierung unter kurzfristigem Druck von außen durchführen zu wollen, denn „by means of propaganda or other means of indoctrination would almost certainly intensify a tendency to ideological reaction. “ Zit. nach: Ron Robin, The Barbed-Wire College. Reeducating German POWs in the United States during World War II, Princeton 1995, 23. Parsons war über die Diskussionen an der Harvard University seit 1940 mit Fragen der Reeducation bzw. Reorientation in Europa befasst und stand mit einer Vielzahl von Wissenschaftern in engem Austausch, so u.a. auch mit dem Harvard-Historiker und Leiter der Research \&Analysis Branch des OSS, William L. Langer. Vgl. Uta Gerhardt, Talcott Parsons. An intellectual Biography, Cambridge 2002, $131 \mathrm{ff}$.

882 Heinz Hartmann (1895-1970), Ich-Psychologe und Psychoanalytiker, Schüler Sigmund Freuds und Sohn des Mediävisten und Volkshochschulpioniers Ludo Moritz Hartmann. Heinz Hartmann emigrierte 1938 nach Frankreich und wechselte ein Jahr später in die Schweiz, wo er am Psychoanalytischen Institut in Genf und Lausanne arbeitete. 1940 emigrierte er in die USA, wo er am New Yorker Psychoanalytischen Institut lehrte und forschte. Siehe: International Biographical Dictionary of Central European Emigrés 1933-1945. Vol. II/Part 1: A-K. The Arts, Sciences, and Literature. Hrsg. v. Hanna Caplan/Belinda Rosenblatt, München - New York - London - Paris 1983, 462; siehe auch: http:/www.adulteducation.at/ de/historiografie/personen/66.

$883 \mathrm{Vgl}$. Eppel, Österreichische Exilpolitik in den USA. In: Österreicher im Exil USA, 1938-1945. Eine Dokumentation. Bd. 2, a.a.O., 33; weiters: Laura Fermi, Illustrious Immigrants. The Intellectual Migration from Europe 1930-1941, Chicago - London 1968, 320 ff.; siehe weiters: Peter Eppel, Die Vereinigten Staaten von Amerika. In: Friedrich Stadler (Hrsg.), Vertriebene Vernunft II. Emigration und Exil österreichischer Wissenschaft 1930-1940. Teilband 2, unveränderte Neuaufl., Münster 2004, 989. Das an die Columbia University angeschlossene „Institute of Social Research“, in dem auch frühere Mitarbeiter des Frankfurter Instituts für Sozialforschung tätig waren, so u.a. auch der Österreicher Paul Lazarsfeld, war ein Hauptzentrum der Exilwissenschaften in den USA. Siehe ebd. 
toritäre Verhalten der Deutschen keineswegs angeboren sei, könne dieser Wandel durch entsprechende Reorientierungs-Maßnahmen „trainiert“ werden:

"The tendencies in the German character which are here discussed are not inherited. They are
acquired through training and education. [...] It was sense of the conference that our only
hope of protecting ourselves against some future recrudescence of this German compulsion
to attack and to destroy, this incredible reversion to barbarism and cruelty, is to maintain a
determined and unremitting attack on the problem of Germany, and to employ every resource
available to effect a gradual and lasting change in the German character. ${ }^{\text {“ } 84}$

Zum anderen wurde die Realisierbarkeit eines derartigen Reeducation-Projekts angesichts des historisch weit zurückreichenden, autoritär-unterwerfenden „way of life“ in Deutschland deutlich pessimistisch eingeschätzt:

"In view of this situation, the political history of the Germans is not surprising. The image they have had of themselves has been that of a dominating nation. The only alternative to being dominant has been to be submissive. Either complete victory, or complete defeat; either glory or dishonor. They have never achieved the ideal of give-and-take; of mutual adjustment; of cooperation with equals. [...] Peace, for him, has always in it the tension of waiting and preparing for war." ${ }^{\prime 85}$

Trotz der schwierigen Ausgangslage gebe es aber keine Alternative dazu, sowohl durch unmittelbare Säuberungen nach der Kapitulation als auch durch nachfolgende Langzeitmaßnahmen - „when the smoke of battle has cleared off and the emergency rehabilitation programe is under way “ - einen Demokratisierungsprozess zu initiieren, der auf Dauer alle falschen Ideale von „Herrenrasse“, „Ehre“ und dergleichen demaskieren würde. ${ }^{886}$

Mit kritischem Blick auf die Fehler nach dem Ende des Ersten Weltkrieges wurde allerdings davor gewarnt, die Verantwortung und das erforderliche Engagement nicht zu früh zu reduzieren, um nicht ein weiteres Mal zu scheitern. ${ }^{87}$

Erfolgsaussichten hätte das Demokratisierungsprojekt nur in Form eines langfristigen Rehabilitierungsprozesses, in dessen Verlauf die Deutschen erkennen würden, dass demo-

884 Report of a Conference on Germany after War. Abstract of the Proceedings of a Conference on Germany after the War, Joint Committee on Post-War Planning, Columbia University, New York City, 29. Mai-4 Juni 1944. Zit. nach: Helmut Moosberg, Reeducation. Umerziehung und Lizenzpresse im Nachkriegsdeutschland, München 1991, IX. Anhang (Auszug), 174.

885 Ebd.

886 Ebd.

887 „We managed to lose the peace after the first World War. We shall lose this peace, too, unless we are more fully alive to the temptations to which our own national character exposes us. Consciousness of our power will tend to make us minimize the danger of future trouble. A strong minority of isolationists may make trouble for the program through lobbying in Congress." Ebd., 180. 
kratische Lebensverhältnisse sowohl in wirtschaftlich-ökonomischer als auch in sozialer Hinsicht eine entwickeltere gesellschaftlich-politische Organisationsform darstellen:

\begin{abstract}
"We must think of the Germans as people who have been trained for many generations to a way of life that simply will not work. It will not work because it is founded on primitive and infantile throwbacks in the thinking not only of leaders but of those who are led. We must realize, and so help them to realize, that what we call 'democracy' is as system that does work, because, unlike the German way of life and the German outlook, it represents an emotionally mature product of experience, and so provides a setting in which a preferable form of character is developed. We must do the kinds of things that will cause the Germans to develop the democratic spirit of give-and-take - of discussion, mutual adjustment, co-operation among equals. This will not mean that we shall be imposing our own particular way of life upon the Germans." 888
\end{abstract}

Vor dem Hintergrund dieser doch sehr weich formulierten und kooperativ gedachten Perspektive einer Nachkriegsdemokratisierung verwundert es nicht, dass das Konferenz-Ergebnis des „Joint Committee on Post-War Planning“ letztlich auf Hilfe zur Selbsthilfe hinauslief:
"It was the consensus of the conference that, no matter what military, political or economic measures are undertaken, they must all be planned with the particular purpose of helping the Ger- mans to achieve a new image of themselves which would substitute for a compulsion to dominate the world, the will to cooperate with other nations." ${ }^{889}$ [Hervorhebung d. Verf.]

Nach weiteren Folge-Konferenzen sowie mehreren vom State Department und vom War Department abgehaltenen Geheimsitzungen fand schließlich im April I945 in New York in Form eines Round Table-Gespräches eine letzte Konferenz des "Joint Committee on Postwar-Planning“ statt, an der 28, zum Teil hochprominente Wissenschafterinnen und Wissenschafter aus den Bereichen Sozialwissenschaft, Psychologie und Psychiatrie teilnahmen. ${ }^{890}$ Obwohl dieses Gremium überwiegend von Vertretern der US-Psychiatrie besetzt war, setzte sich in den interdisziplinären Erörterungen und Diskussionen letztlich ein psycho-kultureller Ansatz durch. Diesem entsprechend sollten Reorientierungs-Maßnahmen in friedlich-kooperativer Form die Grundlage für einen tiefgreifenden demokratischen Wandel der sozialen, politischen und institutionellen Verhältnisse in den ehemals totalitär regierten Ländern bilden, und zwar ohne jegliche ideologisch-propagandistische Zutaten. ${ }^{891}$

888 Ebd., 181.

889 DÖW 16.351/44, Dok. 79, 82, 93. Zit. nach: Eppel, Österreichische Exilpolitik in den USA. In: Österreicher im Exil USA, 1938-1945. Eine Dokumentation. Bd. 2, a.a. O., 127.

890 Füssl, Deutsch-Amerikanischer Kulturaustausch, a.a.O., 127.

891 Ebd., 130. 
Eine weiteres Beispiel für eine private Einrichtung, die sich aktiv und eigenständig mit Nachkriegsplanungen beschäftigte, war das an der New Yorker Universität angesiedelte „Institute for the Re-education of the Axis Countries“, in dem Repräsentanten verschiedener Berufsorganisationen und Angehörige des öffentlichen Dienstes vertreten waren und deren aufklärerische Überlegungen auf eine langfristige Perspektive einer bildungsbezogenen Umorientierung ausgelegt waren. So formulierte etwa einer der Mitarbeiter und Mitglied des „Sub-Committees“, Friedrich Wilhelm Foerster ${ }^{892}$ der im Umfeld dieses Instituts auch publizistisch aktiv war, dass ein gegen Untertanengeist gerichteter Reorientierungs-Prozess nach vorheriger profunder Entnazifizierung aller gesellschaftlichen Bereiche, auf den Werten der „Selbstverwaltung, der Eigenverantwortung, Kooperation und Gleichberechtigung basieren ", ${ }^{893}$ und den Aufbau moderner Erwachsenenbildungszentren „nach dem dänischen Muster Grundtvigs" ${ }^{\text {8994 }}$ miteinschließen sollte.

Das Institut, das mit dem „US Committee on Educational Reconstruction“ kooperierte, beschäftigte sich, unter dem Vorsitz von T.C. Pollock und geleitet von Reinhold Schairer als Sekretär ${ }^{895}$ mit bildungspolitischen und kulturellen Aufgabenstellungen für den unter alliierter Besatzung durchzuführenden Wiederaufbau. Bis zum Sommer 1945 wurden vom „Institute on the Re-education of the Axis Countries" mehrere detaillierte Memoranden und Reports zur Reeducation verfasst, die sich neben dem Bildungswesen auch mit Maßnahmen im Bereich der Massenmedien beschäftigten und die Einrichtung eines „Boards of Educational Advisers" empfahlen, das die Militärbehörden durch hochrangige Experten in allen Agenden der zivilen Reeducation unterstützen sollte. ${ }^{896}$

Ohne hier weiter auf die zahllosen Gremien, universitären Boards, philanthropischen Vereinigungen, publizistischen Erörterungen, wissenschaftlichen Einzelstudien und Memoranden ${ }^{897}$ eingehen zu können, lassen sich im Hinblick auf die mannigfaltigen Akti-

892 Friedrich Wilhelm Foerster (1869-1966), deutscher Philosoph, Pädagoge, und Pazifist, der in seinen Schriften früh vor den Folgen von Militarismus und Nationalismus gewarnt hatte. Foerster, dessen Werke von den Nationalsozialisten verbrannt wurden, emigrierte 1940 über Portugal in die USA. Siehe: Maria Hoschek: Friedrich Wilhelm Foerster (1869-1966). Mit besonderer Berücksichtigung seiner Beziehungen zu Österreich (Europäische Hochschulschriften, 3. Geschichte und ihre Hilfswissenschaften, Bd. 920). 3. Aufl., Frankfurt am Main et al., 2006 [2002].

893 Füssl, Deutsch-Amerikanischer Kulturaustausch, a.a.O., 130.

894 Ebd. Nicolaj Frederick Severin Grundtvig (1783-1872), dänischer Theologe, Dichter, Philosoph, Historiker und Sozialkritiker. Grundtvig erlangte als Erzieher und Begründer des (dänischen) Volkshochschulwesens weltweite Bedeutung. Siehe: Norbert Vogel, Grundtvigs Bedeutung für die deutsche Erwachsenenbildung. Ein Beitrag zur Bildungsgeschichte, Bad Heilbrunn/Obb. 1994.

895 Dem Institutsgremium gehörten neben Pollock, Schairer und Foerster weiters an: F.M. Crowley, J.K. Folsom, S.L. Hamilton sowie E. Hanke.

896 NARA II, RG 260, OMGUS - ECR, Box 89. Report on the Re-education of Germany. Presented by the Sub-Committee, Institute on the Re-education of the Axis Countries, 15. Juni 1945.

897 So z.B. ein 49-seitiges Memorandum der Stanford University, das sich auf Basis einer historischen Analyse insbesondere mit dem Aufbau des Universitätssystems in Deutschland beschäftigte. NARA II, RG 
vitäten der großteils privaten zivilgesellschaftlichen Initiativen doch einige verbindende inhaltliche Charakteristika festhalten. So zum Beispiel die internationale Planungsperspektive, die eine Lösung der Reeducation nur auf Basis einer längerfristigen, multilateralen Kooperation und Kontrolle durch die internationale Staatengemeinschaft als sinnvoll und möglich ansah. Des Weiteren bezogen sich die Überlegungen für Umerziehungsmaßnahmen primär auf die Problematik der mentalen und sozialen Auswirkungen der NS-Erziehung; das hatte zur Folge, dass der Diskurs vor allem unter dem Generalbegriff „German Reeducation“ abgehandelt wurde: separierte Erörterungen zur Frage der Reeducation in Japan, Italien oder Österreich finden sich dabei kaum, bildeten diese Fälle doch lediglich Varianten beziehungsweise Sekundärphänomene der brutalen autoritär-etatistischen Indoktrinierungsmaschinerie des „Dritten Reichs“. ${ }^{898}$

Als weiteres, obwohl nicht immer explizit angeführtes Charakteristikum ist das $\mathrm{Ne}$ beneinander von mentalen und sozialpsychologischen Umerziehungsaufgaben und einem soliden, wirtschaftlich-ökonomischen Wiederaufbau zu nennen. Anders als im Zusammenhang mit den wiederholt als unzureichend eingeschätzten Vorkehrungen der internationalen Staatengemeinschaft nach dem Ersten Weltkrieg, sollte der Erfolg eines nachhaltigen, friedensbezogenen Wiederaufbaues eng mit dem materiellen Aufschwung verknüpft werden.

Als letztes verbindendes Charakteristikum kann festgehalten werden, dass in Bezug auf die demokratische Reorientierung nach Kriegsende (freilich nach vorheriger rigoroser Entnazifizierung), mit deutlicher Warnung vor einer möglichen „democratic reaction“, ein nicht-bestrafender, sondern unterstützender Ansatz der Umerziehung präferiert wurde.

260, OMGUS - ECR, Box 88. Memorandum on Postwar Education Reconstruction in Germany. Prepared by B. Q. Morgan and F.W. Strothmann, Department of German, Stanford University [1944].

898 In Bezug auf Japan wurden mehrfach Parallelen zur verspäteten Industrialisierung und zur ausgeprägten Tradition der Obrigkeitsstaatlichkeit „als Bollwerk gegen liberal-demokratische Entwicklungen“ in Deutschland gezogen, und darüber hinaus konstatiert, dass das „preußische Beispiel für den Aufbau des japanischen Bildungswesens wegweisend war". Zit. nach: Rosenzweig, Erziehung zur Demokratie? Amerikanische Besatzungs- und Schulreformpolitik in Deutschland und Japan, a.a.O., 17 bzw. 19.; siehe weiters: Gordon Daniels, The Re-education of Imperial Japan. In: Nicholas Pronay/Keith Wilson (Eds.), The Political Re-Education of Germany and Her Allies After World War II, Kent 1985, 203-218. In Bezug auf die US-Reeducation-Aktivitäten in Italien, die bereits 1943/44 begannen, existiert bis dato wenig an Forschungsliteratur. Die inmitten des Krieges beginnenden Maßnahmen konzentrierten sich zunächst primär auf den Bereich des Schulwesens, das über lange Jahre vom faschistischen Regime nach autoritärem Muster geprägt und dessen Infrastruktur aufgrund der Bombardierungen stark zerstört war. Schwierigkeiten ergaben sich insbesondere durch den Widerstand der Katholischen Kirche, die kulturellen oder bildungspolitischen Interventionen durch die Amerikaner ablehnend gegenüber stand. Siehe dazu: Cristina Allemann-Ghionda, Dewey in Post-War Italy: The Case of Re-Education. In: Jürgen Oelkers/Heinz Rhyn (Eds.), Dewey and European Education, Dordrecht 2000, 54 ff.; weiters: David Ellwod, From ,Re-education' to Selling of the Marshall Plan in Italy. In: Nicholas Pronay/Keith Wilson (Eds.), The Political Re-Education of Germany and Her Allies After World War II, Kent 1985, 219-240. 
Das edukativ-aufklärerische Stichwort für eine demokratische gesellschaftliche Neuorganisation lautete daher „Selbsterziehung“.

Ein überaus spannend zu lesendes Dokument, in dem die genannten Elemente auf hochreflektiertem Niveau und mit gesellschaftstheoretischem Anspruch zusammengefasst vorliegen, ist in diesem Zusammenhang ein gemeinsam von Paul Tillich, Friedrich Pollock $^{899}$ und Adolf Löwe ${ }^{900}$ - alle Mitbegründer beziehungsweise Unterstützer des emigrierten Frankfurter Instituts für Sozialforschung - verfasstes Positionspapier dar, das die Reorientierung deutlich als politische Aufgabe auffasste: "Even the best methods of educating the German people will be in vain if the political problems of post-war Europe are decided in such a way that educational possibilities are excluded from the very beginning." 901

In diesem sozialwissenschaftlich differenziert argumentierenden Dokument zur Reorientation finden sich gleich zu Beginn klar jene Gefahren angesprochen, die eine langfristig asymmetrische edukative Beziehung zwischen Siegern und Besiegten zur Folge haben würde. Die erste von den Autoren erhobene bildungspolitische Forderung lautete daher:

"The first demand for the post-war education of the German people is the acknowledgement that the relation of victors and vanquished is not an educational relation. Any educational relation is based on natural authority and on natural confidence which cannot grow in such a situation. Not even those numerous Germans who welcome the victory of the Allied nations over Nazism would be willing to accept the victors as educators. - This excludes the idea that Americans or other Allied educators should be sent to the Axis nations for educational purposes." ${ }^{\prime 02}$ [Hervorhebung d. Verf.]

Die zu erwartenden Widerstände gegen eine oberflächliche Demokratie-Propaganda wären enorm, und alle Maßnahmen einer „bildungspolitischen Reaktion“ seitens der Siegermächte nur kontraproduktiv.

899 Friedrich Pollock (1894-1970), deutscher Ökonom und Sozialwissenschafter, Mitbegründer des Frankfurter Instituts für Sozialforschung im Jahr 1923. Pollock emigrierte 1933 mit Max Horkheimer über Genf nach Paris und von dort weiter in die USA. Vgl. Rolf Wiggershaus, Die Frankfurter Schule. Geschichte, theoretische Entwicklung, politische Bedeutung, München 1987, $76 \mathrm{f}$.

900 Adolf Löwe [Loewe] (1893-1995), deutscher Wirtschaftstheoretiker, Soziologe und sozialdemokratischer Mitarbeiter im Wirtschaftsministerium der Weimarer Zeit, Schulfreund von Max Horkheimer und Mitarbeiter am Frankfurter Institut für Sozialforschung. Löwe emigrierte 1933 nach England und kam 1940 in die USA, wo er u.a an der New School for Social Research in New York lehrte. Jay, Dialectical Imagination, a.a.O., 25; zur Biografie Löwes siehe insbesondere: Claus-Dieter Krohn: Der philosophische Ökonom. Zur intellektuellen Biographie Adolph Loewes, Marburg 1996.

901 Paul Tillich (in cooperation with Dr. Pollock and Dr. Loewe), The Post-War Education of the German People [ca. 1944], 9. Hoover Institution Archives, Stanford University, John Doane Hartigan Papers, 1909-1958, Box 7: Military reports and career of John Doane Hartigan.

902 Tillich (Pollock/Loewe), The Post-War Education of the German People, a.a.O., 2. 
Die zweite Forderung, die von den prominenten Sozialwissenschaftern gestellt wurde, betraf die erzieherische Dimension, die sich aus der Faktizität des katastrophalen Zusammenbruches insbesondere für all jene ergebe, die an die Überlegenheit einer militärisch organisierten sozialen Gemeinschaft geglaubt hatten: "No intentional education can add much to the educational power of present events. The only thing to be done by liberal Germans with an international understanding is the interpretation of the German catastrophe [sic] as a judgement over many elements in the German past and as a new hope for a mankind."903

Drittens seien aus demokratie- und bildungspolitischer Sicht alle Maßnahmen abzulehnen, die auf „physische“ oder „psychische Destruktion“ hinausliefen, würde dies doch „building up the new world on the basis of a permanent discrimination against and supression of the German people ${ }^{\text {“904 }}$ bedeuten.

Als eine der wichtigsten Voraussetzungen für eine nachhaltige demokratische Neuorientierung erachteten die Autoren schließlich die profunde Neuausrichtung aller sozialen und gesellschaftlichen Lebensbereiche - „the real educational powers in imperial Germany were the family, the Church and the free associations “; 905 eine Strategie der gesamtgesellschaftlichen Umpolung, die langfristig gesehen selbst zu einem wirkungsmächtigen und nachhaltigen Erziehungsfaktor werden sollte:

"[...] the most important in the long run - for the education of German people is the creation of a social reality which by itself has educational power. This point - more than others - refers to all European nations. It is of no use at all to indoctrinate them with democratic ideas taken from the experience of other nations without giving them an immediate experience of the reality and the significance of these ideas. This means for all European nations the creation of such an amount of social security, that the feeling of fear, anxiety, insecurity, hopelessness and despair are overcome. If the United Nations want a durable peace they must overcome these causes of the last two wars and of all totalitarian ideas. Groups, classes and nations in despair cannot be educated as long as the sources of despair are not removed." ${ }^{906}$ [Hervorhebung d. Verf.]

Hinsichtlich der unterschiedlichen Bedingungen und Voraussetzungen der jeweiligen gesellschaftlichen Bezugsgruppen sah das Autorenteam in der jugendlichen Altersklasse zwischen 17 und 34 Jahren die größte Herausforderung für die Reeducation:

"They are thoroughly indoctrinated believing fanatically in the Fuehrer, in National-Socialism, in the superiority of Germany. Some of this group will be killed on the battle-fields or in the revolts against Nazism or will be eliminated by punishing acts of the victors or by the exporta-

903 Ebd., 3.

904 Ebd.

905 Ebd., 7.

906 Ebd., 3. 
tion of German workers for reparation purposes. The group above, with exceptions of course, never has become national-socialist in any strict sense. Many of them will rightly, some of them will wrongly claim that they never have been Nazis. The group as whole will easily be convinced that Nazism was the cause of the present German tragedy [... ${ }^{.907}$

Anders als bei der breiten „proletarischen“ Masse, die nach Ansicht der Sozialwissenschafter nach wie vor stark von der vorgängigen Arbeiterbewegung geprägt und daher primär als eigenständiger Bildungsfaktor („educational power than as objects of education“) zu betrachten sei - hier sollten besatzungspolitische Maßnahmen eher auf materielle Aspekte, als auf „educating their mind“ gerichtet sein -, sahen die Autoren in der unteren Mittelschicht die eigentlichen Adressaten aller künftigen Reeducation-Maßnahmen:

"The most difficult group from the point of view of education $[\ldots]$ is the lower middle-class. Many of them are already or will be soon proletarized - but without the political education of the original proletariate. They were the bearers of German nationalism, to a great extent of $\mathrm{Na}$ zism and the tool of every reactionary movement in Germany. [...] The influence of the lower (and later of the upper) middle class ideology on all intellectuals was tremendous. The high school teachers were the intellectual bearers of German nationalism, the bureaucracy, $[\ldots]$ the university professors belonging to the most favorable situated group of officials, were conservative in their great majority. Critical intelligentsia was small in numbers, weak in its economic position, revolutionary in its political convictions, hated by the upper and lower middle-classes. [...] Will they be used for the interpretation of the German catastrophe, or will they be treated by the occupation-authorities as they were treated in Imperial Germany? “908

Aufgrund dieser weltanschaulich-ideologischen Prägung der gesellschaftlichen Intelligenzia als Hort deutschnational-reaktionären Gedankengutes prognostizierten die Studienautoren wohl auch in Kenntnis amerikanischer Realpolitik - Schwierigkeiten für den Fall, dass nach Kriegsende restaurative Tendenzen den Prozess der Reorientierung dominieren würden:

"If reactionary trends will prevail in the post-war policy of the United Nations, the education of the majority of the German intelligentsia will be easy; Bureaucracy, intellectuals, teachers will follow the 'democratic reaction' as willingly as they followed the 'autocratic reaction'. But the education of the German people for a new world will be frustrated." ${ }^{909}$

907 Ebd., 5.

908 Hinsichtlich der Intelligenz konstatierten die Autoren u. a. für Österreich ein größeres Ausmaß an weltanschaulicher Autonomie gegenüber der gesellschaftlichen Mitte, als dies im Wilhelminischen Deutschland oder in der Weimarer Zeit der Fall gewesen wäre: „The German intelligentsia was never as independent as the intelligentsia, for instance, of Russia, Austria, France." Ebd., 6.

909 Tillich (Pollock/Loewe), The Post-War Education of the German People, a.a.O., 7. 
Mit Bezug auf methodisch-theoretische Überlegungen resümierten Tillich, Löwe und Pollock, dass sich Reorientierungs-Maßnahmen in Form einer breitangelegten demokratischen „Erwachsenenbildung“vollziehen sollten, also unter medialer Ausnutzung aller verfügbaren Massenkommunikationsmittel wie Rundfunk, Film oder Presse, wobei die Antwort auf die Frage nach der Art der dabei zu vermittelnden Inhalte gleich mitbeantwortet wurde:

"Which content should be used for the education of the German people? The answer must be: Not propaganda because propaganda has defeated itself by the way it was used under Nazism, but information, interpretation, revitalization of the great traditions of the German and European culture. The Germans will be extremely sensitive towards the way they are addressed by the foreign authorities and they will become impenetrable for any educational influence if a shallow interpretation of Nazism and the German history will be presented to them." ${ }^{910}$ [Hervorhebung d. Verf.]

\section{MISSING LINK: FEHLENDE UMSETZUNG DER REORIENTIERUNGS-KONZEPTE} IN DIE MILITÄRISCHEN PLANUNGEN, I943-I945

"The American army of occupation lacked both training and organization to guide the destinies of the nearly one million civilians whom the fortunes of war had placed under its temporary sovereignty."

Col. Irwin L. Hunt, I920

„Das Wagnis, eine ganze Nation ,umzuerziehen', d.h. zu einer moralischen und geistigen Katharsis zu bewegen, hat in der Geschichte, jedenfalls der Neuzeit, kaum seinesgleichen. “912 Henry Kellermann

\section{„Takeover" durch die U.S. Army: Wirrwarr und Kompetenzgerangel-Ausdünnung der Reorientation auf, unpolitische'Säuberungsmaßnahmen}

Vor dem Hintergrund der Versäumnisse der Wilsonschen Friedenspolitik nach dem Ersten Weltkrieg und der bald darauf stattfindenden Rückkehr des deutschen Militarismus in sei-

910 Ebd., 9.

911 Col. Irwin L. Hunt, American Military Government of Occupied Germany, 1918-1920, 4. März 1920, 88. Zit. nach: Earl F. Ziemke, The U.S. Army in the Occupation of Germany 1944-1946 (= Army Historical Series. Center of Military History, United States Army), Washington D.C. 1990 [1975], 3.

912 Henry Kellermann, Von Re-education zu Re-orientation. Das amerikanische Re-orientierungsprogramm im Nachkriegsdeutschland. In: Manfred Heinemann (Hrsg.), Umerziehung und Wiederaufbau. Die Bildungspolitik der Besatzungsmächte in Deutschland und Österreich (=Veröffentlichungen der Historischen Kommission der Deutschen Gesellschaft für Erziehungswissenschaft, Bd. 5), Stuttgart 1981, 86. 
ner bisher extremsten Ausprägung als menschenvernichtende NS-Rassenpolitik hatte die Auseinandersetzung mit Fragen einer demokratisch nachhaltigen Friedensicherung nach 1945 in den USA und in Großbritannien ${ }^{913}$ bereits sehr früh begonnen. Doch obwohl dieser zivile Reorientierungs-Diskurs bereits um 1940/4I einsetzte und rasch zu einer breiten intellektuellen und wissenschaftlich-politischen öffentlichen Debatte führte, finden sich in den dokumentierten Ergebnissen der alliierten Kriegskonferenzen bis zum „V-E-Day“und darüber hinaus - keine Aussagen zur demokratischen Reeducation, ${ }^{914}$ die ja innenpolitisch sowohl in Amerika als auch in Großbritannien durchaus Brisanz hatte.

Die von Roosevelt und Churchill im August 194r beschlossene Atlantik-Charta bildete als alliierte Bündnis-Formel den ersten weltanschaulich-programmatisch verlautbarten Kontrapunkt zur nationalsozialistischen Aggressionspolitik, der - von der militärischen Niederringung der Achsenmächte abgesehen - die Entnazifizierung und Entmilitarisierung sowie der Aufbau einer flankierenden Friedensordnung als Kriegsziele formulierte. Obwohl im Reorientierungs-Diskurs wiederholt auf die Atlantik-Charta Bezug genommen wurde, waren die darin enthaltenen friedenspolitischen Aussagen lediglich Versatzstücke einer allianz-diplomatischen Rhetorik, die zu allgemein und vage gehalten waren, um einen konkreten Ansatzpunkt für brauchbare Konzepte abzugeben. Hinzu kommt, dass das universalistische Prinzip des freien Selbstbestimmungsrechtes der Völker, wie es in der Atlantik-Charta noch zugrundegelegt war, auf den nachfolgenden alliierten Kriegskonferenzen sukzessive durch militärische Realpolitik ersetzt wurde. Ausgehend von der auf der Casablanca-Konferenz 1943 von den USA forcierten Forderung nach bedingungsloser Kapitulation Deutschlands, verstärkten sich auf den folgenden Kriegskonferenzen von Teheran, Quebec und Jalta - freilich ohne jede tiefere Auseinandersetzung und Konkretisierung - Überlegungen in Richtung autoritär-punitiver Umerziehungsmaßnahmen. ${ }^{915}$

Die in den Kriegsjahren intensiv geführte Auseinandersetzung mit der grundsätzlichen Notwendigkeit, den Voraussetzungen und den konkreten Umsetzungsmöglichkeiten für eine demokratische Reorientierung Deutschlands und Österreichs nach Kriegsende fand, wie dargestellt, auf Ebene der US-Regierungsstellen unter anderem in einzelnen Abteilungen des State Department und geheimdienstlichen Aktivitäten auch durchaus Niederschlag.

Im Zusammenhang mit den ab Anfang 1944 ins Rollen gekommenen alliierten militärisch-strategischen Planungen für die konkrete Struktur und den Aufgaben und Zielen der Besatzungsorgane hatte der inhaltlich differenzierte Reorientierungs-Diskurs der zivilen

913 Zur britischen Reorientation siehe: Günter Pakschies, Umerziehung in der Britischen Zone. Untersuchungen zur britischen Re-education-Politik (=Studien und Dokumentationen zur deutschen Bildungsgeschichte. Hrsg. v. Christoph Führ und Wolfgang Mitter). 2. Aufl., Köln - Wien 1984.

914 Günter Pakschies, Re-education und die Vorbereitung der britischen Bildungspolitik in Deutschland. In: Heinemann (Hrsg.), Umerziehung und Wiederaufbau, a.a.O., 103.

915 Ebd., 105. 
Experten allerdings kaum beziehungsweise nur höchst marginale Bedeutung. Zwar nahmen die „Post-Hostilities“-Planungsstäbe in ihren Vorbereitungen für die Militärverwaltung der Besatzungszonen die Reorientierungs- beziehungsweise Reeducation-Aufgaben in ihre Agenda auf, doch die Wahrnehmung dieser demokratiepolitischen Aufgabenstellung, die klar nach einem zivilen Engagement verlangte, scheint die verantwortlichen USMilitärstellen von Anfang an überfordert zu haben - sie entsprach auch nicht den im engeren Sinne militärischen Aufgabenbereichen. Daher bildeten, wie auch James F. Tent unterstreicht, die edukativen und kulturellen Agenden von Anfang an einen Fremdkörper innerhalb der militärischen Planungen:

"From first, control of education was a responsibility that fitted only imperfectly into military-
government operations. It attracted little attention and had the lowest of priorities. The neglect
first became apparent in the North African and Italian campaigns in 1942 and I943, where re-
ports grossly inadequate education staffing surfaced. The same problem materialized again in
1944, during preparations for the invasion of Europe, when SHAEF planning staffs and G-5
civil-affairs detachments were minuscule and unable to obtain adequate information for either
short- or longterm planning."

Es ist daher nicht weiter verwunderlich, dass die Reeducation in ihrer schließlich militärbehördlich vorgesehenen Umsetzung inhaltlich weitgehend undefiniert blieb, und - in enger Junktimierung zum operativen Bereich personaler Entnazifizierung - lediglich als formaler Appendix zu den Handbüchern der alliierten Militärverwaltungen auftaucht: als materiale und ideologische Maßnahme zur „Säuberung“ im Bereich schulischer Curricula, des Lehrmaterials an Universitäten, als „Entnazifizierung“ der Bestände der Bibliotheken, der öffentlichen Büchereien, der Museen und anderen öffentlicher Kultureinrichtungen ${ }^{917}$ sowie als Kontrolle des Rundfunks, der Presse und des Verlagwesens. ${ }^{918}$ Die absolute Priorität eines primär auf Verbote und strikte militärische Kontrolle setzenden Maßnahmenkatalogs - angefangen von Non-Fraternisierungbestimmungen bis hin zu Zensur und „control of public entertainments within Germany“ - dokumentiert auch der „Psychological Warfare Plan“im Rahmen der „Operation Eclipse“ vom März I945. ${ }^{919}$

916 James F. Tent, Mission on the Rhine. Reeducation and Denazification in American-Occupied Germany, Chicago - London 1982, 9.

917 Vgl. NARA II, RG 260, USG CC 1944-45, Box 20, Folder 8. Draft Directive to the US (UK) (USSR) Commander-in-Chief. Control of Educational Institutions in Germany, 14. September 1944.

918 Vgl. NARA II, RG 260, USG CC 1944-45, Box 20, Folder 8. Annex X. Plan for German Information Services Control. Basic Preliminary Plan. Tripartite Occupation and Control of Germany, 17. Februar 1945 [General B.L. Milburn].

919 NARA II, RG 260, USG CC 1944-45, Box 27, Folder 14. P\&PW Annex. Second Draft. Annex No. 5. Publicity and Psychological Warfare. Operations Plan, Operation „Eclipse“. Headquarters Twelfth Army Group. APO 655, 24. März 1945, 1. 
Die Gründe, warum der breite zivilgesellschaftliche Konsens hinsichtlich der Notwendigkeit längerfristiger Reorientierungs-Maßnahmen im Kontext der militärischen Nachkriegsplanungen - anders als zu erwarten stünde - letztlich keine entsprechende inhaltliche Transmission in die administrativ-strategischen Vorbereitungsarbeiten der alliierten Militärbesatzung erfahren hat, sind wohl zu komplex, um auf einen einfachen Nenner gebracht zu werden. Von zentraler Bedeutung war aber sicherlich die Haltung Präsident Roosevelts, der längerfristigen Planungsperspektiven - nämlich denen seiner eigenen Mitarbeiter im US-State Department - mit großer Skepsis begegnete und in Bezug auf die Nachkriegspolitik gegenüber Deutschland zunächst stark dem Bestrafungskonzept seines Finanzministers Henry Morgenthau zuneigte, das die Rückführung Deutschlands in einen vorindustriellen Agrarstaat vorsah. ${ }^{920}$ Das ist in der - sowohl gegen die britischen und russischen Intentionen als auch gegen das Department of State ${ }^{921}$ - formulierten Doktrin der bedingungslosen Kapitulation („unconditional surrender“) ebenso ersichtlich wie in der maßgeblich von Morgenthau inspirierten Geheimdirektive ro67 der "Joint Chiefs of Staff" (JCS) für die Behandlung Deutschlands; sie erging im September 1944 als Direktive bezüglich des „Military Government of Germany“ an General Dwight D. Eisenhower als „Supreme Commander, Allied Expeditionary Force“ (SCAEF) und formulierte als klares Ziel "the prompt defeat of the enemy“. In dem Dokument, das zunächst weder von dem sowjetischen Bündnispartner noch vom amerikanisch-britischen „Combined Civil Affairs Committee" - eingerichtet im Frühjahr 1943 innerhalb der G-5-Abteilung von SHAEF angenommen wurde, findet sich in Bezug auf die geplante Vorgehensweise in Deutschland ein explizit auf Bestrafung ausgerichtetes Konzept, das den zivilen Reorientierungs-Überlegungen geradezu diametral gegenüberstand:

"Pending the receipt of directives containing long range policies, your objectives must be a short term and military character, in order not to prejudice whatever ultimate policies may be later determined upon. Germany will not be occupied for the purpose of liberation but as a defeated enemy

920 Vgl. dazu: Otto Schlander, Der Einfluß von John Dewey und Hans Morgenthau auf die Formulierung der Re-educationspolitik. In: Heinemann (Hrsg.), Umerziehung und Wiederaufbau, a.a.O., $42 \mathrm{f}$; weiters: Jutta-B. Lange-Quassowski, Amerikanische Westintegrationspolitik, Re-education und deutsche Schulpolitik. In: Heinemann (Hrsg.), Umerziehung und Wiederaufbau, a.a. O., 54 f.; siehe auch: Wilfried Mausbach. Zwischen Morgenthau und Marshall. Das wirtschaftspolitische Deutschlandkonzept der USA 1944-1947 (=Forschungen und Quellen zur Zeitgeschichte, Bd. 30), Düsseldorf 1996.

921 Seit der Teheraner Kriegskonferenz wandten sich sowohl die Sowjetunion als auch Großbritannien gegen die Verwendung des Terms „Unconditional Surrender“ in Bezug auf Deutschland. Vgl. Foreign Relations of the United States (FRUS). Diplomatic Papers, 1944. Vol. 1. General. U. S. Government Printing Service 1944. Hrsg. v. Historical Office des Departments of State, Washington D.C. 1966. Mr. William Phillips, Political Advisor at the Headquarters of the Supreme Allied Commander, to the Secretary of State, London 17. Dezember 1944, 484. 
nation. The clear fact of German military defeat and the inevitable consequences of aggression must be appreciated by all levels of German population. The German people must be made to understand that all necessary steps will be taken to guarantee against a third attempt by them to conquer the world. Your aim is not oppression, but to prevent Germany from ever again becoming a threat to the peace of the world." 922 [Hervorhebung d. Verf.]

Dass die JCS-Direktive nach öffentlichem Bekanntwerden - „somebody down the line has handed this out to press“923 (Roosevelt) - offenbar auf vehementen Widerstand des State Departments stieß, lässt sich an einem unmittelbar folgenden „privaten“ Memorandum Präsident Roosevelts an den Secretary of State, Cordell Hull, ablesen. Darin teilte Roosevelt diesem unmissverständlich mit, dass es keinen guten Eindruck machen würde, sollte das State Department querschießen und sich der britischen oder russischen Kritik an der projektierten Deutschlandpolitik anschließen. Außerdem, so Roosevelts Versuch zu beschwichtigen, beabsichtige er keineswegs, wie in der Presse verlautet, „to make Germany a wholly agricultural nation again“. ${ }^{924}$

Obwohl die Planungsdirektive JCS ro67 nach der Weiterleitung an die aus den drei Alliierten Mächten zusammengesetzte „European Advisory Commission“ (EAC) und den Einwänden der alliierten Verbündeten im April 1945 in modifizierter Form angenommen wurde, war das Dokument doch - insbesondere in ökonomischer Hinsicht ${ }^{925}$ dezidiert als „moralische Lektion“926 angelegt. Der gesamte Bereich der „Erziehung“ wurde darin lediglich in einem Paragraphen angesprochen, wobei die Kontrolle des Schulwesens im Vordergrund stand. Immerhin findet sich aber unter Punkt (b) in einem Satz eine vage ,affirmative“ Reorientierungs-Perspektive angesprochen, die klar die Handschrift des State Departments trug: „A coordinated system of control over German education and an affirmative program of reorientation will be established designed com-

922 FRUS, Diplomatic Papers. The Conference of Malta and Yalta 1945, Washington D.C. 1955. Directive to SCAEF Regarding the Military Government of Germany in the Period Immediately Following the Cessation of Organized Resistance (Post Defeat), Washington D.C., 22. September 1944, 143.

923 FRUS, Diplomatic Papers. The Conference of Malta and Yalta 1945, Washington D.C. 1955. The President to the Secretary of State, F[ranklin] D. R[oosevelt]. Private. Memorandum for the Secretary of State, 29. September 1944, 155.

924 Ebd.

925 So warnte U.S. Secretary of State Edward R. Stettinius in einem Memorandum im November 1944 diesbezüglich: „We can't make Germany so week that it will be impossible for her to recover. A look at Russia in 1920 and in 1940 demonstrates how quickly industrial strength can be built up if a country is left alone ,to stew in its own juice. [...] if the security organization is prepared to use force to prevent rearmament, we don't have to cut deep into the German economy [...]".. Memorandum by the Acting Secretary of State, E.R. Stettinius [Washington D.C.], 22. November 1944, „Summary of Department's View on Economic Treatment of Germany“. FRUS, 1944, Vol. I. General, a. a. O., 412.

926 Vgl. Anne Armstrong, Unconditional surrender. The impact of the Casablanca policy upon World War II, New Brunswick/N.J. 1961, 80 f. 
pletely to eliminate Nazi and militaristic doctrines and to encourage the development of democratic ideas.“927

Ein weiterer Grund dafür, dass die in eine Vielzahl ziviler Einrichtungen und Initiativen zersplitterten Redemokratisierungs-Planungen an keiner zentralen Regierungsstelle verantwortlich zusammengeführt und diese zu keiner politischen Generallinie gebündelt wurden, liegt sicherlich auch in dem unsystematisch-chaotischen Politikstil Roosevelts'. Robert H. Keyserlingk beschreibt Roosevelt als „helter-skelter administrator “928 und dessen oftmalige Ad-hoc-Entscheidungen als frustrierend, sowohl für alle dem Präsidenten unmittelbar unterstellten Mitarbeiter als auch für die alliierten Bündnispartner. Darüber hinaus holte Roosevelt in allen weitreichenden außenpolitischen Planungsfragen primär die Expertise militärischer Gremien wie zum Beispiel den "Joint Chiefs of Staff“ (JCS) unter Leitung von General George C. Marshall ein, und überging dabei nicht selten den Secretrary of State, Cordell C. Hull, indem er diesem sensible Informationen schlicht vorenthielt. ${ }^{929}$ Die fehlende Koordinierung aller mit administrativen Agenden befassten Stabstellen sowie die zwischen War Department und State Department stark aufgesplitterten Aufgaben- und Funktionsbereiche in allen Fragen der Nachkriegsplanung hatten unklare Kompetenzverhältnisse im Hinblick auf die Planungen der zivilen Militärverwaltungsaufgaben („civil affairs“) zur Folge, die bis in die Nachkriegszeit bestehen blieben und teils zu gegenläufigen, teils zu überlappenden Aktivitäten führten. ${ }^{930}$

Anders als im Ersten Weltkrieg, als die amerikanischen Streitkräfte den zivilen Verwaltungsaufgaben ohne jede Vorbereitung gegenübergestanden hatten, wollte die US-Army den verschiedenen zivilen Aufgaben im Kriegsverlauf (Internierungslager, Displaced Persons, Seuchenbekämpfung, Infrastrukturaufbau, öffentliche Sicherheit in den besetzten Gebieten et cetera) diesmal besser vorbereitet begegnen und richtete zu diesem Zweck, wie bereits erwähnt, im April 1942 eine erste „School of Military Government“ ein. Hier, wie auch in den weniger spezialisierten Ausbildungsstellen in den verschiedenen „Civilian Affairs Training Schools“(CATS), sollte der Nukleus jener Offiziere ausgebildet werden, die später mit Aufgaben der Militärverwaltung befasst sein würden. ${ }^{931}$ Die Öffnung der ersten

927 Paragraph 14 von JCS 1067 („Education“) gliederte sich in 4 Punkte und sah primär die Kontrolle über das gesamte primäre und sekundäre Schulwesen vor. Die Schulen waren zunächst in toto zu schließen und sollten erst, nach erfolgten ,Säuberungsmaßnahmen', unter alliierter Supervision wieder geöffnet werden. FRUS, Diplomatic Papers, 1945. Vol. III. European Advisory Commission; Austria; Germany, Washington D.C. 1968, 492. Directive to Commander in Chief of the United States Forces of Occupation Regarding the Military Government of Germany, IPCOG, 26. April 1945.

928 Robert H. Keyserlingk, Austria in World War II. An Anglo-American Dilemma, Kingston - Montreal 1988,103

929 Vgl. Robert Dallek, Franklin D. Roosevelt and American Foreign Policy, 1932-1945, New York 1968, 421. Zit. nach: Keyserlingk, Austria in World War II, a.a.O., 103 bzw. 104.

930 Keyserlingk, Austria in World War II, a. a. O., 104.

931 Vgl. Harold Zink, The United States in Germany, 1944-1955, Toronto - New York - London 1957, 11 f. 
Ausbildungsgänge in Charlottesville rief in der US-Presse aber harsche Kritik hervor; sie bezeichnete das Ausbildungszentrum schlichtweg als "School for Gauleiters“, ${ }^{32}$ wobei das diffuse Curriculum sowie das offensichtlich niedrige Niveau der Rekruten, die in Fächern wie Geschichte, Geografie, Ökonomie, Politik, Sprachen oder Gesundheit unterwiesen wurden, selbst seitens der US-Regierung auf Kritik stieß. Spätestens mit Landung der USStreikräfte in Marokko und Algerien im November I942 stellte sich für die US-Militärs jedoch heraus, dass sie die Komplexität ziviler Administrationsaufgaben weit unterschätzt hatten und sich die Armee nicht gleichzeitig dem Kampfgeschehen und der Planung ziviler Aufbaumaßnahmen nach Kriegsende widmen konnte. Daher sollten die verantwortliche Planung und die Kontrolle der zivilen administrativen Angelegenheiten nun künftig in der Autorität des State Department liegen. ${ }^{933}$ Aber selbst für die anstehenden Koordinationaufgaben mit den Abteilungen des State Department schien die US-Army, für die alle „Military Government“-Agenden ohnehin einen deutlich inferioren Stellenwert hatten, höchst unzureichend organisiert zu sein.

Interessanterweise kam die Initiative zum Aufbau einer eigenständigen „Zivil“-Abteilung innerhalb des War Departments von „ziviler“ Seite, namentlich vom Direktor des „Office of Foreign Relief and Rehabilitation“ im State Department, Herbert H. Lehman, ${ }^{934}$ der im Ersten Weltkrieg selbst Colonel in der US-Army gewesen war. Nach Abstimmung mit General Marshall erfolgte am I. März I943 die Einrichtung der „Civil Affairs Division“ (CAD) im Pentagon unter Leitung von General John H. Hilldring. ${ }^{935}$ Mit der Schaffung dieser Armee-Division übernahm das War Department, das auch die Spezialausbildungen ankurbelte, ${ }^{936}$ nun die Verantwortung für alle zivilen Angelegenheiten im Bereich der künftigen Besatzungsgebiete unmittelbar nach Ende der Kampfhandlungen.

Da die nun übernommenen konzeptuellen Aufgabenbereiche die Civil Affairs Division aber sowohl personell als auch hinsichtlich der vorhandenen Qualifikationen überforderten ${ }^{937}$ und die zivilen Planungen aus Sicht der Militärs anscheinend nur schwer mit den

932 Ziemke, The U.S. Army in the Occupation of Germany 1944-1946, a.a.O., 12.

933 Ebd., 14 f.

934 Herbert H. Lehman (1878-1963), achtes Kind des deutsch-jüdischen Mitbegründers der Lehman-Brothers - Mayer Lehman; Demokratischer Gouverneur von New York und von 1942-1946 Mitarbeiter des State Department; 1943-1946 u.a. auch Generaldirektor der United Nations Relief and Rehabilitation Administration (UNRRA). Vgl. Allan Nevins, Herbert H. Lehman and his era, New York 1963, $13 \mathrm{f}$.

935 Ziemke, The U.S. Army in the Occupation of Germany 1944-1946, a.a.O., 17.

936 Die Schätzungen für das benötigte Personal für die künftigen Militärverwaltungsbereiche belief sich seitens des War Department auf etwa 6.000 Offiziere weltweit. Nachdem in Charlottesville jährlich nur rund 450 Offiziere ausgebildet werden konnten, richtete die „Military Government Division“ in Fort Oglethorpe in Georgia eine zweite Ausbildungsstätte ein, die jährlich bis zu 1.200 junge Offiziere zu trainieren imstande war. Vgl. ebd., $17 \mathrm{f}$.

937 „It shortly became apparent that manpower available within the armed forces usually did not possess the qualifications which specialists in the administering of occuppied areas should have." Zink, The United States in Germany, 1944-1955, a.a.O., 8. 
eigentlichen militärischen Operationen zu verknüpfen waren, schlug Präsident Roosevelt im Juni 1943 die Einrichtung eines „Interdepartmental Policy Committee“ vor, das unter Vorsitz des Assistant Secretary of State die Aufbauplanungen in den befreiten Gebieten übernehmen, jedoch gleichzeitig dem Militärkommando unterstehen sollte: die Militärverwaltungen in den von der US-Army besetzten Gebieten bekamen ihre Befehle und Anordnungen ab sofort sowohl vom State Department als auch vom War Department. ${ }^{938}$ Seitens des State Department war künftig das „Office of European Affairs“ unter Leitung von James Clement Dunn für die generelle zivile Rahmenplanung verantwortlich. ${ }^{939}$

In dieser hybriden militärisch-zivilen Konstruktion war die Civil Affairs Division gemeinsam mit dem State Department, dem 1944 eingerichteten „State, War, Navy Coordinating Comittee" (SWNCC) und der nach der Moskauer Konferenz 1943 eingerichteten - aus Sicht der USA allerdings nachgeordneten - alliierten „European Advisory Commission“ (EAC) ${ }^{940}$ für die Ausarbeitung der amerikanischen Militärpolitik, unter anderem auch gegenüber Österreich, verantwortlich. ${ }^{941}$

Das State Department hatte, neben den im vorangegangenen Kapitel bereits ausführlich beschriebenen Aktivitäten, im Bereich der kulturellen Postwar-Reorientation bereits Anfang 194I mit ersten Planungen für die politische Neuordnung in der unmittelbaren Nachkriegszeit begonnen. So wurde unter Leitung von Leo Pasvolsky, eines Ökonomen mit Österreich-Expertise, die „Division of Special Research“ eingerichtet, die in der Folge mit externen Experten ziviler Einrichtungen, wie dem privaten New Yorker Wissenschaftsforum „Council on Foreign Relations“, Informationen über die späteren Besatzungsgebiete in Europa sammelte und Analysen ausarbeitete. ${ }^{942}$ Dabei erfolgten auch Kontaktaufnahmen beziehungsweise Interviews mit Vertretern der österreichischen politischen Emigration in den USA, die sich quer durch die politischen Lager nicht für die Wiederherstellung einer Republik, sondern für die Schaffung eines supranationalen Gebildes nach Kriegsende aussprachen. ${ }^{943}$

938 Ziemke, The U.S. Army in the Occupation of Germany 1944-1946, a.a. O., 21.

939 E.J. Hayes, Coordination of Military and Civil Affairs Planning. In: Annals of the American Academy of Political and Social Science, 1950, 267. Zit. nach: Keyserlingk, Austria in World War II, a.a.O., $107 \mathrm{f}$.

940 Vgl. FRUS, Diplomatic Papers, 1943. Vol. 1. General, Washington D.C. 1968, 801. Establishment of the European Advisory Commission. The Ambassador in the United Kingdom (Winant) to the Secretary of State. London, 3. November 1943.

941 Donald R. Whitnah/Edgar L. Erickson, The American Occupation of Austria. Planning and Early Years (=Contributions in Military Studies, No. 46), Westport - London 1985, $14 \mathrm{f}$.

942 Harley Notter, Postwar Foreign Policy Preparation, 1939-1945, Washington D.C. 1949, 39 ff. Zit. nach: Keyserlingk, Austria in World War II, a.a.O., $108 \mathrm{ff}$.

943 Die Gespräche mit den österreichischen Emigrés wurden vom „Council on Foreign Relations“ geführt. Aufgrund deren einhelliger Präferenz für ein supranationales, konföderatives Gebilde, empfahl das Council in seiner politischen Analyse dem State Department, dass Österreich nach Kriegsende Teil eines supranationalen Donaukonföderation werden solle. Vgl. Keyserlingk, Austria in World War II, a.a. O., 114 bzw. 118. 
Zum vollständigen Takeover der US-Armee im Bereich der „Civil Affairs“-Planungen kam es durch den weiteren Kriegsverlauf und die Konkretisierung der „Overlord“-Invasionspläne Ende 1943. Unter dem Generalkommando von General Eisenhower richtete General Hilldring im Dezember in Shrivenham bei London (später in Manchester) ein "Civil Affairs Center" für rund r.ooo Offiziere ein; aus diesem wurde unter anderem auch die SHAEF-,,German Country Unit" (GCU) gebildet ${ }^{944}$ in der eine kleine „Education and Religious Affairs Subsection" unter gemeinsamer britisch-amerikanischer Expertise existierte, deren Leitung John Taylor, George Geyer und Marshall Knappen für die USA, sowie Donald Charles Riddy und Herbert Walker für Großbritannien innehatten. ${ }^{945}$

Die intensivierte Tätigkeit innerhalb des amerikanisch-britischen „Combined Civil Affairs Committees" (CCAC) führte, nach der bisher wenig effizienten alliierten Besatzungsplanung, umgehend zu ersten militärischen Direktiven für Standard-Verfahrensweisen des zivilen Aufbaues in den besetzten Gebieten. Damit übernahmen nun die Militärs, vom SHAEF-Oberbefehlshaber Eisenhower top down bis zu den Besatzungsoffizieren im jeweiligen Einsatzgebiet, die vollständige Veranwortung für den gesamten Bereich der Militärverwaltung, inklusive aller damit verknüpften Angelegenheiten ziviler Kontrollmaßnahmen. ${ }^{946}$

Die Kooperation zwischen dem War Department, der Civil Affairs Division (CAD) und dem State Department, das vom strategischen Entscheidungsprozess weitgehend ausgeschlossen blieb und lediglich die im engeren Sinne politischen Agenden supervidierte, verlief mit Fortdauer des Krieges und der bevorstehenden Invasion in der Normandie zumindest dem Wortlaut offizieller Dokumente nach - weitgehend ohne größere Friktionen. ${ }^{947}$ In kontroversiellen Fragen oder bei sich abzeichnendem Widerspruch seitens der zivilen Beamten gegenüber den Militärs schaltete sich Präsident Roosevelt mehrmals höchstpersönlich ein, um die Verantwortlichen des State Department zum Gleichschritt aufzurufen („to keep in the linings of their hats") ${ }^{948}$ - so beispielsweise im Zusammenhang mit Detailfragen rund um die für die EAC revidierte Fassung des JCS 1o67.949

944 Ziemke, The U.S. Army in the Occupation of Germany 1944-1946, a.a.O., $80 \mathrm{f.}$

945 James Tent, Education and Religious Affairs Branch, OMGUS und die Entwicklung amerikanischer Bildungspolitik 1944 bis 1949. In: Heinemann (Hrsg.), Umerziehung und Wiederaufbau, a.a. O., 68.

946 Ebd., 33.

947 Für das vergleichsweise reibungslose Agieren zwischen CAD, dem State Department, der US-Botschaft in London und der EAC dürfte wohl auch das besonders gute Verhältnis zwischen General Hilldring dem späteren Assistant Secretary of State for Occupied Areas [!] - und James C. Dunn vom Office of European Affairs und dessen Mitarbeitern verantwortlich gewesen sein, deren Korrespondenz in einem ausnehmend freundlichen, zuweilen geradezu amikalen Ton gehalten war. Z.B. „My dear General Hilldring [...]“. FRUS, Diplomatic Papers, 1944. Vol. 1, General, Washington 1966, 207. The Director of the Office of European Affairs (James Clement Dunn) to Director of the Civil Affairs Division of the War Department (Hilldring), Washington D.C., 5. April 1944, 207.

948 FRUS, 1944, Vol. 1, a.a.O., 414. Memorandum by President Roosevelt to the Secretary of State [Hon. E.R. Stettinius], 4. Dezember 1944.

949 So hatte James Riddleberger vom State Department in einem Memorandum Passagen am Entwurf des JSC 1067 moniert und Veränderungsvorschläge unterbreitet, die der Assistant Secretary of War, John McCloy, 
Anhand einzelner Dokumente lässt sich aber nachvollziehen, dass sich das atmosphärische Verhältnis zwischen dem auf politische Analysen und diplomatisches Prozedere hin orientierten Beamten des State Department und den strategischen Entscheidungsträgern im War Department sowie den Militärstäben der US-Armee in Europa zunehmend abkühlte. Die zur kurzfristigen Begutachtung und allgemeinen Supervision weitergeleiteten militärischen Planungsunterlagen folgten letztlich einem nur formalen Prozedere, und Einsprüche oder kritische Diskussionen fanden hier ebensowenig Platz wie eine inhaltlich vertiefte Auseinandersetzung mit den durchaus komplexen Fragen einer zu implementierenden demokratischen Nachkriegsordnung in den Achsenstaaten.

Die im Zusammenhang mit den Reorientations-Planungen insgesamt eher rigide Haltung der US-Militärs zeigte sich freilich auch und insbesondere gegenüber allen mit dem State Department kooperierenden zivilen Einrichtungen. So richtete Grayson N. Kefauver, Dekan der Stanford University und Vorsitzender der „International Education Assembly“ im Jänner 1944 ein Schreiben an General John H. Hilldring als verantwortlichen Leiter der Civil Affairs Division, worin er diesen zu einer Tagung des „Liaison Committee for International Education“ über die „wichtigen Probleme“ der „Post-War-Education“ einlud; einer Tagung, an der, wie Kefauver gegenüber Hilldring eigens hinwies, neben über 30 Repräsentanten ziviler US-Bildungseinrichtungen ,with special interest in international education " unter anderen auch der Assistant Secretary of State, G. Howland Shaw sowie der U.S. Commissioner of Education, John Studebaker, teilnehmen würden. ${ }^{950}$

Hilldring beantwortete die Einladung des anerkannten Bildungexperten Kefauver reserviert und förmlich, indem er diesen knapp darüber verständigte, dass er Colonel Burnet angewiesen habe, ,to present a brief report on the Army program for educational reconstruction in territories occupied by U.S. forces“. Hingegen wäre es nicht möglich, Informationsmaterial des War Departments bei der Tagung in schriftlicher Form aufzulegen, da "much of the information contained in them has been classified for reasons of military security and cannot be disseminated outside of military circles". Dies obwohl, wie Hilldring eigens betonte, die diesbzüglichen Informationen des War Departments überaus mager („meager") wären. Abschließend gab General Hilldring seinem durch Geheimhaltungserfordernisse bedingten Bedauern im pluralis majestatis Audruck: "It is regretted that we will

in amikaler Form („Dear Doc“) gegenüber dem stellvertretenden Direktor des Office for European Affairs, H. Freemann Matthews, zur Sprache brachte und unmissverständlich klarlegte, dass keine weiteren Änderungen mehr angebracht wären und Detailveränderung ,would be handled in the Control Council or otherwise on a military level." [Hervorhebung d. Verf.] FRUS, 1944, Vol. 1, a.a.O., 410. The Assistant Secretary of War (McCloy) to the Deputy Director of the Office of European Affairs (Matthews), [Washington D.C.], 20. November 1944.

950 The U.S. Occupation of Germany: Educational Reform 1945-1949, Microfilm-Collection Congressional Information Service, edited by Gary H. Tsuchimochi, Tokyo 1991 (Bestand Institut für Zeitgeschichte der Universität Wien, Bibliothek), 2-A-153, 1f. Grayson N. Kefauver to Major General J.H. Hilldring, Chief, Civil Affairs Division, Office of Chiefs of Staff, War Department, Washington D.C., 21. Jänner 1944. 
be unable to furnish your Committee with copies of the report to be delivered orally and that we must insist that it be treated as restricted matter." 951

Soweit dieses illustrative Fallbeispiel zu so manch asymmetrischen Informationsverläufen zwischen Militärs und engagierten Repräsentanten des zivilen US-ReorientierungsDiskurses. Im Fall Kefauvers verwundert die reservierte Haltung Hilldrings besonders, da dieser seit langem intensiv mit Fragen der Reorientierung befasst und auch an den CAME-Konferenzen beteiligt war. Im Juni 1944 leitete Kefauver seine ausgearbeiteten Überlegungen zur „Educational and Cultural Reconstruction“ an Major Boettinger von der Civil Affairs Devision weiter. Erwähnenswert ist dieses Dokument deshalb, weil die darin detailliert ausgearbeiteten Vorschläge sowohl „Short-Term Activities“ als auch „LongTerm Activities“ im Bereich der Reorientierung behandelten. Kefauvers Vorschläge, die er explizit als Anregung beziehungsweise Unterstützung für die alliierten Militärplanungen in London verstand, umfassten im Zusammenhang mit kurzfristig zu ergreifenden Maßnahmen auch den Bereich der Restitution von Kunstgegenständen, Büchern und Archiven sowie Bildungsmaßnahmen im Kontext mit der Rehabilitation von Kriegsverletzten oder psychisch-mental geschockter Personen, spezielle Kinderfürsorgemaßnahmen und die Forcierung intellektueller, philosophisch-ethischer Trainingskurse. Als Langzeitmaßnahmen regte Kefauver neben internationalem Austausch im Bibliotheks- und Büchereiwesen, Studentenaustauschprogrammen, intensivierten internationalen Kulturkontakten sowie der Förderung von „non-governmental agencies in international and cultural developments" insbesondere auch die Durchführung von vergleichenden Studien in der Lehrerausbildung, des Bibliotheks- und Archivwesens, von Umfragen hinsichtlich der Veränderung der öffentlichen Meinung in Bezug auf Bildung und Kultur an. ${ }^{952}$

Die inhaltlich spannenden und auch überaus konstruktiven Vorschläge Kefauvers wurden jedoch, wie nicht weiter verwunderlich, nicht aufgegriffen und landeten wohl in einer Ablage des War Departments.

Die US-Armee war über die übertragene Verantwortung für die zivilen ReorientierungsMaßnahmen ganz offenkundig wenig erfreut und wohl in zweifacher Weise schlicht und ergreifend überfordert: sowohl hinsichtlich der erforderlichen inhaltlichen und intellektuellen Kompetenzen als auch in operativer Hinsicht, als sich die Übernahme ziviler Reorientierungs-Planungen für die Nachkriegszeit mit den laufenden militärischen Kampfhandlungen auf dem europäischen Kriegschauplatz nur schwer in Einklang bringen ließen.

In einem Bericht der US-Armee vom Juni 1944 an das War Department über diesbezügliche Planungen und Aktivitäten kommt die tiefsitzende Frustration der in Italien statio-

951 The U.S. Occupation of Germany: Educational Reform 1945-1949, a.a.O., 2-A-153, 1. J.H. Hilldring, Major General, Director, Civil Affairs Division, to Grayson N. Kefauver, 26. Jänner 1944.

952 NARA II, RG 165, Box 174. Grayson N. Kefauver to Major John Boettinger, United States Army, Civil Affairs Division, „Some Preliminary Suggestions Concerning Program of the United Nations Organizing for Educational and Cultural Reconstruction“, Pentagon, 13. Juni 1944. 
nierten und bereits über konkrete Reeducation-Erfahrungen verfügenden ${ }^{953}$ militärischen Planungsstäbe sowie der latente Konflikt zwischen War Department und State Department hinsichtlich Kompetenzen und Verantwortlichkeit im Bereich der Reeducation klar zum Ausdruck:

"The primary mission of our armies in Europe is to defeat the enemy wherever he may be found. [...] In the matter of education the Army is not the policy-making organization as that prerogative properly belongs to a civilian agency, the Division of Cultural Relations of the State Department, but obviously in military emergencies representatives of the State Department cannot be expected to function immediately, so the Army includes in its agenda the returning of children to school." 954 [Hervorhebung d. Verf].

Über die Kriegsjahre hinweg verwies das War Department, Civil Affairs Division (WARCAD) im Zweifelsfall, das heißt im Kontext kontroversieller Debatten mit dem State Department, wiederholt auf seine Unzuständigkeit hinsichtlich längerfristiger Planungen und Aktivitäten für einen politisch-ökonomischen und kulturellen Wiederaufbau und forderte die Hinzuziehung zusätzlicher ziviler Behörden, deren - aus Sicht der Armee quasi nachrangige - Tätigkeiten allerdings die militärischen Abläufe und Operationen in keiner Weise behindern sollten. ${ }^{955}$

Mit den Aufgaben einer längerfristigen militärischen Besatzung in Europa konnten sich die US-Militärs jedenfalls ebensowenig anfreunden, wie sie auch das Planungsvakuum der

953 Hinsichtlich der schwierigen, großteils unübersichtlichen und für die US-Truppen oftmals schwer einzuschätzenden Situation in Italien vermeldete der militärische Lagebericht: „For instance, a portion of one university faculty approached military officials with detailed plan for the ,purification' of both faculty and curriculum. Unfortunately, in this particular case it would appear that self-interest, as well as the higher cause of patriotism, was the motivating factor. Generally speaking, however, university professors in particular have shown a marked willingness to cooperate with the occupying forces. Pro-allied educators have been placed in charge of the universities. Press dispatches revealed that the University of Catania was reopened in November [1943, d. Verf.] and that the University in Palermo and other universities are expected to be reopened soon. In the universities a priority, generally, has been given to the faculty of the colleges of medicine, veterinary medicine, and agriculture. Vocational and trade schools have been reopened as rapidly as possible but an enormous amount of difficulty has been encountered in opening liberal arts and junior high schools for it is in these classifications that Fascism has demonstrated its greatest tenacity. Many of the elementary schools have been opened both in Sicily and in occupied Italy, and non-Fascist faculties are now virtually complete. Obviously, many problems remain. All education is virtually at a standstill in Apulia, which is the territory controlled by the Badoglio regime, and for which Allied forces have no direct responsibility. The Italian government is attempting to follow the general plan of AMG and supposedly has given a relatively high priority to education but to date little progress has been made."NARA II, RG 165, Box 174, Report on Army Program for Educational Reconstruction in Territory Occupied by U.S. Army, 20. Juni 1944, 6.1988.

954 NARA II, RG 165, Box 174. Report on Army Program for Educational Reconstruction in Territory Occupied by U.S. Army, 20. Juni 1944, 1 f.

955 Tent, Mission on the Rhine, a.a. O., 1944, 15. 
US-Regierung für die Nachkriegszeit, trotz kurzfristiger Hinzuziehung ziviler Experten, nicht aufzufüllen imstande waren. Das primär auf Negativmaßnahmen ausgelegte Planungsdokument JCS 1067, in dem der Komplex der Reeducation als Nebensache abgehandelt wurde, bildete somit nicht nur das einzige offizielle Regulativ für die US-amerikanische Reorientierung nach Kriegsende, sondern für die Alliierte Nachkriegsplanung insgesamt freilich ohne jede Präzisierung konkreter Zuständigkeiten. Die parallel zum JCS ro67 ausgearbeiteten ersten Entwürfe der Handbücher für die Militärverwaltungen in Deutschland sowie Österreich - diese sollten eigentlich bis zu „D-Day“ fertiggestellt sein - mussten ebenfalls revidiert beziehungsweise vom Wortlaut her um Negativ-Formulierungen verschärft werden. ${ }^{956}$ Roosevelt selbst hatte das Handbuch für Deutschland im August 1944 kritisiert "this so-called Handbook is pretty bad“ - und die Einziehung aller Kopien gefordert. ${ }^{957}$

Hinzu kommt, dass - wie Tent hervorhebt - das Wirrwarr amerikanischer Regierungsstellen und deren ungeregelten Zuständigkeiten und Kompetenzen gegen Kriegsende letztlich eine politische Leerstelle („policy gap“) hinterließen, die durch die Potsdamer Konferenz im Sommer 1945 tendenziell noch verstärkt wurde: ,it left the four victors nations each to go its own way with respect to cultural policies in its zone, a fact that later had great significance for the Americans. State Department concern about American educational programs grew as the educators' troubles mounted.“958

Das angesprochene Kompetenzgerangel, die umständlichen und teils verwirrenden Fomalabläufe sowie die unterschiedlichen inhaltlichen Herangehensweisen und Positionen zwischen Militärfachleuten und zivilen Regierungsstellen lassen sich anhand eines Korrespondenzverlaufes rund um einen Entwurf der britischen Vertreter innerhalb der Combined Chiefs of Staff exemplarisch darstellen.

Im Wesentlichen handelte es sich dabei um eine von britischer Seite leicht modifizierte Rohversion des US-Planungsdokuments JCS 1067, die als Handlungsdirektive für den SCAEF-Oberkommandierenden beziehungsweise für alle westalliierten US-Oberbefehlshaber in den Besatzungszonen dienen sollte, etwa in der Form, wie das wenig später im US-amerikanischen „Handbook Military Goverment Austria“ ausformuliert wurde. Ohne an dieser Stelle auf einzelne Punkte des Papiers näher einzugehen, liegt das eigentlich

956 So bezog sich die Originalversion des Handbuchs für Deutschland im Wortlaut des Eingangsparagraphen auf die „Befreiung“ und vermied jede Erwähnung des aggressiven deutschen Militarismus. Der Passus musste überarbeitet werden, und die amerikanischen und britischen Planer, die, wie Ziemke anmerkt, jedes unnötige „psychological handicap“ auf Seiten der Bevölkerung zu vermeiden trachteten, einigten sich trotz Bedenken seitens der SHAEF-Psychological Warfare Division - schließlich auf die Einstiegsformulierung, deren intendierte, zugleich martialische als auch befriedende Konnotation [,at once martial and pacific, forceful and vague“] im deutschen Wort „Eroberer" nicht zum Tragen kam: „We come as conquerers, but not as oppressors“. Ziemke, The U.S. Army in the Occupation of Germany 1944-1946, a.a.O., 88.

957 Roosevelt in einem Memorandum an Henry Stimson vom 26. August 1944. Zit. nach: Ziemke, The U.S. Army in the Occupation of Germany 1944-1946, a.a. O., 85.

958 Tent, Mission on the Rhine, a.a. O., 1944, 10. 
Spannende dieses Entwurfes im nachfolgenden Schriftverkehr, der sowohl das umständliche Prozedere als auch die Auffassungsunterschiede zwischen den amerikanischen und britischen Reeducation-Planern sowie zwischen den amerikanischen zivilen Behörden und US-Militärs deutlich macht.

Bezugnehmend auf die bereits existierende Direktive „CCS ${ }_{55}{ }^{“}$ - ein Vorläufer des späteren JCS Io67 - legten britische Offiziere im August I944 einen Entwurf zur „Control of Education in Germany before Surrender"vor, der als eine Art Orientierungsreglement für den Supreme Commander der Allied European Forces (SCAEF), also den Oberbefehlshaber der britisch-amerikanischen Streitkräfte, dienen sollte. Das Papier, dessen Bestimmungen zur Gänze auch für Österreich gelten sollten, gliederte sich in 23 Paragraphen sowie einen Appendix, der „schwarze“, „graue“ und „weiße Listen“ für die umgehende Entlassung von Personal im Bereich des gesamten Bildungswesens anführte ${ }^{959}$ - Vorschläge, die nach einigem Hin und Her vom amerikanischen „Civil Affairs“-Planungsgremium („US Group CC“) im November 1944 schließlich Wort für Wort übernommen wurden. ${ }^{960}$

Nach Durchsicht des britischen Entwurfs teilte der Vorsitzende des US-Subcommittees, Colonel Horne, dem Leiter der Civil Affairs Division im War Department, General Hilldring, mit, dass der Entwurf den „bekannten britischen Konzepten und Vorstellungen folge" und man um entsprechende Instruktionen aus Washington bitte, um die diesbezügliche Haltung des US-Planungsteams in London festlegen zu können. ${ }^{961}$

959 Unter die „Black-List“ fielen: u. a. Kriminelle, Funktionsträger der NSDAP (vom „Ortsgruppenleiter“ aufwärts) sowie ihrer angeschlossenen Unterorganisationen (NS-Lehrerbund, NS-Dozentenbund, NS-Studentenbund), Angehörige der SS, Offiziere des NSKK oder NSFK (vom Sturmbannführer aufwärts) sowie BDM- oder HJ-Leiter (vom Stammführer bzw. Mädelringführerin aufwärts); unter die „Grey-List“ fielen: u.a. Schulräte oder Schulbeamte vom Regierungsrat aufwärts (die ihren Dienst während des NS-Regimes antraten), Lehrer aller Schultypen, die die Position eines „Jugendwalters“ innehatten; Direktoren/Direktorinnen aller Schultypen, die diese Funktion in der NS-Zeit antraten, Universitätsprofessoren oder Institutsvorstände (ernannt in der NS-Zeit), Funktionsträger des NS-Ärztebunds, des NS-Rechtswahrerbunds, des NS-Reichsbunds für Leibesübungen, sowie des NS-Reichsbunds der Deutschen Beamten; Mitglieder der NSDAP, Offiziere der SA, des NSKK (unterhalb des Grades „Staffelführer“), des NSFK (unterhalb des Grades „Sturmbannführer“); alle Personen, die in ihren Schriften oder öffentlichen Reden den NSRassismus und Militarismus unterstützt haben, sowie alle Personen, gegen die begründeter Verdacht vorliege; die „White-List“ sollte alle Personen umfassen, deren Charakter, berufliche Position, Erfahrung und politische Verlässlichkeit sie als besonders geeignet erscheinen ließen, Positionen mit hoher Verantwortung zu übernehmen. Vgl. The U.S. Occupation of Germany: Educational Reform 1945-1949, Microfilm-Collection Congressional Information Service, edited by Gary H. Tsuchimochi, Tokyo 1991 (Bestand Institut für Zeitgeschichte der Universität Wien, Bibliothek). 2-A-145. Combined Civil Affairs Committee (London). Draft Directive to Supreme Commander Allied Expeditionary Forces on Control of Education in Germany Before Surrender (Memorandum by U.K. Members). Secret, 22. August 1944.

960 NARA II, RG 260, USG CC 1944-45, Box 16, Folder 4, 1944. SHAEF, 1. November 1944, Purge of German Educational Personal.

961 The U.S. Occupation of Germany: Educational Reform 1945-1949, a.a. O., 2-A-139, 1. Thomas S. Horne, Jr., Colonel, G.S.C., U.S. Secretary, London Subcommittee, Combined Civil Affairs Committee, to Ma- 
Daran anschließend wandte sich General Hilldring an den Direktor des Office of European Affairs im State Department, Henry R. Labouisse, mit der Bitte, zu prüfen, ob der britische Entwurf in der vorliegenden Fassung aus Sicht des State Departments in Ordnung gehe. ${ }^{92}$ Das State Departments verwies in seiner Antwort zunächst darauf, dass es zeitsparender gewesen wäre, den Entwurf ohne Umwege gleich vor dem „Combined Civil Affairs Committee“ (CCAC) in London zur Diskussion zu stellen. Darüber hinaus wurde zum Ausdruck gebracht, dass eine derart wichtige Angelegenheit nicht - wie im britischen Entwurf vorgeschlagen - in Form eines „bloß“ formalen Ratgebers gegenüber den SHAEF-Oberkommandierenden abgehandelt werden sollte, freilich ohne an dieser Stelle entsprechende Alternativen zu nennen oder eigene Vorschläge zu unterbreiten. Abschließend monierte das State Department noch den Paragraph 19 des britischen Entwurfs, der rigoros die Neugründung von Studenten- und Lehrerorganisationen sowie Jugendverbänden nach Kriegsende unter Verbot stellte. Hier wünschte sich das State Department eine weicheres, moderateres Vorgehen mit einer eigenen Sicherheitsklausel, die jene Organisationen ausnehmen sollte, für die sich nachweisen ließe, dass sie auf demokratischer Grundlage arbeiten („based upon and governed by democratic principles"). ${ }^{963}$

Im abschließenden Retourschreiben General Hilldrings an Colonel Horne vom Londoner Subcommittee knapp zwei Wochen später wurde - neben dem Hinweis, dass der britische Vorschlag ohne Weiteres im Committee diskutiert werden könne - folgende Verhandlungsposition festgelegt: Zum einen wäre deutlich zu machen, dass der Entwurf entschieden zu weit ins Detail gehe, und daher als Einmischung in die „eigentlichen“ Aufgaben („proper form“) des Supreme Commander zu werten wäre. Zweitens wurde mit Bezug auf die CCS Direktive 55I bürokratisch darauf verwiesen, dass das SHAEF-Oberkommando nach wie vor keine klare Aufgabe im Zusammenhang mit Erziehungsangelegenheiten zugewiesen bekommen habe und von daher kein Handlungsbedarf besteht. Drittens wurde klargestellt, dass - in starker Abwandlung der Auffassung des State Departments und unter implizitem Bezug auf JCS Io67 - neben vielen anderen anfechtbaren Punkten, insbesondere die im Papier vorgeschlagene „weiche“ Behandlung gegenüber dem deutschen Bildungswesen zum gegenwärtigen Zeitpunkt weder im Interesse des US-Subcommittees des „Combined Civil Affairs Committee“ (CCAC) noch im Interesse der Joint Chiefs of Staff liege. Hilldring dazu im Originalwortlaut:

jor General J.H. Hilldring, Director, Civil Affairs Division, War Department, Washington D.C., „Draft Directive to SCAEF on Control of Education in Germany before Surrender", 25. August 1944.

962 The U.S. Occupation of Germany: Educational Reform 1945-1949, a.a.O., 2-A-145. Major General J.H. Hilldring, Director, Civil Affairs Division, War Department, Washington, to Henry H. Labouisse, Jr., Office of European Affairs, to Major General J.H. Hilldring, Director, Civil Affairs Division, War Department, Washington, September 1944, 1.

963 The U.S. Occupation of Germany: Educational Reform 1945-1949, a.a.O., 2-A-143. Henry H. Labouisse, Jr., Special Assistant to the Director, Office of European Affairs, to Major General J.H. Hilldring, Director, Civil Affairs Division, War Department, Washington, September 1944, 1. 
"For your information, the paper has many objectionable features on the whole, suggests a 'soft' treatment of German educational system. It is not in line with the present thinking of the U.S. members of CCAC or the Joint Chiefs of Staff." ${ }^{\prime 64}$

Zuletzt wies Hilldring noch darauf hin, dass das SHAEF-,Handbook for the Military Government of Germany" ohnedies bereits genügend detaillierte Instruktionen hinsichtlich des Schul- und Bildungswesens enthalten würde.

Soweit die technokratische, unkonziliante und harte Position der US-Army zu inhaltlichen Fragen der demokratischen Nachkriegsordnung sowie zu den gegensätzlichen Auffassungen zwischen Amerikanern und Briten, deren bisherige gemeinsame Nachkriegsplanung innerhalb der German Country Unit sich im Sommer 1945 schließlich auflöste. An deren Stelle trat das „US Group Control Council“ (USGCC) sowie die „Control Commission" auf britischer Seite. Durch diese gremiale Trennung waren die US-Planer gegenüber den über qualifiziertere Experten verfügenden Briten künftig auf sich gestellt, wodurch die Planungen aus Sicht der CAD ,ins Schlepptau der Briten“ zu geraten drohten. ${ }^{965}$

Aus diesem sich abzeichnenden planerischen Vakuum heraus erreichte General Hilldring Ende April 1944 gegenüber dem State Department die Einrichtung eines mit zivilen Experten besetzten „Inter-Divisional Committee on Germany“, das umgehend ein Papier zur "Re-Education“ in der Besatzungszeit vorlegte und darin auf die Dringlichkeit verwies, zum Zweck der „psychologischen Abrüstung“ der Deutschen („psychological disarmament“) so rasch wie möglich „a carefully planned program of re-education“ auszuarbeiten, denn die Niederlage allein würde die Deutschen - wie schon nach I9I8 - nämlich keineswegs zu einer konstruktiven und dauerhaft friedlichen Politik bewegen können. ${ }^{966}$ Neben der restriktiven Entnazifizierung sollte zudem jede Anstregung unternommen werden, „to eradicate from the German minds those concepts which have been at the root of Nazi indoctrination", so zum Beispiel Militarismus, Führerkult, die historische Mission der „Weltherrschaft“, der Glaube an die Überlegenheit der deutschen Kultur, der irrationale Nationalismus und der Kult um die Volksgemeinschaft, sowie „Racial megalomania and intolerance“.967

Hinsichtlich der positiven Langzeitmaßnahmen für eine erfolgreiche mentale Rekonstruktion fuhr das zivile „Inter-Divisional Committee“ in seinem Vorschlag mit allen theo-

964 The U.S. Occupation of Germany: Educational Reform 1945-1949, a.a.O., 2-A-153. Major General J, H, Hilldring, Director, Civil Affairs Division, to Colonel Thomas S. Horne, Jr., U.S. Secretary, London Subcommittee, Combined Civil Affairs Committee, c/o G-5 Division SHAEF, New York, 2. September 1944, 1.

965 Tent, Education and Religious Affairs Branch, OMGUS, a.a.O., 69.

966 Germany. Occupation Period: Re-Education. Views of the Inter-Divisional Committee on Germany, CAC-167, Country and Area Committee, 4. Mai 1944, 1. Hoover Institution Archives, Stanford University, John Doane Hartigan Papers, 1909-1958, Box 7: Military reports and career of John Doane Hartigan. Für die Überlassung von Kopien aus diesem Quellenbestand bin ich Herrn Univ.-Prof. DDr. Oliver Rathkolb, zu Dank verpflichtet.

967 Ebd., 4. 
retisch durchdachten Konzepten und Überlegungen des zivilen Reorientierungsdiskurses auf und stellte klar, dass das Reeducation-Experiment nur Erfolg haben kann, wenn dabei die sozialen, ökonomischen und politischen Verhältnisse entsprechend mitberücksichtigt werden und sich die Besatzungsmacht obendrein in jedem Moment bewusst ist, dass jede von ihr getroffene Entscheidung Einfluss auf die Mentalität der Bevölkerung gewinnen wird. ${ }^{968}$ Als kurzfristiges Ziel aller Reeducation-Maßnahmen formulierte das Papier „SelfGovernment" sowie die Beendigung der langwährenden geistigen Isolation:

\begin{abstract}
A " $[\ldots]$ useful beginning in intellectual reorientation can be made by giving the German people straightforward news of world events. Properly chosen motion pictures would likewise make a useful contribution. Gifts from the victors of books and periodical files for university libraries would serve the double ends of providing information and of fostering a demobilization of spirit. Care should be exercised at all times to avoid any implication of superiority of allied cultures to that of Germany." ${ }^{969}$ [Hervorhebung d. Verf.]
\end{abstract}

Die Verfasser plädierten für eine Zusammenarbeit mit ausgesuchten deutschen Intellektuellen und Führungspersönlichkeiten und skizzierten in ihrem Vorschlag ein Maßnahmenkonzept, das neben schulischer Erziehung, Lehrer- und Führungskräftetraining, Erwachsenenbildung, Engagement im Bereich der Jugenderziehung auch Überlegungen zur Nutzbarmachung der spezifisch deutschen Kulturtradition sowie zur systematischen Einbeziehung von Presse, Kino, Theater und Radio in den geistigen Neubeginn beinhaltete.

In geradezu emphatischer Weise verdeutlichte der Diskussionsentwurf der zivilen Experten gegenüber den Militärs, dass es sich bei der gesamten „Reeducation“ beziehungsweise „Reorientation“ um ein progressives Konzept humanistischer Friedenssicherung durch geistige Abrüstung handelt, ein zivilisatorisches Experiment von globaler Dimension, das sowohl Sieger als auch Besiegte miteinschloss:

"German reeducation, if it is to be lastingly effective, should be coordinated with a long-range program of international educational reconstruction. The reeducation of the German nation can never be achieved by unilateral fiat of the victors; it can be effectively conceived only as a special phase of a general policy designed to purify the educational systems of all nations of the excesses of narrow and short-sighted nationalism, of racial intolerance, and of the perversion of scientific truth in the national interest. Such a program should seek to combat the virus of ultra-nationalism in education, both in Germany and elsewhere; to create a corpus of universally accepted knowledge and ideals as the minimum basis for a general meeting of minds; and to achieve psychological disarmament among nations [...]". ${ }^{970}$ [Hervorhebung d. Verf.]

968 Ebd., 5.

969 Ebd., 6 f.

970 Ebd., 10. 
In einem Kommentar zum Entwurf des Inter-Divisional Committees, den der konservative Hardliner George F. Kennan - zum damaligen Zeitpunkt politischer Berater des US-Botschafters in London - verfasste, relativierte dieser die unterbreiteten Vorschläge für ein ziviles Langzeit-Reorientierungs-Programm, wohl auch, weil diese auf eine möglichst frühe Selbstverwaltung („Self-Government“) der Deutschen zielten. Die Deutschen, so Kennan in seiner pessimistischen Sicht, wären „primitive and childish“, „observant and imitative“, sodass ein effizientes Besatzungsregime, in „businesslike, purposeful manner, with firmness and decision [...] making it evident that we are people who know what we want and how we propose to get it" mehr Aussicht auf Erfolg haben würde. ${ }^{971}$ Kennans Beurteilung der „erzieherischen“ Vorschläge - ,well-written paper which contains a great deal that is true" - untergrub mit seinem wenig optimistischen Fazit jede weitere Diskussion innherhalb der militärischen Planungsgremien und stellte sogar - in diametraler I8o-Grad-Wendung - die Kooperation mit unbelehrbaren Nationalisten als womöglich einzige Option des gesellschaftlichen Wandels innerhalb der nächsten Generationen in Aussicht:

"I think we should be extremely circumspect in counting on the existence in Germany of any democratically minded people, strong enough to help us in our purposes. It may well be that we will have to find our support rather in repentant nationalists who have been persuaded by the force of events of the necessity of a less aggressive concept of Germany's destiny. In any case, I think the letter and connotation of the word 'democracy' are both seriously compromised in Germany, and will scarcely be accepted by this generation as an acceptable substitute for a concise and constructive teleology of German national development. ${ }^{{ }^{972}}$ [Hervorhebung d. Verf.]

Wie überaus mager die Ergebnisse der militärischen US-Reorientation-Beratungen ausfielen und wie viele Stellen an diesen hochgradig ineffektiven Planungen zugleich involviert waren, zeigen die in leerformelhafter Sprache verfassten Geheimberichte der Joint Chiefs of Staff, die sich mehr um Fragen der Logistik und Demobilisierung drehten, als um Reeducationsmaßnahmen. So finden sich in Summe neun militärische US-Einrichtungen aufgelistet, die 1944 mit Planungen zur Reorientation befasst waren. ${ }^{973}$

971 George F. Kennan, Department of State, Division of European Affairs, „Comment in the Paper: Germany - Occupation Period: Re-education, CAC-167, 11. Mai 1944, 1. Hoover Institution Archives, Stanford University, John Doane Hartigan Papers, 1909-1958, Box 7: Military reports and career of John Doane Hartigan.

972 Ebd.

973 NARA II, RG 260, USG CC 1944-45, Box 27, Folder 14. Joint Chiefs of Staff, Coordination of Planning for the U.S. Reorientation of Effort Upon the Defeat of Germany. Note by the Secretaries, A.J. McFarland, E.D. Graves, Jr., [Secret], 20. Mai 1944. Unter „Appendix B“ finden sich unter dem Titel „Agencies Currently Engaged In Planning On The Subject Of Reorientation And Summary Of What Is Being Done“ folgenden Einrichtungen aufgezählt: (1) Joint Chiefs of Staff [Joint Strategic Survey Committee 
Tatsächlich einigten sich die Alliierten, wie bereits erwähnt, dann erst im April I945 auf eine erste schriftliche Rahmenrichtlinie für die Besatzungsaufgaben, die unter dem Kürzel JCS ro67 öffentlich bekannt wurde. Abgesehen von der harten Politik der „3 D's“Denazification, Demilitarisation, Deindustrialisation - waren darin jedoch so gut wie keine weiteren Spezifikationen hinsichtlich der intendierten geistigen Reorientierung zu finden.

Der gesamte anstehende Aufgabenbereich der „Reeducation“ blieb in diesem einzigen, zu Kriegsende vorliegenden alliierten Planungsdokument jedoch weitgehend undefiniert. Die zum Zeitpunkt der deutschen Kapitulation vorliegenden Handbücher für die Militärverwaltungen in Deutschland und Österreich konnten diese Leerstelle durch die bloß taxative Auflistung von Entnazifizierungs- und Säuberungsmaßnahmen - noch dazu ohne hinreichend klare Instruktionen für konkrete Verantwortlichkeiten in der Durchführung in keiner Weise füllen.

\section{Randnotiz zu einem fehlgeschlagenen Experiment der US-Armee-POW-Camps zur Reeducation}

Dass die US-Militärs im Bereich der Reeducation-Planungen so wenig Interesse an den Tag legten, erstaunt umso mehr, als die amerikanische Armee ab I943/44 damit begann, auf dem Boden der Vereinigten Staaten eine Reihe von Gefangenlagern für „Prisoners of War“ (POW) einzurichten. In diesen POW-Camps startete die US-Armee Programme zur Umerziehung insbesondere der deutschen Kriegsgefangenen und führte - zum Teil gemeinsam mit den Briten in sogenannten „Combined Services Detailed Interrogation Center “ (CSDIC) - Kriegsgefangenenverhöre und Moralanalysen durch. ${ }^{974}$ Derartige, auf Umerziehung und Verhörpraxis ausgerichtete POW-Lager wurden während des Krieges auch von den Briten ${ }^{975}$ und den

(JSSC), Joint Production Survey Committee (JPSC), Joint Staff Planers (JPS), Joint Logistics Committee (JLC), CAD, Office for Occupied Areas/Navy Department]; (2) The Combined Civil Affairs Committee (CCAC); (3) The Civil Affairs Division (CAD); (4) The United Nations Relief and Rehabilitation Administration (UNRRA); (5) The Foreign Economic Administration (FEA); (6) The Joint Staff Planers; (7) The Joint Logistics Committee; (8) Special Planning Division of the War Department/Special Staff; (9) Chief of Naval Operations.

974 Siehe: Rafael A. Zagovec, „The Mind of the Enemy“. Kriegsgefangenenverhöre und die Moralanalysen der westalliierten Aufklärung. In: Günter Bischof/Stefan Karner/Barbara Stelzl-Marx (Hrsg.), Kriegsgefangene des Zweiten Weltkriegs. Gefangennahme - Lagerleben - Rückkehr (= Kriegsfolgen-Forschung. Hrsg. v. Stefan Karner, Bd. 4.), Wien - München 2005, 267 f.; vgl. dazu weiters: Robert D. Billinger, Jr., Nazi POWs in the Tar Heel State, Gainsville et al. 2008; Arnold Krammer, Nazi Prisoners of War in America, Chelsea 1991.

975 Obwohl die rund 400.000 Kriegsgefangenen der Briten in Reeducation-Lagern wie Ascot Park, Wilton Park oder „373 Camp Wolfsberg“ in der Steiermark mit einem durchaus ambitionierten Programm konfrontiert wurden, war die Teilnahme daran freiwillig - nur eine Minderheit nahm daran teil. Siehe: Kastner, 373 Camp Wolfsberg. Britische Besatzungslager in Österreich von 1945 bis 1948, a.a.O.; wei- 
Sowjets eingerichtet. ${ }^{976}$ Wie die Durchsicht der neueren Literatur zu den amerikanischen POW-Camps zeigt - die Analysen für die britischen und sowjetischen Lager fallen ähnlich aus -, blieben die vom War Department weitgehend unkoordiniert durchgeführten Umerziehungs-Aktivitäten in letzter Konsequenz nicht nur völlig wirkungslos, sondern zementierten darüber hinaus noch bestehende ideologische Vorurteile, Abwehrhaltungen und Ressentiments der darin Inhaftierten. Wenn im Folgenden dieses Experiment trotzdem, wenn auch in aller Kürze, resümiert werden soll, dann weniger, weil den durchgeführten Maßnahmen im Zusammenhang der Reeducation eine bildungspolitische Relevanz für die Nachkriegszeit zukommt, sondern ausschließlich deshalb, um dieses ebenso kuriose wie weitgehend ergebnislose militärische Umerziehungsexperiment hier nicht unerwähnt zu lassen.

ters: Weiß, Re-education. Der Umerziehungsversuch von Kriegsgefangenen in Großbritannien während und nach dem Zweiten Weltkrieg, a.a.O., 109 f.; weiters: Heiner Wember, Umerziehung im Lager. Internierung und Bestrafung von Nationalsozialisten in der britischen Besatzungszone, Essen 1992; Bob Moore, Italienische Kriegsgefangene in britischem und amerikanischem Gewahrsam 1941 bis 1947. Eine vergleichende Sozialgeschichte. In: Bischof/Karner/Stelzl-Marx (Hrsg.), Kriegsgefangene des Zweiten Weltkriegs, a.a.O., $287 \mathrm{ff}$. Von den 15.000 in Großbritannien befindlichen österreichischen Kriegsgefangenen wurde nach „screenings“ nur eine geringe Zahl als „schwarz" (d.h. als Nazis) eingestuft. Vgl. Wolfgang Weber, Großbritannien, Österreich - und ein NS-Erbe. Österreichische Soldaten der deutschen Streitkräfte in britischer Kriegsgefangenschaft 1943 bis 1947. In: Bischof/Karner/Stelzl-Marx (Hrsg.), Kriegsgefangene des Zweiten Weltkriegs, a.a.O., 309; Renate Held, Kriegsgefangenschaft in Großbritannien. Deutsche Soldaten des Zweiten Weltkriegs in britischem Gewahrsam, München 2008; zuletzt: Neville Wylie, Barbed Wire Diplomacy. Britain, Germany, and the politics of Prisoners of War, 1939-1945, Oxford 2010. Zur umgekehrten Perspektive der westalliierten Gefangenen in NS-Gefangenenlagern siehe: Arieh J. Kochavi, Confronting captivity. Britain and the United States and their POWs in Nazi Germany, Chapel Hill 2005.

976 In den sowjetischen Umerziehungslagern sollten aus „,faschistischen 'Gefangenen ,Antifaschisten “ und ,Freunde der Sowjetunion “ " gemacht werden. Siehe: Jörg Morré, Umerziehung in der sowjetischen Kriegsgefangenschaft. Deutsche und Österreicher in der „Antifa“. In: Bischof/Karner/Stelzl-Marx (Hrsg.), Kriegsgefangene des Zweiten Weltkriegs, a.a. O., $152 \mathrm{f}$;; weiters: Michael Pucher, Umerziehung im sowjetischen Kriegsgefangenenlager Talicy, Dipl.-Arb., Univ. Graz 1997; Stefan Karner, In Stalin's Custody: The Soviet Camp System for Prisoners of War during and after World War II. In: Günter Bischof/Fritz Plasser/Barbara Stelzl-Marx (Eds.), New Perspektives on Austrians and World War II (=Contemporary Austrian Studies, Vol. 17) New Brunswick - London 2009, 121 ff.; einen chronologischen Überblick über die Kriegsgefangenenlager beider Weltkriege bietet: Rüdiger Overmans, „Hunnen“ und „Untermenschen" - deutsche und russisch/sowjetische Kriegsgefangenenerfahrungen im Zeitalter der Weltkriege. In: Bruno Thoß/Hans Erich Volkmann (Hrsg.), Erster Weltkrieg. Zweiter Weltkrieg. Ein Vergleich. Krieg, Kriegserlebnis, Kriegserfahrung in Deutschland. Hrsg. im Auftrag des militärgeschichtlichen Forschungsamtes, Paderborn - München - Zürich 2002, 335 ff.; zur unterschiedlichen Behandlung von deutschen und österreichischen Gefangenen in russischen Lagern siehe: Rüdiger Overmans, „Ostmärker“ oder Österreicher? Nationale Differenzierung zwischen Deutschen und Österreichern in sowjetischem Gewahrsam während des Zweiten Weltkriegs. In: Zeitgeschichte, 29. Jg., 2002, Heft 3, 133 ff.; zuletzt: Susan L. Carruthers, Cold War Captives. Imprisonment, escape and brainwashing, Berkely 2009. 
Schon bei der Errichtung erster POW-Camps für die deutschen Wehrmachtsgefangenen des Afrika-Corps im Mai 1943 war das mit Kriegsgefangenen betraute War Department mit dem spezifischen Verwaltungsproblem einer wachsenden Zahl inhaftierter Soldaten konfrontiert, die zum Teil noch an den „Endsieg“ glaubten und in den Camps mitunter regelrechten Gesinnungsterror entfalteten. ${ }^{977}$ Von ursprünglich 2.00o stieg deren Zahl bis Mai I945 auf 378.000 gefangene Wehrmachtsoldaten an; sie wurden im Rahmen des sogenannten „Liberty Ship Program“ in die USA transferiert und dort auf rund 500 POW-Lager verteilt, die, geografisch weit verteilt, zumeist in isolierten ländlichen Gebieten errichtet waren. ${ }^{978}$

Ein zentrales Motiv für die Verschiffung von Kriegsgefangenen in die Vereinigten Staaten war zunächst der große Bedarf an Arbeitskräften insbesondere im Bereich der Landarbeit: „Tens of thousands of POWs, then, fulfilled a vital economic role in rural areas where the War Manpower Commission of the War Food administration had certified that labor was scarce." ${ }^{\text {"979 }}$

Zwischen den abseits der Öffentlichkeit zumeist im Hinterland eingerichteten amerikanischen POW-Lagern - man befürchtete negative Presseberichterstattung - und den anlaufenden militärischen Nachkriegsplanungen gab es nur punktuelle, völlig unsystematische Verbindungen, zum Beispiel in Form der vom OSS durchgeführten „Prisoner of War Interrogations“. Das Ziel dieser Kriegsgefangenenverhöre, die als Teil der psyschologischen Kriegsführung von der „Psychological Warfare Division“ (PWD/SHAEF) durchgeführt wurden, war einerseits die militärische „Feindaufklärung“, zum anderen sollten die Befragungen Einblick in typologische Einstellungsmuster geben, um so Aufschluss über das potenzielle Nachkriegsverhalten der deutschen Bevölkerung zu bekommen. Kürzlich von Sönke Neitzel und Harald Welzer publizierte Abhörprotokolle des britischen militärischen Geheimdienstes geben ein ungemein facettenreiches und geradezu ,unverfälschtes ‘ Zeugnis von Einstellungen und Stimmungslagen deutscher Soldaten während des Krieges. ${ }^{980}$ Nach Kriegsende wurden derartige Kriegsgefangenverhöre mitunter auch durchgeführt, um - teilweise eingebettet in komplexe methodische Settings - von hochrangigen NS-Kadern indirekt Auskunft über mögliche politische Entwicklungsszenarien des reaktionären „vierten“ Lagers und deren Erfolgsaussichten zu bekommen. ${ }^{981}$

977 Vgl. Gerda Theuermann, Umerziehung und Amerikabild: „Der Ruf. Zeitung der deutschen Kriegsgefangenen in den USA“, Dipl.-Arb., Univ. Graz 1992, $70 \mathrm{ff}$.

978 Ron Robin, The Barbed-Wire College. Reeducating German POWs in the United States during World War II, Princeton 1995, 6.

979 Ebd., 6.

980 Sönke Neitzel/Harald Welzer, Soldaten. Protokolle vom Kämpfen, Töten und Sterben, Frankfurt a. Main 2011.

981 So wurde bspw. nach Kriegsende der ehemalige Gauleiter und Reichsstatthalter von Kärnten, sowie Oberste Kommissar der Operationszone „Adriatisches Küstenland“, Friedrich Rainer, gemeinsam mit dem früheren Gauleiter von Wien, späteren SS und Polizeiführer des Distrikts Lublin und Verantwortlichen für die Ermordung der Juden in Polen („Aktion Reinhardt“), Siegfried Uiberreither, im kärntnerischen Krumpendorf interniert, wo Rainer gebeten wurde, sich (in einem zwecks Abhör verwanzten Zimmer) Gedanken 
Der Hauptwert der Kriegsgefangenenverhöre lag, wie Rafael A. Zagovec hervorhebt, darin, dass durch die durchgeführten Vernehmungen und protokollierten Erlebnisberichte auch hochrangiger NS-Offiziere und sonstiger militärischer Führungspersonen eine materiale Grundlage für die Verurteilung der NS-Massenverbrechen bei den Nürnberger Prozessen geschaffen wurde. ${ }^{92}$ Des Weiteren gibt es Indizien, dass die Erfahrungspraxis der Verhöre die Basis für die theoretische Weiterentwicklung der amerikanischen Soziologie in den nachfolgenden Jahrzehnten schuf. ${ }^{983}$

Durchgeführt wurden die unterschiedlich geführten US-Verhöre, deren Ergebnisse allerdings nie zusammengeführt beziehungsweise analysiert wurden, in den meisten Fällen von deutschen und österreichischen Emigranten. ${ }^{984}$

De facto ließ sich dieses großangelegte Kriegsgefangenen-Projekt aber nicht lange vor der US-Öffentlichkeit geheimhalten, die angesichts der großen Zahl an NS-Gefangenen und ruchbar gewordenen Gewalttaten in den Lagern überaus negativ reagierte und die innere Sicherheit gefährdet sah. Wohl nicht zuletzt deshalb, und weil die deutschen Kriegsfangenen weniger „unkorrigierbar" erschienen als die „supposedly fanatical Japanese“, entschloss sich das US-Militär im Herbst 1943 zu einer quasi edukativen Maßnahme durch den Provost Marshall General (OPMG): Unter der Leitung von Col. Edward Davison ${ }^{985}$ innerhalb der neu geschaffenen „Special Projects Division“(SPD) wurden Vorbereitungen für ein zunächst geheimgehaltenes Programm zur „intellectual diversion“ der deutschen Kriegsgefangenen getroffen. ${ }^{986}$ Die Geheimhaltung erfolgte deshalb, weil die Genfer Konvention jede propagandistische Indoktrinierung von Kriegsgefangenen verbot und und man außerdem Vergeltungsmaßnahmen an amerikanischen Soldaten in deutscher Gefan-

über die „Zukunft Österreichs“ zu machen. Dieser brachte seine Ansichten unter dem Titel „The Future of Austria" zu Papier, die nachfolgend den Vertretern der drei politischen Parteien in anonymisierter Form zur politischen Bewertung vorgelegt wurden. Siehe: Christian H. Stifter, NS-Kriegsverbrecher als „intelligente Analysten“ der politischen Nachkriegssituation? Anmerkungen zu einem „Experiment britischamerikanischer Militärstellen in Österreich 1945. In: Zeitgeschichte, 28. Jg., 2001, Heft 6, $321 \mathrm{ff}$.

982 So war bspw. Marcel Prawy als Interview-Ausbildner tätig, oder Klaus Mann als PWB-Verhörspezialist an der italienischen Front eingesetzt. Siehe: Zagovec, „The Mind of the Enemy“, a.a.O., 279.

983 Zagovec, „The Mind of the Enemy“, a.a. O., $270 \mathrm{f}$.

984 Ebd., 271, Anm. 16.

985 Edward Davison, ein gebürtiger Schotte und erst kurz zuvor naturalisierter US-Bürger, war Universitätsprofessor und Poet, der vorher in der „Morale Division“ der US-Army tätig war. Wie Robin schreibt, hatte Davison „no academic or professional experience in the study of German culture; in fact he had no meaningful command of the German language at all." Robin, The Barbed-Wire College, a.a.O., 44. Die im Zuge des anlaufenden Projektes angeworbenen leitenden Mitarbeiter von Davison mit mehrheitlich akademischem Background waren: sein Stellvertreter Maxwell McKnight, Yale-Jurist, Walter Schoenstadt, früherer Herausgeber des Berliner Tagblatts und "glühender Kommunist“, der Amerikanist Howard Mumford Jones, der deutsche Historiker Henry Ehrmann, der 1940 in den USA ankam, der Philosoph T.V. Smith, ein Schüler John Deweys, sowie der Spezialist für Alte Geschichte, Michael Ginsburg. Siehe: ebd., $46 \mathrm{ff}$.

986 Robin, The Barbed-Wire College. Reeducating German POWs, a.a.O., 8. 
genschaft befürchtete. ${ }^{987}$ Mitangeregt worden war das POW-Project vom State Department, als Secretary of State, Cordell Hull, Kriegsminister Henry L. Stimson Ende März I943 vorschlug, , deutschen Kriegsgefangenen Verständnis für amerikanische Institutionen und Ideale beizubringen“. 988

Tatsächlich war der verantwortliche militärische Leiter des gesamten US-POW-Programms, Provost Marshall General Allen W. Gullion, jedoch einer der entschiedensten Gegner der gesamten Reeducation, weil er sie für nutzlos und auch kindisch hielt. ${ }^{989}$ Es verwundert daher weder, dass das War Department - unterstützt vom State Department erst im März I944 erste Überlegungen zur „,indoctrination of German prisoners of War“ formulierte, noch, dass die darin entwickelte Strategie einer Umerziehung wenig durchdacht war und bis über das Kriegsende hinaus auch nicht weiter modifiziert wurde.

Obwohl das POW-Reeducation-Programm im Kern keineswegs auf eine simple ideologische Indoktrinierung der Kriegsgefangenen abzielte, war die kaum durchdachte $\mathrm{Mi}^{-}$ schung aus Laissez-faire, Hinführung zu hochintellektueller Lektüre, Schulunterricht auf eher niedrigem Niveau sowie die unterschiedslose Behandlung unterschiedlicher militärischer Dienstränge nur wenig dazu angetan, einen profunden Einstellungswandel bei den Inhaftierten hervorzurufen.

Ausgehend von der wohl keinesfalls unzutreffenden Annahme, dass die meisten deutschen Kriegsgefangenen Amerika als unkultiviertes, minderwertiges Land betrachteten, sollte die positive „Indoktrinierung“ darauf gerichtet sein, „to reach the Germans by presenting to them in so far as is possible in the circumstances the best aspects of American life and institutions." 990

Die ursprünglich beabsichtigte Vorbildwirkung und das Lernen durch konkrete Erfahrung kamen aber schon allein deshalb nicht zum Tragen, da die Reeducation-Offiziere aufgrund mangelnder Sprachkenntnisse kaum direkten Zugang zu den Gefangenen hatten. Die Hoffnungen, die sich manche zeitgenössische akademische Beobachter des Experiments von außen machten, wie zum Beispiel der emigrierte deutsche Soziologe und Psychiater jüdischer Herkunft, Curt Bondy, erfüllten sich ebenso wenig wie die Warnungen hinsichtlich der negativen Auswirkungen zu großer Freiheiten im spezifischen Setting der Gefangenenlager Beachtung fanden:

987 Theuermann, Umerziehung und Amerikabild, a.a.O., 73; weiters: Robin, The Barbed-Wire College. Reeducating German POWs, a.a.O., 8.

988 Vgl. Hermann Jung, Die deutschen Kriegsgefangenen in amerikanischer Hand - USA (= Zur Geschichte der deutschen Kriegsgefangenen des Zweiten Weltkriegs, Bd. X/1), Bielefeld 1972, 213. Hier zit. nach: Theuermann, Umerziehung und Amerikabild, a.a.O., 73, Anm. 431.

989 Robin, The Barbed-Wire College. Reeducating German POWs, a.a.O., 22.

990 NARA II, RG 389, Box 1603. Department of State, Special War Problems Division, „Indoctrination of German Prisoners of War, 2. März 1944. Hier zit. nach: Robin, The Barbed-Wire College. Reeducating German POWs, a.a.O., 25. 
"German prisoners of war brought to this country have experienced the fact that their ship has not been sunk on her way across the Atlantic, that New York has not been bombed, that there is plenty food etc. German soldiers can learn much from the attitude of the American army: the good relationship between officers and enlisted men, the difference between necessary discipline and false regimentation etc.

The German soldiers must themselves experience what freedom of speech means in this country, by reading periodicals, newspapers, listening to the radio, and by having discussions. In my opinion, however, it would be a false policy to give the prisoners too much freedom. [...] The responsible American officers in the camps should understand that the policy of laissez-faire would be a bad one; that too much freedom, too little discipline, and too little influence would only strengthen the belief of the prisoners that the Americans are weak and sissified, and that they are afraid of the Germans. [...]

Also the extremely strong anti-semitism may be changed by new experiences with American Jewish soldiers. This hatred is not built up on real contact with jews." 991

Und die Zusammenstellung ausgewählter Lektüre - an erster Stelle Bücher wie Stephen Vincent Benéts „Amerika“ oder Wendell Willkies „One World“-, die fallweise Präsentation von Spielfilmen mit erzieherischem Wert, die nicht gerade glücklich ausgewählt waren, da sie vorhandene Negativ-Stereotype über Amerika tendenziell verstärkten, ${ }^{992}$ kollektives Anhören von ausgewählten OWI-Radiosendungen, ${ }^{993}$ Vorträge über die amerikanische Demokratie oder den „American way of life“, die Anregung zu Diskussionen sowie die Ermutigung zur Herausgabe eigener Lagerzeitungen hatten ebensowenig Erfolg wie der gut gemeinte, im Grunde aber naive Versuch der zuständigen POW-Offiziere, hartgesottenen Nazis mit Vorträgen zur Geschichte des Altertums oder klassischer Philosophie beikommen zu können:

"The reeducation program represented an attempt to counteract the notion that humanities were 'archaic' and 'trivial' by proving that hardened Nazis could be transformed when exposed to college-type Western Civilization courses and reading material. [...] Intellectual history, literary criticism, and the teaching of complex ideas and intellectual abstractions furnished the backbone for reeducation." ${ }^{994}$

991 Curt Bondy, Observation and Reeducation of German Prisoners of War. In: Harvard Educational Review, 1944, No. 14, 16. Curt Bondy (1894-1972), Vorkämpfer für die pädagogische Reform des Jugendstrafvollzugs, Mitarbeiter von Martin Buber. Aus dem KZ-Buchenwald gelang Bondy über Holland und England die Flucht in die USA, wo er dann als Universitätsprofessor lehrte. 1950 kehrte Bondy nach Hamburg zurück. Siehe: Uta Schäfer-Richter/Jörg Klein, Die jüdischen Bürger im Kreis Göttingen, 1933-1945. Göttingen - Hann - Münden - Duderstadt. Ein Gedenkbuch. Hrsg. v. Karl-Heinz Manegold. 2. Aufl., Göttingen 1993, $44 \mathrm{f}$.

992 Robin, The Barbed-Wire College. Reeducating German POWs, a.a. O., $109 \mathrm{f}$.

993 Ebd., $147 \mathrm{fff}$.

994 Ebd., 55. 
Im Sommer 1944 wurde schließlich damit begonnen, spezielle POW-Camps einzurichten - so zum Beispiel in Fort Kearny, Fort Wetherill oder Fort Getty (Rhode Island) oder in Camp Van Etten (New York) und in Fort Eustis (Virginia) ${ }^{995}$-, wo rund 25.00o eigens ausgewählte, antinazistisch eingestellte deutsche Kriegsgefangene in kooperativer Zusammenarbeit mit ihren amerikanischen Bewachern demokratische Schulungsprogramme durchlaufen sollten, um danach als Multiplikatoren einer überzeugt antifaschistischen Gesinnung wirksam zu werden. ${ }^{996}$ Eine besondere Einrichtung bildete dabei die im November 1944 im Camp Van Etten eingerichtete „Idea Factory“, die dann nach Fort Kearny auf Rhode Island übersiedelte. Hier wurden 84 ausgewählte POW's mit besonderen intellektuellen Qualifikationen zusammengezogen, hauptsächlich, um eine hochqualitative, sanft propagandistische Kriegsgefangenen-Zeitung für andere Gefangenenlager herauszugeben, ${ }^{997}$ von der unter dem Titel Der Ruf. Zeitung der deutschen Kriegsgefangenen in den USA immerhin 26 Ausgaben in einer Auflage von Ir. 0oo Stück erschienen. ${ }^{998}$ Paradoxerweise wurden die für dieses Projekt ausgewählten, „nicht-nationalsozialistischen“ und hochgradig intellektuellen Gefangenen von den US-Lagerkommandanten - ohne Unterschied zu Kriegsgefangenen in anderen Lagern - als „Kriminelle“ behandelt. ${ }^{999}$

Redaktionell gestaltet wurde die in englischer und deutscher Sprache produzierte Zeitschrift, die von den überzeugten Nazis in den Lagern - trotz der nur vorsichtig artikulierten Distanzierung vom „Dritten Reich“ - nicht zuletzt aufgrund der positiven Darstellung Amerikas öffentlich boykottiert wurde, ${ }^{1000}$ unter anderem von Mitgliedern der späteren

995 Henry W. Ehrmann, An Experiment in Political Education. The Prisoners-of-War Schools in the United States. In: Social Research, 1947, No. 14, 304.

996 Die eher vagen Auswahlkriterien bildeten das bisherige Verhalten in den Lagern, sowie die nachweisliche Nicht-Zugehörigkeit zur NSDAP oder einer ihrer Unterorganisationen. Das Training war auf „democratic leadership" ausgerichtet und sollte auch unter den bereits in Distanz zur NS-Ideologie befindlichen Inhaftierten - so die nachträgliche theoretische Analyse - die demokratische Orientierung befestigen helfen, denn es sei „ [it is] clear that also non-Nazis have to undergo a thorough reorientation before they are able to help in deflecting the development of Germany into new channels." David M. Levy, The German Anti-Nazi: A Case Study. In: American Journal of Orthopsychiatry, Juli 1946, Vol. 16, 507 f. Zit. nach: Ehrmann, An Experiment in Political Education, a.a. O., 305.

997 Tatsächlich existierten bis Kriegsende auf Boden der USA rund 70 andere deutsche Lagerzeitungen, die zum Teil von den Kriegsgefangenen selbst gestaltet wurden; schon allein wegen der Sprachbarriere waren deren Inhalte jedoch kaum im erforderlichen Ausmaß zu kontrollieren. Robin, The BarbedWire College. Reeducating German POWs, a. a. O., 60. Nach der bedingungslosen Kapitulation im Mai 1945 schrieb beispielsweise die im Camp White (Oregon) herausgegebene deutsche Lagerzeitung Heimat von der „blackest hour of our lives“. Zit. nach: Rafael A. Zagovec, Islands of Faith: National Identity and Ideology in German POW Camps in the United States, 1943-1946. In: Zeitgeschichte, 29. Jg., 2002, Heft 3, 116.

998 Theuermann, Umerziehung und Amerikabild, a.a.O., 93.

999 Robin, The Barbed-Wire College. Reeducating German POWs, a.a.O., 59 f.

1000 Theuermann, Umerziehung und Amerikabild, a.a.O., 86. 
„Gruppe $47^{“ 1001}$ wie Alfred Andersch oder Hans Werner Richter, die dann nach dem Krieg und ihrer Rückkehr nach Deutschland bezeichnenderweise deutlich anti-amerikanische Ansichten vertraten. ${ }^{1002}$

Wie Ron Robin verdeutlicht, blieben die POW's in ihrem Lageralltag, der, kaum supervidiert von US-Wachpersonal, von arbeitsbefreiten deutschen Unteroffizieren organisiert wurde, letztlich sich selbst überlassen, wodurch sich innerhalb kürzester Zeit strikte militärische Disziplin und soldatische Hackordnung mit internen Straf- und Vergeltungsmaßnahmen für Abtrünnige sowie ritualisierte NS-Glorifizierung etablierten. Gegenüber den US-Soldaten lebten im Lageralltag ideologische Verhaltens- und Einstellungsmuster auf, die die deutschen Kriegsgefangenen, die weiterhin vom „Endsieg“ träumten, in ein Gefühl der Überlegenheit gegenüber ihren amerikanischen Bewachern versetzten und diese nicht selten sogar verhöhnten:

"The individual soldier's duty was to humiliate the American wardens - the equivalent of sniping. A common tactic was to praise American guards for their treatment and adequate food, promising them that they would be remembered and rewarded after the ultimate German victory. Larger formations and, at times, the entire camp launched more concerted attacks against the enemy, ranging from singing of Nazi marching songs [...]. Ultimately, scorn for the enemy was demonstrated by an elaborate panoply of symbols: the use of the Nazi salute both among themselves and upon confronting an American officer, and the conspicuous and defiant display of Nazi regalia, such as the waving of homemade swastika banners when prisoners passed through American towns on their way to work details. [...] Nazi holidays, including Hitler's birthday, were celebrated routinely in the early stages of captivity. These ceremonies continued secretly after American officials banned them." ${ }^{1003}$ [Hervorhebung d. Verf.]

Unter den kriegsgefangenen Wehrmachtsoldaten befanden sich rund 30.00o Österreicher, ${ }^{1004}$ die, trotz in der New York Times erhobenen Forderungen nach einer Separierung, ${ }^{1005}$ nicht von den deutschen POWs getrennt wurden; sie wurden auch trotz Moskauer Deklaration und der allgemeinen Trendwende der US-Politik gegenüber Österreich

1001 Vgl. Wilfried van der Will, The Agenda of Re-education and the Contributors of Der Ruf 1946-47. In: Stuart Parkes (Ed.), The Gruppe 47. Fifty years on a re-appraisal of its literary and political significance, Amsterdam et al. 1999.

1002 Robin, The Barbed-Wire College. Reeducating German POWs, a.a.O., $66 \mathrm{f.}$

1003 Ebd., $34 \mathrm{f}$.

1004 Zagovec, Islands of Faith: National Identity and Ideology in German POW Camps, a.a. O., 114.

1005 So kritisierte die New York Times die Aussage von Brig. Gen. Bryan, als Provost Marschall zuständig für das POW-Programm, dass die USA sich strikt an die Genfer Konvention halten würden, mit Hinweis auf die nicht erfolgte Trennung der österreichischen von den deutschen Kriegsgefangenen. Siehe: „Austrian Prisoners Harmed - Confinement With Germans Here Viewed as Against Geneva Convention“. In: New York Times, 20. Juli, 1944, 18. 
und trotz Urgenzen des State Departments bis Sommer 1945 nicht als „Österreicher“ identifiziert. $^{1006}$

Major Edward Davison vertrat die Ansicht, dass eine Segregation der Österreicher für das POW-Programm keinen besonderen Vorteil bieten würde, da sich unter diesen viele „rabid Nazis“ befänden. ${ }^{1007}$ Tatsächlich dürften die ideologische Gemeinschaft mit den deutschen Kriegsgefangenen, der aufrechterhaltene Wehrmachtsdrill sowie die Weigerung der US-Militärs, die Österreicher in eigenen Lager-Abschnitten unterzubringen, dafür gesorgt haben, dass so manche österreichische Soldaten erst anlässlich ihrer Heimkehr erkannten, dass sie „Österreicher“ sind. ${ }^{1008}$

Eine völlig andere Auffassung vertrat diesbezüglich die Austro American Tribune, die im August 1943 darlegte, wie immens wichtig die umgehende Separierung der österreichischen Kriegsgefangenen von den Deutschen wäre. Die Alliierten, so der namentlich nicht gezeichnete Beitrag, hätten sich bereits auf die Wiederherstellung eines unabhängigen Österreich als Kriegsziel festgelegt, was die maximale Stärkung des österreichischen Widerstands sinnvoll erscheinen lassen würde; zudem würde sich die Kriegsunwilligkeit der Österreicher mittlerweile auch durch zahlreiche Desertionen in Griechenland, Norwegen, Jugoslawien und insbesondere in Stalingard klar gezeigt haben. ${ }^{1009}$ Darüber hinaus würde die Separierung der österreichischen Kriegsgefangenen - in nationalsozialistischer Diktion ja immerhin ein Teil der deutschen „Herrenrasse“ - auch einen wichtigen propagandistischen Gegenschlag gegen die NS-Propaganda bedeuten:

"The separation of Austrian war prisoners from the Germans would thus not only strengthen the struggle for independence in Austria itself, but would also strike a blow to the Greater German ideology with witch German imperialism has always covered up its misdeeds. [...] The question of reeducation of war prisoners is a subject of legal dispute. But the separation of Austrian war prisoners which would be a significant act for the Germans and a decisive step in reeducation for the Austrian prisoners is legally incontestable. Destroy the Hitler lie of 'one people, one Reich, one Führer' - right here - in the prisoners' camps! "1010 [Hervorhebung d. Verf.]

1006 Vgl. Robert D. Billinger, Jr., „Austrian“ POWs in America, 1942-1946. In: Zeitgeschichte, 29. Jg., 2002, Heft 3, 123 f. Vgl. dazu auch die Darstellung: Hans Ernest Fried (City College, N.Y.), Separation of Austrian War Prisoners. In: Austro American Tribune. Anti-Nazi Monthly, Vol. II, No. 3, Oktober 1943, 1.

1007 Major Edward Davison, Assistant Director, Prisoner of War Division, Memorandum to Chief, Operations Branch. Subject: Segregation of Austrian Prisoners of War, 22. August 1944. Hier zit. nach: Billinger, Jr., ,Austrian“ POWs in America, a.a. O., 125.

1008 Vgl., ebd., 127.

1009 Practical Post-War Planning. In: Austro American Tribune. Anti-Nazi Montbly, Vol. 2, Mid-August 1943, 1.

1010 Practical Post-War Planning. In: Austro American Tribune. Anti-Nazi Monthly, Vol. 2, Mid-August 1943, 2. 
Eine indirekte Auswirkung der Moskauer Deklaration auf die lagerinterne Abgrenzung sowie die Rückkehr eines gewissen „Österreichbewußstein“ unter den Kriegsgefangenen der „Donaugaue“ hatte, wie Zagovec konstatiert, jedenfalls der Umstand, dass diese innerhalb der Lagergemeinschaften nun vermehrt als „Beutedeutsche“ disqualifiziert wurden. ${ }^{1011}$ Kurzfristig laufende Projekte einer aktiven Abgrenzung von den deutschen Kriegsgefangenen wie etwa das in Camp Butner (North Carolina) von den beiden österreichischen POW's Karl Merth und Karl Hirschmann herausgegebene Mitteilungsblatt für die österreichischen Kriegsgefangenen, von dem nur sechs Ausgaben erschienen, ${ }^{1012}$ waren Ausnahmeerscheinungen und in ihrer Wirkung wohl eher bescheiden.

Obwohl die Lagererfahrungen auf Dauer zum Teil eine gewisse Erosion und Desintegration des soldatischen Corpsgeistes unter den Inhaftierten bewirkt haben mögen, lief die nur wenig koordinierte Reeducation der POW's, die vorwiegend den Inhaftierten selbst übertragen wurde, ins Leere. Neben weiterhin existierenden anti-amerikanischen Ressentiments zeigte sich unter den Gefangenen die Tendenz zu politischer Indifferenz sowie zu völligem sozialen Rückzug. ${ }^{1013}$ Ebensowenig Erfolg dürften die Bemühungen der britischen Besatzungsmacht beispielsweise im kärnterischen Straflager „Camp Wolfsberg“ gehabt haben, wo die Vorführung von KZ-Filmen bestehende Einstellungsmuster der Inhaftierten eher verfestigte, denn auflöste. ${ }^{1014}$

Nach Kriegsende durchgeführte Umfragen unter den deutschen POW's zeigten, dass den Wehrmachtsoldaten nach wie vor jedes Gefühl einer Mitverantwortung am Krieg fehlte und sich ihre ideologische Haltung kaum verändert hatte. So gaben ${ }_{2}$ Prozent der Befragten an, dass der Krieg durch Deutschlands Not und Bedarf an „neuem Lebensraum“ verursacht war [6r Prozent unter den unter 30-Jährigen]. Weitere sieben Prozent der Befragten behaupteten, dass Deutschland von außen bedroht worden sei, während nur ${ }_{23}$ Prozent eine Schuld seitens des NS-Regimes eingestanden. Nur 12 Prozent sahen die Niederlage als Ergebnis der nationalsozialistischen Politik - 34 Prozent der unter 30-Jäh-

1011 Zagovec, Islands of Faith: National Identity and Ideology in German POW Camps, a. a. O., 119.

1012 In Camp Butner wurden die österreichischen POW's ebenfalls nicht getrennt untergebracht, durften aber vereinzelt eigene Diskussionsrunden veranstalten. Die Herausgeber agierten jedenfalls mutig und offensiv, indem sie schrieben "We condem everyone who still does not own up to Austria without reservations.“ Siehe: Billinger, Jr., ,Austrian“ POWs in America, a.a. O., 127.

1013 Zagovec, Islands of Faith: National Identity and Ideology in German POW Camps, a.a.O., 116.

1014 So löste bspw. die Aufführung des Films „Die Todesmühlen“ kein Gefühl der Mitverantwortung aus, sondern führte im Gegenteil zur Beurteilung der KZ-Aufnahmen als Feindpropaganda. Die Insassen des „373 Camp Wolfsberg“ waren davon überzeugt, „dass es sich um gestellte Aufnahmen von,Indern“ aus den britischen Kolonialgebieten handelte, oder dass das Filmmaterial aus, Russland von den Kommunisten' stammte. Die Internierten fühlten sich verhöhnt beim Anblick der ausgezehrten und gebrechlichen Körper, denn sie meinten, keinen signifikanten Unterschied zu ihrem eigenen Zustand erkenn zu können“. Kastner, 373 Camp Wolfsberg. Britische Besatzungslager in Österreich von 1945 bis 1948, a.a.O., 104. 
rigen machten „Verräter“ an der Niederlage schuldig [30 Prozent der über 30-Jährigen]. ${ }^{1015}$ Des Weiteren sah die Mehrzahl der Befragten weiterhin in den Juden die Ursache für Deutschlands Probleme, selbst unter den ausgewählten Anti-Nazis im POW Camp Fort Eustis beschuldigten zehn Prozent der Befragten die Juden, für Deutschlands Misere verantwortlich zu sein. ${ }^{1016}$

Vor dem Hintergrund dieser Ergebnisse sowie im Hinblick auf die skizzierte Planung und konkrete Durchführung der POW-Reeducation, die sowohl abseits der sonstigen militärischen Planungszenarien für die Nachkriegszeit sowie insbesondere ohne Kontakt zu allen zivilen Gremien und Initiativen ablief, ist dieses Lager-Experiment als vollständig gescheitert anzusehen.

Interessanterweise erschien bereits 1946 in Berlin ein von Margret Boveri ${ }^{1017}$ verfasstes anti-amerikanisches Pamphlet, worin die Autorin die amerikanische „Hollerith-Kultur “1018 der gesellschaftlichen Standardisierung und Normierung just im Zusammenhang mit der NS-Registrierung und den von George Horst Gallup entworfenen „Fragenbogen“ als der implizit höherwertig gedeuteten - deutschen Kultur wesensfremd darzustellen versuchte dies freilich unter völliger Ausblendung des Kausalzuammenhanges der Entnazifizierung, nämlich des Holocaust, so, als wäre es bloß um ein kurioses Gesellschaftsspiel zur Belustigung der Deutschen gegangen: „Denn darüber sind sich die wenigsten Deutschen klar, daß der Fragebogen nicht als Tortur für die besiegte Nation eigens erfunden wurde, sondern daß jeder Amerikaner sich selbst tausendmal einem Fragebogen unterwirft, daß er über sich selbst nach den gültigen Fragebogenregeln die Summe zieht wie über uns die Angehörigen der Control Councils und des CIC. Der Fragebogen entscheidet in Amerika nicht nur über Schulung, Berufswahl und Fortkommen; es ist gleichzeitig in der Form des, Quiz‘ ein nationaler Sport auf geistigem Gebiet, der am Radio, in der Presse, in großen Versammmlungshallen ebenso eifrig verfolgt wird wie Football und Baseball auf den Spielfeldern."1019

1015 Zit. nach: Ehrmann, An Experiment in Political Education. The Prisoners-of-War Schools, a.a.O., 307.

1016 Robin, The Barbed-Wire College. Reeducating German POWs, a.a.O., $163 \mathrm{f}$.

1017 Margret Boveri (1900-1975), deutsche Journalistin, die während des Nationalsozialismus, obwohl kein NSDAP-Mitglied, von 1939 an als Auslandskorrespondentin der Frankfurter Allgemeinen Zeitung in New York lebte. Ab 1944 arbeitete sie als Autorin bei der Goebbels-Postille Das Reich. Boveri, die in dieser Zeit auch explizit antisemitische Artikel verfasste, war u.a. befreundet mit Ernst Jünger und Gottfried Benn. Vgl. Titus Arnu, „Wir lügen alle“. Margret Boveri 1900-1975. In: Hans-Jürgen Jacobs/Wolfgang R. Langenbucher (Hrsg.), Das Gewissen ihrer Zeit. Fünfzig Vorbilder des Journalismus, Wien 2004, 189-203.

1018 Bei den hier angesprochenen „Hollerith-Maschinen“ handelte es sich zwar um IBM-Technologie, über die „Deutsche Hollerith Maschinen Gesellschaft“ (Dehomag), die über die Kriegsjahre mit der amerikanischen IBM verzahnt blieb, erfolgte allerdings via Lochkarten-Computer die ,effiziente‘ Administration des NS-Vernichtungsapparates. Vgl. Edwin Black, IBM and the Holocaust, The Strategic Alliance between Nazi Germany and America's most Powerful Corporation. 3 Aufl., Washington D.C., 2009, $30 \mathrm{ff}$.

1019 Margret Boveri, Amerika-Fibel für erwachsene Deutsche. Ein Versuch, Unverstandenes zu erklären, Freiburg i. Br. 1946, 50. 
Die Autorin, die nach der Publikation ihrer Schrift, von der sich bis 1947 40.00o Stück verkauften, fünf Jahre Einreiseverbot in die USA erhielt,${ }^{1020}$ sprach sich höhnisch gegen US-Umerziehungsmaßnahmen („Hula-Hula im Frack“) ${ }^{1021}$ aus, und riet zu deutscher Gelassenheit gegenüber der „verarmten“ amerikanischen Kultur:

„Doch während es uns immer überaus schwer, wenn nicht unmöglich sein wird, in eine Denkund Reaktionswelt wie die chinesische einzudringen, weil die andersartigen Ursprünge soweit zurückliegen $[\ldots]$ so sollte es uns heute noch durchaus möglich sein, die neue amerikanische Denk- und Seelenlandschaft zu erkennen, weil ihre Ursprünge zum Teil aus unserer eigenen hervorgingen [...]. Deswegen sollten wir die Fragebogenwirtschaft nicht mit Empörung ablehnen, weil sie auf uns so wenig paßt wie eine Kaffemüble auf Kirschkerne. Wir sollten uns klar machen, daß die Amerikaner auf uns nur eine Technik anwenden, die für sie so selbstverständlich ist wie die tägliche Dusche, und daß diese Technik, statt eine immer neue Quelle von Mißverständnissen zu werden, uns als wertvoller Schlüssel dienen kann, ihre geistige Ausrüstung und die Art ihrer Gedankenfolgen kennenzulernen. ${ }^{.1022}$ [Hervorhebung d. Verf.]

\section{ZUR ROLLE ÖSTERREICHS IN DER REEDUCATION-PLANUNG} DER US-MILITÄRSTÄBE I943/44-I945

\section{Österreich - ein unklarer Planungsfaktor alliierter Politik bis 1944/45}

Wie bereits dargestellt, hatten sich die Vereinigten Staaten erst vergleichsweise spät dazu entschlossen, den „Anschluss“ Österreichs offiziell - quasi nachträglich - nicht anzuerkennen und auch die österreichischen Emigrés in den USA nicht mehr als „Deutsche“ zu klassifizieren. Eine schlüssige und eigenständige Österreich-Politik hatte das aber vorerst nicht zur Folge.In der allgemeinen Postponement-Politik Roosevelts kamen Erörterungen zur politischen $\mathrm{Zu}$ kunft Österreichs nach Kriegsende allenfalls als Appendix beziehungsweise als Funktion der strategischen Deutschland-Planung vor. ${ }^{1023}$ Das gilt in besonderer Weise für alle Überlegungen zur mentalen Reeducation beziehungsweise Reorientierung, deren primärer Bezugspunkt die Überwindung respektive Auslöschung der rassenideologischen Indoktrinierung durch das

1020 Heike M. Görtemaker, Einleitung. In: Boveri, Amerikafibel für erwachsene Deutsche, a.a. O., $4 \mathrm{ff}$.

1021 Boveri parallelisierte hier die Amerikanisierung von Hawaii: „Der Hula-Hula im Frack hat ebensowenig mit dem ursprünglichen Hula-Hula-Tanz zu tun, wie der New Yorker potato-dumpling mit einem fränkischen Kartoffelkloß. Auch hier wirken ökonomischer Zwang und die ungeheure Suggestionskraft zusammen, um den Eingeborenen und seine Produkte zu verwandeln." Boveri, Amerika-Fibel für erwachsene Deutsche, a.a.O., 39.

1022 Boveri, Amerika-Fibel für erwachsene Deutsche, a.a.O., 65.

1023 Vgl. Gerald Stourzh, Geschichte des Staatsvertrages 1945-1955. Österreichs Weg zur Neutralität. 3. Aufl., Graz - Wien - Köln 1980, 3. 
NS-Herrschaftssystem war; und diese Indoktrinierung wurde in den US-Analysen in Bezug auf das okkupierte und gleichgeschaltete Österreich ebenso als gegeben vorausgesetzt.

Als eigenständiger politischer Bezugspunkt für militärisch-strategische Nachkriegsplanungen - abseits vager Überlegungen zur Schaffung einer Donaukonföderation, wie sie unter anderem vom britischen Premier Churchill kurzfristig im Zusammenhang mit einer politischen Schwächung Deutschlands ins Spiel gebracht wurden ${ }^{1024}$ - taucht Österreich erst Mitte 1943 im Rahmen der Moskauer Konferenz auf. Roosevelt war erst gegen Kriegsende bereit, die USA eine aktive Rolle in der politischen Nachkriegsgestaltung Europas spielen zu lassen, wobei die Regelung der Zukunft Deutschlands als vordringlich galt. Abgesehen davon lag es vor dem Hintergrund des historischen Entwicklungsverlaufs sowie der von Vertretern des österreichischen politischen Exils favorisierten supranationalen Lösung keineswegs auf der Hand, die Errichtung eines freien und unabhängigen Österreichs zu befürworten, wie das die Sowjetunion bereits seit einer Besprechung Stalins mit dem britischen Außenminister Anthony Eden seit Ende I94I tat; diese konsequent vertretene Forderung der Sowjets nach einer Wiederherstellung eines unabhängigen Österreich in den Grenzen vor 1938 war indes von der strategischen Überlegung getragen, eine allfällige Blockbildung gegenüber Rußland im mitteleuropäischen Raum zu verhindern. ${ }^{1025}$

Auf westalliierter Seite kam der Vorstoß zur „Wiederherstellung Österreichs als freier und unabhängiger Staat“ in Form eines Memorandums, das der britische Diplomat Geoffrey W. Harrison im Frühjahr I943 unter dem Titel „The Future of Austria“ als Grundlage für die Österreichplanung im britischen War Office verfasste hatte. Auf Basis dieses Memorandums, das zunächst vier gleichrangige alternative Nachkriegsszenarien für ein freies Österreich entwickelte, kam es im Juni darüber hinaus zum ersten Entwurf einer „Erklärung über Österreich“ samt angeschlossener „Verantwortlichkeits-Klausel“. ${ }^{1026}$

Ohne hier auf weitere Details der nachfolgenden diplomatischen Verhandlungen der Alliierten Mächte über das Memorandum einzugehen, verdankte sich die weitere Diskussion rund um eine alliierte Absichtserklärung gegenüber Österreich de facto - wie unter anderen Keyserlingk schlüssig dargestellt hat - amerikanisch-britischen Strategiekonzepten des „Psychological Warfare“ und keineswegs primär politischen Überlegungen:

"What outside observers at that time could not know was that the Moscow Declaration on Austria fitted into a broad propaganda campaign directed against the Nazis. The declaration was issued as part of the Allies political warfare attack on the enemy's morale in the Austrian area." ${ }^{1027}$

1024 Vgl. Fritz Fellner, Die außenpolitische und völkerrechtliche Situation Österreichs 1938. Österreichs Wiederherstellung als Kriegsziel der Alliierten. In: Erika Weinzierl/Kurt Skalnik (Hrsg.), Österreich Die Zweite Republik. Bd. 1, Graz 1972, 53 f.

1025 Vgl. dazu:Wilfried Aichinger, Sowjetische Österreichpolitik 1943-1945, phil. Diss., Univ. Wien 1977, 23 f. 1026 Stourzh, Geschichte des Staatsvertrages 1945-1955, a.a.O., 2 f.

1027 Keyserlingk, Austria in World War II, a.a. O., 124. 
Nach der militärischen Wende durch die Schlacht von Stalingrad Anfang I943, in der auch zwei ,österreichische' Divisionen aufgerieben wurden, mobilisierten die westalliierten militärischen Geheimdienste alle Elemente der Psychologischen Kriegsführung gegen die Achsenmächte, um auf diese Weise die Moral der Deutschen zu schwächen und ein möglichst baldiges Ende des Krieges herbeizuführen.

Nach Berichten des OSS über wachsende Kriegsmüdigkeit und Frustration in der österreichischen Bevölkerung ${ }^{1028}$ sowie zunehmenden passiven Widerstand und Sabotageakte im Bereich der Kriegsindustrie schien es aus Gründen der psychologischen Kriegsführung naheliegend, den Fokus der Propaganda auf Österreich zu konzentrieren. ${ }^{1029}$ So gab das vom britischen Kabinett im Juni 1943 angenommene Memorandum des Foreign Office die nach außen hin offiziell verlautbarte diplomatische Linie der projektierten Österreichpolitik vor; gleichzeitig existierte aber auch der geheime Entwurf eines psychologisch-strategischen Propagandapapiers, worin die Österreich-Erklärung lediglich unter dem Gesichtspunkt einer "psychological attack on the enemy“ gesehen wurde, um auf diese Weise den Widerstand gegen das NS-Regime zu unterstützen. ${ }^{1030}$

Signifikanterweise wurde Österreich auf der von den Sowjets einberufenen Moskauer Außenministerkonferenz im Oktober 1943, wo hauptsächlich die Eröffnung einer zweiten Front im Westen thematisiert wurde, kaum erwähnt. ${ }^{1031}$ Lediglich im Schlusskommuniqué der Konferenz vom r. November I943 wurde die „Moskauer Erklärung über Österreich“ aufgenommen, worin die Alliierten den „Anschluss“ annullierten, die Wiederherstellung eines freien und unabhängigen Österreich in Aussicht stellten und Österreich den Status des „ersten Opfers Hitler-Deutschlands“ zuschrieben ${ }^{1032}$ - allerdings mit dem in britischem Englisch formulierten Zusatz:

1028 Bereits im August 1941 hieß es in einem letzten Bericht des US-Konsulats in Wien, dass die Wiener Bevölkerung bereits kriegsmüde und „apathisch“ sei und nur noch $20 \%$ das NS-Regime unterstützen würden, wohingegen $50 \%$ bereits gegen das Regime eingestellt wären. Günter Bischof, Anglo-amerikanische Planungen und Überlegungen der österreichischen Emigration während des Zweiten Weltkrieges für Nachkriegs-Österreich. In: Manfried Rauchensteiner/Wolfgang Etschmann (Hrsg.), Österreich 1945. Ein Ende und viele Anfänge, Graz - Wien 1997, 32.

1029 Keyserlingk, Austria in World War II, a.a.O., 134.

1030 Ebd., 137. Vgl. auch: Siegfried Beer, Alliierte Planung, Propaganda und Penetration 1943-1945. Die künftigen Besatzungsmächte und das wiederzuerrichtende Österreich, von der Moskauer Deklaration bis zur Befreiung. In: Stefan Karner (Hrsg.), Das Burgenland im Jahre 1945, Eisenstadt 1985, 70.

1031 Fellner, Die außenpolitische und völkerrechtliche Situation Österreichs, a.a.O., 70; weiters: Christian Stifter, Die Wiederaufrüstung Österreichs. Die geheime Remilitarisierung der westlichen Besatzungszonen 1945-1955 (=Wiener Zeitgeschichte-Studien, Bd. 1), Innsbruck 1997, 20.

1032 Vgl. Bernhard Schausberger, Die Entstehung des Mythos Österreich als Opfer des Nationalsozialismus. Eine Dokumentation, Dipl.-Arb., Universität Salzburg 1991. 
"Austria is reminded, however, that she has a responsibility which she cannot evade for participation in the war on the side of Hitlerite Germany, and that in the final settlement account will inevitably be taken of her own contribution to her liberation." 1033

Ohne jedes ernstzunehmende Präjudiz hinsichtlich der weiteren politischen Zukunft Österreichs intendierte die Moskauer Deklaration aus westalliierter Sicht primär die Schwächung Deutschlands und sollte quasi als einer der letzten Sargnägel für das NS-Regime fungieren. ${ }^{1034}$ Tatsächlich entfaltete die Deklaration, die in der NS-Presse auf österreichischem Boden als Angriff propagandistisch ausgeschlachtet wurde - die Alliierten wurden beschuldigt, ein hilflos-schwaches und harmloses Österreich errichten zu wollen ${ }^{1035}$-, bis Kriegsende aber relativ wenig Wirkung auf die österreichischen Bevölkerung. Sowenig die nationalsozialistische Kontrolle und der Terror nachließen, sowenig wurden durch die ÖsterreichErklärung die erhofften Widerstandsaktivitäten in den „Donau- und Alpengauen“ ausgelöst.

Einen spannenden Einblick in die damalige Situation unmittelbar nach Veröffentlichung der Moskauer Deklaration gibt eine im April 1944 verfasste politische Analyse der Research \&Analysis Branch des OSS zu „The Attitude of the Austrian People towards the Moscow Declaration on Austria“, ${ }^{1036}$ in die unter anderem auch eine Auswertung der Zeitungsberichterstattung in den österreichischen „Gauen“ einfloss. Ähnlich wie das dann auch die Experten des britischen Foreign Office sahen, ${ }^{1037}$ konstatierte die OSS-Analyse, dass die Moskauer Deklaration in Österreich auf keinen fruchtbaren Boden gefallen sei und keine nennenswerten Auswirkungen habe - weder auf die breite Masse der Bevölkerung noch

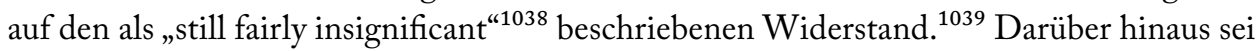
auch „the history of the many Austrian Committees already in existence in exile [...] not

1033 Zit. nach: Stourzh, Geschichte des Staatsvertrages 1945-1955, a.a.O., 214.

1034 Keyserlingk, Austria in World War II, a.a.O., 159.

1035 So z.B. in der Deutschen Allgemeinen Zeitung, 5. November 1943, oder in der Grazer Tagespost, 5. November 1943. Siehe: The Attitude of the Austrian People Towards the Moscow „Declaration on Austria“. Office of Strategic Services. Research and Analysis Branch, R\&B No. 1704. Secret. 14. April 1944. A Guide to O.S.S./State Department Intelligence and Research Reports. Germany and its Occupied Territories during World War II. Part 4 [A Microfilm Project of University Publications of America, Inc.], Washington D.C. 1977. Bestand Institut für Zeitgeschichte, Universität Wien (Bibliothek), Rolle 1 [14-15], 27.

1036 The Attitude of the Austrian People Towards the Moscow „Declaration on Austria“. Office of Strategic Services. Research and Analysis Branch, R\&B No. 1704, a.a.O., 27.

1037 Vgl. Bischof, Anglo-amerikanische Planungen und Überlegungen der österreichischen Emigration, a.a.O., 34.

1038 The Attitude of the Austrian People Towards the Moscow „Declaration on Austria“. Office of Strategic Services. Research and Analysis Branch, R\&B No. 1704, a.a.O., 29.

1039 Vgl. dazu allgemein: Thomas Koch, Der amerikanische Geheimdienst OSS und die Widerstandsbewegungen. - In: Geheimdienste und Widerstandsbewegungen im Zweiten Weltkrieg. Hrsg. v. Gerhard Schulz, Göttingen 1982. 
encouraging. “1040 Zwar würden die Österreicher zum gegenwärtigen Zeitpunkt die Nazis gerne los sein - ,today the prevalent sentiment in Austria is one of resentment against the Germans, and hatred of the Nazis “1041 -, und der Erfolg des Nationalsozialismus in Österreich primär Resultat der bewaffneten Okkupation und nicht von der Bevölkerungsmehrheit gewünscht gewesen sein, aber ein unmittelbar erfolgter begeisterter Umschwung nach dem Einmarsch wäre ebenfalls nicht zu leugnen: „[... [it cannot be denied that at the time of the Anschluss the Nazis could claim the support of a considerable part of the people.“"1042

Der OSS-Bericht führte in diesem Zusammenhang weiter aus:

"It may be that the Austrians were even less enthusiastic about Hitler's war in 1939 than were the Germans. It cannot however be doubted that, with the exception of a minority of avowed opponents of Hitlerism, they rode high on the wave of enthusiasm which followed the early conquests of the Reich. Austrian not only participated as soldiers in the Nazi conquest but they were given their share of the spoils, and formed part of the officialdom ruling the occupation territories, notably in the Balkans, Poland, and Holland." ${ }^{1043}$ [Hervorhebung d. Verf.]

Besonders eigenartig schien den OSS-Analysten, die um den traditionell schwach ausgeprägten österreichischen ,Nationalismus' wussten, dass selbst die Moskauer Deklaration „did nothing to promote her self-respect“. ${ }^{1044}$ Die aktuelle Stimmungslage in der Bevölkerung, die eine Separation von Deutschland befürworte, sei keinesfalls Ausdruck des Wunsches nach staatlicher Unabhängigkeit, sondern lediglich eine pragmatische Reaktion ,to escape a bad situation". In seiner durchaus zutreffenden Analyse berührte der US-Geheimdienst auch sozialpsychologisch interessante Aspekte dessen, was der österreichische Psychiater Erwin Ringel später unter dem Terminus „österreichische Seele“ zusammenfasste, und 1944 wohl den österreichischen, Untertanengeist' betraf: „A virile national proud of its independence does not, whatever the cost, knuckle under completely as the Austrians have done." ${ }^{1045}$

Die einzig emotionale Reaktion, die die Deklaration innerhalb der österreichischen politischen Emigration in den USA ausgelöst habe, sei ein Abwehrreflex gegenüber der Verantwortungs-Klausel gewesen, die immerhin eine gewisse moralische Mitschuld der Österreicher am Krieg zum Ausdruck gebracht habe.

Interessant an dem zitierten Bericht ist außerdem, dass in die Analyse eine „Prisoners of War Interrogation" des OSS unter österreichischen Kriegsgefangenen (POW's) miteinfloss - diese hatten in Bezug auf die Moskauer Deklaration höchst kuriose Antworten parat.

1040 The Attitude of the Austrian People Towards the Moscow „Declaration on Austria“. Office of Strategic Services. Research and Analysis Branch, R\&B No. 1704, a.a.O., Einleitung, v.

1041 Ebd., 19.

1042 Ebd., 12.

1043 Ebd., 17.

1044 Ebd., 3.

1045 Ebd. 
Zunächst ergab die Befragung der österreichischen POW's, dass diese noch nichts von der Moskauer Deklaration gehört hatten. Darüber hinaus vertrat die überwiegende Mehrzahl der Befragten die Überzeugung, dass die Alliierten Österreich nach dem Krieg vermutlich ohnedies von Deutschland trennen würden, und zwar als besondere „Bestrafungsmaßnahme“:

"It also appears that the Austrians take their liberation from Germany for granted as an inevitable outcome of the war. Thus, of a group of Austrian prisoners of war recently questioned, none had ever heard of the Moscow Declaration, but all were convinced that the Allies would separate Austria from Germany after the war, perhaps as a form of punishment." ${ }^{1046}$ [Hervorhebung d. Verf.]

Die Spezialisten der Research \&Analysis Branch kritisierten ihrerseits jedoch den politischen Wortlaut der Moskauer Deklaration, welcher die künftige „Unabhängigkeit“ des Landes gewissermaßen von oben her dekretieren würde, statt diese als Option in Aussicht zu stellen. Ähnlich wie zuvor beim Friedensvertrag von St. Germain sei damit der Wunsch nach Unabhängigkeit als selbstverständlich vorausgesetzt worden, ohne diesen mit Hinweis auf künftige wirtschaftlich-ökonomische Unterstützung zu befördern und $\mathrm{zu}$ festigen. ${ }^{1047}$

Soweit die nicht nur spannend zu lesende, sondern auch inhaltlich überaus interessante Analyse des militärischen US-Geheimdienstes zu den meinungspolitischen Auswirkungen der Moskauer Deklaration, deren Fazit jedenfalls kein weiteres unmittelbares Engagement der USA in Richtung eigenständiger Österreichpolitik nahelegte; tatsächlich geriet Österreich Anfang 1944 rasch wieder aus dem Fokus des westalliierten Planungskalküls. ${ }^{1048}$ Aus militarischer Perspektive blieb Österreich weiterhin feindliches Territorium: so gingen die Combined Chiefs of Staff, zumindest für die Dauer der Kriegshandlungen, auch in Bezug auf Österreich von den „terms of surrender imposed on Germany“ aus. ${ }^{1049}$

Doch selbst wenn der alliierten Verlautbarung ganz offenkundig noch keine klare Österreichpolitik zugrunde lag und die Österreich-Erklärung - zumindest aus westalliierter Sicht - noch kein bindendes Präjudiz für die politische Zukunft des Landes darstellte, begann sich die damit geschaffene Referenzgrundlage für die „Sonder-“ oder "Zwitterrolle“ Österreichs allmählich doch zu verselbständigen und das, trotz oder gerade wegen des Umstandes, dass Österreich, wie Kurt Tweraser treffend formuliert, aufgrund fehlender alliierter Konzepte „politisch im luftleeren Raum hing“. ${ }^{1050}$

1046 Prisoner of War Interrogations, OSS, CID, 54292, 54294. Zit. nach: The Attitude of the Austrian People Towards the Moscow „Declaration on Austria“, a.a.O., 28.

1047 The Attitude of the Austrian People Towards the Moscow „Declaration on Austria“, a.a. O., $24 \mathrm{f}$.

1048 Vgl. Keyserlingk, Austria in World War II, a.a. O., 166.

1049 CCS im Februar 1944. Zit. nach: Keyserlingk, Austria in World War II, a.a. O., 166.

1050 Kurt Tweraser, US-Militärregierung Oberösterreich. Bd. 1: Sicherheitspolitische Aspekte der amerikanischen Besatzung in Oberösterreich-Süd 1945-1950 (= Beiträge zur Zeitgeschichte Oberösterreichs, Bd. 14. Hrsg. v. Oberösterreichischen Landesarchiv), Linz 1995, 18. 
Obwohl sich Roosevelt nach Drängen der Sowjets und den insistierenden Urgenzen von US-Botschafter Winant ${ }^{1051}$ und Stettinius als Secretary of State ${ }^{1052}$ erst am 4. Dezember 1944 davon überzeugen ließ, überhaupt Besatzungsaufgaben in Österreich zu übernehmen - „,...] in regard to Austria, the answer is ,yes - you have my permission“, ${ }^{1053}$ - war mit der Moskauer Deklaration für die Nachkriegsentwicklung Österreichs eine zumindest formal von Deutschland unterschiedliche Behandlung - Befreiung anstelle von militärischer Niederwerfung - in Aussicht gestellt; eine Position, die sich auch in den beiden einzigen militärischen US-Planungsdokumenten mit Bezug auf Österreich (nach Kriegsende) wiederfindet.

Am 28. April 1944 hatten die Combined Chiefs of Staff die oben bereits genannte Direktive CCS 55 I formuliert, die die Besatzungspolitik gegenüber Deutschland für SHAEF beziehungsweise die alliierten Landungstruppen zusammenfasste und eine erste Rohfassung des Handbuches für die Militärverwaltung enthielt. ${ }^{1054}$

Im Großen und Ganzen wurden in der CCS Direktive, die sich sowohl auf Deutschland als auch auf Österreich bezog, kaum wesentliche Unterschiede im Besatzungsregime für beide Länder gemacht. Wie aus einer CCS Meldung hervorgeht, sollte auch die alliierte Propaganda keinen grundsätzlichen Unterschied zwischen Deutschland und Österreich machen, mit einer Differenz: „[...] in the case of Austria the principal emphasis would lie in exploiting the Moscow Declaration showing the Austrians that the consequences of Germany's unconditional surrender include the liberation of Austria $[\ldots]$ “. ${ }^{1055}$

Ohne auf Fragen der Reeducation beziehungsweise Reorientation einzugehen, beinhaltete die Direktive immerhin einen expliziten Österreichbezug: im „Appendix B“ wurde ein kurzer und wenig elaborierter Anhang mit dem Titel „Political Guide for Austria" angeschlossen, der speziell auf Österreich einging. Abgesehen davon, dass die Besatzungstruppen darin aufgefordert wurden, gegenüber der österreichischen Bevölkerung etwas freundlicher zu sein („more friendly than in Germany“), fixierte dieser

1051 NARA II, RG 59, State Department, Box 12. Winant to Secretary of State [urgent]. 4. Dezember 1944. Darin heißte es u.a.: „I feel you should also know that the Russians insist on complete agreement on zones before discussion concrete arrangements regarding control machinery in Austria." Ebd., 2.

1052 NARA II, RG 59, State Department, Box 12. E.R. Stettinius, Jr., Memorandum for the President, Subject: Postwar Occupational Control in Austria, 30. November 1944.

1053 NARA II, RG 59, State Department, Box 12. F.D.R., The White House in Washington, Memorandum for Hon. E. R. Stettinius, 4. Dezember 1944.

1054 Lange-Quassowski, Amerikanische Westintegrationspolitik, a.a.O., 259. Vor der Verschärfung durch JCS 1067 sah das militäradministrative Reglement eine baldige Selbstverwaltung, die Garantie freier Meinungsäußerung und die Bildung freier Gewerkschaften vor. Vgl. Rolf Lutzebäck, Die Bildungspolitik der britischen Militärregierung im Spannungsfeld zwischen, education' und ,reeducation ' in ihrer Besatzungszone, insbesondere in Schleswig-Holstein und in Hamburg in den Jahren 1945-47 (= Europäische Hochschulschriften 11), Frankfurt a. Main - Bern - New York - Paris 1991, 51.

1055 NARA II, RG 260, Box 30, Folder 251/243. Historical File, USACA History. Part I - USA from its Inception to V-E Day, 36. 
„Political Guide“ in Bezug auf Österreich eine - wenn auch sehr vage - von Deutschland verschiedenen Besatzungspolitik, freilich ohne jeden Hinweis auf eine mögliche, künftige Souveränität:

"The political aim of the occupation of Austria will differ fundamentally from those of the occupation of Germany in that her primary purpose will be that of liberation. Though it will be of great importance that the occupying forces in Germany should make a good impression on the inhabitants, this will be of even more importance in Austria and the impression to be aimed at is of a different kind. You should try to insure that occupation by Allied Forces in no way suffers by comparison with occupation by Germans." 1056

Anders verhielt es sich im Fall eines Memorandums, das vom „Committee on Post-War Programs“, einer Abteilung des „Inter-Divisional Committee on Germany“ des State und War Departments, am 8. Juni 1944 unter dem Titel „The Treatment of Austria“ präsentiert wurde: darin wurde die möglichst umgehende Trennung von Deutschland und der Sonderstatus Österreichs bereits deutlich betont.

Obwohl davon auszugehen ist, dass diesem maßgeblich vom State Department ausgearbeiteten Grundsatzpapier, nicht zuletzt auch wegen der schwachen Stellung des Departments, wie Tweraser durchaus stimmig annimmt, als Planungsdokument für Österreich zunächst kaum große Bedeutung zukam, ${ }^{1057}$ ist dieses Memorandum, dem kurz darauf noch separate „Policy Recommendations“ folgten, zumindest in zweifacher Weise interessant. Erstens wurden beide Dokumente - das Memorandum sowie die politischen Empfehlungen - im Juli 1944 von Präsident Roosevelt angenommen und repräsentierten von nun an "the present policy of this government with respect to Austria. “1058 Zweitens verdeutlicht dieses Planungsdokument die Position des State Department in Bezug auf Österreich - eine Position, die ab 1945 im Zusammenhang der Aufwertung zivilbehördlicher US-Langzeitplanungen des State Departments an Relevanz gewinnen sollte und die ihrem gesellschafts- und demokratiepolitischen Kern nach sowohl die staatliche Rehabilitierung Österreichs als auch Deutschlands prägte.

Bereits im Eingangsparagraph nahm „The Treatment of Austria“ Bezug auf die Moskauer Erklärung und hielt, unter Hinweis auf die Verantwortlichkeits-Klausel, fest: „This program is premised on the view that Austria is a victim of Nazi aggression rather than an integral part of Germany and should be dealt with a different basis. ${ }^{1059}$

1056 Appendix B CCC 551, Political Guide for Austria. Zit. nach: Tweraser, US-Militärregierung Oberösterreich, a.a.O., 14.

1057 Tweraser, US-Militärregierung Oberösterreich, a.a.O., 17.

1058 FRUS, 1944, Vol. 1, The Secretary of State to the Ambassador in the United Kingdom (Winant), 8. Juli 1944, 451.

1059 FRUS, 1944, Vol. 1, 439. Memorandum by the Committee on Post-War Programs, „The Treatment of Austria“, 8. Juni 1944. 
Der erste Teil des Memorandums betraf „longe-range interests and objectives of the United States“, der zweite „problems of the occupation period““ ${ }^{1060}$ Ohne an dieser Stelle auf Details einzugehen, liegt die Bedeutung dieses Papiers, neben der bereits beabsichtigten Aufteilung Österreichs in - zum damaligen Zeitpunkt - drei Besatzungszonen, darin, dass nach erfolgter Entmilitarisierung und personellen Säuberungen ${ }^{1061}$ - die Besatzungszeit möglichst kurz und der Übergang zu inter-alliierten zivilen Kontrollbehörden möglichst rasch erfolgen solle, mit der klaren Intention: „demonstrably seeking to establish democratic political life. ${ }^{\text {"1062 }}$ Das politische Ziel war dezidiert auf die Entwicklung und Förderung einer demokratischen, eigenständigen Regierung gerichtet („development of sound democratic self-government“). ${ }^{1063}$ Der angesprochene, kurzgefasste Annex („Policy Recommendations") zum zitierten Memorandum empfahl nochmals nachdrücklich die umgehende („prompt“) Wiederherstellung Österreichs als unabhängiger Staat - daher sollte die Militärverwaltung der österreichischen US-Besatzungszone auch getrennt von Deutschland erfolgen -, jedoch auf Basis eines erst zu erreichenden demokratischen Einstellungswandels in der Bevölkerung, der implizit freilich eine klare Westorientierung bedeutete:

"This Government should support and use appropriate means to foster among Austrians more pronounced loyalty to an independent and democratic Austria under effective protection against external encroachments. ${ }^{1064}$ [Hervorhebung d. Verf.]

Bis Ende des Jahres 1944 kam es in Bezug auf Österreich allerdings zu keinen konkreteren Planungsschritten: noch im Dezember verlautete ein Memorandum der EAC, dass die Beratungskommission nun damit begonnen hat, erste Überlegungen hinsichtlich des österreichischen „Problems“ anzustellen. ${ }^{1065}$

In der militärischen Großplanung für die besatzungspolitische Initialphase unmittelbar nach Kriegsende setzte sich die mit dem CCS $55^{\mathrm{I}}$ erstmals angesprochene, ,andere“ Be-

1060 Ebd., 438.

1061 Das Memorandum ging hier von einem „komplexeren“ Sachverhalt als in Deutschland aus, zumal eine Rückkehr zum „Fascist character of much legislation under the Dollfuss-Schuschnigg regime“ [sic] völlig ausgeschlossen sei. Des Weiteren wurden im Hinblick auf personale, Säuberungsmaßnahmen` sowohl die Entnazifizierung als auch die Eliminierung der faschistischen Wurzeln der österreichischen Regierungsdiktatur unter Dollfuß und Schuschnigg in den Blick genommen: „The essential predicate [...] will be the elimination of the fascist vestiges of the Dollfuss-Schuschnigg regime and the destruction of Nazi authoritarianism." Ebd., 441.

1062 Ebd., 445.

1063 Ebd., 441.

1064 FRUS, 1944, Vol. 1, 447. Memorandum by the Committee on Post-War Programs, „Summary: The Treatment of Austria: Policy Recommendations“, [Washington D.C.], 21. Juni 1944.

1065 „The Commission has now begun its consideration of Austrian problems [...]“. FRUS, 1944, Vol. 1, 478. Memorandum by the United Kingdom Representatives to the European Advisory Commission (Strang), „The Establishment of Self-Government for Austria“, London, 14. Dezember 1944. 
handlung Österreichs im Unterschied zu Deutschland durch. Die politische Zielsetzung einer Wiederherstellung eines freien (und später auch unabhängigen) Österreich spiegelt sich gewissermaßen im Wortlaut der unterschiedlichen Code-Wörter für die unmittelbaren militärischen Aktionspläne nach der bedingungslosen Kapitulation (im Kontext des europäischen Geheimdienst-Rahmenplans „ECLIPSE“) ${ }^{1066}$ wieder: im Fall Deutschlands lautete der Operationsname „RANKING“, ${ }^{1067}$ für Österreich immerhin „FREEBORN““. 1068

\section{Militärisch-gremiale Detailplanung für Österreich- Administrationsunterlagen ohne Reorientation als Ergebnis}

Eine tatsächlich bis in alle Einzelheiten gehende Rekonstruktion der Aktitivitäten und Detailplanungen für die Militärbesatzung Österreichs (SHAEF G-5) würde auf Grund der Fülle des vorliegenden Quellenmaterials sehr umfangreich ausfallen. Zugleich würde eine derartige Darstellung, die wie Josef Leidenfrost meint, „in der Überschau doch ein eher beeindruckendes Ergebnis “1069 ergäbe, im vorliegenden thematischen Zusammenhang wohl auf ein inhaltlich wenig spannendes und auf Basis der bisherigen Literatur zum Thema ohnehin bereits bekanntes Ergebnis hinauslaufen: nämlich zum einen darauf, dass sämtliche Planungen - trotz formaler Trennung - kaum eigenständig, also in enger Verbindung mit der Deutschlandplanung liefen, und selbst in der SHAEF-Medienpolitik keine eigene „Österreichplanung“" existierte $;{ }^{1070}$ zum anderen, dass sich die Planungen letztlich auf die Erstellung militärischer Administrationsunterlagen wie etwa dem „Austria Military Government Handbook“, die I2 „Function Manuals“, einem Rahmenplan für die Militärverwaltung, sowie 39 „Policy Directives“, die sich auf bestimmte Kontrollmaß-

1066 „Eclipse“ war der Fortsetzungsplan der Operation „Overlord“, der auch Österreich inkludierte und von SHAEF bereits im November 1944 ausgearbeitet wurde. NARA II, RG 260, USGCC 1944-45, Box 32, Folder 4. Top Secret: Annex No. 5, Publicity and Psychological Warfare. Operations Plan, Operation „Eclipse“. Headquarters Twelfth Army Group (APO 655), 24. März 1945. Weiters: „[...] operation ,Eclipse' is the military continuitation of ,Overlord" from the moment of a ,German' surrender until control in Germany is taken over from the Supreme Commander by the Tripartite Military Government [...]. The first day of Operation ,Eclipse“ will be known as ,A“ Day“. NARA II, RG 260, USGCC 1944-45, Box 45 / Folder 3, 14. Februar 1945, 1.

1067 NARA II, RG 260, Historical File, Box 30, Folder 251. History of the United States Element. Allied Commission Austria. From its Origin to 31 December 1944, 5.

1068 Ebd., 62.

1069 Leidenfrost, Die amerikanische Besatzungsmacht und der Wiederbeginn des politischen Lebens. Bd. 1, a.a.O., 53. Wobei Leidenfrost einschränkt, dass die ausführliche Beschäftigung mit Österreich, vor allem in der Anfangsphase, „mit einem großen Mangel behaftet war: man wußte über Österreich viel zu wenig." Ebd., 55.

1070 Rathkolb, Politische Propaganda der amerikanischen Besatzungsmacht in Österreich. Bd. 1, a.a.O., 46; weiters: Leidenfrost, Die amerikanische Besatzungsmacht und der Wiederbeginn des politischen Lebens. Bd. 1, a.a.O., 9 f. 
nahmen im Bereich des öffentlichen Lebens bezogen, reduzierten. ${ }^{1071}$ Fragen der Reeducation beziehungsweise Reorientation wurden darin, wie bereits erwähnt, ohne explizite Nennung lediglich als militärische „Säuberungsmaßnahmen“ behandelt; Überlegungen zu einer längerfristigen demokratischen Reorientierung, wie sie von zivilen Stellen ausführlich diskutiert wurden, finden sich darin nicht.

Obwohl nun eine detaillierte Rekonstruktion der militärischen Detailplanung der USA für Österreich in den Jahren 1943/44 bis 1945 bisher aussteht, ${ }^{1072}$ soll im Folgenden - aus den oben genannten Gründen - dennoch nur in Kurzform, auf einige der zentralen Eckpunkte der militärischen Reeducation-Rahmenplanungen eingegangen werden.

Die Austrian Planing Unit (APU), die am 8. April 1944 unter der vorläufigen Leitung von Capt. Harold E. Pomeroy in enger Kooperation mit der German Country Unit (SHA$\mathrm{EF})$ gebildet wurde, setzte sich aus acht britischen und sechs amerikanischen Offizieren zusammen und arbeitete, unter der verantwortlichen Interimsleitung des APU-,,Chief Planner", Lt. Col. Henry Parkman, zunächst auf dem Areal eines aufgelösten Mädchenpensionats in Shrivenham bei London. ${ }^{1073}$ Die Arbeit dieser Einheit, die Anfang Juni ihr Quartier im Prince Gardens in London aufschlug, litt von Anfang an unter extremem Personal- und Ressourcenmangel und verfügte nur über die notdürftigste Büroaustattung. Nach Abkommandierung Parkmans nach Nordafrika übernahm schließlich am ro. Juli 1944 der Chefplaner für Deutschland, Lt. Colonel George H. McCaffrey, gemeinsam mit seinem Stellvertreter Major Charles P. Howard die verantwortliche Leitung für die Austria Planning Unit, die zum damaligen Stand aus I2 amerikanischen und sechs britischen Offizieren, weiteren zehn US-Soldaten sowie einem Briten bestand, wobei kein einziger APU-Offizier mit Aufgaben der Reeducation oder Bildung befasst war. ${ }^{1074}$ Erst vier Tage

1071 Vgl. Leidenfrost, Die amerikanische Besatzungsmacht und der Wiederbeginn des politischen Lebens. Bd. 1, a.a.O., 54.

1072 Auch Leidenfrost, der explizit auf das unglaublich umfangreiche Quellenmaterial der „langwierigen“ militärischen Österreich-Planung verweist, behandelt in seiner Dissertation die Phase bis Anfang 1945 in kaum mehr als 11 Seiten. Vgl. Leidenfrost, Die amerikanische Besatzungsmacht und der Wiederbeginn des politischen Lebens. Bd. 1, a.a. O., $7 \mathrm{ff}$.

1073 NARA II, RG 260, Box 30, Folder 251/243. Historical File, History of the United States Element, A1lied Commission Austria. From its Origins to 31 December 1944, $7 \mathrm{f}$.

1074 Unter den aufgelisteten Offizieren der APU finden sich: Captain Harold E. Pomeroy (U.S. Executive), Captain John Krupa (U.S. Adjutant and Supply Officer), Major Arthur W. Marget (U.S. Finance), Capt. Peter Foerster (Br. Finance), Major Lloyd H. Landau (U.S. Public Administration), Lt. Col. Ralph Mendelson (U.S. Public Health and Public Welfare), Capt. Herman Rutherford (Br. Public Safety), Major Nigel Ferguson (Br. Public Safety), Major Stanly H. Chair (Br. Displaced Persons), 2nd Lt. Herbert A. Fierst (U.S. Legal), Major A.H. Hamilton-Gordon (Br. Property Control), Capt. Louis H. Heilbron (U.S. Labor), Capt. Istvan de Koranyi (U.S. Economics), 1st Lt. Jerry Bell (U.S. Mining and Mineral Resources), Maj. David W. Williams (U.S. Agriculture), Maj. J.P. Davies (Br. Civilian Supply) 1st Lt. Albert Loewy (U.S. Special Legal Unit, German-Austria). Vgl. History of the United States Element, Allied Commission Austria, a.a.O., 12. 
später übernahm Major William B. Featherstone, ${ }^{1075}$ der spätere erste Leiter der USFA Education Division und Autor der Kapitel I2-I4 des „Military Government Handbook Austria“, die Planungsagenden für den Bereich „education, religious affairs, monuments and fine arts“; und am 20. Juli I944 wurde die österreichische Planungsgruppe USGCC/A dann noch um weitere 16 Offiziere aufgestockt. ${ }^{1076}$

Nachdem das britische War Office angesichts einer sich abzeichnenden Übernahme einer Besatzungszone in Österreich durch die Sowjets, die Zahl der britischen Planungsmannschaft rapide auf ${ }_{22} 7$ Offiziere und I8I sonstige Mitarbeiter erweitert hatte, löste sich analog zur Auflösung der German Country Unit - die ohnedies nicht immer einfache britisch-amerikanische Zusammenarbeit auf Drängen der Engländer mit I. September auf; diese übersiedelten mit ihrem Stab unter Leitung von Harold Mack nach Hammersmith in die dortige St. Paul's School. ${ }^{1077}$

Die gremiale Zusammenarbeit von Amerikanern und Briten vor Kriegsende war, wie ein US-Memorandum festhielt, völlig unkoordiniert verlaufen. ${ }^{1078}$ Die amerikanischen Militärs waren gegenüber ihren britischen Kollegen, deren militärische Planungen dem Foreign Office unterstanden und die von Anbeginn einen engen Kontakt zu zivilen Reorientierungs-Aktivitäten suchten, ${ }^{1079}$ insbesondere in allen zivilen Angelegenheiten weitaus weniger sachinformiert und vertraten insgesamt einen eher auf kurzfristige Perspektive ausgelegten, harten Kurs in Richtung rein funktionaler Besatzungsaufgaben.

In dieser Phase, die beinahe zur vollständigen Auflösung der US-Austrian Planing Unit geführt hätte, ${ }^{1080}$ erhöhten die Briten ihren Österreich-Planungsstab bis November 1944 auf insgesamt 190 Offiziere und 480 sonstige Militärs. ${ }^{1081}$

Auf amerikanischer Seite wurde die APU mit 4. September 1944 dem zuvor gebildeten US Group Control Council zugeordnet (USGCC/A). Trotz Urgenzen für eine personale

1075 Zur Biografie von W.B. Featherstone siehe die detaillierte Information in Kapitel 3, Seite 266.

1076 NARA II, RG 260, Box 30, Folder 251/243. Historical File, History of the United States Element, Allied Commission Austria. From its Origins to 31 December 1944, $11 \mathrm{ff}$.

1077 Auf das verwirrende Hin und Her der Planungen zwischen SHAEF in London und dem alliierten Mittelmeerkommando in Caserta in Italien (SACMED) - insgesamt wechselten die Agenden drei mal hin und her - ist hier nicht weiter einzugehen.

1078 NARA II, RG 260, USGCC 1944-45, Box 40, Folder 1. Joint Chiefs of Staff, Post Hostility Planning, A.J. McFarland, E.D. Graves Jr., [Top Secret], 20. Juni 1944, 1. „This memorandum emphasises that there is a great deal of somewhat uncoordinated planning being carried out in the U.K. [...]".

1079 So integrierten die britischen Planer bspw. Vorschläge der zivilen „Joint Commission of the London International Assembly and the Council for Education in World Citizenship“ in ihre strategischen Planungen. Siehe: Heber R. Harper to Harris, Office Memorandum, United States Government, „British Plans re. German Education“, 27. Mai 1944. Hoover Institution Archives, Stanford University, John Doane Hartigan Papers, 1909-1958, Box 7: Military reports and career of John Doane Hartigan.

1080 Rathkolb, Politische Propaganda der amerikanischen Besatzungsmacht in Österreich. Bd. 1, a.a. O., 44; History of the United States Element, Allied Commission Austria, a.a.O., 15.

1081 History of the United States Element, Allied Commission Austria, a.a.O., 14. 
Aufstockung durch General McSherry und General Wickersham auf 70 Offiziere blieb das Problem jedoch weiterhin virulent: Während die deutsche US-Planungsgruppe (USCCG) Anfang Februar 1945 in Summe 465 Offiziere sowie 54 Stabsmitglieder umfasste, musste sich die „US Group CC (Austria)“ mit 27 Offizieren, neun Stabsmitgliedern sowie insgesamt 166 zugeordneten Militärpersonen begnügen ${ }^{1082}$ und verfügte nicht einmal über genügend Büromaterial. ${ }^{1083}$

Nach den erfolgreichen alliierten Vorstößen im Juli I944 erhöhte sich für die US-Truppen des Mittelmeerkommandos (Supreme Commander Mediterranean Theater, SACMED) die Dringlichkeit verfügbarer Planungsgrundlagen für die bevorstehenden Besatzungsagenden in Österreich, wobei noch nicht feststand, ob die USA überhaupt eine Besatzungszone auf österreichischem Boden übernehmen würden. Bis Mitte August lagen jedenfalls erste Fassungen des Militärhandbuches für Österreich vor. ${ }^{1084}$

Nachdem Roosevelt in die Übernahme einer Besatzungszone in Österreich eingewilligt hatte, nominierten die Combined Chiefs of Staff am 28. Dezember 1944 General McNarney, den kommandierenden MTOUSA-General (Mediterranean Theater of Operations, United States Army), zum Hauptverantwortlichen für die Planung und Ausarbeitung der US-Besatzungsagenden innerhalb der künftigen alliierten Militärverwaltung in Österreich. ${ }^{1085}$ Dieser ernannte am 4. Jänner 1945 Brigade-General Lester D. Flory zum planerischen Leiter der „Nucleus Group“ einer amerikanischen Militärverwaltung in Österreich. Gemeinsam mit Colonel George R. Carey, Lt. Robert C. Ruske und Mr. Cecil W. Gray (als politischer Berater des State Departments) begann Flory - in enger Fühlungnahme mit General Hilldring (CAD), General George C. Marshall sowie Secretary of State, Edward Stettinius - zunächst von Bushy Park in London aus gemeinsam mit dem bisherigen leitenden Planungsoffizier Col. McCaffrey mit der detaillierten Planung für die Militärverwaltung der US-Besatzungszone in Österreich, wobei die bisherige Arbeits-Liaison und der Informationsaustausch zur USGCC weiterhin aufrecht blieb. ${ }^{1086}$ Flory selbst schien die übertragene Aufgabe für die unter schwerem Personalmangel leidende Gruppe jedoch keineswegs hinreichend klar profiliert zu sein und meinte diesbezüglich: „I find that we do not have enough officers to do our job. Also we have a nebulous existence. Therefore, our first job will be to get a $\mathrm{T} / \mathrm{O}$ and something firm on which to work. ${ }^{\text {“1087 }} \mathrm{W}$ ie aus einem Abteilungsplan für die 62-köpfige „U.S. Group CC (Austria)“ vom 3r. Jänner 1945

1082 NARA II, RG 260, Box 30, Folder 251/243. Historical File, USACA History. Part I - USA from its Inception to V-E Day, 79 bzw. 82.

1083 Vgl. Leidenfrost, Die amerikanische Besatzungsmacht und der Wiederbeginn des politischen Lebens. Bd. 1, a.a.O., 10.

1084 Historical File, USACA History. Part I - USA from its Inception to V-E Day, a.a. O., 27.

1085 History of the United States Element, Allied Commission Austria, a.a.O., 33.

1086 NARA II, RG 260, EDU-DIV, Box 1, Folder 2. USFA History File, Draft Historical Statement of US Group CC (Austria), Month of January 1945, 2 f.

1087 Ebd., 4. 
hervorgeht, existierte zu diesem Zeitpunkt noch keine gesonderte Education Division: mit diesen Aufgaben war nur Major Featherstone, welcher der „Internal Affairs Division “ zugeteilt war, betraut. ${ }^{1088}$

Gegen Ende Februar 1945 übersiedelte die Einheit dann als „USGCC / A Advance Headquarter“ nach Caserta, womit das „United States Group Control Council Austria“ als Stabstelle formal dem „US-Mediterranean Theatre Command“ unterstellt wurde. ${ }^{1089}$ Durch unvorhergesehene Veränderungen im Kriegsverlauf war schließlich aber nicht die 5 . beziehungsweise I5. US-Armee (MTOUSA) von Süden aus, sondern die schneller auf österreichischen Boden von Norden einrückende i2. US-Armee (ETOUSA) verantwortlich für die initiale Militärbesatzung Österreichs - freilich ohne jede bis dahin ausgearbeitete Planungsunterlage. ${ }^{1090}$

Die einzige Handlungsdirektive für die politische Behandlung Österreichs seit der Moskauer Deklaration war bis zu diesem Zeitpunkt ein von Washington aus am I. Februar I945 an die Österreich-Gruppe MTOUSA zugesandter Entwurf, der eine harsche Vorgehensweise empfahl: „The language of this directive indicated extremely severe treatment of Nazis [...]“. ${ }^{1091}$

Tatsächlich hatte das im Dezember 1944 geschaffene State-War-Coordinating-Committee (SWNCC) als integriertes militärisch-ziviles Sicherheitsgremium viele der von der USGCC/A kommenden Planungsunterlagen verworfen, worin sich, wie Kurt Tweraser anmerkt, „ein Interessenkonflikt zwischen militärischen und zivilen Instanzen über die Formulierung der amerikanischen Europapolitik“1092 abzeichnete; ein Konflikt, der vorerst - im Jänner 1945 war Archibald MacLeish mit der verantwortlichen Leitung für kulturellen und bildungspolitischen Angelegenheiten im „Office of European Affairs“ des State Department betraut worden ${ }^{1093}$ - aber eindeutig von den auf effiziente, unpolitische Verwaltung hin orientierten Militärs für sich entschieden wurde.

Nachdem das „German News Service“ der BBC einzelne für die Besatzung in Deutschland vorgesehene Militär-Direktiven veröffentlichte, wurde erste Kritik an den harten und zugleich wenig ideenreichen US-Reeducation-Konzepten laut. So kritisierte der Economist im Jänner I945: „Education cannot be achieved on the basis of negations [...] the content for the re-education of a new German youth is simply lacking“; ${ }^{1094}$ eine Warnung, die vom State Department sofort registriert wurde. ${ }^{1095}$

\footnotetext{
1088 Ebd.

1089 History of the United States Element, Allied Commission Austria, a.a.O., 52.

1090 Ebd., 65.

1091 Ebd., 59.

1092 Tweraser, US-Militärregierung Oberösterreich, a.a.O., 24.

1093 Vgl. Tent, Mission on the Rhine, a.a.O., 69.

1094 Reeducation in Germany. In: The Economist, Vol. CXLVIII, No. 5289, 6. Jänner 1945, 9.

1095 Vgl. Richard A. Johnson, Third Secretary of the US-Embassy, London, to The Honorable Secretary of State Washington D.C., 12. Jänner 1945. The U.S. Occupation of Germany: Educational Reform
} 
Aber auch innerhalb der militärischen Planungsstäbe scheint es zu ernstzunehmenden Konflikten und Grabenkämpfen im Hinblick auf die Auslegung der bisher vorliegenden Planungsdokumente gekommen zu sein. So beschwerte sich etwa General Hilldring vom War Department in Washington (CAD) im Februar 1945 bei Brigadegeneral Cornelius W. Wickersham (USGCC) als Generalverantwortlichem auch für die US Group CC/A darüber, dass dessen Mitarbeiter sich bei der Ausarbeitung der Pläne für die Militärverwaltung nicht an die Vorgaben halten würden:

"I have sensed a lack of willingness among certain of our people in London to accept and follow the clearly laid down policies established in Washington on the highest levels [...]. I would like to suggest that you employ every means to make certain that the officers under your command understand that the policy of the United States with respect to the Military government of Germany is presently laid down in J. C. S. ro67, and must be followed in letter and spirit. It is particularly important that your officers should be advocates of 1067 and under no circumstances critical of its politics. [...] There is no friction or discord between the Departments of the Government back home on theses issues, and, so far as I know, no differences between responsible U.S. officials in London and their home agencies. I am sure you will agree with me that any public impression to the contrary would be disastrous to our cause." ${ }^{1096}$ [Hervorhebung d. Verf., Unterstreichung im Original]

Nach diesem sehr deutlichen Schreiben General Hilldrings rief Wickersham š obwohl selbst inhaltlich anscheinend nur wenig davon überzeugt š seine ihm unterstehenden „Division Directors“ zur Räson und zur Befolgung der harten „Indoktrinierungs“-Vorschrift auf:

"It is desired that the foregoing information be brought to the personal attention of every officer in your Division. The importance of JCS-I067 will be re-emphasized to the end that they will become thoroughly indoctrinated with the full understanding that this document in not merely to be followed in our planning, but that each officer must be a sincere advocate of 1067, and under no circumstances critical of its policies. [...] It is further desired that new officers reporting for duty be given similar indoctrination, so that it cannot be said that any member of this Command does not give full and active support to JCS-Io67 [...]". 1097

Interessanterweise schien dann selbst das in Caserta ausgearbeitete SACMED-Militärhandbuch für Österreich dem SHAEF Generalkommando unter Eisenhower zu „öster-

1945š 1949, Microfilm-Collection Congressional Information Service, edited by Gary H. Tsuchimochi, Tokyo 1991 (Bestand Institut für Zeitgeschichte der Universität Wien, Bibliothek), 1-A-2.

1096 NARA II, RG 260, OMGUS š ECR, Box 88. Brigadier General C.W. Wickersham, US Group CC, Memorandum to Division Directors (Personal) š Advocacy of JCS-1067 [Secret], 17. Februar 1945, 1. 1097 Ebd. 
reichlastig“ und wegen der angeblichen „Betonung Österreichs als befreites Land“1098 geradezu verdächtig zu sein, was darin mündete, dass SHAEF im Frühjahr I945 in aller Eile schließlich selbst noch ein Österreich-Militärhandbuch ausarbeiten ließ. Dieses „Provisional Handbook Military Government Austria“ nahm in weit weniger expliziter erst in Paragraf 39 (durch bloßes Zitat) auf die Moskauer Deklaration Bezug, wollte dafür aber die genaue Überprüfung von Angehörigen des Austrofaschistischen Regimes - die in der MTOUSA-Fassung des Österreich-Militärhandbuches dann wegfiel - in das StandardReglement mitaufnehmen:

"The term 'Fascist' as used in this Handbook refers, in addition to any foreign Fascist elements
in Austria, to members of, or sympathizers with, Totalitarian Austrian organizations advo-
cating ideologies, programs or organizations similar in nature to the Nazi program or Party
in Germany or the Fascist program or Party in Italy. Examples are Austrian para-military
organizations such as the Heimwehr and the Vaterländische Front. Governmental officials ap-
pointed between I934 and I938, the period of the Dollfuss-Schuschnigg regime, should be very
carefully scrutinzed for 'Fascist' leanings before they are allowed to assume or retain posts of
authority or important governmental or civilian positions."

Das schärfer formulierte SHAEF-Handbuch, das die verantwortliche Durchführung aller Besatzungsaufgaben in Österreich allerdings beim SACMED/MTOUSA-Kommando belassen wollte, ${ }^{1100}$ konnte aber nicht mehr rechtzeitig fertig gestellt werden und blieb daher Entwurf, der nie zur Anwendung kam. ${ }^{1101}$

Unter Leitung von Lt. Colonel C.P. Howard, Major Kretzman und Colonel Jackling begann die in Caserta stationierte „US Group, CC, Austria“ im März I945 jedenfalls damit, die bis dahin - von einer Gruppe in London verbliebenen Planern rund um Col. McCaffrey - schon weitgehend ausgearbeiteten Kapitel des „Handbook for Military Government Austria“1102 für den designierten Oberbefehlshaber General Mark Clark zusammenzufassen und unter Supervision der Intelligence-Abteilung G-5 AFHQ zu überarbeiten. ${ }^{1103}$

In die schleppenden Verhandlungen innerhalb der „European Advisory Commission“, wo die Arbeitsgrundlagen und die Struktur der Alliierten Kommission für Österreich vorbereitet werden sollten, schalteten sich die Planungs-Offiziere der USGCC/A unter

1098 Tweraser, US-Militärregierung Oberösterreich, a.a.O., 29.

1099 NARA II, RG 331, SHAEF, General Staff, G.5 Division, Information Branch, Historical Section, 1943 - Juli 1945, Box 203 [290/7/25/3]. Supreme Headquarters Allied Expeditionary Forces Area, „Provisional Handbook for Military Government in Austria“, April 1945, $37 \mathrm{f}$.

1100 Ebd., 3.

1101 Tweraser, US-Militärregierung Oberösterreich, a.a.O., 26.

1102 NARA II, RG 260, USGCC 1944-45, Box, Folder 3. Field Handbook of Military Government Austria, Draft [Confidential], 15. August 1944.

1103 History of the United States Element, Allied Commission Austria, a.a. O., $59 \mathrm{f}$. 
Flory nicht ein; ${ }^{1104}$ ihre Vorschläge wurden aber letztlich - undiskutiert - in das erste alliierte Kontrollabkommen vom 4. Juli 945 übernommen. ${ }^{1105}$ Bis Kriegsende wurde innerhalb der EAC keine Einigung über einen Kontrollmechanismus für Österreich erzielt: „Machinery for the military government of Austria was under discussion in the European Advisory Commission at the time the war ended in Europe but no agreement had been reached. “1106

Das bereits mehrfach angesprochene Militärhandbuch bildete somit, neben den darauf aufbauenden, jedoch wenig ausgearbeiteten „Field Manuals“ für die praktische Arbeit und insgesamt 45 „Policy Directives“ ${ }^{1107}$ die einzige umfassende Handlungsdirektive für die US-Besatzung Österreichs, und war zum Zeitpunkt, als die ersten US-Truppen - es waren schließlich die 3. und 7. US-Armee ${ }^{1108}$ - Österreich erreichten, noch nicht einmal verfügbar.

Das „Austrian Military Goverment Handbook“ erschien, nach mehreren verworfenen Entwürfen, schließlich im April 1945. Damit existierten, fünf Monate nach der Fertigstellung des Militärhandbuches für Deutschland, zumindest allgemeine Handlungsrichtlinien für die amerikanischen Besatzungsorgane in Österreich, die sich auch auf den Bereich Künste, Museums-, Bibliotheks- und Bildungswesen erstreckten. Eine längerfristige Perspektive für die amerikanische Kultur- und Bildungspolitik fehlte - ebenso wie für Deutschland ${ }^{1109}$ - jedoch völlig.

Das US-Militärhandbuch, das in den einleitenden Passagen Bezug auf die Moskauer Deklaration nahm, entsprach weitgehend dem pragmatischen Konzept einer unpolitischen Militärverwaltung, die sich primär auf Kontrollmaßnahmen beschränkte und die

1104 Vgl. Leidenfrost, Die amerikanische Besatzungsmacht und der Wiederbeginn des politischen Lebens. Bd. 1, a.a.O., 20.

1105 NARA II, RG 59, State Department, Box 12. European Advisory Commission, E.A.C. (45) 4th Meeting, 4. Juli 1945. Minutes of Meeting held at Lancaster House, „Agreement on Control Machinery in Austria“.

1106 History of the United States Element, Allied Commission Austria, a.a.O., 66.

1107 NARA II, RG 260, USGCC 1944-45, Box, Folder 3. Germany and Austria in the Post-surrender period. Policy Directives for the Allied Comanders-In-Chief.

1108 Vgl. Manfried Rauchensteiner, Der Krieg in Österreich ‘45, Graz 1995, 33 ff.

1109 Der Planungswirrwarr und die unklaren Kommunikationsverläufe innerhalb der US-Armee illustriert eine Aussage von OMGUS-Befehlshaber General Lucius D. Clay, dem dann der Karrierediplomat Robert Murphy als politischer Berater zur Seite gestellt wurde. Mit Bezug auf die unmittelbare Nachkriegssituation in Deutschland gab General Clay zu Protokoll: ,Nobody talked to me about what our problems were in Germany. They just sent me over there [...]. I had no policy given to me as to what kind of a democracy we wanted. I did not have very much experience in the field myself [...]. I did not get the American declaration of policy until after I had been over there several months." Lucius D. Clay. Zit. nach: Arthur L. Funk, American and Soviet Views on Europe from Yalta to the Marshall Plan. In: Michel Dumoulin (Ed.), Wartime Plans for Postwar Europe 1940-1947 (= European Community Liaison Committee of Historians, Vol. 5), Paris - Baden-Baden 1995, 401. 
US-Besatzungsoffiziere hinsichtlich der „General attitude towards Austrians“ klar instruierte: „The task of the military government officer is to administer, not to frame, policy, or to discuss with Austrians his own ideas about Austrian politics."

Der grundlegende und zentrale Aufgabenbereich der US-Militärs im Zusammenhang mit einer mentalen Umorientierung der österreichischen Bevölkerung in Richtung einer nachhaltigen demokratischen Entwicklung - für die weder eigenständige Konzepte existierten noch sonstige Maßnahmen vorgesehen waren - betraf zugleich die Grundvoraussetzung aller weiteren Anstrengungen im Bereich von Reeducation beziehungsweise Reorientierung: entschiedene personale „Säuberungsmaßnahmen“ und die Beseitigung aller sonstigen Spuren der NS-Herrschaft im Bereich des gesamten Bildungs- und Erziehungswesens, im Bereich von Kunst und Kultur sowie im Bereich von Museen und Monumenten. Interessant ist, dass im Military Handbook noch von österreichischen „anti-democrats“ die Rede ist, denen zwar mit weniger Argwohn als den aktiven Nationalsozialisten zu begegnen wäre, die aber dennoch mit Vorsicht zu behandeln seien: „Military government officers will treat former active Austrian anti-democrats and former leaders of anti-democratic para-military groups with caution but with less suspicion than that with which they view active Nazis."

Die von William B. Featherstone ausgearbeiteten Kapitel I2 („Education“), I3 („Religious Affairs“) ${ }^{1112}$ und I4 („Monuments, Fine Arts and Archives“) ${ }^{1113}$ beschränkten sich weitgehend auf eine kurz gehaltene Beschreibung der vom NS-Regime getroffenen Maßnahmen beziehungsweise auf eine kurze Charakterisierung der Einrichtungen im jeweiligen Bereich, und gaben anschließend das vorgesehene Szenario der Säuberungsbeziehungweise Schließungsmaßnahmen an. Alle Maßnahmen stünden ab sofort in der Verantwortung und Kontrolle der „Division of Education, Religious Affairs, Monuments, Fine Arts and Archives“ der US-Militärregierung, welche die Formierung eines österreichischen Unterrichtsministeriums anregen solle und auf „Gau-Ebene“ die Aufgabe habe,

1110 Allied Forces Headquarters. Office of the Chief of Staff. Handbook for Military Government in Austria, [W.D. Morgan], April 1945, Chapter 2, 4.

1111 Ebd., Chapter 2, 6.

1112 Kapitel 13 des Military Government Handbook fixierte im wesentlichen, dass die US-Militärbehörden die Kirchen von jeglichem Zwang und jeglicher Kontrolle befreien und in völliger Unparteilichkeit („complete impartiality“) die Freiheit des Glaubens und der Religionsausübung garantieren würde. Ebd., Chapter 13, 2 .

1113 Im Bereich der Kunst, der Museen, der Monumente und des Archivwesens legte das Militärhandbuch fest, dass es, neben ,Säuberungen', hier - nach Möglichkeit - vor allem um den Schutz des wertvollen österreichischen Kulturguts ginge: „It is the policy of the military government to protect and preserve, in so far as military necessity permits, structures, objects and sites of cultural, artistic, religious, archeological, or historical value." Im Bereich des Archivwesens wurde eigens hervorgehoben, dass das Ziel darin bestünde, möglichen Schaden durch Vernichtung von Material abzuwehren: „It is the policy of military government [...] to preserve from dispersal, looting, damage or destruction all archives and records, and to prevent alteration, concealment or unauthorized removal of them.“ Ebd., Chapter 14, 3 bzw. 7. 
durch je einen verantwortlichen Education-Officer „to obtain information on all matters pertaining to education [...]. No educational specialist will be assigned to military government below the Gau. “1114 [Kursiv im Original, d. Verf.]

Neben dem primären und sekundären Schulwesen, den Lehrerbildungsanstalten, den (vom NS-Regime aufgelösten) Erwachsenenbildungseinrichtungen und den NS-Parteischulen wurden im Kapitel I2 immerhin, wenn auch nur an drei Stellen und ohne ausführlichere Angaben und Hinweise auf die reale Situation - über detaillierte Infromation dazu verfügte, wie noch darzustellen sein wird, der miltärischer US-Geheimdienst -, die Universitäten angeführt:

\footnotetext{
"Technical and professional education has reached a low ebb in comparison with pre-war years. It is probable that soon after occupation there will be pressure for opening the universities and higer schools. [...] Training of teachers has been so thoroughly Nazified both in its academic and its technical aspects that there can be said to exist no worth-while training programme for secondary schools. Teachers education will have to be completely reorganized." ${ }^{1115}$
}

Dementsprechend behielt sich die amerikanische Militärregierung laut Militärhandbuch vorläufig das ausschließliche Recht auf personelle Einstellungen im gesamten Bildungsbereich vor, indem erst nach Überprüfung des vollständig ausgefüllten ,security questionnaire (Fragebogen)“ über die weitere Verwendung entschieden werden sollte. Insbesondere würde dieses Prozedere - wie auch in Deutschland ${ }^{1116}$ - für alle Rektoren und Universitätslehrer an österreichischen Universitäten gelten:

\section{"[...] the appointment of rectors of universities and higher schools and of all instructional personnel in universities and higher schools is a responsibility exclusively of the chief military government officer at central military government headquarters." ${ }^{1117}$ [Hervorhebung d. Verf.]}

Wie unsicher die zuständigen US-Militärsstellen über ihre bildungspolitischen Aufgaben in Österreich waren, geht aus einer MTOUSA-Direktive Anfang Mai 1945 hervor, worin die zwei grundlegenden Zielvorgaben der "control of education in Austria“ noch einmal umrissen wurden, so als wüßten die Militärs, wie leicht diese Ziele hinter den anderen besatzungsadministrativen Aufgaben verschwinden könnten. Als erste Zielvorgabe wurde die „Einimpfung“ demokratischer Prinzipien und Werte benannt: „The development of a

1114 Ebd., Chapter 12, 9.

1115 Ebd., Chapter 12, 7 bzw. 2 u. 11.

1116 Siehe: Paulus, Amerikanisierung von Universität und Wissenschaft in Westdeutschland 1945-1976, a.a.O., $103 \mathrm{f}$.

1117 Allied Forces Headquarters. Office of the Chief of Staff. Handbook for Military Government in Austria, [W.D. Morgan], April 1945, Chapter 12, 11. 
system of education inculcating democratic and humanitarian principles and values, and emphasizing the necessity for peace and international cooperation." Als zweite grundlegende Zielvorgabe wurde den verantwortlichen US-Militärs in Österreich die Wichtigkeit der Entnazifizierung in Erinnerung gerufen: „The eradication from the educational system of Nazi influence and doctrine, in particular, instruction giving support to world domination, militarism, pan-Germanism, the Fuhrer [sic] principle and discrimination on the basis of race and religion. “1118

Vor dem Hintergrund dieser bürokratisch formulierten und auch inhaltlich äußerst dürftigen militärischen Planungsunterlagen, aus denen sich kein wie immer geartetes konzeptionelles Reorientierungs-Programm ablesen ließ, erstaunt es umso mehr, dass zum selben Zeitpunkt ein gut ausgearbeiteter „Operational Plan for Austria“ vorlag, den geheimdienstliche Propaganda-Abteilungen des „Office of War Information“ (OWI) ausgearbeitet hatten. Der Plan, dessen primäres Ziel darin bestand, „to break down political, emotional and historically developed relationships with Germany and to forestall the re-emergence of Pan-Germanism“, sah die Einbeziehung aller vorhandenen Medien vor und richtete sich tendenziell an alle Schichten und Altersgruppen der österreichischen Bevölkerung. Detaillierte Bücherlisten in deutscher und englischer Sprache, Informationsbroschüren (z.B. „How We Beat the Wehrmacht“, „You Can’t Win“, „Anti-Semitism“ et cetera), Zeitschriften und Illustrierte, Bildmaterial, Dokumentarfilme, Ausstellungen, Kinofilme oder Radiosendungen sollten in aufeinander abgestimmter und auszutestender Form das Gefühl der Unabhängigkeit von Deutschland unterstützen, ein positives Bild Amerikas zeichnen und demokratische Wertvorstellungen verankern helfen:

"Democracy should be presented as a philosophy of Government which results in a way of life under which liberties are attained and expanded through constant efforts and safeguards through constant vigilance. The most useful stories will be those which contain an objective treatment of the history of American democracy and an explanation of the mechanism of federal, State and Local Government in the USA, the working of Labor Unions in the USA, democratic solutions to political, social, and economic problems of a general or controversial nature." ${ }^{1119}$ [Hervorhebung d. Verf.]

Nachdem das OWI als geheimdienstliche Propagandaeinrichtung des State Department gegen Kriegsende aber zunehmend an Bedeutung verloren hatte und Mitte 1945, wie bereits erwähnt, schließlich aufgelöst wurde, blieb dieser Plan, der dezidiert „als LongeRange Directive for Austria“1120 angelegt war, reiner „Sandkastenentwurf“.

1118 NARA II, RG 260, Education Division, USFA, Historical File, Box 1, Folder 3. MTOUSA Directive No. 16 for Austria - Control of Educational Institutions in Austria, [Secret], 10. Mai 1945, 2.

1119 NARA II, RG 208, Office of War Information, Box 106. Operational Plan For Austria, 12. Mai 1945, 10. 1120 Ebd., 1. 
Mit dem Einmarsch der US-Truppen in Österreich Anfang Mai 1945 - der durchaus in „Siegermentalität ${ }^{“ 121}$ erfolgte - war die verworrene und im Hinblick auf die geplante mentale Umorientierung der österreichischen Bevölkerung hochgradig uneffiziente militärische Planungsphase zu Ende. Im Ressortstreit zwischen den zivilen Experten im State Department und den pragmatischen Hardlinern im War Department, denen es in keiner Phase um die langfristige „politische“ Dimension einer US-Militärverwaltung gegangen war, hatten sich eindeutig die Militärs durchgesetzt. Das bestätigte sich nach Abschluss des ersten alliierten Kontrollabkommens über Österreich am 4. Juli 1945 auch durch die Implementierung der Informationsflusses bezüglich aller die österreichische Besatzung betreffenden Angelegenheiten: wie im Fall der deutschen US-Besatzungszone lief der Kommunikationskanal über die Schiene Joint Chiefs of Staff - War Department - SWNCC; damit war das State Department lediglich formal und am Rande miteinbezogen. ${ }^{1122}$

Das proklamierte Ziel der US-Besatzungsmacht in Österreich bestand damit in der Sicherstellung der öffentlichen Ordnung und der Wiederherstellung einer funktionierenden Administration, und weniger ,in der Wiederbelebung des demokratischen politischen Lebens ${ }^{\text {“ }}{ }^{1123}$ eine Situation, die in den Lageberichten des OSS zur Situation in der unmittelbaren Nachkriegszeit heftig kritisiert wurde:

"The official ban on parties has done much to alienate the political leaders in Upper Austria and to cripple the normal development of democratic life. [...] The impotence imposed upon men who were prominent in Austrian public life before the Anschluss, or who have acquired influence as a result of their anti-Nazi activity, an impotence imposed by cutting them off from the political direction of the Province, and from their followers throughout the Province, is such as to awaken distrust in the democratic 'talk' of the Western Allies." ${ }^{1124}$

1121 Dementsprechend harsch waren die ersten Verlautbarungen und Befehle der US-Besatzungsmacht formuliert. So hieß es etwa in einem am 5. Mai 1945 in Linz angeschlagenen Befehl des amerikanischen Generals Holbrook: „Wenn aus dem Haus geschossen wird, werden 5 Häuser dem Erdboden gleich gemacht.“ Zit. nach: Kurt Tweraser, Die „unpolitische“ Periode der amerikanischen Besatzung in Linz und Oberösterreich. Sommer und Herbst 1945. In: Prinzip Hoffnung. Linz zwischen Befreiung und Freiheit. Ausstellungskatalog. Red. v. Willibald Katzinger und Fritz Mayrhofer, Linz 1995, 36 bzw. 41.

1122 NARA II, RG 260, USGCC 1944-45, Box 34. Folder 14 [390/40/18/4-5]. Joint Chiefs of Staff, Communication Channel with Commander in Chief U.S. Forces of Occupation in Germany and Austria [J.C.S. 1408/1, Secret], 23. Juli $19451 \mathrm{f}$.

1123 Tweraser, Die „unpolitische“ Periode der amerikanischen Besatzung in Linz und Oberösterreich, a.a.O., 40. Zur US-Militärverwaltung in Österreich allgemein siehe auch: George C.S. Benson, American Military Government in Austria May 1945-February 1946. In: American Experiences in Military Government in World War II. Hrsg. v. Carl J. Friedrich, Washington D.C. 1948, 169-194; Arnold Toynbee/Michael Balfour/John Mair, Four-Power-Control in Germany and Austria 1945-1946, Oxford 1972 [Reprint der Ausgabe v. 1956].

1124 Paul R. Sweet/Edgar N. Johnson (OSS), The Formation of the Present Unpolitical Provincial Government, 2. August 1945. Zit. nach: Rathkolb (Hrsg.), Gesellschaft und Politik am Beginn der Zweiten Republik, a.a.O., 234. 
Tatsächlich wurden in der unmittelbaren Nachkriegsphase von der amerikanischen Besatzungsmacht nicht bloß Angehörige lokaler Widerstandsgruppen von der Mitarbeit und Kooperation ausgeschlossen, ${ }^{1125}$ sondern darüber hinaus vermochten sich in zahlreichen Orten Nazis als Beamte im Bereich der Verwaltung oder Exekutive zu halten, die mitunter sogar polizeilichen Druck ausübten, um die Aussendung von „Fragebogen“ für die NSRegistrierung zu verhindern. ${ }^{1126}$

Als besonders krasse Folge der , unpolitischen “ US-Militärverwaltung in der unmittelbaren Nachkriegsphase kann die Bestellung von „Hofrat“ Adolf Eig1 ${ }^{1127}$ zum oberösterreichischen Landeshauptmann durch Oberst Russel A. Snook beziehungsweise Major John D. Hartigan am r6. Mai 1945 gelten: ${ }^{1128}$ die von Eigl gebildete „Beamtenregierung ${ }^{(1129}$ be-

1125 So steht in dem zitierten OSS-Bericht diesbezüglich zu lesen: „The manner in which American authorities have rejected the offer of already established resistance groups to cooperate with the present Provincial Government in carrying out a de-Nazification program does not give much encouragement to democratic anti-Nazi Austrians to trust in the sincerity of American intentions.“ Des Weiteren: „A common complaint, met almost everywhere, was that Nazis apprehended by resistance elements were forthwith released by the Americans." Paul R. Sweet/Edgar N. Johnson (OSS), The Formation of the Present Unpolitical Provincial Government, 2. August 1945. Zit. nach: Rathkolb (Hrsg.), Gesellschaft und Politik am Beginn der Zweiten Republik, a.a.O., 230 bzw. 231.

1126 Vgl. Rathkolb (Hrsg.), Gesellschaft und Politik am Beginn der Zweiten Republik, a.a.O., 235.

1127 Der promovierte Jurist Adolf Eigl (1883-1958), der als NSDAP-Mitglied geführt wurde, hatte nach dem „Anschluss“ als Verwaltungsbeamter Karriere gemacht und wurde, gefördert von Gauleiter Eigruber, zum kommissarischen Regierungsdirektor der Landeshauptmannschaft bestellt. Siehe: Walter Schuster, Politische Restauration und Entnazifizierungspolitik in Oberösterreich. In: Walter Schuster/Wolfgang Weber (Hrsg.), Entnazifizierung im regionalen Vergleich, Linz 2004, 168.

1128 Schreiben von Oberst Snook an „Herr Hofrat and Gentlemen“, 15. Mai 1945. Hoover Institution Archives, Stanford University, John Doane Hartigan Papers, 1909-1958, Box 7: Military reports and career of John Doane Hartigan. 235. Unter Hinweis darauf, dass die Alliierten Mächte dafür gekämpft hätten, „to destroy tyranny, oppression and despotic rule“, ernannte Snook Eigl zum Landeshauptmann: „Herr Hofrat, you will be appointed Landeshauptmann and in that position you will have authority to select and direct your staff and perform in accordance with our approval the duties of your high and important office." Zit. nach: ebd. $1 \mathrm{f}$.

1129 Laut einer rezenten, tendenziell exkulpatorischen Darstellung bei Cornelia Sulzbacher, die sich dabei auf Primärquellenmaterial stützt, habe sich Eigl bei der Erstellung der „Beamtenregierung“ lediglich an den unpolitischen, weniger an der „Wiederrichtung demokratischer Strukturen“ interessierten Verwaltungsvorgaben der US-Militärregierung orientiert, so als hätte Eigl lediglich pflichtgetreu die Anordnungen der amerikanischen Militärs umgesetzt: „Eigl versuchte im Sinne seines Auftrages, eine effektive Verwaltung zu schaffen, weshalb er Verwaltungsfachleute berief und der Frage ehemaliger NSDAP-Mitgliedschaften wenig Aufmerksamkeit schenkte. Die sogenannte ,Beamtenregierung ${ }^{*}$ umfasste daher einige Nationalsozialisten. Zudem repräsentierte sie nicht das politische Spektrum Oberösterreichs und war in allen Entscheidungen von der Militärregierung [bis Mitte Juni 1945, d. Verf.] abhängig." Cornelia Sulzbacher, Adolf Eigl - Landeshauptmann von Oberösterreich. In: Mitteilungen des Oberösterreichischen Landesarchivs, 22. Bd., Linz 2011, 332. 
stand zum Großteil aus überzeugten Vertretern des austrofaschistischen „Ständestaats “"1130 und einzelnen Nationalsozialisten ${ }^{1131}$ und widmete sich in dieser Zusammensetzung der demokratischen Säuberung in höchst unzureichender Weise, wie der OSS kritisierte. ${ }^{1132}$ Nicht zuletzt wegen der Kritik des US-Geheimdienstes und Kritik von Seite einzelner US-Bürger mit Beziehung zur US-Militärregierung, wurde diese erste Landesregierung, die einen Affront gegenüber allen Bemühungen um einen demokratischen Neubeginn darstellte, schließlich aufgelöst, führende Mitglieder, wie Adolf Eigl selbst, verhaftet und in das US-Internierungslager „Camp Marcus W. Orr" (Glasenbach) überstellt. ${ }^{1133}$ Vor der Intervention des OSS und des CIC hatte zwischen Hartigan und Eigl, die sich auf gemeinsamen Inspektionsreisen kennenlernten - Eigl führte dabei souverän Regie -, ein ausgesprochen gutes Verhältnis geherrscht. ${ }^{1134}$

Interessanterweise hatte Lt. Col. Robert C. Hendrickson, der stellvertretende USCommanding Officer, in einem ausführlichen Antwortschreiben an eine ihm persönlich bekannte New Yorker Dame, Frau Ogden Reid, die sich über die peinlichen Vorgänge in Oberösterreich beziehungsweise über das zweifelhafte Vorgehen der US-Militärregierung gegen Josef Walk und Adolf Eigl beschwert hatte, Stellung bezogen. Hendrickson gab in

1130 So etwa Dr. Heinrich Gleißner (geb. 1893), Oberst Dr. Herbert Krögler (geb. 1896), Dr. Josef Schlegel (geb. 1904), Dr. Alois Moser (geb. 1897), Dr. Anton Rußegger, (geb. 1888), Dr. Josef Mahal (geb. 1889), Dr. Ferdinand Reinhardt (geb. 1882), Alois Hobelsperger (geb. 1886), Dr. Justus Schmidt (geb. 1903), Dr. Ing. Karl Öttl (geb. 1902), Dr. Hans Frenzel (geb. 1895), Dr. Viktor Guttmann (geb. 1903), Dr. Josef Walk (geb. 1902), Dr. Ernst Lyro (geb. 1888), Oberregierungsrat Ernst Hodel (geb. 1888), Dr. Hermann Garhofer (geb. 1887), Dr. Franz Lorenzoni (geb. 1890) sowie Gisbert von Wersebe (geb. 1882). Siehe: John D. Hartigan to Russel A. Snook, Col. CMP, Linz, 8. Juni 1945, „Meeting of Land Officials“; weiters: John D. Hartigan, Major, A.C., USACA, Plans and Operations, to Colonel Norcross, Chief, Internal Affairs Division, „Report of Investigation of Land Government officials (Upper Austria), Headquarters United States Forces in Austria, 16. Oktober 1945. Beide Dokumente: Hoover Institution Archives, Stanford University, John Doane Hartigan Papers, 1909-1958, Box 7: Military reports and career of John Doane Hartigan. Siehe dazu auch: Schuster, Politische Restauration und Entnazifizierungspolitik in Oberösterreich, a.a.O., $160 \mathrm{f}$.

1131 Beispielsweise die nach dem „Anschluss“ zu Oberregierungsräten avancierten Anton Rußegger und Josef Walk, weiters die NSDAP-Mitglieder Josef Mahal, Alois Hobelsperger und Herbert Krögler. Vgl. Sulzbacher, Adolf Eigl - Landeshauptmann von Oberösterreich, a.a. O., 335 f.

1132 Paul R. Sweet/Edgar N. Johnson (OSS), The Formation of the Present Unpolitical Provincial Government, 2. August 1945. Zit. nach: Rathkolb (Hrsg.), Gesellschaft und Politik am Beginn der Zweiten Republik, a.a.O., 229.

1133 Vgl. Schuster, Politische Restauration und Entnazifizierungspolitik in Oberösterreich, a.a.O., 173.

1134 So z.B. bei einer Inspektionsreise nach Bad Aussee am 18. Juni 1945, wo interessanterweise Eigl Albrecht Gaiswinkler als Bürgermeister vorschlug: „[... ] Dr. Eigl feels that Herr Gaiswinkler was an excellent man and could be of use as Buergermeister in Bad Aussee with certain general duties in the surrounding area." John F. Hartigan, Major A.C., to Col. Russel A Snook, 19. Juni 1945, 1. Hoover Institution Archives, Stanford University, John Doane Hartigan Papers, 1909-1958, Box 7: Military reports and career of John Doane Hartigan. 
seiner Antwort, die um Kalmierung bemüht war, Einblick in die interne Situation, die sich auch ihm als keineswegs unproblematisch darstellte. Einerseits bemühte sich Hendrickson, ohne die Vorgänge zu verteidigen, darzulegen, dass es für die Militärregierung, die ja im Übrigen bereits über Besatzungserfahrung im ehemals faschistischen Italien verfügte, unumgänglich wäre, auch und insbesondere auf Personen zurückzugreifen, die über entsprechende fachliche Qualifikation verfügten; tatsächlich befand sich Hartigan damit nicht völlig abseits von der Generallinie der Entnazifizierungspolitik der US-Militärs im Beamtenbereich: Säuberungen sollten nach „freiem Ermessen“ und je nach Verwendbarkeit durchgeführt werden, wobei allerdings, und das verdient hervorgehoben zu werden, explizit alle nationalsozialistischen Reichsstatthalter, Landräte, Bürgermeister und NSDAP-Mitglieder vor dem I2. März 1938 ausgenommen waren. ${ }^{1135}$ Nach Auffassung Hendricksons könne es des Weiteren nicht darum gehen, durch ad hoc Relegierungen ohne jedes rechtliche Verfahren nach der Methode „Out-Nazi the Nazi“ zu verfahren. ${ }^{1136}$ Dessen ungeachtet seien aber im vorliegenden Fall Fehler passiert, indem zum Beispiel Vertreter des CIC, trotz der Einladung, Material bei einem Hearing vorzulegen, einfach nicht erschienen seien (,they did not even choose to appear“), ${ }^{1137}$ sodass die Verantwortlichen in Oberösterreich erst mit Verspätung Kenntnis über vorliegendes Belastungsmaterial gehabt hätten. Abschließend teilte Hendrickson Mrs. Reid eine kulturhistorisch eingeleitete Beobachtung mit, die ein interessantes Licht darauf wirft, wie manch leitende US-Offiziere die „komplexe“ Situation vor Ort zu entschuldigen versuchten - im vorliegenden Fall ergänzt um einen Ausbildungsvorschlag für künftige Curricula im Rahmen der Offiziersausbildung der US-Armee:

"[...] take this opportunity to make an observation which I think all Americans should know in respect to the occupation of Austria in particular and to all enemy [sic] nations generally. It is a rule as old as civilization itself and that, namely, that people cannot be governed with any good or lasting effect by any authority, be it military or otherwise, which does not allow for simple justice in all things, handbooks, orders and directives to the contrary not-with-standing. It is my sincere hope that our Service Academy (West Point and Annapolis) in the future will incorporate in their curriculum for those who are to lead our Army and Navy of the fu-

1135 So heißt es im Wortlaut eines „Public Safety Manual for Austria“ in Bezug auf „Discretionary Removal“: „The removal of all other Civilian Servants or officials is discretionary [...]. If it appears that the Civil Servant or Official joined the NSDAP merely to retain his employment and not because of strong belief in its principles, and does not hold any of the party ranks described in para.192, there should be no strong objection to his retention." NARA II, RG 260, Dir. Office, USCA, Box 20. Public Safety Manual for Austria, Section VI, Security and Denazification, 5.

1136 Robert C. Hendrickson to Mrs. Ogden Reid, New York, 15. Juli 1945, 1. Hoover Institution Archives, Stanford University, John Doane Hartigan Papers, 1909-1958, Box 7: Military reports and career of John Doane Hartigan.

1137 Ebd., 3. 
ture, a sound course in Military Government and that course will not overlook a few of the fundamental principles of justice which even make their appearance in the 'Rules of Land Warfare'."1138

Tatsächlich war dann auch der auf Adolf Eigl folgende oberösterreichische ÖVP-Landeshauptmann Heinrich Gleißner keineswegs ein völlig unproblematischer Kandidat. ${ }^{1139}$ Obwohl Gleißner weder in einem am I6. Mai 1945 ausgefüllten Fragebogen der US-Militärregierung noch in einem danach unterfertigten Lebenslauf eine NSDAP-Mitgliedschaft angegeben hatte, war dem ÖVP-Parteipräsidium bereits 1945 durch persönliche Information von Gleißner bekannt, dass dieser, nach Intervention seiner Ehefrau bei der Mutter Himmlers, auf Veranlassung des „Reichsführers SS“ aus der KZ-Haft entlassen und ab I94I in Berlin in einem SS-Betrieb („Braunkohle-Benzin AG“) gearbeitet hatte, wo er, wie Kurt Tweraser berichtet, „ein höchst gefährliches Naheverhältniss zu Persönlichkeiten des deutschen Widerstandes " ${ }^{1140}$ unterhalten haben soll. Die in jener Zeit beantragte NSDAP-Mitgliedschaft Gleißners ${ }^{1141}$ - er war seit dem I. April i94I mit der NSDAPMitgliedsnummer 8.293.06o verzeichnet ${ }^{1142}$ - wurde den US-Militärstellen allerdings erst im Frühjahr 1948 bekannt. Hinsichtlich der 1946 kolportierten Mitwirkung Gleißners an der „Regierung Kaltenbrunner“, die einen Separatabkommen mit den Westalliierten angestrebt hatte, hatte Gleißner im April I946 selbst ein Untersuchungsverfahren beantragt und erklärt, von dieser Angelegenheit nichts zu wissen. ${ }^{1143}$ Aus besatzungspolitischen Interessen wurde die NSDAP-Mitgliedschaft Gleißners, die im Zusammenhang mit einer für 1949 geplanten USA-Reise Gleißners virulent wurde, allerdings vor der Öffentlichkeit

1138 Ebd., 3 f.

1139 Heinrich Gleißner (1893-1985), Corpsstudent und promovierter Jurist. 1930 wird Gleißner Direktor der oberösterreichischen Landwirtschaftskammer. Nach kurzzeitiger Funktion als Staatssekretär im Land- und Forstwirtschaftsministerium wurde Gleißner 1934 oberösterreichischer Landeshauptmann. Infolge seiner Kontakte zu Juden sah sich Gleißner nationalsozialistischen Angriffen ausgesetzt, pflegte jedoch selbst zu „Illegalen“ wie Franz Langoth und Anton Reinthaller gute Kontakte. Unmittelbar nach dem „Anschluss“ wurde Gleißner am 15. März 1938 verhaftet und nach Misshandlungen in das Konzentrationslager Dachau bzw. in das Konzentrationslager Buchenwald transportiert. Vgl. Schuster, Politische Restauration und Entnazifizierungspolitik in Oberösterreich, a.a.O., 176; weiters: Thomas Dostal, Das „braune Netzwerk“ in Linz. Die illegalen nationalsozialistischen Aktivitäten zwischen 1933 und 1938. In: Fritz Mayrhofer/Walter Schuster (Hrsg.), Nationalsozialismus in Linz. Bd. 1, Linz 2001, 64.

1140 Tweraser, US-Militärregierung Oberösterreich. Bd. 1, a.a.O., $233 \mathrm{f}$.

1141 Für den Hinweis auf den „Fall Gleißner“ danke ich an dieser Stelle Herrn Univ.-Prof. DDr. Oliver Rathkolb, der - wenn auch in anonymisierter Form - zuallererst diese Causa erwähnt hat. Siehe: Oliver Rathkolb, US-Entnazifizierung in Österreich zwischen kontrollierter Revolution und Elitenrestauration (1945-1949). In: Zeitgeschichte, 9-10, 1984, 317.

1142 Tweraser, US-Militärregierung Oberösterreich. Bd. 1, a.a.O., 232.

1143 Schuster, Politische Restauration und Entnazifizierungspolitik in Oberösterreich, a.a.O., 183. 
geheimgehalten. ${ }^{1144}$ Wie die ÖVP-Führung, die in Gleißner einen verlässlichen Landeshauptmann hatte, war auch die amerikanische Militärverwaltung an einer Fortführung der bisher reibungslosen Zusammenarbeit sowohl mit Gleißner als auch mit Bundeskanzler Figl interessiert; eine öffentliche Bekanntgabe der Informationen hätte die Regierung Figl zweifelos unter Druck gesetzt. Zudem unterschlug man das brisante Material wohl auch deshalb, um eine öffentliche Diskussion mit den Sowjets zu vermeiden. ${ }^{1145}$

Trotz dieser und manch anderer Ungereimtheiten stand zu Kriegsende als unverrückbare Tatsache fest, dass die amerikanischen Besatzungsoffiziere in ihren jeweiligen Detachments auf Basis der ausgearbeiteten militärischen Direktiven nun mit sofortiger Wirkung zumindest das Kernstück aller bisherigen Überlegungen zur Reorientation umzusetzten hatten: die vollständige Entnazifizierung, unter anderem auch des gesamten Bildungswesens in Österreich.

$1144 \mathrm{Zu}$ weiteren Details der Causa Gleißner siehe die Ausführungen im Zusammenhang des „Exchange Programs“ in Kapitel 6, Seite 623 dieser Arbeit.

1145 Vgl. Schuster, Politische Restauration und Entnazifizierungspolitik in Oberösterreich, a.a. O., 181. 


\section{Beginn der US-Reorientierung nach $1945-$ die Education Division als zentrale US-Militärbehörde}

Mit dem Einmarsch der alliierten Truppen in Österreich und dem im Juli 1945 abgeschlossenen Alliierten Kontrollabkommen, das die Militärverwaltungen in getrennten Besatzungszonen regelte, stand Österreich unter alliierter Militärkontrolle, die in allen Bereichen der Exekutive, der Legislative und der behördlichen Administration de facto die höchste Autorität darstellte.

Die amerikanische Militärverwaltung gliederte sich dabei in das Hauptquartier in Salzburg (Headquarter United States Forces Austria - USFA; General Mark W. Clark), sowie das operative „USFA-Headquarter Command“ (Lt. General Geoffrey Keyes) und die subordinierten Zonenkommandos („Zone Commands“) in Salzburg, Oberösterreich, Wien (7.-9. und 17.-I9. Wiener Gemeindebezirk) und in der interalliierten Zone Wiens in der Inneren Stadt. Mit Installierung der Alliierten Kontrollkommission (ACA) wurde am 5. Juli I945 auch die „United States Allied Commission, Austria“ (USACA) unter Leitung von Col. Dodge geschaffen, die aus I3 Divisionskommandos bestand. ${ }^{1146}$ USACA war für die Überwachung aller zivilen Angelegenheiten und die Aufrechterhaltung der öffentlichen Sicherheit verantwortlich, beriet den US-Oberbefehlshaber in allen Agenden der Militärregierung, administrierte die zonale Militärverwaltung und bildete außerdem das Schnittstellen-Gremium zum Alliierten Rat („US-Element“). ${ }^{1147}$

Eine eigenständige Abteilung innerhalb der US-Militärregierung, die sich übergreifend mit allen Aufgabenbereichen der Reeducation beziehungsweise Reorientation befasst hätte, gab es weder bei Kriegsende noch in den folgenden Jahren der Besatzungszeit. So blieben diese Agenden, die innerhalb der Planungsaktivitäten der US-Army immer eine Art Fremdkörper geblieben waren, letztlich auf verschiedene militärische Stabstellen beziehungsweise Divisionen aufgesplittert.

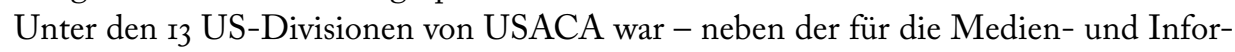
mationspolitik zuständigen „Informations Service Branch“ (ISB) oder der „Internal Affairs Branch“-insbesondere die „Education Branch“, die bezeichnenderweise zu Beginn lediglich als „Branch“ geführt und erst am I5. Juli I946 in „Education Division“ (USACA) umbenannt wurde, für die Reorientierung des gesamten österreichischen Bildungssystems zuständig. ${ }^{1148}$

1146 NARA II, RG 260. Finding Aid, Command and Organization, U.S. Military Government for Austria [Secret], Headquarters USFA, Organization Chart.

1147 NARA II, RG 260, USFA, Historical File, Box 31, Folder 252. Appendixes to USACA History, From its Inception to VE-Day, 1944-45, „Basic Plan of U.S. Participation in Allied Administration and Occupation of Austria“, 30. Mai 1945.

1148 NARA II, RG 260, USFA, Historical File, Box 33. Quarterly Historical Report. USACA Section, U.S. Forces in Austria 1946, 335. 
Der Nukleus der späteren „Education Division“ (USACA) geht auf jenes gemischte anglo-amerikanische Planungsteam zurück, das am ro. April I944 im Civil Affairs Center in Shrivenham bei London als „Austria Planning Unit" eingerichtet worden war. Leiter der geplanten Abteilung „Education and Religious Affairs“ innerhalb USGCC /A war ab I4. Juli 1944 Lt. Colonel (später Major) William B. Featherstone, der zuvor als Professor für Erziehungswissenschaft an der Columbia University gearbeitet hatte. ${ }^{1149}$ Featherstone hielt sich zwischen 1944 und Anfang 1945 in Shrivenham und dann im italienischen Caserta auf, wo er - offenkundig nur unterstützt durch Verbindungsoffiziere in London - die „Section 33, Chapter I2“" des Military Government Handbook Austria vorbereitete.

Am I3. Februar 1945 legte Featherstone der Task Force USGCC/A beziehungsweise deren Leiter General Flory ein überarbeitetes Glossar zur „German-Austrian education“ vor

1149 William B[land] Featherstone (1900-1951), in Iowa geboren, studierte Erziehungswissenschaft an der University of Wyoming, wo er 1932 promovierte. Bereits seit 1924 arbeitete Featherstone als High SchoolLehrer und hatte von 1924-1929 die Funktion eines „superintendent of schools“ in Evanston, Wyoming inne. Von 1932-1935 war er Direktor des „secondary school curriculums“ des „Board of Education“ in Los Angeles. 1935 kam er an das Teachers College der Columbia University in New York, wo er 1939 ordentlicher Professor wurde. Von 1939 bis 1941 war Featherstone als Konsulent des „New York City Board of Education“ der „Speyer School“ mit der Curriculumentwicklung für hochbegabte Kinder beschäftigt. Zudem war er Vorsitzender der „secondary education surveys of the public school system of St. Louis, Pittsburgh. In seinen wenigen wissenschaftlichen Arbeiten (in Summe lediglich 2 Monografien, ein mitherausgegebene Publikation und einige wenige Fachartikel) - Featherstone war ganz offenbar kein großer Schriftgelehrter, sondern eher Erziehungspraktiker - hatte er sich insbesondere mit Behindertenbildung beschäftig: so bspw. in „The Curriculum of the Special“ [1932] und in „Teaching the Slow Learner" [1942]. Dementsprechend übernahm Featherstone nach seiner Rückkehr aus Europa 1946 den Lehrstuhl für „special education“ (Blinden- und Taubstummenbildung) am Teachers College der Columbia University. In einer Würdigung nach seinem Ableben hob Hollis L. Caswell Featherstones „,down-toearth" treatment of educational problems" hervor sowie seine ,intellectual quality that would not tolerate shoddy or illogical work“. Ab 1941/42 nahm Featherstone ein akademisches Sabbatical (ohne Bezüge) in Anspruch und trat als "commissioned officer" in die Dienste der U.S. Armee ein; ab 1943/44 wurde er dann von der Universität freigestellt. Von 1942 bis 1943 arbeitete Featherstone als „assistant secretary" an der "School of Military Government“ in Virgina. Wegen „ausgezeichneter Leistungen“ wurde er von Brigadier General Cornelius W. Wickersham dann für den Einsatz „overseas“ im Stab von General Mark Clark vorgeschlagen, wo er als „Chief Education Division, Austrian Planning Unit SHAEF“, die Planungen für Österreich in Italien übernahm, bevor er 1945 erster Leiter der „US Education Division USACA“ wurde. 1951 verstarb William B. Featherstone in noch vergleichsweise jungen Jahren an einem Herzinfarkt. Siehe: Hollis L. Caswell, William B. Featherstone, 1900-1951. In: Teachers College Record, Vol. 52, 1951, No. 8, 512-514; Dr. Featherstone, Educator, Is Dead. In: New York Times, 14. April 1951; weiters: Konvolut „Biographical Information, W.B. Featherstone“, Gottesman Library, Teachers College, Columbia University sowie „Historical Biographical Files“, Box 91, Folder 8, im Archiv der Columbia University/Butler Library. Ich danke an dieser Stelle John Tofanelli (Research Collections and Services Librarian for British \& American History \& Literature Columbia University Libraries), Jennifer Govan (Gottesman Library, Teachers College, Columbia University) sowie Jocelyn K. Wilk, Public Services Archivist, Columbia University Archives, für die unkomplizierte Zurverfügungstellung von Material. 
und erhielt, nachdem die Education Branch auch für den Bereich Museen, Bibliotheken, Kunst und Monumente zuständig sein sollte, von der EAC-ACA (British Element) auf Anfrage eine vollständige Liste aller zu schützenden Denkmäler, Gebäude, Kunstwerke und Archive in Österreich. ${ }^{1150}$

Dass der Wiederaufbau im Bereich des österreichischen Bildungswesens mit ziemlicher Verzögerung in Gang kam, geht aus einem der ersten Berichte der „Education Branch USACA“ hervor, der am 4. Juni I945, einen Monat nach Kriegsende, festhielt: „Information on the state of education in Austria was still far too meager to draw any conclusions and definite plans as to Austrian schools had therefore to await the Division's entrance into Austria.“1151

Aus einem weiteren Report geht hervor, dass Featherstone schließlich am 23. Juni 1945 von Verona Richtung Salzburg aufbrach, wo er - zunächst im Rahmen des I5. Armeekorps der USFA - die Agenden der „Education, Monuments, Fine Arts, Archives and Records“ übernahm. ${ }^{1152}$

Bei seiner Ankunft in Salzburg war für das Military Detachment des Landes Salzburg interimistisch bereits Captain George A. Selke ${ }^{1153}$ als Officer für „Education, Monument and Arts, and Religious Affairs" eingesetzt; für Oberösterreich hatte Major John D. Hartigan neben seinen Aufgaben als „Administrative and Local Government Officer“ die Agenden der Reeducation und des Wiederaufbaues des Bildungswesens übernommen. ${ }^{1154}$

Der restliche Personalstab der „Education Division“ - die US-Akten sprechen zu jener Zeit tatsächlich von einer „Division“, das heißt die Umwandlung in eine „Branch“ erfolgte womöglich erst in Österreich - befand sich am I. Juli I945 hingegen nach wie vor in Verona,

1150 NARA II, RG 260, Box 31, Folder 252. USFA Historical File, Appendix „B“, History of Divisions of USACA, 1944-45, [Appendixes to USACA History from ist Inception to VE-Day, 1944-45], 7.

1151 Ebd.

1152 NARA II, RG 260, Box 31, Folder 253. USACA Historical File, United States Allied Commission for Austria History. Part II, V-E Day to End 1945, 232.

1153 George Albert Selke (1888-1970), erwarb 1926 sein MA-Diplom am Teachers College der Columbia University. Von 1934-1927 lehrte er an der University of Minnesota bevor er die nächsten 19 Jahre am dortigen St. Cloud State Teacher's College unterrichtete, an dem er von 1927-1946 auch die Funktion des Präsidenten einnahm. Darüber hinaus war Selke in den Jahren 1935-1939 Direktor der „National Youth Administration“ für Minnesota. Während des Zweiten Weltkrieges arbeitete er ab 1943 zunächst für die German Austrian Planning Unit (SHAEF) in London, nachfolgend in Italien. Nach interimistischer Übernahme USFA-Education-Agenden in Salzburg kehrte Selke 1946 in die USA zurück, wo er bis 1951 als Rektor der University of Montana fungierte. 1951 kehrte Selke nochmals in den Militärdienst zurück, diesmal in die US-Besatungszone in Deutschland, wo er im Rahmen der „High Commission für Germany“ (HICOG) die Aufgabe des stellvertretenden Leiters der US-„Education and Cultural Relations Divison“ übernahm und in dieser Funktion maßgeblich an der Ausarbeitung des Fulbright-Abkommens mit Deutschland beteiligt war. 1953 kehrte Selke in die USA zurück wo er u.a. Mitarbeiter von Landwirtschaftsminister Orville in der Kennedy-Adminstration wurde. Siehe: http:// www.monumentsmenfoundation.org/bio.php?id=271 [Zugriff 19.5.2013].

1154 Ebd., 233. 
wo deren Angehörige einen Orientierungskurs zu den bevorstehenden Erziehungsaufgaben verpflichtend besuchten. ${ }^{1155}$

Am 3. Juni wurde von der Education Division noch von Verona aus eine von britischer Seite (M\&FA) zusammengestellte „offizielle Liste“ aller Archive (samt Personalständen) an Colonel McCaffrey (SHAEF) zwecks Verbreitung an alle Offiziere der US-Militärbehörden in Österreich ausgesandt, um durch Kenntnis aller nötigen Unterlagen und Informationen eine möglichst effiziente Vorgehensweise der Militärregierung inklusive der militärischen Geheimdienste zu gewährleisten: „The archives list included the records of state, public, legal, and police administration, of the Nazi Party, of the head offices of such institutions as the great banks and insurance concerns, of the universities and educational and charitable institutions, of the Church, and of private individuals. [...] A similar list had already been prepared for Germany, and was issued down to Lt. Colonel's commands, together with instructions to operational troops for securing, guarding [...] and with special instructions to MG and Intelligence Officers to insure careful handling. Similar instructions were issued with the Austrian list." ${ }^{1156}$

Am 28. Juli 1945 wurden Lt. Rodger V. Holman, Lt. George R. Feldner und Lt. Gregory J. Sandker, die bereits in Italien der Education Branch USGCC/A zugeteilt worden waren, der US-Militärzone in Oberösterreich zugewiesen. Wie eine erste interne Überprüfung der Aufgaben- und Tätigkeitsbereiche der zugewiesenen Offiziere am Io. August 1945 ergab, nahm man in der US-Besatzungszone in Oberösterreich die Agenden des bildungspolitischen Wiederaufbaues aber nicht besonders ernst: „[...] one had been assigned to manage the Military Government garage, and that minor duties out of the field of Education had been assigned to the others. "1157 Womöglich existierten aber auch hier, wie Ute Schmidt und Tilman Fichter für OMGUS recherchiert haben, zu Beginn der Besatzungszeit einfach nur gravierende Personalprobleme. So waren 1945 nur zwei Prozent aller Offiziere im Korps der US-Army Berufsoffiziere, die außerdem stark konservativ geprägt waren. ${ }^{1158}$ Strukturell hatte die USACA-„Education Division“ offenkundig mit ähnlichen Problemen wie die OMGUS-,Education and Religious Affairs Branch“ in Deutschland zu kämpfen: dort waren von den insgesamt 2.00o für die gesamte Militäradministration in der USBesatzungszone zugeteilten Personen ebenfalls zunächst nur zehn für „Erziehungsaufgaben“ abgestellt worden. ${ }^{1159}$ Wie neuere Studien zur Reeducation in Deutschland gezeigt haben, stieg die Belegschaft nach Neuformierung der dortigen „Education and Cultural

1155 NARA II, RG 260, Box 31, Folder 252. USFA Historical File, Appendix „B“, History of Divisions of USACA, 1944-45, [Appendixes to USACA History from its Inception to VE-Day, 1944-45], 7.

1156 Ebd., $7 \mathrm{f}$.

1157 NARA II, RG 260, Box 31, Folder 253. USACA Historical File, United States Allied Commission for Austria History. Part II, V-E Day to End 1945, 233.

1158 Ute Schmidt/Tilman Fichter, Der erzwungene Kapitalismus. Klassenkämpfe in den Westzonen, 194548, Berlin 1971, $98 \mathrm{ff}$.

1159 Ebd., 145. 
Relations"-Division (ECR) ab 1948 jedoch kontinuierlich an - bei sinkenden Zahlen in den anderen OMGUS-Abteilungen -, sodass die ECR-Division dann ab Mai 1949 mit 35 Mitarbeitern bereits die größte Abteilung der Bayerischen Militärregierung darstellte. ${ }^{1160}$

Am 15. August 1945 wurde der Personalstand der Education Branch jedenfalls um Major Leigh M. Lott ${ }^{1161}$ erweitert, der insbesondere den Bereich der Universitäten und Forschungseinrichtungen übernahm. Zuvor war Major Lott der geheimdienstlichen Abteilung „S-2-Combat Intelligence“ der US-Air Force (46rst Bombardment Group) zugteilt gewesen. ${ }^{1162}$

Kurz danach, am 25. August 1945, begab sich die „Education Branch“-Leitung in Person von William B. Featherstone und Corporal Wallace J. Loftsgordon nach Wien, wo Major Joseph M. Murphy ${ }^{1163}$ im Rahmen des US-Vienna Area Command die Erziehungsagenden wahrnahm. Major Murphy war vor allem für die Wiener Schulen (Volks- und Mittelschulen) zuständig und ein Leutnant Fischer übernahm die Betreuung von Kursen für amerikanische Soldaten - quasi eine Form militärinterner Weiterbildung. ${ }^{1164}$ Währenddessen brach „Private First Class“ (Pfc.) ${ }^{1165}$ Kenneth L. Simmons von Verona nach Salzburg auf, wo er als weiterer Education-Officer innerhalb der US-Militärregierung die Arbeit aufnahm. ${ }^{1166}$

In Wien wurden unter Leitung von Featherstone alle Aktenbestände zusammengeführt und systematisiert und bis zum August des Jahres eine überarbeitete Fassung der Military Government Instructions (No. 25), die „educational affairs“ betreffend, ausgearbeitet und der „Plans and Operations Branch“ weitergeleitet. Des Weiteren wurde mit der Erstellung

1160 Latzin, Lernen von Amerika? Das Kulturaustauschprogramm für Bayern und seine Absolventen, a.a.O., 61.

1161 Leigh M. Lott (1899-1986), studierte Geschichte an der Weslyean University in Connecticut, wo er 1926 promovierte. Nach seinem Dienst in der U.S. Army leitete Lott die Division of Humanities am Centenary College for Women in New Jersey.

1162 Vgl. http://www.461st.org/History/461st\%20History/461st\%20History.html [Zugriff12.5.2013].

1163 Joseph M. Murphy (1899-1986), Historiker und Schulpädagoge; nach seinem Studium am Teachers College der Columbia University lehrte Murphy zunächst Geschichte an ländlichen High Schools in Massachusetts bevor er 1925 die "Columbia Scholastic Press Association“ an der Columbia University gründetet, deren Direktor er bis 1969 blieb. Wie Leigh M. Lott trat auch Murphy im Zweiten Weltkrieg in die Dienste der U.S. Air Force ein; 1945 wurde er zur Mitarbeit in der USFA-Education Division abkommandiert. In Anerkennung seiner Tätigkeit für den Wiederaufbau des Schulwesen und der Unterstützung kirchlicher Einrichtungen in Österreich wurde Joseph M. Murphy 1950 von Papst Pius XII. der Ritterorden des H1. Gregor des Großen verliehen. Siehe: http://www.columbia.edu/cu/ cspa/docs/About-us/history/murphy.html [Zugriff 16.5.2013]; siehe auch den Nachruf: Col. Joseph M. Murphy, Founder of School Press Group, Dies. In: New York Times, 12. Februar 1986. [http://www. nytimes.com/1986/02/12/obituaries/col-joseph-murphy-founder-of-school-press-group-dies.html].

1164 UAW, Rektoratsakten, Akademischer Senat, 455-1944/45, Gedächtnisprotokoll über die am Mittwoch, den 26. September 1945 stattgefundene Besprechung, 1.

1165 Eine der niedrigsten Dienstgrade der US-Armee (verliehen nach einjähriger militärischer Dienstzeit).

1166 NARA II, RG 260, Box 31, Folder 253. USACA Historical File, United States Allied Commission for Austria History. Part II, V-E Day to End 1945, 234. 
I4-tägiger Reports der Education Branch begonnen, die an alle militärischen Detachments in der US-Besatzungszone zur Information verteilt wurden. ${ }^{1167}$

Untergebracht war die Leitung der Education Branch beziehungsweise der späteren Education Division am Otto-Wagner-Platz 3, im Nationalbankgebäude im 9. Wiener Gemeindebezirk. Bis Ende der Besatzungszeit verfügte die Education Division über einen zahlenmäßig vergleichsweise geringen Personalstand, der zwischen acht und I4 hauptamtlichen Mitarbeitern schwankte, was aber nur bedingt Auskunft über deren potenzielle Entscheidungs- und Gestaltungsmöglichkeiten gibt: die US-Educational Officers standen mit allen anderen USACA-Divisionen, den jeweiligen USFA-Area-Commands und dem OSS/CIC in enger Verbindung und berieten ab Oktober 1945 in Form des US-,Education Committees“ innerhalb des "Quadripartite Committee on Educational Affairs“1168 des Alliierten Rates für Österreich, gemeinsam mit den russischen, französischen und britischen ACA-Vertretern alle Angelegenheiten des Wiederaufbaues des Bildungs- und Erziehungswesens. ${ }^{1169}$ Nach dem Inkrafttreten des Zweiten Alliierten Kontrollabkommens vom 28. Juni 1946, das die österreichische Regierung unter anderem zur Schaffung eines „progressiven“ Erziehungssystems verpflichtete, um „sowohl alle Spuren der NS-Ideologie zu tilgen als auch die österreichische Jugend mit demokratischen Prinzipien zu erfüllen“ “1170 wurde das Gremium des Alliierten Kontrollrats in „Education Directorate“ umbenannt. ${ }^{1171}$

Mit Beginn der Planungen für einen eigenen Schüler-Rundfunk im November 1945 wurde das Team der Education Division noch um Hardy M. Ray, ${ }^{1172}$ einem früheren Mitarbeiter des Office of War Information, erweitert, der als US-Vertreter im „Quadripartite Committee on Educational Affairs" an der diesbezüglichen Konzepterstellung mitwirkte.

1167 Ebd.

1168 Die Arbeit auf Ebene dieses höchsten alliierten Gremiums in Bildungs- und Erziehungsfragen lief jedoch von Anbeginn an schleppend, weil Berichte nicht oder verspätet einlangten und die jeweiligen Besatzungselemente hier zumeist nur wenig strittige, d.h. im wesentlichen bereits weitgehend akkordierte Fragen behandelten. Vgl. NARA II, RG 260, Box 31/Folder 253, USACA Historical File, United States Allied Commission for Austria History. Part II, V-E Day to End 1945, $267 \mathrm{ff}$.

1169 Vgl. Alfred Hiller, US-amerikanische Schulpolitik in Österreich 1945-1950. In: Österreich in Geschichte und Literatur. Hrsg. v. Institut für Österreichkunde, 24. Jg., 1980, Heft 2, 66; vgl. weiters: Helmut Engelbrecht, Die Eingriffe der Alliierten in das österreichische Schul- und Erziehungswesen nach 1945. In: Heinemann (Hrsg.), Umerziehung und Wiederaufbau, a.a. O., 288.

1170 Hiller, US-amerikanische Schulpolitik in Österreich 1945-1950, a.a. O., 66.

1171 NARA II, RG 260, Box 31, Folder 253. USACA Historical File, United States Allied Commission for Austria History. Part II, V-E Day to End 1945, 274.

1172 Hardy M. Ray, Absolvent der North Carolina State University, hatte in der US-Navy bereits am Ersten Weltkrieg teilgenommen. Ab 1942 arbeitete Hardy für das im selben Jahr gegründete War Production Board in Washington D.C. Siehe: Hardy M. Ray, The War and War Production Now. An American Perspective. In: Industrial Canada, hrsg. v. Canadian Maufacturer's Association, Vol. 43, 1942, Nr. 1-6, 102. Im Mai 1952 scheint Hardy M. Ray dann als Mitarbeiter der „Education and Inquiry Branch“ des US-Department of Commerce auf. Siehe: Official register of the United States 1952. Unites States Civil Service Commission, Washington D.C. 1952, 446. 
Das erste Schüler-Rundfunkprogramm startete am 5. Februar 1946 im Rahmen der RAVAG mit monatlichen Sendungen, deren inhaltliche Gestaltung zuvor im alliierten „Quadripartite Committee" genehmigt werden musste. ${ }^{1173}$ Für die Überprüfung der Schul-Curricula, insbesondere für Mittelschulen, wurden am 21. November 1945 die Spezialistin Catherine Gregg sowie weitere namentlich ungenannte Personen der Education Branch beigezogen, die die Lehrpläne - in direktem Kontakt mit dem österreichischen Unterrichtsministerium und dem Wiener Stadtschulrat - auf ,pangermanische“(Deutschunterricht), sowie ideologisch "gefährliche“ Inhalte (Geschichte, Geografie, Philosophie) untersuchten. ${ }^{1174}$

Nachdem Lt. Gregory J. Sandker Anfang Dezember 1945 zur Verstärkung von Linz nach Wien abgezogen wurde - Sandker übernahm in der Folge die Supervision der Buch und Schulbuchproduktion ${ }^{1175}$-, erfolgte eine Vergrößerung des Personalstabes der USEducation Division um weitere zivile Experten. Am 4. Dezember wurde Eric A. Hirst zugezogen, der für die Zuweisung der schulischen Lehrkräfte zuständig war und darüber hinaus den Bereich der Jugendorganisationen supervidierte. Zusätzlich übernahm Capt. Dexter G. Tilroe ${ }^{1176}$ als Spezialist für das primäre und sekundäre Schulwesen die Observanz über den Wiederaufbau in diesem Bereich. ${ }^{1177}$

Mit der Ankunft von Dr. Thomas Benner ${ }^{1178}$ am 26. Jänner 1946, der Colonel Featherstone als Direktor der „USACA Education Division“ ablöste, erreichte die Stabstelle, deren Mitarbeiter bis zur Aufösung der Einheit im Juni 1950 mehrmals wechselten, schließlich ihren höchsten Personalstand. ${ }^{1179}$

1173 Ebd., 247.

1174 Ebd., 251.

1175 NARA II, RG 260, USFA, Historical File, Box 33. Quarterly Historical Report. USACA Section, U.S. Forces in Austria 1946, 337.

1176 Dexter G. Tilroe (1910-1998; nicht verifiziert), New Yorker Schulpädagoge, der als junger amtierender Schuldirektor der „Wallkill Central School N.Y.“ (gegr. 1938) 1942 als ziviler Angestellter im Rang eines Captain zur US-Army eingezogen wurde und hier ab 1943/44 zunächst beim Wiederaufbau des italienischen Schulsystems mitwirkte. Offenkundig noch während seiner Tätigkeit als Offizier der USFA-Education Division (1945-1948) absolvierte Tilroe 1946 seinen Master am Teachers College der Columbia University. Nach seiner Rückkehr in die USA 1948 wirkte Tilroe als „Associate Supervisor“ des State Education Department, Albany N.Y., ab 1951 dann als „Supervisor of Secondary Education“ des State Education Department in New York. 1952 promovierte er an der New York University mit einer erziehungswissenschaftlichen Dissertation zu seinem beruflichen Erfahrungsfeld: der Titel seiner Doktorarbeit lautete „Holding Power in Six-Year Secondary Schools of New York“. Siehe: The Nation's Schools, Vol. 29, McGraw Hil 1942, 83; weiters: Journal of Education, Vol. 127/128, Boston 1945, 102; American School Curriculum, hrsg. v. American Association of School Administrators, Vol. 31, 1953, 475.

1177 NARA II, RG 260, Box 31, Folder 253. USACA Historical File, United States Allied Commission for Austria History. Part II, V-E Day to End 1945, 278.

1178 Thomas Benner (1894-1979), Professor für Erziehungswissenschaft und Dekan des „College of Education" an der University of Illinois (1931-1945).

1179 NARA II, RG 260, Box 31, Folder 253. USACA Historical File, United States Allied Commission for Austria History. Part II, V-E Day to End 1945, 278. Am 7. November 1946 wurde Major Donald 
Ein wesentlicher Schwerpunkt der Arbeit der Education Division - neben den Universitäten, der Erwachsenenbildung, den Büchereien und den Jugendaktivitäten - waren das Schul- und Bildungswesen, beginnend mit der Wiederöffnung der ersten Schulen bereits im Mai 1945, die Lehrplansäuberungen, die Säuberung der Unterrichtsbücher und Lehrmittelsammlungen von jedem nationalsozalistisch-rassistischen Gedankengut sowie die genaue Supervision der Entnazifizierung der Lehrkräfte, für die im Bereich der US-Vienna Area Command eine eigene „Sub-Section of Education“ eingerichtet wurde.

Auf der Ebene des Quadripartite Committee wurde die Entnazifizierung des öffentlichen Schulwesens am I6. Oktober 1946 das erste Mal behandelt. Nachdem es bis dahin weder ein unilaterales Übereinkommen noch einen Viermächte-Beschluss gab und auch kein offizieller Bericht über die bisher erfolgten Säuberungsmaßnahmen in den Zonen vorlag, präsentierte Lt. Col. Featherstone einen Entwurf für ein gemeinsames alliiiertes Vorgehen in dieser Angelegenheit. Der Kernpunkt seines Vorschlages bestand darin, dass die Entnazifizierung der schulischen Lehrkräfte von den jeweiligen alliierten EducationAbteilungen in ihren Zonen supervidiert und überprüft werden, die konkrete exekutive Durchführung der Entnazifizierungsmaßnahmen allerdings nicht bei den jweiligen Education Branches selbst, sondern bei anderen operativen Militärstellen liege sollte. Die Entnazifizierung der Lehrer in der interalliierten Zone in Wien sollte jedoch ebenso durch ein gemeinsames Viermächte-Entnazifizierungskomitee erfolgen wie die „Säuberungen“ im Bereich der jeweiligen städtischen Ämter und Behörden. Nach einigen Diskussionen wurde der Vorschlag Featherstones am 31. Oktober dem „Exekutiv Komitee“ des Alliierten Rates zur Begutachtung weitergeleitet. Am ıo. Jänner 1946 beschloss der Alliierte Rat schließlich den Vorschlag Featherstones, allerdings mit einer wichtigen Abänderung, die wohl auf Betreiben der Sowjets durchgesetzt wurde: die Entnazifizierung in den unterschiedlichen Besatzungszonen sollte nämlich in der alleinigen Verantwortung der jeweiligen Oberbefehlshaber liegen.

De facto betrachtete das „Quadripartite Committee on Educational Affairs“ die laufende Entnazifizierung im Bereich der Lehrerschaft als höchst unbefriedigend, sah jedoch keine Möglichkeit, auf Ebene des Alliierten Rates zu effizienteren und wirksameren Beschlüssen zu gelangen, sodass sich das alliierte „Education Directorate“ schließlich auf die bloße Berichterstattung vorliegender Fakten beschränkte. ${ }^{1180}$

Ohne hier nun genauer auf die Schul- und Medienpolitik der US-Besatzungsmacht einzugehen - dazu existieren mittlerweile einige zum Teil auf primärer Quellenbasis verfasste

V. Smart als „Administrative Officer“ der Education Division zugewiesen. Siehe: NARA II, RG 260, USFA, Historical File, Box 33. Quarterly Historical Report. USACA Section, U.S. Forces in Austria 1946, 335.

1180 NARA II, RG 260, Box 31, Folder 253. USACA Historical File, United States Allied Commission for Austria History. Part II, V-E Day to End 1945, 247. 
Abeiten ${ }^{1181}$ - ist an dieser Stelle lediglich summarisch hervorzuheben, dass es den ameri-

1181 Obwohl die „Reorientation“-Literatur in Österreich im Vergleich zur bundesdeutschen Forschungslage, wo in den letzten 10 Jahren eine Vielzahl neuer Studien entstanden, nach wie vor eher spärlich ist, existieren mittlerweile doch einige zentrale Arbeiten zum Thema. Neben den grundlegenden Arbeiten zur Medien- und Informationspolitik von Schönberg, Rathkolb, Leidenfrost und Wagnleitner sind dies vor allem Arbeiten zur Schul-, Erziehungs- und Kulturpolitik der Besatzungsmächte. Siehe: Rathkolb, Politische Propaganda der amerikanischen Besatzungsmacht in Österreich. Ein Beitrag zur Geschichte des Kalten Krieges in der Presse-, Kultur- und Rundfunkpolitik. 2 Bde., a.a.O.; Oliver Rathkolb, US-Medienpolitik in Österreich 1945-1950. In: Medien-Journal, 1984, Heft 3, 2-9; Ders., Die Entwicklung der US-Besatzungspolitik zum Instrument des Kalten Krieges. In: Kontinuität und Bruch 1938-1945-1955. Beiträge zur österreichischen Kultur- und Wissenschaftsgeschichte. Hrsg. v. Friedrich Stadler, Wien - München 1988, 35-50; Leidenfrost, Die amerikanische Besatzungsmacht und der Wiederbeginn des politischen Lebens. 2 Bde., a.a.O.; Wagnleitner, Coca-Colonisation und Kalter Krieg, a.a.O.; Ders., Die Kinder von Schmal $(\mathrm{t}) \mathrm{z}$ und Coca-Cola: Der kulturelle Einfluß der USA im Österreich der 50er Jahre. - In: Die „wilden“ fünfziger Jahre. Gesellschaft, Formen und Gefühle eines Jahrzehnts in Österreich. Hrsg. v. Gerhard Jagschitz/Klaus-Dieter Mulley, St. Pölten - Wien 1985, 144-173; Ders., The Irony of American Culture Abroad. Austria and the Cold War. In: Recasting America: Culture and Politics in the Age of Cold War. Hrsg. v. Lary May. In: American Studies International, XXIV, 1989, Heft 1, 285-301; Michael Schönberg, Die amerikanische Medien- und Informationspolitik in Österreich von 1945-1950. 2 Bde. Diss., Univ. Wien 1975; Alfred Hiller, Amerikanische Medien- und Schulpolitik in Österreich (1945-1950), Diss., Univ. Wien 1974; Thomas Liebl, Die Umerziehung der österreichischen Bevölkerung zu demokratischen Grundsätzen durch die US-amerikanischen Besatzer, Dipl.-Arb., Univ. Salzburg 1997; Gudrun Fessler, 1945-46 - das erste Schuljahr. Schulalltag, Entnazifizierung, Umerziehung und Wiederaufbau des steirischen Pflichtschulwesens im ersten Schuljahr nach Kriegsende, Dipl.-Arb., Univ. Graz 1995; Wilhelm Sadofsky, Die Geschmacksbildung an den Wiener Theatern von 1945 bis 1949, Diss., Univ. Wien 1950; Hans Fischl, Schulreform, Demokratie und Österreich 1918-1950, Wien o.J. [1950]; Peter Heinrich, Der Wiederaufbau des österreichischen Schulwesens nach dem Zweiten Weltkrieg. In: International Review of Education, 2. Jg., 1956. Heft 4, 52-65; Rudolf Tschögl, Tagespresse, Parteien und alliierte Besatzung. Grundzüge der Presseentwicklung in der unmittelbaren Nachkriegszeit 1945-1950, Diss., Univ. Wien 1979; Maria Horvath, Die Bildungspolitik des Unterrichtsministeriums Dr. Felix Hurdes unter besonderer Betonung der Schulpolitik und Berücksichtigung der Kulturpolitik, Diss., Universität Wien 1985; Elfriede Sieder, Die Alliierten Zensurmaßnahmen zwischen 1945-1955. Unter besonderer Berücksichtigung der Medienzensur, Diss., Univ. Wien 1983; Christian Hanna, Das Linzer Landestheater 1945-1980. Ein Beitrag zu einer österreichischen Theatergeschichte. 2 Bde., Diss., Univ. Wien 1987; Elisabeth Weber, Österreichische Kulturzeitschriften der Nachkriegszeit 1945-1950, Frankfurt a. Main 1988; Christa Kofler, Die Tagespresse der SPÖ und der KPÖ im Land Tirol von 1945 bis 1950 unter besonderer Berücksichtigung ihrer Darstellung des Nationalsozialismus, Diss., Universität Innsbruck 1989; Ingried Bergmann, Die Kulturpolitik nach 1945 aus Sicht des österreichischen Nationalrates im Vergleich mit dem 3. Reich und im Umfeld des Zeitgeschehens, Dipl.-Arb., Universität Wien 1989; Ulrike Halbritter, Der Einfluss der alliierten Besatzungsmächte auf die österreichische Filmwirtschaft und Spielfilmproduktion in den Jahren 1945-1955, Dipl.-Arb., Univ. Wien 1993: Manuela Aichinger, Rot-Weiß-Rot Linz und das Rundfunkwesen in Oberösterreich 1954 bis 1957/58, Diss., Univ. Salzburg 1992; Hermann Schnell, Bildungspolitik in der Zweiten Republik, Wien - Zürich 1993; Fritz Steiner, „Tiroler Schulpolitik“ im Hauptschulbereich 1945-1990, Dipl.-Arb., Univ. Innsbruck 1994; Doris Graf, Die Kulturpolitik der Besatzungsmächte 1945-1955 und die Auswirkungen auf das Wiener Konzertleben, Dipl.-Arb., Univ. Wien 1995; Michaela 
kanischen Besatzern im Hinblick auf eine nachhaltige Demokratisierung des schulischen Bildungswesens primär um die Implementierung moderner Unterrichtsmethoden und eine verbesserte Lehrerausbildung unter verstärkter Einbeziehung der Erkenntnisse aus dem Bereich der Social Sciences ging: ${ }^{1182}$ daneben sollte durch Herausgabe einer eigenen Zeitschrift („Erziehung“), die immerhin in einer Auflage von 35.00o Stück erschien und den Lehrern kostenlos zur Verfügung gestellt wurde, ${ }^{1183}$ der Diskurs über pädagogische Methoden und Sachthemen angeregt werden und auf diese Weise auch die von amerikanischer Seite favorisierte „Einheitsschule“ auf den Weg gebracht werden, um traditionelle gesellschaftliche Bildungs- und Sozialstrukturen aufzubrechen. ${ }^{1184}$ Die Umsetzung dieses ambitionierten Programmes, das das schwerwiegende Manko aufwies, dass es in keiner auch nur einigermaßen konzise ausgearbeiteten Form für eine praktische Umsetzung vorlag, bildete durchaus einen wesentliches Element für eine längerfristige, geistig-mentale Reorientierung Österreichs. Die Umsetzung der bei den schulpflichtigen Kindern und Jugendlichen ${ }^{1185}$ ansetzenden Reorientierung - in notwendiger Kooperation mit dem Un-

Feuerstein-Prasser, Von der Besatzungspolitik zur Kulturmission. Französische Schul- und Bildungspolitik in Österreich 1945-1955, Diss., Univ. Wien 2002; Marion Knapp, Österreichische Kulturpolitik und das Bild der Kulturnation. Kontinuität und Diskontinuität in der Kulturpolitik des Bundes seit 1945 (= Politik und Demokratie. Hrsg. v. Helmut Kramer und Eva Kreisky, Bd. 4), Frankfurt a. Main et al. 2005; Natalie Schlegel, Die Beurteilung der „US-Kulturmission in Österreich 1945-1955“. Der Bereich der Medien am Beispiel von „Wiener Kurier“, „Salzburger Nachrichten“ und „Radio Rot-Weiß-Rot“, Dipl.-Arb., Univ. Wien 2008; Florian Jetzlsperger, Die Umerziehung der Jugend durch die amerikanischen Militärregierungen 1945-1949. Bayern und Salzburg im Vergleich, Magisterarbeit LMU München 2007; Simone Krienzer, Strategien der Propaganda im frühen Kalten Krieg. Eine Analyse ausgewählter Plakate zum European Recovery Programm der USA in Österreich 1948-1952, Dipl.-Arb., Univ. Graz 2010.

1182 Vgl. Hiller, Amerikanische Medien- und Schulpolitik in Österreich (1945-1950), a.a.O., 244 ff.; so manche Veränderungen in den österreichischen „Klassenzimmern“ mögen unter längerfristiger Perspektive betrachtet wohl auch auf direkte und indirekte Einflussnahmen der westalliierten Mächte zurückzuführen sein. Zum allgemeinen Wandel des schulsituativen Settings siehe: Maria Streßler, Im Klassenzimmer. Der Wandel des Lehrer-Schüler-Verhältnisses in Österreich, Frankfurt a. Main 2008, $78 \mathrm{f}$. Zur Rolle der Social Sciences im Kontext der US-Reorientierung siehe: Bernhard Plé, „Social sciences“ in der Ordnungspolitik der USA. Vom Kriegseinsatz zum Medium der amerikanischen Kulturpolitik im Nachkriegsdeutschland, 1941-1957. In: Jabrbuch für Soziologiegeschichte, 1997/98, Opladen 2001, 195-213.

1183 Hiller, Amerikanische Medien- und Schulpolitik in Österreich (1945-1950), a.a.O., 286 f. Neben der Erziehung gab die US-Education Division noch ein Reihe weiterer Zeitschriften in deutscher Sprache heraus, die, je nach unterschiedlicher Zielgruppe, zu einem positiven Amerikabild in der österreichischen Gesellschaft beitragen sollten. So z.B. Medizinische Nachrichten aus den Vereinigten Staaten, Gewerkschaftliche Nachrichten aus den USA, Die amerikanische Rundschau, Der Monat oder Amerika, um hier nur einige der wichtigsten zu nennen. Vgl. ebd., $100 \mathrm{ff}$.

1184 Amerikanischen Medien- und Schulpolitik in Österreich (1945-1950), a.a. O., 212 ff.

1185 Vgl. Liebl, Die Umerziehung der österreichischen Bevölkerung, a.a.O., 72 ff.; Hiller, Amerikanische Medien- und Schulpolitik in Österreich (1945-1950), a. a. O., 310 ff.; Jetzlsperger, Die Umerziehung der Jugend durch die amerikanischen Militärregierungen 1945-1949, a.a. O., 89 ff.; für Deutschland siehe in 
terrichtsministerium und den Schulbehörden in den Ländern - erwies sich allerdings nicht nur wegen der bald zunehmenden machtpolitischen Spannungen und Querelen unter den Alliierten als ausgesprochen schwierig. So zeigte sich im Hinblick auf die intendierte Erneuerung der in föderaler Kompetenz liegenden Lehrpläne, dass die Schulbehörden der westlichen Bundesländer wie Tirol oder Vorarlberg ,nicht gewillt waren, die Provisorischen Lehrpläne einzuführen" und sich weiterhin an den während des Austrofaschismus festgelegten Curricula orientierten. ${ }^{1186}$ Auch nach mehrfachen Urgenzen der russischen Vertreter im Alliierten Rat im Jahr 1948 konnten sich die westalliierten ReorientierungsFachleute nicht auf ein geschlossenes Vorgehen einigen, sodass die „autoritären“ Lehrpläne des früheren austrofaschistischen Regimes weiterhin in Verwendung blieben. ${ }^{1187}$

Ähnlich schwierig gestaltete sich auch die Entnazifizierung der Lehrerschaft. Nachdem die Schulen in den Besatzungszonen kurzfristig geschlossen worden waren - einige wurden von alliierten Truppen für die Unterbringung ihrer Kontingente in Beschlag genommen ${ }^{1188}$-, sperrten viele der Unterrichtsanstalten ${ }^{1189}$ bereits im Mai 1945 wieder auf, wobei viele Schulgebäude durch das Kriegsgeschehen beschädigt waren. 4.000 Lehrer waren mit sofortiger Wirkung entlassen worden ${ }^{1190}$ und die Wiederverwendung weiterer Io.00o Lehrer musste durch Entnazifizierungsverfahren geprüft werden, ${ }^{1191}$ wobei sich angesichts des eklatanten Lehrermangels - so fehlte 1946 rund ein Drittel der erforderlichen Mittelschulprofessoren ${ }^{1192}$ - allerdings bald eine pragmatische Verfahrensweise durchsetzte. Allein in der US-Besatzungszone Salzburg und Oberösterreich, wo zum Beginn der Screening-Verfahren durch die „Public Safety Special Branch“ der US-„Internal Affairs Division“ sowie durch Einheiten des CIC 50 Prozent der Lehrerschaft vom Dienst

diesem Zusammenhang: Manfred H. Burschka, Re-education und Jugendöffentlichkeit. Orientierung und Selbstverständnis der Nachkriegsjugendpresse 1945-1948. Ein Beitrag zur politischen Kultur der Nachkriegszeit, Diss., Univ. Göttingen 1991; Karl H. Füssl, Die Umerziehung der Deutschen Jugend und Schule unter den Siegermächten des Zweiten Weltkriegs 1945-1955, Paderborn 1994.

1186 Engelbrecht, Die Eingriffe der Alliierten in das österreichische Schul- und Erziehungswesen nach 1945, a.a.O., 292.

1187 Ebd.

1188 So waren etwa in Wien 7 Schulgebäude durch alliierte Truppen besetzt. In den US-Zonen in Salzburg und Oberösterreich wurden 35 Pflichtschulgebäude von den Militärs besetzt; weitere 82 Schulgebäude waren von nicht-militärischen, zivilen Einrichtungen in Beschlag genommen. NARA II, RG 260, Box 31, Folder 253. USACA Historical File, United States Allied Commission for Austria History. Part II, V-E Day to End 1945, 240.

1189 In den US-Zonen in Wien, in Salzburg und in Oberösterreich waren dies nach einer Aufstellung vom 17. September 1945 in Summe 809 Volks- und Hauptschulen, 34 Mittelschulen sowie 40 sonstige Schulen, wobei sich die Gesamtzahl aller Lehrer auf 5422 belief. Ebd., 239.

1190 Dieter Stiefel, Entnazifizierung in Österreich, Wien - München - Zürich 1981, 162; siehe auch: Dimitra Reimüller, Entnazifizierung in Österreich, Dipl.-Arb, Univ. Graz 1988.

1191 Stiefel, Entnazifizierung in Österreich, a.a.O., 162.

1192 Ebd., 164. 
suspendiert werden sollten, waren dies es 1947 letztlich kaum mehr als rund 30 Prozent. In der Steiermark, in Kärnten, Tirol und Vorarlberg blieben bis 1947 allein unter den Pflichtschullehrern rund 50 Prozent der Registrierungspflichtigen weiterhin im Dienst; ${ }^{1193}$ unter den Mittelschullehrern waren es immerhin rund 28 Prozent. ${ }^{1194}$

In welcher Form die Entnazifizierung im Bereich des österreichischen Universitätswesens erfolgte, wie sich der akademisch-universitäre Wiederaufbau gestaltete und welche Rolle dabei die amerikanische Besatzungsmacht spielte, soll im folgenden Kapitel, das zu weiten Teilen auf Primärquellenmaterial beruht, einer eingehenden Analyse unterzogen werden.

1193 In der Steiermark 42\%, in Kärnten 37\%, in Tirol $43 \%$ und in Vorarlberg $45 \%$. Ebd., 165. In der Steiermark wurden bis Mai 1946 rund 51\%, d.h. 1.690 Lehrer (darunter 420 „Ilegale“) entlassen. Vgl. Fessler, 1945-46 - das erste Schuljahr. Schulalltag, Entnazifizierung, a.a.O., 68.

1194 In der Steiermark 33\%, in Kärnten 26\%, in Tirol 21\% und in Vorarlberg $40 \%$. Ebd., 165. 


\title{
4. „The democratic way of life in Austria“"1195 - erste Umsetzungsphase bis zum Nationalsozialistengesetz 1947: Zwischen Laissez Faire, strenger Observation und milder Beurteilung
}

\author{
KOOPERATION STATT INTERVENTION UND DIE FOLGEN FÜR DIE \\ ENTNAZIFIZIERUNG IM BILDUNGSBEREICH: DAS FALLBEISPIEL UNIVERSITÄT
}

\begin{abstract}
"During the years of their confinement, the concentration camp prisoners looked forward to the collapse of the Nazi state as a great day of reckoning in which the Hitleritis [sic] would be punished in one great act of justice imposed by the victor and supported by all Nazi victims. Reality has, naturally, disappointed these hopes. Not only do the liberated prisoners still live under conditions which are in some physical respects as uncomfortable and unhealthy as their former conditions; they are also confronted daily with the site of well-known Nazis who continue to live in their pleasant home and who feed themselves well on their hoarded food. The demand of a more energetic de-Nazification has therefore been louder and the resentment at present con-

ditions more bitter among the liberated prisoners then among parts of the population."1196
\end{abstract}

\section{Ausgangslage: Perspektive nötiger, Säuberungsmaßnahmen`}

Ganz allgemein bildete die Entnazifizierung im Rahmen der US-amerikanischen Nachkriegsplanungen für Deutschland und Österreich - neben der Entmilitarisierung - die zentrale besatzungspolitische Aufgabenstellung. Die Durchführung der politischen Säuberungen bildete nachgerade die Vorbedingung für eine demokratische Neuordnung der Gesellschaft, insbesondere für den Wiederaufbau des gesamten Kultur- und Bildungswesens. Dazu gehörten neben dem Medienbereich (Printmedien, Radio, Film), den Schulen und Lehrerbildungsanstalten, den Museen und Bibliotheken sowie sonstigen Bildungsund Erziehungseinrichtungen unter anderem auch die Universitäten beziehungsweise die Hochschulen.

1195 So der Titel eines ISB-Berichtes aus dem Jahr 1946. Vgl. How USFA projects America and the democratic way of life in Austria through the Information Services Branch, A. van Erden, Deputy Chief, ISB to Deputy Commanding General, Headquarters, USFA, 11. Oktober 1946, NARA II, RG 260, EDUDIV, Box 2, Folder 58.

1196 Lorenz Eitner [OSS], Conditions among Liberated Political Prisoners in Land Salzburg, 21. Juni 1945. Zit. nach: Rathkolb (Hrsg.), Gesellschaft und Politik am Beginn der Zweiten Republik, a.a.O., 257. 
Trotz aller Unterschiede zwischen der amerikanischen Österreich-Politik und der Deutschland-Planung bestand hinsichtlich der als notwendig erachteten Entnazifizierung, trotz mancher Spezifikationen in der Durchführung und trotz der Unterschiede in der generellen Besatzungspolitik, kein Zweifel; auch formal gab es kaum Unterschiede in den diesbezüglichen SHAEF-Planungsdirektiven, die außerdem ,in close connection with German Affairs problems " ${ }^{1197}$ ausgearbeitet wurden.

In einer SHAEF-Direktive vom April 1945 wurden die diesbezüglichen Ziele und Aufgaben der Militärregierung in Österreich - auf Basis eines vorläufigen Fraternisierungsverbotes $^{1198}$ - mit direktem Bezug auf die Moskauer Deklaration ${ }^{1199}$ unter anderem folgendermaßen definiert: "To create conditions favorable to the establishment of a free and independent Austria, based on the rule of law, ready and able to cooperate in international life. It will be possible to give more latitude to political activity in Austria than in Germany, but you will be careful not to lend your support or authority to any political party or policy in Austria." 1200

Das freilich unter der Voraussetzung einer vollständigen Entnazifizierung, wie es dazu in der primär militär-administrativen SHAEF-Direktive („military in nature“) heißt:

“To supress all National Socialist Party organizations in Austria, and to abolish all racial discrimination. It should made clear to the Austrian population that military occupation is intended to destroy Nazism and the Nazi Hierarchy, to liberate Austria from German domination, and to pave the way for a free and independent Austria."1201

1197 NARA II, RG 260, Historical File, Box 30, Folder 251. History of the United States Element. Allied Commission Austria. From its Origin to 31 December 1944, 37.

1198 Trotz der unterschiedlichen besatzungspolitischen Ziele galt sowohl für Deutschland als auch für Österreich striktes Fraternisierungsverbot, das aber in Österreich früher aufgehoben werden sollte als in der deutschen Besatzungszone. De facto wurde aber kurz nach der Verlautbarung des US-Oberkommandos - „in view of the good behavior of the Austrian people it has decided to relax the policy of non-fraternization" im Juli 1945 auch das Fraternisierungsverbot für Deutschland aufgehoben: „In view of the rapid progress made in carrying out Allied de-Nazification policy and in removing prominent Nazis from all positions of responsibility in German life, it is believed desirable and timely to permit the personnel of my command to engage in conversation with adult Germans on the street and in public spaces." Zit. nach: NARA II, RG 260, USGCC 1944-1945, Box 6/Folder 1. Headquarters U.S. Group CC, USFET Main, 13 July 1945, 1 f.

1199 „The Moscow Declaration states that Austria shall be liberated from German domination, and that a free and independent Austria will be re-establisehd as soon as possible. As a general objective, it is therefore desirable that measures taken for the occupation and control of Austria should show a clear distinction between those employed in Germany. "NARA II, RG 260, IMGUS ECR, Box 98, Supreme Headquarters Allied Expeditionary Forces, G-5 Division (SHAEF/G-5/PCS/Fwd/558/1), W.B. Smith, Lieutenant General, U.S. Army Chief of Staff, 15 April 1945, 2.

1200 Ebd.

1201 Ebd. 
Wie es jedoch schon in einem der ersten amerikanisch-britischen Entwürfe zum Handbuch für die künftige Militärregierung hieß š und daran sollte sich bis April 1945 wenig ändern š, ging es, abgesehen von strikten Entnazifizierungs-Maßnahmen, nicht darum, dem österreichischen Bildungswesen eine neue Struktur zu geben:

"It is the policy of AMG Austria to facilitate the rehabilitation of legitimate Austrian education along the lines in keeping with Austrian precedent and tradition, including restoration to the pre-1938 character and condition of institutions so thoroughly Nazified as to have lost all apparent resemblance to their original character. It is not the policy of AMG Austria to reform Austrian education by proposing or enacting new legislation, creating new kinds of schools, or other educational devices, setting up new schemes of administration and control which are unfamiliar to Austrians or clearly out of line with recent (up to 1938) Austrian thought in educational matters." ${ }^{1202}$ [Unterstreichung im Original]

Das galt freilich auch für die Universitäten, die auf Grundlage des Gesetzes zur „Organisation der akademischen Behörden“ von $1873^{1203}$ und der damit verbundenen Autonomie, Privatrechtsfähigkeit und Selbstverwaltung wiedereröffnet wurden š „with the rectors and deans elected by the faculties and only nominal control by the Ministry of Education. " ${ }^{\text {"1204 }}$ Damit verstanden sich die Universitäten keineswegs nur als staatliche Einrichtungen sondern über das Hochschulorganisationsgesetz von I955 hinaus auch als „selbständige juristische Personen im historisch gewordenen Sinn und Umfang. " ${ }^{1205}$

1202 NARA II, RG 260, OMGUS ECR, Box 98. Supreme Headquarters Allied Expeditionary Forces, G-5 Division (SHAEF/G-5 / PCS / Fwd/558/1), Austrian Handbook, Draft, July 1944, 9. Ebd.

1203 Dieses Gesetz war dem provisorischen Gesetz über die Organisation der akademischen Behörden 1849 von Minister Graf Leo Thun-Hohenstein gefolgt, das sich an der preußischen Ordinarienuniversität mit klassischer Rektoratsverfassung und (vier) Professorenkollegien orientierte. Der Akademische Senat wurde mit diesem Gesetz zur obersten akademischen Instanz, dem neben dem Disziplinarrecht über alle Mitglieder der Lehrerkollegien auch die Diensthoheit über die Universitätsbediensteten zustand. Das Universitätsorganisationsgesetz von 1873 regelte die bisherige provisorische Autonomie der Universitäten als staatliche Selbstverwaltungskörper definitiv, wobei die Universitäten durch Herauslösung aus dem Einflussbereich der katholischen Kirche direkt an den Staat und seine ministerialen Behörden gebunden wurden. Ab nun war das Unterrichtsministerium bzw. der Unterrichtsminister oberste Instanz und Aufsichtsbehörde über die Universitäten. Siehe dazu: Günther Winkler, Die Rechtspersönlichkeit der Universitäten. Rechtshistorische, rechtspolitische und rechtstheoretische Untersuchungen zur wissenschaftlichen Selbstverwaltung, Wien š New York 1988, 240 ff.; weiters: Sascha Ferz, Ewige Universitätsreform. Das Organisationsrecht der österreichischen Universitäten von den theresianischen Reformen bis zum UOG 1993 (= Rechts- und Sozialwissenschaftliche Reihe, Bd. 27), Frankfurt a. Main et al. 227 f.; Manuel P. Neubauer, Rektor und Rektorat im UG. Universitätsrechtliche und universitätspolitische Betrachtungen der operativen Führung österreichischer Universitäten, Dipl.-Arb., Univ. Graz 2009, 5 ff.

1204 NARA II, RG 260, USACA Historical File, Box 31, Folder 253. United States Allied Commission for Austria. History. Part II. V-E Day to End of 1945, 235.

1205 Winkler, Die Rechtspersönlichkeit der Universitäten, a.a.O., 267. 
Einmal abgesehen von allen sicherheitspolitischen, wirtschaftlichen, verkehrstechnischen und sozialen Problemen sowie der verwaltungstechnischen Herausforderungen in der administrativen Trennung Österreichs von Deutschland - „disentangling of Austria from Germany “" ${ }^{\text {1206 }}$-, sah man aber in der politischen „Säuberung“ eine der vorrangigen Aufgaben und zugleich eine der größten Herausforderungen, mit denen die Militärregierung in Österreich konfrontiert war.

In dem bereits zitierten, vertraulichen Lagebericht des US-Militärgeheimdienstes „Office of Strategic Services“ (OSS) vom Juni I945 wurde mit Bezug auf die amerikanische Besatzungszone in Salzburg bezüglich der Entnazifizierung allgemein festgehalten: „The work of de-Nazification is generally regarded as the most pressing political task confronting the American authorities, the emerging parties, and the newly created Austrian administration in Land Salzburg. "1207 [Hervorhebung i. Orig.]

Abgesehen von dem im Vergleich zu anderen österreichischen Regionen besonders hohen Anteil an NSDAP-Mitgliedern und ranghohen NS-Funktionären im Raum Salzburg, ${ }^{1208}$ traf die hier formulierte Einschätzung auch auf alle anderen Besatzungszonen zu; das geht auch aus dem „Military Handbook for Austria“ deutlich hervor, in dem sich bereits vage die künftige US-Besatzungspolitik der Reorientierung andeutet:

"Two of the most essential purposes of military government will be to root out Nazism and panGermanism from the Austrian system [...] but pan-Germanism is a state of mind rather than an organization and the only way to eradicate it is by enabling the Austrian people to experience the benefits, political, social and economic, of independence from Germany." ${ }^{1209}$ [Hervorhebung d. Verf.]

Untermauert wurde diese demokratiepolitische Langzeit-Perspektive eines kulturell und wirtschaftlich-ökonomisch entsprechend unterstützten „Säuberungsprozesses“ unter anderem mit Hinweis auf das bisher kaum ausgeprägte österreichische Nationalbewusstein: „The Austrian is, however, lacking in any very profound sentiment of national consciousness and his relief at the removal of Nazi domination will very quickly fade if it is not followed by a visible improvement in his conditions of life. “1210 Dass die Entnazifizierung in Österreich aber generell wie insbesondere im Hinblick auf das Bildungssystem und auf den Kulturbereich „the Nazi Party has established the same internal and external controls which it exercised in

1206 NARA II, RG 260, USGCC 1944-1945, Box 4/Folder 3. Germany and Austria in the Post-Surrender Period. Policy Directives for the Allied Commanders-In-Chief. Amendments and Additions, War Office (A.C.S.), July 1945, 2.

1207 Rathkolb (Hrsg.), Gesellschaft und Politik am Beginn der Zweiten Republik, a.a.O., 258.

1208 Ebd., 259.

1209 Allied Forces Headquarters. Office of the Chief of Staff. Handbook for Military Government in Austria, (W.D. Morgan), April 1945 (Institut für Geschichte der Univ. Wien), Chapter 1, 6.

1210 Ebd., 4. 
Germany “1211 - keineswegs weniger strikt vorgenommen werden müsse als in Deutschland, bildet sich selbst im Wortlaut genuin militärischer US-Planungsdokumente deutlich ab, in denen außerdem auf die Problematik der Rückführung Reichsdeutscher verwiesen wurde. So heißt es in einer im Juli I945 verlautbarten Direktive des US-Kriegsministeriums in Bezug auf die Aufgaben der Entnazifizierung in Österreich - „to destroy the National Socialist party and system in Austria, and to uproot and discredit National Socialist doctrines“:

"In Austria it will be necessary to get rid not merely of extreme National Socialists, who will be, if anything, more firmly in control of the administration there than in Germany, but also of the many Reich Germans who hold Austrian posts." ${ }^{1212}$

Wie aus einem militärischen Ratgeber des War Departments für die US-Armee in Österreich deutlich hervorgeht, den die „Research and Analysis Branch“ des OSS ausgearbeitet hatte und über den Secretary of War, George C. Marshall, im August 1945 an die Besatzungstruppen in Österreich weitergeleitet wurde, waren sich die US-Geheimdienstleute und Militärs über die Rolle, die das vorhergehende austrofaschistische System hinsichtlich der Durchsetzung des NS-Herrschaftssystems in Österreich gespielt hatte, durchaus im Klaren:

"The Nazi task was made somewhat easier by the fact that they installed their system of labor controls after the Austro-Fascist regime of Dollfuss and Schuschnigg had already destroyed the independent economic and political institutions of the working class." ${ }^{1213}$

Ein keineswegs uninteressantes Detail ist, dass die oben zitierte besatzungspolitische Direktive des US-Kriegsministeriums gleich an zwei Stellen explizit österreichische Emigranten für die Neubesetzung von Posten innerhalb der zentralen Verwaltungsbehörden vorschlug - „suitable Austrian emigrés for this purpose“ - und darüber hinaus in einer eigenen Direktive davon sprach, entsprechende Namenslisten an die österreichischen Behörden zur weiteren Verwendung zu übermitteln. ${ }^{1214}$

1211 Ebd., Chapter 12, „Education“, 4.

1212 NARA II, RG 260, USGCC 1944-1945, Box 4, Folder 3. Germany and Austria in the Post-Surrender Period. Policy Directives for the Allied Commanders-In-Chief. Amendments and Additions, War Office (A.C.S.), July 1945, Directive No. 2, 2.

1213 Military Government Guide. The Social Structure of Austria 1933-1944. War Department Pamphlet No. 31-232. Confidential. 31. August 1945, 11. A Guide to O.S.S./State Department Intelligence and Research Reports. Germany and its Occupied Territories during World War II. Part 4 [A Microfilm Project of University Publications of America, Inc.], Washington D.C. 1977. Bestand Institut für Zeitgeschichte, Universität Wien (Bibliothek), Rolle 2 [1-9].

1214 „Lists will also be communicated to you from time to time for transmission to the Austrian authorities of former Austrian subjects resident abroad whose recall will be demanded or whose reception in Austria will be required.“ Zit. nach: Ebd., Directive No. 9, „Recall of German and Austrian Nationals Resident Abroad“. 
Besonders deutlich fällt die Passage in der endgültigen Fassung des „Austria Military Government Handbook“ vom April 1945 aus, dessen Kapitel I2-I4, wie bereits erwähnt, von Colonel William B. Featherstone ausgearbeitet worden waren, der seit Jänner 1944 quasi als Urgestein der „Austrian Planning Unit“ - zunächst in Shrivenham bei London, dann in Caserta, mit der Posthostilities-Planung für Österreich im Bereich „Education“ betraut war. ${ }^{1215}$ Wie schon zuvor in den verschiedenen Entwürfen der Austria Planning Unit seit Sommer 1944, ${ }^{1216}$ steht zur Problematik der Entnazifizierung des Kultur- und Bildungsbereiches im „Military Handbook“ zu lesen:

\begin{abstract}
"Austrian education, always similar to German in structure, purpose and content, was after 1938 integrated with the educational system of the Reich and the Nazi Party. [...] The Nazi Party has established the same internal and external controls which is exercised in Germany and has set up the same scheme of party schools and party youth agencies which have so completely disrupted and demoralized education in the Reich proper. So complete has been the Nazi permeation of education at all levels and in all fields that it is difficult to say where Nazification leaves off and education begins." ${ }^{1217}$ [Hervorhebung d. Verf.]
\end{abstract}

Der Nationalsozialismus, so die soziologische Analyse der Research \&Analysis Branch des OSS, habe in Österreich jedoch keine fundamentale Veränderung in der sozialen Schichtung nach sich gezogen: „[...] old cleavages and political movements, in short, are likely to reappear". ${ }^{1218}$ Ungeachtet der Tatsache, dass in der NS-Presse auf österreichischem Boden bereits 1943 Beschwerden über „unpatriotisches“ Umgehen der militärischen Pflichten sowie Faulenzerei bei der Arbeit aufgetaucht seien, haben doch die Mittelschicht sowie die gesellschaftliche Elite eindeutig mit dem Nationalsozialismus kollaboriert; ein Umstand, aus dem sich allenfalls ein politisches Problem für die Stabilität beziehungsweise für die Westorientierung der gesamten Region ergeben könnte, wobei die Gefahr eines Linksrutsches in Österreich - ,would encounter strong resistance from the strata that would suffer" ${ }^{1219}$ - jedoch als überaus gering eingestuft wurde.

1215 Siehe: NARA II, RG 260, USACA Historical File, Box 31, Folder 253. United States Allied Commission for Austria History. Part II. V-E Day to End of 1945, 232.

1216 Vgl. NARA II, RG 260, OMGUS ECR, Box 98. Supreme Headquaters Allied Expeditionary Forces, G-5 Division (SHAEF/G-5/PCS/Fwd/558/1), Austrian Handbook, Draft, July 1944 bzw. NARA II, RG 260, Office of Director USACA, Box 20, Education, Field Handbook of Military Government Austria, Draft, 20. Oktober 1944.

1217 Handbook for Military Government in Austria, April 1945, a.a. O., Chapter 12, 1.

1218 Military Government Guide. The Social Structure of Austria 1933-1944. War Department Pamphlet No. 31-232. Confidential. 31. August 1945, 11. A Guide to O.S.S./State Department Intelligence and Research Reports, a.a.O., 22.

1219 Ebd. 
"It is likely that local left-wing forces will attempt to effect a reorganization of Austrian society as soon as it is feasible for them to operate 'above-ground'. [...] The fact that most of the elite and a considerable proportion of the middle classes collaborated with the Nazis may result in the initiation of a purge by left-wing forces whose effect would be to further such a reorganization. This reorganization might be accompanied by the establishment of economic ties with the other succession states that may fall within the Soviet political orbit." ${ }^{1220}$

In Bezug auf die Entnazifizierung im Öffentlichen Dienst und die zu erwartenden Personalprobleme findet sich jedenfalls folgende, unter pragmatischen Gesichtspunkten betrachtet, durchaus nachvollziehbare Einschränkung angeschlossen: „Beyond the automatic elimination of these leading figures, all other Austrian Public officials, in the order of their importance, will need to be processed, so that leading or active Nazis are removed while the non-Nazis or merely nominal Nazis are retaining for essential functions of civilian administration." 1221

In einem vertraulichen und überaus umfangreichen Bericht („Civil Affairs Guide“) zur „De-Nazification of Austria“ der Research \& Analysis Branch des amerikanischen militärischen Geheimdienstes Office of Strategic Services (OSS) vom April 1945 wurde das Problem der autoritären Indoktrinierung durch den Nationalsozialismus dezidiert um die doktrinär-ideologische Beeinflussung durch den Austrofaschismus erweitert. Der Bericht des OSS hält diesbezüglich summarisch fest:

"A special problem arises in connection with the second of these major developments. For while the Dollfuß-Schuschnigg regime was opposed to the German National Socialists, it was at the same time anti-democratic and authoritarian. The retention in leading positions of any member of this group would seriously hamper the democratization of Austria. [...] The authoritarian camp in Austria, then, comprised not only Nazis (Reich German and Austrian) but also AustroFascists, who are opposed to Nazism but are anti-democratic in their sentiments and views. [...] The Nazification of Austria was effected not only in political agencies and organizations but also in all spheres of business, trade, finance, and culture. [...] The thorough De-Nazification of these enterprises is one of the most important tasks of Military Government." ${ }^{1222}$ [Hervorhebungen d. Verf.]

Im Hinblick auf den Austrofaschismus als Vorgängerregime zum Nationalsozialismus in Österreich, präzisierte der US-Geheimdienstbericht in seiner Analyse, dass sowohl Pro-

1220 Ebd.

1221 NARA II, RG 260, Office of Director USACA, Box 20. Public Safety Manual for Austria (undatiert), vermutlich vom November 1944.

1222 DÖW 12.684. Civil Affairs Guide, „The De-Nazification of Austria“, R\&A, No. 2905, Research and Analysis Branch. Office of Strategic Services, Washington D.C., 26. April 1945, i. 
gramm als auch Politik des Austrofaschismus viele Gemeinsamkeiten zum Nationalsozialismus aufwiesen:

"The authoritarian Austrian regime was distinguished from the Nazi brand of authoritarianism chiefly by the fact that it leaned upon Mussolini rather than Hitler for material and ideological support, that it was backed by the Catholic Church, and that it did not promulgate any racial legislation. Otherwise, Austrian authoritarianism resembled the Nazi form in its abolition of popular sovereignty and popular representation, prohibition of opposition parties, creation of compulsory and semi-compulsory organizations, destruction of free trade unions, and establishment of concentration camps, etc." ${ }^{1223}$ [Hervorhebung d. Verf.]

Im Kontext der Entnazifizierung wäre daher besonderes Augenmerk auf die mittleren und niederen Chargen der öffentlich Bediensteten zu richten, die vom NS-Regime übernommen wurden ${ }^{1224}$ und die vor dem Hintergrund ihrer undemokratischen „kleriko-autoritären“ Überzeugungen eine Gefahr für den demokratischen Wiederaufbau darstellen würden: „[...] their inclusion in the de-Nazification process requires amplification. ${ }^{1225}$

Neben Wirtschaft, Politik und Ökonomie wäre insbesondere auch der Bereich des kulturellen Lebens, der Bildung und der Wissenschaft gründlich von allen reaktionären Elementen zu säubern, wobei - wie der Bericht einräumte - die Frage nach dabei allenfalls auftretenden personellen Nachbesetzungsproblemen an anderer Stelle und zum gegebenen Zeitpunkt zu klären wäre:

"Writers and editors of newspapers and periodicals since 1938 have been instrumental in the dissemination of Nazi propaganda as have the Nazi-appointed Rectors and Curators of universities and schools." 1226

Ende Mai 1945 wurde dem amerikanischen militärischen Geheimdienst OSS ein von britischer Seite erstelltes Dokument übergeben, das unter dem Titel „German Universities under National-Socialism“ 26 Interviews mit deutschen und österreichischen akademischen „Prisoners of War“(POW’s) zusammenfasste, die Verlässlichkeit ihrer Aussagen bewertete, einen gerafften Überblick über die Situation an den deutschen und österreichischen Universitäten gab und in einem dreifachen Appendix ${ }^{1227}$ die Perspektiven zweier interviewter POW's wiedergab.

1223 Ebd., $1 \mathrm{f}$.

1224 Die höheren Chargen würden, so sie übernommen worden wären, ohnedies unter die regulären Entnazifizierungskategorien fallen. Ebd., 7.

1225 Ebd.

1226 Ebd., 9.

1227 Der dritte Appendix umfasst eine kurze Namensliste mit angefügter politischer Einschätzung des Lehrpersonals an österreichen Universitäten. Auf dieser Liste, die wohl ebenso unter Beiziehung der Einschätzungen der befragten POW's erstellt wurde, wird Fritz Knoll, 1939-1943 NS-Rektor an der Uni- 
Unter den interviewten Gefangenen befanden sich zwei Österreicher beziehungsweise zwei Personen, die unter anderem auch an den österreichischen Universitäten Graz, Innsbruck und Wien studiert hatten. Einer der beiden Österreicher ${ }^{1228}$ - ein Feldwebel und promovierter Mineraloge katholischer Gesinnung - war der einzige Interviewte, der als Zeuge als eher wenig zuverlässig eingeschätzte wurde. ${ }^{1229}$

Hingegen wurden die Aussagen des 38-jährigen Oberstleutnants Friedrich August Freiherr von der Heydte, der in Wien und Innsbruck Jurisprudenz und Ökonomie studiert und in Graz 1932 zum Dr. juris promoviert hatte, als verlässlich eingeschätzt: seine Aussagen wurden in einem der beiden Appendizes zusammengefasst. Heydte, ein anglophiler, katholischer „man of culture and high intelligence“ und "determined anti-nazi“" ${ }^{1230}$ war laut Bericht 1932 kurzfristig enthusiastischer Nazi gewesen, habe sich dann jedoch strikt gegen den Nationalsozialismus gestellt. ${ }^{1231}$ In den Jahren zwischen I932-I935 war Heydte Universitätsassistent bei den Professoren Kelsen, ${ }^{1232}$ Verdross und Hugelmann

versität Wien, als „ardent Nazi“ eingeschätzt, von Srbik hingegen - da sein wissenschaftliches Werk nie durch den Geist der Zeit beinflusst gewesen sei - als „suitable to take part in the reconstruction of German [sic] academic life" betrachtet wurde. NARA II, RG 260, OMGUS ECR, Box 28. PW Paper 99, CSDIC (UK), „German Universities under National-Socialism“, [28. Mai 1945], xxxvii. Zur Vita von Fritz Knoll siehe: Klaus Taschwer, Die zwei Karrieren des Fritz Knoll. Wie ein Botaniker nach 1938 die Interessen der NSDAP wahrnahm - und das nach 1945 erfolgreich vergessen machte. In: Johannes Feichtinger/Herbert Matis/Stefan Sienell/Heidemarie Uhl (Hrsg.), Die Akademie der Wissenschaften in Wien 1938-1945, Wien 2013, 47-54.

1228 Der zweite Österreicher, der Sanitätsgefreite E. PW M/A 1587], der als „intelligent and co-operative anti-Nazi“ und als „reliable“ eingeschätzt wurde, hatte ab 1941 an der Universität Wien Medizin studiert und war dann am 29. Jänner 1944 von der Deutschen Wehrmacht dessertiert. NARA II, RG 260, OMGUS ECR, Box 28. PW Paper 99, CSDIC (UK), „German Universities under National-Socialism“, [28. Mai 1945], ii.

1229 „He is now definitively anti-Nazi. He remains, however, a ,good German', who feels that his oath to the FÜHRER has some binding force.“ [Versalien im Original, d. Verf.] Feldwebel H. [PW DZ/135369] hatte nach Beendigung des Studiums von 1934-1938 als Beamter der Salzburger Elektrizitätsbetriebe gearbeitet und nach dem „Anschluss“ die Stelle eines mineralogischen Assistenten an der Universität Breslau angenommen. H., ein gläubiger Katholik („devout Catholic“) war der NSDAP beigetreten, um seine Anstellung nicht zu verlieren, habe jedoch, so die biografische Angabe im Geheim-Dossier, zu Anfang klare Sympathien für den Nationalsozialismus gehabt. NARA II, RG 260, OMGUS ECR, Box 28. PW Paper 99, CSDIC (UK), „German Universities under National-Socialism“, [28. Mai 1945], iv.

1230 Ebd., ii.

12311935 hatte Heydte (1907-1994) aufgrund der nationalsozialistischen Durchdringung des Universitätssystems angeblich seine akademische Karriere aufgegeben und wäre in die deutsche Reichswehr eingetreten, um der NS-Ideologie zu entgehen. 1942 befand sich Heydte unter den Mitverschwörern des Stauffenberg-Attentats am 20. Juli auf Hitler. NARA II, RG 260, OMGUS ECR, Box 28. PW Paper 99, CSDIC (UK), „German Universities under National-Socialism“, [28. Mai 1945], ii.

12321932 war Heydte seinem Lehrer Hans Kelsen als Privatassistent nach Köln gefolgt, wurde nach dessen Entlassung ein Jahr später von Kelsens Nachfolger Carl Schmitt nicht übernommen. Heydte ging zurück nach Wien, wo er durch Alfred Verdross eine Assistentenstelle an der Konsularakademie erhielt. Siehe: 
und hatte daher eine entsprechende Kenntnis der österreichischen Universitätslandschaft jener Jahre. ${ }^{1233}$

Heydte, ${ }^{1234}$ der hinsichtlich der allgemeinen Situation der akademischen Nachkriegsjugend meinte, dass diese aktuell zwar keineswegs zur Gänze „Nazi-minded“ sei, da das NS-Regime die Jugend nicht in „positiver Weise“ zu gewinnen vermochte - „nowhere is there so much criticism and rejection of National Socialism among the younger generation, especially among the educated ones. Youth as a rule desires and hates compulsion. Youth wants change; it is revolutionary by nature“-, sah jedoch auch einen zugleich nachhaltig negativen Einfluß der NS-Ideologie auf die studentische Jugend:

"National Socialism $[\ldots]$ uprooted youth, took away its veneration for the eternal moral values
which are above 'blood and soil', and then loosened or severed all ties with religion and ethics.
As a result, an exaggerated cynism, which will be frightening to foreigners, has spread among
the academic youth of Germany. The young student, brought up in his boyhood as a National
Socialist, tends to develop into a nihilist when National Socialism has proved disappointing
and he has nothing to put in its place." ${ }^{235}$

Hinsichtlich der auf sekundarer Schulstufe vermittelten grundlegenden Kenntnisse für alle nachfolgenden Studien und Ausbildungsgänge hätte, laut Heydte sowie anderer befragter POW's, in den Kriegsjahren ein dramatisches Absinken sowohl des allgemeinen Bildungsniveaus als auch insbesondere der Kenntnisse in den naturwissenschaftlich-mathematischen Fächern stattgefunden, was sich in Studienrichtungen wie Maschinenbau, Elektrotechnik, Physik, Chemie oder Mathematik deutlich niedergeschlagen habe. ${ }^{1236}$

Vanessa Conze, Das Europa der Deutschen. Ideen von Europa in Deutschland zwischen Reichstradition und Westorientierung (1920-1970), München 2005, $64 \mathrm{f}$.

1233 Fälschlicherweise führt das britische Geheim-Dossier an, Heydte wäre Assistent bei Carl Schmitt gewesen. NARA II, RG 260, OMGUS ECR, Box 28. PW Paper 99, CSDIC (UK), „German Universities under National-Socialism“, [28. Mai 1945], ii.

1234 Nach dem Frankreichfeldzug trat Heydte zur Luftwaffe über und war zunächst Kompaniechef, ab 1944 Bataillonskommandeur der Fallschirmjäger auf Kreta. Nach dem Einsatz an der Ostfront 1942-43 wurde er Major und als solcher in der Normandie Kommandeur des Fallschirmjägerregiments 6. Im Dezember 1944 geriet er in den Ardennen in US-Kriegsgefangenschaft und wurde im Februar 1945 in das britische Kriegsgefangenenlager Trent Park bei London überstellt. Nach 1945 wurde der Ritterkeuzträger Heydte u.a. Abgeordneter der CSU im Bayerischen Landtag und darüber hinaus Ordinarius für Staats- und Völkerrecht an den Universitäten Mainz und Würzburg. 1962 löst Heydte die „Spiegel-Affäre“ aus. Conze, Das Europa der Deutschen., a.a.O., 66; siehe weiters : Der Spiegel, 47, 1962.

1235 NARA II, RG 260, OMGUS ECR, Box 28. PW Paper 99, CSDIC (UK), „German Universities under National-Socialism“, [28. Mai 1945], 5.

1236 Heydte berichtete darüber hinaus, dass unter NS-Offiziersanwärtern grobe Bildungslücken existierten: "Heydte states that out of the 120 officer candidates he had to examine at the beginning of November 1944, half could not spell correctly, a third did not know the capital of SPAIN, and the majority did not know in 
Eine nicht uninteressante, freilich subjektive Innenansicht auf den doktrinären Wissenschafts- und Forschungsbetrieb im Bereich der Jurisprudenz während der NS-Zeit liefert eine kurze Passage des POW-Berichts, den allem Anschein nach Heydte selbst verfasst hat und worin er auf den eingeschränkten Zugang zu wissenschaftlichen Ressourcen und die Limitation durch unhinterfragbare Dogmen verweist. ${ }^{1237}$

Hinsichtlich des Wiederaufbaues des Bildungs- und Universitätsbereiches waren sich die national-konservativen POW's über die Notwendigkeit entsprechend tiefgehender ,Säuberungsmaßnahmen' einig. ${ }^{1238}$ Neben der ,Säuberung' aller Lehr- und Unterrichtsmaterialien sei vor allem, wie Heydte meinte, der Personalbereich einer genauen Prüfung zu unterziehen: „A clean sweep should be made of all Party Professors and Party chairs so as to prevent the infiltration of politically undesirable teachers. ${ }^{\text {"1239 }}$ Und POW Oberst Kurt Hesse, Professor für Militärgeschichte und Ökonomie an der Universität Berlin, sprach sich, neben etwas hölzern artikulierten Säuberungsvorschlägen, auch für einen Austausch und eine Kooperation mit englischen beziehungsweise amerikanischem Lehrpersonal sowie - angesichts der voraussichtlichen universitären Personalknappheit - für die Rückholung vertriebener Professoren aus:

"The personnel of the Reichserziehungsministerium to be purged. All Nazis be replaced by humanists $[\ldots]$. Suspension of all political teacher organizations. [...] Discouragement of an

which centuries NAPOLEON and CROMWELL - of whom many had never heard - lived. All, however, knew when HITLER was born." [Versalien im Original, d. Verf.] NARA II, RG 260, OMGUS ECR, Box 28. PW Paper 99, CSDIC (UK), „German Universities under National-Socialism“, [28. Mai 1945], 9.

1237 „For example, whatever one's personal attitude towards KELSEN may be, anyone who wishes to study law in GERMANY must analyse his works, but this was impossible in Nazi GERMANY as all his books had been eliminated. Even if a scientist had access to the sources mentioned [libraries, foreign publications, d. Verf.] he was not able to work fully. He was tied down by certain Nazi doctrines which he was not allowed to consider but which had to be be accepted as dogmas. One of these dogmas consisted in a conception of the law as giving statutory force to any rule thought to benefit the community (thus denying natural right): another was the Nazi teaching that national law takes precedence over international law (which is derived only from national law supposed to be binding only when necessary); yet another extravagant Nazi thesis was that Roman law was alien and degenerate. Anyone who did not agree with these dogmas had, unless he was a mere parrot-like repeater of paragraphs of the law, to be a mental contortionist in his lectures and writings - an action unworthy of a scientist." [Versalien im Original, d. Verf.] NARA II, RG 260, OMGUS ECR, Box 28, PW Paper 99, CSDIC (UK), „German Universities under National-Socialism“, [28. Mai 1945], 11.

1238 Darüber hinaus waren sich die Befragten lediglich hinsichtlich der Notwendigkeit einer besseren Bezahlung von Forschungsassistenten und Dozenten einig, die einzige Verbesserung, die während des NS-Regimes erzielt worden sei: „All PWs agree that the improved conditions of payment for research assistants as well as for the young Dozenten - so badly needed for such a long time - were generally considered the only valuable achievement of Nazi University policy." NARA II, RG 260, OMGUS ECR, Box 28, PW Paper 99, CSDIC (UK), „German Universities under National-Socialism“, [28. Mai 1945], 12.

1239 Ebd., Appendix I, ii. 
all inclusive, centralized teachers association. Collaboration with English and American teachers. [...] Recall of those university professors who emigrated during the Nazi regime. [...] Foreign professors should be invited to teach in German universities." ${ }^{1240}$ [Hervorhebung d. Verf.]

Mit Bezug auf die geplante geistige Reorientierung durch die Besatzungsmächte prognostizierte Heydte allerdings sowohl eine generelle wie auch eine spezifische Mentalreserve gerade unter Studenten: „The chief difficulties will be the general cynicism and mental defeatism bred amongst the students by National Socialism; this has been increased by the widespread Destruction of historic buildings and works of art during the war, and may make the student mistrustful of Anglo-Saxon efforts in the sphere of reeducation [...].“1241

Soweit die Position der interviewten deutsch-österreichischen POW's zum Neubeginn der Universitäten, die mit ihren wissenschafts- beziehungsweise bildungspolitischen Aussagen keineswegs über das demokratische Ziel hinausschossen und sozusagen ein $\mathrm{Mi}$ nimalprogramm eines post-totalitären Neuanfanges im Wissenschaftsbereich skizzierten.

\section{Bestimmungen zur Entnazifizierung in US-Planungsdirektiven}

So klar und strikt nun sowohl die grundsätzliche Haltung der amerikanischen Besatzungsmacht als auch die des seit Juli 1945 installierten Alliierten Rates und seines „Education Directorate" in der Frage der Entnazifizierung anfänglich auch war, gab es hinsichtlich des konkreten Prozedere jedoch kaum klare und schon gar keine einheitlichen Regelungen, die über die jeweiligen Besatzungszonen hinweg Gültigkeit gehabt hätten.

In Artikel 3, Lit. (e) des zweiten alliierten Kontrollabkommens vom 28. Juni I946 steht im Hinblick auf die primären Aufgaben der Alliierten Kommission unmissverständlich zu lesen:

"To ensure the institution of a progressive long-term educational program designed to eradicate all traces of Nazi ideology and to instil into Austrian youth democratic principles." ${ }^{1242}$

Als Teilsektor der Entnazifizierung im öffentlichen Dienst bildeten die Universitäten und Hochschulen einen Bereich von besonderer politischer Bedeutung, dessen ,Säuberung ' daher eine entscheidende Voraussetzung für eine demokratische, akademische Neuorientierung sowie für die geistige Erneuerung der geistig-intellektuellen Elite des Landes - hier vor allem auch der Jugend - bilden sollte.

1240 Ebd., Appendix II, i f.

1241 Ebd., Appendix I, ii.

1242 Zit. nach: Austria. A Graphic Survey. Prepared by U.S. Element Allied Commission for Austria, December 1948, XXVIII. 
Interessant ist in diesem Zusammenhang, dass die US-Militärbehörden in Österreich die bereits beschriebenen „Mandatory Removal and Exclusion Categories“, jene für die US-Besatzungszone gültigen Arrestierungs- und Enthebungslisten, in etwas abgeschwächter Form bis Herbst 1945 aufrechterhielten und darin dezidiert auch die Enthebung beziehungsweise den Ausschluss (aus dem politischen Leben) für „Austro-Faschisten“verfügten.

Obwohl die für Österreich spezifizierten Bestimmungen der von SHAEF analog zur JCS-Direktive No. 1065 ausgearbeiteten „Automatic Arrest List“ letztlich entscheidend abgeschwächt wurden - in der ursprünglichen Fassung wären unter anderem auch „die Angehörigen der Justiz bis zum Landesgerichtspräsidenten“ ab Stichtag I. September I933 davon betroffen gewesen ${ }^{1243}$-, blieben analog zur „Standard Operating Procedure for Denazification" der USFA-Headquarters vom 3. August 1945 im Hinblick auf ehemalige Funktionäre des austrofaschistischen Regimes bis Herbst 1945 formal doch einige zentrale Bestimmungen aufrecht, die bei konsequenter Durchführung nicht wenigen Führungspersonen der ÖVP ein politisches Amt verschlossen und damit die personelle Basis der ÖVP auf Dauer entscheidend geschwächt hätten:

"All persons who took an active and prominent part in the undemocratic measures of the preNazi Fascist regime or in any of its paramilitary organization such as Heimwehren and the ostmaerkische Sturmscharen will be removed and excluded from the positions enumerated in paragraph 2 above." ${ }^{1244}$

Im Vorfeld der ersten Nationalratswahlen führten diese Bestimmungen in den US-Entnazifizierungsrichtlinien zu einer Kontroverse innerhalb der ÖVP, weil sich die Salzburger Landespartei zunächst gegen die Bundespartei stellte und deren Zahlenangaben über bisher erfolgte Enthebungen von „Austro-Faschisten “1245 in der amerikanischen Besatzungszone in Salzburg gegenüber der amerikanischen Besatzungsmacht stark nach unten korrigierte; laut amerikanischen Quellen schwenkte die Landespartei erst nach einiger Überzeugungsarbeit ein und war dann bereit, sich an den kommenden Nationalrats- und Landtagswahlen

1243 Vgl. dazu: Rathkolb, US-Entnazifizierung in Österreich, a.a.O., 303.

1244 John G. Erhardt, „Transmitting letter from Under Secretary for Foreign Affairs, Dr. Gruber, regarding American Policy on Austro-Fascism“, 24. Oktober 1945, a.a.O., 2.

1245 In Salzburg war es de facto die US-Besatzungsmacht gewesen, die im Mai 1945 Richard Hildmann (1882-1952) als Bürgermeister von Salzburg installierte. Die Einsetzung Hildmanns, der von 1935 bis 1938 austrofaschistischer Bürgermeister von Salzburg gewesen war, stieß nicht nur auf heftige Kritik von Sozialdemokraten und Kommunisten; auch der amerikanische OSS hielt in einem Lagebericht fest: „Hild$\operatorname{man}[\mathrm{n}]$ should be removed if it is US policy to avoid Dol[1]fuss and Schuschnigg men in office." Um daran anschließend gleich entscheidend abzuschwächen: „However, men like Hildman[n] in office are a less important matter than Nazis in office." Edgar N. Johnson [OSS], Telegram from Salzburg, 9. Juni 1945. Zit. nach: Rathkolb (Hrsg.), Gesellschaft und Politik am Beginn der Zweiten Republik, a.a.O., 251. 
im November zu beteiligen. ${ }^{1246}$ Das von August Trummer geleitete Landesparteisekretariat der ÖVP war am 3r. Mai 1945 in das „Generalsekretariat West“ umgewandelt worden, das die Opposition der westlichen und südlichen Bundesländer gegen die als schwach angesehene ÖVP-Parteiführung in Wien koordinierte; unter dem provisorischen Tiroler Landeshauptmann Karl Gruber als Sprecher zog das „Generalsekretariat West“ in einem Forderungsprogramm vom 23. September 1945 sogar die mögliche Trennung von Wien ins Kalkül. ${ }^{1247}$

In einem Schreiben an den amerikanischen Gesandten in Österreich, John G. Erhardt, brachte Unterstaatssekretär Karl Gruber diese für die ÖVP höchst unangenehmen politischen Säuberungsbestimmungen - die von SPÖ und KPÖ freilich massiv unterstützt wur$\operatorname{den}^{1248}$ - ausführlich zur Sprache und ging dabei gleich in die wahlkämpferische Offensive. Zunächst verwies Gruber auf über 300 Fälle, in denen ÖVP-nahe Personen in der US-Zone in Salzburg auf Grund ihrer Aktivitäten in den Jahren 1933-r938 enthoben worden wären eine Zahl, die von Salzburg aus gegenüber dem US-Hauptquartier allerdings auf lediglich sechs bis sieben Fälle - bei ihnen soll es sich um Angehörige der Heimwehr beziehungsweise der Ostmärkischen Sturmscharen gehandelt haben - nach unten korrigiert wurde. Dessen ungeachtet rechnete Gruber, der unter den von ihm genannten 300 Fällen auch Personen ausmachte, die „mehr als sieben Jahre in Konzentrationslagern verbracht“ hätten, Erhardt vor, dass die politischen Säuberungsbestimmungen, umgerechnet auf die gesamte österreichische Bevölkerung, in Summe rund 6.00o Personen betreffen würden, „among them in many cases leadership material of the Volkspartei“. Und weiter im Wortlaut:

"Aside from this computation of numbers it must also be remarked that such measures against persons who have spent many years in Nazi concentration camps, would evoke bitterness in them, and such bitterness can easily have repercussions on wider circles. It is, therefore, not impossible that the inclination to abstain from voting may increase strongly, particularly with the strata who would vote for the Volkspartei. [... If, however, the political leadership of the peasants and the middle class in Austria is to be paralyzed in this manner, then a one-sided party regime can hardly be avoided." 1249

1246 Recordings of the U.S. Department of State relating to the Internal Affairs of Austria 1945-1954 (Mikrofilm-Bestand Institut für Zeitgeschichte der Universität Wien), Decimal File, Reel 1, John G. Erhardt, Office of the Political Officer/USFA, „Transmitting letter from Under Secretary for Foreign Affairs, Dr. Gruber, regarding American Policy on Austro-Fascism“, 24. Oktober 1945, 2.

1247 Vgl. Robert Kriechbaumer, Salzburg 1945-1955: Politische Entwicklungslinien. In: Hans Bayr/Robert Kriechbaumer, Salzburg 1945-1955. Zerstörung und Wiederaufbau. Begleitbuch zur Ausstellung des Salzburger Museums Carolino Augusteum in Zusammenarbeit mit dem Verein „Salzburger Wehrgeschichtliches Museum“, Salzburg 1995, $85 \mathrm{f}$.

1248 Vgl. Kriechbaumer, Salzburg 1945-1955, a.a. O., $87 \mathrm{f}$.

1249 Recordings of the U.S. Department of State relating to the Internal Affairs of Austria 1945-1954 (Mikrofilm-Bestand Institut für Zeitgeschichte der Universität Wien), Decimal File, Reel 1, John G. Erhardt, Office of the Political Officer/USFA, Letter from Dr. Gruber dated October 22, 1945, 2. 
In seiner sichtlich um eine rasche Aufhebung der US-Enthebungsbestimmungen gegenüber „Austro-Faschisten“ bemühten Argumentation sparte Gruber nicht mit teils untergriffiger Kritik gegenüber Kommunisten und Sozialisten: so würden erstere unter dem Begriff „Faschist“ gerne alles subsumieren, was nicht Mitglied der Kommunistischen Partei sei, und bezüglich der SPÖ sei, so Gruber, hinlänglich bekannt, dass diese selbst einen radikalen Flügel (gehabt) habe. Hier empfahl Gruber Erhardt kurzerhand die Lektüre der sozialdemokratischen Zeitschrift Der Kampf sowie des Linzer Parteiprogrammes von I926, wobei er aus beiden Quellen längere Textpassagen als Beleg für die unversöhnliche, klassenkämpferische Haltung der Sozialdemokratie zitierte. Darüber hinaus legte Gruber in diesem Zusammenhang dar - freilich ohne jede Zusammenhang mit den politischen Geschehnissen der Ersten Republik -, dass die Sozialdemokratie mit dem Republikanischen Schutzbund selbst eigene, „hochbewaffnete militärische Formationen“1250 gehabt habe.

Besonders verquer wurde Grubers Bemühen, den Austrofaschismus-Passus in den USSäuberungsdirektiven als demokratiepolitisch geradezu sinnwidrig darzustellen, als er die ,katholischen' Ostmärkischen Sturmscharen als Gegengewicht zur Heimwehr charakterisierte, deren Aufgabe es gewesen sei, die Heimwehr so rasch wie möglich zu übernehmen: außerdem strich er deren quasi ,zivilen ' Charakter hervor, indem er die Heimwehr selbst als aus überaus heterogenen Elementen wie lokalen Schützenverbänden bestehend darstellte, deren Obmänner gleichermaßen automatisch Leiter der Heimwehrabteilungen wurden. Außerdem habe deren Hauptaufgabe, so Gruber weiter, geradezu in einer Schutzfunktion gegenüber der kommunistischen Gefahr bestanden:

"But the purpose was not the establishment of a fascist dictatorship but protection against the dangers of a Communist revolution - at the time when in Hungary, Bavaria and Upper Italy Communist attempts at dictatorship were occurring." ${ }^{1251}$

Inwieweit nun Grubers Einwände, die taktisch gezielt die Gefahr einer politischen Stärkung der Kommunisten - „definite strengthening of influence of certain parties in Austrian politics“ - an die Wand malten, tatsächlich direkten Einfluss auf die Säuberungsdirektiven der amerikanischen Besatzungsmacht nahmen, muss an dieser Stelle nicht zuletzt auf Grund fehlender Quellen dahingestellt bleiben. ${ }^{1252}$ Tatsache ist hingegen, dass die ehe-

\section{Ebd.}

1251 Recordings of the U.S. Department of State relating to the Internal Affairs of Austria 1945-1954 (Mikrofilm-Bestand Institut für Zeitgeschichte der Universität Wien), Decimal File, Reel 1, John G. Erhardt, Office of the Political Officer/USFA, „Transmitting letter from Under Secretary for Foreign Affairs, Dr. Gruber, regarding American Policy on Austro-Fascism“, a.a.O., 2.

1252 Erwähnenswert ist, dass sich Gruber in dem zitierten Schreiben an US-Gesandten Erhardt insbesondere auch gegen die Durchführung der politischen „Säuberung“ seitens der Staatspolizei in Wien wandte, deren Leiter (Heinrich Dürmayer) von den US-Militärbehörden den Befehl erhalten habe, Listen ehemaliger Heimwehr-Angehöriger zu erstellen. Demgegenüber schien Erhardt keinerlei Einwände gegen 
maligen Mandatare und Funktionäre des Austrofaschismus spätestens mit Spätherbst I945 mit keiner Einschränkung ihrer beruflichen oder politischen Tätigkeit mehr zur rechnen hatten. Detaillierte biografische Dossiers prominenter österreichischer Politiker, die Experten von der „Division of Biographic Intelligence“ des U.S. Department of State noch im Verlauf des Jahres I945 angelegt hatten, blieben somit Schubladenmaterial. ${ }^{1253}$

\section{Die Ausgangssituation an den Universitäten im Frühjahr 1945}

Nachdem sich an den österreichischen Universitäten bereits im ausgehenden r9. Jahrhundert deutlich antisemitische Tendenzen manifestiert hatten, ${ }^{1254}$ entwickelten sich die „Ho-

das praktizierte Prozedere zu haben und merkte gegenüber dem State Department an, dass die von der Staatspolizei vorgenommenen Arrestierungen ohnehin vom amerikanischen CIC supervidiert würden; des Weiteren: „The clearly defined arrest and removal categories of the directive were well received by members of the Political Police, who have hitherto been working on ill-defined and loosely worded Austrian authority. Hope has been expressed that uniform denazification policy, based on the Standard Operating Procedure for denazification, will be adopted and enforced by all the Allied powers." Ebd., 3.

1253 Als historische Quelle sind diese geheimen biografischen Dossiers, in die u.a. Material aus persönlichen Befragungen einfloss, allerdings durchaus von Interesse, da sie auch differenzierte Charakterisierungen einzelner politischer Persönlichkeiten enthalten, wie beispielsweise zum (politischen) Werdegangs Leopold Figls, die u.a. von Martin F. Herz bestätigt wurden. Neben Angaben zu dessen politischer Sozialisation, über den niederösterreichen Bauernbund, die von ihm organisierten „Niederösterreichischen Sturmscharen“ š „Figl insists that the Sturmscharen were primarily anti-Nazi, but he does not deny they were also strongly anti-Socialist" [Unterstreichung im Original] š sind vor allem jene Passagen interessant, die sich mit seiner Persönlichkeit beschäftigen, die Ähnlichkeiten zu Dollfuß aufweisen würde: „Especially in somewhat pathetic impression that both at times have given of plain, sincere, determined, little men close to the soil, shouldering heavy responsibilities [...]. A man of great vitality, he is said to require only four hours sleep nightly. “ Hinsichtlich Figls „Character Analysis“ hielt das Dossier fest, dass er sich seiner persönlichen historischen Bedeutung bewusst sei, jedoch weder besondere intellektuelle Neigungen noch überzogene Vorstellungen seiner sonstigen Fähigkeiten habe, wobei in demokratiepolitischer Hinsicht eine keineswegs unbedenkliche Ambivalenz spürbar sei: „FIGL is definitively honest and sincere and a convinced Austrian patriot. On the other hand, his ideas of democracy in the western sense are rudimentary. He knows very little of, and cares very little about, the intricacies of parliamentary politics. His knowledge of the psychology of the working class is minimal. His lack of ideological principles, bis ignorance of international affairs and economic policy, and his tendency to oversimplify political questions, make it easy for him to put expediency above principles. Internationally, he inclines toward friendship with the Western Powers, and has made every effort to cooperate closely with the Americans whom he, like many of his party, half hopes and half believes have come to Austria to save Austria from the Russians [...]“. [Hervorhebung d. Verf.] Recordings of the U.S. Department of State relating to the Internal Affairs of Austria 1945 š 1954 (Mikrofilm-Bestand Institut für Zeitgeschichte der Universität Wien), Decimal File, Reel 1, Headquaters United States Forces in Austria, Office of the Political Advisor to Secretary of State, Washington, „Transmitting sketch describing division of political and economic influence in Austria and accompanying biographic portraits of prominent Austrians“, 30. April 1946, $1 \mathrm{ff}$.

1254 Durch die Tolerierung bzw. Akzeptanz der immer unverhohlener antisemitisch auftretenden deutschnational-schlagenden Studentenverbindungen š mit der „Waidhofener Erklärung“ vom 11. März 
hen Schulen“ in der Zwischenkriegszeit zunehmend zu einem Hort der Reaktion und des aggressiv auftretenden Nationalsozialismus. Antisemitische Krawalle, „völkische“ Überfallskommandos mit Schlagstöcken, Spießrutenläufe für jüdische Studenten, blutige Prügeleien zunächst mit Heimwehr- und immer öfter auch mit Nazistudenten sowie Hakenkreuz-Schmierereien begannen den studentischen Alltag zu dominieren. ${ }^{1255}$ Zusätzlich verschlimmert wurde diese Situation durch den Beschluss des akademischen Senates, nur die „Deutsche Studentenschaft“ (d.i. die Koalition der völkischen Studenten mit dem antisemitischen CV) als Vertretung zu den Hochschulwahlen zuzulassen: „Nicht-Arier“ oder Sozialdemokraten waren ausgeschlossen. ${ }^{1256}$ Nach dem Sieg der Nationalsozialisten an der Universität Graz bereits im Jahr I930 erzielten die nationalsozialistischen Studenten I93I auch bei den Hochschülerschaftswahlen an der Universität Wien, an der Universität für Bodenkultur und an der Technischen Hochschule in Wien die Mandatsmehrheit, ${ }^{1257}$ was

1896 war jüdischen Studierenden von „wehrhaften“ Studentenverbindungen die Satisfaktionsfähigkeit und Ehre abgesprochen worden - erlebte der Rassensantisemitismus im Gefolge der als „Slawisierungspolitik " denunzierten Sprachenverordnungen Minister Badenis einen ersten Höhepunkt, indem, wie Oliver Rathkolb hervorhob, die Universität durch antislawische und antijüdische Demonstrationen erstmals „auch physisch in Geiselhaft“ genommen, somit politischer Druck ausgeübt wurde. Vgl. Oliver Rathkolb, Gewalt und Antisemitismus an der Universität Wien seit der Badeni-Krise. Vortrag bei der Tagung: „Der lange Schatten des Antisemitismus. Kritische Auseinandersetzungen mit der Geschichte der Universität Wien im 19. Jahrhundert", Universitätsarchiv Wien, 11. Oktober 2012. Für die Möglichkeit zur Einsichtnahme in das unveröffentlichte Vortragsmanuskript danke ich an dieser Stelle Herrn Univ.-Prof. DDr. Oliver Rathkolb. Zur biologistischen Instrumentalisierung ostjüdischer Studierender an der Universität Wien im Zusammenhang wissenschaftlichen Konkurrenzkampfes siehe die umfangreiche Studie: Felicitas Seebacher, Das Fremde im „deutschen“ Tempel der Wissenschaften. Brüche in der Wissenschaftskultur der Medizinischen Fakultät der Universität Wien (=Veröffentlichungen der Kommission für Geschichte der Naturwissenschaften, Mathematik und Medizin), Wien 2011. Allgemein siehe: Robert S. Wistrich, Die Juden Wiens im Zeitalter Franz Josephs (=Anton-Gindely-Reihe zur Geschichte der Donaumonarchie und Mitteleuropa 4), Wien Köln - Weimar 1999, 302.

1255 Nachdem sich Engelbert Dollfuß als Gründungsmitglied der „Deutschen Studentenschaft“ bereits 1920 öffentlich für einen akademischen Arier-Paragrafen ausgesprochen hatte, verfasste die „Deutsche Studentenschaft“ 1925 eine Denkschrift, die gegen „sittliche Orientalisierung und rassische[r] Judaisierung“ auf Boden der Universität wetterte; das Dokument wurde auch von Leopold Figl als damaligem Leiter der studentischen katholischen Minderheitsfraktion mitunterzeichnet. Vgl. Kurt Bauer, Lueger und die Lausbuben. In: Die Presse, 27. April 2012.

1256 Vgl. Wolfgang Speiser, Die sozialistischen Studenten Wiens 1927-1938 (=Materialien zur Geschichte der Arbeiterbewegung, Nr. 40), Wien 1986, 57 f. De facto gab es, wie Hartmann eigens hervorhebt, keinen Arier-Paragraph im CV, es wurden, wie er meint, ab 1918 „lediglich“ Studenten „deutsch-arischer“ Abstammung „bevorzugt“ aufgenommen. Siehe: Gerhard Hartmann, Der CV in Österreich. Seine Entstehung - seine Geschichte - seine Bedeutung (= Schriftenreihe der Bildungsakademie des ÖCV, Bd. 4), 4. überarb. Aufl., Kevelaer 2011, $123 \mathrm{f}$.

1257 Vgl. Gerhard Wagner, Von der Hochschülerschaft Österreichs zur Österreichischen Hochschülerschaft. Kontinuitäten und Brüche, Dipl.-Arb., Univ. Wien 2010, 80. 
die Auseinandersetzungen noch weiter verstärkte; ${ }^{1258}$ ab Sommer 1932 galt, analog zum Beschluss auf dem 15. Deutschen Studententag in Würzburg, auch auch in Österreich das „Führerprinzip“ innerhalb der „Deutschen Studentenschaft“. ${ }^{1259}$

Wie Kurt Bauer schlüssig dargelegt hat, ging die von der NSDAP angewandte Strategie der „kalkulierten Eskalation“ auf akademischem Boden voll auf: mehr als 25 Prozent der illegalen Nationalsozialisten in Wien "gehörten dem akademischen Milieu an“, ${ }^{1260}$ wobei deren antisemitische Gewaltakte von der Polizei ${ }^{1261}$ (außerhalb der Universität), dem Wiener Universitätsrektor Wenzel von Gleispach, den universitären Behörden und der antisemitischen Professorenschaft ${ }^{1262}$ entweder stillschweigend geduldet oder offen unter-

1258 Siehe dazu: Wolfgang Speiser, Unter Adolf Hitlers Sturmfahnen. In: Sozialistisch-Akademische Rundschau, 4. April 1931, 42 f.; vgl. auch: Christian Stifter, Kurzcharakteristik der Quellenlage zu Leben und Werk von Wolfgang Speiser. In: Volker Otto/Erhard Schlutz (Hrsg.), Erwachsenenbildung und Emigration. Biographien und Wirkungen von Emigrantinnen und Emigranten (=Tagungsprotokoll der 12. Konferenz des Arbeitskreises zur Aufarbeitung historischer Quellen in der EB, hrsg. v. DVV), Bonn 1999, $119 \mathrm{f}$.

1259 Wagner, Von der Hochschülerschaft Österreichs zur Österreichischen Hochschülerschaft, a.a.O., 81.

1260 Kurt Bauer, „Kalkulierte Eskalation. Antisemitische Ausschreitungen an den Wiener Universitäten und Hochschulen in den frühen 1930er-Jahren“. Vortrag bei dem Workshop „Alma mater antisemitica“ (15.16. Juni 12012) an der Österreichischen Akademie der Wissenschaften in Wien. Ich danke an dieser Stelle Herrn Dr. Kurt Bauer für die freundliche Zurverfügungstellung des unpublizierten Vortragsmanuskriptes, das in Folge in überarbeiteter Fassung in einem Sammelband erscheinen wird. Vgl. dazu auch: http://www.kurt-bauer-geschichte.at/PDF-Materialien/Vortrag_Kalkulierte_Eskalation.pdf

1261 Nach mehrere „Saalschlachten“ und Prügelszenen zwischen jüdischen beziehungsweise sozialdemokratischen Studenten und Nationalsozialisten in Innsbruck und Wien, bei denen Studierende vor den Augen der anwesenden Polizei zusammengeschlagen wurden, ohne dass diese eingriff, steigerten sich diese Ausschreitungen ab 1932 zu gezielten „pogromartigen Krawallen“, bei denen im Mai 1933 nicht nur teure Laboreinrichtung Ziel der nationalsozialistischen Aggression waren, sondern durch Einsatz von Knüppeln und Totschlägern auch 21 teils schwer Verletzte zu verzeichnen waren, wobei der Wiener Polizeipräsident Franz Brandl (bald darauf NSDAP-Mitglied) die Tatenlosigkeit der Exekutive mit der Hochschulautonomie rechtfertigte. Vgl. Kurt Bauer, Lueger und die Lausbuben. In: Die Presse, 27. April 2012; zu den Uni-Krawallen 1932, der vorübergehenden Schließung der Universität Wien samt Nebengebäuden (26.10-30.11.1932) der Aufösung der Deutschen Studentenschaft und die Unterstellung der Österreichischen Hochschülerschaft unter „Sachwalterschaft“ siehe im Detail: Wagner, Von der Hochschülerschaft Österreichs zur Österreichischen Hochschülerschaft, a.a.O., 90 ff.

1262 Tatsächlich verdeutlichen neuere Forschungen, dass die Universität Wien Mitte der Zwanzigerjahre bereits eine regelrechte „Hochburg des Antismitismus“ war. Nicht zuletzt waren es heimlich agierende professorale Kreise, wie etwa die inoffizielle Professorenclique „Bärenhöhle“ - ein der Anschlussbewegung der „Deutschen Gemeinschaft“ nahestehendes Zweckbündnis deutschnationaler Professoren und CVAngehöriger -, die geheime Absprachen trafen, um die Universität ,judenrein“ zu machen beziehungsweise jüdischen Wissenschaftern die universitäre Karriere nach Möglichkeit nachhaltig zu verbauen. Die „Zerstörung wissenschaftlicher Excellenz an Österreichs Hochschulen“ begann, wie Klaus Tascher jüngst dargelegt hat, „nicht erst 1934 oder 1938 [...], sondern bereits in den 1920er-Jahren.“ Vgl. Klaus Taschwer, Hochburg des Antisemitismus. In: Der Standard, 12. Juni 2012. Im Detail: Klaus Taschwer, Die Bärenhöhle und ihr langer Schatten. Über das Wirken und Nachwirken einer geheimen antisemitischen Professorenclique an der Universität Wien nach 1918. Vortrag bei dem Workshop „Alma mater antise- 
stützt wurden. ${ }^{1263}$ NS-Terrorakte wie Sprengstoff- und Bombenanschlagserien in ganz Österreich, schwere Straßenschlachten zwischen Heimwehr und NS-Studenten in Innsbruck oder gewalttätige Ausschreitungen an der Universität Wien führten schließlich am I9. Juni 1933 zum Verbot der NSDAP, was insbesondere an der Hochschule für Bodenkultur in Wien zu weiteren Unruhen durch den Deutschen Studentenbund führte. ${ }^{1264}$ Infolge dieser Ausschreitungen existierte im Hauptgebäude der Universität Wien seit 1933 eine provisorische Polizeistation, die ein Jahr später in ein „ständiges Wachzimmer umgewandelt ${ }^{\text {“1265 }}$ wurde - neben den Prügeleien gehörten von nun an Legitimationszwang sowie allfällige Leibesvisitationen zum studentischen Alltag. Flankierend zur polizeilichen Kontrolle wurde per Verordnung des Unterrichtsministeriums mit 3. Mai 1934 Ministerialrat Otto Skrbensky ${ }^{1266}$ nach den nationalsozialistischen Unruhen an der Wiener Hochschule für Bodenkultur (BOKU) als Regierungskommissär an der BOKU ,im Interesse einer notwendigen Beschleunigung der Geschäftsführung" eingesetzt, womit ihm Rektor Emanuel H. Vogel sowie das Professorenkollegium ab sofort unterstellt waren. ${ }^{1267}$

mitica" (15.-16. Juni 12012) an der Österreichischen Akademie der Wissenschaften in Wien. Ich danke an dieser Stelle Herrn Dr. Klaus Taschwer für die freundliche Einsichtnahme in seine Vortragsunterlagen. Vgl. dazu weiters: Ders., Die Vernunft wurde schon früher vertrieben. Auf: http://science.orf.at/ stories/1700034/. Zur „Deutschen Gemeinschaft“ und deren „Abwehrkampf“ gegen das „Ungeradetum“ („Ugtum“), also gegen alle marxistischen, liberalen, jüdischen und freimaurerischen Einflüsse siehe: Wolfgang Rosar, Deutsche Gemeinschaft. Seyß-Inquart und der Anschluß, Wien - Frankfurt - Zürich 1971, $30 \mathrm{ff}$.

1263 Bauer, Kalkulierte Eskalation, a.a.O., 8.

1264 Paulus Ebner, Politik und Hochschule. Die Hochschule für Bodenkultur 1914-1955 (=Forschungen zur Wiener Stadtgeschichte, Bd. 37), Wien 2002, $74 \mathrm{f}$.

1265 Vgl. ebd., 87. Siehe dazu auch den Artikel von: Manfried Welan, Hans Karl Zeßner-Spitzenberg - Jurist und professor an der Hochschule für Bodenkultur [http://www.austria-lexikon.at/Af/AEIOU/ZessnerSpitzenberg,\%20Hans\%20Kar1\%20von; Zugriff 22.6.2012]

1266 (Baron) Otto Skrbensky (1887-1952) stammte sowohl väterlicher- (Freiherr von Skrbensky-Hrzistie) als auch mütterlicherseits (Tochter des Reichsgrafen von Kuenburg) aus einer altösterreichisch-adeligen Familie, die nach dem ererbten Gut Skrebeny (Kirwein) bei Olmütz ihren Namen führte. Nach dem Studium der Jurisprudenz wurde Skrbensky in der Ersten Republik zum Bezirkshauptmann ernannt und wechselte 1922 ins Unterrichtsministerium. Am 16. März 1938 schwor Skrbensky den „Diensteid“ auf Adolf Hitler, wurde dann aber am 29. November 1938 von Seyß-Inquart mit Dreiviertel des Ruhegenusses in den Ruhestand versetzt. Trotzdem war er nach 1938 Mitglied im NS-Rechtswahrerbund. Nach der Befreiung Österreichs übernahm Skrbensky, der seit März 1944 als Kanzleikraft bei der Union der Journalisten-Verbände und zudem als „Einkäufer, Hausverwalter, Aufseher und Kontrollor" gearbeitet hatte, bereits am 19. April 1945 die Angestelltensammelstelle des vormaligen Bundesministeriums für Unterricht. Am 29. August 1945 wurde Skrbensky durch den politischen Kabinettsrat zum Sektionschef des Staatsamtes für Volksaufklärung, Unterricht und Erziehungs- und Kultusangelegenheiten ernannt, wo er sogleich die Leitung der Hochschulsektion übernahm. ÖSTA/AdR, Bestand 02, BMfU, Personalakt Otto Skrbensky, Antrag Unterrichtsministers Kolb „auf Dank und Anerkennung des Bundespräsidenten anläßlich des Übertrittes in den dauernden Ruhestand mit 31. Dezember 1952“ für Sektionschef Skrbensky, 24.9.1952.

1267 Ebner, Politik und Hochschule, a.a.O., $82 \mathrm{f}$. 
Auf Basis des Bundesgesetzes vom 6. September 1934 wurden die Kompetenzen Skrbenskys als „Kommissär für die Aufrechterhaltung der Disziplin unter den Studierenden an den Hochschulen “ dann auf ganz Österreich erweitert. ${ }^{1268}$ In seiner Funktion als politischer Hochschulkommissär nahm Skrbensky in eigener Person - unter vielen anderen - auch die Relegierung von Bruno Kreisky vor, woran er sich, mittlerweile zum Sektionschef avanciert, in den Fünfzigerjahren Kreisky gegenüber (dieser war mittlerweile Mitarbeiter von Bundespräsident Körner) allerdings nicht mehr erinnern konnte. ${ }^{1269}$

Nach diesen ersten staatlichen Eingriffen in die Hochschulautonomie in der Zeit des Austrofaschismus sowie durch personalpolitische Interventionen infolge des sogenannten „Beamtenabbaugesetzes“von 1933 und dem „Hochschulerziehungsgesetz“ 1935 , das die Universitäten zu vaterländischen Erziehungsanstalten umzufunktionieren trachtete, ${ }^{1270}$ wurden diese mit der Annexion Österreichs durch Hitlerdeutschland schließlich von allen demokratischen Restelementen ,gesäubert' und ideologisch vollends gleichgeschaltet. Nach Erlass des gleichgeschalteten Unterrichtsministeriums vom 23. April 1938, der einen strikten Numerus clausus für inländische jüdische Studierende verfügte und ein Weiterstudium nur noch „auf der Basis individueller Ansuchen im Rahmen dieser Quote bei den jeweiligen Dekanaten möglich war“, ${ }^{1271}$ galten die österreichischen Universitäten und Hochschulen nach mehreren weiteren „Säuberungswellen“ bereits gegen Ende des Jahres I938 als ,judenfrei“. Nach ,Säuberungen“ und massiven Evaluierungen der politischen „Ambitionen“ des Lehrpersonals in Form von Fragebögen ${ }^{1272}$ kam es Anfang des Jahres I940 zur vollständigen Ausrichtung auf die neue NS-Ordnung.

Personelle Säuberung und Adaptierung von NS-Strukturen verlief an den österreichischen Universitäten nach dem Anschluss nicht nur in der selben Weise wie im „Altreich“, sondern - nach , solider ' Vorarbeit des Dollfuß-Schuschnigg-Regimes - noch wesentlich beschleunigt; ${ }^{1273}$ andersdenkende hatten so gut wie keine Chance, an einer Universität

1268 Siehe: BGBL., 232, Jg. 1934, ausgegeben am 17. September 1934, 79. Stück, 554.

1269 Vgl. Schreiben von Bruno Kreisky an Heimo Gruber, vom 13. Juni 1985. Für den freundlichen Hinweis und die Überlassung einer Kopie des Briefes sei an dieser Stelle Heimo Gruber herzlich gedankt.

1270 Herbert Posch, Studierende und die Universität Wien in der Dauerkrise 1918 bis 1938. In: Herbert Posch/Doris Ingrisch/Gert Dressl, „Anschluss“ und Ausschluss 1938. Vertriebene und verbliebene Studierende der Universität Wien (=Emigration - Exil - Kontinuität. Hrsg. v. Friedrich Stadler, Bd. 8), Wien - Berlin 2008, 95.

1271 Herbert Posch, März 1938. „Anschluss“ und Ausschluss: Vertreibung der Studierenden an der Universität Wien. In: Posch/Ingrisch/Dressl, „Anschluss“ und Ausschluss 1938, a.a.O., 105.

1272 Albert Müller, Dynamische Adaptierung und „Selbstbehauptung“. Die Universität Wien in der NSZeit-Zeit. In: Dieter Langewiesche (Hrsg.), Universitäten im nationalsozialistisch beherrschten Europa (Geschichte und Gesellschaft. Zeitschrift für Historische Sozialwissenschaft, 23. Jg., 1997, H. 4), Göttingen 1997, 609.

1273 Vgl. Müller, Dynamische Adaptierung und „Selbstbehauptung“, a.a.O., 596; weiters: Herbert Dachs, Österreichische Geschichtswissenschaft und „Anschluß“ 1918-1938, Wien - Salzburg 1974; Brigitte Lichtenberger-Fenz, Österreichs Universitäten und Hochschulen - Opfer oder Wegbereiter der nationalsozialistischen Gewaltherrschaft? Am Beispiel der Universität Wien. In: Gernot Heiß et al. (Hrsg.), Willfährige 
zu bleiben. Außerdem musste nun neben der verpflichtenden Erbringung eines Abstammungsnachweises auch ein politisches Gutachten seitens des NS-Dozentenbundführers vorgelegt werden. ${ }^{1274}$ Daher ist es nicht weiter verwunderlich, dass bei Kriegsende mehr als zwei Drittel aller Hochschullehrer Nationalsozialisten waren; ${ }^{1275}$ politisch und organisatorisch ebenso gleichgeschaltet wie das Lehrpersonal war freilich auch die Studentenschaft.

Vor diesem Hintergrund erfolgte der Neubeginn der wissenschaftlichen Lehre und Forschung in demokratie- als auch in wissenschaftspolitischer Hinsicht tendenziell geradezu auf einem akademischen "ground zero", ${ }^{1276}$ mit der Chance auf eine fundamentalen Neurorientierung der österreichischen Wissenschaftskultur.

Wissenschaft. Die Universität Wien 1938-1945, Wien 1989; Brigitte Lichtenberger-Fenz, „Es läuft alles in geordneten Bahnen“. Österreichs Hochschulen und Universitäten und das NS-Regime. In: Emmerich Talos et al. (Hrsg.), NS-Herrschaft in Österreich. Ein Handbuch, Wien 2000, 549-569; Marie Tidl, Die Roten Studenten. Dokumente und Erinnerungen 1938-1945. Mit einem Vorwort v. Karl R. Stadler (= Ludwig Boltzmann Institut für Geschichte der Arbeiterbewegung. Materialien zur Arbeiterbewegung Nr. 3), Wien 1976, 46 ff.; Gerhard Benetka, Entnazifizierung und verhinderte Rückkehr. Zur personellen Situation der akademischen Psychologie in Österreich nach 1945. In: Österreichische Zeitschrift für Geschichtswissenschaften, 9. Jg., 1998, H. 2, 194 ff.; Herbert Posch/Doris Ingrisch/Gert Dressel, „Anschluss“ und Ausschluss 1938. Vetriebene und verbliebene Studierende der Universität Wien (= Emigration - Exil - Kontinuität. Schriften zur zeitgeschichtlichen Kultur- und Wissenschaftsforschung, hrsg. v. Friedrich Stadler, Bd. 8), Wien - Berlin 2008; Roman Pfefferle/Hans Pfefferle, Glimpflich entnazifiziert. Die Professorenschaft des Sommersemesters 1944 der philosophischen Fakultät der Universität Wien in den Nachkriegsjahren. Endbericht des Forschungsprojekts: Entnazifizierung an der Universität Wien nach 1945 (philosophische Fakultät). Kontinuitäten und Diskontinuitäten universitärer Wissenschaftseliten (Projektleitung: Walter Manoschek), Wien 2010. [Für den Hinweis und die freundliche Überlassung eines Exemplars des Endberichtes sei an dieser Stelle herzlich Heimo Gruber gedankt]. Zur Rolle der Österreichischen Akademie der Wissenschaften siehe: Herbert Matis, Zwischen Anpassung und Widerstand. Die Akademie der Wissenschaften in den Jahren 1938-1945, Wien 1997; weiters: Johannes Feichtinger/Herbert Matis/Stefan Sienell/Heidemarie Uhl (Hrsg.), Die Akademie der Wissenschaften in Wien 1938 bis 1945. Katalog zur Ausstellung, Wien 2013. Zum Thema allgemein siehe: Helmut Heiber, Universität unterm Hakenkreuz. Teil II: Die Kapitulation der Hohen Schulen. Das Jahr 1933 und seine Themen. Bd. 2, München - New Providence - London - Paris 1994; weiters: Hochschulen 1933-1945. Nachtrag zur Bibliographie sowie Übersichten über Rehabilitationen und Gedenken nach 1945 (= Schriftenreihe des ASTA der Universität Mannheim, Bd. 6), Mannheim 1999. Für diesen Literaturhinweis danke ich meinem Kollegen Mag. Robert Stumpf von der Fachbibliothek für Geschichtswissenschaften an der Universität Wien.

1274 Müller, Dynamische Adaptierung und „Selbstbehauptung“, a.a.O., 602. Die Zahl der aktiven ordentlichen Professoren ging dadurch um 49\%, die der außerordentlichen Professoren um 59\% zurück. Vgl. dazu auch Kurt Mühlberger, Vertriebene Intelligenz 1938. Der Verlust geistiger und menschlicher Potenz an der Universität Wien von 1938 bis 1945, Wien 1990, 9.

1275 Dieter Stiefel, Entnazifizierung in Österreich, Wien - München - Zürich 1981, 171.

1276 Vgl. Friedrich Stadler, Österreich und der Nationalsozialismus - die Folgen für das intellektuelle Leben. In: Friedrich Stadler (Hrsg.), Österreichs Umgang mit dem Nationalsozialismus. Die Folgen für die naturwissenschaftliche und humanistische Lehre. Internationales Symposium 5.-6. Juni 2003, Wien 2004, 15 ff.; weiters: Mitchell G. Ash, Hochschulen und Wissenschaften im Nationalsozialismus und danach - Stand der Forschung und Projekte in Österreich. In: Stadler (Hrsg.), Österreichs Umgang mit dem Nationalsozialismus, a.a. O., $213 \mathrm{ff}$. 
Im Juli 1945 resümierte ein Bericht des Office for Strategic Services (OSS) die Situation an den Österreichischen Universitäten. Darin zeigte man sich erstaunt, dass deren Autonomie in der russischen Besatzungszone bereits wieder hergestellt wäre und selbst der sowjetische Geheimdienst (GPU) keinen Einfluss auf die Hochschulen nehmen würde. ${ }^{1277}$ Und das obwohl, wie es in dem genannten Bericht hieß, so gut wie alle Ordinarien und Dekane der Universität Wien von bürgerlich-konservativen bis reaktionären Professoren gestellt würden. ${ }^{1278}$ Darüber hinaus würde die „Entnazifizierung“ der Studierenden, so der OSS-Bericht, durch die Studentenorganisation selbst und für gewöhnlich so erfolgen, dass (frühere) Nationalsozialisten, sofern sie zuvor nicht besonders aufgefallen beziehungsweise hervorgetreten wären, zum Studium zugelassen würden. ${ }^{1279}$ Tatsächlich stellt die Entnazifizierung des Universitätsund Hochschulbereiches eine Art Sonderkapitel im Gesamtrahmen der Entnazifizierung dar. Obwohl es hier neben der Überprüfung des Lehrpersonals auch um die gerade im Hinblick auf die demokratische Reorientierung zentrale Kontrolle des Zuganges zum Universitätsstudium ging, galten für die Entnazifizierung des Hochschulwesens in Österreich bis Ende 1945 keine gesonderten Richtlinien. ${ }^{1280}$ Hinzu kommt, dass das Verbotsgesetz der Provisorischen Staatsregierung Renner und die nachfolgend erlassenen Durchführungsverordnungen Ausnahmebestimmungen vorsahen, ${ }^{1281}$ wonach zur Vermeidung unnötiger Härten die Möglichkeit einer ,ausnahmsweisen Nachsicht bei der Registrierung ${ }^{\text {“1282 }}$ gegeben werden sollte. In

1277 NARA II, RG 319 [Entry 85], Box 1329, [270/II /30/6]. Records of the Army Staff. Army Intelligence Document File, ID 0203388, OSS, Washington D.C., 26. September 1945, 1.

1278 So z.B. Leopold Arzt (1883-1955), Vorstand der I. Hautklinik, Dekan der Medizinischen Fakultät, Mitglied des Bundeskulturrates und enger Freund von Engelbert Dollfuß, der ursprünglich entlassen, dann aber von den Nationalsozialisten wieder eingestellt worden war; weiters Prof. Leopold Schönbauer, Chirurg und Leiter des Allgemeinen Krankenhauses, ein NS-Sympathisant, dessen Cousin, der Jurist Ernst Schönbauer, laut OSS-Bericht als begeisterter Nazi („ardent Nazi“) einzuschätzen wäre (NARA II, RG 319 [Entry 85], Box 1329, 270/II/30/6, Records of the Army Staff. Army Intelligence Document File, ID 0203388, OSS, Washington D.C., 26. September 1945, 1); zuletzt Prof. Hans Eppinger, der nach dem „Anschluss“ zunächst von der Fakultät entfernt worden sei, dann aber wieder eingestellt worden sei und darauf folgend medizinische Tests in einem KZ durchgeführt habe. Mit Genehmigung des Bundesministeriums für Unterricht wurde im Juni 1947 von Leopold Arzt (Rektor des Studienjahres 1936/37) für die „Sammlung der Porträts der Rektoren der Universität“ - neben dem von Ludwig Adamovich - ein Bild hergestellt. Vgl. Universität Wien. Bericht über den Studienbetrieb an der Wiener Universität vom Sommer-Semester 1945 bis zum Sommer-Semester 1947. Erstattet von Prof. Dr. Ludwig Adamovich, Wien 1947, 42.

1279 NARA II, RG 319 [Entry 85], Box 1329, [270/II/30/6]. Records of the Army Staff. Army Intelligence Document File, ID 0203388, OSS, Washington D.C., 26. September 1945, 1.

1280 Stiefel, Entnazifizierung in Österreich, a.a.O., $171 \mathrm{f}$.

1281 So um Beispiel durch die (1.) NS-Registrierungsverordnung vom 11. Juni 1945 (ausgegeben am 12. Juni 1945), die (2.) NS-Registrierungsverordnung vom 30. Juni 1945 (ausgegeben am 2. Juli 1945) sowie die Verbotsgesetznovelle vom 15. August 1945.

1282 „Art VI § 27: „Ausnahmen von der Behandlung nach den Bestimmungen der Artikel III und IV sind im Einzelfalle zulässig, wenn der Betreffende seine Zugehörigkeit zur NSDAP oder einen ihrer Wehr- 
Summe machten, laut einer von Dieter Stiefel vorgenommenen Auswertung, 85 bis 90 Prozent aller Registrierten von der Ausnahmeregelung Gebrauch. ${ }^{1283}$ Allein in Wien brachten 85,5 Prozent aller bei den Meldestellen der Bezirksämter Registrierten ein Nachsichtsgesuch ein - in den übrigen Bundesländern verhielt es sich ähnlich. ${ }^{1284}$

Für den Staatsdienst - und somit auch für alle Universitätsprofessoren - kamen zunächst lediglich die allgemeinen Bestimmungen des Verbotsgesetzes vom 8. Mai i945 zur Anwendung, das zu weiten Teilen auf einer Selbstregistrierungspflicht beruhte. ${ }^{1285}$

Entlassen wurden zunächst alle NSDAP-Mitglieder (inklusive der Parteianwärter), alle „Illegalen“ (nach Paragraph 4 /VG) sowie alle reichsdeutschen Lehrkräfte. Insbesondere die „Liquidierung“ aller reichsdeutschen Universitätsangehörigen ${ }^{1286}$ und die Entlassung aller sonstigen öffentlich Bediensteten verlief, wie aus den Akten des „Liquidators der Einrichtungen des Deutschen Reiches in der Republik Österreich “1287 hervorgeht, vergleichsweise zügig und unkompliziert: Etwa ein Drittel aller Lehrenden wurde auf diese Weise bis Anfang 1946 entlassen; ${ }^{1288}$ nicht selten kam es aber zu befristeten Enthebungen, die bis zu

verbände (SS, SA, NSKK, NSFK) niemals missbraucht hat und aus seinem Verhalten noch vor der Befreiung Österreichs auf eine positive Einstellung zur unabhängigen Republik Österreich mit Sicherheit geschlossen werden kann." Zit. nach: Stiefel, Entnazifizierung in Österreich, a.a.O., 88. [Hervorhebung der Verfasser]. Zum Bereich Entnazifizierung im Kontext politischer Parteien siehe allgemein auch: Maria Mesner (Hrsg.), Entnazifizierung zwischen politischem Anspruch, Parteienkonkurrenz und Kaltem Krieg. Das Beispiel der SPÖ, Wien - München 2005, sowie: Wolfgang Neugebauer/Peter Schwarz, Der Wille zum aufrechten Gang. Offenlegung der Rolle des BSA bei der gesellschaftlichen Reintegration ehemaliger Nationalsozialisten. Hrsg. vom Bund sozialdemokratischer AkademikerInnen, Intellektueller und KünstlerInnen (BSA), Wien 2005; Walter Manoschek, „Aus der Asche dieses Krieges wieder auferstanden“. Skizzen zum Umgang der österreichischen Volkspartei mit dem Nationalsozialismus und Antisemitismus nach 1945. In: Werner Bergmann/Rainer Erb/Albert Lichtblau (Hrsg.), Schwieriges Erbe. Der Umgang mit Nationalsozialismus und Antisemitismus in Österreich, der DDR und der BRD (= Schriftenreihe des Zentrums für Antisemitismusforschung Berlin, Bd. 3), Frankfurt a. Main - New York 1995, 49-64.

1283 Stiefel, Entnazifizierung in Österreich, a.a.O., 97.

1284 Vgl. Bernd Vogel, NS-Registrierung in Wien. In: Walter Schuster/Wolfgang Weber (Hrsg.), Entnazifizierung im regionalen Vergleich, Linz 2004, 341.

1285 Demnach waren alle ehemaligen Nationalsozialisten gesetzlich verpflichtet, sich bei den Gemeindeämtern oder Arbeitsämtern über den sogenannten „Fragebogen“ registrieren zu lassen. Besonderes Augenmerk legte das Verbotsgesetz dabei auf alle „illegalen“ Nationalsozialisten, d.h. jene Personen, die zwischen dem 1. Juli 1933 und dem 13. März 1938 der NSDAP beigetreten waren. Diese Personen waren fristlos aus dem öffentlichen Dienst zu entlassen, verloren ihr direktes und indirektes Wahlrecht und es wurden ihnen „Sühnepflichten“ in unterschiedlichem Ausmaß auferlegt.

1286 Also alle Universitätsangehörigen, die am 13. März 1938 nicht österreichische Staatsbürger gewesen waren.

1287 Siehe dazu die entsprechenden Erkenntnisse im Bestand 04 BKA, Liquidator, im Österreichischen Staatsarchiv. Der Liquidator war zudem auch für die Entlassung der „Illegalen“ zuständig, was aber bis Frühjahr 1946 nicht alle Dienstellen wussten beziehungsweise beachteten.

1288 Vgl. Christian Fleck, Autochthone Provinzialisierung. Universität und Wissenschaftspolitik nach dem Ende der nationalsozialistischen Herrschaft in Österreich. In: Österreichische Zeitschrift für Geschichtswissenschaften, 7. Jg., 1996, H. 1, 74 f. 
einer schließlich erfolgten Normalisierung auch weiter verlängert wurden. Außerdem wurden alle Ernennungen zu Honorarprofessoren und Privatdozenten, die nach dem März I938 erfolgt waren, für ungültig erklärt. ${ }^{1289}$ An dieser Stelle ist allerdings hinzuzufügen, dass der Wirkungsradius des Verbotsgesetzes trotz Anerkennung der Provisorischen Staatsregierung Renner durch den Alliierten Rat am 20. Oktober 1945 bis Februar 1946 auf die russische Besatzungszone und das interalliierte Wien beschränkt blieb. Die Praxis der Entnazifizierung beziehungsweise die Dienstenthebungen oder Entlassungen in den übrigen Bundesländern orientierte sich hingegen bis Ende 1945 an den jeweiligen - unterschiedlich (streng) gehandhabten - Reglements und Kontrollen der jeweiligen Besatzungsmächte.

$\mathrm{Zu}$ einer anderen, nämlich deutlich milderen Einschätzung der Entnazifizierung an den Wiener Universitäten als der zuvor zitierte OSS-Bericht kam Anfang November 1945 ein Bericht des militärischen Geheimdienstes G-2 der amerikanischen USFA-Truppen. Obwohl entsprechend dem hier präsentierten Zahlenmaterial (siehe dazu die nachfolgende Tabelle) einer Gesamtzahl von ro69 universitären Lehrkräften in Summe nur I28 Entlassungen gegenüber stehen (rund I2 Prozent) - die Medizinische Fakultät findet sich in dieser Statistik allerdings ebenso wenig wie Angaben zur Säuberung der Dozenten -, gelangte der militärische US-Geheimdienstbericht zur Ansicht, dass die Fakultäten, obwohl der ,Säuberungsprozess' keinesfalls als abgeschlossen betrachtet wurde, bereits weitgehend von Nazis gesäubert worden seien, insbesondere was die Professorenschaft betrifft, und man glaubte auch zu wissen, warum:

"De-Nazification in the Vienna universities is still in progress, and has reached a fairly satisfactory state as far as professors are concerned. This is due to three factors: (a) many of the pro-Nazi professors have fled, (b) Nazi professors who are German citizens are automatically excluded from further service with Austrian universities; (c) the existing laws of the Central Government have been applied strictly by the Ministry of Education and all professors of Nazi leanings were immediately suspended." 1290

Von insgesamt 362 Professoren waren zum Berichtszeitpunkt 85 enthoben worden (rund 23 Prozent); ${ }^{1291}$ allerdings lägen noch rund 90 Fälle der Sonderkommission des Ministeriums

1289 Willi Weinert, Die Entnazifizierung an den österreichischen Hochschulen. In: Sebastian Meissl/KlausDieter Mulley/Oliver Rathkolb (Hrsg)., Verdrängte Schuld, verfehlte Sühne. Entnazifizierung in Österreich 1945-1955. Symposion des Instituts für Wissenschaft und Kunst, Wien 1986, 255.

1290 Recordings of the U.S. Department of State relating to the Internal Affairs of Austria 1945-1954 (Mikrofilm-Bestand Institut für Zeitgeschichte der Universität Wien), Decimal File, Reel 6, 1945-1949, Special Report No. 2, The Ministry of Education and the Vienna Universities, 8th November 1945, 4 (Cecil W. Gray, USFA Office of the Political Advisor, Counselor of Mission, to the Secretary of State, Washington D.C., 11. November 1945).

1291 Eine vollständige Namensliste der enthobenen Universitäts- und Hochschulprofessoren (inklusive derjenigen mit „German nationality“) wurde im Appendix „F“ des USFA-Reports - „Names of dismissed University Professors" - beigefügt. Ebd., $15 \mathrm{f}$. 
zur Begutachtung vor, wobei sich allerdings die Hälfte der zu überprüfenden Professoren im Moment nicht in Wien aufhielten. ${ }^{1292}$

Hinsichtlich der personalen Erfordernisse des universitären Lehrbetriebes konstatierte der Bericht, der sich offensichtlich stark auf Material des Unterrichtsministeriums stützte, in überaus pragmatischer Sicht, dass zu einem gegebenen späteren Zeitpunkt - unter Anwendung des Kriteriums „wissenschaftlicher Qualifikationen“ - die Wiedereinstellung von NSDAPMitgliedern beziehungsweise Parteianwärtern, gegen die „keine besonderen Gründe“ sprächen, in Betracht zu ziehen sei. In Bezug auf die Frage nach einem „qualifizierten Ersatz“ für die suspendierten NS-Lehrkräfte seien diese - so der US-Geheimbericht, der sich hier explizit auf die Aussage des Unterrichtsministeriums berief - , available in sufficient numbers “1293; woher dieses „verfügbare“ wissenschaftliche Personal kommen sollte und, vor allem, wer damit konkret gemeint war, wurde an dieser Stelle allerdings nicht weiter ausgeführt.

Eine detaillierte exemplarische Untersuchung zum Entnazifizierungsverlauf der - nach Stand des Sommersemesters I944 - 70 ordentlichen und planmäßig außerordentlichen Professoren an der philosophischen Fakultät der Universität Wien belegt, dass der Prozess der überwiegend formal-juristisch betriebenen Entnazifizierung sowie der oftmals nachfolgenden Amnestierung und Rehabilitierung im Bereich der Professorenschaft keineswegs zu einem Karrierebruch führte, sondern zu „einem erstaunlichen Ausmaß an Kontinuität“. ${ }^{1294}$ Zwei Drittel der entnazifizierten Professoren der philosophischen Fakultät (53, das heißt 77 Prozent) machten - nach mehr oder minder kurzen Außerdienststellungen - nach 1945 eine zweite Karriere: I8 davon allein an der Universität Wien; lediglich I5 wurden ohne Ruhestandsbezüge entlassen. ${ }^{1295}$

Im Hinblick auf die Entnazifizierung der Dozenten, Assistenten und Lektoren kam der oben erwähnte US-Geheimbericht zur Ansicht, dass die bisher getroffenen Maßnahmen keineswegs als zufrieden stellend betrachtet werden könnten. Die Ursache dafür, so mutmaßte man wohl nicht ganz unzutreffend, liege entweder in der allgemeinen Nachsichtigkeit oder in der Milde gegenüber jüngeren Universitätsangehörigen: „This may be due either the leniency on part of the authorities or that de-Nazification began with professors, and the program has not yet been carried with vigor to junior faculty members. "

1292 Auf Basis der bisherigen Erfahrungen würde sich dadurch, wie der Report an dieser Stelle mutmaßte, die Gesamtzahl der entlassenen Professoren wie folgt erhöhen: „Assuming that one out of three of those 90 cases were decided against the incumbent, the total number of professors dismissed would rise to 158,43 percent of the total number of professors." Ebd., 4.

1293 Ebd., 5.

1294 Pfefferle/Pfefferle, Glimpflich entnazifiziert, a.a.O., $107 \mathrm{f}$.

1295 Roman und Hans Pfefferle stützen sich in ihrer Analyse auf eine im Universitätsarchiv Wien aufgefundene, siebenseitige Liste (Kurrentakten 777, 1944/45 GZ-603/4), die einen Großteil der entnazifizierten Professoren enthält und Ende 1945 entstanden sein dürfte. Vgl. ebd., $107 \mathrm{f}$.

1296 Cecil W. Gray, USFA Office of the Political Advisor, Counselor of Mission, to the Secretary of State, a. a. O., 4. 


\section{Statistik der Entlassungen des Lehrpersonals ${ }^{1297}$ („Dismissals“) an Wiener Hochschulen 1945: $:^{1298}$}

\begin{tabular}{|c|c|c|c|}
\hline & Total & entlassen & Prozent \\
\hline $\begin{array}{l}\text { Universität Wien } \\
\text { o. Professoren } \\
\text { ao. Professoren } \\
\text { Lektoren } \\
\text { Assistenten }\end{array}$ & $\begin{array}{l}\frac{587}{89} \\
58 \\
172 \\
268\end{array}$ & $\begin{array}{l}51 \\
24 \\
15 \\
4 \\
8\end{array}$ & $\begin{array}{c}9 \\
27 \\
26 \\
2 \\
3\end{array}$ \\
\hline $\begin{array}{l}\text { Technische Universität Wien } \\
\text { o. Professoren } \\
\text { ao. Professoren } \\
\text { Lektoren } \\
\text { Assistenten }\end{array}$ & $\begin{array}{l}\frac{173}{42} \\
36 \\
35 \\
60\end{array}$ & $\begin{array}{c}13 \\
8 \\
3 \\
1 \\
1\end{array}$ & $\begin{array}{c}8 \\
19 \\
6 \\
3 \\
2\end{array}$ \\
\hline $\begin{array}{l}\text { Hochschule für Bodenkultur } \\
\text { o. Professoren }\end{array}$ & 21 & 10 & 48 \\
\hline $\begin{array}{l}\text { Tierärztliche Hochschule } \\
\text { o. Professoren } \\
\text { ao. Professoren } \\
\text { Lektoren } \\
\text { Assistenten }\end{array}$ & $\begin{array}{l}\frac{30}{12} \\
7 \\
2 \\
9\end{array}$ & $\begin{array}{c}12 \\
3 \\
3 \\
1 \\
5\end{array}$ & $\begin{array}{l}40 \\
25 \\
43 \\
50 \\
56\end{array}$ \\
\hline $\begin{array}{l}\text { Hochschule für Welthandel } \\
\text { o. Professoren } \\
\text { ao. Professoren }\end{array}$ & $\frac{17}{9}$ & $\begin{array}{l}4 \\
3 \\
1\end{array}$ & $\begin{array}{l}24 \\
33 \\
13\end{array}$ \\
\hline $\begin{array}{l}\text { Akademie der Bildenden Künste } \\
\text { o. Professoren }\end{array}$ & 46 & 6 & 13 \\
\hline $\begin{array}{l}\text { Hochschule für Angewandte Kunst } \\
\text { o. Professoren }\end{array}$ & 50 & 2 & $1[4]^{1299}$ \\
\hline $\begin{array}{l}\text { Staatsakademie für Musik } \\
\text { o. Professoren }\end{array}$ & 145 & 30 & 20 \\
\hline
\end{tabular}

In Bezug auf die Studentenschaft hielt der amerikanische Geheimdienstbericht fest, dass die in der Hochschülerschaft der Universität Wien zusammengefassten 8.00o Studenten ${ }^{1300}$

1297 Zur Begriffsklärung der in den Quellen nicht immer leicht nachvollziehbaren Verwendung der Termini „enthoben“, „ausser Dienst gestellt“ bzw. „entlassen“ und der damit verbundenen unterschiedlichen bzw. eben unterschiedlich genauen Zählweise ist anzumerken, dass in den amerikanischen Entnazifizierungsstatistiken unter der Rubrizierung „dismissals“ bzw. „dismissed“ alle „enthobenen“ bzw. „ausser Dienst gestellten“ Personen subsumiert, d.h. mitgezählt wurden, was in den US-Quellen zum allergrößten Teil auch explizit vermerkt wird.

1298 Recordings of the U.S. Department of State relating to the Internal Affairs of Austria 1945 š 1954 (Mikrofilm-Bestand Institut für Zeitgeschichte der Universität Wien), Decimal File, Reel 6, 1945š 1949, Appendix „E“ to USFA Special Report No. 2, 8. „The Ministry of Education and the Vienna Universities, 8. November $1945,14$.

1299 Anscheinend handelt es sich hier um einen statistischen Auswertungs- bzw. Schreibfehler: der korrekte Prozentsatz müsste eigentlich „4“ lauten; ich danke meinem Kollegen Mag. Robert Stumpf für diesen Hinweis.

1300 Worauf die hier angegebene, extrem hochgegriffene Ziffer basiert, lässt sich nicht ermitteln. Ein Bericht, der nach der ersten US-Visite der Universität Wien am 26. September 1945 verfasst wurde, präsentiert 
laut Statut grundsätzlich keine politische Aktivität entfalten dürften, wobei die weitaus größere Zahl der Studierenden ohnehin keine parteipolitische Bindung habe. ${ }^{1301}$ Ungeachtet der Tatsache, dass „aktive Nazis“ von der Inskription ausgeschlossen seien, gebe es doch - obwohl zur Zeit keine Evidenz über subversive Aktivitäten bestehe - klare Indizien für die Existenz altvorderer, rechtsradikal-nazistischer Studenten innerhalb einer Studentenfraktion:

"A number of former Nazis and Nazi sympathizers are presumably among the People's Party students." ${ }^{1302}$

Eine Vergleichsstatistik zur zitierten Tabelle findet sich in einem - auf Drängen des „Alliierten Denazifizierungsbüros“ nach „erschöpfender Auskunft“ - von Staatssekretär Franz Honner am i3. Dezember 1945 vorgelegten Entnazifizierungsbericht, der vom „Staatsamt für Volksaufklärung, für Unterricht und Erziehung und für Kultusangelegenheiten“ für die Generaldirektion für öffentliche Sicherheit im Innenministerium zusammengestellt wurde. Aufgelistet wurden darin alle bisher aus dem Dienst „entlassenen ehemaligen Nationalsozialisten ( $\S_{4}$ des Verbotsgesetzes)“, alle „aus demselben Grunde Pensionierten“, alle „aus demselben Grunde außer Dienst gestellten Beamten“, alle im Dienst stehenden öffentlichen Bediensteten, die derzeit „nicht zu dem im $\S 4$ des Verbotsgesetzes beschriebenen Personenkreis gehören“, alle öffentlichen Bediensteten, die „derzeit noch in Verwendung stehen, obgleich sie unter die im $\S_{4}$ des Verbotsgesetzes genannten Personen fallen“ sowie letztlich alle „der unter dem nationalsozialistischen Regime aus dem Staatsdienst entfernten Beamten (Entlassenen oder Zwangspensionierung)“ ${ }^{1303}$ Bereits

jedenfalls gänzlich anderes Zahlenmaterial. So waren im Sommersemester 1945 insgesamt 4.195 Studierende inskribiert. Davon entfielen auf die Katholisch-Theologische Fakultät 56, auf die EvangelischTheologische Fakultät 4, auf die Rechts- und Staatswissenschaftliche Fakultät 626, auf die Medizinische Fakultät 1.588 und auf die Philosophische Fakultät 1.921. Im Vergleich dazu sahen die Inskriptionsziffern in den Jahren bzw. Dekaden zuvor folgendermaßen aus:

Sommersemester 1924: 8.074

Wintersemester 1937/38: 9.180

Wintersemester 1944/45: 3.446

Siehe dazu: Recordings of the U.S. Department of State relating to the Internal Affairs of Austria 1945-1954 (Mikrofilm-Bestand/Institut für Zeitgeschichte der Universität Wien), Decimal File, Reel 6, Major Leigh M. Lott, Internal Affairs Division/Education Branch, USFA, Report of First Visit to the University of Vienna [26. September 1946], 14 October 1945, 4.

1301 Wohl nicht auf allzu präziser Datengrundlage beruhend wurde dabei vermutet, dass in Summe rund 500 Studierende Mitglieder einer der drei politischen Parteien wären, wovon 250 der ÖVP, 150 den Kommunisten und 100 den Sozialisten zuzurechnen seien. Ebd., 3.

1302 Ebd., 3.

1303 Österreichisches Staatsarchiv (ÖSTA), Staatsamt für Volksaufklärung, für Unterricht und Erziehung und für Kultusangelegenheiten. Republik Österreich, Staatsamt für Inneres. GZ 1739 - Pr. 45, Gen. 
zwei Tage später erfolgte die Zusendung der Aufstellung an das Staatsamt für Inneres. Wie Unterstaatssekretär Karl Lugmayer eingangs anmerkte, würde das Zahlenmaterial das sich wegen der Demarkationslinien und der damit gegebenen Erhebungsprobleme auf Wien und Niederösterreich beschränkte - „nur ein annäherndes, jedoch keineswegs ein mathematisch genaues Bild liefern“ ${ }^{1304}$ Neben der kriegsbedingten „Verlagerung der aktenmäßigen Unterlagen“ konnte „durch die nicht vollständigen Entlassungen aus der Kriegsgefangenschaft eine große Zahl von Bediensteten überhaupt noch nicht erfasst werden [... ] dies ist im übrigen auch ein Grund, warum noch eine Reihe von Nationalsozialisten, wenn auch nur in unbedeutenden Positionen, belassen werden musste “; ${ }^{1305}$ die Frage nach dem Verbleib der zwangsweise ins Exil geflüchteten österreichischen Wissenschafterinnen und Wissenschaftern stellte sich Lugmayer, wohl auch auf Grund vorwiegend bürokratischer Überlegungen hinsichtlich des Dienststellenplanes, in diesem Zusammenhang bezeichnenderweise nicht. Obwohl der Entnazifizierungsbericht keine Zahlenangaben hinsichtlich des Status quo bei den Universitätsassistenten anführte, waren (offenkundig mit Bezug auf alle Wiener Hochschulen) handschriftliche Ergänzungen vermerkt, die - mit Vorbehalt - in die nachfolgende tabellarische Übersicht mitaufgenommen werden.

Säuberung der ordentlichen und außerordentlichen Professoren der wissenschaftlichen Hochschulen in Wien (Zahlen d. Staatsamtes f. Unterricht): ${ }^{1306}$

\begin{tabular}{|l|c|c|c|c|c|c|}
\hline & $\begin{array}{c}\text { Univ. } \\
\text { Wien }\end{array}$ & TU Wien & $\begin{array}{c}\text { Hochschule f. } \\
\text { Bodenkultur }\end{array}$ & $\begin{array}{c}\text { Tierärztliche } \\
\text { Hochschule }\end{array}$ & $\begin{array}{c}\text { Hochschule f. } \\
\text { Welthandel }\end{array}$ & Total \\
\hline Entlassen & 28 & 12 & 11 & 5 & 6 & 62 \\
\hline Pensioniert & 6 & 5 & 2 & - & - & 13 \\
\hline Außer Dienst gestellt & 34 & 9 & 10 & 6 & 7 & 66 \\
\hline Total & 68 & 26 & 23 & 11 & 13 & 141 \\
\hline
\end{tabular}

Dion. F. öff. Sicherh. Z1. 52350-2/45. Betref. „Säuberung des öffentlichen Dienstes von Nationalsozialisten“. An das Staatsamt für Volksaufklärung, 10. Dezember 1945. Zit. nach: Robert Stumpf, Ernst Fischer als Staatssekretär für „Volksaufklärung, Unterricht und Erziehung und Kultusangelegenheiten“ (1945). Versuch einer politischen Biographie unter struktur- und institutionsgeschichtlichen Gesichtspunkten. Bd. 3, Dokumentenanhang, Dipl.-Arb., Univ. Wien 1997, Dok. XXIII, 6 f. Ich danke an dieser Stelle meinem Kollegen Mag. Robert Stumpf für den freundlichen Hinweis auf dieses Dokument.

1304 ÖSTA, Staatsamt für Volksaufklärung, für Unterricht und Erziehung und für Kultusangelegenheiten. Republik Österreich, Staatsamt für Inneres. II. Exp., 1739 - Präs-/45. Z.Z1. 52350/2/45 v. 8.12.1945, Staatsamt für Volksaufklärung, Lugmayer an das Staatsamt für Inneres (Generaldirektion f. d. öffentl. Sicherheit, Betref. „Säuberung des öffentlichen Dienstes von Nationalsozialisten“, 12. Dezember 1945. Zit. nach: Stumpf, Ernst Fischer als Staatssekretär für „Volksaufklärung, Unterricht und Erziehung und Kultusangelegenheiten“. Bd. 3, Dokumentenanhang, a.a.O., Dok. XXIII, 35.

1305 Ebd.

1306 Stand vom 12. Dezember 1945; ebd., 21. 


\begin{tabular}{|l|c|c|c|c|c|c|}
\hline $\begin{array}{l}\text { im Dienst befindliche nicht §4 } \\
\text { VG }\end{array}$ & 36 & 15 & 4 & 6 & 4 & 65 \\
\hline in Verwendung stehende §4 VG & 12 & 10 & - & - & - & 22 \\
\hline $\begin{array}{l}\text { von den Nazis entfernte, wieder } \\
\text { in Dienst gestellte Professoren }\end{array}$ & 10 & 4 & 3 & 1 & 1 & 19 \\
\hline
\end{tabular}

Säuberung der Assistenten der wissenschaftlichen Hochschulen in Wien, Stand vom I2. September $1945:^{1307}$

\begin{tabular}{|l|c|}
\hline & Alle Hochschulen \\
\hline Entlassen, bisher gekündigt & 225 \\
\hline In Ruhestand versetzt & 0 \\
\hline Vorläufig außer Dienst gestellt & 81 \\
\hline Total & 306 \\
\hline im Dienst befindliche nicht §4 VG & 280 \\
\hline in Verwendung stehende §4 VG & 97 \\
\hline von den Nazis entfernte, wieder in Dienst gestellte Professoren & 1 \\
\hline
\end{tabular}

Dass das Zahlenmaterial in sich einigermaßen konsistent sein dürfte, verdeutlicht ein detaillierter Bericht des „Quadripartite Sub-Committee on Denazification in Austrian Universities“vom September 1946, der neben der Universität Wien und der Aufschlüsselung nach einzelnen Fakultäten auch den Stand der universitären Entnazifizierung an den Universitäten in Innsbruck und Graz wiedergibt; zum Zweck der Dokumentation der erfolgten Säuberungen werden die Zahlen in tabellarischer Form nachstehend vollständig angeführt.

Erfolgte Säuberungen an den Universitäten in Wien (inkl. aller Hochschulen) - Stand 7. September 1946:1308

\begin{tabular}{|l|c|}
\hline Zahl der aktuell lehrenden Universitätsprofessoren & 150 \\
\hline Zahl der NS-registrierungspflichtigen Professoren für das WS 1946/47 & 4 \\
\hline Gesamtzahl der "entlassenen" (einschließlich der "enthobenen" Professoren) & 176 \\
\hline Schwebende Verfahren l "cases pending") & 3 \\
\hline Gesamtzahl der "enthobenen" Professoren & 31 \\
\hline
\end{tabular}

1307 Ebd., handschriftliche Ergänzung, 32.

1308 Report of Quadripartite Sub-Committee on Denazification in Austrian Universities, 7. September 1946. NARA II, RG 260, Box 11, Folder 68. Records of the Unites States Occupation Headquarters, World War II, USFA/USACA, Internal Affairs/Displaced Persons Division, Denazification Branch, General Records, 1945-50, 3. Ich danke an dieser Stelle Frau Dr. Amy Schmidt (National Archives Washington D.C., Collegepark/Maryland) herzlich für die freundliche Zusendung einer Kopie des Berichts. 
Erfolgte Säuberungen an den Universitäten in Wien aufgegliedert nach Fakultäten (exklusive Hochschule f. Bodenkultur, TU Wien, Hochschule f.

Welthandel und Tierärztliche Hochschule) - Stand 7. September 1946: ${ }^{1309}$

\begin{tabular}{|l|c|c|c|c|c|}
\hline & $\begin{array}{c}\text { Stand der } \\
\text { verfügbaren } \\
\text { Professoren im } \\
\text { April 1945 }\end{array}$ & $\begin{array}{c}\text { "entlassen" oder } \\
\text { "pensioniert" }\end{array}$ & "enthoben" & $\begin{array}{c}\text { "belastet", } \\
\text { aber in Dienst } \\
\text { belassen }\end{array}$ & $\begin{array}{c}\text { "unbelastet" } \\
\text { und in Dienst } \\
\text { belassen }\end{array}$ \\
\hline $\begin{array}{l}\text { Katholisch-Theolog. } \\
\text { Fakultät }\end{array}$ & 9 & 0 & 0 & 0 & 9 \\
\hline Evangelische Fakultät & 5 & 2 & 1 & 0 & 2 \\
\hline Juridische Fakultät & 17 & 9 & 2 & 0 & 6 \\
\hline Medizinische Fakultät & 27 & 19 & 0 & 4 & 19 \\
\hline Philosophische Fakultät & 72 & 41 & 12 & 0 & 40 \\
\hline Total & 130 & 71 & 15 & 4 & 4 \\
\hline
\end{tabular}

Entnazifizierung an der Technischen Hochschule in Wien, Stand vom 7. September $1946:^{.1310}$

\begin{tabular}{|l|c|}
\hline Zahl der aktuell lehrenden Universitätsprofessoren & 28 [Stand 1945: 56] \\
\hline Zahl der "entlassenen“ Professoren & 20 [4 Reichsdeutsche] \\
\hline Zahl der "pensionierten“ Professoren & 8 \\
\hline Gesamtzahl der "enthobenen“ („suspended“) Professoren & 13 \\
\hline Zahl der "entlassenen“ Dozenten & 30 \\
\hline Zahl der "enthobenen” Dozenten & 22 \\
\hline
\end{tabular}

Entnazifizierung an der Hochschule für Welthandel in Wien, Stand vom 7. September $1946:{ }^{1311}$

\begin{tabular}{|l|c|}
\hline Zahl der aktuell lehrenden Universitätsprofessoren & $\begin{array}{c}6 \text { [Stand 1945: } \\
17]\end{array}$ \\
\hline Zahl der "entlassenen" Professoren & $\begin{array}{c}10 \text { [4 Reichsdeut- } \\
\text { sche] }\end{array}$ \\
\hline Zahl der "pensionierten" Professoren & 1 \\
\hline
\end{tabular}

1309 Ebd., 4.

1310 Unter den „Pending cases“ wurden drei Lehrende als zu Entlassende namentlich angegeben; vier weitere namentlich angeführte Lehrkräfte sollten noch ein weiteres Semester unterrichten, daran anschließend aber entlassen werden. Ebd., 5.

1311 Ebd., 5 a. 


\begin{tabular}{|l|c|}
\hline Gesamtzahl der "enthobenen" (,suspended") Professoren & 2 \\
\hline Zahl der "entlassenen" Privatdozenten & 0 \\
\hline Zahl der "enthobenen" Privatdozenten & 1 \\
\hline Zahl der "entlassenen" Assistenten & 3 \\
\hline Zahl der "enthobenen" Assistenten & 2 \\
\hline
\end{tabular}

\section{Entnazifizierung an der Hochschule für Bodenkultur in Wien, Stand vom 7. September I946: $:^{1312}$}

\begin{tabular}{|l|c|}
\hline Zahl der aktuell lehrenden Universitätsprofessoren & 20 [Stand 1945: 26] \\
\hline Zahl der "entlassenen“ Professoren & 17 \\
\hline Zahl der "pensionierten" Professoren & 3 \\
\hline Zahl der "entlassenen" Privatdozenten & 3 \\
\hline Zahl der "pensionierten" Privatdozenten & 2 \\
\hline Zahl der "entlassenen" Assistenten & 14 \\
\hline
\end{tabular}

\section{Entnazifizierung an der Tierärztlichen Hochschule in Wien, Stand vom 7. September $1946::^{1313}$}

\begin{tabular}{|l|c|}
\hline Zahl der aktuell lehrenden Universitätsprofessoren & 11 [Stand 1945: 17] \\
\hline Zahl der "entlassenen" Professoren & 5 \\
\hline Zahl der "pensionierten" Professoren & 3 \\
\hline Zahl der "enthobenen" Professoren & 3 \\
\hline Zahl der "entlassenen" Privatdozenten & 4 \\
\hline Zahl der "enthobenen" Privatdozenten & 1 \\
\hline Zahl der "entlassenen" Assistenten & 12 \\
\hline
\end{tabular}

1312 Ebd., 5b.

1313 Ein namentlich genannter Professor für tierärztliche Anatomie sollte noch ein weiteres Semester lehren, anschließend daran aber entlassen werden. Hingegen wurde Univ.-Prof. Franz Benesch, tierärztlicher Chirurg und Gynäkologe, früherer Rektor (1937-38), der nach drei Jahren „Anwärterschaft“ 1941 schließlich die NSDAP-Mitgliedschaft erhielt, durch Unterstützung des nunmehrigen Rektors „bis auf weiteres“ im Dienst belassen werden. Ebd., 5b. Sergius Pauser fertigte 1959 ein Porträt von Franz Benesch an. 
Universitäre Entnazifizierung in der Steiermark, Stand vom 7. September $1946:^{: 1314}$

\begin{tabular}{|l|c|c|c|c|c|}
\hline & $\begin{array}{c}\text { Professoren } \\
\text { insgesamt }\end{array}$ & $\begin{array}{c}\text { "entlassen" bzw. } \\
\text { pensioniert }\end{array}$ & "enthoben" & $\begin{array}{c}\text { belastet aber } \\
\text { belassen }\end{array}$ & $\begin{array}{c}\text { unbelastet und } \\
\text { weiterverwendet }\end{array}$ \\
\hline Univ. Graz & & & & & \\
\hline Theolog. Fakultät & 5 & - & - & - & 5 \\
\hline Rechtswiss. Fakultät & 15 & 8 & 1 & 5 & - \\
\hline Medizin. Fakultät & 25 & 14 & 1 & 3 & 11 \\
\hline Phil. Fakultät & 48 & 26 & 3 & 7 & 11 \\
\hline Techn. Hochschule & 30 & 14 & 1 & 10 & 6 \\
\hline Leoben / Montanistik & 13 & 2 & 2 & - & 8 \\
\hline Total & 136 & 64 & 8 & 25 & 41 \\
\hline
\end{tabular}

Entnazifizierung an der Universität Innsbruck, Stand vom 7. September 1946: $:^{1315}$

\begin{tabular}{|l|c|c|c|}
\hline & $\begin{array}{c}\text { Ordentliche } \\
\text { Professoren }\end{array}$ & $\begin{array}{c}\text { Außerordentliche } \\
\text { Professoren }\end{array}$ & Total \\
\hline Zahl der aktuell verfügbaren Universitätsprofessoren & $37[41]^{1316}$ & $9[16]$ & {$[57]$} \\
\hline $\begin{array}{l}\text { Zahl der NS-Registrierungspflichtigen Professoren } \\
\text { für das WS 1946/47 }\end{array}$ & 15 & $8[4]$ & {$[19]$} \\
\hline $\begin{array}{l}\text { Gesamtzahl der "entlassenen" (einschließlich } \\
\text { der "enthobenen"*) Professoren }\end{array}$ & $9[15]$ & $4[10]$ & {$[25]$} \\
\hline Schwebende Verfahren ("cases pending") & - & - & {$[14]$} \\
\hline Gesamtzahl der "enthobenen"* Professoren & $7[9]$ & $1[5]$ & {$[14]$} \\
\hline
\end{tabular}

Im Zusammenhang mit diesen frühen Entnazifizierungsbilanzen nicht uninteressant liest sich ein Bericht der USFA-Education Branch, deren Stellvertreter Major Leigh M. Lott der Universität Wien am 26. September 1945 einen ersten persönlichen Besuch abstattete und dabei mit Rektor Ludwig Adamovich, dem Pro-Rektor Richard Meister und dem Leiter der Rektoratskanzlei, Rudolf Fischer, zu einem Gespräch zusammentraf. Als Dolmetscher und von den US-Militärs als ständiger Verbindungsmann zu den österreichischen Behörden eingesetzt, fungierte dabei der Gründer und nunmehr wieder eingesetzte Direktor des „Austro-American Institutes“ in Wien, Paul Leo Dengler. ${ }^{1317}$

1314 Report on Denazification in Graz - University and two Styrian Colleges, ebd., 7.

1315 Ebd., 3a.

1316 Die in eckige Klammern gesetzten Zahlen finden sich am Originaldokument handschriftlich neben die durchgestrichenen Drucklettern gesetzt, d.h. vermutlich dürfte es sich hier um kurzfristig aktualisierte Zahlenkorrekturen handeln.

13171926 gründete der österreichische Pädagoge Paul Leo Dengler (1886-1977) mittels einer Subvention der Carnegie Foundation in Wien das „Austro-American Institute of Education“. Ziel der Einrichtung 
$\mathrm{Zu}$ diesem Zeitpunkt zeigten sich die zuständigen Militärs allerdings kaum sonderlich an Fakten und Zahlenmaterial in Bezug auf die Entnazifizierung interessiert - man verwies diesbezüglich lapidar auf einen in Vorbereitung befindlichen vertraulichen Report seitens des Counter Intelligence Corps (CIC - 43oth Detachment). Die Offiziere der Education Division, die zum Teil selbst Universitätsprofessoren waren beziehungsweise universitären Hintergrund hatten, ${ }^{1318}$ zeigten sich in ihrem Bericht indes zunächst von der Geschichte der Universität Wien beeindruckt und gaben einen Überblick über den organisatorischen Aufbau sowie den Staus quo der Institute und Laboreinrichtungen.

Hinsichtlich der Entnazifizierung, die zur Zeit die „Effizienz“ der Fakultäten „unterminieren “ würde, plädierte die Education Division, da der ,strong spirit of,Austria for Austrians “" - sozusagen die Gegenreaktion auf den früheren „Pan-Germanismus" - innerhalb der gesellschaftlich-politischen Elite ohnedies stark ausgeprägt sei, für eine „middle-position“, mit anderen Worten: für eine pragmatische Lösung. ${ }^{1319}$ In der zitierten Besprechung informierte der Rektor den Stellvertreter von Oberst William B. Featherstone, Major Leigh M. Lott, über Zusammensetzung und Tätigkeit der Sonderkommission im Staatsamt, der dies „befriedigt“ zur Kenntnis nahm. AufWunsch des US-Offiziers händigte Rektor Adamovich, der nach dem Wortlaut der ursprünglichen Entwürfe der politischen US-Säuberungslisten aufgrund seiner Ämter und Funktionen in der Zeit des Austrofaschismus nach 1945 keine Leitungsfunktion mehr hätte einnehmen können, ${ }^{1320}$ diesem eine Liste der

als „Clearinghouse des Geistes“ war es, „starke Bindungen mit den Vereinigten Staaten“ herzustellen. Nach 1945 wurde das Institut wieder gegründet und veranstaltete Hochschulkurse für Amerikaner und verhalf ,jungen Österreichern zu einer ,American experience.“"Vgl. Wilhelm Schlag, Das AmerikaInstitut und der Studentenaustausch zwischen Österreich und den USA. In: Austro-American Institute of Education (Amerika-Institut). 50 Jahre im Dienste des kulturellen Austausches zwischen Österreich und den U.S.A., 1926-1976, [o.O.], 23.

1318 Neben dem erwähnten William B. Featherstone und Thomas E. Benner (1894-1979), ebenfalls Professor für Erziehungswissenschaft und Dekan des „College of Education“an der University of Illinois (19311945) auch Samuel H[oward] Williams (1893-1968) Professor für Zoologie an der Universität Pittsburgh; Williams folgte am 30. Juni 1947 als Chef der Education Division auf Thomas Benner; darüber hinaus war zum Beispiel Major George Selke Rektor des St. Cloud State Teacher's College in Minnesota.

1319 Recordings of the U.S. Department of State relating to the Internal Affairs of Austria 1945-1954 (Mikrofilm-Bestand/Institut für Zeitgeschichte der Universität Wien), Decimal File, Reel 6, Major Leigh M. Lott, Internal Affairs Division/Education Branch, USFA, Report of First Visit to the University of Vienna [26. September 1945], 14. Oktober 1945, 6.

1320 Ludwig Adamovich (1890-1955), promovierter Jurist, 1914-1918 Kriegsdienst im Ersten Weltkrieg, zuletzt als Oberleutnant; zunächst auf Berufung Bundeskanzler Michael Mayrs im Verfassungsdienst des Bundeskanzleramtes tätig; auf Anregung von Hans Kelsen habilitierte er sich 1924 als Privatdozent für Staats- und Verwaltungsrecht an der Universität Wien. Nach der a.o. Professur an der Deutschen Universität Prag wurde Adamovich 1928 ordentlicher Professor an der Universität Graz, wo er 1932/33 als Dekan der juridischen Fakultät amtierte. 1934 wurde er ordentlicher Professor an der Universität Wien und 1935/36 ebenda auch Dekan der juridischen Fakultät. Adamovich galt als Legitimist und trotz Nichtmitgliedschaft - der christlichsozialen Partei nahestehend. So arbeitete er maßgeblich an der 
aktuell lehrenden Professoren aus und erklärte, dass „die Vorlesungen vollkommen vom nationalsozialistischen Gedankengut gereinigt worden sind.“1321 Des Weiteren fühlte sich der Wiener Rektor auf die Frage, wie es um die „geistige[...] Arbeit der Studierenden“ bestellt sei, veranlasst, Major Lott mitzuteilen, dass es sich „bei vielen Professoren nur um eine rein formale Zugehörigkeit zur NSDAP gehandelt habe", ${ }^{1322}$ wobei er als Beispiel just den Mediziner Leopold Schönbauer anführte. Schönbauer, ${ }^{1323}$ in der Zeit des Austrofaschismus Vorstand der chirurgischen Abteilung des Krankenhauses Lainz, war ab 1939 zum Vorstand der I. Chirurgischen Universitätsklinik avanciert und wurde unmittelbar

Formulierung der „ständisch-autoritären“ Verfassung vom Mai 1934 mit und bekleidete auch offizielle Ämter: von 1934-1938 gehörte er dem Staatsrat an, ab November 1934 war er zudem Mitglied des austrofaschistischen Bundestags. Am 16. Februar 1938 wurde er als Justizminister in das Kabinett Schuschnigg IV berufen. Nach dem „Anschluss“ wurde Adamovich seiner Ämter und Funktionen enthoben und in den Ruhestand versetzt. Siehe: Gertrude Enderle-Burcel, Christlich-Ständisch-Autoritär. Mandatare im Ständestaat 1934-1938. Biographisches Handbuch der Mitglieder des Staatsrates, Bundeskulturrates und Länderrates sowie des Bundestages. Hrsg.v. Dokumentationsarchiv des österreichischen Widerstandes, Wien 1991, $37 \mathrm{f}$.

1321 UAW, Rektoratsakten, Akademischer Senat, 455-1944/45, Gedächtnisprotokoll über die am Mittwoch, den 26. September 1945 stattgefundene Besprechung, 2. Erstmals zitiert wurde dieses Dokument von Gernot Heiß, Wendepunkt und Wiederaufbau: Die Arbeit des Senats der Universität Wien in den Jahren nach der Befreiung. In: Margarete Grandner/Gernot Heiß/Oliver Rathkolb (Hrsg.), Zukunft mit Altlasten. Die Universität Wien 1945 bis 1955, (Querschnitte 19. Einführungstexte zur Sozial-, Wirtschafts- und Kulturgeschichte), Innsbruck - Wien - München - Bozen 2005, 30.

1322 UAW, Rektoratsakten, Akademischer Senat, 455-1944/45, Gedächtnisprotokoll, a.a. O., 1 f.

1323 Leopold Schönbauer (1888-1963), geboren in Thaya, Niederösterreich, Sohn einer Ärztefamilie; Schönbauer studierte Medizin an der Deutschen Universität Prag, wo er 1914 promovierte; nach 1945 wurde Schönbauer Leiter des „Allgemeinen Krankenhauses“. Nach einer Verwundung im Kriegsdienst wurde Schönbauer 1916 einer mobilen militärischen chirurgischen Einsatztruppe der Klinik Eiselsberg zugeteilt; 1919 wurde er Assistent bei Anton Eiselsberg. Nach seiner Habilitation (1924) wurde Schönbauer in der Zeit des Austrofaschismus Leiter der Chirurgischen Abteilung im Krankenhaus Lainz. 1939 wurde er Vorstand der I. Chirurgischen Universitätsklinik im Wiener Allgemeinen Krankenhaus und blieb in dieser Funktion über die gesamte Dauer des Krieges. Siehe: Gabriela Schmidt, „Schönbauer, Leopold“. In: Neue Deutsche Bibliographie, 23, 2007, 383-384; siehe weiters: Karl Heinz Tragl, Chronik der Wiener Krankenanstalten, Wien - Köln - Weimar 2007, 525 f. In einem von Univ.-Prof. Dr. P. Fuchs verfassten Kurzbiografie findet sich kein Hinweis auf Schönbauers Tätigkeit während der NS-Zeit, jedoch eine geradezu heroische Darstellung seiner Persönlichkeit: „Schönbauer war eine starke, durch Unerschrockenheit ausgezeichnete Persönlichkeit, die besonders in kritischen Situationen zur Geltung kam. So ist Schönbauer 1945 die Rettung des Allgemeinen Krankenhauses zu verdanken. Er allein hatte damals die zurückweichenden deutschen Truppen davon abgehalten, das Allgemeine Krankenhaus als Kampfstellung zu mißbrauchen und er allein war es, der wenige Stunden später mit aller Entschiedenheit den Eroberern entgegengetreten war, um sie mit vollem Erfolg in ihre Schranken zu weisen." Siehe: http://www.meduniwien.ac.at/histmed/schoenbauer_biographie.htm [Zugriff 20.9.2011]. Aus Anlass seines 100. Geburtstages wurde Schönbauer 1988 eine Sonderpostmarke (Nennwert 4 österreichische Schilling) gewidmet; auf dem Eintrag auf www.aeiou.at findet sich ebenfalls keinerlei Hinweis auf Schönbauers berufliche Tätigkeit zwischen 1938-1945. 
bei Kriegsende vom Mitarbeiterstab des Allgemeinen Krankenhauses zu dessen Direktor nominiert. Schönbauer ist, wie Ingrid Arias schreibt, als „routinierter Opportunist“ zu charakterisieren. Obwohl er, wie Arias weiter ausführt, „nur Parteianwärter“ gewesen sei, war er ,in allen maßgeblichen Universitätsgremien“ und hatte 1943 immerhin das „Treuezeichen der NSDAP verliehen“"1324 bekommen.

Die an der Medizinischen Fakultät besonders zögerlich durchgeführte Entnazifizierung ${ }^{1325}$ hatte wohl auch damit zu tun, dass den medizinischen Kliniken auf Grund des Beschlusses des Politischen Kabinetts vom August I945 „eine große wissenschaftliche und wirtschaftliche Bedeutung zugesprochen wurde“, ${ }^{1326}$ wonach das Verbotsgesetz nur mehr auf jene angewendet werden sollte, „welche sich durch unmenschliche Praxis und lebensbedrohende Versuche am lebenden Leib als untragbar erwiesen haben. ${ }^{\text {"1327 }}$

Nach dem Wortlaut eines OSS-Entnazifizierungsberichtes scheint Schönbauer, der nach I945 qua Ausnahmeparagraph zum Verbotsgesetz vom Bundespräsidenten - nach mehreren Anläufen von Vizekanzler Adolf Schärf ${ }^{1328}$ - pardoniert worden war, ${ }^{1329}$ seit I940 NSDAP-Mitglied und außerdem „nach 1938 Eigentümer eines vor 1938 im jüdischen Besitz gestandenen Hauses“1330 gewesen zu sein. Nach der „entlastenden“ Aussage seiner bei-

1324 Ingrid Arias, Die Medizinische Fakultät von 1945 bis 1955: Provinzialisierung oder Anschluss an die westliche Wissenschaft? In: Grandner/Heiß/Rathkolb (Hrsg.), Zukunft mit Altlasten, a.a.O., 76; zur Situation der Entnazifizierung an der Medizinischen Fakultät allgemein siehe; Michael Hubenstorf, Medizinische Fakultät 1938-1945. In: Gernot Heiß/Siegfried Mattl (Hrsg.), Willfährige Wissenschaft. Die Universität Wien 1938-1945, Wien 1989, 233-282.

1325 Die von Arias verglichenen Personalstandsverzeichnisse 1949-1951 mit den Listen vor 1944 dokumentieren ein hohes Maß an personeller Kontinuität: von 24 Medizinprofessoren nach 1945 waren 14 schon in den Jahren 1940-1944 verzeichnet, von 109 Privatdozenten galt dies für ganze 63. Rund 57\% des gesamten wissenschaftlichen Personals der medizinischen Fakultät war sowohl während der NS-Zeit als auch danach tätig. Siehe dazu: Ingrid Arias, Entnazifizierung an der Wiener Medizinischen Fakultät: Bruch oder Kontinuität? Das Beispiel des Anatomischen Instituts. In: Zeitgeschichte, 31. Jg., 2004, Heft 6, 347.

1326 Arias, Entnazifizierung an der Wiener Medizinischen Fakultät, a.a.O., 359.

1327 Beschluss des Politischen Kabinetts vom 10. August 1945, 5Z.104-1945/194, 6, UAW, Dekanatsakten der Medizinischen Fakultät. Zit. nach: Arias, Entnazifizierung an der Wiener Medizinischen Fakultät, a.a.O., 359.

1328 Schärf teilte im Dezember 1945 dem Dekan der medizinischen Fakultät, Leopold Arzt, mit: „Bei der Schaffung des Verbotsgesetzes habe ich im Kabinettsrat auf jene Tatsache [der Widerstandshandlung] hingewiesen und damit begründet, dass man den Ausnahmeparagraph des Verbotsgesetzes schaffen soll, der, wie ich dann höre, in der Folge der Besprechungen den Namen Schönbauer-Paragraph erhalten hat. Es war im Kabinettsrat einhellig die Meinung, dass man solche Fälle pardonieren soll." Zit. nach: Neugebauer/Schwarz, Der Wille zum aufrechten Gang, a.a.O., 51.

1329 Ebd., 71. Von 1959-1962 war Schönbauer Abgeordneter zum Nationalrat für die ÖVP. Ebd., 77.

1330 Entnazifizierung der Lehrkräfte der Universität Wien (G.-Z1. 32141/III-7/46). Enthalten in: Appendix „A“, Report of Quadripartite Sub-Committee on Denazification in Austrian Universities, 7th September 1946. NARA II, RG 260, Box 11, Folder 68, Records of the Unites States Occupation Headquarters, World War II, USFA/USACA, Internal Affairs/Displaced Persons Division, Denazification Branch, General Records, 1945-50, 1. 
den Professorenkollegen Lindner und Kahr - beide hatten in der NS-Zeit die Funktion eines Institutsvorstandes inne ${ }^{1331}$ - hätte er sich jedoch „stets verfolgter Personen (Juden, Mischlingen, Antifaschisten) angenommen“. ${ }^{1332}$

In den Apriltagen 1945 hatte Schönbauer als Oberstabsarzt dann noch quasi in letzter Minute die Seite gewechselt, sich nach eigenen Angaben „unter persönlicher Lebensgefahr" der Widerstandsbewegung angeschlossen und so das Krankenhaus sowohl gegen eindringende SS-Truppen als auch gegen die Sowjets verteidigt, was dem Chirurgen - trotz anonymer Anzeigen - dauerhaft ein weiter nicht hinterfragtes "großes Verdienst um Österreich“ sicherte. ${ }^{1333}$ Wie Arias schreibt, hatte Schönbauers „angebliche Involvierung in den Widerstand [...] [ihn, d. Verf.] nicht davon abgehalten, für sechs seiner ehemaligen Assistenten, die alle langjährige Mitglieder der NSDAP waren, einen Belassungsantrag zu stellen und ihnen ihre Glaubwürdigkeit zu bestätigen, obwohl falsche Angaben hinsichtlich der Parteizugehörigkeit auf den Personalbogen verzeichnet waren. “1334

Major Lott zeigte sich über Schönbauer jedenfalls nur wenig oder eben nur einschlägig informiert und würdigte dessen „große Verdienste“ „bei der Verteidigung des Allgemeinen Krankenhauses gegenüber der SS“. ${ }^{1335}$

Der interne US-Bericht über die verhältnismäßig spät zustandegekommene erste Visitation der Wiener Universität beinhaltet auch genauere Zahlen hinsichtlich der erfolgten Enthebungen von Professoren an den Fakultäten der Wiener Universität, kommt dabei aber - im Unterschied zu den zitierten Passagen aus den Rektoratsakten - trotz der betonten Erfolgsmeldung über die durchgeführte Entnazifizierung zu einem deutlich anderen, geradezu widersprüchlichen Ergebnis; danach waren sehr wohl zahlreiche Enthebungen durchzuführen und unter den nunmehrigen Professoren befänden sich viele ehemals durch die Nationalsozialisten Entlassene: "Comparative figures are submitted concerning full and associate professors of the University [of Vienna, d. Verf.]. In interpreting these figures, it is not enough simply to note, that the present number of full and associate professors for I945-46 represent only 50\% of the number for 1937-38. It must be remembered that many of the present 66 Professors were dismissed by the Nazi Party and so were not members of the $1944-45$ faculty. By recalling this fact, one can comprehend the extent of the 'liquidation' of the $1944-45$ faculty." 1336

1331 Siehe: Arias, Entnazifizierung an der Wiener Medizinischen Fakultät, a.a.O., 359.

1332 Ebd., Appendix A, 1.

1333 Arias, Entnazifizierung an der Wiener Medizinischen Fakultät, a.a.O., 359.

1334 Ebd.

1335 UAW, Rektoratsakten, Akademischer Senat, 455-1944/45, Gedächtnisprotokoll, a.a. O., 2.

1336 Recordings of the U.S. Department of State relating to the Internal Affairs of Austria 1945-1954 (Mikrofilm-Bestand/Institut für Zeitgeschichte der Universität Wien), Decimal File, Reel 6, Major Leigh M. Lott, Internal Affairs Division/Education Branch, USFA, Report of First Visit to the University of Vienna, [26. September 1945], 14 October 1945, 4. 
Eine genaue Aufstellung der ordentlichen und außerordentlichen Professoren der einzelnen Fakultäten sollte das verdeutlichen. Allerdings lagen diese Angaben der Internal Affairs Division der US-Education Branch, die auch die medizinische Fakultät umfassten und sich vermutlich auf Zahlenmaterial des Unterrichtsministeriums stützten, mit 54 Prozent enthobenen Professoren weit über der zitierten Entnazifizierungsstatistik des detaillierten US-Geheimdienstberichtes, der bei den enthobenen außerordentlichen und ordentlichen Professoren der Universität Wien auf lediglich 26,5 Prozent kam.

Aufstellung über die Zahl der lehrenden Professoren an der Universität Wien: ${ }^{1337}$

\begin{tabular}{|c|c|c|c|}
\hline $\begin{array}{l}\text { Ordentliche* } u \text {. } \\
\text { a. o. Professoren* * }\end{array}$ & $1937 / 38$ & $1944 / 45$ & $1945 / 46$ \\
\hline Katholisch-Theol. Fakultät & $8^{*}$ bzw. $2^{* *}=10$ & 5 bzw. $1=6$ & 4 bzw. $1=5$ \\
\hline Evangelisch-Theol. Fakultät & 5 bzw. $0=5$ & 4 bzw. $0=4$ & 4 bzw. $0=4$ \\
\hline Rechts- u. Staatswiss. Fakultät & 15 bzw. $4=19$ & 13 bzw. $2=15$ & 11 bzw. $4=15$ \\
\hline Medizinische Fakultät & 19 bzw. $10=29$ & $20 \mathrm{bzw} \cdot 7=27$ & 11 bzw. $1=12$ \\
\hline Philosophische Fakultät & 45 bzw. $22=67$ & 49 bzw. $21=70$ & $20 \mathrm{bzw} \cdot 10=30$ \\
\hline Summe & 92 bzw. $38=130$ & 91 bzw. 31 = 122 & 50 bzw. $16=66$ \\
\hline
\end{tabular}

Legende: *ordentliche Professoren; ${ }^{* *}$ außerordentliche Professoren

Obwohl es sich nicht positiv belegen lässt, steht doch zu vermuten - und die Kontakte und Unterredungen zwischen Offizieren der US-Education Division und Repräsentanten der Universität Wien legen das durchaus nahe -, dass der Darstellung einer erfolgreichen, weil rigoros durchgeführten Entnazifizierung des Lehrpersonals tendenziell eine Entwarnungsfunktion gegenüber übergeordneten US-amerikanischen Behördenstellen innewohnte, um so die politische Säuberung der Hochschulen und Universitäten - für die der Education Division auch kein „key personnel“ zur Verfügung stand ${ }^{1338}$ - rasch ad acta legen und mit positiver Unterstützungsarbeit wie Lehrmaterialspenden, Vermittlung von Gastprofessoren, Experten- und Studentenaustausch-Programmen et cetera beginnen zu können.

In einer weiteren Besprechung, die im Oktober stattfand, ging Major Lott auf die Frage der Entnazifizierung ein und erläuterte dabei die amerikanische Position. Zunächst teilte

1337 Internal Affairs Division/Education Branch, USFA, Report of First Visit to the University of Vienna [26. September 1945], 14 October 1945, a.a. O., 4.

1338 „Key personnel“ gab es innerhalb der USFA-Education Division für a) Elementary Education, b) Youth Activities, c) Teacher Education und d) Secondary Education. Siehe dazu: Recordings of the U.S. Department of State relating to the Internal Affairs of Austria 1945-1954 (Mikrofilm-Bestand/Institut für Zeitgeschichte der Universität Wien), Decimal File, Reel 6, Education Division, Quarterly Historical Report, Governing Period 1 January - 31 March 1949, Enclosure no. 1 to despatch no. 216, dated April 26, 1949, from the American Legation, Vienna Austria, 1. 
er Adamovich die grundsätzliche Ausgangslage mit, wonach zwischen den vier Alliierten Militärkommanden zur Zeit noch keine einheitliche Stellungnahme bezüglich der „Reinigung der öffentlichen Dienststellen", also auch der Hochschulen, vereinbart worden sei. Was die Haltung der amerikanischen Militärstellen betreffe, so stünden diese auf dem Standpunkt, ,dass die Universitäten selbst die Säuberung von Nationalsozialisten durchführen sollten. ${ }^{\text {"1339 }}$

Ein keineswegs nebensächliches Detail dieser Besprechung betraf, wenn auch nur implizit - offenkundig hatte Adamovich das im Hinblick auf den Fall Schönbauer zur Sprache gebracht - die Frage, inwiefern die Universität hinsichtlich konkreter ,Säuberungsmaßnahmen' tatsächlich autonom wäre, wobei Lott hier dem Rektor beziehungsweise der Universität eindeutig den Rücken stärkte.

Mit Bezug auf die kurz zuvor stattgefundene Registrierungsaktion einer US-Dienststelle, die im Allgemeinen Krankenhaus Fragebögen hatte verteilen lassen und angeordnet hatte, dass kein Arzt weiter im Dienst bleiben durfte, der NSDAP-Parteimitglied oder Parteianwärter war, erklärte Lott, dass die amerikanische Militärstelle zu dieser Anordnung nur dann befugt sei, wenn es sich bei diesen Ärzten nicht um Universitätsangehörige handle, da allein seine Dienstelle zu „irgendwelchen Aktionen befugt ${ }^{\text {“1340 }}$ wäre. Da die Kliniken des AKH zur Universität gehören und die Vorstände dieser Kliniken wie auch alle Assistenten und Hilfskräfte Angestellte der Universität seien, wäre allein „sein eigenes Amt [die Education Branch, d. Verf.] zur Kontrolle befugt", daher würde Prof. Schönbauer dahingehend verständigt werden, dass er die Frage nach der (früheren) ,politischen Parteiangehörigkeit" nicht beantworten muss. ${ }^{1341}$

Neben dieser an vielen Beispielen dokumentierten, generell neutralistischen und im genannten Anlassfall zurückhaltend-zögerlichen Entnazifizierungspolitik der amerikanischen Besatzungsmacht sowie der tendenziell auf Eingliederung, das heißt auf Pardonierung ausgerichteten, universitären und ministerialen Gremien auf österreichischer Seite, war es im Zusammenhang mit der Entnazifizierung - insbesondere der österreichischen

1339 UAW, Rektoratsakten, Akademischer Senat, 455-1944/45, Protokoll über die Sitzung des Akademischen Senats der Universität Wien, 20. Oktober 1945, 3. Roman und Hans Pfefferle stießen bei ihrer Recherchen im Universitätsarchiv Wien ebenfalls auf Gesprächsprotokolle zwischen Lott und Adamovich und interpretieren diese als „Beleg für die Versuche der Universitätsleitung, auch bei den Alliierten für die Weiterverwendung von belasteten, aber von der Sonderkommission positiv beurteilten Professoren zu werben und möglicherweise die endgültige Entscheidung vom Staatsamt dazu durchzuführen“. In Kenntnis der US-Akten sowie der Korrespondenz zwischen Adamovich und den Leitern der U.S. Education Division zeigt sich jedoch, dass auch leitende US-Besatzungsoffiziere im Hinblick auf universitäre ,Säuberungsmaßnahmen' nur wenig an einer aktiven Interventionspolitik interessiert waren und einer stillschweigenden Kooperation mit den akademischen Kollegen den Vorzug gaben. Vgl. Pfefferle/Pfefferle, Glimpflich entnazifiziert, a.a.O., 31.

1340 UAW, Rektoratsakten, Akademischer Senat, 455-1944/45, Protokoll über die Sitzung des Akademischen Senats der Universität Wien, 20. Oktober 1945, 3.

1341 Ebd., 4. 
Ärzteschaft - der „Bund sozialdemokratischer AkademikerInnen, Intellektueller und KünstlerInnen“ (BSA), der aus partei- beziehungsweise machtpolitischen Motiven die Reintegration auch belasteter „ehemaliger" Mediziner entscheidend gefördert hat. Durch Hilfe bei der Entregistrierung und durch gezielte Anwerbeaktionen, die sich allerdings nicht auf vertriebene jüdische beziehungsweise linke Funktionäre und Mitglieder erstreckte, ${ }^{1342}$ sollte das durch Faschismus, Emigration und Krieg gegenüber dem katholischen Cartellverband (CV) deutlich dezimierte Potenzial sozialdemokratischer Intellektueller und Akademiker - auch gegen internen antifaschistischen Widerstand - bundesweit angehoben werden. ${ }^{1343}$ Die fatale und ungeprüfte Reintegration ${ }^{1344}$ ehemaliger Nationalsozialisten verlief, gemessen am österreichweiten Schnitt, überaus erfolgreich ${ }^{1345}$ und trug, wie Wolfgang Neugebauer und Peter Schwarz konstatieren, dazu bei, die „offizielle Auseinandersetzung mit dem Nationalsozialismus als Tabu“ zu verfestigen, was „regelrecht eine Mauer des Schweigens, Vergessens, und Verdrängens zementierte“. ${ }^{1346}$

Im weiteren Verlauf des zitierten Gesprächs zwischen Major Lott und Rektor Adamovich kristallisierte sich auch heraus, in welcher Weise sich die Kontakte zwischen der US-Education Branch und der Universitätsleitung künftig gestalten würden. Schon in der

1342 Neugebauer/Schwarz, Der Wille zum aufrechten Gang, a.a.O., $32 \mathrm{f}$.

1343 Der offene Wettlauf und das Buhlen um die Stimmen der ehemaligen setzte spätestens nach der ersten Nationalratswahl zu Beginn des Jahres 1946 ein. Im Zusammenhang mit der Minderbelastetenamnestie Feburar 1947 stieg der Zulauf zum BSA ab 1948 rasch an: bis 1954 vervierfachte sich dessen Mitgliederzahl von 2.312 auf 8.741. Allein beim Wiener BSA-Ärzteverband befanden sich unter den 365 Mitgliedern insgesamt 126 Registrierte, darunter nicht wenige überaus schwer Belastete. Vgl. Neugebauer/Schwarz, Der Wille zum aufrechten Gang, a.a.O., 64 bzw. $238 \mathrm{ff}$.

1344 Wie Neugebauer und Schwarz anhand der Analyse der vorhandenen BSA-Akten sowohl statistisch als auch durch eine Vielzahl von Fallbeispielen belegen, erfolgte die Aufnahme ziemlich umstandslos: „Es wurde weder überprüft, ob die jeweiligen BeitrittskandidatInnen mit dem Nationalsozialismus gebrochen hatten, noch ob sie sich zu den Grundwerten des Humanismus, der Demokratie und insbesondere der Sozialdemokratie bekannten." Zit. nach: Neugebauer/Schwarz, Der Wille zum aufrechten Gang, a.a.O., 218.

1345 „Im Nachkriegsösterreich entsprach die von Historikern genannte Zahl von ca. 700.000 ehemaligen NSDAP-Mitgliedern bei einer Einwohnerzahl von ca. 7.015.000 (Volkszählung 1939) einem Anteil von 10 Prozent (einem Zehntel) an der Gesamtbevölkerung [allerdings inkludierte diese Bevölkerungsziffer zum damaligen Zeitpunkt die Südböhmischen und Südmährischen Gebiete, die im Oktober 1938 der „Ostmark zugeschlagen wurden; 1941 folgten die Untersteiermark und Oberkrain, die der Steiermark bzw. Kärnten zugeschlagen wurden, d. Verf.]. Der Anteil der ehemaligen NSDAP-Mitglieder beläuft sich in unserer BSA-Ärzte-Stichprobe [1.388 ÄrztInnen, d. Verf.] hingegen auf 15 Prozent (208 von 1.388), das heißt der von uns ermittelte NS-Anteil (15 Prozent) liegt um die Hälfte (50 Prozent) über dem gesamtösterreichischen Wert (10 Prozent). Diese Differenz fällt noch dramatischer aus - an die 100 Prozent -, wenn man den Anteil der nach dem NS-Gesetz registrierten ehemaligen Nationalsozialisten (ca. 549.000) an der Gesamtbevölkerung (ca. 7.015.000) im Ausmaß von 7,8 Prozent mit unserem Ergebnis (15 Prozent) vergleicht." Neugebauer/Schwarz, Der Wille zum aufrechten Gang, a.a.O., 226.

1346 Ebd., 221. 
ersten Besprechung hatte Adamovich um materiale Unterstützung bei dringenden Reparaturarbeiten gebeten, und Colonel Featherstone hatte, soweit möglich, größtmögliche Unterstützung zugesagt. ${ }^{1347}$ Rektor Adamovich, der bereits zuvor in einem Schreiben an den „sehr verehrten Herrn Major“ mitteilen musste, dass trotz seines persönlichen Schreibens ein „sehr beleibter Offizier“ des „Vienna Area Command“ das Ansuchen um Zuweisung von Baumaterialien (Glas für das Dach der Universitätsbibliothek) und Kohle für die Universität sofort - „ohne das Schriftstück [...] durchzusehen“1348 - abwies, berichtete Major Lott von der neuerlich erfolglosen Vorsprache eines Beamten der Universitäts-Gebäudeverwaltung. Der stellvertretende Leiter der Education Branch zeigte sich „über das mangelnde Ergebnis dieser Intervention sehr betreten" und erkundigte sich sogleich nach dem Namen des amerikanischen Offiziers. ${ }^{1349}$

Nach weiteren Unterredungen war das Ergebnis für die Universität schließlich überaus positiv: im „Auftrage des Amerikanischen Hauptquartiers, Education Branch (Major Lott)“ gestattete sich Rektor Adamovich, dem Bürgermeister von Wien die Bitte vorzutragen, täglich mindestens ein Lastauto für „den täglichen Antransport von Baumaterialien“ zur Verfügung gestellt zu bekommen und wies Theodor Körner eigens darauf hin, das amerikanische Kommando habe erklärt, „dass diese Maßnahme dem eigenen Wunsche entspreche, da auch die amerikanischen Behörden das dringendste Interesse an dem Wiederaufbau der Universität haben. “1350

Gegenüber Repräsentanten der britischen Besatzungsmacht in der Steiermark, die sich bei Rektor Adamovich im Oktober 1945 über den Fortgang der ,Säuberungsmaßnahmen“ an der Universität Wien erkundigten und diesem gelegentlich eines Gespräches mitteilten, dass in Graz rund 50 Prozent der Professorenschaft entlassen beziehungsweise pensioniert werden musste, erklärte Adamovich, dass die Entnazifizierung des Lehrkörpers an der Universität Wien mit großer Strenge durchgeführt werde und dass „dies eine Härte bedeute, da an der Wiener Universität alle Parteigenossen und Parteianwärter enthoben wurden. Es müsse unbedingt ein Ausgleich gefunden werden, vor allem sollten Professoren, die nur formal einer Partei angehört hatten und auf die die Universität Wien Wert lege, wieder zurückkommen können. " ${ }^{351}$ Die Wiedereinsetzung der durch die Nationalsozialisten vertriebenen Universitätslehrer schien dem Nachkriegsrektor der Universität Wien im Zusammenhang mit dem wissenschaftlichen und forschungspolitischen Neubeginn allerdings kein Anliegen gewesen zu sein.

1347 UAW, Rektoratsakten, Akademischer Senat, 455-1944/45, W.B. Featherstone, USFA, Internal Affairs Divsion - Education Branch, 5. Oktober 1945.

1348 UAW, Rektoratsakten, Akademischer Senat, 455-1944/45, Schreiben von Rektor Adamovich an Major Leigh M. Lott, 17. Oktober 1945, 1.

1349 UAW, Rektoratsakten, Akademischer Senat, 455-1944/45, Protokoll über die Sitzung des Akademischen Senats der Universität Wien, 20. Oktober 1945, 4.

1350 UAW, Rektoratsakten, Akademischer Senat, 455-1944/45, 7. November 1945.

1351 Zit. nach: Pfefferle/Pfefferle, Glimpflich entnazifiziert, a.a.O., 32. 
Nach den Briten wurden im November 1945 schließlich auch noch die französische Besatzungsbehörden bei Adamovich vorstellig und verlangten die Aushändigung einer Übersicht über den Lehrkörper der Universität. ${ }^{1352} \mathrm{Zu}$ direkten Interventionen der Alliierten Mächte kam es aber, wie sich auch in den Protokollen des Alliierten Rates dokumentiert findet, infolge mangelnder Einigkeit der Besatzungsmächte beziehungsweise auf Grund des Prärogativs divergierender machtpolitischer Strategien - wie zu zeigen sein wird - weder zu diesem Zeitpunkt noch später. Ohne den zitierten Besprechungsprotokollen mehr Relevanz zugestehen zu wollen, als diesen als Einzelbildaufnahmen zusteht, stellen diese aber nicht nur bemerkenswerte Dokumente aus der Frühphase des informiert-uninformierten Laissez-faire der lokalen US-Reorientierungs-Politik im universitär-wissenschaftlichen Bereich dar, sondern darüber hinaus ein erstes Indiz für eine in der Folge konsequent durchgezogene, nicht-interventionistische Position, die von Anbeginn durch eine respektvoll-kooperative Zusammenarbeit und geradezu freundschaftlich-vertraute Arbeitsatmosphäre auf beiden Seiten verstärkt wurde - insbesondere im Bereich der Universität, aber auch des Unterrichtsministeriums.

Weitaus mehr besorgt als in Bezug auf Entnazifizierungsfragen zeigten sich die Education-Offiziere hinsichtlich zweier anderer Problembereiche: zum einen, wie die über lange Jahre vom Ausland völlig abgeschnittenen Schulen und höheren Bildungseinrichtungen über gezielten Austausch von Professoren und Studierenden Anschluss an internationale beziehungsweise amerikanische Standards finden könnten; zum anderen war der Stab der Education Division besorgt über die Art und Weise, wie die amerikanische Besatzungsmacht, in deren Besatzungszone sich keine Universität und Hochschule befand, die „Cultural and Spiritual Needs of Austria" missachten würde. Im Unterschied zu den anderen alliierten Besatzungsmächten, die sich, wie die Franzosen oder Briten, um die Verbreitung nationaler Landeskultur via Bücher und Tageszeitungen bemühten und eigene Verlage aufbauten, oder, wie die Sowjets, hohe Summen für den Wiederaufbau der Wiener Oper flüssig machten, eigene Druckereien einrichteten und darüber hinaus auch Hochschullehrer an die Moskauer Universität einladen würden, hätten sich die USA bis dato primär auf den administrativen und materiellen Wiederaufbau in Österreich konzentriert. Trotz der Einrichtung eines ersten US-Informationcenters mit eigenem Leseraum in der Wiener Kärntnerstraße sowie einigen bereits erfolgten größeren Buch- und Zeitschriftenlieferungen amerikanischer Literatur kritisierten die Reeducation-Offiziere, dass die USA gegenüber den anderen Besatzungsmächten langsam ins Hintertreffen geraten würden, und empfahlen sowohl dem „Political Advisor“ als auch den Abteilungen der Information Service Branch (ISB) -, alles Erdenkliche zu unternehmen, um amerikanische Kultur in Österreich zu befördern, zumal dies auch von österreichischer Seite durchaus erwünscht sei:

\footnotetext{
"It may well be that our nation is not as much interested in the future of Austria as are the European powers of occupation. It may well be that our nation has nothing to 'sell' of its democracy
}

1352 Ebd., 33. 
and of its culture to Austria. The fact remains, however, that the United States sent a military force thousands of miles over water and land to impose its will upon Austria. It should now be willing to compete with other nations in imposing its culture upon the same country. Constant demands of dissemination of American culture are being made on the Education Branch by many of the leaders of Austrian thought." ${ }^{1353}$

Tatsächlich scheinen sowohl die USFA-Militärbehörden als auch das Exekutivkomitee der USACA sowie letztlich das US-War Department anfänglich schlicht überfordert gewesen zu sein, den Bemühungen um eine „re-education of the youth of the country“ zu entsprechen, indem beispielsweise keine US-Informations- und Unterrichtsmaterialien, wie dies der Leiter der Education Branch, Colonel W.B. Featherstone, dringend forderte, zur Verfügung stellten. Daher wandte sich Featherstone schließlich über den Politischen Berater der US-Besatzungsmacht an das State Department in Washington und fügte dabei gleich eine umfangreiche Liste benötigter Bücher an. ${ }^{1354}$

\section{Personalsäuberungen durch „Sonderkommissionen“ und deren Senate}

Mit dem Erlass des Unterrichtsamtes vom 8. August 1945, betreffend die Dienstenthebung aller ehemaligen Mitglieder der NSDAP (auch der Parteianwärter) und ihrer Wehrverbände, wurden die Bestimmungen des Ausnahmeartikels des Verbotsgesetzes insofern verschärft, als nun auch jene Personen sofort zu entheben waren, die „ohne zu dem im $\S 4$ des Verbotsgesetzes aufgezählten Personenkreis gehören, die nationalsozialistischen Bestrebungen in einer übermäßigen Art und Weise gefördert haben (zum Beispiels durch Anzeige gegen anders gesinnte Personen, unverhältnismäßig hohe Geldspenden, übertriebene Mundpropaganda und ähnliches“). ${ }^{1355}$ Ausnahmen sollten hier grundsätzlich nicht gestattet sein, „es sei denn, dass die notdürftigste Weiterführung des Amts(Schul)betriebes durch die Enthebung einer der aufgezählten Personen ernstlich in Frage gestellt würde“. ${ }^{1356}$ Ein „allfälliger Antrag auf Weiterbelassung“ wäre „eingehend zu begründen“ und „womöglich gleichzeitig eine geeignete Ersatzkraft namhaft zu machen", ${ }^{1357}$ wie es in einem

1353 Recordings of the U.S. Department of State relating to the Internal Affairs of Austria 1945-1954, Decimal File, Reel 6, Major Leigh M. Lott, Report of First Visit to the University of Vienna, 14 October $1945,8$.

1354 Recordings of the U.S. Department of State, a. a. O., Reel 6, James Orr Denby an den Secretary of State/Washington, Need for Educational Books in Austria, 20 October 1945, 1.

1355 Erlass vom 8. August 1945, Z. 351-Präs. Verordnungsblatt für den Dienstbereich des Bundesministeriums für Unterricht, Jg. 1946, Wien am 1. März 1946, 3. Stück, 58.

1356 Verordnungsblatt für den Dienstbereich des Bundesministeriums für Unterricht, Jg. 1946, Wien am 1. März 1946, 3. Stück, 58.

1357 Österreichisches Staatsarchiv (ÖSTA)/Archiv der Republik (AdR), Bestand 02, Bundesministerium für Unterricht (BMfU), Präsidium 1946, (GZ 401-1250), Ktn. 5, Z1. 351/Präs.-1945, Staatsamt für Volks- 
Rundschreiben des Staatsamtes für Volksaufklärung, Unterricht und Erziehung und Kultusangelegenheiten hieß.

Und genau das war, wie sich in vielfacher Weise zeigen sollte, letztlich auch einer der Knackpunkte: viele dieser „Begründungen“waren gänzlich unzureichend oder fehlten vollends; darüber hinaus argumentierten einige Universitäten und Landesschulbehörden, die bisherige Entnazifizierungspraxis quasi rechtfertigend, dass eine strikte Durchführung der Säuberungsmaßnahmen zur „völligen Lahmlegung“ des Betriebes führen würde. So wurde vom Kärntner Landesschulrat beschlossen, den Erlass des Staatsamtes vom I8. August 1945 nicht zur Anwendung zu bringen, da „eine Durchführung desselben mit Rücksicht auf die politische Struktur des Lehrkörpers in Kärnten einer völligen Lahmlegung des gesamten Unterrichtsbetriebes gleichzusetzen wäre“. ${ }^{1358}$

Ungeachtet so mancher regionaler Unterschiede auf Grund der zonalen Aufsplitterung Österreichs in einzelne Besatzungsbereiche ${ }^{1359}$ (und einer weitgehend uneinheitlichen Judikatur bis Ende 1945) sowie lokaler Abneigung gegenüber den politischen ,Säuberungsmaßnahmen', waren sowohl das Staatsamt für Volksaufklärung, Unterricht und Erziehung und Kultusangelegenheiten in Person von Staatssekretär Ernst Fischer (und seinem Stellvertreter Karl Lugmayer) wie auch danach Felix Hurdes als Unterrichtsminister um eine möglichst sachlich korrekte und demokratiepolitisch klare Lösung des Problems im Sinne des staatlichen Wiederaufbaues bemüht. Ein Umstand, der wohl weniger mit den jeweiligen (partei)politischen Positionen zu tun hatte, als mit der persönlichen Haltung der handelnden Personen in dieser Frage ${ }^{1360}$ - in den politischen Parteien lassen sich hingegen ebenso wie bei hohen Beamten des Unterrichtsressorts zum Teil geradezu diametral

aufklärung, für Unterricht und Erziehung und für Kultusangelegenheiten „Enthebung aller ehemaligen Mitglieder (Anwärter) der NSDAP und ihrer Wehrverbände vom Dienst“, Wien am 8. August 1945.

1358 ÖSTA/AdR, Bestand 02, BMfU, 2C1, Disziplinarkammern, Sonderkommissionen, 1945-1958, Ktn. 378, Z1. 16157-IV/Pb/1946, Landesschulrat für Kärnten an das Bundesministerium für Unterricht, 21. Mai 1946, 2. In Oberösterreich, wo der Landesschulrat in Form von „Monthly reports“ den amerikanischen Militärbehörden penibel über den Stand der Entnazifizierung der Lehrerschaft Bericht zu erstatten hatte, standen für den Zeitraum vom 26. Juni bis zum 26. Juli 1946 insgesamt 1496 nicht entlassenen Lehrern in Summe 299 (wegen „Illegalität“) Entlassene gegenüber. ÖSTA/AdR, Bestand 02 BMfU, 2C1, Disziplinarkammern, Sonderkommissionen, 1945-1958, Ktn. 378, Z1. 26172-46, Landesschulrat für Oberösterreich, Monatsbericht d. Sonderkommission beim Landesschulrat für Oberösterreich, 24. Juli 1946, 2.

1359 Vgl. dazu den Text des ersten Alliierten Kontrollabkommens über Österreich vom 4. Juli 1945, abgedruckt in: Stephan Verosta, Die internationale Stellung Österreichs, Wien 1947, 65 f.

1360 Ernst Fischer (1889-1972) - seines Zeichens kommunistischer Wortführer in der „Nazifrage“- respektive die KPÖ als solche hatten sich von Anbeginn gegen eine rein nach formalistischen Prinzipien vorgehende Registrierung analog zum Verbotsgesetz vom 8. Mai 1945 gewandt, und eine "gerechtere“, stärker auf individuelle Verantwortung entlang der Differenzierungslinie „Hauptschuldige“ und „Mitläufer“ („kleine Nazis“) ausgelegte ,Säuberungspraxis“ präferiert. Vgl. dazu Stumpf, Ernst Fischer als Staatssekretär für „Volksaufklärung, Unterricht und Erziehung und Kultusangelegenheiten“, a.a. O., 289; weiters: Manfred Mugrauer, Die Politik der Kommunistischen Partei Österreichs in der Provisorischen Regierung Renner, Dipl.-Arb., Univ. Wien 2004, 227. 
entgegen gesetzte Tendenzen ablesen. ${ }^{1361}$ Faktum ist aber, dass sowohl Fischer als auch Hurdes - und hier schlagen durchaus parteipolitische Positionen durch - die „prioritäre Auseinandersetzung mit Schulthemen und die Marginalisierung des Hochschulbereichs “1362 geradezu festschrieben; nicht zuletzt hatte Fischer bereits zur Zeit seines Moskauer Exils ein „Volksbildungsministerium“1363 konzipiert, in dem hochschulpolitische Belange kaum ein Rolle spielten. ${ }^{1364}$ Sektionschef Edwin Zellwecker vom Unterrichtsministerium, der bereits in der Ersten Republik als Volksbildner aktiv gewesen war, bemühte sich hingegen anlässlich einer ersten Rektorenkonferenz im Oktober I945, „möglichst viele Hochschullehrer“ für Veranstaltungen „im Rahmen der Volksbildungsstätten“ zur „Hebung des allgemeinen kulturellen Niveaus“"1365 zu gewinnen. So sollten künftig an jeder Hochschule Listen aufliegen, in die sich alle Professoren, Dozenten und Assistenten mit Namen und Wohnadresse eintragen sollten, die zur Übernahme eines Vortrages oder einer sonstigen Mitwirkung bereit wären. Die Initiative Zellweckers fand vor dem Hintergrund der Feiern zum festlich began-

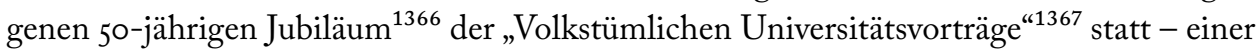
unter anderem von Ernst Mach mitinitiierten Volksbildungsinitiative, die Vorträge und Kurse für Hörerinnen und Hörer aller Fakultäten (primär außerhalb der Universität) anbot. ${ }^{1368}$

Als ein Beispiel für die von Staatssekretär Fischer mitinitiierte bildungspolitische Vernachlässigung der Universitäten und Hochschulen zu Beginn der Zweiten Republik, die auch von seinen Unterstaatssekretären ${ }^{1369}$ weitgehend mitgetragen wurde, ${ }^{1370}$ lässt sich an

1361 Namentlich sei an dieser Stelle auf Sektionschef Otto Skrbensky verwiesen, der die Sonderkommission Sektion Hochschulen im Unterrichtsministerium leitete und damit für die Entnazifizierung der Universitätsprofessoren zuständig war; auf ihn wird weiter unten noch etwas ausführlicher Bezug genommen.

1362 Oliver Rathkolb, Die Universität Wien und die „Hohe Politik“ 1945 bis 1955. In: Grandner/Heiß/Rathkolb (Hrsg.), Zukunft mit Altlasten. Die Universität Wien 1945 bis 1955, a.a. O., 40 bzw. 48.

1363 Stumpf, Ernst Fischer als Staatssekretär für „Volksaufklärung, Unterricht und Erziehung und Kultusangelegenheiten“(1945). Bd. I, a.a.O., 157.

1364 Bezeichnenderweise war es auch Unterstaatssekretär Karl Lugmayer (ÖVP), der für den Kontakt mit den Hochschulen und Universitäten zuständig war.

1365 UAW, Rektoratsakten, Akademischer Senat, 455-1944/45, Protokoll der 17. Sitzung des Akademischen Senats der Universität Wien, 2. Oktober 1945, 3.

1366 Ernst Fischer und Ludwig Adamovich hielten aus diesem Anlass Festreden. Siehe: Die Wiener volkstümlichen Universitätskurse. Ansprache anlässlich der Fünfzigjahrfeier im Auditorium Maximum am 13. Oktober 1945 von Rektor Adamovich. In: Akademische Rundschau, 1. Jg., Folge 3, 1945, 8.

1367 Vgl. dazu u.a. Hans Altenhuber, Universitäre Volksbildung in Österreich 1895-1937, Wien 1995; weiters Christian H. Stifter, „Geistige Stadterweiterung“. Eine kurze Geschichte der Wiener Volkshochschulen, 1887-2005 (= Enzyklopädie des Wiener Wissens, Bd. III), Wien 2005.

1368 Vgl. auch: UAW, Dekanatsakten, Phil. Fakultät, 1482-1946/47.

1369 Dies waren neben Karl Lugmayer der betagte sozialdemokratische Schulreformer und Leiter des „Vereins Freie Schule“ (1905 ff.) Josef Enslein (1870-1952) und der aus Schruns stammende DDr. Ernst Hefel (1888-1979), der allerdings für Kultusangelegenheiten zuständig war.

1370 Gegenüber einem sozialdemokratischen Freund hatte Ernst Fischer, wie Martin F. Herz berichtete, halb scherzhaft gemeint, dass die (bildungs)politischen Positionen von SPÖ und KPÖ größtenteils 
dieser Stelle anführen, dass er erst im Dezember 1945 die Säuberung der großen Bibliotheken Österreichs - der Nationalbibliothek, der Universitätsbibliotheken in Wien, Graz und Innsbruck sowie der Studienbibliotheken in Linz, Salzburg und Klagenfurt - von nationalsozialistischer Literatur anordnete, ${ }^{1371}$ obwohl bereits im Oktober dieses Jahres, noch dazu vom sowjetischen Vertreter im Alliierten Rat, die Entfernung sämtlicher derartiger Literatur aus allen Bereichen zur Sprache gebracht worden war. ${ }^{1372}$

Zur Frage der Entnazifizierung des Universitätsbetriebes hatte sich Fischer, der eine über die Parteiengrenzen hinausgreifende, grundlegend antifaschistische, demokratiepolitische Integration geradezu beschwor, ${ }^{1373}$ zumindest 1945 öffentlich kaum geäußert und in den Sitzungen des Kabinettrates einen rhetorisch-dialektischen Standpunkt eingenommen; dieser österreichspezifische, moderate und pragmatische Zugang ist - wenngleich nicht ganz so geschliffen -, durchaus bei Parteienvertretern aller Couleur anzutreffen: Besiegelt mit dem „Blut unsterblicher Opfer“ und getragen vom „Bündnis zwischen Volk und Intelligenz", sollten die gesellschaftliche Institution Universität als das „geistige Zentrum Österreichs“ ${ }^{1374}$ und das Kulturleben allgemein trotz „ernsthafter“ Säuberung „einen möglichst geringen Schaden“1375 erleiden und insbesondere die Universität zu einem „Vorpos-

übereinstimmten: „You mean, you like our program and wouldn't mind going along with us, but you just don't believe we aren't agent of the Russsians." Recordings of the U.S. Department of State relating to the Internal Affairs of Austria 1945-1954 (Mikrofilm-Bestand Institut für Zeitgeschichte der Universität Wien), Decimal File, Reel 1, Maj. Martin F Herz to Political Divsion USACA, „Views of State Secretary Ernst Fischer" (2nd Report), 10. August 1945, 1. Gemeinsam engagierten sich Ernst Fischer, Staatskanzler Renner und Unterstaatssekretär Enslein im Rahmen der Lehrerausbildung, indem sie beispielsweise laufend Vorträge am Pädagogischen Institut hielten. Vgl. Wiener Monat, 26. November 1945, 3.

1371 Universitätsarchiv Wien (UAW), Dekanatsakten der Phil. Fakultät, Z1. 571-1945/46, Säuberung der Bibliotheken, 7. Dezember 1945.

1372 Bezeichnenderweise konnte aber in allen folgenden Sitzungen des Exekutivkomitees des Alliierten Rates bezüglich eines Literaturreinigungsgesetzes keine Einigung erzielt werden - unter anderem vertraten die US-Vertreter den Standpunkt, dass die Entnazifizierung der Literatur alleinige Angelegenheit der österreichischen Regierung sei, sodass es trotz der seit März 1946 existierenden Regierungsvorlage zu keinem eigenen Gesetz kam. Vgl. Gerhard Renner, Entnazifizierung der Literatur. In: Meissl (Hrsg.), Verdrängte Schuld - verfehlte Sühne, a.a.O., $211 \mathrm{ff}$.

1373 Am 1. Mai 1945 hielt Ernst Fischer, der in der Ersten Republik selbst an Volkshochschulen vorgetragen hatte, als Staatssekretär für Unterricht und Volksbildung die Eröffnungsrede in der Volkshochschule ,Volksheim ' Ottakring. Darin betonte er, dass zum Schutz des Friedens, der Freiheit und des Wiederaufbaus „die Österreicher aller Parteien und Weltanschauungen einen unzerstörbaren Block bilden“ müssen. Zit. nach: Robert Stumpf, Ernst Fischer als Staatssekretär für „Volksaufklärung, Unterricht und Erziehung und Kultusangelegenheiten" (1945). Versuch einer politischen Biographie unter struktur- und institutionsgeschichtlichen Gesichtspunkten. Bd. I, Dipl.-Arb., Univ. Wien 1997, 31.

1374 Ernst Fischer, Für Freiheit und Vernunft. Ansprache an der Universität zur Eröffnung der volkstümliche Hochschulkurse (Schriftenreihe „Neues Österreich“, Heft 1), Wien 1945, 12.

1375 Protokolle des Kabinettsrats der Provisorischen Regierung Karl Renner 1945. Bd. III: Protokolle des Kabinettsrats 12. September 1945 bis 17. Dezember 1945. Hrsg. v. Gertrude Enderle-Burcel u. Rudolf 
ten“ eines neuen „Österreichbewusstseins“1376 werden. Fokussiert wurde in erster Linie auf die „Hauptschuldigen“ der - so Fischer, der hier gänzlich unkritisch die traditionelle Wissenschaftsauffassung reproduzierte - stärker „ideologisch“ ausgerichteten Geisteswissenschaften; ${ }^{1377}$ die naturwissenschaftlich-technischen Fakultäten (Medizin, Jurisprudenz, Technik et cetera), insbesondere die Kliniken, für die der Kabinettsrat aufgrund der wissenschaftlichen und wirtschaftlichen Bedeutung im August 1945 großzügige Ausnahmen beschloss - nur jene Personen waren zu entfernen, die „sich durch unmenschliche Praxis und lebensbedrohende Versuche am lebenden Leib als untragbar erwiesen "1378 hatten blieben in dieser naiven beziehungsweise technokratischen Sicht ausgeklammert. ${ }^{1379}$

Entsprechend der dritten Durchführungsverordnung des Verbotsgesetzes wurden die Rektorate der Universitäten mit Erlass des Staatsamtes für Volksaufklärung, Unterricht und Erziehung und Kultusangelegenheiten vom I8. August $1945^{1380}$ aufgefordert, „Sonderkommissionen“ für die Überprüfung des Lehrkörpers einzurichten. Die Arbeit dieser auch „Ehrenkommissionen“ genannten Gremien und ihrer Senate lag zunächst allerdings weitgehend im Autonomiebereich der Universität und vollzog sich unter Ausschluß der Öffentlichkeit.

Analog zur zitierten Verordnung vom 22. August $1945{ }^{1381}$ wurden dann bereits im Oktober 1945 unter Federführung von Staatssekretär Fischer im „Staatsamt für Volksaufklärung, für Unterricht und Erziehung und für Kultusangelegenheiten“ insgesamt I2 „Sonderkommissionen I. Instanz gebildet“, um die Personalsäuberungen im öffentlichen Dienst durchzuführen: ${ }^{1382}$

Jerabek, Wien 2003, 33. Sitzung des Kabinettsrats am 3. Oktober 1945, 426. Hier zit. nach: Mugrauer, Die Politik der Kommunistischen Partei Österreichs, a.a.O., 244.

1376 Heiß, Wendepunkt und Wiederaufbau. In: Grandner/Heiß/Rathkolb (Hrsg.), Zukunft mit Altlasten, a.a.O., 17.

1377 So beispielsweise die NS-Professoren Othmar Spann, Heinz Kindermann oder Josef Nadler.

1378 Protokolle des Kabinettsrats der Provisorischen Regierung Karl Renner 1945. Bd. III, 426f. Vgl. Arias, Die Medizinische Fakultät von 1945 bis 1955. In: Grandner/Heiß/Rathkolb (Hrsg.), Zukunft mit Altlasten, a.a.O., 70 .

1379 UAW, Senatssitzungsprotokoll vom 22. Mai 1946; siehe auch: Robert Stumpf, „Dieses Mittelstück und die zwei Enden“. Ernst Fischer in der österreichischen Nachkriegspolitik (1945-1948). In: Bernhard Fetz (Hrsg.), Ernst Fischer. Texte und Materialien, Wien 2000, 147; weiters: Heiß, Wendepunkt und Wiederaufbau: Die Arbeit des Senats der Universität Wien in den Jahren nach der Befreiung. In: Grandner/Heiß/Rathkolb (Hrsg.), Zukunft mit Altlasten, a.a.O., 31.

1380 ÖSTA/AdR, Bestand 02, BMfU, 2C1, Disziplinarkammern, Sonderkommissionen, 1945-1958, Ktn. 378, GZ $4115 /$ III-4a/45.

1381 Gemäß $§ 13$, Abs. 1 der Verordnung der Staatsamtes für Volksaufklärung, für Unterricht und Erziehung und für Kultusangelegenheiten vom 22. August 1945 zur Durchführung des Verbotsgesetzes und der Verbotsgesetznovelle (3. Durchführungsverordnung zum Verbotsgesetz StGbl. Nr. 131/45). Vg1. ÖSTA/AdR, Bestand 02, BMfU, 2C1, Disziplinarkammern, Sonderkommissionen, 1945-1958, Ktn. 378, GZ 4115/III-4a/45, An die Rektorate der wissenschaftlichen Hochschulen, 1.

1382 Derartige Sonderkommissionen wurden auch innerhalb aller anderen öffentlichen Einrichtungen sowie innerhalb der anderen Ministerien eingerichtet, so beispielsweise im Bundesministerium für Land- 
a. Eine Sonderkommission für die eigenen Bediensteten im „hierortigen Staatsamte“, für die Bediensteten der Staatstheaterverwaltung und die Verwaltungsstelle der Wiener Hochschulen sowie die Bediensteten aller dem Staatsamt unmittelbar unterstehenden „nicht schulmäßigen Institutionen aus Kunst und Wissenschaft“; ${ }^{1383}$ diese Sonderkommission gliederte sich wiederum in zehn Senate, für die auch Beisitzer von der Gewerkschaft der öffentlichen Bediensteten vorgeschlagen wurden.

b. Insgesamt acht Kommissionen für die „eigenen Bediensteten“ bei den Hochschulen.

c. Zwei Sonderkommissionen beim Stadtschulrat für Wien, beim Landesschulrat für Niederösterreich, für die Lehrer an Mittel-, Haupt- und Volksschulen sowie an den übrigen öffentlichen Lehranstalten.

d. Eine Sonderkommission bei der Staatstheaterverwaltung für das Personal der Staatstheater.

Mit dieser Verordnung waren auch die Rektorate der Universitäten aufgefordert, entsprechende Sonderkommissionen einzurichten.

Die Sonderkommission I. Instanz innerhalb des „Staatsamtes für Volksaufklärung, für Unterricht und Erziehung und für Kultusangelegenheiten“ war selbst wieder in zehn Senate aufgeteilt. ${ }^{1384}$ Die Leitung des „Senats Nr. 2“, zuständig für „Wissenschaftliche Hochschulen und wissenschaftliche Institute“, hatte Sektionschef Dr. Otto („Baron“) Skrbensky inne, zu seinem Stellvertreter wurde Ministerialrat Dr. Hans Kenda ernannt. ${ }^{1385}$

und Forstwirtschaft, wo neun Senate die Entnazifizierung durchführten. Vgl. ÖSTA/AdR, Bestand 02, BMfU, Sonderkommission 1945-1946, Z1. 1078 - Pr./45, 30. Dezember 1945, 1.

1383 ÖSTA/AdR, Bestand 02, BMfU, Sonderkommission 1945-1946, Z1. 830/Präs./1945, Staatssekretär Fischer an den Liquidator der Einrichtungen des Deutschen Reiches in der Republik Österreich, Herrn Min. Rat Dr. W. Troll, 31. Oktober 1945, 1. Kopie im Besitz d. Verfassers.

1384 „Senat Nr. 1“im Staatsamt - zuständig für das Staatsamt selbst, die Staatstheaterverwaltung und die Verwaltungsstelle der Wiener Hochschulen - leitete Gen. Dir. Dr. Josef Bick (Stellvertreter: Min. Rat Dr. Josef Musil); „Senat Nr. 2“ im Staatsamt - zuständig für Wissenschaftliche Hochschulen und wissenschaftliche Institute - leitete Sektionschef Dr. Otto Skrbensky (Stellvertreter: Dr. Hans Kenda); „Senat Nr. 3“, zuständig für die Kunsthochschulen, leitete Sektionschef Dr. Alfred Eckmann (unter den Beisitzern befanden sich unter anderem Prof. Franz Schuster und Prof. Sergius Pauser), den „Senat Nr. 5"zuständig für den Stadtschulrat für Wien, Sektionschef Dr. Heinrich Gassner (Stellvertreter war Sektionschef Dr. Edwin Zellwecker); „Senat Nr.6“, zuständig für den Landesschulrat für Niederösterreich, wurde ebenfalls von den beiden zuvor Genannten geleitet (beide sozialdemokratische Reformer), allerdings in umgekehrter Hierarchie: den Vorsitz hatte Zellwecker, Gassner war Stellvertreter; „Senat Nr. 7“ (Kunsthistorisches Museum) und „Senat Nr. 8“ (Naturhistorisches Museum) leitete beide Dir. Dr. August v. Loehr mit Dir. D. Hans v. Demel als Stellvertreter; „Senat Nr. 9“, (Österreichische Galerie, staatliche graphische Sammlung Albertina, Museum für Völkerkunde und Museum für Volkskunde), leitete ebenfalls Hans v. Demel und „Senat Nr. 10“, zuständig für die das Kunstgewerbemuseum und Staatsdenkmalamt, Hofrat Dr. Konrad Thomasberger. ÖSTA/AdR, Bestand 04, Bundeskanzleramt (BKA), Sonderkommission 1945-46, Z. 2434, Senatseinteilung, 10. November 1945, 1.

1385 Dieser zahlenmäßig größte Sonder-Senat bestand aus (ordentlichen und außerordentlichen) Universitätsprofessoren und setzte sich für alle Universitäten und Hochschulen und deren Fakultäten aus je- 
Ebenfalls per Verordnung vom 22. August I945 (StGB1. N4. I3I ${ }^{1386}$ eingerichtet, begann Mitte November 1945 eine eigene „Sonderkommission I. Instanz beim Bundeskanzleramt “1387 ihre Arbeit, deren 2I Senate unter dem Vorsitz von Sektionschef Dr. Johann Kaftan standen, und die für die Entnazifizierung der Beamten des Bundeskanzleramtes einschließlich des Auswärtigen Dienstes, der Beamten und Vertragsbediensteten des Archiv- und Bibliotheksdienstes, des Rechnungshofes, für Richter und Beamte des Verwaltungsgerichtshofes sowie des Statistische Zentralamtes zuständig waren. ${ }^{1388}$

Die Aufgabe dieser Sonderkommissionen bestand darin, alle öffentlich Bediensteten, auf die die Bestimmungen des Paragraf 2I des Verbotsgesetzes zur Anwendungen kamen - „unabhängig davon, ob diese aus den NS-Registrierungslisten gestrichen werden oder nicht“ -, danach zu beurteilen, ob sie nach ihrer „bisherigen Betätigung Gewähr dafür bieten, dass sie jederzeit rückhaltlos für die unabhängige Republik Österreich eintreten werden“. ${ }^{1389}$ Im Falle einer negative Beurteilung sollte von der Sonderkommission entweder eine (Ruhe-)Bezugskürzung oder eine Entlassung festgelegt werden, wobei die diesbezüglichen Beamten-Richtlinien der Staatskanzlei vom November 1945 eine gewisse Ambivalenz im Wortlaut aufweisen: Zum einen wurde darin als „dringend notwendig“

weils einem „1. Beisitzer“ (plus einem Beisitzerstellvertreter) sowie einem „2. Beisitzer“ (plus einem Beisitzerstellvertreter) zusammen. Namentlich waren dies für die: Universität Wien (theol. u. jur. Fakultät): R. Köstler (A. Verdross)/W. Winkler (Hans Mayer); Universität Wien (med. Fakultät): K.D. Lindner (H. Chiari)/W. Denk (H. Kahr); Universität Wien (Phil. Fakultät): W. Havers (J. Keil)/F. Faltis (E. Späth) - auch zuständig für die „Zentralanstalt für Körperbildung“; Universitätsbibliothek Wien (inkl. Österreichische Nationalbibliothek, Akademie der Wissenschaften und Meteorologische Zentralanstalt): Hans Pauer (Heinrich Hrdliczka)/Ernst Trenkler (Josef Fickl); Technische Hochschule und Geologische Staatsanstalt: P. Kirste (Böck)/K. Wolf (E. Melan); Hochschule für Bodenkultur: M. Schreiber (A. Steden)/H. Flatscher (Josef Kisser); Tierärtzliche Hochschule: F. Zaribnicky (E. Böhm)/F. Habacher (O. Henneberg); Hochschule für Welthandel: A. Winkler (A. Steden)/G. Riegler (W. Bouffier). ÖSTA/AdR, Bestand 04, BKA, Sonderkommission 1945-46, Z. 2434, Senatseinteilung, 10. November 1945.

1386 ÖSTA/AdR, Bestand 04, BKA, Sonderkommission 1945-46, 27-SK/1946, Schreiben des Vorsitzenden der Sonderkommission I. Instanz beim Bundeskanzleramt an Herrn Senatspräsidenten Dr. Vitus Schmidt beim Bundesgerichtshof vom 2. Jänner 1946, 1. Kopie im Besitz des Verfassers.

1387 ÖSTA/AdR, Bestand 02, BMfU, 47161/IV/Pb/1946, Sonderoberkommission beim BKA, Zuständigkeit der Senate VI und VII, 2. Kopie im Besitz d. Verfassers.

1388 Neben richterlichen Beisitzern waren hier auch Mitglieder „auf Grund der Vorschläge der drei demokratischen Parteien“ vertreten. So zum Beispiel Fritz Bock, Josef Dengler oder Anton Fritsch für die ÖVP, Rosa Jochmann, Bruno Pittermann, Franz Popp und Paul Schärf für die SPÖ sowie Olga Cermak, Franz David oder Johann Dostal für die KPÖ. ÖSTA/AdR, Bestand 04, BKA, Präs. I, Ktn. 3, Bericht der Sonderkommission I. Instanz zur Note der Alliierten Denazifizierungsabteilung vom 19. März 1946, D/2. Kopie im Besitz d. Verfassers.

1389 ÖSTA/AdR, Bestand 04, BKA, Sonderkommission 1945-46, Z1. 7257-3b/45, Staatskanzlei (Dr. Heiterer), Beurteilung öffentlicher Bediensteter durch Sonderkommissionen ( 21 des Verbotsgesetzes), 21. November 1945, 1. 
erachtet, „möglichst bald [...] Klarheit zu gewinnen“, wer für eine „aktive Verwendung in Frage kommt“, zum anderen signalisierte man deutlich, dass ein kulantes Vorgehen manchmal angebracht wäre:

„Wenn Bedarf im allgemeinen und unter Berücksichtigung des besonderen Falles vorhanden ist, wenn ein entsprechender Dienstposten zur Verfügung steht und wenn es die Lage des Falles auch sonst gestattet, ist unter Bedachtnahme auf alle sonst hierfür maßgebenden Umstände die Verwendung (Übernahme auf einen neuzubildenden Personalstand) des betreffenden Bediensteten in Betracht zu ziehen. “1390

Als oberste Kontrollinstanz wurde im Dezember 1945, ebenfalls im Bundeskanzleramt, die sogenannte „Sonderoberkommission“ eingerichtet, die als „zweite Instanz“ - unter dem Vorsitz des Bundeskanzlers beziehungsweise seines Stellvertreters Dr. Heinrich Montel - Entscheidungen über Berufungen gegen die Erkenntnisse der Sonderkommissionen I. Instanz zu treffen beziehungsweise neuerliche Überprüfungen anzuordnen hatte. ${ }^{1391}$ Diese Sonderoberkommission gliederte sich ihrerseits in ${ }_{5}$ Senate, wobei der Senat VI die „Öffentliche[n] Lehrpersonen und sonstige Bedienstete[n] an Schule[n] außer an Hoch- und Mittelschulen“ umfasste, Senat VII hingegen Lehrer und sonstige Bedienstete an Hoch- und Mittelschulen. ${ }^{1392}$ Die Tätigkeit der Sonderoberkommission wurde jedoch erst im Verlauf des Jänner 1946, nachdem die Mitglieder der Senate bestellt waren, aufgenommen.

An dieser Stelle ist hervorzuheben, dass die alliierte Kontrolle der österreichischen Säuberungsmaßnahmen - trotz allmählich spürbar werdender geostrategischer Konflikte ${ }^{1393}$ und Friktionen im Vorfeld des Kalten Krieges und der damit einhergehenden Degradierung von Entmilitarisierung und Entnazifizierung auf bald inhaltsleere Formeln - durch schwerwiegende Vorkommnisse beziehungsweise die Säumigkeit österreichischer Stellen regelrecht herausgefordert wurde und, zumindest temporär, zu einem konsensualen Vorgehen aller vier Besatzungsmächte führte. ${ }^{1394}$

1390 Ebd., 2.

1391 ÖSTA/AdR, Bestand 04, BKA, Präs. I, Kt. 3, Bericht der Sonderoberkommission zur Note der Alliierten Denazifizierungsabteilung vom 19. März 1946, D/2. Kopie im Besitz d. Verfassers.

1392 Sektion III, Abt. 7 des Senats VII war für die Hochschulen und Universitäten zuständig. ÖSTA/AdR, Bestand 02, BMfU, 47161/IV/Pb/1946, Sonderoberkommission beim BKA, Zuständigkeit der Senate VI und VII; an das Bundesministerium für Unterricht, Anhang, 3. Kopie im Besitz d. Verfassers.

1393 So zum Beispiel im Bereich der ursprünglich von den alliierten Besatzungsmächten gemeinsam projektierten Entmilitarisierung des Landes, eine Frage, zu der sich die Fronten langsam zu verhärten begannen. Vgl. dazu Christian Stifter, Die Wiederaufrüstung Österreichs. Die geheime Remilitarisierung der westlichen Besatzungszonen 1945-1955 (=Wiener Zeitgeschichte-Studien 1), Wien 1997, 45 f.

1394 Bis November 1945 beschränkte sich die Tätigkeit des interalliierten Denazifizierungskomitees auf kurze, zumeist repetitive Darstellungen über den Status quo. Der erste derartige ,Bericht' (eigentlich nur 
Ausgehend vom schwerwiegenden Verdacht des Wahlbetruges mit NS-Wählerstimmen bei der ersten Nationalratswahl am 25. November $1945^{1395}$ artikulierte sich vermehrt auch harsche Kritik an der Art und Weise, wie die Entnazifizierung von den verantwortlichen österreichischen Stellen gehandthabt wurde. Das Exekutivkomitee des Alliierten Rates beschloss eine Resolution, mit der sich die alliierten Mächte ab sofort das Recht einräumten, Entlassungen von Angestellten im Bereich von Regierung oder Wirtschaft auszusprechen, sofern diese ein Naheverhältnis zum Nationalsozialismus aufwiesen. ${ }^{1396}$ Des Weiteren wurde ein „Allied Denazification Bureau“1397 als Kontrollgremium eingerichtet. Dessen Kompetenz bezog sich aber nicht auf alle Besatzungszonen und hatte lediglich die Funktion, die Entnazifizierungstätigkeit der Regierung Figl zu supervidieren. Wie sich bei der Durchsicht der Protokolle des Alliierten Rates zeigt, trat dieses Gremium allerdings kaum in Erscheinung.

Am I9. Jänner 1946 kam es schließlich zur Einrichtung eines von den Alliierten zwar nicht dezidiert geforderten - zumindest findet sich dazu kein Hinweis in den Akten -, sicherlich aber erwünschten ministeriellen Entnazifizierungskomitees. ${ }^{1398}$ Dass sich die Installierung dieses Komitees der Initiative Figls verdankt haben soll, ${ }^{1399}$ scheint aufgrund

eine Kürzestzusammenfassung des mündlich vorgetragenen Reports) findet sich im EXCO-Protokoll 4. Oktober 1945. Allied Commission for Austria, Executive Committee (EXCO), Mikrofilm Österreichische Nationalbibliothek (ÖNB), Reel 1 of 22, De-Nazification. Oral report by committee chairman, August 1945-Dezember 1945.

1395 So wurde unmittelbar nach der ersten Nationalratswahl vom 25. November 1945, aus der die ÖVP als stimmenstärkste Partei hervorgegangen war, im Exekutivkomitee des Alliierten Rates die umgehende Einrichtung eines eigenen Sub-Komitees fixiert, das den stattgefundenen Wahlbetrug („electoral fraud“) und "the manner in which the Austrian authorities apply legal sanctions in respect of electoral fraud" kontrollieren bzw. examinieren sollte. Weiter heißt es an dieser Stelle: „It will examine the report on the proceedings instituted against NSDAP party members, who voted fraudulently [...]. It will take all necessary steps that careful examination be made of all other documents in the possession of the Austrian Government dealing with known cases of NSDAP party members participating in the elections, and who have not been handed over to justice." Allied Commission for Austria, Allied Council (ALCO), Mikrofilm Österreichische Nationalbibliothek (ÖNB), ALCO/P(45)40, Reel 1-23, May 1945-Feb. 1946, Plan for the study of illegalities in the Austrian elections, 16. Dezember 1945, 1.

1396 ÖNB, Allied Commission for Austria, Executive Committee (EXCO), EXCO/P(46)17, Reel 2-15, Jan. 1945-May 1946, Denazification of Austrian Government machinery, 23. Jänner 1946, 1.

1397 Vgl. Robert Knight, Britische Entanzifizierungspolitik 1945-1949. In: Zeitgeschichte, 9-10/1984, 293.

1398 Im Protokoll des Alliiierten Rats steht zu lesen, dass das Komitee auf Initiative des Bundeskanzlers eingerichtet worden war. Den Vorsitz des ministeriellen Denazifizierungskomitees hatte Bundeskanzler Figl inne; als Mitglieder gehörten ihm ferner an: Vizekanzler Schärf (SPÖ), Innenminister Oskar Helmer (SPÖ), Außenminister Karl Gruber (ÖVP) sowie Energieminister Karl Altmann (KPÖ). Allein die personelle Zusammensetzung dieses Gremiums lässt erahnen, wie intensiv und nachhaltig die Agenden wohl diskutiert wurden. ÖNB, Allied Commission for Austria, Executive Committee (EXCO), EXCO/P(46)17, Reel 2-15, Jan. 1945-May 1946, EXCO/P(46)59, 17th February 1946, Programme of the Austrian Government. Memorandum from the Austrian Chancellor, 2.

1399 Vgl. Pfefferle/Pfefferle, Glimpflich entnazifiziert, a.a.O., 19 f. 
der Vorgeschichte und der nachfolgenden Tätigkeit dieses Gremiums jedenfalls wenig plausibel. Das Gremium tagte ab sofort zweimal wöchentlich und war gegenüber den Alliierten Besatzungsmächten hinsichtlich Stand und Fortgang der Entnazifizierung berichtspllichtig.

Die Arbeit dieses Komitees erfüllte jedoch kaum die Minimalerwartungen, sodass sich erste Gewitterwolken am Horizont des Alliierten Rates abzeichneten. Hier, wie auch in allen späteren Fällen, waren es aber vor allem die Sowjets und Franzosen, die zu einer offenen und scharfen Kritik der österreichischen Entnazifizierungspolitik ansetzten und diese Kritik unter ihrer jeweiligen Vorsitzführung auch deutlich gegenüber den Verantwortlichen auf österreichischer Seite artikulierten - wozu sich die Briten und insbesondere auch die Amerikaner (jedenfalls im Alliierten Rat) kaum durchzuringen vermochten. Lediglich im Februar 1946 hätten sich - was allerdings nicht aus den Protokollen des Alliierten Rates hervorgeht - die britischen Besatzungsbehörden im alliierten Entnazifizierungsausschuss über das fehlende Verständnis der Dringlichkeit und den mangelnden Fortschritt der Entnazifizierung in ihrer Zone überaus enttäuscht gezeigt: in den meisten Fällen beschäftigten sich die von österreichischen Stellen gesetzten ,Säuberungsmaßnahmen' nämlich mit „Enthaftungen und Wiedereinsetzungen in Ämter“. ${ }^{1400}$ Und der kommunistische Kärntner Volkswille lieferte sogleich die „Gründe für die Unzufriedenheit mit den Säuberungskommissionen“: „Wir finden bei uns in Kärnten Nationalsozialisten, ja sogar Illegale und SS-Männer als Bürgermeister, als leitende Beamte in den Stadtverwaltungen und Bezirkshauptmannschaften [...]. Wir können feststellen, daß in einzelnen Gebieten die Gendarmerie zu 60 bis zu 8o Prozent aus Nationalsozialisten besteht, und daß faktisch das gesamte öffentliche Leben bei uns in Kärnten heute noch eindeutig von den Nationalsozialisten beherrscht wird." 1401

In einem scharfen Statement vor dem Alliierten Rat brachte der sowjetische Oberbefehlshaber General Vladimir V. Kourasov die Problematik offen zur Sprache, indem er die Entnazifizierung österreichischer Behörden als völlig unzureichend abqualifizierte: insbesondere im Bereich der staatlichen Administration und in der Wirtschaft würden sich nach wie vor zahlreich Nazis tummeln. Des Weiteren formulierte Kourasov mit sarkastischem Unterton:

"Those Nazis expelled from one organization are going into others and something in the nature of a migration of Nazis is going on, but not denazification." ${ }^{1402}$ [Hervorhebung d. Verf.]

1400 „Britische Kritik an mangelnder Nazisäuberung“. In: Österreichische Volksstimme. Zentralorgan der kommunistischen Partei Österreichs, Nr. 31, 6. Februar 1946, 1.

1401 Volkswille, 7. Februar 1946, 2.

1402 ÖNB, ALCO, Reel 1 of 23, May 1945-Feb. 1946, Annex II to ALCO/M(46)18, 18th Meeting of the Allied Council, Statement by Col. General Kourasov made at the meeting of the Allied Council on 11th March 1946, 1. 
In einem Schreiben an Bundeskanzler Figl vom I9. März I946 legte dann Brigadegeneral Paul D.R. Cherrière, Oberkommandierender der französischen Streitkräfte in Österreich, als Vorsitzender des Exekutivkomitees die schwelenden Vorbehalte gegenüber der österreichischen Entnazifizierungspolitik auf den Tisch. Anlässlich des letzten Berichtes des inter-ministeriellen Entnazifizierungskomitees sei der Alliierte Rat zu Auffassung gelangt, dass der Fortschritt in der Entnazifizierung unbefriedigend sei und auch die von der Bundesregierung bisher erzielten Ergebnisse in dieser „wichtigen Angelegenheit [...] inadequat“ sind. Die Entnazifizierung, so Cherrière weiter, schreite nur „sehr langsam“ voran: "To this date a considerable number of former NSDAP members are still employed in the majority of the Federal, Provincial and Economic offices of the Austrian State (Ministry of Transport, of Trade, Reconstruction, Social Administration, Legal Courts, etc. ${ }^{\text {“1403 }}$ - die Situation an den Universitäten wurde an dieser Stelle nicht explizit miteinbezogen.

Darüber hinaus ließ Cherrière Bundeskanzler Figl wissen, dass der Alliierte Rat die bisherige Art der Berichterstattung des ministeriellen Entnazifizierungskomitees nicht weiter zu akzeptieren bereit ist, da die Berichte kein klares und umfassendes Bild geben und vor allem die dabei angeführten Statistiken einen völlig irreführenden Eindruck vermittelten. ${ }^{1404}$ Zuletzt wurde moniert, dass es der Alliierte Rat für inakzeptabel halte, dass vom Dienst suspendierte Personen weiterhin ihre Pension beziehen würden. ${ }^{1405}$

Soweit die Kritik des Alliierten Rates, die es an Deutlichkeit nicht fehlen ließ. Vor dem Hintergrund zunehmender alliierter Verstimmung hinsichtlich der verschleppenden österreichischen ,Säuberungspraxis' kam schließlich, beginnend mit dem neuen Erlass zur Durchführungsverordnung zum Verbotsgesetz vom 22. Jänner 1946, doch ein wenig Bewegung in die Tätigkeit der bisher kaum aktiven Sonderkommissionen. ${ }^{1406}$

Auf Landesebene waren für die Personalsäuberungen im Schulwesen „Sonderkommissionen I. Instanz" bei den Landeschulräten eingerichtet worden - zunächst nur für Wien und Niederösterreich, dann auch für die restlichen Bundesländer -, deren Entscheidungen aber den alliierten Militärbehörden zur Begutachtung vorgelegt werden mussten.

Die Tätigkeit dieser Sonderkommissionen I. Instanz sah das Unterrichtsministerium, nicht zuletzt wohl auch angesichts der verstärkten alliierten Kontrolle der Entnazifizie-

1403 ÖNB, ALCO, Reel 1 of 23, May 1945-Feb. 1946, SECA/175, Le General de Brigade Cherrière, Chairman of the Executive Committee, Allied Commission for Austria to Federal Chancellor of State, Figl, 19. März 1946, 1.

1404 Ebd.

1405 Künftig, so Cherrière abschließend, erwarte sich der Alliierte Rat vom Ministerkomitee an jedem ersten und 14. des Monats einen umfassenden Bericht über den Fortschritt in der Entnazifizierung, der u.a. auch die Länder einschließen solle. Ebd.

1406 So datieren beispielsweise die ersten Verfahren der Sonderkommission im Bundeskanzleramt - bis Februar 1947, als die Arbeit der Sonderkommissionen qua „Minderbelastetengesetz“ eingestellt wurde, waren es in Summe nicht mehr als 499 Fälle - auf den 10. Dezember 1945. ÖSTA/AdR, Bestand 04, BKA, Sonderkommission 1945-46, Index für die Akten der Sonderkommission im BKA, 1945-1947. 
rungsmaßnahmen, mit einiger Beunruhigung und sparte dabei auch keineswegs mit offener Kritik an so mancher der getroffenen Entscheidungen und der dafür angeführten Begründungen.

Die Programmatik und das Ethos des Ministeriums ist im Geleitwort von Unterrichtsminister Hurdes zum ersten Verordnungsblatt für den Dienstbereich des Bundesministeriums für Unterricht Anfang Februar 1946 nachzulesen, wo es heißt, dass nach den „Jahre[n] des Schweigens, des bitteren Duldens und des erbitterten Kampfes um Wiedergewinnung einer freien österreichischen Heimat“ nun die Herausforderung im „notwendigen Neubau“ und vor allem im „Abbau alles Unösterreichischen, aller nationalsozialistischen, aller unhumanen Tendenzen“1407 liege.

In einer Weisung des Bundesministeriums, das hinsichtlich der eigenmächtigen Vorgehensweise und der Arbeitsauffassung der Landes-Sonderkommissionen ernste Vorbehalte hegte, wurde dringend darauf hingewiesen, dass eine „Wiederindienststellung ohne vorherige Genehmigung der Alliierten Behörde und Zustimmung des Bundesministeriums für Unterricht [...] unbedingt zu unterlassen“ sei. Interessanterweise sah man sich im $\mathrm{Mi}$ nisterium auch veranlasst, eigens darauf hinzuweisen, „dass dieses Verbot der Wiedereinstellung politisch belasteter Lehrkräfte sinngemäß auf deren Bezüge anzuwenden ist. “1408

Dass die Vertreter der Dienstbehörde im Verfahren vor den Landes-Sonderkommissionen voreilig, oft auch den nachweislichen Sachverhalten zuwider regelrechte Freibriefe erteilten und damit Anlass zu Auseinandersetzungen gaben, geht auch aus einem Schreiben von Minister Hurdes an den Stadtschulrat für Wien und an den Landesschulrat für Niederösterreich hervor. Angesichts der Tatsache, dass in Presse und Öffentlichkeit - und „ganz besonders von den Alliierten“ - ständig auf das „viel zu langsame Fortschreiten der Säuberung des Beamtenapparates von nationalsozialistischen Elementen hingewiesen“ würde, betonte Unterrichtsminister Hurdes, selbst ein Opfer des NS-Regimes, ${ }^{1409}$ dass dieses „Problem nun endlich einmal mit aller Gründlichkeit angefaßt und gelöst werden“ müsse. Entschieden und in differenzierter Argumentation verwahrte er sich gegen eine Praxis voreiliger Exkulpationen auf Grund bloß behaupteter Mitarbeit in der Widerstandsbewegung oder sonstiger Aktivitäten gegen den Nationalsozialismus und forderte ein Mindestmaß an formal korrektem Vorgehen:

1407 Verordnungsblatt für den Dienstbereich des Bundesministeriums für Unterricht, Jg. 1946, Wien am 1. Februar 1946, 1./2. Stück, 1.

1408 ÖSTA/AdR, Bestand 02, BMfU, 2362/IV/1946, Wiedereinstellung politisch belasteter Lehrpersonen nach positiven Erkenntnissen der Sonderkommission I. Instanz, Wien am 22. Juni 1946, 1. Kopie im Besitz d. Verfassers.

1409 Felix Hurdes (1901-1974) war in den 1930er-Jahren als christlichsozialer Landesrat in der Kärntner Landesregierung tätig. 1938 kam er zunächst ins Konzentrationslager Dachau und, nach seiner Freilassung 1939, betätigte er sich im Widerstand. 1944 wurde er ins Konzentrationslager Mauthausen deportiert. Vgl. http://www.wienerzeitung.at/nachrichten/Archiv/197980_Der-Letzte-der-Generation-1945.html 


\begin{abstract}
„Der Behördenvertreter wird aber sein besonderes Augenmerk darauf zu richten haben, dass derartige Behauptungen auch wohlbegründet und stichhaltig sind. Es ist eine nur allzubekannte Tatsache, dass mit der Behauptung, in der Widerstandsbewegung gekämpft zu haben, sehr oft Unfug getrieben wird. Und nicht jeder, der einmal irgend einen Gegner des nationalsozialistischen Regimes aus vielleicht ganz anderen Motiven und ohne jedes Risiko unterstützt hat, wird dies schon als aktive Betätigung gegen den Nationalsozialismus bezeichnen dürfen. Jedenfalls muss feststehen, dass der Betreffende nicht zu gleicher Zeit oder nachher auch noch im nationalsozialistischen Sinne tätig war und sich durch seine angebliche Unterstützung politisch Verfolgter nur eine Art Rückendeckung verschaffen wollte. Auch die in manchen Fällen begründete Behauptung, nur unter starkem Druck der NSDAP beigetreten zu sein, wird genauestens geprüft werden müssen. [...] Viele sind der NSDAP nur deshalb beigetreten, weil sie immer schon gewohnt waren, sich nach der jeweils politischen mächtigen Seite auszurichten. Solche Personen bieten natürlich auch keine Gewähr dafür, sich jederzeit und rückhaltlos für Österreich einzusetzen. “1410 [Unterstreichungen im Original]
\end{abstract}

Hurdes äußerte deutliche Kritik an der offensichtlich weit verbreiteten, schlampigen und „weichen“ Entnazifizierungspraxis. Wie die Lektüre zahlreicher Beratungsprotokolle und der darin enthaltenen Erkenntnisse deutlich macht, war dieser ,Modus operandi“ ebenso für die gängige Spruchpraxis der Sonderkommission I. Instanz im Bundeskanzleramt charakteristisch.

Um hier zumindest ein (allerdings anonymisiertes) Beispiel für diese Spruchpraxis zu geben, sei an dieser Stelle auf ein Erkenntnis der „Sonderkommission I. Instanz beim Landesschulrat für Niederösterreich“ verwiesen, wonach gegenüber einer 42-jährigen Lehrerin erkannt wurde, dass sie jederzeit rückhaltlos für die unabhängige Republik eintreten werde. Als Entscheidungsgrund für dieses Erkenntnis wurde vom Vorsitzenden angeführt:

„Sie ist zwar seinerzeit aus Überzeugung zur NSDAP gegangen, doch hat die durchgeführte Verhandlung ergeben, dass sie sich in vielen Fragen des Unterrichts, der Religion und der Jugendbehandlung [sic] im Laufe der Zeit von der Ideologie des Nationalsozialismus abgewandt hat, sodass angenommen werden kann, dass sie die Gewähr bietet und in ihrer jetzigen Geisteshaltung die Jugend im österreichischen Sinne erziehen kann und wird. “1411

1410 ÖSTA/AdR, Bestand 02, BMfU, 2C1 š Disziplinarkammern, Sonderkommissionen, 1945š 1958, Ktn. 378, Zl. 3011/IV/P/1946, Bundesminister Hurdes an den Stadtschulrat für Wien und an den Landeschulrat für Niederösterreich. Verhalten des Vertreters der Dienstbehörde im Verfahren vor der Sonderkommission, Wien, 13. Februar 1946, 2. Die Erkenntnisse aller Sonderkommissionen fokussierten auf die Beurteilungsformel, ob der/die Betreffende ,jederzeit rückhaltlos für die unabhängige Republik Österreichs eintreten werde." Siehe dazu z.B. ÖSTA/AdR, Bestand 02, BMfU, 936/1946 [I-1216/1], Sonderkommission I. Instanz beim Landesschulrat für Niederösterreich, betref. Beurteilung nach § 21 Verbotsgesetz. Senatsbeschluss vom 22. Oktober 1945, Wien am 5. November, 1. Kopie im Besitz d. Verfassers.

1411 ÖSTA/AdR, Bestand 04, BKA, Liquidator 1945š1 946, Unterricht (1-) 5700š9400, Z 6691, 1. Juni 1946, 1. Kopie im Besitz d. Verfassers. 
An dieser, selbst elementare rechtliche Verfahrensgrundsätze außer Acht lassenden Praxis der Sonderkommissionen übte die „Sonderoberkommission“ des Bundeskanzleramtes schließlich harsche Kritik. In den im Mai 1946 erlassenen „Richtlinien für die Sonderkommissionen I. Instanz" - geradezu ein Schlüsseldokument für die gängige Entnazifizierung im öffentlichen Dienst - werden weit verbreitete Gepflogenheiten der Spruchpraxis, gravierende juridische Mängel und unzulängliche Schlußfolgerungen der Sonderkommissionen scharf kritisiert, wobei anhand der beanstandeten Beschlussverfahren ein insgesamt geradezu fahrlässiges Vorgehen im Bereich der Entnazifizierung an Universitäten und im höheren Schulwesen deutlich wird.

Einmal abgesehen davon, dass über die Beratungen und Abstimmungen oftmals keine Verhandlungsprotokolle angefertigt wurden, die Erhebungsakten mitunter seltsame Wege nahmen und bei Prüfungsverfahren oft nicht verfügbar waren und bei negativen Erkenntnissen zuweilen keine Rechtsfolgen ausgesprochen wurden - zum Beispiel Entlassungen oder Ruhestandskürzungen -, kritisierte die Sonderoberkommission vor allem die Art und Weise, in der teils voreilige, teils „widersprüchliche“ und unsachliche, jedenfalls unzulässige „Erklärungen“ angeführt wurden, wie solche, dass die zu beurteilende Person aufgrund "gute[r] dienstliche[r] Qualifikationen“ oder der „Unentbehrlichkeit“ die besprochene Gewähr bieten würde - eine Argumentation, so die Sonderoberkommission, der "nicht zugestimmt werden kann [...], da die bezeichneten Umstände ein positives Erkenntnis nicht zu rechtfertigen " 1412 vermögen.

In der bereits zitierten Schrift der „Demokratischen Hochschullehrer Österreichs“ wurde ausdrücklich auf dieses in jener Zeit wiederholt verwendete „Lücken-Argument“ Bezug genommen und den Sonderkommissionen empfohlen, die Entfernung von ehemaligen NSDAP-Mitgliedern unter den Hochschullehrern beziehungsweise Lehrern als „eine Art von Kriegsfolge zu betrachten“ - da ja der Krieg auch in sonstiger Hinsicht Lücken gerissen habe. In der Schrift heißt es dazu weiter:

„Der Begriff der Unersetzbarkeit muß zunächst überhaupt vom Gesichtspunkt der Größe des möglichen Schadens betrachtet werden. Im Fall der nationalsozialistischen Hochschullehrer handelt es sich um die Frage, ob ihre Entfernung rein fachlich einen größeren Schaden bedeutet als ihre weitere Tätigkeit als Lehrer [...]. Glaubt wirklich jemand, darin keine Schädigung, keine schwere Gefährdung der Zukunft unseres Landes sehen zu können, wenn dort, wo es um die geistige Formung der akademischen Jugend geht, ein Hochschullehrer, der [...] für

1412 ÖSTA/AdR, Bestand 02, BMfU, Sonderkommission 1945-1946, Richtlinien für die Sonderkommissionen I. Instanz, 22. Mai 1946, beigefügt dem Schreiben Z1. 510/34-SOK/46, Der Stellvertreter des Vorsitzenden der Sonderoberkommission beim Bundeskanzleramt (Dr. Urbantschitsch) an den Liquidator des Deutschen Reiches in der Republik Österreich, 18. September 1946, 10. Kopie im Besitz d. Verfassers. 
den Nationalsozialismus eingetreten ist, sein Lehramt weiter ausüben würde?"1413 [Kursiv im Original, d. Verf.]

Aber zurück zum besagten Richtlinien-Bericht der BKA-Sonderoberkommission. Unter den bemängelten Vorgehensweisen wurde weiters angeführt, dass manche positive Erkenntnisse mit der Formel begründet worden seien, dass gegen den betreffenden Bediensteten „nichts Nachteiliges vorliegt“. Laut Sonderoberkommission enthielte eine derartige Begründung aber „einen inneren Widerspruch. Das ,Nachteilige' im Sinne des Verbotsgesetzes besteht eben in der Zugehörigkeit zur NSDAP usw. Eben weil dieses ,Nachteilige vorliegt, wurde das Verfahren vor der Sonderkommission durchgeführt. ${ }^{\text {(1414 }}$

Auch in diesem Zusammenhang ist nochmals die Schrift der „Demokratischen Hochschullehrer" als eines der raren Dokumente jener Zeit heranzuziehen, in dem sich eine kritische Gegenstimme zum damaligen Entnazifizierungsprozedere im Bereich der akademischer Lehrberufe manifestiert - so sie überhaupt öffentlich bekannt wurde. In dieser Schrift wurde die Auffassung vertreten, dass die rechtliche und moralische Seite in der

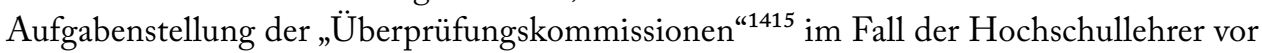
keiner besonderen Schwierigkeit stehe, da hier, wie sonst bei keinem anderen Berufszweig, „die Gefahr, durch ein Generalisieren unrecht zu tun, geringer ist als sonst."Wohl im Wissen um die realen Vorgänge an den Universitäten gab die Vereinigung der „Demokratischen Hochschullehrer Österreichs“ in Bezug auf die Entnazifizierung des Lehrpersonals ein klare Empfehlung:

„Die Überprüfungskommissionen gehen nach dem Grundsatz der Unterscheidung von ,belasteten' und ,unbelasteten' Parteigenossen vor. Dem ist im allgemeinen nichts entgegenzuhalten, im besonderen Fall der Hochschullehrer und beruflich verwandter Akademiker in leitenden Stellungen ist er aber ganz unbrauchbar. Der Universitätsprofessor, der Parteigenosse war, ist eben eo ipso schon belastet, und vor der Diffamierung kann ihn keine Entregistrierung, keine ,Durchschleusung bewahren. ${ }^{\text {"1416 }}$

1413 Die Wehrlosen. Zum Problem der nationalsozialistischen Hochschullehrer. Vereinigung demokratischer Hochschullehrer Österreichs, Wien 1946, 13.

1414 ÖSTA/AdR, Bestand 04, BKA, Sonderoberkommission. Richtlinien für die Sonderkommissionen I. Instanz, 22. Mai 1946, 10. Kopie im Besitz d. Verfassers. Ebd., 11.

1415 Fallweise findet sich in den Akten dieser Terminus mit Bezug auf die „Sonderkommissionen“. Allerdings wurden erst mit dem Nationalsozialistengesetz von Februar 1947 an Stelle der bisherigen Sonderkommissionen nunmehr „Überprüfungskommissionen“ als „besondere Kommissionen“ in den Bundesministerien eingerichtet, die über die Zulassung von Minderbelasteten in Form von Einzelfallprüfungen zu entscheiden hatten. Vgl. Stiefel, Entnazifizierung, a.a.O., 146.

1416 Die Wehrlosen. Zum Problem der nationalsozialistischen Hochschullehrer. Vereinigung demokratischer Hochschullehrer Österreichs, Wien 1946, 9. 
Einen breiten Raum in den Entnazifizierungsverfahren nahmen laut Bericht der Sonderoberkommission - insbesondere bei Vorliegen von Verdachtsmomenten in Bezug auf die „Illegalität“ - häufig Erklärungen ein, die diese Verdachtsmomente zu widerlegen versuchten; jedoch „mit Unrecht“, wie die Richtlinien der Sonderoberkommission strikt herausstellten. ${ }^{1417}$

Schon im Jänner 1946 hatte sich das Unterrichtsministerium darum bemüht, einem allzu konzilianten Behandlungsmodus durch die Sonderkommissionen in dieser Frage zuvorzukommen. Es verwies auf die prinzipielle Zuständigkeit des „Liquidators der Reichseinrichtungen“1418 in der Beurteilung der „Illegalen“, ${ }^{1419}$ wonach im Falle der Annahme der „Illegalität“ das Verfahren von der Sonderkommission „durch Beschluß endgiltig [sic] einzustellen “ ${ }^{1420}$ sei - ein Umstand, der bereits am I8. August 1945 von Unterstaatssekretär Karl Lugmayer ${ }^{1421}$ in einem Rundschreiben an die Rektorate der wissenschaftlichen Hochschulen hervorgehoben worden war, indem „Illegale und ihnen Gleichgestellte ( $\S_{\text {I4 }}$ Verbotsgesetz) $[. .$.$] nicht der Beurteilung durch die Sonderkommis-$ sion unterliegen." ${ }^{1422}$

Nun hielt auch die Sonderoberkommission im Bundeskanzleramt in dieser Angelegenheit unmissverständlich fest, dass sich mit „der Frage der Illegalität der zu beurteilenden Person [...] weder der Spruch noch die Gründe des Erkenntnisses einer Sonderkommission zu befassen [haben]. Die Entscheidung dieser Frage steht einzig und allein der Dienstbehörde (Liquidator) zu. " ${ }^{423}$

Große Rechtsunsicherheit bei den Sonderkommissionen I. Instanz herrschte offensichtlich auch in der Frage, was zu geschehen habe, wenn eine Person vor Einleitung oder Beendigung eines Beurteilungsverfahrens stirbt. So wurden, laut dem zitierten Bericht der Son-

1417 Ab Anfang 1946 wurden, nach alliiertem Druck auf die österreichische Bundesregierung, zudem die sogenannten „Gauakten“ zur Überprüfung herangezogen.

1418 Bei diesem handelte es sich um den Min. Rat Dr. W. Troll.

1419 Gemäß dem Erlass vom 25. Jänner 1946 (Z1. 232/Pr/46). ÖSTA/AdR, Bestand 04, BKA, Präs. I., Kt. 3, 232 /Präs./1946 1.b. Kopie im Besitz d. Verfassers.

1420 Ebd., 2. Einlageblatt zur Z1. 718/Präs./1946. Kopie im Besitz d. Verfassers.

1421 Dr. Karl Lugmayer (1892-1972), war Gymnasiallehrer und ab 1923 Volksbildungsreferent für Niederösterreich. 1934 wurde er vom austrofaschistischen Bürgermeister Richard Schmitz zum Volksbildungsreferenten für Wien bestellt. Nach 1945 war Lugmayer neben Ernst Fischer Unterstaatssekretär im „Staatsamt für Volksaufklärung, für Unterricht und Erziehung und für Kultusangelegenheiten“ und darüber hinaus Ideologe und Programmatiker der ÖVP (wie zuvor in der Ersten Republik des christlichsozialen Lagers). Vgl. dazu Christian H. Stifter, Geistige Stadterweiterung. Eine kurze Geschichte der Wiener Volkshochschulen, 1887-2005, Weitra 2006, 86.

1422 ÖSTA/AdR, Bestand 02, BMfU, 2C1 - Disziplinarkammern, Sonderkommissionen, 1945-1958, Ktn. 378, Z. 4115/III/4a/45, Rundschreiben Unterstaatssekretär Lugmayers an die Rektorate der wissenschaftlichen Hochschulen, 18. August 1945, 1.

1423 ÖSTA/AdR, Bestand 04, BKA, Sonderoberkommission. Richtlinien für die Sonderkommissionen I. Instanz, 22. Mai 1946, 12. Kopie im Besitz d. Verfassers. 
deroberkommission, in mehreren Fällen Erkenntnisse ausgesprochen, dass ein ,verstorbener öffentlicher Bediensteter die Gewähr [biete], dass er jederzeit rückhaltlos für die selbständige Republik Österreich eintreten werde. Offenbar hat diese Sonderkommission vermeint, die Beurteilung des betreffenden Bediensteten sei trotz seines Ablebens wegen der Versorgungsansprüche der Hinterbliebenen vorzunehmen. Diese Rechtsauslegung ist abzulehnen. “1424

Des Weiteren wurden, wenn es sich zum Beispiel bei den betreffenden Personen um „keine öffentlichen Bediensteten“ handelte, gemäß dem Fehlen der Tatbestandserfordernis laut Paragraf 2I des Verbotsgesetzes, von Sonderkommissionen ,automatisch positive Erkenntnisse“ ausgesprochen, mit der „Begründung“, dass die betreffenden Personen eben „nicht zu dem Kreis der zu beurteilenden Personen“ ${ }^{1425}$ gehören würden. [Unterstreichungen im Original]

Ganz besonders kritisierte die Sonderoberkommission aber den Umstand, dass zur Begründung positiver Erkenntnisse gänzlich unzulässige Formulierungen angeführt wurden, wie zum Beispiel, dass die Sonderkommission in ihrer Entscheidung „Gnade vor Recht“ habe ergehen lassen oder dass die zu beurteilende Person sich des ihr gewährten „Vertrauensvorschusses“würdig erweisen „werde“. „Derartige Begründungen haben zu unterbleiben. Es kann nicht die Aufgabe der Sonderkommissionen sein, Gnade für Recht ergehen zu lassen, ebenso wenig haben sie Vertrauensvorschüsse zu erteilen. ${ }^{\text {1426 }}$

Eine kursorische Durchsicht der positiven Erkenntnisse der universitären Senatskommission I. Instanz bestätigt die Verwendung wiederkehrender Standardformulierungen in den Protokollen, die allerdings wenig bis gar nichts mit sachlichen Begründungen zu tun hatten. So hatten die überprüften Personen „in ihrem Leben viel Unglück gehabt“, sie unterlagen „im Jahre I938 einem (ihm) völlig fremden Einfluß“, waren „unter Druck [...] der Partei“ ${ }^{1427}$ beigetreten oder hatten „nur aus einer gewissen Furcht und Unbeholfenheit die Mitgliedschaft angestrebt“ ${ }^{1428}$ So nimmt es nicht Wunder, dass etwa das Naturhistorische Museum Wien im Jänner 1947 unter seinen insgesamt 57 Bediensteten š von seinem „illegalen“ Direktor Josef Wastl ${ }^{1429}$ einmal ganz abgesehen š alle, bis auf eine Person, die

\footnotetext{
1424 Ebd., 14.

1425 Ebd., 15.

1426 Ebd., 16.

1427 ÖSTA, AdR, O2 Unterricht, Präsidium 1946, GZ 401š1.250, Ktn. 5, so z.B. GZ 1237/46, Senatsvorsitzender Verdross an Rektorat Univ. Wien, SK I. Instanz, Senat 3, 1. Februar 1946, 1.

1428 ÖSTA, AdR, O2 Unterricht, Präsidium 1946, GZ 401š1.250, Ktn. 5, z.B. Senatsvorsitzender Verdross an Rektorat Univ. Wien, SK I. Instanz, Senat 3, 8. Februar 1946, 1.

1429 Der Rassenanthropologe Dr. Josef Wastl (1892š 1968) wurde am 18. Februar 1938 zum Leiter der Anthropologischen Abteilung am Naturhistorischen Museum in Wien ernannt, am 20. Oktober $1942 \mathrm{zu}$ dessen Direktor. Im Auftrag des Reichsministeriums des Innern und der deutschen Gerichte führte Wastl anthropologisch-erbbiologische Gutachten in Vaterschafts- und Abstammungsprozessen durch. Wastl trat bereits 1932 der NSDAP bei und galt daher als „Alter Kämpfer“ (NSDAP-Mitgliedsnr. 1.302.356); nach 1934 gründete er eine illegale „Betriebszelle“ der NSDAP im Naturhistorischen Museum. Nach dem „Anschluss“ wurde seine illegale Tätigkeit „Kopieren von Protokollen der österreichi-
} 
„nur“ Blockwart war, NSDAP-Mitglieder, und darunter zu einem sehr großen Teil Illegale, beschäftigte. ${ }^{1430}$

Wie die zitierten Stellen belegen, waren die übergeordneten Instanzen im Unterrichtsministerium beziehungsweise im Bundeskanzleramt von der Entnazifizierungspraxis der Sonderkommissionen - darüber kann auch der juristisch-sachliche Ton der Argumentation nicht hinwegtäuschen - gelinde gesagt vor den Kopf gestoßen. Abgesehen davon, dass in zahlreichen Fällen die „ratio legis“ schlicht ignoriert wurde, indem einige Erkenntnisse die Überschrift „Im Namen der Republik“ trugen - was nur im Fall gerichtlicher Urteile zulässig ist - oder grundlegende juristische Verfahrensbestimmungen außer Acht gelassen wurden, wie zum Beispiel die Durchführungsverordnungen zum Verbotsgesetz, stellt der Bericht der Sonderoberkommission im Bundeskanzleramt der gängigen Spruchpraxis jener Zeit angesichts eigenmächtiger und sachlich nicht zu rechtfertigender Exkulpationen ein rechtsstaatlich geradezu vernichtendes Urteil aus.

Nicht uninteressant scheint in diesem Zusammenhang, dass die Universität Innsbruck in Person ihres Rektors Karl Brunner ${ }^{1431}$ im Mai I946, nachdem das ministerielle Entnazifizierungskomitee weitere personale Säuberungsmaßnahmen durchgeführt sehen wollte, offiziell protestierte, da man die Entnazifizierung für abgeschlossen hielt; den nun „Gefährdeten“ galt es, nach Ansicht Brunners, Schutz zuteil werden zu lassen.

Möglicherweise in indirektem Zusammenhang mit diesen Ereignissen kam es - mit großer Verspätung und aller Wahrscheinlichkeit nach auf alliierten Druck hin - Anfang Mai 1946 gegenüber dem Bundesministerium für Unterricht zu einem eher ungewöhnlichen Antrag der Landeshauptmannschaft Tirol. Man bat darum, für die „Behandlung der ordentlichen und außerordentliche Professoren, der Landesschulinspektoren und Mittelschuldirektoren, sowie Beamte von der 3. Dienstklasse aufwärts“, eine Sonderkommission des Unterrichtsministeriums für Tirol einzurichten. ${ }^{1432}$

schen Ministerratssitzungen, Werfen von Hakenkreuzfähnchen“ besonders gewürdigt; ÖStA, ADM 04, 76660 (Gauakt Wastl), siehe dazu auch: Beförderungsanträge der „alten Kämpfer“: ÖStA, AVA, BMU 15, NHM Fasz. 3207, 313662/39 und Z/GK.6073-Id/1940. Zit. nach: Maria Teschler-Nicola/Margit Berner, Die Anthropologische Abteilung des Naturhistorischen Museums in der NS-Zeit. Berichte und Dokumentation von Forschungs- und Sammlungsaktivitäten 1938-1945. In: Untersuchungen zur Anatomischen Wissenschaft in Wien 1938-1945. Akademischer Senat der Universität Wien, Wien 1998, 333 ff. Vgl. auch: Annalen des Naturhistorischen Museums Wien, 74, Wien 1970, 687 f.

1430 ÖSTA, AdR, O2 Unterricht, Präsidium 1946, GZ 401-1.250, Ktn. 5, GZ 1030/Präs/46, Museum: Illegale Bedienstete. Auszug aus dem Quellenmaterial über die Nationalsozialistischen Bediensteten des Naturhistorischen Museums in Wien, 23. Jänner 1947, 1.

1431 Der Anglist Karl Brunner (1887-1965), von dem es in einem Gestapobericht vom Juli 1938 hieß, dass er "fanatisch vaterländisch eingestellt" sei, wurde nach dem „Anschluss" als Rektor und Professor außer Dienst gestellt. Vgl. Goller/Oberkofler, Universität Innsbruck, a.a.O., 34.

1432 Diese Sonderkommission des Unterrichtsministeriums für Tirol, für deren Vorsitz, wie das Ministerium bat, man selbst „eine Persönlichkeit“ vorschlagen solle - diese wurde schließlich in Dr. Anton Petzer gefunden -, wurde in zwei Senate geteilt, wobei Sektionschef Skrbensky für die Universität, Ministerialrat 
Aber auch in Wien artikulierte sich vereinzelt Widerwille, die vorgeschriebenen,Säuberungsmaßnahmen' durchzuführen, wie sich anhand der Technischen Universität verdeutlicht, die mit der Sonderkommission des Bundeskanzleramtes in Konflikt geriet; dies, obwohl TU-Prorektor Rektor Adalbert Duschek ${ }^{1433}$ tendenziell eine eher klare Entnazifizierungslinie vertrat. ${ }^{1434}$ Den Anfang nahm ein kleiner Artikel in der bereits genannten Wochenzeitung Wiener Montag. Studenten der Technischen Universität Wien hätten sich, so der Zeitungsbericht, an das Medium gewandt, das bisher als einziges den Mut gehabt habe, die „krasse[n] Übelstände“ an den Hochschulen zu kritisieren. Die TU-Studenten wandten sich an die Zeitung, da auch an der TU, trotz monatelanger Tätigkeit der Sonderkommissionen, sonderbare Vorgänge im Lehrkörper zu beobachten wären:

„Die meisten der suspendierten Herren sind unter Hinweis auf deren angebliche Unersetzbarkeit wieder nach einem längeren Aufenthalt im Salzkammergut zurückgekehrt und nehmen ihre Lehrtätigkeit wieder auf.. ${ }^{1435}$

Kenda für die Schulen nominiert wurde. ÖSTA/AdR, Bestand 02, BMfU, 2C1 - Disziplinarkammern, Sonderkommissionen, 1945-1958, Ktn. 378, Z1. 13859-III-7/46, Behandlung der ordentlichen und außerordentlichen Universitätsprofessoren ...", 9. Mai 1946.

1433 Adalbert Duschek (1895-1957), Mathematiker, Dozent an der Technischen Universität (TU) Wien bis 1936, a.o. Professor an der TU bis 1938; da seine Ehefrau von den „NS-Rassegesetzen“ betroffen war, wurde er nach dem „Anschluss“ als Professor in den Ruhestand versetzt, arbeitete jedoch in den Jahren 1940-1945 als wissenschaftlicher Konsulent der ELIN AG. Nach seiner Rückkehr nach Österreich erfolgte die Ernennung zum ordentlichen Professor an der TU Wien. 1945/46 war Duschek, der auch SPÖ-Abgeordneter des Bundesrates war 19.12.1945-7.6.1957, Rektor der TU. Vgl. Juliane Mikoletzky, ,Von jeher ein Hirt starker nationaler Gesinnung“. Die Technische Hochschule in Wien und der Nationalsozialismus, Wien 2003, 4. Siehe auch: http://www.nachkriegsjustiz.at/prozesse/projekte/ diskussion_45-49.php [Zugriff 1.6.2012]; weiters: SPÖ Vetrauensmann. Hrsg. v. Parteivorstand der Sozialistischen Partei Österreichs, Bd. 12, Wien 1957, 191.

1434 So stellte sich Duschek etwa trotz positiven Bescheides (!) der Sonderkommission gegen die Wiederindienststellung von Josef Krames (1897-1986), der nach seiner Professor an der TU Graz (1932-1939) seit 1.10.1939 die II. Lehrkanzel für Darstellende Geometrie an der TU Wien innehatte - laut Duschek ein "prononcierter Nationalsozialist“ und „Inhaber der Ostmarkmedaille“. Dessen ungeachtet kehrte Krames aber bereits 1957 als ordentlicher Professor an die TU zurück und wurde 1961 schließlich Rektor; darüber hinaus kehrte auch der letzte Rektor der NS-Zeit, Heinrich Sequenz, nach zwischenzeitlicher Außerdienstsstellung bereits 1954 als ordentlicher Professor an die TU zurück. Vgl. dazu: Sarah Reisenbauer, Die Entnazifizierung des Lehrpersonals der Technischen Hochschule in Wien. In: Österreichische Hochschulen im 20. Jahrhundert. Austrofaschismus, Nationalsozialismus und die Folgen. Hrsg. v. der Österreichischen Hochschülerschaft, Wien 2013, 366 bzw. 371; siehe auch den lexikalischen Eintrag in: Felix Czeike (Hrsg.), Historisches Lexikon Wien (in 5 Bänden). Band 3: Ha-La, Wien 1994, 590.

1435 Und die Technik? Sonderbares Wirken der Sonderkommission - Naziprofessoren kehren zurück. In: Wiener Montag, 7. Jänner 1946, 4. 
Erst nahezu zwei Monate später begann man sich im Unterrichtsministerium - vermutlich über Nachfrage übergeordneter Stellen - für die Vorgänge an der TU zu interessieren, und bekam von der TU mitgeteilt, dass von den Beamten des nichtwissenschaftlichen Personalstandes bisher noch „kein einziger ehemaliger $\mathrm{Pg}$ [Parteigenosse, d. Verf.] vom Dienst enthoben worden ist.“ Rektor Duschek vertrat dabei die Auffassung, dass „bei Enthebung aller Nationalsozialisten der Betrieb der Techn. Hochschule sofort hätte eingestellt werden müssen“, und überhaupt „sei dies einer der typischen Erlässe vom grünen Tisch, der der Wirklichkeit in keiner Weise Rechnung“ trage. Des Weiteren sei von Sektionschef Skrbensky mündlich die Bewilligung erteilt worden, „die Nationalsozialisten, die er benötige, weiter im Dienst zu belassen. “1436 In demselben Schreiben wurde dann auch gleich hochoffiziell die Weiterbelassung von 23 NSDAP-Mitgliedern beziehungsweise Parteianwärtern - bei diesen Beamten handelte es sich um nichtwissenschaftliches Personal - beantragt; dem Antrag wurde im April 1946 mit dem handschriftlichen Vermerk stattgegeben, „von einem formellen Weiterbelassungsbescheid [...] mit Rücksicht auf die fortschreitende Tätigkeit der Sonderk. und des langen Zeitraumes seit Sept. 945 (wo die Enthebung durchzuführen bzw. die Weiterbelassung zu beantragen gewesen wäre)“,1437 abzusehen.

Interessant ist dieses an sich kleine Detail nicht zuletzt deshalb, weil am 22. März I946 eine alliierte Delegation, bestehend aus Mr. Hardy M. Ray, Repräsentant der US-Education Division des Alliierten Kontrollrates, und dem französischen Kapitän Espiau de Lamaestre von der französischen Unterrichtsabteilung, „unangemeldet“ im Unterrichtsministerium am Minoritenplatz erschien und dort die Ausfolgung der Akten der Sonderkommission für jene Professoren der Technischen Hochschule in Wien verlangte, die als „tragbar“ erklärt wurden und die nun durch das Entnazifizierungsbüro der Alliierten Kommission einer „eingehenderen Prüfung ““1438 unterzogen werden sollten; ${ }^{1439}$ über das Ergebnis geht aus den Akten leider nichts hervor.

1436 ÖSTA/AdR, Bestand 02, BMfU, 2C1 - Disziplinarkammern, Sonderkommissionen, 1945-1958, Ktn. 378, R. Z1. 785 /45, Enthebung der Parteimitglieder vom Dienste, 25. Februar 1946, 2. Kopie im Besitz des Verfassers.

1437 ÖSTA/AdR, Bestand 02, BMfU, 2C1 - Disziplinarkammern, Sonderkommissionen, 1945-1958, Ktn. 378, Z1. 1125 / Präs. 46, Bundesministerium für Unterricht an die Technische Hochschule in Wien, Weiterbelassung von Parteimitgliedern im Dienst, 12. April 1946, 2.

1438 ÖSTA/AdR, Bestand 02, BMfU, 2C1 - Disziplinarkammern, Sonderkommissionen, 1945-1958, Ktn. 378, GZ. 8850-III/6-1946, Staatsamt für Volksaufklärung [Unterrichtsministerium] an das Bundeskanzleramt, Alliierte Kontrollkommission, Einsichtnahme in die Sonderkommissionsakten für die Professoren der Technischen Hochschule in Wien, 22. März 1946.

1439 Die Durchsicht der Protokolle des Alliierten Rats sowie die des alliierten Exekutivkomitees zeigt, dass dieses Ereignis aber nicht auf der Agenda des obersten interalliierten Kontrollgremiums stand. Die Protokolle des ALCO und EXCO sind allerdings weder vollständig (lesbar), noch enthalten sie die Besprechungen bspw. des „Quadripartite Denazification Bureaus“ und schon gar nicht die des „Quadripartite Denazification Bureaus“. 
Wie sich in mehrfacher Hinsicht zeigt, war die exekutive Position der amerikanischen Militärdienststellen in Österreich hinsichtlich der Entnazifizierung in konkreten Anwendungsbereichen bereits Anfang des Jahres r946 keineswegs einheitlich, geschweige denn auf eine entschiedene Vorgehensweise hin ausgelegt. Im Gegenteil: anders als bei übergeordneten militärischen oder zivilen Stellen in Frankfurt oder Washington, die sich aus der räumlichen Distanz wiederholt über Vorgänge in Österreich besorgt zeigten, und abseits inter-alliierter Gremien dominierte bei den verantwortlichen US-Offizieren vor Ort letztlich eine überaus pragmatische, nachgerade konziliante Haltung des Laissez-faire, die fallweise sogar - wie sich noch zeigen wird - dazu führte, einschlägige Vorfälle in quasi austrifizierter Form gegenüber übergeordneten Dienststellen in Washington zu verharmlosen beziehungsweise überhaupt zu beschwichtigen.

Ein Beispiel dafür, wie von amerikanischer Seite mitunter geradezu ,Brücken' gebaut wurden, stellt das einvernehmliche Vorgehen im Bereich der Säuberung des öffentlichen Kulturund Kunstsektors dar. Nach einer Besprechung bei Brigade-General Arthur J. McChrystal, dem Chef der militärischen US-Nachrichtendienstabteilung Information Service Branch (ISB), ${ }^{1440}$ bei der unter anderen Bundesminister Hurdes, Sektionschef Hans Pernter und Viktor Matejka als Wiener Stadtrat für Kultur und Volksbildung teilnahmen, wurde die virulente Frage aufgeworfen, wie mit jenen nationalsozialistisch belasteten Künstlern oder Musikern umzugehen sei, die in keinem Dienstverhältnis mit den Staatstheatern stehen.

In eigens ausgearbeiteten „formellen Leitlinien“, die zwar wenig mit einem demokratischen Kunstverständnis, jedoch viel mit technokratisch-indolenter Kulturpolitik zu tun haben, regte ISB-Chef Brigadegeneral Arthur J. McChrystal an, die in Frage kommenden Personen zunächst in zwei Kategorien zu teilen: in die „Künstler von größerer Bedeutung“ und jene „geringerer Bedeutung“. Darüber hinaus sei unter Vorsitz des Unterrichtsministers eine eigene Kommission zu bilden, die die Überprüfung und mögliche Rehabilitierung im Bereich von „Oper, Schauspiel und Musikleben“vornehmen sollte. Die Aufgabe dieser Kommission liege, so McChrystal weiter, unter anderem darin, festzustellen, welche „Vorteile“ die Personen abseits „formeller Mitgliedschaft“ gezogen hätten, und vor allem zu berücksichtigen, ob „der Künstler persönlich auf diese Vorteile hingearbeitet hat oder ob ihm diese Mitgliedschaft aufgezwungen wurde“. Schließlich sei das „Mass der Notwendigkeit, den Künstler mit Rücksicht auf die Wiederherstellung des österreichischen Kulturlebens heranzuziehen“ beziehungsweise ,in welchem Ausmass das österreichische Publikum das Wiederauftreten wünscht" für die Beurteilung heranzuziehen. Zuletzt ließe sich, so Mc-

1440 Arthur J. McChrystal war zunächst Kommandant der Information and Censorship (INC) und wurde Ende Dezember 1944 mit dem Aufbau des US-Informationsdienstes Information Service Branch (ISB) betraut. In Österreich bestand die Aufgabe des ISB v. a. in der Propagagierung und - in Zusammenarbeit mit anderen Abteilungen wie bspw. auch der Education Division - in der Popularisierung und Durchsetzung des „American way of life. Siehe: Oliver Rathkolb, Politische Propaganda der amerikanischen Besatzungsmacht in Österreich 1945 bis 1950. Ein Beitrag zur Geschichte des Kalten Krieges in der Presse- Kultur und Rundfunkpolitik. Bd. I, Diss., Univ. Wien 1981, 52-57. 
Chrystal, wenn die Umstände es erforderten, auch eine gewisse „Wartezeit“ vorschreiben, „nach deren Ablauf der Fall aufs neue in Behandlung genommen werden könnte“; ${ }^{1441}$ Vorschläge, die vom Unterrichtsministerium dann auch exakt übernommen wurden. Ins Auge fällt auch die geradezu barocke Art, mit der McChrystal das „gemeinsame“ Vorgehen unterstrich (in deutscher Übersetzung):

„Es liegt mir daran, nochmals zum Ausdruck zu bringen, wie sehr ich den Geist erspriesslicher Zusammenarbeit zu würdigen weiss, welcher von Ihnen und Ihren Kollegen bei unserem gemeinsamen Bemühen eine befriedigende Lösung dessen zu finden, was wirklich ein gemeinsames Problem ist. " ${ }^{1442}$

Ungeachtet derartiger ,Fraternisierungen“ formierte sich zunehmend alliierter Druck, diesmal von sowjetischer Seite im Hinblick auf die Situation an den Wiener Schulen. So richtete der sowjetische Volkskommissar für nationale Verteidigung der Militärregierung in Wien, General Nikolaj Lebedenko, am 29. Dezember 1945 ein Schreiben an Bürgermeister Theodor Körner, in dem er wissen ließ, dass die Schulen nach wie vor „in beträchtlichem Maße von nationalsozialistischen Elementen durchsetzt“ sind. „Über 400 Lehrkräfte sind frühere Mitglieder der nationalsozialistischen Partei. [... In Anbetracht des akuten Lehrermangels will ich nicht auf ihrer unmittelbaren Entfernung bestehen, aber ich empfehle Ihnen, eine Kommission zu bilden, welche um den Io. Jänner 1946 bestimmen sollte, welche dieser Lehrkräfte aktive Mitglieder der nat. soz. Partei gewesen sind. Diese Lehrer sollen ohne Verzögerung entlassen werden, ohne Rücksicht auf die Möglichkeit, sie zu ersetzen oder nicht.“1443

Aber auch hinsichtlich der Entnazifizierung der Universitätsprofessoren kam es, nachdem es schon im Sommer 1945 einzelne kleinere kritische Zeitungsartikel gegeben hatte, im November und Dezember 1945 in der Wochenzeitung Wiener Montag ${ }^{1444}$ erstmals zu heftigen öffentlichen Anschuldigungen. Unter der Überschrift „Rückkehr von Naziprofessoren an die Wiener Universität?" berichtete die Zeitung, dass von Prorektor Richard Meister und Dekan Wilhelm Czermak ${ }^{1445}$ - in der Zwischenkriegszeit beide Mitglieder

1441 ÖSTA/AdR, Bestand 02, BMfU, Präsidium (GZ. 401-12500), Ktn. 5, GZ. 982-Präs./46, Bundesministerium für Unterricht, 1. Februar 1946 (Besprechung mit McChrystal vom 28. Jänner 1946), $1 \mathrm{f}$.

1442 Ebd., 2.

1443 ÖSTA/AdR, Bestand 02, BMfU, Z. 5.833/1946, Sowj. Volkskommissar für nat. Verteidigung, Militärregierung in Wien, Nr. 910, 1. Kopie im Besitz d. Verfassers.

1444 Eigentümer und Verleger der Zeitung war die „Französisch-österreichische Verlagsgesellschaft“ mit Sitz in der Mariahilferstraße 47; verantwortlicher Redakteur war Franz Ebenstein.

1445 Wilhelm Czermak (1889-1953) österreichischer Ägyptologe; Assistent bei Hermann Junker an der Universität Wien; ab 1911/12 Grabungsassistent der österreichischen Ausgrabungen bei den Pyramiden in Gizeh unter der Leitung von Junker, der 1923 das Institut für Ägyptologie und Afrikanistik an der Universität Wien gründete. Nach seiner Habilitation im Jahr 1919 wurde Czermak im September 1925 zum ao. Professor für Afrikanistik an der Universität Wien bestellt und folgte im Oktober 1931, 
sowohl der „Deutschen Gemeinschaft" als auch der streng antisemitischen Professorenclique der „Bärenhöhle“ ${ }^{1446}$ - versucht wird, schwer belastete Kunsthistoriker ${ }^{1447}$ zurückzuberufen, und nun auch die Wiener Universität droht, ,zum Schlupfwinkel für Naziprofessoren“ zu werden, „wie es die medizinische Fakultät [...] schon ist“ ${ }^{\text {“ }}{ }^{1448}$

Kurz darauf ging die Zeitung - vor dem Hintergrund der Engerau-Prozesse ${ }^{1449}$ - mit der Universität noch härter ins Gericht. „Untersuchungs- oder Rechtfertigungskommissi-

nach dem Ausscheiden seines Lehrers Junker - ein deklarierter Anhänger des Nationalsozialismus und NSDAP-Mitglied -, als ordentlicher Professor für Ägyptologie und Afrikanistik nach. Czermak leitete das Institut auch während der NS-Zeit. Siehe dazu u. a.: Alois Pumhösel, Ägyptologe, Antisemit, weit mehr als ein Mitläufer (Hermann Junker). In: der Standard, 19. Februar 2013, download unter: http://derstandard.at/1361240485214/Aegyptologe-Antisemit-weit-mehr-als-ein-Mitlaeufer [Zugriff 10.5.2013]; weiters: Christina Köstner-Pemsel/Markus Stumpf, „Machen Sie es ordentlich, damit man nachher, wenn wir die Bücher ihren Besitzern zurückgeben, nicht sagt, es hätten Schweine in der Hand gehabt." In: Mitteilungen der VÖB, 65, 2012, Nr. 1, Anm. 9, 69; zu biografischen Hinweisen betreffend Wilhelm Czermak, die allerdings die Zeit des Nationalsozialismus zur Gänze aussparen, siehe: Erich Sommerauer, Wilhelm Czermak - Afrikanistik, Ägyptologe, 20010. Download unter http://www.afrikanistik.at/pdf/personen/czermak_wilhelm.pdf [Zugriff 10.5.2013] sowie: Wolfdieter Bihl, Orientalistik an der Universität Wien. Forschungen zwischen Maghreb und Ost- und Südasien. Die Professoren und Dozenten, Wien - Köln - Weimar 2009, $103 \mathrm{f}$.

1446 Vgl. dazu die kurzen Ausführungen in Anm. 1262.

1447 Dabei handelte es sich um Hans Sedlmayr (1896-1984) und Karl Oettinger (1906-1979). Auf der Homepage des Kunstgeschichtlichen Instituts der Universität Erlangen wird mit keinem Wort auf Oettingers NS-Vergangenheit hingewiesen - siehe: http://www.kunstgeschichte.uni-erlangen.de/institut/ geschichte.shtml. In dem Nachruf auf Karl Oettinger von Walter J. Hofmann wird auf die NS-Zeit ebenso wenig Bezug genommen. Vgl. Zeitschrift für Kunstgeschichte, 43. Bd., 1980, H. 2, 222-224. Vg1. zur Sedlmayr und Oettinger auch: Sebastian Meissl, Der „Fall Nadler“ 1945-1950. In: Meissl (Hrsg.), Verdrängte Schuld - verfehlte Sühne, a.a.O., 282. 1961 erhielt Sedlmayr schließlich - u.a. durch massive Unterstützung von Unterrichtsminister Heinrich Drimmel, der 1934-1937 als „Sachwalter der Hochschülerschaft Wiens“ (bzw. ab 1935 für ganz Österreich) sowie als Schulungsreferent der Vaterländischen Front eine "gewisse Toleranz“ (Gerhard Wagner) gegenüber den „Nationalen“ bzw. Nationalsozialisten an den Tag gelegt hatte, eine Professur an der Kunstgeschichte in Wien. Vgl. Hans H. Aurenhammer, Das Wiener Kunsthistorische Institut nach 1945. In: Grandner/Heiß/Rathkolb (Hrsg.), Zukunft mit Altlasten, a.a.O., 186 f.; vgl. Wagner, Von der Hochschülerschaft Österreichs zur Österreichischen Hochschülerschaft, a.a.O., $119 \mathrm{ff}$.

1448 Rückkehr von Naziprofessoren an der Wiener Universität? In: Wiener Montag, 3. November, 4. In einer weiteren Ausgabe wurde die Situation an der medizinischen Fakultät dann ein wenige näher präzisiert. Neben dem Histologen Patzelt (siehe auch Kapitel 4, S. 353, Anm. 1395) wurden dabei folgende Namen aufgezählt: der Histologe Wessely (NSDAP-Mitglied), die „Illegalen“ Dozenten Käuffler an der Frauenklinik, Karl Chiari an der Ersten Chirurgisch-orthopädischen Klinik, Paul Morio von der II. Chirurgischen Klinik, sowie Herbert Kraus von der I. Chirurgischen Klinik. Vgl. Naziprofessoren an der medizinischen Fakultät. In: Wiener Montag, 21. Jänner 1946, 4.

1449 Vgl. Claudia Kuretsidis-Haider, „Das Volk sitzt zu Gericht“. Österreichische Justiz und NS-Verbrechen am Beispiel der Engerau-Prozesse 1945-1954 (=Österreichische Justizgeschichte, Bd. 2), Innsbruck 2006. 
onen“ würden Belastete wie zum Beispiel die Germanistikprofessoren Dietrich Kralik ${ }^{1450}$ oder Hans Rupprich „durchschleusen“, und Richard Meister und Wilhelm Czermak betätigten sich dabei als „Protektoren der Naziprofessoren“. Insbesondere sei Meister für die „Streichung des Professors Sedlmayer [sic] von der Liste der registrierten Pgs.“1451 eingetreten. In einem weiteren Artikel, der mittlerweile von der Universität zugespieltes Material miteinbeziehen konnte, wurde die philosophische Fakultät sowie die bereits Genannten beschuldigt, jeden „Besetzungsvorschlag für nazigegnerische Professoren“ zu „sabotieren“ und vor allem „nazistischen Herren“ auf die Lehrkanzeln zu verhelfen. ${ }^{1452}$

Vor allem an der philosophischen Fakultät, so der Bericht des Wiener Montag, würden mittlerweile „unhaltbare Zustände herrschen“, da durch die Bestellungspraxis, die zahlreiche ehemalige NS-Professoren rehabilitiert habe, ${ }^{1453}$ eine „schwere Bedrohung der Entwicklung des Kulturlebens und unseres wissenschaftlichen Nachwuchses" gegeben sei. Bedauerlich sei dabei insbesondere die „schwache Haltung der Unterrichtsverwaltung, die sich nicht zu einem energischen Einschreiten entschließen kann. Hier ist es vor allem der in Hochschulangelegenheiten führende Unterstaatssekretär Dr. Lugmayer [sic], der für die Dinge verantwortlich ist und der, obwohl ihm Material gegen die Naziprofessoren übergeben wurde, diese Material versperrt hält, ohne es der nunmehr tagenden Rechtfertigungskommission vorzulegen. ${ }^{1454}$

Rektor Adamovich sah sich daraufhin zu einer Sachverhaltsdarstellung gegenüber den Vertretern des Erziehungsdirektorates im Alliierten Rat, Oberst Featherstone, Mr. Woodcook, Major L. Ruche und Prof. Ivan V. Ustinow, veranlasst. In einem Schreiben wehrte er sich gegen die wiederholten „Schmähartikel“, in denen die Behauptung aufgestellt wurde, dass „die Professoren der Wiener Universität in Wahrheit versteckte Nazi seien und alles tun, um die Reinigung des Lehrkörpers von Nazielementen hintanzuhalten." Insbesondere sah sich Adamovich veranlasst, Prorektor Richard Meister sowie

1450 Zur Rolle Dietrich Kraliks in der NS-Zeit siehe: Irene Ranzmaier, Germanistik - Kontituitätsstiftende Ansätze der Wissenschaft. In: Mitchell G. Ash/Wolfram Nieß/Roman Pils (Hrsg.), Geisteswissenschaften im Nationalsozialismus. Das Beispiel der Universität Wien, Göttingen 2010, 430 ff.

1451 Protektoren der Naziprofessoren. In: Wiener Montag, 3. Dezember, 4.

1452 Die Wiener Universität, Keimzelle des Nationalsozialismus. In: Ebd., 3. November, 3.

1453 Der Wiener Montag führte dabei auch gleich eine ganze Reihe von Professorennamen an, wie beispielsweise den Historiker (Otto) Brunner, den Mathematiker (Anton) Huber, den Physiker Höfler, die Philologen (Johannes) Mewaldt und (Rudolf) Egger, die (Paläo)biologen Othenio Abel - „Nazi“-Rektor 1932/33 an der Universität Wien und Gründer der antisemetischen Professorenclique der „Bärenhöhle“ - und (Kurt) Ehrenberg, Schwiegersohn Othenio Abels; weiters folgende Dozentennamen: die Psychologin (Sylvia) Klimpfinger, den Musikwissenschafter (Robert) Haas, den Zoologen (Ludwig von) Bertalanffy, den Mineralogen (Franz) Raaz, die Chemiker (Anton von) Wacek und (Otto) Hromatka, die Physiker Schintlmeyer und Herzog. Vgl. ebd.; zu Abel siehe: Taschwer, Die Bärenhöhle und ihr langer Schatten, a.a.O., 4; zu Kurt Ehrenberg siehe: Nachruf Kurt Ehrenberg (22.11.18966.10.1979). In: Mitteilungen der Österreichischen Geologischen Gesellschaft, 72. Jg., 1980, 255-260.

1454 Ebd. 
den Dekan der Philosophischen Fakultät, Wilhelm Czermak, zu verteidigen: gegen sie wurden Vorwürfe laut, sie würden es „mit allen Mitteln durchzusetzen verstehen, daß ehemalige Parteimitglieder wieder in Dienst gestellt oder vor einer Entlassung geschützt werden“. ${ }^{1455}$ Im Bemühen, die Genannten von allen Vorwürfen frei zu halten, schoss der Rektor allerdings weit über das Ziel hinaus, indem er - in nicht besonders glaubwürdiger Argumentation - eingehend versicherte, dass beide „nicht den geringsten Einfluß auf die Frage der neuerlichen Einstellung ehemaliger Parteimitglieder im aktiven Dienst als Hochschulprofessoren nehmen und nehmen können“, da die Entscheidung darüber „ausschließlich einer im Staatsamte für Unterricht gebildeten Sonderkommission“ zustehe, die, so Adamovich weiter, ,ihren Spruch vollkommen frei und unabhängig nur nach ihrer eigenen Überzeugung trifft. “" ${ }^{1456}$

Obwohl nun zweifellos zutrifft, dass die beiden Genannten nominell nicht in den Senaten der Sonderkommission vertreten waren, fällt an dieser Stelle, ohne in psychologische Spekulationen verfallen zu wollen, doch ins Auge, dass der Rektor der Universität Wien hier gegenüber den alliierten Offizieren jegliche Verantwortung formal auf die übergeordnete Instanz abwälzte und zudem bestritt, dass es an der Universität Wien eigene Sonderkommissionssenate mit Entscheidungsbefugnis gab. Hinzukommt, dass Richard Meister ${ }^{1457}$ als Prorektor - wenn schon nicht die Leitung - de facto die Supervision der Sonderkommission innehatte und daher bestens informiert war. Des Weiteren war es auch Meister, der wiederholt an Stelle des abwesenden Dekans der Philosophischen Fakultät, Czermak, der wiederum selbst direkt mit den politischen Säuberungsmaßnahmen an seiner Fakultät befasst war, in den Sitzungen des Akademischen Senats über den Stand der Entnazifizierung Bericht erstattete. ${ }^{1458}$

Daraus ist freilich nicht der Schluss zu ziehen, dass der Pädagogikprofessor im Sinne der zitierten Anschuldigungen gehandelt hat. Wie die Lektüre der Protokolle des Akademischen Senates verdeutlicht, war man sich der heiklen Situation und der exponierten Lage gegenüber der Öffentlichkeit jedenfalls bewusst und trachtete danach, mögliche Konflikt-

1455 UAW, Dekanatsakten der Phil. Fakultät, GZ. 1548-1945/46, 3. Dezember 1945 Akademischer Senat 1945,1 .

1456 Ebd.

1457 Richard Meister (1881-1964), Pädagoge, Philologe, Kulturphilosoph. 1923-38 Universitätsprofessor für Pädagogik, 1938-45 für klassische Philologie, 1945-56 wieder für Pädagogik an der Universität Wien (1949/50 Rektor); 1945-51 Vizepräsident, 1951-63 Präsident der Österreichischen Akademie der Wissenschaften. Vgl. Gernot Heiß, „... wirkliche Möglichkeiten für eine nationalsozialistische Philosophie“? Die Reorganisation der Philosophie (Psychologie und Pädagogik) in Wien 1938 bis 1940. In: Kurt R. Fischer/Franz M. Wimmer (Hrsg.) Der geistige Anschluß. Philosophie und Politik an der Universität Wien 1930-1950, Wien 1993, $140 \mathrm{f}$. Richard Meister war in den Zwanzigerjahren auch Mitglied der streng antisemitischen Professorenclique „Bärenhöhle“ an der Universität Wien. Siehe: Taschwer, Die Bärenhöhle und ihr langer Schatten, a.a.O., 7.

1458 Vgl. UAW, Senats-Sitzungs-Protokoll, 8. Sitzung, Akademischer Senat der Universität Wien, GZ. 1-1946/47, 8. Jänner 1947, 6. 
punkte im Vorfeld zu vermeiden. So wurden die Mitglieder des Lehrkörpers - allerdings erst nach einschlägigen Vorkommnissen an der Universität - „,nachdrücklich ermahnt“, ,in allen ihren Vorträgen, Übungen, Themenstellungen, jede Formulierung zu vermeiden, die das Ansehen eines großdeutschen oder gar nationalsozialistischen gedanklichen Zusammenhanges erwecken könnten. ${ }^{\text {"1459 }}$ Darüber hinaus sprachen sich Rektor und Senat auf Grund der politischen Lage auch hinsichtlich der Habilitation von „Entregistrierten“ für vorsichtiges Zuwarten aus ${ }^{1460}$ und legten - entgegen der keineswegs gesetzeskonformen Unbedenklichkeitszusicherung durch Sektionschefs Skrbensky - bei der Zulassung von Belasteten und Minderbelasteten, die „sehr gefährlich erscheine“, große Vorsicht an den Tag. In einer Besprechung mit Skrbensky wurde ihm mitgeteilt, dass die „Universität [...] es sich nicht leisten [könne], Belastete zur Promotion zuzulassen, weil sonst mit Krawallen bei diesen Anlässen gerechnet werden müsse. “1461

Im Jänner 1946 intensivierten sich dann nochmals die öffentlichen Vorwürfe im Wiener Montag, der nun von einer „Naziseuche an unseren Hochschulen“ sprach und unter Berufung auf den Historiker Alfons Dopsch ${ }^{1462}$ auch schwere Vorwürfe gegen die Österreichische Akademie der Wissenschaften (ÖAW) richtete, wo ehemalige Nationalsozialisten auch nur höchst unzureichend entfernt worden seien. ${ }^{1463}$

1459 UAW, Senats-Sitzungs-Protokolle, Studienjahr 1946. Hier zitiert nach: Heiß, Wendepunkt und Wiederaufbau: Die Arbeit des Senats der Universität Wien in den Jahren nach der Befreiung. In: Grandner/Heiß/Rathkolb (Hrsg.), Zukunft mit Altlasten, a.a.O., 24.

1460 Vgl. Heiß, Wendepunkt und Wiederaufbau: Die Arbeit des Senats der Universität Wien in den Jahren nach der Befreiung. In: Grandner/Heiß/Rathkolb (Hrsg.), Zukunft mit Altlasten, a.a.O., 25.

1461 Nachdem Skrbensky in einem Gespräch dem Dekan der juristischen Fakultät, Rudolf Köstler, erklärt hatte, dass die „Betreffenden zugelassen werden könnten“, ging Adamovich in vorsichtige Distanz zum Sektionschef, indem er diesen darum ersuchte, beim Verfassungsdienst des Bundeskanzleramtes eine Weisung darüber einzuholen, wie die Bestimmung des Minderbelastetengesetzes, wonach alle Minderbelasteten „bis zum 30. April 1950 von der Zulassung zum Hochschulstudium ausgeschlossen“ werden sollten, korrekt zu interpretieren sei. UAW, Senats-Sitzungs-Protokoll, 12. Sitzung, Akademischer Senat d. Universität Wien, GZ. 1-1946/47, 1. März 1947, 2.

1462 Alfons Dopsch (1868-1953), deutschnationaler, antisemitischer österreichischer Historiker mit großem internationalem Einfluss, Mitglied der „Deutschen Gemeinschaft“, wurde nach scharfen Angriffen seines karrierebewußten Kollegen Otto Brunner, der bereits als dessen Nachfolger im Historischen Seminar gehandelt wurde, und unterstützt durch „schwer identifizierbare Kreise“ - wie Thomas Buchner anmerkt -, bereits 1936 vorzeitig pensioniert. Siehe: Thomas Buchner, Alfons Dopsch (1868-1953). Die „Mannigfaltigkeit der Verhältnisse“. In: Karel Hruza (Hrsg.), Österreichische Historiker 1900-1945. Lebensläufe und Karrieren in Österreich, Deutschland und der Tschechoslowakei in wissenschaftsgeschichtlichen Porträts, Wien - Köln - Weimar 2008, $161 \mathrm{ff}$.

1463 Auch hier wurde neuerlich Richard Meister als Schutzpatron der Ehemaligen verdächtigt. Immerhin habe dieser die Wahl Professor Keils in den Akademischen Senat ermöglicht, jener Person, die nach Aussage des von der Staatspolizei verhafteten Archivdirektors der Universität Wien seinerzeit die Verbrennung der Akten von belasteten NS-Professoren angeordnet habe. Siehe: Die Naziseuche an unseren Hochschulen. In: Wiener Montag, 7. Jänner 1946, 3. 
Tatsächlich hatte Alfons Dopsch, wie Johannes Feichtinger und Dieter J. Hecht nachgezeichnet haben, in der Akademie-Sitzung am 22. Juni I945 „Vorschläge für den Neuaufbau“ gemacht, deren zentraler Kern darin bestand, alle ehemaligen NSDAP-Mitglieder „automatisch von der Ehrenstellung eines Akademie[mit]gl[ieds]“ auszuschließen, ,auch wenn sie an der Universität belassen werden sollten. “1464 Dieser Vorschlag, demzufolge mehr als die Hälfte aller wissenschaftlichen und Dreiviertel aller korrespondierenden Akademie-Mitglieder hätte austreten müssen, scheiterte allerdings an Richard Meister, der als Vizepräsident der Akademie diesen Vorschlag einer „generellen Lösung“ offensichtlich geschickt zu Fall brachte. ${ }^{1465}$ Alle Akademiemitgliedschaften ehemaliger NSDAPMitglieder wurden nun - Einzelfall für Einzelfall - zunächst ruhend gestellt, jedoch: „Im Jahr 1949 scheinen aber beinahe sämtliche vormalige NSDAP-Mitglieder, die ab 1945 an den Universitäten (zumindest vorübergehend) ihre Stellen aufgeben mussten, wieder im Mitgliederverzeichnis der ÖAW auf."1466

Dass man die ganze Angelegenheit der Entnazifizierung generell eher als lästige Hürde auf dem Weg zur Normalisierung des universitären Betriebes ansah, denn als Chance und Vorbedingung für einen profunden demokratischen Neubeginn im Wissenschaftsund Hochschulbereich, zeigt sich auch unterschwellig in retrospektiven Bemerkungen von Rektor Adamovich, in denen sich jene Ambivalenz klar widerspiegelt:

„Vom staatspolitischen Standpunkte bedeutete es eine Selbstverständlichkeit, dass Lehrkräfte nicht mehr weiter an der Hochschule wirken durften, die im Hinblick auf ihr früher gezeigtes Verhalten für das wiedererstandene Österreich als politisch untragbar galten. Der Hochschulbetrieb aber musste durch die sich unvermeidlich ergebenden Vakanzen bedrohlich gefährdet werden, da für manche Lehrkanzeln nicht einmal im Wege einer aushilfsweisen Supplierung vorgesorgt werden konnte. “1467

Etwas deutlichere Worte fand Adamovich dann im Vorfeld des neuen Verbotsgesetzes („Minderbelastetengesetz“) im Februar 1947, als er meinte, „dass diese unangenehme Aufgabe leider [sic] durchgeführt werden müsse“. ${ }^{1468}$

1464 Johannes Feichtinger/Dieter J. Hecht, Die Entnazifizierung an der Akademie der Wissenschaften. In: Feichtinger/Matis/Sienell/Uhl (Hrsg.), Die Akdemie der Wissenschaften 1938 bis 1945, a.a.O., 171.

1465 Ebd., 173. Meister vertrat die beschwichtigende und durch nichts zu begründende Ansicht, dass die Akademie in den Jahren 1938-1945 „nur verschwindend wenige, unbedeutende und ihr auferlegte Konzessionen gemacht" hätte.

1466 Ebd., 174. So u. a. auch Otto Brunner, Josef Nadler, Ernst Schönbauer, Hans Sedlmayr, Heinrich Srbik oder Fritz Knoll. Siehe: ebd., 183.

1467 Universität Wien. Bericht über den Studienbetrieb an der Wiener Universität vom Sommer-Semester 1945 bis zum Sommer-Semester 1947. Erstattet von Ludwig Adamovich, Wien 1947, 75 (Anlage I).

1468 Vgl. UAW, Senats-Sitzungs-Protokoll, 7. Sitzung, Akademischer Senat der Universität Wien, GZ. 1-1946/47, 12. Dezember 1946, 3. 
Wie die genannten Beispiele - freilich in unterschiedlicher Tiefenschärfe - zeigen, waren die politischen Säuberungen de facto, und zwar keineswegs nur an der Universität Innsbruck, wie es Gerhard Oberkofler und Peter Goller im Hinblick auf die dortigen Entnazifizierungsmaßen formulierten, längst „ein viele legistische Auswege bietendes Verfahren ohne reale demokratische Basis geworden“. ${ }^{1469}$ Die universitäre Wiedergutmachung konzentrierte sich vor allem auf die Rehabilitierung der 1938 entlassenen Personen - teils Funktionäre des Dollfuß-Schuschnigg-Regimes ${ }^{1470}$ - und nachweislich nicht auf die Rückholung der zur Emigration gezwungenen österreichischen Wissenschafter aus dem Exil. Verbunden mit diesen restaurativen Tendenzen im Universitätsbereich vollzog sich „Vergangenheitsbewältigung“ komplementär durch (latentes) Fortbestehen vordemokratischen, deutschnationalen und antisemitischen Gedankengutes; keineswegs nur in Einzelfällen kam es, wie sich anhand zahlreicher Fallbeispiele zeigt - trotz Entnazifizierungsverfahren - auch zur Rehabilitierung von Universitätslehrern mit einschlägiger NS-Vergangenheit. Dieter Stiefel hat diesen moralischen Umschuldungs- und Entschuldungsprozess auf die allgemeinen Entnazifierungsmaßnahmen in pointierter Weise folgendermaßen charakterisiert:

„Das war der Sinn der Entnazifizierung: Strafe und Rehabilitierung gleichzeitig zu sein. Und diesem doppelten Sinn entsprach auch die Logik des Ablaufs der politischen Säuberung in Österreich: Zuerst auf den Tisch hauen, dann Ordnung machen und schließlich alles verzeihen. ${ }^{\text {1471 }}$

1469 Peter Goller/Gerhard Oberkofler, Universität Innsbruck. Entnazifizierung und Rehabilitierung von Nazikadern (1945-1950), Innsbruck 2003, $13 \mathrm{f}$.

1470 Um hier nur ein Beispiel zu geben, das sonst leicht untergehen könnte, sei auf Prof. Josef G[eorg] Kisser (1899-1984) verwiesen. Der Botaniker und Pflanzenhysiologe Kisser, der sich 1927 habilitiert hatte und 1936 ao. Professor und Vorstand des Botanischen Instituts der Hochschule für Bodenkultur wurde, war im Austrofaschismus Fachreferent für Volksbildung innerhalb der Vaterländischen Front. Nach der Enthebung Viktor Matejkas als operativer Leiter der „Volkshochschule ,Volksheim ' Ottakring“ wurde Kisser von Bürgermeister Richard Schmitz gemäß dem neuen autoritären „Stadtgesetz zur Regelung des Volksbildungwesens“ vom 12. August 1936 neuer Leiter dieser nun vollständig auf vaterländischkatholische Bildungsinhalte umgepolten Bildungseinrichtung. 1938 wurde Kisser „beurlaubt“ und 1940 wurd ihm die Lehrbefugnis entzogen. Nach 1945 kehrte Kisser, der 1941 als Offizier zur Wehrmacht eingezogen wurde, an die Hochschule für Bodenkultur zurück, wo er bald darauf Ordinarius wurde. Kisser saß neben anderen Exponenten des „Ständestaats“, wie u.a. dem Leiter Skrbensky, auch in der Sonderkommission I. Instanz des Staatsamtes für Volksaufklärung, für Unterricht und Erziehung und für Kultusangelegenheiten. Österreichisches Volkshochschularchiv (ÖVA), Wien, Personenkartei, Josef Georg Kisser. Siehe dazu auch das Forschungsprojekt „Eliten/dis/kontinuitäten im Wissenschaftsbereich in der Zweiten Republik. Zur Reintegration der im Nationalsozialismus aus spolitischen Gründen vertriebenen Lehrenden der Universität Wien nach 1945“: http://www.univie.ac.at/universitaet/forumzeitgeschichte/projekte/elitendiskontinuitaeten/[Zugriff 14.5.2013].

1471 Dieter Stiefel, Nazifizierung plus Entnazifizierung = Null? Bemerkungen zur besonderen Problematik der Entnazifizierung in Österreich. In: Meissl (Hrsg.), Verdrängte Schuld - verfehlte Sühne, a.a.O., 35. 
In einer Hinsicht unterschied sich die Situation an den Universitäten und Hochschulen jedoch von anderen gesellschaftlichen Bereichen: auf den „Tisch gehauen“ wurde hier nie. Wie wenig effizient die Arbeit der Sonderkommissionen verlaufen sein muss, lässt sich unter anderem indirekt daraus ersehen, dass es mit der Intensivierung der „Säuberungen“ Anfang 1946 zum Beispiel an der Universität Wien zu „immer heftiger werdenden Angriffe[n]“ auf diese Gremien kam, sodass die den „Sondersenaten“ zugewiesen Behördenvertreter schließlich beim Rektor vorstellig wurden und mitteilten, „ihr Amt nur dann weiterführen zu können, wenn der Herr Bundesminister diesen Wunsch äußert und ihnen damit zu erkennen gibt, dass er in die Art ihrer Amtsführung Vertrauen setzt ${ }^{\text {“1472 }}$ - so Rektor Ludwig Adamovich am I4. Jänner 1946 in einem Brief an Sektionschef Skrbensky.

\section{Entnazifizierung am Beispiel der Universität Wien}

An der Universität Wien, deren Hauptgebäude durch 23 Bombentreffer an elf Stellen schwer beschädigt war - elf Prozent der gesamten Bodenfläche und 65 Prozent der Dacheindeckung waren zerstört ${ }^{1473}$ - traten die „aufbauwilligen Kräfte des Lehrkörpers“ bereits ab Mitte April 1945 zu täglichen Beratungen zusammen. Die erste dieser Sitzungen - eine vom Judaistikassistenten Kurt Schubert ${ }^{1474}$ „einberufene“ und von Wilhelm Czermak in seinem Institut geleitete „Professorenkonferenz" ${ }^{1475}$ - fand am I5. April I945 in den Räumlichkeiten des Institutes für Ägyptologie und Afrikanistik in der Frankgasse I im 9. Wiener Gemeindebezirk statt, eine Adresse auf „zumindest mittelbar »arisiertem«

1472 ÖSTA/AdR, Bestand 02, BMfU, 2C1 - Disziplinarkammern, Sonderkommissionen, 1945-1958, Ktn. 378, Z1. 1000-46, Rektor der Universität Wien an Sektionschef Skrbensky im Bundesministerium für Unterricht, 14. Jänner 1946, 1.

1473 Universität Wien. Bericht über den Studienbetrieb, a.a.O., 75 (Anlage I).

1474 Kurt Schubert (1923-2007), Schüler des Orientalisten und Dekans der geisteswissenchaftlichen Fakultät in der NS-Zeit, Viktor Christian, bei dem er noch kurz vor Kriegsende im März 1945 am Institut für Altorientalische Philologie zu einem assyrologischem Thema promoviert hatte. Nach Kriegsende arbeitete Schubert im „Displaced Persons-Camp Alserbachstraße“, wo er laut Dirk Rupnow „seine Kenntnisse der modernen hebräischen Sprache und der talmudischen Literatur bei Rabbinern“ erwarb. Vgl. dazu: Dirk Rupnow, Brüche und Kontinuitäten. Von der NS-Judenverfolgung zur Nachkriegsjudaistik. In: Ash/Nieß/Pils (Hrsg.), Geisteswissenschaften im Nationalsozialismus, a.a.O., 9 ff bzw. 104. Schubert zählt zur Gruppe der illegalen Widerstandsbewegung der Katholischen Hochschuljugend rund um den Geistlichen Karl Strobl. Nach dem Krieg wurde Schubert 1956 ao. Professor und schließlich Ordinarius und Vorstand des 1966 eingerichteten Institutes für Judaistik der Universität Wien. Vgl. dazu: Karl Strobl, Gruppe Calvarienberg - Wien XVII. In: Siegwald Ganglmair (Red.), Jahrbuch 1995. Dokumentationsarchiv des österreichischen Widerstands, Wien 1995, 124-137.

1475 Vgl. Eszter Bokor, Kurt Schubert: „Unser Haus für das neue Österreich, 2. Mai 2005. Download unter: http://www.dieuniversitaet-online.at/dossiers/beitrag/news/kurt-schubert-unser-haus-fur-das-neueosterreich/258.html [Zugriff 11.5.2013]. 
Institutsboden“ ${ }^{1476}$ an die das Institut 1939 nach „A risierung“ der dort zuvor bestehenden Privatwohnung ${ }^{1477}$ gewechselt hatte.

Am 26. April 1945 versammelten sich die „politisch nicht belasteten Mitglieder des Lehrkörpers“ zur Wahl eines neuen Akademischen Senats. In einstimmiger Wahl wurden die Universitätsfunktionäre - Rektor Ludwig Adamovich, die Dekane der Fakultäten und deren Stellvertreter - gewählt. ${ }^{1478}$ Sowohl bei Rektor und Prorektor, beide prononcierte Proponenten des „Ständestaats“, als auch bei den gewählten Professoren handelte es sich überwiegend um Personen, die 1938 als „Anhänger und Funktionäre des autoritären Ständestaats entlassen worden “1479 ${ }^{14}$ waren; lediglich drei konnten auf persönliche Benachteiligungen durch das NSRegime verweisen. Einzelne Mitglieder waren bald nach ihrer Entlassung wieder in Dienst gestellt worden, da sie „Fürsprecher unter den neuen Machthabern hatten“, ${ }^{1480}$ oder, wie Gustav Entz (dazu später), nach wie vor „nur“ deklarierte Verteidiger eines ,ideellen“ Nationalsozialismus waren. Schon allein auf Grund dieser „Elitenrestauration“ ${ }^{1481}$ im höchsten universitären Gremium - die zweifellos nachhaltige Auswirkungen sowohl auf die Bestellungspraxis als auch auf die Tradierung einer bestenfalls konservativ-deutschnationalen Wissenschaftskultur allgemein hatte - ist der Einschätzung von Gernot Heiß völlig zuzustimmen, der die personelle Erneuerung als „,Rückbruch“ in den Austrofaschismus “1482 interpretiert.

1476 Vgl. Pumhösel, Ägyptologe, Antisemit, weit mehr als ein Mitläufer, a.a.O., 2.

1477 Die Wohnung in der Frankgasse 1 hatte ursprünglich Adolf Loos 1910 für das Ehepaar Arnim und Rosemarie Horowitz eingerichtet. Siehe dazu: Ruth Hanisch, Vom Wienerwald zum Central Park: Wiener Wohnen im New Yorker Exil. In: Eva B. Ottilinger (Hrsg.), Wohnen zwischen den Kriegen. Wiener Möbel zwischen den Kriegen 1914-1941, Wien-Köln-Weimar 2009, 131.

1478 Zum Prorektor gewählt wurde Richard Meister; zum Dekan der kath.-theolog. Fakultät Karl J. Jellouschek (Prodekan: Johannes Gabriel); zum Dekan der evangel.-theolog. Fakultät Gustav Entz; zum Dekan der rechts- und staatsw. Fakultät Ferdinand Degenfeld-Schonburg (Prodekan: Hans Mayer); zum Dekan der med. Fakultät Leopold Arzt (Prodekan: Wilhelm Kerl); zum Dekan der Phil. Fakultät Wilhelm Czermak (Prodekan: Ernst Späth); zum Senator der kath.-theolog. Fakultät: Ernst Tomek; zum Senator der rechtsund staatsw. Fakultät: Alfred Verdross; zum Senator der med. Fakultät: Friedrich Reuter; zum Senator der Phil. Fakultät: Josef Keil. Universität Wien. Bericht über den Studienbetrieb, a.a.O., 6 f. Der Ägyptologe und Professor der Afrikanistik Wilhelm Czermak (1889-1954) wurde 1952 zum Rektor der Universität Wien ernannt und hatte, nach den persönlichen Worten des damaligen Prorektors Richard Meister, die Agenden der Entnazifizierung und „Selbstreinigung“ der Universität mit „Umsicht und kollegialer Herzlichkeit“ gehandhabt. Vgl. Pfefferle/Pfefferle, Glimpflich entnazifiziert, a.a.O., 99. In den Zwanzigerjahren war Wilhelm Czermak sowohl Mitglied der „Deutschen Gemeinschaft“ als auch der streng antisemitischen und deutschnationalen Professorenclique der sogenannten „Bärenhöhle“. Siehe: Rosar, Die Deutsche Gemeinschaft, a.a.O., 32 bzw. Taschwer, Die Bärenhöhle und ihr langer Schatten, a.a.O., o. P. (S. 7).

1479 Heiß, Wendepunkt und Wiederaufbau: Die Arbeit des Senats der Universität Wien in den Jahren nach der Befreiung. In: Grandner/Heiß/Rathkolb (Hrsg.), Zukunft mit Altlasten, a.a.O., 27.

1480 Ebd., 27.

1481 Vgl. Oliver Rathkolb, U.S.-Entnazifizierung in Österreich zwischen kontrollierter Revolution und Elitenrestauration (1945-1949). In: Zeitgeschichte, 11. Jg., 1984, $302 \mathrm{ff}$.

1482 Heiß, Wendepunkt und Wiederaufbau: Die Arbeit des Senats der Universität Wien in den Jahren nach der Befreiung. In: Grandner/Heiß/Rathkolb (Hrsg.), Zukunft mit Altlasten, a.a.O., 27. 
Nach der Genehmigung der Provisorischen Staatsregierung Renner durch die Sowjetarmee wurde die Wahl am 2. Mai 1945 vom zuständigen Staatssekretär für Unterricht, Ernst Fischer, jedenfalls per Erlass genehmigt und damit eine Weichenstellung vorgenommen, die auch später von den zuständigen US-Militärorganen kein einziges Mal in Frage gestellt wurde. ${ }^{1483}$ Noch während der laufenden Schutt- und Räumungsarbeiten konnte der Studienbetrieb, nach Genehmigung des Oberkommandos der Sowjetarmee am 29. Mai 1945, an der Universität Wien als erster Unterrichtsanstalt in Österreich wieder aufgenommen werden.

Noch schwieriger als der „beklagenswerte bauliche Zustand“ und der Mangel an Heizmaterial in den Wintermonaten ${ }^{1484}$ gestaltete sich, so Rektor Adamovich im Rückblick, die "personelle Seite des Betriebes“. Nachdem eine große Zahl der Mitglieder des Lehrkörpers für untragbar erklärt worden war, stand eine „Reihe wichtiger Lehrkanzeln mit einem Schlag vakant, geeignete Nachfolger waren nur zum geringen Teil zu finden." Und das, obwohl - wie Adamovich weiter ausführte - an zahlreiche ehemalige Lehrkräfte der Wiener Universität „die vom nationalsozialistischen Regime zur Emigration gezwungen wurden $[\ldots]$ zu wiederholten Malen die Einladung gerichtet“ wurde, „zu ihrem Lehramt nach Wien zurückzukehren. ${ }^{\text {"1485 }}$ Eine Darstellung, die, wie sich noch zeigen wird, an der Realität freilich gänzlich vorbeiging.

Tatsächlich wurde die politische Überprüfung des Lehrkörpers und der Studierenden (dazu später) bis zur Einsetzung der Sonderkommissionen im August 1945 in Eigenregie vom Rektor, in Zusammenarbeit mit den Dekanaten der Universität, selbst vorgenommen. Mit der Etablierung der manchmal auch „Ehrenkommissionen“ genannten Überprüfungsgremien wurde die Entnazifizierung beziehungsweise die Feststellung der politischen Tragbarkeit der Universitätslehrer drei Senaten übertragen: „Senat I“1486 war zuständig für die Assistenten und wissenschaftlichen Hilfskräfte der medizinischen Fakultät, „Senat II ${ }^{“ 1487}$ für das

1483 Recordings of the U.S. Department of State relating to the Internal Affairs of Austria 1945-1954, Major Leigh M. Lott, Report of First Visit to the University of Vienna, a.a. O., 6. Vgl. UAW, Rektoratsakten, Akademischer Senat, 455-1944/45, Gedächtnisprotokoll a.a.O., 2 f.

1484 So sah sich der Rektor bzw. der Akademische Senat im Winter 1945 - nachdem alle Versuche, Heizmaterial aufzutreiben, gescheitert waren -, gezwungen, den Studienbetrieb einzustellen. UAW, Rektoratsakten, Akademischer Senat 1945, G/80-45 /46, Kundmachung, 4. Dezember 1945.

1485 Ebd., $17 f$.

1486 Vorsitzender des „Senats I“ war Prof. Rudolf Köstler, Beisitzer: Prof. Karl David Lindner; Ersatzmänner waren: Prof. Hermann Chiari und Prof. Heinrich Kahr; 2. Beisitzer (gewählt von der Gewerkschaft der Öffentlich Bediensteten) war: Ass. Paul Grüneis, Ersatzmänner: Ass. Adolf Kronfeld, Ass. Hans Langer, Ass. Fritz Driak, wiss. Hilfskraft Franz Matschnig. ÖSTA/AdR, Bestand 02, BMfU, 2C1 - Disziplinarkammern, Sonderkommissionen, 1945-1958, Ktn. 378, Z. 6721/45, Sonderkommissionen an den Hochschulen, 10. September 1945, 2.

1487 Vorsitzender des „Senats II“ war Prof. Wilhelm Winkler, Beisitzer: Prof. Hans Leitmeier; Ersatzmänner waren: Prof. Franz Faltis, Prof. Josef Keil und Prof. Hans Schima; 2. Beisitzer (gewählt von der Gewerkschaft d. Öffentlich Bediensteten) war: Ass. Otto Brunner, Ersatzmänner: Ass. Walther Schienerl, Ass. 
wissenschaftliche Personal der anderen Fakultäten und „Senat III“1488 für die Überprüfung der übrigen Bediensteten der Universität Wien, mit dem Rechtsphilosophen und Völkerrechtswissenschafter Alfred Verdross ${ }^{1489}$ an der Spitze.

Die Senate setzten sich jeweils aus vier Mitgliedern zusammen, die vom Staatsamt für Volksaufklärung (StVUEK) bestellt wurden: aus jeweils einem Professor der Juridischen Fakultät als Vorsitzendem, einem Ordinarius, einem Dozenten oder nicht-habilitierten Assistenten und einem Behördenvertreter. ${ }^{1490}$ Als ständige Vertreter für die drei Senatsvorsitzenden wurden drei weitere Professoren gewählt: Karl Wolff, Hans Planitz ${ }^{1491}$ und

Hans Arthur Betz und Ass. Alfred Bönisch. ÖSTA/AdR, Bestand 02, BMfU, 02, 2C1 - Disziplinarkammern, Sonderkommissionen, 1945-1958, Ktn. 378, Z. 6721/45, a.a.O., 2.

1488 Vorsitzender des „Senats III“ war Prof. Alfred Verdross, Beisitzer: Prof. Ernst Tomek; Ersatzmänner waren: Prof. Josef Weninger, Prof. Hans Schima und Prof. Johannes Gabriel; 2. Beisitzer (gewählt von der Gewerkschaft der Öffentlich Bediensteten) war: Techn. Oberoff. Karl Jistel, Ersatzmänner: Operpedell Hans Hammerschmid, Quästor Josef Litschauer, Oberlaborant Rudolf Rauscher, Gärtnermeister Josef Honomann, Oberoff. Johann Lukas, Oberoff. Georg Roch, Laborant Franz Kriwanek, Oberlaborant Johann Schwella, Ing. Leopold Borowicka. ÖSTA/AdR, Bestand 02, BMfU, 2C1 - Disziplinarkammern, Sonderkommissionen, 1945-1958, Ktn. 378, Z. 6721/45, a.a.O., 3.

1489 Alfred Verdross-Droßberg (1890-1980), Sohn eines Generals der österreichisch-ungarischen Armee. Verdross studierte an den Universitäten Wien, München und Lausanne Rechts- und Staatswissenschaften und promovierte 1913 in Wien zum Dr. jur. 1916 wurde er als „Oberleutnant-Auditor“ an den Obersten Militärgerichtshof berufen. Nach Kriegsende habilitierte sich Verdross und arbeitete bis 1924 als Sektionsrat im Außenministerium. 1924 wurde er a.o. Professor und erhielt ein Jahr später den Lehrstuhl für Internationales Recht und Rechtsphilosophie. Daneben war Verdross auch als Vortragender an Wiener Volkshochschulen tätig und lehrte an der Wiener Konsularakademie. Vgl. Oliver Rathkolb, Die Rechts- und Staatswissenschaftliche Fakultät der Universität Wien zwischen Antisemitismus, Deutschnationalismus und Nationalsozialismus 1938, davor und danach. In: Heiß et al. (Hrsg.), Willfährige Wissenschaft, a.a.O., 216 ff. Zur Biografie Alfred Verdross' siehe weiters: Eintrag „Alfred Verdross(-Drossberg)“ im Online Munziger-Archiv. [http://www.munzinger.de/search/portrait/Alfred+Verdross+Drossberg/0/6796.html]; siehe weiters: Heribert Franz Köck, Leben und Werk des österreichischen Rechtsgelehrten Alfred Verdross. In: Zeitschrift für öffentliches Recht, Bd. 42, 1991, 31 ff. Neben Josef Dobretsberger, Georg Fleischer, Margit Fuchs, Leo Gross, Felix Kaufmann, Josef Laurenz Kunz, Adolf Merkl, Rudolf Aladár Métall, Leonidas Pitamic, Gisela Rohatyn, Sigmund Rohatyn, Fritz Sander, Fritz Schreier, Alfred Schütz und Eric Voegelin gehörte auch Verdross zum „Wiener Kelsen-Kreis“. Vgl. Tamara Ehs, Vertreibung in drei Schritten. Hans Kelsens Netzwerk und die Anfänge österreichischer Politikwissenschaft. In: Österreichische Zeitschrift für Geschichtswissenschaften [Schwerpunkt: „Vertriebene Wissenschaft“], 21. Jg., 2010, Bd. 3, 154.

1490 Den Behördenvertretern kam sozusagen die Rolle des Staatsanwalts zu. Der Behördenvertreter für den „Senat I“ war der Leiter der Rektoratskanzlei Rudolf Fischer, für „Senat II“ Priv.-Doz. August Knoll, für „Senat III“ Roland Grassberger. ÖSTA/AdR, Bestand 02, BMfU, 2C1 - Disziplinarkammern, Sonderkommissionen, 1945-1958, Ktn. 378, Z.6721/45.

1491 Der deutsche Rechtswissenschafter Hans Planitz (1882-1954), war von 1929-1930 Rektor der Universität Köln und von 1936-1939 ebendort Dekan der Rechtswissenschaftlichen Fakultät; 1941 folgte er - maßgeblich unterstützt von Dekan Ernst Schönbauer - einem Ruf an die Universität Wien als Professor für „Deutsches, Bürgerliches und Handelsrecht“. In seiner Rektoratszeit in Köln hatte er sich eigener Aussage nach gegen nationalsozialistische Aktivitäten gewandt, indem er, wie auf der Home- 
Hans Mayer. Die Senate legten ihre Beurteilungen der übergeordneten Kommission, die am Dekanat oder Rektorat amtierte, vor. ${ }^{1492}$

Die Professoren wurden, wie bereits erwähnt, direkt von der Hochschul-Sonderkommission des Unterrichtsministeriums überprüft, die unter der Leitung des für das Hochschulwesen zuständigen, als unberechenbar und hocharistokratisch-skurril beschriebenen Sektionschefs Skrbensky ${ }^{1493}$ und seinem Stellvertreter Hans Kenda stand; ihr gehörten noch jeweils zwei Ordinarien der Universitätsfakultäten beziehungsweise Hochschulen (inklusive zweier Ersatzmänner) als Beisitzer an, wobei einer von der Gewerkschaft der öffentlich Bediensteten ernannt wurde. ${ }^{1494}$

page der Universität Köln unter „Rektorenportraits“ zu lesen steht, „z.B. dem Nationalsozialistischen Deutschen Studentenbund verbot, eine Anschlagtafel im Gebäude der Universität anzubringen“; Planitz ist ein Beispiel für so manch ungewöhnliche Kontinuität reichsdeutscher Professoren, die nicht, wie im Beamten-Überleitungsgesetz festgelegt, tatsächlich entlassen wurden, sondern die österreichische Staatsbürgerschaft zuerkannt bekamen und anschließend durch den „politischen Kabinettsrat" neuerlich zu Professoren ernannt wurden. Die Weiterverwendung reichsdeutscher Professoren an der juridischen Fakultät nach 1945, so u. a. auch die von Hans Kreller - der ohne „innerliche Bindung bei der Partei gewesen“ wäre -, betraf insbesondere die „historischen Fächer“. Siehe: Margarete Grandner, Das Studium der Rechts- und Staatswissenschaftlichen Fakultät der Universität Wien 1945-1955. In: Grandner/Heiß/Rathkolb (Hrsg.), Zukunft mit Altlasten, a.a.O., 297f.; weiters: Vgl. Heiß, Wendepunkt und Wiederaufbau. In: Grandner/Heiß/Rathkolb (Hrsg.), Zukunft mit Altlasten, a.a.O., 33; zum massiven Einsatz Ernst Schönbauer als Dekan der Rechts- und Staatswissenschaftlichen Fakultät und bekennenden Nationalsozialisten bei der Berufung von Planitz siehe insbesondere: Oliver Rathkolb, Die Rechts- und Staatswissenschaftliche Fakultät der Universität Wien zwischen Antisemitismus, Deutschnationalismus und Nationalsozialismus 1938, davor und danach. In: Heiß et al. (Hrsg.), Willfährige Wissenschaft, a.a.O., $204 \mathrm{f}$.

1492 ÖSTA/AdR, Bestand 02, BMfU, 2C1 - Disziplinarkammern, Sonderkommissionen, 1945-1958, Ktn. 378, Z. 4115/III/4a/45, Rundschreiben Unterstaatssekretär Lugmayers an die Rektorate der wissenschaftlichen Hochschulen, 18. August 1945. Vgl. auch Vgl. Reinhold Knoll, Die Entnazifizierung an der Universität Wien. In: Meissl (Hrsg.), Verdrängte Schuld - verfehlte Sühne, a. a.O., 277 f.

1493 In der hausinternen Chronik, die Ober-Staatsbibliothekar Dr. Otto Guglia - seit 1945 Leiter der Amtsbibliothek des Bundesministeriums für Unterricht - für die Jahre 1948-1953 angelegt hat, heißt es zu Skrbensky als „typische[m] Vertreter der österreichischen Hocharistokratie“: „Auch die, die ihn gut zu kennen glaubten, überraschte er manchmal durch seine Unberechenbarkeit und nicht selten auch durch seine Skurrilität, beides wohl Symptome eines alten und hochgezüchteten Stammes. In diesem Zusammenhang mag hervorgehoben werden, daß Skrbensky in Hochschulkreisen vielfach den Beinamen „der rote Baron“ führte: ein bezeichnender, aber nicht ganz treffender Ausdruck, denn er berührte mehr die Peripherie als den Kern der Erscheinung Skrbenskys. Sein oben geschildertes Verhalten im Verkehr mit der Umwelt ließ ihn, der im Grunde ebenso konservativ empfand wie die Schicht, aus der er stammte, manchmal mit politischen Äußerungen kokettieren, die bei ihm vor allem bezweckten, zu verblüffen." Zit nach: Chronik des Bundesministeriums für Unterricht seit dem Jahre 1948 [bis 1953], o. O., o.J., hier: 1952, 6 (ohne Pagina); an dieser Stelle danke ich meinem Kollegen Mag. Robert Stumpf herzlich für die Überlassung einer Kopie; diese befindet sich heute im Bestand des Österreichischen Volkshochschularchivs.

1494 Für die Sonderkommission I. Instanz an der Universität Wien wurde jedoch nur der „Senat III“ im Einvernehmen mit der Gewerkschaft bestellt. ÖSTA/AdR, Bestand 02, BMfU, 2C1 - Disziplinarkam- 
Wie Martin F. Herz, „einer der klügsten amerikanischen Beobachter dieser Zeit“, 1495 der zuvor für das „Office of War Information“ beziehungsweise für die US-„,Psychological Warfare Division“ gearbeitet hatte ${ }^{1496}$ und nun als „Political Officer“ der US-Botschaft in Wien vertrauliche Informationen zusammenstellte, mit Bezug auf das Unterrichtsministerium anmerkte, war gegenüber der demokratie- und bildungspolitischen Einstellung von dessen ranghöchsten Beamten durchaus Skepsis angebracht:

\begin{abstract}
"This ministry is the bulwark of the Cartellverband since Minister Hurdes himself is an Alter Herr' (CV member). Actively cooperating with him is Dr. Hans Pernter, a former Minister of Education under Dollfuss and Schuschnigg, present member of Parliament and chief of 'cultural affairs' of the Peoples's Party. Perhaps the most powerful single official, however, is Sektionschef Dr. Otto Skrbensky, a CV member who controls university appointments. Part, at least, of the appalling decline of Austria learning must be charged to the narrowly conservative orientation of these personalities." ${ }^{1497}$ [Hervorhebungen i. Orig., d. Verf.]
\end{abstract}

Die hier zum Vorschein kommende, sachlich-kühle, kritisch-analytische Distanz eines hochinformierten, langjährigen US-Informationsoffiziers wurde allerdings - wie sich noch zeigen wird - von den Beamten der einschlägig befassten US-Militärstellen keineswegs geteilt, im Gegenteil: die leitenden Offiziere der amerikanischen Education Division pflegten mitunter einen geradezu amikal-barocken Umgangston, der Kritik oder sachliche Distanz förmlich ausschloss.

Aber zurück zur Tätigkeit der Sonderkommissionen. Die Rektorate und Dekanate hatten umgehend das "gesamte vorhandene oder noch zu beschaffende belastende Material“ an das Staatsamt zu übergeben, allfällig erhobene Zeugen zu benennen, Entlastungsmaterial sowie die Ansuchen um Ausnahme von der Registrierungspflicht und eine Liste der „derzeit Anwesenden einer Beurteilung nach § 2 I des Verbotsgesetzes zu unterziehenden ordentlichen und ausserordentlichen Hochschulprofessoren jeder Hochschule“ vorzulegen. ${ }^{1498}$

mern, Sonderkommissionen, 1945-1958, Ktn. 378, Z1. 7463/45, Österreichischer Gewerkschaftsbund. Gewerkschaft der Öffentlichen Angestellten an das Staatsamt für Volksaufklärung, für Unterricht und Erziehung und für Kultusangelegenheiten, Errichtung von Sonderkommissionen, 11. Oktober 1945.

1495 Manfried Rauchensteiner, Die Zwei. Die Große Koalition in Österreich 1945-1966, Wien 1987, 61.

1496 Major Martin F. Herz (1917-1983) arbeitete 1944/45 als Spezialist für psychologische Kriegsführung („Chief combat leaflet writer of Psychological Warfare Division“, SHAEF, London/Paris). Siehe: Wagnleitner, Understanding Austria. Curriculum Vitae, a.a.O., 18; vgl. auch: Rathkolb (Hrsg.), Gesellschaft und Politik am Beginn der Zweiten Republik, a.a.O., 2 bzw. 415.

1497 Reinhold Wagnleitner (Ed.), Understanding Austria. The Political Reports and Analyses of Martin F. Herz, Political Officer of the US Legation in Vienna 1945-1948, Salzburg, 1984, 572 f. Ich danke meinem Kollegen Mag. Robert Stumpf an dieser Stelle für diesen Hinweis.

1498 ÖSTA/AdR, Bestand 02, BMfU, 2C1 - Disziplinarkammern, Sonderkommissionen, 1945-1958, Ktn. 378, Z. 4115/III/4a/45, Rundschreiben Unterstaatssekretär Lugmayers an die Rektorate der wissenschaftlichen Hochschulen, 18. August 1945, 3. 
Dass es dabei nicht nur zu großen zeitlichen Verzögerungen kam - die Tätigkeit der Sonderkommissionen begann eigentlich erst Ende November 1945 anzulaufen -, sondern auch zu mitunter heillosem Durcheinander im Aktenverlauf, ist leicht vorzustellen. Rektor Adamovich brachte die zum Teil offenbar schier chaotischen Zustände gegenüber dem Unterrichtsministerium in harmlos anmutenden Worten zum Ausdruck:

„Insbesondere ergibt sich in den Fällen der Prüfung der politischen Zuverlässigkeit von Lehrkräften, wissenschaftlichem Personal und Angestellten der Hochschulen immer wieder ein Durcheinandergehen von Akten der Rektorate, des Bundesministeriums und der Verwaltungsstelle.“"1499

Dass die Übergabe der verlangten Akten beziehungsweise die Aufstellung der bereits erfolgten Suspendierungen selbst im März I946 noch nicht erfolgt war, geht aus einem Rundschreiben von Rektor Adamovich an die Dekane der fünf Fakultäten hervor, worin er mitteilte, dass das Bundesministerium für Unterricht auf dringenden Wunsch der alliierten Militärbehörden, eine genaue „namentliche Aufstellung über die durch das Verbotsgesetz belasteten Lehrkräfte der Universität Wien“, eine „namentliche Liste der an der Universität Wien seit 1945 ausgeschiedenen NS-Lehrkräfte“ sowie eine Liste der „an der Universität [...] seit April I945 ausgeschiedenen NS-Lehrkräfte“ dringlichst - „bis längstens Montag, den I8. März I946, 9 Uhr“ - erbat. ${ }^{1500}$

Damit war die Angelegenheit, wie sich bald darauf zeigten sollte, allerdings noch nicht erledigt. Ganz offensichtlich verursacht durch alliierte Kontrollen beziehungsweise die Urgenz des ministeriellen Entnazifizierungskomitees, ${ }^{1501}$ wandte sich Sektionschef Skrbensky am I3. März I946, stellvertretend „für den Bundesminister“, an das Rektorat der Universität Wien und forderte, alle Lehrkräfte und Angestellte, deren „Weiterbelassung trotz Zugehörigkeit oder Anwartschaft zur NSDAP von hier aus bis zur Erledigung des Falles durch die zuständige Sonderkommission zugestanden wurde“, im „Falle eines negativen Spruches der Sonderkommission I. Instanz vom Dienst zu entheben, bis die Sache im Berufswege durch die Oberkommission rechtskräftig entschieden" ${ }^{1502}$ werde. [Hervorhebung d. Verf.]

1499 ÖSTA/AdR, Bestand 02, BMfU, Präsidium (GZ. 401-12500), Ktn. 5, Rektorat der Universität Wien an das Bundesministerium für Unterricht, 14. Februar 1946, 1.

1500 UAW, Sonderbestand 90, Sonderkommission 1945, GZ. 154-45/46, 15. März 1946, 1.

1501 In einem Rundschreiben (Nr. 50) des Unterrichtsministeriums, das auf Anordnung des Ministerkomitees „zur ,Säuberung“ der höchsten Staats- und Wirtschaftsämter von Nazielementen“ an alle Dienststellen in Wien erging, wurde ,sehr dringend“ die Ausfertigung der genannten Listen bis „spätestens Freitag, den 29. März 1946, 16 Uhr“ gefordert. UAW, Dekanatsakten der Phil. Fakultät, Zl. 1142-1945/46, 28. März 1946, 1.

1502 UAW, Dekanatsakten der Phil. Fakultät, Zl. 1058-1945/46, BmfU, Einstweilige Dienstbelassung von negativ durch die Sonderkommission Beurteilten bis zur Berufungsentscheidung, 13. März 1946. 
Der Wortlaut dieses Schreibens ist in mehrfacher Hinsicht aufschlussreich, weil daraus hervorgeht, dass Skrbensky als der für die Hochschulen zuständige Leiter der „Sonderkommission I. Instanz" im Unterrichtsministerium offenbar keine Evidenz über die laufenden Verfahren in seinem Ressort hatte, und auch nicht über die „vorläufig“ im Dienst Belassenen sowie jene, über die negativ entschieden und die daher zu entheben waren.

Zugleich stellte der Leiter der Überprüfungskommission aber - und das scheint doch bemerkenswert - die Möglichkeit in den Raum, dass die Entscheidungen der Sonderoberkommission die erfolgten Enthebungen letztlich wieder „rechtskräftig“ rückgängig machen würden.

An einem einige Tage später ausgesandten Rundbrief von Rektor Adamovich an alle Dekanate lässt sich ablesen, dass es keinesfalls gängige Praxis war, nach negativen Entscheidungen der Sonderkommission die ,sofortige Enthebung aller in Betracht kommenden Lehrkräfte“ zu veranlassen. ${ }^{1503}$ Wie aus den Antwortschreiben der einzelnen Dekanatsleitungen

1503 So entschied der Akademische Senat, politisch „belastete“ Professoren, die nach einer positiven Beurteilung durch die Sonderkommission weiter lasen, in den Vorlesungsverzeichnissen namentlich nicht zu nennen, sondern lediglich mit N.N. (nach Nennung) anzukündigen. Wie Prorektor Meister in einer Sitzung verlautete, durften auf Weisung des Unterrichtsressorts insbesondere an der medizinischen Fakultät unter den „belasteten Professoren“ nur drei namentlich angeführt werden, nämlich Schönbauer, Antoine und Patzelt; Tassilo Antoine (1895-1980), NSDAP-Parteimitglied, Professor für Geburtshilfe und Frauenheilkunde und Ordinarius an der Innsbrucker Universitätsklinik, der 1943 Nachfolger von Amreich an der Wiener Universitätsklinik wurde; Antoine habe sich lediglich als NS-Parteianwärter gemeldet, weil er „sonst nicht die Professur erlangen hätte können.“ Zudem habe Antoine „niemals den am Anfang von Vorlesungen vorgeschriebene Hitlergruss geleistet und Frauen von Antifaschisten grundsätzlich kostenlos behandelt." Zit. nach: Entnazifizierung der Lehrkräfte der Universität Wien (G.-Zl. 32141/III-7/46). Enthalten in: Appendix „A“, Report of Quadripartite Sub-Committee on Denazification in Austrian Universities, 7. September 1946. NARA II, RG 260, a.a. O., 1. Isabelle Ackerl schreibt: „Das offizielle Österreich wusste um seine Verdienste und hat mit zahlreichen Ehrungen dem Rechnung getragen: Tassilo Antoine erhielt das Große Silberne Ehrenzeichen, das Ehrenzeichen für Wissenschaft und Kunst (1972), den Ehrenring der Stadt Wien (1965), den Preis der Stadt Wien für Naturwissenschaften und die Billrothmedaille der Gesellschaft der Ärzte, deren Präsident und Ehrenpräsident er jahrelang gewesen war." Zit. nach: Vereinigung der Alt-Hietzinger, http://www.alt-hietzinger.at/Archiv/ personen/tassiloantoine. [Zugriff 23.1.2011]. Die NS-Behörden attestierten Antoine: „Er bietet die Gewähr sich jederzeit rückhaltlos für den NS-Staat einzusetzen.“ Zit. nach: Arias, Entnazifizierung an der Wiener Medizinischen Fakultät, a.a.O., 359. Antoine wurde wie Leopold Schönbauer angerechnet, sich bei der Verteidigung des Allgemeinen Krankenhauses verdient gemacht zu haben.

Hingegen habe Viktor Patzelt (1887-1956), Professor für Histologie und Embryologie, ,sich gegenüber Studierenden als Nationalsozialist gebärdet“. Allerdings sei er „der einzige verfügbare Supplent für die beiden anatomischen Lehrkanzeln, da im Inland geeignete Anatomen nicht vorhanden sind.“ Zit. nach: Entnazifizierung der Lehrkräfte der Universität Wien (G.-Z1. 32141/III-7/46). Enthalten in: Appendix „A“, Report of Quadripartite Sub-Committee on Denazification in Austrian Universities, 7th September 1946. NARA II, RG 260, a.a. O., 1. Am histologischen Institut habe Pazelt zudem eine „wahre nationalsozialistische Zelle etabliert". Vg1. Wiener Montag am 21. März 1946, 4. Vgl. UAW, Senats-Sitzungs-Protokoll, 13. Sitzung, Akademischer Senat der Universität Wien, GZ. 568-1946/47, 15. März 
hervorgeht, die zusätzlich dazu aufgefordert worden waren, entsprechende Namenslisten zuzusenden - die Antworten trafen erst über einen Monat später ein -, waren von der Sonderkommission (Senat II und III) an 37 Universitätsinstituten in Summe nur ${ }_{3}$ Personen negativ beurteilt worden, ${ }^{1504}$ und diese waren - bis auf einen Fall - auch alle bereits entlassen. ${ }^{1505}$

Womöglich um dem spürbar zunehmenden Druck auf die Universitäten durch eine positive Entlastungsstrategie im Sinne einer,Flucht nach vorne' etwas Wind aus den Segeln zu nehmen, startete das Unterrichtsministerium unter dem Titel „Rotbuch gegen den $\mathrm{Na}$ ziterror" ein Dokumentationsprojekt, im Zuge dessen ,alle erreichbaren Unterlagen über den Abwehrkampf Österreichs gegen den Nazismus, über die NS-Okkupation und die Gleichschaltung, über den Naziterror sowie über die österreichische Widerstandsbewegung“" an den Universitäten zusammengetragen werden sollten, um so unter anderem die „zur Abwehr des Nationalsozialismus getroffenen Massnahmen" ${ }^{1506}$ schließlich in einer Edition vorzulegen. Die Ausbeute war aber, trotz einzelner spannender Berichte über Vorkommnisse an Instituten, ${ }^{1507}$ eher gering - wodurch das Vorhaben schließlich im Sande verlief.

1947, 3. Siehe auch: Arias, Die Medizinische Fakultät von 1945 bis 1955. In: Grandner/Heiß/Rathkolb (Hrsg.), Zukunft mit Altlasten. Die Universität Wien 1945 bis 1955, a.a.O., 33.

1504 Dies betraf folgende Institute: II. Physikalisches Institut (4), Universitätssternwarte (1), II. Chemisches Labor (1), Österreichisches Institut für Geschichtsforschung (1), Mineralogisch-petrographisches Institut (1), Musikwissenschaftliches Institut (4), Institut für Lebenswirtschaftskunde (1). UAW, Dekanatsakten der Phil. Fakultät, Z1. 1058-1945 / 46.

1505 Dies bedeutet, dass die auf Basis des Verbotsgesetzes stattgefundenen Enthebungen (Reichsdeutsche, „Illegale“, NSDAP-Mitglieder etc.) bereits zuvor bzw. durch den „Liquidator“ stattgefunden haben, und die Praxis der Sonderkommission I. Instanz im Unterrichtsministerium primär darin bestand, Wiedereinstellungsansuchen (positiv) zu behandeln.

1506 UAW, Dekanatsakten der Phil. Fakultät, Z1. 1300-1945/46, Rotbuch über den Naziterror. Beschaffung von Unterlagen, 20. April 1946.

1507 So zum Beispiel der Bericht des Assistenten am I. Chemischen Laboratorium, Otto Hoffmann-Ostenhof, der gemeinsam mit Kurt Horeischy und Hans Vollmar - in Kontakt mit der Widerstandsgruppe um Major Carl Szokoll - für Sprengkommandos Chemikalien aushändigte und u.a. auch versuchte, die Zerstörung wertvoller Instrumente zu verhindern. Beim Versuch, Prof. Jörn Lange (1903-1946), seit 1942 ao. Professor für physikalische Chemie, am 25. April 1945, mit Unterstützung des desertierten Polizeiwachtmeisters und Widerstandskämpfers Slama, an der Zerstörung des Elektronenmikroskops zu hindern - dieser Akt erfolgte auf Weisung des Prorektors Viktor Christian -, wurden beide, Horeischy und Vollmar, von Lange erschossen. Vgl. auch: Ein Naziprofessor vernichtete Elektronenmikroskop, und mordete zwei Menschen. In: Neues Österreich, Freitag, 27. April 1945, 2; weiters: Der Mordprozeß gegen den Naziprofessor Lange. In: Neues Österreich, Freitag, 27. April 1945, 2. Teile des kriegswichtigen Elektronenmikroskops waren zuvor vom Direktor des Instituts Ludwig Ebert bereits nach Strobl/Wolfgangsee verfrachtet worden. Im Keller des I. Chemischen Instituts in der Währingerstraße 39-42 befand sich zudem die Kontaktstelle der seit Oktober 1944 existierenden Widerstandsgruppe „Tomsk“, eine Gruppe, die, wie Pfefferle/Pfefferle eruierten, aus „Widerstandskämpfern, politisch Verfolgten, Deserteuren, ,Wehrunwilligen“ und jüdischen Menschen“ bestand, darunter „auch der Chemietechniker und spätere Bestsellerautor Johannes Mario Simmel“. Kurzfristig von der Polizei festgenommen, wurde der fanatische Nazi und „Werwolf-Befehlsempfänger“ Lange jedoch entlassen, sodass es ihm gelang, das Elektronenmikroskop schließlich doch noch mit Ham- 
Welche Art von ,Abwehr' an den Hochschulen nunmehr geübt wurde - von der Frage einmal ganz abgesehen, inwiefern bei der politischen Säuberungspraxis Zusammenhänge zwischen Nazifizierung, „Entjudung“ und Entnazifizierung von Bedeutung waren - und welche (womöglich riskanten) ,Maßnahmen' für einen demokratiepolitisch ernst zunehmenden antifaschistischen Neubeginn an den,Hohen Schulen' getroffen wurden, darüber geben unter anderem die Schriftstücke der Sonderkommissionen beredte Auskunft.

Bei Durchsicht der Verhandlungsschriften der Senate I und II sowie der Überprüfungskommission im Unterrichtsministerium fällt auf, dass offenkundige Fakten oder auch Zeugenaussagen mitunter schlichtweg ignoriert wurden. ${ }^{1508}$ Darüber hinaus führen die Protokolle zum Teil keine Begründung dafür an, warum der oder die Betreffende „die Gewähr dafür bietet“, dass er/sie ,jederzeit rückhaltlos für die unabhängige Republik Österreich eintreten werde“. Schließlich finden sich überaus kuriose ,Begründungen' für positive Entscheidungen, die in leicht verändertem Wortlaut wiederholt aufscheinen, wie die, dass das betreffende NSDAP-Mitglied ,kein grosses Interesse an der Bewegung gezeigt“ ${ }^{1509}$ oder die ,illegale“ Mitgliedschaft zur NSDAP „lediglich einem Zufall zuzuschreiben" ${ }^{1510}$ sei.

Bezeichnenderweise wurde versucht, den Historiker Otto Brunner, ${ }^{1511}$ der von I94I1945 Professor für „mittlere und neuere Geschichte“ an der Universität Wien war und auf

mer und Meißel zu zerstören. Der Hinrichtung nach dem Urteil des Volksgerichtsprozesses entzog sich Lange durch Selbstmord. Siehe: Pfefferle/Pfefferle, Glimpflich entnazifiziert, a.a.O., a.a.O., 50.

1508 So zum Beispiel: Sonderkommission zur politischen Überprüfung an der Universität Wien, Senat I. Gegenstand: Dr. E.Z. Verhandlungsschrift über die am 28. Jänner 1946 vorm. an der Univ.-Kinderklinik stattgefundene mündliche Verhandlung, Vorsitzender: Prof. Dr. Hans Planitz. UAW, Sonderbestand 90, Sonderkommission (SK) 1945.

1509 Überprüfungskommission beim Bundesministerium für Unterricht (Vorsitz: Sekt.-Chef. Dr. Skrbensky), Erkenntnis betreffend Gestaltung einer Lehrkanzel für deutsche Sprache und Literatur für Dr. Hans Rupprich, 28. Juli 1947, UAW, Dekanatsakten der Phil. Fakultät, 1946/47, GZ. 3847/307/2-46/47, Sonderkommission (SK) 1945.

1510 Sonderkommission zur politischen Überprüfung an der Universität Wien, Senat I. Gegenstand: Dr. L. B. Verhandlungsschrift über die am 19. Dezember 1945 vorm. a. der Univ.-Kinderklinik stattgefundene Mündliche Verhandlung, Vorsitzender: Prof. Dr. Rudolf Köstler. UAW, Sonderbestand 90, SK 1945.

1511 Otto Brunner (1898-1982), Mediävist und Archivar, war seit 1938 Parteianwärter und trat am 1. September 1943 rückwirkend bis 1941 in die NSDAP ein und leitete von 1942-1945 das Österreichische Institut für Geschichtsforschung in Wien. Daneben hielt er an der Luftkriegsschule Vorträge über Geschichte. Laut den Entlastungsaussagen der Professoren Havers und Rohracher sei „über seine Lehrtätigkeit an der Universität selbst nichts Nachteiliges bekannt." Dessen ungeachtet qualifizierte der OSS-Entnazifizierungsreport Brunner mit den Worten: „too dangerous to allow a P.G. to teach History“. Zit. nach: Entnazifizierung der Lehrkräfte der Universität Wien (G.-Z1. 32141/III-7/46). Enthalten in: Appendix „A“, Report of Quadripartite Sub-Committee on Denazification in Austrian Universities, 7. September 1946. NARA II, RG 260, Box 11, Folder 68. Records of the Unites States Occupation Headquarters, World War II, USFA/USACA, Internal Affairs/Displaced Persons Division, Denazification Branch, General Records, 1945-50, 2 bzw. 4. 1954 wurde der 56-jährige Sozialhistoriker schließlich als ordentlicher Professor nach Hamburg berufen. Vgl. Pfefferle/Pfefferle, Glimpflich entnazifiziert, a.a.O., 71. 
Grund seiner breitangelegten Studien über ein für einen Historiker „untypisches theoretisches Rüstzeug verfügte“, ${ }^{1512}$ mit einem seltsam anmutenden, quasi „ideengeschichtlichen“ Entschuldigungsargument zu entlasten, dessen Kern die ,Anschlussidee“ weiter nicht in Frage stellte: Zwar sei Brunner NSDAP-Mitglied gewesen, aber er habe, so die Begründung der Sonderkommission, den „Beitritt deshalb vollzogen, weil er irrtümlich [sic], wie er jetzt einsieht, in der Annexion Österreichs die Verwirklichung des Anschlussidee sah" ${ }^{1513}$ Allerdings sprach sich im Fall Brunners (oder auch im Fall Walter Goldingers $)^{1514}$ - anders als etwa im Fall Heinrich Fichtenaus ${ }^{1515}$ - selbst Skrbensky gegen seine, also Brunners Verwendung aus, bis er 1948 schließlich fünfzigjährig vorzeitig pensioniert wurde. ${ }^{1516}$ Ein möglicher Grund, warum Brunner trotz des für ihn positiven Gutachtens der Sonderkommission nicht rehabilitiert wurde, mag, wie Gernot Heiß wohl zur Recht vermutet, darin gelegen sein, dass Brunner als Protestant nicht in die „einflussreichen katholisch-konservativen Netzwerke eingebunden war. “1517

Auf Basis derartiger Begründungen ließ sich freilich nahezu alles irgendwie rechtfertigen beziehungsweise exkulpieren und so verwundert es kaum, dass es nicht allzu lange dauern sollte, bis dann auch Leute wie der „illegale“ Volkskundler und Leiter der „Lehr- und For-

15121939 war Brunners Werk „Land und Herrschaft. Grundfragen der territorialen Verfassungsgeschichte Österreichs im Mittelalter“ erschienen, das 1941 den „Verdun-Preis“ erhielt. Pfefferle/Pfefferle, Glimpflich entnazifiziert, a.a.O., 90.

1513 ÖSTA/ADR, 04, BKA Liquidator 1045-1946, Unterricht (1-) 5700-9400, GZ 6422, Otto Brunner, Erkenntnis vom 7. Mai 1946, Sonderkommission I. Instanz, unter Vorsitz, von Hans Kenda, Beisitzer Havers und Rohracher.

1514 ÖSTA/ADR, Staatskanzlei (BKA), Sektion I., Präsidium, Ktn. 3, Z1. 261-500, 1945, Bundeskanzleramt betref. Verfahren bei der Sonderkommission I. Instanz Archivrat Dr. Walter Goldinger. Wegen der „schweren Belastung“ Goldingers wurde dessen sofortige Enthebung vom Dienst veranlasst. Allerdings war der Historiker und Archivar Goldinger (1910-1990) bereits 1957 Präsident des Verwaltungsgerichtshofes, 1973 bis 1975 nahm er schließlich die Position des Generaldirektors des Österreichischen Staatsarchivs ein.

1515 Nachdem zuvor bereits die Sonderkommission I. Instanz zu einem positiven Bescheid gelangt war, ergab das Verfahren der Überprüfungskommission unter Vorsitz von Skrbensky bezüglich der Lehrbefugnis des Mediävisten Heinrich Fichtenau, dass dieser im Mai 1938 zwar um Aufnahme in die NSDAP angesucht hatte, jedoch nie aufgenommen bzw. dessen Aufnahmeansuchen durch die NS-Reichsleitung am 26. Oktober 1940 zurückgestellt worden war. Da sich Fichtenau ,überhaupt nur deshalb um die Aufnahme in die Partei beworben hatte, um die ihm drohende Entfernung vom Institute zu verhindern“, sonst aber „stets eine dem Nationalsozialismus abholde Einstellung annahm“ wurde Fichtenau kurzerhand für politisch „einwandfrei“ befunden. UAW, Dekanatsakten Phil. Fakultät, 2004-1946/47, Erkenntnis der Überprüfungskommission beim Bundesministerium für Unterricht betref. Dr. phil Heinrich Fichtenau, 28. Juli 1947, $1 \mathrm{f}$.

1516 Vgl. Gernot Heiß, Von der gesamtdeutschen zur europäischen Perspektive? Die mittlere, neuere und österreichische Geschichte sowie die Wirtschafts- und Sozialgeschichte an der Universität Wien 19451955. In: Grandner/Heiß/Rathkolb (Hrsg.), Zukunft mit Altlasten, a.a.O., 190 f.

1517 Heiß, Wendepunkt und Wiederaufbau. In: Grandner/Heiß/Rathkolb (Hrsg.), Zukunft mit Altlasten, a. a.O., 191. Zit. nach: Pfefferle/Pfefferle, Glimpflich entnazifiziert, a.a.O., 91. 
schungsstätte für germanisch-deutsche Volkskunde“ innerhalb der „Außenstelle Süd-Ost“ des NS-Ahnenerbes in Salzburg, Richard Wolfram, ${ }^{1518}$ wiederbestellt wurde, oder der NSTheaterwissenschafter Heinz Kindermann ${ }^{1519}$ - zunächst laut OSS-Bericht „not even recommend for retention by Bundesministerium “1520 , der trotz Negativ-Gutachtens des Literaturwissenschafters Oskar Benda, ${ }^{1521}$ I954 wieder einen, nämlich „seinen“ Lehrstuhl ${ }^{1522}$

15181954 erlangte Richard Wolfram (1901-1995) die Venia legendi wieder, fünf Jahre darauf wurde er erneut zum außerordentlichen Professor an der Universität Wien ernannt. Siehe: Albert Ottenbacher, Richard Wolfram, http://www.doew.at/thema/thema_alt/ns_wissen/wolfram/wolfram.html. Zu Wolframs Rolle in der NS-Zeit siehe im Detail: Olaf Bockhorn, „Die Angelegenheit Dr. Wolfram, Wien“. Zur Besetzung der Professur für germanisch-deutsche Volkskunde an der Universität Wien. In: Mitchell G. Ash/Wolfram Nieß/Roman Pils (Hrsg.), Geisteswissenschaften im Nationalsozialismus. Das Beispiel der Universität Wien, Göttingen 2010, 199-224.

1519 Heinz Kindermann (1894-1985), rassenbiologischer Literatur- und Theaterwissenschafter, war 1919 zunächst gemeinsam mit Anton Lampa im von Otto Glöckel geschaffenen Volksbildungsamt des Unterrichtsministerium tätig, lehrte 1926-1936 Literaturgeschichte in Danzig und übernahm dann als deklarierter Anhänger des Nationalsozialismus 1942 das Theaterwissenschaftliche Institut in Wien. ÖVA, Konvolut „H. Kindermann“. Kindermann war, wie er selbst betonte, noch vor der „Machtübernahme in Danzig“ am 1. Mai 1933 der NSDAP beigetreten. Siehe: Birgit Peter, „Wissenschaft nach der Mode“. Heinz Kindermanns Karriere 1914-1945. Positionen und Stationen. In: Birgit Peter/Martina Payr (Hrsg.), „Wissenschaft nach der Mode“? Die Gründung des Zentralinstituts für Theaterwissenschaften an der Universität Wien 1943.2.Aufl., Berlin 2008, 32; zuletzt: Wolfram Nieß, Von den Chancen und Grenzen akademischer Selbstbestimmung im Nationalsozialismus: Zur Errichtung des Instituts für Theaterwissenschaft 1914-1943. In: Ash/Nieß/Pils (Hrsg.), Geisteswissenschaften im Nationalsozialismus, a.a.O., 223-259.

1520 Siehe: Report of Quadripartite Sub-Committee on Denazification in Austrian Universities, 7. September 1946. NARA II, RG 260, Box 11, Folder 68. Records of the Unites States Occupation Headquarters, World War II, USFA/USACA, Internal Affairs/Displaced Persons Division, Denazification Branch, General Records, 1945-50, 1.

1521 Oskar Benda (1886-1954), promovierter Philologe (Deutsch und Englisch), ab 1925 Landesschulinspektor für Wien, nach dem „Anschluss“ 1938 enthoben und mit gekürzten Bezügen in den Ruhestand versetzt. Nach 1945 lehrte Benda als ordentlicher Professor für Literaturwissenschaft und war Vorstand des Literaturwissenschaftlichen Instituts der Universität Wien. Das Gutachten Bendas vom Mai 1948 verhinderte zunächst die bereits geplante Wiederbestellung des „Hymnikers der Volkheit“, aber bereits 1954 konnte Kindermann wieder als Extraordinarius an die Universität zurückkehren; 1959 wurde er zum Ordinarius ernannt. Siehe: Pfefferle/Pfefferle, Glimpflich entnazifiziert, a. a. O., 89. Der Teilnachlass zu Otto Benda befindet sich im Literaturarchiv der Österreichischen Nationalbibliothek in Wien.

1522 Der Lehrstuhl war, nach dem gescheiterten Plan zur Errichtung eines deutschen Nationaltheaters in Wien als „Erziehungs- und Forschungsinstitut“, auf anhaltendes Drängen Kindermanns durch Erlass des NS-Reichministers Rust am 19. Jänner 1943 neugeschaffen und Kindermann mit dem Lehrstuhl bzw. einer ordentlichen Professur betraut worden. Paul M. Delavos /Caroline Hefert, „Alltagsgeschäft“ Daten und Fakten zur Gründung des Zentralinstituts für Theaterwissenschaft. In: Peter/Payr (Hrsg.), „Wissenschaft nach der Mode“, a.a.O., 53. 
bekam, den zuvor Eduard Castle ${ }^{1523}$ bis 1949 innegehabt hatte. ${ }^{1524}$ Nach Erkenntnis der Sonderkommission I. Instanz beim Staatsamt für Volksaufklärung im November 1945 unter Vorsitzführung von Skrbensky wurde zunächst die Gewähr dafür ausgesprochen, dass Kindermann ,jederzeit rückhaltlos“ für die Unabhängigkeit Österreichs eintreten werde. Nach Berufung durch das Staatsamt für Unterricht wurde dieses Erkenntnis jedoch wieder aufgehoben; ${ }^{1525}$ aber trotz eines weiteren vernichtenden Gutachtens von Oskar Benda vom r. Juli 1953, worin er Kindermann hinsichtlich der „inneren Geschichte des Nationalsozialismus eine bedeutende Rolle“1526 attestierte und ihn als „einen der prominentesten Mitschöpfer der nationalsozialistischen Ideologie“ (im Range eines Alfred Rosenberg oder Ernst Krieck) ${ }^{1527}$

1523 Der Germanist und Volkshochschulvortragende Eduard Castle (1875-1959) wurde 1934 ordentlicher Universitätsprofessor in Wien. 1938 verlor der als „liberal-marxistisch“ eingeschätzte Gelehrte seine Professur. Nach 1945 wurde Castle wieder berufen und - aufgrund des allgemeinen Lehrermangels - u.a. auch mit der (Nach-)Prüfung bereits promovierter Kandidaten für das Lehramt betraut: Der Professor, der das Niveau nicht allzutief sinken lassen wollte, wurde von Prüflingen angeschwärzt, bei den Prüfungen autoritär, unfair und auch „rassistisch“ gegen ehemalige Opfer des NS-Regimes vorzugehen. Castle erwiderte „als Mischling ersten Grades“, der wegen seiner antinationalsozialistischen Einstellung in Gefahr der Abschiebung in ein Konzentrationslager gestanden sei, mit Bezug auf die Verleumdungen der Kandidaten und deren fachliches Niveau, dass die „Eigenschaft, ,geschädigt‘ zu sein [...] keinen Freibrief gewähren [kann], dass wir völlig unwissende Lehramtskandidaten auf unsere Schuljugend loslassen und unser bereits tiefgeschädigtes Unterrichtswesen immer weiter herunterbringen." UAW, Rektoratsakten, Akademischer Senat, Z1. 209-1945/46, 29. Jänner 1946.

1524 Entgegen seiner Selbstdarstellung als quasi-Opfer des NS-Regimes - 1938 war Castle zwangspensioniert worden und sei eigenen Angaben zufolge ,unter Gestapo-Aufsicht“ gestanden - finden sich jedoch, wie rezente Forschungen belegen, auch bei Castle, der zuvor gewisse Affinitäten gegenüber dem „ständestaatlichen“ Regime an den Tag gelegt hatte, ansatzweise „Annäherungsversuche“ an das NS-Regime. Klaus Illmayer, Ein folgenloser Wechsel. Die Ablösung Heinz Kindermanns durch Eduard Castle. In: Peter/Payr (Hrsg.), „Wissenschaft nach der Mode“, a.a.O., 153f. Tatsächlich erfur Castle aber, wie Ranzmaier darlegt, keine Unterstützung seitens des NS-Dozentenbundes. Siehe: Ranzmaier, Germanistik - Konitnuitätsstiftende Ansätze der Wissenschaft, a.a.O., 435 f.

1525 Veronika Zangl, „Ich empfinde diese Maßnahme persönlich als ungerecht.“ Heinz Kindermanns Entlastungsstrategien 1945-1954. In: Peter/Payr (Hrsg.), „Wissenschaft nach der Mode“, a.a.O., 173.

1526 Oskar Benda: Gutachten zu Dr. Heinz Kindermann. Literarische Tätigkeit 1933-1945, Wien 1.7.1953, ÖSTA, AdR, PA Kindermann, fol. 218-232. Zit. nach: Illmayer, Ein folgenloser Wechsel. Die Ablösung Heinz Kindermanns durch Eduard Castle, a.a.O., 164.

1527 In seinem Negativ-Gutachten zu Kindermann, das sich in einem Kurzauszug im Bestand „Karl R. Stadler“ im Österreichischen Volkshochschularchiv (ÖVA) findet, verwies Benda darauf, dass Kindermann sich „immer wieder seiner emsigen illegalen Tätigkeit in der sogenannten ,Verbotszeit““ rühmte, und strich hervor, dass dieser mit seinem 1937 erschienenen Buch „Dichtung und Volkheit. Grundzüge einer neuen Literaturwissenschaft“ „Herrn Goebbels die Richtlinien für eine nationalsozialistische Kulturpolitik geliefert hat." Siehe: ÖVA, B-Stadler, Karl R., Korrespondenz, 1950-1953. Nachdem Kindermann 1952 an der University of Birmingham einen Vortrag gehalten hatte, bemühte sich der nach wie vor in der englischen Emigration verweilende Karl R. Stadler, der als Lecturer in Derby lehrte und von der bevorstehenden Rehabilitierung Kindermanns von einem befreundeten Universitätsdozenten in Wien in Kenntnis gesetzt worden war, darum, bei britischen Institutionen bzw. Kollegen die Distan- 
bezeichnete, stimmte das Fakultätsgremium der Philosophischen Fakultät schließlich im zweiten Wahlgang mit $35 \mathrm{Ja}$-Stimmen, 2r Nein-Stimmen und vier Stimmenthaltungen für die Nachbesetzung des Lehrstuhls für Theaterwissenschaft an der Universität Wien durch Kindermann, der somit vollständig rehabilitiert war. ${ }^{1528}$

Wie neuere soziologische Analysen zeigen, war es nach dem „Anschluss“ I938 vor allem für die Dozenten, die die entlassenen Ordinarien ersetzten, auf breiter Basis zu einer signifikanten Aufwärtsmobilität gekommen. Paradoxerweise blieben, wie Christian Fleck schlüssig dargelegt hat, die österreichischen Nutznießer des NS-Systems, die ja nicht erst mit März 1938 installiert wurden, sondern „lediglich auf die „frei“ gewordenen Stellen nachrückten, von den Säuberungsmaßnahmen verschont: „Je höher sich Ostmärker währen der NS-Periode hinaufarbeiten konnten, desto unwahrscheinlich war es, dass sie $1945 \mathrm{ff}$. entlassen wurden. “1529

Tatsächlich waren 1945 an den Wiener Universitäten rund 8o Prozent aller Hochschullehrer von einer Entnazifizierungsmaßnahme betroffen, wobei nahezu jeder Zweite gemäß den gesetzlichen Bestimmungen (Verbotsgesetz, Behörden- beziehungsweise Beamtenüberleitungsgesetz) zu entlassen gewesen wäre. Allein von den insgesamt 235 außerordentlichen und ordentlichen Professoren wären somit an die 200 Stellen an den Wiener Universitäten und Hochschulen neu zu besetzen gewesen. ${ }^{1530}$

Die Arbeit der Sonderkommissionen sowie der nachfolgenden Überprüfungskommissionen lässt sich daher, insbesondere vor dem Hintergrund der ungleich umfassenderen

zierung von weiteren Einladungen zu erreichen: „I have received a letter from a friend who is a lecturer at the University of Vienna and who solicits my support in a campaign which he and his colleagues are waging against the re-appointment of a Dr. H. Kindermann to a university chair. It appears that this man was one of the principal propagandists for the Nazi State, and who is now working his passage back into an academic career. In this he is helped by the fact that he has certain contacts with Universities in England, has lectured at Birmingham University last year, and is said to be planning another lecture tour covering five universities in the United Kingdom [...]. I have no doubt about the authenticity of the various accusations against this man, but have told my Viennese friend that it is impossible to interfere with the freedom of university departments to invite guest speakers of their choice. Nevertheless, the problem remains whether we in this country ought to help in the rehabilitation of particularly unpleasent types of careerists and political fanatics [...]“. Karl R. Stadler to Dr. V.E. Cosslett, President, Association of University Teachers, Cambridge, 24th March 1953. ÖVA, B-Stadler, Karl R., Korrespondenz, 1950-1953. Für den Hinweis auf dieses Dokument sei an dieser Stelle meinem Kollegen Mag. Thomas Dostal herzlich gedankt.

1528 Siehe: Zangl, „Ich empfinde diese Maßnahme persönlich als ungerecht.“, a.a.O., $188 \mathrm{f}$.

1529 Christian Fleck, Österreichs Universitäten am Beginn der Zweiten Republik: Entnazifizierung und Nicht-Rückkehr der Vertriebenen, 2. An dieser Stelle zitiert nach: http://www.uni-graz.at/ fleck/ pdf/texte/2002c_Zweite_Republil_Unis_scienceexile.pdf [Zugriff 20.1.2011]; weiters: Ders., Autochthone Provinzialisierung. Universität und Wissenschaftspolitik nach dem Ende der nationalsozialistischen Herrschaft in Österreich. In: Österreichische Zeitschrift für Geschichtswissenschaften, 7. Jg., 1996, Nr. 1, 67-92.

1530 Fleck, Österreichs Universitäten am Beginn der Zweiten Republik, a.a.O., 3. 
rassistisch-politischen Säuberungswellen nach dem Anschluss 1938, von der Tendenz her als eine Art Diensttauglichkeitsüberprüfung zwecks beruflicher Weiterverwendung charakterisieren. Nur in äußerst seltenen Fällen wurde, wie Ingrid Arias bestätigt, „Einsicht in Originallisten der NSDAP oder ihrer Organisationen genommen. “1531 Hinzukommt, dass die vor der Vernichtung durch die Nationalsozialisten sichergestellten NS-Personalakten der Gauleitung Wien durch persönliche Weisung Karl Renners zunächst unter „sicherer Verwahrung gehalten werden “1532 mussten, und ein Zugriff auf diese für die gesamte Entnazifizierung wichtigen Dokumente erst ab April I946 - durch alliierten Druck auf die österreichische Regierung ${ }^{1533}$ - ermöglicht wurde.

Wie nicht anders zu erwarten, spiegelt sich der lediglich äußerlich-formale, von keiner ernsthaften inneren Überzeugung getragene Prozess der Entnazifizierung an den Universitäten auch an der führenden außeruniversitären Forschungseinrichtung des Landes - der I847 gegründeten Österreichischen Akademie der Wissenschaften. So wurden die entnazifizierten Professoren, darunter auch solche mit erheblicher NS-Vergangenheit wie Josef Nadler, Otto Brunner, Heinrich Srbik, ${ }^{1534}$ Fritz Knoll, Hans Sedlmayr oder Camillo Praschniker, ${ }^{1535}$ ohne Unterbrechung durchgängig als Mitglieder der Akademie der Wissenschaften geführt. ${ }^{1536}$

1531 Arias meint damit vermutlich die Einsichtnahme in die sogenannten „Gauakten“. Vgl. Arias, Entnazifizierung an der Wiener Medizinischen Fakultät, a.a.O., 345.

1532 Entdeckt wurde das unter Gauleiter Bürkel ab 1938 entstandene NS-Gauaktenarchiv in den Großöfen der Zentralheizung des Parlaments, die so vollgestopft waren, „daß das offenbar beabsichtigte Verbrennen derselben mangels Luftzufuhr nicht gelungen“ ist. In weiterer Folge wurden die Akten von Minister Helmer im Innenministerium unter Verschluss gehalten. Siehe dazu: Wilhelm Svoboda, Die Partei, die Republik und der Mann mit den vielen Gesichtern. Oskar Helmer und Österreich II. Eine Korrektur, Wien 1993, 62 f.

1533 Nach einer Sitzung der Alliierten Kommission am 29. April 1946 wurde beschlossen, dass die Gauakten nicht der Bundespolizeidirektion Wien zu übergeben seien, sondern im Gewahrsam des Innenministeriums zu verbleiben hätten, ,, mit der Verpflichtung, jeder alliierten Dienstelle auf Verlangen Auskunft zu geben.“ Zit. nach: Svoboda, Die Partei, die Republik, a.a. O., 68; Vgl. auch Arias, Entnazifizierung an der Wiener Medizinischen Fakultät, a.a.O., 345.

1534 Zur „Wiener Schule der Geschichtswissenshaft“ in der NS-Zeit siehe: Gernot Heiß, Die „Wiener Schule der Geschichtswissenschaft“ im Nationalsozialismus: „Harmonie kämpfender und Rankescher erkennender Wissenschaft“? In: In: Ash/Nieß/Pils (Hrsg.), Geisteswissenschaften im Nationalsozialismus, a.a. O., 397-426.

1535 Zur Rolle Camillo Praschnikers am Institut für Klassische Archäologie 1934-1945 siehe jüngst: Gudrun Wlach, Klassische Archäologie in politischen Umbruchszeiten. Wien 1938-1945. In: Ash/Nieß/Pils (Hrsg.), Geisteswissenschaften im Nationalsozialismus, a.a. O., $351 \mathrm{ff}$.

1536 Der Mathematiker und Illegale Anton Huber, der Prähistoriker und Unterrichtsminister in der Regierung Seyß-Inquart (1938) Oswald Menghin oder der letzte NS-Rektor der Universität Wien, Viktor Christian - die beiden Letztgenannten waren Mitglieder in der streng antisemitischen Professorenclique der „Bärenhöhle“ in den Jahren bis 1934 (vgl. Taschwer, Die Bärenhöhle und ihr langer Schatten, a.a.O., o.P. (S. 7) -, scheinen nur vorübergehend nicht in den Mitgliederlisten geführt und tauchen dann Ende der 1950er-Jahre - jedoch ohne Hinweis auf jede Unterbrechung - wieder als ÖAW-Mitglieder 
Kurzer Einschub: Auch in der amerikanischen Besatzungszone in Oberösterreich sah die Situation - hier allerdings (auf Grund des Fehlens einer Universität) den Schulbereich betreffend - nicht viel anders aus. Eine harte Entnazifizierung, die rund 70 Prozent des gesamten Lehrpersonals betroffen hätte, wurde von den Amerikanern letztlich nicht durchgeführt, womöglich auch deshalb, weil man vor der Unsicherheit über die zu entscheidenden provisorischen Übergangslösungen zurückscheute ${ }^{1537}$ - wobei die Entnazifizierung im Schulwesen, wie Stiefel hervorhebt, mit deutlichen regionalen Unterschieden erfolgte. So wurden etwa in Tirol an die 40 Prozent der "minderbelasteten“ Pflichtschullehrer im Dienst belassen, während in Wien 1947 - wohl nicht zuletzt auch auf Grund der Urgenzen der sowjetischen Besatzungsmacht - nur ein Minderbelasteter, ein Blindenlehrer, weiterhin lehren durfte. ${ }^{1538}$

Die grundsätzliche Chance für einen fundamentalen Neubeginn in der österreichischen Wissenschaftskultur wurde jedenfalls - ähnlich wie in Deutschland ${ }^{1539}$ - nicht ergriffen, zumal die entscheidenden Weichenstellungen bereits zuvor erfolgt waren: Die maßgeblichen Personen, sowohl im Akademischen Senat der Universität Wien als auch innerhalb der Ministerialbürokratie, waren in keiner Weise an wissenschaftspolitischen Innovationen und schon gar nicht an der Rückholung vertriebener jüdischer Wissenschafter interessiert. ${ }^{1540}$ Wie von Robert Stumpf bereits zu Recht hervorgehoben wurde, schuf der an

auf. Siehe: Pfefferle/Pfefferle, Glimpflich entnazifiziert, a.a.O., 82; vgl. auch Matis, Zwischen Anpassung und Widerstand, a.a.O., 16 f.; zu Viktor Christian siehe den jüngst erschienenen quellenbasierten Beitrag: Irene Maria Leitner, „Bis an die Grenzen des Möglichen“. Der Dekan Viktor Christian und seine Handlungsspielräume an der philosophischen Fakultät 1938-1943. In: Ash/Nieß/Pils (Hrsg.), Geisteswissenschaften im Nationalsozialismus, a.a.O., 49-77, sowie: Dirk Rupnow, Brüche und Kontinuitäten - Von der NS-Judenverfolgung zur Nachkriegsjustiz. In: Ebd., 79-110; zu Oswald Menghin siehe: Otto H. Urban, Die Ur- und Frühgeschichte an der Universität Wien vor, während und nach der NS-Zeit. In: Ebd., $386 \mathrm{ff}$.

1537 Vgl. Gabriele Hindinger, Das Kriegsende und der Wiederaufbau demokratischer Verhältnisse in Oberösterreich im Jahre 1945 (Publikationen des Österreichischen Instituts für Zeitgeschichte, Bd. 6), Diss., Univ. Wien 1968, $104 \mathrm{f}$.

1538 Stiefel, Entnazifizierung, a.a.O., 166.

1539 Auch in Deutschland blieb die Entnazifizierung durch die amerikanische Besatzungsmacht in Form des eigens eingerichteten „University Planning Committee“, dessen Aufgaben in etwa den Sonderkommissionen in Österreich entsprachen, trotz schärferer Durchführung und Enthebung von Rektoren, zunächst eine Maßnahme ohne jede Tiefenwirkung. Im Unterschied zu Österreich kam es jedoch in den Folgejahren in Deutschland zu einer intensiv geführten wissenschaftspolitischen Auseinandersetzung, die amerikanischerseits durch eigenständige Reformvorschläge der OMGUS-Hochschulabteilung begleitete wurde, die schließlich in einer adapierten Form im sogenannten „Blauen Gutachten“ (1948) mündeten, worin der Weg in Richtung einer demokratischen Öffnung der Deutschen Universitäten vorgezeichnet wurde und die Gründung der „Freien Universität Berlin“ (1948) zur Folge hatte. Vgl. Paulus, Amerikanisierung von Universität und Wissenschaft in Westdeutschland 1945-1976, a. a. O., 95 ff. bzw. $171 \mathrm{ff}$.

1540 Bezeichnenderweise empfahl Karl Renner, der in Gloggnitz seinen eigenen Worten zufolge „Physik nachgeholt hatte", in einem Schreiben an Rektor Adamovich den Physiker und „dreifachen“ [sic] Nobel- 
vordemokratischen, restaurativen Werthaltungen orientierte, alles liberale oder gar sozialistische Gedankengut strikt ablehnende, korporative Traditionalismus an den österreichischen Hochschulen mit seinen reetablierten Seilschaften und Gesinnungsgemeinschaften eine - so ein zeitgenössischer Kommentar - akademische,Spinnwebenatmosphäre‘, deren Qualität sich insbesondere der „weltanschaulich wohl geschlossenste[n] akademischen[n] Lehrerschaft westlich des Eisernen Vorhanges, Spanien und Portugal ausgeschlossen “1541 verdankte.

Angesichts der wiederholt publik gewordenen und auch öffentlich kritisierten Vorgänge im Zusammenhang mit der Entnazifizierung der Universitäten fand ausgerechnet der selbst schwer belastete SPÖ-Nationalratsabgeordnete und spätere Justizminister Otto

preisträger Erwin Schrödinger, mit dem er über seinen Schwiegersohn in Dublin bekannt war, für eine Berufung - die auch zustande kam - damit, dass dieser „Österreicher und Arier [sic] und weltbekannte Autorität“ ist und „ein enormer Gewinn für die Wiener Universität“ sei. UAW, Dekanatsakt Phil. Fakultät, GZ 238-1945 /46, Der Bundespräsident an Rektor Adamovich, 30. Jänner 1946, 1. Schrödinger hatte zuvor Renner gegenüber klargestellt, dass er gerne zurückkäme, ihm aber sowohl hinsichtlich der rechtswidrigen Entlassung von der Universität Graz 1938 sowie von Berlin „gewisse Kompensationsrechte, zum mindesten Pensionsrechte“ zustehen als auch Unterstützung bei der „Zurstelleschaffung von Mobiliar und Hausrat“. UAW, Dekanatsakt Phil. Fakultät, GZ 238-1945 /46, Erwin Schrödinger, Dublin, an Dr. Renner, 6. Jänner 1946, 1. Erwin Schrödingers Ansinnen wurde sowohl vom Rektor als auch vom Dekan begrüßt und als Ehre aufgefasst. Inwieweit hier, und auch im Hinblick auf die persönliche Unterstützung, die Renner Schrödinger zuteil kommen ließ, der Umstand eine Rolle spielte, dass Schrödinger sich in einem Artikel in der Grazer Tagespost vom 31. März 1938 (Unter dem Titel: „Bekenntnis zum Führer - Ein hervorragender Wissenschafter meldet sich zu Wort“) ,inmitten der jubelnden Freude“ selbst voll und ganz auf die Seite des „Anschlusses“ gestellt hatte und in „treuer Mitarbeit und Gehorsam dem Willen des Führers“ gegenüber in einer öffentlichen Erklärung die ,selbstverständliche Meinung eines alten Österreichers“, vertrat, dass angesichts der bevorstehen Wahl ,jedes Nein in der Wahlurne dem völkischen Selbstmord gleichkäme“, mag dahin gestellt bleiben. UAW, Dekanatsakt Phil. Fakultät, GZ 238-1945/46, Abschrift aus der Tagespost (Graz) vom Donnerstag, den 31. März 1938, Erklärung des Universitätsprofessors Dr. E. Schroedinger. Zur jüngsten Debatte darüber, inwieweit sich Schrödinger von diesem öffentlichen „Bekenntnis“ nach 1945 distanziert bzw. „entschuldigt“ hätte, siehe den Leserbrief von Univ.-Prof. a. D. Dr. Peter Cerwenka bezugnehmend auf einen Standard-Artikel des Physikers Anton Zeilingers, in: Der Standard, 15./16. Jänner 2011, 30 sowie Ders., in: Der Standard, 21. Jänner 2011, 31. Dass Schrödingers politische Haltung eher verquer bzw. störrisch-naiv gewesen sein muss, geht u.a. aus Aussagen von Zeitzeugen hervor. Unmittelbar nachdem Schrödinger gemeinsam mit seiner Frau nach England emigriert war, befand er sich als Gast im Haus von Franz Simon in Oxford. Bei dieser Gelegenheit sprach Simon Schrödinger auf seine ominöses öffentlichen Bekenntnis an, da dieses in England durchaus für Irritationen gesorgt hatte. Dabei soll Schrödinger geantwortet haben: „What I have written, I have written. Nobody forced me to do anything. This is supposed to be a land of freedom and what I do is nobody's concern.“ Zit. nach: Walter John Moore, Schrödinger. Life and thought, Cambridge 2001 [1989], 345.

1541 Günther Steinbach, Unterrichtswesen zwischen Restauration und Demokratie. In: Jaques Hannak (Hrsg.), Bestandsaufnahme Österreich, 1945-1963, Wien - Hannover - Bern 1963, 305 bzw. 292. Zit. nach: Stumpf, Ernst Fischer als Staatssekretär für „Volksaufklärung, Unterricht und Erziehung und Kultusangelegenheiten“, Bd. 2, a.a.O., $200 \mathrm{f}$. 
Tschadek ${ }^{1542}$ im Mai 1946 im Parlament klare Worte, die vielleicht auch andere Parlamentarier moralisch teilten, aber nur wenige offen aussprachen. In Tschadeks Fall waren dessen kritischen Äußerungen vermutlich auch unterschwellig dadurch motiviert, durch eine pointierte Abgrenzung zum Nationalsozialismus möglichst keinen Verdacht hinsichtlich der eigenen Täterschaft aufkommen lassen:

„Hohes Haus! Die Hochschulen sind immer ein Sorgenkind der österreichischen Demokratie gewesen $[\ldots]$ was wir von einer Hochschule verlangen, das ist mehr als daß sie etwa bloß eine Fachschule darstellt. Wir wollen eine Hochschule, an der Akademiker erzogen werden, die für Freiheit und Demokratie keine Gefahr mehr darstellen. [... D Diese Aufgabe hat die österreichische Hochschule Jahrzehnte hindurch nicht erfüllt.

Wir haben es deshalb erlebt, dass gerade der österreichische Akademiker als erster dem Schwindel des Nationalsozialismus in Österreich erlegen ist. Und wenn wir heute in der zweiten Republik unsere Hochschulen aufbauen, dann müssen wir darauf Wert legen, dass die Hochschulen aus einer Stätte des reaktionären Geistes zu einer Stätte der freien Wissenschaft und der Demokratie werden. [Starker Beifall.]

Um dieses Ziel zu erreichen, müssen wir in erster Linie die Hochschulen entnazifizieren. Wir müssen unsere Lehrkörper von allen nationalsozialistischen Elementen säubern. Wir haben Entnazifizierungskommissionen und diese haben ehemaligen Nationalsozialisten in sehr großzügiger Weise Beurteilungen ausgestellt, dass sie für den österreichischen Staat und seinen Wiederaufbau tragbar seien [...]. Ich bin der Meinung, dass die Entnazifizierung auf den Hochschulen grundsätzlich und ausnahmslos zu erfolgen hat und dass zunächst jeder Hochschullehrer zu verschwinden hat, der nationalsozialistisch belastet ist. [Beifall.] “1543

1542 Otto Tschadek (1904-1969), Nachfolger Christian Brodas als sozialdemokratischer Justizminister 1960, von 1941 bis zum Kriegsende Marinerichter am „Gericht des Küstenbefehlshabers westliche Ostsee in Kiel“, wo er nach 1945 kurzfristig das Amt des Oberbürgermeisters innehatte. Als „Marinegerichtsrat“ hatte Tschadek mehrere Todesurteile wegen „Fahnenflucht“ verhängt sowie einzelne schwere Zuchthaustrafen wegen „Wehrkraftzersetzung“ ausgeprochen. Auf Betreiben des stellvertretenden SPÖ-Vorsitzenden Oskar Helmer kehrte Tschadek 1945 nach Österreich zurück und zog nach den ersten Nationalratswahlen als Abgeordneter in den Nationalrat ein. Vgl. Thomas Geldmacher, Der gute Mensch von Kiel? Marinerichter Otto Tschadek (1904-1969). In: Thomas Geldmacher/Magnus Koch/Hannes Metzler/Peter Pirker/Lisa Rettl (Hrsg.), „Da machen wir nicht mehr mit...". Österreichischer Soldaten und Zivilisten vor Gerichten der Wehrmacht, Wien 2010, 215 f. bzw. 217 ff. Vgl. dazu auch: Peter Mayr, Ex-Justizminister Tschadek war ein „Blutrichter“. In: Der Standard, 4./5. September 2010, sowie Christa Zöchling, Die gefälschte Biografie. In: Profil, 6. September 2010, Heft 36, 30-33; zuletzt: Maria Wirth, Christian Broda. Eine politische Biografie (=Zeitgeschichte im Kontext 5), Göttingen 2011, $202 \mathrm{f}$.

1543 Stenographische Protokolle des Nationalrates der Republik Österreich (Stenogr. Protoll. d. NR), 18. Sitzung, V. Gesetzgebungsperiode, 1945-1946, 1. Bd., 1.- 30. Sitzung, 24. Mai 1946, 338. Vgl. auch: Schicksal der Hochschulen. Große Rede von Nationalrat Tschadek im Parlament. In: Strom. Jugend, Geist und Welt, Hochschul-Sonderausgabe, 2. Jg., Folge 17/18, Juni 1946, 20. 
Im Hinblick auf die notwendigen Nachbesetzungen vertrat Tschadek die Ansicht, dass „wir alles tun sollten, um die vertriebenen Hochschullehrer internationalen Rufes, die einmal an unseren Universitäten gelehrt haben, an die Wiener Hochschulen zurückzubringen“, und bezog sich an dieser Stelle exemplarisch auf einen renommierten Gelehrten im Exil:

„Ich erinnere nur an einen Namen: Professor Dr. Hans Kelsen, der heute noch im Auslande
tätig ist, an den Schöpfer der ersten österreichischen Bundesverfassung, den Schöpfer der
modernen Verfassungsgerichtsbarkeit, den Schöpfer der modernen Staatslehre, den großen
Rechtslehrer, der aus Österreich vertrieben wurde, allerdings nicht erst von den Nationalsozi-
alisten, sondern wegen seines mannhaften Eintretens für die Verfassungsgerichtsbarkeit von
den Faschisten des Jahres I934. Ich bin der Meinung, dass wir diese politische Wiedergutma-
chung unter allen Umständen verlangen müssen, und dass wir unseren Hochschulen durch die
Rückberufung der vertriebenen großen Geister neues Blut und neuen Wert geben sollten. "1544

Aus der von Tschadek in diesem Zusammenhang projektierten Wiedergutmachung wurde allerdings, wie sich bald darauf zeigen sollte, nicht viel. In derselben Parlamentssitzung hielt auch Ernst Fischer eine bildungspolitische Grundsatzrede, in der er unter anderem eine Lanze für die durch den Nationalsozialismus instrumentalisierte Jugend brach, die nichts anderes kennengelernt habe, ,als faschistische Atmosphäre, nichts anderes als Führerprinzip, Kathedergehorsam und militaristische Organisation“, dabei - in seltener Dringlichkeit - auch auf die Situation an den Hochschulen zu sprechen kam und nicht mit Kritik an deren reaktionärem Geist sparte:

„Die Hochschulen in Österreich waren zweifellos in der Vergangenheit zu einem wesentlichen Teil Hochburgen der Reaktion, Brutstätten einer nazistischen, deutschnationalen und faschistischen Vorbildung der akademischen Jugend. Wir hatten unter den Hochschulprofessoren, unter den leitenden Akademikern sehr viele Menschen, die alle akademischen Grade besessen haben; nur ein Grad hat ihnen gefehlt: Rückgrat! Und ich glaube, es ist sehr notwendig, dass wir endlich nicht diese akademischen, sondern die allgemein menschlichen Grade, nämlich das demokratische, das antifaschistische Rückgrat in unseren Akademikern höher schätzen als alle möglichen anderen Diplome, Grade usw. ${ }^{\text {1545 }}$ [Hervorhebung d. Verf.]

In der Frage der Hochschulprofessoren, die „strenger, rigoroser“ gehandhabt werden müsse, wandte sich Fischer an dieser Stelle strikt gegen jede Rehabilitierung, im Besonderen bei geisteswissenschaftlichen Fächern: „Es geht einfach nicht an, dass ein Mann vorgestern großdeutsche Geschichte, gestern Geschichte des Nationalsozialismus und heute Geschich-

1544 Stenogr. Protoll. d. NR, 18. Sitzung, V.G.P., 24. Mai 1946, 338.

1545 Ebd., $318 \mathrm{f}$. 
te des demokratischen Österreich vorträgt. ${ }^{1546}$ Und hinsichtlich der frei gewordenen Lehrstühle, die - wie Fischer meinte - durch ,andere, bessere, augenblicklich nicht“ hätten besetzt werden können und nun von mittelmäßigen Professoren okkupiert würden, sprach sich der frühere Staatssekretär für die Rückholung von Exil-Wissenschaftern aus - eine Initiative, die Fischer während seiner kurzen Amtszeit selbst nicht gesetzt hatte. Ohne sich selbst noch sonderlich dafür verantwortlich fühlen zu müssen, verwies Fischer aber sogleich auf die Widerstände, die ein derartiges Unterfangen ohnedies zum Scheitern verurteilen würden:

„Ich habe schon im Budgetausschuß darauf hingewiesen, wie viele weltberühmte Gelehrte sich noch im Auslande befinden. Man hat gewisse Versuche unternommen, sie nach Österreich zurückzubringen, aber es ist mir bekannt, daß solche Versuche aus den Kreisen der Hochschullehrerschaft immer wieder konterminiert [sic] werden, weil diese Herren Angst vor der größeren Begabung, vor der legitimen Begabung jener haben, die zurückkommen und die ihnen gebührenden Lehrstühle an den österreichischen Hochschulen einnehmen könnten. “1547

\section{Rückkehr unerwünscht ? $^{1548}$ - Maßnahmen zur Rückholung österreichischer WissenschafterInnen aus der Emigration}

Einen ersten Aufruf „an die österreichischen Künstler und Wissenschaftler in den U.S.A.“ um Mithilfe beim Wiederaufbau hatte der Wiener Stadtrat für Kultur und Volksbildung, Viktor Matejka, am ıo. Oktober 1945 veröffentlicht. Darin umriss er die bisher erfolgten Wiederaufbaumaßnahmen im Bereich der Theater, der Kinos, Cabaretts und Varietes sowie auf die erfolgte „Säuberung“ und Wiederherstellung von Schulen, Hochschulen und Volksbildungseinrichtungen und lud die „Freunde Österreichs in den Vereinigten Staaten“ ein, diese Arbeit zu unterstützen, etwa durch dringend benötigtes Lehr- und Lernmaterial für Schulen und Bibliotheken. Der Aufruf Matejkas, der in der Austro American Tribune veröffentlicht wurde, enthielt allerdings keine explizite Einladung zur Rückkehr an vertriebene beziehungsweise emigrierte österreichische Universitätslehrer. ${ }^{1549}$

Vor dem Hintergrund der heftigen öffentlichen Kritik an der Wiedereinstellung ehemaliger NS-Professoren wandte sich nun Rektor Adamovich im Jänner 1946 in einem Interview an die Öffentlichkeit und signalisierte darin Bereitschaft, sich um die Rückholung vertriebener beziehungsweise emigrierter Dozenten und Professoren zu bemühen.

\section{Ebd., 319.}

1547 Ebd.

1548 Vgl. Christian Fleck, Rückkehr unerwünscht. Der Weg der österreichischen Sozialforschung ins Exil. In: Friedrich Stadler (Hrsg.), Vertriebene Vernunft I. Emigration und Exil österreichischer Wissenschaft 1930-1940 (=Veröffentlichungen des Ludwig Boltzmann-Institutes für Geschichte der Gesellschaftswissenschaften, Sonderband 2), Wien - München 1987, 182-213.

1549 Stadtrat Viktor Matejka, An die österreichischen Künstler und Wissenschaftler in den U.S.A., Wien, 10. Oktober 1945. In: Austro American Tribune. Anti-Nazi Monthly, Vol. IV, No. 4, 1945, 1. 
Namentlich aufgezählt wurden von Adamovich, der erklärte, dass alle „,gemaßregelten Professoren, zu denen auch ich gehöre [...] automatisch wieder in Dienst “"1550 seien, bei dieser Gelegenheit jedoch nur drei Professoren-Kollegen, nämlich Brocha und Kupka [sic; recte: Hupka] ${ }^{1551}$ die im Konzentrationslager Theresienstadt verstorben seien, sowie der in London verstorbene Prof. Goldmann. ${ }^{1552}$ Von ,vielen wissen wir noch nicht, was aus ihnen geworden ist" ${ }^{1553}$ fügte Adamovich hinzu, verwies aber auf eine kurz zuvor von den Briten übergebene Liste, die darüber Aufschluss gebe: „Die englische Militärregierung übergab uns eine Liste österreichischer emigrierter Gelehrter in England. Wir sind mit einigen von ihnen bereits in Verbindung getreten und hoffen, sie bald in unserer Heimat wieder begrüßen zu können. “1554

Darüber hinaus hätten sich sowohl Rektor Adamovich als auch die Unterrichtsverwaltung entschlossen, im Wege über die neuernannten Gesandten in Washington, Paris und London einen „Appell an alle ehemaligen Professoren und Dozenten der Universität zur

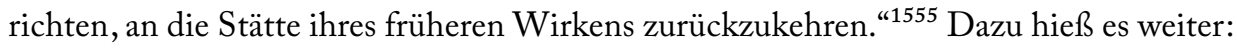

„Es ist zu hoffen, dass die Herren, soweit sie noch am Leben und erreichbar sind, diesem Rufe zum großen Teil folgen werden, dies um so mehr, als sich unter ihnen Gelehrte von Weltruf befinden, die jeder Universität Glanz und Ansehen geben. ${ }^{11556}$ [Hervorhebung im Orig., d. Verf.]

1550 Wiederaufbau an der Universität. Gespräch mit dem Rektor Prof. Dr. Adamovich. In: Wiener Montag, 21. Jänner 1946, 3.

1551 Vermutlich war der Handelsrechtler und Dekan an der juridischen Fakultät Josef Hupka (1875-1944) gemeint, der dem NS-Terror zunächst durch Flucht nach Holland entkommen konnte, nach seiner Verhaftung 1939 jedoch in das KZ Theresienstadt verbracht wurde und dort am 23. April 1944 starb. Vg1. Ratkolb, Rechts- und Staatswissenschaftliche Fakultät, a.a.O., 214; weiters: Werner Ogris, 1884-1984. Einhundert Jahre Rechtswissenschaften im Hause am Ring. In: Günther Hamann/Kurt Mühlberger/Franz Skacel (Hrsg), 100 Jahre Universität am Ring. Wissenschaft und Forschung an der Universität Wien seit 1884 (=Schriftenreihe des Universitätsarchivs, Bd. 3), Wien 1986, 57; siehe auch: Oliver Rathkolb, Zur Archäologie über österreichische Juristen im Exil. In: Friedrich Stadler (Hrsg.),Vertriebene Vernunft II. Emigration und Exil österreichischer Wissenschaft, Wien - München 1988, 435.

1552 Dabei dürfte es sich um den im englischen Exil in Cambridge verstorbenen Professor für Deutsche Rechtsgeschichte, Emil Goldmann (1872-1942), gehandelt haben. Siehe: Oliver Rathkolb, Überlegungen zum Exodus der „Jurisprudenz“. Rechts- und staatswissenschaftliche Emigration aus dem Österreich der Zwischenkriegszeit. In: Friedrich Stadler (Hrsg.), Vertriebene Vernunft. Bd. 1. Emigration und Exil österreichischer Wissenschaft, Wien - München 1987, 295; weiters Wolfgang Speiser, Zeitzeuge. In: Friedrich Stadler (Hrsg.), Vertriebene Vernunft. Bd. II. Emigration und Exil österreichischer Wissenschaft, Wien - München 1988, 907. Der Nachlass von Emil Goldmann befindet sich heute in der Universitätsbibliothek der Universität Graz.

1553 Wiederaufbau an der Universität. Gespräch mit dem Rektor Prof. Dr. Adamovich. In: Wiener Montag, 21. Jänner 1946, 3.

1554 Ebd.

1555 Der Wiederaufbau der Universität. In: Wiener Montag, 4. Februar 1946, 3.

1556 Ebd. 
Tatsächlich hatte Major Needham von der britischen „Education Branch/Internal Affairs Division“ des Alliierten Rates am Ir. Jänner 1946 an Rektor Adamovich eine Liste mit insgesamt 175 entfernten bzw. vertriebenen Universitätslehrern ${ }^{1557}$ übergeben. Die Liste beinhaltete das Geburtsdatum, die frühere Stellung, das Spezialgebiet und den aktuellen Aufenthaltsort der jeweiligen Person. Unter den Aufgezählten finden sich, nach Disziplinen geordnet, unter anderen zum Teil prominente Namen wie Emilie Bondy, Karl Bühler, Ernst Gombrich, Engelbert Broda, Friedrich Feigl, Maximilian Chameides, Friedrich Engel-Jánosi, Hugo Hantsch, Karl Menger, Egon Wellesz, Elise Richter ${ }^{1558}$ Friedrich Waismann, Gustav Ichheiser, Gertrud Wagner, Felix Ehrenhaft oder Victor Franz Hess.

Lediglich neun Personen auf dieser umfangreichen Liste hatten an der Universität Wien bereits wieder ihre Lehrtätigkeit aufgenommen, darunter bezeichnenderweise kein einziger Exilant und auch keine einzige Frau, ${ }^{1559}$ an 37 weiteren Lehrkräften zeigte sich der Akademische Senat zumindest interessiert: darunter an Felix Ehrenhaft, Karl Bühler, Friedrich Feigl, Karl Przibram oder Erwin Schrödinger.

Auffällig an der Wunschliste des Akademischen Senates ist, dass sie, neben vier Assistenten und einem Bibliothekar sowie einigen mittlerweile prominenten Exil-Wissenschaftern, vor allem ehemalige Ordinarien umfasst und damit - Parteigänger des,Ständestaats'; Juden enthält diese Liste hingegen kaum. Damit zeichnen sich drei Merkmale ab, die in der Frage der Rückberufungen sowohl die Linie der Universität als auch die des Unterrichtsministeriums bestimmten sollten: ,prominent, katholisch-konservativ bis monarchistisch und arisch". ${ }^{1560}$

Wie der Offizier der britischen Education Branch gegenüber Rektor Adamovich hervorhob, bliebe es „selbstverständlich [...] der Hochschule vollkommen frei gestellt“, sich

1557 Als einzige Person, die vor 1938 keinen Lehrauftrag hatte, befand sich interessanterweise der bereits als Stadtrat für Kultur und Volksbildung in Wien tätige Viktor Matejka auf der genannten Liste. UAW, Dekanatsakten der Phil. Fakultät, 628-1945/46, Allied Commission for Austria (British Element), 14. Jänner 1946.

1558 Die Sprachwissenschafterin Elise Richter (1865-1943) - eine der ersten Frauen, die an der Universität Wien promoviert (1901) hatte und die erste Universitätsprofessorin Österreichs (1921) -, war 1942 gemeinsam mit ihrer Schwester in das KZ Theresienstadt deportiert worden, wo sie 1943 ums Leben kam. Siehe: Elisabeth Andraschko, Elise Richter - eine Skizze ihres Lebens. In: Waltraud Heindl/Marina Tichy (Hrsg.), „Durch Erkenntnis zu Freiheit und Glück...“ : Frauen an der Universität Wien ab 1897, Wien 1990, 221-231; weiters: Wolfgang Bandhauer, Niemals vergessen! Elise Richter zum Gedenken. In: Semiotische Berichte, H. 1-2, 1985, 165-179; siehe auch: http://www.onb.ac.at/Ariadne/vfb/bio_richterelise.htm

1559 Frauen finden sich darunter keine: Alfred Wolfgang Wurzbach, Alois Dempf, Viktor Kraft, Kasimir Graff, Hans Thirring, Eduard Castle, Karl Mras, Hans Mzik, Hans Leitmeier, Josef Weninger und Richard Pittioni. UAW, Dekanatsakten der Phil. Fakultät, 628-1945/46, Allied Commission for Austria (British Element), 14. Jänner 1946.

1560 Vgl. Fleck, Österreichs Universitäten am Beginn der Zweiten Republik, a.a. O., 6. Unter den ehemaligen Exponenten des „Ständestaats“ finden sich Namen wie Hans Mokre oder Johannes Messner; als Legitimisten traten Victor F. Hess, Robert Heine-Geldern oder Willibald M. Plöchl in Erscheinung. 
mit „einem auf dieser Liste angeführten Lehrer in Verbindung zu setzen zwecks eventueller Berufung “. ${ }^{1561}$ Bis Mitte 1947 waren es letztlich auch nur vier Professoren sowie eine Dozentin, die aus der Emigration zurückkehrten.

Auch von amerikanischer Seite wurde dem Unterrichtsministerium und der Universität Wien eine - noch umfangreichere - Liste emigrierter Wissenschafter ausgehändigt. Im Mai 1946 übergab der Leiter der US-Education Division in Wien, Oberst William B. Featherstone, Rektor Adamovich eine Liste mit 370 Namen und Adressen (zum Großteil vertriebener) österreichischer Gelehrter für die Medizinische und Philosophische Fakultät, die jetzt in den USA lebten und, organisiert in der „Austrian University League of America“ ${ }_{1562}$ an einer Rückkehr in ihre Heimat interessiert wären; darunter befanden sich auch die Namen von 39 Frauen. ${ }^{1563}$ Hinsichtlich ihrer ideologischen Provenienz waren die hier versammelten österreichischen Exil-Wissenschafter tendenziell eher dem katholisch-konservativen Milieu zuzurechnen. Besonderes Interesse verdient dabei, dass, neben dem Nobelpreisträger und League-Präsidenten Victor F. Hess, der Chef der USEducation Division höchstpersönlich Vizepräsident der „League“ war und die erstellte Liste - so bleibt zu vermuten - wohl mit entsprechendem Nachdruck weitergegeben haben wird. ${ }^{1564}$

Dieser Liste, die vorwiegend jüngere, im US-Exil noch nicht etablierte Lehrkräfte umfasste, folgte ein bereits im Juli 1945 verfasstes, I6-seitiges „Memorandum on the Reconstruction of Austrian Universities", das unter anderen an den Bundespräsidenten, den Bundeskanzler und den Unterrichtsminister gesandt wurde. Neben Vorschlägen zum Wiederaufbau des Universitätswesens, die hauptsächlich in gründlichen personalen Säuberungsmaßnahmen und in der Aberkennung in der NS-Zeit erworbener akademischer Grade bestanden, jedoch keinerlei Angaben zu strukturellen Veränderungen enthielten,

1561 UAW, Dekanatsakten der Phil. Fakultät, 628-1945/46, Allied Commission for Austria (British Element), 14. Jänner 1946.

1562 Erster Präsident der „League“ war der Pharmakologe Ernest P. Pick, die beiden Vizepräsidenten waren der Nobelpreisträger für Physik, Victor F. Hess, sowie William B. Featherstone der Leiter der USFAEducation Division. Angehörige des Direktoriums der „League“ waren Robert Heine-Geldern, Fritz Lieben, die Religionswissenschafter Karl Beth und Thomas A. Michels, der Mathematiker Alfred E. Basch, die Mediziner Ludwig Adler, William V. Berger, Bela Schick und Hans Mauthner, der Chemiker Hermann Mark sowie die Juristen Eric[h] C. Hula, Robert Langer, Georg(e) Petschek, weiters Herbert Elias, der Physiker Felix Ehrenhaft, Charles Smith und, als Generalsekretärin der „League“, die Histologin Clara Zawitsch-Ossenitz; letztere wurde nach 1945 wieder an die Universität Wien berufen, war aber vom NS-Regime aus nicht-rassistischen Gründen entfernt worden, und stammte ,aus dem adeligen, katholisch-konservativen Umfeld“. Ilse Korotin, „Keine Rückkehr der weiblichen Vernunft nach dem Nazi-Regime“. In: Der Standard, 15. Juni 2005; weiters: ÖSTA/AdR, Bestand 02, BmfU, GZ 26742 /46 bzw. GZ. 36270/48.

1563 Siehe: Ilse Korotin, Wissenschaftlerinnen und Remigration - die „Austrian University League of America". In: IWK-Mitteilungen, 1-2, 2005, 7.

1564 ÖSTA/AdR, Bestand 02, BmfU, GZ 26742/46 bzw. GZ. 36270/48. 
beanstandete das Memorandum der „League“, dass in bisherigen Einladungsschreiben an EmigrantInnen von österreichischer Seite „keinerlei Details über Arbeits- und Lebensbedingungen enthalten “1565 waren.

Tatsächlich hatte die Hochschulsektion des Unterrichtsministeriums unter Leitung von Skrbensky, wie dieser in einem Schreiben an den Leiter der US-Education Division Thomas E. Benner ${ }^{1566}$ im Juli 1946 mitteilte, erwartet, dass sich die vertriebenen Professoren „nach der sicherlich auch im Auslande bekannt gewordenen Wiederherstellung der österreichischen Hochschulordnung von selbst melden und für die Wiederaufnahme ihrer durch die Nazi unterbrochenen Lehrtätigkeit in Österreich interessieren würden. [...] Anscheinend erwartet die Mehrzahl der in Frage kommenden Wissenschaftler eine förmliche Einladung unsererseits“ ${ }^{1567}$ Von sich aus waren die zuständigen Behörden beziehungsweise die verantwortlichen Ministerialbeamten, die die League verächtlich als „Emigrantenregierung “ ${ }^{1568}$ bezeichneten, weder unmittelbar nach Ende der NS-Barbarei noch in den darauf folgenden Jahren daran interessiert, vertriebenen WissenschafterInnen entgegenzukommen, ihnen aktiv Berufungsangebote zu unterbreiten oder gar Entschädigungen anzubieten. ${ }^{1569}$

Die Namensliste verschwand in ministerialen Schubladen und blieb letztlich Makulatur - trotz einzelner erfolgreicher anderweitiger Interventionen bei zuständigen amerikanischen Militärstellen und beim Department of State, ${ }^{1570}$ immerhin war ja der erste Leiter

1565 Fleck, Österreichs Universitäten am Beginn der Zweiten Republik, a.a.O., 7.

1566 Dieser war Ende Juni 1946 auf Oberst Featherstone nachgefolgt.

1567 ÖSTA/AdR, Bestand 02 BmfU, Z1. 22.824/47. Hier zitiert nach: Christian Fleck, Rückkehr unerwünscht. Der Weg der österreichischen Sozialforschung ins Exil. In: Vertriebene Vernunft. Bd. I. Emigration und Exil österreichischer Wissenschaft 1930-1940 (Veröffentlichungen des Ludwig BoltzmannInstitutes f. Geschichte der Gesellschaftswissenschaften, Sonderband 2), Wien - München 1987, $202 \mathrm{f}$.

1568 ÖSTA/AdR, Bestand 02, BmfU, Z1. 26742/46. Zit. nach: Fleck, Österreichs Universitäten am Beginn der Zweiten Republik, a.a.O., 7.

1569 Vgl. dazu auch: Christian Fleck, Verbliebene Unvernunft. In: heureka!, 2, 1998.

1570 So versuchte beispielweise der Vizepräsident der „Austrian University League of America“, Ernest P. Pick, der davon ausging, dass „the Provisional Austrian Government does not yet know the facts stated“, über Einschaltung des State Department und des War Department November 1945 die Enthebung zweier belasteter Universitätsangehöriger, nämlich Dr. Georg Stettner und Dr. Gerhard Kirsch, zu erreichen, indem er den US-Behörden eidesstattliche Erklärungen zukommen ließ, die bezeugten, dass es sich in beiden Fällen um aktive Mitglieder der NSDAP handelte. In Stellvertretung des Secretary of State bedankte sich James W. Riddleberger als Chief der „Division of Central European Affairs“ im State Department für die Information und antwortete Pick, dass er die Hinweise an die zuständigen US-Stellen für Österreich weiterleiten werde: „I am sure they will be given consideration.“ Recordings of the U.S. Department of State relating to the Internal Affairs of Austria 1945-1954 (Mikrofilm-Bestand Institut für Zeitgeschichte der Universität Wien), Decimal File, Reel 1, James W. Riddleberger an Ernest P. Pick, Vice President, Austrian University League of America, 7 November 1945, 1. Auf Basis des neugefassten Nationalsozialistengesetzes 1947 wurde die Enthebung von Kirsch im Juli des Jahres aufgehoben und ihm die zurückgelegte Dienstzeit zwischen 1938 und 
der USFA-Education Division Mitinitiator des Papiers der „Austrian University League of America" gewesen:

„Das BMU reagierte auf diese Listen, die es möglich gemacht hätten, im Schnitt für jede 1946 noch nicht besetzte Stelle unter vier Kandidaten auszuwählen, mit totaler Ignoranz. Mit keinem der auf den Listen Angeführten, mit dem das BMU nicht bereits in Kontakt stand, wurde der Kontakt gesucht.“1571

In einem Schreiben der US-Education Division vom September 1947 wurde Sektionschef Skrbensky erneut darum ersucht, für die Besetzung von 47 Lehrkanzeln endlich den Nachweis der politischen Unbedenklichkeit der in Frage kommenden Personen vorzulegen, was nahelegt, dass es sich dabei um keine Lehrkräfte handelte, die auf den kursierenden Listen der an einer Rückkehr interessierten Exil-Wissenschafter zu finden waren. Skrbensky antwortete schließlich, es seien nur neun Emigranten für die Besetzung der vakanten Ordinariate vorgesehen, darunter ein politisch Verfolgter. ${ }^{1572}$

Zweifellos noch schwerer ins Gewicht fällt im Zusammenhang mit den genannten Wissenschafter-Listen, dass neben aller offensichtlichen und hinhaltenden Ignoranz, allen unterschwelligen antisemitischen Vorbehalten, aller Bereitschaft zur wohlwollenden „Nachsicht“ gegenüber ehemaligen NS-Professoren und dem Bemühen um Wiedereinsetzung konservativ-katholischen Lehrpersonals aus der austrofaschistischen Ära, zuweilen auch absichtlich Fehlinformationen weitergeleitet wurden - wie beispielsweise an Karl und Charlotte Bühler, denen Sektionschef Skrbensky in einem Schreiben vom Juni I946 falsche Angaben hinsichtlich angeblich nicht möglicher finanzieller Entschädigungsansprüche machte. ${ }^{1573}$

Ganz abgesehen davon, dass mit der Frau von Karl Bühler, Charlotte Bühler - vor ihrer Emigration außerordentliche Professorin und Direktorin am Wiener Institut für Psycho-

1945 auf seinen künftigen Ruhegenuss angerechnet. Siehe: Pfefferle/Pfefferle, Glimpflich entnazifiziert, a.a. O., 95.

1571 Fleck, Österreichs Universitäten am Beginn der Zweiten Republik, a.a.O., 7.

1572 Wobei, wie Christian Fleck dargelegt hat, der hierunter angeführte Victor F. Hess nie und der ebenfalls genannte Historiker Friedrich Engel-Jánosi zwar 1959, aber eben erst nach seiner Emeritierung zurückkehrte. Vgl. Fleck, Rückkehr unerwünscht. Der Weg der österreichischen Sozialforschung ins Exil, a. a. O., 207. Hingegen berichtet Erika Weinzierl, dass Engel-Jánosi 1949 das Angebot eines Lehrstuhls für neuere Geschichte an der Universität Wien „vor allem aus Rücksicht auf Frau und Tochter abgelehnt" hatte. Als er 1959 zurückkehrte - Engel-Jánosi lehrte in den USA u. a. an der John Hopkins University -, zeigte sich ihm hingegen „die österreichische Bürokratie nicht von ihrer besten Seite. Weil er sechzig Jahre alt war, erhielt er zwar alle Rechte eines Ordinarius, aber nur den Titel eines Honorarprofessors, und die Frage seiner Pension blieb ungelöst." Erika Weinzierl, Friedrich Engel-Janosi. In: Stadler (Hrsg.), Vertriebene Vernunft. Bd. II. Emigration und Exil österreichischer Wissenschaft, a. a. O., 518.

1573 Fleck, Rückkehr unerwünscht. Der Weg der österreichischen Sozialforschung, a.a. O., 208 f. 
logie - gar keine Verhandlungen geführt wurden, bekam ihre Stelle, nach rascher Entnazifizierung, das NSDAP-Mitglied Sylvia Klimpfinger, die sich 943 bei Arnold Gehlen mit einer Arbeit über volksdeutsche Umsiedler in Bessarabien habilitiert hatte. ${ }^{1574}$

Im Hinblick darauf ist die Analyse von Oliver Rathkolb zweifellos mehr als zutreffend, wonach der auf unterschiedlichen Ebenen des zivilen und militärischen Reeducation-Diskurses projektierte Elitentausch - als ein Aspekt der Entnazifizierung - unter Supervision der US-Militärbehörden in Österreich schließlich in eine Elitenrestauration kippte. ${ }^{1575}$ Und auch der Einschätzung von Christian Fleck ist grundsätzlich zuzustimmen, wenn er im Hinblick auf das Agieren vor allem der Briten und Amerikaner im Kontext der ,Erneuerung des österreichischen Wissenschaftssystems davon spricht, dass durch die bald eintretende „ausschließliche [...] Orientierung auf vermeintliche militärstrategische Vorteile und taktische Erfordernisse im Kalten Krieg“ geradezu eine „zweite Gegenreformation“1576 - in diesem Fall eine Ent-Intellektualisierung ohne nachfolgende Re-Katholisierung - stattfand.

Inwieweit diese „Gegenreformation“ tatsächlich eine „mögliche re-education“ ersetzte und die „Bemühungen um eine demokratische Erneuerung Österreichs“1577 dadurch obsolet wurden, muss dahin gestellt bleiben - dies nicht zuletzt auch vor dem Hintergrund des hochdifferenziert geführten Reorientierungs-Diskurses vor und nach Kriegsende und der zum Teil konterkarierenden Aktivitäten amerikanischer ziviler Behörden und US-Besatzungsorgane. An die Stelle eines Elitenaustausches - der weitaus größte Teil der intellektuellen Elite des Landes hatte sich im Verlauf des anwachsenden Ost-West-Konflikts ohnedies als verlässlich westorientiert erwiesen ${ }^{1578}$ - trat jedenfalls, wie noch darzustellen sein wird, bald ein kultureller Elitentransfer nach Amerika, und zwar im Zuge des „Visiting Experts Program“. Intendiert wurde damit in der Hauptsache die Popularisierung des „American way of life“: Ein Projekt, das aus amerikanischer Sicht bereits seit der Reeducation-Diskussion der Kriegsjahre als wirksamstes und nachhaltigstes Mittel demokratischer Reorientierung angesehen wurde.

Die zivilen Überlegungen hinsichtlich einer umfassenden Demokratisierung nach Kriegsende, die die Grundlage für die nachfolgenden Aktivitäten innerhalb der militärischen Besatzungsorgane bildeten, waren von vornherein auf „Reorientation“, also auf eine langfristig angelegte Rekulturalisierung nach Maßgabe amerikanisch-westlicher, demokratischer Wer-

1574 Korotin, Wissenschafterinnen und Remigration, a.a.O., 6.

1575 Rathkolb, U.S.-Entnazifizierung in Österreich zwischen kontrollierter Revolution und Elitenrestauration, a.a.O., 317.

1576 Fleck, Österreichs Universitäten am Beginn der Zweiten Republik, a.a.O., 4. Vgl. auch: Gottfried Ellemauer, Rückkehr unerwünscht. Remigration in Österreich nach 1945, Dipl.-Arb., Universität Wien 1992.

1577 Fleck, Österreichs Universitäten am Beginn der Zweiten Republik, a.a.O., 4.

1578 Siehe: Rathkolb, Die Universität Wien und die „Hohe Politik“ 1945 bis 1955, a.a. O., 48. 
te und Handlungsnormen angelegt, mithin als Westorientierung oder Westernization ${ }^{1579}$ gedacht. Inwieweit nun unter einem derart weit gefassten, über personelle Säuberungsmaßnahmen weit hinausreichenden Planungshorizont mit der Initiierung selbstverantworteter Demokratisierungsprozesse ohne externe Bevormundung (wenngleich auf Basis vorheriger Entnazifizierung) die Ausbildung einer post-nationalsozialistischen gesellschaftlichen Identität im Sinne demokratischer Werte und Normen befördert oder beeinträchtigt wurde, lässt sich vorerst noch nicht beantworten.

Dass sich das Interesse sowohl der Unterrichtsverwaltung als auch der Universität in den Jahren nach I945, wie Ilse Korotin meint, primär „auf die realistisch gesehen eher unwahrscheinliche Rückkehr prominenter männlicher Wissenschafter "1580 richtete und all jene vernachlässigte, die auf wissenschaftlich niederen Hierarchieebenen tätig gewesen waren, ist zwar grundsätzlich richtig, geht meines Erachtens aber doch insofern an der Realität vorbei, als offizielle Rückholaktionen - von einigen wenigen Kontaktaufnahmen einmal abgesehen ${ }^{1581}$ - zu keinem Zeitpunkt ernsthaft betrieben wurden. Darüber hinaus wurden ernstzunehmende Gespräche mit international wirklich prominenten emigrierten Wissenschaftern wie Kurt Gödel, Lise Meitner, Marie Jahoda, Fritz Machlup, Paul F. Lazarsfeld oder Philipp Frank, um hier nur einige Namen zu nennen, erst gar nicht aufgenommen.

Hinzu kommt, dass es keineswegs immer nur allein an den entsprechenden österreichischen Stellen lag, wenn prominente Personen entweder abgelehnt wurden oder sich ihre Rückkehr kompliziert und überaus langwierig gestaltete. Um dies zumindest punktuell ein wenig näher zu beleuchten, soll im Folgenden exemplarisch auf drei Fallbeispiele eingegangen werden.

1579 Vgl. Bischof/Pelinka (Eds.), The Americanization, Westernization of Austria, a.a.O.

1580 Korotin, Ilse Korotin, Wissenschaftlerinnen und Remigration - die „Austrian University League of America“. In: Frauen im Exil: die weibliche Perspektive. In: Mitteilungen des Instituts für Wissenschaft und Kunst, 60. Jg., 2005, 1-2, 7.

1581 Ausnahmen sind hier die beiden Nobelpreisträger in Physik Erwin Schrödinger, und Victor F. Hess. Der 1946 bereits 63-jährige Hess kehrte aus der amerikanischen Emigration allerdings nicht mehr zurück, und Schrödinger kam erst 1956 nach Wien zurück. Vgl. UAW, Personalakten Schrödinger und Hess. 


\section{Fallbeispiel: Ernst Karl Winter (1895-1959)}

"Having been one of the first exiles to reach these shores I am now by the wheel of fortune among the last to find my place." 1582

„Ich habe in der Tat die Idee heimzukehrem niemals aufgegeben, ohne daß ich wüßte, wie sie realisierbar sein wird. Was Du von der Möglichkeit einer Position für mich sagst, zeigt, daß Du Deine und meine Landsleute noch immer zu wenig kennst. Meine schon von der Grazer Fakultät erworbene Berufung ist, wie mir ernsthaft versichert wurde, an dem leidenschaftlichen Widerstand von Gorbach, Funder, Knoll, denen schließlich Hurdes nach anfänglicher Sympathie erlag, schon vor Jahren gescheitert. “1583

Als Beispiel sind in dem genannten Zusammenhang die Bemühungen Ernst Karl Winters zu nennen, nach Kriegsende aus der US-amerikanischen Emigration nach Österreich zurückzukehren, um - endlich - an der Universität Wien zu lehren. Das Remigrationsvorhaben wurde zwar im zweiten Anlauf von Unterrichtsminister Hurdes unterstützt, verzögerte sich aber durch das Negativ-Lobbying der Universität schier endlos; selbst von den zuständigen US-Militärbehörden bekam der prononcierte „Anti-Nazi““1584 und ausgewiesene sozialwissenschaftliche Gelehrte ${ }^{1585}$ keinerlei Unterstützung.

1582 U.S. Office of Strategic Services. Foreign Nationalities Branch Files 1942-1945. Indexes, Bethesda 1998 [Mikrofiche-Bestand, Institut für Zeitgeschichte der Universität Wien, Bibliothek], INT-4AU-159, Ernst Karl Winter an Office of Strategic Services, 15. August 1942, 6. Für den Hinweis auf dieses Quellenmaterial des amerikanischen Geheimdienstes bin ich Herrn Univ.-Prof. DDr. Oliver Rathkolb zu Dank verpflichtet.

1583 Ernst Karl Winter in einem Brief an Kurt Schuschnigg vom 1. April 1950. Zit. nach: Hugo Pepper, Ernst Karl Winter und die Sozialdemokratie - im Spiegel von $A Z$ und Kampf. In: Siegwald Ganglmair (Red.), Jahrbuch 1996. Dokumentationsarchiv des österreichischen Widerstandes, Wien 1996, 171.

1584 Vgl. dazu u.a. Karl Hans Heinz, War der „Anschluß“ unvermeidlich? Dr. Ernst Karl Winters Briefwechsel mit Dr. Kurt Schuschnigg. In: Die Zukunft, Jänner 1981, Heft 1, 30 ff.; Ders., Ernst Karl Winter. Ein Katholik zwischen Österreichs Fronten 1933-1938, Wien - Köln - Graz 1984, 253 ff.; Gerd-Peter Mitterecker, Der Publizist Ernst Karl Winter. Möglichkeiten und Grenzen oppositioneller Medienarbeit im autoritären Staat, Dipl.-Arb., Univ. Wien 1995, 75 f.; zuletzt: Erwin Bader, Ernst Karl Winter und die Versöhnung der politischen Lager. In: Ulrich E. Zellenberg (Hrsg.), Konservative Profile. Ideen \& Praxis in der Politik zwischen FM Radetzky, Karl Kraus und Alois Mock, Graz u.a. 2003, 366 f.

1585 Vgl. Reinhold Knoll, Die Soziologie in der Geschichte am Beispiel von Ernst Karl Winter. In: Michael Benedikt/Reinhold Knoll/Cornelius Zehetner (Hrsg.), Verdrängter Humanismus - verzögerte Aufklärung. Bd. V: Im Schatten der Totalitarismen. Vom philosophischen Empirismus zur kritischen Anthropologie. Philosophie in Österreich 1920-1951, Wien 2006, 1065 ff.; des Weiteren: Alfred Missong, Ernst Karl Winter - Denker, Bekenner, Kämpfer. In: Ernst Karl Winter - Bahnbrecher des Dialogs. Ausgewählt und eingeleitet von Alfred Missong (= Ernst Karl Winter, Gesammelte Werke. Bd. 1. Hrsg. v. Ernst Florian Winter), Wien - Frankfurt - Zürich 1969, 12 ff. 
Im Folgenden geht es freilich nicht darum, die in sich komplexe Causa Winter in allen Details nachzuzeichnen - die Verhinderung seiner Habilitation in der Ersten Republik wurde von Robert Holzbauer bereits detailreich rekonstruiert; ${ }^{1586}$ es geht auch nicht darum, das letztendliche Scheitern seiner Bemühungen für eine Berufung auf den Lehrstuhl für Soziologie der juridischen Fakultät der Universität Wien nach 1945 zu rekapitulieren auch das wurde bereits dargestellt. Von Interesse im hier behandelten Kontext ist, wie und in welcher Form Winters Bemühungen um eine rasche Rückkehr nach Kriegsende von österreichischen und amerikanischen Stellen Rechnung getragen wurde, was im Folgenden unter Einbeziehung einiger neuer amerikanischer Dokumente dargestellt werden soll.

Der gläubige und streitbare Katholik Ernst Karl Winter, langjähriger Legitimist, Soziologe, Schriftsteller, Leiter des Verlages „Gsur \&Co. ${ }^{\text {"1587 }}$ und dritte Vizebürgermeister von Wien in der austrofaschistischen Ära, ${ }^{1588}$ konstatierte nach Durchsicht des Lehrpersonals der juridischen Fakultät in einem Antwortschreiben an seinen Freund Viktor Matejka am 25. März 1946, dass sich an der „Alma Mater nichts geändert hat, woran wohl auch die unausgenützte kurze Herrschaft der Linken mitschuldig ist“ ${ }^{1589}$ In diesem Brief wettete er darauf, „dass

$1586 \mathrm{Zu}$ Winters Biografie allgemein sowie insbesondere zu seinem verschleppten Habilitationsverfahren vgl. Robert Holzbauer, Ernst Karl Winter (1895-1959). Materialien zu seiner Biographie und zum konservativ-katholischen politischen Denken in Österreich 1918-1938, Diss., Univ. Wien 1992, 161 ff.; weiters: Ders., Ernst Karl Winter und die Legitimisten. In: „Anschluß“ 1938. Eine Dokumentation. Hrsg. v. Dokumentationsarchiv des österreichischen Widerstands. Ausgewählt, bearbeitet und zusammengestellt von Heinz Arnsberger, Winfried R. Garscha und Christa Mitterutzner, Wien 1938, 33 ff.; Ders., Ernst Karl Winter. In: Friedrich Stadler (Hrsg.), Vertriebene Vernunft. Bd. II. Emigration und Exil österreichischer Wissenschaft, Wien - München 1988, 458-462.

1587 Winters 1930 gegründeter Verlag publizierte - teils unter Pseudonymen - u.a. auch scharf antinationalsozialistische Propagandaschriften wie z.B. Zyrill Fischer (d.i. Johann Fischer), „Die Hakenkreuzler (1932, 329 S.), Ders., „Die Nazisozi“ (1932, 111 S.), Thomas Murner (d.i. Alfred Missong), „Der Nazispiegel“ (1932, 111 S.), Ders., „Das Tagebuch der nationalen Revolution“ (1933) oder den Roman von Hermynia zur Mühlen, Unsere Töchter die Nazinen (1935). Vgl. Reinhard Müller, Für Österreich! Ernst Karl Winters Verlag Gsur \&Co., Wien, 1930-1939. In: Nerwsletter - Archiv für die Geschichte der Soziologie in Österreich, 1998, Heft 17, 18 f.; vgl. weiters: Murray G. Hall, Österreichische Verlagsgeschichte 1918-1938. Bd. II: Belletristische Verlage der Ersten Republik, Wien - Köln - Graz 1985, 178-192.

1588 Auf Drängen von Dollfuß, mit dem Winter während des Ersten Weltkriegs im selben Regiment war, übernahm er nach dem Februar 1934 das Amt des 3. Vizebürgermeisters von Wien, mit dem „Spezialauftrag“, die „Kooperation“ zwischen Arbeiterschaft und autoriärer Regierungsdiktatur Dollfuß herzustellen. Winter scheiterte und musste, als strikter Nazigegner, - eingeleitet durch das Juli-Abkommen 1936 zwischen Schuschnigg und Hitler -1937 letztlich demissionieren. Vgl. U.S. Office of Strategic Services. Foreign Nationalities Branch Files 1942-1945, Ernst Karl Winter an Office of Strategic Services, 15. August 1942, Curriculum Vitae, a.a.O., 3 f. Zum quasi vorprogrammierten Scheitern Winters als Vermittler und „Brückenbauer zum Austromarxismus“ siehe im Detail: Pepper, Ernst Karl Winter und die Sozialdemokratie, a.a.O., $150 \mathrm{ff}$.

1589 Zit. nach: Österreicher im Exil. USA 1938-1945. Eine Dokumentation. Bd. 2. Hrsg. v. Dokumentationsarchiv des österreichischen Widerstandes. Einleitungen, Auswahl und Bearbeitung: Peter Eppel, Wien $1995,726 \mathrm{ff}$. 
Othmar Spann und Reinhold Lorenz, ${ }^{1590}$ die m.E. eingesperrt gehörten, früher wieder im Amt und Würden sein werden, als etwa ich auch nur habilitiert “1591 - immerhin hatte Winter bereits im Jahr 1929 versucht, sich im Fach Soziologie an der Universität Wien zu habilitieren.

Nach Winters eigenen Angaben, die Holzbauer anhand des originalen Habilitationsaktes ${ }^{1592}$ im Detail verifiziert hat, scheiterte er mit diesem Vorhaben trotz Unterstützung von Kardinal Piffl und seinem Lehrer Hans Kelsen an seinem universitären und politischen Gegenspieler Othmar Spann, der seit I. Mai I933 illegales NSDAP-Mitglied war. ${ }^{1593}$ Trotz mehrfacher Bemühungen und Anläufe wurde das Habilitationsgesuch des kompromisslosen „Anschluss“-Gegners ${ }^{1594}$ vom deutschnational dominierten Fakultätskollegium verzögert, ignoriert und letztlich verhindert. Im amerikanischen Exil in New York nahm Winter in seinem an den amerikanischen militärischen Geheimdienst Office of Strategic Services (OSS) adressierten Lebenslauf, worin er sich als Experte für die Geschichte und Psychologie des Deutschen Nationalismus sowie als Kulturhistoriker zur Mitarbeit empfahl, zur Verhinderung seiner Habilitation an der Universität Wien folgendermaßen Stellung:

"After I received my Doctors's degree, I intended to become 'Privatdozent' at the Juridical Faculty of the University of Vienna, but was checked in my hopes by the ruling group of professors

1590 Tatsächlich erfolgte bereits im Dezember 1945 eine Unterschriftenaktion für die Wiedereinsetzung Reinhold Lorenz'. Vgl. Volkstimme, 15. Dezember 1945, 2.

1591 Österreicher im Exil. USA 1938-1945, a.a.O., 727.

1592 Durch Zufall hat der Habilitationsakt der rechts- und staatswissenschaftlichen Fakultät den Bombentreffer des juridischen Dekanats überdauert, da, wie Holzbauer anführt, dieser noch im März 1938 von Unterrichtsminister Oswald Menghin in der Zeit des zweitägigen Kabinetts unter Arthur Seyß-Inquart angefordert und dem Unterrichtsministerium übergeben worden sei. Von hier gelangte der Akt offenbar in die Hände Winters, der im US-amerikanischen Exil bereits über die Unterlagen verfügte, die darin enthaltene Information interessanterweise aber weder gegenüber amerikanischen noch gegenüber österreichischen Stellen ausspielte. Dies, obwohl Winter in einem 1942 verfassten Lebenslauf, den er auch an das Department schickte, darauf hinwies: „By some strange coincidence I was able to procure from the disbanding Austrian Ministry of Education after March 1938 the entire file of official documents concerning my application and its refusal, which still is in my hand." Siehe: Ernst Karl Winter, Curriculum Vitae, beigelegt einem Schreiben an James Riddleberger, Department of State, Washington D.C. vom 5. März 1945. DÖW 21.011/11, 1. Der Akt befindet sich heute laut Holzbauer im Familienarchiv im schweizerischen Sargans. Vgl. Holzbauer, Ernst Karl Winter (1895-1959), a.a.O., 162.

1593 Vgl. dazu Gertraud Resele, Othmar Spanns Ständestaatkonzeption und politisches Wirken, Dipl.-Arb., Univ. Wien 2001, 786 ff.; weiters: John Haag, Othmar Spann. 1878-1950. In: Research Guide to European Historical Biography. Vol. 8, Washington D.C. 1993, 4651-4662; Klaus-Jörg Siegfried, Universalismus und Faschismus. Das Gesellschaftsbild Othmar Spanns, Wien 1974, $152 \mathrm{f}$.

1594 Sowohl mit dem Programm des von ihm 1930 gegründeten und geführten Gsur-Verlages, den von Winter ab 1933 herausgegebenen Wiener Politischen Blättern, dem publizistischen ,Organ“ der „Österreichischen Aktion“ als auch mit den politischen Integrationsbemühungen der „Aktion Winter“ hatte sich Winter öffentlich als strikter und vehementer Gegner von „Anschluss“-Denken und Nationalsozialismus deklariert. Vgl. Holzbauer, Ernst Karl Winter und die Legitimisten, a.a.O., 43 f. 
(Gleispach, Hold, Hugelmann, Schönbauer, Schwind, Spann, Voltelini), who were pro-Nazis. They were so powerfully entrenched in the University of Vienna long before 1938, that they were able to prevent my appointment simply because they were aware of my political opposition to the 'Anschluss', an attitude which they regarded as 'Volksverrat'."1595

Mit Bezug auf eine angeblich 1936 angefertigte Abschrift des seinerzeitigen Berufungsverfahrens erinnerte man sich nach 1945 universitätsintern bezeichnenderweise an einen völlig anderen Verlauf des Habilitationsprozederes. Das Dekanat der Universität Wien sandte diese Abschrift, die den Brand überstanden hatte, Ende Februar 1946 an das Unterrichtsministerium. ${ }^{1596}$ Dem Wortlaut des Schriftstückes nach habe die damalige Habilitierungskommission dem Bewerber Winter, der, quasi in arbeitseifrigem Überschwang, gleich drei Habilitationsschriften eingereicht habe ${ }^{1597}$ in der Sitzung vom 20. Mai 1935 die Venia legendi einstimmig

1595 U.S. Office of Strategic Services. Foreign Nationalities Branch Files 1942-1945. INT-4AU-159, Ernst Karl Winter an Office of Strategic Services, 15. August 1942, Curriculum Vitae, a.a. O., 1.

1596 Das Original des Habilitationsansuchens Ernst Karl Winters und die anschließende Korrespondenz war jedenfalls im Jahr 1946 nicht mehr auffindbar, da dieser - so wurde an der juridischen Fakultät der Universität Wien gemutmaßt -, mit den anderen Dekanatsakten verbrannt sei. Lediglich eine Sachverhaltsdarstellung, die 1936 an das damalige Bundesministerium geschickt worden sei, fand sich 1946 in einer Abschrift, die allerdings nicht nur die Querelen zwischen Othmar Spann und Winter völlig unerwähnt lässt, sondern darüber hinaus den tatsächlichen Verlauf des Habilitationsansuchens beziehungsweise dessen schlussendliches Scheitern inhaltlich-sachlich vollständig ins Gegenteil verkehrt. Vg1. UAW, Personalakt Ernst Karl Winter/23, Dekanat der Universität Wien an das Bundesministerium für Unterricht, Dek. Zl. 372 aus 1946, 28. Februar 1946, Abschrift Zl. 1 aus 1936.

1597 Am 24. Mai 1929 hatte Winter erstmals um Erteilung der venia legendi für „Allgemeine Gesellschaftslehre“ angesucht und zwar unter Vorlage der Schrift „Die Sozialmetaphysik der Scholastik“. Die Habilitationskommission, die aus den Professoren Hans Voltelini, Hans Kelsen, Gustav Walker, Ferdinand Degenfeld-Schonburg und Ernst Schönbauer bestand, habe ihre Sitzung jedoch vertagt, nachdem Kelsen erklärt haben soll, man möge die Erscheinung einer soeben in Druck gehenden größeren Arbeit Winters abwarten. Winter selbst habe am 8. Oktober 1929 Professor Alexander Hold-Ferneck gebeten, seine Habilitation ruhen zu lassen, da er an einer neuen Schrift arbeite; die neugefasste und zugleich erweiterte Arbeit über Platon habe Winter dann zusammen mit weiteren Veröffentlichungen bereits am 5. Mai 1930 vorgelegt, mit der Bitte um Weiterführung seines Verfahrens. Im Mai 1930 habe Prof. Degenfeld nach einer Kommissionsbesprechung die Aufgabe übernommen, „Dr. Winter zu eröffnen, dass ein öffentlich abgegebenes klares und deutliches Bekenntnis zur deutschen Kulturgemeinschaft seine Habilitierung möglicherweise erleichtern würde." UAW, Personalakt Ernst Karl Winter, Habilitationsakt, Z1. 1-1936, 1.UAW, Personalakt Ernst Karl Winter/23, Dekanat der Universität Wien an das Bundesministerium für Unterricht, Dek. Zl. 372 aus 1946, 28. Februar 1946, Abschrift Zl. 1 aus 1936, $1 \mathrm{ff}$. Winter kam dieser Aufforderung nach, indem er eine Veröffentlichung über den „paternalen Staat“ aus der Zeitschrift für öffentliches Recht gemeinsam mit einer persönlichen Nachbemerkung nachreichte, die „geeignet“ schien, ,jene Bedenken gegen seine Habilitierung zu zerstreuen, die aus der Art und Weise, wie er seine politischen Meinungen geäußert hat, sich ergeben." Das Verfahren sei dann aber neuerlich auf Bitte Winters gestoppt worden, da dieser zunächst gegenüber dem damaligen Dekan Prof. Gustav Walker, dann im Jänner 1932 in einem schriftlichen gestellten Ersuchen, die Einreichung 
erteilt, allerdings mit der Einschränkung auf das Fach „Wirtschaftsgeschichte“ ${ }^{1598}$ Winter, dessen fachliche Qualifikation damit außer Frage gestanden sei, habe sich mit dieser vorläufigen Einschränkung der Lehrbefugnis auch einverstanden erklärt, jedoch durch öffentliche Vorwürfe und Volten gegenüber der Fakultät und insbesondere gegen Othmar Spann sowie durch sein insgesamt unkonziliantes Verhalten dazu beigetragen, dass sein Habilitationsansuchen wegen des „sachlich ungerechtfertigten und formell mehr als ungehörigen Verhaltens“ vom Unterrichtsministerium schließlich abgewiesen worden ist. ${ }^{1599}$ De facto waren Winters Habilitationsbemühungen - im genauen Gegenteil zum Wortlaut der vom Dekanat verwendeten „Abschrift“ - von Anbeginn durch die deutschnationale, pronazistische Ausrichtung des Fakultätskollegiums ${ }^{1600}$ behindert worden. Winter war als glühendem Verfechter einer österreichischen Eigenständigkeit ein öffentliches Bekenntnis, eine Art Ehrenerklärung zur "deutschen Kulturgemeinschaft" und zum „verfassungsmäßigen deutschen Charakter der Universität" ${ }^{1601}$ noch dazu im Organ der österreichischen NSDAP, abverlangt ${ }^{1602}$ bezie-

einer neuen Habilitationsschrift angekündigt habe. Diese habe er am 5. Jänner 1935 unter dem Titel „Rudolf IV. von Österreich“ für das Fach Soziologie mit den Nebenfächern „Sozialpolitik und Wirtschaftsgeschichte" eingereicht. Aufgrund des stark historischen Einschlags der Schrift habe die Kommission, die aus Spann, Hold-Ferneck, Hans Mayer, Degenfeld-Schonburg, Heinrich Mitteis und Emil Goldmann bestand, beschlossen, die Professoren Alfons Dopsch und (Hans?) Hirsch um ein Gutachten zu ersuchen. Nach deren Vorliegen sowie weiterer Gutachten von Spann und Degenfeld-Schonburg sei die Kommission dann zu einem positiven Entschluss gekommen.

Diese stark weichgezeichnete Darstellung, deren faktische Grundstruktur zutrifft, verdreht jedoch in entscheidender Weise die kausalen Zusammenhänge, weil es keineswegs Winters Initiative gewesen ist, jeweils neue Arbeiten als Bewerbungsgrundlage für seine Habilitierung einzureichen bzw. das Habilitationsverfahren zu unterbrechen, sondern dies geschah eindeutig aufgrund des Drucks seitens des Professorenkollegiums. Vgl. Holzbauer, Ernst Karl Winter (1895-1959), a.a.O., 163 f.

1598 Vgl. UAW, Personalakt Ernst Karl Winter/23, Abschrift Zl. 1 aus 1936, 3. In demselben Schreiben an die Fakultät, das dann an die Öffentlichkeit gelangte sei - z.B. im Telegraph vom 4. Dezember 1935 -, habe Winter indes den Vorwurf der Intoleranz und Minderwertigkeit gegenüber den Kommissionsmitgliedern erhoben - insbesondere gegenüber Othmar Spann - und sich damit in einen offenen Konflikt mit der gesamten rechts- und staatswissenschaftlichen Fakultät gebracht.

1599 Gemäß dem Wortlaut der „Abschrift“ habe das Professorenkollegium beantragt, das Bundesministerium für Unterricht möge die Berufung des Habilitationswerbers wegen des „sachlich ungerechtfertigten und formell mehr als ungehörigen Verhaltens nunmehr" abweisen und „die persönliche Eignung zum Hochschulamte ab(zu)sprechen“. Noch im Juli 1935 sei Winter nahe gelegt worden, seine gegen die Fakultät und eines seiner Mitglieder gerichteten Vorwürfe „bedingungslos mit dem Ausdrucke des Bedauerns zurückzuziehen“, um die Angelegenheit beizulegen, was Winter allerdings in einem Retourschreiben vom 10. Juli 1935 verweigert habe. UAW, Personalakt Ernst Karl Winter/23, Abschrift Zl. 1 aus 1936, 4.

1600 Winter, Curriculum Vitae, Schreiben an James Riddleberger, a.a. O., 1.

1601 Vgl. Holzbauer, Ernst Karl Winter (1895-1959), a.a. O., 165 f.

1602 So hatte Dekan Hold-Ferneck gegenüber Winter 1929/30 gemeint: „Solange Sie nicht in der ,Dötz‘ [Deutschösterreichische Tageszeitung, Organ der österreichischen NSDAP, der Verfasser] einen Leitartikel für den Anschluß schreiben werden, werden Sie nicht habilitiert werden“. Zit. nach: Holzbauer, Ernst Karl Winter (1895-1959), a.a.O., 165. 
hungsweise seine wissenschaftliche Eignung mit hanebüchenen Einwänden in Frage gestellt worden, wobei sich neben Hold-Ferneck insbesondere Spann, der als Lehrstuhlinhaber für Soziologie (in völkisch-ständischer Auslegung) ${ }^{1603}$ in Winter einen fachlichen Konkurrenten und „nationalpolitischen“ Gegner sah, in die Quere legte. ${ }^{1604}$ Hingegen trifft zu, dass Winter, nach den langjährigen Querelen schließlich Spann und die Fakultät dafür kritisierte, keine andere soziologische Methode (als die Spannsche, universalistisch-völkische Ständelehre) zulassen zu wollen, womit er einen willkommenen Anlass lieferte, sein Habilitationsgesuch auf Grund mangelnder persönlicher Eignung abzuweisen. ${ }^{1605}$

Aus der verzerrten Sachverhaltsdarstellung, die das Professorenkollegium am 25. Februar 1946 als Replik auf Winters persönliches Ansuchen bei Unterrichtsminister Hurdes um Erteilung der Venia für Soziologie an das Ministerium retournierte, wird deutlich, dass sich die geistig-ideellen Kräfteverhältnisse an der juridischen Fakultät kaum geändert hatten und man Winter, in direkter Anknüpfung an die Ablehnung von 1935, neuerlich verhindern wollte. Das Scheitern des Habilitationsansuchens in der Zwischenkriegszeit wurde mit Verweis auf die Abschrift erneut gänzlich dem „Verhalten des Habilitationswerbers“ zugeschrieben, weshalb ihm von der Fakultät seinerzeit die „persönliche Eignung abgesprochen “1606 worden war. Damit schien sich nach I945, unter nunmehr gänzlich veränderten gesellschaftlichen Rahmenbedingungen, eine Wiederholung jenes geradezu grotesken Beispiels einer reaktionären Wissenschaftskultur abzuzeichnen.

Nachdem ihm bereits im Oktober 1936 sein ehemaliger Universitätslehrer Hans Kelsen, der Ernst Karl Winter während eines Aufenthaltes in den USA besuchte, eindringlich zur Emigration geraten hatte, ${ }^{1607}$ war Winter mit seiner Familie unmittelbar nach dem „Anschluss“ 1938 über die Schweiz in die Vereinigten Staaten emigriert: „[...] I left my country, because I did not want to be a citizen of Greater Germany in the world struggle which lay ahead. " ${ }^{1608}$ Hier arbeitete er als Berater des Guardian und lehrte auf Einladung von Alvin Johnson ${ }^{1609}$ bis ins Frühjahr 1942 als „Assistant Professor“ für Soziologie an der Graduate

1603 Vgl. Karl Bruckschwaiger, Othmar Spann. Ein österreichischer Vertreter der konservativen Revolution? In: Benedikt et al. (Hrsg.), Verdrängter Humanismus. Bd. V, a.a.O., $468 \mathrm{ff.}$

1604 So drängte Spann, der insbesondere in Winters deklariert proösterreichischer Haltung ein Habilitationshindernis sah, bereits 1931 gegenüber Dekan Verdross auf eine Beendigung des Habilitationsverfahrens für das Fach Soziologie. Vgl. Holzbauer, Ernst Karl Winter (1895-1959), a.a. O., 170.

1605 Ebd., 175.

1606 UAW, Personalakt Ernst Karl Winter/23, Abschrift Zl. 1 aus 1936, 1.

1607 Bader, Ernst Karl Winter und die Versöhnung der politischen Lager, a.a. O., 373.

1608 U.S. Office of Strategic Services. Foreign Nationalities Branch Files 1942-1945. Ernst Karl Winter an Office of Strategic Services, 15. August 1942, Curriculum Vitae, a.a.O., 1.

1609 Der Leiter der New School for Social Science, Alvin Johnson, hatte Winter, neben Erich Hula und dem Kelsen-Schüler Felix Kaufmann, bereits unmittelbar nach dem „Anschluss“ als Lehrkraft ins Auge gefasst, was u.a. durch die direkte Empfehlung des Theologen Reinhold Niebuhr noch forciert wurde. Vgl. Johannes Feichtinger, Wissenschaft zwischen den Kulturen. Österreichische Hochschullehrer in der Emigration 1933-1945, Frankfurt a. Main - New York 2001, 316. 
Faculty der renommierten New School for Social Research in New York. Der Grund für sein erzwungenes Ausscheiden aus der New School für Social Science, das für die Dauer der Jahre danach im US-Exil die äußerst bescheidene Existenz eines Privatgelehrten zur Folge hatte, war Winters Aussage nach seinem Beharren, Österreicher zu bleiben, das heißt sich nicht einbürgern lassen zu wollen, geschuldet, wie er es selbst 1952 darstellte. ${ }^{1610}$ $\mathrm{Ob}$ es tatsächlich Winters Ablehnung war, die ihn seinen Job an der New School kostete, sei dahingestellt; immerhin hatte er 1942 in seinem an den US-Militärgeheimdienst gerichteten Lebenslauf formuliert: „In spite of my honest intention of becoming an American citizen, thus far I am still an Austrian, and one who knows something of Austria, her civilization, culture, people, psychology and economic conditions. ${ }^{\text {"1611 }}$

Laut einem Bericht des Office of Strategic Services (OSS) wurde Winter, der sich um seine politische Unabhängigkeit zu bewahren - trotz seiner acht Kinder geweigert haben soll, eine andere Universitätsstelle beziehungsweise einen Job im War Department anzunehmen, aus folgendem Grund entlassen: „he was too Austrian for an American institution. "1612 Damit ist freilich angedeutet, dass es sich tendenziell eher um inhaltliche Probleme beziehungsweise um Differenzen hinsichtlich der wissenschaftlichen Arbeitsauffassung und der kulturellen Umgangsformen gehandelt haben mag, als um staatsbürgerschaftliche formale Hürden.

Der Aussagewert des zitierten OSS-Berichts ist quellenkritisch allerdings doch etwas in Zweifel zu ziehen, da Winter dezidiert und mehrfach gegenüber US-Stellen seine Mitarbeit und Expertise angeboten hat. Seine mehrfachen Bemühungen, unter anderem dem Office of Strategic Services, ${ }^{1613}$ dem US-Secretary of War, Henry L. Stimson beziehungsweise dem US-State Department seine Mitarbeit zur Rekonstruktion Österreichs anzubieten, blieben jedoch ohne Ergebnis. So schrieb Winter diesbezüglich im bereits zitierten Schreiben an James Riddleberger im März I945: „Principally, I have offered my

1610 UAW, Personalakt Ernst Karl Winter/23, Brief Winters an Dekan Theodor Puetz vom 21. November 1955, 2. Zum anderen sah sich Winter an der von deutschen Emigrés dominierten Einrichtung Ressentiments gegenüber seiner kritischen Behandlung des Deutschnationalismus ausgesetzt. Was letztlich den Ausschlag für seine Entlassung gab, ist unklar. Vgl. Holzbauer, Ernst Karl Winter (1895-1959), a. a. O., 357.

1611 U.S. Office of Strategic Services. Foreign Nationalities Branch Files 1942-1945. INT-4AU-159, Ernst Karl Winter an Office of Strategic Services, 15. August 1942, Curriculum Vitae, a.a. O., 1.

1612 U.S. Office of Strategic Services. Foreign Nationalities Branch Files 1942-1945. INT-10EU-310. Interoffice Memo. Office of Strategic Services, Sgt. Friedinger to Mr. Dewitt C. Poole, 4 Feburary 1944, 1. Der Bericht irrt hinsichtlich des Datums von Winters Demissionierung von der New School of Social Research, indem sie dieses auf Frühjahr 1943 verlegt.

1613 U.S. Office of Strategic Services. Foreign Nationalities Branch Files 1942-1945. INT-4AU-159, Ernst Karl Winter an Office of Strategic Services, 15. August 1942, a.a.O., 1. Hierin bietet sich Winter mit folgenden Worten an: „Moreover, I am ready at any moment to prepare for anyone interested in this matter [,the ideological situation concerning the Austrian problem“, d. Verf.] a special memoir which would illuminate the situation up to date." Ebd. 
services to the Department of State and other governmental agencies for several times, yet without success." 1614

Tatsächlich dürfte Winters Ausscheiden aus der New School for Social Research aber einem geheimen Dossier des Office of Strategic Services zufolge - einer Intrige seitens "Leftist and Communist refugees at New School“ geschuldet gewesen sein. ${ }^{1615}$ Trifft das $\mathrm{zu}$ - und es erscheint angesichts der wissenschaftspolitischen Ausrichtung der Einrichtung, in der zahlreiche linke Emigranten aus Deutschland und Österreich tätig waren, immerhin wahrscheinlich - ist es umso kurioser, als Winters politische Ambitionen in den USA von legitimistisch-konservativer Seite durch die Verweise auf seine angeblich intensiven kommunistischen Aktivitäten torpediert und wohl auch zu Fall gebracht wurden.

Winter, der in den USA zwar auch nach dem Ende seiner Lehrtätigkeit an der New School wissenschaftlich produktiv weiterarbeitete, letztlich aber nirgends akademisch reüssieren konnte, vielleicht auch deshalb, weil er unbeirrbarer, Österreicher ' blieb, der sich, eigenen Angaben zufolge, letztlich gegen eine Naturalisierung sperrte, ${ }^{1616}$ war im US-Exil zunächst politisch überaus aktiv.

Bereits ab Jänner 1939 war Winter in New York mit dem Aufbau des „Austro-American-Center" beschäftigt, der ersten politischen Plattform österreichischer Emigranten

1614 DÖW 21.011/14. Anders als beispielsweise Hans Kelsen war Winter davon überzeugt, dass sich die Emigranten an der Seite der USA bzw. der Alliierten in den Wiederaufbau Österreichs aktiv beteiligen sollten. Vg1. Holzbauer, Ernst Karl Winter (1895-1959), a.a.O., 353-354, 361. Wie aus einem im Dokumentationsarchiv des österreichischen Widerstands (DÖW) befindlichen Dokument hervorgeht, fand Winters Bemühen um Mitarbeit auf Seite amerikanischer Stellen - vermutlich gänzlich unintendiert - Unterstützung in befremdlich antisemitischem Wortlaut. 1943 richtet Dr. Helene Wastl ein Schreiben an das Office of War Information, worin diese Winter als Mitarbeiter empfahl, der - im Unterschied zu Julius Deutsch oder Friedrich Adler - rein arisch („pure Aryan“) wäre und wertvolle "connections with the Roman Catholic sections of the Austrian people“ habe. Die Verfasserin des Empfehlungsschreibens, deren Einbürgerungsverfahren in die USA gerade lief, gab sodann noch ihren "privaten Gefühlen“ Ausdruck, indem Sie hoffnungsfroh orakelte, was sich im Endergebnis letztlich bewahrheiten sollte, nämlich dass „no government after the War in Austria, no matter how liberal, can afford to reimport these Jews into leading positions." NARA II, RG 208, Brief Helene Wastls an Alan Cranston, Office of War Information, 23. Juni 1943. Zit. nach: Österreicher im Exil. USA 1938-1946. Bd. 2, a.a.O., 173 [DÖW E 20.222]. Ob es sich bei besagter Helene Wastl um die Innsbrucker Medizinerin Dr. Helene Wastl (1896-1948) handelt, die bereits in den Dreißigerjahren als Professorin in den USA lehrte, ließ sich nicht verifizieren. [Auskunft von Dr. Peter Goller/Univ. Innsbruck und Dr. Peter Eppel/Wien vom 23. August 2007].

1615 U.S. Office of Strategic Services. Foreign Nationalities Branch Files 1942-1945. INT-10EU-310. Interoffice Memo. Office of Strategic Services, Sgt. Friedinger to Mr. Dewitt C. Poole, 13 January 1944, $2 \mathrm{f}$.

1616 Um die österreichische Staatsbürgerschaft nicht zu verlieren, suchte Winter - der auch nach 1945 über keine US-Staatbürgerschaft verfügte - angeblich nicht um die amerikanische an. Wie er im März 1945 an Riddleberger schrieb, habe er sich nach der Moskauer Konferenz definitiv entschieden, nicht um die US-Staatsbürgerschaft anzusuchen. Winter an Riddleberger, 5. März 1946, DÖW 21.011/14. 
in den USA, die Verbindung mit dem „Entr'aide Autrichienne“ in Paris hielt. ${ }^{1617}$ Die Programmatik des „Austro-American Center“, in dem unter anderen Irene Harand, ${ }^{1618}$ der Ethnologe Robert Heine-Geldern ${ }^{1619}$ oder Winters Kollege an der New School, der Politikwissenschafter und Jurist Erich Hula ${ }^{1620}$ mitarbeiteten, bestand, laut Aussage

1617 U.S. Office of Strategic Services. Foreign Nationalities Branch Files 1942-1945. INT-4AU-308, „Foreign Politics in the United States: The Austrians“. Foreign Nationalities Branch. Office of the Coordinator of Information, August 1942, 26.

1618 Irene Harand (1900-1975), Autorin, Zeitungsherausgeberin, überzeugte Katholikin und aktive Vorkämpferin gegen Armut, Antisemitismus/Rassismus und Nationalsozialismus; gemeinsam mit dem jüdischen Anwalt Moritz Zalman gründete sie die „Weltbewegung gegen Rassenhass und Menschennot“ („Harand-Bewegung“), die in der Zeit des Austrofaschismus in der „Vaterländischen Front“ aufging. Die Biografie Harands sperrt sich in höchst eigentümlicher Weise gegen die bekannten Narrative über Widerstandskämpferinnen: sie war Anhängerin des „Ständestaats“ und darüber hinaus monarchistisch gesinnt. Siehe: Christian Klösch (Hrsg.), Gegen Rassenhass und Menschennot. Irene Harand, Leben und Wirken einer ungewöhnlichen Widerstandskämpferin, Innsbruck 2004. U.S. Office of Strategic Services. Foreign Nationalities Branch Files 1942-1945. INT-4AU-114. Coordinator of Information. Office Memomrandum, A. Heckscher to Mr. Wiley, 18 May 1942, Informationsbericht Papaneks, 12.

1619 Der Ethnologe, Archäologe und Südostasienexperte Robert Heine-Geldern (1885-1968), Großneffe von Heinrich Heine, erhielt 1931 eine Professur an der Universität Wien und war seit 1922 auch an Wiener Volkshochschulen als Kursleiter und Vortragender überaus aktiv. Für seine Verdienste war ihm von Kaiser Franz Joseph I. der Titel „Baron und Freiherr von“ verliehen worden. Als jüdischer Flüchtling kam er nach New York, wo er zunächst am Naturkundemuseum arbeitete und am Arthur Upham Institute lehrte. Gemeinsam mit Margaret Mead und anderen gründete Heine-Geldern 1941 das „East India Institute of America“. 1950 kehrte er nach Österreich zurück, wo er das Institut für Ethnologie neu aufbaute. Die Angaben Jan Papaneks, wonach Heine-Geldern, nachdem seine Aspirationen an einer Professur an der Universität Wien ins Leere gelaufen seien, bereits 1937 durch Unterstützung Schuschniggs in die USA gekommen sei, treffen offenkundig nur bedingt zu, und gründen womöglich in einem persönlichen Konflikt. HeineGeldern schrieb 1942 ein Memorandum mit dem Titel „Austria and the War“. Siehe: U.S. Office of Strategic Services. Foreign Nationalities Branch Files 1942-1945. INT-4AU-114. Coordinator of Information. Office Memomrandum, A. Heckscher to Mr. Wiley, 18 May 1942, Informationsbericht Papaneks, 15.

1620 Erich Hula (1900-1977), Wiener Jurist und Politikwissenschafter und als solcher von 1931-33 Privatassistent Hans Kelsens an dessen Völkerrechtslehrstuhl an der Universität Köln; nach Kelsens Entlassung in Köln kehrte Hula nach Wien zurück, wo er in der Arbeiterkammer tätig war. 1938 emigierte er schließlich in die USA. Bis 1967 lehrte Hula an der New School for Social Research, wo er versuchte, ,die Theoreme Kelsens in die amerikanische Diskussion einzubringen“. Zit. nach: Oliver Rathkolb, Überlegungen zum Exodus der „Jurisprudenz“. Staatswissenschaftliche Emigration aus dem Österreich der Zwischenkriegszeit. In: Friedrich Stadler (Hrsg.), Vertriebene Vernunft I. Emigration und Exil österreichischer Wissenschaft 1930-1940, Wien - München 1987, 286. In einem OSS-Bericht wird Hula als "Catholic with slight monarchist leanings, considered highly intelligent but an opportunist" charakterisiert. Siehe: U.S. Office of Strategic Services. Foreign Nationalities Branch Files 1942-1945. INT-4AU-710, DeWitt C. Poole to John G. Erhardt, Department of State, Washington, D.C., 6 February 1945, 7. Der Nachlass von Erich Hula befindet sich im Archiv der University of Albany/New York [http://library.albany.edu/speccoll/findaids/ger044.htm]. Vgl. dazu auch die Anm. 19 bei: Jürgen Busch, Alfred Verdross - Ein Mann des Widerspruchs? Teil 2. Verdross im Gefüge der Wiener Völkerrechtswissenschaft vor und nach 1938. In: Thomas Olechowski/Ilse Reiter et al. (Hrsg.), Vertriebenes 
Jan Papaneks, ${ }^{1621}$ in einer alten Idee Winters, nämlich: ,joining of the left wing of the Christian Socialists with the right wing of the Social Democrats and thus create a group of the center", which could receive additional groups from both sides. "1622 Dem AustroAmerican Center war nicht lange Erfolg beschieden: nach Unstimmigkeiten anlässlich einer Gedenkfeier am ersten Jahrestag des „Anschlusses“ spalteten sich unter anderem legitimistisch orientierte Mitglieder ab und das Austro-American Center - „numerically weak in exile perhaps, but spiritually strong by its contacts"1623 - ging noch 1939 in der neugegründeten Austro-American-League unter Leitung von Otto Kallir ${ }^{1624}$ auf. Winters darauffolgenden Aktivitäten ${ }^{1625}$ war allerdings ebenso wenig Erfolg beschieden, wie es die verschiedenen politischen Gruppen österreichischer Emigranten in den USA insgesamt nicht zustande brachten (beziehungsweise erst gar nicht beabsichtigten), ein gemeinsames Nationalkomitee zu etablieren.

Das politische Scheitern Winters in der amerikanischen Emigration, wurde unterschiedlich interpretiert. So hielt die Spezialabteilung zu ausländischen Nationalitäten des amerikanischen Militärgeheimdienstes I94I in einem Memorandum bezüglich Winters Persönlichkeit fest: „[...] he is a very honest man, but his political ideas are not very stable.

Recht - Vertreibendes Recht. Die Wiener Rechtswissenschaftliche Fakultät zwischen 1938 und 1945, Wien 2010, 5. [Unpubliziertes Manuskript im Erscheinen; der Autor dankt an dieser Stelle Kollegen Mag. Jürgen Busch für die freundliche Überlassung des Textes].

1621 Der Tscheche Jan Papanek (1892-1991), war in den Jahren zwischen 1932-1935 parlamentarischer Berater von Eduard Benesch, nachfolgend tschechischer Konsul in Pittsburgh/USA und ab 1939 als Mitarbeiter in der Exilregierung Benesch in den USA tätig. Ab 1946 war Papanek Chef der tschecholowakischen Delegation bei der UN. Siehe dazu: www.munzinger.de/search/portrait/Jan+Papanek/0/2234.html [Zugriff 31.7.2009].

1622 U.S. Office of Strategic Services. Foreign Nationalities Branch Files 1942-1945. INT-4AU-114. Coordinator of Information. Office Memomrandum, A. Heckscher to Mr. Wiley, 18 May 1942, Informationsbericht [Jan] Papaneks, 12.

1623 U.S. Office of Strategic Services. Foreign Nationalities Branch Files 1942-1945. INT-4AU-159, Ernst Karl Winter an Office of Strategic Services, 15. August 1942, a.a. O., 2.

1624 Otto Kallir (1894-1978), österreichischer Kunsthistoriker jüdischer Herkunft; Gründer der „Neuen Galerie“ (1923-1938) sowie Vizepräsident des „Hagenbundes“; 1939 gelang Kallier die Flucht in die USA, wo er u.a. von 1939-1941 Vorsitzender der „Austro-America League“ war. Kallir verstarb als Galerieinhaber in New York. Siehe: http://www.univie.ac.at/geschichtegesichtet/o_kallir.html [Zugriff 26.9.2011].

1625 So war er an der Gründung des antilegitimistischen „American Committee on European Reconstruction" beteiligt, in dem neben einer österreichischen auch eine tschechische und eine polnische Gruppe aktiv waren, und rief 1941 das von ihm editierte Austrian Bulletin ins Leben. Zur Zielsetzung der neugeschaffenen Plattform gab die New York Times die Worte von „one of its founders, Dr. Ernst Karl Winter“ wieder: das „Reconstruction Committee“ wurde eingerichtet „[... [ by a group of Austrians, CzechoSlovaks and Polish exiles to unite European victims and opponents of Hitler Germany to continue the fight against Hitlerism and work for equitable European reconstruction was announced yesterday." In: New York Times, 18 October 1940, 4. Unter den Sponsoren dieses Komitees waren nach Aussage Winters u. a. auch Alvin Johnson und Lewis Mumford. Siehe: Ernst Karl Winter an Office of Strategic Services, 15. August 1942, a.a.O., 5. 
Many Austrians base their hopes on his person, but it seems that he has isolated himself lately more and more." 1626

Und nur wenig anders und im Kern wohl auch zutreffend beschrieb ihn I945 ein Geheimdienstdossier als „lone wolf now completely detached from all party affiliations; very sincere but entirely impractical“. ${ }^{1627}$

Es blieb Otto Habsburg vorbehalten, bezüglich der Charakteristik Winters und dessen politischen Versagens nicht nur seine „erratische Persönlichkeit“ verantwortlich gemacht zu haben, sondern - und insbesondere - dessen politisch „zunehmende[n] Radikalismus“ in Richtung Kommunismus:

"Mr. Winter had more and more communistic ideas, put its [sic] hopes to make Austria free again more and more in communism and tried to give the Austrian Center a more or less communist leadership, headed by a notorious Austrian communist, Mr. Creilsheimer [sic]. Although Mr. Winter personally was a very cultivated and learned man, most of the Austrians in the Austrian Center the greater part of them living in or near New York - disapproved finally entirely Mr. Winter's nearly communist ideas, lost completely confidence in his leadership and quit the Austrian Center." ${ }^{1628}$ [richtig: Austro-American Center, d. Verf.]

Dieses ideologische Zerrbild der Person Winters, das Otto Habsburg „strictly confidential“ an amerikanische Geheimdienstsstellen adressierte, wohl um den politischen Gegner - im vorliegenden Fall einen dezidierten Anti-Monarchisten - damit zu desavouieren, ${ }^{1629}$ ist insofern erwähnenswert, als dies ein Schlaglicht auf so manch operettenhafte Facetten und Zerwürfnisse der österreichischen Emigration in den Vereinigten Staaten wirft, die sich ob der auf amerikanischem Boden besonders seltsam ausnehmenden politischen Restaurati-

1626 U.S. Office of Strategic Services. Foreign Nationalities Branch Files 1942-1945. INT-4AU-55, Memorandum. OSS / Foreign Nationalities Branch, 11 December 1941, 6.

1627 U.S. Office of Strategic Services. Foreign Nationalities Branch Files 1942-1945. INT-4AU-710, DeWitt C. Poole to John G. Erhardt, Department of State, Washington, D.C., 6 February 1945, 10.

1628 U.S. Office of Strategic Services. Foreign Nationalities Branch Files 1942-1945. INT-4AU-36. Brief survey of the history of the Austrian organisations in the United States [handschriftlicher Vermerk: submitted by Otto Habsburg], 14 April 1942, 1.

1629 Enthüllend ist folgende Passage in dem genannten „Survey“ Habsburgs, die seinen Begriff von „Kommunismus“ konkretisiert: „His [Winters, d. Verf.] communist leanings brought a complete disintegration of the Austrian Center. He then carried on nearly alone and collaborated partly with Czechs partly with Polish groups. Became again active in Austrian politics in 1941, when he tried vainly to coordinate all the non monarchist groups in the united republican front. This attempt failed when the leaders of the non monarchist groups declared him, that their organisations would undoubtedly collapse, if they came out openly with an republican program. “ [Hervorhebung d. Verf.] Ebd., 16. Darüber hinaus wusste Habsburg zu berichten, dass Winter unmittelbar nach Pearl Harbour allen österreichischen Organisationen per Brief mitgeteilt habe, sich aus allen Belangen der Politik zurückzuziehen, da er davorstehe, die amerikanische Staatsbürgerschaft zu erlangen und sich von daher nicht mehr für politische Agenden seines Heimatlandes einsetzen könne. Ebd. 
onstendenzen des legitimistischen Lagers kaum zu einem ernsthaften politischen Faktor entwickeln konnte. ${ }^{1630}$

Dass Winter nicht sehr umgänglich gewesen sein dürfte und auch durch so manche formale und inhaltliche Eigenwilligkeit seiner gelehrten Aussagen auffiel, davon zeugt ein geheimdienstliches OSS-Dossier, das im Jänner 1944 vor dem Hintergrund seiner öffentlichen Statements zur Moskauer Deklaration angelegt wurde. ${ }^{1631}$ Der Bericht, verfasst auf der auf Grundlage eines Interviews, zeichnet ein wenig schmeichelhaftes Psychogramm Winters, dessen Verhalten und Einstellungen als charakteristisch für die rückwärtsgewandte Flüchtlingsmentalität österreichischer und deutscher Emigrés - „most likely to lecture about the advantages of their homeland“- beurteilt wurde; freilich ohne dabei viel auf Zwischentöne zu achten. Dem Wortlaut des Berichts zufolge habe Winter kein gutes Haar am Zustand der US-Armee gelassen, die seiner Meinung nach weit hinter dem Organisationsgrad des alt-österreichischen Heeres zurückliege und in Europa höchstens für einen Blitzkrieg geeignet sei; neben der Armee, die völlig neuorganisiert werden müsse, übte Winter im Gespräch mit dem Mitarbeiter des militärischen Geheimdienstes zugleich Kritik an der „Überorganisation“ („over-organization“) des US-War Departments. Im Hinblick auf die Österreich-Frage gab Winter unmissverständlich zu verstehen, dass Österreich seiner Ansicht nach von den Alliierten nach der Annexion in Stich gelassen worden sei („Austria was let down“). Mit Bezug auf die kommende Nachkriegszeit habe Winter nach Meinung des Geheimdienstmitarbeiters ziemlich „arrogante Ansichten“ geäußert: so zeigte er sich erbost über den Wortlaut der Moskauer Deklaration, die Österreich „warnte“, zur Befreiung einen Beitrag zu leisten. Wie Ernst Karl Winter bereits in einem in der New York Times veröffentlichten Brief dargestellt hatte, sah er keinerlei historische Verantwortung der österreichischen Bevölkerung für die unfreiwillige Teilnahme am Krieg Hitler-Deutschlands. ${ }^{1632}$ Im Gegenteil: In seinen Darlegungen verstieg sich Winter zu einem völlig aus dem Rahmen fallenden Vergleich, indem er die in den Reihen der Deutschen Armee gefallenen Österreicher mit den tschechischen zivilen Opfern beim SS-Massaker in Lidice verglich.

1630 Besonders deutlich formuliert findet sich dies in dem zitierten Bericht Jan Papaneks: „The Austrian emigration in the USA boasts several grotesque phenomena which make the solution of the Austrian problem still harder $[\ldots]$ The presence of a representative of the House of Habsburg, who is to a number of people ,His Majesty', makes many, who are not acquainted with European problems, believe the thesis that the solution of all Central European questions would be reached by placing a monarch in Vienna [...]“. U.S. Office of Strategic Services. Foreign Nationalities Branch Files 1942-1945. INT-4AU-114. Coordinator of Information. Office Memorandum, A. Heckscher to Mr. Wiley, 18 May 1942, Informationsbericht Papaneks, 12.

1631 Office of Strategic Services. Interoffice Memo, Sgt. Friediger to Mr. DeWitt C. Poole, „The Reverend Franc Gabrovsek, Dr. E.K. Winter: Two Sceptical and Critical Exiles“, 13. Jänner 1944. U.S. Office of Strategic Services. Foreign Nationalities Branch Files 1942-1945. INT-33AU-120.

1632 „Austrian Objects - Moscow Declaration Viewed as Unfair to People“ (Letter from Ernst Karl Winter). In: New York Times, 7. November 1943, E11. Vgl. auch: „Austrian Exiles and the Moscow Declaration on Austria. Memorandum for the Office of Strategic Services“, 17. November 1943, 4. U.S. Office of Strategic Services. Foreign Nationalities Branch Files 1942-1945. INT-33AU-120. 
Darauf hingewiesen, dass „unfortunately too many Austrians had too willingly fought in the German ranks“, habe Winter entgegnet, dass daraus keineswegs die moralische Verpflichtung zu Opferleistungen erwachse, da die Alliierten - bei dieser Pointe argumentierte Winter wohl aus einer historisch weit ausholenden Perspektive ${ }^{1633}$ - deutlich mehr für den "Anschluss“ verantwortlich zu machen seien als die Österreicher selbst. Die Intention der Moskauer Deklaration, die österreichische Bevölkerung zum Widerstand zu bewegen und sie damit in die alliierte Kriegsführung miteinzubeziehen, nannte der deklarierte Pazifist kurzerhand „immoral and criminal“. Im Wortlaut des Dossiers wird Winter des Weiteren mit folgenden, geradezu prognostischen Worten zitiert:

"If the Moscow signatories think that the Austrians will be incited to guerilla warfare and sabotage by the Moscow Declaration, they are mistaken. The Austrians are smart and have a keen sense of politics. They are going to wait for the invasion and will hide in their basements when the war comes to the country. They are not going to spill their blood unnecessarily." 1634

Derartige Wortspenden wurden vom US-Geheimdienst zwar zweifellos als interessante Information über die innere Einstellung prominenter Emigrés gewertet - dokumentierte Werthaltungen, die nach Kriegsende in Österreich womöglich weit verbreitet sein konnten -, erfreut war man über derartige „Attitüden“ aber keineswegs, nicht zuletzt deshalb, weil sich darin zuweilen auch antiamerikanische Ressentiments widerspiegelten:

"These are the opinions of individual refugees but they are, unfortunately, typical of many. The over critical attitude of the refugees is strongest at the moment among Germans, then come the Austrians, where, for instance, Ernest Hoor ${ }^{1635}$ and Frederick Taylor ${ }^{1636}$ are well-known

1633 Dies lassen zumindest seine Ausführungen zur Moskauer Deklaration vermuten, die Winter unter elaborierter und geradezu enthusiastischer Bezugnahme auf das in den 8 Punkten der Atlantik-Charta von Roosevelt und Churchill proklamierte Selbstbestimmungsrecht der Völker vortrug, und dabei den historischen Bogen bis zu den 14 Punkten Woodrow Wilsons spannte. Winter rekapitulierte hier einen Artikel, den er zuvor im Journal of Cenral European Affairs (April 1941) veröffentlicht hatte. Siehe: U.S. Office of Strategic Services. Foreign Nationalities Branch Files 1942-1945. „Austria and the Eight Points." Ernst Karl Winter an Office of Strategic Services, 15. August 1942, a.a. O., 1.

1634 Office of Strategic Services. Interoffice Memo, Sgt. Friediger to Mr. DeWitt C. Poole, a.a.O., 13. Jänner 1944, 3. U.S. Office of Strategic Services. Foreign Nationalities Branch Files 1942-1945. INT-33AU-120.

1635 Ernst Hoor, Mitglied des „Austrian National Committee“ und der liberal-unabhängigen „Austrian Action“; Hoor war Jurist und junger Experte für Internationales Recht und - laut Otto Habsburg - „expert on Danubian questions", der bereits in Wien und Stockholm Professuren innegehabt hatte; Hoor kam 1939 in die USA und lehrte dort an der Yale University. Siehe: Office of Strategic Services. Foreign Nationalities Branch Files 1942-1945. Brief Survey of the history of the Austrian organisations in the United States [handschriftlicher Vermerk: submitted by Otto Habsburg], 14. April 1942, a.a. O., 8.

1636 Frederick [E.] Taylor (ursprünglicher Name: Friedrich Krejci), erster Vorsitzender des konservativen „Austrian National Committee“ in New York; Taylor, ehemaliger Polizeibeamter, „Playboy und Globe- 
for their constant diatribes against America and its way of life, but in a less intense degree the same outlook can be found among western Europeans especially the Belgians and, of course, among the Italians. These opinions are not voiced publicly, and least of all in writing, but interrefugee conversations are full of them. Since these psychopathic mentalities will be transplanted to Europe after the war it is well to be aware of them." ${ }^{1637}$ [Hervorhebungen d. Verf.]

Inwieweit das hier zitierte Dossier Winter nach 1945 geschadet haben mag - immerhin wurde es an eine Reihe weiterer US-Geheimdienstabteilungen und Abteilungen für Psychologische Kriegsführung weitergeleitet-, lässt sich aufgrund fehlenden Quellenmaterials vorerst nicht eindeutig beantworten. Faktum ist, dass sich im Zusammenhang mit Winters Rückkehrbestrebungen nach Kriegsende im Schriftverkehr des State Departments keine diesbezüglichen Hinweise finden, was allerdings wenig aussagekräftig ist. Es ist zu vermuten, dass die Informationen des Office of Strategic Services den einschlägigen Stellen durchaus bekannt waren, und dass Winters Bemühungen um baldige Rückkehr zwar nicht behindert, diesen aber ebensowenig klar erkennbare Unterstützung zuteil wurden. Winter war ein unbequem-umständlicher Intellektueller, ein universal-gelehrtes Fossil, ein Repräsentant eines vergangenen Österreich und einer untergegangenen Kultur. Sein unabhängiger, konservativ-reformerischer, in verzweigten kulturhistorischen Dimensionen denkender Geist, der noch dazu harsche Kritik an der amerikanischen Politik artikulierte und Amerika der Mitverantwortung für Österreichs Untergang geziehen hatte, wurde womöglich - das bleibt allerdings reine Spekulation - tendenziell als größeres Hindernis für die Durchsetzung des „American way of life“ betrachtet, als die zahlreichen Reaktionäre und Ex-Nazis unter den österreichischen Universitätslehrern.

Wie sehr Winter daran gelegen war, nach Kriegsende rasch nach Österreich zurückzukehren und - in der berechtigten Hoffnung auf eine universitäre Karriere - seine intellektuellen Fähigkeiten dem Land zur Verfügung zu stellen, zeigt sich anhand der Briefe, die er aus dem Exil an die Repräsentanten des neuen Staates richtete. Zunächst hatte Winter, nach einer Besprechung mit Eleanor Dulles, ${ }^{1638}$ in einem Schreiben an das State Department seine Dienste angeboten, sofern ,this is compatible with my primary allegiance to

trotter", verheiratet mit einer wohlhabenden Frau. Später anscheinend Vizepräsident der Österreichischen Handelskammer in den 1950er-Jahren. Siehe: U.S. Office of Strategic Services. Foreign Nationalities Branch Files 1942-1945. INT-4AU-710, DeWitt C. Poole to John G. Erhardt, Department of State, Washington, D.C., 6. Februar 1945, 9; siehe weiters: Österreicher im Exil. USA 1938-1945. Bd. 1, a.a. O., 299 sowie Bd. 2, 454.

1637 Office of Strategic Services. Interoffice Memo, Sgt. Friediger to Mr. DeWitt C. Poole, a.a.O., 13. Jänner 1944, 4. U.S. Office of Strategic Services. Foreign Nationalities Branch Files 1942-1945. INT33AU-120.

1638 Eleanor Lansing Dulles (1895-1996), Schwester von State Secretary John Foster und von Allen Welsh Dulles, CIC bzw. CIA Chef, war im State Department mit ökonomischen Aspekten des „post-war planning" befasst. 
my own country, Austria. "1639 Wie schon zuvor, stieß auch dieses Ansuchen, dem Winter einen ausführlichen Lebenslauf beigelegt hatte, auf eine höfliche Absage. ${ }^{1640}$

Nach Berichten in US-Tageszeitungen, wonach die Möglichkeit für „Austrian refugees“, in ihre Heimat zurückzukehren, nun in eine neue Phase eingetreten sei, wandte sich Winter im Jänner 1946 neuerlich an Riddleberger, diesmal um Fragen der Einreisebestimmungen (Pass, Visa, Staatsbürgerschaft) abzuklären. Winter teilte Riddleberger mit, dass er und seine Familie ,are interested in returning to Austria, as soon as we technically are allowed to do" und bedankte sich für die Weiterleitung eines diesbezüglichen Schreibens an Bundeskanzler Figl, „to whom I have been able to write in the meantime through ordinary mail." ${ }^{1641}$

Im Jänner 1946 richtete sich Winter also direkt an Bundeskanzler Figl, dem er seine Dienste für das „Vaterland“ anbot und gleichzeitig den Wunsch nach einer universitären Lehrtätigkeit äußerte, indem er „auf Wiener akademischem Boden an der festen Neubegründung einer österreichischen Staatsgesinnung, eines österreichischen Volksbewusstseins mitzuwirken " 1642 anbot. Des Weiteren wandte sich Winter auch an Unterrichtsminister Hurdes, den er darum ersuchte, zu veranlassen, sein Habilitationsverfahren wiederaufzunehmen. Nachdem Hurdes aber von der juridischen Fakultät mit der genannten „Abschrift“ einschlägig vorinformiert worden war, zeigte er sich zunächst wenig geneigt, die Angelegenheit vor einer definitiven Rückkehr Winters nach Wien zu unterstützen. $^{1643}$

Mit Beharrlichkeit erreichte Winter schließlich doch, dass sich Hurdes der Sache annahm und angesichts der Obstruktionspolitik der Wiener juridischen Fakultät versuchte, Winter als Professor für Soziologie an die Universität Graz zu holen, was, in der Darstellung Winters, allerdings durch das Finanzministerium mit Hinweis auf fehlende Mittel blockiert worden sei. ${ }^{1644}$ Obwohl sich Hurdes weiter für Winters Habilitation an der Uni-

1639 Schreiben von Ernst Karl Winters an James Riddleberger, Department of State, Washington D.C., 5. März 1945, DÖW 21.011/14.

1640 Schreiben von James Riddleberger an Ernst Karl Winter, 21. März 1945, DÖW 21.011/14.

1641 Schreiben von Ernst Karl Winters an James W. Riddleberger, Division for Central European Affairs, Department of State, Washington D.C., 11. Jänner 1946, DÖW 21.011/14; Winter unterschrieb den Brief mit „former Vice-Mayor of Vienna“.

1642 DÖW 15.060/21. Zit nach: Holzbauer, Ernst Karl Winter (1895-1959), a.a.O., 365.

1643 Über die abermalige Verschleppung seines Habilitationsgesuches zeigte sich Winter in einem Brief an Figl schwer enttäuscht und irritiert: „Ich dachte die Wiedergutmachung des mir durch fast 20 Jahre zugefügten Unrechtes, das in der Verweigerung der venia legendi durch die an der juridischen Fakultät herrschenden deutschnationalen Clique bestand, sei eine Selbstverständlichkeit. Aus Hurdes Brief glaube ich entnehmen zu müssen, dass dem keinesfalls so ist und dass damit neuerdings Klauseln und Bedingungen verbunden sind, die ich schon einmal abgelehnt habe." DÖW 15.060/21. Erstmals zit. bei: Holzbauer, Ernst Karl Winter (1895-1959), a.a. O., 366.

1644 Ernst Karl Winter to James W. Riddleberger, Division of Central European Affairs, Department of State, Washington D.C., 10. Februar 1948. Recordings of the U.S. Department of State relating to the 
versität Wien einsetzte, wollte er zugleich nicht in die inneren Angelegenheiten der Universität eingreifen und die Causa der universitären „Autonomie“ ${ }^{1645}$ überlassen.

Auf Grund welcher Bemühungen und Urgenzen Winter, der sich insbesondere durch ÖVP-nahe Kreise blockiert sah, ${ }^{1646}$ dann doch die Habilitation erreichte, ist unklar. Jedenfalls wurde Winter am 2. Oktober 1946 an der Rechts- und Staatswissenschaftlichen Fakultät zum Privatdozenten für Wirtschaftsgeschichte ernannt; sein abermaliges Ansuchen um eine Ausweitung der Lehrbefugnis auf Soziologie wurde durch Beschluss des Professorenkollegiums jedoch abgelehnt. ${ }^{1647} \mathrm{Als}$ Begründung für die Ablehnung einer erweiterten Venia legendi gab das Fakultätsgremium gegenüber dem Unterrichtsministerium an, dass Winter als Professor an der New School for Social Research in New York einen Artikel mit dem Titel „Austria, guilt and virtue“ im Fachjournal Social Research veröffentlicht hatte, ${ }^{1648}$ worin er im Schlussabsatz folgendes - freilich durchaus diskussionswürdiges - Resümee zog: „Francis Joseph and Hitler are the two Austrians who bear the symbolic responsibility. Hitler is Francis Joseph's guilt." ${ }^{\text {"1649 }}$

Dieser von Winter angestellte Vergleich wurde von der rechtswissenschaftlichen Fakultät der Universität Wien - Winter selbst vermutete seinen Kontrahenten August Maria Knoll als Negativ-Gutachter ${ }^{1650}$ - in grob vereinfachender und den Inhalt regelrecht verzerrender Weise uminterpretiert: die Fakultät behauptete, Winter habe konstatiert, Österreich habe „beide Weltkriege und zwar den ersten durch Kaiser Franz Joseph I. und den zweiten durch den Österreicher Hitler verschuldet“. ${ }^{1651}$ Der genannte Aufsatz wurde im Sinne eines Beschlusses des Professorenkollegiums vom 19. April I947 „mit Rücksicht auf die Frage der persönlichen Würdigkeit des Habilitationswerbers“ als „keine geeignete

Internal Affairs of Austria 1945-1954 (Mikrofilm-Bestand Institut für Zeitgeschichte der Universität Wien), Decimal File, Reel 6, 1945-1949, 2.

1645 Winter selbst sprach vom „Missbrauch der Autonomie“. Vgl. Ernst Karl Winter, Bericht an die Herren Professoren der Rechts- und Staatswissenschaftlichen Fakultät in Wien (aus Anlass meiner vorläufigen Rückkehr in die USA, undatiert (Jänner 1957), UAW, Phil. Fakultät, Personalakt Ernst Karl Winter/23, 1.

1646 So etwa durch Friedrich Funder, Musil, August Maria Knoll, und Alfons Gorbach. DÖW 15.060/105; zit. nach: Holzbauer, Ernst Karl Winter (1895-1959), a.a.O., 370.

1647 UAW, Personalakt Ernst Karl Winter/23, Dekanat der Universität Wien an das Bundesministerium für Unterricht, 29. April 1947.

1648 Vgl. Austria. Guilt and Virtue. In: Social Research, Jg. 1940, VII, 480-496; Jg. 1941, VIII, 106-125.

1649 Winter an Riddleberger, Recordings of the U.S. Department of State, a.a. O., 2.

1650 Immerhin hatte sein Jugendfreund und Studienkollege, nun bereits wieder Professor an der Fakultät wie Winter vermutete -, im Oktober jenen anonymen Hetzartikel gegen die „Aktion Winter“ in der Reichspost verfasst, worin ihm Angriff gegen die Regierung und bolschewistische Propaganda vorgeworfen wurde, was dann zu seiner Enthebung als Vizebürgermeister führte. Vgl. Bader, Ernst Karl Winter und die Versöhnung der politischen Lager, a.a.O., 372.

1651 UAW, Personalakt Ernst Karl Winter/23, Dekanat der Universität Wien an das Bundesministerium für Unterricht, 29. April 1947. 
Grundlage ${ }^{\text {“1652 }}$ bietend charakterisiert und das Ansuchen daher, wie Winter in einer ausführlichen Darstellung gegenüber James W. Riddleberger, ${ }^{1653}$ dem Österreich-Experten und Chef der Division of Central European Affairs im State Department in Washington mitteilte, abgelehnt. Winter interpretierte das mit folgenden Worten und bat Riddleberger gleichzeitig mit bereits leicht resignativem Unterton ${ }^{1654}$ um Unterstützung in der Angelegenheit, die sich nun bereits über zwei Jahre hin zog:

\footnotetext{
"The grotesque situation now stands that the majority of the same professors in Vienna, who under Nazi leadership from 1929 to 1938 rejected me for my 'anti-German' views, now reject me again for my 'un-Austrian' utterance in exile. (As I am quite reliably informed, the Vienna Faculty of Law is now led by Legitimists, who think that I 'betrayed' the cause of Legitimists in exile). On the basis of all these facts, summarized here for the sake of convenience I take the liberty to ask your advice in the following directions. Is there any possibility to submit a case like this, with all the experience and materials of a twenty year struggle against Nazism on the University of Vienna, to the Allied Council in Vienna?"1655
}

Die Antwort, die Winter vom neuen Leiter der Division of Central European Affairs, Jacob D. Beam, bekam, war zurückhaltend, kurz gehalten und von der Generallinie her sicherlich im Einklang mit den längerfristigen zivilen Reorientierungs-Planungen, wie sie sowohl die „German-Austrian Branch, Division of Occupied Areas, Office of Information and Educational Exchange“ des US-State Department als auch das War Department in seiner Reorientation Branch, Civil Affairs Division (CAD) für Österreich und - freilich mit Abstrichen - für Deutschland konzipierten und durchführten:

"After careful consideration of this matter we have reached the conclusion that the Department is not in a position to intervene on your behalf. We understand that submission of the case to the Allied Council would be without precedent since this body has apparently never reviewed or recommended individual appointments to the universities in Austria. Such a step would be inconsistent with United States policy of treating Austria as a free and independent State

\section{Ebd.}

1653 James W[illiams] Riddleberger (1904-1982), war von 1944 bis 1947 Leiter der Division of Central European Affairs, im U.S. Department of State, von 1947-1950 Botschaftsleiter und Chef der "political section“ des OMGUS in Berlin sowie „acting political adviser“ des Oberbefehlshabers der US-Besatzungstruppen in Deutschland, 1949-50. Von 1962-1967 war Riddleberger US-Botschafter in Österreich.

1654 So schrieb Winter im Februar 1948 an Riddleberger: „I would greatly appreciate your kind advice and instruction which I am ready to follow. I am still an Austrian citizen and hoped to return to Austria on the basis of an academic career, to which I feel entitled. As long as such primitve kind of morale reparation is not carried out, however, by present Austrian set-up and the old ghosts still rule the scene of the universities, I am greatly disappointed in my hope to be able to do anything valuabel in Austria today." Ebd. 3.

1655 Ebd., 2 f. 
in every practicable way under the conditions of occupation. It would hamper our efforts to extend maximum administrative responsibility to the Austrian Government under the New Control Agreement of June 28, I946 while progressively reducing the powers of the Austrian authorities." $^{1656}$ [Hervorhebung d. Verf.]

In dem zitierten Schreiben des State Departments - das im Übrigen erst erfolgte, nachdem der stellvertretende Leiter der Division of Central European Affairs in Berlin, Allan K. Lightner, das Ansuchen Winters unverrichteter Dinge wieder nach Washington retourniert hatte - wurde auf den aufgeworfenen Fragekomplex unzureichender universitärer Entnazifizierung mit keinem Wort eingegangen. Das ist aber insbesondere für die Dienststellen des State Department in Washington in keiner Weise als repräsentativ anzusehen und auch nicht für die militärischen Stabsstellen innerhalb der Civil Affairs Division (CAD) sowie der kooperierenden US-Informations- und Geheimdiensteinrichtungen; womöglich war das Ausblenden der an sich naheliegenden Entnazifizierungs-Problematik auch dem Umstand geschuldet, dass die Division of Central European Affairs nicht direkt mit Reorientierungs-Fragen befasst und mit den spezifischen Agenden anderer Abteilungen nur unzureichend vertraut war, oder auch, weil sie sich nicht in die Angelegenheiten der lokalen militärischen Besatzungsorgane einmischen wollte: schließlich war es in der genannten Angelegenheit offenkundig zu keinem Kontakt mit den zuständigen USFAStellen gekommen, obwohl sich Winter, wie erwähnt, dezidiert darum bemüht hatte. ${ }^{1657}$

Die abermalige Verhinderung seiner Bemühungen um Ausweitung der Lehrbefugnis auf Soziologie sowie deren Begründung betrachtete Winter als „Bosheit“ und das Verhalten der österreichischen Regierung kommentierte er, der mit seiner neunköpfigen Familie - zwei seiner Söhne hatten am Columbia beziehungsweise am Barnhard College studiert und sein Sohn Ernst Florian hatte an der Invasion in der Normandie teilgenommen $^{1658}$ - nach wie vor in New Jersey saß, mittlerweile mit scharfen Worten: diese hätte

1656 Jacob D. Beam an Ernst Karl Winter, 23. April 1948. Recordings of the U.S. Department of State relating to the Internal Affairs of Austria 1945-1954 (Mikrofilm-Bestand Institut für Zeitgeschichte der Universität Wien), Decimal File, Reel 6, 1945-1949, 1.

1657 Winter überlegte darüber hinaus, seine Angelegenheit vor den Verfassungsgerichtshof zu bringen. Vg1. Winter in einem Brief an Dr. Walter Berger vom 12. September 1947. Zit nach: Holzbauer, Ernst Karl Winter (1895-1959), a.a.O., 369.

1658 Ernst Florian Winter (geb. 1923), studierte Japanisch an der University of Michigan und Politikwissenschaften und Internationales Recht an der Columbia University. Als junger Mann trat er der US-Army bei; im Mai 1945 marschierte Winter mit der 86. Division der 3. US-Armee bei Burghausen ins Innviertel ein. Nach Kriegsende war er u. a. Professor für Geschichte und Politikwissenschaft am Iona College in New Rochelle/New York und Gastprofessor an der Flechter School of Law and Diplomacy an den Universitäten in Princeton, Georgetown/Washington und Indiana. Bruno Kreisky machte Ernst Florian Winter 1964 zum ersten Nachkriegs-Direktor an der Diplomatischen Akademie in Wien (1964-1967), wo künftig eine neue Generation von Diplomaten ausgebildet werden sollte.

Vgl. http://de.wikipedia.org/wiki/ernst_Florian_Winter [Zugriff 19.7.2009]. 
„nicht nur außenpolitisch vollkommen versagt [...], nicht nur nicht die Wiedergruppierung des Nazismus verhindert“, sondern wäre darüber hinaus „auch zur primitivsten Wiedergutmachung unfähig“. ${ }^{1659}$

Winter, der sich bis zum Abschluss des Staatsvertrages wiederholt durch Leserbriefe in amerikanischen Tageszeitungen zu Fragen des Staatsvertrages und zur Zukunft Österreichs einbrachte, ${ }^{1660}$ kam schließlich erst im November 1955 , nachdem ihm eine Gemeindewohnung zugewiesen worden war, als kranker Mann ${ }^{1661}$ und ohne Familie das erste Mal wieder nach Wien. ${ }^{1662}$ Sogleich wandte er sich mit soziologisch ausgerichteten Vorlesungsvorschlägen - so unter anderem über den „Amerikanismus in der Atomzivilisation“ - an den Dekan der rechts- und staatswissenschaftlichen Fakultät und erneuerte seinen „Antrag um Ausdehnung der venia legendi auch auf Soziologie im kürzesten möglichen Verfahren“. ${ }^{1663}$ Dieses wiederholte, in beharrlich gelassenem Ton gestellte Ansuchen wurde nach kurzem Hin und Her durch Beschluss des Professorenkollegiums am i7. Dezember 1955 schließlich genehmigt. ${ }^{1664}$ Kurz darauf führte Winter mit Unterrichtsminister Drimmel bereits Gespräche betreffend die Schaffung eines Lehrstuhls für „österreichische Geschichte an der juridischen Fakultät“, an dem künftig österreichische Wirtschafts-, Sozial-, Kultur- und Geistesgeschichte in Verbindung mit politischer Theorie gelehrt werden sollten. Zugleich bemühte sich Winter, der gerade seine Studie über „Christentum und Zivilisation“ fertig gestellt hatte, um Verleihung einer Titularprofessur, auf die er sowohl wegen seiner wissenschaftlichen Qualifikation als auch hinsichtlich der früheren „staatsfeindlichen"Verhinderung „ein moralisches Anrecht zu besitzen“1665 glaubte.

Aber so einfach sollte die Angelegenheit für Winter nicht laufen. Ausgerechnet August Maria Knoll, der Winter noch im Juni mitgeteilt hatte, dass die „Causa in diesem

1659 Holzbauer, Ernst Karl Winter (1895-1959), a.a. O., 369.

1660 Zwei Beispiele: „The Role of Austria. Importance to Peace of Granting Independece Discussed“ (Letter from Ernst Karl Winter)“. In: New York Times, 13 September 1953, E10 oder „Austria‘s Role Assessed. Status said to enable Her to act as Mediator for Central Europe (Letter from Ernst Karl Winter)“. In: New York Times, 15 May 1955, E8.

1661 Winter litt zum damaligen Zeitpunkt an einer Retinalthrombose und war bereits halb erblindet. Siehe: Ernst Karl Winter, Bericht an die Herren Professoren der Rechts- und Staatswissenschaftlichen Fakultät in Wien (aus Anlass meiner vorläufigen Rückkehr in die USA, undatiert [Jänner 1957]), UAW, Phil. Fakultät, Personalakt Ernst Karl Winter/23, 2.

1662 UAW, Phil. Fakultät, Personalakt Ernst Karl Winter/23; Vgl. weiters: Österreicher im Exil. USA 19381945, a.a. O., 699; zudem: Der Freiheitskämpfer, Nr. 11-12, 1956, 5.

1663 UAW, Phil. Fakultät, Personalakt Ernst Karl Winter/23, Brief Winters an Dekan Theodor Puetz vom 21. November $1955,1 \mathrm{f}$.

1664 Ebd., Dek.Zl. 1773 aus 1955, Schreiben des Dekanats der Universität Wien an Karl Ernst [sic] Winter vom 12. Jänner 1956; weiters ebd. Z1. 108.377-I/1-55, Schreiben von Bundesminister Drimmel an Winter vom 9. Jänner 1956.

1665 UAW, Phil. Fakultät, Personalakt Ernst Karl Winter/23, Schreiben Ernst Karl Winters an Dekan Theodor Puetz vom 19. Juni 1956, 1. 
Semester noch anzuschneiden ungünstig“"1666 sei, stellte am I3. Oktober 1956 gegenüber der Fakultät den Antrag auf Verleihung eines außerordentlichen Professors an Winter und fügte (mit Rufzeichen) an, dass die Kommission mit ihm der Meinung sei, „dass die beantragte Titulierung ein Akt der Wiedergutmachung ist!“; ${ }^{1667}$ der Antrag erhielt aber nicht die dafür erforderliche Mehrheit der Kollegen und wurde aus formalen Gründen, nämlich dem Fehlen der vorgeschriebenen Jahre der Lehrausübung als Dozent, abgelehnt. Tief enttäuscht kehrte Winter für die Zeit von Jänner bis Herbst 1957 in die USA zu seiner Familie zurück, unter anderem auch wegen der amerikanischen Edition seines Buches „Christentum und Zivilisation“. Vor seiner Abreise nahm er, dem es mittlerweile schon „peinlich“ war, „in alten, obsoleten Dingen zu wühlen“, in einem persönlich gehaltenen Rechenschaftsbericht an seine Kollegen ausführlich Stellung zum vorläufig "gescheiterten Experiment“ einer „Wiederverwurzelung in der alten Heimat“ ${ }^{1668}$ Das angesprochene Scheitern war in Summe wohl vielgestaltig, hatte aber primär mit der als Demütigung empfundenen, „nicht vollständig durchgeführten Wiedergutmachung“ an seiner Person zu tun. Schließlich könne es, wie Winter formulierte, „nicht mit rechten Dingen zugehen [...] wenn meine lebenslangen wissenschaftlichen Leistungen nicht einmal für die Titularprofessur ausreichen, nachdem ich an einer amerikanischen Universität doch Universitätsprofessor war“. ${ }^{1669}$

Kaum ein Jahr nach Österreich zurückgekehrt, suchte Winter - „teils aus visatechnischen Gründen“ - bei der Fakultät um einen einjährigen Urlaub für einen Aufenthalt in den USA an. ${ }^{1670}$ Dazu kam es allerdings nicht mehr - am 4. Februar I958 verstarb Winter „unbedankt und kaum registriert“, ${ }^{1671}$ wie Hugo Pepper konstatierte - in Wien. ${ }^{1672}$

1666 Ebd., Schreiben Ernst Karl Winters an Dekan Theodor Puetz vom 18. Juni 1956.

1667 Ebd., Antrag von August M. Knoll an die rechts- und staatswissenschaftliche Fakultät der Universität Wien, 13. Oktober 1956, 2.

1668 Ernst Karl Winter, Bericht an die Herren Professoren der Rechts- und Staatswissenschaftlichen Fakultät in Wien (aus Anlass meiner vorläufigen Rückkehr in die USA), undatiert (Jänner 1957), UAW, Phil. Fakultät, Personalakt Ernst Karl Winter/23, 1.

1669 Ebd., 4. Mit stolzer Verbitterung und zugleich einem Rest an Hoffnung auf eine womöglich doch noch realisierbare Integration in die Wiener Universität adressierte er an seine Kollegen: „[...] die österreichischen politischen Wissenschaften sind nicht so überreich an reifen Kräften, dass die Universität das Recht hat, jemanden, der etwas leisten kann, einfach wieder sang- und klanglos ziehen zu lassen." Ebd.

1670 Winter unterfertigte das Schreiben als „Altvizebürgermeister der Stadt Wien“, als „Univ.Prof.i. R. (New York)“ und als „Univ.Dozent (Wien)“. UAW, Phil. Fakultät, Personalakt Ernst Karl Winter/23, Schreiben Winters an die Rechts- und staatswissenschaftliche Fakultät der Universität Wien vom 3. Dezember 1958.

1671 Pepper, Ernst Karl Winter und die Sozialdemokratie, a.a. O., 150.

1672 Die New York Times druckte immerhin einen kurzen Nachruf. Siehe: New York Times, 22 Februar 1959, 88. 
Fallbeispiel: Hans Kelsen (1881-1973)

Ein anders gelagertes Beispiel, bei dem allerdings USFA-Stellen in Österreich involviert waren, bietet Hans Kelsens' Ansuchen um eine Gastprofessur an der Universität Wien im Jahr 1947 - ein biografisches Detail, das aber doch eine gewisse Signifikanz besitzt und das hier zumindest kurz erwähnt werden soll; auch dieses Projekt scheiterte, wenn auch aus anderen Gründen als im Fall von Ernst Karl Winter.

Ende der Zwanzigerjahre, als Kelsen bereits ein international hochangesehener Rechtsgelehrter war, hatte sich das Arbeitsklima und seine persönliche Lebenssituation an der juridischen Fakultät der Universität Wien, an der er I9I9 zum ordentlichen Professor für Staats- und Verwaltungsrecht ernannt worden war, zunehmend schwieriger gestaltet. ${ }^{1673}$

Den intellektuell überaus wehrhaften Demokraten Kelsen, der sich zwar nie direkt politisch betätigte, aber neben seiner wissenschaftlichen Karriere bereits früh auch als humanistischer Aufklärer und Volksbildner Popularität erlangte, indem er sich um die Vermittlung einer parteifreien, neutralen politischen Bildung und Staatsbürgerkunde bemühte, ${ }^{1674}$ haben die Veränderung des innenpolitischen und geistigen Klimas in Österreich Ende der I920er-Jahre sicherlich ebenso getroffen wie die gegen ihn persönlich beziehungsweise gegen die von ihm begründete „Reine Rechtslehre“ gerichteten Anfeindungen.

$1673 \mathrm{Zu}$ Kelsens Biografie siehe v.a. die Studie von Rudolf Aladár Métall, Hans Kelsen. Leben und Werk, Wien 1969; zur Zeit läuft am Wiener Hans Kelsen-Institut (in Kooperation mit der Hans-KelsenForschungsstelle-Erlangen) ein groß angelegtes Kelsen-Editionsprojekt, innerhalb dessen - unter Einbeziehung einer möglichst breiten Quellenbasis - bis 2012 die Biografie Kelsens neu untersucht und dargestellt werden soll. Gespräch mit Univ.-Prof. Dr. Thomas Olechowski am 3. April 2007.

1674 So war Hans Kelsen ab 1911 Vortragender an Wiener Volkshochschulen und bis 1925/26 Mitglied des Ausschusses für „Volkstümliche Universitätskurse“ (University Extension) der Universität Wien. Vgl. UAW, Dekanatsakten der Juridischen Fakultät, Lfnr. 32. Die Frau des späteren Bundespräsidenten Adolf Schärf besuchte Kelsens volkstümliche Vorträge während des Ersten Weltkriegs und schrieb darüber: „Der Vortrag von Dr. Kelsen ist ausgezeichnet; mit einfachster Art behandelt er ein ziemlich schwieriges Thema, macht es so interessant, dass man den Wunsch hat, die Stunde möchte sich verdoppeln. Von einem Kurs freue ich mich auf den anderen“. Brief seiner Frau Hilde (Hammer) an Adolf Schärf vom 4. März 1916. Diese Aussage teilte Schärf in einem Gratulationsschreiben an Kelsen anlässlich dessen 75. Geburtstages mit. Zit. nach: Métall, Hans Kelsen, a. a. O., 88; siehe weiters: Tamara Ehs, Die Entzauberung von Staat und Recht. Hans Kelsen als Vortragender in der Wiener Volksbildung. In: Spurensuche. Zeitschrift für Geschichte der Erwachsenenbildung und Wissenschaftspopularisierung, 17. Jg., 2006, Heft 1-4, 61 ff.; weiters: Karin Renner, Hans Kelsen: Der Philanthrop, Dipl.-Arb., Univ. Wien 2001; zuletzt: Deborah Holmes, Die Schwarzwaldschule und Hans Kelsen. In: Robert Walter/Werner Ogris/Thomas Olechowski (Hrsg.), Hans Kelsen: Leben - Werk - Wirksamkeit. Ergebnisse einer Internationalen Tagung, veranstaltet von der Kommission für Rechtsgeschichte Österreichs und dem Hans Kelsen-Institut (= Schriftenreihe des Hans Kelsen-Instituts, Bd. 32), Wien 2009, 97-109. 
Nicht zuletzt waren es antisemitische Verunglimpfungen, Anfeindungen und massive Schmähschriften seitens seiner Fachkollegen gewesen, ${ }^{1675}$ die den Mitautor der Österreichischen Verfassung und Schöpfer des Verfassungsgerichtshofes ${ }^{1676}$ - neben seiner Relegierung als Mitglied des Verfassungsgerichtshofes auf Lebenszeit infolge der neuen autoritären Heimwehrverfassung von 1929 - einen Ruf nach Köln annehmen ließ. ${ }^{1677}$ Zwar kam Kelsen mit dieser Entscheidung einer späteren zwangsweisen Emigration aus Österreich zuvor, nach der Machtergreifung der Nationalsozialisten 1933 wurde er aber in Köln - ebenso wie Max Horkheimer oder Karl Mannheim - sogleich ,beurlaubt' und ohne Ansprüche abgesetzt. ${ }^{1678}$ Nach zwischenzeitlicher Lehrtätigkeit in Genf und einer 1936 angetretenen Professur an der Deutschen Universität Prag, die von nazistischen Attacken und Drohungen völkischer Studentengruppen gegen seine Person geprägt war, emigrierte Kelsen - ebenfalls mit persönlicher Visum-Hilfestellung durch Alvin Johnson von der New School for Social Science in New York, deren Lehrauftrags-Offert er aber ablehnte,

1675 So versuchten z.B. Alexander Hold-Ferneck, Ernst Schwind oder Fritz Sander, denen der liberale und mit einer Reihe von Sozialdemokraten in intellektuellem Austausch stehende Kollege, der sich noch dazu für die Habilitierung Max Adlers eingesetzt hatte, ein Dorn im Auge war, in hinterhältigen ,Kampfschriften' die wissenschaftliche Seriosität der kelsenschen Rechtslehre in Zweifel zu ziehen, was allerdings - nicht zuletzt aufgrund der prompten Gegenwehr Kelsens - misslang. Vgl. Métall, Hans Kelsen, a.a.O., 39 bzw. 56. Vgl. dazu weiters: Gerhard Oberkofler, Die Wahl von Leo Stern in die Deutsche Akademie der Wissenschaften. In: Mitteilungen der Alfred Klabr Gesellschaft, 1, 1999, $1 \mathrm{ff}$.; Rathkolb, Rechts- und Staatswissenschaftliche Fakultät, a.a.O., 197 f.; [Baron] Alexander Hold-Ferneck (18751955), Völkerrechtler und gleichaltriger Karrierekonkurrent Kelsens, 1922 Ordinarius für Völkerrecht und Rechtsphilosophie, 1929/30 Dekan der Juridischen Fakultät; 1932-34 Senator und 1934/35 Rektor der Universität Wien. Er vertrat eine militant deutsch-völkische Position und stand dem Nationalsozialismus schon vor 1938 nahe. So hatte er als Rektor die Machtergreifung Hitlers 1933 begrüßt. Seine radikal antisemitische Grundhaltung dokumentiert sich darin, dass er mehrfach die Habilitierung jüdischer Kollegen (und Anhänger Kelsens) hintertrieb. Im Herbst 1938 hatte Hold-Ferneck um Aufnahme in die NSDAP angesucht und war, obwohl gläubiger Katholik, aus der Kirche ausgetreten. Das Erkenntnis des Entnazifizierungsverfahren der Sonderkommission des Unterrichtsministeriums vom 8. März 1946 bescheinigte Hold-Ferneck die Gewähr, ,jederzeit rückhaltlos für die unabhängige Republik Österreich eintreten“ zu wollen. Vgl. dazu: Jürgen Busch/Kamila Maria Staudigl-Ciechowicz, „Ein Kampf ums Recht“? Bruchlinien in Recht, Kultur und Tradition in der Kontroverse zwischen Kelsen und Hold-Ferneck an der Wiener Juristenfakultät. In: Szabolcs Hornyák/Botond Juhász/Krisztina Korsósné Delacasse/Zuszsanna Peres (Eds.), Turning Points and Breaklines (= Jahrbuch Junge Rechtsgeschichte 4), München 2009, $111 \mathrm{ff}$. und $131 \mathrm{ff}$. [Ich danke an dieser Stelle Kollegen Mag. Jürgen Busch herzlich für die Zurverfügungsstellung einer Kopie des Artikels].

1676 Vgl. Gerhart Klaus Wielinger, Hans Kelsen. In: Wolfgang Mantl (Hrsg.), Politik in Österreich. Die Zweite Republik - Bestand und Wandel (= Studien zu Politik und Verfassung 10), Wien - Graz 1992, 769; weiters: Métall, Hans Kelsen, a.a.O., 54.

1677 Betrieben hatte den Ruf der Kölner Rektor und „überzeugte Demokrat“ Fritz Stier-Somlo. Vgl. Ehs, Vertreibung in drei Schritten, a.a.O., 158; vgl. weiters: Métall, Hans Kelsen, a.a.O., 56 f.

1678 Siehe dazu: Oliver Lepsius, Hans Kelsen und der Nationalsozialismus. In: Walter/Ogris/Olechowski (Hrsg.), Hans Kelsen: Leben - Werk - Wirksamkeit, a.a.O., 273. 
da es lediglich eine befristete Anstellung versprach ${ }^{1679}$ - über Genf schließlich 1940 in die USA, wo er zunächst einen Lehrauftrag an der Harvard Law School inne hatte ${ }^{1680}$ der Präsident dieser Einrichtung, James Bryant Conant, hatte ihm bereits 1936 als ,a leader of jurist thought" das Ehrendoktorat verliehen. ${ }^{1681}$ Im Unterschied zu Winter und anderen Wissenschaftsemigrés war Kelsen in der Emigration politisch kaum aktiv. ${ }^{1682}$

Kelsen, der bald in Englisch zu publizieren begann und bereits in den Zwanzigerjahren als Wissenschafter internationale Reputation besaß, konnte sich in der US-Emigration gut etablieren: 1942 erhielt er einen Ruf nach Berkeley, wo er drei Jahre später zum „Full Professor" ernannt und amerikanischer Staatsbürger wurde. ${ }^{1683}$

Kelsen und auch seine Schüler vermochten sich, anders als zahlreiche andere österreichische Wissenschaftsemigranten, bereits im „extramuralen Exil“ innerhalb Österreichs ${ }^{1684}$ sowie insbesondere in den USA in den neu entstandenen „social sciences“ zu etablieren, insbesondere profitierten seine Schüler von den gut funktionierenden Netzwerken ihres akademischen Lehrers. ${ }^{1685}$

Außerdem war Kelsen, der bald von einem Gastvortrag zum nächsten reiste, ab 1944 in mehreren Funktionen als wissenschaftlicher Berater für amerikanische Regierungsbehörden in Washington tätig. So wurde er, laut seinem Biografen Rudolf Aladár Métall, der die Fragment gebliebene Autobiografie Kelsens auswertete, vom „Bureau of Areas, Liberated Areas Branch, Economic Institutions Staff“ für die Planung der Verwaltung der von den Alliierten zu befreienden Gebiete inklusive Österreich beigezogen. Darüber

1679 Feichtinger, Wissenschaft zwischen den Kulturen, a.a.O., $216 \mathrm{f}$.

1680 Der renommierte Dekan Roscoe Pound, der Kelsen nach Harvard holte, charakterisierte Kelsen als „unquestionable the leading jurist of his time“. Zit. nach: International Biographical Dictionary of Central European Emigrés 1933-1945. Vol. II, Part 1: A-K. The Arts, Sciences, and Literature, ed. by Herbert A. Strauss/Werner Röder, München - New York - London - Paris 1983, 612.

1681 Zit. nach: Oliver Lepsius, Hans Kelsen und der Nationalsozialismus, a.a.O., 328.

1682 Lediglich im Zusammenhang des im November 1943 in London konstituierten überparteilichen „Austrian National Committee" taucht Kelsens Name auf: neben Julius Deutsch, Richard Schueller und Franz Czernin wurde auch er eingeladen, dem London-Komitee, dem Franz Novy als Vorsitzender vorstand und dem u.a. auch der Soziologe Friedrich Hertz, der Christlich-Soziale Franz Schneider, der Gewerkschafter Karl Zernitz [sic; recte: „Czernetz“] oder Oskar Pollack angehörten, beizutreten. Siehe: Pvt. Friedinger to Mr. DeWitt C. Poole, 10. November 1943, Office of Strategic Services. Interoffice Memo. U.S. Office of Strategic Services. Foreign Nationalities Branch Files 1942-1945. Indexes, Bethesda 1998 [Mikrofiche-Bestand, Institut für Zeitgeschichte der Universität Wien, Bibliothek], INT-4AU-389.

1683 Robert Walter, Hans Kelsens Emigration aus Österreich im Jahre 1930. In: Stadler (Hrsg.), Vertriebene Vernunft. Bd. II, a.a.O., 466.

1684 Vgl. Tamara Ehs, Vertreibung in drei Schritten. Hans Kelsens Netzwerk und die Anfänge österreichischer Politikwissenschaft. In: Österreichische Zeitschrift für Geschichtswissenschaften [Schwerpunkt: „Vertriebene Wissenschaft“], 21. Jg., 2010, Bd. 3, 155.

1685 Vgl. Johannes Feichtiger, Transatlantische Vernetzungen. Der Weg Hans Kelsens und seines Kreises in der Emigration. In: Walter/Ogris/Olechowski (Hrsg.), Hans Kelsen: Leben - Werk - Wirksamkeit, a.a.O., $329 \mathrm{f}$. 
hinaus wirkte Kelsen innerhalb der „War Crimes Commission“ auch an der juristischen Vorbereitung der Nürnberger Prozesse mit. ${ }^{1686}$

Tatsächlich hatte Kelsen, neben frühen völkerrechtlichen Überlegungen einer zukünftigen, internationalen Friedensicherung, ${ }^{1687}$ Anfang Mai 1944 im Zusammenhang einer staatsrechtlichen Rekonstruktion Österreichs mit Experten der European Affairs Division im US-State Department über diesen Problemkomplex („Future of Austria“) ${ }^{1688}$ diskutiert ${ }^{1689}$ und kurz darauf auch ein Memorandum über Österreichs Rechtsstellung und Wiederrichtung als unabhängiger Staat verfasst. ${ }^{1690}$

$\mathrm{Ob}$ und inwiefern diese juristischen Reflexionen Kelsens, die sich im Wesentlichen an der Moskauer Deklaration orientierten und diese positiv untermauerten, allerdings tatsächlich Einfluss auf die konkrete US-Nachkriegsplanung hatten, scheint schon allein wegen der tatsächlich erfolgten Wiederanknüpfung an die Bundesverfassung von $1929 \mathrm{mehr}$ als unwahrscheinlich. ${ }^{1691}$ Auch Kelsens Vorschläge, die er im Oktober 1945 im Vorfeld der Ausarbeitung einer Charta für die Vereinigten Nationen an das State Department übermittelt hatte, fanden bei den zuständigen Stellen kein Interesse. ${ }^{1692}$

1686 Métall, Hans Kelsen, a.a. O., 80 f.; vgl. auch Eppel, Die Vereinigten Staaten, a.a.O., 993.

1687 Dabei kritisierte Kelsen das völlige Versagen des Völkerbunds als Friedensicherungsinstrument, insbesondere auch im Hinblick auf Österreich: „Nothing can demonstrate this more clearly than the fact that the violation of the territorial integrity of member states, when it came from outside and led actually to the complete annihilation of these states, as in the case of Austria, Czechoslovakia, and Poland, in open opposition to the provisions of Articles 10 and 11, did not even reach the stage of discussion in the League [...]“. Hans Kelsen, International Peace - By Court Or By Government? In: The American Journal of Sociology, Vol. XLVI, Jan. 1941, No. 4, 580.

1688 Ein nicht uninteressantes Detail ist, dass das Gesprächsprotokoll der Unterredung mit Kelsen unter dem Titel abgelegt wurde („The Future of Austria“), unter dem das geheime Memorandum des britischen Foreign Office vom 12 Juli 1943 verfasst wurde. In einem US-Evaluationsbericht darüber heißt es u. a.: „The British take it for granted that the movement toward ,Anschluss' was so deep-seated in Austrian political thinking that it becomes the major problem in determining the means of safeguarding Austrian independence, if re-established." Department of State, Division of European Affairs, Memorandum: Evaluation of the British Foreign Office secret paper „The Future of Austria“, 1. DÖW 10:010 [21.011/14].

1689 In diesem Gespräch plädierte Kelsen - anders als im Fall Deutschlands - für die umgehende Wiederherstellung eines unabhängigen Österreichs, wobei er, obwohl Ko-Autor der Verfassung von 1919, vorschlug, diese aufgrund ihrer betont föderalen Struktur und der daran geknüpften Probleme nicht wieder einzusetzen: „Federalism was expensive and seems unnecessary for a future Austrian state." Hans Kelsen, Memorandum „Future of Austria“, 5. Mai 1944, 3. DÖW 21.011/14. Teilnehmer an diesem Gespräch waren: Philip E. Mosely, David Harris, Harry N. Howard und Howard M. Smyth.

1690 Kelsen bewegte sich darin ganz auf Linie der Moskauer Deklaration. Memorandum Hans Kelsen, Department of Political Science, University of California, 1. Juni 1944. DÖW Bibliothek 3017/14. Zit. nach Österreichischer im Exil. USA 1938-1945, a.a. O., 236. Das Dokument ließ sich unter der angegebenen Signatur im DÖW allerdings nicht auffinden.

1691 Vgl. dazu auch Eppel, Die Vereinigten Staaten, a.a.O., 993.

1692 In einem elaborierten Memorandum hatte Kelsen die Einrichtung eines „United Nations Institute of International Studies" proponiert; und auch für die Ausarbeitung einer UNO-Charta wurde er nicht beigezogen, da man auf „legalistic technicalities“ keinen großen Wert legte. Zit. nach: Métall, Hans Kelsen, a.a.O., 80. 
Kurioserweise stand Hans Kelsen ab Ende 1944 wiederholt im „Visier des FBI“. ${ }^{693}$ I953 wurde Kelsen im Zuge der von Senator Joseph McCarthy ab 1950 geleiteten Gesinnungs-Überprüfungen schließlich im Rahmen des „loyalty program for all federals employees“ einer „full field investigation“ des FBI unterzogen: ${ }^{1694}$ gegenüber dem „House Un-American Activties Committee (HUAC)“ hatten die aufgeforderten Personen einen antikommunistischen Loyalitätseid zu leisten und nachzuweisen, „dass sie nicht Mitglieder der Kommunistischen Partei waren. “1695 Obwohl Kelsen von einem - anonymisierten - Freund an der University California/Berkeley attestiert wurde, „one of the strongest and best informed opponents of Communism“ ${ }^{1696}$ zu sein, zog sich die Untersuchung in die Länge, da das FBI Kelsen eines Naheverhältnisses zu sozialistischen Ideen, somit einer potenziell subversiven, gefährlichen Gesinnung verdächtigte. ${ }^{1697}$ Wie Rathkolb resümiert, konnte die Reputation Kelsens, der längst als „höchst renommierter Rechtsgelehrter von internationalem Rang“ galt, selbst durch „Fangfragen [...] subalterner FBIAgenten bezüglicher seiner Stellung zu Kommunismus und Sozialismus nicht erschüttert werden". 1698

Obwohl Kelsen nun nach Kriegsende umgehend den Kontakt zu Freunden und Kollegen in Europa aufnahm, unter anderem auch nach Wien, ${ }^{1699}$ stand für ihn, wohl nicht zuletzt auf Grund seiner erfolgreichen akademischen Karriere in den USA, eine tatsächliche Rückkehr nach Österreich nicht zur Debatte - wohl aber die Option auf eine universitäre Lehrtätigkeit.

Anders als im Fall Winter war es die alte Heimat, die an ihn herantrat. Im Herbst 1946 sandte der Bürgermeister von Wien, Theodor Körner, Glückwünsche zu Kelsens 65. Ge-

1693 Vgl. Oliver Rathkolb, Hans Kelsen und das FBI während des McCarthysmus in den USA. In: Walter/Ogris/Olechowski (Hrsg.), Hans Kelsen: Leben - Werk - Wirksamkeit, a.a. O., 339 ff. Verdächtigt wurde Kelsen zunächst aufgrund eines Kontaktes zu Charles Gulick und Briefkontakten zu den als kommunistisch beziehungsweise linksintellektuell eingeschätzten Wissenschaftern William Marias Malisoff und Emile Grünberg. 1948 zogen schließlich Kelsens Unterstützung eines politischen Kandidaten der „Independent Progressive Party“ in San Franscisco, der die Kandiatur von Henry A. Wallace unterstützte und gegen den Kalten Krieg votierte, seine Unterstützung des entlassenen Kollegen Harold Winkler in Berkeley, der sich geweigert hatte, einen verschärften Loyalitätseid zu leisten, sowie einzelne seiner Aussagen, z.B. dass er beispielsweise öffentlich seine Bewunderung Personen gegenüber ausgesprochen hatte, die sich aus ihnen wichtigen Grundüberzeugungen entschlossen hatten, ihre berufliche Position aufzugeben, die Aufmerksamkeit des FBI auf sich. Ebd., 343 bzw. 346.

1694 Zur Zusammenarbeit amerikanischer Universitäten und dem FBI u.a. zu Beginn des Kalten Krieges siehe: Sigmund Diamond, Compromised Campus. The Collaboration of Universities with the Intelligence Community, 1945-1955, New York - Oxford 1992.

1695 Rathkolb, Hans Kelsen und das FBI während des McCarthysmus, a.a. O., 342.

1696 Ebd., 344.

1697 Ebd., 347.

1698 Ebd., 348.

1699 So z.B. zu seinem früheren Schüler und Kollegen Alfred Verdross-Droßberg. Vgl. Métall, Hans Kelsen, a.a.O., 81. 
burtstag und gratulierte ihm zu dessen „bedeutungsvolle[r] Arbeit für Wissenschaft und Freiheit“. ${ }^{1700}$ Kurz darauf stellte das Professorenkollegium der rechts- und staatswissenschaftlichen Fakultät der Universität Wien - nach persönlicher Zustimmung Kelsens gegenüber Verdross - den Antrag auf Ernennung zum Honorarprofessor des „unter den aus Österreich stammenden, noch lebenden Juristen“ zweifellos „in der ganzen Welt anerkanntesten[n] Gelehrte[n]. "1701 In der Begründung durch Verdross wurde die Verleihung dieser höchsten Würde der Fakultät als „patriotische Pflicht“bezeichnet, da Kelsen viel für Österreich geleistet habe und „auch im Ausland“ stets „für den Ruhm, der österreichischen Wissenschaft ${ }^{\text {“1702 }}$ eingetreten sei. Mit keinem Wort erwähnt wurde dabei allerdings Kelsens persönlich und beruflich schwierige Situation Ende der Zwanzigerjahre in Österreich, die antisemitischen Anfeindungen, die ihn geradezu gezwungen hatten, einen Ruf nach Deutschland anzunehmen. Das moralisch wieder gut zu machende „Unrecht“ hatte Kelsen quasi außerhalb Österreichs erfahren: „Diese Ehrung bedeutet zugleich eine moralische Wiedergutmachung für das von den Nazis an Kelsen begangene Unrecht, die ihn I933 von seinem Lehrstuhl aus Köln vertrieben haben. “1703

Es ist vielleicht nicht ganz unbedeutend, dass Alfred Verdross-Droßberg die Ernennung seines Lehrers zum Honorarprofessor, zu dem er ein amikales Verhältnis hatte, maßgeblich betrieben hatte. ${ }^{1704}$ Nachdem sich Verdross relativ früh von der rechtspositivistischen Lehre Kelsens distanziert hatte, war es $1934 \mathrm{Zu}$ „ernsthaften persönlichen Verstimmungen “1705 rund um das erzwungene Ausscheiden Kelsens als jüdischer Herausgeber der Zeitschrift für öffentliches Recht gekommen, dessen Hauptschriftleitung nun Verdross übernahm. Nach Kriegsende versöhnte sich Kelsen aber wieder mit seinem hochgelehrten Kollegen.

Anders als Kelsen hatte Verdross ein keinesfalls klares Verhältnis zum Nationalsozialismus. Nicht nur hatte er während der NS-Zeit durchgehend an der juridischen Fakultät gelehrt, sondern darüber hinaus einen geradezu „phönixhafte[n] Aufstieg“1706 machen können. Obwohl kein Mitglied der NSDAP, verhielt er sich dem Nationalsozialismus gegenüber nicht nur wohlwollend positiv - Verdross' naturrechtlich orientierte Lehrmeinung fand im NS-Deutschland überaus große Verbreitung und stand mit Sicherheit

1700 Métall, Hans Kelsen, a.a.O., 82.

1701 UAW, Personalakt Hans Kelsen/13, Prof. Dr. Hans Kelsen, Ernennung zum Honorarprofessor, Abschrift der Begründung. Bundesminister Hurdes an das Dekanat der rechts- und staatswissenschaftlichen Fakultät der Universität Wien, Z1.21287-III/7-47, 24. Juni 1947,1.

1702 Ebd., 2.

1703 Ebd.

1704 Vgl. Busch, Alfred Verdross, a.a.O., 37.

1705 Vgl. ebd., 27 f. bzw. 36.

1706 Oliver Rathkolb, Die Rechts- und Staatswissenschaftliche Fakultät der Universität Wien zwischen Antisemitismus, Deutschnationalismus und Nationalsozialismus 1938, davor und danach. In: Heiß et al. (Hrsg.), Willfährige Wissenschaft, a.a.O., 216. 
nicht in Opposition zum Nationalsozialismus ${ }^{1707}$-, sondern hatte sich, wie Oliver Rathkolb klar nachgewiesen hat, auch schon in illegalen NSDAP-Kreisen engagiert. ${ }^{1708}$ Eine klare persönliche Stellungnahme oder deutliche Distanzierung zur NS-Zeit hat Verdross, der sich selbst nach Kriegsende zum NS-Gegner beziehungsweise zum „Opfer“ stilisierte von halbherzigen Rechtfertigungen abgesehen ${ }^{1709}$ - nie abgegeben; immerhin hatte sich für seinen universitären Verbleib nach 1938 Wehrmachtsgeneral Alfred Jodl eingesetzt und immerhin hatte Verdross I943 per Führererlass das „silberne Treuedienstzeichen“ verliehen bekommen. ${ }^{1710}$ Nach Beschluss des Fakultätsgremiums ${ }^{1711}$ wurde Kelsen am 28. April I947 von Bundesminister Hurdes zum Honorarprofessor ernannt, in der Hoffnung, damit würde Kelsen „die Möglichkeit gegeben werden, an unserer Fakultät wieder Vorlesungen zu halten, was zweifellos von allen Kollegen und Hörern wärmstens begrüßt werden würde."1712

Nach einer Einladung der Universität Wien, Vorlesungen über „Probleme politischer Theorie“ zu halten, wandte sich Kelsen schließlich im September 1947 an die Reorientation Branch der Civil Affairs Division im Pentagon. In einem Schreiben gab Kelsen zu verste-

1707 In diesem Zusammemhang konstatiert Anthony Carty: „There is no doubt but that Verdross thought he could work with National Socialists [...]. In particular the records available, mainly Nazi police archives, show that his scholarly work and academic and political activity were all closely scrutinized, leading to the firm conclusion that Verdross was not of their society, albeit he could hardly be accused of being in opposition to them. "Anthony Carty, Alfred Verdross and Othmar Spann: German Romantic Nationalism, National Socialism and International Law. In: European Journal of International Law, 6, 1995, $78 \mathrm{f}$. Für diesen Literaturhinweis danke ich Herrn Univ.-Prof. DDr. Oliver Rathkolb.

1708 Rathkolb, Rechts- und Staatswissenschaftliche Fakultät, a.a.O., $217 \mathrm{f}$.

1709 Vgl. Irmgard Marboe, Alfred Verdross - Ein Mann des Widerspruchs? Teil 1. Verdross' Völkerrechtstheorie vor dem Hintergrund des Nationalsozialismus. In: Alfred Verdross - Ein Mann des Widerspruchs? Verdross im Gefüge der Wiener Völkerrechtswissenschaft vor und nach 1938. In: Thomas Olechowski/Ilse Reiter et al. (Hrsg.), Vertriebenes Recht - Vertreibendes Recht. Die Wiener Rechtswissenschaftliche Fakultät zwischen 1938 und 1945, Wien 2010, 15 [unveröffentlichtes Manuskript. Für die Einsichtnahme sei an dieser Stelle Kollegen Mag. Jürgen Busch herzlich gedankt]; in einer Beurteilung von Verdross' Verhalten nach dem Anschluss hatte der kommissarische Dekan Ernst Schönbauer geschrieben: „Nach dem Umbruche benahm er sich zunächst radikal nationalsozialistisch. Als ich ihm aber freundschaftlich sagte, das passe nicht für ihn, liess er davon ab und benahm sich seither würdig“. Zit. nach: Busch, Alfred Verdross, a.a.O., 33. In den Erinnerungen von Joseph T. Simon wird Verdross' im Hinblick auf seine Haltung gegenüber jüdischen Studierenden entlastet, indem dieser schrieb, dass Verdross einer der wenigen Universitästprofessoren war, der jüdische Studenten bei Ausschreitungen an der Universität über die Hintertüre ins Freie verhalf. Vgl. Joseph T. Simon, Augenzeuge. Erinnerungen eines österreichischen Sozialisten. Eine sehr persönliche Zeitgeschichte. Mit einem Vorwort von Charles Gulick. Hrsg. v. Wolfgang Neugebauer, Wien 1979, 82

1710 Vor diesem Hintergrund kommt Verdross' Bemühen um Verleihung einer Honorarprofessur an Kelsen eine unzweifelhaft psychologisch interessante Dimension zu. Busch, Alfred Verdross, a. a. O., 34 bzw. 36.

1711 UAW, Personalakt Hans Kelsen/13, Dekanat der Universität Wien an das Bundesministerium für Unterricht, Dek.Z1.50 aus 1142 aus 1947, Antrag auf Erteilung der Hon. Professur an Prof. Kelsen, 28. April 1947.

1712 UAW, Personalakt Hans Kelsen/13, Prof. Dr. Hans Kelsen, Ernennung zum Honorarprofessor, Abschrift der Begründung, a.a.O., 2. 
hen, dass er diese Einladung anzunehmen bereit wäre, allerdings „only under the condition that I am sent to Vienna in some official mission for the government of the United States“, und fügte, nach kurzen Angaben zu seinem Lebenslauf und seiner beruflichen Karriere in den USA, ${ }^{1713}$ selbstbewusst hinzu: „I think that these circumstances enable me to do satisfactory work for the United States in Austria. “1714

Dass die Bemühungen anderer in die USA emigrierter österreichischer Juristen, die ihre Dienste dem U.S. War Department anboten, erfolglos blieben beziehungsweise im Sande verliefen, zeigte sich anhand eines Memorandums der Vereinigung früherer österreichischer Juristen in den Vereinigten Staaten, das bereits Mitte 1945 verfasst wurde und die bisherigen negativen Erfahrungen resümierte. ${ }^{1715}$

Das Ansuchen Kelsens wurde vom War Department umgehend an die USACA-Education Division mit dem Hinweis weitergeleitet, dass es die Möglichkeit gibt, ihn in das „Visiting Experts Program“ aufzunehmen, sodass seinem Wunsch nach einer offiziellen Funktion entsprochen wäre. Der in Österreich befindlichen US-Militärstelle wurde dabei überaus deutlich signalisiert, dass die Entscheidung zwar bei der Militäradministration vor Ort läge, es aber lediglich eines Telegrammes bedürfe, um Kelsen anzufordern, mit dem Nachsatz: „Understand he is personal friend of president Renner.“"1716 In einem vierzeiligen Retourtelegramm teilte die US-Information Service Branch in Österreich daraufhin mit, dass sich Kelsen auf einer „tentativen Liste“ befinde, genauere Informationen beziehungsweise die Bestätigung dessen aber erst nach Beratung der zuständigen Experten vor Ort nachfolgen würden.

1713 NARA II, RG 165, Box 324. Hans Kelsen an die Reorientation Branch der Civil Affairs Division in Washington, Captain Bateson, vom 9. September 1947. Kelsen beschrieb hier seinen Kurzlebenslauf mit folgenden Worten: „I was professor of constitutional law and political theory at the University of Vienna from 1911 to 1929; legal advisor of the first Goverment of the Austrian Republic from 1918 to 1921. In this capacity I drafted the Constitution of 1920 which is now again in force in Austria. I was member and permanent reporter of the Austrian Constitutional Court and Dean of the Law School of the University of Vienna. I know personally President Renner and many other people now in official position in Austria. For further information, I wish to tell you that I am an American citizen and Professor of Political Science at the University of California, Berkely. I was Oliver Wendell Holmes Lecturer at Harvard Law School and I am Honorary Member of the American Academy of Art and Science in Boston and of the American Society of International Law, Doctor Honorer Causa of Harvard University and of the University of Chicago."

1714 Ebd.

1715 American Association of Former Austrian Jurists [sic]. Armand Eisler to Department of War, 19 October 1945, Memorandum of Former Austrian Jurists Overseas, drafted by Paul L. Baeck and Robert Langer, 23 August 1945. Darin heißt es unter dem Punkt „Employment of former Austrian Jurists in U.S. Sevices Overseas“ mit deutlich frustriertem Unterton unter Bezugnahme auf eine behördliche Stellungnahme: „We learned that allegedly the U.S. Government, is unwilling to impose on the population of an occupied country its former nationals who are forced to emigrate, and subsequently acquired American citizenship، “ Zit. nach: ebd., 9.

1716 NARA II, RG 165, Box 324. Telecon 23. September 1947, WD-2, Lt.Col. Joseph R. Groves, INF. Executive, USACA. 
Eine erste Reaktion vom Leiter der Education Division in Österreich kam erst einen Monat nach dem Telegramm aus Washington und fiel lapidar aus. Darin wurde bestätigt, dass Kelsen eine Einladung zu einem Gastvortrag an der Universität erhalten habe und man daher empfehle, ihn auf die „Visiting Experts“-Liste zu setzen. Allerdings hatte die Education Division eine Woche zuvor bereits selbst eine derartige Liste zusammengestellt; auf dieser kam der Name Kelsen jedoch nicht vor. Bei den dort angeführten Experten handelte es sich um Pädagogen, die Vorträge im Bereich der Lehrerfortbildung, für Schulgruppen, für Frauengruppen oder für Lehrer im ländlichen Bereich halten sollten. ${ }^{1717}$ Das Verhalten des Leiters der Education Division in dieser Angelegenheit ist insofern seltsam, als sowohl die Behörden in Washington als auch die Universität Wien am Zustandekommen einer Gastprofessur Kelsens überaus interessiert waren. Ohne klare empirisch-faktische Klarheit auf Basis von Quellenmaterial lässt sich an dieser Stelle vorerst lediglich vermuten, dass - wie in anderen Fällen auch - das Unterrichtsministerium beziehungsweise Sektionschef Skrbensky die Angelegenheit auf die lange Bank schoben und dadurch schließlich verhinderten.

Am I9. Dezember 1947 erhielt Kelsen - der Anfang Oktober während eines Aufenthaltes in Washington kurz darüber informiert worden war, dass er sich auf einer tentativen Liste befindet -, ein Antwortschreiben von der Reorientation Branch in Washington, worin bedauert wurde, dass es nach wie vor nicht möglich sei, ihm auf sein Ansuchen eine definitive Antwort zu geben. Wie ihm Edgar Erskine Hume mitteilte, wurde dieses nun bereits seit geraumer Zeit („some time“) durch die zuständigen US-Militärbehörden in Österreich geprüft, aber - wie entschuldigend hinzugefügt wurde -, auf Grund bereits erfolgter Zusagen sowie unzureichender Mittel sei es leider nicht möglich, so viele „Konsulenten" nach Österreich zu entsenden, wie man sich das wünschte:

"Due to previous commitments and insufficient funds to allow for as many consultants as are desired in Austria, it has been possible for them to decide definitively whether or not they would be able to include you." 1718

Wie aus einem dem zitierten Schreiben beigefügten ,Memo' hervorgeht - darin wurde nochmals hervorgehoben, dass Kelsens Ansuche nicht zuletzt wegen seines Prestiges als verdienstvoll („meritorious“) erachtet werde -, hatte das War Department am 9. Dezember I947 nochmals direkt bei den zuständigen USFA-Stellen nachgefragt. Diese hatten betreffend Kelsens Wunsch, eine Gastprofessur in Wien zu übernehmen, geantwortet, „that his [Kelsens, d. Verf.] presence is not deemed to be of,vital importance', but that he might be considered on later requests for visiting experts. ${ }^{\text {"1719 }}$

1717 Ebd., Eduction Division, USACA, 10. Oktober 1947, Education Specialists to Visit Austria, 2.

1718 NARA II, RG 165, Box 324. Colonel Edgar Erskine Hume, GSC Chief, Reorientation Branch Civil Affairs Division, an Hans Kelsen, 19. Dezember 1947.

1719 Ebd. 
In einem weiteren Interims-Schreiben wurde Kelsen von der Reorientation Branch $(\mathrm{CAD})$ von dieser insgesamt eher unerquicklichen Situation in Kenntnis gesetzt.

Im April 1948 schrieb Alfred Verdross an Kelsen, das Professorenkollegium der juridischen Fakultät habe auf Anregung des in London befindlichen Friedrich Hayek beschlossen, ihn (sowie Eric Voegelin) im Rahmen eines Vortragszyklus' von Nationalökonomen zur Abhaltung von Vorlesungen einzuladen. Diese Vorlesungen sollten im Juli I948 an der Universität Wien stattfinden, wobei die Aufenthaltskosten für einen dreiwöchigen Aufenthalt durch einen „hiesigen Fonds gedeckt“ seien, nicht jedoch die Reisekosten, die von der Rockefeller-Stiftung übernommen werden sollten. ${ }^{1720}$

De facto - und das ist das eigentlich Unglaubliche an der ganzen Angelegenheit - kam von den zuständigen USFA-Stellen, das heißt von der Education Division beziehungsweise der Information Service Branch - bis Juli 1948 keine weitere Nachricht in der Causa Kelsen, sodass Captain Batson die Akte mit den Worten schloss:

\section{"Since reply has not been received from USFA, it is assumed USFA is not interested in his ser- vices. NO FURTHER ACTION NECESSARY." ${ }^{1721}$ [Versalien im Original]}

Damit war das Projekt einer Gastprofessur in Österreich für Kelsen, der Gastprofessuren auf der ganzen Welt innehatte, gescheitert. Abgesehen davon, dass Kelsen in der Folge vom offiziellen Österreich mit einer Reihe von Ehrungen überhäuft ${ }^{1722}$ und zumindest mit einer kleinen Wiedergutmachung entschädigt wurde, ${ }^{1723}$ kam es zu keinem Angebot, das den weltberühmten Rechtsgelehrten längerfristig an die Universität Wien beziehungsweise nach Österreich hätte zurückbringen können.

Einen Vortrag in seiner früheren Heimat hielt Kelsen dann erst 1962. Auf Einladung von Justizminister Christian Broda nahm er in diesem Jahr mit einem Vortrag über „Richter und Verfassung“" an der Österreichischen Richterwoche teil. Anlässlich dieses Aufenthaltes in Wien fand er auch Zeit für einen Vortrag an der Wiener Urania, bei dem sein ehemaliger Schüler Josef Dobretsberger die einleitenden Worte sprach. ${ }^{1724}$

1720 UAW, Personalakt Hans Kelsen/13, Dekanat der Universität Wien an Hans Kelsen, Berkeley, vom 8. April 1948.

1721 NARA II, RG 165, Box 324. Exchange Professor Candidate Hans Kelsen, Captain Bateson, 9. Juli 1948.

17221949 wurde Kelsen zum korrespondierenden Mitglied der Akademie der Wissenschaften ernannt; 1960 folgte das Ehrendoktorat der Staatswissenschaften an der Universität Wien sowie die Verleihung des Österreichischen Ehrenzeichens für Kunst und Wissenschaft.

1723 Parallel zur deutschen Wiedergutmachung in Form der Zuerkennung von Pensionsansprüchen zehn Jahre zuvor wurde Kelsen, dessen Einkommen bescheiden war, vom damaligen Bundespräsidenten Adolf Schärf mit Entschließung vom 22. September 1961, ein bescheidener „außerordentlicher Versorgungsgenuß“ gewährt. Vgl. Métall, Hans Kelsen, a.a.O., 87.

1724 Am 5. Juni 1962 hielt Kelsen im Klubsaal der Wiener Urania einen Vortrag unter dem Titel „Was ist Gerechtigkeit?" In den einleitenden, humorvollen Worten sprach Dobretsberger, dem Kelsen vergeblich 
I965 feierte die Wiener Universität ihr 6oo-jähriges Bestandsjubiläum, ${ }^{1725}$ zu deren Feierlichkeiten auch Kelsen eingeladen wurde, einen Vortrag zu halten. Bevor es aber dazu kam, wurde er von Professor Taras Borodajkewycz ${ }^{1726}$ an der Hochschule für Welthandel, unter Applaus neonazistischer Studenten, mit antisemitischen Verbalattacken bedacht, sodass Kelsen, trotz einiger - wie sein Biograf Métall schreibt - „die Vorfälle bagatellisierender Berichte aus Wien“, ${ }^{1727}$ seine Teilnahme zurückzog. Im April I965 schrieb Kelsen an Justizminister Broda, dass er aufgrund der Tatsache, dass bei den Demonstrationen, „wie man mir aus Wien schreibt, sogar ein alter Mann getötet wurde“ ${ }^{1728}$ gezwungen sei, die Reise nach Wien abzusagen. Erst der Beschluss der österreichischen Bundesregierung, Kelsen nicht als Gast der Universität Wien, sondern der Regierung einzuladen, vermochte ihn schließlich umzustimmen. ${ }^{1729}$

Immerhin wurde 1973, im Todesjahr Kelsens, von der Bundesregierung ein Hans-Kelsen-Institut eingerichtet und im November I984 wurde schließlich, nicht zuletzt initiiert durch die Aktivitäten des Kelsens-Institutes, im Gedenken an den „großen Gelehrten und hervorragenden Österreicher “1730 eine Büste enthüllt.

zur Emigration in die USA hatte verhelfen wollen, auch von der „späte[n] Dankespflicht unseres Landes, Kelsen gebührend zu ehren. Universität und Öffentlichkeit haben dies im Vorjahr durch die Verleihung des Ehrendoktorates getan. Sein Vortrag an der Urania wird beweisen, daß er in den langen Jahren der Abwesenheit seine Heimat nie vergessen hat."In: Mitteilungen der Wiener Urania, Juni 1962, 2.

1725 Vgl. dazu den Hinweis bezüglich der 600-Jahr-Feierlichkeiten auf Seite 652 dieser Arbeit.

1726 Nach einer (anonymen) Vorlesungsmitschrift Ferdinand Lacinas wurden die antisemitischen und revisionistischen Äußerungen des ehemals illegalen NSDAP-Mitglieds Borodajkewycz', der 1949 bereits im Kontext der Oberweiser Geheimgespräche der ÖVP mit ehemaligen Nationalsozialisten hervorgetreten war, publik und sorgten für eine veritable Staatsaffäre mit Ausschreitungen, die schließlich zum Totschlag von Ernst Kirchweger führten. Vgl. Maria Zimmermann, Die Affäre Borodajkewycz. Höhe- und Wendepunkt eines antisemitischen und antidemokratischen Hochschulskandals im Jahr 1965 - inhaltsanalytisch untersucht am Beispiel von sechs österreichischen Tageszeitungen, Dipl.-Arb., Univ. Wien 2001, 27, 32 f.; Gerard E. Kasemir, Die Borodajkewycz-Affäre 1965. Spätes Ende für „wissenschaftlich“ vorgetragenen Rassismus, Dipl.-Arb., Univ. Wien 1994, 29; weiters: Erich Schmidt, Albrecht Karl Konecny, „Heil Borodajkewycz“. Österreichs Demokraten im Kampf gegen Professor Borodajkewycz und seine Hintermänner, Wien 1966.

1727 Métall, Hans Kelsen, a.a.O., 92 f.

1728 Hans Kelsens, Berkely, an Justizminister Christian Broda, 17. April 1965. Zit. nach: Heinz Fischer (Hrsg.), Einer im Vordergrund: Taras Borodajkewycz. Eine Dokumentation [unter Mitarbeit von Hugo Pepper], Wien - München 1966, 133.

1729 Kabinettssitzung vom 22. April 1965. Zit. nach: Métall, Hans Kelsen, a.a.O., 92 f. Auch Verdross war bemüht gewesen, Kelsen brieflich umzustimmen, indem er freilich die Situation in unglaublich realitätsverzerrender Weise schönzureden versuchte: „Der sehr bedauerliche Zwischenfall an der Welthandelshochschule war eine ganz isolierte Erscheinung [...]. Abgesehen vielleicht ein paar Narren und Hinterwäldlern gibt es in Österreich seit 1945 keinen Antisemiten mehr, auch nicht an den Universitäten. " Zit. nach: Busch, Alfred Verdross, a.a.O., 38.

1730 Robert Walter, Hans Kelsen - ein Leben im Dienste der Wissenschaft. Bericht über die Enthüllung der Büste Kelsens mit Ansprache der Herrn Bundesministers Dr. Heinz Fischer (= Schriftenreihe des Hans Kelsen-Instituts 10), Wien 1985, 7. 


\section{Fallbeispiel: Felix Ehrenhaft (1879-1952)}

Ein letztes Fallbeispiel illustriert, mit welcher kuriosen Einstellung die zuständigen USOffiziere der Education Division in Österreich Rückkehrwünschen emigrierter Wissenschafter begegneten und über welch seltsame Kanäle derartige Ansuchen mitunter verhandelt wurden. Im konkreten Fall handelt es sich um den jüdischen Experimentalphysiker, ehemaligen Vorstand des III. Physikalischen Instituts ${ }^{1731}$ und langjährigen Freund von Albert Einstein in Wien, Felix Ehrenhaft; ${ }^{1732}$ er war nach seiner „Beurlaubung von allen Dienst- und Amtshandlungen“ am I. April $1938^{1733}$ und seiner nachfolgenden Verhaftung aus „rassischen“ Gründen über London und Rio de Janeiro in die USA emigriert, wo er im Juni 1939 ankam. ${ }^{1734}$ In Amerika konnte Ehrenhaft - nicht zuletzt wegen der widrigen materiellen Situation - nicht wirklich Fuß fassen und stand, ebenso wie sein Freund Albert Einstein, seinem Gastland äußerst kritisch gegenüber. ${ }^{1735}$

In der vom Monarchisten Otto Günther in den USA herausgegebenen Zeitschrift Austria, die den - ohnehin kaum statt gefundenen - Ansätzen einer Kontaktaufnahme mit jüdischen Emigranten seitens österreichischer Stellen mit deutlich antisemitischem Unterton begegnete, wurde am 5. Juli I946 Unterrichtsminister Felix Hurdes zitiert, der seiner besonderen Freude darüber Ausdruck gab, „dass es mir gelungen ist, von hervorragenden Gelehrten, die Österreich wegen Hitler verließen, Zusagen zur Rückkehr in die sie freudig erwartende Heimat zu erhalten, so z.B. gerade in diesen Tagen von Professor Dr. Ehrenhaft, derzeit in New York. " ${ }^{1736}$

1731 Mit Erlass des Staatsamtes für Inneres und Unterricht vom 21. Oktober 1920, Z1. 5770-I-Abt. 2, wurde Ehrenhaft ad personam zum ordentlichen Professor der Wiener Universität und zum Vorstand des des neuerrichteten III. Physikalischen Instituts ernannt. UAW, Phil. Fakultät, GZ 423, Sch. 67, Personalakt Felix Ehrenhaft, Zl. 1618.

1732 Joseph Braunbeck, Der andere Physiker. Das Leben von Felix Ehrenhaft, Wien - Graz 2003. Vgl. auch Christian H. Stifter, „Sehr geehrter Herr Kollege!“ Albert Einstein und die (Wiener) Volksbildung. In: Die Österreichische Volkshochschule. Organ des Verbandes Österreichischer Volkshochschulen, 57. Jg., 2006, Heft 220, $3 \mathrm{f}$.

1733 UAW, Phil. Fakultät, GZ 423, Sch. 67, Personalakt Felix Ehrenhaft, GZ. 5226/690 aus 1937/38, Der kommissarische Rektor an Felix Ehrenhaft, 22. März 1938. Mit der interimistischen Leitung des Instituts wurde der Hochschulassistent Dr. Gerhard Kirsch betraut, der - wie erwähnt - nach 1945 weiter an der Universität verblieb, was von der Austrian University League of America aber über das US-State Department beanstandet wurde.

1734 Unterstützung bei der Ausreise bekam Felix Ehrenhaft unter vielen anderen von Max Planck, den beiden Nobelspreisträgern Sir William Bragg und Owen Richardson, Janos Plesch sowie dem German Jewish Aid Committee in London, das schließlich das Einreisevisum in die USA bereitstellte. Siehe dazu: Joseph Braunbeck, Der andere Physiker. Das Leben von Felix Ehrenhaft, Wien 2003, 75 ff.; weiters: Wolfgang L. Reiter, 1938 und die Folgen für die Naturwissenschaften an Österreichs Universitäten. In: Stadler (Hrsg.), Vertriebene Vernunft. Bd. II. Emigration und Exil österreichischer Wissenschaft, a.a.O., 668.

1735 Braunbeck, Der andere Physiker, a.a.O., $81 \mathrm{f}$.

1736 Austria, 15. Juli 1946, 2 [DÖW Bibliothek 3020]. Zit. nach: Österreicher im Exil. USA 1938-1945. Bd. 2, a.a.O., 694. 
In seiner eigenen Darstellung hatte Ehrenhaft am 15. März 1946 vom Unterrichtsministerium eine formale Einladung zur Wiederaufnahme seines Ordinariats erhalten, ${ }^{1737}$ die er auch sogleich angenommen hatte. ${ }^{1738}$ Bei dieser formalen Einladung, die von der Universität Wien befürwortet worden war, blieb es vorläufig auch, da Ehrenhaft seine amerikanische Staatsbürgerschaft nicht aufzugeben bereit war, was aus österreichischer Sicht eine Formalhürde darstellte.

Tatsächlich hatte sich Ehrenhaft selbst bereits im Februar 1946 an die Universität Wien gewandt und sich, neben dem Wunsch nach einer Rückberufung, auch für die Wiedererrichtung des nach seiner erzwungenen Emigration aufgelösten III. Physikalischen Institutes ausgesprochen. Wie Skrbensky der Lehrkanzel für Physik im April mitteilte, käme die Wiederrichtung des III. Physikalischen Institutes „dermalen nicht in Frage“ und wegen des an Ehrenhaft zu erteilenden Lehrauftrages ,wird ehestens einem Antrag des Professorenkollegiums entgegengesehen. “1739

De facto hatte die Universität Wien, nach der bereits ausgesprochenen Einladung an Ehrenhaft und dessen Annahme der Rückberufung, Kontakt zu Albert Einstein aufgenommen und bei diesem angefragt, wie er dessen Rückberufung einschätze; dies wohl nicht ganz ohne den Hintergedanken, dass sich Einstein - der wegen Ehrenhafts mitunter äußerst spekulativen wissenschaftlichen Arbeiten mittlerweile auf fachliche Distanz gegangen war - kritisch über seinen Kollegen äußern würde. ${ }^{174}$

In einem Antwortschreiben im Mai 1946 teilte Einstein der Universität Wien mit, dass er Ehrenhaft immer hoch geschätzt hatte und dieser hinsichtlich seiner wissenschaflichen Kapazität ein „fähiger Experimentator“ sei, auch wenn „er [...] seine Experimente oft falsch deutet“. Darüber hinaus gab Einstein der Universität einen Fingerzeig, wie mit Ehrenhaft - „ein fähiger und seinem Fache ergebener Mensch, selbstständig, wenn auch etwas primitiv in seinem Denken und Urteile ${ }^{\text {“1741 }}$ - am Besten zu verfahren wäre; dabei dürfte wohl auch eine persönliche Differenz des weltberühmten PhysikGenies gegenüber seinem langjährigen Freund für diese Ablehnungsunterstützung eine Rolle gespielt haben:

„Ihr Problem, dessen Härte ich wohl fühle, wird dadurch erleichtert, dass er die Altersgrenze erreicht haben dürfte. Ich würde ihn emeritieren und ihn einladen, ein Kolleg zu halten über

1737 Bundesministerium für Unterricht, Z1. 5763/111/4b /46, 15. März 1946. Zit. nach: NARA II, RG 260, Education Division, Box 1/68, Felix Ehrenhaft an das State Department, Passport Division, Washington D.C., 7. März 1947, 1.

1738 UAW, Dekanatsakten, Phil. Fakultät, GZ 567-1945/46, Schreiben von Skrbensky an das Dekanat der Philosophischen Fakultät der Universität Wien, 23. Februar 1946.

1739 UAW, Dekanatsakten, Phil. Fakultät, 567-1945/46, F. 1-2, Z. 11041/III-4b/46, Skrbensky an die Philosophische Fakultät der Universität Wien, Lehrkanzel für Physik, 10. April 1946.

1740 Vgl. Braunecker, Der andere Physiker, a.a.O., 105.

1741 Ebd. 
die Geschichte der Physik, worüber er ziemlich viel weiß. Dies wäre nobel und gefahrlos zugleich, und er könnte ohne Bitterkeit den Weg zu Ende gehen. “1742

Dieses Statement Einsteins gab quasi den indirekten Startschuss für die darauf folgenden Intrigen gegen Ehrenhaft. So teilte etwa Hans Thirring in einem Schreiben an Skrbensky mit, dass „inzwischen eine ganze Reihe von zwei [sic!] teilweise vernichtenden Gutachten über Prof. Ehrenhaft - auch von seinen jüdischen Fachkollegen eingelaufen sind." Und im Postscriptum fügte Thirring noch als mögliche Abschreckungsmaßnahme an, „es schiene mir wichtig zu sein, Ehrenhaft mitzuteilen, wie hoch die Bezüge sein werden, die er hier äußerstenfalls erhält und wie groß die Lebensmittelrationen voraussichtlich im nächsten Jahre sein werden. ${ }^{\text {"1743 }}$

Lediglich der remigrierte Physikerkollege und Nobelpreisträger Victor Francis Hess solidarisierte sich mit Ehrenhaft und berichtete diesem vertraulich, „dass in Wien die Absicht besteht, das I. Physik. Institut Mattauch zu geben, während Sie nur das Recht haben sollen, die Vorlesungssammlung zu benutzen und die allg. Vorlesung für Mediziner zu halten [...]. Meiner Ansicht nach rechnet die Clique in der Fakultät damit, dass Sie diese Berufung entweder nicht annehmen oder nach Lokalaugenschein sofort wieder nach USA zurückkehren $[\ldots]^{\text {“. }} .{ }^{1744}$

Weitere drängende Schreiben von Ehrenhaft an die zuständigen österreichischen Stellen blieben jedenfalls sowohl von Sektionschef Skrbensky als auch vom Leiter der USFAEducation Division, Thomas E. Benner, unbeantwortet.

Nach einem Gespräch mit dem bereits wieder an die Columbia University in New York zurückgekehrten Ex-Chef der Education Division in Österreich, William B. Featherstone, im November 1946 stellte sich heraus, dass Ehrenhaft nach wie vor keine verbindliche Einladung in der Hand hatte, aber so rasch wie möglich nach Wien zurückkehren wollte. Ehrenhaft bat Featherstone daher - immerhin waren beide in der "Austrian University League of America" aktiv gewesen und Ehrenhaft auch deren Präsident ${ }^{1745}$ - nachdrücklich um Hilfestellung in der Angelegenheit seiner Rückberufung, um endlich eine verbindliche Zusage von Wien zu erhalten und die Rückübersiedlung für sich und seine Familie planen zu können. ${ }^{176}$ In geradezu cowboyhaft-derber Art wandte sich Featherstone daraufhin an seinen Nachfolger Benner und bat diesen um Unterstützung in dieser für ihn ganz offensichtlich unan-

1742 Ebd.

1743 Hans Thirring an Sektionschef Skrbensky, 30. Juli 1946. Zit. nach Braunecker, Der andere Physiker, a.a.O., 106.

1744 Ebd., $106 \mathrm{f}$.

1745 Bundesministerium für Unterricht, Z1.5763/111/4b/46, 15. März 1946. Zit. nach: NARA II, RG 260, Education Division, Box 1/68, Felix Ehrenhaft an das State Department, Passport Division, Washington D.C., 7. März 1947,1.

1746 De facto war Ehrenhaft Anfang 1947 bereits von seiner Frau geschieden, da diese nicht nach Österreich zurückkehren wollte. Siehe: Braunecker, Der andere Physiker, a.a.O., 107. 
genehmen Angelegenheit, wobei er die Situation, insbesondere die Passivität des zuständigen Ministeriums, aus persönlicher Erfahrung heraus wohl nicht ganz falsch einschätzte:

"I wonder if you could build a little fire under Dr. Skrbensky and get some action on the case of Professor Ehrenhaft. The old boy is in my hair most of the time lately, because he can get no word from the Ministry of Education. The point is that Hess and Pich [sic; recte: Pick] have been invited to return as guest professors, but the Ministry has not yet invited Ehrenhaft. You will recall that their original invitation was to return as a permanent member of the faculty, but Ehrenhaft declined this invitation on the grounds that he would lose his American Citizenship. [...] I have a slight suspicion that Skrbensky is doddling. I do not think that he was very anxious to have Ehrenhaft return. Now that I know Ehrenhaft pretty well, I can understand Skrbensky's delaying action. Nevertheless, Ehrenhaft had a proper invitation originally from the University authorities and I do not think that Skrbensky should be allowed to sidestep the University's desire. ${ }^{\text {1747 }}$

Am I8. Oktober erhielt die „Austrian University League of America“ vom österreichischen US-Gesandten in New York, Ludwig Kleinwächter, ein Schreiben, wonach in der Angelegenheit der Rückberufung ehemaliger österreichischer Hochschulprofessoren, die - wie im Fall zahlreicher Wissenschafter auf der Liste der „League“ - ihre mittlerweile erworbene ausländische Staatsbürgerschaft nicht zurückzulegen bereit waren, laut Bundeskanzleramt nunmehr über die Verleihung einer Gastprofessur auf Zeit - „fünf Jahre oder länger“ - gelöst werden könne. Weiter hieß es in dem genannten Schreiben, dass das Unterrichtsministerium auch in Einzelfällen dazu bereit sei, eine Lehrkanzel für eine gewisse Zeit vakant zu halten, um diese mit einem Gastprofessor zu besetzen. Hinsichtlich einer „begünstigten Behandlung der zurückkehrenden Hochschulprofessoren“, die ja immerhin von Null an beginnen mussten, und bezüglich „Wohnung, Lebensmittelzuteilung, Reiseerleichterung usw." Unterstützung benötigten, machte das Schreiben des österreichischen Gesandten aber keinen Hehl daraus, dass man damit nichts zu tun haben wolle, da dies ,in die Zuständigkeit der amerikanischen Besatzungsbehörden in Österreich fallen würde. ${ }^{\text {1748 }}$

Ehrenhaft, der bereits über ein Schiffsticket für die Überfahrt mit der „Queen Elisabeth“ nach London verfügte, hatte zuvor selbst eine Gastprofessur-Variante ins Spiel gebracht und drängte nun, aus verständlichen Gründen, mit Nachdruck darauf, noch vor seiner bevorstehenden Überfahrt - zunächst nach England - ein offizielles Einladungsschreiben in Händen zu halten, wie er in Telegrammen an Unterrichtsminister Hurdes und Außenminister Karl Gruber schon im September 1946 deutlich gemacht hatte.

1747 NARA II, RG 260, Box 2, Folder 58, W.B. Featherstone an Thomas Benner, Education Division USACA Section, 25. November 1946, 1.

1748 NARA II, RG 260, Box 2, Folder 58. Austrian University League of America, Abstract from a letter received from the Representative of the Austrian Federal Government, Dr. Ludwig Kleinwächter, 18. Oktober 1946, 1. 
In einem Schreiben an Thomas Benner, das unmittelbar auf die Besprechung mit Featherstone folgte, beschwerte sich Ehrenhaft über die für ihn schwer nachvollziehbare Funkstille seitens der US-Militärbehörden in Österreich und auch der Unterrichtsverwaltung, die auch nach über drei Monaten nicht imstande waren, ihm eine klare Antwort zu geben, obwohl ihn die Universität ja bereits eingeladen hatte:

"It is extremely disagreeable not having the answer to my letter of Sept. IIth I946 addressed to you [Th. Benner, d. Verf.] containing enclosures for the Minister of Education Dr. Felix Hurdes. All I have heard in the meantime was the word from you and Dr. Loewy, Captain, that this matter is lying on the desk of Dr. Skrbensky. Since the question regarding guest-Professors is already decided in a general way $[\ldots]$ it is impossible for me to understand why this matter should take such a long time." ${ }^{1749}$

Einen Monat später ließ Benner Featherstone wissen, dass Ehrenhaft, wie eine zwischenzeitliche Nachfrage ergab, ohnedies bereits die Einladung zur Gastprofessur vom Unterrichtsministerium telegrafiert bekommen habe und damit das Problem für Ehrenhaft wohl vom Tisch sei. ${ }^{1750}$

Ehrenhaft, der seine Rückkehr mit ungeheurem Nachdruck und insistierender Hartnäckigkeit betrieb, war schließlich - trotz Rückschlägen ${ }^{1751}$ - erfolgreich. Mitte März I947 kehrte er in seine Heimat zurück und wurde bald darauf von Bundesminister Hurdes zum Gastprofessor für Physik unter „Zuerkennung einer Entschädigung [...] im Ausmasse der jeweiligen systemmässigen Höchstbezüge eines ordentliches Hochschulprofessors “"1752 bestellt, was freilich kein hohes Einkommen bedeutete. Gleichzeitig wurde Ehrenhaft mit der Leitung des I. Physikalischen Instituts der Universität Wien betraut. ${ }^{1753}$

1749 NARA II, RG 260, Box 2, Folder 58. W.B. Featherstone an Thomas Benner, a.a.O., 1.

1750 Des Weiteren erwähnte Benner in dem Schreiben, dass noch unklar ist, wann er von den österreichischen Stellen eine Liste von Professoren, Beamten und Lehrern bekommen wird, um die zugesagten CARE-Pakete zustellen zu können NARA II, RG 260, Box 2/58, Thomas E. Benner an Felix Ehrenhaft, 7. Mai 1947.

1751 Aus einem Schreiben Williams an Benner geht hervor, dass ersterer bei der Rockefeller Foundation nachgefragt hatte, ob diese die Rückkehr allenfalls finanziell unterstützen würde. Die Foundation beantwortete diese Anfrage in zweifacher Weise abschlägig: zum einem wäre die "politische Situation“ in Österreich noch nicht restlos geklärt, wodurch zum gegebenen Zeitpunkt keine Wissenschaftsausgaben gemacht würden, zum anderen würde im Fall von Ehrenhaft keine Unterstützung gegeben „because he is to old and because his work is not regarded as very important." NARA II, RG 260, EDU-DIV, Box 5, Folder 3, W[illam] B. Featherstone (Teacher College, Columbia University) to Thomas E. Benner, Education Division, USACA Section, USFA, 31. März 1947, 2.

1752 UAW, Dekan. Akten, Phil. Fakultät, DZl. 1962-1946/47, Z.36278-III-8/47, Bundesminister Hurdes an Felix Ehrenhaft, Wien Grinzingerstraße, 23. Juli 1947.

1753 Ehrenhaft war die Leitung entweder des I. oder II. Physikalischen Instituts angeboten worden, „die Errichtung eines III. Physikalischen Institutes“ - das Ehrenhaft bis zu seiner Emigration geleitet hatte käme nicht in Betracht. Ebd. 
Besonders glücklich schien man im Ministerium über die Rückberufung aber nicht gewesen zu sein. Wie in einem der Abschrift des Briefes hinzugefügten Schreiben an die Philosophische Fakultät der Universität Wien angeführt wurde, könnten Ehrenhaft, der „bereit ist, sämtliche Pflichten eines ordentlichen Professors zu erfüllen [...] außer dem Anspruch auf seinerzeitige Ruhegenüsse der ausschließlich Inländern zusteht, die sonstigen Rechte eines ordentlichen Professors [... ] nicht versagt werden. ${ }^{\text {"1754 }}$ [Hervorhebung d. Verf.]

Die Probleme, vor allem des täglichen Lebens im Nachkriegsösterreich, waren für Ehrenhaft mit der Ernennung zum Gastprofessor freilich keineswegs vorbei. In einem Schreiben an ihn teilte Benner im Mai 1947 - mit ausgesuchter Höflichkeit und in Anspielung auf den höheren Zweck seiner Gastprofessur -, die harte Information mit, dass er, trotz früherer Zusicherung, keine zusätzliche Unterstützung in Bezug auf Essensrationen bekomme:

"In view of the fact that you were persuaded to return to Austria to contribute to the democratic reorientation of Austrian education and of the assurance which I am told you were given in the United States, I particularly regret that this unfavorable decision on your request seems necessary." ${ }^{1755}$

Im selben Monat hielt Ehrenhaft in der Wiener Urania seinen ersten Vortrag über „Der magnetische Strom - einzelne nord- und südmagnetische Pole“, wohl auch, um damit sein bescheidenes Salär etwas aufzubessern. ${ }^{1756}$

Der 68-jährige Physiker, der mit großer Umtriebigkeit an die neue „alte“ Aufgabe heranging, ${ }^{1757}$ das Institut bereits während der Sommerferien 1947 übernahm und mit USUnterstützung eine Reihe physikalischer Instrumente organisierte, war außerdem bald mit spezifisch österreichischen Verhältnissen und Problemen konfrontiert.

In einem ausführlichen Schreiben an Minister Hurdes bemühte sich Ehrenhaft nach knapp einjähriger Tätigkeit, „hinsichtlich der Regelung meines Ruhegenusses die Einreichung der im Auslande verbrachten Dienstzeit", zu erreichen, was ihm, wie er hervorhob, I946 bei Annahme der Rückberufung zugesichert worden war: ${ }^{1758}$

1754 UAW, Dekanatsakten, Phil. Fakultät, DZ1. 1962-1946/47, Z.36278-III-8/47, Bundesminister Hurdes an Felix Ehrenhaft, a.a.O., Mitteilung an das Dekanat der phil. Fakultät, 2.

1755 Ebd.

1756 Den Garten seines Hauses in der Grinzingerstraße hatte Ehrenhaft vom Botaniker Konrad Liebeswar in eine Gemüseplantage umwandeln lassen. Bei seinem Vortrag in der Urania brachte er, laut Braunecker, einen spitze Bemerkung über Albert Einsteins Versuch an, Elektrizität, Magnetismus und Gravitation einheitlich darzustellen. Vgl. Braunecker, Der andere Physiker, a.a.O., 107.

1757 So wurde bereits am 13. August 1947 auf Antrag Ehrenhafts vom Unterrichtsministeriums - als „Maßnahme des innerbetrieblichen Personalausgleiches" - verfügt, Personal vom II. Physikalischen Institut (ein Mechaniker) zum I. Phys. Institut zu verschieben. UAW, Dekanatsakten, Phil. Fakultät, DZ1. 19621946/47, Unterrichtsministerium an Rektorat der Universität Wien, 13. August 1947.

1758 UAW, Dekanatsakten, Phil. Fakultät, 1109-1946/47, Brief von U.S. Guest Professor Felix Ehrenhaft an Bundesminister Hurdes vom 27. August 1948, 1. 
„Ich ersuche daher um die obbezeichnete Regelung im Wege eines Vertrages und bin natürlich auch gerne bereit weitere Pensionsbeitragszahlungen, so wie ich sie bis 1938 in Goldwährung bereits in 46 anrechenbaren Dienstjahren dem österreichischen Bund eingezahlt hatte zu leisten. [...] Ich bitte daher nochmals um eine vertragsmässige Regelung, wobei ich die Versicherung abgebe, daß die Loyalität gegen den Österreichischen Staat durch Beibehaltung der Amerikanischen Staatsbürgerschaft in keiner Weise abnimmt und, daß ich es mir zur Aufgabe gestellt habe, das von mir geleitete Physikalische Institut international wieder in eine ganz erste Reihe zu bringen [...]." ${ }^{1759}$

Bei diesem postalischen ,Canossagang، verwies Ehrenhaft mehrmals und eindringlich darauf, dass ,gerade die amerikanische Staatsbürgerschaft [...] für die Lösung der übernommenen Aufgabe nicht nur vom ethischen, sondern auch vom materiellen Standpunkt von allergrößter Bedeutung“" sei: Nicht zuletzt habe er innerhalb nur weniger Monate Spendenbeträge der amerikanische Großindustrie in „relevanter Größe“ aufgetrieben; darüber hinaus würden „alle Postsendungen der Apparate und die Briefe an mich als amerikanischer Staatsbürger zu einem ungleich niedrigeren Betrag erfolgen als mit der regulären Post [... “ ${ }^{1760}$ Knapp ein Jahr später wurde dem Gastprofessor nach Vollendung des 7o. Lebensjahres und knapp drei Jahre vor seinem Tod mitgeteilt, dass er „von Amts wegen in den Ruhestand zu versetzen ist“, vom Unterrichtsministeriums aber immerhin die „Zuerkennung eines ,Ehrenjahres ““1761 gewährt bekam.

\section{Wissenschaftspolitische Restauration und amerikanisch- österreichische Beziehungen. Ein Zwischenresümee}

Wie sich anhand der dargestellten Fallbeispiele zeigt, standen dem Rückkehrwunsch prominenter Wissenschaftsemigranten beziehungsweise ihrem bekundeten Interesse an einer universitären Lehrtätigkeit nach Kriegsende unterschiedliche, mitunter überaus seltsam anmutende Schwierigkeiten und Hindernisse entgegen. Ein Bemühen um Rückholung von durch den Nationalsozialismus vertriebenen Wissenschafter - von Wissenschafterinnen ganz zu schweigen - ist weder auf Seite österreichischer Stellen noch der amerikanischen Militärbesatzung vor Ort nachzuweisen. Und das, obwohl es die amerikanische Education Division als eine ihrer zentralen Aufgaben ansah, , assisting all Austrian universities and the Ministry of Education in establishing communication with Austrian scholars and teachers who were forced to leave the country during the period of Nazi occupation. "1762

1759 Ebd., 4.

1760 Ebd., 3.

1761 UAW, Dekanatsakten, Phil. Fakultät, DZL. 2719-1948/49, Z1.26470/III.8/49, Bundesminister Hurdes an das Dekanat der Philosophischen Fakultät der Universität Wien, 18. Juni 1949.

1762 Thomas E. Benner, Synopsis of Post-war Education in Austria, USACA/Education Division, 10. März 1947, 5. University of Illinois Archives, Thomas E. Benner Papers 1930-1979, Austrian Materials, Rec. Series No. 10/1/21 [Kopie im Besitz des Verfassers]. 
Zuweilen hat es den Anschein, als ob die Reaktionen österreichischer Behörden und die Aktivitäten der US-Besatzungsorgane nach getrennt verlaufenden, einander fallweise sogar verstärkenden, jedenfalls kaum zu Konflikten führenden Regelkreisen abliefen

So sehr ein wahrhaft demokratischer Neubeginn im Bereich der österreichischen Wissenschaftskultur strikter Entnazifizierungsmaßnahmen sowie einer klaren und transparenten Personalpolitik samt temporärer (externer) Supervision bedurft hätte, so wenig fand genau dies statt. Unter der weder von den Amerikanern noch von den anderen alliierten Besatzungsmächten in Frage gestellten „Autonomie“ der Universität gestaltete sich der hausgemachte universitäre Neubeginn nicht einmal rudimentär nach Grundsätzen einer international orientierten, offen-demokratischen Wissenschaftspolitik geschweige denn nach Grundsätzen einer moralischen Wiedergutmachung, die über bloße Lippenbekenntnisse hinausging. Unter der akademischen Hegemonie einer konservativreaktionären Ideologie, die reformorientierte, liberale oder progressive Positionen in die Defensive drängte, war eine rasche Elitenrestauration absehbar beziehungsweise geradezu unausweichlich. Durch die konservative wissenschaftspolitische Festlegung der Universität auf ausschließliche Anfragen bei ordentlichen und außerordentlichen Professoren war ein akademischer Elitenaustausch, wie Oliver Rathkolb konstatiert, überdies weitgehend unmöglich:
„Mit dieser Festlegung auf Professoren war bereits das mögliche Konzept eines Elitenaustau- sches begraben - eine Mischung aus antisemitischen bzw. politischen Reservationen gegen- über den Exilanten, die rasche Wiedereinstellung der aus politischen Gründen 1938 entlas- senen oder pensionierten, aber in Österreich verbliebenen ehemaligen NSDAP-Mitglieder in der Professorenschaft besorgten letztlich die Chancenlosigkeit von Rückholaktionen $[\ldots]^{\alpha} \cdot{ }^{1763}$

Trotz zunehmenden Drucks der Alliierten nach einer strikten Säuberung der Universitäten - der sich allerdings primär auf Kontrolle und Berichtspflicht richtete, nicht aber auf tatsächliche Strukturmaßnahmen zielte ${ }^{1764}$ - war die Arbeit der Sonderkommissionen, wie sich in vielfältiger Weise gezeigt hat, der Tendenz nach eher auf Pardonierung beziehungsweise Akzeptanz der zur Entlastung vorgelegten „Unbedenklichkeitsbeweise“ hin angelegt. Das bestätigt auch eine von Reinhold Knoll für das Fallbeispiel Universität Wien vorgelegte Reihe anonymisierter Fallstudien. Die Durchsicht der schriftlichen Aufzeichnungen von Einvernahmeprotokollen durch die Sonderkommissionen im Zeitraum Herbst 1945 bis Sommer 1946 ${ }^{1765}$ die sein Vater August Maria Knoll als ehemaliger Behördenvertreter

1763 Rathkolb, Die Universität Wien und die „Hohe Politik“ 1945 bis 1955, a.a.O., 43.

1764 Ebd., 44.

1765 Zuweilen bediente sich die Sonderkommission Auskunftspersonen, die selbst erheblich vorbelastet waren, wie z. B. der frühere NS-Dozentenbundführer Arthur Marchet, der mehrmals zu Beurteilungen 
hinterlassen hat, führen Knoll zu folgendem, in kritischer Gegenlektüre zum Quellenmaterial anderer Provenienz durchaus zutreffenden Urteil:

„Sicher mussten sich die Kommissionsmitglieder eingestehen, dass wohl so ziemlich alle Begriffe akademischer Aufrichtigkeit und Toleranz für immer nutzlos geworden sind, so dass sie nur formal urteilen konnten und nicht nach Kriterien von Schuld. “1766

Mit der Tätigkeit dieser sowie auch aller anderen, direkt bei den jeweiligen akademischen Behörden und Dienststellen, dezentral installierten Sonderkommissionen konnten die Alliierten, zumindest in den interalliierten gremialen Zusammenkünften, jedenfalls "gar nicht zufrieden ${ }^{\text {“1767 }}$ sein - immerhin waren bis Februar 1946 viele Sonderkommissionen, vor allem in den westlichen Bundesländern, noch gar nicht eingerichtet worden. ${ }^{1768}$

Durch das am 18. Februar 1947 in Kraft getretene Bundesverfassungsgesetz vom 6. Februar 1947 (BGBL. Nr. 25) über die Behandlung der Nationalsozialisten („Nationalsozialistengesetz") wurde der Überprüfung der öffentlich Bediensteten durch Sonderkommissionen schließlich die gesetzliche Grundlage entzogen. ${ }^{1769}$

Trotz klarer Vorgaben und dem deklarierten Interesse an einer strikten Entnazifizierung, selbstverständlich auch der Universitäten, waren die diesbezüglichen Kontrollaktivitäten der US-Militärorgane - sowie der alliierten Gremien allgemein -, keineswegs von einheitlicher Qualität. Die prinzipielle Akzeptanz der universitären Autonomie hatte eine nichtinterventionistische Position gegenüber universitären Agenden zur Folge, die letztlich in eine Politik des Laissez-faire - mit fallweisen Beanstandungen - einmündete.

herangezogen wurde, oder auch der (namentlich ungenannte) ehemalige Vertrauensmann des NS-Hochschullehrerbundes. Vgl. dazu Reinhold Knoll, Die Entnazifizierung an der Universität Wien. In: Meissl (Hrsg.), Verdrängte Schuld - verfehlte Sühne, a.a. O., 276.

1766 Reinhold Knoll, Die Entnazifizierung an der Universität Wien. In: Meissl (Hrsg.), Verdrängte Schuld verfehlte Sühne, a.a.O., $278 \mathrm{f}$.

1767 Stiefel, Entnazifizierung, a.a.O., 95.

1768 Ebd.,132.

1769 ÖSTA/AdR, Bestand 04, BKA, Liquidator, Kt. 154, 14699-SDOK/1947, 1. Kopie im Besitz d. Verfassers. Im Bundesministerium für Unterricht wurde daraufhin eine Kommission mit sogenannten „fliegenden Senaten" eingerichtet, die - wie schon zuvor - neben einem Vertreter des Bundesministeriums aus je einem Vertreter der drei „anerkannten politischen Parteien“ sowie einem Vertreter der Gewerkschaft des Öffentlichen Dienstes bestanden. Den Vorsitz hatte Sektionschef Ernst Hefel inne, Stellvertreter war Hans Kenda. Vgl. ÖSTA/AdR, Bestand 04, 2C1, Disziplinarkammern, Sonderkommissionen, 19451958, Ktn. 378, Z1. 25563-IV/Pb, Unterrichtsminister Hurdes an das Bundeskanzleramt, Bildung der Kommissionen gemäß $§ 19$ (2) des Verbotsgesetzes 1947, 19. Juli 1947, 1f. Per Weisung wurde Sektionschef Skrbensky im März vom Liquidator der Einrichtungen des Deutschen Reiches in der Republik Österreich mit der „zusammenfassenden Behandlung der Arbeiten zur Liquidierung jener Einrichtungen [...] (die) nunmehr zum Wirkungsbereich III (Hochschulen und administrative Angelegenheiten der übrigen Schulen) des Bundesministeriums für Unterricht gehören“ betraut. „Hierzu gehört auch die Besorgung der im Rahmen des Beamten-Überleitungsgesetzes und des Nationalsozialistengesetzes, dem Liquidator der Reichseinrichtungen zukommenden Aufgaben." ÖSTA/AdR, Bestand 04, BKA, Liquidator, Kt. 154, Z1.2694/47, Liquidator Dr. Troll an Sektionschef Skrbensky, 13. März 1947. 
Zudem zeigen sich bei den zuständigen US-Stellen in Österreich - hier besonders bei den Offizieren der Education Division - mitunter bildungspolitische Austrifizierungstendenzen, ${ }^{1770}$ die im Zweifelsfall - selbst bei Urgenzen übergeordneter Stellen aus Washington - eher zu Kooperation und Konfliktvermeidung, als zu Konfrontation oder gar Intervention führten.

Dass die amerikanische Besatzungspolitik im Bereich der Rekonstruktion des Universitätswesens nicht nur wenig schlüssig und weitgehend unkoordiniert verlief, sondern wahrlich skurrile wissenschaftspolitische Blüten treiben konnte, zeigt sich an Aktivitäten wie zum Beispiel der Tätigkeit der OMGUS-US-Field Information Agency, Technical (FIAT). Im Februar 1947 hatte sich ein Vertreter der ,amerikanische(n) Stelle für wissenschaftliche Forschung in den besetzten Gebieten Deutschlands und Österreichs" an Rektor Adamovich gewandt und ihm mitgeteilt, dass FIAT eine 5o-bändige Publikationsreihe zu je 200 Seiten vorbereitet, in der die naturwissenschaftlichen und medizinischen Ergebnisse der „wichtigsten wissenschaftliche Forschungen im Deutschen Reich während der Jahre 1939 bis I946 [sic] festgehalten werden" ${ }^{1771}$ sollten. Hinsichtlich der von amerikanischer Seite gewünschten Mitarbeit österreichischer Gelehrter an diesem Projekt antwortete Adamovich Mr. Miller von FIAT, dass er das „nicht für opportun halten würde, da die Mitarbeit österreichischer Gelehrter an einer solchen, der deutschen Wissenschaft gewidmeten Publikationsreihe leicht mißdeutet werden könnte. “1772 Daraufhin regte der Repräsentant der OMGUS-Stelle an, dass die österreichischen Wissenschafter in Eigenregie eine Publikation herausgeben sollten, und zwar unter dem Titel „Austrian [sic!] Science $1939-1945^{\text {“ }} ;{ }^{1773}$ diese sollte dann mit Unterstützung der amerikanischen Militärverwaltung gedruckt werden. Von Major Ray von der USFA-Education Division bekam Rektor Adamovich umgehend den Plan für die Herausgabe der „FIAT Review of Austrian Science 1939-I945“, wobei das Wort „German“ lediglich handschriftlich gestrichen und durch „Austrian“ ersetzt worden war. ${ }^{1774}$ Das Ziel des „Rückblickes“ quer durch alle naturwissenschaftlichen-medizinischen Fachgebiete jener Jahre sollte paradoxerweise just darin bestehen, „die Verbindung mit der internationalen Wissenschaft wieder herzustellen“, wie es im Wortlaut des Planes hieß. ${ }^{1775}$

1770 Der mittlerweile in der Ökonomie, der Politikwissenschaft oder auch im Bereich des Sportes weithin eingespielte Begriff „Austrifizierung“ meint hier nicht die quasi devote Unterordnung unter die Suprematie einer Großmacht (wie z.B. beim Begriff „Finnlandisierung“), sondern die prozesshafte Überformung von andersartigen Werthaltungen, Einstellungen bzw. Verhaltensweisen durch österreichspezifische Gepflogenheiten bzw. Interessensmuster.

1771 UAW, Dekanatsakten, Phil. Fakultät, 858-1946/47, Rektor Adamovich an den Dekan der Philosophischen Fakultät, 18. Februar 1947.

1772 Ebd.

1773 Ebd.

1774 Ebd., GZ461 aus 1946/47, Rektor Adamovich an den Dekan der Philosophischen Fakultät, 19. Februar 1947.

1775 Ebd., Office of Military Government for Germany (US), Field Information Agency, Technical, Review of Austrian Science, 1. Mai 1939-1. Mai 1946, Plan und Aufgaben der FIAT Reviews; FIAT c/o USFET, 
Ein derart ,salopper' Umgang mit der kaum zweieinhalb Jahre zurückliegenden NSVergangenheit seitens amerikanischer Stellen - auch wenn derartige Vorkommnisse wohl eher Ausnahmen waren - war dem verantwortungsbewussten Neubeginn einer demokratischen, strikt antifaschistischen Wissenschaftskultur sicher nicht besonders förderlich.

Ein nicht ganz uninteressantes Detail stellt in diesem Zusammenhang der Umstand dar, dass es der Zoologe und verantwortliche Leiter der US-Education Division in Österreich war, der den Anatomischen Atlas des früheren NS-Rektors Eduard Pernkopf ${ }^{1776}$ amerikanischen Universitäten als großartiges Lehrbuch empfahl und zukommen ließ ${ }^{1777}$ Ohne dass Williams ${ }^{1778}$ im Hinblick auf das dem Atlas zugrunde liegende Illustrationsmaterial vorgeworfen werden kann, gewusst zu haben, was erst die Zeitgeschichteforschung vor einigen Jahren wieder ans Tageslicht brachte, wirft allein die Art und Weise, in der hier mit dem höchsten ministerialen Wissenschaftsbeamten korrespondierte wurde, ein bezeichnendes Licht auf die für den bildungspolitischen Neubeginn in Österreich maßgeblichen US-Militärstelle; immerhin war Pernkopfs NS-Vergangenheit wohl bekannt. ${ }^{1779}$ Bis Jän-

Frankfurt a. Main. Auffällig ist, dass bei der detaillierten Aufzählung der jeweiligen wissenschaftlichen Fachgebiete, inklusive der namentlich angeführten Reviewer, im Bereich (NS-)Medizin u.a. auch eindeutig schwer belastete „Forschungsbereiche“ wie beispielsweise Pathologie (Einsatz der Pathologie im Kriege, Traumen, Geschosswirkungen, Wundheilung, Effects of Bombing, Höhenflug/Höhenkrankheit, Hunger, Epidemics etc.) mit aufgezählt wurden. Inwieweit das Projekt realisiert wurde, geht aus dem Aktenverlauf im Universitätsarchiv Wien leider nicht hervor.

1776 Eduard Pernkopf (1888-1955), Wiener Anatom, trat im April 1933 der NSDAP bei und blieb während der Verbotszeit Mitglied der SA Gruppe Hardegg. Im März 1938 wurde er umgehend zum SA-Sanitäts-Obersturmbannführer ernannt. Wie Ingrid Arias recherchierte, wurde Pernkopf bereits 1935 ,in einem anonymen Schreiben als ,Nazi durch und durch““ charakterisiert. 1943 wurde Pernkopf zum Rektor der Universität Wien ernannt. Arias, Entnazifizierung an der Wiener Medizinischen Fakultät, a. a. O., 349.

1777 NARA II, RG 260, EDU, Box 1, Folder 1.W.S. McEllroy, Dean of the University of Pittsburgh, School of Medicine, Pennsylvania, an Samuel H. Williams, Chief, Education Division United States Forces in Austria/USACA, 28. Oktober 1948.

1778 Samuel H. Williams hatte in Berlin, Breslau, Italien und Jugoslawien studiert; von 1922 bis 1942 war er ordentlicher Professor an der Universität Pittsburgh und als Ehrenmitglied verschiedener wissenschaftlicher Gesellschaften auch in Europa gut vernetzt: so war Williams beispielsweise Mitglied der Deutschen Entomologischen Gesellschaft oder der Linnean Society of London. Als Zoologe hatte er zahlreiche wissenschafliche Expeditionen geleitet - so z.B. in die Dschungel von British Guinea, Venezuela, West Indien, zu den Südseeinseln oder zwischen 1925-1932 als Leiter der Amazonas- und Orinoko-Expedition. UAW, Dekanatsakten, Phil. Fakultät, 2491-1 949/50, Curriculum Vitae Prof. Dr. Samuel H. Williams, 1.

1779 Ein zwar nebensächliches, aber keineswegs uninteressantes Detail ist in diesem Zusammenhang die Tatsache, dass Pernkopfs „Topographische Anatomie des Menschen“ hinsichtlich dessen fachlich-anatomischer Qualität später just von einem amerikanischen medizinischen Illustrator verteidigt wurde: „Nazi science and art of merit, regardless of its contribution to mankind, can be difficult to fully appreciate in light of incredible cruelties the regime inflicted on Jews and others it considered its enemy. For this reason Pernkopf's Topographische Anatomie des Menschen will always be controversial and will, unfortunately, 
ner 1947 war Pernkopf in dem für ehemalige Nationalsozialisten und Kriegsverbrecher eingerichteten US-Lager Glasenbach („Camp Marcus W. Orr“) ${ }^{1780}$ interniert und anschließend kurzfristig wegen der Einleitung einer Voruntersuchung in Untersuchungshaft. ${ }^{1781}$ Nach Enthaftung und Überstellung nach Wien im Juni I947 wurde am Landesgericht für Strafsachen Anzeige wegen § Io und § II des Verbotsgesetzes erhoben; trotz klarer Aktenlage wurde das Verfahren wegen Hochverrats jedoch im November 1948 eingestellt - einen Monat davor war Pernkopfs Sühneansuchen vom Bundespräsidenten bewilligt worden und damit der Weg zur akademischen Rehabilitierung frei. ${ }^{1782}$ Kurz darauf setzte Pernkopf mit einigen seiner früheren Mitarbeiter im Neurologischen Institut der Universität Wien die Arbeit an Folgebänden des Anatomischen Atlas fort: der dritte Band erschien 1952 bei Urban \&Schwarzenberg. ${ }^{1783}$

Offen ist, wie viel man bereits zum damaligen Zeitpunkt - insbesondere als naturwissenschaftlicher Gelehrter mit Zugang zu geheimdienstlichen Informationen - über die Herkunft der den Farbabbildungen des Anatomieatlas zugrundeliegenden Präparate ${ }^{1784}$

never be acknowledged by some as the masterpiece it truly is. For others it will remain the greatest work yet done in anatomic illustration. "David J. William, The History of Eduard Pernkop's Topographische Anatomie des Menschen. In: Journal of Biocommunication, Vol. 15, 1988, Nr. 2, 8. Vgl. dazu auch die kritische und wohl auch stark überzeichnete journalistische Antwort auf den „Nazi apologist“ Williams: Michael Paterniti, The Most Dangerous Beauty. In: GQ, September 2002, $468 \mathrm{ff}$.

1780 Vgl. dazu: Oskar Dohle/Peter Eigelsberger, Camp Marcus W. Orr. „Glasenbach“ als Internierungslager nach 1945 (= Mitteilungen des Salzburger Landesarchivs 15), Linz - Salzburg 2009; siehe auch: Wilhelm Svoboda, „...vorbehaltlos meine Pflicht erfüllt.“ Das Internierungslager Glasenbach. In: Zeitgeschichte, 22. Jg., 1995, Heft 1-2, 3-29

1781 Peter Malina, Eduard Pernkopf. Versuch einer „Stratigraphischen“ Biographie. In: Senatsprojekt der Universität Wien. Untersuchungen zur Anatomischen Wissenschaft in Wien. 1938-1945. Hrsg. v. Akademischen Senat der Universität Wien, Wien 1998, 431 [Der Verfasser dankt Dr. Peter Malina für die Zurverfügungstellung eines Exemplars des Berichtes]. Allerdings entschloss sich das Unterrichtsministerium bereits 1953 auf Pernkopfs Ansuchen hin, dessen NS-Dienstzeiten für den „Ruhegenuß“ anzurechnen. Vgl. Peter Malina, Eduard Pernkopfs Anatomie oder: Die Fiktion einer „reinen“ Wissenschaft. In: Wiener Klinische Wochenschrift. The Middle European Journal of Medicine, 109. Jg., 23. Dezember 1997, Heft 24, 939.

1782 Siehe dazu detailliert: Arias, Entnazifizierung an der Wiener Medizinischen Fakultät, a.a.O., 351.

1783 Unter seinen früheren Mitrarbeitern fanden sich die Illustratoren Franz Batke, Ludwig Schrott, Karl Endtresser, Erich Lepier sowie der neu hinzugekommene Anatom Werner Platzer und die Illustratoren Wilhelm Dietz und Elfie von Silber. Vgl. Williams, The History of Eduard Pernkop's Topographische Anatomie des Menschen, a.a.O., 8.

1784 Die anatomischen Farbabbildungen beruhten - wie sich durch eine Vielzahl an Indizien erschließen lässt -, u.a. auf präparierten Leichenteilen von Opfern des NS-Regimes, die zuvor im Wiener Landesgericht hingerichtet worden waren. Siehe: Daniela Angetter, Erfassung der von der NS-Justiz in Wien in der Zeit von 1938-1945 Hingerichteten, die als Studienleichen dem Anatomischen Institut der Universität Wien zugewiesen wurden. In: Senatsprojekt der Universität Wien. Untersuchungen zur Anatomischen Wissenschaft in Wien, a.a.O., 85; weiters: Gustav Spann, Untersuchungen zur anatomischen Wissenschaft in Wien 1938-1945. Senatsprojekt der Universität Wien. Eine Zusammenfassung. In: 
wusste oder zumindest hätte vermuten können, immerhin tauchte diese Frage bereits Anfang der Fünfzigerjahre auch in der Öffentlichkeit zum ersten Mal auf. ${ }^{1785}$

In einem vertraulichen und amikal gehaltenen Schreiben wandte sich Samuel H. Williams š aus „rein akademischen Interesse“ š an Sektionschef Skrbensky:

"A few years back I had the opportunity to examine a magnificent anatomical work by Eduard Pernkopf, who was formerly a professor in the University of Vienna. The titel of the work was "Topographische Anatomie des Menschen", the first two bands of which are in my library at home. Upon inquiry here concerning the third band I learned that Prof. Pernkopf was banned from University and that he is not permitted to do the necessary research for the preparation of the third band. While I am thoroughly aware of the impossibility of Prof. Pernkopf working at University, I am unfamiliar with the prohibition against his working in private libraries, in order to complete what I consider an outstanding textbook of anatomy.

This letter is not suggesting that any existing barriers to further anatomical studies by Prof. Pernkopf be broken down. Certainly the matter lies entirely within the province of the Austrian Government and possibly within the Ministry of Educations' responsibilities. If and when you can find time from your already overburden schedule to clarify my interpretation I should certainly appreciate discussing the matter with you at luncheon on any day which you could find convenient to be my guest at the Bristol. I am sure that all of my contacts with the Ministry up to the present time indicate my confidence in the Education Ministry of Austria and that they reflect our position of noninterference. [...] I trust that you are exercising the discretion necessary [...]". ${ }^{1786}$ [Hervorhebungen d. Verf.]

Die hier zur Sprache gebrachte „nichtinterferierende Position“ der US-Education Division tendierte also eher zu sachlicher Kooperation in vergleichsweise unverfänglichen Bereichen als zu inhaltlicher Konfrontation. Neben materiellen Unterstützungsleistungen (Bücherspenden ${ }^{1787}$

Dokumentationsarchiv des österreichischen Widerstandes. Jahrbuch 1999 (Red. Siegwald Ganglmair), Wien 1999, 51.

1785 Der Montag vom 31. März 1952. Interessanterweise brach die Debatte über den politischen Hintergrund des lange Zeit weithin als Standardwerk der Anatomie geschätzten Atlas dann Ende der 1980er-Jahre just in der medizinischen Öffentlichkeit der USA los, die schließlich zu einer eingehenden historische Untersuchung führte. Vgl. Malina, Eduard Pernkopfs Anatomie, a.a.O., 937.

1786 NARA II, RG 260, EDU, Box 1 / Fo 3, Samuel H. Williams, Chief Education Division USFA/USACA, an Sektionschef Otto Skrbensky, 19. Februar $19481 \mathrm{f}$.

1787 So bedankte sich bspw. der Präsident des Wiener Stadtschulrates, Leopold Zechner, im Juni 1947 persönlich bei Thomas E. Benner für die „Spende einer Kollektion amerikanischer Schulbücher, die Sie dem Wiener Stadtschulrat zur Verfügung gestellt haben." In einer kurzen Dankesrede hatte sich der Stadtschulratspräsident bei Benner vor allem für dessen „großmütige Spende“von Schulbüchern für die Jugend und „Lehrerschaft aller Grade“ bedankt š ein „bedeutender und wertvoller Beitrag dazu, die Klüfte in Wissen und Gewissen auszufüllen, die eine langjährige Absperrung von der Welt hervorgerufen hat“. „Aus Trümmern aufbauen ist uns allen als Aufgabe gesetzt und da wir durch geistige Entartung in solche Not 
beziehungsweise Ersetzung von NS-Büchern, ${ }^{1788}$ Beschaffung von Büromaterial, ${ }^{1789}$ Wiederherstellung des zerstörten Universitätsgebäudes, erste Schritten in Richtung eines Austausches zwischen österreichischen und amerikanischen Studierenden ${ }^{1790}$ et cetera.) erfolgte auch organisatorische Hilfe: Zum Beispiel im Zusammenhang mit dem Rücktransport der gegen Ende des NS-Regimes nach Strobl/St. Wolfgang verlagerten Materialien verschiedener universitärer Institute und Laboreinrichtungen nach Wien. ${ }^{1791}$ Auch das nach Thumersbach bei Zell am See verlagerte Material des Pharmakologischen Institutes der Polizei wurde durch Hilfestellung des US-Majors George A. Selke, im zivilen Leben Rektor eines US-College, nach Wien zurück gebracht und dem Institut für gerichtliche Medizin übergeben. ${ }^{1792}$ In Summe wurden bis Mitte 1946 rund 500 Tonnen an evakuierten

gekommen sind, müssen wir vor allem an der geistigen Erneuerung, die gleichzeitig eine Rückkehr zu den ewigen Quellen ist, arbeiten [...] Der Mensch ist, was er liest und denkt und so war unser erstes Bemühen, der Jugend Schulbücher zu geben, die in Abkehr von allem nationalen- oder rassemäßigen Hochmut das Menschliche schon im Kinde zur Geltung bringen." [Unterstreichungen im Original] Schreiben Leopold Zechners an Thomas Benner vom 19. Juni 1947. University of Illinois Archives, Thomas E. Benner Papers 1930š 1979, Austrian Materials, Rec. Series No. 10/1/21 [Kopie im Besitz des Verfassers].

1788 UAW, Dekanatsakten, Phil. Fakultät, 1165š1945/46, Geographisches Institut der Universität Wien, betref.: Tausch nationalsozialistischer Literatur gegen amerikanische Literatur, 8. April 1946.

17891948 bedankte sich der Rektor der Universität Wien, Johann Sölch, persönlich bei dem bereits in die USA zurückgekehrten Thomas E. Benner dafür, dass dem Geographischen Institut bzw. ihm selbst auf Vermittlung von Benner von den Studenten der Universität Illinois eine neue Remington Schreibmaschine zur Verfügung gestellt wurden. Die Schreibmaschine wurde dann hochoffiziell im Beisein von E. Boyd Graves und Gregory J. Sandker von der Sekretärin des Rektors, Frau Christiane Mayer, eingeweiht. Schreiben von Rektor Sölch an Thomas E. Benner, 9. Juni 1948. University of Illinois Archives, Thomas E. Benner Papers 1930š 1979, Austrian Materials, Rec. Series No. 10/1/21 [Kopie im Besitz des Verfassers].

1790 So wurde auf private Vermittlung des Bibliothekars der Universität Harvard, dessen Mutter in Wien wohnte, bereits im März 1946 in Kooperation mit der University of Harvard ein erster Anlauf unternommen, gemeinsam mit dem kurz zuvor eingerichteten „Internationalen Institut“ der Universität Wien fünf Studierende der Universität Wien im Austauschverfahren nach Harvard zu bringen. UAW, Dekanatsakten, Phil. Fakultät, 1165š 1945 /46, Richard Meister an Bundesminister für Unterricht, Felix Hurdes, 26. März 1946, 1.

1791 Dabei handelte es sich neben Bergungsgütern der Tierärztlichen Hochschule, der Hochschule für Welthandel, des Schauspiel-Seminars, der Akademie für Musik und darstellenden Kunst und des Amtes des ehemaligen Kurators der Wiener Hochschulen um zehn Kisten des Orientalistik Instituts, um Bücher und Mikroskope des Mineralogischen Instituts, um 13 Kisten des Zoologischen Instituts sowie um 120 $\mathrm{m}^{3}$ Material des I. und II. Chemischen Instituts, deren Rücktransport nach Wien durch Bereitstellung von acht Güterwaggons ein US-Kommando unter Major Lott organisierte. UAW, Dekanatsakten, Phil. Fakultät, 217š 1945/46, Rektor Adamovich an den Dekan der Philosophischen Fakultät Wien, 5. November 1946.

1792 Universität Wien. Bericht über den Studienbetrieb an der Wiener Universität vom Sommer-Semester 1945 bis zum Sommer-Semester 1947. Erstattet von Prof. Dr. Ludwig Adamovich, Wien 1947, 65 f. Von Verbänden der Sowjet-Armee wurden hingegen Teile der an verschiedene Orte in Niederösterreich verlagerten Bücherbestände der Universitätsbibliothek Wien rückgeführt. Vgl. ebd., 86 ff. 
wissenschaftlich-technischen Apparaten, Gegenständen und Bibliotheksgut an die Universität Wien respektive an einzelne Hochschulen zurück transportiert. ${ }^{1793}$

Während die Universität Wien der sowjetischen Besatzungsmacht 1947 für die Lieferung größerer Mengen von Kohle, Öl und Petroleum dankte, wurde durch Vermittlung von Major Robert D. Murphy von der Abteilung „Education Relief“ des U.S. State Department sowie von der Information Service Branch (ISB) der USFA darüber hinaus immer öfter auch Material für die wissenschaftliche Lehre und Forschung zur Verfügung gestellt. ${ }^{1794}$

Als Dank für die Hilfeleistungen einerseits sowie als Ausdruck der gegenseitigen kollegialen Wertschätzung andererseits ehrte die Universität Wien in Folge eine Reihe amerikanischer Besatzungsoffiziere und US-Dienststellenleiter. So wurden bereits am Ir. Februar I946 Oberst William B. Featherstone, Major Leigh M. Lott und Major George A. Selke von der USFA-Education Division ,in Würdigung ihrer erfolgreichen Bemühungen um die Rückführung des wertvollen Universitätsguts“ ${ }^{1795}$ sowie als Dank für die „Beschaffung des notwendigsten Bau- und Brennmaterials " ${ }^{1796}$ anlässlich einer Festveranstaltung, an der neben den Rektoren der Wiener Hochschulen und Vertretern der Hochschülerschaft auch US-General Haynes und Unterrichtsminister Hurdes teilnahmen, zu Ehrenmitgliedern der Universität Wien ernannt. In seiner Festrede nahm Minister Hurdes die Gelegenheit wahr, darauf hinzuweisen, dass „es notwendig sei, gerade jetzt, wo die Hochschulen so sehr im Blickfeld der Öffentlichkeit stehen, zu betonen, daß ein Großteil der Professoren nicht durch den Nazismus verseucht sei, zumal ja viele sofort nach der Besetzung [d.i. der „Anschluss“, d. Verf.] wegen ihrer österreichischen Gesinnung ihres Postens enthoben worden waren." ${ }^{\text {"1797 }}$

Am I8. Mai 1946 folgte auch die Überreichung der Ehrenmitgliedschaft an Oberst Thair C. Rich und Major Joseph M. Murphy. Und nach Verleihung des Ehrendoktorates der Staatswissenschaften an General Mark W. Clark bekam schließlich auch Thomas Eliot Benner am I2. Juni I947 „als wahrer Freund und Förderer des österreichischen Hochschulwesens" ${ }^{1798}$ nach eineinhalb Jahren Tätigkeit, noch kurz vor seiner Rückreise in die USA, anlässlich einer Feier im Sitzungssaal des akademischen Senats die Ehrenmitgliedschaft der Universität Wien verliehen.

1793 Benner, Synopsis of Post-war Education in Austria, a.a.O., 4.

1794 So zum Beispiel mehrere hunderte Exemplare wirtschaftswissenschaftlicher, sozialwissenschaftlicher oder philosophischer Werke sowie mehrere Jahrgänge (1936-1945) des Magazins „Readers Digest“. Universität Wien. Bericht über den Studienbetrieb an der Wiener Universität vom Sommer-Semester 1945 bis zum Sommer-Semester 1947. Erstattet von Prof. Dr. Ludwig Adamovich, Wien 1947, 66.

1795 Universität Wien. Bericht über den Studienbetrieb an der Wiener Universität vom Sommer-Semester 1945 bis zum Sommer-Semester 1947. Erstattet von Prof. Dr. Ludwig Adamovich, Wien 1947, 35 f.

1796 Akademische Rundschau. Organ der Österreichischen Hochschülerschaft. Wochenschrift für Wissenschaft, Kultur, Kunst und Wirtschaft, 1. Jg., 1946, Folge 16, 6.

1797 Ebd.

1798 Universität Wien. Bericht über den Studienbetrieb an der Wiener Universität vom Sommer-Semester 1945 bis zum Sommer-Semester 1947. Erstattet von Prof. Dr. Ludwig Adamovich, Wien 1947, 36. 
Adamovich, der sich Benner freundschaftlich verbunden fühlte, hob in seiner Festansprache zu einer regelrechten Eloge auf dessen Wirken und dessen „warmes mitfühlendes Herz" als Leiter der US-Education Division an, wobei er die zugrunde liegende (historische) Realität allerdings regelrecht schön redete beziehungsweise grob verzerrte:

„Ihrer Fürsorge verdanken wir es, daß wir aus der geistigen Isolierung, in die wir sieben Jahre gegen unseren Willen gedrängt worden sind, allmählich herausgeführt wurden und den $\mathrm{Zu}$ sammenhang wieder gewinnen, mit den Zentren des kulturellen Lebens in Ihrem großem Vaterlande, daß wir mit wissenschaftlichen Institutionen dieses Ihres Landes wieder in gedanklichen Austausch treten, daß wir mit österreichischen Gelehrten, die ein grausames Schicksal aus ihrer Heimat vertrieben und jahrelang verbannt hatte, die Fühlung wieder aufnehmen und manche von ihnen zur dauernden Rückkehr in ihre Heimat bewegen konnten. [...]

Mögen Sie, wenn Sie wieder zurückgekehrt in Ihre Heimat, mit gleicher Tatkraft und gleichem Erfolg fortarbeiten zur Wiederherstellung und Festigung der kulturellen Beziehungen zwischen Ihrem großem mächtigen Lande und unserem heute so schwer geprüften, so tief gedemütigten Vaterlande Österreich. ${ }^{" 1799}$ [Hervorhebung d. Verf.]

Dass der Rektor der Universität Wien 1947 in einer offiziellen Rede gegenüber einem hochrangigen Offizier der US-Militärbehörden die „Demütigung“ Österreichs beinahe unverklausuliert auf die Situation der Besatzung und nicht auf die zurückliegende NS-Herrschaft bezog, lässt - einmal abgesehen von der verzerrten Darstellung der realen Wissenschaftsremigration - darauf schließen, dass man zumindest bei hochrangigen Vertretern der USEducation Division - allesamt selbst im akademischen Betrieb beheimatete Kollegen - keine demokratiepolitischen Korrekturen zu befürchten hatte; dies, obwohl darin die von weiten Teilen der Bevölkerung geteilte, ambivalente Einstellung zum Ausdruck kam, wonach Österreich zwar einerseits objektiv durch die Alliierten vom Nationalsozialismus als befreit betrachtet, das Kriegsende andererseits aber zugleich als eine Niederlage gewertet wurde. ${ }^{1800}$ Derartige Ungereimtheiten im ,Mindset' der österreichischen Nachkriegsgeneration sowie die damit verknüpfte Ausgangslage für einen Einstellungswandel im Hinblick auf antisemitische und autoritäre Tendenzen zeigten sich mehrfach in den von der Survey-Section des US-amerikanischen ISB durchgeführten Umfragen in den Jahren nach I946. ${ }^{1801}$

1799 Manuskript der Rede von Rektor Ludwig Adamovich anlässlich der Verleihung der Ehrenmitgliedschaft an der Universität Wien an Dr. Thomas E. Benner am 12 Juni 1947, 3. University of Illinois Archives, Thomas E. Benner Papers 1930-1979, Austrian Materials, Rec. Series No. 10/1/21 [Kopie im Besitz des Verfassers].

1800 Vgl. Barbara Kaindl-Withalm, Demokraten wider Willen. Autoritäre Tendenz und Antisemitismus in der 2. Republik, Wien 1990, 91.

1801 Seit dem September 1946 führte das Institut zur Erforschung der öffentlichen Meinung (unter Supervision der ISB-Survey Section) Befragungen der Bevölkerung (Personen über 18 Jahre) im amerikanischen Sektor (Wien, Oberösterreich, Salzburg) durch, die u. a. die politische Stimmungslage erkunden, 
Zu guter Letzt bekam dann auch noch Samuel H. Williams, der seinen Dienst als Chef der USFA-Education Division am 30. Juni 1947 angetreten hatte, am 24. Februar 1949 für „besondere Verdienste [...] für den Lehr- und Forschungsbetrieb“ das Ehrendoktorat der philosophischen Fakultät der Universität Wien verliehen. ${ }^{1802}$ In der Begründung hieß es unter anderem, dass Williams - gut vertraut mit den Verhältnissen an deutschsprachigen Universitäten durch sein Studium in Breslau und Berlin - ,in persönlicher Hinsicht bei Berufungen (Engel-Janozci, [sic]) und Veranstaltungen von Gastvorlesungen von USAProfessoren sein Möglichstes getan [hat], erstklassige Kräfte für Wien zu beschaffen.“1803 Insbesondere habe er sich ,gegenüber Zumutungen, unqualifizierte Kräfte in den Lehrbetrieb einzubauen, stets ablehnend“ gezeigt und in „Wort und Schrift seine Hochachtung vor dem System und der Verfassung unserer Hochschulen stets bewiesen. “1804

Abgesehen von der erwähnten Unterstützung der Berufung von Friedrich Engel-Jánosi, der jedoch erst 1959 nach Österreich remigrierte, ${ }^{1805}$ handelte es sich zum damaligen

sowie Einstellungs- und Werthaltungen sondieren helfen sollten. Das Design der soziodemografischen Fragebogenuntersuchungen, die um Repräsentativität ( $n=$ jeweils zw. 500 und 1.000 je Zone) bemüht waren, deutet darauf hin, dass man amerikanischerseits wußte, wie die Stimmungslage in den Ländern aussieht, d.h. es wurden Personen offenkundig bewußt nach vorherigem Screening ausgesucht („Quotenstichprobe"). Der Aufbau der Umfrage (Fragestruktur inkl. Kontrollfragen, relative Prozentangaben sowie die Interpretation der Ergebnisse) ist, trotz fehlender Rohdaten, auch nach heutigem Stand als professionell zu werten. [Auskunft von DDr. Thomas Benesch vom 17.7.2010]. Unter den abgefragten Themen finden sich u.a.: Meinung der Wiener Bevölkerung über die Neuorganisation Europas [Nr. 13]; Meinung über den Österreichischen Staatsvertrag [Nr. 15]; Ansichten der Wiener Bevölkerung über Politik und Regierung [Nr. 19]; Ansichten über den Nationalsozialismus [Nr. 20]; Der Marshall Plan [Nr. 21]; Die Zeitungsleserschaft [Nr. 23]; Zeitungsleser und Radiohörer [Nr. 25]; „Die Vierte Partei“ - ein Vergleich Wien, Linz, Salzburg [Nr. 27]; Meinung der Bevölkerung über die Polizei [Nr. 28]; Meinung der Bevölkerung über die Meinung der Bevölkerung von Wien, Linz, Salzburg über die Lebensmittelknappheit und die „Amerika Hilfe“ [Nr. 31]; Der „Wiener Kurier“, der Sender „RotWeiss-Rot“ und die „Stimme Amerikas“ [Nr. 32]; Die Einstellung der Bevölkerung zu den Flüchtlingen und DPs [Nr. 33]; Meinungen über Geschlechtskrankheiten [Nr. 39]; Die Regierungsumbildung in der Tschechoslowakei [Nr. 40]; Meinungen über den Nationalsozialismus [Nr. 41]; AntisemitismusUmfragen 1946-49 [Nr. 43]; Die Bevölkerung und der Film [Nr. 45]; USFA-Broschüre „Offen gesagt “ [Nr. 46]; Die Radiohörerschaft in der US-Zone [Nr. 47]; Die Gewerkschaften in Österreich [Nr. 48]; Wirkung auf den Weltfrieden [Nr. 49]; Die Amnestie der Minderbelasteten im Spiegel der öffentlichen Meinung [Nr. 50]; In den Demokratien lebt der Mensch besser [Nr. 51]; Die Österreichischen Parteien und die Besatzungsmächte [Nr. 52]; Die Radiohörer und ihre Empfangsgeräte [Nr. 55]; Zeitschriften- u. Magazinleser [Nr. 57]; Meinungen der Wiener Mittelschullehrer [Nr. 58]; Die United Nations - Die Idee eines Westeuropäischen Staatenbundes und ich [?]; Auswanderungslust der Österreicher [Nr. 61]. Die genannten Umfragematerialien befinden sich im Besitz des Verfassers.

1802 UAW, Dekanatsakten, Phil. Fakultät, 3734-1958/59, D.Zl. 1115 aus 47/48, Wahl des Dr. Samuel H. Williams zum Ehrenmitglied der Univ. Wien, Februar 1949, 1.

1803 Ebd.

1804 Ebd.

1805 Siehe dazu: Kap. 2, S. 188, Anm. 822 bzw. Kap. 4, S. 371, Anm. 1572. 
Zeitpunkt namentlich lediglich um zwei Fälle, in denen sich Williams höchstpersönlich eingesetzt hatte, wobei der bürokratische Ablauf dann ungewöhnlich rasch und ohne alle Verzögerungen auf österreichischer Seite vonstatten ging. ${ }^{1806}$ An diesen Beispielen zeigt sich geradezu exemplarisch, wie rasch, effizient und reibungslos die Bestellung von Gastprofessuren vor sich gehen konnte, obwohl oder gerade weil die amerikanischen und österreichischen Stellen einander versicherten, nichts ohne beidseitiges Einverständnis unternehmen zu wollen. So unterstützte Samuel H. Williams in einem Schreiben von Juli I948 gegenüber dem Dekan der Geisteswissenschaftlichen Fakultät, Prof. Duda - er brach im Frühjahr 1949 selbst als erster Teilnehmer des „Austrian Experts“-Progamm zu einem Gastaufenthalt in die USA auf ${ }^{1807}$-, die Bewerbung eines gewissen Dr. van Hofe von der University of Southern California für Gastvorträge an der Universität Wien (die letztlich in einer Absage mündeten): ${ }^{1808}$

"Please be assured that the Education Division has not invited and does not intend to invite any individuals for lectures at the University without first conferring with you. As you know, our policy is strictly one of non-interference [...]" ${ }^{1809}$ [Hervorhebung d. Verf.]

Postwendend antwortete Richard Meister als Dekan-Stellvertreter Williams, dass „in dieser Angelegenheit seitens der Universität und insbesondere des Dekanates, nichts unternommen werden wird, ohne vorher mit Ihnen das Einverständnis gepflogen zu haben. “1810

Dass aber trotz der deklarierten „Politik der Nichteinmischung“ en passant mitgeteilten Berufungsvorschlägen seitens der Education Division sowohl von der Universität Wien

1806 Es handelt sich um den Anglisten der Northwestern University Prof. Howard Jantz und den Historiker Arthur J. May von der Univ. Rochester/New York.

1807 Recordings of the U.S. Department of State relating to the Internal Affairs of Austria 1945-1954 (Mikrofilm-Bestand/Institut für Zeitgeschichte der Universität Wien), Decimal File, Reel 6, Education Division, Quarterly Historical Report, Governing Period 1 January - 31 March 1949, Enclosure no. 1 to despatch no. 216, dated April 26, 1949, from the American Legation, Vienna Austria, 3.

1808 Schuld daran war offenbar ein Formfehler, den ein Privatdozent Dr. Sieberer begannen hatte, indem er sich - unter Umgehung der österreichischen Behördenstellen - direkt an die amerikanische Besatzungsmacht gewandt hatte. In einem Antwortschreiben teilte Samuel H. Williams Harold van Hofe von der University of Southern Cailfornia/Los Angeles mit: „Inasmuch as we do not interfere in the operations of Austrian educational institutions all I could do was to indicate to the Dean that you had received an invitation from Dr. Sieberer and to submit your qualifications. [...] I regret exceedingly that Sieberer did not submit his invitation through proper channels which I am sure would have resulted in an opportunity for you. "UAW, Dekanatsakten, Phil. Fakultät, 3734-1958/59, USACA, Education Division APO 777, U.S. Army, Samuel H. Williams an Dr. Harold van Hofe, 21. Juli 1948, 1.

1809 UAW, Dekanatsakten, Phil. Fakultät, 3734-1958/59, USACA, Education Division APO 777, U.S. Army, Samuel H. Williams an Professor Dr. Duda, 21. Juli 1948, 1.

1810 UAW, Dekanatsakten, Phil. Fakultät, 3734-1958/59, Richard Meister an Samuel H. Williams, Education Division, APO 777, Friedrich Schmidtplatz 5, VIII. Wien, 30. Juli 1948, 1. 
als auch vom Unterrichtsministerium sehr wohl und zwar innerhalb kürzester Zeit entsprochen wurde, zeigt unter anderem der Fall des 4I-jährigen Historikers Arthur J. May, der sein Sabbatical in Europa verbringen wollte und den Williams ebenso erfolgreich für eine Gastprofessur vorschlug wie den Spezialisten für Amerikanische Literatur und für Österreichisch-Amerikanische Geistesbeziehungen, Howard Jantz. ${ }^{1811}$ Dieses Ansuchen wurde sogleich vom stellvertretenden Leiter der Information Services Branch (ISB) in Österreich, Albert van Eerden, sofort unterstützt. Jantz, dessen Antrag auf Gastprofessur das Unterrichtsministerium bereits einen Monat nach Antragstellung, nämlich am 20. April I948, genehmigt hatte, war es wegen seiner Vortragsverpflichtung an der Northwestern University dann doch nicht möglich, nach Wien zu kommen, ${ }^{1812}$ doch nach Bereitstellung einer Unterkunft konnte Arthur May bereits am 24. Mai 1948 seinen ersten Vortrag im Audi Max der Universität Wien halten. ${ }^{1813}$

In seiner persönlichen Dankesrede für die Verleihung der Ehrenmitgliedschaft, der er die Grüße des US-Hochkommissars General Keyes voranstellte und deren blumiger Wortlaut einen gläubigen Humanisten zum Vorschein bringt, brachte Samuel H. Williams Zivilisationskritik am vorherrschenden technokratischen Materialismus an, durch dessen Konkurrenzkampf und Genußstreben „die Menschheit die Schönheiten der Liebe, der Freundschaft, ja sogar die des sonnenerhellten Himmels vergisst“ und „die Linie zwischen Freiheit und Konzession vernichtet “. ${ }^{1814}$ Mit Bezug auf Österreich merkte Williams an:

„Gott sei Dank behauptet sich aber noch in Ihrem und auch in meinem Lande mehr als die blossen Spuren von diesen traditionellen Begriffen, auf welchen die Hoffnungen der Menschheit in ihrem kulturellen Fortschritt beruht.

1811 UAW, Dekanatsakten, Phil. Fakultät, 3734-1958/59, USACA, Education Division APO 777, U.S. Army, Samuel H. Williams an Professor Dr. Duda, 16. März 1948, 1. Handschriftlicher Zusatz von Dekan Duda: „Dr. Williams USA Ed. Div. legt bes. Wert auf Einladung des A.J. May, Unterlagen über ihn werden geliefert. D.“

1812 UAW, Dekanatsakten, Phil. Fakultät, 3734-1958/59, Z1. 253524/III-8/48, Bundesministerium für Unterricht, Skrbensky an das Dekanat der Philosophischen Fakultät der Universität Wien, 20. April 1948, 1.

1813 Den Vortrag zum Thema „Der amerikanische Geist im kulturellen Leben“ hielt May in deutscher Sprache. UAW, Dekanatsakten, Phil. Fakultät, 3734-1958/59, USACA, Education Division APO 777, U.S. Army, USFA Information Services Branch, Albert van Eerden, Deputy Chief, an Dekan der Universität Wien, 5. April 1948, 1. Ein kleines Detail am Rande: für den Sohn des U.S. Gesandten für Österreich, John G. Erhardt, der soeben sein Studium an der University of Vermont abgeschlossen hatte und der in Wien Politikwissenschaften zu studieren beabsichtigte, wurde von der Education Division sogleich der Dekan der Geisteswissenschaftlichen Fakultät der Universität Wien bemüht, der auch umgehend das Verzeichnis der staatswissenschaftlichen Vorlesungen sowie Inskriptionsmodalitäten kommunizierte. Vg1. dazu: UAW, Dekanatsakten, Phil. Fakultät, 2909-1947/48, D.Z1. 2909 aus 1947 /48, Richard Meister an Samuel H. Williams, 24. Juli 1948, 1.

1814 UAW, Dekanatsakten, Phil. Fakultät, 1115-1947/48, Rede von Professor Dr. Samuel H. Williams anlässlich der Ernennung zum Ehrenmitglied der Wiener Universität am 24. Februar 1949, 2. 
Gerade so, wie uns in Amerika innere Wogen von Gefühlen beim Anblick der Freiheits-Statue übermannen, da sie das Sinnbild der geistigen und sozialen Freiheit ist, haben Sie in Ihrem Stephansdom und vielen anderen Gebäuden, die gegen den Himmel ragen - gleich Stufen, die dahin führen - Symbole einer hochentwickelten Kultur, welche die Hoffnungen, die Bestrebungen und das Trachten eines intelligenten und idealistischen Volkes aufrecht halten.

Österreich mit seinen majestätischen Bergen, seiner grossartigen Kunst und mit der schönsten Musik der Welt, besitzt alle nötigen Voraussetzungen, um eine Atmosphere [sic] zu schaffen, in welcher eine gequälte Menschheit ihr Gleichgewicht wieder erlangen und eine langersehnte Ruhe und Sicherheit erreichen kann.

In Anerkennung von Österreichs kulturellem Aufbau und seines Beitrages zur Wissenschaft, Kunst und Musik, hat meine Regierung ihre Hand ganz spontan in wieder vereinter Freundschaft und sofort nach Beendigung eines unnützen und wertlosen Krieges ausgestreckt. In Unterstützung dieser Freundschaft und wegen unserer Ehrfurcht für Österreichs angeborene Kultur sind wir hier. Um diese Freundschaft zu fördern und um die wissenschaftlichen Verbindungen wieder aufzunehmen, darum wurde ich hierher gesandt. “1815 [Hervorhebungen d. Verf.]

Es steht außer Zweifel: Williams fühlte sich in diesem operettenhaft weichgezeichneten Österreich, dem seine großartige Kultur ebenso wie seine majestätischen Berge angeboren schienen, ebenso wohl wie in seiner Rolle und Funktion als Leiter der Education Division, die er persönlich zur Gänze auf freundschaftliche Kooperation hin anlegte und dabei dissonante Momente des wissenschaftlich-kulturellen Wiederaufbaues erst gar nicht in Blick nahm. So schloss er hinsichtlich der Universität mit hoffnungsfrohen Worten, die jedoch nur sehr bedingt mit der Realität der damaligen Situation zu tun hatten: „Sicherlich wird diese grosse Universität mit den Fähigkeiten ihrer grossen Geister ihren Teil für die Wiedergeburt des kulturellen Idealismusses [sic] beitragen." ${ }^{1816}$

Einen spannenden Einblick in die Haltung und Wertschätzung der Education Division gegenüber den österreichischen Universitäten bietet ein interner Report Samuel H. Williams zu „Austrian and American Education“, der vermutlich auf bereits ausgearbeiteten Darstellungen seiner Vorgänger aufbaute. Spannend liest sich das Papier insofern, als der die Universitäten betreffende Abschnitt primär auf die formale Organisationsstruktur und die Autonomie der Universitäten Bezug nimmt und die österreichischen Universitäten dabei im Vergleich zu den amerikanischen ganz klar als Vorbild ausgewiesen werden. Zum einem attestiert Williams den Universitäten eine effiziente und ökonomische Planung, von der amerikanische Universitäten lernen könnten; darüber hinaus werde seitens der akademischen Behörden ein respektvoller Umgang mit dem jeweiligen Universitätspersonal gepflogen, der an vergleichbaren amerikanischen Einrichtungen in dieser Form selten zu finden sei.Zum anderen - und diese Einschätzung war eindeutig einer Außenperspektive 
ohne jeden Bezug zu den realen Gegebenheiten und der politischen Vorgeschichte geschuldet - sei das österreichische Universitätssystem weitaus weniger autokratisch als die meisten amerikanischen Colleges, in denen der Präsident oder Vorsitzende die Macht habe, durch finanzielle Mittel politischen Druck auszuüben und so in die akademische Freiheit der Professoren einzugreifen. Vor offensichtlicher Begeisterung darüber, dass es im Unterschied zu Amerika keine „overpaid athletic coaches“ gäbe, kommt Williams in seinem unkritischen Lob der demokratischen Gegebenheiten an den Universitäten schließlich zu einem deutlich verzerrten Bild der Realsituation an den österreichischen Universitäten, das Fakten und Fiktionen - womöglich auf der Grundlage eigener schlechter Erfahrungen in den $\mathrm{USA}^{1817}$ - vermischt:

“There are no \$30,000 a year Chancellors in Austrian universities, and a Rektor [sic] is elected yearly by the various faculties. The Rektor receives only a small stipend in addition to this regular salary and the position is one of sufficient honor to compensate for the administrative duties it involves. Only outstanding scholars attain the honor of being elevated to its position. [...] Furthermore, it removes the discouraging disparity between the salaries of scholarly professors and those of high-paid Chancellors, which so frequently constitutes an injustice in American universities." ${ }^{1818}$

Soweit die vom dritten und letzten Leiter der US-Education Division in Österreich unterfertigte, insgesamt äußerst oberflächliche Einschätzung der hiesigen Universitäten, die zwar nicht unbedingt als repräsentativ für die US-Besatzungsmacht anzusehen ist, aber in zumindest zweifacher Weise Wirksamkeit entfaltete: einerseits wurde auf Basis dieser tiefen Sympathie die Realsituation in binnen-amerikanischen US-Reports tendenziell weichgezeichnet, andererseits garantierte diese Haltung im Fall von Konflikten und Angriffen wegen unzureichend durchgeführter Entnazifizierungsmaßnahmen - wie noch zu sehen sein wird - gewissermaßen eine Pufferzone sowohl gegenüber russischen Forderungen als auch gegenüber Kritik übergeordneter US-Behörden.

Ein frühes Beispiel für die Kooperation zwischen amerikanischer Besatzungsmacht und Universität in unverfänglichen, die Fragen der Entnazifizierung beziehungsweise Reorientierung nicht einmal rudimentär betreffenden Bereichen der wissenschaftlichen Lehre stellt die Einrichtung eines „Internationalen Instituts“ an der Universität Wien im August

1817 Tatsächlich stand Samuel H. Williams vor seinem Einritt in die USFA-Dienststelle in Pittsburgh als Zoologe, Buchautor, Forschungsreisender und Universitätslehrer hoch im Kurs: so sollte er 1943 die neuausgeschriebene und mit $\$ 4200$ hochdotierte Stelle als Zoo-Direktor in Pittsburgh übernehmen, was infolge einer Malariainfektion letztlich scheiterte. Siehe dazu: „Pitt Zoologist sick: Can't take Zoo Post“. In: Pittsburgh Post-Gazette, 23. Mai 1941, 13.

1818 NARA II, RG 260, EDU-DIV, Box 5/Folder 12 [7/18/5/5/3-4], Samuel H. Williams, Chief Education Division, „Austrian and American Education“, 10. März 1948, 8. 
I945 dar ${ }^{1819}$ - eine Kooperation, in die die anderen Besatzungsmächte freilich sogleich mit einbezogen wurden. Auf amerikanische Initiative wurde, nach einer Besprechung von Prorektor Meister mit Major Joseph M. Murphy sowie nachfolgenden Beratungen mit Vertretern der amerikanischen und britischen Erziehungsabteilungen, ein „Internationales Institut der Universität Wien “ mit drei Sektionen geschaffen: einer anglo-amerikanischen, einer französischen und einer russischen. ${ }^{1820}$

Im Statut der Einrichtung, deren Leitungsgremium sich aus dem Rektor der Wiener Universität sowie aus je einem Bevollmächtigten der vier alliierten Militärregierungen zusammensetzte, wurde die „Pflege enger geistiger Beziehungen zwischen den alliierten Ländern und Österreich“"1821 als Aufgabe angegeben. De facto reduzierten sich die Aktivitäten des Institutes allerdings darauf, Studierenden ,aus den alliierten Ländern, die ein ordnungsgemäßes Studium mit dem Ziele der Anrechnungen der zurückgelegten Semester “1822 absolvierten, die Möglichkeit einer Immatrikulierung als ordentliche Hörer zu gewährleisten und Gastvorträge in den jeweiligen Landessprachen anzubieten. Darüber hinaus sollten allen „Angehörigen der alliierten Militärregierungen, der alliierten Kommissionen für Österreich und der Truppen der alliierten Armeen “1823 die Gelegenheit gegeben werden, als Gasthörer

1819 Ein weiteres Beispiel - mit allerdings nicht ganz so deutlichem Bezug zur Universität - ist die Gründung der Österreichisch-Amerikanischen Gesellschaft, bei deren Gründungsfestakt am 6. Jänner 1946, an dem Bundeskanzler Figl und hohe Vertretern der alliierten Mächte teilnahmen, General Mark Clark in seiner Ansprache formulierte: „Amerika will mithelfen, daß Wien wieder erste Kunstund Kulturhauptstadt Europas werde“. Clarks Rede wurde „mit tosendem Beifall“ bedankt, nachdem er bekannt gegeben hatte, dass „die Reichskleinodien unter schärfster Bewachung wieder nach Wien gebracht und dem rechtmäßigem Eigentümer, dem österreichischen Staate, zurückgeben worden sind." Zit. nach: Akademische Rundschau. Organ der Österreichischen Hochschülerschaft. Wochenschrift für Wissenschaft, Kultur, Kunst und Wirtschaft (unter Genehmigungs-Nummer 146 der Nachrichtenkontrolle der Militärregierung veröffentlicht), 1. Jg., 26. Jänner 1946, Nr. 11/12, 1. Der hier gepflegte Kulturaustausch beschränkte sich auf freundlich-ephemere Image- und Kontaktpflege, wie aus den Worten des ersten Präsidenten der Gesellschaft, Univ.-Prof. Dr. Otto Kauders, hervorgeht. Dieser stellte die „amerikanische Seele“ in den Mittelpunkt seiner Ausführungen und wies darauf hin, dass - entgegen der Annahme der „Europäer im allgemeinen“ - die Bewohner des bis ins letzte industrialisierten und mechanisierten Erdteils „keine Marionetten, sondern Menschen mit Fleisch und Blut, mit einer Seele sind. [...] Und wer diese Seele kennt, kann Amerika verstehen, kann verstehen, warum es gerade auch Österreich solche Sympathie entgegenbringt“, denn „Gastfreundschaft und Hilfsbereitschaft“ sowie „Empfänglichkeit für alles Gute von außen“ seien sowohl Amerikanern als auch Österreichern eigen. Zit. nach: ebd., 1.

1820 Universität Wien. Bericht über den Studienbetrieb an der Wiener Universität vom Sommer-Semester 1945 bis zum Sommer-Semester 1947. Erstattet von Prof. Dr. Ludwig Adamovich, Wien 1947, 46.

1821 Ebd.

1822 Ebd., 47.

1823 Ebd., 48. Im Vorlesungsverzeichnis der Universität Wien wurden verstärkt Vorlesungen zur „Orientierung über die Bereiche aus Österreichs Natur, Geschichte und Kultur“ sowie über Geschichte und Kultur alliierter Länder angeboten. Ebd., 49. 
Vorlesungen beziehungsweise populäre Vorträge zu besuchen. Nicht unähnlich zu den bereits im Sommersemester 1945 wieder eröffneten „Volkstümlichen Universitätsvorträgen “ ${ }^{1824}$ die sich ,an einen weiteren Hörerkreis wenden und die geistige Erneuerung Österreichs aus der Überlieferung seiner Geschichte und durch Wegweisung in die Zukunft zu ihrem Gegenstande nehmen sollten ", ${ }^{1825}$ bestand auch die Aufgabe des Internationalen Institutes in der beabsichtigten popularisierenden Außenwirkung: „Die Hauptleistung des Instituts bestand in der Veranstaltung repräsentativer Vorträge für einen weiteren Hörerkreis innerhalb der drei Sektionen, die vornehmlich von auswärtigen Gelehrten gehalten wurden, aber auch Angehörige des Lehrkörpers, der Universität und andere wissenschaftliche Persönlichkeiten aus Wien steuerten solche Vorträge bei. ${ }^{\text {" }} 826$ Diese Ähnlichkeit beziehungsweise das verbindende Moment zu den Volkstümlichen Universitätskursen, ${ }^{1827}$ nämlich die Öffnung der Universität zum Zweck der Popularisierung von Wissenschaft, hob Rektor Adamovich anlässlich der Fünfzigjahrfeier am I3. Oktober 1945 in seiner Festrede ausdrücklich hervor:

„Mit Genehmigung der alliierten Militärmissionen wird im Rahmen unserer Universität ein Internationales Institut errichtet werden [...]. Das Institut wird die Aufgabe haben, durch Vorträge der eigenen Lehrkräfte der Universität und durch Vorträge von Gastprofessoren wechselseitige Kenntnisse über die kulturellen, sozialen und wirtschaftlichen Verhältnisse der beteiligten Staaten zu vermitteln [...]. Überdies aber - und hier liegt die Verbindung mit den Volkstümlichen Universitätskursen - sollen im Rahmen dieses Internationalen Instituts auch Vorträge veranstaltet werden, die der Allgemeinheit zugänglich sein werden und ihr Kenntnisse über grundlegende kulturelle Einrichtungen anderer Staaten vermitteln sollen. ${ }^{\text {“1828 }}$

1824 Die volkstümlichen Universitätsvorträge waren 1895 auf Initiative von Ludo Moritz Hartmann in Wien nach dem Vorbild der Universität Cambridge und Oxford als extramurale Vorträge für HörerInnen aller Klassen und Stände eingerichtet worden. Vgl. Hans Altenhuber, Universitäre Volksbildung in Österreich 1895-1937 (= Nexus. Zur Geschichte der Erwachsenenbildung), Wien 1995, 23 ff. Am 22. Mai 1945 eröffnete Staatssekretär Ernst Fischer die volkstümlichen Universitätsvorträge neu mit einem Vortrag über „Die Aufgaben der Universität im neuen Staat“ im Hörsaal 38 der Wiener Universität. Daran anschließend folgten drei Vortragsreihen zur „Geschichte Österreichs“ (Ernst Fischer), zu „Einzeldarstellungen aus dem Gebiete der christlichen Weltanschauungslehre"(Karl Lugmayer; Oskar Kattan; August Maria Knoll; Michael Pfliegler) sowie zum „Dialektischen Materialismus“ (Ernst Fischer; Leo Stern). Vg1. Universität Wien. Bericht über den Studienbetrieb an der Wiener Universität vom Sommer-Semester 1945 bis zum Sommer-Semester 1947. Erstattet von Prof. Dr. Ludwig Adamovich, Wien 1947, 54.

1825 Universität Wien. Bericht über den Studienbetrieb an der Wiener Universität vom Sommer-Semester 1945 bis zum Sommer-Semester 1947. Erstattet von Prof. Dr. Ludwig Adamovich, Wien 1947, 54.

1826 Ebd., 50.

1827 Diese wurden, wie schon zuvor in Monarchie und Erster Republik, als sechswöchige, auf Vertiefung des Wissens angelegte Vortragszyklen neben der Universität als Veranstaltungsort auch an den Wiener Volkshochschulen abgehalten.

1828 Akademische Rundschau. Organ der Österreichischen Hochschülerschaft. Wochenschrift für Wissenschaft, Kultur, Kunst und Wirtschaft (unter Genehmigungs-Nummer 146 der Nachrichtenkontrolle der Militärregierung veröffentlicht), 1. Jg., 1946, Folge 3, 8. 
Das Internationale Institut, dessen administrative Leitung bei Prorektor Richard Meister lag - dabei unterstützt vom Leiter des Amerika-Institutes, Paul Dengler -, beteiligte sich auch an den Vorbereitungen für die Einrichtung der von der USFA finanzierten Unit-School für amerikanische College-Studierende (USFA I and II Command School of University of Vienna). ${ }^{1829}$ Wie Rektor Adamovich berichtete, habe das Internationale Institut neben der Verteilung der „hochherzigen Spenden von medizinischen Büchern, Reißzeugen, Rechenstäben und Schreibmaterial [...] durch die ,Schwedenhilfe “"1830 auch an der Berufung von Gastprofessoren und an der Durchführung ihrer Lehrveranstaltungen beratenden und helfenden Anteil genommen. Unter den vornehmlich amerikanischen und britischen Gastprofessoren, die meistens in englischer Sprache vortrugen, finden sich allerdings, wie kaum anders zu erwarten, keine Remigrés.

\section{Rabmenrichtlinien und Entnazifizierung der Studentenschaft an Österreichs Universitäten}

In der Verordnung des Staatsamtes für Volksaufklärung, Unterricht, Erziehung und Kultusangelegenheiten über die „allgemeine Studienordnung für die wissenschaftlichen Hochschulen“ vom 3. September 1945 wurde auf die Entnazifizierung der Studierenden mit keinem Wort eingegangen. ${ }^{1831}$ Hingegen wurde bereits im April I946 per Erlass - als „Wiedergutmachung der begangenen Verletzung des Volksgefühls“ - die Wieder-Anbringung der Kreuze in den Schulen geregelt. ${ }^{1832}$

Bis Ende 1946 lag die Entnazifizierung der Studierenden de facto ausschließlich bei den Universitäten beziehungsweise bei den sich ab Mai I945 analog zu den politischen Parteien konstituierenden Studentenorganisationen ${ }^{1833}$ und dem sich daraus entwickelnden

1829 In der anglo-amerikanischen Sektion trug beispielsweise Paul Dengler über das „Antlitz amerikanischer Städte (New York, San Francisco, Chicago, New Orleans)“ vor, Augusta Bronner über „Moderne amerikanische Literatur“, Richard Meister hielt einen Vortrag zur „Vergleichenden Darstellung des amerikanischen, englischen, französischen und österreichischen Bildungssystems“; in der französischen Sektion trug neben Eduard Castle und Rektor Sölch, Chefredakteur Robert Aron über „Elements d'un renouveau spiritual français“ vor; in der russischen Sektion referierte Frau Elise Riesel, Professorin an der Universität Moskau, über „Das sowjetische Hochschulwesen“, ebd., 50.

1830 Ebd., 52.

1831 Verordnungsblatt für den Dienstbereich des Bundesministeriums für Unterricht, Jg. 1946, Wien am 1. Februar 1946, 1./2. Stück, 1.

1832 Erlass vom 8. April 1946, Z. 6048/III-6. Verordnungsblatt für den Dienstbereich des Bundesministeriums für Unterricht, Jg. 1946, Wien am 1. März 1946, 3. Stück, 97.

1833 Dies waren die aus dem „Strobl“-Kreis hervorgegangene und bereits im Mai von Minister Hurdes als offizielle Vertretung der ÖVP anerkannte „Freie Österreichischen Studentenschaft“ (FÖST), der Verband Sozialistischer Studenten (Josef Schneeweiß, Otto Hoffmann-Ostenhof, Peter Rubel) und der kommunistischen Studentenbund (Peter Feldl). Christine H. Forster, Die Geschichte der Österreichischen Hochschülerschaft 1945-1955 (= Dissertationen der Universität Wien 166), Wien 1984, 15 ff. 
zentralen Selbstverwaltungskörper: ${ }^{1834}$ der Österreichischen Hochschülerschaft $(\mathrm{ÖH}) .{ }^{1835}$ Deren Hauptaufgabe bestand in den ersten Monaten allerdings in der Organisation von Aufräumarbeiten - sogenannte „Schutteinsätze -, in der Versorgung der Mensa sowie in der Beschaffung und Verteilung von Unterkünften, Hilfsspenden und Arbeit. Politische Meinungsverschiedenheiten wurden in der Anfangsphase wegen dringenden materiellen Problemen und der Notwendigkeit zur Kooperation hintangestellt. ${ }^{1836}$ Darüber hinaus bekannten sich die entstehenden Studentenfraktionen als Folge der historischen Erfahrungen im Großen und Ganzen zunächst zu einer unpolitischen, oder besser: politisch neutralen Hochschülerschaft. ${ }^{1837}$

In einer Verordnung vom 27. September 1945, betreffend die rechtlichen Grundsätze der ÖH, wurde festgelegt, dass nicht Studentenvertreter werden kann, wer „der NSDAP oder einem ihrer Wehrverbände angehört hat, Parteianwärter gewesen ist oder in der nationalsozialistischen Studentenschaft in führender Stellung tätig war.“1838

Da die Inskription bereits Anfang Mai 1945 begonnen hatte, ${ }^{1839}$ wurden während des laufenden Sommersemesters von Staatssekretär Ernst Fischer per Erlass des Bundesministeriums für Unterricht vom I6. August I 945 (Z.3423/45) zumindest allgemeine „Richtlinien“ für die Inskriptionszulassung an den österreichischen Hochschulen erlassen. ${ }^{1840}$

1834 Vgl. Kurt Schubert, Die Wiedereröffnung der Universität Wien im Mai 1945. Vortrag im Rahmen der Veranstaltungsreihe „625 Jahre Universität Wien“ am 10. Mai 1990 im Kleinen Festsaal der Universität Wien (=Wiener Universitätsreden, NF, 1), Wien 1991, 5 ff.

1835 Vorgänger war der „Sechserausschuss“, der sich bald zum „Zehnerausschuss“ (Österreichisch-Demokratische Studentenschaft) erweiterte und dann unter Bewilligung von Unterstaatssekretär Karl Lugmayer zum eigentlichen Vorgänger der ÖH, dem „Hauptausschuss der Demokratischen Studentenschaft Wiens“ wurde. Per Verordnung vom 3. Oktober 1945 (StGbl. Nr. 170) des Staatsamtes für Unterricht, Erziehung, Volksaufklärung und Kultusangelegenheiten wurden die ordentlichen österreichischen Hörer und Hörerinnen in ihrer Gesamtheit zur „Hochschülerschaft“ zusammengefasst. Vgl. Christine H. Forster, Die Geschichte der Österreichischen Hochschülerschaft 1945-1955 (= Dissertationen der Universität Wien 166), Wien 1984, 18 bzw. 33.

1836 Ariane Heilingsetzer/Maria Mesner/Heinz Rögl/Fritz Weber, Projektendbericht: Zur Geschichte des VSSTÖ 1945-1970, unveröffentlichtes Manuskript, Wien 1989, 103. Der Autor ist Herrn Heimo Gruber für die Überlassung einer Kopie des Berichts zu Dank verpflichtet.

1837 Ebd., 104.

1838 Auf Basis des Hochschulermächtigungsgesetzes aus dem Jahr 1935, StGB1. vom 27. September 1945, Nr. $170, \S \S 1-37$.

1839 Inskriptionen an der Wiener Universität. In: Neues Österreich. Organ der demokratischen Einigung, 2. Mai 1945, 4.

1840 Auszuschließen waren demnach vom Hochschulstudium „Illegale, Angehörige der SS und Funktionäre der Partei, beziehungsweise einer ihrer Wehrverbände (SA, NSKK, NSFK)“, wobei „bei Vorliegen rücksichtswürdiger Gründe“ auch „Studierende, die in führender Stellung in den nationalsozialistischen Studentenschaften tätig waren“, zur Inskription zugelassen wurden. Zit. nach: Andreas Huber, Entnazifizierung und Rückbruch. Studierende 1945-1950. In: Andreas Huber/Katherina Kniefacz, Alexander Krysl/Manès Weisskircher, Universität und Disziplin. Angehörige der Universität Wien und der 
Zu diesem Zweck wurden einstimmig beschlussfähige Kommissionen (auch „Ehrenkommissionen“ genannt) eingerichtet; unter Vorsitz eines vom Rektor bestimmten und ständig mit der politischen Überprüfung beauftragten Mitgliedes des Lehrkörpers als Vorsitzenden, bestanden die Kommissionen auch aus drei Mitgliedern der Hochschülerschaft (je ein Vertreter der politischen Studentenverbände) als Beisitzer, die ,je einer der demokratischen Parteirichtungen angehören“ und selbst ein „polizeiliches Zeugnis über ihre politische Unbedenklichkeit vorzulegen“1841 hatten. Bei Stimmengleichheit „dirimierte“ (entschied) der Vorsitzende; die Letztentscheidung über Zulassung oder Nicht-Zulassung lag beim Rektor.

Unter allen Umständen vom Studium auszuschließen waren „Illegale“, politische Funktionäre der NSDAP vom Zellenleiter aufwärts, Angehörige der zivilen SS, Angehörige der NS-Wehrverbände vom Unteroffizier aufwärts, Angehörige der HJ und des BDM vom Oberscharführer/in aufwärts, Funktionäre des Nationalsozialistischen Stundenbun-

Nationalsozialismus, (= Emigration - Exil - Kontinuität. Schriften zur zeitgeschichtlichen Kultur- und Wissenschaftsforschung. Hrsg. v. Friedrich Stadler, Bd. 11), Wien - Berlin 2011, 190. Lediglich bei Inskribenten, die schon vor dem April 1945 eingeschrieben waren, „griffen die überprüfenden Studenten auf die Karteikarten aus der NS-Zeit zurück." Zit. nach: ebd., 207.

1841 UAW, Dekanatsakten, Phil. Fakultät, 513-1945/46, Erlass des Unterrichtsministeriums (Z.3040/III46) [auf Basis des Erlasses vom 16.8.1945, Z.3423/45] betref. der politischen Überprüfung der Inskribierenden an den österreichischen Hochschulen, Bundesminister Hurdes an die Rektorate aller wissenschaftlichen Hochschulen, 2. Februar 1946, 1. Wie es um die politische Zuverlässigkeit einzelner Nominierter bestellt war, zeigt u.a. das Beispiel des Kommissionsvorsitzenden der Gruppe Geisteswissenschaften an der philosophischen Fakultät der Universität Wien, Erich Schenk (1902-1974). Dieser war zwar nie NSDAP-Mitglied, aber seit 1934 Mitglied der „Reichschaft Hochschullehrer im NSLehrerbund“ und machte ab 1938 Karriere: 1939 wurde der Salzburger Mozartforscher Schenk, der sich in Rostock habilitiert hatte und dort bereits 1936 zum Professor bestellt worden war, nach Wien berufen, und übernahm als Ordinarius das Musikwissenschaftliche Institut; in dieser Funktion war er auch maßgeblich an der Zwangsenteignung („Arisierung “) der Privatbibliothek Guido Adlers 1941 beteiligt. Als nach Kriegende deshalb Anzeige gegen Schenk erstattet wurde, deckte Otto Skrbensky Schenk, indem nach Untersuchung der Vorkommnisse keine „nachweisbaren Taten“ festgestellt wurden; zudem verschwanden Teile von Schenks Personalakten aus der NS-Zeit sowohl im Unterrichtsministerium als auch im Archiv der Universität Wien. Vgl. Murray G. Hall/Christina Köstner, „... allerlei für die Nationalbibliothek zu ergattern ...". Eine österreichische Institution in der NS-Zeit, Wien - Köln - Weimar 2006, 298; weiters: Yukiko Sakabe, Die Bibliothek von Guido Adler. In: Mitteilungen der Alfred Klabr Gesellschaft, Nr. 1, 2007, 12. [Ich danke Herrn Dr. Klaus Taschwer an dieser Stelle für den Literaturhinweis]. Auch nach 1945 verhielt sich Schenk offen antisemitisch: in den 1950er-Jahren lehnte er unverhohlen Dissertationen über Franz Schreker oder Gustav Mahler „mit dem Hinweis auf deren jüdischen Abstammung“ ab. Siehe dazu auch folgende Angaben auf: http://www.oeaw.ac.at/ikt/Archiv/jourfixe/08_06/080929sakabe_staudinger.pdf; siehe insbesondere auch: Michael Staudinger, Musikwissenschaft an der Universität Wien 1945-1955. In: Grandner/Heiß/Rathkolb (Hrsg.), Zukunft mit Altlasten, a.a.O., 163. 1950 wurde Schenk Dekan der Philosophischen Fakultät, 1957 schließlich Rektor. 1970 erhielt er das österreichische Ehrenzeichen für Wissenschaft und Kunst. Alljährlich wird in Wien der Erich Schenk-Preis der Mozartgemeinde Wien vergeben. Siehe. Pfefferle/Pfefferle, Glimpflich entnazifiziert, a.a.O., 43. 
des (NSDSTB) vom Kameradschaftsführer beziehungsweise von der Referentin aufwärts sowie nationalsozialistische Führungsoffiziere der Wehrmacht. ${ }^{1842}$

Alle anderen Inskriptionswerber, insbesondere ehemalige Offiziere der Deutschen Wehrmacht, Mitglieder anderer NS-Organisationen, Förderer der NSDAP und „nichtorganisierte Nationalsozialisten, die sich durch Denutiation [sic], Mitarbeit oder sonst wie hervorgetan haben, sind einer strengen Prüfung zu unterziehen“ - dabei wurde der Nachweis antifaschistischer Betätigung „noch vor der Befreiung Österreichs sowie Kriegsversehrtheit positiv gewertet":
„Minderbelastete dieser Art, deren österreichische und demokratische Einstellung für die Zu- kunft ausser Zweifel stehen, kann gelegentlich ihrer Zulassung zur Inskription eine Sühne in Form von Arbeitsleistung für den Wiederaufbau der Hochschule in der Dauer von ein bis sechs Monaten vorgeschrieben werden, die in das Studienbuch einzutragen ist und von deren Erfüllung die Semesterbestätigung abhängt. “1843

In einer Verordnung des Staatsamtes für Unterricht vom Ir. August 1945 wurde zur politischen ,Säuberung، der Studierenden durch die Studentenvertretungen festgehalten:
„Die Mitarbeit bei der den akademischen Behörden obliegenden Säuberung der öster- reichischen Hochschulen von politisch untragbaren oder unerwünschten Studenten gehört zum Aufgabenkreis der demokratischen Studentenschaft. Durch diese Mitarbeit wird jedoch weder die den akademischen Behörden in Inskriptions- und Immatrikulationsangelegenheiten obliegende Entscheidungsgewalt, noch auch Diziplinargewalt der akademischen Behörden berührt. Demgemäß wird sich die demokratische Studentenschaft auf die Durchführung der Vorerhebungen für das Rektorat zu beschränken haben, um dessen Entscheidung über den Ausschluß antiösterreichischer oder antidemokratischer Personen vom Studium oder die Er- greifung sonstiger Maßnahmen gegen solche Elemente vorbereiten zu helfen. “1844

Der am r. Februar 1946 von den drei demokratischen Studentenorganisationen ernannte Vorsitzende der österreichischen Hochschülerschaft, Karl Leutgeb, der Rudolf Wengraf ${ }^{1845}$ nachfolgte, formulierte die Grundsätze der Studentenvertretung: sie hielten neben der „Ver-

1842 UAW, Dekanatsakten, Phil. Fakultät, 513-1945/46, Erlass des Unterrichtsministeriums (Z.3040/III46) [auf Basis des Erlasses vom 16.8.1945, Z.3423/45].

1843 Ebd., 2.

1844 Verordnung Z 3153/III/4a/45 vom 11. August 1945. Zit. nach: Forster, Die Geschichte der Österreichischen Hochschülerschaft 1945-1955, a.a.O., 24.

1845 Wengraf war im April 1945 von Staatssekretär Ernst Fischer im Einvernehmen mit dem neugebildeten akademischen Senat der Universität Wien an die Spitze der Studentenschaft gesetzt worden. Vgl. dazu: Eduard Rabovsky [sic; recte: Rabofsky], Die kommunistischen Studenten. In: Akademische Rundschau, 1. Jg., 1946, Nr. 19, 6. 
pflichtung dem gesamten Volke, den Arbeitern und Bauern und in besonderem Maße auch den Alliierten gegenüber, die uns mit schweren Opfern befreiten“, der „absoluten Unparteilichkeit in der Geschäftsführung“ auch die „sofortige Durchführung einer strengen und endgültigen Entnazifizierung sämtlicher österreichischen Hochschulen “1846 fest.

Stichproben bei der Lektüre der Protokolle der Überprüfungskommissionen an der Philosophischen Fakultät zeigen, dass sich in der Überprüfungspraxis allerdings Probleme auftaten, die nicht nur den fehlenden Unterlagen zu den Inskribierenden š vorzulegen waren in der Regel, neben polizeilichen Führungszeugnissen, ausgefüllte Fragebögen sowie "eidestaatliche Erklärungen š geschuldete waren. ${ }^{1847}$ Zum einen war die Kommission š wie im Übrigen auch an anderen Fakultäten š mit der ihr übertragen Arbeit völlig überfordert, sodass im Frühjahr 1946 bereits die Einsetzung eines zusätzlichen Gremiums verlangt wurde. ${ }^{1848} \mathrm{Zum}$ anderen gab es wiederholt Konflikte mit (kommunistischen) Vertretern der Hochschülerschaft, die den Sitzungen wegen zu geringer Vorinformationen aus Protest fernblieben. ${ }^{1849}$ Darüber hinaus wurde die Ableistung auferlegter Sühnearbeiten verweigert und häufig Berufung gegen die Entscheidung eingelegt. ${ }^{1850}$ Rekurse von Studierenden wurden dann in der Regel entweder nochmals geprüft und die endgültigen Bescheide per Listen an die Überprüfungssenate beim Bundesministerium für Unterricht, die nach den Ausschreitungen bei den ersten Hochschülerschaftswahlen im November 1946 gebildet worden waren, zur weiteren Behandlung weitergeleitet. ${ }^{1851}$ Obwohl die Zulassungsbescheide des Rektors auf Basis der Kommissionsbeschlüsse „endgültig“ ${ }^{\text {“1852 }}$ waren, wurden sie zum Teil vom Bundesministerium beziehungsweise von Sektionschef Skrbensky mehrfach revidiert oder den StudienbewerberInnen nach Durchsicht der „Einsichtsakten“ der Rat erteilt, im folgenden Semester einfach neuerlich um Inskription anzusuchen. ${ }^{1853}$

1846 Karl Leutgeb, Vor neuen Aufgaben. In: Akademische Rundschau, 1. Jg., 1946, Nr. 15, 16. Februar 1946, 1. 1847 Vgl. Huber, Entnazifizierung und Rückbruch, a.a.O., $187 \mathrm{f}$.

1848 UAW, Dekanatsakten, Phil. Fakultät, 513š 1945/46, Musikwissenschaftliches Institut der Universität Wien an den Dekan der Philosophischen Fakultät, 2. März 1946, 1. Darin heißt es: „Nach den bisher gemachten Erfahrungen ist es vollkommen unmöglich durch eine Kommission die notwendige Überprüfung zeitgerecht durchzuführen, selbst wenn, wie dies bisher der Fall war, wöchentlich vierzig Fälle behandelt werden." [Unterstreichung im Original]

1849 Z.B. UAW, Dekanatsakten, Phil. Fakultät, 513š1945/46, Musikwissenschaftliches Institut der Universität Wien an den Dekan der Philosophischen Fakultät, 14. Mai 1946, $1 \mathrm{f}$.

1850 UAW, Dekanatsakten, Phil. Fakultät, 513š 1945/46, DZ 774 aus 1945/46, Dekan Meister an Bundesministerium für Unterricht, 10. Mai 1946. Hier erhoben gleich 17 Studierende Berufung gegen Nichtzulassung zum Studium aus Gründen der Betätigung in der NSDAP. Insgesamt acht Personen wurden nach dem Rekursverfahren schließlich doch zum Studium zugelassen.

1851 UAW, Dekanatsakten, Phil. Fakultät, Z1. 591/III/7/47, 11. Februar 1947, 1 f.

1852 UAW, Dekanatsakten, Phil. Fakultät, 513š 1945/46, Z1. 42818/IIIš 4a/46, Politische Überprüfung der Inskribierenden, Bundesminister Hurdes an die Rektorate der Universität Wien, 8. März 1946, 1.

1853 UAW, Dekanatsakten, Phil. Fakultät, $513 s ̌ 1945$ /46, Bundesministerium f. Unterricht (Skrbensky) an das Dekanat der philosophischen Fakultät betref. Studiengenehmigung für Frau G.W., 17. Oktober 1946. 
In der Regel reichte die Berufung gegen die Registrierung selbst beziehungsweise der Hinweis, die NSDAP-Mitgliedschaft habe sich durch automatische „Überstellung“von der $\mathrm{HJ}$ oder dem BM aus ergeben, für eine bedingte Inskription, was über kurz oder lang in ein Normalstudium mündete. ${ }^{1854}$

Dass die politische Säuberung der Studierenden auch von den damaligen Studentenfraktionen von Anfang an - vorsichtig formuliert - nicht mit besonderem Nachdruck verfolgt wurde, geht auch aus einzelnen Kommentaren in der Presse hervor. So schrieb beispielsweise die kommunistische Österreichische Zeitung dazu in seltener politischer Äquidistanz:

\begin{abstract}
„Es muß leider ausgesprochen werden, daß in der allerersten Zeit auch von studentischen Vertretern, deren politische Gesinnung über jeden Zweifel erhaben war, die Entnazifizierung der Hochschulen mit einer schon heute sträflich erscheinenden Sorglosigkeit und Oberflächlichkeit begonnen wurde. [...] Zur Inskriptionszulasssung genügte eine mündliche, nicht einmal eidesstaatliche Versicherung, politisch nicht belastet zu sein, wobei die Auslegung dieses Ausdruckes der eigenen Weitherzigkeit überlassen war. Schon im Sommersemester konnte es daher vorkommen, daß geschädigte Studenten und Heimkehrer aus der Kriegsgefangenenschaft in Seminaren und Laboratorien, die damals noch sehr eingeschränkt arbeiteten, keinen Platz fanden, weil alles von zum Teil schwerstbelasteten Nazis besetzt war. “1855
\end{abstract}

Tatsächlich verlief die Entnazifizierung auch aus Sicht damaliger Studentenvertreter letztlich „eher mild“; ${ }^{1856}$ anstelle eine Ausschlusses vom Studium hatten das Gros der belasteten Studenten als „Sühneleistung“ Arbeitseinsätze für den Wiederaufbau zu erbringen. ${ }^{1857}$ Das findet sich auch in der Diplomarbeit von Andreas Huber bestätigt, in die unter anderem auch Interviews mit damaligen Studentenvertretern eingeflossen sind. So gibt zum Beispiel Heinz Damian, damals als Student selbst Mitglied einer Überprüfungskommission, zu Protokoll: „Die Entnazifizierung, [...] die ist ja durchgeführt worden in einer relativ einfachen Weise [...] dann hat man halt in fast 90 von roo Fällen gesagt: , ja der soll studieren ““. ${ }^{1858}$

Insbesondere die - voraussichtlich stimmenstärkste - konservative „Freie Österreichische Studentenschaft“ (FÖST), die sich als Bollwerk gegen den Marxismus verstand und

1854 Vgl. Andreas Huber, Studenten im Schatten der NS-Zeit. Entnazifizierung und politische Unruhen an der Universität Wien 1945-1950, Dipl.-Arb., Univ. Wien 2009, 120; vgl. auch die 2011 publizierte und etwas modifizierte Kurzffassung: Huber, Entnazifizierung und Rückbruch. Studierende 1945-1950, a.a.O., 157-302.

1855 „Zur Situation an den Hochschulen“. In: Österreichische Zeitung, 16. Oktober 1946, 2.

1856 Laut Aussage von Dr. Friedrich Langer, damaliger Leiter des Kulturreferats der ÖH, dessen Mitarbeiter u.a. Michael Kehlmann, Helmut Qualtinger, Hilde Sochor, Kurt Sobotka oder Gerhard Bronner waren. Zit. nach: Forster, Die Geschichte der Österreichischen Hochschülerschaft 1945-1955, a.a.O., 23.

1857 Heilingsetzer/Mesner/Rögl/Weber, Projektendbericht: Zur Geschichte des VSSTÖ, a.a.O., 106.

1858 Huber, Studenten im Schatten der NS-Zeit, a.a.O., 83. 
deren Hauptziel in der Durchsetzung „eines echt österreichischen Geist(es)“1859 bestand, war um die Zulassung jugendlicher Mitglieder von NS-Organisationen bemüht, um „aus ihnen Demokraten zu machen“" ${ }^{1860}$

In der Frage der Entnazifizierung formulierte der Verband Sozialistischer Studenten Österreichs (VSStÖ) eine klare programmatische Position, die im Hinblick auf die Lehrerschaft ein entschiedenes Vorgehen auch und insbesondere gegenüber den „zahllosen Nazi, die nicht Parteigenossen waren, das nationalsozialistische System aber geistig, wirtschaftlich, propagandistisch und praktisch gestützt und getragen haben“, forderte. Vor dem geschichtlichen Hintergrund, dass „die Hochschulen der ersten Republik Österreich alles eher waren, als Pflegestätten eines wirklich freien Geistes und ihre Professoren in diesem Zusammenhang sehr selten das, was sie ihrem Namen nach sein sollten, nämlich seine Bekenner“, ${ }^{1861}$ wurde die aktuelle demokratische Herausforderung der Universitäten unmissverständlich und radikal benannt:

„Auf den Hochschulen Österreichs muß sowohl personell als auch bis in die kleinsten und unscheinbarsten Winkel des Lehrstoffes und der Lehrtätigkeit jede, auch die geringste Spur pangermanistischer [sic], deutsch-völkischer, nationalsozialistischer Gedankengänge (oder unter welchem Decknamen sich eine faschistische Spielart auch noch verkriechen mag) mit der Wurzel ausgerottet werden, ebenso wie jede andere Beeinträchtigung des freien demokratischen Geistes überhaupt, sei es durch konfessionelle oder wirtschaftliche Rücksichten. “1862

Mit Bezug auf die Studierenden schrieb „Cand. jur.“ Viktor Heller, ${ }^{1863}$ damals als VSStÖVertreter Mitglied des Bildungsausschusses der Österreichischen Hochschülerschaft, es sei „unbestreitbar, dass von einer Anzahl Studenten noch immer faschistisch-nazistische Ansichten vertreten werden.“ Allerdings seien die „in der Presse und anderen Stellen verbreiteten Meldungen, daß die Hochschulen Hochburgen des Nazismus wären, maßlos übertrieben“. ${ }^{1864}$ Damit auch die „Überreste einer vergangenen Epoche [...] radikal ausgemerzt werden“, sollten - wie auch der Bildungsausschuss der ÖH forderte - Pflichtvor-

1859 Der Student, 1. Jg., 1945, F. 3, 2. Zit. nach: Forster, Die Geschichte der Österreichischen Hochschülerschaft 1945-1955, a.a.O., 52.

1860 Dr. Kurt Schubert. Zit. nach: Forster, Die Geschichte der Österreichischen Hochschülerschaft 19451955, a.a.O., 23.

1861 „Entnazifizierung“. In: Strom, 2. Jg., 13/14, Mai 1946, 9.

1862 Felix Hubalek, Vergangenheit und Zukunft unserer Hochschulen. In: Strom. Hochschulsonderausgabe, 2. Jg., Folge $17 / 18$, Juni 1946, $18 \mathrm{f}$.

1863 Viktor Heller (1925-1987), Jurist, Sektionschef im Unterrichtsministerium; 1984 wurde er Präsident des Verwaltungsgerichtshofes. Ab 1964 unterrichtete Heller an der Gewerkschaftsschule, 1974 wurde er ehrenamtlicher Präsident der Volkshochschule Hietzing, 1984 Präsident des Verbandes Österreichischer Volkshochschulen.

1864 Viktor Heller, Entnazifizierung des Geistes. In: Strom, 2. Jg., 13/14, Mai 1946, 28. 
lesungen über „Demokratie“ und die „nationale Frage Österreichs“ kombiniert mit Diskussionen für alle angehenden Akademiker abgehalten werden. ${ }^{1865}$

Als politische Interessensvertretung schwenkten aber auch die sozialistischen Studenten durchaus im Einverständnis mit der SPÖ-Parteilinie - letztlich auf eine milde und pragmatische Vorgehensweise ein, indem eindeutig Belastete zwar von den Hochschulen auszuschließen waren, sonst aber auf Umerziehung durch demokratische Diskussionen gesetzt wurde. In der VSStÖ-Zeitschrift Strom heißt es dazu: „Wir lehnen es ab, jungen Menschen wegen eines Fehltrittes - sei es aus jugendlicher Begeisterung, infolge Unkenntnis der wahren Situation, oder aus wirtschaftlichen Gründen - den Weg in eine bessere sozialistische Zukunft zu versperren. Aber wir weisen Hofratsprotektionen für SS-Leute, Funktionäre und andere aktive Nazi, die sich ihrer Verantwortung sehr wohl bewußt waren, entschieden zurück." ${ }^{1866}$ Ähnlich verhielt es sich auch mit der entsprechenden Position der kommunistischen Studenten. Bei einer Versammlung des kommunistischen Studentenbundes sprach Nationalrat Ernst Fischer über „Probleme der Hochschule“ und betonte dabei - freilich etwas paradox - die allgemein-menschliche Dimension in der universitären Entnazifizierung, ohne die spezifisch inhaltlichen Herausforderungen im Bereich wissenschaftlicher Forschung und Lehre mit in den Blick zu nehmen, indem er meinte: „Ich halte den Nationalsozialismus für falsch, aber ich werde mir nie anmaßen, einen menschlich anständigen Nationalsozialisten zu verachten. " ${ }^{1867}$

Spätestens im Vorfeld der bevorstehenden Hochschülerschaftswahlen wurde allerdings von den Studentenfraktionen, analog zum Stimmenfang durch die politischen Großparteien - hier insbesondere durch den FÖST und den VSStÖ - bereits um Stimmen auch unter ehemaligen Nationalsozialisten gebuhlt. ${ }^{1868}$

Dass unter den Studierenden der Universität Wien Anfang I946 Personen mit einschlägig nationalsozialistischer Vergangenheit offenkundig keineswegs Einzelfälle waren, dokumentiert ein Schreiben des zweiten Präsidenten des Stadtschulrates für Wien, Leopold Zechner, an das Bundesministerium für Unterricht. In diesem Schriftstück wird die „groteske“ Praxis einer Bevorzugung von belasteten Studenten gegenüber unbelasteten Kommilitonen zur Sprache gebracht und kritisiert:

„Nach Mitteilungen, die dem Stadtschulrat für Wien zugekommen sind, sollen an Wiener Hochschulen Lehrpersonen inskribiert sein und studieren, die gemäss dem Verbotsgesetz registrie-

1865 Ebd.

1866 Strom, 2. Jg., Folge 7/8, 1946. Zit. nach: Heilingsetzer/Mesner/Rögl/Weber, Projektendbericht: Zur Geschichte des VSSTÖ, a.a.O., 106.

1867 Ernst Fischer, „Ich achte jeden überzeugten anständigen Nationalsozialisten“. In: Akademische Rundschau, 2. Jg., Nr. 8., 16. November 1946, 4.

1868 „Wenn sich ein Nazi zu einer Partei schlug, konnte er auf jeden Fall studieren.“ Aussage von Dr. Alexander Kragora (FÖST). Zit. nach: Forster, Die Geschichte der Österreichischen Hochschülerschaft 1945-1955, a.a.O., 24. 
rungspflichtig und derzeit vom Wiener Schuldienst enthoben sind. Diese Lehrpersonen - es soll sich vorwiegend um jüngere handeln - sollen sogar von den amtlichen Arbeitseinsatzstellen ausdrücklich von anderen Arbeiten befreit und zum Hochschulstudium freigegeben worden sein. Wenn die Mitteilungen den Tatsachen entsprechen, so würde sich der groteske Fall ergeben, dass solche Lehrpersonen, welche, trotzdem sie für den Staat nichts leisten, seit fast einem Jahr und bis auf weiteres aus öffentlichen Mitteln allmonatlich 15o,- S beziehen, sozusagen als Staatsstipendisten besonders bevorzugter Art die Möglichkeit haben, akademische Grade zu erwerben und sich in höchstqualifizierten Berufen z. B. zum Arzt, Juristen, Ingenieur etc. auszubilden, um dann, wenn die Gesetze für sie als ehemalige Nationalsozialisten günstiger werden, derartige in die Gesellschaft führende Berufe zu ergreifen, während ihre nichtnationalsozialistischen Kolleg(inn)en Volksschullehrer(innen) bleiben müssen und bei dem gegenwärtigen Lehrermangel nicht einmal in die Lage kommen, zum Zweck ihrer Fortbildung auch nur den bescheidensten Studienurlaub zu erhalten.

Der Stadtschulrat für Wien gestattet sich, die Aufmerksamkeit des Bundesministeriums für Unterricht auf diesen Zustand zu lenken und zu bitten, durch geeignete Massnahmen handgreifliche Bevorzugungen abzustellen. “1869

Als direkte Reaktion auf dieses Schreiben - die dessen Inhalt fraglos bestätigte - folgte am r. Mai 1946 ein Beschluss des Akademischen Senates, wonach ab sofort „die mit der Vorbegutachtung der Studierenden befassten Kommissionen anzuweisen“ waren, ,jedem Inskriptionswerber die Frage vorzulegen, ob er bereits in einem Beruf steht" beziehungsweise „etwa aus Gründen der Parteizugehörigkeit derzeit enthoben sei. Letzterenfalls wäre die Zulassung seitens Ew. Spektabilität [der jeweilige Dekan, d. Verf.] zu verweigern. “1870

Das Unterrichtsministerium sah sich jedoch erst im Dezember I946 - durch alliierten Druck infolge der Ausschreitungen rund um die ersten ÖH-Wahlen - per Erlass zu einer „neuerlichen Überprüfung der Studierenden nach strengeren Grundsätzen“ genötigt, da die Vorfälle bei der Durchführung der Hochschülerschaftswahlen „darauf hindeuten, dass die Ideologien des Nationalsozialismus noch nicht überall restlos ausgemerzt sind“; ${ }^{1871}$ damit wurden die Bestimmungen für die Studenten schließlich deutlich strenger gehandhabt als etwa die für das Lehrpersonal an den Universitäten.

1869 UAW, Dekanatsakten, Phil. Fakultät, 1309-1945/46, Z.I.2722/46, Hochschulstudium registrierpflichtiger und vom Schuldienst enthobener Lehrpersonen, Schreiben des Stadtschulrats für Wien, Dr. Zechner, an Bundesministerium für Unterricht, Wien 21. März 1946.

1870 UAW, Dekanatsakten, Phil. Fakultät, 1309-1945/46, GZ. 85-1945/46, Schreiben des Rektors der Universität Wien (Adamovich) an „seine Spektabilität den Herrn Dekan der Philosophischen Fakultät“ (Prof. Dempf), 14. Mai 1946.

1871 Von nun an waren alle Belasteten und Minderbelasteten bis einschließlich 30. April 1950 vom Studium auszuschließen. Erlass zur „Politischen Überprüfung der Hochschüler“ vom 6. Dezember 1946, Z. 45.675-III / 7. Verordnungsblatt für den Dienstbereich des Bundesministeriums für Unterricht, Jg. 1946, Wien am 1. März 1946, 3. Stück, 19. 
Dennoch: angesichts der schleppenden und im Ergebnis als unzufriedenstellend erachteten ,Säuberung' der Universitäten - die Ausschlussquote von Inskribenten beziehungsweise von Studierenden der Universität Wien im Sommersemester 1946 lag bei lediglich zwei Prozent ${ }^{1872}$ - machte der Bildungsausschuss der Österreichischen Hochschülerschaft den Vorschlag, den Akademischen Senat zu ersuchen, Pflichtvorlesungen über „Staat und Philosophie“, „Staat und Recht“ und „Österreichische Geschichte" an allen Fakultäten einzuführen. Alle Studenten sollten künftig vor Ablegung von Staatsprüfungen oder Rigorosen ein Kolloquiumzeugnis über diese Vorlesungen erbringen. ${ }^{1873}$ Wie nicht weiter verwunderlich, kam dieser Vorschlag, der als flankierende Maßnahme zur verschärften Überprüfung durch Entnazifizierungskommissionen gedacht war, von den Studierenden und nicht von den Universitätsprofessoren, die sich aber umgehend an die konkrete Planung und Durchführung verpflichtender Vorlesungen zur Politischen Bildung machten.

Nach einem vorangegangenen Antrag von Professor Hans Thirring sowie der Vorlage eines „Motivenberichtes“, der auf die „aus verschiedensten Kreisen des In- und Auslandes“ wiederholt vorgebrachte Forderung, ,daß die geistige Loslösung der Studentenschaft von der nationalsozialistischen Ideologie durch die Hochschulen nicht bloß auf dem der Wissenschaft nächstliegenden und vor allem zukommenden Wege der Erziehung zu strengster Objektivität, sondern auch in positiver Beeinflußung durch Vermittlung antinationalsozialistischen Gedankengutes erfolgen möge “, nahm der Akademische Senat im Dezember 1946 den Antrag an. Nun waren ab dem Studienjahr $1947 / 48$,alle inländischen Studierenden, die an einer Fakultät der Universität Wien als ordentliche oder außerordentliche Hörer ein ordnungsgemäßes Studium betreiben und mit der hierfür vorgeschriebenen Schlußprüfung beenden wollen, bis auf weiteres verpflichtet (sind), eine zweistündige Vorlesung über ,Die psychologischen Grundlagen der Weltfriedensidee' zu besuchen " ${ }^{1874}$ und auch nachzuweisen. Allerdings scheint die Vorlesung letztlich dann doch keinen verpflichtenden Charakter

1872 Huber, Entnazifizierung und Rückbruch, a.a. O., 159. Die Ausschlussquote betrug an der medizinischen Fakultät 2\%, an der juridischen Fakultät 2,8\%, im geisteswissenschaftlichen Bereich der philosophischen Fakultät 2,4\%, wohingegen der Ausschluss im Bereich der Naturwissenschaft unter einem Prozent lag. Ebd., 214. Wie Andreas Huber ausführt, erreichte der „Ansturm“ im WS 1946/47 an der Universität Wien (sowie in Österreich allgemein: 35.381) mit 12.527 Studierenden seinen Höhepunkt. Siehe: ebd., 181. Eine zahlenmäßig detaillierte Darstellung der Entnazifizierung der Studierenden liegt mit der Studie von Platzer für die medizinische Falkultät vor: Rachel Platzer, Entnazifizierung der Studierenden an der Universität Wien unter besonderer Berücksichtigung der medizinischen Fakultät, Dipl.-Arb., Univ. Wien 2005. So wurden etwa im WS 1945/46 insgesamt 64 Studierende ausgeschlossen, wobei der Prozentsatz der negativen Kommissionsentscheide gegenüber den zur Überprüfung Geladenen mit 89\% hoch ausfiel (im SS 1946 waren es 77,8\%). Ebd., 76-77. Zit. nach: Huber, Entnazifizierung und Rückbruch, a.a.O., 192 bzw. 213.

1873 Erziehung zum Österreicher. In: Akademische Rundschau, 1. Jg., 1946, Nr. 23, April 1946, 5.

1874 UAW, Senats-Sitzungsprotokolle des Studienjahres 1946/47, Sitzung des Akademischen Senates am 14. Dezember 1946, 1. 
gehabt zu haben, da das, wie Richard Meister meinte, mit dem Verlust von Semestern ein-

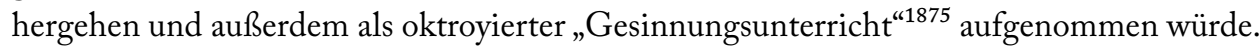

Dass die politische ,Säuberung' an den Universitäten insbesondere in den Bundesländern trotz allem überaus unbefriedigend verlief, zeigte sich unter anderem auch daran, dass sich Bundeskanzler Figl genötigt sah, den zuständigen Institutionen und Behörden in aller Öffentlichkeit zu drohen, hier gegebenenfalls rücksichtslos durchzugreifen:

„Ich verwarne alle zuständigen Institutionen und Behörden zum letzten Mal, hier rücksichtslos durchzugreifen, sonst werde ich mich, wenn es sein muß, nicht scheuen, einzelne Hochschulen schließen zu lassen“. 1876

In dieser durchaus nicht wenig prekären ,Zwickmühlsituation' gegenüber den alliierten Besatzungsmächten, den akademischen Behörden und der (politischen) Öffentlichkeit bemühte sich Bundeskanzler Figl mit einigem rhetorischem Kraftaufwand - in ausdrücklicher Anlehnung an den „Geist der Lagerstraße“ - um einen Schulterschluss der „Studenten, Akademiker, Arbeiter und Bauern“, indem er diese zu einem „gemeinsamen Gelöbnis“, „nicht von Parteien, sondern von Menschen, die nebeneinander und miteinander leben und leben wollen “1877 beschwor. Anlässlich einer Kundgebung der Österreichischen Hochschülerschaft im Auditorium Maximum der Universität Wien strich Fig1 dabei - en passant auf die erkämpften Freiheiten durch die Französische Revolution und die I848er-Barrikaden-Kämpfer à la Hans Kudlich Bezug nehmend - interessanterweise die „Tätigkeit unserer Hochschüler in der Widerstandsbewegung und in den ersten Tagen nach der Befreiung Österreichs durch die alliierten Mächte“ hervor. Als „Akademiker zu Akademikern“ sprechend mahnte er - als ob die zukünftige demokratische „Freiheit“ der Universitäten allein vom goodwill und Ethos aller (somit auch der Ehemaligen) abhängen würde - überaus vage und in völliger Ausklammerung der realen Probleme im Hinblick auf die Säuberung der Universitäten: „Dieser große revolutionäre Geist, der aus der Erkenntnis und dem Bekenntnis zur Zukunft entspringt, und der gleichzeitig die stolzeste Tradition aller Hochschulen bedeutet, muß erhalten bleiben. “1878 Im Hinblick auf das Wie vermied Figl an dieser Stelle allerdings jedes klare Wort und zeigte sich seltsam beruhigt darüber, dass ohnedies bereits die „alte akademische Demokratie in Österreich [...] wieder hergestellt" ${ }^{\text {1879 }}$ wäre.

1875 Zit. nach: Huber, Studenten im Schatten der NS-Zeit, a.a.O., 211. [ÖSTA, AdR, BMfU, GZ 80511947, Meister an Lenz, 18. Dezember 1947].

1876 Bundeskanzler Figl: Keine Parteipolitik an den Hochschulen. In: Akademische Rundschau, Folge 28, 1946, 2. Vgl. auch Wiener Zeitung, 11. Mai 1946.

1877 Bundeskanzler Figl: Studenten müssen Träger der sozialen Revolution sein. In: Akademische Rundschau, 1. Jg., 1946, Nr. 31, 8. Juni, 1.

1878 Ebd.

1879 Ebd., 2. 
Bereits Ende des Jahres 1945 existierte ein eigenes „Quadripartite Sub-Committee on Denazification in Austrian Universities" innerhalb des im November eingerichteten Alliierten Entnazifizierungsbüros ${ }^{1880}$ das mit Inkrafttreten des Verbotsgesetzes am 5. Februar 1946 für ganz Österreich die Tätigkeit des im Jänner eingesetzten ministeriellen „Figl“-Entnazifizierungskomitees überwachte. Die Tätigkeit dieses Gremiums beschränkte sich, analog zur alliierten Standpunkt, die Entnazifizierung von den österreichischen Behörden selbst durchführen zu lassen, im Wesentlichen auf Supervision und informelle Empfehlungen („technical recommendations “). ${ }^{1881}$ Immerhin wurden vom alliierten Denazification Sub-Committee aber vollständige Listen des enthobenen und vorhandenen Lehrpersonals an österreichischen Universitäten, teilweise mit detaillierten Informationen über die jeweilige demokratisch-politische Verlässlichkeit der einzelnen Personen geführt sowie darüber, wer trotz NSDAPMitgliedschaft nach dem März 1938 von den österreichischen Sonderkommissionen für tragbar erklärt worden war und nun - aufgrund alliierter Entscheidung - zu entheben war.

Nach den Nationalratswahlen im November 1945 kam es auch auf dem Boden der Universität zur Verschärfung der parteipolitischen Gegensätze, zumal nun auch wieder die traditionellen Studenten-Korporationen, insbesondere der Cartellverband (CV), bei dem auch Bundeskanzler Figl Mitglied war, um Zulassung bemüht waren. ${ }^{1882}$

Bereits in der ersten Sitzung des Unterrichtsausschusses des Nationalrates im Jänner I946 hatte der SPÖ-Abgeordnete Erwin Scharf Unterrichtsminister Hurdes darauf aufmerksam gemacht, dass an den Hochschulen die Absicht bestehe, den „Unfug der farbentragenden Studentenverbindungen“ wieder zuzulassen. Die Arbeiterzeitung verwies in diesem Zusammenhang auf die Gefahr einer Reetablierung reaktionären, akademischen Standes- und Klassendünkels, der die Universitäten schon einmal zu „Brutstätten des Faschismus" gemacht habe:

„Man komme uns auch nicht mit der Autonomie der Hochschulen! In Wahrheit - und darum ist das Wiederaufleben des Farbenstudententums keine reine Hochschulfrage, sondern eine Frage allgemeinen und öffentlichen politischen Interesses - könnte unter den gegenwärtigen Umständen in Österreich die Wiederherstellung des Korpsstudententums nur eines von zwei üblen Dingen bedeuten. Entweder man will den deutschnationalen Tendenzen in dieser Ver-

1880 Dieses „Quadripartite Denazification Bureau“ stand unter Supervision der alliierten „Internal Affairs Division“ und setzte sich zur Aufgabe, ,carrying out a complete denazification of the Austrian state machinery and economic apparatus." Allied Commission for Austria, Allied Council, ALCO/P(46)4, Reel 1-23, 1945 May-Feb. 1946, The denazification of Austrian state machinery, 8th January 1946, 1.

1881 Dem Komitee gehörten an: Vorsitzender Mr. Needham (GB), Mr. Ray (US), Capitaine de la Maestre (Fr) und Mles. Strojteleva und Smirnova (UdSSR). Report of Quadripartite Sub-Committee on Denazification in Austrian Universities, 7th September 1946. NARA II, RG 260, Box 11, Folder 68, Records of the United States Occupation Headquarters, World War II, USFA/USACA, Internal Affairs/Displaced Persons Division, Denazification Branch, General Records, 1945-50, 1.

1882 Forster, Die Geschichte der Österreichischen Hochschülerschaft 1945-1955, a.a.O., 58. 
kleidung doch noch eine Ecke retten, ihnen ein schmales Bett bereiten, in dem sie kulturhistorisch getarnt und durch die Hochschulautonomie gedeckt, aber darum nicht weniger anrüchig, fortleben können, bis daraus wieder einmal eine ,Bewegung' mit faschistischen ,Farben` wird oder man will den Cevauern zu ihrer politischen Monopolstellung auch noch die alleinige Demonstrationsmöglichkeit geben. Entweder Nazi-Keimzelle oder Cevauer-Parade - es ist nichts anders. " 1883

Und auch der von der amerikanischen Besatzungsmacht finanzierte Wiener Kurier sprach in diesem Zusammenhang vom fehlenden Bemühen, die „nazistischen Elemente aus den Kreisen der Hörer- und Lehrerschaft auszumerzen“. ${ }^{1884}$

Noch am 21. Dezember 1945 hatte die britische Militärregierung den Cartellverband an der Universität Graz verboten, ${ }^{1885}$ im Mai 1946 wurde dieser vom Innenministerium aber dennoch offiziell genehmigt, wobei jedoch die Wiedereinführung des „Farbenrechtes“ zunächst verboten blieb; ${ }^{1886}$ daraufhin nahm der Einfluss des CV in der ÖVP-nahen Akademiker-„Union“ zu. Ansuchen einzelner Studentenverbindungen um Genehmigung des Farbentragens wurden von Minister Hurdes, trotz vorheriger Ablehnung durch den Akademischen Senat, allerdings gewährt. ${ }^{1887}$ I948 kam es bei einem Farbenaufmarsch des CV zu ersten Prügeleien und im Mai 1949 führte ein Aufmarsch von rund 2.00o CVern trotz Versammlungsverbotes durch den Akademischen Senates der Universität Wien - zu schweren Zusammenstößen mit etwa 200 sozialistischen Studenten vor der Universitätsrampe. ${ }^{1888}$ Im Jänner 1950 wurde schließlich das Couleur bei Festveranstaltungen des Cartellverbandes genehmigt und bald darauf auch den deutschnationalen Studentenverbindungen gewährt, indem der Akademische Senat am 27. Februar 1954 generell das Tragen von „Mütze und Band auf akademischen Boden“ gestattete. ${ }^{1889}$

Nachdem es an der Universität Wien bereits ab August 1945 mehrfach zu Zwischenfällen gekommen war - so wurden nazistische Flugzettel gestreut, antisemitische Schreiben

1883 Arbeiterzeitung, 26. Jänner 1946, 2.

1884 Was geht an der Universität vor? In: Wiener Kurier, 2. Jg., Nr. 6, vom 8. Jänner 1946, 3.

1885 Gerhard Hartmann erklärt diesen Erlass u.a. damit, dass im Juli 1945 die Labour-Party an die Regierung kam, „so daß der Erlaß der britischen Militärregierung aus diesen Gesichtspunkten erklärbar ist. " Hartmann, Der CV in Österreich, a.a.O., 128.

1886 Siehe dazu: Grazer Hochschulen und österreichische Hochschülerschaft. In: Strom. Jugend, Geist und Welt, 2. Jg., 10. März 1946, Folge 7/8, 24; weiters: Forster, Die Geschichte der Österreichischen Hochschülerschaft 1945-1955, a.a.O., 63.

1887 Vgl. Huber, Studenten im Schatten der NS-Zeit, a.a.O., 228, [UAW, Senats-Sitzungsprotokolle AprilMai 1948].

1888 Heilingsetzer/Mesner/Rögl/Weber, Projektendbericht: Zur Geschichte des VSSTÖ, a.a.O., 110; weiters: Huber, Studenten im Schatten der NS-Zeit, a.a.O., 229. [ÖSTA, AdR, BMfI, GZ 108.690-2/ 49]

1889 Zit. nach: Huber, Studenten im Schatten der NS-Zeit, a.a.O., 229. [UAW, Senats-Sitzungsprotokolle, 24. Februar 1954, 19]. 
an das Rektorat verfasst ${ }^{1890}$ und antisemitische Plakate angebracht, die auch bei der Staatspolizei zur Anzeige gebracht wurden ${ }^{1891}$-, häuften sich Ende 1945 und Anfang des Jahres I946 in der Presseberichterstattung ${ }^{1892}$ - vor allem in den sozialistischen und kommunistischen Zeitungen, aber auch im Dreiparteienorgan Neues Österreich - vermehrt negative Berichte über antisemitische Kundgebungen und stürmische studentische Solidaritätsveranstaltungen für enthobene, belastete Professoren an den Universitäten. ${ }^{1893}$

Ausgelöst durch den „Fall Nadler“1894 kam es zu betont scharfen Gegenreaktionen der „Vereinigung Demokratischer Hochschullehrer Österreichs“ unter Vorsitz von Edwin Rollet. In einer im Jänner 1946 unter anonymer Autorschaft ${ }^{1895}$ veröffentlichten Schrift wurde exemplarisch auf die verqueren Exkulpierungsversuche belasteter Professoren eingegangen und die Tätigkeit der Sonderkommissionen einem kritischen Blick unterzogen. Gegen das wiederholt vorgebrachte Entlastungsmotiv, die meisten Menschen, somit auch geistig tätige Personen, hätten von den NS-Gräueln in den Konzentrations- beziehungsweise Vernichtungslagern nichts gewusst, argumentiert der Text schlüssig, dass der „Superlativ des Grauenvollen“ gegenüber „professionell geistige[n] Menschen“, also gegenüber ehemaligen nationalsozialistischen Hochschulprofessoren, erst gar nicht zur Sprache kommen muss, um diesen vor Augen zu führen, dass es keine Möglichkeit gibt, sich auf Basis von ,Unkenntnis 'vom Massenmord zu distanzieren:

1890 So verteilten „deutsch-arische“ Studenten an der Universität Wien Flugblätter und schrieben an Rektor Adamovich einen Brief antisemitischen Inhalts. Vgl. Akademische Rundschau, 2. Jg., Juni 1946, 13.

1891 Siehe: Huber, Studenten im Schatten der NS-Zeit, a.a.O., 131 f. So z.B. gefälschte Anschläge einer Vorlesung Leo Sterns an der Rechts- und Staatswissenschaftlichen Fakultät: „Herr Prof. STERN (von der Universität Moskau) beginnt seine Vorlesungen über die Sauwirtschaft in der Sowjet-Union. “ Zit. nach: ebd., 133; vgl. dazu auch Volksstimme, 4. Dezember 1945, 3.

1892 So u.a. auch in der Austro American Tribune, wo über wüste Auseinandersetzungen und Krawalle zwischen Sympatisanten der Professoren Kindermann, Sedlmayr und Oettinger berichtet wurde, die erst durch Intervention des Rektors - und supervidiert durch die Staatspolizei - beendet wurden. Siehe: „Die Universitätskrawalle beginnen wieder". In: Austro American Tribune. Anti-Nazi Monthly, New York,Vol. IV, No. 6, Jänner 1946, 1.

1893 So z.B. für den Germanisten Josef Nadler oder die Kunsthistoriker Karl Oettinger und Hans Sedlmayr, für die studentische Anhänger im November 1945 in „zwei stürmischen Kundgebungen unter den Augen der Staatspolizei“ ihre Sympathie bekundeten. Vgl. Meissl, Der „Fall Nadler“ 1945-1950. In Meiss1 (Hrsg.), Verdrängte Schuld - verfehlte Sühne, a.a.O., 282.

1894 Vgl. Meissl, Der „Fall Nadler“, a.a.O., 281 ff. Vgl. auch: Der Fall Nadler. In: Wiener Montag, 17. Dezember 1945,3 .

1895 Tatsächlich wurde die Broschüre „Die Wehrlosen“ - der Titel knüpft ironisch an die Stellungnahme des belasteten Germanisten Josef Nadler gegenüber seinen Kritikern an, der sich als einen ,auch heute noch Wehrlosen" bezeichnet hatte - vom Kunsthistoriker und nachmaligen Direktor der Österreichischen Galerie Fritz Novotny (1903-1983) verfasst. Ich danke an dieser Stelle Kollegin Dr. Maria Wirth für die Überlassung einer Kopie der Broschüre (mit handgeschriebener Annotation vom 3. April 1965) aus dem Nachlass von Christian Broda. 
„Hat sie zum Beispiel niemals der Gruß,Heil Hitler!' allein schon gestört, waren sie nicht imstande, seine abgründige Idiotie zu empfinden, und von da aus aufsteigend Kausalitäten zu erfassen, die eben zum Äußersten, zum Krieg und zu dem anderen, anfangs straff organisierten, zum Schluß in Paroxysmus ausgeübtem Massenmord der Konzentrationslager führte - sie, deren Beruf als Wahrheitssucher es doch ist, Kausalitäten zu durchschauen?“1896

Wenn sich demnach - so die durchdachte Argumentation jener zeitgenössischen Kritiker der Wissenschaftspolitik nach I945 - ehemalige nationalsozialistische Hochschulprofessoren, die während des NS-Regimes zu den ,geistigen Führern der Nation“ zählten, nun als ideologisch Verführte zu entschuldigen versuchten, hätten sie damit gewissermaßen selbst ihr ,intellektuelles Vernichtungsurteil gesprochen. “1897 Dass kritische Reflexionen dieser Art keineswegs nur auf öffentlich verhandelte Einzelfälle zugeschnitten, sondern gleichsam ein Reflex auf die gesellschaftliche Praxis einer spezifisch eindimensionalen Form von „Vergangenheitsbewältigung“ (nicht nur im akademischen Bereich) waren, zeigt sich unter anderem auch am Beispiel der universitären ,Säuberungsmaßnahmen' in den einzelnen Bundesländern.

Besonders stark ausgeprägte restaurative Tendenzen sind im Fall der Universität Innsbruck festzustellen, wo die Diskriminierung liberaler, rational-moderner und demokratischer Ansätze zugunsten einer katholisch-konservativen, vormodernen, antiintellektuellen sowie antisemitischen Grundhaltung den traditionellen geistigen Humus bildeten. Trotz der Suspendierung zentraler NS-Hochschulfunktionäre wie des Historikers und „Anschluss“-Rektors Harold Steinacker und anderer exponierter NS-Parteigenossen, ${ }^{1898}$ zeigt sich in der Säuberungspraxis nicht nur eine gewisse Beliebigkeit, die nicht selten persönliche Konkurrenz zur Grundlage hatte, sondern darüber hinaus auch dezidiert Bemühungen um eine Rehabilitierung der „Opfer“ der Befreiung im Jahr i945. Einige, mit seltsam verdrehten Argumenten begründete Weiterverwendungen von Lehrpersonen konnten erst auf massiven Druck der französischen Militärbehörden (temporär) rückgängig gemacht werden. ${ }^{1899}$ Und das, obwohl auch in Tirol im Oktober 1945 Sonderkommissionen

1896 Die Wehrlosen. Zum Problem der nationalsozialistischen Hochschullehrer. Vereinigung demokratischer Hochschullehrer Österreichs, Wien 1946, 7.

1897 Ebd., 9 f.

1898 So bspw. die belasteten Philosophen Walter Schultze-Soelde und Walter Del Negro, der Althistoriker Franz Miltner oder der Volkskundler Adolf Helbok. Vgl. Peter Goller/Gerhard Oberkofler, Universität Innsbruck. Entnazifizierung und Rehabilitation von Nazikadern (1945-1950), Innsbruck 2003, $14 \mathrm{ff}$.

1899 So im Fall des Leiters des 1939 errichteten „Erb- und rassenbiologischen Instituts“, Friedrich Stumpfl, der erst 1946 auf Druck der französischen Besatzungsmacht entfernt wurde, wobei allerdings andere NS-Aktivisten wie der Psychiatrieprofessor Hans Ganner oder der Physiologe Theodor Wense nachrückten. Ein anderer Fall in diesem Zusammenhang ist der am 15. April 1946 trotz positiven Erstüberprüfungsverfahrens an der Universität Innsbruck durch das ministerielle Entnazifizierungskomitee enthobene Geograf Hans Kinzl (1898-1979), der 1934 in Heidelberg dem SA-Sturm beigetreten war und somit in Österreich nicht als „Illegaler“ gezählt wurde. Rektor Karl Brunner setzte sich gegen starken Druck der französischen Militärverwaltung für die Belassung Kienzls ein, und zwar mit Erfolg: 
zur politischen Überprüfung gebildet wurden, denen - anders als etwa in Wien oder der Steiermark - neben einem Vertreter der Widerstandsbewegung auch ein Vertreter der französischen Besatzungsmacht angehörte. ${ }^{1900}$ Die Zahl der, Ehemaligen' im öffentlichen Dienst war in Tirol „im Vergleich zu anderen Bundesländern überproportional“ ${ }^{\text {1901 hoch }}$ und die französische Besatzungsmacht, allem Anschein nach, - trotz anfangs harten Vorgehens in der Frage der „Desintoxication“ - insgesamt eher pragmatisch orientiert ${ }^{1902}$ und außerdem geprägt durch eine „Politik der Improvisation“; ${ }^{1903}$ über eigene Direktiven zur Entnazifizierung verfügte die französische Besatzungsmacht nicht.

Jedenfalls schafften es teilweise schwer belastete Universitätsprofessoren - und das ist wohl als sprichwörtliche ,Spitze des Eisbergs' zu sehen - trotz Entnazifizierungsverfahren im Amt zu bleiben und ihre Karriere nach 1945 ohne Brüche fortzusetzen. Ein Beispiel unter anderen bildet hier der Fall des Pathologen Franz Josef Lang - nach dem „Anschluss“ Dekan der Medizinischen Fakultät Innsbruck und deklarierter Verfechter der NS-Ideologie -, der trotz nachweislicher „Illegalität“ und „fördernder Mitgliedschaft“ bei der SS als Universitätsprofessor im Amt bleiben konnte: von seinem Nachfolger wurde ihm bestätigt, ab I94I an „Sitzungen“ der Widerstandsgruppe der Medizinischen Fakultät teilgenommen zu haben. Der Überprüfungsausschuss der Universität exkulpierte den „ausgezeichneten Wissenschaftler“ lapidar damit, charakterlich ein ,unpolitischer 'Mensch zu sein, „der sich den gegebenen Verhältnissen sehr gut anzupassen versteht. Zivilcourage scheint ihm, wie er selbst zugibt, völlig abzugehen. ${ }^{\text {1904 }}$

1947 wurde Kienzl, der bald darauf mit antisemitischen Aussagen gegenüber Kollegen auftrat, entregistriert, und zwar mit der Begründung, er selbst sei Opfer der Nazis, da diese seine Beförderung zum Ordinarius verzögert hätten. Siehe: Goller/Oberkofler, Universität Innsbruck. Entnazifizierung und Rehabilitation von Nazikadern, a.a.O., 18 bzw. 24 f. Darüber hinaus hielt neben den schwerbelasteten Medizinprofessoren Otto Stolz und (Felix?) Siegelbauer der ehemalige SA-Standartenführer Professor Franz Josef Lang Pathologievorlesungen. Weiters bekleidete der „Illegale“ und frühere stellvertretende Gaustudentenführer Franz Aubela die Stelle eines wissenschaftlichen Assistenten am Wirtschaftswissenschaftlichen Institut der Universität Innsbruck; zuletzt habe mit dem früheren Referenten der NS-Studentenführung, Harry Klein-Ehrenwalter, der erste „Illegale“ promoviert. Siehe: Suspendierte Professoren setzen ihre Tätigkeit fort. In: Österreichische Zeitung, 15. Oktober 1946, 2.

1900 Jürgen Klöckler, Ici l'Autriche - Pays Ami! Frankreich und die Entnazifizierung im besetzten Österreich 1945/46. In: Schuster/Weber (Hrsg.), Entnazifizierung, a.a.O., 468.

1901 Wilfried Beimrohr, Entnazifizierung in Tirol. In: Schuster/Weber (Hrsg.), Entnazifizierung, a.a.O., 109. Vgl. auch Stiefel, Nazifizierung plus Entnazifizierung = Null?, a.a.O., 30 .

1902 Vgl. Klöckler, Ici l'Autriche - Pays Ami! In: Schuster/Weber (Hrsg.), Entnazifizierung, a. a. O., 470. Vgl. auch Edith Petschnig, Alliierte Entnazifizierung in Österreich. In: Stefan Karner/Gottfried Stangler (Hrsg.), „Österreich ist frei!“ Der Österreichische Staatsvertrag 1955. Beitragsband zur Ausstellung auf Burg Schallaburg 2005. Unter Mitarbeit von Peter Fritz und Walter M. Iber, Horn Wien 2005, $110 \mathrm{f}$.

1903 Klaus Eisterer, Französische Besatzungspolitik. Tirol und Vorarlberg 1945/46 (Innsbrucker Forschungen zur Zeitgeschichte. Hrsg. v. Rolf Steininger, Bd. 9), Innsbruck 1992, 163.

1904 Goller/Oberkofler, Universität Innsbruck. Entnazifizierung und Rehabilitation von Nazikadern, a.a. O., 29. 
Auch an der in der britischen Besatzungszone gelegenen Universität Graz kam es im Frühjahr I946 zu Vorfällen, die auf das Fortwirken reaktionärer Kräfte beziehungsweise auf eine nur unzureichend durchgeführte Entnazifizierung hindeuten - angesichts dieser Vorfälle soll das Unterrichtsministerium kurzfristig sogar die Schließung der Universität erwogen haben. ${ }^{1905}$

Nachdem ein vom Unterrichtsministerium herausgegebener Erlass zu einer Verschärfung der Zulassungsbestimmungen durch die Sonderkommissionen führte und zusätzlich ein stärkeres Mitbestimmungsrecht der Österreichischen Hochschülerschaft vorsah, ${ }^{1906}$ planten, wie die Wahrheit, das „Organ der kommunistischen Partei für Steiermark“, vermeldete, die „faschistischen Kreise der steirischen Akademiker“, insbesondere die Medizinstudenten, aus Anlass von Verhaftungen und Entlassungen politisch belasteter Professoren sowie wegen Angriffen auf den Rektor einen großangelegten Streik an den Grazer Hochschulen. ${ }^{1907}$

Die Akademische Rundschau, ${ }^{1908}$ die unter Führung ihres Vorsitzenden Karl Leutgeb (ÖVP) für die „weitgehende Entpolitisierung der Hochschulen“1909 eintrat, berichtete im März ı946, dass der „zündende Funke“ die Verhaftung des Grazer Pathologen Friedrich Feyrters ${ }^{1910}$ gewesen sei, der „als verlässliche Stütze der steirischen Naziärzte“ seine Amtsgewalt dazu missbraucht hatte, „um unter anderem das klinische Nichtkönnen des SS-Untersturmführers Prof. Erhart [sic] zu decken." ${ }^{1911}$ Flugzettel und anonyme Briefe

1905 Zur Wahl des Akademischen Senats an der Grazer Universität. In: Akademische Rundschau, 1.Jg., 12. Oktober 1946, Nr. 3, 13.

1906 Bundesministerium für Unterricht, Erlass Z 3040/III-46, vom 2. Februar 1946.

1907 Wahrheit, vom 21. Februar 1946.

1908 Organ der Österreichischen Hochschülerschaft.

1909 Akademische Rundschau, 1. Jg., Nr. 15, Februar 1946, 1.

1910 Friedrich Feyrter (1895-1973), zunächst in Wien, Breslau und Danzig tätig, wurde 1941 an das Institut für Pathologie der Universität Graz berufen. Zu Feyrter, der nach seiner Suspendierung in Graz schließlich nach Göttingen ging, steht auf der Homepage der Medizinischen Universität Graz zu lesen (Stand: 20. August 2006): „Seine wissenschaftlichen Verdienste aufzuführen, würde den Rahmen dieser Seite sprengen. [...] Die Ungunst der Zeit, vielleicht auch unterstützt durch den markanten Charakter Feyrters, setzte seinem Wirken in Graz 1945 ein Ende. [Vgl. H. Denk, Die Pathologie in Graz, siehe: http://www. meduni-graz.at/pathologie/909; Zugriff 28.1.2013]. Auch in der medizinischen Doktorarbeit von Michael Davis Shappiro, The Role of Connective Tissue Growth Factor (CTGF) in Fibrosis. Associated With Intestinal Neuroendocrine Tumors, Yale 2005, 23, werden die Forschungsarbeiten Feyrters aus den Jahren 1938 ff. unkommentiert übernommen. Vgl. auch Huber, Studenten im Schatten der NS-Zeit, a.a.O., 85.

1911 Student sein in Graz! In: Akademische Rundschau, 1. Jg., März 1946, Folge 20, 4. Vermutlich war hier der Gynäkologe Karl Erhardt gemeint, der 1939-1945 die Universitätsfrauenklinik Graz geleitet hattte, und gegen den im März 1946 ein Verfahren wegen schwerer ärztlicher Kunstfehler, mangelndem chirurgischem Können und tödlichen Menschenexperimenten (u.a. an Schwangeren) eingeleitet wurde; nachdem sich Erhardt nach Deutschland abgesetzt hatte, wurde das Verfahren 1954 wegen Verjährung eingestellt. Siehe: Gabriele Czarnowski, NS-Menschenversuche an der Grazer Frauenklinik. Gedenktagung: 60 Jahre Nürnberger Ärzteprozess (11.9.2007), 4. [Siehe: http://smz.at/wp-content/uploads/2011/03/ Bericht_Tagung.pdf, Zugriff 29.7.2012] 
sowie eine „fieberhafte Gerücht- und Flüsterpropaganda“"1912 drängten auf einen Streik der Studentenschaft, zu dem es dann schließlich doch nicht kam.

Erleichtert über den geringen Widerhall der Provokateure und die „ehrliche“ Empörung der meisten Grazer Studierenden, sah sich die Akademische Rundschau angesichts der Realität des Studienbetriebes dennoch zur Kritik am Status quo genötigt - sie stellte fest, dass sich der „Geist der Vorlesungen [...] kaum geändert“ hätte. Immer noch werde „Preußen verherrlicht und Österreichs, Großdeutsche Sendung 'im Südosten betont. Selbst in total unpolitischen Fächern kann man sich Seitenhiebe auf Österreich, einzelne Parteien und Alliierte nicht enthalten. Kein Wunder bei der politischen Vergangenheit des überwiegenden Teiles der Professoren! Fast jeder war Pg. und füllte als solcher seinen Posten voll und ganz aus, er war vielleicht sogar höherer SA- oder SS-Führer, was hier bis jetzt durchaus nicht immer ein Hindernis ist, den Lehrstuhl weiter zu behalten. “1913

Wie aus einem Bericht des alliierten De-Nazifizierungskomitees hervorgeht, befanden sich unter den 66 Professoren an der Universität und den Hochschulen in Graz und Leoben insgesamt 25, die - aufgrund ihrer NSDAP-Mitgliedschaft belastet - wegen „Unersetzbarkeit" weiter in Dienst belassen wurden: „[...] in all cases, the Landeshauptmann and the professorial committee recommended retention on grounds of indispensibility. “1914

Inwieweit die geschilderten Zustände mit der zonalen Politik der Britischen Militärbehörden im Zusammenhang stehen, lässt sich zum gegenwärtigen Stand nur vermuten, da über die britische Hochschulpolitik im Zusammenhang mit den politischen ,Säuberungsmaßnahmen' bisher noch keine Fallstudie vorliegt. Tatsache ist, dass die lokalen britischen Militärbehörden nach einer harten, auf Bestrafung zielenden ,Säuberungsphase' nach Abzug der Sowjets Ende Juli 1945 - wobei die „Illegalen“ allerdings weitgehend verschont blieben ${ }^{1915}$ - bald einen pragmatisch-formalen Kurs in der Entnazifizierung einschlugen, der jedoch von Ambivalenzen geprägt war. Gegenüber den Anhängern des Austrofaschismus war man deutlich „milder gestimmt“, ${ }^{1916}$ um die „gesellschaftliche Versöhnung Österreichs ${ }^{\text {“1917 }}$ nicht zu gefährden, ging in der Verhaftungs- und Entnazifizierungspraxis aber vergleichsweise strikt vor. Grundsätzlich vertraten die Briten die Ansicht, dass die

1912 Ebd., 4.

1913 Ebd.

1914 Der Bericht enthält die vollständigen Namenslisten und Kurzangaben (inklusive NSDAP-Beitrittsdatum) aller belasteten aber weiter in Dienst gestellten Professoren sowie die Namenslisten aller enthobenen Lehrkräfte. Siehe: Report of Quadripartite Sub-Committee on Denazification in Austrian Universities, 7. September 1946. NARA II, RG 260, Box 11, Folder 68. Records of the United States Occupation Headquarters, World War II, USFA/USACA, Internal Affairs/Displaced Persons Division, Denazification Branch, General Records, 1945-50, 3.

1915 Siegfried Beer, Die britische Entnazifizierung in Österreich 1945-1948. In: Schuster/Weber (Hrsg.), Entnazifizierung, a.a.O., 406.

1916 Robert Knight, Britische Entnazifizierungspolitik 1945-1949. In: Zeitgeschichte, 14. Jg., 1987, Heft 9-10, 289.

1917 Ebd. 
personellen Säuberungen von österreichischen Stellen durchzuführen waren; andererseits wurde die Ineffizienz der österreichischen Komitees wiederholt kritisiert und insbesondere „Mängel an Kooperationsbereitschaft, häufige Hinhaltetaktik“ ${ }^{1918}$ sowie „Freunderlwirtschaft ${ }^{\text {“1919 }}$ als Problemfelder benannt.

Die Akademische Rundschau resümierte die beschriebenen Vorgänge in nüchterner Art und Weise. So hielt die Zeitschrift lapidar fest, dass der Umstand, dass es nicht zur geplanten Studentendemonstration gekommen war, „wahrlich kein Verdienst einer klugen staatlichen oder politischen Lenkung ${ }^{\text {“1920 }}$ sei.

Anlässlich der im Herbst 1946 durchgeführten Grazer Hochschulwoche, an deren Eröffnung neben den Vertretern der britischen Militärregierung, österreichischen Landespolitikern und Vertretern des katholischen Klerus auch Professoren ausländischer Hochschulen teilnahmen, war dann bereits wieder Grund zum Feiern gegeben. In seinen Eröffnungsworten wies Rektor Karl Rauch auf die besondere Bedeutung der Feier hin, die immerhin mit der 950-Jahr-Feier der Namensgebung Österreichs zusammenfalle. Der Leiter der Education Branch hielt eine „Ansprache in deutscher Sprache, die von allen $\mathrm{Zu}-$ hörern mit lautem Beifall aufgenommen wurde.“ Darin gedachte er der Aufgaben, „die den österreichischen Hochschulen heute gestellt sind und gab seiner Überzeugung Ausdruck, dass die Grazer Hochschulen ihrer Sendung auf dem vorgeschobensten Posten deutschen Kulturkreises gerecht werden“. ${ }^{1921}$

An der in der Französischen Besatzungszone gelegenen Universität Innsbruck sah die Situation im Übrigen nicht anders aus: von den insgesamt ${ }_{7}$ Professoren waren im Herbstsemester 1946 nur I9 "belastet“, weitere I4 Fälle unentschieden und noch in Verhandlung, lediglich ${ }_{4}$ Professoren waren „enthoben“ ${ }^{1922}$

$\mathrm{Zu}$ einer deutlichen Verschärfung der Zugangsbestimmungen für Studenten kam es schließlich durch den Erlass des Unterrichtsministeriums vom 2. Februar 1946 (Z1. 3040/III), wonach nun alle Studierenden noch vor ihrer kommissionellen Überprüfung zunächst ein politisches Zuverlässigkeitszeugnis der Staatspolizei vorlegen mussten. $\mathrm{Zu}-$ sätzlich wurde im universitären Personalreferat der Universität eine Kartei aller österreichischen Studierenden angelegt, um zu verhindern, dass an einer Universität abgewiesene Studenten an einer anderen Aufnahme finden konnten. ${ }^{1923}$

1918 Beer, Die britische Entnazifizierung in Österreich 1945-1948. In: Schuster/Weber (Hrsg.), Entnazifizierung, a.a.O., 406.

1919 Felix Schneider, Aspekte britischer Sicherheitspolitik zur Zeit der Besatzung in Österreich 1945-1948. Unter besonderer Berücksichtigung der Steiermark, Dipl.-Arb, Univ. Graz 1993, 53.

1920 Student sein in Graz! In: Akademische Rundschau, 1. Jg., März 1946, Nr. $20,4$.

1921 Die Grazer Hochschulen - ein wertvolles Glied unseres Geisteslebens. In: Akademische Rundschau, 2. Jg., 26. Oktober 1946, Nr. $5,9$.

1922 Report of Quadripartite Sub-Committee on Denazification in Austrian Universities, 7th September 1946, a.a.O., 3a.

1923 Wiener Kurier, 2. Jg., Nr. 62, 14. März 1946, 3. 
Von nun an wurden drei Gruppen unterschieden: politisch unbelastete Studenten, minderbelastete Studenten wie HJ-Mitglieder vom Gefolgschaftsführer aufwärts und BDMMitglieder sowie all jene, die wegen ihrer politischen Tätigkeit - also Illegale, Angehörige der SS, der NS-Wehrverbände vom Unteroffizier aufwärts, NSDAP-Funktionäre, NSFührungsoffiziere der deutschen Wehrmacht ${ }^{1924}$ Funktionäre des Nationalsozialistischen Deutschen Studentenbundes (NSDStB) sowie der Arbeitsgemeinschaft Nationalsozialistischer Studentinnen (ANST) - ausgeschlossen waren. Besonders überprüft wurden auch Offiziere der deutschen Wehrmacht, selbst wenn sie nicht Mitglieder der NSDAP waren. ${ }^{1925}$ Ein Umstand, der von Bundeskanzler Figl anlässlich der Feier zum Gründungstag des FÖST kritisiert wurde, indem er sich als Parteiobmann dagegen aussprach, dass ,heute versucht wird, diesen jungen Kämpfern für Österreich [sic], auch wenn sie Offiziersdistinktionen trugen, Schwierigkeiten zu machen. ${ }^{\text {“1926 }}$

Wie die Akademische Rundschau berichtete, brachte dieser Erlass ${ }^{1927}$ neben einer ,gewissen Verschärfung" auch ein stärkeres Mitbestimmungsrecht der Österreichischen Hochschülerschaft. Eine zweite Gruppe - darunter insbesondere Wehrmachtsoffiziere, Mitglieder von nicht schon grundsätzlich ausgeschlossenen NS-Organisationen sowie NSDAP-Förderer und nichtorganisierte Nationalsozialisten -, , die sich durch Denunziation, Mitarbeit oder sonst wie hervorgetan haben“, war „einer besonders strengen Prüfung zu unterziehen“ ${ }^{1928}$ wobei der „Nachweis antifaschistischer Betätigung noch vor der Befreiung Österreichs und Kriegsversehrtheit höheren Grades positiv gewertet werden“1929 könnte. Die Akademische Rundschau schrieb dazu weiter:

„Minderbelasteten dieser Art, deren österreichische und demokratische Einstellung für die Zukunft außer Zweifel steht, kann gelegentlich ihrer Zulassung zur Inskription eine Sühne in Form einer Arbeitsleistung für den Wiederaufbau der Hochschule in der Dauer von ein bis sechs Monaten vorgeschrieben werden. Von der Erfüllung des Arbeitsdienstes wird die Anrechnung des Semesters abhängig gemacht. ${ }^{(1930}$

Dem von den sozialistischen Studenten geleiteten „Komitee geschädigter Hochschüler“ rund r. 000 Studierende (ca. ro Prozent aller Inskribierten) der Universität Wien waren

1924 Akademische Rundschau, 1. Jg., Nr. 23, 13.

1925 Wiener Kurier, 2. Jg., Nr. 62, 14. März 1946, 3.

1926 Der Student, 1. Jg., 1945, F. 9, 6. Zit. nach: Forster, Die Geschichte der Österreichischen Hochschülerschaft 1945-1955, a.a.O., 106.

1927 Vgl. dazu weiters die Berichterstattung über die Novellierung des Erlasses (Z1. 30494/III-7/46): Politische Überprüfung von belasteten Studierenden. In: Akademische Rundschau, 2. Jg., 1946, Nr. 5, 26. Oktober 1946, 2.

1928 Ebd.

1929 Ebd.

1930 Ebd. 
als Naziopfer registriert ${ }^{1931}$ - gelang es außerdem gegen den Widerstand des FÖST, dass diese Gruppe mit Sitz und Stimme in den Zentralausschuss der ÖH aufgenommen wurde, um das „enorme Übergewicht konservativer Kräfte“ ein wenig zu schwächen. ${ }^{1932}$

Dessen ungeachtet ereigneten sich ab dem Frühjahr 1946 weiterhin Vorfälle an der Universität Wien, die deutlich machten, dass die Entnazifizierung sowohl innerhalb der Professorenschaft als auch im Bereich der Studierenden keineswegs mit der nötigen Gründlichkeit erfolgte. So kam es unter anderem im März an der juridischen Fakultät im Hörsaal 33 während einer gut besuchten Vorlesung von Hans Planitz - wie bereits erwähnt, einer der beiden ständigen Vertreter der Senatsvorsitzenden der Sonderkommissionen an der Universität Wien -, in der unter anderem auch die „entrechtete und menschenunwürdige Stellung der Juden im Mittelalter" angesprochen wurde, zu antisemitischen Kundgebungen von Studierenden, die sich bemüßigt fühlten, ,durch längeres Fußgetrampel und ein Radaukonzert seiner Sympathie für die Judenverfolgung des Mittelalters Ausdruck zu geben. ${ }^{\text {“1933 }}$ Planitz, der eigenen Angaben zufolge die ungebührlichen Äußerungen sofort mit der Bemerkung „Ich bitte alle politischen Demonstrationen zu unterlassen!“1934 abgeschnitten habe, sprach im Wortlaut eines nachfolgenden Protokolls bezeichnenderweise ganz selbstverständlich von Äußerungen einer kleinen Gruppe nationalsozialistisch gesinnter Hörer: „Ich habe damals über die wirtschaftliche Bedeutung der Juden gesprochen und gewann den Eindruck, daß dies bei Hörern nat.soz. Gesinnung ein Mißfallen auslöste. ${ }^{\text {"1935 }}$

Planitz bemühte sich - und das ist wohl als signifikant für die damalige geistige Situation an den Universitäten anzusehen - diesen Vorfall als Ausdruck der existierenden „Lehrund Lernfreiheit" hinunterzuspielen. ${ }^{1936}$ Obwohl diesem Ereignis - die Österreichische Zeitung ausgenommen - in der öffentlichen Berichterstattung keine weitere Beachtung geschenkt wurde, interessierte sich immerhin das amerikanische CIC für diesen Vorfall. Der die Untersuchung führende US-Offizier Mr. Martin forderte eine Liste mit Namen von Zeugen beziehungsweise Informanten an ${ }^{1937}$ und wies darauf hin, dass bei allen künf-

1931 Diesen wurde eine staatspolizeiliche Überprüfung erspart, die Studiengebühren erlassen und alle Arbeitseinsätze erspart.

1932 Forster, Die Geschichte der Österreichischen Hochschülerschaft 1945-1955, a.a. O., 110.

1933 Österreichische Zeitung, 23. März 1946.

1934 UAW, Rektoratsakten GZ 342-1945/46, Planitz an Rektor Adamovich, 29. März 1946, 1 [GZ 342/ 2791].

1935 UAW, Rektoratsakten GZ 342-1945/46, Protokoll vom 11. April 1946 im Institut für Kriminologie mit Univ.-Prof. Dr. Hans Planitz, 1.

1936 Dieser Fall findet sich in der Diplomarbeit von Andreas Huber erstmals dokumentiert. Vgl. Huber, Studenten im Schatten der NS-Zeit, a.a.O., 143.

1937 Genannt wurden hierbei die studentischen Zeugen Josef Dörfl, Leonhardt Hechtl und Gerald Mader, sowie der Informant „stud. Jur.“ Eduard Rabowsky [sic]. Siehe: Österreichische Hochschülerschaft an Rektor Ludwig Adamovich, betref. Rücksprache des Fachgruppenleiters am 4. April 1946 über die Behandlung der Affäre „Planitz“ vor dem amerikanischen CIC. UAW, Rektoratsakten, GZ 342-1945/46. 
tigen Vorfällen dieser Art der CIC „a priori unterrichtet werden sollte. “1938 Dass sich der amerikanische Militärgeheimdienst für diese Angelegenheit interessierte - bei der Unterredung mit dem CIC waren auch Parteienvertreter anwesend ${ }^{1939}$ - ist nicht weiter verwunderlich und dürfte auch keineswegs ein Einzelfall gewesen sein, nur: Auswirkungen hatten derartige informelle Kontaktaufnahmen keine. ${ }^{1940}$

Und dass es sich bei den erwähnten nazistischen Provokationen und Vorfällen auf dem Boden der Universität keineswegs um akademische Randerscheinungen handelte, die fern der gesellschaftlichen Realität stattfanden, sondern darin grassierende Einstellungen und Stimmungen in der breiten Bevölkerung deutlich werden, illustrieren die polizeilichen Situationsberichte für Wien. So hielt ein Wochenbericht im August 1946 fest:

„In der letzten Zeit ist die Stimmung unter den ehemaligen Nationalsozialisten etwas lebhafter geworden. Sie zeigen Freude an der schlechten Ernährungslage und anderen zutage tretenden Missständen. Der Einfluss, den sie auf diese Weise ausüben, ist nicht unbeachtlich. Selbst die den Nazis keineswegs zugeneigten Leute hört man öfters klagen, dass es unter Hitler doch besser gewesen sei. Wiederholt wird beobachtet, dass jüngere Burschen ohne Scheu Abzeichen und Ausrüstungsgegenstände wie Koppel, Edelweiß und Wehrsportabzeichen aus der Nazizeit tragen. Nach einem stark verbreiteten Gerücht sollen bereits illegale Organisationen am Werk sein, welche Weisungen und Material aus den westlichen Bundesländern erhalten und Terroraktionen vorbereiten $[\ldots] .{ }^{“ 1941}$

\section{ÖH-Wablen November 1946: erste Großdemonstration gegen "nazistische Umtriebe" in der Zweiten Republik und die Folgen}

Anlässlich der ersten Österreichischen Hochschülerschaftswahlen, die am I9. November I946 an allen Universitäten des Landes abgehalten wurden, kam es zur ersten Großdemonstration ${ }^{1942}$ gegen nazistische Umtriebe in der Zweiten Republik, die in tumultartigen Auseinan-

\section{Ebd.}

1939 So Fritz Köhler für die ÖVP, Viktor Heller für die SPÖ und Hans Kaes für die KPÖ. Ebd.

1940 Als im Mai 1946 der Leiter der Rektoratskanzlei, Rudolf Fischer, eine studentische Aussage protokollierte, wonach wiederholt Studierende in SS-Stiefeln und SS-Hosen auf Boden der Universität gesichtet worden seien und diese auch Vorlesungen besuchten, führte dies zur Weisung des akademischen Senats, künftig alle Verdächtigen „anzuhalten, ihre Nationale aufzunehmen und dem Rektorate Meldung zu erstatten“; Meldungen dieser Art blieben aber Ausnahmefälle. UAW, RA GZ 100/III-1945 /46, O.-Nr. 228, Amtsvermerk von Rudolf Fischer, 10. Mai. Zit. nach: Huber, Studenten im Schatten der NS-Zeit, a.a.O., 145.

1941 Zit. nach: Friedrich Wilhelm Schembor, Polizeiliche Situationsberichte für die Jahre 1945 und 1946. In: Studien zur Wiener Geschichte. Jahrbuch des Vereins für Geschichte der Stadt Wien. Hrsg. v. Ferdinand Oppl/Maria Altfahrt/Karl Fischer. Bd. 59, Wien 2003, 275.

1942 Die vermutlich allererste Großdemonstration in der Zweiten Republik fand kurz zuvor am 25. Oktober 1946 in der Sowjetischen Zone in Wiener Neustadt statt, wo 4.000 Werktätige für die Erhöhung der 
dersetzungen und Schlägereien gipfelte und dabei 3r zum Teil schwer Verletzte $^{1943}$ forderte. Obwohl mit der Diplomarbeit von Andreas Huber, die nach der Niederschrift dieses Kapitels fertiggestellt wurde, nun eine erste, auf Primärquellen basierende Arbeit zur Entnazifizierung der Wiener Studentenschaft vorliegt und unter anderem auch detailliert auf die Geschehnisse rund um die erste ÖH-Wahl eingeht, scheint es dennoch sinnvoll zu sein, dieses Ereignis im Folgenden - unter Einbeziehung des von Huber bearbeiteten Materials - etwas eingehender zu behandeln. Zum einen deshalb, weil der thematische Schwerpunkt der vorliegenden Studie eine andere Kontextualisierung und eine andere Interpretation jener Ereignisse ermöglicht, zum anderen, weil zum Teil andere beziehungsweise zusätzliche Quellen verwendet wurden, die einander zudem gut ergänzen.

Laut österreichischem Hochschulgesetz vom 3. September 1945 war für das Studienjahr 1946 / 47 eine allgemeine freie Wahl der Hochschulvertreter vorgesehen. Die alliierten Behörden machten das Plazet für die Wahl von der strikten Säuberung der Hochschulen abhängig, wodurch sich der Termin verzögerte und die Wahl erst im Wintersemester stattfinden konnte; zuletzt hatten noch die Sowjets im Alliierten Rat Einwände geäußert, weil sie eine politische Meinungsbildung an den Universitäten zum damaligen Zeitpunkt verhindern wollten. Am ro. Oktober wurde die Durchführung der ersten ÖH-Wahlen vom Unterrichtsministerium aber schließlich für Dienstag, den 19. November 1946 genehmigt. Die Wahl sollte als Listenwahl der drei wahlwerbenden Studentenorganisationen (FÖST, VSStÖ, KSBV $)^{1944}$ stattfinden, wobei am Wahltag im Umkreis von roo Metern Entfernung jegliche Wahlwerbung von den Hochschulen untersagt war.

Von den amerikanischen und britischen Besatzungsbehörden wurde beanstandet, dass die Wahl auf die drei wahlwerbenden Studentenfraktionen beschränkt wurde, worin man eine ernstzunehmende demokratiepolitische Einschränkung sah. Nach scharfen Angriffen gegen die Wiener Hochschulen im Neuen Österreich und im Wiener Kurier kam es zu einer Aussprache zwischen dem Leiter der US-Education Division Thomas Benner und Rektor Adamovich. Dabei beanstandete Benner insbesondere die Beschränkung der Wahl auf die drei wahlwerbenden Gruppierungen, zeigte sich aber mit der Absicht der Rektoren einverstanden, die Wahl nicht auf dem Boden der Universität, sondern in den jeweiligen Räumlichkeiten der Hochschülerschaft durchführen zu lassen. ${ }^{1945} \mathrm{Am}$ 26. September hatte

Lebensmittelrationen und für bessere soziale Verhältnisse auf die Straße gingen. Zudem wurde von den Demonstranten heftig kritisiert, dass es in Wiener Neustadt auch 17 Monate nach der Befreiung noch immer keinen Gemeinderat gab. Vgl. Österreichische Zeitung, 26. Oktober 1946, 2.

1943 Akademische Rundschau, 2. Jg., Nr. 10, 30. November 1946, 36.

1944 Die Vereinigung demokratischer Studenten (VdS), die sich nominell als unparteiliche Gruppierung gerierte, war vom Innenministerium abgelehnt worden, da man in ihr eine Tarnorganisation extrem linker Kräfte vermutete. Siehe dazu: Forster, Die Geschichte der Österreichischen Hochschülerschaft 19451955 , a.a.O., 114.

1945 UAW, Senats-Sitzungsprotokolle des Studienjahres 1946/47, Protokoll der 4. Sitzung des Akademischen Senates der Universität Wien, 16. November 1946, 2. 
eine neuerliche Rektorenkonferenz stattgefunden, bei der die Wünsche für die Gestaltung der Wahlordnung festgelegt wurden. Dabei wurde insbesondere verlangt, dass „die Wahlen nicht in den Räumen der zuständigen Hochschülerschaft durchgeführt werden. ${ }^{1946}$ Diesem Ansinnen widersprach jedoch das Bundesministerium für Unterricht und verfügte mit Erlass vom ro. Oktober (Z1.34.558/III-7/46) und der angeschlossenen Wahlordnung, dass die Wahlen auf Universitätsboden durchgeführt werden müssen und dass Wahlwerbung seitens der Studentenfraktionen - mit Ausnahme des Wahltages selbst -, entgegen dem Beschluss der Rektorenkonferenz, zugelassen sein sollte. ${ }^{1947}$ Dieses Hinwegsetzen über die Beschlüsse der Rektorenkonferenz hatte einen tiefen Riss im Verhältnis zwischen Universität Wien und dem Unterrichtsministerium beziehungsweise Minister Hurdes zur Folge, ${ }^{1948}$ und führte auch zu einer Protestnote von Rektor Adamovich an das Unterrichtsministerium und einem ersten Rücktrittsgesuch, das allerdings ebenso unbeantwortet blieb wie die Protestnote. ${ }^{1949}$

Interessanterweise war es Thomas Benner als Leiter der US-Education Division, der Adamovich in einem Schreiben „inoffiziell“ und als „persönlichen Freund“ darauf drängte, „weise zu sein“, sein Rücktrittsgesuch im Sinne der Kollegenschaft und der bevorstehenden ÖH-Wahlen zu überdenken: „We feel, therefore, that your experienced leadership is greatly needed at this time. " 1950

Noch vor Beginn der Wahlversammlungen am I2. November I946 kam es zu einem ersten Eklat, nachdem die Rektorenkonferenz fünf Tage zuvor beschlossen hatte, eine auf breiter Basis durchgeführte Plakat- und Flugblattwerbung auf Universitätsboden zu verbieten. ${ }^{1951}$ Außerdem war gegen Heribert Husinsky, Unions-Mitglied und Chefredakteur des interfraktionellen ÖH-Organs Akademische Rundschau, ein Disziplinarverfahren eingeleitet worden, da dieser gewagt hatte, in einem Artikel die Bürokratie einzelner akade-

1946 In Wien standen der Hochschülerschaft die Räume des vier Stockwerke hohen Gebäudes in der Kolingasse 19, im 9. Wiener Gemeindebezirk zur Verfügung, die vom früheren Nationalsozialistischen Studentenwerk übernommen wurden.

1947 UAW, Senats-Sitzungsprotokolle des Studienjahres 1946/47, Protokoll der 4. Sitzung des Akademischen Senates der Universität Wien, 16. November 1946, Sachverhaltsdarstellung. Rektor Adamovich an das Bundesministerium für Unterricht zuhanden Herrn Sektionschef Wilhelm Krechler, 15. November 12946, 1.

1948 UAW, Senats-Sitzungsprotokolle des Studienjahres 1946/47, Protokoll der außerordentlichen Senatssitzung, 20. November 1946, 3. Hier erklärte Adamovich, dass er der Ansicht sei, „daß man sich dem Rektor der größten Universität Österreichs gegenüber nicht so benehmen könne, wie es der Minister tue. Der Prorektor müsste vom Senat ersucht werden, bei Sektionschef Skrbensky oder Minister Dr. Hurdes vorstellig zu werden, um diesem Zustand endlich ein Ende zu bereiten. " Zit. nach: ebd.

1949 Huber, Studenten im Schatten der NS-Zeit, a.a.O., 156.

1950 ÖSTA/AdR, BMfU, GZ 38648-1946, Thomas E. Benner an Ludwig Adamovich, 28. Oktober 1946; zit. nach: Huber, Studenten im Schatten der NS-Zeit, a.a.O., 157.

1951 „Gesamte Hochschülerschaft nimmt gegen Rektoratsverfügung Stellung“. In: Wiener Kurier. Herausgegeben von den Amerikanischen Streitkräften für die Wiener Bevölkerung, 14. November 1946, 4. 
mischer Stellen zu kritisieren und sie „lächerlich mache“1952 beziehungsweise „jede Kritik die akademischen Behörden lächerlich mache und die Universität in Mißkredit bringe.“ Das Rektorat der Universität Wien erklärte, künftig keinerlei Kritik an den akademischen Behörden zu dulden und verfügte, dass die Akademische Rundschau künftig nicht mehr auf Hochschulboden vertrieben beziehungsweise verkauft werden darf. ${ }^{1953}$

Als Reaktion auf dieses Verbot richtete die US-Information Services Branch gemeinsam mit der britischen ISB ein verklausuliertes Unterstützungsschreiben an die Leitung der Akademischen Rundschau, worin in Form einer allgemein gehaltenen, philosophischpädagogischen Reflexion zu Fragen einer vorurteilslosen Bildung und Erziehung - wenn auch mit deutlich anglo-amerikanischer Einfärbung - Mut zur Kritik ausgesprochen wurde: „Eine menschliche Gemeinschaft, die ihren Mitgliedern nicht gestattet, an ihren Zielen und Methoden Kritik zu üben, wird mit der Zeit erstarren, wenn nicht zugrunde gehen. Lebendiger, aggressiver Individualismus, der niemals vor Kritik zurückschreckt, ist eine Vorbedingung für ein gesundes menschliches Zusammenleben auf demokratischer Grundlage. “1954

In einer gemeinsamen Resolution gegen Inhalt und „Geist“ dieser Beschlüsse appellierten die Hochschülervertretungen der drei wahlwerbenden Parteien an die „demokratische Presse und die gesamte Öffentlichkeit“: „Die drei wahlwerbenden Gruppen sind der Ansicht, dass dadurch die Freiheit der Wahl und die damit verbundene Wahlwerbung nicht mehr gewährleistet erscheint und diese Verfügungen in keinerlei Einklang mit der Demokratie zu bringen sind. “1955

Bereits zu Beginn der Wahlversammlungen am I2. November 1946 war es zu ersten Zwischenfällen an der Tierärztlichen Hochschule gekommen, bei denen es sich primär um antisowjetische „Ausfälle“ gehandelt haben soll. ${ }^{1956}$ Auch in einer darauf folgenden Wahlversammlung im Auditorium Maximum der Universität Wien soll es zu desavouierenden, „wüsten Zurufen und Gejohle“ von FÖST-Anhängern gegenüber Vertretern der kommunistischen und sozialistischen Studentenfraktionen gekommen sein, wobei auch deutlich antisemitische Ressentiments laut wurden. ${ }^{1957}$

1952 Heribert Husinsky, Vertrieb der „Akademischen Rundschau“ auf Hochschulboden von der Rektorenkonferenz verboten. In: Akademische Rundschau, 2. Jg., 16. November 1946, Nr. 8, 1.

1953 Für die Freiheit der Hochschulen. Arbeiterzeitung, Nr. 261, 9. November 1946, 2. Am 28. November 1946 folgte eine Hausdurchsuchung der Staatspolizei in der Redaktion der Akademischen Rundschau in der Kolingasse, nachdem diese am 23. November unter dem Titel „Unerhörte Provokation am Wahltag“so der Vorwurf - die Behörden herabgewürdigt hätte. Vgl. Vertrieb der „Akademischen Rundschau“ auf Hochschulboden von der Rektorenkonferenz verboten. In: Akademische Rundschau, 2. Jg., 1946, Nr. 8, 1; vgl. weiters: Akademische Rundschau, 2. Jg., 1946, Nr. 11, 6. Dezember 1946; siehe auch: Forster, Die Geschichte der Österreichischen Hochschülerschaft 1945-1955, a.a.O., $130 \mathrm{f.}$

1954 „Mut zur Kritik“. In: Akademische Rundschau, 2. Jg., 1946, 16. November 1946, Nr. 8, 2.

1955 „Für die Freiheit der Hochschulen“. In: Arbeiterzeitung, 9. November 1946, Nr. 261, 2.

1956 ÖSTA/AdR, BMI, Mappe: Die Hochschulwahlen in Wien, Anhang zu Tagesbericht Nr. 339 der PD Wien, 16. November 1946, 2. Zit. nach: Huber, Studenten im Schatten der NS-Zeit, a.a.O., 162.

1957 Siehe: Huber, Studenten im Schatten der NS-Zeit, a.a.O., 162 f. 
Am I4. November kam es dann bei einer allgemeinen Wahlversammlung im Auditorium Maximum, an der laut Polizeibericht rund 200 Studierende niedrigen Semesters hauptsächlich Medizinstudenten - teilgenommen hätten und bei der auch Rektor Adamovich zugegen war, bereits zu heftigen Auseinandersetzungen, die in der Presse breit kommentiert wurden. Insbesondere nahmen aber die Volksstimme und die von den Sowjets kontrollierte Österreichische Zeitung - wohl nicht zuletzt auch wegen der offen antikommunistischen Anfeindungen - die Ereignisse zum Anlass, die Gefahr eines Wiederauflebens von nazistischem Gedankengut sowie die bisherige, als völlig unzureichend erachtete Entnazifizierung an den österreichischen Hochschulen hervorzuheben. Nachdem es auch an der Hochschule für Welthandel, ${ }^{1958}$ an der Juridischen Fakultät und am I. Chemischen Institut zu antisemitischen und nazistischen Ausschreitungen mit „wüsten sowjetfeindlichen Ausfällen“ gekommen war, bei denen dem Ex-Offizier und kommunistischen Spitzenkandidaten Lothar Kloimstein „abknallen, diese Sau!“1959 entgegengebrüllt und in provokativen Sprechchören „Wir wählen nicht schwarz, wir wählen nicht rot, wir wählen schwarzweißrot" skandiert worden sein soll, hatten sich die Wiener Hochschulen in den Augen der kommunistischen Presse in „eine Keimzelle der verbrecherischen Tätigkeit faschistischer Wehrmachtsoffiziere verwandelt." 1960

Tatsächlich wurden die tumulthaften Vorfälle samt der nazistischen Provokationen auch im Organ der sozialistischen Studenten bestätigt, das sich insbesondere angesichts der deutlichen Resonanz derartiger Provokationen in der anwesenden Menge besorgte zeigte:

\begin{abstract}
„SS-Männer, Ritterkreuzträger und kriegslüsterne Rufer werden mit Beifall empfangen, KZler hingegen will man mit Gejohle und Pfeifkonzerten zum Schweigen bringen, österreichische Freiheitskämpfer nennt diese Menge Feiglinge und der Militarismus jeglicher Art feiert fröhliche Urständ.

Dem Arbeiter, dem Antifaschisten, dem Manne mit gesundem Menschenverstand, bleibt es ein Rätsel, wieso man in unserer Republik Eichenlaubträgern, Obersten und verbissenen Nazi vor Ablauf einer gewissen Arbeitsfrist in einem Bleibergwerk das Studium und somit die Ausbildung zum faschistischen General der Reserve gestatten konnte. “1961
\end{abstract}

Diese Geschehnisse sowie die folgenden Ausschreitungen bei der ÖH-Wahl veranlassten dann auch den US-Gesandten in Österreich, John G. Erhardt, der grundsätzlich davon

1958 Dort war es u.a. nach Anwürfen gegen den sozialistischen Kandidaten Josef Schneeweiß, der als ehemaliger politischer KZ-Häftling als ,Feigling' beschimpft wurde, zur offenkundig einzig dokumentierten Verhaftung eines Studenten durch die Staatspolizei gekommen, der in das Auditorium gerufen hatte: „Heut lauft ihr dem Julius Deutsch nach, dem Saujuden, der in Amerika gesessen ist.“ Zit. nach: Huber, Studenten im Schatten der NS-Zeit, a.a.O., 167.f.

1959 Volksstimme, Nr. 267, 16. November 1946, 1.

1960 Österreichische Zeitung, 16. November 1946, 1.

1961 „Provokationen und ihr Widerhall“. In: Strom, 2. Jg., Folge 39, 23. November 1946, 10. 
überzeugt schien, die Großdemonstration sei von kommunistischer Seite geplant und „gesponsert" worden und der Nationalratsabgeordnete Ernst Fischer hätte sich dabei „unzweifelhaft“ einer „unscrupulous demagoguery“ schuldig gemacht, ${ }^{1962}$ nach den Wahlen zu folgendem Lagebericht an das State Department:

\begin{abstract}
"There can be no doubt that a good number of Nazis are among the student body, and that some members of the faculty are still open to political objections. Present rules for admission to the university exclude only those Nazis who are considered to have compromised themselves [...]. Occasional reports have come to hand that ex-Nazis, ex-officers and pan-Germans were present in in large numbers among the students, and that they felt themselves sufficiently secure to make occasional minor demonstrations." ${ }^{1963}$ [Hervorhebung d. Verf.]
\end{abstract}

Bei der angesprochenen großen Wahlversammlung im Auditorium Maximum sei, wie die Polizeidirektion Wien gegenüber dem Alliierten Rat mitteilte, ein Spanienkämpfer und KZ-Überlebender - es handelte sich um Josef Schneeweiß, ${ }^{1964}$ einen der Mitbegründer des VSStÖ -, ${ }^{1965}$ aus den Reihen des Auditoriums mit Rufen wie „schade dass sie dich nicht umgebracht haben “1966 angegriffen worden. Nachdem Schneeweiß erwähnte, dass er mit Bundeskanzler Figl im Konzentrationslager gewesen war, sei ihm mit schallendem Gelächter erwidert worden: „Recht so, da gehört ihr hin. “1967 Des Weiteren hätten andere Zwischenrufer die Hinrichtung von Angeklagten im Nürnberger Prozess bedauert. ${ }^{1968}$

Nach den Wahlreden des FÖST-Kandidaten Karl Leutgeb und des VSStÖ-Kandidaten Raoul Schmiedek kam Eduard Rabofsky für den KSV zu Wort. Seine Erklärung, er habe sich, „wie viele andere Österreicher geweigert, für Hitler in den Krieg zu ziehen und wäre deswegen zusammen mit dem Bruder des Erzbischofs von Salzburg Dr. Rohracher

1962 John G. Erhardt an Secretary of State/Washington D.C., Communist Riot and Demonstration Against Vienna University, 22. November 1946, No. 2063, 3. NARA II, RG 84, Foreign Service Posts of the Department of State. Austria, POLAD \&USCOA, Classified Records 1945-55, Box 3, 3. Erhardt irrt allerdings hinsichtlich des Datums der ersten tumulthaften Wahlversammlung, die er fälschlich mit 15. November 1946 angibt.

1963 Ebd.

1964 Schneeweiß war Überlebender des Konzentrationslager Dachau und nach 1945 als Mediziner u.a. im Vorstand der BSA-Ärzteschaft aktiv. Seine offen bekundete Ablehnung der Remilitarisierung Österreichs gegenüber SPÖ-Führung und BSA-Vorstand bescherte ihm 1955 ein mehrjähriges Funktionsverbot im BSA. Siehe dazu: Neugebauer/Schwarz, Der Wille zum aufrechten Gang, a.a.O., $234 \mathrm{f}$.

1965 Vgl. Heilingsetzer/Mesner/Rögl/Weber, Projektendbericht: Zur Geschichte des VSSTÖ, a.a.O., 107. Die AutorInnen des Projektberichtes geben den 14. November 1946 fälschlicherweise als Wahltag an.

1966 Memorandum - Information Hofrat Dr. Walitschek der Bundespolizeidirektion Wien an Colonel Rose (60259-2/033.3, NA). Zit. nach: Stiefel, Entnazifizierung in Österreich, a.a.O., 177.

1967 Volksstimme, Nr. 267, 16. November 1946, 1.

1968 Vgl. Österreichische Zeitung, 16. November 1946, 1. 
ins Gefängnis geworfen worden“1969 wurde mit wüsten Drohrufen beantwortet, wobei Anwesende den Redner als „Feigling“ und als „Verräter“ beschimpft haben sollen. Im weiteren Verlauf sei es zwischen einer kleinen Gruppe kommunistischer Studenten und der rechtskonservativen Mehrheit zu heftigen Wortgefechten gekommen; dabei hätten die Kommunisten in Sprechchören „Kultura, Kultura“ skandiert, worauf die Gegenseite mit Rufen wie „Geht nach Rußland!“1970 geantwortet haben soll. Laut dem Bericht anwesender Beamter der Staatspolizei habe daraufhin „tosender Beifall der Mehrheit der Anwesenden“ eingesetzt; mit Bezug auf Rabofskys Feststellung, dass sein Bruder für „Österreichs Unabhängigkeit“ sein Leben gelassen hatte, seien Zurufe wie „,Nicht schade um dieses Schwein. Warum leben Sie noch. Niederknallen' u.Ä.“" ${ }^{1971}$ laut geworden. Zu besonderer Entrüstung habe schließlich der ,stolze‘ Ausruf eines Studierenden, er sei ein SS-Mann gewesen, geführt, worauf das Publikum mit lautem Applaus geantwortet habe. ${ }^{1972}$

Wie die Akademische Rundschau in der Analyse der Zeitungsberichterstattung rückblickend auf diese Vorfällen feststellte - worauf sich im Übrigen auch ein Bericht der USEducation Division bezog -, habe sich dieser Vorfall jedoch deutlich anders als in der Tagespresse kolportiert zugetragen. Bei einer Diskussion darüber, in welcher Form zurückgekehrten Soldaten, Kriegsgefangenen oder Invaliden bei ihrem Studium geholfen werden könnte, habe ein ehemaliger KZ-Häftling ausgerufen, dass er sich weigere, neben früherem KZ-Wachpersonal oder SS-Spitzeln auf den Hörsaalbänken Platz zu nehmen. Dem habe ein anderer Student entgegnet, dass das wohl ein extremes Beispiels sei, zumal derartige Personen ohnedies nicht zum Studium an der Universität zugelassen würden. ${ }^{1973}$ In diesem Moment habe sich ein weiterer, gesundheitlich angeschlagener Student mit schwer vernehmbarer, leiser Stimme zu Wort gemeldet und mit dem Satz begonnen: „Ich war ein SSMann“.Wie sich herausstellte, hatte dieser Student, der Mitglied der Waffen-SS gewesen war, ${ }^{1974}$ im Krieg einen Kehlkopfdurchschuss erlitten. Auf Zuruf, er solle lauter sprechen, habe sich der Vorsitzende der Wahlversammlung an die anwesenden Medizinstudenten gerichtet und gemeint, es sei wohl unschwer zu erkennen, dass es dem Invaliden nicht möglich wäre, lauter zu sprechen. Dieser habe aber fortgesetzt und gesagt, dass er es heute sehr bedauere, der SS angehört zu haben. In krauser Argumentation, die sein Recht auf Zulassung

1969 „Freche Nazi-Provokationen an der Wiener Universität“. In: Österreichische Zeitung, 15. November 1946, 2.

1970 Erhardt an Secretary of State/Washington, D.C. Communist Riot and Demonstration Against Vienna University, November 22, 1946, No. 2063, 3. NARA II, RG 84, Foreign Service Posts of the Department of State. Austria, POLAD \&USCOA, Classified Records 1945-55, Box 3, 2.

1971 ÖSTA/AdR, BMfI, Mappe: Die Hochschulwahlen in Wien, Anhang zu TB Nr. 340, 18. November 1946, 1. Zit. nach: Huber, Studenten im Schatten der NS-Zeit, a.a.O., 165.

1972 Erhardt an Secretary of State/Washington D.C., Communist Riot and Demonstration Against Vienna University, a.a.O., 2.

1973 Ebd., 2.

1974 UAW, MED S8, 419, Eidesstaatliche Erklärung des Studenten L. vom 19. September 1946. Vgl. nach: Huber, Studenten im Schatten der NS-Zeit, a.a.O., 178. 
zum Studium wohl unterstreichen sollte, führte er weiter aus, dass er als Jugendlicher zur SS eingezogen worden sei und nicht dem Führer, sondern dem Volk dienen wollte, dabei aber lediglich seine Gesundheit verloren habe, worauf er Applaus vom Auditorium erhielt. ${ }^{1975}$

Bei diesem ,SS-Studenten “ handelte es sich um „stud. phil.“ Günther Langhammer, der Wien zwei Tage später, nämlich am ı6. November, verließ, nachdem - wie der Dekan der Philosophischen Fakultät wusste - „vor seinem Wohnhause eine kommunistische Kundgebung stattgefunden “1976 hatte. Seither sei Langhammer nicht mehr gesehen worden und werde nun von seiner Familie gesucht, wobei die Mutter es bisher nicht gewagt habe, Anzeige zu erstatten. Die Abgängigkeit Langhammers sei dem Dekan dadurch zur Kenntnis gelangt, „daß der Genannte nunmehr überprüft werden sollte und auf Grund seiner Vorladung seine Mutter erschienen sei, um das Ausbleiben des Sohnes zu entschuldigen." ${ }^{1977}$ Auf Anfrage teilte die Polizei der Universität mit, dass auch sie keine Informationen über den Aufenthalt Langhammers hatte. Laut einer US-Informationsquelle soll Langhammer - allerdings ohne empirische Evidenz - später in Linz gesehen worden sein. ${ }^{1978}$ Erst im Februar 1948 kehrte Langhammer nach Wien zurück und meldete sich im Dekanat der medizinischen Fakultät. ${ }^{1979}$

Der bereits zitierte Bericht der Education Division vom März 1947, der eine Bilanz der „Post-war Education in Austria“ enthält, spielte diese Ereignisse in einer Darstellung gegenüber dem USFA-Headquarter allerdings deutlich herunter. Zum einen habe der Mann nicht, wie in der linken Presse behauptet, gesagt „Ich bin ein SS-Mann“, sondern lediglich „Ich war ein SS-Mann“. Zum anderen habe sich klar gezeigt, „that no Nazi provocation or exclamation of fascist conviction was made, but it was only the question of whether an invalid former member of the military SS should be allowed to study or not, a question which had already been decided positively [!] by the Austrian government, together with the Allied Powers, long ago. “1980 Bei dieser Lageeinschätzung handelt es sich jedoch ganz

1975 Akademische Rundschau, 2. Jg., 23. November 1946, 1.

1976 UAW, Senats-Sitzungsprotokolle des Studienjahres 1946/47, Protokoll der 9. Sitzung des Akademischen Senates der Universität Wien, 11. Jänner 1947, 3.

1977 Ebd.

1978 Benner, Synopsis of Post-war Education in Austria, a.a.O., 8.

1979 UAW, MED S8, 419, Amtsvermerk des medizinischen Dekanats, 4. Februar 1948. Vgl. Huber, Studenten im Schatten der NS-Zeit, a.a.O., 178. Der Inhalt des Aktenvermerks des medizinischen Dekanats, den Huber zitiert, wonach Langhammer auf dem Weg nach Ischl war, um sich dort einer Operation zu unterziehen, ist nicht nur wegen dessen fluchtartiger Abreise, von der nicht einmal seine Mutter Bescheid wusste, stark in Zweifel zu ziehen, sondern auch wegen dessen immerhin 14-monatiger Absenz, die kaum durch eine Operation zu erklären ist. Eher ist wohl anzunehmen, dass sich Langhammer nach den Vorfällen und deren öffentlicher Berichterstattung in der amerikanischen Besatzungszone sicherer gefühlt haben dürfte als in Wien.

1980 Thomas E. Benner, Synopsis of Post-war Education in Austria, USACA/Education Division, 10th March 1947, 8. University of Illinois Archives, Thomas E. Benner Papers 1930-1979, Austrian Materials, Rec. Series No. 10/1/21 [Kopie im Besitz des Verfassers]. 
offensichtlich um einen (besatzungs)politisch motivierten Kalmierungsversuch, der die vorliegende Faktenlage kurzerhand ignorierte.

Auch wenn die Zeitungsberichterstattung über diese Vorfälle sowie über die späteren Ausschreitungen bei den ÖH-Wahlen deutliche parteipolitische Schlagseiten erkennen lässt - das Gros der Berichterstattung fällt auf die linke Presse, hier vor allem auf kommunistische Blätter, die auch die wenigen beziehungsweise verharmlosenden Artikel in anderen Tageszeitungen kritisierten. ${ }^{1981}$ So lässt sich durch Lektüre und Gegenlektüre doch unschwer erkennen, dass es sich bei den genannten Vorgängen keineswegs um harmlose studentische Meinungsverschiedenheiten handelte, sondern - wie auch schon zuvor - um (neo-)nazistische Provokationen. Nicht zuletzt überlegten auch alle drei Studentenvertretungen - laut einer bei Huber zitierten, vertraulichen Information' an die Staatspolizei angesichts dieser Vorfälle, gemeinsam die Schließung der Universität zu fordern, die erst nach einer gründlichen Säuberung wieder geöffnet werden sollte. ${ }^{1982}$

Am Tag nach den Zwischenfällen bei den Wahlversammlungen erschienen im Auftrag des Innenministeriums Beamte der Staatspolizei im Rektorat und baten um Aufklärung. Rektor Adamovich, der sogleich einen schriftlichen Bericht an das Ministerium übermittelte, ${ }^{1983}$ bat darum, dass künftig „Organe der Kriminalpolizei den Wahlversammlungen beiwohnen und allenfalls politische Ruhestörer zur Ausweisleistung verhalten “1984 sollten.

Ohne mit einem Wort auf die nachweislich neonazistischen Äußerungen und die daraus resultierenden heftigen Debatten einzugehen, die man ja auch als Zeichen eines kritischen, demokratiepolitisch wachen Bewusstsein hätte werten könnten, sorgte sich Rektor Adamovich in erster Linie um die schlechte Presse und gab in seinem Bericht an das Ministerium seinem tiefsitzenden Pessimismus gegenüber der Studentenschaft Ausdruck:

„Ich bin nach meinen ganzen Erfahrungen der letzten Tage restlos überzeugt, daß die Studierenden nicht reif genug sind, die ihnen anvertrauten Angelegenheiten in einer solchen Weise zu führen, wie es das Ansehen und der Ruf unserer Hochschulen erfordern. “1985

1981 Insbesondere zeigte sich die Volksstimme angesichts der Bagatellisierung durch die Presse und die „beiden anderen Parteien“ alarmiert und sprach den Verdacht aus, dass die „Unterrichtsbehörden [...] die Hochschulnazi“ decken. Nach „authentischen Berichten“, so die Volksstimme, sei des Weiteren „ein volles Drittel der Gesamthörerzahl Wiens derart belastet, daß es vor die Überprüfungskommission gebracht werden muß. Unter Hinzurechnung der übrigen politisch belasteten Hörerschaft kann von hundert Studierenden zumindest ein Prozentsatz von achtzig in Zusammenhang mit der NSDAP genannt werden." Volksstimme, Nr. 368, 17. November 1946, 2.

1982 ÖSTA/AdR, BMfI, Anhang zu TB Nr. 340, 18. November 1946, 5. Vgl. Huber, Studenten im Schatten der NS-Zeit, a.a.O., 171.

1983 UAW, Senats-Sitzungsprotokolle des Studienjahres 1946/47, Protokoll der 4. Sitzung des Akademischen Senates der Universität Wien, 16. November 1946, 2.

1984 Ebd., 3. Bei dieser Gelegenheit sprach Senatsmitglied Prof. Meister die Befürchtung aus, dass „im Falle von Aggressionen die Polizei von der Waffe Gebrauch machen könnte“. Ebd.

1985 Ebd., 3. 
Angesichts dieser Ereignisse kam es am I6. November 1946 mittags zu einer Besprechung der Rektoren der Wiener Hochschulen bei Unterrichtsminister Hurdes, der gemeinsam mit den Rektoren einen sofortigen Legitimationszwang für die Wahlveranstaltungen festlegte, um hochschulfremde Personen fernzuhalten.

In einem Interview mit dem Berichterstatter des Neuen Österreich meinte Unterrichtsminister Hurdes, der eine neuerliche Überprüfung der Studierenden anordnete ${ }^{1986}$ dass die Vorfälle nach dem ihm vorliegenden amtlichen Berichten „nicht überschätzt“, aber ausdrücklich „auch nicht unterschätzt werden“ dürften. „Es steht jedenfalls fest“, meinte Hurdes weiter, „dass sich trotz der sehr gründlichen durchgeführten Säuberung der Hochschülerschaft einzelne noch immer nationalsozialistisch angekränkelte Studenten zu halten vermochten. Die endgültige Eliminierung ist nach den heutigen mit den Rektoren beschlossenen Maßnahmen nur mehr eine Frage der Zeit. "1987 Angesichts dieser durchaus kritischen Situation zeigte sich Hurdes hinsichtlich der Studentenschaft zuversichtlich, weil sie - wie er meinte -, sehr gut wisse, dass weitere Zwischenfälle unvermeidlich die Intervention der Besatzungsmächte und womöglich eine vorübergehende Schließung der Hochschulen nach sich zögen. ${ }^{1988}$

Auf die Frage, ob er denn glaube, dass die Entnazifizierung der Hochschulen bereits abgeschlossen und keine weiteren gründlichen Maßnahmen mehr erforderlich wären, fand Hurdes - vielleicht auch im Hinblick darauf, dass die bevorstehende Außenministerkonferenz in New York den Beginn der Staatsvertragsverhandlungen auf Anfang 1947 festlegen wird, ${ }^{1989}$ und gerade im Hinblick auf Fragen der Entnazifizierung eine Verstimmung seitens der Alliierten nicht opportun wäre - zugleich klare und diplomatische Worte:

„Solange die nationalsozialistische Idee nicht wirklich tot ist, sondern - in welcher Form immer - irgendwo wieder lebendig zu werden versucht, verlangt die Sicherheit des Staates die allergrößte Wachsamkeit. Wir haben uns in den letzten Monaten sehr entscheidend darum bemüht, wie im gesamten öffentlichen Leben so auch an den Hochschulen auszumerzen, was nicht tragbar erschien. Ich will - um nicht mehr zu sagen, als ich verantworten kann - das Resultat dieser Aktion als befriedigend, aber deswegen noch nicht als abschließend bezeichnen. Es werden in der Öffentlichkeit immer wieder Fälle aufgezeigt, die zu denken geben. Seien

1986 Gemeinsam mit einem Vertreter des akademischen Senatse sowie einem Vertreter des Unterrichtsministeriums sollten die Delegierten der drei politischen Studentenorganisationen neuerlich die Listen der inskribierten Hörer durchgehen, um „nach den allerstrengsten Grundsätzen jeden auszuschalten, der keine volle Garantie für die Einhaltung der österreichischen Linie an den Hochschulen bietet." Zit. nach: Neues Österreich. Organ der demokratischen Einigung, 2. Jg., Sonntag, 17. November 1946, (Nr. 268), Nr. 482, 1.

1987 Neues Österreich. Organ der demokratischen Einigung, 2. Jg., Sonntag, 17. November 1946, (Nr. 268), Nr. $482,1$.

1988 Ebd.

1989 Vgl. Gerald Stourzh, Geschichte des Staatsvertrages 1945-1955. Österreichs Weg zur Neutralität, Graz Wien - Köln 1985, 15. 
Sie davon überzeugt, daß ich persönlich mit allem Nachdruck auf ihrer sofortigen gründlichen und rücksichtslosen Untersuchung bestehe. Ich habe den Nationalsozialismus am eigenen Leibe kennen gelernt und bin fest entschlossen, seine Macht in meinem Wirkungskreis zu brechen [...]. Die Hochschulwahlen werden nach den heute Vormittag getroffenen Verfügungen ruhig, würdig und ihrem Sinn entsprechend verlaufen. ${ }^{\text {1990 }}$

Eine Konferenz der Delegierten der drei wahlwerbenden Studentenorganisationen hatte sich am I6. November ebenfalls mit den Zwischenfällen bei der Wahlversammlung beschäftigt. Dabei sprachen sich neben den zwei Studentenvertretungen FÖST und VSStÖ sowohl die Sozialistischen Akademiker als auch die konservative „Union der österreichischen Akademiker “1991 für die Abhaltung der ÖH-Wahl aus; die kommunistischen Studentenvertreter entfernten sich, wie das Neue Österreich meldete, ohne Stellungnahme von der Konferenz und ließen lediglich wissen - ob als kryptische Anspielung gedacht oder nicht -, dass für sie „die Arbeiterschaft sprechen werde.“1992 Dazu kam es am I9. November dann tatsächlich.

Bei der letzten Wahlversammlung im Auditorium Maximum am I8. November, die ruhig verlief - immerhin waren 8o Staatspolizeibeamte anwesend ${ }^{1993}$-, gingen die Vertreter des VSStÖ auf Distanz zur konservativen akademischen „Union“; sie erklärten, dass sie „trotz aller behördlichen Maßnahmen“ die Ansicht vertreten, dass sich „noch eine beträchtliche Anzahl pronazistischer Studenten in den Hochschulen “1994 aufhält. Als Vertreter der Kommunistischen Studenten erklärte Eduard Rabofsky zunächst, dass diese an der Wahl teilnehmen werden, und weiter, dass „nicht nur die Säuberung der Studentenschaft, sondern vor allem der Professoren notwendig “1995 ist.

Die kolportierten nazistischen Provokationen bei den studentischen Wahlversammlungen hatten innerhalb der organisierten Arbeiterschaft tatsächlich derart große Irritationen ausgelöst, dass es unmittelbar vor den Hochschülerschaftswahlen zu heftigen Protesten kam. So hatten sich am I8. November Floridsdorfer Arbeiter der Wiener Lokomotivfabrik (Lofak), von Austro-Fiat und Hofherr-Schrantz und der Siemens-Kabelwerke in der Lofak-Kantine zu einer Protestveranstaltung gegen die Zustände an den Wiener Hochschulen versammelt. Nachdem ein Student die Vorfälle bei den Wahlversammlungen geschildert hatte, sprach ein Arbeiter namens Singer, der auch Gasthörer der

1990 Neues Österreich. Organ der demokratischen Einigung, 2. Jg., Sonntag, 17. November 1946, (Nr. 268), Nr. 482,1 .

1991 Vgl. Forster, Die Geschichte der Österreichischen Hochschülerschaft 1945-1955, a.a. O., 63.

1992 Neues Österreich. Organ der demokratischen Einigung, 2. Jg., Sonntag, 17. November 1946, (Nr. 268), Nr. $482,1$.

1993 ÖSTA/AdR, BMfI, Anhang zu TB Nr. 340, 18. November 1946, 4. Zit. nach Huber, Studenten im Schatten der NS-Zeit, a.a.O., 172.

1994 Wiener Zeitung, 239. Jg., Dienstag, 19. November 1946, Nr. 269, 2.

1995 Ebd. 
volkstümlichen Universitätsvorträge war, ${ }^{1996}$ den Ärger der Versammlungsteilnehmer aus. Dabei erklärte er:

„Wir Arbeiter fordern [...], daß man einige tausend Söhne und Töchter [sic] von Proletariern in die Hochschule entsenden und dafür die Faschisten nach Hause schicken soll, die nur den Platz wegnehmen, um dort ihre Kader zu organisieren!“1997

Eine Arbeiterin namens Krieger forderte mit Bezug auf die „Exterritorialität der Hochschulen“ Zutritt und Kontrollmöglichkeit für die Arbeiterschaft: „Die Arbeiterschaft hat ein Recht darauf, zu wissen, wer die künftigen Juristen, Richter, Staatsanwälte, Ärzte, Ingenieure und Direktoren sein werden. Es muß uns die Möglichkeit geschaffen werden, Einfluß zu nehmen, daß nicht wiederum solche Menschen die geistige Leitung im Staat übernehmen können, wie diese, die uns 1938 dem Faschismus ausgeliefert haben!"Und ein weiterer Arbeiter namens Zach fügte an:

„Wir haben den Schattendorfer Prozeß nicht vergessen. Die Richter, die damals die Schattendorfer Mörder frei ausgehen ließen, und jene Staatsanwälte, die die Hinrichtung der Schutzbündler I934 durchsetzen, sind aus den Wiener Hochschulen hervorgegangen. Dort sind auch die Vorbereiter für die gewaltsame Annexion Österreichs geschult worden. Es sind dies aber nicht nur die Studenten, sondern auch vor allem ihre Lehrer, die Professoren! [...] Es geht nicht an, daß der Rumpf Österreichs demokratisch, der Kopf reaktionär ist! "1998 [Hervorhebung d. Verf.]

Gegen Ende der Versammlung wurde eine Resolution angenommen, „die Bundesminister Hurdes von den Vertretern der Arbeiterschaft, Fritsch (Shell), Marek (Wiener Lokomotivfabrik), Dobritzhofer (Fiat), Reicher (Siemens-Kabel) und anderen überreicht werden soll

1996 Als solcher habe er auch bemerkt, dass „nicht nur politisch untragbare Elemente, sondern auch ausländische Schleichhändler das Universitätsstudium für ihre dunklen Zwecke ausnützen." Österreichische Zeitung, 19. November 1946, 2. Ein Bericht über „ausländische Faschisten an den Hochschulen“ fand sich bereits zwei Monate zuvor in der Volksstimme, worin es hieß: „Auf dem Welt-Studentenkongreß in Prag erklärte ein österreichischer Delegierter [...], daß die österreichischen Hochschulen der Tummelplatz einer großen Zahl von Ausländern sind, die hier eine rege faschistische Tätigkeit entfalten. Das Akademische Auslandsreferat hat sich - besonders unter dem jetzigen Leiter Doktor Dänemark - bemüht, in dieses Chaos faschistischer Agenten und D.P. Ordnung zu bringen. Auf seine Anordnung wurden zur politischen Überprüfung Kommissionen aus Studenten der betreffenden Nationalität eingesetzt, die von den Behörden ihres Heimatlandes anerkannt sein mußten. Durch die Arbeit dieser Kommissionen gelang es, eine größere Anzahl schwerbelasteter Ausländer zu entlarven und so ihre Zahl an den Wiener Hochschulen von 3.366 im Wintersemester 1945/46 auf auf 2.800 im Sommersemester 1946“ zu senken. Volksstimme, 8. September 1946, Nr. 209, 4.

1997 Österreichische Zeitung, 19. November 1946, 2.

1998 Ebd. 
und die Forderungen der Arbeiter zur Demokratisierung der Hochschulen “1999 enthielt. Darüber hinaus richtete der Arbeiterbetriebsrat der Siemens-Schuckert-Werke AG ein Schreiben an den Vorstand der Gewerkschaft der Metall- und Bergarbeiter Österreichs, in dem die Arbeiter „ihrer Empörung über die nazistischen Kundgebungen an den Hochschulen Ausdruck" verliehen und zu einer einheitlichen Kundgebung der Gewerkschaft aufriefen. In überaus heftiger ideologischer Zuspitzung hieß es darin:

„Die Schuldigen und Nutznießer des Kriegs und des heutigen Elends [...] werden wieder frecher, da sie von allen reaktionären Kräften gestützt und gefördert werden. Die ungezählten Toten der KZler und des Zweiten Weltkriegs mahnen, auf der Wacht zu sein. Aus der Vergangenheit ist bekannt, daß die Hochschulen die Brutstätten der mordenden Reaktion und des Faschismus waren." 2000

Ein weiteres Schreiben an den „Landesverband Wien ehemals politisch verfolgter Antifaschisten und KZ-Häftlinge" forderte ein gemeinsames, einheitliches Vorgehen gegen diese „Umtriebe“. Außerdem hatte die gesamte Belegschaft der Firma „Reichhold, Függer und Boecking“ eine Resolution aufgesetzt, die schärfsten Protest gegen die „nazistischen Provokationen“ auf universitärem Boden erhob: „Wir fordern die Regierung auf, diesem Treiben sofort Einhalt zu gebieten. Wir dulden es nicht, daß Nazioffiziere die Opfer des Nazifaschismus schmähen und beschimpfen. Hinaus mit den Faschisten aus den Hochschulen!“2001 Auch der Bundesvorstand des Gewerkschaftsbundes nahm zu den Vorgängen Stellung und verlangte, dass der „Nazismus mit Stumpf und Stiel ausgerottet und die nazistischen Elemente rücksichtslos entfernt werden. “2002 Weitere Protestversammlungen, die zum Teil von Sprechern der KPÖ - unter anderem hielten auch Friedl Fürnberg und Ernst Fischer Reden ${ }^{2003}$ - dominiert waren, fanden in der Leopoldstadt, im Sokoll-Saal in Favoriten, in Stadlau und in der Brunner Glasfabrik statt, wo unter stürmischem Beifall die „rücksichtslose Säuberung“ der Hochschulen gefordert wurde. Darüber hinaus beschloss die KPÖ für den 2r. November eine Konferenz der Vertrauensmänner der Betriebe und Wiener Bezirke, wo „eine mächtige, umfassende Aktion aller Wiener Bezirke und Betriebe gegen die faschistischen Provokationen" geplant werden sollte. Beigefügt wurde die Empfehlung,

1999 Ebd.

2000 Ebd.

2001 Österreichische Zeitung, 19. November 1946, 12.

2002 Volksstimme, 20. November 1946, Nr. 270, 1.

2003 Abgeordneter Ernst Fischer wurde mit den folgenden, drohenden Worten zitiert: „Wir wollen energisch und unmißverständlich erklären, daß schöne Worte und Bekenntnisse nicht mehr genügen, sondern daß wirklich eine ,Säuberung` und Erneuerung der Hochschulen erfolgen muß. Wenn die Behörden in absehbarer Zeit keine Änderung treffen werden, dann allerdings könnte der Tag kommen, wo die Arbeiter auf eigene Faust und mit eigener Faust solchen Ereignissen ein für allemal einen Riegel vorschieben." $Z$ it. nach: Volksstimme, 19. November 1946, Nr. 269, 1. 
„die Beschlüsse dieser Konferenz abzuwarten und von Teildemonstrationen abzusehen.“2004 Die Großdemonstration fand dann aber - wie „spontan“ ${ }^{2005}$ auch immer beschlossen - bereits am folgenden Tag statt. Am späten Abend informierte Staatspolizeichef Heinrich Dürmayer das Innenministerium von der bevorstehenden Demonstration; die Nachricht wurde an Innenminister Helmer weitergeleitet, der den Polizeipräsidenten sogleich anwies, die Demonstration durch Gespräche mit dem Gewerkschaftsbund „unter allen Umständen“ zu verhindern, da dies einen ungünstigen Eindruck [...] bei den Alliierten machen “ ${ }^{2006}$ würde.

Der Vormittag des Wahltages - bereits ab acht Uhr früh konnte gewählt werden - verlief zunächst ruhig und bis gegen ir Uhr hatten rund 50 Prozent der Studierenden ihre Stimme abgegeben. Wie Andreas Huber unter Auswertung staatspolizeilicher Protokolle des Innenministeriums feststellen konnte, waren bereits ab acht Uhr 64 Kriminal- und 8o Sicherheitsbeamte zur Sicherung der Universität abgestellt, letztere unter Führung des Kommunisten Hans Marsalek, dem Referenten für Abwehr der Abteilung I. Und noch vor Eintreffen der ersten Demonstranten wurden die Sicherheitskräfte um weitere 230 Beamte aufgestockt. ${ }^{2007}$

Nach neuerlichen Betriebsversammlungen stellten die Arbeiter aus mehreren Großbetrieben - alle in der sowjetischen Zone gelegen - die Arbeit ein und marschierten gegen Io.30 Uhr auf der Ringstraße vor der Universität auf, wo sie in Sprechchören „Nieder mit den Nazistudenten“ oder „Werft die Faschisten raus!“2008 skandierten. Den - laut Augenzeugenberichten - rund 2.000 bis 3.000 Arbeitern $^{2009}$ aus Betrieben der Floridsdorfer Lokomotivfabrik, den Siemens-Schukert-Werken, wo der sozialistische Betriebsrat Aigner zur Kundgebung aufrief, ${ }^{2010}$ des Großbetriebes Krause, der Nova-Werke in Schwechat, der DDSG, Waagner \&Biro, der Firmen Tondloff-Wamag und Rothmüller-Newa folgten Fahnen schwenkende Demonstrationszüge der kommunistischen „Freien österreichischen Jugend“ (FÖJ); aber auch teilweise junge sozialistische Arbeiter sowie gewerkschaftliche Vertrauensleute der SPÖ versammelten sich vor der Universität. ${ }^{2011}$

2004 Volksstimme, Nr. 269, 19. November 1946, 1.

2005 „Die Erregung führte dazu, daß gestern außer Delegationen von Wiener Betrieben die Belegschaften mehrerer Großbetriebe spontan den Beschluß faßten, vor die Universität zu ziehen.“ Zit. nach: Volksstimme, 20. November 1946, Nr. 270, 1. [Hervorhebung d. Verf.]

2006 Zit. nach: Huber, Studenten im Schatten der NS-Zeit, a.a.O., 178.

2007 ÖSTA/AdR, BMfI, GZ 164231-2/46, Bericht des BMfI, 26. November 1946.1.Zit. nach: Huber, Studenten im Schatten der NS-Zeit, a.a.O., 180.

2008 Vgl. Wiener Zeitung, 239.Jg., Nr. 270, Mittwoch, 20. November 1946, 1. Angesichts der aufmarschierenden Arbeiter hatte Hans Hammerschmid, der Pedellenkanzlei-Leiter, umgehend die Universitätstore schließen lassen. UAW, Rektoratsakten, GZ 216, O.-Nr. 75, Bericht von Hans Hammerschmid, 23. November 1946, 9. Vgl. Huber, Studenten im Schatten der NS-Zeit, a.a.O., 181.

2009 Ebd. Die Staatspolizei berichtete hingegen von 4.000 bis 6.000 Demonstranten um die Mittagszeit. Vgl. Huber, Studenten im Schatten der NS-Zeit, a.a.O., 182.

2010 Volksstimme, Nr. 270, 20. November 1946, 1.

2011 Persönliche mündliche Mitteilung von Prof. Rudolf Gelbard/Wien, 12. Oktober 2005, der die Vorgänge als Augenzeuge miterlebt hat. Der US-Gesandte John G. Erhardt berichtete in diesem Zusammenhang 
Während zur gleichen Zeit im Parlament der Budgetausschuss tagte, wurde auf dringende Forderung der Demonstranten eine Delegation unter Führung des kommunistischen Gemeinderates Theodor Maller und des Betriebsrates Huber vom Stahlbauunternehmen Waagner \&Biro zu Rektor Adamovich vorgelassen. Die Delegation verlangte von diesem die Bekanntmachung sofortiger ,Säuberungsmaßnahmen'.

Wie die Wiener Zeitung schrieb, habe Rektor Adamovich die fünfköpfige Delegation wissen lassen, dass er die „Entwicklung der Dinge schon seit langem vorausgesehen“ habe, „da entgegen seinem Willen die Siebung der Studentenschaft viel zu wenig streng vorgenommen wurde. Er habe deshalb schon am 23. Oktober seinen Rücktritt angeboten, der jedoch abgelehnt wurde. Im übrigen stehe aber die Säuberung der Hochschulen nicht allein in seinem Machtbereich.“2012

Obwohl Vertreter der ÖH ihre Kollegen dazu aufriefen, Ruhe zu bewahren und „sich jeder Tätlichkeit zu enthalten“, ${ }^{2013}$ war es inzwischen vor der Universität zu schweren Zusammenstößen zwischen Demonstranten und Studierenden gekommen. Dabei wurden, wie die Akademische Rundschau berichtete, etliche niedergetrampelt und andere durch Messerstiche verletzt. ${ }^{2014}$

Wie die Volksstimme tags darauf berichtete, hätten „Nazistudenten von den Fenstern aus“ und auch vor den Universitätstoren die „disziplinierte Menge“ ${ }^{2015}$ verhöhnt. Die Meldung eines anwesenden Beamten der Sicherheitswache bestätigt Provokationen gegenüber den demonstrierenden Arbeitern: selbst Steine seien vom Dach der Universität auf die Demonstranten geworfen worden. ${ }^{2016}$

Hingegen berichtete die Arbeiterzeitung - interessanterweise ohne jede Angabe, was der eigentliche Anlass für die Demonstrationen gewesen war -, dass „sozialistische Studenten von kommunistischen Demonstranten bedroht, geschlagen und verletzt wurden.“

an das State Department gleichlautend: „Some Socialist shop stewards called on Socialist-organized workers to participate in the demonstration and were subsequently admonished in the Socialist press that such actions must be authorized by the party and the labor union leadership. It may be stated, therefore, that while the demonstration was Communist-led and Communist instigated, Socialist workers did also participate in it.“ John G. Erhardt, Headquarters United States Forces in Austria/Office of the Political Advisor, to Secretary of State/Washington D.C., ,Communist Riot and Demonstration Against Vienna University“, 22. November 1946, No. 2063, 3. NARA II, RG 84, Foreign Service Posts of the Department of State. Austria, POLAD \&USCOA, Classified Records 1945-55, Box 3, 2.

2012 Vgl. Wiener Zeitung, 239. Jg., Mittwoch, 20. November 1946, Nr. 270, 1.

2013 Akademische Rundschau, 2. Jg., 23. November 1946, Nr. 9, 9.

2014 Ebd.

2015 Volkstimme, 20. November 1946, Nr. 270, 1.

2016 UAW, Rektoratsakten GZ 447 /I-1946/47 (Disziplinarakt Senat S 185.1316), O.-Nr. 3, 26. November 1946. Zit. nach: Huber, Studenten im Schatten der NS-Zeit, a.a.O., 187. Einem Bericht der Staatspolizei zufolge wäre u.a. auch „von einzelnen Studenten aus den Fenstern der Hochschule hinuntergespuckt“ worden. ÖSTA/AdR, BMfI, Anhang zu TB Nr. 342, 20. November 1946, 1. Zit. nach: Huber, Studenten im Schatten der NS-Zeit, a.a.O., 187. 
Als Josef Schneeweiß, der Obmann der sozialistischen Studenten „verlangte, daß von den kommunistischen Parteifahnen die sozialistischen Abzeichen entfernt werden “2017 - aus Sicht des VSStÖ sollte die ,gemeine und nahezu kriminelle Verwendung sozialistischer Embleme“ ${ }^{2018}$ den Wahlerfolg der sozialistischen Wahlgruppe schmälern -, soll auch er mit Schlägen bedroht worden sein.

Obwohl die Arbeiterzeitung die Entnazifizierung der Studenten und der Professoren mit Vehemenz forderte, ${ }^{2019}$ ging sie entschieden auf Distanz zu den Ausschreitungen bei den Hochschülerschaftswahlen und rückte dabei die kommunistisch dominierte Demonstration - zumindest hinsichtlich der vermuteten Folgen - gewissermaßen ins rechte Eck:

"Jeder Wiener Sozialist und jeder Wiener Arbeiter wird ebenso wie die sozialistischen Studenten alle Maßnahmen zur Bekämpfung der Naziumtriebe an den Hochschulen begrüßen. Aber die Art, in der gestern von kommunistischer Seite, demonstriert' wurde, muß schärfstens abgelehnt werden. Das ist die beste Methode, die Demokratie zu diskreditieren! - also genau das, was die Nazi wollen. “2020

Durch die beanstandete Einbeziehung der Protestnote des Österreichischen Gewerkschaftsbundes am Tag zuvor konnte außerdem der Eindruck entstehen, dass sich die Gewerkschaften mit ihrem Protest gegen den „rein nazistischen Charakter“ der Kundgebung nur auf die Demonstrationszüge am Wahltag bezogen. ${ }^{2021}$

Dass man als Sozialistische Partei aber jederzeit gewillt war, den Kampf gegen die „Reaktion an den Hochschulen“ organisiert und aktiv zu führen, wird unter anderem an einer Rede deutlich, die der damalige Floridsdorfer Bezirksvorsteher Franz Jonas am Tag nach den Ausschreitungen bei einer Parteiversammlung hielt:

„Der krepierende Kapitalismus ist nicht mehr imstande, die Wirtschaft in Ordnung zu halten; er versagt auch auf dem Gebiet der Bildung und Erziehung. Wie die Sozialistische Partei heute die Wirtschaft plant, so wird sie morgen auch Kultur und Wissenschaft planmäßig fördern. Wir versichern unseren Genossen an den Hochschulen: wenn ihr einmal im Kampf gegen die

2017 Arbeiterzeitung, 20. November 1946, Nr. 270, 2.

2018 Strom, 2. Jg., 23. November 1946, Folge 39, 1.

2019 So schrieb Walter Hacker in der Arbeiterzeitung: „Die Ausbildung und Erziehung unserer Studenten obliegt heute einem Lehrkörper, dessen Angehörige zum überwiegenden Teil den Übergang von der Demokratie zum Faschismus in den Jahren 1934 und nachher willkommen hießen oder widerstandslos akzeptierten. Zum überwiegenden Teil konnten sie ihre Lehrtätigkeit auch unter den Nazi fortsetzen und sind heute bestenfalls, unbelastet' oder ,minderbelastet'. Sie sind aber nicht die Künder und Lehrer einer positiven Demokratie, derer wir zur Erziehung einer neuen Generation von demokratischen Akademikern bedürfen." Arbeiterzeitung, 20. November 1946, Nr. 270, $1 \mathrm{f}$.

2020 Arbeiterzeitung, 20. November 1946, Nr. 270, 2.

2021 Vgl. ebd. 
Masse der früheren Faschisten nicht mehr weiter könnt, dann ruft die sozialistischen Arbeiter - sie werden kommen! ${ }^{\text {2022 }}$

Ein Teil der protestierenden Arbeiter besetzte jedenfalls die Universitätsrampe und hinderte die Studenten, das Gebäude zu betreten, um ihre Wahlstimme abzugeben. Als die Demonstranten versuchten, in die Universität einzudringen, wurden die Tore verschlossen, worauf es zu neuerlichen Prügeleien mit Studenten kam. Der während der Tumulte im Hauptgebäude der Universität tagende Akademische Senat beschloss daraufhin kurzerhand die Sperre der Universität. ${ }^{2023}$

Damit wurde die Wahl unterbrochen, Ausweichlokale wurden eingerichtet und die rund 400 im Universitätsgebäude befindlichen Studierenden aufgefordert, sich möglichst ruhig zu verhalten und den Fenstern fern zu bleiben, um weitere Ausschreitungen und Übergriffe zu verhindern. Und im Rundfunk wurden stündlich Aufrufe durchgegeben, welche die Studenten aufforderten, Mut zur Demokratie zu beweisen und an anderen Hochschulen zu Wahl zu gehen. ${ }^{2024}$

Die rund um die Universität bereits zusammengezogenen Polizeieinheiten in Stärke von 250 Mann griffen vorerst allerdings nicht ein, inhaftierten dann aber insgesamt 29 Personen (davon 26 attackierte Studierende), von denen 16 bis I7.30 Uhr in der Polizeiwachstube Rathausstraße festgehalten wurden. ${ }^{2025}$ Die „Anhaltungen“ erfolgten, wie Innenminister Helmer am 26. November im Ministerrat erklärte, „zum Teil wegen Störung der Ordnung, zum Teil zum Schutz der Festgenommenen. “2026

Erstaunlicherweise findet sich bei Durchsicht der Tages- und Wochenberichte der Wiener Polizeidirektion, die üblicherweise überaus detailliert geführt wurden ${ }^{2027}$ und die beispielsweise jede Hakenkreuz-Streuaktion protokollierten, kein Hinweis auf die Großdemonstration vor der Universität; lediglich im Monatsbericht finden sich zwei kurze

2022 Arbeiterzeitung, 21. November 1946, Nr. 271, 1.

2023 UAW, Senats-Sitzungsprotokolle des Studienjahres 1946/47, Protokoll der 5. Sitzung des Akademischen Senates der Universität Wien, 30. November 1946, $1 \mathrm{f}$.

2024 Forster, Die Geschichte der Österreichischen Hochschülerschaft 1945-1955, a.a. O., 121.

2025 Ebd., 122.

2026 Wiener Zeitung, 239. Jg., 27. November 1946, Nr. 276, 1.

2027 Ein Beispiel unter vielen: der Situationsbericht für den IX. Wiener Gemeindebezirk vom 20. August 1945 vermeldet zunächst in „staatspolizeilicher Hinsicht [...] keine Vorkommnisse“ und fügt dann an: „Es ergeht Mitteilung, dass die amerikanischen Besatzungstruppen (Neger) ihr Quartier in dem Häuserblock: Severingasse - Wilhelm Exnergasse - (Versuchsanstalt für Krfz.) - Michelbeuerngasse (Schule d. Kleidermachergewerbes) aufgeschlagen haben. Im Zusammenhang damit muss gemeldet werden, dass dort arger Schleichhandel und Tauschgeschäfte getrieben werden, desgleichen ereignen sich Vorkommnisse, die unhaltbar sind. Es ist z. B. der Fall, dass sich minderhübsche Mädchen um 2 Konservenbüchsen für Liebesabenteuer verschenken, hübschere Mädchen bereits 4 Dosen fordern und somit auch in dieser Art ,Geschäfte' getrieben werden." Archiv der Bundespolizeidirektion Wien (BPDW), Amerikanische Besatzungsmacht 1, Akte Juli 45-Sept. 55 (1947-1948), 1. 
Anmerkungen. ${ }^{2028}$ Darüber hinaus fehlt auch der vom Leiter des Präsidialbüros, Anton Walitschek, zu den Ereignissen verfasste Bericht in der Registratur, was darauf schließen lässt, dass entweder ein interner Maulkorberlass befolgte wurde oder die Berichte der gesamten Angelegenheit - vermutlich in Absprache mit alliierten Militärstellen ${ }^{2029}$ - direkt an das Innenministerium ergingen. Im Österreichischen Staatsarchiv finden sich jedenfalls staatspolizeiliche Mitteilungen sowie vereinzelt Tagesberichte der Wiener Polizeidirektion an das Innenministerium, die Andreas Huber ausfindig gemacht und im Rahmen seiner Diplomarbeit mitausgewertet hat.

Keine Frage ist auch, dass die amerikanischen Militärstellen über diese politisch hochgradig instrumentalisierte Demonstration alles andere als erfreut sein konnten, die sowohl die Kommunisten als auch die sowjetische Besatzungsmacht dafür nützten, um Druck auf die Universitäten auszuüben und die bisher erfolgten Entnazifizierungsmaßnahmen im universitären Bereich in Zweifel zu ziehen. Dass die amerikanische Besatzungsmacht womöglich direkt „Druck auf die sowjetische Besatzungsmacht ${ }^{\text {“2030 }}$ ausgeübt haben könnte, die Kundgebung abzublasen, ist jedoch weder aus einschlägigen Akten abzulesen, noch ergäbe dies politisch betrachtet eine Pointe. Hätte es doch bedeutet, sich auf die Seite der Reaktion zu stellen und die ganz unzweifelhaft unzureichende Entnazifizierung der Universitäten offen zu verteidigen. Dies wiederum hätte einen inhaltlich schwer argumentierbaren Konflikt mit der russischen Besatzungsmacht heraufbeschworen - einen Konflikt, der womöglich einen tiefen Riss in der alliierten Besatzung des Landes zur Folge gehabt hätte und obendrein den eigenen macht- und sicherheitspolitischen Überlegungen

2028 So vermeldete der polizeiliche Monatsbericht für die Zeit vom 1. bis 30. November 1946: „Die Vorfälle an der Universität wurden von einem großen Teil der Wiener Bevölkerung als eine rein kommunistische Propagandaaktion ablehnend beurteilt. Es wurde hierbei betont, dass von Seiten der Studenten nie versucht worden war, auf Arbeiterbetriebswahlen irgendeinen Einfluss zu nehmen. Anderseits [sic] wurde auch die Meinung vertreten, dass bei der Zulassung von nationalsozialistisch belasteten Hochschülern zu großzügig verfahren wurde. Letzten Ende befürchtet man aber, dass durch dergleichen Vorfälle den Besatzungsmächten Grund zu einem verlängerten Aufenthalt gegeben wird.“ Und weiter: „Die Vorfälle anlässlich der Hochschulwahlen zeigten, dass in der Studentenschaft verschiedene antisemitische Elemente an der Arbeit sind, weshalb eine neuerliche Überprüfung sämtlicher Hörer sich als notwendig erwiesen hat." Zit. nach: Schembor, Polizeiliche Situationsberichte für die Jahre 1945 und 1946, a. a. O., 291.

2029 Lediglich ein indirekter Hinweis lässt sich finden: Bei einer „Vorsprache“ des Wiener Polizeipräsidenten beim russischen Generalleutnant Lebedenko wünschte dieser - womöglich wollte er sich gegenüber den öffentlichen Anwürfen einer kommunistischen Infiltration der Wiener Polizei wappnen - Information darüber, „Von wem in Wien Demonstrationen organisiert werden. Eine weitere Frage Lebedenkos war, „ob nicht die Polizei auch Demonstrationen organisiert“, was freilich verneint wurde. BPDW, Russische Besatzung 5, Akte 1946-1950, Aktenvermerk 19. Dezember 1946, 1.

2030 Dies vermutet Andreas Huber mit Verweis auf die Aussage des Zeitzeugen Robert Rosner, wonach ein Demonstrationszug nur wenige hundert Meter vor Erreichen der Universität zurückgepfiffen worden sei. Vgl. Huber, Studenten im Schatten der NS-Zeit, a.a.O., 188. 
in Österreich beziehungsweise in Europa zuwider gelaufen wäre. ${ }^{2031}$ Obwohl die Polizeieinheiten für ihr mangelndes Einschreiten zum Teil heftig kritisiert wurden, ${ }^{2032}$ außerdem im Verdacht kommunistischer Infiltration standen ${ }^{2033}$ und Rektor Adamovich noch am

2031 Zu Beginn des Jahrs 1947 war Österreich aus Sicht der Joints Chiefs of Staff (JCS), dem obersten USMilitärgremium, bereits strategische „key area“ inmitten des frühen Kalten Krieges. Vgl. dazu: Christian Stifter, Die Wiederaufrüstung Österreichs. Die geheime Remilitarisierung der westlichen Besatzungszonen 1945š 1955, Innsbruck š Wien 1997, 68 f.

2032 Vgl. dazu „Was man nicht wegleugnen kann. Authentische Berichte über die Zwischenfälle an der Universität.“ In: Akademische Rundschau, 2. Jg., Nr. 10, 30. November 1946, 2. „Weiters verdient hervorgehoben zu werden, daß aus allen Protokollen eine vollkommen indifferente Haltung der österreichischen Polizeiorgane festzustellen ist. Obwohl im Verlauf der Geschehnisse eine größere Anzahl von österreichischen Sicherheitsorganen hinzugezogen wurde, bemühten sich diese nicht im geringsten, auf die Demonstranten einzuwirken. Erst das Eingreifen weniger amerikanischer Militärpolizisten ermöglichte die weitere ruhige Durchführung der Hochschulwahlen.“ Zit. nach: Akademische Rundschau, 2. Jg., Nr. 10, 30. November 1946, 9. [Hervorhebung d. Verf.] Des Weiteren brachte auch Dekan Prof. Rudolf Köstler bei der tags darauf stattgefundenen außerordentlichen Sitzung des Akademischen Senats den Antrag ein, das Verhalten der Polizei zum Thema einer weiteren, außerordentlichen Sitzung zu machen. Köstler äußerte sein Befremden darüber, „daß die Polizei, die der Universität keine Warnung zukommen ließ, doch offenbar Kenntnis von den geplanten Demonstrationen hatte, aber keine Vorkehrungen traf." Vgl. UAW, Senats-Sitzungsprotokolle des Studienjahres 1946/47, Protokoll über die außerordentliche Senatssitzung, 20. November 1946, 2.

2033 US-Gesandter Erhard berichtete hierzu nach Washington: „The demonstration was openly sponsered by the Communist party [...]. Russian occupation power permitted an organized mob to march from their zone to another [...]." John G. Erhardt, Headquarters United States Forces in Austria/Office of the Political Advisor, to Secretary of State/Washington D.C., „Communist Riot and Demonstration Against Vienna University“, 22. November 1946, No. 2063, 3. NARA II, RG 84, Foreign Service Posts of the Department of State. Austria, POLAD \&USCOA, Classified Records 1945š55, Box 3, 1. Major Thomas Benner hielt in seinem Bericht gleichlautend fest, dass der leitende Polizeioffizier vor der Universität ein „fellow traveler“ des demonstrierenden „Mobs“ gewesen sei: „The Austrian police [...] „arrested every student who was mistreated but not one of the attacking workers." [Unterstreichungen im Original] Benner, Post-war Education in Austria, a.a. O., 9. Und die Akademische Rundschau schrieb: „Es nimmt einigermaßen wunder, daß die Polizei es für notwendig erachtete, die verprügelten Studenten festzunehmen und den Raufbolden zum Teil behilflich war. Es verdient festgehalten zu werden, daß ein kommunistischer Polizeioffizier die Menge selbst auf die Rampe der Universität hinaufführte." Akademische Rundschau, Nr. 9, 2. Jg., 23. November 1946, 9. Tatsächlich lag die Leitung der Personalabteilung der Sicherheitswache Wien seit 7. November 1945 beim Spanienkämpfer und Mitkämpfer der französischen und jugoslawischen Partisanen, Zalel Schwager (1908š 1984), der aktiver KPÖ-Funktionär war. Polizeileiter für den I. Bezirk war zum damaligen Zeitpunkt jedenfalls Hauptmann Kurt Frisch bzw. Abteilungskommandant Nobert Burgert. Gegen den kommunistischen Polizeioberstleutnant Schwager, der zudem Jude war, wurde dann im Frühjahr 1955 öffentlich polemisiert. Vgl. dazu: „Ein zweiter Fall Kaes? In: Volksstimme, 12. Februar 1955). Bundes-Polizeidirektion Wien, Personalakt Zalel Schwager. Der Autor ist Herrn Michael Winter vom Archiv der BPD für die Einsichtnahme zu Dank verpflichtet. Bekannt ist hingegen, dass die Staatspolizei unter der anfänglichen Leitung von Heinrich Dürmayer stark kommunistisch durchsetzt war, Ende 1946 von Innenminister Helmer aber durch Beamte seines Vertrauens umstrukturiert wurde. Anfang 1947 wurden die STAPO-Einheiten auf Wiener Bezirksebene aufgelöst und deren 
Nachmittag des I9. November bei SektionschefWilhelm Krechler vorsprach, um sich über das Verhalten der Polizeiorgane zu beschweren, ${ }^{2034}$ ist doch zu konstatieren, dass es auch unter den Polizisten Verletzte gab. Wie Innenminister Helmer nach den Ereignissen vor dem Ministerrat feststellte, waren die Sicherheitskräfte einfach überfordert: zusätzliche Sicherheitskräfte seien keine abgestellt worden, da „von den Veranstaltern der Demonstrationen die Zusicherung gegeben worden war, daß die Demonstrationen völlig ruhig verlaufen und mit der Vorsprache einer Abordnung beim Rektor beendet würden.“ ${ }^{2035}$ [Unterstreichungen im Original]

Bei den Schlägereien wurde der Kommandant der 6o Mann starken Polizeiwache auf der Universitätsrampe, der die Demonstranten abzudrängen versuchte, angeblich „derart gegen das Torgitter gepresst, dass er Quetschungen des Brustkorbes erlitt und zusammenbrach.“2036

Als die Arbeiter-Delegation von der Universitätsrampe herab die Erklärung des Rektors verkündete und anfügte, dass für den nächsten Tag eine Vertrauensmännerkonferenz der gesamten Arbeiterschaft angesetzt sei, die eine eigene Deputation zum Unterrichtsminister entsenden werde, forderte die aufgebrachte Menge laut Bericht der Arbeiterzeitung die sofortige Schließung der Universität. ${ }^{2037}$

Nachdem Rektor Adamovich die Universitätstore mit Eisenriegeln hatte verschließen lassen, brachen gegen I3.30 Uhr rund 5o Demonstranten die Türe an der Rückseite des Universitätsgebäudes in der Reichsratsstraße auf, überrannten angeblich den „Wachriegel“ der Polizei ${ }^{2038}$ und stürmten in Richtung Rektorat und hissten vom zweiten Stockwerk herab rote Fahnen. Bei den ins Gebäude eingedrungenen Demonstranten handelte es

Agenden neugeordnet. In einer Lagebesprechung der Polizeibezirksleiter in der US-Zone am 17. März 1947 wurde die dadurch notwendig gewordene Neuordnung der bisherigen informationsdienstlichen Zusammenarbeit geregelt. Jeder Bezirksleiter (Bezirke 7š 9, 17š19) hatte künftig in einem Wochenbericht an den USFA/CIC u.a. über „neugebildete Untergrundbewegungen, keimende Tätigkeit der Nationalsozialisten“ zu berichten. Archiv der Bundespolizeidirektion Wien (BPDW), Amerikanische Besatzungsmacht 1, Akte Juli 45š Sept. 55 [Kopie im Besitz des Verfassers]. Am 15. November 1946 hatte der sowjetische Generalleutnant Lebedenko bei einer Aussprache mit dem Präsident der Wiener Polizei, Dr. Artur Klauser, u.a. kritisiert, dass „demokratische Elemente aus der Polizei entlassen werden." BPDW, Russische Besatzung 5, Akte 1946š 1950, Aktenvermerk 18. November 1946, 2; Vgl. dazu allgemein auch Gerald Theimer, Die Wiener Staatspolizei in den Jahren 1945š1947, Diss., Univ. Wien 1995, 150 ff.; weiters: Wolfgang Mueller, Die politische Mission der sowjetischen Besatzungsmacht in Österreich 1945š 1955, Diss., Univ. Wien 2004, 165 f.

2034 UAW, Senats-Sitzungsprotokolle des Studienjahres 1946/47, Protokoll der 6. Sitzung des Akademischen Senates der Universität Wien, 7. Dezember 1946, 2.

2035 „Bericht des Innenministers über die Vorfälle an der Wiener Universität.“ In: Neues Österreich, 27. November 1946, 3. Auch Ernst Fischer hatte mehrfach beteuert, dass die Arbeiter-Demonstration friedlich verlaufen würde. Siehe dazu: Huber, Studenten im Schatten der NS-Zeit, a.a.O., 181.

2036 „Bericht des Innenministers über die Vorfälle an der Wiener Universität“, a.a.O.

2037 Arbeiterzeitung, 20. November 1946, Nr. 270, 1.

2038 Zumindest laut Angabe im Bericht der Polizeidirektion. Siehe: Huber, Entnazifizierung und Rückbruch, a.a.O., 249. 
sich laut Bericht der Staatspolizei um FÖJ-Aktivisten. ${ }^{2039}$ Die Eindringlinge stellten dem Rektor das Ultimatum, innerhalb von zehn Minuten die Universitätstore zu öffnen; andernfalls, so die vage Drohung, würde „Österreich etwas erleben, was sich bisher in seiner ganzen bisherigen Geschichte noch nie zugetragen hätte“2040 - so Major Benner ex post in seinem Bericht.

Zuvor hatten die gewaltsam eingedrungenen Demonstranten versucht, die mittlerweile in Sicherheit gebrachten Wahlurnen zu finden, und dabei einen Studenten aus einem der Fenster des zweiten Stockes geworfen, der sich lebensgefährliche Verletzungen zuzog. ${ }^{2041}$ Rektor Adamovich, der zuvor bereits um verstärkten Polizeischutz gebeten hatte, informierte nun auch telefonisch den Leiter der US-Education Division, Thomas E. Benner, mit dem er persönlich gut bekannt war, über die gefährliche Situation.

Wie aus dem detaillierten Bericht Major Benners über die Ereignisse hervorgeht, hatte er bereits am frühen Morgen an seiner Privatadresse in der Strudelhofgasse Nachricht von den Demonstrationszügen erhalten. Nach eigener Aussage hatte er unmittelbar darauf das US-Hauptquartier informiert und zudem versucht, die französische Besatzungsbehörde innerhalb des „Vienna Area Command“ zu erreichen - allerdings erfolglos.

Noch deutlicher formulierte diesen Umstand US-Gesandter John G. Erhardt in einem Bericht an den US-Staatsekretär in Washington. Seiner Einschätzung nach wäre es völlig klar gewesen, dass die französischen Militärbeamten hinsichtlich der Demonstration ganz offenkundig keinerlei Absicht zeigten, zu intervenieren oder gar einzuschreiten.

Immerhin hatten die Franzosen im November 1946 den Vorsitz über das monatlich wechselnde Kommando über den I. Wiener Gemeindebezirk, der Interalliierte Zone war, daher konnten nur sie die interalliierte Militärpatrouille offiziell zum Eingreifen befehligen. Benner stellte die Vermutung an, dass sich das französische Besatzungselement - womöglich im Zusammenhang mit den einige Wochen zuvor abgehaltenen Wahlen in Frankreich, bei denen die Kommunisten als stimmenstärkste Partei hervorgegangen waren - aus dieser Angelegenheit heraushalten wollte. Gleichlautend sah das auch US-Gesandter Erhardt, der sich in seinem Lagebericht an das State Department auch über Staatssekretär Ferdinand Graf beschwerte:

"When, in the early afternoon, the demonstration appeared to get out of hand, with beatings going on and red flags appearing at university windows, USFA Headquarters telephoned the French officials who at that time headed the inter-Allied Kommandatura, but they professed ignorance of the demonstrations. It is conceivable that they did not wish to intervene. [...] State Secretary Graf, who is responsible for security matters, is reported to have been reluctant to

2039 ÖSTA/AdR, BMfI, GZ 164.321-2/46, Abschlussbericht der PD Wien, 25. November 1946. Zit. nach: Huber, Studenten im Schatten der NS-Zeit, a.a.O., 189.

2040 Benner, „Unhappy Austria“, a.a. O., 8.

2041 Benner, Synopsis of Post-war Education in Austria, USACA/Education Division, 10th March 1947, 9. 
make full use of the police, in view of the strong Communist penetration of the force." ${ }^{2042}$ [Hervorhebung d. Verf.]

Abgesehen von den angesprochenen ideologischen Motiven, die eine Rolle für die kritisierte Passivität gespielt haben mögen, hatten die Franzosen allerdings ihren militärischen Organisationapparat als Besatzungsmacht in Wien auf Grund von Einsparungsmaßnahmen seit Mitte des Jahres 1946 längst stark zurückgebaut und das Besatzungspersonal deutlich reduziert: die von der französischen Besatzungsmacht wahrgenommenen Kompetenzen beschränkten sich primär auf verwaltungstechnische Kontrolle - alle anderen Agenden überließ man der Eigenverantwortung österreichischer Stellen. ${ }^{2043}$

Jedenfalls informierte Benner über Kurzwellen-Funk umgehend den US-Provost Marshall (d.i. Kommandant des amerikanischen Korps der Wiener Militärpolizei), Colonel W.P.Yarborough, von dem gestellten Ultimatum an Rektor Adamovich. Der Colonel teilte Benner mit, er würde einen illegalen Einsatz der interalliierten Patrouille, der regulär nur von den Franzosen befehligt werden dürfte, nur durchführen, wenn Benner dafür die volle Verantwortung übernähme, was dieser akzeptierte.

Dass es in der Rektoratskanzlei noch einen „Schlagabtausch zwischen US-General Baker und dem Polizeichef des ersten Bezirks “2044 gegeben habe, wonach dieser später die Ansicht vertrat, die Demonstration hätte verhindert werden müssen, mag zutreffen, ist aber wohl eher als rhetorische Ersatzhandlung zu werten denn als seriöse Intervention seitens der US-Militärbehörden: sofern es sich bei dem Amtsvermerk nicht um eine leicht überzeichnete Darstellung handelt, war der Polizeikommandant des ersten Bezirks sicher ein schwacher und hierarchisch vergleichsweise tiefgestellter ,Sündenbock'. Noch vor Ablauf des FÖJ-Ultimatums erreichten schließlich mehrere Jeeps der interalliierten Militärpolizei - anscheinend ausnahmslos US-Soldaten mit Gummiknüppeln - das Universitätsgebäude, woraufhin sich die Demonstration - „without a blow“2045 - umgehend auflöste.

Interessanterweise wurde diese ungeplante und keineswegs unheikle Initiative seitens der amerikanischen Militärbehörde später mit keinem Wort thematisiert - weder in der Öffentlichkeit, noch in den Gremien des Alliierten Rates. Im Gegenzug verlangten die Sowjets unmittelbar nach den Hochschulereignissen im Exekutivkomitee des Alliierten Rates energisch die sofortige Schließung der Universität, bis die Studentenschaft endlich vom nationalsozialistischen Einfluss, gesäubert' wäre.

2042 John G. Erhardt an Secretary of State/Washington D.C., „Communist Riot and Demonstration against Vienna University, November 22, 1946, No. 2063, 3. NARA II, RG 84, Foreign Service Posts of the Department of State. Austria, POLAD \&USCOA, Classified Records 1945-55, Box 3.

2043 Stefan Vogel, Der französische Sektor in Wien 1945-1955. In: Studien zur Wiener Geschichte. Jahrbuch des Vereins für Geschichte der Stadt Wien. Hrsg. v. Karl Fischer. Bd. 61, Wien 2005, 302.

2044 Huber, Studenten im Schatten der NS-Zeit, a.a.O., 191.

2045 Benner, „Unhappy Austria“, a.a.O., 8. 
Eine Schließung der Universität - wie vom Alliierten Rat in seiner Sitzung vom 2r. November 1946 unter Vorsitz des französischen Kommandanten General Jopê zumindest erwogen und von den Sowjets und den österreichischen Kommunisten gefordert wurde, stand immerhin die Gefahr einer zeitweiligen Schließung der Universitäten im Raum ${ }^{2046}$ - konnte nur durch die vehemente Gegenposition der amerikanischen und auch der britischen Besatzungsmacht verhindert werden: sie wiesen darauf hin, dass eine derartige Maßnahme den bisherigen Aufbauprozess im gesamten höheren Bildungswesen Österreichs empfindlich zurückwerfen würde. Ganz im Sinne eines besatzungspolitischen quid pro quo wollte man den Sowjets mit der Unterstützung der Forderung nach einem Re-Screening der Universitäten aber die Möglichkeit geben, im Hinblick auf die von den demonstrierenden Arbeitern gestellten Forderungen nach einer Säuberung der Hochschulen das Gesicht zu wahren.

"In the progress of this political battle, in order to prevent the closing of the universities, in order to allow the Soviet Element to "save face", and particularly in order to avoid the creating issues which might obstruct the drafting of the peace treaty for Austria, it was necessary to pass over in silence the dangerous and anti-democratic activities of the Communist and Soviet sponsored workers". ${ }^{2047}$

Immerhin hatte sich nach den Ereignissen, die keineswegs - wie in der kommunistischen Presse kolportiert -, völlig spontan' zustande gekommen, sondern durchaus organisiert waren, laut Major Benner herausgestellt, dass den demonstrierenden Arbeitern von der Roten Armee ein volles Tagesgehalt für die Teilnahme an der Protestkundgebung sowie ein „beer and goulash dinner ${ }^{\text {“2048 }}$ danach versprochen worden war.

Entgegen der auch in der Tagespresse verbreiteten Ansicht, die Tumulte seien von kommunistischen Randalierern verursacht worden, stellte der VSStÖ nach den Ereignissen allerdings klar: „Die Volksparteipresse spricht es zwischen den Zeilen aus, daß, hochschulfremde', linksradikale Elemente, die Krawalle ausgelöst hätten. Wir glauben dies nicht. “2049

Sicherlich in gewissem Bemühen, die Studentenschaft im Nachhinein zu exkulpieren, sprach die Österreichische Hochschülerschaft die Schuld an den Ausschreitungen sowohl kommunistischen Provokateuren als auch vom Studium ausgeschlossenen Nazi-

2046 Angesichts der alarmierenden Vorgänge und dem Misstrauen gegenüber der Aktivität der österreichischen ,Säuberungskommission` stellte Generalleutnant Lebedenko den Antrag, die Universität während der neuerlichen Entnazifizierungsmaßnahmen zumindest für die Dauer von einem Monat zu schließen. Zudem sollten „präzise Aufnahmeregeln“ festgesetzt werden, wonach künftig nur mehr a) österreichische Staatsbürger per Erlaubnis der österreichischen Regierung, b) Staatsbürger der vier Besatzungsmächte per Erlaubnis der Behörden sowie c) sonstige Personen nach Überprüfung ihrer politischen Zuverlässigkeit durch Vertreter der drei demokratischen Parteien“ inskribieren dürften. Vgl. Volksstimme, 23. November 1946, Nr. $273,1$.

2047 Benner, Synopsis of Post-war Education in Austria, USACA, Education Division, 10. März 1947, 10.

2048 Benner, „Unhappy Austria“, a.a.O., 5.

2049 „Provokationen und ihr Widerhall“. In: Strom, 2. Jg., 23. November 1946, Folge 39, 10. 
Studenten zu. Zusätzlich bemühten sich die Akademische Rundschau und auch die USEducation Division darum, herauszustreichen, dass sich unter den insgesamt 36 Verletzten keine Studierenden befanden, die in irgendeiner Form durch eine „Nazivergangenheit“ belastet waren. Eine gesonderte Untersuchung dazu habe ergeben, dass vier der verletzten Mitglieder des antinazistischen Wiener Untergrundes und sieben von ihnen Überlebende von Konzentrationslagern waren. ${ }^{2050}$ Allerdings decken sich diese Angaben nicht mit der Darstellung der Staatspolizei, die die Verhaftungen durchgeführt und - ganz anders als die ÖH - offenkundig allerhöchstes Interesse daran hatte, einen allfälligen nationalsozialistischen Background der verhafteten Studenten zu recherchieren. Wie Huber auf Grundlage der von Dürmayer ans Innenministerium übermittelten staatspolizeilichen Protokolle detailliert dargestellt hat, waren unter den 25 verhafteten Studenten 13 Verletzte. Laut Staatspolizei seien 16 der Inhaftierten Mitglied einer NS-Organisationen gewesen: der Großteil in NS-Jugendorganisationen (HJ/DJ/BDM), ein Mitglied der Waffen-SS und zwei Studenten, die die Registrierungspflicht unterlaufen und ihre SA-Zugehörigkeit verschwiegen hätten. ${ }^{2051}$

In Bezug auf die Zeitungsberichterstattung über die Vorfälle bei den ersten Hochschülerschaftswahlen - erstaunlicherweise sind lediglich in der Welt-Illustrierten und in der Weltpresse Fotos aufzufinden ${ }^{2052}$ - ist an dieser Stelle anzumerken, dass diese eine erhebliche Verzerrung aufweist: der Wiener Kurier merkte signifikanterweise nur in einem Artikel an, dass während der Wahlen „eine gewisse Störung eingetreten ist, weil Massen von Arbeitern mit feindseligen Rufen vor der Universität vorübergezogen“ seien und verwies - mit einer den Tatsachen nicht entsprechenden Stellungnahme zur universitären Personalpolitik von Minister Hurdes - auf angebliche wissenschaftspolitische Anstrengungen, wonach dieser „wiederholt, die österreichischen Gelehrten und Professoren, die noch im Auslande weilen, unter anderem die Nobelpreisträger Schrödinger und Heß sowie Prof. Hochmeister aufgefordert [habe], ihre Lehrtätigkeit in Österreich aufzunehmen und ihnen entsprechende Lehrkanzeln an den Hochschulen bis zum heutige Tage frei-

2050 Thomas E. Benner, „Unhappy Austria“. Manuskript. University of Illinois Archives, Thomas E. Benner Papers 1930-1979, Austrian Materials, Rec. Series No. 10/1/21,7 [Kopie im Besitz des Verfassers]; vgl. dazu auch: Akademische Rundschau, 2. Jg., 30. November 1946, Nr. 10, 2.

2051 Vgl. dazu ausführlich: Huber, Studenten im Schatten der NS-Zeit, a.a.O., 201-204. Interessanterweise verliefen die Vorerhebungen für ein Disziplinarverfahren im März 1946 gegen die inhaftierten Studierenden im Sande, da für die Kriminalbeamten keine Personalunterlagen mehr aufzufinden waren und sich diese - die Verhaftungen waren ja durch Beamte der Staatspolizei erfolgt - an keine provokatorischen Äußerungen von Studenten erinnern konnten. Ebd., 203. Demgegenüber wurden die Verfahren gegen die beiden SA-Mitglieder eingestellt; einer der beiden promovierte bereits Februar 1947. Ebd., $203 \mathrm{f}$.

2052 Siehe dazu Huber, Studenten im Schatten der NS-Zeit, a.a.O., 184-185. Eine Recherche in zentralen Fotoarchiven fiel ergebnislos aus. Erstaunlicherweise findet sich weder im Bestand des Bildarchivs der Österreichischen Nationalbibliothek, im Fotoarchiv des Instituts für Zeitgeschichte der Universität Wien, im Archiv des Vereins zur Geschichte der Arbeiterbewegung, im Archiv der Bundespolizeidirektion Wien, im Archiv der Universität Wien noch im Archiv der Firma Votava eine Aufnahme. 
gehalten “2053 habe. Die einschlägigen Berichte - von der um eine ,wahrheitsgetreue‘ Darstellung bemühten Akademischen Rundschau und den Organen der Studentenfraktionen einmal abgesehen - in den anderen Tageszeitungen fielen hingegen deutlich anders aus. Im Neuen Österreich, in der Arbeiterzeitung, in der Volksstimme und in der Österreichischen Zeitung wurde sowohl quantitativ als auch in weitaus detaillierteren Schilderungen viel ausführlicher und genauer Bericht erstattet, wobei die Zahl und der Umfang der zugespitzt verfassten Artikel bei den kommunistischen Blättern deutlich überwiegen. ${ }^{2054}$

In ihrer Analyse der Presseberichterstattung zu den Ereignissen versuchte die Akademische Rundschau darzulegen, dass Informationen oftmals selektiv aufgegriffen und teils grob verzerrt wiedergegeben worden waren. Manche der Zwischenrufe und Reden bei den stattgefundenen Wahlversammlungen seien keineswegs „Ausdruck nazistischer Gesinnung“ sondern „in Wirklichkeit nur eine Ablehnung kommunistischer Redner“ gewesen. ${ }^{2055}$ Dennoch sah sich auch die Österreichische Hochschülerschaft - anders als einzelne Vertreter der Studentenfraktionen ${ }^{2056}$-, die nach der Wahl sichtlich um ein entspannteres Verhältnis zum Rektor bemüht waren und durch die bekundete „Bereitwilligkeit, unter seiner bewährten Leitung tatkräftig am Wiederaufbau der Universität mitzuarbeiten “2057 zu kalmieren trachteten, genötigt, die Vorgänge nicht gänzlich unter den Tisch zu kehren:

„Die Tatsache der Auslegung antikommunistischer Parteiäußerungen als nazistische und faschistische Provokationen durch die kommunistische Presse ändert aber nichts an der Tatsache, daß diese Einzelerscheinungen auch Tatsache sind. “2058

Noch in den Nachtstunden des ÖH-Wahltages führten der unter erheblichen Druck geratene Rektor Adamovich und Dekan Thirring Gespräche mit Vertretern von SPÖ und KPÖ; sie ersuchten die Politiker darum, dass bei den kommenden Versammlungen „keine Resolutionen gefasst werden, die unmöglich sind." Des Weiteren wurde den Parteienvertretern signalisiert, dass die Absicht bestehe, den Entnazifizierungskommissionen Vertreter der Gewerkschaft beizuziehen und die „Kommissionen von einer Stelle außerhalb der Universität durchführen zu lassen. “2059

2053 Wiener Kurier, Mittwoch 20. November 1946, 1.

2054 Das Neue Österreich brachte in Summe vier Artikel, die sich direkt auf die Ereignisse und die Folgen bezogen, die Wiener Zeitung fünf, die Arbeiterzeitung acht, die Volksstimme neun, die Österreichische Zeitung fünf.

2055 Akademische Rundschau, 2. Jg., 23. November 1946, Nr. 9, 9.

2056 So dementierte - laut Volksstimme - zum Beispiel der Verbandsobmann der Sozialistischen Studenten, Raoul Schmiedek, die in mehreren Wiener Zeitungen, auch in der Arbeiterzeitung, erschienenen „Beschönigungsversuche der Nazihetze“ und erklärte ,ausdrücklich [...], daß es sich um nazistische, großdeutsche und antisemitische Demonstrationen gehandelt habe. "Siehe: Volksstimme, 19. November 1946, Nr. 269, 2.

2057 UAW, Senats-Sitzungsprotokolle des Studienjahres 1946/47, Protokoll der 6. Sitzung des Akademischen Senates der Universität Wien, 7. Dezember 1946, 2.

2058 Ebd.

2059 UAW, Senats-Sitzungsprotokolle des Studienjahres 1946/47, Protokoll über die außerordentliche Senatssitzung, 20. November 1946, 2. 
Trotz der geschilderten Ausschreitungen bei der ÖH-Wahl war die Wahlbeteiligung mit über 80 Prozent sowohl in Wien ${ }^{2060}$ als auch österreichweit hoch. Die Wahl selbst gewann der ÖVP-nahe FÖST mit 75,3 Prozent der Stimmen vor dem VSStÖ mit 2I,7 Prozent und den kommunistischen Studenten mit drei Prozent. ${ }^{2061}$

Am Tag nach den Hochschulkrawallen fand eine außerordentliche Sitzung des Akademischen Senates statt, an der auch die beiden Sektionschefs Skrbensky und Musil teilnahmen, um sich persönlich über die Vorfälle zu erkundigen. Dabei gab Skrbensky bekannt, „daß die Regierung gegen die Sperre [der Universität, d. Verf.] sei und der Beschluß des Senats zurückzunehmen sei“2062 - aus Sicht des Rektors eine weitere autoritäre Anmaßung des Unterrichtsministers gegenüber der Alma Mater und ihrem Rektor, die die existierenden Differenzen noch vertiefte.

Am gleichen Tag fand im Wiener Konzerthaus eine stürmische Protestkundgebung des „Landesverbandes Wien ehemals politisch verfolgter Antifaschisten“ statt (d.i. KZ-Verband, Häftlingsverband, Verband der Abstammungsverfolgten), bei der Vertreter aller drei politischen Parteien sowie Vertreter der Studentenfraktionen anwesend waren; etwa 5.000 Personen nahmen an dieser Versammlung teil, die Bundesvorstand Ministerialrat Dr. Franz Sobek eröffnete. Nach dem Obmann der sozialistischen Studenten, Raoul Schmiedek, sollte ein Vertreter des FÖST zu Wort kommen, doch die Versammlung geriet in einen derart heftigen Tumult, dass der Vorstand des Präsidiums abtrat. Sowohl die Versammlung - als Sprecher hatten insbesondere Dr. Wolken und Horn (KPÖ) sowie Felix Slavik (SPÖ) die Zustände an der Universität heftig kritisiert - als auch die Hochschülerschaft distanzierten sich energisch von den Vorkommnissen und den dabei verübten „Exzessen“. ${ }^{2063}$

Ebenso wie die Teilnehmer dieser Versammlung distanzierten sich sowohl der Österreichische Gewerkschaftsbund als auch die Bundesregierung vom „Terror“ der Demonstranten, wobei aber gleichzeitig auf die Notwendigkeit gründlicher Nachsäuberungsmaßnahmen verwiesen wurde.

Der Gewerkschaftsbund versicherte darüber hinaus - nicht ganz unzweideutig - der „um die Demokratisierung der Hochschulen kämpfende[n] Studentenschaft nicht nur seiner Sympathie, sondern auch seiner Unterstützung“2064 und vertrat die eindeutige For-

2060 In Summe waren an der Universität Wien 12.527 wahlberechtigt gewesen. Vgl. Synopsis of Post-war Education in Austria, USACA/Education Division, 10th March 1947, 7.

2061 Arbeiterzeitung, 21. November 1946, Nr. 271, 1. Mit der Zulassung des Rings Freiheitlicher Studenten (RFS) bei den ÖH-Wahlen im Jahr 1953 kam dann erstmals das vorhandene Potenzial deutschnationaler und rechtsextremer Kräfte auf universitärem Nachkriegsboden zum Vorschein, indem dieses Sammelbecken auf Anhieb 32\% bei den Hochschülerschaftswahlen erreichte. Vgl. Heribert Schiedel/Martin Tröger, Zum deutschnationalen Korporationswesen in Österreich. Siehe dazu: http://www.doew.at/ thema/thema_alt/rechts/burschen/burschis.html [Zugriff 16.8.2011].

2062 Ebd., 1.

2063 Wiener Zeitung, 239. Jg., Mittwoch, 20. November 1946, Nr. 270, 2.

2064 Ebd. 
derung, den Nazismus, dessen „letzte Zufluchtsstätte [...] anscheinend die Hochschulen bilden“, „,mit Stumpf und Stiel“2065 auszurotten.

Hingegen erklärte Bundeskanzler Figl bei einer Jugendtagung in Klosterneuburg am 23./24 November 1946 mit Bezug auf die Vorfälle bei den Hochschulwahlen direkt an die Adresse der Kommunisten gerichtet:

„Und wenn die Herren meinen [...], dass sie ihre Schwäche auf akademischem Boden mit Terror von Außenstehenden verschleiern können, so haben sie sich geirrt. Die Wahlen sind durchgeführt worden trotz den Demonstrationen und haben das bekannte Ergebnis gezeitigt. Und weil der erste Wurf nicht geglückt ist, will man jetzt die Schließung der Universität haben. Die Regierung denkt nicht daran. Wir werden an den Hochschulen gründlich nachsäubern. Wir haben heute bereits mehr als 800 Universitäts- und Hochschulprofessoren entlassen und enthoben. Wir werden aber auch weitersorgen und bei der Studentenschaft nochmals eine genaue Prüfung durchführen. Aber das, was hier zu geschehen hat, machen die zuständigen Behörden und nicht der Mob der Straße. “2066 [Unterstreichung im Original]

Auf welcher Informationsgrundlage die hier von Kanzler Figl angesprochene Zahl auch immer beruhen mochte, mit der Realität hatte sie wenig zu tun und zeugte höchsten vom Wunsch einzelner Politiker, das Entnazifizierungsproblem an den Universitäten rhetorisch beziehungsweise mit möglichst hoch gegriffenen Erfolgszahlen herunterzuspielen.

Tatsächlich belief sich die Zahl der enthobenen Professoren (außerordentliche und ordentliche) in Gesamtösterreich im September 1946 auf 273, wobei 20 Fälle noch unentschieden waren. ${ }^{2067}$ Zum Zeitpunkt der Befreiung Österreichs im April 1945 gab es 246 Professoren an Wiener Hochschulen, davon waren I80 durch NSDAP-Mitgliedschaft beziehungsweise durch NSDAP-Parteianwärterschaft kompromittiert. Von diesen wurden bis Februar 1947 I09 permanent außer Dienst gestellt (neben Entnazifizierung auch altersbedingte Pensionierung beziehungsweise Tod), 36 ohne weitere Lehrbefugnis pensioniert, 3r zeitweilig suspendiert (da nicht zum Dienst erschienen beziehungsweise kein Aufenthaltsort bekannt) und vier wieder voll in Dienst genommen. Von den übrigen Professoren wurden I7 die Forschungserlaubnis, nicht aber die Lehrbefugnis erteilt, und elf wurde die Lehrbefugnis bis Ende des Sommersemester 1946 erteilt. $^{2068}$

Angesichts der öffentlichen Kritik an den universitären Zuständen und den seit der Rektoratskonferenz vom 26. September 1946 schwelenden Differenzen mit dem Unterrichts-

2065 Arbeiterzeitung, 20. November 1946, 1.

2066 „Straßenterror darf nicht diktieren. Der Kanzler über die Vorgänge bei den Hochschulwahlen“. Wiener Zeitung, 239. Jg., Dienstag, 26. November 1946, Nr. 275, 1.

2067 Report of Quadripartite Sub-Committee on Denazification in Austrian Universities, 7. September 1946. NARA II, RG 260, Box 11, Folder 68, 3.

2068 Headquarters United States Forces in Austria, APO 777, to Chief, Civil Affairs Division, War Department Washington: „Reorientation of Austrian Universities“, 9. April 1947, 1. NARA II, RG 165, Box 322, 3. 
ministerium, die sich durch die ministerielle Kritik an der verhängten Universitätssperre ${ }^{2069}$ noch vergrößerten, brachte Rektor Adamovich neuerlich ein Rücktrittsgesuch ein, das von Minister Hurdes allerdings auch diesmal nicht angenommen wurde. ${ }^{2070}$

Zusätzlich angeheizt wurde die Situation dann durch die offene Forderung der Kommunisten nach politischen Konsequenzen. Bei einer „Konferenz der Vertrauensmänner der Wiener Betriebe und Bezirke“ pochte der KPÖ-Vorsitzende Johann Koplenig angesichts der Vorfälle auf die sofortige Abhaltung von Neuwahlen zum Nationalrat, denn, so die plakativ formulierte Anklage: „Die reaktionäre Clique, die an unserem Elend schuld ist, muß aus der Regierung verschwinden.“2071 Unter dem Druck der Ereignisse waren sich sowohl Nationalrat als auch Bundesregierung hinsichtlich der Notwendigkeit weitgehend einig - bei allem Bemühen, die Studentenschaft gegen die Provokateure in Schutz zu nehmen -, den Alliierten gegenüber eine klare Position in dieser Angelegenheit einzunehmen.

Aus Sicht der österreichischen Regierung bestand darüber hinaus die Gefahr, gerade im Hinblick auf die Entnazifizierungsfragen neuerlich als säumig zu erscheinen und damit vor allem den Sowjets - Argumente gegen die Aufnahme von Staatsvertragsverhandlungen zu liefern. In einem Schreiben an den Alliierten Rat räumte Figl jedenfalls ein, dass derartige Zwischenfälle darauf hin deuten, „dass die bisherigen Säuberungsmaßnahmen nicht ausgereicht haben, um nationalsozialistische Tendenzen an den österreichischen Hochschulen restlos auszumerzen. “2072

De facto spielten die Vorkommnisse rund um die ÖH-Wahlen, trotz so mancher negativer Schlagzeilen auch im Ausland, ${ }^{2073}$ realpolitisch im Hinblick auf die Aufnahme von Staatsvertragsverhandlungen weder bei der vorbereitenden Außenministerkonferenz im

2069 Aufgrund der massiven Kritik an der verhängten Sperre der Universität seitens des Unterrichtsministeriums und der Regierung wurde ein eigenes Rechtsgutachten in Auftrag gegeben, das sich u.a. auf einen Ministeriumserlass vom Juli 1851 bezog, worin es hieß, dass „die akademischen Behörden im allgemeinen eine zu grosse Ängstlichkeit in dem Gebrauche der ihnen [...] eingeräumten Freiheit und zu weit gehendes Streben gezeigt [hätten], jede Verantwortlichkeit für ihre Geschäftsführung von sich abzuwälzen." UAW, Senats-Sitzungsprotokolle des Studienjahres 1946/47, Protokoll der 5. Sitzung des Akademischen Senates der Universität Wien, 30. November 1946, Rechtsgutachten über die vom Akademischen Senat am 19. d. Mts. verfügte Sperre der Universität, 1 f. Hierin wurde vermerkt, dass das geeignete Mittel zur Aufrechterhaltung von „Ruhe und Ordnung auf akademischem Boden“ und zum Schutz des staatlichen Eigentums „einzig und allein die Sperre“ gewesen sei.

2070 UAW, Senats-Sitzungsprotokolle des Studienjahres 1946/47, Protokoll der 4. Sitzung des Akademischen Senates der Universität Wien, 16. November 1946, 1.

2071 Volksstimme, 22. November 1946, Nr. 272, 1.

2072 Bundeskanzler Figl an den Alliierten Rat, 8. Dezember 1946, 60258-2/033, NA. Zit. nach: Stiefel, Entnazifizierung in Österreich, a.a.O., 180.

2073 So sei Rektor Adamovich von dem in den USA weilenden Außenminister Karl Gruber darüber informiert worden, dass das „Echo auf die Vorfälle bei den Wiener Hochschulwahlen sehr schwerwiegend gewesen sei“. Zit. nach: Huber, Studenten im Schatten der NS-Zeit, a.a.O., 206. [UAW, Rektoratsakten, GZ 260-1946/47, O.-Nr. 43a, Protokoll zur Rektorenkonferenz am 18. Jänner 1946 (recte 1947!), 6]. 
Dezember 1946 in New York noch auf der Londoner Konferenz der Sonderbeauftragten im Jänner 1947 und der darauffolgenden Außenministerkonferenz in Moskau eine Rolle, wo unter anderem bereits die Militärklauseln des künftigen Staatsvertrages verhandelt beziehungsweise fixiert wurden. ${ }^{2074}$

Ebenfalls am 20. November 1946 fand in den voll besetzten Stefanie-Sälen in Wien Hütteldorf eine Versammlung der SPÖ zu den Hochschulereignissen statt. Dabei sprachen sich die anwesenden Vertreter der sozialistischen Studenten unter großem Beifall für ,Säuberungsmaßnahmen' unter der Studentenschaft aus, die nun "gegen alle Faschisten, nicht nur gegen Nazi“ gerichtet sein sollten. Neu in die Diskussion gebracht wurde von den VSStÖ-Vertretern die womöglich unumgängliche Einrichtung eines scharfen politischen Numerus clausus. Immerhin sei es besser, ,heute zehntausend Studenten und unter ihnen vielleicht auch ein paar Unschuldige vom Studium auszuschließen, als in einigen Jahren auch nur tausend Nazi wieder in wichtigen Stellungen zu haben." ${ }^{2075}$

Künftig sollten Studenten in folgender Reihenfolge zugelassen werden: „,. Aktive Antifaschisten. 2. Durch den Faschismus geschädigte Studenten. 3. Solche, die währen der letzten anderthalb Jahre positive Aufbauarbeit geleistet haben, und dann erst - wenn noch Platz ist - 4. die sogenannten,Unbelasteten “'.2076

Der Vorschlag zur Einführung eines politischen Numerus clausus war bereits zuvor von Walter Hacker in der Arbeiterzeitung angesprochen worden, wobei er die kausale Begründung - in direkter Anlehnung an die Argumentation des Verbandes demokratischer Hochschullehrer in der bereits erwähnten Broschüre die „Wehrlosen“-, noch weiter trieb, indem er sich gegen die des öfteren vorgebrachten Einwände gegen Professoren-Enthebungen im Zusammenhang des bestehenden Personalmangels wandte: „Zur gleichen Zeit wird die Verminderung der Zahl der Studierenden eine wirkliche und wirksame Säuberung der Professorenschaft ermöglichen, da nicht länger auf den großen Bedarf an Lehrkräften Rücksicht zu nehmen sein wird."2077

Darüber hinaus wurde auch über die notwendige „Reinigung der Professorenschaft“ debattiert, immerhin würde für den ,jungen Studenten [...] sein Professor das wichtigste Beispiel“" geben. Der sozialistische Nationalratsabgeordnete Alfred Migsch, seines Zeichens auch parlamentarischer Berichterstatter zur Entnazifizierung, merkte diesbezüglich an, dass „der Großteil aller Studierenden niemals demokratische Verhältnisse kennengelernt ${ }^{\text {"2078 }}$ habe.

Schließlich wurde - mit deutlich revanchistischem Unterton in Bezug auf die vorbereitende Rolle „klerikaler Wissenschafter und Professoren“ zur Zeit des „Ständestaates“-, gegenüber der „Union“ als Akademikerorganisation der ÖVP große Bedenken geäußert,

2074 Stifter, Die Wiederaufrüstung Österreichs, a.a.O., $57 \mathrm{f}$.

2075 „Arbeiter und Studenten kämpfen gemeinsam.“ Arbeiterzeitung, Nr. 271, 21. November 1946, 1.

2076 Ebd.

2077 Walter Hacker, Hochschulen und Demokratie. In: Arbeiterzeitung, 20. November 1946, Nr. 270, 2.

2078 Ebd. 
da man schließlich nie wisse, „wo der Demokrat aufhört und der Faschist beginnt“. ${ }^{2079}$ Angesicht der trotz aller Erfolge bei der ÖH-Wahl geringen Zahl sozialistischer Studenten und der gesellschaftspolitisch bedeutenden Aufgabe der Hochschulen wurde der Wunsch nach demokratischer Kontrolle laut:

„Die Hochschulen kosten das österreichische Volk jährlich 24 Millionen Schilling. Wir werden keiner Hochschule, die nicht Demokraten für den demokratischen Staat erzieht, auch nur einen Schilling gewähren. Die Überprüfung der Studierenden und Professoren kann nicht allein durch die Herren vorgenommen werden, die Herr Minister Hurdes bestellen wird. Sie muß von den Vertretern der Arbeiter und Angestellten, vom Österreichischen Gewerkschaftsbund durchgeführt werden (Stürmischer Beifall).“2080

Dem Vorschlag einer Einbeziehung auch von Repräsentanten der Gewerkschaft wie auch anderer Vertreter der Öffentlichkeit in die Untersuchungskommission schloss sich im Parlament dann auch der KPÖ-Abgeordnete Ernst Fischer an. ${ }^{2081}$

\section{Auswirkungen der Hochschulkrawalle: Turbulenzen im Alliierten Rat, Re-Screening der Studierenden und Lehrkräfte - ein letzter Anlauf zur Entnazifizierung parallel zur NS-Gesetznovelle 1947}

Auf der Ebene konkreter administrativer Maßnahmen kam es, nicht zuletzt durch Forderungen, die im Alliierten Rat erhobenen wurden, per Erlass des Unterrichtsministeriums bereits mit 6. Dezember 1946 zu einer neuerlichen Überprüfung der Studierenden. In dem Erlass an die „Rektorate und Dekanate sämtlicher österreichischer Hochschulen wissenschaftlicher und künstlerischer Richtung" sowie an die Österreichische Hochschülerschaft verwies Unterrichtsminister Hurdes darauf, dass auf Grund der Vorfälle bei „der Vorbereitung und Durchführung der Hochschülerschaftswahlen [...] die darauf hindeuten, daß die Ideologien des Nationalsozialismus noch nicht überall ausgemerzt sind, [...] sich eine neuerliche Überprüfung der Studierenden nach strengeren Grundsätzen notwendig erwiesen “2082 habe.

Entsprechend diesem Erlass waren an allen Fakultäten umgehend Überprüfungskommissionen einzurichten. ${ }^{2083}$ Die neu bestellten Gremien sollten darüber hinaus, wie

\section{Ebd.}

2080 Ebd.

2081 Erhardt an Secretary of State/Washington D.C., „Communist Riot and Demonstration Against Vienna University, November 22, 1946, No. 2063, 3. NARA II, RG 84, Foreign Service Posts of the Department of State. Austria, POLAD \&USCOA, Classified Records 1945-55, Box 3, 3.

2082 UAW, Dekanatsakten, Phil. Fakultät, 493-1946/47, Z1. 45675-III/7/46, Politische Überprüfung der Hochschüler, Erlass Bundesminister Hurdes, 6. Dezember 1946, 1.

2083 An der Universität Wien wurden daraufhin an der Rechts- und Staatswissenschaftlichen Fakultät 4 Überprüfungskommissionen, an der Medizinischen Fakultät zunächst 8, dann 12, und an der Philoso- 
in eigens erlassenen Durchführungsbestimmungen festgelegt wurde, auf Hochtouren arbeiten, „da bis längstens 15. Februar 1947 ein Bericht über die Durchführung der Entnazifizierung der Hochschülerschaft dem Alliierten Rat vorzulegen ist. ${ }^{\text {"2084 }}$ Der Vorsitz der jeweiligen Kommission oblag dem Rektor beziehungsweise Dekan oder einem von diesen zu bestellenden Stellvertreter, „der womöglich dem Kreise der in den Jahren 1938 bis 1945 gemassregelten akademischen Lehrer angehören soll“. ${ }^{2085}$ Der Kommission waren auch drei von der ÖH zu nominierende Studierende beizuziehen, „womöglich dem Kreise der Freiheitskämpfer oder politisch bzw. aus Abstammungsgründen Geschädigten“ ${ }^{2086}$

Einstimmige Erkenntnisse - der Vorsitzende hatte im jeweiligen Verfahren seine Stimme zuletzt abzugeben - waren als endgültig zu werten. In jenen Fällen, wo keine Einstimmigkeit erzielt wurde, waren diese dem übergeordneten Überprüfungssenat beim Bundesministerium für Unterricht vorzulegen -, der wurde allerdings erst per Erlass vom II. Februar 1947 eingerichtet, da zuvor die Arbeit der universitären Kommissionen abgeschlossen sein sollte; er umfasste, neben Professoren und Studenten, auch Vertreter der politischen Parteien. ${ }^{2087}$

phischen Fakultät 10 Kommissionen eingesetzt. Vgl. UAW, Dekanatsakten Phil. Fakultät, 493-1946/47, G.Z. 260-1946/47, Rektor Adamovich an die Herren Rektoren sämtlicher österreichischer Hochschulen, 1. Die Vorsitzende der 10 Kommissionen an der Philosophischen Fakultät waren: Prof. Alphons Lhotzky, Prof. Paul Müller, Prof. H.W. Duda, Prof. V. Sas-Zaloziecky, Prof. R. Bleichsteiner, Dr. Fritz Novotny, Pd. Herbert Günther, Prof. Otto Storch, Prof. Johann Sölch, Prof. Karl Przibram, Prof. L. Fuchs; als „unbelastet“ (ub), „politisch verfolgt“ (pv), politisch geschädigt“ (pg) oder aktiv in der Widerstandsbewegung (W) waren folgende Beisitzer nominiert: Walter Hauptmann (pg), Franz Bauer (pv), Philipp (Freiheitskämpfer), Kornelius Fleischmann (Freiheitskämpfer), Johann Fernbach (pg), Herbert Gutfreund (pg), Leopold Boris (pg), Wilfried Daim (W), Edith Haas (ub), Günther Hamann (W), Margarete Siegel (ub), Hans Elsner (ub), Ursula Jus (ub), Erna Ernst (ub), Werner Mann (ub), Fritz Fexner (ub), Robert Weisner (ub), Walter Exinger (ub), Eduard Stuhr (ub), Ambros Köppner (ub), Günther Doppler (ub), Eduard Rott (ub), Weinzirl [sic] (ub), Claudius v. Saar (ub), Ernst Faltis (ub), Hermann Rösner (ub), Friedrich Kauer (ub), Oskar v. Burckher (ub), Margarete Partsch (ub), Lilly Dalbosco (ub), Johann Moser (ub), Friedrich Putscher (ub). UAW, Dekanatsakten, Phil. Fakultät, 4931946/47, Dekan der Phil. Fakultät an das Rektorat der Universität Wien, 13. Februar 1947, 1 f.

2084 UAW, Dekanatsakten, Phil. Fakultät, 493-1946/47, Z1. 47081-III/7, Durchführung der politischen Überprüfung der Hochschüler gemäß ha. Erlass Zl. 45675/46, 16. Dezember 1946, 1.

2085 UAW, Dekanatsakten, Phil. Fakultät, 493-1946/47, Z1. 45675-III/7/46, Politische Überprüfung der Hochschüler, Erlass Bundesminister Hurdes, 6. Dezember 1946, 1.

2086 Ebd., 3.

2087 Überprüfungssenat an der Theologischen und Rechts- und Staatwissenschaftlichen Fakultät:

Vorsitzender: Dr. Otto Skrbensky, Stellvertreter: Ministerialoberkommissär Dr. Karl Haertl; Vertreter des Lehrkörpers: o.Prof. Dr. Ferdinand Degenfeld-Schonburg, Ersatz: ao. Prof. Dr. August M. Knoll; Vertreter der ÖH: stud.theol. Karl Rassl, cand. jur. Hans Oberhammer, Ersatz: stud. theol. Johannes Todt, Karl Faustmann, Raimund Hayer; Vertreter der ÖVP: Dr. Wilhelm Gibisch, Ersatz: Gen. Rudolf Puchinger, Ing. Wilhelm Guha; Vertreter der SPÖ: NR Dr. Bruno Pittermann, Ersatz: Dr. Johann Kurz, Dr. Richard Bamberger; Vertreter der KPÖ: nicht genannt.

Überprüfungssenat für die Studierenden der Philosophischen Fakultät: 
Neben allen, durch einstimmige Beschlüsse von Überprüfungskommissionen bisher schon rechtskräftig vom Studium Ausgeschlossenen, waren folgende Studierende „ab sofort unbedingt auszuschließen“: alle „hauptamtlichen Funktionäre sämtlicher nationalsozialistischer Organisationen“, „Angehörige der SD, der Gestapo, der zivilen SS und der Totenkopfverbände“, „Angehörige der Waffen-SS“, die Träger „politischer Auszeichnungen“ (Blutorden, Goldenes Ehrenzeichen der NSDAP, Goldenes Ehrenzeichen der HJ, Dienstauszeichnungen der NSDAP), alle „Dienstgrade der SA vom Scharführer aufwärts“, weiters alle „Führer der HJ und der DJ vom bestätigten Gefolgschaftsführer bzw. Fähnleinführer oder der Diensteinstellung eines Stammführers bzw. Jungstammführers aufwärts“, die „Führerinnen des BDM und der Jung mädel von der bestätigten Gruppenführerin oder der Dienststellung einer Ringführerin aufwärts“ sowie „sämtliche Führer des RAD im Offiziersrang “. 2088

Allerdings waren diese verschärften Inskriptionsbestimmungen nur kurze Zeit in Kraft und wurden mit dem zweiten Verbotsgesetz vom I8. Februar 1947 zum Teil wieder zurückgenommen. Eine Anfrage Rektor Adamovichs an das Bundeskanzleramt ergab zum Beispiel, dass „nur die Angehörigen der allgemeinen SS“, aber nicht die ehemaligen Angehörigen der Waffen-SS ,unter die belasteten Personen fallen und demnach bis 30 . April I950 vom Studium auszuschließen wären." ${ }^{\text {2089 }}$

Die Interpretation der Ereignisse rund um die ÖH-Wahl fiel zwischen den einzelnen Studentenfraktion klarerweise überaus kontrovers aus und führte zu heftigen Anwürfen gegenüber der Union (FÖST) seitens kommunistischer und sozialistischer Studenten, zu heftiger Kritik an der Bagatellisierung der Naziprovokationen seitens der Akademischen

Vorsitzender: Ministerialrat Dr. Otto Starnbacher, Stellvertreter: Ministerialsekretär Dr. jur. Otto Perchter; Vertreter des Lehrkörpers: o.Prof. Dr. Wilhelm Koppers, Ersatz: o.Prof. Dr. Hans Leitmeier, o.Prof. Dr. Karl Mras, o.Prof. Dr. Josef Weninger; Vertreter der ÖH: stud.phil. Günther Hamann, Ersatz: stud.phil. Otto Riedl, Johann Tuppy, Johann Moser; Vertreter der ÖVP: Rechtsanwalt Dr. Adolf Keindl, Ersatz: Dr. Franz Nowotny, Prof. i.R. Josef Holzmann; Vertreter der SPÖ: NR Dr. Otto Tschadek, Ersatz: Dr. Wilhelm Rosenzweig, Dipl. Ing. Erich Werner; Vertreter der KPÖ: nicht genannt.

Überprüfungssenat für die Studierenden der Medizinischen Fakultät:

Vorsitzender: Ministerialrat Dr. Hans Kenda, Stellvertreter: Sektionsrat Dr. Ladislaus Thiel; Vertreter des Lehrkörpers: o.Prof. Dr. Otto Kauders, Ersatz: o.Prof. Dr. Walter Schwarzacher, tit.ao. Prof. Privatdozent Dr. Paul Huber, tit.ao. Prof. Privatdozent Dr. Hans Heidler; Vertreter der ÖH: stud.med. Walter Schwarz, Ersatz: stud.med. Reinhard Jagenbrein; Vertreter der ÖVP: Dr. Hans Jiresch, Ersatz: Rechtsanwalt Dr. Magnus Kahl, Richard Straub; Vertreter der SPÖ: NR Anton Proksch, Ersatz: Dr. Wilhelm Stemmer, Dr. Ernst Glaser; Vertreter der KPÖ: nicht genannt.

Siehe: UAW, Dekanatsakten, Phil. Fakultät, 493-1946/47, Z1. 591/III/7/47, Bundesministerium für Unterricht, an das Rektorat der Universität Wien, 11. Februar 1947, $1 \mathrm{ff}$.

2088 UAW, Dekanatsakten Phil. Fakultät, 493-1946/47, Z1. 45675-III/7/46, Politische Überprüfung der Hochschüler, Erlass Bundesminister Hurdes, 6. Dezember 1946, $1 \mathrm{f}$.

2089 UAW, Dekanatsakten Phil. Fakultät, 493-1946/47, GZ. 495-546/47, Rektor Adamovich an den Dekan der Philosophischen Fakultät, 25. März 1947,1. 
Rundschau ${ }^{2090}$ beziehungsweise dessen Chefredakteurs Husinsky sowie des ÖH-Vorsitzenden Karl Leutgeb, der im Mai I947 schließlich zurücktrat. ${ }^{2091}$

Mit Bezug auf die neuerliche Entnazifizierung der Studierenden übermittelte der studentische Hauptausschuss der Universität Wien eine Resolution an das Unterrichtsministerium, worin zwecks „Wiederherstellung des Ansehens der Studentenschaft in der breiten Öffentlichkeit“ bekräftigt wurde, dass das Studium „grundsätzlich nur jenen offenstehen“ solle, „deren proösterreichische und demokratische Haltung einwandfrei erwiesen ist.“ Selbst die konservative „Union“ (FÖST) nahm angesichts des enormen öffentlichen Legitimationsdrucks in der Auseinandersetzung mit sozialistischen und kommunistischen Studentenvertretern eine radikal neue Position ein, indem sie nun die Errichtung eines eigenen „antifaschistischen Referats“ unterstützte, dessen Aufgaben in der „Umerziehung“ der ehemaligen nationalsozialistisch Belasteten - unter anderem unter Verwendung von Unterlagen aus Konzentrationslagern - liegen sollte. ${ }^{2092}$ De facto dürfte dieses „antifaschistische Referat" aber keine nennenswerte Aktivität entfaltet haben. ${ }^{2093}$

Tatsächlich zeigten sich in der konkreten Durchführung der neuerlichen politischen Überprüfung der Studierenden in den Überprüfungskommissionen der Universität sehr bald „schwere Mißhelligkeiten“. ${ }^{2094}$

Infolge der mit knapp zwei Monaten überaus kurz bemessenen Zeit bis zum geforderten Abschluss der Überprüfung bis Ende Jänner 1947, sahen sich sowohl die Kommissionsvorsitzenden als auch die Beisitzer regelrecht überfordert. Allein an der Medizinischen Fakultät lagen 480 Fälle zur Überprüfung vor, ${ }^{2095}$ die Fachgruppe Naturwissenschaften hatte in 20 Sitzungen 230 Fälle zu begutachten ${ }^{2096}$ und die Fachgruppe Geisteswissenschaften benötigte dringend die Einrichtung sechs weiterer Kommissionen. ${ }^{2097}$ Angesichts dieses im Eiltempo durchzuführenden Re-Screeningverfahrens kündigten die Sozialistischen Studen-

2090 Vgl. Akademische Rundschau, 2. Jg., 14. Dezember 1946, Nr. 9, 9.

$2091 \mathrm{Zu}$ einzelnen Details des Rücktritts von Leutgeb siehe: Huber, Studenten im Schatten der NS-Zeit, a.a. O., $213 \mathrm{ff}$.

2092 Der Student, 2. Jg., 1946, F. 6, 17. Zit. nach: Forster, Die Geschichte der Österreichischen Hochschülerschaft 1945-1955, a.a.O., 134.

2093 Nach den Vorfällen im Zusammenhang der ersten ÖH-Wahlen assimilierte sich der VSSTÖ schließlich der allgemeinen Parteilinie der SPÖ: die Problematik der NS-,Säuberungen' wurde kaum mehr thematisiert. Ein letztes Mal wurde am SPÖ-Parteitag 1949 vom VSSTÖ-Delegierten Fritz Marsch ein Antrag auf Bildung eines „Zentralreferats zur Überwachung der Personalpolitik an den Hochschulen“ eingebracht, um, wie es hieß, die „Renazifizierung“ der Universitäten zu verhindern. Der Antrag wurde gegen Widerstand der Antragsprüfungskommission - von den Parteitagsdelegierten angenommen. Vg1. Heilingsetzer/Mesner/Rögl/Weber, Projektendbericht: Zur Geschichte des VSSTÖ, a.a.O., $13 \mathrm{f}$.

2094 UAW, Senats-Sitzungsprotokolle des Studienjahres 1946/47, Protokoll über die außerordentliche Sitzung des Akademischen Senates der Universität Wien, 20. November 1946, 3.

2095 Ebd., 4.

2096 Ebd., 7.

2097 Ebd., 8. 
ten bereits im November 1946 die Zusammenarbeit auf und teilten dem Rektor mit, dass sie es „nicht verantworten könnten, an einer Überprüfung in der vom Unterrichtsministerium vorgeschriebenen Art und Weise mitzuarbeiten. “2098 Auch die kommunistischen Studentenvertreter an der Philosophischen Fakultät zogen sich vollständig aus den Kommissionen zurück, was Senatsmitglied Richard Meister zur Befürchtung veranlasste, dass bei einer zu milden Überprüfung „allein der ÖVP“ deswegen Vorwürfe gemacht würden, bei einer zu strengen Vorgehensweise hingegen die Gefahr bestünde, „große Ungerechtigkeiten zu begehen. “2099 Nach dem Rückzug der linken Fraktionen aus den Überprüfungskommissionen verblieb als einzige kooperationsbereite Studentengruppe somit zunächst die konservative Union; nach weiteren Gesprächen lenkte der VSStÖ schließlich ein, allerdings zu einem so späten Zeitpunkt, als eine aktive Mitwirkung an den Säuberungsmaßnahmen kaum mehr möglich war. ${ }^{2100}$

Selbst Rektor Adamovich äußerte Bedenken gegenüber dem ministerial verordneten Überprüfungsprozedere, das ohne Einbeziehung der Universitäten zustande gekommen war. Insbesondere sei die geforderte Überprüfung der Studenten für die akademischen Behörden sehr unangenehm, „da alle Parteien, vor allem die Alliierten [sic], aus der Entnazifizierung der Hochschulen eine hochpolitische Angelegenheit gemacht haben." Adamovich weiter im Wortlaut des Senatssitzungsprotokolls:

\begin{abstract}
„Dem Senat stehe aber keine Wahl offen, als entweder zu erklären, er könne in der verlangten
Weise die Überprüfung nicht durchführen und trete aus diesem Grunde geschlossen zurück, oder er müsse die Überprüfung unter allen Umständen durchführen. [...] Außerdem werde im Erlaß des Unterrichtsministeriums [...] unter anderem verlangt, daß Vorsorge zu treffen sei, daß die von den Kommissionen endgültig ausgeschlossenen Personen die Hochschule nicht mehr betreten. Der Rektor stellt hiezu fest, daß er nicht wisse, wie man eine derartige Sicherung wirksam durchführen könnte, ohne daß die Ausgeschlossenen, wie früher etwa die Juden oder Polen, öffentlich gekennzeichnet würden. “2101
\end{abstract}

De facto zeigten sich vor allem hinsichtlich der vorgesehenen Mitwirkung der Studentenverbände bei der Arbeit der Überprüfungskommissionen gröbere Schwierigkeiten und Ungereimtheiten. So waren die sozialistischen Studenten an der Medizinischen Fakultät nicht in der Lage, eine ausreichende Zahl an studentischen Beisitzern zu nominieren und somit an den Tagungen teilzunehmen, „so dass nichts anderes übrig blieb, als den sozialistischen Studentenführern die Akten zur Einsichtnahme zu übergeben. "Hingegen hatte sich die kommunistische Studentenfraktion „im Prinzip zur Teilnahme bereit er-

2098 Ebd., 3.

2099 Ebd., 6.

2100 Vgl. dazu Huber, Studenten im Schatten der NS-Zeit, a.a.O., 100.

2101 UAW, Senats-Sitzungsprotokolle des Studienjahres 1946/47, Protokoll über die außerordentliche Sitzung des Akademischen Senates der Universität Wien, 20. November 1946, 4. 
klärt, jedoch in der Praxis nicht daran teilgenommen.“ Weitere Schwierigkeiten ergaben sich, weil - insbesondere an der medizinischen Fakultät - Studierende „teils entschuldigt, teils unentschuldigt" den Sitzungen fernblieben. ${ }^{2102}$ Probleme besonderer Art traten in der Überprüfungskommission an der juridischen Fakultät auf, wo Kommissionsvorsitzender Ehrenzweig „über schwere Mißstände bei der Fachgruppe Juristen Beschwerde führt, die geeignet wären, das weitere Arbeiten der Kommissionen überhaupt in Frage zu stellen.“ Ehrenzweig bat den Dekan um sofortige Abhilfe und wies mit Nachdruck darauf hin, „daß sich aus diesen Mißständen eventuell sogar außenpolitische Folgen ergeben könnten. "2103

Anlass für die Beschwerde war die Amtsführung des Kommissionsvorsitzenden an der juridischen Fakultät, Dozent Otto Weinberger, dem der Vorwurf gemacht wurde, in Überprüfungsverfahren fahrlässig vorgegangen zu sein und dabei Inskriptionswerber beziehungsweise Studierende zu Unrecht vom Studium ausgeschlossen zu haben. Konkret wurde Weinberger dabei vorgeworfen, über „Studenten in Abwesenheit verhandelt“ zu haben, „ohne daß vorher überprüft wurde, ob ihnen die Ladung zur Sitzung entsprechend den in Österreich hiefür geltenden Vorschriften ordnungsgemäß zugestellt worden sei.“ Des Weiteren wären Verhandlungsprotokolle „derart mangelhaft verfasst worden $[\ldots]$, daß sie nicht einmal die notwendigen Personalangaben über die zu kommissionierenden Studenten enthielten, geschweige denn eine Begründung der erfolgten Ablehnung“. Darüber hinaus seien „Studenten einstimmig ausgeschlossen worden, deren Belastung zweifellos nicht so war, daß ein derart schwerwiegender Beschluß hätte gefaßt werden können. “2104

Angesichts dieser Anwürfe bat Weinberger bei Rektor Adamovich um seine Enthebung als Kommissionsvorsitzender und begründete das schriftlich damit, dass er sich „als ehemals politischer Verfolgter befangen erklären müßte“. Rektor Adamovich sah sich angesichts dieser „befremdenden“ Begründung genötigt, Weinberger zu erklären, dass er sich „auf Grund seiner politischen Verfolgung [durch das NS-Regime, d. Verf.] nicht für befangen erklären [könne], da laut Verordnung des Unterrichtsministeriums ausdrücklich nur solche Herren als Mitglieder der Kommission zu berufen seien, die politisch oder rassisch verfolgt wurden oder sich in der Widerstandsbewegung betätigt haben. “2105

Nachdem Weinberger aber, wie Adamovich im Akademischen Senat ausführte, mit dem Ausschluss eines Studenten, der Angehöriger des NS-Rechtswahrerbundes und des NSV gewesen war, „die Gleichheit vor dem Gesetz auf das Gröbste verletzt “2106 sah, wurde Weinbergers Rücktritt letztlich doch angenommen und ein neuer Kommissionsvorsitzender bestellt.

2102 UAW, Dekanatsakten Phil. Fakultät, 493-1946/47, G.Z. 260-1946/47, Rektor Adamovich an die Herrn Rektoren sämtlicher österreichischer Hochschulen, 8. Februar 1947, 8.

2103 UAW, Senats-Sitzungsprotokolle des Studienjahres 1946/47, Protokoll über die außerordentliche Sitzung des Akademischen Senates der Universität Wien, 20. November 1946, 8.

2104 Ebd., 5.

2105 Ebd., 4.

2106 Ebd., 5. 
Interessanterweise wurde in derselben Senatssitzung darüber berichtet, dass Major Benner am Vortag bei Adamovich gewesen war und diesem ein Schreiben von Colonel Featherstone übergeben hatte. Bei dieser Besprechung war jedoch mit keinem Wort auf die Entnazifizierungsaktivitäten an der Universität eingegangen, sondern die Frage amerikanischer Unterstützungsleistungen für bedürftige Universitätsangehörige thematisiert worden. ${ }^{2107}$

Erst im Februar 1947, knapp vor Ablauf der Vorlagefrist gegenüber dem Alliierten Rat, sprach Major Needham von der U.S. Education Division dann bei Rektor Adamovich vor und verlangte eine namentliche Aufstellung der Vorsitzenden und Beisitzer der Überprüfungskommissionen. ${ }^{2108}$ Bei dieser Besprechung erklärte Needham, dass analog zum soeben novellierten Nationalsozialistengesetz im Falle von Bedenken hinsichtlich des unbedingten Ausschlusses von Studierenden bis 30. April r950 allfällige Listen an ihn weitergegeben werden könnten, und er diese - nach Möglichkeit - „verwerten“ würde; dabei gab er zu erkennen, dass „das Nationalsozialistengesetz nur im Hinblick auf die unbedingte Notwendigkeit des abzuschließenden Staatsvertrages angenommen wurde. “2109 Damit signalisierte die US-Besatzungsbehörde gegenüber dem Rektor der Universität Wien, dass man die Entnazifizierung künftig als eine rein formale Angelegenheit betrachten würde.

Hingegen zeigt sich mit Blick auf die Protokolle des Alliierten Rates für Österreich deutlich, dass die Ereignisse bei der ÖH-Wahl und der Status quo der Entnazifizierung innerhalb des höchsten interalliierten Besatzungsgremiums durchaus kontroversiell, bisweilen auch heftig diskutiert wurden und für einen Moment sogar eine Schließung der österreichischen Universitäten im Raum stand.

Bereits am 22. November 1946 hatte General Aleksej S. Zheltov vor dem Exekutivkomitee der Alliierten Kommission die russische Position - die die Umstände freilich besatzungspolitisch zu nützen trachtete und daher rhetorisch entsprechend formuliert wurde - unmissverständlich dargelegt. Angesichts der „faschistischen Demonstrationen“, der „antialliierten Kundgebungen“ und dem „open praise of the Hitler regime and its bandit-army “2110 auf Boden der Universität zeigte sich Zheltov hochgradig irritiert:

2107 Bei dieser Gelegenheit machte der Dekan der Evangelischen Fakultät, Professor Gustav Entz, von dem weiter unten noch kurz die Rede sein wird, eine seiner wenigen Wortmeldungen, die sich auf die Frage bezog, ob in die zu erstellende Liste an bedürftigen Universitätsangehörigen ,auch pensionierte Professoren“ aufgenommen werden dürften. UAW, Senats-Sitzungsprotokolle des Studienjahres 1946/47, Protokoll über die außerordentliche Sitzung des Akademischen Senates der Universität Wien, 20. November $1946,9$.

2108 UAW, Senats-Sitzungsprotokolle des Studienjahres 1946/47, Protokoll über die 11. Sitzung des Akademischen Senates der Universität Wien, 15. Februar 1947, 2.

2109 Ebd.

2110 Allied Commission for Austria, Executive Committee (EXCO), Mikrofilm Österreichische Nationalbibliothek (ÖNB), Reel 2 of 8, 62nd Meeting, Annex „A“, Statement by the Soviet Member, made at the Meeting of the Executive Committee on 22nd November 1946, 1. 
"It is difficult to believe that after Nuremberg [...]. Nevertheless it has been possible, in the centre [sic] of a state which calls itself democratic, for a small group of fanatical Nazis openly to express its regret that Hitler did not succeed in destroying all the Jews, to applaud its excesses, to boast of the party they played in Hitlers aggression and to place savage obstructions in the way of students who once refused in the Hitler army of bandits. It has been possible in a country liberated by the Allied Powers, from Hitler occupation, for manifestations of Fascist youth to take place, openly insulting to the Allies. The Nazi and Hitler officers who have found refuge in the University and other Austrian High Schools, have become so bold that they have unmercifully beaten certain democratically-minded students who protested against their Nazi propaganda. The feelings of profound indignation and anger aroused in democratic and working-class circles in Austria as a consequence of this Nazi provocation, are quite understandable."2111

Und Zheltov legte auch Zahlen vor, die belegen sollten, dass insbesondere die Universität Wien eine Brutstätte („hotbed“) der NS-Propaganda geworden sei und die Jugend hier im Geiste des Faschismus erzogen würde: so wären allein an der Universität Wien 72 Nazis als Professoren beschäftigt. Darüber hinaus seien in der britischen Besatzungszone 36 und in der französischen 33 Nazis als Universitätsprofessoren angestellt. Auch im Theologischen Seminar in Salzburg wäre - General Zheltovs Quellen zufolge - eine ähnlich große Zahl an früheren Nazis beschäftigt, ebenso an höheren Schulen: „Former Nazis who either held or still hold Headmasters posts in High Schools, throw open the doors, not to democratic elements, but to ex-Nazis, Hitler-officers, and Germans. “2112 Im Bereich der Studentenschaft sei die Situation nicht besser: bei 2I Prozent aller Studierenden an den Universitäten in Innsbruck, Graz und Wien handle es sich um ausländische Studenten, darunter 580 Reichs- und II76 Volksdeutsche. Allein an der Universität Wien befänden sich - entsprechend den Zheltov vorliegenden Unterlagen - 4I5 frühere Hitler-Offiziere unter den Studenten. ${ }^{2113}$ Angesichts dieser Situation und der fehlenden Bereitschaft der österreichischen Regierung stellte Zheltov folgende Diagnose, die bereits auf die von russischer Seite erwünschten nächsten Schritte hindeutete und dabei ehemals gemeinsam festgelegte alliierte Übereinkommen beschwor:

"These events, which have an influence far beyond the confines of the University, have clearly revealed how deeply-rooted is Nazism in Austria, and how real is the danger of resurgence of Fascism unless radical measures are taken to extirpate all trace of Nazi ideology, and to instill into the Austrian people, and particularly into his youth, the principles of democracy, as we undertook to do in the Allied Council Declaration of September irth, I945, and later reaffirmed in Article 3 of the New Control Agreement."2114

2111 Ebd.

2112 Ebd., 2.

2113 Ebd.

2114 Ebd., 3. 
Die von General Zheltov vorgeschlagenen Maßnahmen, wonach die Universität Wien und die Hochschule für Welthandel für die Dauer nochmaliger Säuberungen auf unbestimmte Zeit geschlossen und die Entnazifizierung - angesichts der Säumigkeit österreichischer Stellen - zudem dem Alliierten Rat übertragen werden sollten, wurde vom Exekutivkomitee der Alliierten Kommission allerdings nur zur Kenntnis genommen („took note“). ${ }^{2115}$ Beschlossen wurde lediglich, dass sich das „Internal Affairs Directorate“ in Verbindung mit dem alliierten „Education Directorate“ und der Interalliierten Kommandantur in Wien mit den Vorfällen beschäftigen und Vorschläge unterbreiten sollte, die dann im nächsten regulären Meeting der Alliierten Kommission diskutiert würden.

Wie stark der Kalte Krieg bereits zum damaligen Zeitpunkt Einzug in die Arbeit des Alliierten Rates gehalten hatte, lässt sich auch am Protokoll der folgenden Besprechung des Exekutivkomitees am 4. Dezember 1946 ablesen, in der die bereits präsentierten Vorschläge des alliierten „Internal Affairs Directorate“ diskutiert wurden. Während die sowjetische Besatzungsmacht nach wie vor auf eine rasche Schließung der Universitäten und Hochschulen drängte, die Briten sich immerhin für geeignete Maßnahmen aussprachen, die nötig seien, um die Entnazifizierung an der Universität Wien und an anderen Universitäten „abzuschließen“, und die Franzosen die Öffnung der Universitäten nach den Weihnachstfeiertagen davon abhängig machen wollten, dass der Alliierten Kommission gegenüber versichert würde, bis dahin eine Säuberung durchgeführt zu haben, gab die US-Militärregierung zu keinem der diskutierten Vorschläge ihr Einverständnis. Die Empfehlung des US-Vertreter innerhalb des „Internal Affairs Directorate“ zementierte die bisher praktizierte Politik der Nichteinmischung in ,österreichische Angelegenheiten` und beschränkte sich auf drei weitgehend formale Punkte: zum einen sollte seitens des Interalliierten Kommandos in Wien (VIAC) ermittelt werden, ob die Demonstration entsprechend der Bestimmungen des VIAC überhaupt autorisiert gewesen sei; zweitens sollte ausgerechnet Bundeskanzler Figl in seiner Funktion als Vorsitzender des ministeriellen Entnazifizierungskomitees bis Mitte Jänner 1947 einen Überblicksbericht über die bisher erfolgten Entnazifizierungsmaßnahmen an den Universitäten vorlegen; und zuletzt sollte dem Unterrichtsminister empfohlen werden, zu untersuchen, ob sich unter den Studierenden an Österreichs Universitäten Fälle finden, die eine Verletzung der Weisungen des Unterrichtsministeriums bedeuten. ${ }^{2116}$

Die von den Amerikanern in dieser Sitzung unterbreiteten Vorschläge waren weich und überaus vage formuliert und zielten mit der Frage nach der Autorisierung der Demonstration durch das VIAC zudem direkt darauf ab, durch Prüfung allfälliger formaler Verstöße

2115 Ebd., 4.

2116 Allied Commission for Austria, Executive Committee (EXCO), Mikrofilm Österreichische Nationalbibliothek (ÖNB), Reel 2 of 8, EXCO/P(46)372, Denazification of Vienna University and High Schools. Annex A, Recommendation by the U.S. Element of the Internal Affairs Directorate, submitted for consideration by the Executive Committee, 4 December $19461 \mathrm{f}$. 
der Intention der russischen Militärs, nämlich eine „inhaltliche“ Debatte zu führen, entgegen zu wirken.

Nachdem die Sowjets der Angelegenheit aber große Bedeutung zumaßen, der österreichischen Regierung Untätigkeit vorwarfen und nach wie vor die sofortige Schließung der Universität verlangten, kam es in einer weiteren Sitzung des Exekutivkomitees unter Vorsitz von General G.K. Tsinov, bei der unter anderem auch die Novellierung des Verbotsgesetzes debattiert wurde, ${ }^{2117}$ zu einer langen und heftigen Auseinandersetzung, bei der die US-Vertreter mit einem „neuen“ Vorschlag aufwarteten, der allerdings wieder vage formuliert war. Brigade-General E.H. Tate bekräftigte für die amerikanische Seite, dass man die Vorfälle sehr genau beobachtet habe und wie alle anderen alliierten Besatzungsmächte beunruhigt wäre „to see that any bad conditions that exist in the higher schools of learning“ - eine Situation, die rasch behoben werden müsste. Darüber hinaus wiederholte General Tate lediglich aufs Neue, dass der österreichische Bundeskanzler in einem Brief gebeten werden sollte, einen Lagebericht zu geben, mit dem einen Unterschied, dass nämlich auf Basis dieses Berichtes entschieden werden sollte „whether we take over or allow the Austrian Goverment to continue to clean it up. “2118

General Tsinov zeigte sich ob der Verzögerungspolitik von amerikanischer Seite, die in dieser Sitzung lediglich dazu bereit war, der Alliierten Kommission besagten Brief an Bundeskanzler Figl vorzuschlagen und weiterführende Diskussionen der Angelegenheit auf spätere Sitzungen des Exekutivkomitees vertagen wollte, wenig erfreut:

"The position taken by the US Element excludes any possibility of taking a unanimous decision on this item today. The French, British and Soviet Elements are prepared to discuss the question today, but the US Element is not prepared to discuss it on the basis of the recommendation of the

2117 Ein interessantes Detail der hier zitierten Sitzung, das an dieser Stelle nicht unerwähnt bleiben soll, betraf die nachfolgende Debatte rund um die Neufassung des Verbotsgesetzes, welches seit 24. Juli 1946 fertig ausgearbeitet vorlag und in das nach Durchsicht und Ergänzung des „Legal Directorate“ der Alliierten Kommission lediglich die von den Besatzungsmächten monierten Änderungen („Annex A“) eingearbeitet werden sollten, damit das Gesetz schließlich vom österreichischen Parlament verabschiedet werden konnte. Um den Gesetzwerdungsprozess zu beschleunigen, vertrat General Tsinov die Ansicht, dass laut Artikel 1(a) des alliierten Kontrollabkommens die österreichische Regierung die Änderungen ohnedies akzeptieren müsse, sodass eine längere Begutachtung durch das Parlament entfallen könne. Obwohl sich die Diskussion der Neufassung des Verbotsgesetzes nun schon lange hinzog, beharrte General Tate hingegen darauf, dass der Gesetzesentwurf samt Annex „still must go through Parliament and Parliament is an independent body which has views of its own [...]“. Im Zusammenhang dieser Debatte wurde u.a. auch das Internierungsgesetz („Detention Law“) diskutiert, wobei es in der Frage rund um die Einrichtung von alliierten Internierungslagern zu einem heftigen Schlagabtausch kam, indem das US-Element der sowjetischen Seite „Gestapomethoden“ vorwarf. Ebd., 8.

2118 Ebd., EXCO/P(46)372, Allied Commission for Austria, Executive Committee, 63rd Meeting, 6th December 1946, 4. 
Directorate. [...] I believe if the Austrian Government and the Chancellor were as anxious about it we would have had a letter from them already without asking for it. I quite agree with General Cherrière, that the letter is merely a matter of formality. I don't know what information my colleagues have, but according to my information the Austrian Government has not yet taken any serious steps about those incidents at the University. [...] It seems to me, in view of the arrests which we made in the igth of November, and the demands of the workers and trade unions and those who were imprisoned in concentration camps, that the universities should be closed for the purpose of making purges." ${ }^{2119}$ [Hervorhebung d. Verf.]

Auf französischer Seite schloss sich General Cherrière der Position des Vorsitzenden zwar grundsätzlich an, meinte aber, dass dem Alliierten Rat vielleicht doch zuvor das Schreiben an Bundeskanzler Figl empfohlen und weitere Diskussionen auf eine gesonderte Sitzung des Exekutivkomitees vertagt werden sollten - eine Position, der sich im Übrigen auch Brigadier B.B. Cook für die Briten anschloss. Nachdem schließlich nur der Vorschlag, an Bundeskanzler Figl einen Brief zu senden, mit allen Stimmen beschlossen werden konnte, akzeptierte General Tate dann auch bereitwillig die von russischer Seite gewünschte Sprachregelung, der sich auch die Briten anschlossen: nämlich im Hinblick auf die Ausschreitungen vor der Universität in Hinkunft nicht mehr von „Nazi demonstrations“ zu sprechen, sondern - angesichts des „speziellen Charakters“ dieser Vorfälle, wie General Zheltov meinte - von „anti-democratic Demonstrations“. ${ }^{2120}$ Die monierte semantische Ausweitung auf, antidemocratic“ hatte aus russischer Sicht wohl zwei Gründe: zum einen bot sie die Möglichkeit, antikommunistische Parolen auch künftig als gegen die Alliierten gerichtete, undemokratische Äußerungen zu klassifizieren und allenfalls zu ahnden, zum anderen bot diese begriffliche Erweiterung, die ja alle nazistischen Aktivitäten inkludierte, eine gegenüber den westalliierten Besatzungsmächten ideologisch offenbar weniger verfängliche Einspruchsmöglichkeit. Womöglich schien den Sowjets, angesichts der schleppenden und oberflächlich durchgeführten Entnazifizierung, die bisher vor allem von der russischen Besatzungsmacht ständig kritisiert worden und daher fast schon zu einem Spezifikum russischer Besatzungspolitik geworden war, die Charakterisierung „undemokratisch“ mittlerweile politisch schwerer zu wiegen, als „nazistisch“. 2121

\section{Ebd., 7.}

2120 Ebd., 8.

2121 Besonders sensibel reagierte allerdings General Aleksej auf die in der Presse den Sowjets zugeschobene Verzögerung beim Zustandekommen der Neufassung des Verbotsgesetze und verwies abermals auf die auch alliierterseits im März 1946 festgehaltene unzureichende Entnazifizierung durch österreichische Stellen. In einem Statement vor dem Alliierten Rat machte sich Zheltov am 13. Dezember 1946 Luft und betonte nachdrücklich, dass es seit November 1945 insbesondere das sowjetische Besatzungselement war, das hinsichtlich der Entnazifizierung als wichtigem Bestandteil der Demokratisierung Österreichs eine konsistente und unnachgiebige Position eingenommen hat. In deutlicher Überzeichnung der eigenen Position, aber mit durchaus zutreffendem realen Kern, strich Zheltov dabei hervor: „However, on 
Der Wortlaut des ursprünglichen, vom russischen Besatzungselement vorgelegten Briefentwurfes an Bundeskanzler Figl war länger und entschieden härter formuliert als die letztlich gemeinsam beschlossene Fassung - immerhin war davon die Rede, dass die neuerlichen,Säuberungsmaßnahmen ' unter direkter Kontrolle der Alliierten Kommission durchgeführt und die Säuberung des universitären Lehrpersonal außerdem vom „Internal Affairs Directorate“ sowie dem alliierten „Education Directorate“ vorangetrieben würde.

Der einzige Vorschlag, der von allen Mitgliedern des Alliierten Rates schließlich gemeinsam akzeptiert und beschlossen werden konnte, bestand, wie erwähnt, darin, der österreichischen Regierung eine „careful investigation in order to punish the instigators of Nazi propaganda" nahezulegen. ${ }^{2122}$ In einem Schreiben an Bundeskanzler Figl vom 6. Dezember 1946 wurde dieser von der Alliierten Kommission aufgefordert, bis 9. Dezember einen schriftlichen Bericht darüber vorzulegen, welche Maßnahmen von österreichischer Seite angesichts der Ereignisse an den Universitäten und Hochschulen nunmehr geplant würden. ${ }^{2123}$

In seinem termingerecht an den Alliierten Rat abgelieferten Bericht bemühte sich Bundeskanzler Figl dann mit einigem argumentativen Aufwand darzulegen, dass sowohl Unterrichts- als auch Innenministerium im Vorfeld der ÖH-Wahlen über keinerlei Hinweise darüber verfügt hätten, dass es am Wahltag zu Ausschreitungen kommen könnte. Dadurch - so die logisch nicht ganz schlüssige Argumentation Figls -, dass für den Wahltag eine Ausweispflicht für das Betreten der Universitäten bestimmt worden war, wäre evident, dass die „nationalsozialistischen Provokationen“ von Personen ausgegangen seien, die nicht zur Wahl zugelassen waren. Überdies habe, so der Bundeskanzler weiter, von den "3I verletzten Jugendlichen“ keine einzige Person „irgendeine Verbindung zum Nationalsozialismus", womit Figl die vorliegenden staatspolizeilichen Hinweise vermutlich bewusst unerwähnt ließ. ${ }^{2124}$ Dessen ungeachtet resümierte Figl mit Bezug auf das bereits laufende, neuerliche Re-Screening der Studentenschaft, die Geschehnisse würden klar zeigen, dass die bisher durchgeführten,Säuberungsmaßnahmen` ungenügend waren:

consideration of this question in the Allied Council only the Soviet Element supported the point of view of the Internal Affairs Directorate and of the Executive Committee, insisting that effective measures be taken to hasten denazification; the other three Elements expressed to the Chancellor their satisfaction with the progress of denazification. Later events fully justified the position that the Soviet Element took at that time." Allied Commission for Austria, Allied Council (ALCO), Mikrofilm (ÖNB), Reel 2/24-44, ALCO/M(46)38, 38th Meeting, „Annex „C“, Statement by Colonel General Zheltov on the Denazification Law at the Allied Council Meeting of 13th December 1946, 1.

2122 Ebd., EXCO/P(46)372, Denazification of Vienna University and High Schools, 4th December 1946, $1 \mathrm{f}$.

2123 Ebd., EXCO/P(46)372, Allied Commission for Austria/Allied Secretariat, 4 Stalinplatz, Vienna, to Federal Chancellor of the Austrian Republic, 6 December 1946, 1.

2124 Ebd., EXCO/P(46)372, Republic of Austria/Federal Chancellor to the Chairman Allied Council for Austria, 8. Dezember 1946, 2. 
"However, although it can be justly assumed that the national-socialist provocations were started by persons who were not entitled to vote at the universities, the possibility of such incidents shows that the purge-measures carried out of to the present have not been efficacious enough to fully eradicate national-socialist tendencies on the Austrian Universities." ${ }^{2125}$

Sonderlich aufschlussreich war diese schriftliche Stellungnahme Bundeskanzler Figls gegenüber der Alliierten Kommission nicht: in gewisser Hinsicht bestätigte Figl neuerlich nur offiziell, dass man auch auf österreichischer Seite die bisherigen Entnazifizierungsmaßnahmen als unzureichend einschätzte - etwas anderes hatte aber auch keine der Besatzungsmächte erwartet.

Angesichts des universitären Wirbels sowie im Hinblick auf das bevorstehende neue ,Verbotsgesetz‘ war Bundespräsident Karl Renner in seiner Neujahrsansprache 1946/47 darum bemüht, seine Landsleute auf typisch österreichische Art zu beruhigen, indem er ihnen sein Verständnis staatspolitischer Räson im Zusammenhang von Entnazifizierung erläuterte und Interventionsbereitschaft versicherte: „As a President of the Republic, I say to you: The constitution gives me the right of pardon of even the capital criminal. And even the most debased citizen is for me an Austrian. I recognize no ostracism. "2126 [Hervorhebung d. Verf.]

Trotz aller zuweilen heftig artikulierten Kritik am Status quo der Entnazifizierung blieben die weiteren Debatten in den Gremien der Alliierten Kommission auf Grund der nur selten erzielten Einstimmigkeit letztlich ohne entscheidende Wirkung und ebbten zu Beginn des Jahres 1947, kurz vor Beschlussfassung des Minderbelastetengesetzes, auch entsprechend ab. Für die österreichische Bundesregierung verbindlich war jedoch die Aufforderung zur Vorlage des Re-Screening-Berichts, der der Alliierten Kommission bis zum I5. Februar 1947 auszuhändigen war.

Dass die neuerliche Entnazifizierung an der Universität und den Hochschulen Wiens im Vergleich zu Graz, Leoben oder Innsbruck, wo zum Teil noch gar keine Kommissionen eingerichtet waren, relativ zügig voranging, wie Andreas Huber konstatiert, ${ }^{2127}$ trifft zwar zu, sagt aber nur wenig über die Qualität des geleisteten Re-Screenings aus; hier mögen neben lokalen beziehungsweise regionalen Empfindlichkeiten gegenüber den verordneten politischen ,Säuberungen' wohl auch verschiedene andere Faktoren eine Rolle gespielt haben. ${ }^{2128}$

\section{Ebd., 1.}

2126 NARA II, RG 260, USFA, Historical File, Box 32, Folder 252. Quarterly Historical Report. USACA Section, U.S. Forces in Austria 1946, 125.

2127 Huber, Studenten im Schatten der NS-Zeit, a.a.O., 99.

2128 So eine gewisse föderale Reserviertheit hinsichtlich der unmittelbaren Umsetzung ministerialer Verordnungen aus Wien oder das unterschiedliche Agieren der Alliierten Militärbehörden in den Besatzungszonen. Letzteres legt der Wortlaut eines Schreibens des Britischen Besatzungselements an die Alliierte Kommission nahe, worin quasi exkulpierend mitgeteilt wurde, dass die Studentenvertretungen an der Universität Graz sich weigerten, an der Arbeit der Überprüfungskommissionen teilzunehmen,$[\ldots]$ on the grounds that $[\ldots]$ the work had already been done twice and $[\ldots]$ it would in any 
Immerhin - und das verdient hervorgehoben zu werden - inspizierten nun die alliierten Mitglieder des „Sub-Committee on University Denazification“ die Arbeit der universitären Säuberungskomitees, indem sie, sofern es möglich war, ${ }^{2129}$ auch an deren Sitzungen teilnahmen. Wie Major Needham ${ }^{2130}$ als Vorsitzender des alliierten Sub-Committees protokollierte, seien allein an der Universität Wien 22 Sonderkommissionen ${ }^{2131}$ eingesetzt worden, für die neun Professoren, ,all of whom suffered under the Nazis“, als Mitglieder in die übergeordnete Senatskommission nominiert wurden. ${ }^{2132}$

Das US-Kommissionsmitglied Major Hardy M. Ray zeigte sich darüber hinaus sogar "impressed by the business-like and conscientious conduct of investigations" und meinte, dass auftauchende Probleme in der praktischen Durchführung der Screenings lediglich mit Umfang und Organisation des Aktenmaterials zu tun hatten:

"Some of the practical difficulties surmounted are indicated by the fact that the files of incriminated Nazis held by the Minister of Interior totals 90.000 , stored in a grotto-like basement of the Ministry and inadequately staffed by a bandful of officials."2133 [Hervorhebung d. Verf.]

Allein die Repräsentantin des sowjetischen Besatzungselements äußerte Kritik und bezeichnete die Säuberungsmaßnahmen an der Hochschule für Welthandel als "unsatisfactory". 2134

Wie ein Blick in die personelle Zusammensetzung der neuerlich gebildeten „Inskriptionskommissionen“2135 - deren Vorsitz möglichst „Nazi-Opfer“ beziehungsweise geschä-

case have to be done again as soon as the terms of the Law were known." DÖW, 20683-6, Nr. 23B, Baty/Education Division to Director/Internal Affairs, 10. Februar 1947, 2. Zit. nach: Huber, Studenten im Schatten der NS-Zeit, a.a.O., 103.

2129 So heißt es bezeichnenderweise im Wortlaut eines Protokolls: „Mr. Needham was unable to attend any meetings since the work of the committees had already been concluded." Zit. nach: NARA II, RG 260, EDU-DIV, Box 2/Folder 58. Allied Commission for Austria (British Element). Sub-Committee on University Denazification. Report on Meetings held at Allied Secretariat on February 7 and 15, 1947, 3.

2130 Die einzelnen Mitglieder des Sub-Committees teilten sich die Inspektionsarbeit dabei folgendermaßen auf: Mr. Ledowsky (USSR) übernahm die Hochschule für Welthandel und die Hochschule für Bodenkultur, M. Jakob ( $\mathrm{Fr}$ ) die Tierärztliche Hochschule und die Akademie für Bildende Künste, Mr. Ray (US) die Technische Hochschule und Mr. Needham (GB) die Universität Wien. Siehe ebd.

2131 Darunter vier Kommissionen an der Rechtswissenschaftlichen Fakultät, acht an der Medizinischen und zehn and der Philosophischen Fakultät.

2132 NARA II, RG 260, EDU-DIV, Box 2 /Folder 58. Allied Commission for Austria (British Element). Sub-Committee on University Denazification. Report on Meetings held at Allied Secretariat on February 7 and 15, 1947, 3 .

2133 Ebd., 2.

2134 Ebd.

2135 Das Protokoll des Sub-Committees enthält vollständige Namenslisten aller Kommissionsmitglieder sowie aller Beisitzer - darunter finden sich auch die Namen von Wilfried Daim und (Erika) Weinzierl sowie zahlenmäßige Angaben zu den Ergebnissen der neuerlichen ,Säuberungen‘. 
digte Professoren innehaben sollten - zeigt, finden sich hier auch Personen, auf die, obwohl als „politisch nicht belastet“ eingestuft, eben genau das nicht zutrifft: so etwa der Dekan der Evangelischen Fakultät, Gustav Entz. ${ }^{2136}$

Auch unter den jeder Screening-Kommission beizuziehenden Vertretern der drei Studentenfraktionen dürften sich zum Teil Personen befunden haben, die offenbar nur wenig geeignet waren. Das geht unter anderem aus einem anonymisierten Schreiben an das alliierte Sub-Komitee hervor, worin es in Bezug auf die Philosophische Fakultät heißt:

"The undersigned permit themselves to draw the attention of the competent authorities to the fact that in the university a man is directing dismissals who ought to be dismissed himself. This is Mr. $\mathrm{XX}^{2137}$ who is still continuing to call himself inspector, according to German law. [...] How is it possible that an officer of German army is directing the dismissal of university-officials? [.... As German officer he should have been screened according to the directions of the Education Ministry, but this was not done." 2138 [Hervorhebung d. Verf.]

Dass das alliierte „Sub-Committee on University Denazification“ seine Arbeit formal gründlich anlegte - nicht zuletzt wurde seitens der russischen Besatzungsmacht Kritik am Fortschritt der Entnazifizierung geübt -, zeigt sich unter anderem daran, dass vom Unterrichtsministerium Namenslisten aller entlassenen, enthobenen, pensionierten und pardonierten Universitätsprofessoren sowie Listen aller Lehrkräfte, die entweder ehemalige Offiziere der Deutschen Wehrmacht waren oder keine österreichische Staatsbürgerschaft besaßen und daher zu repatriieren gewesen wären, angefordert wurden. ${ }^{2139}$ Durch die bevorstehende Beschlussfassung des Minderbelastetengesetzes, das ehemalige Wehrmachtsoffiziere gar nicht mehr als eigenen Punkt anführte, waren diese Listen aber mittlerweile obsolet geworden.

Immerhin verlautete das alliierte Entnazifizierungskomitee, das die Arbeit der österreichischen Re-screening-Kommissionen in einer eigenen Resolution grundsätzlich posi-

2136 Ebd., Appendix A.

2137 Name vom Verfasser anonymisiert. Auf den Namenslisten der Beisitzer für die Sonderkommission für die Philosophische Fakultät taucht der hier angeführte Name allerdings nicht auf, was verschiedene Gründe haben kann: entweder waren die Listen, die ja von universitärer Seite angelegt wurden, nicht aktuell und beinhalteten lediglich die bereits bei den früheren Überprüfungskommissionen angeführten Namen, oder die besagte Person war bereits aus der Inskriptionskommission entfernt worden.

2138 NARA II, RG 260, EDU-DIV, Box 2/Folder 58. Allied Commission for Austria (British Element). Sub-Committee on University Denazification. Report on Meetings held at Allied Secretariat on February 7 and 15, 1947, Appendix A.

2139 NARA II, RG 260, EDU-DIV, Box 2/Folder 58. Republic Austria, Federal Ministry of Education (Skrbensky) to Quadripartite Universities Denazification Sub-Committee, Chairman Mr. Needham, 25. Jänner 1947, 1. 
tiv beurteilte - offenkundig auf Druck des sowjetischen Elements ${ }^{2140}$-, folgende, höchst bemerkenswerte Feststellung:

„The Hochschule für Welthandel did not act in accordance with the spirit of the decree of 6th Dec. In that some of the members of the screening commissions were politically unreliable. The committee views with special concern the fact that Prof. Oberparleiter, whose dismissal we recommended in April 1946, is not only still at the Hochschule, but is Rektor. “2141 [Hervorhebung d. Verf.]

Trotz alliierter Supervision und Berichterstattungspflicht gegenüber der Alliierten Kommission steht aufgrund derartiger Beispiele zu vermuten, dass die verordnete Durchführung, nicht zuletzt auch wegen des knapp bemessenen Durchführungszeitraums und dem erwähnten partiellen Rückzug der Studentenfraktionen, kaum gründlicher erfolgt sein dürfte als zuvor. Hinzukommt, dass durch die latente Obstruktionspolitik der US-Besatzungsbehörden in allen Fragen der Entnazifizierung - unter anderem durch Rückzug auf formale Bestimmungen - in den Gremien der Alliierten Kommission kaum Einigung zwischen den Besatzungsmächten hinsichtlich eines gemeinsamen, konsequenteren und härteren Vorgehens zu erzielen war. Die US-Position einer Nichteinmischung in Fragen der Entnazifizierung trat nach Beschlussfassung des Nationalsozialistengesetzen von 1947 noch deutlicher hervor: dieser Fragenkomplex wurde in den alliierten Gremien inhaltlich kaum mehr diskutiert und man beschränkte sich zunehmend auf lapidare Formal-Kommentare. ${ }^{2142}$

Obwohl das Re-screening mit 15. Februar 1947 hätte abgeschlossen sein sollen, legte das Bundeskanzleramt der Alliierten Kommission erst mit 29. März einen ersten Zwischen-

2140 NARA II, RG 260, EDU-DIV, Box 2/Folder 58. Appendix E.S. Ledovsky, Data on the progress of Denazification in the Hochschule für Welthandel, Februar 1947, 1.

2141 Neben dem Rektor Karl Oberparleiter (1886-1968) war auch der Pro-Rektor Dürfell durch NSDAPMitgliedschaft belastet. Siehe: NARA II, RG 260, EDU-DIV, Box 2/Folder 58. (ACA/ER/14/12a) Quadripartite Sub-Committee on University Denazification to Allied Commission for Austria. Recommendations submitted for Education Directorate, 3rd March 1947, 1f.; zu Karl Oberparleiter siehe: http://agso.uni-graz.at/sozio/biografien/o/oberparleiter_karl.htm [Zugriff 10.2.2013].

2142 Während Franzosen und Sowjets im „Education Directorate“ die punktuelle Überprüfung der Vorlesungsverzeichnisse sowie einzelner Vorlesungen, insbesondere in Fächern wie Geschichte, Geografie, Literaturwissenschaft oder Biologie selbst vorschlugen, wies der US-Vertreter eine derartige Kontrolle zurück und verwies kurz und bündig auf den „Fakt“, dass „all professors at the Universities had been screened and accepted by the Education Directorate according to the provisions of Denazification Law 1947.“ Die britische Position fiel hier deutlich differenzierter aus, indem die Sinnhaftigkeit einer Überprüfung der Vorlesungsverzeichnisse und Vorlesungen generell durchaus bejaht wurde, man aber - anders als Sowjets und Franzosen - angesichts der bisherigen Insuffizienz des offiziellen Report-Systems durch österreichische Stellen ein anderes Berichtsystem vorschlagen wollte, denn: „The Austrians would give us just what they thought we should like. "[Hervorhebung d. Verf.] NARA II, RG 260, EDU-DIV, Box 2, Folder 58. Allied Commission for Austria (British Element). Education Directorate. Report on meeting of Working Party on Universities (ACA/ER/14/12a), 12th May 1947, $1 \mathrm{f}$. 
bericht vor, der außerdem nicht sonderlich elaboriert ausfiel: er hätte gut auf eine Postkarte gepasst. Darin wurde lediglich angeführt, dass von den insgesamt rund 26.000 Studenten bisher 4.392 untersucht, und davon 680 vom Studium ausgeschlossen worden seien; weitere 3.628 belastete Studenten seien noch zu überprüfen. ${ }^{2143}$

In der darauffolgenden Sitzung des Exekutivkomitees vom ro. April zog der unvollständige Bericht prompt harsche Kritik des Vorsitzenden Colonel Ivan I. Ilitchev (UdSSR) auf sich. Abgesehen davon, dass dieser keine Angaben darüber enthielt, an welchen Universitäten die Ausschlüsse erfolgt seien und unter welche Kategorien die ausgeschlossenen Studenten jeweils zu reihen wären, fänden sich in dem Bericht, wie Ilitchev monierte, auch keine Angaben darüber, ob und inwiefern Maßnahmen gegenüber den Verantwortlichen an den Hochschulkrawallen ergriffen worden seien. Letzteres wurde von amerikanischer Seite sogleich strikt zurückgewiesen, da der Bundeskanzler ja nicht aufgefordert gewesen sei, einen derartigen Bericht dazu vorzulegen. Dessen ungeachtet konnte aber auch die US-Vertreter nicht über „the meager information submitted in the Chancellor's report “2144 hinwegsehen. Dennoch, einer Verurteilung der von der österreichischen Regierung vorgelegten Arbeit und einer Aufforderung nach stringenterer Berichtslegung - wie von sowjetischer Seite gefordert -, wollte sich Colonel Rose als US-Vertreter im Exekutivkomitee nicht anschließen: „The US Member said he lacked sufficient evidence to condem [...] the work that has been done in the denazification of institutions of higher learning. “2145

Letztlich einigte man sich auch in dieser Sitzung des alliierten Exekutivkomitees lediglich darauf, die österreichische Bundesregierung abermals aufzufordern, „to submit a final report on the purge of Austrian universities in which they shall indicate the number of students excluded from each university and the categories excluded, as the report of 29 March 1947 failed to provide this information." 2146

Eine mögliche Ursache für die verzögerte Berichtslegung durch die Bundesregierung beziehungsweise das Unterrichtsministerium mag darin liegen, dass das Re-ScreeningVerfahren parallel zur Beschlussfassung des neu ausgearbeiteten Verbotsgesetzes vom I8. Februar 1947 („Minderbelastetengesetz“) lief, dessen Entwurftext fast ein Jahr zwischen Alliiertem Rat und Nationalrat hin und her gewandert war. ${ }^{2147}$ Bereits in der zweiten Ver-

2143 NARA II, RG 260, EDU-DIV, Box 2, Folder 58. Austrian Republic, Federal Chancellery to Chairman, Directorate for Internal Affairs, Allied Commission for Austria, Summary on the result of the denazification of the Austrian universities, 29. März 1947,1.

2144 NARA II, RG 260, EDU-DIV, Box 2 /Folder 58. Allied Commission for Austria. Internal Affairs \&Education Directorates, 105th Meeting, 10th April 1947, 4.

2145 Ebd., 5.

2146 Ebd., 8.

2147 Bereits am 30. März 1946 hatten sich die drei Parteien SPÖ, ÖVP und KPÖ auf neue Richtlinien und Grundsätze für eine Neufassung des Nationalsozialistengesetzes geeinigt. Vgl. Claudia Kuretsidis-Haider, Das Nationalsozialistengesetz 1947. Weiterentwicklung von Verbotsgesetz und Kriegsverbrechergesetz 
botsgesetz-Novelle vom I6. November 1946, die zwar verlautbart, aber nicht mehr durchgeführt wurde, hatten die Vertreter der drei Parteien vorgesehen, die bisherige individuelle Amnestie durch eine Gruppenamnestie zu ersetzen.

Mit dem neuen Verbotsgesetz ging man nun davon ab, „Illegalität“ wie bisher quasi mit Hochverrat gleichzusetzen - diese hatte nur mehr im Zusammenhang mit konkreten Straftaten Bedeutung -, sondern machte zum Kriterium, ob Personen während der Zeit des Nationalsozialismus führende politische Funktionen in der NSDAP innegehabt hatten oder nicht. ${ }^{2148}$ Dabei wurden die Nationalsozialisten nun in zwei Gruppen unterteilt: zum einen die zu bestrafenden hohen Funktionäre der NS-Organisationen, die Offiziere der NS-Wehrverbände (SA, NSKK, NSFK), die Hoheitsträger der Partei sowie Mitglieder der SS, zum anderen die „Belasteten“ und „Minderbelasteten“- „Parteianwärter“ waren ab sofort nicht mehr registrierungspflichtig-, die ab nun, je nach Grad ihrer Aktivität und Involvierung, nicht mehr als straf- sondern als „sühnepflichtig“" galten. ${ }^{2149}$ Nach dreijähriger Bezahlung eines finanziellen Sühnebetrags konnten sich Minderbelastete jetzt freikaufen, und auch für Belastete galt - je nach Grad ihrer Belastung -, dass sie nach einer gewissen Zeit (fünf oder mehr Jahre), in der sie Gehalts- und Pensionskürzungen akzeptieren, Dienstverbote hinnehmen mussten und vom aktiven Wahlrecht ausgeschlossen waren, ihre Schuld tilgen konnten. ${ }^{2150}$

Entgegen der mit dem ,Minderbelastetengesetz' erlassenen versöhnlichen Haltung gegenüber Mitläufern kam es im universitären Bereich für die Studierenden allerdings zu temporären - Verschärfungen. Vor dem Hintergrund der geschilderten Ausschreitungen bei den Hochschülerschaftswahlen hatte der Nationalrat im Rahmen des neuen Verbotsgesetzes begonnen, neben den Belasteten nun auch Minderbelastete fallweise und zeitweilig vom Hochschulstudium auszuschließen. Diese gesetzliche Regelung wurde dann auf Drängen der russischen Vertreter im Alliierten Rat noch zusätzlich verschärft, indem

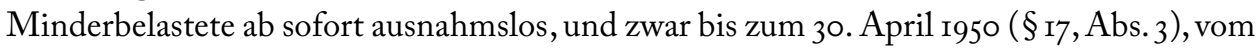
Studium auszuschließen waren.

Am 21. April 1947 wurde dem Alliierten Rat der Re-Screening-Endbericht schließlich vorgelegt, der nun auch die gewünschten Präzisierungen enthielt. ${ }^{2151}$ Unter den 680 Stu-

NSG 1947 [2001]. Vgl. www.nachkriegsjustiz.at/service/gesetze/nsg1947.php [Zugriff am 7.1.2011]. Siehe auch den Hinweis bei: Pfefferle/Pfefferle, Glimpflich entnazifiziert, a.a.O., $7 \mathrm{f}$.

2148 Stiefel, Entnazifizierung, a.a.O., 102.

2149 BGB1. Nr. 25/1947, §19. Bundesverfassungsgesetz vom 6. Februar 1947 über die Behandlung von Nationalsozialisten (Nationalsozialistengesetz).

2150 Stiefel, Entnazifizierung, a.a.O., $103 \mathrm{f}$.

2151 Wie wenig aufeinander abgestimmt und offenkundig heillos unkoordiniert im Zusammenhang der Übermittlung des genannten Endberichtes an den Alliierten Rat vorgegangen wurde, zeigt sich daran, dass das Unterrichtsministerium eine identische Fassung dieses Berichtes Ende Mai 1947 als „Ergänzung“ zum Bericht des Bundeskanzleramtes vom 29. März 1947 dem Bundeskanzleramt zur Vorlage an den Alliierten Rat zugesandt hat. NARA II, RG 84, (84/350/49/09/5), Box 12 [Entry 2062]. Foreign 
dierenden, die bis zum I5. April I950 vom Studium ausgeschlossen waren, befanden sich 3I2 ehemalige NS-Funktionäre und 368 ehemalige Offiziere der Deutschen Wehrmacht; von diesen 680 waren 85 belastet, 43I minderbelastet und I64 unbelastet. Allein 546 Ausschlüsse betrafen die Universität und die Hochschulen Wiens; anders war die Situation an der Universität Innsbruck, wo nur elf Studienausschlüsse verzeichnet wurden, an der Universität Graz waren es immerhin ro6 (im Detail siehe dazu nachstehende Tabelle).

Tabelle: Entnazifizierungsbericht des Unterrichtsministeriums, April I947 ${ }^{2152}$

\begin{tabular}{|l|c|c|c|c|c|c|}
\hline $\begin{array}{l}\text { Ausgeschlossene } \\
\text { Studierende: davon: }\end{array}$ & I & II & total & b & mb & nb \\
\hline Universität Wien & 60 & 104 & 164 & 15 & 128 & 21 \\
\hline TU Wien & 55 & 125 & 180 & 12 & 98 & 70 \\
\hline Tierärztliche Hochschule & 7 & 4 & 11 & 3 & 7 & 1 \\
\hline Hochschule für Bodenkultur & 21 & 39 & 60 & 7 & 38 & 15 \\
\hline Hochschule für Welthandel & 45 & 57 & 102 & 16 & 60 & 26 \\
\hline Musikhochschule & 10 & 13 & 23 & 4 & 16 & 3 \\
\hline Akad. der Bildenden Künste & 3 & 1 & 4 & 0 & 3 & 1 \\
\hline Graphische Versuchsanstalt & 1 & 1 & 2 & 0 & 2 & 0 \\
\hline Universität Graz & 39 & 18 & 57 & 12 & 36 & 9 \\
\hline TU Graz & 49 & 0 & 49 & 12 & 27 & 10 \\
\hline Universität Innsbruck & 5 & 6 & 11 & 2 & 6 & 3 \\
\hline Montanistik Leoben & 17 & 0 & 17 & 2 & 10 & 5 \\
\hline Total & 312 & 368 & 680 & 85 & 431 & 164 \\
\hline
\end{tabular}

Legende: $\mathrm{b}=$ belastet: $\mathrm{mb}=$ minderbelastet; $\mathrm{nb}=$ nichtbelastet $\mathrm{I}=\mathrm{NS} ; \mathrm{II}=\mathrm{Wehrmacht}$

Service Post of the Department of State. Austria, U.S. Element of the Allied Commission for Austria. General Records, 1945-195 (Education), (Translation) Federal Ministry for Education (GZ 19873III / 7 /47), to the Federal Chancellory, Liaison Office to the Allied Council Vienna, „Denazification of the University Students, Report to the Allied Council, 27. Mai 1947,1.

2152 Denazification of the University Students, Report to the Allied Council. To Re. No. 15.611-III/7/47, 21 April 1947. NARA II, RG 84, 84/350/49/09/5, Box 12 [Entry 2062], Foreign Service Post of Dep. of State. Austria. U.S. Element of the Allied Commission for Austria. General Records, 1945-1951 (Education). Die zahlenmäßigen Angaben decken sich mit dem von Andrea Huber zitierten Zahlen des Bundesministeriums an den Alliierten Rat vom 27. Mai 1947 aus dem Dokumentationsarchiv des österreichischen Widerstandes (DÖW), wobei sich zusätzlich die Gesamtzahlen der Studierenden (WS 1946/47) angeführt finden: 23.241 (Wien), 12.140 Bundesländer. Vgl. Huber, Entnazifizierung im Rückbruch, a.a.O., 278. 
Bereits fünf Monate nach Verlautbarung des NS-Gesetzes 1947 bemühte sich die österreichische Regierung mit Unterstützung der Westalliierten allerdings darum, den Zugang für Minderbelastete durch eine weitere Novelle der kommissionellen Überprüfung möglich zu machen.

Ausgangspunkt für dieses Bemühen um eine Revision der hochschulspezifischen Passagen des NS-Gesetzes waren Urgenzen der Österreichischen Hochschülerschaft, deren Zentralausschuss am 4. Februar 1947 unter Vorsitz von Otto Kudlacek ein ausführliches Memorandum an den Alliierten Rat gerichtet hatte, in dem sie sich gegen die darin zu Ausdruck kommenden „Kollektivschuld“ und gegen die unnachsichtige Härte in Behandlung der Studierenden wandte, die in Summe 5.00o inskribierte Hörer betreffe. ${ }^{2153}$

Als Verfassungsgesetz bedurfte die Novelle allerdings der Zustimmung des Alliierten Rates, die auf Grund des zunehmenden Misstrauens der Sowjets gegenüber der österreichischen Haltung in Entnazifizierungsfragen freilich nicht zustande kam. Bis zur Jugendamnestie am 3. Mai 1948 fielen Studierende somit formal unter die strengsten aller Entnazifizierungsbestimmungen überhaupt. ${ }^{2154}$

Im April 1947 folgte die Durchführungsverordnung des Verbotsgesetzes im öffentlichen Dienst, ${ }^{2155}$ die zwar einige von Amerikanern, Franzosen und Russen gegenüber dem österreichischen Entwurf eingeforderte Verschärfungen ${ }^{2156}$ enthielt, in Summe aber viele der Entscheidungen der Sonderkommissionen - insbesondere gegenüber den „Illegalen“- aufhob. Mit Inkrafttreten dieser Gesetzesnovelle gab es, wie Dieter Stiefel berechnet hat, auf einmal 25.520 Nationalsozialisten weniger. ${ }^{2157}$

2153 NARA II, RG 84, (84/350/49/09/5), Box 12 [Entry 2062]. Foreign Service Post of the Department of State. Austria, U.S. Element of the Allied Commission for Austria. General Records, 1945-195 (Education), Association of Austrian University Students to the Allied Commission for Austria, „The New National-Socialist Law“, 5th February 1947, 1.

2154 Verordnung des Bundesministeriums für Unterricht, RA.GZ Z 28.987-III//78/48, vom 3. Mai 1948. Die Amnestierung der Minderbelasteten wurde auch von der KPÖ, hier insbesondere von Ernst Fischer, gefordert. Die Jugendamnestie kam am 27. Februar vor den Alliierten Rat und wurde am 28. Mai 1948 mit Einstimmigkeit genehmigt. Vgl. Stiefel, Entnazifizierung in Österreich, a.a.O., 307. Die endgültige Regelung brachte erst das Bundesgesetz vom 22. April 1948, das im $\$ 1$ bestimmte: „Minderbelastete Personen im Sinne des $\$ 17$ Abs. (3) des Verbotsgesetzes 1947, die nach dem 31. Dezember 1918 geboren wurden, sind mit Inkrafttreten diese Bundesverfassungsgesetzes von den Verbotsgesetzen 1947 und von sonstigen Gesetzen enthaltenen Sühnefolgen befreit." BGBl., 1948, Stück 1 bis 51, Nr. 70, 16. Stück, 28. April 1948, 331.

2155 Erlass vom 16. April 1947, Z. 2159-Präs./I. Verordnungsblatt für den Dienstbereich des Bundesministeriums für Unterricht, Jg. 1946, Wien am 1. März 1946, 3. Stück, 51.

2156 So z.B. die Erweiterung des registrierungspflichtigen Personenkreises um Angehörige der Gestapo, der SA sowie NS-Autoren und wirtschaftliche Kollaborateure, die Einschränkung auf die von der Sühnepflicht befreiten Personen, hier insbesondere auch der Jugendlichen von Jahrgang 1924 aufwärts, und der Verschärfung der Sühnefolgen.

2157 Stiefel, Entnazifizierung in Österreich, a.a.O., 118. 
Einmal abgesehen davon, dass die überwiegende Mehrzahl der relegierten Studenten („Minderbelastete“) nur zeitlich befristet vom Studium ausgeschlossen war, verliefen insbesondere die Entnazifizierungsmaßnahmen innerhalb der Lehrkörper der Universitäten wenig effizient, da durch Revisionsverfahren sukzessive Wiedereingliederungen bereits entlassener Lehrpersonen erfolgten. ${ }^{2158}$ So wurden, wie aus einem Bericht des alliierten Education Directorate hervorgeht, nach Beschlussfassung des Minderbelastetengesetzes eine Reihe zuvor ausgeschlossener Professoren - darunter wohl auch „Illegale“ - wieder als Lehrkräfte aufgenommen, deren Namen allerdings nicht in den Vorlesungsverzeichnissen auftauchten:

"In view of the need of qualified personnel, a certain number of professors, less incriminated according to the Denazification Law of ${ }_{1947}$, who were originally suspended (enthoben) have been permitted by decision of the Denazification Committee of the 'Ministerrat' to continue teaching temporarily until the end of Summer term 1947. The decision to suspend is thereby not invalidated. ${ }^{2159}$

Eine prononciert scharfe Kritik an der „Nazi-Amnestie“ übte der Widerstandskämpfer und SPÖ-Nationalrat Albrecht Gaiswinkler ${ }^{2160}$ im Strom, wo er erbost und schonungslos -

2158 Auch bei den Studierenden wurde in vielen hunderten Fällen, die nach Paragraf 18 und 19 des Verbotsgesetzes 1947 als Mitglieder der HJ oder des BDM vom Studium auszuschließen waren, die Studienzulassung gewährt, da diese „ohne ihren Aufnahmsantrag oder aber während ihrer militärischen Dienstleistung ohne ihr Wissen in die Partei überstellt wurden." UAW, Dekanatsakten Phil. Fakultät, 493-1946/47, Rektor Adamovich an das Bundesministerium für Unterricht, 2. Juni 1947, 1.

2159 NARA II, RG 260, EDU-DIV, Box 2/Folder 58. Allied Commission for Austria. Education Directorate (ACA/ER/14/12a), Education Directorate. Working Party on Universities, „University Professors originally suspended and now teaching“, 20 May 1947, 1.

2160 Albrecht Gaiswinkler (1905-1979), mehrmonatige politische Haft 1934; bildete ab 1940 gemeinsam mit Valentin Tarra, Johann Moser und dem später - im Februar 1945 - von der Gestapo im Zuge einer Wohnungsdurchsuchung erschossenen Karl Feldhammer die Widerstandsbewegung Ausseerland, die große Aktivitäten entfaltete. Aufgrund seiner Weigerung, der NSDAP beizutreten, wurde Gaiswinkler strafweise zur Deutschen Wehrmacht eingezogen. Im Juli 1944 desertierte er mit einem größeren Munitionstransport und schloss sich als Partisan dem französischen Maquis an. Im September 1944 trat Gaiswinkler in die Dienste der US-Armee ein und wurde nach England gebracht, wo ihn die Briten für ein Trainingsprogramm für Leiter von Widerstandsgruppen rekrutierten. Ab Ende 1944 arbeitete er im Rahmen der britischen Armee für die „British Special Operations Executive“. Am 8. April 1945 sprang Gaiswinkler - im englischen Auftrag über dem Höllengebirge im Salzkammergut ab und setzte gemeinsam mit Valentin Tarra, Johann Moser und Hans Renner die Widerstandsbewegung Ausseerland fort, der sich rund 360 weitere Personen anschlossen und die unter anderem einen eigenen „Freiheitssender Ausseerland“ installierte und die Sprengung der geraubten Kunstschätze im Salzbergwerk Altaussee mitverhinderten. 1945 wurde Gaiswinkler Bürgermeister von Bad Aussee und Bezirkshauptmann und von 1945 bis 1949 bekleidete er das Amt eines Abgeordneten zum Nationalrat für die SPÖ. Vgl. Rot-Weiss-RotBuch. Gerechtigkeit für Österreich. Darstellungen, Dokumente und Nachweise zur Vorgeschichte und 
eine derartige Äußerung war wohl auch für einen Abgeordneten keineswegs karrierefördernd $^{2161}$ - auf den seiner Ansicht nach höchst prekären Status quo der Entnazifizierung mit beklemmenden Worten Bezug nahm:

"So unglaublich es klingen mag, aber es sind Beweise dafür vorhanden: reichsdeutsche Nazi stehen heute als Dolmetscher in alliierten Diensten, bei den österreichischen Gerichten finden wir Nazi in Hülle und Fülle, in der Exekutive gibt es Nazi noch mehr als genug und die Ämter und Behörden bilden geradezu ein Musterbeispiel hierfür, wie man die Entnazifizierung des Bürokratieapparates nicht durchführen soll.

Das NS-Gesetz ist überhaupt noch gar nicht richtig in Anwendung gekommen, das Kriegsverbrecher- und das Verbotsgesetz wird umgangen, so gut es geht, der nazireiche Beamtenapparat findet immer Mittel und Wege, um Kriegsverbrecherprozesse so weit als nur möglich hinauszuschieben, und schon reden, kaum drei Jahre nach dem Zusammenbruch der größten Mörderpartei aller Zeiten, sich namhafte Politiker die Zunge wund, um ein Amnestiegesetz als Taufpate aus der Taufe heben zu können, das die ach so unschuldige nazistische Jugend gänzlich von den Folgen ihrer braunen Vergangenheit befreit. Jugendliche von damals, sie sollten restlos entregistriert werden. Aber die Jugendlichen vom Jahre 1938 sind heute restlos reife Männer. Es sind leider vielfach solche Männer, welche heute wieder in ihren naziverseuchten Gehirnen das,Vierte Reich'erträumen und die auf den österreichischen Hochschulen Naziideologien vertreten, die in den Kinos zu lachen beginnen, wenn ein österreichischer Minister oder Kanz-

Geschichte der Okkupation Österreichs. Erster Teil (nach amtlichen Quellen), Wien 1946, 146 f.; weiters: Rathkolb (Hrsg.), Gesellschaft und Politik am Beginn der Zweiten Republik, a.a.O., 221 f.; Rainer Hilbrand, Der Freiheitssender Ausseerland. In: Ausseer Beiträge zur Kultur und Zeitgeschichte (= Schriftenreihe des Heimatmuseums „A “, Bd. 7). Hrsg. v. Hans Michael Roithner, Bad Aussee 1985, 91; zuletzt: Albrecht Gaiswinkler. Sprung in die Freiheit, Ried-Verlag, Wien-Salzburg, 1947.

2161 Tatsächlich geriet Gaiswinkler bald in Konflikt zur SPÖ-Spitze und schied aus der Partei aus. Siehe dazu: Rathkolb (Hrsg.), Gesellschaft und Politik am Beginn der Zweiten Republik, a.a.O., 214f. Aus Sicht des US-amerikanischen OSS-Mitarbeiters Paul R. Sweet stellte sich die Person Gaiswinklers folgendermaßen dar: „[...] Albrecht Gaiswinkler, is certainly one of the most imposing personalities to have come to the force in the new Austria. Young, forthright, and intelligent, he is present Buergermeister of Bad Aussee and head of the Resistance [...]." Ebd., 211. Wie aus einem US-Geheimdienstdokument (G-2) hervorgeht, stand Gaiswinkler, dem u. a. vorgeworfen wurde, als selbsternannter Bezirkshauptmann „removing Nazi functionaries with no other authority than his own“, im „Verdacht kriminellen Verhaltens“, da er von der amerikanischen Militärpolizei anvertrautes Material unerlaubter Weise behalten hätte, woraufhin das Gericht in Wels den Antrag auf Aufhebung seiner parlamentarischen Immunität und die US-Militärpolizei einen Haftantrag stellte. Darüber hinaus war Gaiswinkler, so das US-Geheimdossier weiter, durch einen Artikel in der Grazer Neuen Zeit negativ aufgefallen, in welchem er behauptet hatte, dass Ing. Raab, Gleißner und Bischof Rohracher an der „Regierung Kaltenbrunner“ beteiligt gewesen seien. Recordings of the U.S. Department of State relating to the Internal Affairs of Austria 1945-1954 (Mikrofilm-Bestand Institut für Zeitgeschichte der Universität Wien), Decimal File, Reel 1, Political Advisor Vienna, Erhardt, to Department of State, „Report G-2, USFA - The Gaiswinkler Case“, 11. June 1946, 1. 
ler erscheint. Jugendliche, welche schon wieder ganz offen ,Antisemitismus' predigen. Jugendliche, welche schon wieder in Begeisterung den Krieg gegen die Sowjetunion erwarten [...]. Amnestie ja! Aber vorher restlose Entnazifizierung!“2162 [Hervorhebung d. Verf.]

Soweit die Kritik und der dramatische Befund Albrecht Gaiswinklers zum Resultat der Entnazifizierung: eine Diagnose, die sich - trotz vieler gleichlautender Aussagen aus jener Zeit - im empirischen Sinne freilich nur teilweise verifizieren lässt; aber - und das verdient an dieser Stelle hervorgehoben zu werden -, falsifizieren lässt sich der hier ausgesprochene Befund auf Grundlage des verfügbaren Quellenmaterials noch weitaus weniger. ${ }^{2163}$

Anhand der Personalstandsverzeichnisse einzelner Fakultäten der Universität Wien hat Weinert überprüft, dass der Prozentsatz aller Lehrkräfte an der Juridischen Fakultät im Wintersemester 1945/46 infolge der Säuberungsmaßnahmen auf 29 Prozent schrumpfte, I949/50 aber bereits wieder die 50 Prozentgrenze erreichte, wobei die Zahl der wieder eingestellten Professoren bereits 59 Prozent betrug. An der Philosophischen Fakultät lag die Vergleichszahl aller Lehrkräfte bei 44 Prozent, bei den Professoren bei genau 6o Prozent. ${ }^{2164}$ Bis $1956 / 57$ kletterte die Zahl der wieder eingegliederten ehemaligen NS-Lehrkräfte an der Juridischen Fakultät, deren Grundtendenz seit den i92oer-Jahren radikal antisemitisch-deutschnational geprägt war, ${ }^{2165}$ immerhin bereits auf 66 Prozent. ${ }^{2166} \mathrm{Wie}$ bereits erwähnt, machte an der Philosophischen Fakultät der Universität Wien zwei Drittel der Professorenschaft nach 1945 eine zweite Karriere. ${ }^{2167}$

Wie unter anderem aus den Protokollen des „Quadripartite-Subcommittees“ hervorgeht, zog sich die Entnazifizierung der Universitäten - wie schon zuvor die Entnazifizierung allgemein - als endlose Geschichte bis 1949 dahin. In geradezu ritualisierter Form lieferten Bundeskanzleramt und Unterrichtsministerium der Alliierten Kommission regelmäßig neue Berichte zum Fortschritt der Entnazifizierung, ${ }^{2168}$ die im Wesentlichen den

2162 Albrecht Gaiswinkler, Nazi-Amnestie? In: Strom, 4. Jg., Folge 2, 31. Jänner 1948, 3 f.

2163 Ein Indikator für die Schwierigkeiten im Bereich der Entnazifizierung war zweifellos auch die Überlastung der Behörden und Kommissionen. Im August 1946 meldete der polizeiliche Situationsbericht für Wien den Abschluss der NS-Registrierung im 8. Wiener Gemeindebezirk: 2790 Personen hatten sich gemeldete, ,jedoch 2450 Gesuche um Nachsicht eingebracht“. Zit. nach: Schembor, Polizeiliche Situationsberichte für die Jahre 1945 und 1946, a.a. O., 258.

2164 Vgl. Weinert, Entnazifizierung an den Hochschulen, a.a. O., 262.

2165 Vgl. dazu Oliver Rathkolb, Die Rechts- und Staatswissenschaftliche Fakultät der Universität Wien zwischen Antisemitismus, Deutschnationalismus und Nationalsozialismus 1938, davor und danach. In: Heiß et al. (Hrsg.), Willfährige Wissenschaft, a.a.O., $198 \mathrm{f}$.

2166 Vgl. Weinert, Entnazifizierung an den Hochschulen, a.a.O., 262.

2167 Pfefferle/Pfefferle, Glimpflich entnazifiziert, a.a.O., $46 \mathrm{ff}$.

2168 Vgl. etwa NARA II, RG 84, [84/350/49/09/5], Box 12 [Entry 2062]. Foreign Service Post of the Department of State. Austria, U.S. Element of the Allied Commission for Austria. General Records, 1945-195 (Education), Republic of Austria, Federal Chancellory [(Albert) Markovics] to Allied Commission for Austria, Allied Denazification Bureau, „Technical High School in Vienna; denazification 
jeweils zuletzt referierten Status quo mit unmerklichen Änderungen wiederholten, worauf die sowjetischen Militärbeamten in der Regel Kritik vorbrachten und darauf drängten, endlich einen finalen Bericht abzuliefern. Des Weiteren brachte der sowjetische Vertreter im „Education Directorate“ regelmäßig Resolutionen ein, die darauf abzielten, wegen der nach wie vor lehrenden Nazi-Professoren oder unbesetzten Lehrstühlen dringende „Empfehlungen " an das Unterrichtsministerium zu beschließen. ${ }^{2169}$ Die Westalliierten - hier vor allem die US-Besatzungsmacht - hielten sich mit eigenen Stellungnahmen zurück und beschränkten sich darauf, russische Forderungen mit formalen Hinweisen auf bereits durchgeführte Säuberungsmaßnahmen beziehungsweise auf die österreichische Gesetzeslage zu konterkarieren. ${ }^{2170}$

Noch im Dezember 1949 kam es im Exekutivkomitee zu einer kurzen, aber atmosphärisch überaus aufschlussreichen Auseinandersetzung über die Entnazifizierung an Österreichs Universitäten. Von russischer Seite war zuvor im alliierten Education Directorate ein detaillierter Bericht vorgelegt worden, der das Wiedererstarken nazistischer Kräfte auf universitärem Boden mit Bezug auf einzelne Beispiele thematisierte. Demnach hätte an der Universität Graz am 26. und 27. Oktober eine studentische Versammlung in Verbindung mit der „Union der Unabhängigen“ stattgefunden, bei der nazistische und deutschnationale Reden gehalten worden seien. Darüber hinaus wurde auf die Situation an der Hochschule für Welthandel verwiesen, wo nach wie vor belastete Professoren unterrichten würden. Des Weiteren monierten die Sowjets, dass am II. Chemischen Institut der Universität Wien - laut Bericht in der Arbeiter Zeitung - eine Gruppe von „Nazi hooligans“ die Gedenktafel an den antinazistischen Widerstand entweiht und antisemitische Sprüche an die Wände geschmiert habe. Zuletzt wurde noch beanstandet - und das war zweifellos der schwächste Punkt -, dass der angeblich „deutschnationale“ Historiker Hugo Hantsch ${ }^{2171}$

of the professoriate and of the employees of the Technical High School in Vienna (2nd Supplement), 20. August 1947.

2169 NARA II, RG 84, [84/350/49/09/5], Box 12 [Entry 2062]. Foreign Service Post of the Department of State. Austria, U.S. Element of the Allied Commission for Austria. General Records, 1945-195 (Education), Allied Commission for Austria. Executive Committee [EXCO/P(48152], Lectures in the University Institutions, Summer Term 1948. Recommendation by the Soviet Member of the Education Directorate, 11. Juni 1948, $1 \mathrm{f}$.

2170 Vgl. NARA II, RG 260, EDU-DIV, Box 2/Folder 53, Headquarters United States Forces in Austria, Liaison Section/Russian Sub-Section (APO 777), Samuel H. Williams, Chief Education Division, Soviet Protest against Nazi Professors, 10. Juni 1948, 1.

2171 Tatsächlich war Hugo Hantsch (1895-1975) als Benediktiner-Pater ausgeprägt katholisch und ein ,aufrechter ' Vertreter der österreichischen Mission, u. a. in der „Vaterländischen Front“. Nach eigenen Angaben verbrachte Hantsch nach einjähriger Haft im Konzentrationslager Buchenwald die Zeit ab 1939 in der niederösterreichischen Gemeinde Ravelsbach als Pfarrer. Im September 1945 wurde Hantsch vom OSS interviewt und dabei nicht zuletzt wegens seiner harschen anti-sowjetischen Haltung (,things that took place in Austria under the Russians were far worse than the situation under Hitler") als Reaktionär eingeschätzt, der aus US-amerikanischer Perspektive versuchte, „to stirr up trouble between us and the Russians.“ Darüber hi- 
an der Universität lehrte. Das sowjetische Mitglied des „Education Directorate“ empfahl daher die Annahme folgender Resolution:

\begin{abstract}
"The EC draws the attention of the Ministry of Education to the fact that Nazi activity is being reviewed in a number of Austrian universities. On the basis of the tasks of the $\mathrm{AC}$, deriving from the Control Agreement, and the AC decision on the Nazi question, the EC proposes that the Ministry of Education investigate all the facts and take the necessary steps to prohibit, throughout all educational institutions, any pro-nazi activity. The $\mathrm{EC}$ must be informed of the results of this investigation and of the implementation of this decision." ${ }^{2172}$
\end{abstract}

Im Exekutivkomitee bezog sich der russischer Vertreter Medvedev auf diesen Bericht und verlangte ein entschiedenes Vorgehen. Interessant scheint diese Angelegenheit weniger hinsichtlich der Faktenlage sondern hinsichtlich der Einstimmigkeit, mit der die sehr knappe Stellungnahme von US-Vertreter Brigadier A.J. Edney, der „no evidence to support the resolution“ sah und kurz und bündig festhielt, „I do not prescribe, in any way, such a resolution“, von westalliierter Seite unterstützt wurde. Der britische Vertreter Fry konstatierte, dass er keinerlei Informationen über ein Ansteigen des Nazismus hätte und das Thema daher gerne fallenlassen möchte. Und auch der französische Vertreter betrachtete die russische Resolution „not a serious working paper. ${ }^{\text {“173 }}$ Damit war die Angelegenheit ohne weitere Diskussion vom Tisch.

Nach diesem Muster verliefen auch die interalliierten Debatten über die Verwendung verbotener NS-Schulbücher an österreichischen Schulen ${ }^{2174}$ oder über die Weiterver-

naus verharmloste Hantsch das faschistische Spanien unter Franco: „[...] why the world is so against Franco Spain [...] not evil like Hitlers's, not basically anti-civilization. " Der OSS-Interviewer Paul R. Sweet stufte Hantsch’ Äußerungen als unerträgliche und unverantwortliche Hetze (,irresponsible war-mongering“) ein schließlich hatte dieser sich für die sofortige Vertreibung der Russen aus Österreich durch die Alliierten ausgeprochen -, und sah die darin zum Ausdruck kommende Haltung zudem als symptomatisch für weite Teile der Bevölkerung an: „I am in the moment in an anti-Austrian mood. That they have suffered much more than they feel they should have is certainly true, but the perpetual running to us with talks about the Russians is getting to have just the opposite effect from what they intend. Many of them make no secret of the fact that they simply want to sew discord between us and the Russians." Zit. nach: Rathkolb, Gesellschaft und Politik am Beginn der Zweiten Republik, a.a.O., 269, 300 f. bzw. 302. Paul R. Sweet, Letter to Kath (Ravelsbach), 17. September 1945. Siehe weiters: Anton Staudinger, Austrofaschistische „Österreich“Ideologie. In: Emmerich Tálos/Wolfgang Neugebauer (Hrsg.), Austrofaschismus. Politik - Ökonomie Kultur 1933-1938, 5. überarb. Aufl. (Red. Christine Schindler), Wien 2005, 33 ff.

2172 NARA II, RG 84,(84/350/49/09/5), Box 12 [Entry 2062]. Allied Commission for Austria. Executive Committee, Rescrudescence of Nazis Activity in Austrian Universities. Report and Recommendation by the Soviet Member of the Education Directorate, 13th December 1949, $12 \mathrm{f}$.

2173 Ebd., 13.

2174 Vgl. NARA II, RG 84, (84/350/49/09/5), Box 12 [Entry 2062]. Allied Commission for Austria. Executive Committee, Use of Prohibited Textbooks in Austrian Schools. Report by the Soviet Member of the Education Directorate, 13th December 1950, $1 \mathrm{f}$. 
wendung belasteter Lehrer an öffentlichen Schulen. ${ }^{2175}$ Die Einmischung in Fragen der Entnazifizierung war nach dem Minderbelastetengesetz dezidiert keine Angelegenheit mehr, mit der sich amerikanische Militärstellen befassen wollten - eine Position, der sich Briten und Franzosen insofern anschlossen, als dass Stellungnahmen des US-Vertreters in den alliierten Gremien - grosso modo - letztlich nicht konterkariert wurden.

\section{Turnaround in der Entnazifizierungspolitik - Kontroversen zwischen State Department und War Department}

Im April I948 sandte der Direktor der USACA/Executive Section, Colonel Joseph R. Groves, an alle amerikanischen Militärdienststellen in Österreich ein internes Positionspapier aus, das die aktuelle amerikanische Haltung in der Frage der Entnazifizierung zusammenfasste. Darin bekräftigte die US-Militärregierung die Notwendigkeit der Eliminierung allen nationalsozialistischen Einflusses in Wirtschaft und öffentlichem Leben und bekannte sich dazu, die Arbeit der österreichischen Stellen auch künftig, sowohl unilateral als auch im Rahmen des „Quadripartite Denazification Committees“, zu beobachten und zu unterstützen. Doch mit Bezug auf das vom Alliierten Rat angenommene Verbotsgesetz, wonach die Durchführung und Verantwortung für die Entnazifizierung bei der österreichischen Regierung lag, und nachdem „denazification in Austria has progressed to a point where the possibility of a resurgence of Nazi ideology is remote“, wollte das US-Besatzungselement sich nur mehr in Ausnahmefällen einbringen:

"Except under unusual circumstances, the U.S. Element will neither initiate nor agree to any further directive to the Austrian Government to take action with respect to either denazification in general or to specific cases. If, however, the Central Austrian authorities should fail to act when flagrant violations of the law have been brought to their attention, the U.S. Element retains the right, in exceptional cases, to secure corrective action, either unilaterally within its own Zone or in quadripartite participation." 2176 [Hervorhebung d. Verf.]

Damit war der Rückzug von jeder direkten Einmischung in Entnazifizierungsangelegenheiten auch offiziell ausgesprochen.

Noch deutlicher wurde dieser formal und inhaltlich begründete Rückzug aus der Entnazifizierung dann in einer internen Stellungnahme des US-Hochkommissars, die unter dem Titel „Statement of U.S. Position on Denazification“ im Dezember 1948 an die USMilitärstellen ausgesandt wurde, und worin indirekt bereits der Kalte Krieg beziehungs-

2175 Vgl. NARA II, RG 84, (84/350/49/09/5), Box 12 [Entry 2062]. Allied Commission for Austria. Executive Committee [EXCO/F(4798)], Replacement of Nazi Teachers. Report by the Education Directorate with the Various Points of View and Proposals of the Elements, 29 April 1947.

2176 NARA II, RG 260, EDU-DIV, Box 8/Folder 56. U.S. Denazification Policy (restricted), 28. April 1948, 2. 
weise Österreichs geostrategische Rolle - Österreich stand bereits im „Western Camp“ablesbar ist. Darin heißt es unter anderem:

\begin{abstract}
"It is the position of the U.S. High Commissioner that the completion of denazification in Austria to its final conclusion, now that the war criminals and chief offenders have been largely disposed of, is a responsibility of the Austrian Government under Austrian laws. It is believed that the democratically elected Government of Austria will carry forward the solution of this problem under the provision of Articles 9 and ro of the draft treaty drawn up in Moscow on 25 April I947 in a positive and constructive manner. Denazification has progressed to the point where Nazi ideology does not constitute the principle threat to democratic government or to its institutions. To force denazification beyond a reasonable point might develop an unassimilable group, barred from normal participation in public life and private pursuits, which would be subversive in attitude."2177 [Hervorhebung d. Verf.]
\end{abstract}

Die vollständige Überantwortung der Entnazifizierung an österreichische Stellen - im Glauben an deren „positive“ und "konstruktive“ Vorgehensweise - sowie der sozialpsychologisch inspirierte Hinweis auf die Gefahr einer überzogenen NS-Säuberung markieren den Übergang zu einer besatzungspolitisch generösen Haltung gegenüber einem strategischen Kooperationspartner; in der Folge kam es primär auf die Sicherstellung einer positiven Einstellung gegenüber Amerika beziehungsweise gegenüber dem „American way of life" an - auch wenn es dabei zunächst noch zu Konflikten zwischen zivilen und militärischen Stellen hinsichtlich des bisherigen Vorgehens kam.

Die Tumulte bei den österreichischen Hochschülerschaftswahlen hatten jedenfalls Diskussionen zwischen zivilen und militärischen US-Behördenstellen zur Folge, wobei sich erstere insbesondere über die negativen Auswirkungen wegen der Passivität der amerikanischen Besatzungsmacht in der Frage der Entnazifizierung Sorgen machten - wohl auch im Hinblick auf die Auswirkungen auf die inneramerikanische Öffentlichkeit. ${ }^{2178}$

2177 NARA II, RG 260, EDU-DIV, Box 8/Folder 56. Statement of U.S. Position on Denazification, 15 December 1948, 1.

2178 Welchen Stellenwert man der inneramerikanischen Berichterstattung über Erfolge oder Misserfolge der US-Besatzung in Österreich beimaß, zeig sich u.a. daran, dass selbst im Fall positiver Berichterstattung durch die Washington Post im Juni 1946, die über große Erfolge bei der Einführung neuer Methoden im österreichischen Geschichtsunterricht berichtete - „Austria is stated to be the first country to adopt history teaching methods breaking with hero worship, and replacing them by respect for human beings" -, intern umgehend reagiert wurde, da dies eben gerade nicht den Tatsachen entspreche und der Öffentlichkeit ein falsches Bild der Situation vermittelt würde. So teilte John G. Erhardt dem Secretary of State in einem Schreiben mit: "There has been no important change as yet in Austrian teaching methods of the sort suggested." Recordings of the U.S. Department of State relating to the Internal Affairs of Austria 1945-1954 (Mikrofilm-Bestand Institut für Zeitgeschichte der Universität Wien), Decimal File, Reel 6, 1945-1949, USFA, Office of the Political Advisor, John G. Erhardt to Secretary of State, Washington D.C., Educational Methods in Austria, 21 June 1946, 1. 
In einer vertraulichen Note des US-Gesandten John G. Erhardt an den Secretary of State in Washington, George C. Marshall, wurde die Problematik vier Monate nach den Hochschulkrawallen klar beim Namen genannt: ,scandals, one more preposterous than the other, show that much remains to be done in denazification." ${ }^{2179}$

Quellenkritisch von Interesse ist, dass sich in diesem Papier die sowjetische Berichterstattung ${ }^{2180}$ beziehungsweise die pointierte Kritik an der Entnazifizierung seitens der KPÖ indirekt gespiegelt finden und damit Evidenz über den tatsächlichen Status quo in dieser Frage gegeben ist:

"Although it has repeatedly been reported that denazification is a major theme of Austrian Communist propaganda, it is well to re-emphasize that the Austrian scene is replete with excellent material for this campaign, and that the Communist press continues to be the most aggressive and uncompromising critic of governmental laxness in denazification." ${ }^{2181}$ [Hervorhebung d. Verf.]

Eine weitere, indirekte Auswirkung der Ereignisse zeigte sich darin, dass der OMGUSLeiter der Education \& Religious Affairs Branch, John W. Taylor, im Jänner I947 eine Stellungnahme zu einem Bericht über die Entnazifizierung der Universitäten innerhalb der US-Zone verfasste, der von der Internal Affairs Division stammte; darin sprach sich Taylor š im Sinne einer Reintegration in Form von Reeducation-Maßnahmen š für eine pragmatische Lösung aus ${ }^{2182}$ und verwies dabei auf die schwierige Situation der Education Branch in Deutschland, die, trotz besserer Ausstattung als etwa in Österreich, inner-

2179 Recordings of the U.S. Department of State relating to the Internal Affairs of Austria 1945 š 1954 (Mikrofilm-Bestand Institut für Zeitgeschichte der Universität Wien), Decimal File, Reel 1, John G. Erhardt, Analysis of Vienna Communist Propaganda During December, 7. Jänner 1947, 1.

2180 So erschien beispielsweise im Dezember 1946 ein Artikel in der Izvestia, der in scharfen Worten den „Augiasstall des österreichischen Faschismus“ anprangerte; der Artikel wurde anschließend in der Österreichischen Zeitung vom 31. Dezember 1946 unter dem Titel „Brief aus Wien“ veröffentlicht.

2181 Der Bericht führte weiter aus: „VOLKSSTIMME carried pertinent material on April 4, 16, 17, 18, 19, $20,22,23,24$ and 27. Welcome material was supplied by a) the release of a Wehrwolf leader, because the time spent awaiting trail would in any event exceed the possible verdict'; b) the disappearance of Nazis files from the Interior Ministry; c) the escape of a prominent war criminal who was used for rubbleclearing work under the alleged protection of other Nazis; d) the consequent exposure of a Nazi ,cell' in the economic section of the Vienna police; e) Nazi demonstrations in Styria on the occasion of Hitler's birthday. In all these cases corrective action was taken by the authorities. Whether this was because of the indignation of the leftist press, it is hard to determine." Recordings of the U.S. Department of State relating to the Internal Affairs of Austria 1945 š 1954 (Mikrofilm-Bestand Institut für Zeitgeschichte der Universität Wien), Decimal File, Reel 2, John G. Erhardt, American Legation/Vienna, to Secretary of State/Washington D.C., No. 3060, „Analysis of Austrian Communist Propaganda During April, 12. Mai 1947, 1.4. [Unterstreichung bzw. Versalien im Original]

2182 John W. Taylor, Chief of Branch, to IA \&C Div., Report on Denazification of Universities in US Zone by Policy Enforcement Br., CAD, OMGUS, 22 January 1947. NARA II, RG 260, OMGUS, ERA, Box 58. 
halb der Architektur der Militärbehörden eine eher untergeordnete Stellung einnehme. Schließlich, so Taylor mit realistischem Blick, müsse man sich bewusst sein, dass eine stichprobenartige Überprüfung des Personals von Erziehungs- und Bildungseinrichtungen in Deutschland mit großer Wahrscheinlichkeit Personen auffinden würde, die entweder illegal beschäftigt, durch einen Fehler in der Überprüfungskommission im Dienst belassen oder ohne Genehmigung der Militärregierung angestellt wären:

"Were this not true, it would mean that the few education officers assigned to control of German higher education had done an impossible task. [...] Until adequate personnel have been assigned, it cannot be expected that even the denazification functions of this job can be effectively or adequately carried out." 2183

Interessant ist in diesem Zusammenhang, dass neben den Problemen der Entnazifizierungtrotz der abschlägigen internen Statements durch USACA-Militärdienststellen -, gegenüber dem State Department erstmals auch die Frage einer möglichen Gefahr des Wiederauflebens des Nationalsozialismus in Österreich thematisiert wurde. So übermittelte das Büro des „Political Advisor USFA“ im März I947 das Memorandum eines österreichischen Universitätsprofessors mit dem Titel „Nationalsozialismus in Österreich“2184 an das USState Department. Der Autor, der es vorzog, anonym zu bleiben, dem US-Gesandten aber als „authority with representative views on the subject“ bekannt war, setzte sich darin ausführlich und mit politisch-strategisch interessanten Argumenten damit auseinander, wie der diagnostizierten, als real angesehenen Gefahr eines Wiederauflebens des Nationalsozialismus begegnet werden könne. Neben externen Gefahrenmomenten wie der Infiltration des nach wie vor existierenden deutsch-nationalen, „pangermanischen“ Gedankengutes im Zusammenhang eines wieder erstarkenden, einheitlichen Deutschland, sah der Autor die eigentliche Gefahr jedoch in der inneren Situation Österreichs, wobei die Pointe in der expliziten, aber nicht weiter begründeten Schuldzuweisung gegenüber den Sowjets liegt:

"Nobody should entertain any too great optimism and ignore the internal national socialist danger in Austria. It should be openly admitted that such a danger exists. [...] The reason why this danger exists must be sought in the political development of the two years after the war. They are the result of tactical blunders which were made. The principal tactical error is the fundamental

2183 John W. Taylor, Chief of Branch, to IA \&C Div., Report on Denazification of Universities in US Zone by Policy Enforcement Br., CAD, OMGUS, 22. Jänner 1947. NARA II, RG 260, OMGUS, ERA, Box 58, 2.

2184 Recordings of the U.S. Department of State relating to the Internal Affairs of Austria 1945-1954 (Mikrofilm-Bestand Institut für Zeitgeschichte der Universität Wien), Decimal File, Reel 2, James Orr Denby, Counselor of Legation, Headquarters United States Forces in Austria, Office of the Political Aviso, American Legation/Vienna, „National Sozialist in Austria“, 6. März 1947, „Dangers of a Return of National Socialism in Austria and How to Overcome Them, 1. 
question at issue of whether Austria is to be regarded as a liberated or occupied country; a question which is to this very day not been clearly answered by all allied powers, particularly not by Russia. This is the root of all other evils.

If no clear decision is passed about this principal problem, national socialist elements in Austria will be able to point out that they were right in saying that no difference is made between Austria and Germany [...]. If Austria is no liberated country then it can be treated as an enemy country. This view is held by the Russian element, in spite of all the propagandistic promises made before the military occupation of Austria. [...] This fundamental evil contributes largely to the fact that national socialism in Austria has not yet been overcome. The Soviet element is mainly guilty for this. If the Soviets no longer were in this country, it might well be said that national socialism in Austria had already been overcome, at any rate in spiritual and political respects." ${ }^{2185}$ [Hervorhebungen d. Verf.]

Als conditio sine qua non für die nachhaltige geistige Überwindung nationalsozialistischen Gedankengutes in Österreich nannte der Autor gegenüber den Vertretern der amerikanischen Besatzungsmacht - in kurioser Umkehrung der Position insbesondere sowjetischer Stellen ${ }^{2186}$ - unumwunden die Unabhängigkeit Österreichs:

"A essential preliminary condition for the establishment of an atmosphere conducive to the absorption of national socialism is the establishment, or rather the re-establishment of an independent, politically and economically viable Austria." ${ }^{2187}$

Hinsichtlich konkreter Maßnahmen sprach sich der Autor des Memorandums - der offensichtlich keinen Zweifel daran hegte, dass die bloße Eliminierung von Nationalsozialisten aus dem öffentlichen Leben keineswegs bedeute, dass der Nationalsozialismus als totalitäre Ideologie gesellschaftlich überwunden wäre - für wohldurchdachte und gut organisierte Erziehungsprojekte insbesondere für die Jugend aus - ähnlich, wie das dann auch bald von den US-Militärstellen gesehen und implementiert wurde:

"Such an educational project would necessitate system, perseverance, patience, and above all tact and love. It is essential, therefore, that ideas must be uprooted which were implanted in

2185 Ebd., 3.

2186 Die kommunistische Kritik der schleppenden Entnazifizierung, die sich erfolgreich als „Austria’s formost advocate of denazification" etabliert habe - wurde auch in US-Dossiers im Hinblick auf einen Staatsvertrag mit Österreich problematisiert: „In connection with a State Treaty, Russian criticism of insufficient denazification must be considered." Recordings of the U.S. Department of State relating to the Internal Affairs of Austria 1945-1954 (Mikrofilm-Bestand Institut für Zeitgeschichte der Universität Wien), Decimal File, Reel 1, John G. Erhardt, Analysis of Vienna Communist Propaganda During December, 7. Jänner 1947, $1 \mathrm{f}$.

2187 Ebd., 4. 
the souls of young people throughout years by national socialism. This poison must be attacked stubbornly by a spiritual therapy. It will be a slow and organic process." 2188 [Hervorhebung d. Verf.]

Die hier ausführlich zitierte, an den Secretary of State, George C. Marshall, vertraulich weitergeleitete Analyse eines österreichischen Gelehrten, bediente sich einer Argumentation, die den pragmatischen, zunehmend auf Einflusssphärenpolitik orientierten amerikanischen Interessen auch in geostrategischer Hinsicht durchaus entgegen kam.

Ihrem politischen Grundgehalt nach war die Argumentation zwar klar von demokratischem Geist geprägt, in ihrem überzogenen antisowjetischen Ressentiment ${ }^{2189}$ spielte sie aber bereits auf der rhetorischen Klaviatur des Kalten Krieges, um so österreichische Ziele - vorrangig die Wiedererlangung der staatlichen Souveränität - zu fördern; eine wohl ebenso verdrehte wie weit verbreitete Haltung, auch um den Preis, dass eine schonungslose Thematisierung der von den Sowjets teilweise zu Recht angeprangerten Missstände im Bereich der Entnazifizierung künftig nur mehr unter der Verdächtigung kommunistischer Ideologie möglich war.

Wie überaus real das Überdauern reaktionären Gedankengutes in den Köpfen österreichischer Universitätsprofessoren jener Zeit mitunter war, und mit welcher Selbstverständlichkeit bereits zwei Jahre nach Kriegsende der Nationalsozialismus öffentlich verharmlost werden konnte, ohne Sanktionen nach sich zu ziehen, davon zeugt unter anderem das Fallbeispiel des Theologen Gustav Entz. ${ }^{2190}$

Gustav Entz, Dekan der Evangelisch-theologischen Fakultät der Universität Wien vor 1938 und auch während der NS-Zeit, seines Zeichens NSDAP-Parteianwärter und überzeugter Nationalsozialist, ${ }^{2191}$ befand sich 1946 bereits wieder als Dekan in Amt und

2188 Ebd., 5.

2189 Der hier vorgetragene Rösselsprung, wonach die besatzungspolitische Präsenz der Sowjets am Fortleben des Nationalsozialismus in Österreich schuld wäre, bedient sich freilich unterschwellig, und das erscheint an der Argumentation als besonders fatal, nationalsozialistischer Stereotype, wonach der Bolschewismus quasi als Ursache für den nationalsozialistischen ,Abwehrkampf anzusehen sei. Eine „logische“ Analyse des kuriosen Rösselsprungs ließe sich so lesen: Dadurch, dass die Sowjets das befreite Österreich ex post als Feindesland behandelten (sofern der Fall), das Österreich aber gar nie war, kann in Österreich fortleben, was vorher gar nicht existiert hat.

2190 Gustav Entz (1884-1957), bis 1922 Pfarrer der Gemeinde Wien; ab 1922 Ordinarius für Praktische Theologie an der Universität Wien, wo er 1938 Dekan wurde. Entz war Gegner des „christlichen Ständestaats“ und glühender Anhänger des Nationalsozialismus. 1939 wurde er Mitarbeiter am „Institut zur Erforschung und Beseitigung des jüdischen Einflusses auf das deutsche kirchliche Leben“. Seinem Antrag auf Mitgliedschaft in der NSDAP wurde angeblich wegen früherer Zugehörigkeit zu einer Freimaurerloge nicht gefolgt. Siehe: http://de.wikipedia.org/wiki/Gustav_Entz [Zugriff 21.2.2008]

2191 In einem Brief gegenüber dem Gauleiterstellvertreter von Wien, SS-Oberführer Scharizer, vom Mai 1940, worin er neuerlich auf Aufnahme in die NSDAP drängte, stellte sich Entz diesem gegenüber als ein schon in der „Verfolgungszeit“ „anerkannter treuer Kämpfer“ dar. DÖW-Mikrofilm. Zit. nach: Weinert, Entnazifizierung der Hochschulen, a.a.O., 266. 
Würden. Als solcher richtete er angesichts der jüngsten Hochschulereignisse und der neuerlichen Säuberungen im Universitätsbereich ein „freimütiges Wort“ zur Frage der Entnazifizierung bezeichnenderweise an das US-Denazifizierungskomitee der amerikanischen Besatzungsmacht. In dieser öffentlichen „Denkschrift“ erlaubte sich Entz, der „wahrhaftig nicht als Anwalt und Apologet des Nationalsozialismus“ erscheinen wollte, ,im Interesse einer wirklich gerechten Beurteilung vieler Parteigenossen und damit zugleich im Interesse der wirklichen Vernichtung des eigentlichen Nazismus auf die folgende „unleugbare Tatsache“ aufmerksam zu machen:
„Der Nationalsozialismus hat in seinen Anfängen eine Gestalt gezeigt, die seine spätere ka- tastrophale Entwicklung noch nicht erkennen ließ. Ja, Hitler selbst hat ursprünglich Ideen proklamiert und in sein offizielles Programm aufgenommen, die das strikte Gegenteil von dem waren, was er und die Partei später schamlos praktizierten. “2192

Sein geradezu dreister Versuch einer Rehabilitierung der „ursprünglichen“ nationalsozialistischen Idee - quasi gegen Hitler und dessen Politik selbst - und damit auch aller Nationalsozialisten, ist hier nicht näher zu erörtern. Dass öffentliche Einschätzungen wie die nachfolgend zitierte von österreichischen Universitätsprofessoren zwei Jahre nach Kriegsende überhaupt möglich waren und noch dazu auf eine atmosphärisch positive bis wohlwollende Aufnahme hoffen durften, wirft allerdings ein doch recht bezeichnendes Licht auf die Inhomogenität des demokratischen Neubeginns innerhalb der akademischen Elite des Landes:
„Zusammenfassend wird man sagen müssen, dass die überwiegende Zahl der Parteianwärter und Parteigenossen ihren Anschluß an die Partei nicht aus verwerflichen, sondern aus durch- aus verständlichen, ja vielfach aus ehrenhaften Gründen vollzogen haben.“2193

Das zitierte Pamphlet führte zu einer Diskussion im „Education Directorate“ der Alliierten Kommission, die durch heftige Anfragen seitens der französischen und russischen Vertreter ausgelöst wurde. Die überaus ungehalten formulierte Stellungnahme des USVertreters Major Ray machte allerdings unmissverständlich klar, dass man sich mit dieser Angelegenheit nicht weiter befassen wollte:

"[...] the fact that the pamphlet had been addressed to the U.S. Element was immaterial: it could have been addressed just as well to the Chancellor or the Pope. U.S. Internal Affairs were not entiteld to act unilaterally and had already brought the subject up at Internal Affairs Direc-

\footnotetext{
2192 Gustav Entz, Denkschrift über das Problem der Entnazifizierung. Gerichtet an die Internal affairs Division USACA, Section De-Nazification, Wien 27. November 1946, 1 [Kopie im Besitz des Verfassers]. 2193 Ebd., 3.
} 
torate. The incident was therefore, as far as Education Directorate was concerned closed." 2194 [Hervorhebung d. Verf.]

Dieser Auffassung schloss sich im Übrigen auch der britische Vertreter an, der überdies meinte, dass es besser sei, in dieser Angelegenheit noch weitere, aussagekräftige Informationen einzuholen: „He thought it would be better to collect more evidence than was yet available before making any detailed criticism. “2195 Und so verlief die Affäre schließlich im Sand.

Die Hochschulkrawalle und die öffentliche Berichterstattung über die Universitäten als „Brutstätten des Faschismus“ drangen jedenfalls sowohl ins State Department als auch ins War Department sowie deren Civil Affairs Division (CAD) nach Washington. Insbesondere das State Department („Division of Research in Europe“) zeigte sich besorgt über die Vorfälle in Österreich und zog bereits in einem vertraulichen Bericht vom ro. Dezember I946 den Erfolg der US-Reorientierungs-Bemühungen an österreichischen Universitäten stark in Zweifel:

"There is little evidence of a positive program of reorienting Austrian Universities along democratic lines. Student body and faculty alike dominated by groups traditionally affiliated with upper-class, right wing interest, and traditionally hostile to democratic reorganization of higher education." 2196

Das War Department bat daraufhin das USFA-Headquarter um einen Kommentar zum Report, wobei das USFA-Headquarter den Bericht allerdings noch gar nicht in Händen hatte und erst beim State Department anfordern musste.

Nachdem der Leiter der Civil Affairs Division im State Department, Generalmajor Daniel Noce, am 29. Jänner 1947 den Acting Chief der Division of Research for Europe, H. Stuart Hughes, angewiesen hatte, besagten Bericht („Reactionary tendencies among Viennese university students“) umgehend an den kommandierenden General der „U.S. Forces Austria“ zu senden, stand die USFA-Education Division nun unter Zugzwang beziehungsweise unter dringendem Erklärungsbedarf. ${ }^{2197}$

2194 NARA II, RG 260, EDU-DIV, Box 2/Folder 58. Allied Commission for Austria. Education Directorate (ACA/ER/14/12a), Education Directorate. Meeting of Working Party on Universities, 9th June $1947,2$.

2195 Ebd., 3.

2196 Chief, Civil Affairs Division, War Department Washington: „Reorientation of Austrian Universities“, 9 April 1947, 1. NARA II, RG 165, Box 322.

2197 The U.S. Occupation of Germany: Educational Reform 1945-1949, Microfilm-Collection Congressional Information Service, edited by Gary H. Tsuchimochi, Tokyo 1991 (Bestand Institut für Zeitgeschichte der Universität Wien, Bibliothek), 2-A-166, WDSCA/71680, Major General, Chief Civil Affairs Division, Daniel Noce to H. Stuart H. Hughes, Acting Chief, Division of Research for Europe, Department of State, 29 January 1947, 11. 
Die Antwort des War Department an die Reorientation Branch, die zwar formell direkt vom Oberkommando der US-Streitkräfte in Österreich gezeichnet wurde, aber ganz klar von der Education Division formuliert worden war, ${ }^{2198}$ ließ allerdings keinen Zweifel daran, dass man die Kritik der zivilen Stellen in Washington für unangebracht hielt, weil sie zu weiten Teilen auf unzureichenden Informationen beruhen würde.

Interessant dabei ist, dass auf den erhobenen Vorwurf des State Department, dass die Entnazifizierung an Österreichs Universitäten offenbar noch nicht weit fortgeschritten sei, nur ausweichend Bezug genommen und in der Beantwortung nur auf nebensächliche Details des Reports eingegangen wurde. So wurde zum Beispiel die im Bericht des State Department aufgeworfene Frage, ob die soziale Zusammensetzung der österreichischen Studentenschaft sowie der Fakultätsmitglieder positive demokratische Überzeugungen beziehungsweise „positive guidance and reorientation along democratic lines“ verhindere, mit einem seltsam holprigen Argument zur nicht-sozialen Selektionsfunktion der österreichischen Mittelschulen beantwortet:

"In Austria, as in every European country, admission to institution of higher education is rigidly selective and based on a rigidly selective middle school. Of itself, this is an intellectual barrier, not a class barrier." ${ }^{2199}$

Hinsichtlich der von der zivilen Reorientation-Branch geforderten Anstellung neuer, demokratisch orientierter Lehrkräfte an den österreichischen Hochschulen wurde lakonisch angemerkt, dass es sich dabei um ein Langzeitprogramm handle, das mehrere Jahre in Anspruch nehmen würde. Schließlich: „University faculty members are not made overnight. There is no available source from which a supply can be secured at a moments notice. ${ }^{\text {22200 }} \mathrm{Zudem}$ wäre man ohnedies bereits seit längerem darum bemüht, „to persuade liberal Austrian professors who fled from the threat of Dollfuß-Schuschnigg or Nazi persecution to return to their University positions. “2201 Einziges Hindernis stelle hierbei die ökonomische Situation dar, die es Österreich unmöglich mache, am „Weltmarkt“ für Professoren zu konkurrieren.

Diese Antwort der US-Reorientierungs-Verantwortlichen in Österreich liest sich seltsam austrifiziert, wobei neben dem unterschwelligen Exkulpationsgestus und der offenkundigen Schönung der Realsituation auch grobe Widersprüche in der eigenen Darstellung in Kauf genommen wurden. So gestand die Entgegnung des US-Headquarters - nicht

2198 So wurde darin unter anderem dezidiert auf den bereits am 24. März 1947 an WARCAD gesandten Bericht der Education Division „Synopsis of Post-war Education in Austria“ als Informationsgrundlage verwiesen.

2199 Lt. Col. B.W. Saurel, Acting Adjutant General, Headquarters United States Forces in Austria, APO 777, to Chief, Civil Affairs Division, War Department Washington: „Reorientation of Austrian Universities“, 9 April 1947, 1. NARA II, RG 165, Box 322, 1.

2200 Ebd.

2201 Ebd., 2. 
zuletzt wohl auf Grund der dem U.S. Department of State längst vorliegenden Entnazifizierungsberichte -, zu, dass in der unmittelbaren Anfangszeit der Besatzung bis Februar I946 „very little positive progress had been made in denazification“, und nennenswerter Fortschritt erst mit den jüngsten ,Säuberungen“ („recent purge of university faculty and students“) erzielt worden sei.

Ein Indikator dafür, wie unzureichend die US-Entnazifizierung in Österreich tatsächlich verlaufen ist, zeigt sich in der ungeheuren Frustration des zuständigen Chefs der amerikanischen $\mathrm{G}_{2}$-Entnazifizierungs-Sektion in Österreich, Joseph Zaring, der angesichts der offenkundigen Bedeutungslosigkeit seiner Sektion - zahlreiche Entscheidungen in der US-Entnazifizierungspolitik wurden unter völliger Umgehung seiner Stelle getroffen - im Juni 1948 um seine Entlassung ansuchte. Wie Kurt Tweraser dargelegt hat, wollte Zaring „nicht länger zu der Illusion beitragen, daß das Entnazifizierungsprogramm erfolgreich abgeschlossen sei.“2202

In der Entgegnung des USFA-Headquarters sah man sich indes bemüßigt, in argumentativ verschwommener Weise auf den durchschlagenden „wissenschaftlichen“ und „inhaltlichen“ Demokratisierungserfolg der US-Reorientierungs-Maßnahmen hinzuweisen, der sogar - und das verdient hervorgehoben zu werden - bereits unmittelbar mit der Befreiung durch die Besatzungsmächte eingetreten sei:

\begin{abstract}
"University reorganization is commonly understood to mean change in the objectives, the program or the administration of the institution. The central objective of a modern university is 'objective scholarship'. Austrian institutions of higher education were quick to seize the opportunity to repudiate Nazi interference with scholarship. In this important aspect of democratic education the reorientation of Austrian universities became complete almost as soon as the liberation had occured." 203 [Hervorhebung d. Verf.]
\end{abstract}

Das stand nun ganz im Gegensatz sowohl zu traditionell amerikanischen Bildungskonzeptionen als auch zu den vergleichbaren Forschungsergebnissen moderner Sozialpsychologie im Zusammenhang der Reeducation. So verwies etwa Charlotte Bühler, die sich seit langem wissenschaftlich mit Fragen der Re-education befasst hatte, in einem Brief an den OMGUS-Leiter der „Education and Religious Affairs Division“ [mit gemeinsamen Briefkopf ihres Mannes] auf ihre jüngsten Forschungsergebnisse:

"It was a very happy moment when I found out that you are in charge of the German re-education program. For a long time I had been trying to inform myself on the matter of German

2202 Tweraser, US-Militärregierung in Oberösterreich. Bd. 1., a.a.O., 230.

2203 Lt. Col. B.W. Saurel, Acting Adjutant General, Headquarters United States Forces in Austria, APO 777, to Chief, Civil Affairs Division, War Department Washington: „Reorientation of Austrian Universities“, 9 April 1947, 1. NARA II, RG 165, Box 322, 3. 
re-education, and to hear that this serious matter is in your hands makes me hopeful for the future. Ever since the defeat of the Nazis seemed close, and we began to think about a possible re-education of Germany, I have worked on this problem. [...] I have not yet published a longer study in which I have used all my European material. In this study, I compared the attitudes of parents in England, Norway, Holland, Germany, Austria and the United States, as to the general problems of life connected with up-bringing and education. This study led to two interesting conclusions regarding German (not only Nazi) stubborn adberence to tradition, to intuitive, subjective thinking, and their greater inaccessibility to being enlightened by psychology. I came to the conclusion that only in starting with democratic nursery and demonstrating to the parents the favorable effects of a tolerant educational system, could we achieve anything effective." 2204 [Hervorhebung d. Verf.]

Ohne hier nun weiter auf die geradezu sinnwidrige und die Fakten vollständig ignorierende Argumentation des Antwortschreibens der USFA-Education Division näher eingehen zu wollen - die Verantwortlichen verteidigten hier klar und um jeden Preis die österreichischen Verhältnisse -, dokumentiert sich darin einerseits das Fortbestehen von Divergenzen und Spannungen zwischen State Department und War Department, die bereits in der Österreichplanung ab 1944 aufgetaucht waren, und sich auch in der Besatzungszeit zwischen USACA und State Department fortsetzten. Andererseits existierten seit Beginn der amerikanischen Österreich-Planung Divergenzen beziehungsweise Misstrauen innerhalb der USFA, und zwar zwischen den „rein“ militärischen Stellen und den zivilen „Experten“ innerhalb der USACA/Wien.

In einer Überblicksdarstellung der USACA-Divisionen I944-45 wurden diese Konflikte klar und ohne Umschweife benannt:

"There was a general impression among the people who were working behind the lines in military headquarters that the personnel who had been placed in the Group Council for planning purposes were culls-misfits from the war. This caused a considerable amount of dissension, hard feeling, and mistrust. Justifiably or not, that feeling has never been wholy overcome to this day." 2205

Aus Sicht der Militärs handelte es sich beim zivilen Personal der USACA in Wien lediglich um „supposed experts“, die Vorbehalte gegen eine intelligente Diskussion mit den Militärs über Sachfragen zu Ökonomie, Land- oder Forstwirtschaft gezeigt hätten; einige dieser zivilen Fachleute im Dienst der US-Armee hätten jedoch nur wenig Erfahrungen in ihren Be-

2204 NARA II, RG 60, OMGUS ECR, Box 21, Karl und Charlotte Bühler to Thomas Alexander OMGUS, Box 17, January 17, 1948, 1.

2205 United States Allied Commission for Austria History. Part II. V-E Day to End of 1945, USACA Appendix „B“, 1944-45, 35. USACA History File, NARA II, RG 260, Box 31/253. 
reichen mitgebracht und seien zum Teil lediglich Soldaten mit wenig ziviler Berufserfahrung gewesen: "The Chief of Staff of United States Forces in Austria was allegedly conscious of the inefficiency of many United States Allied Commission for Austria employees. “2206 „Experts' were made overnight “2207 heißt es dazu in besagtem Bericht. Bemängelt wurde darin auch der Informationsfluss, da es manchmal eineinhalb Monate dauerte, bis eine telegrafierte Mitteilung des War Department überhaupt beantwortet wurde, obwohl unablässig Berichte eingefordert worden seien. Selbst die simple Inventarführung von Berichten, Rechnungen und beschlagnahmten Gegenständen lief aus Sicht der Militärs völlig aus dem Ruder:

"Civilian Supply Branch lost track of what had been issued. Finally an inventory had to be taken of the stocks in warehouses in Vienna. It was found that of the amount supossedly on hand, from the incomplete records existing, three-fourth had disappeared."2208

Nach Vorfällen in Salzburg im Juli I945 wurde der Aktionsradius von USACA schließlich auf Wien reduziert: „In Salzburg, six weeks after our entrance, newspaper reporters complained about the condition of the Jews still not removed from concentration camps. The Chief of Staff insisted on correction - nothing was done for weeks. The Chief of Staff finally took away from United States Allied Commission for Austria any administration in the Zones, and allowed them only policy-making in Vienna." ${ }^{2209}$

Die Abteilungen der USACA hatten somit keinerlei direkte Jurisdiktion über das „Military Government“ und mussten ihre „Befehle“ über General Clarks Schreibtisch beziehungsweise seine Unterschrift aussenden. ${ }^{2210}$

Obwohl aus derartigen Statements sicher keine voreiligen Schlüsse zu ziehen und Generalisierungen unangebracht sind, lässt die Darstellung der USACA-History Section doch den Schluss zu, dass es im Bereich einzelner US-Besatzungsorgane von Anfang an Probleme zwischen den eingesetzten zivilen Experten und den Militärs gab.

In einem vertraulichen Bericht des Leiters der „Reorientation Branch“ innerhalb der Civil Affairs Division ${ }^{2211}$ des War Department, Oberstleutnant Robert B. McRae, an den Assistent Secretary of State vom Februar 1947 wurde angesichts der bisherigen Arbeit der Education Division, die vom State Department überaus kritisch betrachtet wurde - „the

2206 Ebd., 37.

2207 Ebd., 36.

2208 Ebd., 36.

2209 Ebd., 36.

2210 Ebd., 39.

2211 Die mit 1. Juli 1946 im Pentagon eingerichtete „Reorientation Branch“ (CAD) war auch mit der Reorientation für Österreich befasst und gliederte sich in vier Abteilungen: die Presseabteilung, die Film- und Theaterabteilung, die Special Projects Section (Urheberrechtsangelegenheiten etc.) und die Abteilung für Erziehungs- und Kirchenfragen unter Leitung von Edward F. D’Arms. Vgl. Bungenstab, Umerziehung zur Demokratie, a.a.O., 65. 
Education Division does not appear to have made substantial progress“2212 -, Überlegungen angestellt, diese Abteilung, die inzwischen nur mehr aus fünf Stabsmitgliedern bestand, aufzulösen beziehungsweise besser auszustatten und als separate Abteilung der Information Service Branch (ISB) zuzuteilen, ,whose position in the USFA T/O is compatible with the importance of overall reorientation job":

"While amalgamation would not correct the shortage of staff, it would bring education within the field of a competent administrative staff [...]. If amalgamated, I would recommend that the Education Division staff be increased with very able personnel recruited from the United States. Such additions might be the provision of personnel on the Vienna staff for Adult Education, for Teacher Education and for Youth activities [...]. I would recommend that those five to seven personnal include necessary high-ranking U.S. educators to assist and encourage the Austrians in higher education, elementary and secondary education, vocational education, youth activities, adult education and teacher's education."2213 [Hervorhebung d. Verf.]

$\mathrm{Zu}$ der hier vorgeschlagenen Auflösung der Education Division kam es allerdings vorerst nicht; erst nach einer Trendwende in der allgemeinen US-Reorientierungs-Politik, die I948 einsetzte und zu weiten Teilen auf zivilen Diskussionen aus der Zeit vor Kriegsende basierte, wurden deren Agenden im Spätherbst 1950 schließlich dem Department of State übertragen, das künftig die zentrale Leitung aller Reorientierungs-Maßnahmen übernahm.

Dass die leitenden Offiziere der US-Education Division - wie erwähnt allesamt Wissenschafter und, abgesehen von William B. Featherstone, kaum eingearbeitet in die Reeducation- beziehungsweise Reorientierungs-Überlegungen - in der Art und Weise ihres Umganges mit ihren österreichischen „Kollegen“ rasch einen eigenwillig austrifizierten Kurs der freundlichen Nichteinmischung einschlugen, in erster Linie kollegial-amikale Unterstützung anboten und dabei existierende militärische oder zivile Planungsdirektiven tendenziell als obsolet ansahen, scheint offensichtlich zu sein. Bestätigt findet sich das indirekt auch durch eine Aussage Samuel H. Williams in einem behördeninternen Papier, die deutlich macht, worin die Arbeit der US-Education Division im Kontext der Alliierten Kommission aus Sicht des US-Offiziers letztlich bestand beziehungsweise wozu sie sich machen ließ:

"Its Quadripartite functions [d. Education Division, d. Verf.], which have been concerned chiefly with textbook production, curricula reconstruction and supervision, denazification on teaching personnel, the denazification of the Allied Control Agreement, have largely degenerated into

2212 NARA II, RG 59, State Department - Records of the Assistant Secretary of State for Occupied Areas 1946-1949, Austrian Report by Lt. Col. R(obert) B. McRae, February 1947, 2.

2213 Ebd., 3. 
a defense of the Austrian Ministry of Education against vicious and unfair unilateral attacks."2214 [Hervorheb. d. Verf.]

Ein interessantes Detail am Rande stellt in diesem Zusammenhang die Tatsache dar, dass die guten gegenseitigen Kontakte zuweilen auch der Realisierung eigener wissenschaftlichen Projekte dienten, die während der Besatzungszeit fertiggestellt wurden, was auf entsprechende Zeitressourcen schließen lässt. ${ }^{2215}$

Wohl ohne jede strategische Absicht nahmen die Offiziere der Education Division mit dieser Form praktizierter materialer Unterstützung und freundschaftlich-kollegialen Austausches jedoch vorweg, was US-Geheimdienststellen bald als Königsweg im „Crusade of Ideas“ beziehungsweise im „Struggle for Austrian Minds“ ansahen, nämlich die nachhaltige ideologische Überzeugungskraft materialer und systemisch-technischer Überlegenheit sowie die - zunächst - zurückhaltende Propagierung des „American way of life“.

2214 NARA II, RG 260, EDU-DIV, Box 5 /Folder 12 (7/18/5/5/3-4), Samuel H. Williams, Chief Education Division, „Austrian and American Education“, 10. März 1948, 9.

2215 So publizierte Samuel H. Williams während seiner Zeit als Leiter der USFA-Education Division (19471950) in Wien eine Studie, die in englischer Fassung im Verlag Jugend \& Volk erschien. Auch wenn die Studie, wie aus dem Vorwort hervorgeht, bereits im Juni 1947 fertig gestellt worden ist, bedeutete die Drucklegung aus primär wissenschaftlichem Interesse sicherlich einen gewissen Arbeitsaufwand. Die Publikation beschäftigte sich mit dem Voodoo-Kult in Westindien, war aber zur ausschließlichen Verwendung durch den Autor hergestellt worden und erschien nicht im Buchhandel. Vgl. Samuel H. Williams, Voodoo Roads, Wien 1949. [Kopie im Besitz des Verfassers]. 



\title{
5. US-Reorientierungs-Planungen im Frühen Kalten Krieg: Zwischen Popularisierung des „American Way of Life“ und Psychologischer Kriegsführung, 1947-1950
}

\author{
LONGE RANGE POLICY I946/47 - PARADIGMENWECHSEL: LANGFRISTIGE ZIVILE \\ REORIENTIERUNGS-KONZEPTE ANSTELLE MILITÄRISCHER KONTROLLE
}

\author{
"Reeducation is a slow process of reorientation of society \\ providing the means of education rather than education itself."2216 \\ Isaac L. kandel/Walter Maria Kotschnig [1943]
}

\begin{abstract}
"Our national history has proved the value of community cooperation in exchanging knowledge and ideas. The American conquest of the frontier was a cooperative undertaking of a people of many religions, races, and national origins who exchanged knowledge and ideas freely and voluntarily." 2217 U.S. Advisory Commission on the Educational Exchange [1949]
\end{abstract}

Die in der zivilen US-Bildungsreform-Diskussion nach I94I oft wiederholte Gleichsetzung von Demokratie und amerikanischem Wirtschaftssystem taucht, wenn zunächst auch etwas abgeschwächt, in ähnlicher Form in den zivilen Reeducation-Konzepten der Nachkriegszeit auf. Wie schon zuvor, war das modellhafte Vorbild für die friedensichernde Rekulturalisierung des post-totalitären Europa an die demokratischen Maßstäbe der ,freien Welt' auch jetzt keine abstrakte Variable, sondern die gesellschafts- und wirtschaftspolitische Realverfassung Amerikas mit seinem weltanschaulich-ideologischen Überbau.

Die Übernahme der zivilen Demokratisierungs-Konzepte in die konkrete Aufgabenplanung der militärischen Besatzungsapparate erfolgte durch die damit einschlägig befassten Militärgremien während der letzten beiden Kriegsjahre jedoch höchstens in Ansätzen; dies nicht zuletzt wohl auch deshalb, weil es, wie bereits dargestellt, neben Kompetenzkonflikten zwischen State Department und War Department auch Unübersichtlichkeit und Wirrwarr in den US-Planungsgremien für die künftigen Militäradministrationen in den zu besetzenden Gebieten gab. ${ }^{2218}$

So war auch die „Austria Planning Unit“vor allem mit Aufgaben der künftigen Militäradministration befasst gewesen; dabei reduzierten sich die Planungsgrundlagen zur „pri-

2216 Kandel/Kotschnig, The Messianic Complex, a.a.O., 157.

2217 Trading Ideas with the World. International Educational and Technical Exchange. Report of the United States Advisory Commission on the Educational Exchange, 31. März 1949, 1.

2218 Vgl. John L. Gaddis, The United States and the Origins of Cold War, 1941-1947, New York 2000, $97 \mathrm{ff}$. 
mary Mission“ der alliierten Besatzung formal darauf, analog zu den Planungen innerhalb der „European Advisory Commission“ (EAC) den Weg zur Umsetzung des in der Moskauer Deklaration festgelegten Zieles zu ebnen: der Wiederherstellung eines freien und unabhängigen Österreich. ${ }^{2219}$ Der Fokus der Handlungsrichtlinien innerhalb der Direktiven für die US-Militärregierung in Österreich, die durch die Potsdamer Konferenz im Juli/August 1945 nochmals bestärkt wurden, lag daher primär auf personellen und materialen ,Säuberungsmaßnahmen', auf deren Supervision und auf der anschließend durchzuführenden Wiederöffnung der Bildungs- und Kultureinrichtungen auf der Basis materieller Hilfeleistungen.

Inhaltlich-konzeptuelle Überlegungen im Hinblick auf koordinierte und längerfristige Strukturmaßnahmen zum Zweck einer nachhaltigen demokratischen Reorientierung wurden im „Military Handbook Austria“ ebenso wenig formuliert wie die Wörter „Reeducation“ oder „Reorientation“, die darin nicht zu finden sind.

Dessen ungeachtet hatten aber weder das Department of State noch die zivilgesellschaftlichen, mit Reeducation- beziehungsweise Reorientierungs-Fragen beschäftigten amerikanischen Institutionen und Gremien die noch während der Kriegsjahre angestellten Überlegungen für eine dauerhafte Friedensicherung - auch ein zentrales Motiv für die Gründung der Vereinten Nationen -, aus den Augen verloren. ${ }^{220}$

Die inhaltliche Verkürzung der besatzungspolitischen Agenden auf primär (punitive) Formal-Maßnahmen im Zusammenhang mit Entnazifizierung und Entmilitarisierung die punktuelle, jedoch vergleichsweise unkoordinierte Reeducation-Aktivitäten wie beispielsweise Filmvorführungen miteinschlossen ${ }^{2221}$ - zog jedoch zunehmend Kritik des Sta-

2219 Im Originalwortlaut liest sich die US-Mission folgendermaßen: „The primary mission of Allied Military Government in Austria is to prepare the way for implementing the Moscow Conference,Declaration of Austria‘ [...]“. In: Handbook for Military Government in Austria, April 1945, a.a. O., Chapter I, 1.

2220 Hinsichtlich der zivilen Reeducation-Aktivitäten im US-Privatsektor heißt es etwa in einem Bericht des „Instituts on Re-Education of the Axis Countries“, auf den nachfolgend noch kurz einzugehen sein wird: „Since the fall of 1944, we, educators and friends of education from many of the United Nations, have been holding meetings at New York University as an Institute on the Re-Education of the AxisCountries to study and formulate constructive proposals concerning the problems of re-constructing education in the conquered Axis countries." NARA II, RG 260, OMGUS - ECR, Box 89. Institute on Re-Education of the Axis Countries. Report on the Re-education of Germany. Presented by the SubCommittee (T.C. Pollock, R. Schairer; F.M. Crowley, F.W. Foerster, J.K. Folsom, S.L. Hamilton, E. Hanke), 15. Juni 1945, 1.

2221 In der unmittelbaren Nachkriegsphase sollten Filme mit „punitivem Tenor“ die Besatzungsherrschaft legitimieren helfen. So wurden zu Reeducation-Zwecken, jedoch weitgehend ohne äußeren Zwang, der Bevölkerung beispielweise in der Urania 1945/46 der unter Leitung von Billy Wilder von OMGUS produzierte Film „Die Todesmühlen“, der während des Nürnberger Prozesses gezeigt wurde (April 1946 wurden 65 Kopien für die Vorführung in Österreich freigegeben) oder der französische KZ-Film „Les Camps de la Mort“ („Lager des Grauens“, Uraufführung im Haydn Kino am 16.11.1945) gezeigt, welche die von Deutschen begangenen Gräueltaten in den Konzentrations- und Vernichtungslagern darstellten. Siehe: Michaela Anderle, Todesmühlen in Wien. Auf den Spuren eines Films im Dienste der 
te Department ${ }^{2222}$ sowie der amerikanischen Öffentlichkeit nach sich. Die Maßnahmen der US-Besatzungsmacht und die Aktivitäten der anderen Alliierten hatten sich in den ersten beiden Jahren der Besatzungszeit in Österreich auf Supervision der Schuleinrichtungen sowie auf die Kontrolle der Medien (Presse, Rundfunk) oder der Verlage beschränkt und dabei grosso modo nur weiche Propaganda betrieben, wobei weder Entnazifizierungs- noch Reorientierung-Maßnahmen als Agenden der US-Militärverwaltung explizit hervorgehoben wurden: so findet sich darauf etwa auf den US-Plakaten kein Hinweis. ${ }^{2223}$

In jener Phase blieb es Ausnahmepolitikern wie beispielsweise Viktor Matejka ${ }^{224}$ vorbehalten, bei der öffentlichen Aufführung von Dokumentarfilmen über nationalsozialistische Konzentrations- und Vernichtungslager in deutlichen Worten auf den Status quo

Re-education, Dipl.-Arb., Univ. Wien 2009, $21 \mathrm{ff}$; weiters: Thomas Tode, KZ-Filme in Wiener Kinos. Überlegungen zu zwei „Atrocity-Filmen“. In: Karin Moser (Hrsg.), Besetzte Bilder. Film, Kultur und Propaganda in Österreich 1945-1955, Wien 2005, 357-373; weiters: Franz B.N. Suppan, Film und Kino in Graz von 1945 bis zum Beginn der Fünfziger Jahre. In: Friedrich Bouvier/Helfried Valentinitsch (Red.), Graz 1945 (=Historisches Jahrbuch der Stadt Graz, Bd. 25), Graz 1994, 612f.; vgl. weiters: Filmankündigungsplakat/Exponat auf der Burg Schallaburg 2005 im Rahmen der Ausstellung „,Österreich ist frei!' Der Österreichische Staatsvertrag 1955“; weiters: Brigitte J. Hahn, Dokumentarfilme im Dienste der Umerziehung. Amerikanische Filmpolitik 1945-1953. In: Heiner Roß (Hrsg.), Lernen Sie diskutieren! Re-education durch Film. Strategien der westlichen Alliierten nach 1945, Babelsberg 2005, 21; zuletzt siehe die Studie von Ulrike Weckel, die einen differenzierten und kritischen Blick auf die Rezeptions- und Wirkungsweisen jener insgesamt zehn US-„Atrocity“-Filme über die Befreiung von Konzentrations- und Vernichtungslagern wirft, mit denen die amerikanische Besatzugngsmacht die Bevölkerung in den westlichen Besatzungszonen in Deutschland konfrontierte: Ulrike Weckel, Beschämende Bilder. Deutsche Reaktionen auf alliierte Dokumentarfilme über befreite Konzentrationslager (=Transatlantische Historische Studien - Bd. 45), Stuttgart 2012. Für den Literaturhinweis danke ich meiner Kollegin Mag. Daniela Savel.

2222 Vgl. James F. Tent, Mission on the Rhine. Reeducation and Denazification in American-Occupied Germany, Chicago - London 1982, 10.

2223 Vgl. Simone Krienzer, Strategien der Propaganda im frühen Kalten Krieg. Eine Analyse ausgewählter Plakate zum European Recovery Program der USA in Österreich 1948-1952, Dipl.-Arb., Univ. Graz 2010, 99.

2224 Viktor Matejka (1901-1993), bei Ludo Moritz Hartman an der Universität Wien promovierter Historiker, Publizist und ab 1926 Wiener Volkshochschul-Dozent. Ab dem Jahr 1934 geschäftsführender Obman der Volkshochschule Volksheim Ottakring in Wien. Nach heftigten Querelen wurde der Friedensaktivist, Antifaschist und „Extremdemokrat“ vom autoritären Wiener Bürgermeister Richard Schmitz als Volkshochschulleiter enthoben. Unmittelbar nach dem „Anschluss“ 1938 wurde Matejka mit dem ersten Transport in das KZ Dachau transportiert, wo er bis 1944 inhaftiert blieb. Nach dem Krieg avancierte Matejka zum ersten - kommunistischen - Stadtrat für Kultur und Volksbildung in Wien, wo er sich bis 1949 in beispielhafter und zugleich gänzlich unorthodoxer Art und Weise für zeitgenössische Kunst und Literatur, d.i. für KünstlerInnen und LiteratInnen einsetzte. Zu Matejka siehe u.a.: „,Volksbildung mach ich wo immer ... ¿Viktor Matejka, 1901-1993“, Schwerpunktausgabe der Zeitschrift Spurensuche. Zeitschrift für Geschichte der Erwachsenenbildung und Wissenschaftspopularsierung, 16. Jg., Heft 1-4 16. Jg., 2005. 
der geistigen Erneuerung und die moralische Verantwortung angesichts der unfassbaren Gräuel zu verweisen, wie beispielsweise im Frühjahr 1946:

\begin{abstract}
„Dieses System dauerte in Deutschland seit 1933, in Österreich seit 1938. Warum konnte es so lange dauern? Weil die grosse und vor allem auch die repräsentative deutsche und österreichische Öffentlichkeit dazu geschwiegen hat. Weil sie feig und blind war. Weil sie sagte, sie wüsste nichts davon, weil sie befürchtete, bei einer entscheidenden Stellungnahme dagegen selbst ins $\mathrm{KZ}$ zu kommen. [...] Heute wird zwar zunächst ein bisschen registriert und dann wieder entregistriert. Dann wird vertuscht und gelogen. Es wird entschuldigt und entstellt. Es wird im Trüben gefischt und die Spuren werden raffiniert verwischt. Das geht aber nur eine Zeitlang. [...] Um aber zu verhindern, dass bis dorthin das Gedächtnis und das Gewissen einschläft, rufen die Filme des Grauens die bisher Unbelehrbaren schon jetzt zur Besinnung, zur Einkehr, zur Umkehr. Wer bisher noch nicht seine Schuld oder Mitschuld erkannt hat, wird es von hier ab tun. Die Wahrheit des Filmstreifens die den Weg zur unausschöpflich grausamen Wirklichkeit weist, wird zur letzten Mahnung.“2225 [Hervorhebung der Verfasser].
\end{abstract}

Die weitgehend „unpolitische“ Kontrolle der US-Militärbesatzung in der unmittelbaren Nachkriegszeit wurde ab 1946/47 von einem neuen Paradigma abgelöst, das zumindest einen langfristigen Planungshorizont der Demokratisierungs-Bemühungen aller mit dieser Problematik befassten amerikanischen Einrichtungen - ob nun ziviler oder militärischer Provenienz - zur Grundlage hatte, und Reeducation- beziehungsweise demokratische Reorientierungs-Maßnahmen in den Vordergrund rückte: die bisherige ,Säuberungspolitik' im Sinne eines - mehr oder minder verlässlichen - Austausches nur der Führungspositionen hatte demnach als Paradigma vollends ausgedient.

Bereits im Jänner 1945 hatte der militärische US-Geheimdienst OSS ein Memorandum verfasst, das OSS-Interviews mit fünf prominenten deutschen Schriftstellern - Thomas Mann, Alfred Döblin, Lion Feuchtwanger, Emil Ludwig und Bruno Frank - zur Frage „What to do with Germany“ zusammenfasste. Darin zeigten sich die Befragten in Bezug auf die Reeducation-Maßnahmen tendenziell skeptisch und vertraten den Standpunkt, dass Reeducation nur in Form einer demokratischen „Selbsterziehung“ Sinn machen würde. Feuchtwanger sah die Reeducation sogar als entbehrlich an, da die Wurzeln des „Hitlerismus“ seiner Meinung nach in der deutschen Gesellschaft nicht besonders tief verankert wären: schon eine länger dauernde militärische Präsenz würde demnach effizient genug sein, um insbesondere in der Jugend einen Einstellungswandel zu bewirken. Thomas Mann meinte, dass die demokratische Vorbildwirkung und Führung der Alliierten die wohl beste Form einer „Umerziehung“ wäre. Döblin sprach sich hingegen zwar für

2225 Viktor Matejka, Lager des Grauens. Rede gehalten anlässlich der Aufführung von Dokumentarfilmen über die Lager Dachau, Buchenwald, Belsen, Majdanek, Auschwitz etc. In: Austro American Tribune. Anti-Nazi Monthly, Vol. IV, No. 9, April 1946, 9. 
Reeducation-Aktivitäten aus, zeigte sich im Hinblick auf deren mögliche Wirkungen aber wenig hoffnungsfroh:

"Educating the Germans is almost hopeless because of the majority of the professional classes are Nazis. The spiritual forces of the Germans are in the universities and schools which are reactionary."2226

Trotz aller Vorbehalte hinsichtlich einer adäquaten, also letztlich wirksamen Durchführung von Reorientierungs-Maßnahmen häuften sich zwischen Frühjahr und Sommer 1945 Anregungen, Anfragen und zum Teil auch massive Kritik ziviler Einrichtungen oder privater Einzelpersonen gegenüber State Department und US-Kriegsministerium, die die Dringlichkeit entsprechender Maßnahmen hervorhoben und dabei mitunter deutliche Skepsis gegenüber allzu simplen methodisch-didaktischen Konzepten einer Reeducation formulierten. ${ }^{2227}$

Ein besonders interessantes Dokument stellt in diesem Zusammenhang ein vom „Institute on Re-education of the Axis Countries“ im Juni 1945 verfasster Bericht dar, an dem unter anderen auch Friedrich Wilhelm Foerster mitgearbeitet hatte. Der Report zur „Re-

2226 The U.S. Occupation of Germany: Educational Reform 1945-1949, Microfilm-Collection, a.a.O., 1-A223, a.a.O. Foreign National Groups in the United States. Memorandum to the Director of Strategic Services from the Foreign Nationalities Branch. No B-304, 18 January 1945, $4 \mathrm{f}$.

2227 Ein Beispiel unter vielen ist das engagiert ausgearbeitete Pamphlet des Lehrers William F. Sollmann (Pendle Hill, Pennsylvania) vom April 1945, das dieser unter dem Titel „Educational Reconstruction in Germany" an die Division of Central European Affairs im Department of State gerichtet hatte. Darin schrieb dieser: „The Germans have an old satirical story about an invention made centuries ago by the citizens of Nuremberg and therefore called, der Nuernberger Trichter', the Nuremberg Funnel. It was a method by which one aquired learning without any effort by teacher or pupil. The teacher simply poured knowledge through the funnel into the heads of the students and they willingly accepted it. I am sometimes reminded of that Nuernberg Funnel when I read certain plans for the re-education of the Germans. It seems that with the best intentions some people would send an army of teachers from the thirty United Nations into Germany, to occupy all schools from kindergarden to university and reshape the learning and the character of the Germans by mechanical devices prefabricated in the victorious nations. [....] We will not excuse the millions of crimes committed by masses of criminals during these years in the name of Germany. We will not minimize the heavy responsibility which Germany carries for the preparation and the outbreak of the two world wars and some earlier conflagrations. However, before we come to a final judgement we may look into certain historical facts and ask ourselves a few questions. It is true that the war lords, Frederick the Great, Bismarck, Wilhelm II, and Hitler have started furious European battles. But were these the only wars? Is it not also true that the great wars in Asia, America, and Africa were caused by non-German powers and fought by non-German war lords and conquerors? Were not empires created and expanded by blood and iron thousands of years before Germans had entered history? Is our perspective not much too shortsighted if we seek the enemies of peace only in Germany and her allies? Should we not learn a lesson from the prehistoric story in the Bible, the symbolic legend of Cain and Abel? The old Jewish writer had neither a German, nor an Italian, nor a Japanese as model. He thought of the Cains in all races, perhaps in every human soul.“ Zit. nach ebd., $3 \mathrm{ff}$. Hoover Institution Archives, Stanford University, John Doane Hartigan Papers, 1909-1958, Box 7: Military reports and career of John Doane Hartigan. 
education of Germany" strich abermals die Reorientierung der vormaligen Achsenstaaten als Aufgabe von höchster Bedeutung für die gesamte zivilisierte Welt heraus, da deren Erfolg - oder Misserfolg - direkten Einfluss auf die Aufrechterhaltung des Weltfriedens und somit auf das Leben künftiger Generationen haben würde. Angesichts der schockierenden Bilder der ersten Film-Dokumentationen über die verübten Gräuel in den nationalsozialistischen Konzentrations- und Vernichtungslagern und der bisherigen, wenig überzeugenden Verlautbarungen der US-Militärverwaltung in Deutschland, urgierte der Report die Notwendigkeit eines langfristigen, von entsprechender Expertise begleiteten Reorientierungs-Programmes der jeweiligen zonalen US-Militärregierungen:

"In the months during which we have been meeting, documentary reports concerning the
crimes and brutalities committed by the Germans, conformed anew by recent reports from
death camps and torture-chambers, have made us not only feel deep indignation and shame at
the spectacle of this extreme degeneration of human nature, but also the urgent importance of the task
of re-educating Germany. [...] Only an inflexible long-term occupation authority will be able
to lead the Germans to a fundamental revision of their recent political philosophy and practice
and to the development of new patterns which will embody the best of the former German
federalism and non-nationalistic traditions." ${ }^{2228}$ [Hervorhebung d. Verf.]

Obwohl die akademischen Experten für Reorientierungs-Fragen die Bedeutung des politischen und wirtschaftlichen Wiederaufbaues keineswegs unterschätzen ${ }^{2229}$ und die Wichtigkeit gezielter Maßnahmen der US-Militärregierung in diesen Bereichen eigens hervorhoben, monierten sie hinsichtlich der erforderlichen mentalen Umorientierung "destroying the evil roots of Nazism in the German mind and character" - doch mit Nachdruck die eminent wichtige Aufgabe eines gezielten, längerfristigen erzieherisch-bildungspolitischen Engagements:

"The problem of re-educating Germany is not that of teaching an ignorant or an untutored people. It is rather that of redirecting the energies and reforming the attitudes of a highly trained people who suffer from the effects of a perverted education. To an extraordinary degree, the problem in Germany is a problem of education. Nazism and Prussianism are not, of course, inevitable outgrowths of an innately bad German nature. [...] The German people were educated into Na-

2228 NARA II, RG 260, OMGUS - ECR, Box 89. Institute on Re-Education of the Axis Countries. Report on the Re-education of Germany. Presented by the Sub-Committee (T.C. Pollock, R. Schairer; F.M. Crowley, F.W. Foerster, J.K. Folsom, S.L. Hamilton, E. Hanke), 15. Juni 1945, 1.

2229 So schlugen die US-Bildungsexperten gerade im Hinblick auf die fatalen mentalen und psychischen Folgewirkungen der Zerstörungen einen möglichst raschen Wiederaufbau von Gebäuden, Straßen und Brücken vor, wobei insbesondere Kinder umgehend aus den devastierten Städten in ländliche Versorgungsgebiete gebracht werden sollten, um sie nicht dem unweigerlichen Chaos und der moralischen Depression der unmittelbaren Nachkriegszeit auszusetzen. Ebd., 9. 
zism. Unfortunately, the pattern of Prussian education and thought in pre-Hitler Germany prepared the German character for a too docile acceptance of Nazi teaching [...]. The problem of such a re-education is not to be solved by new textbooks alone, or by mere teaching of items of knowledge and specific skills. Nor can it be solved in a few days or years, or by casual effort. It calls for a fundamental reorientation of German attitudes towards life, codes of behavior and moral and spiritual values. It calls for a carefully developed, carefully supervised educational program which will continue until re-education has been achieved."2230 [Hervorhebung d. Verf.]

Die in dem Report unterbreiteten, zum Teil sehr detaillierten Vorschläge umfassten das gesamte Erziehungs- und Bildungswesen, angefangen vom Kindergarten über Schulen, Universitäten, Erwachsenenbildungseinrichtungen und Massenmedien, wobei ganz besonderes Augenmerk auf die Einbeziehung von Überlebenden der Konzentrationslager, von Widerstandskämpfern, nachweislichen Gegnern des NS-Regimes sowie von ideologisch unverdächtigen Emigranten gelegt wurde: „The core of the German staff which is to reconstruct and administer German education should be recruited as far as possible from men and women whom the Nazis imprisoned in Buchenwald, Dachau, and other prison and concentration camps. [...] We recommend that the fullest possible use be made [...] of any anti-Nazi members of the teaching profession, churches, or trade unions the reality of whose opposition to Nazism was evidenced by their being dismissed or persecuted for their convictions, and [...] of German exiles who have proved that they are strongly and convincingly anti-Nazi, and are not believers in the doctrine of German superiority. “2231

Im Gegenzug sollte allen Personen, die auch nur im Ansatz mit dem NS-Regime kooperiert hatten oder in NS-Bildungseinrichtungen tätig waren, aus Gründen einer nachhaltigen „Purification“ vorerst rigoros jeder erzieherische Kontakt zur Jugend untersagt werden. $^{2232}$

Von besonderem Interesse ist, dass dem Report des „Institute on Re-education of the Axis Countries“ ein von Foerster, Schairer und Jacques Maritain ausgearbeiteter Vorschlag zur Einrichtung eines „Board of Educational Advisors“ beigefügt wurde, der bereits am I6. März 1945 in einer Instituts-Besprechung unter Vorsitz von Ruth Bryan Owen Roh$\mathrm{de}^{2233}$ angenommen worden war. Um den schwierigen Transformationsprozess der Bil-

2230 Ebd., 2.

2231 Ebd., 7.

2232 Ebd.

2233 Ruth Bryan Owen [Rohde] (1885-1954), geboren in Florida als Tochter des demokratischen Abgeordneten und Außenministers (1913-1915) William Jennings Bryan; Owen war Erwachsenenbildnerin (Chautauqua lectures), Universitätslehrerin, demokratische Kongressabgeordnete (1928-1930) und wurde 1930 von Präsident Theodore Roosevelt als erste Frau zur US-Gesandten in Dänemark ernannt. Danach war Rohde Mitarbeiterin des State Departments und ab 1945 u.a. Delegierte der „United Nations General Assembly“. Owen war einflussreiche Vorkämpferin für Frauenrechte und setzte sich in ihrer politischen Laufbahn darüber hinaus für Kinderfürsorge und Gesundheitsfragen ein. Vgl. Jo Freeman, 
dungs- und Erziehungssysteme in den ehemaligen Achsenstaaten zu unterstützen und zu begleiten, sollten den US-Militärverwaltungen, zusätzlich zur bereits bestehenden Infrastruktur, hochrangige zivile Experten beigestellt werden; sie sollten - neben der primären Aufgabe der Reorientierung des gesamten Erziehungs- und Bildungswesens - auch alles verfügbare Quellenmaterial „concering the efforts of Nazism to penetrate German and foreign educational systems, openly or secretly“ zusammentragen, um auf Grundlage dieser Materialsammlung künftig gezielte Studien zur NS-Erziehung und Indoktrinierung betreiben zu können. ${ }^{2234}$

"Outstanding educators, both men and women, should be invited to serve on the Board of Educational Advisors. Educational experts who were prominent in the underground fight against the Axis should be among the first to be invited. [...] The different fields of education, from infant to adult education, should be represented [...]. The members of the Board should be ready to give their advice in written form or orally, individually or in groups. If such activity takes a large portion of their time, they should be released from part of their regular functions."2235

Wie weit die zitierten Vorschläge des New Yorker „Institute on Re-education of the Axis Countries" tatsächlich Einfluss auf die Planungen im State Department hatten, lässt sich auf Basis der verfügbaren Quellen nicht ermitteln. Die Einrichtung eines eigenständigen zivilen Reorientierung-Boards sowie die Ausarbeitung einer langfristigen mentalen Demokratisierungs-Agenda, die das bisherige Paradigma der US-Militärverwaltung ablöste, wurde jedenfalls knapp eine halbes Jahr später Realität.

Angesichts der zunehmenden Skepsis von US-Auslandskorrespondenten und RadioKommentatoren in Bezug auf die verlautbarten Ankündigungen der kommandierenden US-Militärs, sich nach den ,Säuberungsmaßnahmen' rasch aus allen Agenden der Reorientierung zurückzuziehen und sämtliche Bildungsinstitutionen in die Verantwortung der Deutschen zu legen, führte das State Department im Dezember 1945 eine verdeckte Umfrage in der US-Bevölkerung durch. Deren Ergebnis bedeutete in gewisser Hinsicht Wasser auf die Mühlen des State Departments, da sich die überwiegende Mehrheit der Befragten klar für eine Langzeit-Kontrolle der deutschen Bildungseinrichtungen aussprach. ${ }^{2236}$ Des Weiteren erstellte das State Department - angesichts der wachsenden öf-

We will be heard. Women's struggles for political power in the United States, Lanham 2008, 110; siehe insbesondere: Sarah Pauline Vickers, The Life of Ruth Bryan Owen. Florida's First Congresswoman and America's First Woman Diplomat, Diss., Florida State University 1994.

2234 Report on the Re-education of Germany, a.a.O., 12.

2235 Ebd., 11.

2236 Auf die Frage „As you know, the United States has taken charge of young people's education in the part of Germany [...]. Do you feel that we will have to continue education in Germany for a long time, or can we turn this over to the Germans in a year or two?" antworteten $77 \%$ für „continue for long time“, $15 \%$ „turn over in a year or two“ und $8 \%$ „no opinion“. Zit. nach: U.S: Public Opinion on the German Reedu- 
fentlichen Kritik an der schlecht kommunizierten Reeducation-Politik der US-Regierung in Deutschland - im Februar 1946 Dossiers, die eine Analyse der Kritik nach Schwerpunkten und Medien gliederte und deren Fazit ebenfalls auf eine „longe range policy“ hinauslief: „A large majority of the American public believes that it will be a long time before we can afford to let the Germans manage their own education." ${ }^{2237}$

Durchaus auch im stillen Einvernehmen mit den US-Militärstellen, die sich schon zu Beginn der Posthostilities-Planungen für die Bereiche Bildung und kulturelle Wiederaufbau-Angelegenheiten nicht wirklich zuständig gefühlt hatten, begann das State Department im Frühjahr I945 schließlich damit, einen zivilen Expertenstab einzurichten: in diesem befanden sich neben prominenten Schul- und Universitätsfachleuten, Spezialisten für Sozial- und Jugenderziehung unter anderem auch Fachleute für Erwachsenenbildung. Sie sollten künftig als Beratungsgremium - als „Advisory Committee“ - für die langfristige „Reeducation“ fungieren und dabei die zuständigen Beamten des State Department, des Office of War Information (OWI) und auch des War Department mit Information versorgen.

Die ursprüngliche Anregung, ein „Advisory Committee on German Education“ einzurichten, kam vom zivilen Bildungsexperten Bryn J. Hovde, der im Februar I945 - nach einer Besprechung mit Mitgliedern der European Branch - gegenüber Archibald MacLeish im U.S. Department of State den Vorschlag unterbereitet hatte, ein „Advisory Committee“ zu schaffen, das heißt ein aus zivilen Experten zusammengesetztes Gremium, das die „Reorientation-Policy“ in den US-Besatzungszonen künftig maßgeblich mitplanen sollte. ${ }^{2238}$ In diesem Fall wurden die Pläne bald Realität und das „Advisory Committee“ innerhalb des State Departments mit der klaren Zielvorgabe eingerichtet, die in einen längerfristigen Planungshorizont eingebetteten komplexen Reorientierungs-Aufgaben nun in die Hand ziviler Stellen zu legen:

"Since the problem [reeducation, d. Verf.] is one of the greatest difficulty, the Department invited a group of citizens distinguished and experienced in the field of education to advise with

cation Program, 7 February 1946, 2 f. The U.S. Occupation of Germany: Educational Reform 1945-1949, Microfilm-Collection Congressional Information Service, edited by Gary H. Tsuchimochi, Tokyo 1991 (Bestand Institut für Zeitgeschichte der Universität Wien, Bibliothek), 1-A-15.

2237 Ebd., Analysis, 2.

2238 Seinem Vorschlag beigefügt waren die Namen von zivilen Experten, die Hovde für die Besetzung dieses Komitees vorschlug, wobei Hovde selbst, Lindemann und Day dann tatsächlich im neugeschaffenen Gremium vertreten waren: Calvin Hoover (geb. 1897), der Dekan der Duke University, Reinhold Niebuhr (geb. 1892), Edmund E. Day (geb. 1883), Ökonom, Präsident der Cornell University und u.a. Direktor des „Education Boards“ der Rockefeller Foundation 1933-1937, Eduard Lindemann (geb. 1885), Professor für Social Work an der Columbia University und Spezialist für Deutsches Bildungswesen, N.L. Engelhardt (geb. 1882), Superintendent der New York Public Schools mit Deutschlanderfahrung, sowie Ruth Benedict (geb. 1887), Anthropologieprofessorin an der Columbia University, die bereits im OWI sozialwissenschaftlichen Analysen durchgeführt hatte. The U.S. Occupation of Germany: Educational Reform 1945-1949, Microfilm-Collection, a.a.O., 1-A-223, a.a.O., 1-A-15. 
it. The Chairman of the Committee was President Edmund E. Day of Cornell. Members were: President George Shuster of Hunter College, President Frank Graham of the University of North Carolina, President John Milton Potter of Hobart College, Dean Martin McGuire of the Graduate School of Catholic University, Professor Eduard C. Lindemann of Columbia University, and Professor Reinhold Niebuhr of Union Theological Seminary."2239

Des Weiteren gehörten dem Advisory Committee an: Harvard H. Arnason vom (noch bestehenden) OWI, Major John Taylor von der OMGUS-Allied Control Commission, sowie vom State Department Archibald MacLeish, David Harris, Leon W. Fuller, Bryn J. Hovde, Gordon T. Bowles, Eugene N. Anderson und E.W. Fox ${ }^{2240}$ einzelne vom State Department angesprochene Personen lehnten die Einladung zur Mitarbeit allerdings $\mathrm{ab.}^{2241}$

Zur Koordinierung der Aufgaben, die nun sowohl den Bereich der öffentlichen Meinung als auch sämtliche „cultural relations“ mit dem Ausland umfassen sollten, wurde innerhalb des State Departments die Position eines „Assistant Secretary of State for $\mathrm{Pu}$ blic and Cultural Relations“ geschaffen. Mit der verantwortlichen Leitung dafür betraute Edward Stettinius, ${ }^{2242}$ der frühere „Cultural Affairs Officer“ während der Kriegsjahre und nunmehrige Secretary of State, Archibald MacLeish in direktem Auftrag Präsident Roosevelts, mit dem MacLeish befreundet war. ${ }^{2243}$ Allein schon aus kulturpolitischer Perspektive war MacLeish an der Wiederaufnahme und Stärkung kulturdiplomatischer Außenbeziehungen sehr interessiert und reaktivierte sogleich frühere Mitarbeiter des „Office of Facts and Figures“ (OFF). ${ }^{2244}$ MacLeishs diesbezüglicher intellektueller Ansatz findet sich bei Arndt pointiert zusammengefasst:

2239 The U.S. Occupation of Germany: Educational Reform 1945-1949, Microfilm-Collection, a.a. O., 1-A223, a.a. O. Archibald MacLeish, Longe-Range Policy for German Reeducation, 4. Juli 1945, 2.

2240 NARA II, RG 165, Box 174, Coordinating Committee, Longe-range Policy for German Reeducation (CC-59a), 13. Juni 1945, 1.

2241 So bspw. der Präsident der University of North Carolina, Frank P. Graham, der seine bedauernde Absage - „regret to have to decline the great opportunity afforded in your request to represent America in making policies and carrying through the program for the re-education of the German people“ - wegen Arbeitsüberlastung per Telegramm direkt an US-Präsident Truman richtete. Frank. P. Graham, President of the University of North Carolina to the Honorable Harry S. Truman, President of the United States, The White House, Telegram, 20. Juni 1945, 1. The U.S. Occupation of Germany: Educational Reform 1945-1949, Microfilm-Collection Congressional Information Service, edited by Gary H. Tsuchimochi, Tokyo 1991 (Bestand Institut für Zeitgeschichte der Universität Wien, Bibliothek), 1-A-9.

2242 Im Jänner 1945 war Edward R. Stettinius dem früheren US-Außenminister Cordell Hull als Secretary of State nachgefolgt, wurde allerdings bereits im Juni 1945 von Präsident Truman wieder abgesetzt. Als Vorsitzender der US-Delegation spielte Stettinius dann eine zentrale Rolle bei der Gründung der Vereinten Nationen. Vgl. Arndt, The First Resort of Kings. American Cultural Diplomacy, a.a.O., 98.

2243 Vgl. Donaldson, Archibald MacLeish. An American Life, a.a. O., 379.

2244 Arndt, The First Resort of Kings. American Cultural Diplomacy, a.a.O., 100. 
"In 1945 hearing for the job in State, he [MacLeish, d. Verf.] was [...] asserting that education and culture were the core of US foreign affairs and among its 'most important foreign relations'. In world history no one had dared articulate such an idea particularly before a hostile and under-informed legislature. Beginning a longe-range educational campaign with Congress, he took control by commanding attention. As Roosevelt had labored to convince legislators that intellect was a factor of good government, MacLeish tried to bring intellect and culture nearer to the center of foreign affairs." 2245

Unter der Leitung von MacLeish wurde sogleich mit der Arbeit an einem langfristig tragfähigen Reeducation-Planungsdokument begonnen, das die Arbeit der US-Militärstellen in Europa auf ein neues Konzept, nämlich auf eine kulturpolitische Grundlage, stellen sollte; dies, wie Arndt meint, im vollen Bewusstsein um die politisch überaus schwierige Ausgangslage jeglicher offensiver Kultur- und Reorientierungs-Politik gegenüber konservativen Gegenstimmen: „Yet the vulnerability of the original idea, even before wartime distortions, was obvious to anyone aware of the reigning cynicism of Washington or the gathering anti-New Deal backlash.“"2246

Das Advisory Committee traf sich im Mai und Juni 1945 in jeweils zweitägigen Sitzungen und arbeitete einen Entwurf aus, der dem Coordinating Committee des Department of State und dem Secretary's Staff Committee zugleitet und von diesem auch genehmigt wurde. Im Anschluss daran wurde das Strategiepapier vom Komitee-Mitglied Frank Graham mit John McCloy, zum damaligen Zeitpunkt Secretary of War, und General John H. Hilldring von der Civil Affairs Division (CAD) des War Departments diskutiert. Um Verzögerungen zu vermeiden, fanden parallel dazu direkte Gespräche zwischen MacLeish und Finanzminister Henry Morgenthau statt. ${ }^{2247}$

Wie schon zuvor erreichten auch in dieser Phase zahlreiche Manuskripte, Memoranden und Vorschläge, die von privaten Bildungsorganisationen oder privaten Bildungsexperten verfasst wurden, das State Department. Obwohl derartige Anregungen von privater Seite wohl kaum direkten Einfluss auf die Reorientierungs-Politik des State Departments gehabt haben dürften, setzten sich die US-Regierungsbeamten mit den unterbreiteten Vorschlägen, die schon für sich genommen spannende Dokumente des ungebrochenen zivilgesellschaftlichen Engagements Amerikas zur Reorientation darstellen, doch intensiv auseinander. Darunter finden sich zum Teil überaus interessante Analysen und Vorschläge, wie zum Beispiel ein Papier des in Brünn geborenen Emigranten Dr. Hugo Iltis, ${ }^{2248}$

2245 Ebd., 102.

2246 Ebd., 100.

2247 Archibald MacLeish, Longe-Range Policy for German Reeducation, 4. Juli 1945. The U.S. Occupation of Germany: Educational Reform 1945-1949, Microfilm-Collection, a.a.O., 1-A-223, a.a.O., 1.

2248 Hugo Iltis (1882-1952), in Brünn geborener Biologie, Genetiker und Volksbildner jüdischer Herkunft. Nach seiner Promotion an der Deutschen Universität Prag 1905 arbeitete Iltis bis 1936 als Lehrer am Deutschen Gymnasium in Brünn sowie am Polytechnischen Institut in Brünn. 1921 gründete er die 
ehemals Dozent und Senatsmitglied am Polytechnischen Institut in Brünn, während des Ersten Weltkrieges Delegierter des österreichischen Roten Kreuzes und Gründer der Masaryk-Volkshochschule in Brünn (I92I), ${ }^{2249}$ der größten Erwachsenenbildungseinrichtung der Tschechoslowakei in der Zwischenkriegszeit. ${ }^{2250}$ Iltis, der sich als Geologe, Biologe und Genetiker unter anderem intensiv mit der Mendelschen Vererbungslehre auseinandergesetzt hatte, bekämpfte bereits ab I930 in Publikationen die Unsinnigkeit bzw. Stupidität der nationalsozialistischen Rassentheorie. ${ }^{2251}$ Unter aktiver Mithilfe Albert Einsteins und des aus Deutschland stammenden US-Anthropologen Franz Boas konnte Iltis I939 in die USA emigrieren, ${ }^{2252}$ wo er eine Professur an der University of Virginia erhielt.

Thomas-Masaryk Volkshochschule in Brünn, deren Direktor er bis 1938 blieb. Während des Ersten Weltkriegs war Iltis u.a. Leiter eines Feldlazaretts der k.k. Armee. Nach seiner Emigration in die Vereinigten Staaten 1939, wo er 1944 die US-Staatsbügerschaft erhielt, arbeitete er u.a. an der University of Virginia. Der Nachlass von Hugo Iltis, der - neben biografischen Arbeiten zu Gregor Mendel (etwa: Hugo Iltis, Gregor Johann Mendel: Leben, Werk und Wirkung, Berlin 1924; Ders., Life of Mendel, New York 1932) - mit mehreren wissenschaftlichen Publikation in Erscheinung trat, befindet sich am „Hunt Institute for Botanical Documentation“, Carnegie Mellow University, Pittsburgh/Pennsylvania. The U.S. Occupation of Germany: Educational Reform 1945-1949, Microfilm-Collection, a.a.O., $1-\mathrm{A}-13$.

2249 Vgl. Hugo Iltis, Die Volkshochschule Brünn: Gründung - Aufbau - Ausgestaltung, Brünn 1924.

2250 Das volksbildnerische Engagement von Iltis reicht aber weiter zurück. So hatte er bereits 1911 an der Wiener Volkshochschule „Volksheim Ottakring“ gemeinsam mit Dr. F. Oppenheim in der „Naturhistorischen Fachgruppe“ eine „Exkursion in die Mährische Schweiz“ organisiert. 1928/29 folgte, auf Einladung des Schönberg-Schülers Paul Amadeus Pisk und Josef Luitpold Stern, ein weiterer Vortrag von Iltis zu „Der Mährische Karst und der Ursprung des Menschengeschlechts“; während seines Aufenthaltes in Wien referierte Iltis als „Leiter der Brünner Volkshochschule“ auch innerhalb der sozialdemokratischen Bildungsorganisationen. Siehe: Österreichisches Volkshochschularchiv, Wien. Datenbank "Theseus".

2251 Vgl. Hugo Iltis, Volkstümliche Rassenkunde (= Buchbeigabe der „Urania“ - kulturpolitische Monatshefte über Natur und Gesellschaft, 1929/30), Jena 1930; Hugo Iltis, Der Mythos von Blut und Rasse, Wien [R. Harand] 1936.

2252 Am 23. April 1938 schrieb Albert Einstein an Franz Boas, der an der Columbia University in New York lehrte und gemeinsam mit L.C. Dunn im „Emergency Committee for Displaced Persons“ aktiv war, in Bezug auf Iltis: „In dieser Zeit allgemeiner Bedrängnis, in der alle einflußreichen Menschen so sehr mit Briefen und Hilferufen überschwemmt werden, fällt es mir doppelt schwer, Sie mit Angelegenheiten eines Einzelnen zu belästigen. In dem Fall des Professor Iltis in Brünn muss ich eine Ausnahme machen. Professor Iltis ist Biologe, wie Sie aus dem beiliegenden Publikations-Verzeichnis sehen. Er ist dadurch ,politisch belastet', dass er eine kleine Kampfschrift gegen den Schwindel der deutschen Rassen-Mystik hat erscheinen lassen, und die gegenwärtige Situation hat es auch schon mit sich gebracht, dass er seines Lebens in der Czechoslowakei nicht mehr sicher ist. Ich glaube, dass es unsere Pflicht ist, unser Möglichstes zu tun, diesen Mann zu retten, solange es noch Zeit ist. [...] Auch wenn Sie nichts direkt sollten unternehmen können, wäre ich Ihnen für Rat dankbar, da ich an der Sicherung dieses mir persönlich nicht bekannten Mannes sehr interessiert bin." American Philosophical Society (APS), Philadelphia, Franz Boas Papers (E-G), 1862-1942. Mss.B.B61.inventory05

Siehe: http://www.amphilsoc.org/exhibits/treasures/einstein.htm [Zugriff 27.8.2011] 
Im Juni 1945 hatte Iltis auf der Basis eigener Erfahrungen mit dem deutschen Wissenschaftssystem und, wie er formulierte, um einen „Dritten Weltkrieg“" zu vermeiden, ein kurzes Manuskript mit dem Titel „Proposals regarding Control of German Science and Education“ an den Secretary of Commerce, Henry A. Wallace, ${ }^{2253}$ gesandt, der dieses $\mathrm{Pa}-$ pier umgehend an Unterstaatssekretär Archibald MacLeish im State Department weiterleitete. Mit seinen Vorschlägen zum Wiederaufbau des deutschen Wissenschaftssystems beabsichtigte Iltis nach eigener Aussage, einen Beitrag zu einer dauerhaften Friedensicherung zu leisten; er schlug vor, sein Papier nach Möglichkeit an politische Entscheidungsträger weiterzuleiten, er selbst wollte jedoch anonym bleiben.

Das Manuskript ist insofern von Interesse, als die darin ausgeführten Überlegungen scharfsinnig und pointiert formuliert sind und sich darüber hinaus in einem zentralen Punkt von allen anderen Konzepten zur Rekonstruktion des Wissenschaftsbereiches unterschieden: Iltis plädierte für ein mindestens zweijähriges Moratorium bis zur Wiedereröffnung der Universitäten und Hochschulen in Österreich und Deutschland nach Kriegsende. Iltis begründete seinen Vorschlag für eine längerfristige Schließung - im Gegensatz zur möglichst frühen Öffnung der Volks- und Mittelschulen - damit, dass die Universitäten sowie das gesamte Wissenschaftssystem in der Zeit des Nationalsozialismus die zentralen „Brutstätten“ der Reaktion sowie der nationalsozialistischen Rassenideologie waren, deren autoritär-antidemokratische Wurzeln freilich weit in die Geschichte zurückreichen. Neben dem „Land der Dichter und Denker“, das, so Iltis in seiner durchaus zutreffenden Einschätzung, zu weiten Teilen durch die wissenschaftlich-kulturellen Leistungen der jüdischen Intelligenz mitgeprägt war, existierte jenes dumpf-völkische, reaktionäre und rassistische Überlegenheits-Ressentiment unter Universitätsprofessoren und Oberlehrern (,in Knickerbockers“), das auch Adolf Hitler als prägend für seine eigene Entwicklung beschrieb - ein geistiges Klima, das den Weg zum „Land der Richter und Henker “2254 ebnen half. In „Mein Kampf“ hatte sich Hitler bei seinem „an das nationale Ehrgefühl appellierende[n]" Geschichte-Lehrer an der Realschule in Linz, Dr. Leopold Pötsch, ${ }^{2255}$ bedankt, der in ihm das „revolutionäre“ Interesse für „Geschichte“ entfacht hätte; ein „Interesse“,

2253 Henry A. Wallace (1888-1965), 1933-1940 amerikanischer Landwirtschaftsminister, als Demokrat von 1941-1945 Vizepräsident unter Präsident Roosevelt. Nachfolgend Handelsminister in der Regierung Truman. 1948 Präsidentschaftskandiat für die „Progressive Party“. Siehe: Graham White/John Maze, Henry A. Wallace. His Search for a New World Order, Chapel Hill 1995; John C. Culver/John Hyde, American Dreamer. The Life and Times of Henry A. Wallace, New York 2000.

2254 Hugo Iltis, Proposals Regarding Control of German Science and Education, 6. Beigefügtes Manuskript zur Korrespondenz: Henry A. Wallace, Secretary of Commerce, Washington D.C., to Honorable Archibald MacLeish, Assistant Secretary of State, 11. Juni 1945. The U.S. Occupation of Germany: Educational Reform 1945-1949, Microfilm-Collection, a.a. O., 1-A-13.

2255 Adolf Hitler, Mein Kampf. Zwei Bände in einem Band, ungekürzte Ausgabe, München 1938, 12. Zu Hitlers Schrift siehe: Othmar Plöckinger, Geschichte eines Buches. Adolf Hitlers „Mein Kampf“': 19221945, 2. aktualisierte Aufl., München 2011. 
das indes nicht bei der Geschichte Halt machte, sondern die gesamte „deutsche“ Wissenschaft als Instrument nationalsozialistischen, deutsch-arischen „Herrenmenschentums“ und technokratisch-technischer Machtsicherung miteinbezog: „Der völkische Staat wird für sein Dasein kämpfen müssen. [... ] nicht Festungswälle werden ihn beschirmen, sondern die lebendige Mauer von Männern und Frauen, erfüllt von höchster Vaterlandsliebe und fanatischer Nationalbegeisterung. Auch in der Wissenschaft hat der völkische Staat ein Hilfsmittel zu erblicken zur Förderung des Nationalstolzes [...].“2256 [Spationierung im Original, d. Verf.]

Schon lange vor Hitler, so Iltis, hatten sich die deutschen Universitäten zu einem Hort antisemitisch-rassistischer Ideologien entwickelt, die in der NS-Zeit - ausgerichtet nach der Lehre des Wegbereiters der NS-Rassenhygiene, Eugen Fischer, nach den eugenischen Übermenschen-Ideen des „Rasseforschers“ Hans F.K. Günther oder der aggressiv-geopolitischen „Lebensraum“-Theorie des NS-Geologen Karl Haushofer - vollends zu „factories of the mental poison gas of Nazi propaganda" wurden. ${ }^{2257}$

"The spirit of brutality, of violence and presumption was cultivated among the students of the German Universities since old times. The color-bearing 'student corporations', the 'Corps', the 'Burschenschaften', etc. with their caste feeling, their fanatical chauvinism, their obligatory duels, their excessive drinking, etc. were representatives of German mentality. Here, at German Universities were the real breeding places of the spirit of Hitlerism, of rassistic antisemitism, of Teutonic megalomania long before Hitler. Professors and students of German Universities were among the first fanatical supporters of the Nazi Movement. They played the leading role in that disgusting spectacle of 'book burnings', which occurred at all places of 'higher learning' throughout Germany a short time after Hitler came to power. [...] By the act of burning the books, by this revolting attack against the holy spirit of mankind, the German students committed a crime, by which they excluded and separated themselves from the international brotherhood of science." 258 [Hervorhebung d. Verf.]

Diese schleichende Vergiftung des deutschen Geisteslebens, für die Iltis insbesondere die Universitäten verantwortlich machte, mündete seiner Analyse nach direkt in die katastrophale Verbindung von deutscher Wissenschaft, autoritärem Kadavergehorsam und rassistischer Indoktrinierung, die über Bücherverbrennungen weit hinausging:

2256 Hitler, Mein Kampf, a.a.O., 473. In der Übersetzung von Hugo Iltis lautet die Passage: „The nationalsocialist state has to consider science as a tool for increasing national pride. Not only history, but also all of cultural history must be taught from this point of view. "Iltis, Proposals Regarding Control of German Science and Education, a.a.O., 7.

2257 Iltis, Proposals Regarding Control of German Science and Education, a.a. O., 2 f.

2258 Ebd., 5. 
"The German people as a whole are responsible not so much for the development of the political situation by which Hitler came to power, but for the fact that, through all the years of death and destruction, of unbelievable terror and cruelty committed by the Nazis and their armies, when millions of Germans died and died readily and enthusiastically for Hitler, no great movement against Hitlerism could arise, and a real German underground could never develop. [...]

The dangerous mentality of the German people has been the result of a dangerous situation of German science and of a dangerous education. German Science is and has been one of the helpers of German conquest. German Universities, German Scientific Institutions and German higher schools were not only the shining centers of human progress as pictured by the Germans, but also the breeding places of German megalomania and the arsenals for the fabrication of both chemical and mental poison gas. To eliminate the dangerous preponderance and arrogance of German Science, to control German schools and German education will be one of the conditions for a lasting peace." 2259 [Hervorhebung d. Verf.]

Angesichts der tiefreichenden, geistig-mentalen Indoktrinierung, der ungeheuer brutalen Unterdrückung von Humanität und individueller Freiheit, die über die gesamte Dauer der nationalsozialistischen Herrschaft keinen größeren Widerstand in der Bevölkerung hervorgerufen habe, sei es im Hinblick auf eine glaubwürdige und verantwortungsvolle Reorganisation des deutsch-österreichischen Wissenschaftssystems durchaus zumutbar, dass die Universitäten so lange geschlossen blieben, bis sich - unter Mithilfe eines eigens zu schaffenden „Advisory Board for the Allied Science Control Commission“ - sukzessive qualifizierte und politisch-weltanschaulich vertrauenswürdige Lehrkräfte finden ließen. Für Iltis, der - trotz aller Kontrollmaßnahmen von außen - im demokratischen Selbstlernprozess der Deutschen das einzig nachhaltig wirksame Veränderungspotenzial sah, ${ }^{2260}$ schien eine zweijährige Schließung - ohne jedweden revanchistischen Unterton - auch deshalb durchaus vertretbar, da diese Zeitspanne nur einen Teil jener Zeit ausmachen würde, die die Universitäten in den von Deutschland besetzten Gebieten geschlossen gewesen seien.

$\mathrm{Zu}$ einem ähnlichen, wenn auch weniger pointiert formulierten Ergebnis, kam auch der US-amerikanische Kulturhistoriker Carl E. Schorske in einer 1947 vom „Council of Foreign Relations“ herausgegebenen Schrift, in der er unter anderem das Problem des universitären Wiederaufbaues thematisierte. Auch Schorske betrachtete die voreilige Restauration der Universitäten („premature restoration“) als das größte Hindernis für einen nachhaltigen ge-

2259 Ebd., 2 f.

2260 „This gigantic problems of reeducation of the German people will not be solved by any educational efforts of the allied nations. It will be, however, inaugurated by the direct effect of the lost war, by the destruction of the German homeland, and by the complete change in the economic situation of Germany. It can be accomplished only by the German people themselves, whose attitudes will be changed by terrible experiences." Iltis, Proposals Regarding Control of German Science and Education, a.a.O., 11. 
sellschaftlichen Demokratisierungsprozess. Die bloße Tatsache, dass die universitären Fakultäten nun mehrheitlich „non-Nazi“ seien, wäre, so Schorske, für sich alleine genommen noch keine hinreichende Voraussetzung für die zentrale Aufgabe, der akademischen Jugend künftig die Werte eines offenen und demokratischen Gemeinwesens zu vermitteln. ${ }^{2261}$ Anders als Iltis vermochte Schorske 1947 bereits die bisher angelaufene Reorientierung der deutschen Universitäten - deren Wiederöffnung seiner Meinung nach viel zu schnell erfolgt war - zu beurteilen, und kam dabei, angesichts der unzureichenden Entnazifizierung, des rasch etablierten ,unpolitischen Spezialistentums' und der dominierenden reaktionären Grundhaltung an den Universitäten, zu einem ernüchternden Ergebnis:

\begin{abstract}
"Since most of the actively democratic academicians emigrated from the Third Reich, the newly reopened universities have drawn heavily on men previously retired because of age, and on those who, while non-Nazi, retained their posts under the Nazis by a reasonable degree of conformity. Together these two groups compose the majority of the faculties. Progressive ideas concerning the reorientation of the universities to meet the new situation have been all too few." 2262
\end{abstract}

Ähnlich wie Iltis verwies auch Schorske in seiner Analyse der universitären Realsituation auf den entwicklungsgeschichtlichen Zusammenhang zwischen den historisch zurückreichenden, reaktionär-antidemokratischen Tendenzen deutscher Wissenschaftsorganisation und der späteren, vergleichsweise leicht zu erreichenden Instrumentalisierung durch den Nationalsozialismus - ein kausaler Zusammenhang, der freilich einer besonders verantwortungsvollen Reorientierungs-Politik bedurft hätte, die weit über nur formale und oberflächlich durchgeführte Entnazifizierungsmaßnahmen hätte hinausgehen müssen, um - wie Carl Zuckmayer es formulierte - die „Köpfe und Herzen“2263 der nachfolgenden Generation zu erreichen:

2261 Carl E. Schorske [mit einem Vorwort von Allen W. Dulles], The Problem of Germany. Part II: Social and Cultural Aspects of the German Problem. In: Hoyt Price/Carl. E. Schorske (Eds.), The Problem of Germany (= Studies in American Foreign Relations. Hrsg. v. Percy W. Bidell, No. 5), New York 1947, 130.

2262 Ebd., 128.

2263 So meinte Zuckmayer in einem ursprünglich für das CAD im War Department formulierten Lagebericht: „Wir [d.i. die US-Besatzungsmacht, d. Verf.] erreichen die Menschen nicht. Wir finden keinen Weg in ihre Köpfe und Herzen. Wir beeinflussen die Schüler und Universitätsstudenten nicht wirklich [...] was bisher getan und versucht worden ist, ist zu wenig, zu theoretisch, zu akademisch. Es berührt Körper und Seele der deutschen Jugend nicht." Zit. nach: Carl Zuckmayer, Zusammenfassender Bericht über einen Auftrag in Deutschland und Österreich, November 1946 bis 31. März 1947. In: Carl Zuckmayer, Deutschlandbericht für das Kriegsministerium der Vereinigten Staaten von Amerika. Hrsg. v. Gunther Nickel et al., Frankfurt a. Main 2007, 79. 
"As the training ground of the future leaders of German society, the universities occupy a strategic position in democratic reconstruction. For the German universities to fill adequately the vital role which they are called upon to play, far more is needed than simple de-Nazification. Their pre-I933 structure, and the attitudes of the majority of the academicians who dominated them, made Hitler's conquest of the universities a relatively simple matter. The ground had been well prepared by the two seemingly opposed tendencies in the universities during the Hohenzollern regime: the cult of nationalism and the 'un-political' scientific tradition - the former filling the vacuum left by the latter." ${ }^{264}$ [Hervorhebung d. Verf.]

Soweit die klarsichtigen und von großem Weitblick getragenen Überlegungen und Beobachtungen von Hugo Iltis und Carl E. Schorske, die lediglich weitere Beispiele für den überaus ernsthaften und sehr reflektierten zivilen US-Reorientierungs-Diskurs darstellen; Überlegungen, die vor dem Hintergrund des sich bald verschärfenden Kalten Krieges allerdings keinen direkten Einfluss auf den konkreten Wiederaufbau der Universitäten nach I945 ausübten.

Bereits am 7. Juni I945 wurde vom genannten „Advisory Committee“ jedenfalls ein erster Entwurf des „Longe-Range Policy Statement for German Reeducation“vorgelegt und zur weiteren Bearbeitung durch das „Coordinating Committee for submission to the Staff Committee" weitergeleitet. ${ }^{265}$

Wie MacLeish hervorhob, basierte das Longe-Range-Strategiepapier auf spezifischen Annahmen hinsichtlich der besonderen Rolle und Bedeutung der US-Militärregierung im Zusammenhang mit der ökonomisch-wirtschaftlichen, sozialen, politischen und kulturellen Reorganisation in Deutschland und deren Bedeutung für die künftige US-Außenpolitik. In den ersten Entwürfen, in denen an einigen Stellen noch der Einfluss Morgenthaus spürbar ist, finden sich vergleichsweise harte Formulierungen, die in der Folge aber aufgeweicht beziehungsweise ganz entfernt wurden. So heißt es etwa in Paragraph I:

"The Advisory Committee has pointed out that an educational program cannot be devised in an economic, social, and political vacuum. The reeducation of the German people should be an integral part of a comprehensive program of rehabilitation which would eliminate Nazi and militaristic influences and convince the German people of their defeat in the war and their responsibility for the inhuman manner in which it was conducted." ${ }^{2266}$ [Hervorhebung d. Verf.]

2264 Schorske, The Problem of Germany. Part II: Social and Cultural Aspects of the German Problem, a.a.O., 127.

2265 NARA II, RG 165, Box 174, Coordinating Committee, Longe-range Policy for German Reeducation (CC-59a), 13. Juni 1945, 1.

2266 Archibald MacLeish, Longe-Range Policy for German Reeducation, 4. Juli 1945. The U.S. Occupation of Germany: Educational Reform 1945-1949, Microfilm-Collection, a.a.O., 1-A-223, a.a.O., 2. Siehe auch: NARA II, RG 165, Box 174, Coordinating Committee, Longe-range Policy for German Reeducation (CC-59a), 13. Juni 1945, 1. 
Ein wesentlicher Aspekt des Strategiepapiers war aber bereits in der ursprünglichen Fassung enthalten, nämlich die Betonung der demokratischen Eigenverantwortlichkeit, das heißt, dass Reeducation-Maßnahmen von der US-Militärregierung künftig eher supervidiert und angeregt, als von oben herab durchgeführt werden sollte:

"The Committee assumes that it is the policy of the United States Government, while avoiding interference in the domestic affairs of other nations, to encourage the self-government of peoples on the ground that tyrannies have been demonstrated to be dangerous to the security of the world and that nations in which the people govern themselves are more likely to keep the peace and to promote the common interest of mankind. It is therefore the assumption of the Committee that the Government of the United States whishes to see Germany emerge from the period of occupation as a self-governing nation in which individuals are responsible for the conduct of the state, rather than as a totalitarian nation in which the state exercises responsibility for the individual citizens." ${ }^{267}$ [Hervorhebung d. Verf.]

Und weiter: „The occupation authorities will bear in mind that permanent cultural changes can be affected only as they are developed and maintained by the Germans themselves. Having first eliminated the Nazi elements, they will seek to effect the progressive transfer of authority in reeducation to responsible Germans as rapidly as conditions permit. "2268 Darüber hinaus sollte, wie es im „Longe Range Policy Statement“ heißt, die langjährige geistige Isolation Deutschlands - und damit war in den Dokumenten der Abteilungen des State und War Department, auch wenn oft keine explizite Erwähnung erfolgte, tendenziell immer auch Österreich mitgemeint ${ }^{2269}$-, durch Aufnahme kultureller Außenkontakte überwunden werden:

"During the Nazi epoch, Germany was virtually cut off from outside cultural influences and a perverted German culture was deliberately used both home and abroad as an insidious political weapon. Under no circumstances must this be permitted to happen again. The best way to prevent it, after the occupation authorities have taken the necessary measures of control, and

2267 Archibald MacLeish, Longe-Range Policy for German Reeducation, 4. Juli 1945. The U.S. Occupation of Germany: Educational Reform 1945-1949, Microfilm-Collection, a.a.O., 1-A-223, a.a.O., 3.

2268 NARA II, RG 165, Box 174, Coordinating Committee, Longe-range Policy for German Reeducation (CC-59a), 13. Juni 1945, 3.

2269 Dies findet sich u.a. auch im Namen einer der für die „Reorientierung“ zuständigen Abteilungen des State Department dokumentiert: „Division of German and Austrian Information and Reorientation Affairs/Office of German and Austrian Affairs“. Des Weiteren war die „Civil Affairs Division“ im War Department seit 1944 verantwortlich für die Planung und Durchführung der militärischen Besatzungspolitik in Deutschland und Österreich. Vgl. Donald R. Whitnah/Edgar L. Erickson, The American Occupation of Austria. Planning and early Years (= Contributions in Military Studies, No. 46), Westport $1985,14 f$. 
subject to the willingness of individuals and cultural communities outside of Germany, is to encourage a resumption of carefully selected activities in the field of cultural relations between other nations an non-Nazi elements in Germany." 2270

Konkret sollte das, wie sich bald zeigen sollte, neben der Bereitstellung einer breiten Palette von Büchern, Zeitschriften, Zeitungen, Filmen, Lehrmaterialien, wissenschaftlichen Objekten, Musik, Literatur und Werken Bildender Kunst, insbesondere in Form von Austausch- beziehungsweise Besuchsprogrammen erreicht werden. Ausgewählte Personen, bevorzugt (künftige) Opinionleader oder Multiplikatoren, sollten die Möglichkeit erhalten, sich auf direktem Weg ein Bild von der Entwicklung in der freien Welt zu machen, wobei mit ,freier Welt ${ }^{*}$ - unausgesprochen - natürlich die USA gemeint waren.

Intendiert war - wie aus einem Anhang mit dem Titel „Assumptions on which policy statement is based“ hervorgeht -, neben der vollständigen Entfernung aller nazistisch-militaristischen Personen aus dem öffentlichen Leben und aus allen Bildungs- und Wissenschaftseinrichtungen sowie der Eliminierung aller Reste nationalsozialistischen Propagandamaterials, vor allem der ökonomische Wiederaufbau und die fundamentale Veränderung der gesellschaftlichen Sozialstruktur in Richtung offener Demokratie. ${ }^{2271}$

Zentral an diesem, von US-Bildungsexperten unter Leitung von MacLeish ausgearbeiteten, zivilen Reeducation-Konzept - das an die Arbeit des „Instituts on Re-education of the Axis Countries“ anschloss - ist, dass es kein strategisches Planungsdokument des Kalten Krieges darstellt. Im Gegenteil: Die Verfasser waren davon überzeugt, dass ein umfassendes, demokratisches Rehabilitierungs-Programm nur umgesetzt werden kann, wenn es gelingt, einen gemeinsamen Nenner in der alliierten Besatzungspolitik zu finden, um dadurch die Gefahr einer ideologischen Instrumentalisierung demokratischer ReorientierungsBemühungen zu vermeiden, wie es im Zusammenhang anlaufender politischer Planungen zur Psychologischen Kriegsführung jedoch bald Realität des Kalten Krieges werden sollte:

"It was recognized that a basic policy directive in the field of education would be applicable not only to formal education in schools and universities but also to programs of adult education through mass media and otherwise. The Committee was acutely conscious of the danger that, unless the occupying powers agreed among themselves, Germany might be turned into a cockpit of an ideological war with serious future implications. It was felt, therefore, that every effort should be made to discover a common denominator of policy in this field which would be acceptable to all occupying powers." ${ }^{272}$ [Hervorhebung d. Verf.]

2270 NARA II, RG 165, Box 174, Coordinating Committee, Longe-Range Policy for German Reeducation (CC-59a), 13. Juni 1945, 3.

2271 Ebd., 2.

2272 The U.S. Occupation of Germany: Educational Reform 1945-1949, Microfilm-Collection, a.a. O., 1-A223, a.a. O. Archibald MacLeish, Longe-Range Policy for German Reeducation, 4. Juli 1945, 3. 
Obwohl bereits Ende Mai I945 ein Entwurf für eine konkrete Neuorientierung der Reeducation ausgearbeitet vorlag, ${ }^{273}$ verschwand dieser auf Grund von Kompetenzkonflikten zwischen State Department und War Department jedoch vorerst in der Schublade und das „Committee on German Re-education“ wurde aufgelöst. ${ }^{2274}$ OMGUS-Befehlshaber General Lucius D. Clay sah vorerst keine Notwendigkeit, die Vorschläge des State Department umzusetzen und die Reeducation-Politik unter neuer Leitung auf eine neue Grundlage zu stellen.

Erst Ende Februar 1946 wurde den Joint Chiefs of Staff (JCS) der streng geheime 2275 und leicht modifizierte Entwurf des Longe Range Policy Statements zur Begutachtung und Kommentierung - „from a military point of view“2276 - vorlegt, um es anschließend durch das „European Subcommittee“ des SWNCC umzusetzen.

Zusätzlich löste die zunehmende und teilweise heftige Kritik innerhalb der amerikanischen Öffentlichkeit über das Versagen der US-Entnazifizierungs- und ReeducationMaßnahmen in Deutschland im Frühsommer 1946 , insbesondere in Bayern, ${ }^{2277}$ schließlich einen Umdenkprozess aus. So hatte die New York Times im April unter dem drastisch gewählten Titel „Nazi Virus Thrives in American Zone. German Democrats Hounded, Racism thought by a Cabal Aiming at Resurgence“ geschrieben: „Elements hostile to everything for which the United States fought the war are still clinging to power in the American zone of occupation despite the denazification program. ${ }^{\text {"2278 }}$

Nun begann auch der OMGUS-Generalstab damit, die Angelegenheit zu untersuchen. So wurde Walter L. Dorn - Theologe und Spezialist für preußische Geschichte des I8. Jahrhunderts und unter anderem Mitarbeiter in der „Research \&Analysis Branch“ des OSS -

2273 The U.S. Occupation of Germany: Educational Reform 1945-1949, Microfilm-Collection, a.a. O., 1-A223 , a.a. O. Longe Range Policy Statement for German Re-Education. Draft by Committee on German Re-education, 28./29. Mai 1945.

2274 Tent, Mission on the Rhine, a.a.O., $34 \mathrm{f}$.

2275 Im geheimen Schreiben des JCS-Joint Secretariats heißt es diesbezüglich: „This document contains information affecting the national defense of the United States with the meaning of Espionage Act, 80 U.S.C., 31 and $32[\ldots]$. Its transmission or the revelation of its contents $[\ldots]$ to an unauthorized person is prohibited by law." The U.S. Occupation of Germany: Educational Reform 1945-1949, Microfilm-Collection, a.a.O., 1-A-223, a.a.O., J.C.S. 1067/17, 27 February 1946 (Secret), Joint Chiefs of Staff, Longe Range Policy Statement for German Re-Education. Note by the Secretaries, A.J. McFarland, C.J. Moore.

2276 Ebd., Memorandum by the Acting State Member, State-War-Navy Coordinating Committee.

2277 Zur sogenannten „Patton-Affäre“ vgl. Lutz Niethammer, Entnazifizierung in Bayern. Säuberung und Rehabilitierung unter amerikanischer Besatzung, Frankfurt a. Main 1972, $229 \mathrm{ff}$. Nach Aufhebung der Armeezensur für Interviews mit Generälen hatte der kommandierende General der 3. US-Armee, Smith Patton Jun., in Bad Tölz ein Presseinterview gegeben, das zu einem veritablen Skandal führte, indem Patton unverblümt und quasi in Cowboymanier aus der Schule plauderte, und die Entnazifizierung kritisierte, da sie den Aufbau behindere; schließlich, so Patton: „This Nazi thing is just like a democraticrepublican election fight." Zit. nach: Niethammer, Entnazifizierung in Bayern, a.a. O., 235.

2278 Raymond Daniell, Nazi Virus Thrives in American Zone. In: The New York Times, 22 April 1946, 1. 
im Juni I946 von General Clay zu seinem persönlichen Berater in Entnazifizierungsfragen ernannt und mit einer Inspektionsreise durch die US-Zone beauftragt: ${ }^{2279}$ eine Inspektion, die mit sachkundig-kritischem Blick durchgeführt wurde, und deren Endbericht entsprechend ernüchternde Resultate zu Tage förderte. Bereits im Mai hatte Dorn in einer Denkschrift über die „antidemokratische Reaktion in Bayern“ geschrieben:

\begin{abstract}
„Nach einem Jahr intensiver Entmilitarisierung und Entnazifizierung, die keinen Zweig des deutschen Lebens ganz unberührt gelassen haben, gewinnen antidemokratische und reaktionäre Kräfte wieder an Stärke. Es kristallisiert sich eine neonazistische, nationalistische und militärische Einstellung heraus. Das gilt besonders für Bayern, das konservativste Land der US-Zone [...]. Diese bayerische Reaktion drückt sich in einer ostentativen Sympathie für hinausgeworfene Nazis aus, in der notorischen Neigung, demokratische Institutionen, die ihr als fremd und korrumpierend gelten, lächerlich zu machen $[\ldots]$ “.2280
\end{abstract}

Es war dann insbesondere die Unzufriedenheit oberster Beamter des State Departments an der US-Militärregierung in Deutschland, ${ }^{2281}$ die schließlich zu einer Trendwende führte. So hatten Archibald MacLeish, Assistant Secretary of State for Public and Cultural Relations, seit langem intensiv mit Fragen der Reeducation befasst, ${ }^{2282}$ Robert D. Murphy, Leiter des „Bureaus for German Affairs“ im State Department und weitere US-Bildungsexperten $^{2283}$ neuerlich Kritik geäußert. Sie nahmen die unzureichende Ausstattung der

2279 OMGUS General Order No. 40 vom 10. Juni 1946: „Organization of Denazification Responsibilities“. In: OMGB Special Branch (Ed.), German Denazification Law and all Implementations and American Directives, 1947, D 7. Zit. nach: Walter L. Dorn, Inspektionsreisen in der US-Zone. Notizen, Denkschriften und Erinnerungen aus dem Nachlaß übersetzt und herausgegeben von Lutz Niethammer, (=Schriftenreihe der Vierteljahreshefte für Zeitgeschichte Nr. 26), Stuttgart 1973, 88.

2280 Dorn, Inspektionsreisen in der US-Zone, a. a. O., 79.

2281 Obwohl Österreich hier nicht eigens erwähnt wurde, kann keineswegs davon ausgegangen werden, dass die US-Militärregierung in Österreich von der Kritik ausgenommen wurde - aus Sicht der mit Reorientierungs-Fragen befassten Abteilungen des War und State Department war die Besatzungszone in Österreich quasi nur eine spezifisch kleindimensionierte, Verlängerung' der Planungseinheit Deutschland.

2282 Leish erstellte 1945 bspw. Listen hochkarätiger US-Bildungsexperten - auf diesen befand sich auch der Name von Hermann B. Wells -, die sich für "top jobs“ in der Reeducation eignen würden und war wiederholt Ansprechperson für zivile US-Beobachter und ihren Befürchtungen gegenüber den amerikanischen Reeducation-Aktivitäten nach erfolgten Fact-Finding-Missions in Deutschland, wie in folgendem Beispiel: „Twelve years of their lives [...] have been dominated by Nazi ideology. Twelve years in which a democratic thought was a crime against the state. [...] It seems to me that we are allowing ourselves to forget about the education $[\ldots]$ and do the re-education $[\ldots]$ of the German people." Edward O. Hascall to Archibald Leish, UNESCO, 25. Februar 1946, 1. Zit. nach: The U.S. Occupation of Germany: Educational Reform 1945-1949, Microfilm-Collection, a.a. O., 1-A-34.

2283 An der (marginalen) Überarbeitung des finalen Entwurftextes des „Longe Range Policy Statements“ waren Gordon Bowles, Leon Fuller und Eugene N. Anderson beteiligt. Vgl. Tent, Mission on the Rhine, a.a.O., 33 . 
OMGUS-Abteilung „Educational and Religious Affairs“ (E \& RA) sowie das generelle Fehlen einer demokratiepolitischen Perspektive zum Anlass, das noch immer zwischen den Gremien hin und her wechselnde Strategiepapier endlich als Planungs- und Handlungsdirektive einer Beschlussfassung durch das SWNCC-Coordinating Subcommittee for Europe zuzuführen.

In einem Memorandum, das Eugene N. Anderson ${ }^{2284}$ - mittlerweile zum Acting Chief der German-Austrian Branch im State Department avanciert - im April 1946 unter anderen Hans Speier vorlegte, um es dann in einer Sitzung des Advisory Committees zu diskutieren, wurde im Hinblick auf langfristig wirksame Reorientierungs-Maßnahmen vor allem die Notwendigkeit eines raschen Beginns von Personenaustausch-Programmen hervorgehoben.

Im Unterschied zur Auffassung leitender Offiziere der US-Education Division in Österreich, die - wie bereits dargestellt - das österreichische Universitätssystem in völlig unkritischer Distanz zur Realsituation mitunter geradezu in den ,akademischen Olymp hoben, war Anderson zu einem differenzierten Befund der restaurativen österreichischen Wissenschaftspolitik gelangt. Anlässlich einer vom „American Council of Learned Societies“ (ACLS) vorgeschlagenen und von Alonzo G. Grace als Leiter der „Education and Cultural Relations Division“ der US-Besatzungsmacht in Deutschland genehmigten Studienreise, die in den Monaten Mai bis Juli 1949 stattfand, diagnostizierte Anderson eine geistige Enge, die das österreichische und deutsche Geistesleben von innen und außen gleichermaßen bedrohe: „[...] the German and Austrian Academicians are the first victim of their own intellectual training “. 2285

Der ausführliche Abschlussbericht Andersons fasste neben Eigenbeobachtungen die Ergebnisse mehrstündiger Gespräche mit über 200 Universitätslehrern in Deutschland und über 30 Professoren und Dozenten ${ }^{2286}$ an den drei österreichischen Universitäten zusammen. Die Untersuchung kam zu einem ernüchternden Ergebnis hinsichtlich der angewandten Lehr- und Lernmethoden, des intellektuellen Selbstverständnisses der akademischen Elite, der vorhandenen Ausstattung mit relevanter Forschungsliteratur, der internationalen Kooperationsbereitschaft, dem Blick über die fachlichen Grenzen sowie

2284 Eugene N. Anderson (1900-1984), US-Historiker an der University of Chicago, der University of Nebraska und an der UCLA. Anderson war spezialisiert auf Deutsche Geschichte des 19. und 20. Jahrhunderts. Anfang der 1930er-Jahre kam er bei seinen Forschungsarbeiten in Berlin mit Friedrich Meinecke in Kontakt und war mit dessen Schülern befreundet. Im Zweiten Weltkriegs wurde Anderson 1944 als Nachfolger von Walter Dorn zum Leiter der Mitteleuropaabteilung der „OSS Research and Analysis Branch“. Siehe: Gerhard A. Ritter (Hrsg.), Friedrich Meinecke. Akademischer Lehrer und emigrierte Schüler. Briefe und Aufzeichnungen 1910-1977, München 2006, 318, Anm. 21.

2285 Eugene N. Anderson, The Humanities in the German and Austrian Universities, Washington D.C. 1950, 86-97. Hier zit. nach: Wagnleitner, Coca-Colonisation, a.a.O., 194.

2286 Sowohl in Deutschland als auch in Österreich bestand jeweils ein Drittel der Befragten aus Angehörigen der amerikanischen, französischen oder der britischen Militärbehörden. 
hinsichtlich der allgemeinen Einschätzung gegenüber der Notwendigkeit universitärer Reformen.

Der Fokus dieser investigativen Untersuchung war mit Bedacht auf die Situation der Geisteswissenschaften („humanities“) gerichtet, wobei neben traditionell geisteswissenschaftlichen Disziplinen wie Philosophie, Philologie, Literaturwissenschaft und Geschichte auch Jurisprudenz, Nationalökonomie sowie Naturwissenschaften mit in den Blick genommen wurden. Diesen akademischen Disziplinen komme, so Anderson, besonders großer Reformbedarf zu, zumal die politisch-gesellschaftlichen Schwierigkeiten der jüngeren Vergangenheit nicht im Bereich von Technik und Formalwissenschaften („science") ihren Entstehungsgrund gehabt hätten, sondern vielmehr in jenen akademischen Fächern, wo mitunter auch individuelle Werteinstellungen, gesellschaftliche Moralvorstellungen und Stereotype - wie explizit oder unterschwellig auch immer - hineinreichen. ${ }^{2287}$

Obwohl die Ergebnisse für Deutschland und Österreich ähnlich ausfielen - hier wie dort käme den Geisteswissenschaften aufgrund des Fehlens sozialwissenschaftlicher Ansätze und der Dominanz gesellschaftsferner Historizität primär „dekorativer“ Charakter zu, denn gesellschaftliche Funktion -, zeigten sich auch Unterschiede insbesondere hinsichtlich der finanziellen Ressourcen ${ }^{2288}$ sowie der Einflussmöglichkeiten gegenüber der, die geistige Isolation tendenziell perpetuierenden Ministerialbürokratie:

\footnotetext{
"University administration remains so sketchy and amateur that the ministry in Vienna wields far too much influence. The lack of initiative on the part of the professors in university reform in curriculum, methods of teaching, research, and career training can hardly cause surprise. The professors do not have adequate administrative stimulation for cooperative activity in these matters and for exerting concerted pressure upon ministry. The few Dozenten [sic] in each university thinking along modern lines have less influence than their colleagues in the German universities."2289
}

Und hinsichtlich der von Behörden und Regierungsstellen verursachten „economic handicaps“ im Bereich der wissenschaftlichern Lehre - eine Passage, der ein gewisser Aktuali-

2287 Eugene N. Anderson, The Humanities in the German and Austrian Universities, Washington D.C. 1950, 5. Für die Zurverfügungstellung einer Kopie des Berichtes danke ich an dieser Stelle meinem Kollegen Mag. Robert Stumpf.

2288 Die großen Einkommensunterschiede zwischen Österreich und Deutschland - im Wesentlichen eine Relation in der Größenordnung von 1 zu 2,6 - beziffert der Bericht folgendermaßen: „At the University of Vienna, a Privatdozent receives about 150 schillings a month, or less; in Heidelberg he may receive as much as $\mathbf{3 0 0}$ marks or more, a remuneration which Vienna cannot afford. (The schilling is worth about one-third of a mark.) A full professor receives about 2000 schillings a month in Vienna; in Graz from 1200 to 1600, in Innsbruck, about the same." Anderson, The Humanities in the German and Austrian Universities, a.a.O., 82.

2289 Ebd., 81. 
tätsbezug nicht abgesprochen werden kann - führt der I950 publizierte Bericht Andersons weiter aus:

"The government controls the purchase of foreign works so rigidly that, at least in the humani-
ties, the Austrians complain of being more isolated than at the close of the war. [...] A profes-
sor at one of the universities is teaching contemporary philosophy with almost no material on
British and American thought of the past hundred years. The examples of isolation could be
multiplied, and as long as the government remains so parsimonious in making funds available
to libraries, Austrian scholarship will be dependent, for its foreign publications, upon gifts and
exchanges. [...] Government officials in Austria seem to have forgotten that they once learned some-
thing from a book, that publications, both domestic and foreign, are essential to intellectual activity,
that our civilization is built on knowledge, and that the intellectual starvation and isolation of the
universities will ruin the future of their people." 290 [Hervorhebung d. Verf.]

Besonders problematisch bewertete Anderson in seinem Report an die ACLS - dies mit durchaus selbstkritischem Blick auf die Rolle und die Aktivitäten der amerikanischen Besatzungmacht -, dass in der bisherigen Zeitspanne seit Kriegsende, trotz prinzipiell vorhandener politischer Freiheiten, die Möglichkeit zu einer grundlegenden Reform des Universitätssystems vollständig verabsäumt wurde und sich anstelle dessen sowohl im Bereich der Ministerialbürokratie als auch an den Universitäten eine vormoderne, restaurative Geisteshaltung konservieren konnte, ${ }^{2291}$ der eine potenzielle Mitverantwortung oder gar Mitschuld am Nationalsozialismus nicht einmal ansatzweise in den Blick kam, zu groß waren die Abwehr- und Verdrängungsmechanismen: „The split between idea and practice was unwittingly revealed in many conversations concerning the personal behavior of the people under Nazism. [...] One rarely found an individual who understood the ethical dilemma which he had brought upon himself. Usually the intellectual seemed to be unwilling to admit his own share in helping the Nazis whose ultimate world victory he would have deplored."2292

\section{Ebd., $84 \mathrm{f}$.}

2291 „In contrast to Germany, up to the present time (summer 1949) Austria has had a central government, which could be expected to assist in the revival of intellectual activity, to stir the personnel to action, to provide essential funds and to see that they are well spent. That the government has done very little in this respect cannot be attributed to penury alone [...] As a liberated nation, Austria under effective leadership could have decided on the most useful way to employ its limited funds; it had officials in a position of sufficient freedom to take the initiative in working out policies for the reform of higher education and for persuading and enabling the intellectuals in the universities to consider their function in Austria and Western society. [...] The future of Austrian cultural life, particularly in the humanities, threatens to be the victim of a policy based upon thinking of the years prior to the airplane, the rocket, and the atomic bomb. In addition, each of the three resident western powers has kept the Austrian in its zone relatively isolated from the culture of the other two powers. [...] Cooperation in cultural affairs among the three porwers is a markedly absent in Austria as in Germany." [Hervorhebung d. Verf.]. Ebd., $86 \mathrm{f}$.

2292 Ebd., $97 \mathrm{f}$. 
Vor dem Hintergrund zahlreicher Aussagen deutscher und österreichischer Universitätslehrer, die, trotz ihrer Karriere während der NS-Zeit, auf der sozialen Unverantwortlichkeit der Intellektuellen in der Zeit des Nationalsozialismus beharrten, skizzierte Anderson abschließend mit großer prognostischer Treffsicherheit ein mögliches Gefahrenszenario hinsichtlich der politischen Verlässlichkeit des akademischen Lehrpersonals, das aus dem Gefühl der Unverantwortlichkeit sowie aus der nur unzureichend beziehungsweise zu wenig differenziert durchgeführten Entnazifizierung erwachsen könnte, nämlich ein neuerlicher intellektueller Rückzug aus öffentlicher Verantwortung sowie die Abneigung, sich mit dem Thema Nationalsozialismus auf akademischen Boden inhaltlich konkret auseinanderzusetzen:

"Two great dangers arise out of this situation. The first is related to the failures of the United States and the British in de-nazification. We are the countries of common law, of equity, of defense of the rights of each individual, yet in de-Nazification we attempted to solve a problem calling for the exercise of our best judgment by applying a few general categories and statistical averages to a highly complex situation. We violated our own tradition. We showed no appreciation for the complexity of motives involved in nonresistance and for the difficulty of gauging individual responsibility in each case, especially among th academic group. After confusing the whole matter, we dumped the problem into the lapse of the ill-prepared Germans and Austrians.We and they for years to come will have to live with the effects, namely, a sense of injustice, a desire to shrink from responsibility in public life, an endeavor once again to survive by being politically neutral. We have augmented the academic curse of the urge to separate knowledge and life. The second danger in the present frame of mind of the intellectuals is seen in their disinclination to teach about Nazism or Communism except as theory."2293

Soweit das wissenschaftspolitische Resümee des US-Experten Eugene N. Anderson zur Situation an den österreichischen Universitäten im Jahr 1949 gegenüber dem American Council of Learned Societies (ACLS).

Ein weiterer, streng vertraulicher Bericht des U.S. Department of State, der bereits im März 1946 an Anderson ergangen war, kam hinsichtlich der aktuellen Situation des geistig-kulturellen Wiederaufbaues - allerdings unter ausschließlicher Bezugnahme auf Deutschland, was dennoch Rückschlüsse auf die österreichische Situation zulässt - zu einer ähnlich kritischen Einschätzung. Das Memorandum, das Frederick H. Burckhardt² ${ }^{229}$

2293 Ebd., 99.

2294 Frederick H[enry] Burckhardt (1912-2007), Sohn deutscher Einwanderer, war Pädagoge am Bennigton College sowie an der New York State University und zudem Vorsitzender des „American Council of Learned Societies“ (ACLS). Ab 1946/47 war Burckhardt Mitarbeiter des State Department im Rahmen der „Cultural-Exchange Programs“. Siehe: Frederick H. Burckhardt, a Prominent Educator, dies at 95. In: New York Times, 5. Oktober 2007. 
im Auftrag des Department of State verfasst hatte, spricht von einem grassierenden Zynismus in Bezug auf intellektuelle und moralische Werte innerhalb der deutschen Jugend und konstatiert des Weiteren:

"At present, the collective mentality of German youth, insofar as it does not remain nationalistic, must be considered an intellectual vacuum. [...]

Up to the present time no such systematic reorganization of the bases of German education has been attempted in the western occupation zones. Survival of traditional conservativenationalist outlook of the German universities is apparent from reports of nationalist student manifestations which have occurred at several of these institutions [...] with the result that the nationalistically-minded upper and middle classes continue to form the great majority of German university students. [...]

Moreover, the de-Nazification of the teaching staffs of the universities has not resulted in any substantial alteration of their fundamental outlook. [...] The de-Nazification undertaken since the Nazi collapse has concentrated on the removal of members of the Nazi Party, with the result that the university faculties are now composed mainly of scholars who were not Nazis, but belonged to the old conservative camp [...]". 2295 [Hervorhebung d. Verf.]

Unter den spezifischen Voraussetzungen der unmittelbaren Nachkriegszeit sprach das Memorandum insbesondere allen Formen freier Erwachsenenbildung š anders als es in der Vergangenheit der Fall gewesen $\operatorname{sei}^{2296}$ š einen zentralen Stellenwert zu:

"Information on recent events is necessary not only for young people but also for adults, who have been separated from the outside world for more than ten years. Adult education, evening schools, week-end and holiday camps, may therefore be more important for shaping of public opinion than under ordinary circumstances." ${ }^{2297}$

2295 "Notes on the Problem of American Aid to Education in Post-War Germany“. Office Memorandum, US Government from Frederick H. Burckhardt (EAI) to Eugene N. Anderson (OIC), 28. März 1946. Zit. nach: The U.S. Occupation of Germany: Educational Reform 1945š 1949, Microfilm-Collection, a.a. O., $1-A-365,2 f$.

2296 Das Urteil hinsichtlich der geringen Wirksamkeit deutscher Erwachsenenbildung in der Weimarer Zeit und davor ist als grob verzeichnet anzusehen, jedenfalls von geringer Sachkenntnis getragen: „[...] German adult education in the past never has had great influence; the Volkshochschulen, especially, were usually far more leisure than educational institutions. The education provided was on the whole superficial, and quite frequently conformist. The more serious work was done at professional and political schools, like those connected with the trade-unions, the crafts and the political parties." Ebd., 12. [Unterstreichung im Original]

2297 Ebd. 
Einen spannenden Einblick in die akademisch-universitäre Anfangsphase der Zweiten Republik geben auch zwei Reiseberichte amerikanischer Österreich-Besucher, die Christian Fleck recherchiert und bereits dokumentiert hat, aus denen hier wegen der darin enthalten pointierten Stellungnahmen aber doch ein wenig ausführlicher zitiert werden soll. Der erste Bericht wurde von den beiden US-Sozialwissenschaftern Philip E. Mosely und Norman S. Buchanan im Auftrag der Rockefeller Stiftung in New York verfasst, die darin Eindrücke ihres Aufenthaltes im Juli 1947 in Österreich wiedergaben. Ausgehend von der Beobachtung, dass es der österreichischen Regierung offenbar gelinge, als besetztes Land „die vier ,Elemente“ gegeneinander auszuspielen“, ${ }^{2298}$ beschrieben die Visitatoren in ihrem Bericht Raunzen, Initiativlosigkeit und den Hang zu Ausreden als charakteristische Elemente des österreichischen Habitus. Hinsichtlich der Situation an den österreichischen Universitäten konstatierten die US-Sozialwissenschafter, dass diese, bedingt durch die Emigration und Vertreibung sowie die Entnazifizierungsmaßnahmen einen „Mangel an Talenten“ aufweisen und insgesamt einen „traurigen Eindruck“ abgeben, der „dadurch noch verstärkt werde, dass junge Wissenschafter mittleren Alters ,einfach fehlten “ “.2299

Weitere, überaus detaillierte Berichte verfasste der US-Physiker Robert J. Havighurst - er hatte sich auch mit vergleichenden Bildungsstudien befasst und sprach zudem Deutsch anlässlich zweier Reisen nach Österreich für die Rockefeller Stiftung: die erste im Sommer I947, die zweite ein Jahr später. Seine Berichte und Tagebuchaufzeichnungen geben ein erschütterndes Bild von der „Malaise der österreichischen Universitäten der Zweiten Republik und die Vergeudung von Humankapital durch den Protektionismus konservativer Verbände wie eben jenes CV““ ${ }^{2300}$ Besonders fiel Havighurst bei seinen zahlreichen Gesprächen auf universitärer Ebene, die er in seinen Berichten zum Teil dokumentiert finden, die akademisch-ministeriale „Großmannssucht“ sowie das allgegenwärtige „Desinteresse an wissenschaftlicher Forschung “2301 ins Auge. Anlässlich eines Gespräches mit Sektionschef „Baron Otto Skrbensky“, der sich dafür gerade einmal zehn Minuten Zeit nahm, teilte dieser dem amerikanischen Wissenschaftsemissär mit, wo es seiner Ansicht allenfalls Förderbedarf gäbe:

"[...] there were many small needs in Austria with which he thought the RF [Rockefeller Foundation, d. Verf.] should not be bothered [sic]. As the economic basis becomes stronger, these will be met automatically. But there are certain substantial projects that he would like to command to RF attention. First would be a great Library, perhaps to be called the "Rockefeller Library", to house the present National Bibliothek and the Universitaets Bibliothek". ${ }^{2302}$

2298 Christian Fleck, Österreichs Wissenschaften in den Augen amerikanischer Besucher. In: Thomas Fröschl/Ursula Prutsch (Hrsg.), Österreich und die Amerikas (=Wiener Zeitschrift zur Geschicbte der Neuzeit, 5. Jg., 2005, Heft 1), 120.

2299 Ebd., 120.

2300 Ebd., $123 \mathrm{f}$.

2301 Ebd., 124.

2302 Ebd., $124 \mathrm{f}$. 
Wie Fleck resümiert, versuchte Skrbensky dem amerikanischen Besucher ein „Großprojekt schmackhaft“ zu machen, „das von geringem Nutzen für die darniederliegende Forschung sein würde, statt konkrete und lösbare Anliegen zu nennen, über deren Vorhandensein er nicht in Unkenntnis gewesen sein konnte, da alle anderen österreichischen Gesprächspartner Havighursts ihn mit solchen geradezu bombardierten. “2303

Besonders bedenklich erschien Havighurst die Lage an der Wiener Universität, die ihm, bis auf wenige Ausnahmen, vorwiegend von älteren Professoren dominiert schien, die sich „einzig für die Veröffentlichung ihrer in der Vergangenheit geschriebene Arbeiten interessierte[n]“. ${ }^{2304}$ Zum Zweck einer notwendigen, stärkeren Orientierung Österreichs an der internationalen Scientific community empfahl er daher Auslandsaufenthalte für Studenten sowie eine bessere Förderung junger Wissenschafter. ${ }^{2305}$ In Auswertung der Berichte und Reiseeindrücke der genannten US-Wissenschaftsemissäre resümiert Fleck, dass sich - im Unterschied zu den westlichen Besatzungszonen Deutschlands, wo dem Wiederaufbau des Universitätssystems seitens der Alliierten weitaus größere Aufmerksamkeit geschenkt wurde - in Österreich die Rekonstruktion des Hochschulwesens ohne aktive Einflussnahme der Besatzungsmächte vollzog:

„Sich selbst überlassen, kamen an Österreichs Universitäten jene Kräfte ans Ruder, denen es vor allem um eine Restauration vermeintlich vergangener Größe ging. Die Folge davon waren die Rückkehr von Nationalsozialisten und eine nahezu vollständige Abkoppelung von den wissenschaftlichen Entwicklungen in den westlichen Ländern, die begleitet war von einer neuen Welle der Abwanderung junger Intellektueller, wie beispielsweise von Paul Feyerabend und Heinz Foerster. “2306

Soweit der ungeschönte, im Grunde dramatische Befund über den Zustand des österreichischen Universitäts- und Bildungswesens jener Zeit, dessen gesamtgesellschaftliche Auswirkungen wohl auch heute noch keineswegs vollständig überwunden sind.

In einem Memorandum des Department of State vom Mai I946 wurde das bisherige, primär auf Negativmaßnahmen setzende militärische „Stars and Stripes reeducation pro-

2303 Ebd., 125.

2304 Ebd., 125.

2305 Ebd., 125. Ähnliche Beobachtungen machte auch der in die USA emigrierte österreichische Ökonom Friedrich Hayek (1899-1992), der, ebenfalls finanziert durch die Rockefeller Foundation, bis 1948 insgesamt sieben Mal nach Österreich reiste, und keinen guten Eindruck von der „moralischen Situation“ und der Qualität des Lehrpersonal an den österreichischen Universitäten mitnahm. Vgl. Ebd. 131.

2306 Ebd., 127. Spätere Neugründungen im außeruniversitären Bereich wie bspw. das 1963 in Wien ins Leben gerufene „Institut für Höhere Studien“ vermochten an dieser Situation nur wenig zu ändern. Vg1. dazu: Christian Fleck, Wie Neues nicht entsteht. Die Gründung des Instituts für Höhere Studien in Wien durch Ex-Österreicher und die Ford-Foundation. In: Österreichische Zeitschrift für Geschichtswissenschaften, 11. Jg., 2000, Heft 1, 129-177. 
gram“ der USA š das mittlerweile selbst von OMGUS-General McClure kritisch kommentiert wurde š als gescheitert betrachtet:

"Stars and Stripes does disservice to the American reeducation program. With its emphasis on sensationalism and its failure to stress the democratic ways of life of the common American it misrepresents the United States [...]. Our information and education policies are predominantly negative in character: both on the policy and the operating levels it is relatively easy to reach agreement and get action on matters of de-Nazification and de-militarization. It is difficult to promote a positive program." ${ }^{2307}$ [Unterstreichung im Original]

Das Department of State urgierte daher die umgehende „Zivilisierung“ („Civilianization“) aller Reorientierungs-Aufgaben und die Ausarbeitung eines zivilen Langzeit-Demokratisierungsprogramms, das sowohl Medien- als auch Bildungs- und Kulturpolitik umfassen sollte:

\section{"In principle it appears reasonable not to attempt to demilitarize the minds of a conquered nation by means of a military organization. It is, therefore, desirable, in principle, that the work in the fields of information control, education, and religious affairs in Germany be turned over as soon as possible from the Office of Military Government to a civilian agency."2308}

Übernommen sollte diese Aufgabe einer nationalen Rekulturalisierung freilich š unter der Voraussetzung einer entsprechenden Personalaufstockung š vom State Department selbst werden, ${ }^{2309}$ wobei es galt, die negativen Auswirkungen der langjährigen geistigen Isolation durch das NS-Regime insbesondere durch die Intensivierung entsprechender kulturelle Außenkontakte zu überwinden. ${ }^{2310}$

Die hier vorgeschlagene internationale Öffnung galt insbesondere auch für den akademisch-universitären Bereich. Akademische Austauschaktivitäten auf breiter Basis sollten, so der Tenor, künftig dazu beitragen, verkrustete universitäre Strukturen aufzubrechen und einer modernen Lern- und Lehrkultur nach amerikanischem Vorbild zum Durchbruch zu verhelfen, und darüber hinaus eine weltoffene, anglophile Führungselite in den Bereichen Medien, Wirtschaft und Politik zu verankern.

Unterstützt durch eine Reihe privater amerikanischer Institutionen sollten sorgfältig ausgewählte Führungspersönlichkeiten und Studenten einige Monate in den Vereinigten

2307 NARA II, RG 59, Assistant Secretary, Box 6. Department of State Washington D.C., Memorandum „Immediate and Future Responsibilities of the Department of State for the Reeducation of Germany“, 28. Mai 1946, 5.

2308 Ebd., 7.

2309 „The Department of State must also plan in the realization that at some future date, as yet undetermined, it might be called upon to take over the functions in the fields of information, education, religious and cultural affairs, for which OMGUS is now responsible." Ebd., 1.

2310 Ebd., $1 f$. 
Staaten verbringen und auf diese Weise zu Proponenten eines demokratischen Gemeinwesens werden: „The advantage of bringing over leaders and students of well known antiNazi standing would lie in enabling these persons to re-acquaint themselves with the ways of a democratic society“, wobei Anderson - wohl angesichts nach wie vor vorhandener anti-amerikanischer Ressentiments - bereits im Vorfeld auf mögliche Probleme in der öffentlichen Reaktion hinwies: „[...] the receptivity of the idea to the American public, the possible danger to the prestige of the Germans after their return home [... “ “. 2311

Im Hinblick auf die inhaltliche Begründung des geplanten Reorientierungs-Programms für Deutschland, das freilich in gleicher Weise für Österreich gelten würde - „the same line would apply for the Austrians“-, sprach sich Anderson für eine möglichst freiwillige, nicht auf Zwang, sondern auf Überzeugungsarbeit basierende Vorgehensweise aus, denn „a too rigid program might defeat its own purpose. “2312 Wie aus dem Anderson-Memorandum hervorgeht, zielte das Reorientierungs-Vorhaben tatsächlich auf eine profunde Demokratisierung aller gesellschaftlichen Bereiche:

"That there are certain psychological attitudes of the Germans, such as political docility and authoritarianism, which our program should aim to influence in a democratic way. The influence should be exerted not merely on the behavior of the Germans but also on the institutions which at present maintain these attitude." ${ }^{2313}$

Zu diesem Zweck sollten künftig auch US-Experten in Deutschland und Österreich eingesetzt werden - für 1947 sah das Budget des War Departments 250 solcher Experten vor -, um amerikanische Erziehungsmethoden, Diskussionsformen und demokratischere Verfahren den spezifischen Gegebenheiten und Bedürfnissen auf lokaler, regionaler und nationaler Basis anzupassen: „The German will need to adapt the American forms to their own special needs, and no blueprint for precise use in Germany can be prepared in this country. "2314

Interessant ist, dass auch in den Textentwürfen für das „Longe Range Policy Statement“ explizit festgehalten wurde, dass dessen inhaltliche Bestimmungen - insbesondere im Hinblick auf die projektierten Austauschprogramme - auch für Österreich galten. ${ }^{2315}$ In einem eigenen, Österreich betreffenden „Appendix B“ - „United States policy on exchange of

2311 Eugene N. Anderson, Department of State [ADO] to Leverich and Speier, 9. April 1946, 1. Zit. nach: The U.S. Occupation of Germany: Educational Reform 1945-1949, Microfilm-Collection, a.a.O., 1-A-36.

2312 Eugene N. Anderson, Department of State [ADO], Memorandum, to Leverich and Speier (for Hilldring), 5. April 1946, 3. Zit. nach: The U.S. Occupation of Germany: Educational Reform 1945-1949, Microfilm-Collection, a.a.O., 1-A-36.

2313 Ebd., 2.

2314 Ebd., 1.

2315 The U.S. Occupation of Germany: Educational Reform 1945-1949, Microfilm-Collection, a.a.O., 1-A-223, a.a.O., Longe Range Policy Statement for German Re-Education (a. SWNCC 269; b. SWNCC 269/4/D). Memorandum by the State-War-Navy Coordinating Subcommittee for Europe, Appendix B. 33. 
cultural material between the United States and Austria“ - wurde unter neuerlicher Bezugnahme auf die Moskauer Deklaration sowie auf das Kontrollabkommen des Alliierten Rates vom 28. Juni 1946 das bildungspolitische Ziel der Vereinigten Staaten in Österreich formuliert: „To ensure the institution of a progressive long-term educational program designed to eradicate all traces of Nazi ideology and to instill into Austrian youth democratic principles. “ Erreicht werden sollte dies insbesondere durch die „speedy restoration of normal cultural relations with Austria. “2316 [Hervorhebung d. Verf.]

Das „Longe Range Policy Statement“ wurde schließlich am 2I. August 1946 vom StateWar-Navy Coordinating Committee als „Policy Statement 269/5“ (SWNCC 269/5) als offizielles Planungsdokument veröffentlicht und bis Oktober 1946 noch mehrmals geringfügig modifiziert; insbesondere die hart formulierten Passagen der ursprünglichen Fassung wurden überarbeitet beziehungsweise gestrichen. Das Dokument erklärte jedenfalls erstmals und ab sofort die Reeducation zum zentralen Kern der US-Reorientierungs-Politik. Darin heißt es unter anderem:

"The reeducation of German People can be effective only as it is an integral part of a comprehensive program for their rehabilitation. The cultural and moral reeducation of the nation must, therefore, be related to policies calculated to restore the stability of a peaceful German economy and to hold out hope for the ultimate recovery of national unity and self-respect. In the initial phases of control, Military Government has been concerned with the elimination of Nazi and militaristic doctrines and practices and the permanent exclusion of objectionable persons from posts of influence. At the same time, a program for the reconstruction of German cultural life has been initiated.

The political and moral re-education of the German people will foster the re-establishment of universally valid principles of justice." 2317

Zusätzliche Unterstützung erhielt die neue Perspektive der US-Besatzungspolitik durch die Ergebnisse der sogenannten zivilen „Zook-Kommission“ („United States Education Mission of Germany“), die im August 1946 die US-Besatzungszone in Deutschland bereiste und dabei den Status quo der kulturellen und bildungsbezogenen Wiederaufbaumaßnahmen inspizierte. Die Kommission, der elf US-Bildungsexperten angehörten, ${ }^{2318}$

2316 Ebd., 45.

2317 Zit. nach: Velma Hastings Cassidy (Ed.), Germany 1947-1949 (Department of State Publication 3556. European and British Commonwealth Series 9), Washington D.C. 1950, $541 \mathrm{f}$.

2318 Neben renommierten US-Erziehungswissenschaftern wie Bess Goodykoontz, Paul M. Limbert, Earl J. McGrath, Pater Felix N. Pitt, Lawrence Rogin und Helen C. White, befanden sich der evangelische Theologe Reinhold Niebuhr, Eugene N. Anderson vom US-State Department sowie die beiden deutschen Emigrés und Reformpädagogen Franz Hilker und Erich Hylla unter den Kommissionsmitgliedern. Vgl. Birgit Braun, Umerziehung in der amerikanischen Besatzungszone. Die Schul- und Bildungspolitik in Württemberg-Baden von 1945 bis 1949 (Geschichte, Bd. 59), Münster 2004, 30. 
stand unter Leitung von George F. Zook und zeigte sich nach der einmonatigen Studienreise schockiert über den chaotischen Zustand und die nach wie vor von nationalsozialistischen Einflüssen und Untertanengeist keineswegs bereinigte Bildungslandschaft. ${ }^{2319}$

Im Endbericht der Kommission, der in hoher Auflage gedruckt, auch auf Deutsch publiziert wurde und erstmals die breite Öffentlichkeit über die geplante US-Reeducation informierte, wurde die zentrale Bedeutung der Reeducation für einen demokratischen Wiederaufbau betont, die bisherigen Maßnahmen kritisiert und Vorschläge für eine entsprechend neu gewichtete US-Besatzungspolitik unterbreitet. ${ }^{2320}$ So sollten insbesondere die Curriculum-Gestaltung an Schulen, die Lehrerausbildung, die Einführung sozialwissenschaftlicher Lehr- und Lernmethoden, die Jugendarbeit und die Supervision der Universitäten im direkten Kontakt und Gedankenaustausch mit US-Experten diskutiert und verbessert werden, wobei die Verantwortung - im Sinne eines demokratischen Neubeginns - bei den Deutschen (beziehungsweise bei den Österreichern) selbst liegen sollte. Nachdem George F. Zook bereits mehrmals Vorschläge für den raschen Beginn eines groß angelegten Austauschprogramms unter Einbeziehung privater USBildungseinrichtungen unterbreitet hatte, ${ }^{2321}$ wurde im Bericht der Zook-Kommission neben dem darin enthaltenen Plädoyer für die Einrichtung einer Einheitsschule nach dem Muster der amerikanischen „comprehensive school“2322 - insbesondere der Aufbau eines Experten-Austauschprogrammes hervorgehoben, das abgesehen von staatlichen Stellen auch von privaten Geldgebern beziehungsweise Organisationen finanziert werden sollte. ${ }^{2323}$

\section{ELITENBILDUNG ÜBER „AUSTAUSCHPROGRAMME“: ZENTRALES ELEMENT DER BESATZUNGSPOLITISCH AUFGEWERTETEN US-REORIENTIERUNG AB I947/48}

Obwohl der amerikanische Kongress bereits am I. August 1946 mit dem „Fulbright Act“ (Public Law 584 of the 79 th Congress) ${ }^{2324}$ eine gesetzliche Grundlage für ein globales

\section{Ebd.}

2320 In der deutschen Fassung erschien der umfangreiche Kommissionsbericht, der eine Auflage von über 130.000 Exemplaren erreichte, unter dem Titel „Der gegenwärtige Stand der Erziehung in Deutschland. Bericht der amerikanischen Erziehungskommission“. Hrsg. v. Der Neuen Zeitung, München 1946.

2321 Siehe: Herman B. Wells, Being Lucky. Reminiscences \& Reflections, Bloomington 1980, 311.

2322 Siehe dazu: Winfried Müller, Schulpolitik in Bayern im Spannungsfeld von Kultusbürokratie und Besatzungsmacht 1945-1949, München - Wien - Oldenbourg 1995, 136.

2323 Henry J. Kellermann, Cultural relations as an Instrument of U.S. Foreign Policy. The Educational Exchange Program between the United States and Germany 1945-1954 (= Department of State Publication 8931), Washington D.C. 1978, $23 \mathrm{f}$.

2324 Der „Fulbright Act“ beinhaltetet die Verwendung der durch den Verkaufserlös überschüssigen US-Militärausrüstungsmaterials im Ausland eingenommenen Fremdwährungsguthaben für einen weltweiten 
Kulturaustausch-Programm auf bilateraler Grundlage geschaffen hatte, war diesem akademischen Transferprojekt zunächst kein nennenswerter Erfolg beschieden. ${ }^{2325}$ Das wohl auch deshalb, weil, wie Oliver M. Schmidt konstatiert, der Zeitpunkt dieses Vorhabens, das auf die ,promotion of international good will through the exchange of students in the fields of education, culture, and science “2326 zielte, dafür einfach zu früh gesetzt war: „[...] government circles and army officials concluded, that it was too early to extend such a deeply symbolic gesture of good will towards the defeated enemy. “2327 Erst die besatzungspolitische Aufwertung der Reorientierung als zentraler US-Besatzungsagenda und deren sukzessive Einbettung in großangelegte Planungszenarien psychologischer Kriegsführung im Zusammenhang mit dem Kalten Krieg führten schließlich zur Umsetzung im großen Maßstab. Dabei wurden von amerikanischer Seite sowohl die gesetzlichen Rahmenbedingungen erweitert, als auch die entsprechenden finanziellen Mittel bereitgestellt.

Mit der übergreifenden SWNCC-Direktive 269/8 vom 3r. März I947 waren nun erstmals nach Kriegsende wieder Auslandsaufenthalte von Deutschen (und Österreichern) in den Vereinigten Staaten auf regulärer wechselseitiger Basis möglich: ${ }^{2328}$ „SWNCC 269/8 provides for the interchange of persons between Austria and the United States and Germany and the United States [... “. 2329

Das Überprüfungsverfahren für die Ausstellung einer befristeten Aufenthaltsgenehmigung konnte zu Beginn allerdings bis zu neun Monate dauern. Zu entscheidenden Erleichterungen, die diese Verfahren auf zwei Wochen abkürzten, kam es erst durch entsprechende Erlässe der US-Militärregierung im Zuge der anlaufenden kulturellen Austauschprogramme I948. ${ }^{2330}$

akademisch-universitären Austausch zwischen den Vereinigten Staaten von Amerika und rund 20 anderen Ländern. Siehe: Trading Ideas with the World. International Educational and Technical Exchange. Report of the United States Advisory Commission on the Educational Exchange, 31. März 1949, 3.

2325 Das Fulbright-Austauschprogramm verlief auch hinsichtlich der quantitativen Beteiligung innerhalb der ersten zehn Jahre in vergleichsweise bescheidenem Rahmen: bis 1951 nahmen weltweit insgesamt lediglich 4.000 Personen am Fulbright-Programm teil. Siehe: Educational Exchange. Under the Fulbright Act. Department of State Publication 3637. International Information and Cultural Series 9, Dezember 1949, $1 \mathrm{ff}$.

2326 Randall Bennet Woods, J. William Fulbright, Vietnam and the Search for a Cold War Foreign Policy, Cambridge/New York 1998, 9; siehe weiters: Arthur Power Dudden/Russel R. Dynes, The Fulbright experience. Encounters and Transformations. Foreword by J. William Fulbright, New Brunswick 1987, 1.

2327 Schmidt, Civil Empire by Co-optation, a.a.O., 302.

2328 Im angesprochenen SWNCC-Dokument lautet der diesbezügliche Passus: „[...] to permit and encourage the revival of visits of Germans to the United States [...] and of persons from the United States to Germany“. Zit. nach: Wells, Being Lucky, a.a.O., 311.

2329 Daniel Noce, Major General, GSC, Chief, Civil Affairs Division, Standard Operating Procedure (SOP), Interchange of Persons Program, 5. Mai 1947, 1. Zit. nach: The U.S. Occupation of Germany: Educational Reform 1945-1949, Microfilm-Collection, a.a. O., 1-A-36.

2330 Vgl. Schmidt, Civil Empire by Co-optation, a.a. O., 90. 
Im unmittelbaren Zusammenhang mit dem Longe Range Policy Statements versandte das US-Department of War bereits im Juli 1947 Serienbriefe an eine Vielzahl privater Organisationen in den Vereinigten Staaten, da eine finanzielle Bedeckung durch US-Regierungsmittel nicht möglich war. ${ }^{2331}$

Im offiziellen Schreiben des unterzeichnenden Assistant Secretary of War, der die neue, von den zivilen Experten des State Department ausgearbeitete Position zur Gänze widerspiegelt, heißt es:

"In accordance with the published policy, the United States Government will permit and encourage the revival of visits of Germans and Austrians to the United States [...]. It is recognized that the Nazi heritage of Germany's spiritual isolation must be overcome by restoring as rapidly as possible those cultural contacts which will foster the assimilation of the German people into the society of peaceful nations. [...] To plan such a program, it is essential that the available private resources for scholarships and funds for maintenance and transportation be ascertained. Private participation may consist of scholarships, training opportunities for specialists and experts, funds for maintenance or transportation, or any special project that is considered appropriate for this program." ${ }^{2332}$ [Hervorhebung d. Verf.]

In einem vertraulichen Bericht des State Departments zum geplanten PersonenAustauschprogramm zwischen Österreich und den USA, der als Grundlage für eine Presseaussendung diente, wurde ausgeführt, über welche Voraussetzungen die Kandidat/innen für einen 6- bis I2-monatigen Aufenthalt verfügen müssten:

"It is contemplated that there will be brought to the United States a carefully selected group of Austrian specialists in the aforementioned fields [education, religion, public opinion, d. Verf.] to observe practices in this country; trainees for specialized training, including persons of outstanding promise who are about to enter upon or who are in the early years of their careers in such fields; and students to study at United States educational institutions. Only such persons

2331 Angeschrieben wurden dafür eine Vielzahl an Einrichtungen, darunter die Rockefeller Foundation, das Carnegie Endowment for International Peace, die National Education Association, das American Council for Education, das Institute of International Education, das American Council of Learned Societies, das Social Sciences Research Council, die Association of American Colleges, die American Association of University Women, die American Library Association, die Motion Picture Association of America, die World Wide Broadcasting Foundation Inc., die National Catholic Welfare Conference, das American Friends Service Committee, das National Lutheran Council, die American Federation of Labor, den Congress of Industrial Organizations, die Society of Independent Motion Picture Producers, die National Social Welfare Assembly, die American Society of Newuspaper Editors oder das Unitarian Service Committee.

2332 Howard C. Peterson, Assistant Secretary of war to Rockefeller Foundation (Identical letter to: see attached list), 26. Juni 1947, 1 f. Zit. nach: The U.S. Occupation of Germany: Educational Reform 19451949, Microfilm-Collection, a.a. O., 1-A-34. 
will be selected for this program as can be expected to play part in the revival of Austrian cultural life in an Austrian democratic reconstruction. Austrian nationals coming to the United States must have a satisfactory record as regards past and present political activity and affiliation, and preference will be given to persons who have demonstrated their opposition to Nazism and their belief in democratic principles." ${ }^{2333}$ [Hervorhebung d. Verf.]

Obwohl nun das „Longe Range Policy Statement“ und der Endbericht der Zook-Kommission dazu führten, dass die Reeducation beziehungsweise Reorientation ab sofort als integraler und wichtiger Bestandteil der US-Besatzungspolitik festgeschrieben ${ }^{2334}$ und die bisher geltende Direktive der Joint Chiefs of Staff vom April I945 (JCS ro67) damit außer Kraft gesetzt wurde - dessen zentrale Schlüsselwörter hatten hatten ja „Entnazifizierung“ und „Entmilitarisierung“ gelautet -, zeigten sich weder das OMGUS-Oberkommando noch das War Department zunächst sonderlich daran interessiert, die Empfehlungen der Kommission und die damit verbundenen Aufgaben auch umzusetzen. Unterstützt wurde der neue Kurs, der die demokratische Rekonstruktion - wie Hans Speier es formulierte von der militärisch-moralischen auf die politische Ebene transferierte ${ }^{2335}$ und dabei die bildungspolitisch-kulturelle „Rehabilitation“ direkt mit politischen und wirtschaftlichen Reformfragen verband, hauptsächlich vom State Department beziehungsweise seinen zivilen Bildungsbeamten. „Reeducation“ oder besser: „Reorientierung“ sollte - im Sinne US-amerikanischen Eigeninteresses - in pragmatisch-realistischer Verbindung mit dem ökonomischen Aufbau künftig eine profunde, weltanschaulich-politische „Immunisierung“ gegen jede Form anti-amerikanischer Aggression garantieren und durch Westintegration zur politischen Stabilität beitragen.

In klarer Distanz zur unmittelbaren Nachkriegsphase wurde nun die Eigenverantwortlichkeit der künftigen strategischen Partner sukzessive zu einem wesentlichen

2333 „Interchange of Persons between the United States and Austria“. Confidential Release for Publication, Department of State, 31. März 1947, 1 f. Zit. nach: The U.S. Occupation of Germany: Educational Reform 1945-1949, Microfilm-Collection, a.a. O., 2-A-233.

2334 Mit der SWNCC Direktive JCS 1779 wurde dieser neue Reeducation-Kurs im Frühsommer 1947 ein weiteres Mal von höchster Stelle autorisiert: „[...] to encourage and assist in the development of educational methods, institutions, programs and materials designed to further the creation of democratic attitudes and practices through education." Zit. nach: Velma Hastings Cassidy (Ed.), Germany 1947-1949. The Story in Documents (European and British Commenwealth Series, 9; Department of State Publication No. 3556), Department of State, Washington D.C. 1950, 180.

2335 So meinte der deutschstämmige Soziologe Hans Speier (1905-1990), der während der Kriegsjahre mit Reeducation-Fragen befasst war und zwischen 1944-45 u.a. als „Propaganda Policy Adviser“ innerhalb der „Overseas Branch“ des Office of War Information (OWI) tätig war und daran anschließend als „Assistant Chief of Occupation Areas“ im Department of State arbeitete: „American policy toward Germany was initially conceived in military and moral terms rather than as a political issue". Zit. nach: Kellermann, Cultural relations as an Instrument of U.S. Foreign Policy, a.a.O., 22; vgl. auch: Hans Speier, From the Ashes of Disgrace. Journal from Germany 1945-1955, Amherst 1981. 
Maßstab der demokratischen Reorientierung: ein Aspekt, den auch der US-Secretary of State, James F. Byrnes, schon in einer Note im September 1946 hervorgehoben hatte, indem er in Anknüpfung an die Potsdamer Konferenz davon sprach, dass der demokratische Neuaufbau von Grund auf erfolgen müsse, und bekräftigte: „never was the intention of the American Government to deny to the German people the right to manage their own internal affairs“; ${ }^{2336}$ von nun an war auch im Hinblick auf Deutschland nicht mehr von „Niederlage“, sondern von „Befreiung“2337 die Rede.

Der Kurswechsel in der Besatzungspolitik der amerikanischen Militärbehörden schlug sich zwar erst zeitversetzt in konkreten Maßnahmen nieder, doch der zentrale Stellenwert und die Bedeutung der demokratischen Reorientierung standen nun auch für die USMilitärs fest. Das zeigt sich unter anderem auch daran, dass General Clay mit Hermann B. Wells, ${ }^{2338}$ dem Präsidenten der Universität Indiana, eine neue Leitungspersönlichkeit für die Reorientierungs-Agenden einsetzte, die im Bereich der privaten U.S. Kultur- und Bildungseinrichtungen hervorragend vernetzt und auch im Fundraising versiert war: „[...] it was felt that improvement of the situation required an outside person. "2339

Wells trat seine überaus kurze Amtszeit im November 1947 an $^{2340}$ und richtete umgehend ein Gremium ein, in dem private beziehungsweise zivile Experten - „key persons in fields of education, religion, youth activities, citizenship“2341 - sowie philanthropische US-Institutionen, wie die Rockefeller oder die Guggenheim Foundation, zusammengefasst wurden. $^{2342}$

Des Weiteren zeigt sich die neue besatzungspolitische Zielsetzung in der nur kurze Zeit später erfolgten Umbenennung der bisher für Reeducation-Angelegenheiten zuständi-

2336 James F. Byrnes, 6. September 1946. Zit nach: Cassidy (Ed.), Germany 1947-1949, a.a. O., 3-8.

2337 Kellermann, Cultural relations as an Instrument of U.S. Foreign Policy, a.a.O., 18.

2338 Herman B. Wells (1902-2000), liberaler Ökonom, Finanzadministrator, Banker, Universitätslehrer und Präsident der Indiana University, der 1943 dem „American Council for Education“ (ACE) beigetreten war und 1944-1945 zu dessen Vorsitzendem gewählt wurde. Von 1943 bis 1944 arbeitete Wells zudem für das „Office of Foreign Economic Cooperation“ im U.S. State Department. Nach Kriegsende verbrachte er 1946 als Angehöriger einer amerikanisch-französisch-englischen Wahlbeobachtungskommission einige Monate in Griechenland. Während seiner Zeit in Berlin soll Wells auch eine zentrale Rolle bei der Einrichtungen der Freien Universität gespielt haben. Wells, Being Lucky, a.a. O., 375.

2339 Wells, Being Lucky, a.a.O., 302.

2340 Tatsächlich belief sich die Amtszeit von Wells, der Thomas R. Alexander, einem Pädagogen des Teachers College an der Columbia University, beziehungsweise John Taylor, dem Präsidenten der University of Louisville, in der Position des Acting Directors der OMGUS E \&RA-Divsion nachfolgte, auf nur ganze sechs Monate: vom 21. November 1947 bis 27. Mai 1948. Siehe: Wells, Being Lucky, a.a. O., 304.

2341 Memorandum to Mr. James L. Sundquist, „Meeting with Mr. Wells with respect to German reorientation problem“, New York City, 15. November 1947. The U.S. Occupation of Germany: Educational Reform 1945-1949, Microfilm-Collection Congressional Information Service, edited by Gary H. Tsuchimochi, Tokyo 1991 (Bestand Institut für Zeitgeschichte der Universität Wien, Bibliothek), 2-A-408, 1.

2342 Vgl. Schmidt, Civil Empire by Co-optation, a.a.O., 90. 
gen - und völlig unzureichend ausgestatteten - „Education and Religious Affairs Division“ (E\&RA) in „Education and Cultural Relations Division“, ${ }^{2343}$ die künftig alle kulturellen und bildungspolitischen Reorientierungs-Agenden in einer zentralen Einheit zusammenfasste:

"My first assignment was to assemble cultural activities in a single division and to arrange to have them administered under a unified policy in contrast to the somewhat divergent policies that had been followed in some division previously. Thus the Education and Cultural relations Division was created. Elementary, secondary, university, and adult education; religious affairs; youth activities; women's affairs; theaters; music; the coordination of cultural exchanges; and the allocation of textbooks and materials - all were brought under the management of a single unit of the military government. Provision was made to include in this unit also, but a some later date, the indirect media of education such as publication, press and radio."2344

Besonderen Nachdruck legte Wells in seiner neuen Funktion auf den zügigen Ausbau der Austauschprogramme und bereitete durch die angestrebte, möglichst breite Einbeziehung nicht-staatlicher beziehungsweise privater US-Bildungseinrichtungen die mittelfristige Übernahme der vorbereiteten Exchange-Programme durch das Department of State vor.

Das von Wells im Rahmen von OMGUS am I3. Februar 1948 vorgelegte Konzept mit dem Titel „Development of an Organization in the United States to Support a Cultural Exchange Program“ wurde im State Department in Washington intensiv diskutiert und von Frank G. Wisner, dem „Deputy to the Assistant Secretary for Occupied Areas“, gegenüber dem Unterstaatssekretär im U.S. Verteidigungsministerium ausführlich kommentiert. Wisner, der die bisherige Reorientierungs-Politik der US-Army als „Fiasko“ qualifizierte, ${ }^{2345}$ teilte dem Undersecretary of Army mit, dass das State Department die von Wells vorgeschlagenen Maßnahmen prinzipiell positiv beurteile und das Exchange-Programm zu einem möglichst frühen Zeitpunkt starten sollte. Insbesondere unterstrich Wisner den Vorschlag von Wells, die Austauschprogramme ab sofort als integralen Teil umfassend geplanter USReorientierungs-Anstrengungen zu sehen. Unter Einbeziehung bereits laufender Projekte auf Basis des Fulbright Act beziehungsweise des Smith-Mundt Act - auf diesen wird noch kurz näher einzugehen sein -, sollte die offizielle Einbindung privater Einrichtungen in die Exchange-Programme „be presented as part of an overall program for all occupied territories designed to advance the reeducation and democratization of local populations. ${ }^{\text {"2346 }}$

2343 Tent, Mission on the Rhine, a.a.O., $300 \mathrm{f}$.

2344 Wells, Being Lucky, a.a.O., 307.

2345 NARA II, RG 59, Assistant Secretary, Box 1. Howland H. Sargant, to Henry J. Kellermann, „Mr. Wisner's Memo Regarding German Reorientation and the Occupation Statute“, 27. September 1948, 1.

2346 Frank G. Wisner, Deputy to the Assistant Secretary for Occupied Areas to William H. Draper, Under Secretary of the Army, 19. Februar 1948, 1. The U.S. Occupation of Germany: Educational Reform 1945-1949, Microfilm-Collection Congressional Information Service, edited by Gary H. Tsuchimochi, Tokyo 1991 (Bestand Institut für Zeitgeschichte der Universität Wien, Bibliothek), 2-A-457. 
Als Geheimdienstfachmann, Experte für Psychologische Kriegsführung und glühender Antikommunist, sprach Wisner, ${ }^{2347}$ der zum selben Zeitpunkt die Leitung des halboffiziellen „dirty tricks department“, ${ }^{2348}$ der Geheimdienstabteilung „Office of Policy Coordination“ (OPC) ${ }^{2349}$ innerhalb der neugegründeten CIA übernahm, vergleichsweise deutlich aus, was die unausgeprochene, asymmetrische Präambel aller künftig von amerikanischer Seite finanzierten und administrierten Austauschprogramme darstellen sollte: primäres Ziel war keineswegs mehr nur der gegenseitige Erfahrungsaustausch, sondern - wie indirekt auch immer angelegt - die nachhaltige Reeducation beziehungsweise Reorientierung durch gezielte ,positive‘ Beeinflussung über die Verbreitung amerikanischer Lebensweise, Produktion, Demokratie, Wissenschaft und Bildung sowie deren Bezüge zu individueller Freiheit und wirtschaftlich-technischer Effizienz.

Darüber hinaus ließ Wisner durchblicken, dass das State Department die Übernahme der Agenden im Hinblick auf die eigenen Kapazitäten nicht nur für machbar, sondern auch für sachlich sinnvoll halten würde. Wie aus der Antwort von Unterstaatssekretär Wil-

2347 Frank Gardiner Wisner (1909-1965), Rechtsanwalt, Chef des Office of Strategic Services (OSS), 1947 von Staatssekretär Dean Acheson mit Unterstützung von George F. Kennan in das State Department geholt, wurde 1948 Leiter des auf Sabotage, Propaganda, Guerrilla und ökonomische Kriegsführung spezialisierten OPC und stieg in der Folge zu einem der einflussreichsten Männer in der CIA auf, die er mit Richard Helms zu einer finanzkräftigen Einrichtung mit großen Personalressourcen ausbaute. Vg1. Sarah-Jane Corke, US Covert Operations and Cold War Strategy. Truman, Secret Warfare and the CIA, 1945-53, New York 2008, 16 ff. Wisner wird in seinem Vorgehen wenig moralischer Skrupel attestiert so hatte er von Wiesbaden aus den ehemaligen „Fremde Heere Ost“ SS-General Reinhard Gehlen für die Einrichtung der nachrichtendienstlichen „Organisation Gehlen im Dienste der USA engagiert; siehe dazu: John Prados, Safe for democracy. The secret wars of the CIA, Chicago 2006, 42 f. bzw. 50; ein CIA-Kollege meinte diesbezüglich: „Wisner brought in a whole load of fascists after the war, some really nasty people." Zit. nach. Frances Stonor Saunders, The Cultural Cold War. The CIA and the World of Arts and Letters, New York 2000, 40. Tatsächlich spielte Wisner u.a. auch in der streng geheimen "Operation Bloodstone“ 1948-1950 die zentrale Schlüsselrolle - eine Operation, die vom obersten militärischen US-Sicherheitsausschuss, dem „State, Army, Navy, Airforce Coordinating Committee“ (SANACC) und dem Nationalen Sicherheitsrat der USA (NSC) durchgeführt wurde. Dieses Projekt zielte darauf, die „Elite der Nazis und Kollaborateure, die Führer, die Geheimdienstspezialisten und die Wissenschaftler, die ihre Kenntnisse in den Dienst der Nazis gestellt hatten “ in die Vereinigten Staaten zu bringen und diese für sogenannten „Sonderoperationen“ einzusetzen, d.h. für Aktivitäten hinter den feindlichen Linien wie etwa „Subversion, Sabotage [...] Morde, Gefangennahme von bestimmten Personen und die Rettung von zur Landung gezwungenen Fliegern." Zit. nach: Christopher Simpson, Der amerikanische Bumerang. NS-Kriegsverbrecher im Sold der USA, New York - Wien 1988, 128 bzw. 130.

2348 Saunders, The Cultural Cold War, a.a.O., 40.

2349 Die geheimen Aktivitäten der OPC waren primär auf psychologische Kriegsführung im Kampf gegen den Kommunismus angelegt: sie bestanden u. a. in Spionage, Feind- und Freund-Propaganda, der Ausarbeitung von Evakuierungsplänen, von Sabotage und Gegensabotage, Guerrilla-Taktiken hinter dem „Eisernen Vorhang“ sowie in ökonomischer Kriegsführung. Siehe: Alfred H. Paddock, Jr., US-Army Special Warfare. Its Origins. Psychological and Unconventional Warfare, 1941-1952, Lawrence/Kansas 2002 [1982], 76. 
liam H. Draper hervorgeht, lenkte die Armee in der ungeliebten Reorientierungs-Frage gerne ein und war bereit, diesbezüglich Kompetenzen abzutreten:

\begin{abstract}
"Accordingly, implementation of an interchange program can hardly get under way before the date upon which the Department of State will assume responsibility for reorientation activities in Germany. It seems to me that [...] the Department of State should assume responsibility now for establishing the non-governmental unit and perfecting plans for implementation under Department of State control [...]."2350
\end{abstract}

Die stärkere Öffnung gegenüber nicht-staatlichen Agenturen hatte allerdings zur Folge, dass sich im Hinblick auf Reorientierungs-Fragen vermehrt private und semi-staatliche Einrichtungen in den Vereinigten Staaten, und zwar durchaus kritisch, zu Wort meldeten. So beschloss der erste Kongress der „United States Student Association“ im August 1948 die Durchführung eines „educational research projects in Germany and Austria“:

\begin{abstract}
"Because the United States, as one of four occupying powers in Austria and Germany and responsible for the educational system of these countries, must recognize a special responsibility to fill the material needs of students, to break their isolation from the main currents of academic and intellectual thought, and to carry out the educational reforms to which our government is committed, it falls upon the students of the United States to assume a role in discharging these commitments $[\ldots]$. Research shall be undertaken into the material and intellectual conditions of German and Austrian students and on the progress in the development and growth of their educational system since the war." ${ }^{2351}$
\end{abstract}

Daneben hatten die US-Militärregierung sowie die zuständigen Stellen im Department of State fallweise mit kritischer Presseberichterstattung im Heimatland zu kämpfen, die den mangelnden Fortschritt im Bereich von Entnazifizierung und Reeducation anprangerte und den Westmächten insgesamt schwere Versäumnisse in dieser Frage vorwarf. ${ }^{2352}$ Mit

2350 William H. Draper, Under Secretary of the Army to Frank G. Wisner, Deputy to the Assistant Secretary for Occupied Areas, 25 February 1948, 1. The U.S. Occupation of Germany: Educational Reform 1945-1949, Microfilm-Collection Congressional Information Service, edited by Gary H. Tsuchimochi, Tokyo 1991 (Bestand Institut für Zeitgeschichte der Universität Wien, Bibliothek), 2-A-457.

2351 Mildred Kiefer, United States National Student Association to Mr. Boderman, Reeducation Division OMGUS, 1 February 1949. „German Educational Research Project Report“, 2. The U.S. Occupation of Germany: Educational Reform 1945-1949, Microfilm-Collection Congressional Information Service, edited by Gary H. Tsuchimochi, Tokyo 1991 (Bestand Institut für Zeitgeschichte der Universität Wien, Bibliothek), 2-A-457.

2352 So titelte die Washington Post am 20. Juni 1949: „Denazification Fails, German Editor Says“. Im Wortlaut: „The western powers have definitively failed to de-Nazify the Germans because of the military government's ignorance of German psychology, a prominent German publisher stated here last night. 
Anlaufen der Personen-Austauschprogramme vermengte sich derartige Kritik zuweilen mit populistischen Ressentiments gegenüber Fremden, die nun auf Kosten der amerikanischen Steuerzahler in Elite-Bildungsinstitutionen gesteckt würden, die sich US-Staatsbürger für ihre Kinder of nicht leisten könnten. ${ }^{2353}$

Abgesehen von derartiger Negativ-Berichterstattung war es wohl auch die seit 1946 wiederholt formulierte ${ }^{2354}$ und teilweise scharfe Kritik privater Bildungseinrichtungen beziehungsweise deren Vertreter am Realzustand des Bildungswesens in Deutschland und Österreich, die zu zusätzlichem Veränderungsdruck führte. Bereits im Mai I946 hatte Major General J.P. Echols dem US-Oberbefehlshaber in Österreich mitgeteilt, dass sich in letzter Zeit Nachfragen häuften und Information über den Status quo erbeten würde: ,The Office of International Information and Cultural Affairs, Department of State indicates that is its receiving frequent inquiries concerning the progress of rehabilitation of Austrian educational system. ${ }^{23355}$

Die ab 1948 erleichterten Einreisebedingungen für amerikanische Staatsbürger ${ }^{2356}$ führten zu weiteren halb-privaten Investigationen in den Besatzungszonen -, sie ließen den Militärbehörden eine verstärkte Kooperation mit dem State Department beziehungs-

The statement was made in an interview with Franz Joseph Schönigh, publisher and editor of the Süddeutschen Zeitung, largest newspaper in southern Germany [...].“ Zit. nach: The U.S. Occupation of Germany: Educational Reform 1945-1949, Microfilm-Collection, a.a. O., 2-A-847.

2353 Der Boston Daily Record vom 10. Juni 1949 schrieb diesbezüglich: „Nine aliens will be imported from Germany and educated at the expense of the American taxpayers at such foremost educational institutions as Harvard, Duke and Bryn Mawr [...] funds are provided by American taxpayers who cannot afford to send their own children to college." Zit. nach: The U.S. Occupation of Germany: Educational Reform 1945-1949, Microfilm-Collection, a.a.O., 2-A-457. In einem Schreiben an den Secretary of the Army, Kenneth C. Royall, machte sich ein US-Bürger bezugnehmend auf die Pressebereichterstattung (,if true“) Luft, indem er schrieb. „These Nazis and Japs that fought against us and killed our soldiers, you are going to educate in American universities! I happen to have a boy who graduates from High School in June, and can only go to college if he gets a free scholarship, which is doubtful. But you are going to take money I pay and give these Nazis a free education." Richard Strasburger, to Hon. Kenneth C. Royall, Secretary of the Army, Washington D.C., 23. März 1949, 1. The U.S. Occupation of Germany: Educational Reform 1945-1949, Microfilm-Collection, a.a.O., 2-A-709.

2354 So hatte sich bspw. im April 1946 die „Society for the Prevention of World War III, Inc.“ in Sorge um die demokratische Erziehung der deutschen Jugend mit einer schonungslosen Kritik an der Reeducation-Politik der US-Besatzungsmacht an William Benton, den Assistant Secretary of State gewandt. Siehe: The U.S. Occupation of Germany: Educational Reform 1945-1949, Microfilm-Collection, a.a. O., 1-A-37.

2355 J.P. Echols, Major General USA, Director, Civil Affairs Division, to Commanding General, U. S. Forces, Austria, 11 May 1946, 1. Zit. nach: The U.S. Occupation of Germany: Educational Reform 1945-1949, Microfilm-Collection, a.a.O., 2-A-82.

$2356 \mathrm{Ab}$ 1. Jui 1948 wurden die bisher geltenden restriktiven Einreisebeschränkungen für amerikanische Staatsbürger auf Basis von SWNCC 269/8 aufgehoben, und die Visa-Bestimmungen mit Deutschland (und Österreich) normalisiert. CSCAD/71646/5-16/467 [CSCAD 350], 16. May 1949, The U.S. Occupation of Germany: Educational Reform 1945-1949, a.a.O., 2-A-806. 
weise die sukzessive Kompetenzabtretung in Fragen der Reorientierung keineswegs unvorteilhaft erscheinen ${ }^{2357}$-, bis das Department of State dann im Dezember 1949 die Gesamtverantwortung für alle Besatzungsagenden, somit auch für die ReorientierungsProgramme, übernahm.

Offiziell zementiert wurde der neue Kurs der US-Besatzungspolitik jedenfalls auf der Berchtesgadener Reorientierungs-Konferenz im Dezember 1948. Hier erklärte General Lucius D. Clay den versammelten OMGUS-Bildungsexperten die geradezu historische Bedeutung und Dimension ihrer Aufgaben: "It is a great gamble, this experiment in occupation [...]. Probably never before in history has such an experiment been conducted. [...] Will succeed only if you in the Education and Cultural Relations Division have succeeded in implanting the seeds of desire for freedom [...]". ${ }^{2358}$ [Hervorhebung d. Verf.]

Alonzo G. Grace, ${ }^{2359}$ der neue Leiter der „Education and Cultural Relations Division, OMGUS“ strich in seiner daran anschließenden Antrittsrede mit dem Titel „Beyond material reconstruction. Reorientation of the German People“ den direkten Zusammenhang von geistig-mentaler Reorientierung und materiellem Wiederaufbau in einprägsamer Weise hervor:

"Heartening strides in material reconstruction have occurred under Military Government even before the Marshall Plan became effective. [...] European recovery and German reconstruction are one problem. The nearer we approach the solution to this problem, however, the more intricate becomes the problem of spiritual, moral intellectual and cultural redemption. A distressed but redeemed people may sell jewels and Meissen for bread, but an unredeemed

2357 So formulierten beispielsweise Mitglieder der „Educational Press Association of America“ nach einer Reise durch die US-Besatzungszone in Deutschland und Österreich Anfang 1948, die auf Einladung des War Department erfolgt war, gegenüber US-Verteidigungsminister James Forrestal geharnischte Kritik an der Politik der US-Militärregierung: ,From the reports of these individuals, it is our feeling that much more emphasis must be placed immediately, on giving support to the rehabilitation of the schools system $[\ldots]$. To date, it appears that a very small percentage of the effort on the part of our military government towards rehabilitation of the countries has gone into the field of education. Materials and personnel are needed immediately if the occupation is not to fall in its most important task." Siehe: The U.S. Occupation of Germany: Educational Reform 1945-1949, Microfilm-Collection Congressional Information Service, edited by Gary H. Tsuchimochi, Tokyo 1991 (Bestand Institut für Zeitgeschichte der Universität Wien, Bibliothek), 2-A-457.

2358 The U.S. Occupation of Germany: Educational Reform 1945-1949, Microfilm-Collection, a.a. O., 3-B473, Office of Military Government for Germany (U.S.), Education and Cultural Relations Division, December 1948, 2.

2359 Alonzo G. Grace, 35-jähriger Professor für Erziehungswissenschaft an der Universität Chicago und zuvor auch „State Commissioner for Education“ im US-Bundesstaat Connecticut, löste im Dezember 1948 Herman B. Wells als Leiter der OMGUS Education Cultural Affairs Division offiziell ab und behielt diese Position bis Ende 1949. Vgl. Alonzo G. Grace, Education in Occupied Germany. In: The Phi Delta Kappan, Vol. 31, No. 7, March 1950, 305. 
people will sell freedom and the rights of man again as easily as they did some fifteen years ago." 2360 [Hervorhebung d. Verf.]

Nach Evaluierung existierender OMGUS-Programme schaltete sich im Frühjahr I949 das U.S. State Department über die „Public Affairs Branch“ (Leiter: Robert D. Murphy) und deren „German and Austrian Affairs Office“ direkt in die Reorientierungs-Planungen ein, indem Henry J. Kellermann sowie sein aus Wien abgezogener Stellvertreter Martin F. Herz $^{2361}$ für die verantwortliche Leitung des Kulturaustausches eingesetzt und direkt dem Hochkommissar unterstellt wurden. ${ }^{2362}$ Auf organisatorischer Ebene schlug sich das in der Einrichtung der „Division of International Exchange of Persons“ (IEP) nieder, die direkt dem Assistant Secretary of State for Public Affairs unterstellt war, und die globalen Austauschprogramme - unter Einbeziehung privater und halbprivater amerikanischer Institutionen - analog zum „U.S. International Information and Educational Exchange Program“ koordinierte. ${ }^{2363}$ Wie sich zeigt, hatte die insbesondere vom State Department aus forcierte Reorientierung, also die Kooperation in Erziehungs- und Bildungsfragen sowie der kulturelle Austausch auf allen Ebenen, spätestens Ende 1948 hohe besatzungspolitische Priorität und bildete im Verein mit der anvisierten wirtschaftlichen und politischen Konsolidierung das Konzept für eine stabile und nachhaltige Rehabilitierung Europas.

Das Herzstück dieser US-Reorientierungs-Doktrin die sich sowohl in der deutschen als auch in der österreichischen Besatzungszone durchsetzte und deren Kernelemente bereits im zivilen inner-amerikanischen Diskurs vor 1943 ausformuliert vorlagen, bestand in der spezifischen Verknüpfung von friedensliebendem Humanismus, sozialer Toleranz und maximalen individuellen Entfaltungsmöglichkeiten mit ökonomischer Freiheit beziehungsweise durchschlagendem wirtschaftlichen Erfolg und technischer Effizienz.

Die sukzessive Zuspitzung des Kalten Krieges ab i947/48 veränderte dieses Paradigma der US-Reorientierungs-Politik allerdings insofern, als sich nun zunehmend Konzepte und Überlegungen psychologischer Kriegsführung und Propaganda mit der ,edukativen“ und ursprünglich primär demokratiepolitischen Intention einer effizienten und nachhaltigen Popularisierung des „American way of life“ zu vermischen begannen.

2360 The U.S. Occupation of Germany: Educational Reform 1945-1949, Microfilm-Collection, a.a. O., 3-B473, Office of Military Government for Germany (U.S.), Education and Cultural Relations Division, December 1948, 2.

2361 Der Spezialist für psychologische Kriegsführung Martin F. Herz hatte zuvor (1945-1948) als USBotschaftssekretär in Wien gearbeitet. Siehe: Wagnleitner, Understanding Austria. Curriculum Vitae, a.a.O., 18.

2362 Ziel der Abteilung war ,to develope a broad and effective program of cultural exchange, aiming especially at the participation of those groups which are likely to promote the future democratic leadership in Germany." Zit. nach: Schmidt, Civil Empire by Co-optation, a.a. O., 127 f. bzw. 133.

2363 Die Leitung des IEP hatten Francis J. Colligan und sein Stellvertreter Frederic O. Bundy inne. Siehe: ebd., 133. 
Auf der politischen Großwetterkarte kam es im Sommer 1946 durch die anwachsende Einflusssphärenpolitik der Sowjetunion und ihrer Satellitenstaaten zu hegemonialen Interessenkonflikten, die schließlich in einer gravierenden Trendwende der bisherigen - ohnedies schon längst brüchigen - alliierten Kooperation mündeten und dazu führte, dass die USA ihre bisherige Politik des politischen Isolationismus zur Gänze aufgaben. Ausgelöst wurde die I80-Grad-Wende unter anderem dadurch, dass Bulgarien bei der Pariser Konferenz im August 1946 Teile Nord-Griechenlands beanspruchte, die Sowjetunion auf eine Vormachtrolle in Bezug auf Libyen und Eritrea abzielte und auch die Kontrolle über die Dardanellen nachverhandeln wollte. Der Abschuss zweier US-Transportmaschinen durch Jugoslawien auf ihrem Weg von Österreich nach Italien -, das außerdem Triest beanspruchte, sowie massive sowjetische Truppenbewegungen an der Südgrenze des Kaukasus, die Druck auf die Türkei und den Iran ausüben sollten, führten schließlich zur Schubumkehr der USAußenpolitik gegenüber der Sowjetunion beziehungsweise dem Kommunismus: dessen militärisch-propagandistischer Einfluss auf die ,freie Welt' sollte nun mit allen Mitteln durch eine Politik der Stärke und Intervention eingedämmt („,contained“) werden. ${ }^{2364}$

Nachdem von amerikanischer Seite bereits im September 1946 über Militärhilfe für Griechenland und die Türkei nachgedacht worden war und sich Großbritannien im Februar 1947 schließlich nicht mehr imstande sah, die, nach Aufösung der griechischen kommunistischen „Nationalen Befreiungsfront“ (EAM), von kommunistischen Guerillatruppen in Thrakien ausgelösten Aufstände zu kontrollieren, ${ }^{2365}$ gingen Präsident Harry S. Truman und sein Beraterstab in die - propagandistische - Offensive. Nach einer Besprechung mit seinem Kabinett sowie leitenden Kongressabgeordneten ließ Staatssekretär Dean Acheson einen Entwurf für eine Kongress-Rede Trumans ausarbeiten. Der dritte Entwurf der „new policy“, die unter dem Titel „Truman Doktrin“ bekannt wurde - der ersten formellen Präsidenten-Doktrin seit der Monroe-Doktrin von I823 - wurde von George C. Marshall genehmigt und formulierte den ,Turning point' der US-Außenpolitik in Richtung eines „war of nerves“, eines „political battle with ideological, strategic and economic elements“. ${ }^{2366}$

Am I2. März 1947 - 48 Stunden nach Beginn der Außenministerkonferenz in Moskau hielt Präsident Truman vor beiden Häusern des US-Kongresses seine berühmt gewordene Rede, die den weltanschaulich-ideologischen Überbau beziehungsweise die politische Legitimation für die nachfolgende US-Containment- beziehungsweise „Roll-Back“Politik lieferte.

Im Kern der Truman-Doktrin findet sich zunächst ein Plädoyer für die Demokratie: "No government is perfect [...]. One of the chief virtues of a democracy, however, is

2364 Vgl. Elizabeth Edward Spalding, The First Cold Warrior. Harry Truman, Containment, and the remaking of Liberal Internationalism, Lexington 2006, 62.

2365 Vgl. Howard Jones, „A new Kind of War“. Americas Global Strategy and the Truman Doctrine in Greece, New York 1989, 24 f. bzw. 31.

2366 Spalding, The First Cold Warrior, a.a.O., 61. 
that its defects are always visible and under democratic processes can be pointed out and corrected.“2367

Ausgehend vom Selbstbestimmungsrecht der Völker und dem Recht auf Freiheit, für das die Vereinigten Staaten in den Krieg gezogen seien, entwickelte Truman in seiner Rede in weiterer Folge allerdings das Szenario zweier grundsätzlich antagonistischer gesellschaftlicher Lebensformen, die sich aktuell in globalem Konflikt befänden, wobei deren eine sich auf die „Freiheit des Einzelnen“, die andere sich auf „Terror und Unterdrückung“ gründe:

"One of the primary objectives of the foreign policy of the United States is the creation of conditions in which we and other nations will be able to work out a way of life free from coercion. This was a fundamental issue in war with Germany and Japan. Our victory was won over countries which sought to impose their will, and their way of life, upon other nations. [...]

One way of life is based upon the will of the majority, and is distinguished by free institutions, representative government, free elections, guarantees of individual liberty, freedom of speech and religion, and freedom from political oppression.

The second way of life is based upon the will of a minority forcibly imposed upon the majority. It relies upon terror and oppression, a controlled press and radio, fixed elections, and the suppression of personal freedom. ${ }^{\text {"2368 }}$

Wesentlich ist, dass der in dieser Doktrin angesprochene Antagonismus zwischen westlichem Kapitalismus und expansivem (sowjetischem) Kommunismus nicht mehr in Form friedlich-kooperativer Politik lösbar schien, sondern einzig durch defensive wirtschaftpolitisch-propagandistische Eindämmung und materiale Unterstützung, deren geforderte Höhe Truman mit zunächst 750 Millionen Dollar bezifferte. ${ }^{2369}$ In Kombination mit dem von US-Hardlinern geforderten aggressiven „Roll-Back“ bestand das ordnungspolitische Ziel der US-Außenpolitik in Europa nun darin, den Aufbau eines nach marktwirtschaftlichen Kriterien organisierten Investitions- und Handelsraumes sicherzustellen, und den Kommunismus notfalls auch mit militärischen Mitteln zurückzuwerfen. In Bezug auf Österreich hatte das zur Folge, dass „die Verhandlungen über einen Staatsvertrag seitens der USA zunehmend unter die Perspektive einer geopolitischen und mit militärischen Mitteln umzusetzenden Einflusssphärenpolitik gestellt wurden, innerhalb derer die Eigenständigkeit und Unabhängigkeit Österreichs nur insofern auftauchte, als damit das $\mathrm{Zu}^{-}$

2367 Special Message to the Congress on Greece and Turkey by Harry S. Trumann, 12. März 1947. In: George R. Goethals/Georgia J. Sorenson/James MacGregor Burns (Eds.), Encyclopedia of Leadership. Vol. 1, Thousand Oaks/Calif. 2004, 1760.

2368 Ebd., 1761.

2369 Ebd., 1762. 
rückdrängen sowjetischer Ansprüche geknüpft war. ${ }^{\text {“2370 }}$ Mit diesem neuen Paradigma der US-Außenpolitik ging Truman, wie Elizabeth Spalding anmerkt, weit über den Ansatz Woodrow Wilsons hinaus, indem die USA nun klar die machtpolitische Führungsrolle eines neuen und globalen ,internationalen Liberalismus" einnahmen und alle freien Völker, die durch bewaffnete Minderheiten unterdrückt würden, ab sofort künftig mit Unterstützung der Vereinigten Staaten von Amerika rechnen durften. ${ }^{2371}$

Im globalen, weltanschaulich-ideologischen Konflikt mit der Sowjetunion ließen sich die selbstverständlichen edukativen Bemühungen unschwer im Bereich von Schule, Universität oder Jugenderziehung mit medien- beziehungsweise informationspolitischen, ökonomischen, gewerkschaftlichen, sicherheitspolitischen oder geheimdienstlichen Interessen verknüpfen und auf einen propagandistischen Nenner bringen.

Diese Veränderung der US-Reorientierungs-Politik durch Subsummierung unter die strategischen Ziele und Vorgaben psychologischer Kriegsführung vollzog sich allerdings keineswegs als offene Trendwende, sondern vielmehr als graduell verstärkte, gezielte Forcierung jener Kernelemente einer weltanschaulich-geistigen Reorientierung, die mit dem ,Role Model' Amerika zu tun hatten.

Obwohl mit dem Wechsel der für Re-Demokratisierung zuständigen Behörden vom War Department zum State Department (von OMGUS zu HICOG/HICOM) im Dezember 1949 nun in offiziellen Verlautbarungen immer weniger von Reorientierung oder gar Reeducation sondern immer mehr von Erfahrungsaustausch die Rede war, blieb die zugrunde liegende Motivation - "the spirit of reorientation“2372 - nicht nur unverändert, sondern verstärkte sich sogar, allerdings um den Preis eines nun unmöglich gewordenen offenen demokratischen Diskurses, um eine aktiv betriebene antikommunistische Propaganda zur psychologischen Beeinflussung der Bevölkerung. Die enorme Aufwertung der US-Reorientierung zeigt sich in jener Phase unter anderem auch daran, dass das zuständige „Office of Public Affairs“ (HICOG) seinen Mitarbeiterstab bereits I950 auf insgesamt II 83 Personen anhob. ${ }^{2373}$

Bedingt durch den unübersehbar gewordenen Kalten Krieg zielte die halboffizielle politische Stoßrichtung aller Reorientierungs-Programme nach 1947/48 auf direkte propagandistische Beeinflussung der Adressaten ab: Maßnahmen, die insbesondere der Mitinitiator und Mitschöpfer des „Longe range Policy statements“, MacLeish, im Zusammenhang mit kulturellen Reorientierungs-Maßnahmen entschieden ablehnte:

2370 Stifter, Die Wiederaufrüstung Österreichs, a.a.O., 68.

2371 Spalding, The First Cold Warrior, a.a.O., 71.

2372 Schmidt, Civil Empire by Co-optation, a.a.O., 130.

2373 Latzin, Lernen von Amerika? Das Kulturaustauschprogramm für Bayern und seine Absolventen, a.a.O., 103. Davon waren 530 Amerikaner und 680 Deutsche. 1954 verfügt das „Office of Public Affairs“ immerhin noch über 2538 Mitarbeiter. Ebd. 
“The 'psy-war' temptation, for a moment at least, was actively resisted by MacLeish, who was totally focused on building structures of peace. The issue was not whether to do propagandaall nations must. Rather, with 'black' propaganda consigned to clandestinity, planners like MacLeish saw dangers in the theory that the American style of 'white' or 'true' propaganda was fully compatible with US values and appropriate to a nation at peace, as alleged by the informationists. He considered 'true propaganda' a hilarious oxymoron." 2374

Im Kontext der globalen US-Containment-Politik und der Planungen zur Abwehr des Kommunismus durch Mittel der psychologischen Kriegsführung gerieten die ursprünglich genuin humanistischen und pazifischen Überlegungen des amerikanischen Senators James William Fulbright bald zu einer überholt idealistischen, geradezu anachronistischen Nebensächlichkeit. Selbst Fulbright, der mit seinem Konzept eines weltweiten akademischen Austausches beitragen wollte „to erode the culturally rooted mistrust that sets nations against one another“, 2375 schwenkte bald, wenn auch „widerwillig“, wie Kurt Tweraser formulierte, auf die Position eines strategischen „containment“ gegenüber der Sowjetunion ein. ${ }^{2376}$

\section{DIE IDEOLOGISCHE ÜBERFORMUNG DER US-REORIENTIERUNG DURCH PROPAGANDAKAMPAGNEN DES KALTEN KRIEGES}

"American reaction to world events in the twentieth century was delayed by the fetish of isolationism until it became an over-reaction, with moral and idealistic overtones, hardly suited to rational or realistic peace settlements."2377

\section{Cultural Exchange - Rahmenbedingungen der US-Kulturoffensive}

Für die Umsetzung der vom des „Longe Range Policy Statement“ im großen Maßstab geplanten weltweiten Reorientierungs- und Propagandamaßnahmen im politisch-ideologischen Kampf gegen den Kommunismus fehlte es zunächst noch an der gesetzlichen Grundlage, die unter anderem auch die Voraussetzung für die Bereitstellung der dafür benötigten, umfangreichen Geldmittel war.

2374 Arndt, The First Resort of Kings. American Cultural Diplomacy, a.a.O., 104.

2375 J.William Fulbright [1969]. Zit. nach: Walter Grünzweig, Seeing the World as Others See it: J. William Fulbright, International Exchange, and the Quest for Peace. In: Lonnie Johnson/Karin Riegler (Eds.), Fulbright at Fifty. Austrian-American Educational Exchange 1950-2000, Wien [2000], 9.

2376 Kurt Tweraser, The „Operational Code“ of Senator Fulbright and International Education: Belief System, National Missions, Political Contexts. In: Österreichische Zeitschrift für Politikwissenschaft, 41. Jg., 2012, Heft 1, 26 f.

2377 Robert E. Elder, The Information Machine. The United States Information Agency and American Foreign Policy, New York 1968, 30. 
Die ersten Anläufe für die Schaffung gesetzlicher Grundlagen für ein breit angelegtes kulturelles Austausch- und Reorientierungs-Programm waren bereits 1944 erfolgt. ${ }^{278} \mathrm{Un}$ terstützt durch das State Department unter Leitung von Secretary of State James F. Byrnes und seinem Stellvertreter William Benton, hatte der demokratische Kongressabgeordnete Sol Bloom ${ }^{2379}$ (New York) - Vorsitzender des „House Committee on Foreign Affairs“am I5. Oktober 1945 im Kongress eine Gesetzesvorlage eingebracht; sie zielte darauf ab, die schon während des Krieges erfolgten ersten Ansätze einer Auslandskulturoffensive für Amerika durch das State Department ${ }^{2380}$ beziehungsweise das Office of War Information (OWI) aufzugreifen und nun, nach Ende des Krieges, auf eine breite Planungs- und Finanzierungsbasis zu stellen. ${ }^{2381}$

In der von Bloom eingebrachten Gesetzesvorlage, die auf einen „weichen“ Informationsund Kulturtransfer ziviler edukativer Einrichtungen abzielte - wie das im Übrigen auch das State Department favorisierte - sollte die Supervision des gesamten Programmes klar beim Secretary of State liegen. Im zweiten Abschnitt der „Bloom-Bill“ hießt es dazu: „The Secretary is authorized $[\ldots]$ to provide for the $[\ldots]$ preparation and dissemination abroad of information about the United States, its people, and its policies, through press, publications, radio, motion pictures and other information media, and through information centers [...].“2382

Auf Grund politischer Skepsis seitens konservativer US-Kongressabgeordneter, die in der Finanzierung einer großangelegten Kulturoffensive für das post-totalitäre Europa ebenso wenig Sinn sahen, wie sie sich die Leitung einer derartigen Offensive durch das als links-liberal eingestufte U.S. Department of State vorstellen konnten, ${ }^{2383}$ fand der Ge-

2378 Vgl. Frank A. Ninkovich, The diplomacy of ideas. U.S. foreign policy and cultural relations 1938-1950, Cambridge 1981, 121.

2379 Sol Bloom (1870-1949), erfolgreicher Selfmademan jüdischer Herkunft, war seit den Dreißerjahren als Demokrat politisch aktiv. Nach Kriegsende war Bloom als US-Repräsentant für die UNO und die UNESCO tätig war; von ihm stammen die ersten Worte der Präambel der UNO-Charter. Siehe: http:// bioguide.congress.gov/scripts/biodisplay.pl?index=B000565 [Zugriff 30.7.2012]

2380 Mit Ende des Zweiten Weltkrieges wurden die beiden US-Informations- bzw. Propagandaeinrichtungen "Office of Inter-American Affairs" (OIAA) und das OWI unter Leitung von Secretary of State for Public and Cultural Relations, William Benton, dem State Department unterstellt, wo die Aktivitäten zunächst ausliefen. Anfang 1946 wurde mit dem Office of International Information and Cultural Affairs eine Interimseinrichtung innerhalb des State Departments geschaffen, die allerdings in der Anfangszeit unter großen finanziellen und personellen Schwierigkeiten litt. Vgl. Elder, The Information Machine. The United States Information Agency and American Foreign Policy, a.a.O., 35.

2381 Burton Paulu, The Smith-Mundt Act: A Legislative History. In: Journalism Quarterly, Summer 1953, 300. Der Artikel basiert auf einer Dissertation des Autors an der University New York: Burton Paulu, Factors in the Attention to Establish a Permanent Instrumentality for Administration of the International Broadcasting Services of the United States (Ann Arbor: University Microfilms, 1950).

2382 Ebd., 301.

2383 Anlässlich eines neuerlichen Versuchs, die Bloom-Bill Februar 1946 im Kongress durchzubringen, charakterisierte der Vorsitzende des „House Rules Committee“ das State Department als „chock full of reds“. Zit. nach: Ninkovitch, The diplomacy of ideas, a.a.O., 121. 
setzesantrag allerdings nicht die nötige Unterstützung des „House Rules Committee“. Wie Frank A. Ninkovich anmerkt, resultierte die Ablehnung neben der von konservativer Seite vermuteten „Communist infiltration and pro-Russian policy “2384 des U.S. Department of State insbesondere aus der grundlegenden Skepsis der isolationistischen Republikaner gegenüber der politischen Wirksamkeit jeglicher Kulturoffensiven:

"It was apparent from previous appropriations struggles that the program was unpopular with some of the more conservative congressman. Their criticisms derived from doubts as to the program's efficiency, and, more fundamentally, its effectualness. Many of the items in the program the art exhibits in particular were a favorite target - appeared to be 'of little or no value'. [...] The word 'culture' left a politically sour taste in the mouths of many conservatives, and the appointment of the liberal MacLeish to the post of assistant secretary for public and cultural affairs did little to remove it. Given these sentiment against the program, Representative Bloom was quoted as

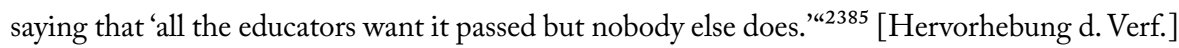

Darüber hinaus manifestierten sich in dieser Kultur-Debatte zwischen Modernisten beziehungsweise liberal-internationalistischen New Dealern und konservativ-isolationistischen Traditionalisten - die unterschiedliche nationale Identitätskonstruktionen des „symbolischen ,Amerika““2386 zur Ansicht brachte -, rasch Bruchlinien im Verständnis davon, was unter (amerikanischer) Kunst überhaupt zu verstehen sei. So entlud sich Ende 1946 im Zusammenhang mit einer vom Department of State organisierten Wanderausstellung unter dem Titel „Advancing American Art“ als große Vernissage moderner amerikanischer Kunst, in der 48 amerikanische Maler ihre Bilder in Europa und Lateinamerika präsentieren sollten, in den Medien eine heftige Kontroverse darüber, inwiefern die ausgewählten avantgardistischen Arbeiten adäquate Zeugnisse „demokratischer“ amerikanischer Malerei darstellten; insbesondere in konservativen Zeitungen und in der Yellowpress (Hearst Newspapers) wurde die Schau als unverständlich, hässlich und absurd, daher als nicht repräsentativ abqualifiziert und außerdem kommunistische Agitation vermutet. ${ }^{2387} \mathrm{Nach}$ heftigen Diskussionen im US-Kongress, wo unter anderem der Assistant Secretary of State for Public Affairs, William Benton - selbst Kunstsammler -, das Ausstellungskonzept darlegte und hervor strich, worum es dem State Department im Kern gegangen sei, nämlich dem nicht nur in Europa weit verbreiteten Vorurteil entgegenzutreten, „that Americans are $[\ldots]$ a materialistic, money-mad race, without interest in art and without appre-

2384 Ninkovitch, The diplomacy of ideas, a.a. O., 122.

2385 Ebd., 121.

2386 Laura A. Belmonte, Selling the American Way. U.S. Propaganda and the Cold War, Philadelphia 2008, 6.

2387 So verwies der Chefermittler des „House Committee of Un-American Activities“, Robert E. Stripling, in in einem gesonderten Bericht darauf, einige der Künstler, die an der Ausstellung des State Department teilnahmen, hätten angeblich „Communist affiliations“. Paulu, The Smith-Mundt Act: A Legislative History, a.a.O., 304 bzw. 306. 
ciation of artists or music “2388 musste die Ausstellung schließlich eingezogen werden. Auf konservativer Seite wurde grundsätzlich die Frage gestellt, wofür es überhaupt gut sein solle, mit amerikanischen Kunstausstellungen das Ausland beeindrucken beziehungsweise Amerika auf diese Weise „verkaufen“ („to sell America“) zu wollen. ${ }^{2389}$

Obwohl die beim Repräsentantenhaus eingebrachten Ansuchen des State Department nach Erhöhung der Ausgaben für die Programmschiene des „Office of International Information and Cultural Affairs“ (OIC) zunächst keinen Erfolg hatten ${ }^{2390}$ wurde Anfang I947 schließlich doch vor allem der Ausbau der US-Rundfunkprogramme entscheidend weiter vorangetrieben. Nachdem die US-Regierung die privaten US-Kurzwellensender wie etwa die „National Broadcasting Company“ (NBC) oder das „Columbia Broadcasting System" (CBS) sowie eine Reihe weiterer Sender ab 1942 quasi verstaatlicht hatte und diese nun unter der zentral koordinierten „Voice of America“ (VOA) zu senden begannen, entstanden nun zusätzlich zum bereits 1946 in Berlin eingerichteten „Rundfunk im Amerikanischen Sektor" (RIAS) ${ }^{2391}$ weitere Sendestationen. Im Kontext der geheimdienstlichen Operationen des CIA entstand 1949 das vom „National Committee for a Free Europe“ gegründet „Radio Free Europe“ (RFE), 195I folgte „Radio Liberty“ (RL), das vom "American Committee for Freedom for the Peoples of the USSR“ finanziert wurde. ${ }^{2392}$ Zusätzlich wurde die Sendungsschiene von „Voice of America“2393 (VOA) entscheidend ausgebaut und durch Installation neuer Sender, wie einer 85.000 Watt Kurzwellenstation nahe München, Sendungen - nun auch in russischer Sprache hinter den „Eisernen Vorhang“" gerichtet. ${ }^{2394}$ Wie US-Außenminister George C. Mar-

\section{Ebd.}

2389 Auf den Punkt gebracht findet sich diese gewissermaßen, fundamentalistische ' konservative Position in der bei Ninkovich zitierten Aussage des Republikanischen Kongressabgeordneten John Bennet (Michigan): „For more than 200 years - even in the remotest corner of the earth - people have known that the United States meant freedom in the fullest connotation of the term [...]. Things which are self-evident require no proof." Siehe: Ninkovitch, The diplomacy of ideas, a.a.O., 124.

2390 Vgl. David F. Krugler, The Voice of America and the Domestic Propaganda Battles, 1945-1953, Columbia/Univ. of Miss. Press 2000, 53; weiters: Paulu, The Smith-Mundt Act: A Legislative History, a.a.O., 302.

2391 Ausgelöst durch die bevorstehenden Wahlen in Deutschland 1946 und die Befürchtung, die Kommunisten könnten zu stark werden, baute die US-Army mobile Rundfunksendeanlagen im amerikanischen Besatzungssektor in Berlin auf, der antisowjetische Propaganda ausstrahlte. Vgl. Ohmstedt, Von der Propaganda zur Public Diplomacy, a.a.O., 47.

2392 Vgl. Lowell H. Schwartz, Political Warfare against the Kremlin. US and British Propaganda Policy at the Beginning of the Cold War, Basingstoke 2009, $124 \mathrm{ff}$;; weiters: Shawn J. Parry-Giles, The Rhetorical Presidency. Propaganda and the Cold War, 1945-1955, Westport 2002, 5; schließlich (die allerdings eher journalistische und nur wenig systematische Darstellung): Arch Puddington, Broadcasting Freedom. The Cold War Triumph of Radio Free Europe and Radio Liberty, Univ. of Kentucky Press 2000, $20 \mathrm{ff}$.

2393 Zur Geschichte der 1942 im Umfeld des OWI gegründeten VOA siehe insbesondere: Alan L. Heil jr., Voice of America. A History, Columbia 2003.

2394 Vgl. Walter L. Hixson, Propaganda, Culture and the Cold War, New York 1998, 32. Der im Krieg gegründeten VOA, die nach dem Krieg unter einschneidenden Einsparungen zu leiden hatte, rettete der 
shall gegenüber dem „appropriations subcommittee“ des US-Senats 1947 diesbezüglich festhielt, ging es angesichts gezielt verbreiteter Fehlinformationen - unter anderem von Radio Moskau 2395 - darum, der Welt die „Wahrheit“ über die USA zu vermitteln: „They should have a true understanding of American life. We should broadcast the truth to the world through all media of communication." ${ }^{2396}$

Als Folge der laufenden anti-amerikanischen Sowjet-Propaganda in Europa schien eine gezielte Gegenstrategie in Form einer koordinierten Informations- und Kulturoffensive, gewissermaßen als Implementierung der Truman-Doktrin, auch über die politischen Lager hinweg immer mehr vorstellbar. Außerdem sprach sich im Dezember 1947 auch das „National Security Council“ (NSC) für eine aktive Gegenoffensive aus, „to influence foreign opinion in a direction favorable to U.S. interests and to counteract effects of anti-U.S. propaganda“. 2397

Vor dem Hintergrund der angespannten weltpolitischen Großwetterlage brachte der republikanische Kongressabgeordnete, frühere Lehrer und spätere Vorsitzende des „House of Un-American Activities Committee“, Karl Mundt (South Dakota), ${ }^{2398}$ auf Anregung des State Department in einem neuerlichen Anlauf eine Gesetzesvorlage für eine großangelegte Kulturoffensive ein: „On July 2, 1947, Secretary of State George C. Marshall in his testimony before Congress on H.R. 3342, introduced by Congressman Karl Mundt and entitled the ,United States Information an Educational Exchange Act of I948', urged legislative action that would permit this country to engage in activities that would provide ,opportunity for contacts which develop lasting impression of the United States “ “2399

Diese Gesetzesvorlage beruhte zu einem großem Teil auf dem ausgearbeiteten Entwurf der früheren Bloom-Bill und wurde, mit Unterstützung von Senator Alexander Smith aus New Jersey, nach mehreren Querelen am 27. Jänner I948 unter dem Namen „Smith-Mundt

Kalte Krieg gewissermaßen das Überleben. Trotz heftiger Angriffe auf die ideologisch-propagandistische Informationspolitik der VOA, wie sie bspw. Walter Lippmann, der Vorsitzende der amerikanischen Journalistenvereinigung, der die VOA-Sendungspolitik als unvereinbar mit der amerikanischen Demokratie erachtete und die Meinung vertrat, dass sich „the roaring voices of our public life“ niemals auf bloß eine einzige Stimme Amerikas reduzieren ließe wurden die Mittel ab 1947 enorm angehoben und in Europa, Asien und Lateinamerika Sendungsstationen auf- und ausgebaut. Siehe: Ebd., $30 \mathrm{f}$.

2395 Vgl. Heil jr., Voice of America, a.a.O., $47 \mathrm{ff}$.

2396 Paulu, The Smith-Mundt Act: A Legislative History, a.a.O., 303. Das „Wahrheitsargument“ unterstützte gegenüber dem US-Senat auch der demokratische Abgeordnete John W. Cormack: „It is a wellknown fact that adherence, even a limited adherence, to the truth in its propaganda activities, is not one of the elements of Soviet Unions's policy." Zit. nach: ebd., 304.

2397 Ninkovitch, The diplomacy of ideas, a.a.O., 135.

2398 James G. Ryan/Leonard Schlup (Eds.), Historical Dictionary of the 1940s, New York 2006, $261 \mathrm{f}$.

2399 International Educational Exchange. United States Advisory Commission and The Program of the Department of State. Department of State Publication 3313. International Information and Cultural Series 3, March 1951, 1. 
Act" (Public Law 402 of the 8oth Congress) schließlich angenommen. ${ }^{2400}$ Das Gesetz authorisierte ein weltweites Offensivprogramm zum Zweck des ,educational, cultural, scientific and technical exchange“ sowie zur ,international information “. 2401

Vorausgegangen waren der Beschlussfassung des „Smith-Mundt Act“, der nun ausdrücklich den bilateralen Kulturaustausch in Form von Personen, Wissen und Know-how vorsah, allerdings heftige und kontroversielle Debatten darüber, inwiefern das von konservativer Seite nach wie vor mit Misstrauen betrachtete State Department mit der zentralen Leitung und Supervision des gesamten Programmes betraut sein sollte, beziehungsweise welche Gefährdung ein derartiger Personenaustausch für die amerikanische Demokratie nach sich ziehen könnte. Insbesondere die Vorstellung eines freien Personenaustausches setzte xenophobe Ängste vor einer Infiltration Amerikas durch fremdländisch-europäisches Gedankengut beziehungsweise kommunistische Lehrer und Studenten frei. Aus republikanischer Perspektive erschien das als nicht zu rechtfertigendes und obendrein teures Risiko:

"We are appropriating money on the one hand to 'stop communism' in Greece and Italy, and now $[\ldots]$ we are asked to authorize the expenditure of other millions to bring teachers of communism here where $[. .$.$] they can, and they will, advocate the acceptance of communism." { }^{2402}$

Als Ergebnis dieser Debatte wurden in den „Smith-Mundt Act“ Klauseln aufgenommen, die sowohl die national-patriotische Loyalität des Beamtenstabes des Department of State sicherstellen als auch garantieren sollten, dass keine subversiven Kräfte durch die bilateralen Austauschprogramme ins Land kämen. Zu diesem Zweck sollten analog zu Abschnitt 20I des Smith-Mundt Acts alle Personen, deren Aktivitäten sich als nicht vereinbar mit der nationalen Sicherheit erweisen sollten, sofort des Landes verwiesen werden. Darüber hinaus mussten sich künftig alle Angestellten des State Department, die mit Operationen im Kontext des Smith-Mundt-Act betraut waren, einem Loyalitäts-Check durch das FBI unterziehen, ,even more stringent than the one given to people working on the atomic bomb“ ${ }^{2403}$ wie Mundt in Verteidigung des gesamten „Cultural Exchange-Program“ betonte.

Zuletzt schränkte das beschlossene Gesetz zur Umsetzung einer großangelegten USKulturoffensive, ${ }^{2404}$ das alle bisherigen Aktivitäten des State Department auf eine klar

2400 Trading Ideas with the World. International Educational and Technical Exchange. Report of the United States Advisory Commission on the Educational Exchange, 31. März 1949, 3; vgl. weiters: Ralph Sanders/Fred R. Brown, National Security Management: Global Psychological Conflict, Washington D.C. $1961,36$.

2401 Trading Ideas with the World, a.a.O., 3.

2402 So die bei Paulu zitierte Aussage des Kongressabgeordneten Hoffmann (Michigan). Zit. nach: Paulu, The Smith-Mundt Act: A Legislative History, a.a.O., 310.

2403 Ebd., 309.

2404 Das Budget der gesamten unter Public Law 402 laufenden Projekte stieg noch 1948 auf 24 Millionen US-Dollar und erreichte 195047 Millionen US-Dollar. Das dabei weltweit eingesetzte Personal stieg 
geregelte legale Grundlage stellte, den autonomen Handlungsspielraum des State Department insofern ein, als gefordert wurde, dass möglichst viele private amerikanische Informations-, Medien- und Bildungseinrichtungen bei der Umsetzung zur Kooperation herangezogen werden sollten. ${ }^{2405}$

Ausschlaggebend für die Zustimmung der Republikaner zur großangelegten Informations- und Kulturoffensive waren letztlich der Kalte Krieg beziehungsweise die anlaufenden strategischen Überlegungen eines - neben ökonomischen und militärischen Maßnahmen auch ideologischen „Containments“ beziehungsweise „Rollbacks“2406 gegenüber der als aggressiv-expansionistisch angesehenen Sowjetunion und ihrer Satellitenstaaten:

“Public Law 402 passed the Congress because 'junketing' senators and representatives observed Soviet propaganda efforts in Europe firsthand during fall 1947 and were convinced that the people of other countries had to get a better understanding of the United States if they were to withstand the 'aggressive psychological warfare' being conducted against America by the Communists. Public Law 402 enjoined the information service to tell the truth, explain United States motives, bolster morale of foreign populations, give a true picture of American life, counter misrepresentations, and support American foreign policy. The idea was to 'sell' America." ${ }^{2407}$ [Hervorhebung d. Verf.]

Ähnlich wie die korrespondierenden Passagen zum Personal-Exchange des Public Law 402 sah auch der Fulbright Act von 1946 den bilateralen Kultur-Austausch zwischen den USA und anderen Ländern vor, allerdings mit primärer Zielrichtung auf den akademisch-universitären Bereich. Die Durchführung des Programmes oblag ebenfalls dem Department of State, wobei das Board of Foreign Scholarships - direkt ernannt vom US-Präsidenten die Auswahl der Personen beziehungsweise der qualifizierten Wissenschafts- und Bildungsinstitutionen vornahm. Die Fulbright-Aktivitäten liefen vorerst eigenständig neben den Planungen auf der Basis des „Smith-Mundt Act“, wurden aber nach Einrichtung des

von anfänglich 2500 auf 4370 Personen im Jahr 1950 an. Vgl. Elder, The Information Machine. The United States Information Agency and American Foreign Policy, a.a.O., 36.

2405 Paulu, The Smith-Mundt Act: A Legislative History, a.a.O., 309.

2406 Zur Begriffsgeschichte und den politischen Implikationen des U.S. „Containment“ siehe: John Lewis Gaddis, Strategies of Containment. A Critical Appraisal of American Security Policy during the Cold War. Revised and Expanded Edition, Oxford 2005, 24 ff.; zum „Rollback siehe u. a. die vorzügliche Synopsis bei: Bernd Stöver, Rollback. An Offensive Strategy for the Cold War. In: Detlef Junker (Ed.), The United States and Germany in the Era of the Cold War, 1945-1990. A Handbook. Volume I: 19451968, Cambridge 2005, 97 ff.; siehe auch detaillierter: Ders., Die Befreiung vom Kommunismus. Amerikanische Liberation Policy im Kalten Krieg 1947-1991 (=Zeithistorische Studien. Hrsg. v. Zentrum für Zeithistorische Forschung Potsdam, Bd. 22), Köln - Weimar - Wien 2002, 54 ff.

2407 Elder, The Information Machine. The United States Information Agency and American Foreign Policy, a.a.O., 36 . 
„Information and Educational Exchange Programm“ (USIE) 1949 immer enger an die Aktivitäten unter Public Law 402 angegliedert. ${ }^{2408}$

Im Vergleich mit der Zahl jener Personen, die durch die über Kurzwellensender ausgestrahlten US-Radioprogramme (VOA, RFE, RL), die US-Film- und Kinoproduktionen, ${ }^{2409}$ die massenweise produzierten Broschüren und Flugblätter, die in hoher Auflage verbreiteten (übersetzen) Publikationen (Bücher, Zeitschriften, Magazine) sowie durch die Aktivitäten der US-Information Centers erreicht wurden, war der quantitative Erfolg der Exchange-Programme freilich eher bescheiden. So wurde im Rahmen der Personen-Austauschprogramme 1950/5I der Aufenthalt für 916 ausländische Studenten aus 50 Ländern in den USA finanziert; im Gegenzug hielten sich in diesem Zeitraum 654 amerikanische Studenten zum Studium in insgesamt 23 Ländern auf. ${ }^{2410}$ Bis Ende 1951 hatten weltweit insgesamt nicht mehr als 4.000 Personen am Fulbright-Austauschprogramm teilgenommen. ${ }^{2411}$ Österreich schloss erst am 6. Juni 1950 das Fulbright-Austauschabkommen $\mathrm{ab}^{2412}$ Zwischen 1950/5I und 1960/6r belief sich die Gesamtzahl der österreichischen Fulbright-Stipendiaten („Grantees“) nach der Aufstellung von Thomas König - neben etwa jährlich 30 Studierenden und fünf bis sechs schulischen Lehrkräften ${ }^{2413}$ - auf ${ }_{444}$ Personen,

2408 Bis Anfang April 1949 waren auf Basis des Fulbright Acts bilaterale Austauschabkommen mit folgenden Ländern abgeschlossen: China, Frankreich, Griechenland, Italien, Neuseeland, den Philippinen und Großbritannien. Vertragszeichnungen mit folgenden Ländern waren bereits im Gange: Australien, Österreich, Ägypten, Indien, Iran, Niederlande, Norwegen, Pakistan und der Türkei. Siehe: Trading Ideas with the World, a.a.O., 7.

2409 Für die spätere Phase des Kalten Krieges siehe dazu überblicksartig die Diplomarbeit von: Gregor Christian Egon Höller, Feind- und Konfliktbilder des Kalten Krieges in Fernsehen, Film und Literatur, Dipl.-Arb-., Univ. Wien 2011.

2410 Siehe dazu: Launching the Campaign of Truth. First Phase. Sixth semiannual Report of the Secretary of State to Congress on the International Information and Educational Exchange Program (July 1 to December 31 1950), Department of State Publication 4375. International Information and Cultural Series 19, Division of Publications. Office of Public Affairs, Washington D.C. 1950, 18.

2411 Educational Exchange. Under the Fulbright Act. Department of State Publication 3637. International Information and Cultural Series 9, December 1949, $1 \mathrm{ff}$.

2412 Vgl. Birgit Raunig, The first two years of the Fulbright Commission in Austria. First hand reports by American students - How did they perceive Austria?, Dipl.-Arb., Univ. Wien 2010, 32 f. Interessanterweise kämpften die US-Fulbright-Stipendiaten - 1952/53 waren dies in Summe 46 US-amerikanische Studierende - in Österreich gegen Stereotype und Klischees den USA gegenüber, von denen sie annahmen, dass die Präsenz der US-Besatzungstruppen bzw. amerikanische Touristen sie verfestigt hätten: So zum Beispiel, dass die US-Politik von einem „hysterischen Antikommunismus“ beherrscht wäre, dass „America has no real culture and [...] is naive and immature in political thinking - that it is hopelessly idealistic about the problems of mankind and terribly crass and commercialized about material things." Zit. nach: Raunig, The first two years of the Fulbright Commission in Austria, a.a.O., 60.

2413 So kamen bspw. 1952/53 in Summe 81 österreichische Studierende via Fulbright-Austauschprogramm in die USA; davon waren 31 Studentinnen. Vgl. Raunig, The first two years of the Fulbright Commission in Austria, a.a.O., $55 \mathrm{f}$. 
darunter waren I6 Frauen. ${ }^{2414}$ Bis I955 kamen über das „Exchange of Persons Program“ 634 Personen aus Österreich in die USA. ${ }^{2415}$

Obwohl nun der Smith-Mundt Act Aktivitäten in weltweitem Maßstab legalisierte, blieb das Programm, aufgrund fehlender finanzieller Mittel, noch im Fiskaljahr I949 weitestgehend auf Lateinamerika beschränkt, mit Ausnahme von 63 US-Büchereien in der östlichen Hemisphäre, ${ }^{2416}$ einem kleinen Buch-Ausstellungsprojekt sowie der Förderung inoffizieller, gegenseitiger Exchange-Aktivitäten durch das Foreign Service, wie zum Beispiel dem Fulbright-Programm.

Um all die im Smith-Mundt Act vorgesehenen, weitgespannten Aufgaben im Bereich des „mutual understanding between the peoples of the United States and the peoples of other countries“2417 umsetzen zu können, reorganisierte das Department of State im Sommer 1947 zunächst das - im Dezember 1945 geschaffene - „Office for International and Cultural Affairs“ (OIC) und dessen im Ausland tätige Stabsstelle United States Information Service (USIS) unter dem neuen Namen „Office of Information and Cultural Exchange“. ${ }^{2418}$ Am 22. April I948 erfolgte eine neuerliche Umbenennung dieser Abteilung des State Departments in „Office of International Educational Exchange“ (OIE), ${ }^{2419}{ }^{\text {wo- }}$ bei zwei neue Stabstellen eingegliedert wurden: zum einen das „Office of International Information“ (OII), das speziell mit dem Bereich Massenmedien befasst sein sollte, zum anderen das „Office of Educational Exchange“ (OEX), dessen Aufgabe die Administration der Personenaustausch-Programme sowie die weltweite Hilfe und Unterstützung für

2414 Thomas König, Das Fulbright Program in Wien: Wissenschaftspolitik und Sozialwissenschaften am „versunkenen Kontinent“, Diss., Univ. Wien 2008, 306 ff.; siehe dazu auch die überarbeitete und gekürzte Publikationsfassung: Thomas König, Die Frühgeschichte des ,Fulbright Program ' in Österreich. Transatlantische „Fühlungnahme auf dem Gebiet der Erziehung“ (=Transatlantica, hrsg. v. Günter Bischof, 6), Innsbruck - Wien - Bozen 2012.

2415 Siehe: Wagnleitner, Coca-Colonisation, a.a. O., 195.

2416 In einem darauf folgenden Bericht steht in Bezug auf die weltweiten Aktivitäten im Jahr 1949 zu lesen, dass 67 US-Bibliotheken in 60 Ländern unterhalten wurden, die mit insgesamt 22 „reading rooms“ in Summe 3.000.000 Leserinnen und Leser erreichten. Siehe: Trading Ideas with the World. International Educational and Technical Exchange. Report of the United States Advisory Commission on the Educational Exchange, a.a.O., 14.

2417 Vgl. Kennon H. Nakamura/Matthew C. Weed, U. S. Public Diplomacy: Background and Current Issues (Congressional Record Service. Report for Congress), [Washington D.C.] December 2009, 4.

2418 Die Einrichtung war u. a. mit der Produktion von Bulletins für über 70 US-Gesandtschaften weltweit betraut, gab das russischsprachige Magazin America in einer Auflage von 50.000 Stück heraus, produzierte Rundfunksendungen für über 30 Sendestationen von „Voice of America“ (VOA) in 25 Sprachen und organisierte Ausstellungen sowie Filmdokumentationen. 1948 übernahm George V. Allen die Leitung der umbenannten Einrichtung von William Benton. Siehe: Elder, The Information Machine. The United States Information Agency and American Foreign Policy, a.a.O., 36; vgl. weiters: Belmonte, Selling the American Way. U.S. Propaganda and the Cold War, a.a.O., XI.

2419 International Educational Exchange. United States Advisory Commission and The Program of the Department of State, a.a.O., 9. 
Bibliotheken/Büchereien und Bildungseinrichtungen war. ${ }^{242}$ Den genannten, Offices' waren exekutive Abteilungen („Divisions“) zugeordnet, denen die operative Leitung oblag. ${ }^{2421}$ Als ausführender Programmdienst für alle „schnellen“ medialen Aktivitäten wurde 1949 zusätzlich die Stabstelle „Information and Educational Exchange“ (USIE) eingerichtet, die die Programmplanungen von OII und OEX koordinierte beziehungsweise umfasste. ${ }^{2422}$

Die inhaltlich-konzeptionelle Ausrichtung und die konkreten Umsetzungen des USIEProgrammes wurde in einer offiziellen Broschüre des State Department folgendermaßen kurz und bündig zusammengefasst:

"The USIE program keeps the world currently informed by radio and press; it visualizes the story through motion pictures, photo displays, and exhibits; it provides outposts of American life and learning in information centers and American centers abroad; and finally, it develops mutual understanding through the interchange of persons, knowledge, and skills. [...] Overseas, the program is guided by some 575 public-affair officers, aided by an average of 15 local employees attached to each of $\mathrm{I}_{42}$ U.S. diplomatic and consular missions [...]."2423

“[...] Movies have a universal appeal [...]. Each month about to million people all over the world see American documentary films in their own languages screened under the direction of the Division of International Motion Pictures. About 300 different films are shown each month, and they are usually made up in 15 different languages. Some films are in 29 language versions besides English. In some areas the films are borrowed by schools, churches, labor groups, and other organizations. In rural and isolated communities the films are brought to the people by means of over roo mobile motion-pictures units. These mobile units also carry films strips, recordings, photo displays, books and magazines [...].

2420 Sanders/Brown, National Security Management, a.a.O., 36.

2421 So z.B. die „Division of International Exchange of Persons“, deren Aufgabe wie folgt spezifiziert wurde: „[...] assists in movement of academic personnel which is, for the most part, carried on under private auspices. It carries out Department responsibilities for certain programs involving the use of government funds for the exchange of students, trainees, professors, research specialists, teachers, and lecturers; it also gives nonfinancial assistance to individuals and private organizations here and abroad, as well as to foreign governments having exchange programs with the United States“. Des Weiteren die „Division of Libraries and Institutes“, deren Aufgabe wie folgt umrissen wurde: „[...] carries out the Department's programs relating to United States libraries, cultural centers, aid to American-sponsored schools, and the dissemination of American books, periodicals, Government documents, music art, and educational and cultural materials generally. “ Zit. nach: International Educational Exchange. United States Advisory Commission and The Program of the Department of State, a.a.O., 9.

2422 Telling America's Story abroad. The State Department's Information and Educational Exchange Program. Department of State Publication 4075. International Information and Cultural Series 14, March 1951, 5; vgl. weiters: Elder, The Information Machine. The United States Information Agency and American Foreign Policy, 36.

2423 Ebd., 4. 
The documentaries reflect the basic philosophy underlying American life: the importance of the individual in the affairs of his community, State and nation." 2424

Im Rahmen des Office of Educational Exchange (OIE) wurde im Frühjahr I949 mit der „U.S. Advisory Commission on Education Exchange“ zusätzlich vom US-Präsidenten selbst ein Beratungsgremium eingerichtet, das aus externen Fachleuten ziviler Bildungseinrichtungen zusammengesetzt war, das die bisher existierende Commission for International Educational Reconstruction ablöste und künftig dem U.S. Kongress über die laufenden Aktivitäten Bericht erstatten sollte. ${ }^{2425}$ Eine Kernaufgabe der Advisory Commission bestand darin, für den Secretary of State Vorschläge zu konkreten Austauschverfahren zu entwickeln und Konzepte für die Umsetzung vorzuschlagen - mit zwei Einschränkungen: "[...] with the exception of matters provided by the Fulbright act and those within the jurisdiction of the United States National Commission for UNESCO.“2426

Die Aufgaben der aus extern hinzugezogenen Erziehungsfachleuten bestehenden Advisory Commission, die wohl das im Smith-Mundt Act eingeforderte Engagement privater US-Einrichtungen gewährleisten sollte, umriss deren Vorsitzender Harvie Branscomb in mahnenden Worten: sie sollten angesichts der aktuellen kommunistischen Bedrohung der individuellen Freiheit und der Selbstbestimmungsmöglichkeiten des Einzelnen durch „some superior authority backed by force“2427 erneut die humanistisch-philanthrope, friedensliebende und auf Kooperation setzende Dimension des Reorientierungs-Diskurses ziviler Stellen zur Zeit des Krieges wachrufen und zugleich davor warnen, die Informationsund Kulturoffensive nicht als Werkzeug propagandistischer Beeinflussung einzusetzen.

"We do have a stake in the preservation of a world order in which countries can live at peace without the maintenance of vast military forces and in which trade and travel flow beneficially across national borders. [...] As champions and defenders of the hard-earned liberties of the ordinary man and of the freedom of nations from aggression, we have many companions and allies. It will be cooperation among those nations and people who believe that the spiritual heritages of race are worth preserving that the present difficulties will be overcome and the problems of our time resolved. [...] The program of educational and cultural exchange - not cultural penetration - rests thus upon a simple and familiar principle. Neighbors who are to cooperate need to

2424 Telling America's Story abroad, a.a.O., $8 \mathrm{f}$.

2425 Vorsitzender des Komitees war Harvie Branscomb (Rektor der Vanderbilt University); stellvertretender Vorsitzender war Mark Starr (Educational Director der International Ladies' Garment Workers Union); weitere Kommissionsmitglieder waren: Harold Willis Dodds (Präsident der Princeton University), Edwin B. Fred (Präsident der University of Wisconsin), Martin R.P. McGuire (Professor an der Catholic University). Siehe: Trading Ideas with the World, a.a.O., 1.

2426 International Educational Exchange. United States Advisory Commission and the Program of the Department of State, a.a.O., $1 \mathrm{f}$.

2427 Ebd., 3. 
become acquainted. In the modern world all nations are neighbors, and all need to cooperate." 2428 [Hervorhebung d. Verf.]

Und George C. Marshall fügte 1949 als Secretary of State hinsichtlich des neugeschaffenen „Office of Educational Exchange“ (OIE) hinzu: „This sort of development is more important now than in the past [...]. When American intelligence and purpose are correlated, the end is bound to be a very important result for the general good of the country. ${ }^{\text {"2 } 429}$

\section{Reorientierung und psychologische Kriegsführung: "War of ideas"- "Campaign of Truth“- „Struggle for Minds"}

Seit Ausbruch des Kalten Krieges sahen sich die Planer des State Departments hinsichtlich der demokratischen Umorientierung der über Jahre hinweg geistig pervertierten „Deutschen“ - trotz aller Betonung der „Selbsterziehung“ - für deren zukünftige Entwicklung in der Rolle eines, Vormundes' oder,Sachwalters' (,custodian“): „Specifically, the question arises as to whether democracy or communism will be made most attractive to the Germans and fill up the vacuum. “2430

Als grundlegende Voraussetzung für die intendierte geistig-kulturelle Westorientierung wurde in so gut wie allen zivilen Planungskonzepten die wirtschaftlich-ökonomische Rehabilitierung und Stabilisierung angesehen, Zusammenhang, der auch von Hermann B. Wells früh angesprochen worden wurde: „It is imperative that minds and bodies be fed at the same time if the German people are to be able in the long run to develop the hope for the future and the resources necessary to feed their bodies. “2431

Die propagandistische Mission bestand nun zusätzlich darin, das demokratische System sowie die ,freie Marktwirtschaft' nicht nur im Hinblick auf die nationalsozialistische Terrorherrschaft, sondern auch gegenüber dem Kommunismus als das überlegene System darzustellen und diese Überlegenheit bis in die Lebenswelt des Einzelnen hinein erfahr- und nachvollziehbar zu machen: „Democracy is not merely a political system. It is a way of life that must be incorporated into the individual behavior of ist adherents in all phases of their lives. ${ }^{\text {“2432 }}$

2428 Ebd.

2429 Ebd., 4.

2430 James L. Sundquist (Director of Management Control under General Clay) to Donald C. Stone (Executive Office of the President), „A Vitalized Program for German Educational, Religious, Information, and Related Affairs, 10. Juni 1947. The U.S. Occupation of Germany: Educational Reform 1945-1949, Microfilm-Collection Congressional Information Service, edited by Gary H. Tsuchimochi, Tokyo 1991 (Bestand Institut für Zeitgeschichte der Universität Wien, Bibliothek), 2-A-408, 2.

2431 Memorandum to Mr. James L. Sundquist, „Meeting with Mr. Wells with respect to German reorientation problem", New York City, 15. November 1947. The U.S. Occupation of Germany: Educational Reform 1945-1949, Microfilm-Collection Congressional Information Service, a.a.O., 2-A-408, 2.

2432 Ebd., 4. 
Um die ausgebrannte und desillusionierte Nachkriegsbevölkerung nachhaltig für das Projekt einer Demokratie nach westlich-amerikanischem Muster zu gewinnen, bedurfte es auch eines inneren, gefühlmäßigen Einstellungswandels - ,a change of heart on the part of the German people“2433 -, der in Form einer konzertierten Aktion in allen medienpolitischpropagandistischen, erzieherischen und bildungspolitischen Belangen erreicht werden sollte; dabei sollte insbesondere auch die individuell erlebbare Dimension des wirtschaftlichen Aufschwungs seitens der Konsumenten propagandistisch miteinbezogen werden.

In diesem Zusammenhang ist auch der vom U.S. Senat erlassene „Foreign Assistance Act ${ }^{\text {“2434 }} \mathrm{zu}$ sehen, der als „Marshall-Plan“ rund 6,2 Milliarden US-Dollar für materielle Hilfestellungen und Rohstoffspenden sowie für Kredite mit einer Laufzeit von vier Jahren bereitstellte. Als „krisenvermeidende Interventionsstrategie “2435 besaßen MarshallplanHilfe und „European Recovery Program“ (ERP) gerade auf Grund der spürbaren materiellen Hilfestellungen eine hochgradig politische Wirksamkeit, da sie „das wirkungsvollste Mittel gegen die politische Radikalisierung von Rechts wie von Links "2436 darstellten und durch die Stärkung und Stabilisierung der nationalen europäischen Wirtschaften auch eine „Abwehr des Wachsens sowjetisch-kommunistischen Einflusses“2437 erzielen konnten. Es ist daher nicht weiter verwunderlich, dass die Sowjets anlässlich der offiziellen Teilnahme Österreichs am Marshallplan am 2. Juli 1948 mit heftigem Protest auf dieses bilaterale Abkommen reagierten, da es aus ihrer Perspektive einer Art politischer Blockbildung gleichkam. ${ }^{2438}$

Vor dem Hintergrund des Kalten Krieges begann die neue Stoßrichtung der US-Reorientierungs-Planungen jedenfalls zusehends, die früheren soziologisch-pädagogischen beziehungsweise sozialpsychologischen Ansätze der zivilen Demokratisierungsdebatte mit gezielten Überlegungen zur psychologischen Kriegsführung zu vermischen: unterschwellig und nahtlos sollte die intendierte ,Selbsterziehung، in eine möglichst freiwillige Adaptierung westlich-amerikanischer, sozio-ökonomischer Standards münden und eine politischlebensweltliche Orientierung nach dem idealtypischen Vorbild einer „freien“ Gesellschaft nach amerikanischem Muster sicherstellen. Für die Planung und Unterstützung der neuen Besatzungsaufgaben zur geplanten ,indoctrination in Europe [...] to bring about better attitudes and a greater respect for American democracy ${ }^{\text {“2439 }}$ sollten künftig - neben dem

2433 James L. Sundquist (Director of Management Control under General Clay) to Donald C. Stone (Executive Office of the President), a.a.O., 3.

2434 Vgl. Hannes Hofbauer, Westwärts. Österreichs Wirtschaft im Wiederaufbau, Wien 1992, $100 \mathrm{f}$.

2435 Arno Einwitschläger, Amerikanische Wirtschaftspolitik in Österreich 1945-1949, Diss., Univ. Wien 1984, 148.

2436 Dieter Stiefel, „Hilfe zur Selbsthilfe“. Der Marshall-Plan in Österreich 1948-1952. In: Ernst Bruckmüller, Wiederaufbau in Österreich 1945-1955. Rekonstruktion oder Neubeginn? Wien 2006, 90.

2437 Stourzh, Geschichte des Staatsvertrages, a.a.O., 42.

2438 Wilfried Mähr, Der Marshallplan in Österreich, Graz - Wien - Köln 1989, 112 ff.

2439 James L. Sundquist (Director of Management Control under General Clay) to Donald C. Stone (Executive Office of the President), a.a.O., 4. 
entsprechend zu schulenden Militärpersonal ${ }^{2440}$-, auch Experten aus den Bereichen Psychologie, Bildung, Anthropologie, Religion, Information und Administration beigezogen werden.

Generell ist davon auszugehen, dass es wohl weniger inhaltliche demokratiepolitische Argumente waren, sondern vor allem die überdeutliche materielle Überlegenheit der USA, die - trotz aller nach wie vor grassierenden anti-amerikanischen Ressentiments ${ }^{241}-$, die größte positive Überzeugungskraft für den „American way of live“ entfaltete. Bereits in der unmittelbaren, von enormen existenziellen und materiellen Nöten geprägten Nachkriegszeit, boten die über Io. 000 in Österreich einmarschierenden jungen ${ }^{2442}$ und wohlgenährten US-Soldaten $^{2443}$ einen sichtbaren Ausdruck der materiellen Prosperität und Überlegenheit der USA. Abgesehen von der großen Anziehungskraft von Nahrungsmittelkonserven, Lucky Strikes, Coca-Cola, Schokolade, Kaugummis oder Nylonstrümpfen für eine in jeder Hinsicht ausgehungerte Bevölkerung, ${ }^{244}$ symbolisierten manche der Konsumgüter allein schon durch ihre Verpackung die „beautiful new world of modernity“, ${ }^{2445}$ wie Reinhold Wagnleitner in diesem Zusammenhang konstatiert:

2440 So wurden im Sommer 1947 im Einverständnis u.a. von General Clay erstmals 150 US-Militärs zu Schulungszwecken im Rahmen der „Moral Rearmament Group“ in Caux-sur-Montreux in der Schweiz zusammengezogen. Memorandum to Mr. James L. Sundquist, „Meeting with Mr. Wells with respect to German reorientation problem“, a.a.O., 1.

2441 So manche österreichischen Politiker - wie beispielsweise der damalige Innenminister Oskar Helmer gewichteten die ,kulturellen' Unterschiede innerhalb der US-Besatzungstruppen nach dem Muster traditioneller Stereotype: „Die Besetzung war auch im Westen hart zu ertragen, ganz besonders dort wo Negertruppen [sic] ins Land kamen und viele Übergriffe der Besatzungstruppen erfolgten. "Zitiert nach: Oskar Helmer, 50 Jahre erlebte Geschichte, Wien 1957, 320.

2442 Günter Bischof verweist in diesem Zusammenhang auch auf die quasi sexuelle Dimension der US-Besatzung: „Still after a long war, when all the young men had left in the Wehrmacht and many returned as cripples or not at all, the sex starved ladies regarded the healthy, cocky young GIs as highly desirable apparitions from another planet." Siehe: Günter Bischof, Two Sides of the Coin: The Americanization of Austria and Austrian Anti-Americanism. In: Alexander Stephan (Ed.), The Americanization of Europe. Culture, Diplomacy, and Anti-Americanism after 1945, New York - Oxford 2006, 154; zur „sexuellen“ Dimension der Besatzungszeit siehe weiters: Ingrid Bauer, „USA-Bräute“: Österreichisch-Amerikanische Eheschließungen auf dem Salzburger Standesamt. In: Erich Marx (Hrsg.), Befreit und Besetzt. Chronik der Stadt Salzburg 1945-1955, Salzburg 1996; Dies., Die „Ami-Braut“ - Platzhalterin für das Abgespaltene? Zur (DE-)Konstruktion eines Stereotyps der österreichischen Nachkriegsgeschichte, 1945-1955. In: L'Homme: Zeitschrift für feministische Geschichtswissenschaft, 7, 1996, Heft 1, 107-121; Barbara Stelzl-Marx, Freier und Befreier. Zum Beziehungsgeflecht zwischen sowjetischen Besatzungssoldaten und österreichischen Frauen. In: Stefan Karner/Barbara Stelzl-Marx (Hrsg.), Die Rote Armee in Österreich. Sowjetische Besatzung, 1945-1955, Graz 2005, 421-448.

2443 Diese lag mit 4200 Tageskalorien fast dreimal höher als jene der Bevölkerung in den Besatzungsgebieten. Vg1. Ralph Willet, The Americanization of Germany, 1945-1949.2. Aufl., London - New York, 1992, 3.

2444 Vgl. Bischof, Two Sides of the Coin, a.a.O., 154.

2445 Willet, The Americanization of Germany, a.a. O., 14. 
"In der Psyche der Besiegten wurden die Vereinigten Staaten [...] bald zu den relativ harmlosesten [...] Siegern ernannt. Die USA avancierten zur Chiffre des eigentlichen Gewinners schlechthin, auf dessen Seite 'man' eigentlich ohnehin gekämpft hatte. Wenn sich das reale Verhalten der GIs in vielen Belangen auch kaum von dem der Soldaten anderer Besatzungsarmeen unterschied, dann doch in einem wesentlichen Punkt. Sie verfügten nicht nur über Dollars, sondern über eine damals noch härtere Währung: Nahrungsmittel, Zigaretten, Nylonstrümpfe, Penicillin - kurzum, über die Überlebensnotwendigkeiten für die geplagten, hungernden, verwirrten Menschen." ${ }^{2446}$

Obwohl sich - insbesondere in der älteren Generation - ein Gefühl kultureller Überlegenheit hielt - „Die haben zwar das Geld und alles, aber die Bildung haben wir $[\ldots]^{\text {“2447 }}$-, man „kulturell [...] ein bißchen auf die Amerikaner heruntergeschaut" hat und angesichts der sich verbreitenden, amerikanischen Sitten " das „Herabsinken unserer noblen Kultur“ befürchtete, ${ }^{2448}$ entwickelte die mit den US-Besatzungssoldaten ins Land gekommene fremde Lebensweise - ,irgendwie waren sie ,Wesen vom anderen Stern “'2449 - in der nach Orientierung suchenden Jugend rasch geradezu magnetische Anziehungskraft. Im Kontrast zu Marschtritt und Walzer nannten in einem Oral-History Projekt befragte ZeitzeugInnen die „Rhythmen der amerikanischen Populärmusik - Swing, Boogie und später dann Rock'n Roll - und die damit verbundenen körperbetonten Tänze [...] besonders häufig als, Teil der Befreiung ““. ${ }^{2450}$ Die größere Freizügigkeit des amerikanischen Lebensstils im Vergleich zu den Gepflogenheiten der eigenen Herkunftsmilieus bot gerade für die jüngere Generation faszinierende Abgrenzungsmöglichkeiten gegenüber den Wert- und Moralvorstellungen der Elterngeneration. Bald waren Jeans das „Non-Plus-Ultra“, ${ }^{2451}$ das Trinken von Coca Cola sowie das besonders irritierende Kauen von Kaugummi mit der „Erotik der Sieger“2452 ebenso gleichbedeutend wie deren Habitus: „ässig, selbstbewußt und ungebunden, eigenen Ideen und Bedürfnissen statt den Befehlen anderer verpflichtet“. 2453

Coca Cola wurde - „5O Groschen per bottle plus normal loss and breakage charges“in Salzburg seit Dezember 1948 verkauft und ab Februar 1949 auch in Oberösterreich. Im Frühjahr 1949 wurde in Absprache mit Samuel H. Williams, Leiter der USFA-Education Division, ein Plan zur schrittweisen Ausweitung des Cola-Verkaufes in der amerikanischen

2446 Wagnleitner, Coca-Colonisation und Kalter Krieg, a.a. O., 84.

2447 Ingrid Bauer, Welcome Ami Go Home. Die amerikanische Besatzung in Salzburg 1945-1955. Erinnerungslandschaften aus einem Oral-History-Projekt, Salzburg - München 1998, 212.

2448 Ebd., 214.

2449 Ebd., 217.

2450 Ebd., 220.

2451 Ebd., 219.

2452 Bauer, Welcome Ami Go Home. Die amerikanische Besatzung in Salzburg 1945-1955, a.a.O., 216.

2453 Bernd Greiner, „Test the West“. Über die „Amerikanisierung“ der Bundesrepublik Deutschland. In: Mittelweg 36. Zeitschrift des Hamburger Instituts für Sozialforschung, 6, 1997, 20. Zit. nach: Bauer, Welcome Ami Go Home. Die amerikanische Besatzung in Salzburg 1945-1955, a.a. O., 223. 
Besatzungszone erarbeitet, um mit den damit zu erzielenden Einnahmen die US-Jugendaktivitäten (AYAA) in Österreich mitzufinanzieren. Um keine unnötigen Konflikte zu

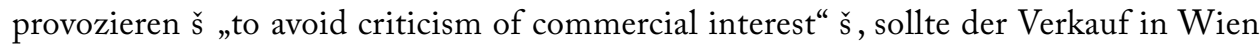
allerdings durch das „Special Service“ hauptsächlich bei Filmvorführungen in Kinos innerhalb der US-Besatzungszone erfolgen. ${ }^{2454}$

Den pragmatisch ausgerichteten US-Demokratisierungsansatz, der auf die handfeste Überlegenheit des amerikanischen Systems setzte und davon ausging, dass sich die mentale Umorientierung quasi unweigerlich über die unübersehbaren materiellen Vorzüge einstellen würde, brachte ein Mann auf den Punkt, der hinsichtlich seiner kulturphilosophischen oder gar idealistischen Motive vergleichsweise unverdächtig erscheint. Henry Ford II., Präsident der Ford Motors Company, hielt am 29. September 1947 vor den Mitgliedern der Automobil- und Flugzeugteilehersteller in Cleveland einen Vortrag über „Production for Peace and Freedom". Dabei sprach Ford von den großen Verwüstungen durch den vorhergehenden Weltkrieges, und zwar durchaus nicht nur im materiellen Bereich:

"It is not merely things which have been destroyed. The landscape is littered with wrecked ideas and faith [...]. Perhaps the greatest havoc has been wrought in the spirit of man." ${ }^{455}$ [Unterstreichung im Original]

Im Hinblick auf die zu ergreifenden Maßnahmen für einen raschen wirtschaftlichen Wiederaufbau š „um eine bessere Welt zu schaffen“ $\check{s}$, merkte Ford allerdings leicht entmutigt an, dass „viele Länder anscheinend die Verbindung zwischen „America's all-out ability to produce“ und dem amerikanischen Systems der "freedom-plus-opportunity ${ }^{\text {“2456 }}$ noch nicht ganz begriffen hätten š dies, obwohl Amerika weltweit und vor allem gegenüber dem Kommunismus bisher klar gezeigt habe, ,that the greatest and most resourceful dynamo is a free man š still the best gamble in history. ${ }^{2457}$

Die demokratische Überlegenheit des amerikanischen Modells im Hinblick auf individuelle Freiheit und Lebensgestaltung š im Wesentlichen also den, Tellerwäscher-zum-MilliardärMythos š übersetzte Ford in eine leicht nachvollziehbare Relationsgröße: „If a Russian wants a bottle of beer, he has to work eight hours to get it. An American works ten minutes. “2458

Ford erläuterte seine Sicht der amerikanischen „Freiheit“ in Abgrenzung zur Rassendoktrin des Nationalsozialismus, wobei er,kulturellen' Fortschritt hauptsächlich in Begriffen naturwissenschaftlicher und technisch-ökonomischer Leistungsfähigkeit deutete: der

2454 NARA II, RG 260, Youth Activities, Box 1. R.L. Novarine, Public Welfare Branch, Headquarters Zone Command Austria US Army, to Col. H.C. Dellert, Chief Civil Affairs, 2. März 1949, 1.

2455 NARA II, RG 165, Box 326. Henry Ford II, Production für Peace and Freedom, 29. September 1947, 5. 2456 Ebd.

2457 Ebd., 6.

2458 Ebd., 7. 
vermeintlichen „Überlegenheit der Rasse“ stellte Ford die reale Überlegenheit des freien Amerika gegenüber - und zwar in Form der erprobten wirtschaftlichen und damit auch ,mentalen' Überlegenheit des kapitalistischen Systems:

\begin{abstract}
"What has been achieved by America has been achieved not because of any superiority of race or resources, but because of a superiority of method. By giving freedom and opportunity to millions of people, we have released the greatest productive force the world has ever known. Long before America found out how to achieve the terrific release of power which results from splitting the uranium atom and effecting a chain reaction, America discovered the even greater power to be derived by freeing the individual from monopolistic restraints of kings, dictators, privileged classes, governments or any other institution. The wealth and strength of America today is the product of a tremendous chain reaction in the field of the human spirit." ${ }^{245}$ [Hervorhebung d. Verf.]
\end{abstract}

An dieser Stelle ist hervorzuheben, dass die zitierten Aussagen Henry Fords als durchaus gewichtig anzusehen sind, zumal die seit 1936 bestehende Ford Foundation in den Vierzigerund Fünfzigerjahren Milliarden Dollars in kulturpolitische beziehungsweise propagandistische Unternehmungen investierte und auch schon vor dem Wechsel des Marshall-Planers Richard M. Bissell zu Ford 1952 eng mit CIA-Stellen zusammenarbeitete und an deren verdeckten Aktivitäten teilnahm. ${ }^{2460}$ Frances Stonor Saunders meint dazu in ihrer gut recherchierten Studie zum „Kalten Kultur-Krieg“: „At times, it seemed as if the Ford Foundation was simply an extension of government in the era of international cultural propaganda." ${ }^{2461}$

Ähnlich, wenn auch in weitaus weniger blumiger Sprache wie Henry Ford, äußerte sich dann auch Staatsekretär Dean Acheson anlässlich der Inaugural-Rede Harry Trumans im Jänner 1949, worin dieser sein „4-Punkte-Programm“ („The Truman ,Point Four ‘ Program“) zur Ausweitung der technisch-ökonomischen Hilfe an unterentwickelte Länder präsentierte. Mit Bezug auf die Rede Trumans stellte Acheson klar, was nunmehr deklariert Ziel der amerikanischen Politik war:

"[...] to make clear in our own country and to all the world the purpose of American Life and the purpose of the American system. That purpose is to enable the individual to attain the freedom and dignity, the fullness of life which should be the purpose of all government and of all life on this earth [...]. To me the essential thing about it is the use of material means to a nonmaterial end." ${ }^{2462}$ [Hervorhebung d. Verf.]

2459 Ebd., 7.

2460 Vgl. Berghahn, Transatlantische Kulturkriege. Shepard Stone, die Ford-Stiftung und der europäische Antiamerikanismus, a.a.O., $270 \mathrm{ff}$.

2461 Saunders, The Cultural Cold War, a.a.O., 139.

2462 „The Truman ,Point Four Program, 4. Februar 1949, Department of State. Office of Public Affairs. Information Memorandum No. 36, 1., NARA II, RG 59, 250/49/25/07, Lot 52-95 [Entry 1374] Box 1. General Records of the Department of State. Record of Public affairs. Information Memorandums, 1948-1952. 
Um die materielle Überlegenheit (gegenüber Russland) und dem daraus resultierenden Nutzen für die individuellen Arbeits- und Lebensmöglichkeiten glaubhaft zu untermauern, wurde in Schriften ziviler Reorientierungs-Experten, die sich bereits auf der Basis des „war of ideas" bewegten, auch Statements externer Experten propagandistisch verwertet - so zitierte die "United States Advisory Commission on Education Exchange“ die Aussage eines leitenden europäischen Gewerkschaftsfunktionärs, der sich eine Zeit lang in den USA aufgehalten und sich dabei ein Bild von den Gegebenheiten gemacht hatte:

"I don't speak a word of English - everything I know about the United States, I saw with my own eyes. We have seen pictures of American factories with large groups of automobiles along the side. The Russians told us that these were false pictures, that they were not true. While in the United States, we have seen such factories and, even more convincing, we have talked (through interpreters) with the workers who own these cars." ${ }^{2463}$

Dementsprechend bildete die positive Selbstzeichnung der politisch-wirtschaftlichen Hilfestellung der USA, also die Verknüpfung von Wohlstand und wirtschaftlicher Sicherheit durch die Marshallplan-Hilfe ein zentrales Element der affichierten US-Plakate in Österreich. ${ }^{2464}$

Obwohl die für die US-Kulturoffensive einbezogenen Einrichtungen und Personen des privat organisierten, philanthropischen Gesellschaftsbereiches primär auf die humanistisch-friedliebenden Aspekte einer kulturellen Reorientierung der europäischen Nachkriegsgesellschaften setzten - wie das noch in einem von US-College-Lehrern an Präsident Truman im Jänner 1948 gerichteten Brief hervorgeht ${ }^{2465}$ - lieferten die strategischen Planungen des Kalten Krieges in diesem Bereich längst die zentralen Grundlagen für Inhalt und Ausrichtung der aktuellen und künftigen Aktivitäten.

Mit dem ab 1947 voll ausbrechenden Kalten Krieg, der umgehenden Remilitarisierung und der Schwerpunktverlagerung der Reorientation-Programme auf den Fokus antikommunistischer Propaganda und Abwehr, verengte sich die grundsätzlich „demokratische Perspektive" der Reorientierung - die ursprünglichen Konzepte und die Arbeit der ausführenden Stellen waren ja, wie gezeigt, durchaus als ernsthafte friedensichernde Rekulturalisierung-Maßnahmen gedacht - allerdings zum Teil auf die pro-westliche Kooperationsbereitschaft in wirtschaftlichen und militärischen Angelegenheiten.

Mit der Direktive SWNCC 304/I wurde am 30. April I947 schließlich ein eigenes „Subcommittee on ,Psychological Warfare““ innerhalb des State-War-Navy-coordinating

2463 Zit. nach: Trading Ideas with the World, a.a.O., 1.

2464 Vg1. Krienzer, Strategien der Propaganda im frühen Kalten Krieg, a.a.O., 99.

2465 Diese betrachteten die im Anlaufen befindlichen Cultural-Exchange Programme geradezu als einen Grundstein für eine Weltfriedensordnung („foundation of world peace“). Vgl. Ninkovitch, The diplomacy of ideas, a.a.O., 129. 
Committees eingerichtet, das direkt dem US-Präsidenten unterstand und dem Prozess der Westintegration und der politischen Auseinandersetzung mit der sowjetischen Einflusssphärenpolitik zu Friedenszeiten eine neue Dimension hinzufügte. ${ }^{2466}$

Nach den Prager Ereignissen im Februar 1948 fielen die Agenden der „Reorientation“ zunehmend in die Observanz zum Teil neugeschaffener geheimdienstlicher Abteilungen, wie dem bereits genannten „Office of Policy Coordination“ (OPC) oder der „Psychological Warfare"-Abteilungen des State Departments sowie der CIA. Unter dem Vorwand eines möglichen Krieges mit der Sowjetunion beziehungsweise ihrer Satellitenstaaten, militarisierten sich die ursprünglichen zivilen Demokratisierungs-Konzepte alsbald zur invasiv konzipierten „Campaign of Truth" beziehungsweise zum „Crusade for Freedom“, also zum propagandistischen Kreuzzug gegen jede Form mentaler Vorbehalte gegenüber Amerika. Das geschah nun aber mit doppelter Stoßrichtung: in den westlichen Besatzungszonen Deutschlands und Österreichs, ebenso wie in den anderen westeuropäischen Ländern, ging es um die Aufrechterhaltung und Sicherstellung pro-westlicher, also letztlich pro-amerikanischer Haltung sowie um die Ausschaltung jeglichen kommunistischen Einflusses; hinter dem Eisernen Vorhang um (vor allem über Kurzwellensender betriebene) systemdestabilisierende Propaganda und Desinformation.

Ab 1948 begann die „Advisory Commission on Education Exchange“2467 fortlaufend Broschüren zu publizieren, in denen die ideologische Stoßrichtung der kulturellen Austauschaktivitäten in unmissverständlicher Weise offen gelegt wurde. So steht darin unter anderem zu lesen:

"Although hostilities ceased in 1945 , in a sense we are still at war - a war of ideas which cannot be won by military weapons. Antifreedom forces, advocating censorship, suppression, and coercion of men's minds, are attacking the United States' motives, principles, and way of life." ${ }^{2468}$

Dementsprechend sollte der intensivierte Ideen- und Meinungstransfer in Form persönlicher Kontakte sowie über den Austausch von „professors, specialists, teachers, and students“ selbst ausgeprägt kritische Geister überzeugen oder zumindest zu differenziert-gemäßigteren Ansichten über Amerika führen: „[...] those who have returned and still criticize us do so with knowledge, constructively and without rancor. ${ }^{\text {“2469 }}$

Nachdem Präsident Truman am 20. April 1950 in einer Rede vor der Amerikanischen Gesellschaft der Zeitungsherausgeber erklärt hatte, dass entsprechende Informations-

2466 NARA II, RG 59, Box 17. Office Memorandum. United States Government [Top Secret]. Ralph Block to W.T Stone, 18. August 1948, 1.

2467 Dieses Komitee folgte der bereits existierenden „Commission for International Educational Reconstruction" des „American Council on Education“ (ACE) nach.

2468 Trading Ideas with the World. International Educational and Technical Exchange. Report of the United States Advisory Commission on the Educational Exchange, 31. März 194, 1.

2469 Ebd., 24. 
politik ab sofort von gleicher Bedeutung sei wie „armed strength or economic aid“, 2470 wurde mit der „Campaign of Truth“2471 ein weltweiter, antikommunistischer Propagandafeldzug begonnen, der neben dem Radio („Voice of Amerika“ beziehungsweise „Radio Free Europe“ ${ }^{2472}$ alle Medien im Sinne einer psychologischen Kriegsführung gegen das Agitprop-Programm der Sowjets und ihrer Bündnisstaaten umfassen sollte. Vor dem Hintergrund des bevorstehenden Koreakrieges teilte Truman den Medienvertretern den Beginn einer großangelegten, globalen Informationsoffensive der US-Regierung mit, die alle Informationskanäle umfassen sollte:

"Our task $[\ldots]$ is to present the truth to the millions of people who were uninformed or misinformed or unconvinced. [...] We must make ourselves heard round the world in a great campaign of truth." ${ }^{2473}$

Etwa zeitgleich kommentierte der US-Politologe Richard L. Brecker die Trumansche Propagandadoktrin als notwendige Gegenwehr im Kampf für ,Wahrheit‘ und ,Freiheit‘: „The use of propaganda as the Soviet Union's principal means of nonmilitary aggression has obliged the free nations of the world to take effective countermeasures on behalf of truth and freedom ".2474

Unmittelbar nach der Invasion nordkoreanischer Truppen in Südkorea legten Secretary of State, Dean Acheson, und General Eisenhower dem Foreign-Relations Subcommittee des Senates im Juli 1950 die Pläne zur umfassenden „Truth-Campaign“ dar und erklärten darin: „Truth could almost be classified as our T-bomb (truth-bomb) in this warfare. “2475 Zeitgleich mit der Gründung des „Congress for Cultural Freedom“ (CCF) in Berlin, der eine große Zahl deklariert antikommunistischer Intellektueller miteinbezog, ${ }^{2476}$ wurde dieser umfas-

2470 Richard L. Brecker, Truth as a Weapon of the Free World. In: Annals of the American Academy of Political and Social Science, Vol. 278, November 1951, 1.

2471 Vgl. „Truth Campaign. Counteract Propaganda“. In: The Hart County News, 27. Juli 1950, Nr. 33, 2.

2472 Vgl. David F. Krugler, The Voice of America and the Domestic Propaganda Battles, 1945-1953, Columbia/Univ. of Miss. Press 2000, 96 f.; siehe weiters: Andrew Defty, Britain, America and Anti-Communist Propaganda 1945-53, London 2004, 169.

2473 Telling America's Story abroad. The State Department's Information and Educational Exchange Program. Department of State Publication 4075. International Information and Cultural Series 14, März $1951,2$.

2474 Brecker, Truth as a Weapon of the Free World, a.a.O., 1.

2475 „Truth Campaign. Counteract Propaganda“, a.a. O., 2.

2476 Gegründet wurde der streng antimarxistische und antikommunistische „Congress for Cultural Freedom“ unter maßgeblicher Initiative u. a. von Melvin J. Lasky, Arthur Koestler, Nicolas Nabokov, Manès Sperber und Ignacio Silone anlässlich der ersten Versammlung in Berlin vom 26.-30. Juni 1950 als „Weltparlament der Intellektuellen“, wobei insgesamt 118 Personen aus 21 Ländern teilnahmen - darunter sechs aus Österreich. Administriert und finanziert wurde der CCF als „Marshall Plan in the field of ideas“ vom CIA u.a. über Michael Josselson als dessen Agent. Nach dem Berliner Kongress wurde in Paris das 
sende antikommunistische Propagandafeldzug - gewissermaßen das außenpolitische Präludium zum nachfolgenden McCarthysmus - von höchster Planungsebene als neues, durchaus aggressives Paradigma US-amerikanischer Informationspolitik zementiert. Die Supervision und die inhaltliche Neudefinition der Reorientierung auch als psychologische Beeinflussung und „Stärkung der westlichen Moral“ fiel damit verstärkt an die Intelligence-Abteilungen des State Department beziehungsweise des Department of Defense; ${ }^{2477}$ diese wurden von George F. Kennan unterstützt und schufen gemeinsam mit der CIA am 4. April 195I eine eigene, mit Sonderaufgaben ausgestattete, unabhängige Geheimdienstabteilung - das „Psychological Strategy Board“ (PSB) unter Leitung von Gordon Gray. ${ }^{2478}$ Zuvor hatten sich aber bereits US-Geheimdienstabteilungen mit Eventualplanungen, Szenarien psychologischer Kriegsführung und harter Aktionen auch auf europäischem Boden auseinandergesetzt.

Schon Ende des Jahres 1948 hatte sich - vor dem Hintergrund der Ereignisse in der Tschechoslowakei - eine Studie der „Special Warfare Division“ mit dem Titel „Instantaneous War“ mit einem Putsch der französischen Kommunisten beschäftigt und dabei geradezu Horrorszenarien eines Blitz-Krieges mit modernen Waffen entworfen. Darin wurde insbesondere auf die Bedeutung der psychologischen Kriegsführung als einer „systematic drainage“ verwiesen: „In the psychological domain, propaganda and its effect on the brain has shown itself to be a forerunner and gives an insight into the possible future effects of biological warfare. ${ }^{\text {2479 }}$

Hauptquartier des CCF errichtet und als Gegenmaßnahme zur Sowjet-Propaganda u.a. eine Reihe von Zeitschriften gegründet, die - insbesondere die intellektuelle Meinungsbildung in Europa maßgeblich beeinflussen helfen sollten. Darunter: Encounter (London), Preuves (Paris), Der Monat (Hamburg), Tempo Presente (Rom) und das Forum in Wien unter redaktioneller Leitung des aus der US-Emigration zurückgekehrten Friedrich Torberg. Mit Ausnahme des Forum, das sich hauptsächlich der kulturellen Renaissance der Wiener Fin de siècle-Kultur widmete, zielten die anderen genannten CCF-Zeitschriften in ihrer Kulturberichterstattung auf Propagierung rezenter US-amerikanischer „high brow culture“ im Bereich von Moderner Kunst, Malerei, Musik oder Literatur. In Österreich trug Torberg in seiner medialen Schlüsselposition im Forum mit seinem Negativurteil maßgeblich zum langjährigen BrechtBoykott in den Österreichischen Theatern bei. Zum CCF siehe: Saunders, The Cultural Cold War, a.a.O., 73 ff.; Michael Hochgeschwender, Freiheit in der Offensive? Der Kongreß für kulturelle Freiheit und die Deutschen, München 1998, 229 ff.; Felix W. Tweraser, Paris Calling Vienna: The Congress for Cultural Freedom and Friedrich Torberg's Editorship of Forum. In: Austrian Studies, Vol. 13: Austria and France, 2005, 158-172; Ders., „Our Man in Vienna“: Friedrich Torberg's Journal Forum and the Popularization of American Letters in Austria. In: TRANS. Internet-Zeitschrift für Kulturwissenschaften, Nr. 17, Februar 2010, siehe: http://www.inst.at/trans/17Nr/1-11/1-11_tweraser17.htm [Zugriff 28.3.2013]; Kurt Palm, Vom Boykott zur Anerkennung. Brecht und Österreich, Wien 1983. Siehe auch die offizielle Information zum CCF auf der CIA-Website: https://www.cia.gov/library/center-for-the-study-of-intelligence/ csi-publications/csi-studies/studies/95unclass/Warner.html [Zugriff 28.3.2013].

24771947 wurde das 1789 ins Leben gerufene U.S. War Department in „Department of the Army“ umbenannt, bis 1949 die Reorganisation des Ministeriums unter dem neuen Namen „Department of Defense“ erfolgte.

2478 Vgl. Prados, Safe for democracy, a.a.O., 80 f.; weiters: Saunders, The Cultural Cold War, a.a.O., $148 \mathrm{f}$.

2479 Instantaneous War [1948], 9. NARA II, RG 319, 279/18/19/1, Records of the Army Staff. Records of the Office of Special Warfare. Secret Correspondence, 1951-58, Box 05 [Entry 338]. 
Eine Studie, die übrigens - wie eine zweite mit dem Titel „The Order of Urgence of Adaptions “ [1948] - dem US-Botschaftssekretär in Wien, Martin F. Herz, der zuvor als Major Mitarbeiter der SHAEF-Psychological Warfare Division eingesetzt war, zur inhaltlichen Beurteilung vorgelegt wurde. „I am extremely interested in participating in real psychological warfare planning and that I will always be only too glad to analyze any papers you may have on the subject" strich der PW-Spezialist Herz in seiner Replik heraus und fügte an, dass die Studie interessante psychologische Probleme aufwerfen würde, die sie jedoch, so Herz, nicht weiter ausführte: so etwa die Frage, ob im Fall einer kommunistischen TerrorKampagne mit Gegen-Terror geantwortet werden sollte.

Wie tief sich die brutale Sachzwanglogik des Kalten Kriegs bereits vier Jahre nach Kriegsende selbst in intellektuelle Diplomatenköpfe eingegraben hatte, dokumentiert der knappe Wortlaut der folgende Aussage von Herz im Original: „The immediate shooting, out of hand, of a large number of selected Communist leaders would in my opinion, if attended by sufficient publicity, have most salutary effect in the event of an uprising." ${ }^{2480}$

Die oben zitierte zweite Studie der Special Warfare Division, die sich, wenn auch äußerst abstrakt, mit dem Fallbeispiel Frankreich beschäftigte, ging noch einen Schritt weiter. Mit einem Seitenhieb auf die Haltung amerikanischer Liberaler, wurde zunächst negativ vermerkt, dass Frankreich in den letzten Jahren die Verbreitung liberaler Ideen toleriert habe:

“There has been a 'non-war' psychosis; a desire to return to the 'simple life', such as one finds in the attitude of WALLACE [der links-liberale Präsidentschaftsgegenkandidat Henry Wallace, d. Verf.]. This sort of attitude is popular in France, and therefore this attitude must strongly be opposed and thoroughly denounced." ${ }^{2481}$ [Versalien im Orig., d. Verf.]

Darüber hinaus wurden in diesem Report ausdrücklich Pläne „offensiver Aktionen hinter dem Eisernen Vorhang“ als Politik eines „Angriffs von hinten“ („from the rear“) skizziert: "It is by use of a policy of attacking from the rear, by the use of a psychosis of non-collaboration, by waking the people up as to what is really happening, by sorting them, and developing an acute sense of nationalism that behind the Iron Curtain a climate of insecurity can be built up. This psychosis of doubt and general insecurity will be prelude of the collapse of the Soviet conquests." 2482

2480 Comments on „The Order of Urgence if Adaptions“ and „Instantaneous War“ [1949], by Major Martin F. Herz. NARA II, RG 319, 279/18/19/1, Box 05 [Entry 338].

2481 Bleeker Dee, The Order of Urgence if Adaptions [Nov. 1948] NARA II, RG 319, 279/18/19/1, Box 05 [Entry 338].

2482 Bleeker Dee, The Order of Urgence if Adaptions, a.a. O., 26. Und weiter: „Without being lured by separatist movements [national communism] a precise course must be shown, utilizing the exiled national leaders. This will take the form of clandestine activity, and those involved must accept the risks of activity of this nature. These national action groups located behind the Iron Curtain, and will be under the aegis of the West [...]." Ebd. 
Allerdings zeichneten sich aber auch hier Konfliktlinien und Auffassungsunterschiede zwischen dem Department of State und dem War Department ab, auf die an dieser Stelle aber nicht eingegangen werden muss. Die genannten Beispiele mögen an dieser Stelle genügen, um zu verdeutlichen, welche weitreichenden Planungsszenarien zu Beginn des Jahres 1949 - und bei Teilen der US-Diplomatie bekannt - bereits im Spiel waren.

Der Beginn der weltweiten „Truth-Campaign“ bedeutete, wie Außenminister Dean Acheson in Bezug auf die enormen finanziellen Aufwendungen hervorstrich, „not only a sharp step-up in operations bust also a redirection of the total effort to meet the Soviet challenges“. 2483

Von nun an erhöhte sich nicht nur das Tempo aller Operationen, sondern auch das Budget für die Produktion des benötigten Propagandamaterials: „Production of pamphlets, a top priority item in the psychological offensive, was greatly increased [...] Film production was expanded and redirected more specifically to the critical areas [...] opening new U.S. Information Centers [...] a book translation program was also stepped up [... “..2484

Besondere Aufmerksamkeit galt dem Ausbau der täglichen Radioprogramme der „Voice of America" (VOA), deren Fokus auf die Berichterstattung über die sowjetischen Pläne zur „Welteroberung“ und die notwendige Konsolidierung der westlichen Demokratien im $\mathrm{Zu}$ sammenhang mit einer beschleunigten Wiederaufrüstung im Rahmen des Atlantikpaktes gerichtet war. ${ }^{2485} \mathrm{Ab}$ I950 erreichten die VOA-Programme mit einer täglichen Sendezeit von einer halben Stunde über Deutschland auch Österreich. ${ }^{2486}$

Darüber hinaus wurden in der Presse antikommunistische Artikel lanciert, ${ }^{2487}$ entsprechende Broschüren und Magazine - zum Beispiel Amerika ${ }^{2488}$ - in millionenfacher Auflage gedruckt, ${ }^{2489}$ leicht verständliche antikommunistische Cartoons gestaltet ${ }^{2490}$ und Filme für „key audiences“ in den jeweiligen Ländern gedreht, „to expose communism and

2483 Launching the Campaign of Truth. First Phase. Sixth semiannual Report of the Secretary of State to Congress on the International Information and Educational Exchange Program (July 1 to December 31 1950), Department of State Publication 4375. International Information and Cultural Series 19, Division of Publications. Office of Public Affairs, Washington D.C. 1950, 1.

2484 Launching the Campaign of Truth, a.a.O., 2.

2485 Ebd., 4.

2486 Ebd., 53.

2487 Ebd., 8.

2488 „The Magazine Amerika continued to carry the truth about the United States to the people of the Soviet Union despite drastic Soviet efforts to throttle distribution. “ Zit. nach: Launching the Campaign of Truth. First Phase, 10.

2489 Ebd., 10.

2490 Vorgesehen war: „[... ] production more than a dozen cartoon-style booklets, revealing in simple, dramatic presentation the false claims and direct personal threat of Communist aggression to the individual farmer and worker in vital areas of Europe, Asia, and Latin America." Zit. nach: Launching the Campaign of Truth. First Phase, 9. 
to document Soviet-inspired aggression. ${ }^{\text {2491 }}$ Neben Filmen sollten die USIE-Abteilungen insbesondere einschlägig propagandistisches Bildmaterial, dessen ideologische Aussage keiner weiteren Erklärung bedurfte, für die „Truth-Campaign“ massenhaft verteilen:

"Photographic output was centered mainly on the production and distribution of hard-hitting, tactical photo releases for placement in foreign publications by USIE posts. These photographs stressed the strength of the United States and its determination to repel or forestall Communist aggression in the Orient and elsewhere [...]. News paper cartoons, from both U.S. and foreign newspapers, debunking and deriding Communist tactics." ${ }^{2492}$ [Hervorhebung d. Verf.]

Als zentrale Stützpunkte und Vermittlungsorte dieser mit Mitteln der psychologischen Kriegsführung vorangetriebenen US-Kulturoffensive - „to interpret United States and to combat communism“2493 - fungierten 1950 unter anderem weltweit 103 „U.S. Information Centers", in denen neben einer Vielzahl lokaler Personen immerhin auch 6o amerikanische Bibliothekare angestellt waren. ${ }^{2494}$

Dass diese Propaganda-Offensive rasch Erfolg hatte, ist zum Beispiel aus der Statistik des „U.S. Information Centers“ in Budapest ersichtlich, wonach die Benützungzahlen von I8.872 im Jahr 1949 auf 96.000 Personen im Jahr 1950 anstiegen. ${ }^{2495}$ Und wie aus einer Auflistung des weltweiten USIE-Personals hervorgeht, lag Österreich 1950 im Vergleich zu allen anderen angeführten Ländern mit insgesamt 30 Personen am höchsten. ${ }^{2496}$

Was Österreich sonst anbelangt, so ist dem Wortlaut eines Memorandums des Departments of State zur „Politik der USA gegenüber Österreich“vom 8. Dezember 1950 kaum sonderlich Spannendes zu entnehmen. Unter dem Punkt „Information and Cultural Policies" wird darin lediglich die bisherige, hochoffizielle Linie der US-Diplomatie sowie der amerikanischen Besatzungsmacht gegenüber Österreich resümiert.

Deren Ziel bestehe in der Wiederaufnahme und dem Ausbau normaler internationaler Kulturbeziehungen mit Österreich, sowie darin, die Errichtung eines demokratischen Erziehungswesens sowie entsprechender Informationsmedien zu unterstützen. Weiters wäre die US-Politik gegenüber Österreich so auszurichten, den Respekt und die Freundschaft Österreichs gegenüber den USA zu befördern. Durch US-Informationsmedien solle zu-

2491 Ebd., 11.

2492 Ebd., 8.

2493 Ebd., 14.

2494 Von Juli bis Dezember 1950 wurden in Summe 47.288 Bücher nach Europa verschifft, 9.359 US-Magazine, 10.492 „music items“ und 132.124 publizierte Dokumente von US-Regierungsstellen. Vgl. Launching the Campaign of Truth. First Phase, a.a.O., 14.

2495 Launching the Campaign of Truth. First Phase, 14.

2496 Im Vergleich zu Österreich führte die USIE-Personalstatistik 1950 für Indien 29, für Frankreich 28 und für Italien ebenfalls 28 Personen an. Vgl. Launching the Campaign of Truth. First Phase, Appendix, 66 . 
dem jeder Form von Totalitarismus und feindlicher Propaganda in Österreich vorgebeugt werden. ${ }^{2497}$

Soweit, so unspektaktulär. Freilich darf der hier angeschlagene freundschaftlich-kooperative Ton, der auf der seit der Moskauer Deklaration festgeschriebenen Position alliierter Politik gegenüber Österreich gründete, keineswegs darüber hinweg täuschen, dass die Behandlung Österreichs - wie sich auch im Gesamtkontext der RemilitarisierungsPlanungen zeigt - im Planungsbereich der überseeischen Stellen, wie der „Reorientation Branch der Civil Affairs Division“ (CAD) im War Department und der „Division of German and Austrian Information and Reorientation Affairs“ - „Office of German and Austrian Affairs“ - im State Department weitgehend an Deutschland beziehungsweise an die deutsche Besatzungszone angelehnt war. ${ }^{2498}$ Darüber hinaus fanden innerhalb der CAD wöchentliche Besprechungen „on German and Austrian Reorientation Problems“ statt, an denen auch die leitenden Beamten der „Austrian-German Branch“ des State Department teilnahmen. ${ }^{2499}$

Ein wenig deutlicher sind in dieser Hinsicht die Hinweise in den „Field Programs“ für Österreich, wo die erwähnte „Campaign of Truth“ entsprechend durchschlug. So erfolgte der intensivierte Ausbau der Ausstattung und Aktivitäten der US-Information Center im September 1950 ausdrücklich „in view of the intensity of the struggle for Austrian minds. " ${ }^{2500}$ Und in einem Memorandum, das sich mit Medienpakten für eben diese Information Centers in Deutschland und Österreich befasste, ist nachzulesen, welches Gesamtkonzept diesem Programm zu Grunde lag. Ausgehend davon, dass diese Einrichtungen mittlerweile in beiden Ländern sehr guten Anklang fänden und auch entsprechend frequentiert würden, gelte es unbedingt zu vermeiden, die Glaubwürdigkeit dieser Ein-

2497 Department of State. Office of Public Affairs. Information Memorandum No. 102, „United States Policy Toward Austria“, 8. Dezember 1950, 4. NARA II, RG 59, 250/49/25/07, Entry 1324 [Lot File 52-95], Box 2, General Records of the Department of State. Records of the Office of Public Affairs. Information Memorandums, 1948-1952.

2498 Acting Chief dieser Einrichtung im Department of State war 1949 Thomas E. Goldstein. CSCAD 3540, CSCAD/71646/7-6/80 [CSCAD 350], 8. Juli 1949. The U.S. Occupation of Germany: Educational Reform 1945-1949, Microfilm-Collection a.a. O., 2-A-844, 1. Daneben gab es im State Department noch die German-Austrian Branch, Division of Occupied Areas, Office of Information and Educational Exchange (OIE); deren Acting Chief war bis 1949 Henry J. Kellermann.

2499 Für die CAD nahmen teil: Edward D’Arms, Henry Ehrmann; für das State Department: Hans Speier, Eugene N. Anderson, Henry Kellermann, Frances Butler und Joseph Roland. Siehe: Minutes of the Meeting on German and Austrian Reorientation Problems, 12. Februar 1947 (Confidential). Zit. nach: The U.S. Occupation of Germany: Educational Reform 1945-1949, Microfilm-Collection, a.a. O., 2-A-847.

2500 „The program outlined here for reading rooms in smaller cities is also regarded as an interim arrangement, but in view of the intensity of the struggle for Austrian minds, USFA has regarded this steps as urgently important." [Hervorhebung d. Verf.]. Plan for Extending Reading Rooms to smaller Cities of Austria (Draft), 21. September 1950, NARA II, RG 59,150/71/34/07, Box 1, General Records of the Department of State. International Information Administration. Field program for Austria. 
richtungen durch allzu offene beziehungsweise prononcierte Propaganda - die außerdem durch die zuständigen Abteilungen (IBS beziehungsweise IPS) innerhalb des Gesamtrahmens besser umgesetzt werden könne - zu gefährden und damit in der Bevölkerung an Glaubwürdigkeit zu verlieren. Detaillierte Statistiken des Information Service der USIE für Österreich illustrieren den Umfang und die Reichweite dieser Einrichtungen: so zählte man allein für das vierte Quartal I952 I. 000.746I Besucher - davon waren I07.459 eingeschriebene EntlehnerInnen beziehungsweise BenützerInnen. ${ }^{2501}$

Für die als eminent wichtig angesehene Kulturmission der US-Information Centers, also der sogenannten Amerika-Häuser, von denen es in Österreich zwölf gab, ${ }^{2502}$ wurde in

2501 The America Haus in Austria. Report on a Questionaire Survey. Prepared for Office of Research and Evaluation U.S. Information Agency (IEV.Aus.23), 65. Bureau of Social Science Research. The American University, Washington, D.C., Robert T. Bower, Director, April 1954. NARA II, RG 306, Records of the US Information Agency. Office of Research. Country Projects, 1931-1964, Box 5.

2502 Unter den 12 „U.S. Information Centers“ („Amerika-Häuser“) in der US-Besatzungszone wurde 1952 eine repräsentative Umfrage unter den BesucherInnen bzw. LeserInnen (60\% Männer, 39\% Frauen) durchgeführt und neben dem Alter (33\% fielen in die Altersgruppe der 15- bis 29-Jährigen), der sozialen Schichtung (Studierende, White Collar Workers' und ,Professionals' machten rd. 60\% aus, Arbeiter waren mit nur $11 \%$ vertreten; $32 \%$ hatten Universitätsabschluss und $51 \%$ Matura), dem Leseverhalten (rd. $48 \%$ der LeserInnen gaben an, mehr als 3 Bücher pro Monat zu lesen, wobei Belletristik mit rd. $70 \%$ am populärsten war), der Nutzung (so suchten insbesondere junge NutzerInnen die Amerika Häuser wegen „light reading recreation or entertainment“ auf) auch die Benutzerzahlen (mit Ausnahme von Klagenfurt und Hallein) erhoben wurden:

1. Wien: eröffnet im Frühjahr 1946 [im 4. Quartal 1952: 329.580 BesucherInnen; 38.560 registrierte BenützerInnen];

2. Linz: [1946] neueröffnet am 19. September 1952 [im 4. Quartal 1952: 180.608 BesucherInnen; 16.598 registrierte BenützerInnen];

3. Salzburg: eröffnet 1948 [im 4. Quartal 1952: 146.363 BesucherInnen; 10.418 registrierte BenützerInnen];

4. Steyr: eröffnet am 15. Juli 1948 (im Rathaus); [im 4. Quartal 1952: 31.638 BesucherInnen; 6.010 registrierte BenützerInnen];

5. Wels: eröffnet am 10. September 1948 (als Zweigstelle von Linz); [im 4. Quartal 1952: 18.132 BesucherInnen; 6.195 registrierte BenützerInnen];

6. Zell am See: eröffnet im Jänner 1949 (Kurverwaltungsgebäude, Bahnhofstraße 152); [hier führte der Bericht keine Zahlenangaben an];

7. Innsbruck: eröffnet im Herbst 1949 (im ehemal. Cafe München, Erlerstraße 17); [im 4. Quartal 1952: 99.583 BesucherInnen; 15.180 registrierte BenützerInnen];

8. Hallein: eröffnet 1950 [im 4. Quartal 1952: 17.118 BesucherInnen; 3.988 registrierte BenützerInnen];

9. Gmunden: eröffnet 1952 [im 4. Quartal 1952: 27.640 BesucherInnen; 3.180 registrierte BenützerInnen];

10. Graz: eröffnet 1952 [im 4. Quartal 1952: 25.000 BesucherInnen; 4.372 registrierte BenützerInnen];

11. Klagenfurt: eröffnet 1952 [hier führte der Bericht keine Zahlenangaben an];

12. Ried: eröffnet 1952 [im 4. Quartal 1952: 24.340 BesucherInnen; 29.858 registrierte BenützerInnen]; NARA II, RG 306, Records of the U.S. Information Agency, Office of Research, Country Projects, Box 5. The Amerika Haus in Austria. Report on a Questionnaire Survey (Draft). Prepared for the Office of 
besagtem Memorandum daher die Empfehlung ausgesprochen, sich möglichst auf „indirekte Propaganda“ zu beschränken: „The tremendous ,captive“ audience might well be lost for all practical purpose if there is any confusion on our part about the indirect nature of the Information Center mission. “2503

Wie diese „indirekte Natur“ der hier zu betreibenden Propaganda zu verstehen war, wurde anhand eines Beispiels illustriert. Ausgehend vom aktuellen Erfordernis, kommunistische ,Verleumdungen' bezüglich der inferioren amerikanischen Behandlung eigener nationaler Minderheiten zurückzuweisen, wurde ein „Brotherhood Week Media Packet“ zusammengestellt, das durch ausgewählte, einschlägige Literatur zum Thema „Negro in the United States“2504 - in Summe rund roo Titel - sowie durch Vorträge und Ausstellungen eine entsprechend öffentlichkeitswirksame Korrektur dieser Anwürfe gewährleisten sollte.

Im Zusammenhang der zunehmend härteren Gangart der US-Propaganda ab spätestens 1953 geriet diese weiche Form der amerikanischen Reorientierungs-Politik aber ins interne Schussfeld, wie ein diesbezügliches Positionspapier mit dem Titel „How the Label of ,Propaganda' can be avoided without sacrificing effectiveness“ dokumentiert. Darin wehrt sich der zuständige IBS-Mitarbeiter (ein gewisser Ralph White) ganz im Sinne einer effizienten Reorientierungs-Politik gegen die Kritik des „Plans Board IIA“, wonach die antikommunistische Informationspolitik der US-Stellen - insbesondere im Bereich der Radiosendungen der „Voice of America“ - zu wenig effizient wäre. Der Sachbearbeiter strich dabei heraus, dass es sich in der Frage nach dem Zuviel oder Zuwenig an direkter Beeinflussung um ein zentrales, wenn nicht sogar um das größte Transmissionsproblem der amerikanischen Informationspolitik in der „freien Welt“ handle. Die geäußerte Kritik des „Plans Board IIA“ erfolge nämlich auf Basis zweier gegensätzlicher Annahmen beziehungsweise Sachverhalte: einerseits werde die US-Informationspolitik als zu propagandistisch, mit viel zu geringem realpolitischem Wert und Nutzen und einem zu geringem „political punch“ beurteilt; andererseits sei soeben vom „Hickenlooper Subcommittee“2505 _ einer Senator Joseph McCarthy unterstehenden Untersuchungskommission ${ }^{2506}$ - in einer Analyse („Analysis of Reports from American Correspondents Overseas“) festgestellt worden, dass die meisten westeuropäischen Länder „übersättigt mit amerikanischer Propagan-

Research and Evaluation U.S. Information Agency. Bureau of Social Science Research, The American University Washington, D.C., Robert T. Bower, Director (Project Director: Stanley K. Bigman; Analyst: Laure M. Sharp), April 1954.

2503 NARA II, RG 59, 150/71/34/07, Box 1, General Records of the Department of State. International Information Administration. Field program for Austria. Media Packet for Information Centers in Germany and Austria (6. November 1952), 2.

2504 Ebd.

2505 Benannt nach dem republikanischen Gouverneur von Iowa und nachfolgenden US-Senator Bourke B. Hickenlooper (1896-1971).

2506 Vgl. Krugler, The Voice of America and the Domestic Propaganda Battles, a.a.O., 186. 
da" wären und man bereits gegenüber jeglicher, offen anzutreffender Propaganda überaus sensibel reagiere. ${ }^{2507}$

Im Zuge der „Truth-Campaign“ wurden schließlich auch die akademischen Austauschprogramme stark forciert. Der offizielle US-Bericht für 1950 führt an, dass in Summe 916 ausländische Studierende aus 50 Ländern einen durch die US-Regierung finanzierten Studienaufhalt in den USA absolvierten und umgekehrt für 654 US-Studenten Studienaufhalte in 23 Ländern bezahlt wurden. ${ }^{2508}$ Des Weiteren kamen im selben Zeitraum 436 Lehrer, Dozenten und Forscher aus 33 Ländern über Austauschprogramme in die Vereinigten Staaten, gleichzeitig brachen 4Io US-Gelehrte zwecks Vortragstätigkeit in insgesamt 3I Staaten auf. ${ }^{2509}$

1952 kamen dann bereits rund 8.00o Studierende, Lehrer, Professoren und öffentliche Meinungsträger wie Journalisten, Gewerkschafter, Regierungsbeamte sowie wirtschaftliche Führungskräfte auf der Basis der Austauschprogramme in die USA, um danach - so die „hidden agenda“ - zu Hause die ,Wahrheit über Amerika zu verbreiten: „There is no more effective answer to the ,big lie than to expose it first-hand." ${ }^{2510}$

Die Ausgaben für diese immense US-Propagandakampagne - die auf der gesetzlichen Grundlage des Smith-Mundt Act durchgeführt wurde - stiegen bereits 1951 auf das Vierfache der Gesamtausgaben des Jahres 1949 an. ${ }^{2511}$ Hinzu kommen die zahlreichen, kofinanzierten Kooperationen mit philanthropischen US-Einrichtungen und Organisationen wie der Rockefeller Foundation oder dem Carnegie Endowment sowie mit privatwirtschaftlichen Unternehmen wie der Chase National Bank, der National City Bank, E.R. Squibb International, der Remington-Rand Cooperation, US Steel, Ford, American Express, Standard Oil und vielen anderen, ${ }^{2512}$ die alle über die Schaltstelle des U.S. „Information and Educational Exchange" (USIE) $)^{2513}$ organisiert wurden.

2507 NARA II, RG 306, Special Reports, Box 2. Ralph White (IBS /E) through Leo Lowenthal (IBS/E) to IIA-Plans Board, Proposed Suggestions to All Media on „How to Label of ,Propaganda' can be avoided whitout sacrificing Effectiveness", 25. Mai 1953, 1.

2508 Launching the Campaign of Truth. First Phase, a.a.O., 18.

2509 Ebd., 19.

2510 The Voice of America at the Water's Edge. Department of State Publication 4609. International Information and Cultural Series 23, [Address by Wilson Compton, Administrator, U.S. International Information Administration, Department of State, before the Atlantic Union Committee, Washington D.C., 21. Mai 1952, 6.

2511 Bezüglich der finanziellen Ausgaben heißt es in der US-Regierungsbroschüre: „The expanded 1951 program measured in terms of dollars is $2 \frac{1}{2}$ times that for 1950 and 4 times that for fiscal 1949, the first full year of operation under Public Law 402. Approximately $\$ 41$ million or about 37 percent of the funds authorized are for expansion of radio broadcasting facilities. These new and expanded facilities will provide a more powerful Voice of America to penetrate the iron air-curtain of Soviet jamming stations. [...] About a half of the approximately $\$ 69$ million in operating funds is allocated to the fast communications media, including radio, press, and publications, and motion pictures." Launching the Campaign of Truth, a.a.O., 1.

2512 Launching the Campaign of Truth. First Phase, Appendix, a.a.O., 60.

2513 Telling America's Story abroad, a.a. O., 2. 
Um mit Unterstützung des US-Kongress zusätzliche Mittel für das „Information and Educational Exchange Program “ zu lukrieren, verfasste Staatssekretär Acheson am I3. September 1950 ein vertrauliches Memorandum, das die Richtlinien der neuen Propagandadoktrin zusammenfasste. Im Rahmen der beschlossenen „Psychologischen Offensive“ sollten ab sofort sämtliche Reorientierungs-Aktivitäten sowie alle USIE-Programme in die Gesamtstrategie der „Campaign of Truth“ eingebunden werden, deren Hauptstoßrichtung nunmehr dem ideologischen Kampf gegen den Kommunismus galt:

"Propaganda activities of the USSR now border on open psychological warfare against the Free World and are a major threat to [the] foreign policy objectives of the United States [...] a psychological offensive based on truth is essential if the United States is to succeed in its foreign policy objectives." 2514

Im Zusammenhang dieser ideologischen Abwehrszenarien kam es zur Umkehrung der ursprünglichen Reeducation- beziehungsweise Reorientierungs-Ziele, deren Notwendigkeit bisher auf die Bedrohung durch den Nationalsozialismus zurückgeführt worden waren.

Anstelle des Nationalsozialismus wurde von den US-Propaganda-Strategen nun der Kommunismus als die primär zu bekämpfende Ideologie identifiziert und die Sowjetunion als globaler Aggressor an den Pranger gestellt. Die Begründungsmuster der ursprünglichen Reeducation-Konzepte wurden dabei auf das neue Feindbild beziehungsweise auf dessen ideologischen Kern übertragen, wobei die inhaltliche Vermittlung in weitaus aggressiverer, schärferer und rhetorisch zugespitzter Form die Popularisierung des "American way of life“ mit antikommunistischer Propaganda verknüpfte. Dabei wurde die Verknüpfung von Freiheit, Demokratie und Propaganda - anders als das noch Archibald MacLeish gesehen hatte nun auch von Vertretern ziviler US-Einrichtungen, die zum Großteil freilich in enger Abstimmung mit der US-Regierungsstellen agierten, als legitim erachtet. So unterschied etwa Paul Gray Hoffman als frisch gewählter Präsident der Ford Foundation 1951 Zwischen ,good propaganda and bad propaganda“, indem er ausführte, Propaganda sei nicht per se schlecht, sondern je nach der zugrunde liegenden Intention als positiv oder negativ zu werten:

"[...] the very word propaganda is suspect and even evil. It has be become associated in our thinking with deceit and trickery, with totalitarian rather than democratic methods. As employed by Stalin and Hitler, it has become the synonym for the Big Lie. Yet propaganda need not to be these things. The word originally meant to propagate an idea or a faith. From the standpoint of his original meaning, it can be used to serve creative and moral as well as destructive amoral end." $^{2515}$ [Hervorhebung d.Verf.]

2514 NARA II, RG 59, Box 17, Department of State, Psychological Offensive [Confidential], 13. September 1950, 1.

2515 Paul Gray Hoffman, Peace Can Be Won (1951). Zit. nach: Schmidt, Civil Empire by Co-optation, a.a. O., 244. 
Die rhetorische Militarisierung der ursprünglich primär auf Demokratisierung gerichteten US-amerikanischen Reorientierungs-Pläne war dann zugleich Folge wie auch Legitimation der voranschreitenden NATO-Aufrüstung und machte, wie Wilson Compton in einem Bericht des State Departments ausführte, auch nach innen gegenüber dem zivilen Amerika klar, dass künftig für differenzierte Meinungen kein Raum mehr existiere: „This great Campaign of Truth on which we are engaged is no place for half-harted Americans. “2516

Die Militarisierung der „Reorientierung“, die Verknüpfung von ideologischer Umorientierung und „Aufrüstung“ im Zusammenhang mit dem ausgerufenen, geradezu biblischen „Kreuzzug der Weltanschauungen“ („Crusade of Ideas“) führte zur propagandistischen Einebnung der vormals differenzierten Demokratisierungs-Konzepte auf simple Beschwörungsformeln: zum Zweck einer Unterstützung der US-Aufrüstung wurden kurzerhand die „Ideen“ - in diesem Fall also unter anderem die Idee der Freiheit - selbst zu „Waffen“ erklärt:

"Wars have been won by arms and armaments. But peace has never been won that way, nor kept. [...] In the long run, ideas are more powerful than guns. The march of history has proven that. Our own national history is essentially the history of an idea - the idea of freedom, the freedom and the chance to choose. [...] We are making gigantic investments in armaments. We are doing this because we must. [...] If we want to try to avoid or prevent a world-wide war of arms, we must make a greater investment in the world-wide war of ideas. [...] We need an armament of ideas as much as we need an armament of guns. Above all, the whole free world needs a spiritual rearmament, a renewed allegiance to the ideals which have made the free world free, which are vital to keep it free." ${ }^{2517}$ [Hervorhebung d. Verf.]

Der Ausgang des beschworenen Armageddon der Weltanschauungen, in dem es nach Ansicht der US-Regierung um nichts weniger als um „the men's minds“ ging, würde, je nach Erfolg oder Misserfolg der eigenen Freiheitspropaganda, Weltfrieden oder Weltkrieg bedeuten:

"This is a day of decisions [...] whether collectively we are able to make and willing to make the effort needed to win the contest for men's minds [...] the outcome of this struggle may well mean ultimately the difference between world peace and world war." ${ }^{2518}$ [Hervorhebung d. Verf.]

2516 Crusade of Ideas. Department of State Publication 4696. International Information and Cultural Series 25, [Address by Wilson Compton, Administrator, U.S. International Information Administration, Department of State, Washington D.C., September 1952, 10.

2517 Crusade of Ideas, a.a.O., 6.

2518 The Voice of America at the Water's Edge. Department of State Publication 4609. International Information and Cultural Series 23, [Address by Wilson Compton, Administrator, U.S. International Information Administration, Department of State, before the Atlantic Union Committee, Washington D.C., 21. Mai 1952, 4]. 
Wilson M. Compton, ${ }^{2519}$ der frühere Präsident der Washington State University (I944I95I), der im Jänner I952 die Leitung des neugegründeten „United States International Information Administration “ (IIA) im Department of State übernommen hatte, ${ }^{2520}$ machte am 23. Dezember 1952 in einer amerikaweit ausgestrahlten Rundfunkrede Stimmung für die kostenintensive, weltweite US-Kulturmission und Propagandainitiative. Dabei erklärte er die Notwendigkeit eines gezielten Angriffs mit einem populären Vergleich zu den taktischen Finessen des US-Nationalsports Baseball:

"No baseball game is ever won merely by good fielding, however good. Nor is any war - hot or cold - won merely by a good defense. Country by country throughout the world we are now setting up individual information programs [...]. These programs are initiated by our own missions in each country subject to review by Washington to assure that what we do overseas is properly within the framework of United States policy. [...] To do this we must have publicaffairs officers in each country competent and willing to accept the responsibility and to take an initiative, who see in this 'crusade of ideas' not a job but a mission [...]". ${ }^{2521}$

Compton unterstrich in seinem landesweiten Aufruf zur Unterstützung im „Struggle for men's minds“, dieser antikommunistische „Kreuzzug“ sei keinesfalls eine einfach zu lösende Aufgabe, sondern geradezu eine „Mission“ - „not a job but a mission“-, die er - durchaus humorbegabt - kurioserweise am Beispiel Wiens als bereits vollständig erfüllt ansah:

“Two weeks ago I visited our modest Information Center on a prominent corner in Vienna. It was crowded - overcrowded. I saw two young men who couldn't find a place to sit down using the wall as a 'table' on which to copy from some well-thumbed magazines. During that day 3.85I persons used the United States Information Center in Vienna. A few blocks distant, the Soviet Union has a large building which houses the Soviet Union Information Service. Its library and exhibits are very attractive in appearance. But there were fewer than 40 persons in

2519 Wilson Martindale Compton (1890-1967), studierter Ökonom, der zunächst in der Holzindustrie zu arbeiten begann, bevor er 1944 zum Präsidenten der Washington State University ernannt wurde. Compton stammte aus einer einflussreichen Wissenschafter-Dynastie: Sein Vater war Dekan des Wooster College und seinen beiden Brüder Physiker: Sein Bruder Karl war Rektor des Massachusetts Institute of Technology (MIT) und sein zweiter Bruder Arthur Vorstand der Washington University in St. Louis. Siehe: http://president.wsu.edu/presidents/compton.html [Zugriff 24.9.2011]

2520 Vgl. FRUS, 1952-1954, Vol. II. National Security Affairs, Part. 2, 1591. Department of State Departmental Announcement No. 4, 2. Establishment of the United States International Information Administration (IIA), Washington D.C., 16. Jänner 1952.

2521 Progress in the War of Ideas. Department of State Publication 4858. International Information and Cultural Series 30, [Report by Wilson Compton, Administrator, U.S. International Information Administration, Department of State, broadcast to a Nation-wide audience, 23. Dezember 1952, Washington D.C., 1953, 2 f.]. 
the library at that time. Strangely, the wide street in front of the Soviet Information Center was that day being taken over as a convenient market for the sale of Christmas trees, a curious paradox. But the Viennese always have had a sense of humor."2522

2522 Ebd., 4. 



\title{
6. Endphase der Besatzung: \\ Akademische Austauschprogramme und ihre Umsetzung in Österreich, 1950-1955
}

\begin{abstract}
"The break between the United States intellectual community and Germany in the thirties was radical and complete. With few exceptions the postwar effort to restore the broken ties started from point zero." ${ }^{2523}$
\end{abstract}

\begin{abstract}
"Each country approached its cultural diplomacy differently. Austria, technically speaking an enemy power for the U.S., quickly devised an ingenious cultural policy to help

the world overlook the war years, exporting costly cultural products like the Vienna Opera and Philharmonic, the Vienna Boys Choir, the Lippizaner Stallions, and dozens of solo musicians. The goal, as an unsympathetic Austrian put it, was to convince the world that Brahms and Beethoven were Austrians, but Hitler was German."2524
\end{abstract}

BEGINN DER „U.S. EXCHANGE“-PROGRAMME - SELTSAMKEITEN UND PANNEN

Unmittelbar nach der offiziellen Bekanntgabe des Anlaufens der ersten ,interchange of person's programs" auf der Basis der SWNCC-Direktive 269/8 im März 1947 erhielten sowohl die CAD-Reorientation Branch im War Department als auch die korrespondierende zivile „German-Austrian Branch“ des Department of State unter Leitung von Henry Kellermann) eine Vielzahl an Anfragen, unter anderem auch von österreichischen Privatpersonen, die an einem Studienaufenthalt in den USA interessiert waren. ${ }^{2525}$

Obwohl die Austauschprogramme im Rahmen der US-Kulturoffensive grundsätzlich breit angelegt waren und Personen verschiedener sozialer Schichten und Berufe einbezogen werden sollten, war der Fokus doch primär auf potenzielle Führungspersönlichkeiten gerichtet, die ihre (möglichst positiven) persönlichen Erfahrungen und Eindrücke in den Vereinigten Staaten als Multiplikatoren mit entsprechendem gesellschaftlichen Einfluss weitergeben sollten. Das galt insbesondere für die akademischen Austauschprogramme wie das „Visiting Experts Program“, bei denen die Kandidaten, wie Oliver Schmidt kon-

2523 Kellermann, Cultural relations as an Instrument of U.S. Foreign Policy, a.a. O., 3.

2524 Richard T. Arndt, The First Resort of Kings. American Cultural Diplomacy in the Twentieth Century, Dulles 2005, 110.

2525 Edgar Erskine Hume, Colonel, Chief Reorientation Branch to Henry J. Kellermann, Acting Chief, German-Austrian Branch, Office of Information and Educational Exchange (OIE), Department of State, 30. Oktober 1947, 1. NARA II, RG 260. The U.S. Occupation of Germany: Educational Reform 1945-1949, Microfilm-Collection, a.a.O., 2-A-330. 
statiert, von den zuständigen US-Stellen eher nach „Headhunting“-Kriterien ausgesucht wurden, ${ }^{2526}$ als dass sie sich eigenständig beworben hätten. Ein Vorgehen, das durchaus auf Kritik stieß, da etwa US-Bildungsfachleute davor warnten, die akademische Integrität aufs Spiel zu setzen - „using higher education as a conscious device for the achievement of immediate political goals“2527 - beziehungsweise sie aus Gründen politischer Zweckmäßigkeit leichtfertig zu instrumentalisieren.

Ungeachtet dieser zweifellos berechtigten Kritik kamen nun erstmals nach 1945 österreichische Wissenschafter und Studierende wieder in Kontakt mit amerikanischen Universitäten, so zum Beispiel mit der Columbia University, der Stanford University ${ }^{2528}$ oder dem Massachusetts Institute of Technology (MIT).

In Zusammenarbeit mit US-amerikanischen Bildungsorganisationen und Philanthropischen Einrichtungen wie dem Haverford College in Pennsylvania, ${ }^{2529}$ der „National Student Association“, der „American Association of Colleges for Teacher Education“, ${ }^{2530}$ dem "Institute of International Education“ ${ }^{2531}$ in New York, der „United Nations World Health Organization“2532 (WHO), der Solomon R. Guggenheim Foundation oder der Rockefeller

2526 Schmidt, Civil Empire by Co-optation, a.a.O., 138.

2527 Ebd., 158.

2528 Thomas A. Spragens, Assistant to the President, Stanford University, to Civil Affairs Division, War Department, 15. April 1947, 1. Zit. nach: The U.S. Occupation of Germany: Educational Reform 19451949, Microfilm-Collection, a.a.O., 2-A-195.

2529 F.P. Munson, Col., General Staff Corps, Executive to the Assistant Secretary of War to Gilbert F. White. President, Harverford College, Pennsylvania, 9. April 1947. The U.S. Occupation of Germany: Educational Reform 1945-1949, Microfilm-Collection, a.a.O., 2-A-208.

2530 Nachdem der US-Lehrerverband im Februar 1948 beschlossen hatte, die Lehrerausbildung in Deutschland und Österreich durch Austauschprogramme zu unterstützen („A Plan for Assisting in the Reconstruction of Teacher Education in Germany and Austria"), und über die Rockefeller Foundation Mittel zur Verfügung gestellt wurden, sollten sechs deutsche und zwei österreichische „key persons“ zu Schulungszwecken an das Wilson Teachers College in Washington D.C. gebracht werden. Die beiden österreichischen Kandidaten, die im Juli 1948 für das Programm bewilligt wurden, waren Hermann Schnell und Wilhelm Zöchling. G.P. Lynch, Acting Executive, Civil Affairs Division, to Immigration and Naturalization Service. Washington D.C., 15. Juli 1948, 1. The U.S. Occupation of Germany: Educational Reform 1945-1949, Microfilm-Collection, a.a.O., 2-A-483.

2531 So finanzierte bspw. das „Institute of International Education“ bereits im Oktober 1947 sowohl die Reisekosten als auch den dreisemestrigen Studienaufenthalt für die Wiener Studentin Maria Sakrawa, die an der Columbia University „Indo-Iranian Comparative Linguistics“ studierte. Siehe: Laurance Duggan Director, Institute of International Education, to Civilian Affairs Division, War Department, The Pentagon Building, Washington D.C., 24. Oktober 1947, 1. The U.S. Occupation of Germany: Educational Reform 1945-1949, Microfilm-Collection, a.a.O., 2-A-330.

$2532 \mathrm{Im}$ September wurden fünf österreichische Mediziner über die UN-WHO Studienaufenthalte an USamerikanischen Universitäten finanziert. Hierbei handelte es sich um Alfons Miller (geb. 1913) [Harvard University], Paul Speiser (geb. 1920) [u.a. Johns Hopkins Hospital Baltimore], Paul Johann Wilfingseder (geb. 1916) [Harvard University], Friedrich Blodi (geb. 1917) [u.a. Columbia University] sowie Friedrich Hermann (geb. 1913) [Harvard University]. J. Vesely, Deputy Director, Financial Ser- 
Foundation, ${ }^{2533}$ die, wie zuvor bereits in den I920er-Jahren, in der Regel die Reisekosten in die USA übernahmen, kamen auf diese Weise zwischen Dezember 1947 und Juli 1948 II5 AustauschstudentInnen aus Deutschland und Österreich für einen maximal einjährigen Studienaufenthalt in die Vereinigten Staaten, wobei nach Erleichterung der Einreisemodalitäten die Zahl bis Mai 1949 auf I75 anstieg. ${ }^{2534}$

Unter den insgesamt 84 (postgradualen) Studierenden, denen ein dreieinhalbmonatiger Studienaufenthalt ermöglicht wurde, trafen Anfang I948 neben vier Deutschen auch zwei Österreicher in Massachusetts ein. ${ }^{2535}$ Alle StudentenInnen (wie auch alle Lehrer und Professoren) mussten zuvor überprüft werden, bevor sowohl das Department of State als auch das Department of the Army die Einreise freigaben. ${ }^{2536}$

Wie unter anderem auch aus dem Ansuchen des Massachusetts Institute of Technology an das U.S. Department of the Army deutlich wird, waren es zumeist US-Wissenschaftseinrichtungen selbst, die entweder die Initiative ergriffen oder auf Anregung des „Instituts of International Education“2537 in New York Ansuchen für Austauschkandidaten an Re-

vices, United Nations, World Health Organization, Interim Commission, to Colonel Hume, Chief, Reorientation Branch, Civil Affairs Division, Pentagon, Washington D.C., 1. September 1947, 1. The U.S. Occupation of Germany: Educational Reform 1945-1949, Microfilm-Collection, a.a.O., 2-A-292.

$2533 \mathrm{Ab} 1949$ finanzierte die Rockefeller Foundation US-Aufenthalte für österreichische Zeitungs- und Radio-Journalisten. Unter der Leitung des ersten Rockefeller Exchange-Directors, des emigrierten österreichischen Soziologen Paul Lazarsfeld, wurden darüber hinaus vereinzelt auch US-Aufenthalte österreichischer Studierender finanziert. Siehe: Schmidt, Civil Empire by Co-optation, a.a. O., 199.

2534 Capt. Bateson, Civil Affairs Division, to Mr. Morris L. Kaplan, The New York Times, 18. Mai 1949, 1. The U.S. Occupation of Germany: Educational Reform 1945-1949, Microfilm-Collection, a.a. O., 2-A-806.

2535 Lloyd A. Haynes, Chairman, International Acticities Committee, Massachusetts Insitute of Technology. Foreign Student Summer Project, Cambridge/Mass., 14. Februar 1948, 1. NARA II, RG 260, Tsuchimochi 2-A-442.

2536 In September kamen drei Studenten auf Basis von SWNCC 269/8 in die USA: Manfred Mautner Markhof Jr. (1927-2008), der am Bowdoin College, in Brunswick/Maine Ökonomie studierte; weiters Walter Dantine, der am California Institute of Technology „electrical engineering“ studierte; sowie Walter Toman (1920-2003), der am Haverford College in Pennsylvania „humanities“ und „social sciences“ studierte. NARA II, RG 260. The U.S. Occupation of Germany: Educational Reform 1945-1949, Microfilm-Collection, a.a.O., 2-A-306. Henry J. Kellermann, Acting Chief, German-Austrian Branch, Division of Occupied Areas, Office of Information and Educational Exchange, to Col. Edgar Erskine Hume, Chief, Reorientation Branch CAD, Department of the Army, 25. September 1947, $1 \mathrm{f}$.

2537 Wie aus der Korrespondenz zwischen dem „Institute of International Education“ und dem U.S. War Department hervorgeht, waren die Mittel für den Studentenaustausch noch 1949 sehr knapp, sodass die Durchführung der Austausch-Programme weiterhin stark auf private Sponsoren angewiesen war. Bis Sommer 1949 konnten anstelle der geplanten 125 Plätze lediglich für 58 deutsche und österreichische Studierende Aufenthalte in den USA finanziert werden. Ralph A. Burns, Chief of Branch, Cultural Affairs Branch, OMGUS, to Reorientation Branch, Civil Affairs Division, Department of the Army, Special Staff, Washington D.C., 9. Juni 1949, 1. The U.S. Occupation of Germany: Educational Reform 1945-1949, Microfilm-Collection, a.a.O., 2-A-821. 
gierungsstellen richteten. ${ }^{2538}$ Die amerikanischen Universitäten waren an einem intensivierten Wissenschaftsaustausch sehr interessiert und betonten, wie im Fall des MIT, dass es eine „wunderbare Gelegenheit“ für die ausländischen Besucher bieten würde, „to observe the life of a typical American student at first hand. "Der MIT-Repräsentant Lloyd A. Haynes bewarb gegenüber dem Department of the Army die gute Ausstattung, das Curriculum sowie das erstellte Programm für die Austauschstudenten und strich die friedensichernde Wirkung eines Studienaufenthaltes hervor:

\begin{abstract}
"Besides the curricula to be offered at M.I.T special additional courses will be offered at Harvard and other nearby schools. Week-end trips to nearby girl schools and summer theatre parties have also been arranged. We feel that it is important for graduate students in Austria in the fields of science and engineering to have a better international understanding than their predecessors had if the future peace of this world is to be assured. Strengthening that understanding is the purpose of our project." 2539
\end{abstract}

Doch die Zusammenarbeit der mit der Organsiation befasssten Stellen in Washington mit der Education Division in Österreich erwies sich, wie sich bald zeigen sollte, als nicht gerade einfach. So wunderten sich die Beamten des CAD darüber, dass sie für das angelaufene USAustauschprogramm „Visiting Experts Program for Austria“ trotz Urgenzen im September I947 nach wie vor keine Vorschläge erhalten hatten, obwohl die Anlaufzeit, wie Washington eigens hervorhob, infolge des bürokratischen Aufwands beträchtlich war:

"Since estimate it will take approximately two months from time of receipt of program until first experts get under way it is important that it be received here soonest if your needs are to be met." ${ }^{2540}$

Dass der administrative Aufwand für die (auch geheimdienstliche) Überprüfung ${ }^{2541}$ und Zulassung von AustauschkandidatInnen ${ }^{2542}$ - die rechtliche Zuteilung von Visa für die Einreise

2538 Aus Perspektive der OMGUS-Leitung wurde diesbezüglich festgestellt: „It is felt here that the people, and particularly the colleges, in the United States are enthusiastic about the democratization program and are increasingly willing to contribute to it." Ebd. 1.

2539 Lloyd A. Haynes, Chairman, International Activities Committee, Massachusetts Institute of Technology, Foreign Student Summer Project, 14. Februar 1948, 1. The U.S. Occupation of Germany: Educational Reform 1945-1949, Microfilm-Collection, a.a.O., 2-A-442.

2540 C.R. Smith, Administration Officer CSCAD, 18. September 1947 to COMGENUSA, Vienna Austria, NARA II, RG 260. The US Occupation of Germany: Educational Reform 1945-1949, Microfilm-Collection, a.a.O., 2-A-315.

2541 Wobei vom US-Geheimdienst, z.T. im Rückgriff auf OSS-Files, insbesondere auch allfällige kommunistische Aktivitäten erhoben wuden. Siehe: „Fall Karl Reinhard“. The U.S. Occupation of Germany: Educational Reform 1945-1949, Microfilm-Collection, a.a.O., 2-A-483.

2542 Vor Ausstellung eines „Travel Documents“ mussten die studentischen Austauschkandidaten („bona fide students“) bestimmte Anforderungen erfüllen. Neben einem nachweislich guten Gesundheitszustand, 
lag zur Gänze beim Department of State ${ }^{2543}$ - beträchtliche Zeit in Anspruch nahm, zeigt sich an vielen Einzelfällen; sogar bei hochrenommierten US-Antragsstellern wie beispielsweise dem Atomphysiker Robert Oppenheimer dauerte es sechs Monate, bis das Prozedere durchlaufen war und grünes Licht für die Visa-Erteilung gegeben wurde. ${ }^{2544}$

Hinsichtlich der Austauschstudierenden aus Österreich war das Department of State allerdings um eine möglichst „liberale“ Handhabung der Einreisebestimmungen bemüht, hob jedoch hervor, dass gewisse Mindeststandards erfüllt sein sollten, damit gewährleistet sei, dass die jungen Besucher „will be competent to follow the course of study proposed for them and will be able derive maximum benefit from their visit to the United States. ${ }^{\text {"2545 }}$ Die definitive Zulassung der StudentInnen für einen US-Auslandsaufenthalt sollte jedenfalls von der vorhergehenden Bestätigung der lokalen Autoritäten abhängig sein.

Als Leiter der USFA Education Division konzentrierte sich Samuel H. Williams in seinen besatzungspolitischen Initiativen - obwohl er auch für den akademischen Austausch zuständig war - allerdings hauptsächlich auf Jugendaktivitäten, auf Fragen der Schulerziehung sowie auf die Lehrerfortbildung. In einem Schreiben vom Oktober 1947 deklarierte Williams gegenüber John W. Studebaker, dem U.S. Commissioner of Education (U.S. Office of Education), seine bildungspolitischen Ziele, die primär auf Reorientierungs-Maßnahmen in Klassenzimmern gerichtet war:

"The rehabilitation and reconstruction of Austria's educational system has been, up to the present time, pretty largely concerned with the procurement of repair materials, de-Nazification,

einer „sufficient scholastic preparation and adequate knowledge of English“ betraf dies vor allem auch „satisfactory evidence of good character and political integrity“. The U.S. Occupation of Germany: Educational Reform 1945-1949, Microfilm-Collection, a.a.O., 2-A-559

2543 Siehe: Ray J. Laux, Lt. Col. GSC, Executive Civil Affairs Division, 3. Dezember 1947, 1. The U. S. Occupation of Germany: Educational Reform 1945-1949, Microfilm-Collection, a.a.O., 2-A-356.

2544 Vgl. G.P. Lynch, Acting Executive, Civil Affairs Division, to Mr. Robert Oppenheimer, Director, The Institute for Advanced Study Princeton, New Jersey, betreffend Professor Herbert Seiffert, Mathematisches Institut, Heidelberg, 31. Dezember 17. Juni 1948, 1. The U.S. Occupation of Germany: Educational Reform 1945-1949, Microfilm-Collection, a.a.O., 2-A-329. Ausnahmen bestätigten aber wohl auch hier die Regel: so wurde etwa das Ansuchen der Witwe des wegen militärischer Widerstandsaktivitäten in Berlin Plötzensee hingerichteten Carl Friedrich Goerdeler, Benigna Goerdeler, von höchster Stelle aus behandelt: nach kaum zwei Monaten und Gutachten von u.a. Theodor Bäuerle und Martha Steinmetzz wurde ihr Ansuchen um einen zweijährigen Studienaufenthalt am Briarcliff Junior College bewilligt. Hans Speier, Acting Chief, Division of Ocupied Areas, Office of International Information and Cultural Affairs, to Colonel Edgar E. Hume, Chief, Reorientation Branch, Civil Affairs Division, War Department, Washington D.C., 11. August 1947, 1. The U.S. Occupation of Germany: Educational Reform 1945-1949, Microfilm-Collection, a.a.O., 2-A-329.

2545 Hans Speier, Acting Chief, Division of Ocupied Areas, Office of International and Educational Exchange, to Colonel Edgar E. Hume, Chief, Reorientation Branch, Civil Affairs Division, War Department, Washington D.C., 15. September 1947, 1. The U.S. Occupation of Germany: Educational Reform 1945-1949, Microfilm-Collection, a.a.O., 2-A-319. 
textbook production, etc. The time is now ripe for the infiltration of traditional American concepts into classroom levels." 2546

Ungeachtet des persönlichen Interessensschwerpunktes von Williams auf Schulbildungsangelegenheiten, war die Education Division jedoch für das akademische Austauschprogramm verantwortlich. Williams selbst, wie auch sein Mitarbeiterstab, nahmen sich dieser Aufgabe auch an, jedoch, wie schon zuvor, in gewohnt austrifizierter Art und Weise.

Alle Nominierungen für den Austausch von Führungskräften, Lehrern oder Wissenschaftern im Zuge des „Visiting Experts Programs“ mussten zunächst vom österreichischen Unterrichtsministerium genehmigt werden, bevor die genannten Personen anschließend von der US-Education Division beziehungsweise von den zuständigen Stellen in Washington überprüft wurden. Das traditionell gute Einvernehmen zwischen den USOffizieren und den österreichischen Ministerialbeamten auf der Grundlage der bisherigen Nichteinmischungs-Politik der US-Besatzungsmacht manifestierte sich zuweilen in höchst seltsamen und zuweilen geradezu barocken Verkehrsformen, die mit Supervision oder Kontrolle ebenso wenig zu tun hatten wie mit US-Kulturaustausch oder der projektierten Reorientierung. So schrieb Samuel Williams im Juli 1948 an Ministerialrat Skrbensky, dass er soeben erfahren habe, im vergangenen Jahr habe ein "gewisser Max Graf" ohne Wissen der Education Division an der Hochschule für Musik gelehrt, wofür sich Williams geradezu devot bei Skrbensky entschuldigte. Tatsächlich handelte sich um den bedeutenden Musikwissenschafter und Musikkritiker Max Graf, der unter anderem bei Eduard Hanslick und Anton Bruckner studiert hatte. Ab 1909 hatte Graf als Professor für Musikgeschichte an der Wiener Musikakademie gewirkt und war in den Jahren 1928 bis 1936 als musikalischer Leiter der Wiener Mai-Musik-Fest tätig gewesen, bevor er 1938 in die USA emigrierte. ${ }^{2547} 1947$ war Graf bereits nach Österreich zurückgekehrt, wo er unter anderem am Salzburger Mozarteum lehrte und für den Österreichischen Rundfunk arbeitete. ${ }^{2548}$

2546 NARA II, RG 260, EDU-DIV, Box 1, Folder 9, Schreiben Samuel H. Williams, U.S. Civilian Chief, Education Division, to John W. Studebaker, US Commissioner of Education at the U.S. Office of Education Department, 8. Oktober 1947, 1.

2547 Vgl. Walter Pass/Gerhard Scheit/Wilhelm Svoboda, Orpheus im Exil. Die Vertreibung der österreichischen Musik, Wien 1995, 272.

2548 Max Graf (1873-1958), Wiener Musikwissenschafter jüdischer Herkunft; Vater des Opernregisseurs Herbert Graf. Neben seiner Lehrtätigkeit an der „Akademie für Musik und darstellenden Kunst“ war Graf Vortragender am Austro-American Institute in Wien sowie an Wiener Volkshochschulen und war für eine Reihe an Zeitungen als Korrespondent tätig, wie bspw. für die Weimarer Zeitung, die Frankfurter Zeitung oder das Neue Wiener Journal. In seiner Eigenschaft als Musikwissenschafter, Publizist und Übersetzer war Graf mit einer Vielzahl moderner Komponisten persönlich gut bekannt, wie etwa mit Claude Debussy, César Franck, Gustav Mahler, Hugo Wolff oder Arnold Schönberg. Nach seiner Emigration in die USA lehrte Graf u.a. an der New School for Social Research in New York und ab 1940 als Visiting Professor am Carnegie Institute of Technology in Pittsburgh. Siehe: International Biographical Dictionary of Central European Emigrés 1933-1945. Vol. II / Part 1: A-K, 
Wie Samuel Williams in seinem Schreiben an Skrbensky vorauseilend hinzufügte, würde er Grafs Visum freilich nur verlängern, wenn seitens des Unterrichtsministeriums nichts dagegen sprechen würde:

"For some reason or other, this Division was not informed of Graf's entry into Austria, and it was never called upon to approve the employment of an American citizen in an Austrian school. Had the matter been brought to my attention, I should have immediately contacted the Ministry for an opinion before making any decision. Graf has now asked for an extension of his visa until the end of December, and we will not extend it unless the Ministry of Education gives its approval." 2549

Als Williams' Vorgänger Thomas E. Benner den Versuch unternahm, den wissenschaftlichuniversitären Austausch zwischen den USA und Österreich anzukurbeln, endete dieses Vorhaben in geradezu grotesker Weise und enthüllte dabei sowohl die Einstellung so mancher Verantwortlicher auf amerikanischer Seite als auch die spezifisch austrifizierte Form der dabei gepflogenen Kommunikation mit dem österreichischen Unterrichtsministerium. Vor dem Hintergrund des bevorstehenden Beginns breitangelegter US-amerikanischer akademischer Austauschprogramme beabsichtigte Benner, den Kontakt zur „Austrian University League of America“" zu aktivieren, der in Österreich - wie bereits dargestellt kaum aktiv aufgenommen worden war. Auf der Suche nach Unterstützung sandte Benner einen Entwurf für ein derartiges Austauschprogramm an den früheren Leiter der Education Division, William B. Featherstone, der vor seiner Tätigkeit als USFA-Offizier immerhin stellvertretender Vizepräsident der League gewesen war, und versuchte diesem die Idee eines österreichischen wissenschaftlichen „Who's is Who" schmackhaft zu machen. Featherstone war jedoch weder zur Zeit seiner verantwortlichen Leitung der USFA Education Division noch zum gegenwärtigen Zeitpunkt davon überzeugt, dass ein derartiger akademischer Austausch Sinn haben würde, und meinte in seiner insgesamt doch eher skurrilen Antwort gegenüber Benner:

"The Austrian University League turns out to be a very feeble and impoverished organization. I did manage to drive through the preparation and circulation of the list of names you sent me months ago of professors and others needing help, but I doubt if much comes of it. If I had nothing else to do, I could probably nurse that crowd along to some kind of energetic action on a few projects, but since I have plenty else to do, I can't give them much time. Nothing much happens. The great difficulty at the moment is that the Executive Secretary, Prof. Heine-Geldern, is on

a.a.O., 411. Ich danke an dieser Stelle Herrn Univ.-Prof DDr. Oliver Rathkolb für den Hinweis auf die Bedeutung Max Grafs.

2549 NARA II, RG 260, EDU-DIV, Box 1/Folder 9, Schreiben Samuel H. Williams, U.S. Civilian Chief, Education Division, to Otto Skrbensky, Section Chief, Higher Education, 20. Juli 1948, 1. 
the pacific coast for a few months and none of the other officers know how to get anything done. ${ }^{2550}$ [Hervorhebung d. Verf.]

Vom Teachers College der Columbia University aus, wo Featherstone mittlerweile wieder lehrte, schloss er sein Antwortschreiben an seinen militärischen Amtskollegen in unbekümmert salopper Art:

"Perhaps by the time you receive this, the Moscow crowd will have decided on something regarding to Austria and you will be making plans to wind up your work there. The indications are not too favorable at present, but I still hope for the best. Istill think that Austrians would get along better if we all went home and allowed them to work out their own problems." 2551 [Hervorhebung d. Verf.]

Ungeachtet dieser wenig ermutigenden Auskunft, ergriff Benner die Initiative und kontaktierte - nach Gesprächen mit österreichischen Stellen - im Februar 1947 die im Smithsonian Institute in Washington angesiedelte „Association for the Advancement of Science“ und schlug dieser im Rahmen der US-Reorientierungs-Programme österreichische Wissenschafter als „visiting experts“vor:

"At my request a committee of Austrian scholars has prepared the enclosed list of the most prominent, active scholars in Austria at the present time. [...] In addition it seems to me most desirable that contacts between American and Austrian scholars be restored, as rapidly as possible in the interest both of scholarship and of assisting in the democratic reorientation of Austrian education which was liberated two years ago from the Nazi regime."2552

Möglicherweise als Reaktion auf die gewalttätigen Ausschreitungen bei den ersten ÖHWahlen im November 1946 und die dabei bis nach Washington vorgedrungenen Vorwürfe einer mangelhaften Entnazifizierung an Österreichs Universitäten, schwebte Benner vor, mit einer Art positiver Gegenzeichnung der universitären Lage in Österreich zu antworten, indem er Pläne für die Herausgabe eines wissenschaftlichen „Austrian Who's Who“ schmiedete. In diesem Zusammenhang schlug Benner Rektor Adamovich vor, eine Liste führender österreichischer Gelehrter zu erstellen, um auf der Basis dieser Referenzliste künftig die wissenschaftlichen Kontakte zwischen Österreich und den USA über die Besatzungszeit hinaus zu vertiefen. Die Liste sollte breit angelegt sein und neben Wis-

2550 NARA II, RG 260, EDU-DIV, Box 1/Folder 9, Schreiben William B. Featherstone, Teachers College/Columbia University, to Thomas E. Benner, U.S. Civilian Chief, Education Division, 31. März $1947,1$.

2551 Ebd., 2.

2552 NARA II, RG 260, EDU-DIV, Box 1, Folder 9. Schreiben Thomas E. Benner, U. S. Civilian Chief, Education Division, an F.R. Moulton, American Association for the Advancement of Science, Smithsonian Institute, Washington D.C., 27. Juni 1947, 1. 
senschaftern im engeren Sinne auch Bildungsexperten, Künstler oder Bibliothekare umfassen sowie wissenschaftliche Gesellschaften, Bibliotheken und sonstige Wissenschaftseinrichtungen anführen. ${ }^{253}$

Die von den Offizieren der Education Division geprüfte finale Liste führte schließlich 49 österreichische Wissenschafter an, die für das „exchange of persons program“ vorgeschlagen wurden. Darunter befanden sich auch acht bereits emeritierte beziehungsweise in den Ruhestand versetzte Professoren. ${ }^{2554}$

Unter den restlichen vorgeschlagenen Wissenschaftern wurden unter anderem auch Personen mit unterschiedlicher Belastung aufgrund ihrer NS-Vergangenheit angeführt: so zum Beispiel die Professoren Leopold Schönbauer, ${ }^{2555}$ Hans Planitz, ${ }^{2556}$ Ernst Schönbauer; ${ }^{2557}$

2553 NARA II, RG 260, EDU-DIV, Box 1, Folder 9. Schreiben Thomas E. Benner, U. S. Civilian Chief, Education Division, an William B. Featherstone, Teachers College, Columbia University, 28. Februar 1947, 1.

2554 NARA II, RG 260, EDU-DIV, Box 1/Folder 9. Schreiben Thomas E. Benner, U. S. Civilian Chief, Education Division, an F.R. Moulton, American Association for the Advancement of Science, Smithonian Institute, Washington D.C., 27. Juni 1947, 2 f.

2555 Siehe Kapitel 4, S. 310, Anm. 1323.

2556 Siehe Kapitel 4, S. 349, Anm. 1491.

2557 Ernst Schönbauer (1886-1966), laut OSS-Bericht „begeisterter Nazi“ („ardent Nazi“); siehe: NARA II, RG 319 [Entry 85], Box 1329, 270/II/30/6, Records of the Army Staff. Army Intelligence Document File, ID 0203388, OSS, Washington D.C. 26. September 1945, 1; geboren in Windigsteig in Niederösterreich, Cousin Leopold Schönbauers. Schönbauer, der 1911 zum Doktor der Philosophie promovierte und 1915 sein Studium der Rechtswissenschaften abschloss, hatte zuvor an den Universitäten Wien, Prag und Berlin studiert. Danach studierte er noch an der Universität für Bodenkultur in Wien. 1924 wurde Schönbauer außerordentlicher Universitätsprofessor. Ab 1929 hatte Schönbauer die Position eines Professors für Antike Rechtsgeschichte inne und lehrte als Dozent für Papyrologie. Von 1938-1940 war Schönbauer Dekan der Rechtswissenschaftlichen Fakultät der Universität Wien. Laut Eintrag auf der Parlamentshomepage war er von 1929 bis 1948 [sic] ordentlicher Professor für Bürgerliches und Römisches Recht und für antike Rechtsgeschichte sowie für Papyrologie. Siehe den Eintrag auf: http://www.parlament.gv.at/ WWER/PAD_01757/index.shtml [Zugriff 26.9.2011]; 1918/19 hatte Schönbauer als Experte an den Friedensverhandlungen in St. Germain teilgenommen; danach war er für die Großdeutsche Volkspartei Mitglied der konstituierenden Nationalversammlung; von 1920-1930 war er als Mitglied des Landbunds Nationalratsabgeordneter. Vgl. Ernst Klee, Das Personenlexikon zum Dritten Reich, Wer war was vor und nach 1945, Frankfurt am Main 2003, 555. (Zit. nach: Herbert Posch/Doris Ingrisch/Gert Dressel, „Anschluss“ und Ausschluss 1938. Vertriebene und verbliebene Studierende der Universität Wien, (=Emigration - Exil - Kontinuität. Schriften zur zeitgeschichtlichen Kultur- und Wissenschaftsforschung, hrsg. v. Friedrich Stadler. Bd. 8, Berlin 2008, 111.) Seit März 1934 war Schönbauer, der den Beitritt zur „Vaterländichen Front“ verweigerte, Obmann der Gesellschaft für Rechtswissenschaften, die „als Sammelpunkt für alle ,NS-Rechtswahrer' agierte; der antisemitische Rechtswissenschafter war früh illegales NSDAPMitglied und während der Propagandakampagne 1938 ,als Gauredner im Waldviertel höchst aktiv“. Nach dem „Anschluss“ wurde er zum kommissarischen Dekan der Rechts- und Staatswissenschaftlichen Fakultät ernannt. Zit. nach: Rathkolb, Rechts- und Staatswissenschaftliche Fakultät, a.a.O., 201. Wie die NSDAP-Ortsgruppenleitungen im Juli und Oktober 1940 bestätigten, hatte Schönbauer, der Mitglied beim „NSV, RLB, DRK, RWB“ war und seit Mai 1938 auch NSDAP-Mitglied, als Nationalsozialist 
Tassilo Antoine, ${ }^{2558}$ weiters Richard Meister, ${ }^{2559}$ Leopold Arzt,${ }^{2560}$ Alfred Verdross-Droß-

einen „einwandfreien Ruf“. Vgl. Irmgard Schartner, Die Staatsrechtler der juridischen Fakultät der Universität Wien im „Ansturm“ des Nationalsozialismus. Umbrüche mit Kontinuitäten, Frankfurt a. Main 2011, 261; siehe dazu auch: Report of Quadripartite Sub-Committee on Denazification in Austrian Universities, 7. September 1946. Appendix “A”, Vienna University. NARA II, RG 260, Box 11, Folder 68, Records of the United States Occupation Headquarters, World War II, USFA/USACA, Internal Affairs/Displaced Persons Division, Denazification Branch, General Records, 1945-50. Interessanterweise wurde die Universitätslaufbahn Schönbauers, der weiterhin Mitglied der Österreichischen Akademie der Wissenschaften blieb, nach Kriegsende nach einem Erkenntnis der Sonderkommission I. Instanz mit 2.8.1945 durch Enthebung seitens des Staatsamtes beendet. Trotz mehrfacher Berufungen und Beschwerden, u.a. beim Verfassungs- und Verwaltungsgerichtshof, wurde Schönbauer am 31.5.1948 schließlich per Dekret des Bundesministeriums für Unterricht in den Ruhestand versetzt. Siehe dazu im Detail: Schartner, Die Staatsrechtler der juridischen Fakultät der Universität Wien im „Ansturm“ des Nationalsozialismus, a.a.O., 288 ff. Politisch war Schönbauer nach Kriegsende bei der Formierung des „Vierten Lagers“ aktiv beteiligt, das sich im Februar 1949 als „Verband der Unabhängigen“ (VdU) zusammenschloss. Zuvor war Schönbauer ab 1946/47 - neben Fritz Stüber für Oberösterreich und anderen - als „Wiener Vertrauensmann“ Leopold Stockers tätig und hatte 1947 zudem den ersten Vereinsnamen „Verfassungstreue Vereinigung“ (VV) vorgeschlagen. Schönbauer, der laut Höbelt in der Ersten Republik als „Chefintellektueller der Landbund-Fraktion“ galt, und auf seinen Visitenkarten „Universitätsprofessor und Bauer“ stehen hatte, ermöglichte über die guten gesellschaftlich-politischen Verbindungen seines Cousins Leopold Schönbauer „die Wiederaufnahme der Pensionszahlungen für den Historiker und Unterrichtsminister von 1930, Heinrich v. Srbik“. Lothar Höbelt, Von der Vierten Partei zur Dritten Kraft. Die Geschichte des VdU, Graz 1999, 17. Wie Margarete Grandner schreibt, durfte Schönbauer, anders als Kreller und Planitz, die „vor und nach dem April 1945 zu den Stützen der Juridischen Fakultät“ zählten, seit Kriegsende nicht mehr lehren und wurde „1948 im Alter von 63 Jahren pensioniert“. Zit. nach: Margarete Grandner, Das Studium an der Rechts- und Staatswissenschaftlichen Fakultät der Universität Wien 1945-1955. In: Grandner/Heiß/Rathkolb (Hrsg.), Zukunft mit Altlasten, a.a.O., 298. In einem Leserbrief an das Nachrichtenmagazin Profil (1/1998) schrieb Frau Dr. Edith Kaufmann (geb. Verdross), Schönbauer habe sich schon in den frühen Dreißigerjahren bei der Verprügelung von Juden in Vorlesungen amüsiert [Hinweis bei: Irmgard Marboe, Alfred Verdross - Ein Mann des Widerspruchs? Teil 1. Verdross' Völkerrechtstheorie vor dem Hintergrund des Nationalsozialismus, a.a.O., 22].

2558 Tassilo Antoine (1895-1980), Gynäkologe, NSDAP-Parteimitglied, war Ordinarius an der Innsbrucker Universitätsklinik und wurde 1943 Nachfolger Amreichs an der Wiener Universitätsklinik. Isabelle Ackerl schreibt: „Das offizielle Österreich wusste um seine Verdienste und hat mit zahlreichen Ehrungen dem Rechnung getragen: Tassilo Antoine erhielt das Große Silberne Ehrenzeichen, das Ehrenzeichen für Wissenschaft und Kunst (1972), den Ehrenring der Stadt Wien (1965), den Preis der Stadt Wien für Naturwissenschaften und die Billrothmedaille der Gesellschaft der Ärzte, deren Präsident und Ehrenpräsident er jahrelang gewesen war.“ Zit. nach: Vereinigung der Alt-Hietzinger, http://www.althietzinger.at/Archiv/personen/tassiloantoine.shtml [Zugriff 23.1.2011]; die NS-Behörden attestierten Antoine: „Er bietet die Gewähr sich jederzeit rückhaltlos für den NS-Staat einzusetzen.“ Zit. nach: Arias, Entnazifizierung an der Wiener Medizinischen Fakultät, a.a.O., 359. Antoine wurde wie Leopold Schönbauer angerechnet, sich bei der Verteidigung des Allgemeinen Krankenhauses verdient gemacht zu haben. (Ebd.)

2559 Siehe Kapitel 4, S. 342, Anm. 1457.

2560 Siehe Kapitel 4, S. 310, Anm. 1278. 
berg $^{2561}$ und - schließlich - kurioserweise Rektor Ludwig Adamovich selbst. ${ }^{2562}$ Diese nicht gerade besonders wissenschaftsinnovative und zukunftsorientierte Namensliste wurde auf Ansuchen Benners von der Universität Wien selbst erstellt, ihm von Rektor Adamovich zugesandt, und daraufhin - offensichtlich ohne weitere Einwände seitens der US-Besatzungsoffiziere - weitergeleitet. ${ }^{2563}$

Diese blind-vertrauliche Form der Zusammenarbeit zwischen der USFA-Education Division einerseits und österreichischen Ministeriums- und Universitätsstellen andererseits, zeitigte - wie sich schon kurze Zeit später zeigen sollte - ebenso eigenartige wie für die amerikanische Besatzungsmacht nachgerade peinliche Ergebnisse.

Unmittelbar nachdem das Department of State Verfahrensrichtlinien für die Handhabung der Austauschprogramme mit Österreich übermittelt hatte - das Budget für das Fiskaljahr 1950/5I sah die Finanzierung eines Aufenthaltes für insgesamt 150 österreichische Studierende und Lehrkräfte vor -, kam es zu einem bemerkenswerten Zwischenfall.

Sowohl der Direktor der USACA, Col. C.G. Dodge, als auch dessen Stellvertreter maßen den anlaufenden USIE-„Exchange“-Programmen große Bedeutung bei, nachdem das Department of State im Mai 1949 ein Memorandum übermittelt hatte, das die Intensivierung

2561 Siehe Kapitel 4, S. 349, Anm. 1489.

2562 Siehe Kapitel 4, S. 309, Anm. 1320.

2563 Auf der Liste befanden sich folgende Namen (die mit einem „+“ versehenen waren minderbelastet, die mit einem „p“ versehenen waren bereits im Ruhestand): (p) + Leopold Wenger [Römisches Recht, Wien], + Artur Steinwenter [Römisches Recht, Graz], (p) + Ernst Schönbauer [ Römisches Recht, Wien], Hans Planitz [Deutsche Rechtsgeschichte, Wien], Rudolf Köstler [Kirchenrecht, Wien], Franz Gschnitzer [Zivilrecht, Wien], Theodor Rittler [Strafrecht, Wien], Ludwig Adamovich [Staatsrecht, Wien], Alfred Verdross [Völkerrecht, Wien], Josef Dobretsberger [Nationalökonomie, Graz]; Tassilo Antoine + [Gynäkologie, Wien], Heinrich Kahr [Gynäkologie, Wien], (p) Josef Mellner [Augenheilkunde, Wien], Karl D. Lindner [Haut- und Geschlechtskrankheiten, Wien], Leopold Arzt [Haut- und Geschlechtskrankheiten, Wien], Emil Schlander [Oto-Laryngologie, Wien], Camillo Wiethe [Oto-Laryngologie, Wien], (p) + Arnold Durig [Physiologie, Wien], Hermann Chiari [Pathologische Anatomie, Wien], Marius Kaiser [Hygiene, Wien], Ernst Lauda [Interne Medizin, Wien], Karl Fellinger [Interne Medizin, Wien], (p) Nikolaus Jagic [Interne Medizin, Wien], Otto Kauders [Psychiatrie u. Nervenkrankeiten, Wien], + Leopold Schönbauer [Chirurgie, Wien], Wolfgang Denk [Chirurgie, Wien], + Burghart Breitner [Chirurgie, Innsbruck], Hans Finsterer [Chirurgie, Wien], + Camillo Praschniker [Archäologie, Wien], Josef Keil [Archäologie, Wien], Hugo Hassinger [Geographie, Wien], (p) + Hermann Junker [Ägyptologie, Wien], Wilhelm Haverss [Indogermanische Sprachwissenschaften, Wien], (p) Paul Kretschmer [Indogermanische Sprachwissenschaften, Wien], Alois Dempf [Philosophie, Wien], (p) Robert Reininger [Philosophie, Wien], (p) Adolf Wilhelm [Klassische Philologie, Wien], Richard Meister [Pädagogik, Wien], Heinrich Ficker [Meterologie, Wien], [?] Fenat [Meterologie, Innsbruck], Arthur March [Physik, Wien], (p) Stefan Meyer [Physik, Wien], Kasimir Graff [Astronomie, Wien], Hans Radon [Mathematik, Wien], Otto Storch [Zoologie, Wien], Karl Frisch [Zoologie, Wien], Felix Machatschki [Mineralogie, Wien], Bruno Sander [Mineralogie, Innsbruck], Hubert Rohracher [Psychologie, Wien]. NARA II, RG 260, EDU-DIV, Box 1, Folder 5. Ludwig Adamovich an Thomas Benner, 5. April 1947, 2 ff. 
der U.S. „Exchange of Persons“-Programme in Österreich forderte. Umgehend wurde dafür ein eigenes „exchange-committee“ unter Vorsitz des stellvertretenden USACA-Direktors J.H. Whiting eingerichtet. ${ }^{2564}$ In Zusammenarbeit zwischen dem Leiter der Education Division, dem Leiter der Information Service Branch (ISB) sowie dem „Public Affairs Officer“ der US-Gesandtschaft in Österreich sollte dieses Komitee künftig die Organisation und Administration der akademischen Austauschprogramme koordinieren und durchführen.

Die US-Gesandtschaft in Wien erklärte ihr völliges Einverständnis sowohl mit dem Plänen des Department of State als auch mit deren Umsetzung durch die USACA-Leitung: ,[...] complete accordance with the memorandum in its emphasis upon the importance of reorientation and the value of sending to the United States persons whose promise and fields of activity will give the wide influence on their return to Austria." ${ }^{2565}$

Als aber eine erste Liste mit Namen von Austauschkandidaten zirkulierte, die erneut solche überaus problematischer Personen enthielt, zeigten sich sowohl der US-Gesandte in Wien als auch der USACA-Direktor alarmiert. Der Umstand, dass sich belastete Personen auf dieser vom Unterrichtsministerium vorgeschlagenen Liste befanden, beunruhigte die US-Offiziere hochgradig, zumal sie im Fall einer Zurückweisung unangenehme Folgen befürchteten:

"The Director of USACA has referred to two cases where clearances have become matters of great embarrassment to all concerned. It is obvious that the final rejection of well-known persons whose plans for visiting the United States have been widely discussed by the Austrian associates may be productive of considerable threat. If such persons are clearly objectionable the final negative decision may be properly understood. If, however, the community has accepted the individual despite some unfortunate past connections, his rejection may produce more than momentary embarrassment." 2566 [Hervorhebung d. Verf.]

Um abzuklären, wie in dieser heiklen Angelegenheit nun weiter zu verfahren sei, richtete die US-Gesandtschaft in Wien ein Schreiben sowohl an das Department of State als auch an das War Department (CAD) in Washington und erläuterte den mit den österreichischen Usancen nicht vertrauten zivilen Beamten und Militärs die Problematik in ihrer vielschichtigen Dimension:

"Would like State Department and CAD guidance and/or policy determination relative to problem which has arisen in connection with Austrian experts visiting US General policy

2564 The Foreign Service of the United States of America. American Legation, Vienna, to State Department: Exchange of Persons Program for Austria, 19. Mai 1949, 1. The U.S. Occupation of Germany: Educational Reform 1945-1949, Microfilm-Collection, a.a.O., 2-A-698.

2565 Ebd., 2.

2566 Ebd., 1. 
as previously determined by US legation and USFA has been that individuals with any semblance of National Socialist backgrounds would not be considered. Into this category falls an individual for whom considerable pressure is being brought to bear by interested USFA staff sections and Austrian agencies to include in present program. CIC report indicates subject applied for party membership I940 and was admitted 194I with Membership No. 9,030.000; was member of the NSKK I943; and supporting member of the SS for two months 1938 with Membership No. I,400.000. Further investigations indicated inactive party membership. [...] Subject was granted presidential amnesty June 1947 as of a less implicated person. He has since been restored to former position as head of a medical clinic in the University of Vienna. Subject has rendered considerable assistance to medical personnel of Army Hospital Vienna in his professional capacity, which is still continuing. [...] He is highly recommended by Education Division USACA; USFA Surgeon; Austrian Ministry of Education, and by many influential Austrian medical circles and individuals. [...] Although subject obviously falls under category previously determined to be ineligible for participation in visiting experts program, it must be remembered that under Austrian law which the US has recognized, he has been restored to full status in local professional circles through his amnesty. Question arises whether passive participation in National Socialist organizations should still be construed as a barrier to inclusion in Project 4I4. The Program Committee for Austrian Experts now in existence here is charged with responsibility of formulating and recommending policy. Program Committee believes that, although basic decision is in order, consideration might well be given in individual cases for inclusion of persons with National Socialist or Leftist backgrounds who can be counted upon to represent their field or profession adequately [...]". ${ }^{2567}$ [Hervorhebung d. Verf.]

Die sachliche, zugleich unterschwellig wohl auch etwas unwirsche, jedenfalls unmissverständliche Antwort von Colonel L.P. Irvin von der Civil Affairs Division in Washington ging auf die geschilderten Verwicklungen und allfälligen Empfindlichkeiten österreichischer Stellen erst gar nicht ein und beschränkte sich auf den inhaltlichen Kern des Problems:

"Thank you transmitting this. Visiting Experts program does involve reorientation policy considerations and State Department has live interest in it. Nevertheless, since this specific case involves operational decision and possible modification of policy which was fixed locally in Vienna, we consider it inadvisable to give definite decision from here. Purely by way of advice, after checking with other interested office, we give Program Committee following to consider:

A) German program, which is much larger in size than Austrian program, has never yet included person who was member of NSDAP, regardless of whether or not he was subsequently amnestied.

2567 Col. Curtin CSOCI, to Chief, CAD, „Visiting Experts Program, 26. Mai 1949, 1. The U.S. Occupation of Germany: Educational Reform 1945-1949, Microfilm-Collection, a.a.O., 2-A-698. 
B) Publicity attendant to Visiting Experts Program is consideration which must not be overlooked. One unsavory case receiving wide publicity in US might conceivable jeopardize appropriations for entire program.

C) Doctors are in specially sensitive position due to presence of substantial numbers refugee doctors in this country. CAD has found that refugee doctors in Kansas, for instance, protested when German doctor (who was no Nazi) was assigned there temporarily by Public Health people, under Visiting Experts Program."2568 [Hervorhebung d. Verf.]

Soweit der „Ratschlag“ des War Departments an die verantwortlichen Offiziere der USMilitärregierung in Österreich, der freilich ein bezeichnendes Licht auf die unklare und wohl auch unangemessene Handhabung der Angelegenheit in Wien wirft.

In welcher Form diese zweifellos unangenehme Angelegenheit schließlich bereinigt wurde, lässt sich anhand der verfügbaren Quellen nicht nachvollziehen. Es ist jedoch davon auszugehen, dass dem Ratschlag, der einer impliziten Weisung gleichkam, von höchster Stelle entsprochen worden sein dürfte und zumindest die inkriminierten Personen von der Liste gestrichen wurden.

Dass es abgesehen von derart peinlichen Vorfällen darüber hinaus auch zu - freilich weitaus weniger brisanten - administrativen Problemen und Pannen im Ablauf der Austausch-Aufenthalte für österreichische KandidatInnen kam, zeigt sich an einzelnen Fällen.

Ein Beispiel für die zuweilen offenbar mangelhafte Planung und Koordinierung seitens der Education Division stellt die Abwicklung des Studienaufenthaltes für die Grazer Studentin Irmgard Rollett dar, die im Februar 1949 an der Niagara University für einen einjährigen Studienaufenthalt eintraf; sie war von der USFA Education Division (Mr. Harold E. Howland, Acting Chief) offensichtlich nicht darüber aufgeklärt worden, dass die USFA lediglich die Abdeckung der Reisekosten übernahm, die finanzierte Studienbeihilfe jedoch nur einen Teil der jährlichen Studiengebühren abdecken würde: „Miss Rollett had no information of any ,Scholarly allowance'. She came, in faith' that something could be arranged. “2569 Ganz offenbar hatten sich die Verantwortlichen der USFA Education Division nur höchst unzureichend mit dem Institute of International Education, das die studentischen Austauschprogramme ab 1949 in Absprache mit der Civil Affairs Division (CAD) administrierte, koordiniert. ${ }^{2570}$

2568 Chas. S. Johnson, Col. GSC Executive, CSOCI to Chief CAD, 26. Mai 1949, 2. The U.S. Occupation of Germany: Educational Reform 1945-1949, Microfilm-Collection, a. a. O., 2-A-818.

2569 Capt. Bateson, Civil Affairs Division, to Commanding General, United States Forces in Austria, „Contract with institute of International Educatioon - Austrian Interchange of Students“, 31. Mai 1949, 1. The U.S. Occupation of Germany: Educational Reform 1945-1949, Microfilm-Collection, a.a. O., 2-A804.

2570 Auch in diesem Fall war die Mitteilung der Civil Affairs Division in Washington klar und unmissverständlich: „If Miss Rollet was approved for inclusion thereunder [Exchange Program, d. Verf.] she would be fully subject to the terms prescribed by the Institute of International Education and subject to 
KURZER EXKURS: DAS SALZBURG-SEMINAR -

AKADEMISCHE FREIHEIT MIT HINDERNISSEN

"The seminar has proved that individual scholars from many nations can work happily and profitably together. It has restated concretely the ideal, the potential unity (not of course the homogeneity) of Occidental culture. Its contribution is to have demonstrated this possibility." ${ }^{2571}$

Henry Nash Smith, 1949

Ein Spezialfall des wissenschaftlichen Austausches zwischen den Vereinigten Staaten und Österreich, der jedoch nur eine vergleichsweise schmale Elite betraf und ein von Beginn an genuin akademisches Unterfangen darstellte, war das 1947 eingerichtete „Salzburg Seminar“. ${ }^{2572}$ Die Initiative dazu ging von Clemens Heller aus, einem 30-jährigen Harvard-Geschichtsdoktoranden mit österreichischen Wurzeln, ${ }^{2573}$ der die Idee hatte, im besetzten Österreich ein Zentrum für intellektuellen Austausch zu schaffen - einen „Marshall Plan of the Mind“2574 -, in dessen Rahmen sich amerikanische Wissenschafter mit europäischen Gelehrten und Studierenden zu freiem Gedankenaustausch treffen sollten.

the scholastic and administrative requirements of that Institute under the responsibility of the subject contract. Upon concurrence of your office in this regard, the contractor will be instructed by the Department of the Army to conduct further investigation to ascertain the eligibility of subject student under the Austrian quota for the coming scholastic year." Ebd., 1.

2571 Henry Nash Smith, The Salzburg Seminar. In: American Quarterly, 1949, No. 1, 37.

2572 Zum „Salzburg Seminar“ im Detail siehe die Dissertation von: George Holt Blaustein, Jr., To the Heart of Europe: Americanism, the Salzburg Seminar, and Cultural Diplomacy, Diss., Harvard University 2010, 136 ff. Ich danke an dieser Stelle Herrn Dr. George Holt Blaustein Jr. für die freundliche Überlassung einer Kopie seiner Studie.

2573 Clemens Heller (1917-2002), Sohn des Wiener Verlegers Hugo Heller - in dessen Verlag die Werke Sigmund Freuds erschienen waren -, wurde angesichts der nationalsozialistischen Bedrohung von seinen Eltern 1937 gemeinsam mit seinem Bruder in die USA geschickt, um dort - zunächst am Oberin College sowie an der Ohio State University, später dann an der Harvard University - eine gute Ausbildung zu erhalten, die Heller mit seinem Geschichtestudium abschloss. Nach seinem Versuch, mit dem Salzburg Seminar einen „Marshall-Plan of the Mind“ zu schaffen - ein Projekt, das infolge des rigiden Kulturkonservatismus des Kalten Krieges letztlich scheiterte -, ging Heller nach Beendigung seines Doktorats nach Paris. Hier lernte er u.a. Fernand Braudel und Lucien Febvre kennen, die damals die 6. Abteilung der Ecole Pratique des Hautes Etudes leiteten und Heller für die Mitarbeit gewannen. Braudel wurde Hellers freundschaftlich-wissenschaftlicher Mentor; mit ihm gemeinsam gründete Heller in den 1960er-Jahren das auf sozialwissenschaftlich innovative Methoden und Interdisziplinarität angelegte Maison des Sciences de l'Homme (MSH), das er - zunächst als Assistent - nach Fernand Braudels Tod im Jahr 1985 leitete. Siehe: Maurice Aymard, In memoriam: Clemens Heller (1917-2002). In: Social Sciences Information, Vol. 42, 2003, No. 3, $285 \mathrm{f}$.

2574 Vgl. Clemens Heller - Founder of the "Marshall Plan of the Mind”. In: Austrian Press and Information Service, Washington D.C., Vol. 55, September/October 2002. Zit. nach: http://www.salzburgglobal.org/ current/history-b.cfm?goto=heller [Zugriff 2.1.2013]. 
Unterstützt von Scott Elledge, einem jungen Englischlehrer vom Carleton College im US-Bundesstaat Minnesota, dem Harvard-Literaturwissenschafter Francis O. Matthiessen und Richard Campbell, einem älteren Harvard-Kollegen, ${ }^{2575}$ gelang es Heller, in Kooperation mit dem „Harvard College University Student Council“ und dem „International Student Service" in Genf, ein erstes Programm für einen sechswöchigen Kurs zusammenzustellen, der vom 15. Juli bis 3r. August 1947 stattfand. Als Seminarort stellte die österreichische Schauspielerin und Witwe Max Reinhardts, Helene Thimig, das in der US-Besatzungszone gelegene Rokoko-Schloss Leopoldskron zur Verfügung, das ihr verstorbener Mann in den Jahren des Ersten Weltkriegs erworben hatte. ${ }^{2576}$ Finanzielle Unterstützung erhielt Heller dabei sowohl vom österreichischen Unterrichtsministerium als auch vom Carnegie Endowment, wobei die USFA Education Division zunächst in administrativer Hinsicht behilflich war und über das US-Information Service (USIS) Bücher für die Einrichtung einer kleinen Bibliothek bereitstellte. ${ }^{2577}$

Ziel und Zweck des methodisch offenen, internationalen und auf intellektuelle Auseinandersetzung mit amerikanischer Lebensart, Kultur und Politik ausgerichteten Seminars war der Abbau von negativen Vorurteilen und Stereotypen über das gesellschaftliche, ökonomische und politische Amerika seitens der teilnehmenden StudentInnen, jungen UniversitätslehrerInnen, KünstlerInnen, JournalistInnen und gewerkschaftlichen Führungskräfte, die, nach Rückkehr in ihre Heimatländer - ähnlich wie im Fall der US-Personenaustauschprogramme - als einflussreiche gesellschaftliche Multiplikatoren wirken sollten. Henry Nash Smith - Englischprofessor an der University of Minnesota und selbst Vortragender im Salzburg-Seminar - fasste diese Intention 1949 folgendermaßen zusammen:

"But the major result of the seminar must be sought in the experiences of about one hundred and seventy-five Europeans. This is not a large number, yet many of the participants are already persons of influence in their own countries, and most of them will acquire greater influence

2575 Vgl. dazu die Ausführungen von Timothy W. Ryback, vormaliger Direktor bzw. Vizepräsident des „Salzburg Global Seminars": Timothy W. Ryback, "The Salzburg Seminar- A Community of Fellows". Zit. nach: http://www.salzburgglobal.org/current/history-b.cfm?goto=community [Zugriff 10.1.2013].

2576 Nach dem „Anschluss“ wurde Schloss Leopoldskron sowie sämtlicher Besitz Max Reinhardts von der Gestapo als „volks- und staatsfeindliches Vermögen“ beschlagnahmt bzw. von der Landesverwaltung „arisiert“. Das Schloss fungierte daraufhin kurzzeitig als NS-Parteischule bevor Hermann Göring dieses sowie das zirka 50 Hektar große Anwesen an Prinzessin Stephanie von Hohenlohe mit dem Auftrag übergab, ein Gästehaus für prominente Festspielgäste einzurichten. Nachdem Stephanie von Hohenlohe bald darauf selbst in Ungnade fiel und im Frühjahr 1939 nach England emigrierte, wandelte der damalige Salzburger Gauleiter Friedrich Rainer Schloss Leopoldskron kurzerhand in ein Gästehaus für NS-Prominenz um. Nach Kriegsende wurde der Besitz nach eingebrachtem Rückstellungsantrag Helene Thimig als Nachlassverwalterin restituiert. Vgl. dazu Johannes Hofinger, Max Reinhardts Schloss Leopoldskron: Beutegut der Nationalsozialisten. In: David. Jüdische Kulturzeitschrift, 17. Jg., April 2005, Heft 64, 3 ff.; weiters: Ders., Die Akte Leopoldskron. Max Reinhardt - Das Schloss - Arisierung \& Restitution, Salzburg 2005.

2577 Schmidt, Civil Empire by Co-optation, a.a.O., $317 \mathrm{f}$. 
as they follow their careeres in teaching, scholarship, or other professional work. [...] Perhaps their greatest immediate value was to destroy some of the stereotyped images that Europeans have of Americans (just as Americans have stereotyped images of the Frenchman, the Norwegian, the German, the Italian). No one could stay at Leopoldskron without realizing that the conceptions of the American character held even by cultivated Europeans are vastly oversimplified if not downright misleading." 2578 [Hervorhebung d. Verf.]

In seiner Eröffnungsansprache hielt Matthiessen ausdrücklich fest, dass es sich bei dem Seminar um keine Veranstaltung handle, die unter den Teilnehmenden doktrinär die „Pax Americana“ befördern solle, betonte aber gleichzeitig, dass diese intellektuelle Zusammenkunft vom Bekenntnis zu den Werten der amerikanischen Demokratie getragen sei: „All of us come nonetheless with a strong conviction of values of American democracy $[\ldots]^{\text {“. }}{ }^{2579}$

Einer dieser Werte war aus Sicht der Veranstalter und der Seminar-Vortragenden ${ }^{2580}$ der freie Gedankenaustausch. In ihrem Erfahrungsbericht meinte die US-amerikanische Anthropologin Margaret Mead als eine der ersten Vortragenden in Schloss Leopoldskron hinsichtlich des strikt unpolitischen Charakters der Zusammenkünfte:

"The Salzburg Seminar plan was a product of the sort of crossnational thinking on which it will be necessary to rely in constructing a more closely knit and more mutually intelligible world [...]. To make American civilization a genuine area of communication meant that the Seminar had to be strictly disassociated from any government or propagandic venture and that the content had to be cultural, and relatively free from political controversy."2581

2578 Smith, The Salzburg Seminar, a.a. O., $34 \mathrm{f}$.

2579 Zit. nach: Schmidt, Civil Empire by Co-optation, a.a.O., 319.

2580 Dies waren 1947: Margaret Mead (American Museum of Natural History), F.O. Matthiessen (Harvard), Alfred Kazin, Vida Ginsberg (New School of Social Research), Richard Schlatter (Rutgers), Elspeth Davies (Sarah Lawrence), Benjamin Wright (Harvard), Neil McDonald (New Jersey College for Women), Vasilly Leontieff (Harvard), Lyman Bryson (Columbia) und Walt Rostow (Oxford). 9. NARA II, RG 260, EDU-DIV, Box 5. Martin F. Herz, American Legation, Vienna [Draft Despatch], 1948, Policy considerations in connection with the „Seminar on American Civilization“ at Leopoldskron Castle, Salzburg, 1.1948 bestanden die vortragenden „Faculty members“ aus folgenden Personen: Henry Nash Smith (University of Minnesota), Randall Jarrell (University of North Carolina), John Finch (Dartmouth College), Walter Johnson (University of Chicago), Thomas D. Clark (University of Kentucky), Robert Horn (University of Chicago), Wasilly Leontief [sic] (Harvard University), William G. Rice (University of Wisconsin), Talcott Parsons (Harvard University), James Johnson Sweeny (Former curator of the Mueseum of Modern Art, New York). Siehe: Recordings of the U.S. Department of State relating to the Internal Affairs of Austria 1945-1954 (Mikrofilm-Bestand Institut für Zeitgeschichte der Universität Wien), Decimal File, Reel 6, 1945-1949, Report to the Secretary of State, Washington D.C., 21. Oktober 1948, 2 f.

2581 NARA II, RG 260, EDU-DIV, Box 5. Martin F. Herz, American Legation, Vienna [Draft Despatch], 1948, Policy considerations in connection with the „Seminar on American Civilization“ at Leopoldskron Castle, Salzburg, 3. 
Die insgesamt ıı Seminarteilnehmer des ersten Zyklus des Salzburg-Seminars - bis Sommer 1948 nahmen in Summe 175 Personen aus Europa teil ${ }^{2582}$ - kamen, abgesehen von Österreich ${ }^{2583}$ und Amerika, aus Frankreich, Holland, Belgien, Deutschland, Dänemark, Schweden, Finnland, Großbritannien und Australien. Der Umstand, dass außerdem zwei Teilnehmer aus Ländern hinter dem „Iron Curtain“ teilnahmen, nämlich aus der Tschechoslowakei und Ungarn, erregte bald den Verdacht „linker“ Umtriebe.

Obwohl sich Samuel H. Williams noch Anfang September 1947 in einem Schreiben an den Präsidenten der Harvard University, James B. Conant, grundsätzlich positiv über den ersten Kurs in Leopoldskron geäußert hatte, ${ }^{2584}$ trug die Leitung der USFA Education Division bald maßgeblich dazu bei, die Leitung des „Salzburg Seminars“ zu diskreditieren und das Experiment eines internationalen, akademisch-freien und intellektuellen Diskurses hart an den Rand des Scheiterns zu führen.

Nachdem ein CIC-Report, datiert vom 26. Juli 1947, kommunistische Aktivitäten beim Salzburg Seminar festgestellt hatte und dabei unter anderen Heller und Matthiessen der Subversion verdächtigte, ${ }^{2585}$ entschloss sich die Leitung der Education Division um-

2582 Smith, The Salzburg Seminar, a.a.O., 34.

2583 Unter den Teilnehmenden aus Österreich finden sich einige (später) prominente Personen. Die Namen der österreichischen TeilnehmerInnen des Kurses im Jahr 1947 lauten: George Berner (Salzburg), Rea Sylvia Cicin (DP Camp Hellbrünn/Salzburg), Fritz Czerwenka (Wien), Nataly Engelhardt (DP Camp Parsch/Salzburg), Edith Farcas (Salzburg), Heinz Fuchs (Graz), Otto Haindl (Wien), Wilhelm Hein (Wien), Otto Hietsch (Wien), Hans-Heiriek Isenbarth (Wien), Justine Krünes (Wien), Judith Lukacs (Salzburg), Wolfram Moeckel (Tirol), Fritz Molden (Wien), Gustav Otruba (Kritzendorf/NÖ), Benita Petkovic (Innsbruck), Felix Pronay (Wien), Rudolf Rhomberg (Wien), Leopold Rosenmayr (Wien), Tatiana Sayoka (Salzburg), Kurt Seidel (Wien), Otto H. Smital (Wien), Ingeborg Sreck (Wien), Adam Wandruzka (Wien). Am Kurs im Jahr 1948 nahmen folgende österreichische Personen teil: Leonhard J. Bianchi (Innsbruck, „Economics“), Lisbeth Eisler (Wien, „Art“), France [sic] Halberg (Universität Innsbruck/Histologisches Institut), Robert Hindel (Wien, „History“), Peter Hirt (Wien, „History“), Engelbert Knosp (Salzburg, „Literature“), Justine Krunes [sic] (Wien), Judith Lukacs (Salzburg), Gertrud Maresch (Wien, „Literature“), Max Neureiter (Klagenfurt), Anton Rainer (Salzburg), Ferdinand Reichel (Wien, „Literature“), L.G. Scheidl (Graz, „Economics“), Anton Sieberer (Wien, „Literature“), Ilse Winter (Wien), Erich Zöllner (Wien, „History“). Siehe: Recordings of the U.S. Department of State relating to the Internal Affairs of Austria 1945-1954 (Mikrofilm-Bestand Institut für Zeitgeschichte der Universität Wien), Decimal File, Reel 6, 1945-1949, Report to the Secretary of State, Washington D.C., 21. Oktober 1948, $4 \mathrm{f}$.

2584 So schrieb Williams am 3. September 1947 an Conant: „We watched the experiment very closely because of the Division's Education Mission is in an extremely delicate situation. It was imperative that we guard against any activities which might negate the occupation mission or which might be deliterious to the interest's of our Government's benefit attempts to re-establish Austrians autonomy [...] it is a pleasure for us to submit a most favorable report to General Keyes and the State Department." Zit. nach: Schmidt, Civil Empire by Co-optation, a.a.O., 337.

2585 Laut CIC-Report habe Heller u.a. gegen die US-Miliärregierung polemisiert, den Wiener Kurier als US-finanziertes, kriegstreiberisches Propagandamedium denunziert und seine Abscheu vor dem tschechischen Außenminister Jan Masaryk zum Ausdruck gebracht. NARA II, RG 260, USACA Education 
gehend zu harten Kontrollmaßnahmen, um den vermeintlichen kommunistischen Aktivitäten künftig von vornherein das Wasser abzugraben. Bereits Ende 1947 wurden für das neueingerichtete „Student Rest Center“ in Leopoldskron unter Leitung von Richard D. Campbel1 ${ }^{2586}$ routinemäßige Überprüfungen durch die USFA G2-Abteilung angeordnet und die Studierenden bei ihrem Eintreffen in Salzburg von CIC-Offizieren einem Verhör unterzogen: „If the student is undesirable he will not be granted“, ${ }^{2587}$ wie Lt. Sandker seinem Chef Williams mitteilte.

Kurioserweise war es aber gerade die Erfahrung eines freien, akademischen Austausches in kollegialer Atmosphäre gewesen, die TeilnehmerInnen des Seminars einen besonders nachhaltigen, positiven Eindruck US-amerikanischer Wissenschafts- und Diskussionskultur vermittelt hatte. So zitierte US-Gesandter Martin F. Herz in seinem Bericht die Mitteilung des italienischen Teilnehmers - „in touching language“-Dr. Luigi Meschieri aus Rom:

"[...] the particular behavior of American teachers has been one of the most shocking experiences I lived. The kind of approach they used towards their students as well as European members was unimaginable for me before the Salzburg experience. After my six years of University I didn't know what a Seminar was, and I could speak with my teachers only at the examinations. This is the reason why, seeing some aspects of American university life, I get impressive example, or maybe an ideal to be followed." ${ }^{2588}$

Und wie ein in der ungarischen Wochenzeitung UJ Magyarország abgedruckter Bericht eines Teilnehmers des Harvard-Seminars vom 20. September 1947 deutlich machte, kam das offene Konzept der Salzburger Veranstaltung, das Raum für kritische Auseinandersetzungen bot, gerade auf Grund des völligen Fehlens einer propagandistischen Absicht ganz offenkundig auch bei Teilnehmern aus Ländern hinter dem „Eisernen Vorhang“ gut an:

"The sons of Eastern European countries regarded this summer school with a certain degree of suspicion when they received the invitation. Judging from past experiences they suspected with some justification that this summer seminar was only a cover to give lessons in American democracy, that type of democracy which shows no willingness to recognize its own faults and contradictions while it sees only too well the faults of other nations. This suspicion, however, proved to be unfounded, because there was not even a trace of propaganda in Salzburg. The American hosts openly pointed out their own faults and showed no hostility or intolerance

Division, Box 2, Folder 57. Zit. nach: Blaustein, To the Heart of Europe: Americanism, the Salzburg Seminar, a.a.O., 194.

2586 Nash, The Salzburg Seminar, a.a.O., 30.

2587 NARA II, RG 260, EDU-DIV, Box 5. Sandker to Dr. Williams, Leopoldkron Winter program, 22. Dezember 1947, 1.

2588 Herz, Policy considerations in connection with the „Seminar on American Civilization“ at Leopoldskron Castle, a.a.O., 2. 
toward the ideas or opinions of others [... In this magnificent atmosphere devoid of any political and ideological prejudice, the problems of spiritual co-operation between Europe and America were aired." 2589

Die Auseinandersetzung mit Fragen akademischer Freiheit, offener intellektueller Gesprächskultur und demokratischem Pluralismus dürfte die verantwortliche Leitung der Education Division aber ebenso wenig bekümmert haben wie Hinweise der Austrian Branch im State Department, dass eine Einschränkung des freien Gedankenaustausches sowie eine zu intensive Observierung die Absicht und den Zweck des Seminars zerstören würden und womöglich der Eindruck entstünde, die Studenten „had been invited under false pretenses “'.2590

Für zusätzliche Irritation sorgte schließlich eine Mitteilung Fritz Moldens in einem Gespräch mit Gregory J. Sandker und B. Kempel von der US-Gesandtschaft, worin dieser schwere Vorwürfe gegen Clemens Heller vorbrachte. Molden, der im Sommer 1947 mehrmals am Leopoldskroner-Seminar teilgenommen hatte und das Seminar, beeindruckt von den dortigen Erfahrungen einer „unlimited freedom“,Jahrzehnte später in höchsten Tönen preisen sollte, ${ }^{2591}$ gab zu Protokoll, dass „the managing elements representing the Harvard Student Council were rather immature and had certain, leftist' tendencies." Auf Nachfrage präzisierte Molden seine Anwürfe und meinte:

“[...] Mr. Clemens Heller, in particular, defended what is transpiring behind the Iron Curtain. Mr. Heller asked him (Molden) for a list of Austrians that might serve as Committee to select Austrian students for the anticipated 1948 Summer Seminar at Leopoldskron [...]. When this list was submitted to Heller, he rejected all names of Conservatives and specifically asked for names of Socialists." 2592

In ungewohnter Weise und im Unterschied zu der sonst wenig ambitionierten Interventionspraxis im Zusammenhang der ,Säuberung“ der österreichischen Universitäten, legte sich Williams im Zusammenhang des „Salzburg Seminars“ kraft seines Amtes beim USACA-Direktor entschieden quer und verlangte ab sofort die direkte Kontrolle und Verantwortlichkeit seiner Abteilung für das Harvard-Seminar:

\section{Ebd., 4.}

2590 Schmidt, Civil Empire by Co-optation, a.a. O., 339.

2591 Molden schrieb später mit Bezug auf seinen Besuch in Leopoldskron: „I thought, as many millions of Europeans in the nineteenth century had thought before me, that I had discovered a paradise on earth." Fritz Molden, Exploding Star: A Young Austrian Against Hitler, London 1978, 215 f. Zit. nach: Blaustein, To the Heart of Europe: Americanism, the Salzburg Seminar, a.a.O., 143.

2592 NARA II, RG 260, EDU-DIV, Box 5. Samuel H. Williams, U.S. Civilian Chief, Education Division, USACA, Daily Info, 19. Jänner 1948, 1. 
"The Education Division reiterance its reluctance to assume the role of a mechanical assistance in, and share the responsibility for a program in which Command has no voice concerning policy and operating procedures. [...] the one-man control of the program, presents an annoying project that does not come within the defined responsibilities and duties if the Education Division which is charged with the administration of educational policies and procedures outlined by the Commanding General. [...] Nothing achieved by this program under its present organization will reflect credit upon this Command as was demonstrated by the publicity given to the Harvard Seminar last summer but unfavorable developments would undoubtedly prove embarrassing." 2593

Wie Oliver Schmidt in seiner Analyse dieser Vorgänge pointiert zusammenfasst, hatte der Geologe Williams Probleme mit dem offenen intellektuellen und kritischen Diskurs innerhalb des Salzburger Seminars, der sich offenbar allzu sehr von seinem persönlichen Verständnis „akademischer Freiheit“ und seinem Verständnis traditioneller amerikanischer Werte unterschied: „Translated into plain English, the chief U.S. re-educator in Austria had a problem with a) the autonomy of the Harvard Student Council, and b) a program, plus its personnel, which he feared was not ,typical' or ,traditional' enough - that is, to left of his own political convictions. “2594

Mit Bezug auf überlieferte Aussagen des österreichischen Politikwissenschafters Adolf Sturmthal (1903-1986) formuliert George Holt Blaustein Jr. den Verdacht, dass sich bei Williams möglicherweise gelegentlich auch antisemitische Tendenzen zeigten. Sturmthal, der 1938 in die USA emigriert und selbst jüdischer Herkunft war, kam anlässlich zweier geplanter Gastvorträge nach Wien und dabei mit Williams persönlich in Kontakt. Dabei legte der Leiter der Education Division befremdliche, geradezu autoritär-paternalistische Verhaltensweisen an den Tag und verlangte von Sturmthal, er müsse zuvor persönlich um Genehmigung seiner Vorträge ansuchen und ihm darüber hinaus seine Redeunterlagen vorlegen. Sturmthal wies dies zurück, worauf Williams mit folgenden Worten reagiert habe: „Sergeant, if Professor Sturmthal gives even one more speech without my permission, put him on the next train leaving Austria. “2595

Obwohl Heller und Matthiessen, nicht zuletzt auf Grund der Urgenzen von Williams, im Mai 1948 auf Beschluss von General Keyes schließlich nicht mehr nach Österreich

2593 Ebd.

2594 Schmidt, Civil Empire by Co-optation, a.a. O., 340.

2595 Zit. nach: Blaustein, To the Heart of Europe: Americanism, the Salzburg Seminar, a.a. O., 202. Im Original: Adolf Sturmthal, Democracy Under Fire: Memoirs of a European Socialist (übersetzt v. Suzanne Sturmthal Russin, Durham 1989, 169-170. Siehe auch die deutsche Übersetzung: Zwei Leben. Erinnerungen eines sozialistischen Internationalisten zwischen Österreich und den USA [Democracy under fire] (= Böhlaus zeitgeschichtliche Bibliothek, Bd. 12). Hrsg. v. Georg Hauptfeld/Oliver Rathkolb, unter Mitarb. v. Christina Westmann, Wien - Köln 1989. 
einreisen durften, ${ }^{2596}$ lief das „Salzburg Seminar“ unter neuer Leitung weiter, veränderte aber im Verlauf des Kalten Krieges bald seinen Charakter, und zwar sowohl thematisch als auch hinsichtlich der Zusammensetzung der Teilnehmenden, wie Henry Nash Smith bereits hinsichtlich des zweiten Sommer-Seminars festhielt: „Unfortunately, the issue of West versus East that had become so acute by the summer of 1948 could not be confronted directly because no Eastern Euroepaen country except Czechoslovakia sent representatives to Salzburg. “2597

Die zeitgleich sukzessive um sich greifende Militarisierung der US-ReorientierungsBemühungen machte die humanistischen Ideale und hochfliegenden Hoffnungen auf einen freien, transnationalen intellektuellen Austausch jedenfalls bald zunichte: „In time the Seminar came to have a more conventional orientation: a pronounced commitment to the west in line with the broader contours of the postwar period.“ ${ }^{2598}$

\section{UMSTRUKTURIERUNG UND EXPANSION: NEUER ANLAUF \\ UNTER SUPERVISION DES U.S. DEPARTMENT OF STATE}

Zurück zu den USIS-Exchange-Programmen. Hinter den Kulissen wurde das bisher eher unkoordiniert angelaufene Studentenaustausch-Programm in Österreich bereits als eigenständiger Schwerpunkt der USFA Education Division ausgebaut und von deren Leitung ab sofort auch als ,an integral part of our mission of re-education and reorientation in Austria“2599 angesehen. Neuerlich hatten US-Regierungsstellen in Washington den Eindruck gewonnen, dass die bisher unternommenen Anstrengungen der verantwortlichen US-Militärstellen in Österreich, sich aktiv in die angelaufenen akademischen Reorientierungs-Programme einzubringen, ganz und gar unzufriedenstellend waren. In einem Schreiben des stellvertretenden US-Außenministers, George V. Allen, im April I949 an den Leiter der Civil Affairs Division im US-Verteidigungsministerium, Major General C.B. Magruder, forderte dieser eine deutliche Intensivierung der akademischen Austauschprogramme, zumal Österreich zum gegenwärtigen Zeitpunkt nicht am Fulbright-Programm teilnehmen könne, eine staatliche Unabhängigkeit in absehbarer Zeit aber durchaus wahrscheinlich sei:

"I would appreciate it if you could convey to the Commanding General, United States Forces in Austria, the opinion of the Department of State that the current program of educational ex-

2596 Schmidt, Civil Empire by Co-optation, a.a.O., 351.

2597 Smith, The Salzburg Seminar, a.a.O., 36.

2598 Blaustein, To the Heart of Europe: Americanism, thKape Salzburg Seminar, a.a.O., 221.

2599 NARA II, RG 260, EDU-DIV, Box 8, Folder 32. Harold E. Howland, Acting Chief, Education Division, Student Exchange Division Project, 22. April 1949, 1. 
change (in this instance, particularly that part of the program which deals with the study of Austrian students in the United States) is too limited in scope and that an increase should be sought for the financial year 1951, to bring it into balance with similar programs scheduled for occupied countries.

It is the considered opinion of the Department of State that the exchange program for students from Austria fulfills a very important purpose, and that, particularly as Austria is further advanced on the road to full sovereignty than most other occupied countries, there is good reason for laying heavier stress on making educational facilities available to Austrians. As a token of this Government's sincere desire to facilitate the re-establishment of fruitful cultural relations with the Austrian people." ${ }^{2600}$ [Hervorhebung d. Verf.]

Darüber hinaus mahnte das Department of State gegenüber dem Department of the Army, dass der USACA-Direktor künftig die „Visiting Experts“-Programme forcieren sollte, und erbat genaue Auskünfte darüber, welche US-Behörden über welche Kommunikationskanäle für die Ausstellung der „travel orders“ für die österreichischen TeilnehmerInnen am Experten-Austauschprogramm zuständig waren. Schließlich lud das Department of State Williams, sofern es seine Zeit zuließe (,if time permits“), zu einer persönlichen Aussprache mit dem Vorsitzenden des für die „Visiting Experts“-Programme zuständigen „Advisory Committees“, Harold E. Snyder, in Washington ein. ${ }^{2601}$ Dass es zu diesem Gespräch dann tatsächlich gekommen ist, ist indirekt aus einer tabellarischen Aufstellung Samuel H. Williams zu ersehen, die dieser unter dem Titel „Briefing for Washington Trip“2602 anfertigte. Darin listete Williams primär die bisherigen Ausgaben der Education Division für die Exchange-Programme auf und formulierte Fragen zur Folgefinanzierung beziehungsweise deren Abdeckung. ${ }^{2603}$

Über die Ergebnisse dieser Besprechung in Washington geht aus den vorliegenden Akten leider nichts hervor. Snyder unternahm danach jedenfalls selbst eine Inspektionsreise in die US-Besatzungszonen in Deutschland und Österreich. Faktum ist jedoch, dass die US-Reori-

2600 NARA II, RG 260 EDU-DIV, Box 8, Folder 32. George V. Allen, Assistant Secretary, to General C.B. Magruder, Department of the Army, Chief, Civil Affairs Division, Pentagon, Washington D.C., 4. April 1949, 2. Letter included in: Francis M. Wray, Lt. Cl. [for Edgar Erskine Hume, Chief], Reorientation Branch, Department of the Army, Special Staff, Washington D.C., to Headquarters United States Forces in Austria, „Appropriations FY 1951 for Exchange Program for Austrian Students“, 7. April 1949, 1.

2601 Ebd., Anhang.

2602 Samuel H. Williams, Briefing for Washington Trip, 19. Mai 1949. Anhang. NARA II, RG 260 EDUDIV, Box 8, Folder 32.

2603 Analog zur Aufstellung Williams' wurden jeweils folgende Ausgaben vorgesehen: AYA-Jugendprogramme (1949-50) - 100.000 \$; Student Exchange (1948-49) - 64.666 \$; Student Exchange (195051) - 315.000 \$; Austrian Experts (1949-50) - finanziert von CAD; Visiting Consultants (1949-50) finanziert von CAD; Summer Courses for Austrian Teachers (1948-49) -14.000 \$. Siehe: ebd. 
entierungs-Aktivitäten im Zusammenhang der Exchange-Programme noch im Sommer des Jahres 1949 vollständig neu organisiert wurden. So wurde für die Durchführung der akademischen Austauschprogramme vom Direktor USACA, Col. Dodge, ein eigenes „Reorientation Committee“ eingerichtet, dem Joseph Z. Schneider als „Chairman“vorstand, mit Major Galen als Koordinator sowie drei weiteren „qualifizierten“ Mitgliedern. Nachdem sich erwiesen hatte, dass „early briefing experience indicated a tendency [...] to emphazise routine professional activities in the US rather than the broad implications of the mission", ${ }^{2604}$ wurde nun die Supervision der österreichischen Austauschprogramme der „Education \&Information Section“ des State Department unterstellt. ${ }^{2605}$ Die Verantwortlichkeit für die Durchführung aller Exchange-Programme in Österreich lag ab sofort beim genannten „Reorientation Committee“, das auf Basis der Empfehlungen der Abteilungen von USACA und USFA die Auswahl und das Screening der am besten geeigneten Kandidaten vornahm:

"Screening and selection of best candidates are accomplished by the Reorientation Committee. [...] Processing, which includes CIC screening, procurement of US sponsors, visas, preliminary arrangement of US itineraries, accomplishment of working agreement between consultant and US Government, procurement of travel orders and travel accommodations, and advance payments, is handled by the Operational Coordinator member of the Committee."2606

Für das „briefing“ der AustauschkandidatInnen waren weiterhin die Leiter der USACA Divisions - in Koordinierung mit dem „Reorientation Committee“ - zuständig. Nach erfolgter Rückkehr der „Visiting Experts“ aus den USA hatte die Education Division nun aber Berichte der TeilnehmerInnen vorzulegen, in denen die Ergebnisse ihrer USA-Reisen („results of their reorientation trips“) zusammenzufassen waren. ${ }^{2607}$

Hinsichtlich der Auswahl potenzieller Kandidaten - die auf ihrer Reise in die USA möglichst keinen Kontakt mit Deutschen haben sollten ${ }^{2608}$ - empfahl das State Department, beim Screening möglichst alle Personen sorgfältig auszuscheiden, die einen USAufenthalt lediglich aus persönlichen oder gar familiären Gründen anstrebten. Vor dem Hintergrund sozialpsychologischer Erwägungen sollten grundsätzlich möglichst Personen „hohen Kalibers“ ausgewählt werden, wobei sich hier das grundsätzliche Problem ergab, dass Führungspersönlichkeiten mit beruflicher Verantwortung kaum längere Zeit abkömmlich waren:

2604 NARA II, RG 260 EDU-DIV, Box 5, Folder 3. Joseph Z. Schneider, Chairman, Reorientation Committee, Maj. Galen Snow, Coordinator, The Reorientation of Austrian National Leaders' Program. Report of Reorientation Committee for FY 1949 and Recommendation for Future, 2. September 1949, 8.

2605 Ebd., 16.

2606 Ebd., 6.

2607 Ebd., 8.

2608 „It was deemed very undesirable to have Austrians closely associated with Germans as would result from 20-25 days of army transport travel.“ Ebd., 3. 
"Experience in Austria to date favors mature types, although of course younger men are not ruled out. A person who has 'arrived' in his business or profession is a known quantity - the youngster on his way up is not. He may or may not attain a position of responsibility. The older men also appear to set a higher value on the opportunity which the reorientation program affords. It was almost universally found that the men of real caliber could not spend over 60 days on a trip to the US. Also, the limited salary offered was not an important inducement to such men. Those candidates who could get away for 6 month or more almost invariably turned out to occupy positions of little or no importance." ${ }^{609}$ [Hervorhebung d. Verf.]

Der Aufenthalt in den Vereinigten Staaten selbst sollte vom Programm her möglichst nicht zu dicht gestaltet werden, damit genügend Zeit für kulturelle Aktivitäten bliebe: „observation of cultural activities and every-day life (concerts, theaters, sports, luncheon clubs, libraries, museums, public buildings, state or national capitols, courts, etc.) [...]“. Außerdem sollten sich die Besichtigungstouren, wie von den österreichischen „Visiting Experts“ oft gewünscht wurde, nicht nur auf die großen Städte beschränken, sondern ebenso kleinere, allenfalls auch ländliche Gemeinden umfassen:

"Every effort is made now to include smaller cities and institutions, because Austria is a small nation of small towns, cities, and institutions, except Vienna. Also American democracy, tolerance, neighborly spirit, political life, etc., can be better seen and understood in the smaller communities." 2610

In Summe wurden in diesem ersten Jahr der USIE-Austauschprogramme in Österreich, die unter anderem aus Mitteln des „Government and Relief in Occupied Areas“ (GARIOA Project 4I4-4I5) finanziert wurden, 25 „Austrian National Leaders“ für einen eineinhalb- bis dreimonatigen Aufenthalt in den Vereinigten Staaten ausgewählt. ${ }^{2611}$

Wie aus dem ersten Jahresbericht hervorgeht, dürften sich in dieser Anlaufphase allerdings einige organisatorische und administrative Probleme ergeben haben: „The program was slow in starting for various reasons: definitive information on the funds available was somewhat late, guidance and information on this very gradually $[\ldots]^{“ 2612}$

Auch in umgekehrter Richtung schien nicht alles zu klappen: Von den ursprünglich ${ }_{5}$ für Österreich vorgesehenen „US Expert Consultants“ kamen I949 schließlich nur ganze drei an. ${ }^{2613}$

2609 NARA II, RG 260 EDU-DIV, Box 5, Folder 3. Joseph Z. Schneider, Chairman, Reorientation Committee, Maj. Galen Snow, Coordinator, The Reorientation of Austrian National Leaders' Program. Report of Reorientation Committee for FY 1949 and Recommendation for Future, 2. September 1949, 7.

2610 Ebd., 9.

2611 Ebd., 1.

2612 Ebd.

2613 Dies waren: Stanley N. Brown („Industrial Finance“, für 3 Monate), Jay H. Hubell („American Literature“, für 3 Monate), William E. Brewster („Industrial Administration“, für 5 Monate); NARA II, RG 
Die Auswahl der österreichischen „Visiting Experts“ beziehungsweise der „National Leaders of the high type" - dabei ging es keineswegs um akademischen Austausch im engeren Sinne - erfolgte nach einem Kriterienkatalog, der unter anderem folgende Voraussetzungen miteinschloss: Die KandidatInnen mussten „politically irreproachable, of good character and personal habits“ sein, wenig Wissen über die USA mitbringen, in Form von Interviews auf ihre Eignung ,gescreent' werden, nachweislich qualifizierte „Experten“ in unterschiedlichen Bereichen sein, berufliches und gesellschaftliches Renommee haben, vom österreichischen Unterrichtsministerium oder einer ähnlichen Behörde nominiert werden und schließlich - potenziell erfolgreiche Meinungsmacher des „American way of life“ sein: „[Die Kandidaten, d. Verf.] must be mature enough to benefit from the trip, but young enough to absorb new ideas and to disseminate them with enthusiasm and perseverance to a substantial portion of Austria's population. “2614

Von den vorgeschlagen Kandidaten wurden 2I abgelehnt: vier wegen ihres „bedenklichen" politischen Hintergrundes, zwei wegen unzureichender englischer Sprachkenntnisse, zwei aus Gesundheitsgründen, weitere zwei aus Kostengründen, weil sie die Reise nur mit ihren Frauen anzutreten bereit waren, drei wurden auf das Programm des nächsten Jahres verschoben (einer davon war der Ökonom Richard Kerschagl), die Übrigen wurden einem speziellen technischen Austauschprogramm zugeordnet. ${ }^{2615}$

Unter den sowohl von der Education Division, als auch von der „Internal Affairs Division“ (5) beziehungsweise von der Information Service Branch (3) schließlich ausgewählten 25 österreichischen Experten befanden sich zwei Frauen; ein Kandidat, der HNO-Chirurg Camillo Wiethe, war bereits verstorben: ${ }^{2616}$

\begin{tabular}{|l|l|l|l|}
\hline \multicolumn{1}{|c|}{ Visiting-Experts Kandidaten } & \multicolumn{1}{|c|}{ Selektion } & \multicolumn{1}{c|}{ Spezialgebiet } & Tage \\
\hline Kirste, Leo A. & Edu. Div. & Technical and Engineering Education & 75 \\
[Präsident TU Wien] & Edu. Div. & College and University Education & 60 \\
Duda, Herbert W. & & & \\
[Dekan, Phil. Fakultät, Univ. Wien] & Edu. Div. & Public Safety & 50 \\
Suetter, Reuff & Intern. Affairs & $==$ & 50 \\
Mayer, Franz & Intern. Affairs & $==$ & 50 \\
Ruppertsberger, Franz & Intern. Affairs & $==$ & 50 \\
Heger, Franz [Polizei Experte] & Intern. Affairs & $==$ & 50 \\
Kraft, Rudolf & Edu. Div. & Teacher Education \\
Lareiter, Matthias [Lehrerbildung] & Edu. Div. & Education Psychology \& Child Develop. & 90 \\
Danzinger-Schenk, Lotte & 60 \\
[Wr. Stadtschulrat] & & \\
\hline
\end{tabular}

260 EDU-DIV, Box 5, Folder 3. The Reorientation of Austrian National Leaders' Program. Report of Reorientation, 2.

2614 Ebd., 4.

2615 Ebd., 5.

2616 Ebd., $4 \mathrm{f}$. 


\begin{tabular}{|l|l|l|l|}
\hline \multicolumn{1}{|c|}{ Visiting-Experts Kandidaten } & \multicolumn{1}{|c|}{ Selektion } & \multicolumn{1}{|c|}{ Spezialgebiet } & Tage \\
\hline John, Ernst & Edu. Div. & Economic Research & 60 \\
[Inst. f. Economic Research] & & & \\
& & General Surgery, Neurosurgery, Brain & 60 \\
Kraus, Herbert & Edu. Div. & Skin and Venereal Diseases & 52 \\
Arzt, Leopold & Edu. Div. & Public Finance, Extern. Monetary Affairs & 45 \\
Teufenstein, Wilhelm & Edu. Div. & Psychiatry and Neurology & 60 \\
Kauders, Otto & Edu. Div. & Pathology & 60 \\
Chiari, Hermann & ISB & News Agencies & 45 \\
Siepen, Karl & Edu. Div. & Agriculture and Civil Engineering & 90 \\
Lorenz, Karl & Edu. Div. & Medical Chemistry & 90 \\
Stoehr, Richard & Economic & Internal revenues & 45 \\
Melichar Irwin & Advisor & Pathology, Medical Radiology & 60 \\
Zdansky, Erich & Edu. Div. & Pharmacology, Therapeutics, Endocrinolgy & 59 \\
Schaumann, Otto & Journalism, women's \& children's pages & 60 \\
Santner, Inge [Wiener Kurier] & SSB & Journalism & 60 \\
Cyrus, C. Franz [Wiener Kurier] & ISB & Political Economy \\
Bayer, Hans [Prof. f. Ökonomie, Univ. Innsbruck] & Edu. Div. & & 60 \\
\hline
\end{tabular}

Die nach erfolgter Rückkehr nach Österreich an die Education Division abgelieferten Erfahrungsberichte und Rückmeldungen der AustauschkandidatInnen wurden von der „Education \&Information Section“ des State Department ausgewertet, wobei die „Reports“ einem schablonenhaft-formalisierten Schema folgten: So wurden in der Regel der Aufenthalt sowie das arrangierte Programm als interessant und gut organisiert gelobt und bestätigt, dass die „positiven“ Erfahrungen mit der amerikanischen Lebenskultur ebenso in die jeweiligen beruflichen Arbeitsfelder einfließen würden wie die neuen beruflichen Erkenntnisse im Hinblick auf die eigenen Spezialbereiche und das diese Erfahrungen zudem auch in geeigneter Form verbreitet würden. So meinte etwa Hans Bayer, er werde in seine Vorlesungen künftig einen Überblick über US-amerikanische ökonomische Theorien einbauen. Lotte Schenk-Danziger schrieb, dass sie die Kinderbetreuungsarbeit in den USA überaus beeindruckt habe, und strich hervor: „I am fully aware of the fact that it's not only America's wealth that makes this work possible - it is the conviction of those concerned with education that every child is a worthwile being. It is this attitude that we need to acquire and I hope that I shall be able to take an active part in communicating it to those responsible for our children $[\ldots] “ .2617$ Und auch Dr. Matthias Lareiter von der Salzburger Lehrerbildungsanstalt zeigte sich angesichts der edukativen Erfahrungen in den Vereinigten Staaten sehr beeindruckt und versicherte: „[...] I shall make every effort to utilize my newly-gained impressions to the best results of Austrian education by publishing articles, giving talks at teachers' meetings, and bringing into our Teachers' Training College and similar institutions in Austria the same broad-minded cooperation and educational optimism I experienced in the United States. ${ }^{\text {2618 }}$

2617 NARA II, RG 260 EDU-DIV, Box 5, Folder 3. Joseph Z. Schneider, Chairman, Reorientation Committee, Maj. Galen Snow, Coordinator, The Reorientation of Austrian National Leaders' Program. Report of Reorientation Committee for FY 1949 and Recommendation for Future, 2. September 1949, 11.

2618 Ebd. Lareiter publizierte seine Erfahrung dann auch im Wiener Kurier. Vgl. Wagnleitner, Coca-Colonisation, a.a.O., 190. 
Franz C. Cyrus stellte enthusiastisch fest, die US-Presse sei „really,free and independent““, und kündigte ebenso wie seine Kollegin Inge Santer an, dass die positiven US-Erfahrungen in Vorträge sowie in die Berichterstattung des Wiener Kurier einfließen würden. ${ }^{2619}$ Der Polizei-Experte Dr. Franz Heger hielt in seinem Erfahrungsbericht einen offenkundig markanten Unterschied zur heimischen Exekutive fest:

"We were not only able to study all of the police institutions, but also to convince ourselves that all of the policemen are very democratic. Furthermore, it was noticed that the police behave in a very friendly way to the people. The policeman does not consider himself standing above the average of other people. ${ }^{2620}$ [Hervorhebung d. Verf.]

Von den US-Regierungsstellen wurde dieses erste Austausch-Programm auf neuer Schiene jedenfalls als Erfolg gewertet und ein weiterer Ausbau in Aussicht genommen, dessen Gesamtkosten mit 271.00o US-Dollar beziffert wurden. Künftig sollten jährlich zwischen 80 und roo österreichische „Visiting Experts“ beziehungsweise „National Leaders“ in die USA transferiert und umgekehrt jährlich acht bis zehn US-Experten nach Österreich gebracht werden. ${ }^{2621}$

Neben den Erfahrungsberichten wurden - zur Evaluierung der Auswirkungen der „Exchange“-Programme auf die individuellen Einstellungsmuster der deutschen und österreichischen KandidatInnen gegenüber den USA - ab I949 auch Meinungserhebungen mit Fragebögen durchgeführt. Wie sich dabei zeigte, waren die „positiven“ Beeinflussungen durch einen USA-Aufenthalt bei Jugendlichen im vorstudentischen Alter größer als bei der Gruppe der Studierenden, der „Visiting Experts“ oder der „Leaders“, wobei die Studenten insgesamt die am deutlichsten „sceptical observers of American foreign policy“2622 blieben. Mit Blick auf die deutschen AustauschkandidatInnen konstatierte die Auswertungsstudie („Analysis of Attitude Change Among German Exchanges“), dass die 392 Befragten mit der politischen Intention der kulturellen Austauschaktivitäten offenbar kein Problem hatten: „[...] grantees seemed to buy the overall political rationale behind the cultural exchange“. ${ }^{2623}$

Eine weitere, ebenfalls auf der Grundlage von Fragenbogen erfolgte Auswertung unter 634 österreichischen AustauschkandidatInnen - rund 50 Prozent waren Studierende, 33 Prozent „leaders“, ein Drittel Frauen - kam zu ähnlichen Ergebnissen. Auch die österreichischen „Grantees“ zeigten sich beeindruckt vom amerikanischen Lebensstandard und den dortigen Arbeitsbedingungen, äußerten jedoch im Unterschied zu den Deutschen auch Kritik an der

2619 The Reorientation of Austrian National Leaders' Program. Report of Reorientation Committee for FY 1949 and Recommendation for Future, a.a.O., $11 \mathrm{f}$.

2620 Ebd., 12.

2621 Ebd., 17.

2622 Schmidt, Civil Empire by Co-optation, a.a.O.,426.

2623 Ebd., 423. 
allgegenwärtigen Werbung, dem Wahlsystem, ${ }^{2624}$ den Medien sowie den sozialen Problemen, wobei auch hier die Kritik unter den Studierenden am deutlichsten ausfiel. ${ }^{2625}$ Die Ergebnisse dieser Umfrage zusammenfassend konstatiert Oliver Schmidt, dass die Wirkung der USA-Besuchsreisen auch im Fall der österreichischen KandidatInnen positiv bewertet wurde: „In accordance with American intentions and not unlike their German exchange fellows Austrian exchanges returned home with a keener interest in analyzing domestic problems, and a professed desire to contribute to their solutions. “2626

Dass die Austauschkandidaten im Zusammenhang der „Exchange Programs“ offenkundig genauer auf ihre politische Verlässlichkeit beziehungsweise auf ihre NS-Vergangenheit geprüft wurden, als das bei der Entnazifizierung durch US-Militärstellen im allgemeinen der Fall war, dokumentiert der Fall des Landeshauptmannes Heinrich Gleißner. Im April 1948 wurde im Zuge einer routinemäßigen Überprüfung der amerikanischen $\mathrm{G}_{2-}$ Entnazifizierungssektion in Österreich anhand des beschlagnahmten „NSDAP Central Index File“ in Berlin (die zentrale NSDAP-Mitgliederkartei) festgestellt, dass Gleißner im Gegensatz zu seinen eigenen Angaben - seit April I94I als NSDAP-Mitglied geführt worden war. Diese Information wurde von der US-Militäradministration aber unterdrückt, „in der vagen Hoffnung, daß sich die Sache von selbst erledigen werde. “2627 Tatsächlich hatte sich der Leiter der US-Entnazifizierungssektion in Österreich, Joseph L. Zaring, nach anfänglichem Zögern wegen der Prominenz Gleißners dafür ausgesprochen, die österreichische Bundesregierung über die zweifelhafte Informationslage zur Person Gleißners in Kenntnis zu setzen und die üblichen Entnazifizierungsgesetze anzuwenden, da zu vermuten stehe, dass die Informationen früher oder später ohnehin an die Öffentlichkeit kommen würden. Immerhin verfügte der CIC im Dezember 1948 über Hinweise, dass einzelne Informationen bereits an die Kommunisten durchgesickert waren. ${ }^{2628}$ Zaring riet daher - allerdings vergeblich - dazu, die Angelegenheit der österreichischen Regierung zur Entscheidung zu überlassen, da die USA andernfalls riskieren würden, „dass die betreffende Information zu einem überraschenden und ungünstigen Zeitpunkt bekannt werde. “2629 Die Angelegenheit blieb unentschieden, bis die (angebliche) NSDAP-Mitgliedschaft Gleißners im Zusammenhang mit der geplanten Teilnahme der beiden Landeshauptleute Josef Klaus $^{2630}$ und Heinrich Gleißner am US-Austauschprogram wiederholt themati-

2624 So bewerteten drei von vier Visitatoren das US-amerikanische Wahlsystem im Hinblick auf die Wahl von Einzelpersonen zwar als grundsätzlich positiv, lehnten dieses hinsichtlich der Wahl politischer Parteien jedoch ab. Ebd., $423 \mathrm{f}$.

2625 Schmidt, Civil Empire by Co-optation, a.a. O., 423.

2626 Ebd., 438.

2627 Tweraser, US-Militärregierung Oberösterreich. Bd. 1, a.a.O., 232.

2628 Schuster, Politische Restauration und Entnazifizierungspolitik in Oberösterreich, a.a.O., 180.

2629 Ebd.

2630 Josef Klaus (1910-2001), promovierter Jurist, ÖVP-Landeshauptmann von Salzburg 1949-1961 und Kanzler der ersten ÖVP-Alleinregierung in den Jahren 1961-1971, war zwischen 1933-1934 als (frühe- 
siert wurde und nach neuerlichem Screening am Tisch des US-Hochkommissars General Geoffrey Keyes landete. Nach Vorinformation durch den militärischen US-Geheimdienst verhinderte dieser kurzerhand die USA-Reise Gleißners, ließ aber allem Anschein auch die belastenden Unterlagen aus dem Berlin Document Center, das sich unter amerikanischer Verwaltung befand, entfernen. ${ }^{2631}$ In dem bei Kurt Tweraser zitierten Memorandum des US-Directors of Intelligence heißt es bezüglich des Falles Heinrich Gleißner:

"The fact (Gleißners Parteimitgliedschaft) has been known to this headquarter since 20 May I948. It is almost certainly known to the Austrian Government, or at least to the People's Party leaders, although the government has not been informed by us, nor we by them. It has not been considered wise, in view of Dr. Gleißner's superlative record as provincial governor and the high regard in which he is held by both parties, to take any action on it. It would seem unwise, however, to sponsor a trip by Dr. Gleißner to the United States. If the above information were exposed in connection with such a visit, the result would be most embarrassing both to this headquarters and to the Austrian Government."2632

Wie Walter Schuster dargestellt hat, kam die Angelegenheit dann noch ein letztes Mal während der Präsidentschaftskandidatur Gleißners im April I95I zur Sprache, als der frühere Leiter der US-Entnazifizierungsstelle, Zaring - der seine Erinnerungen an die Entnazifizierungsarbeit in Österreich als „rather painful“ beschrieb - noch einmal gegenüber dem nunmehrigen US-Hochkommissar Walter Donnelly Vorbehalte hinsichtlich der politischen Integrität Gleißners äußerte. ${ }^{2633}$

Nach Abschluss des Staatsvertrages und der wiedererlangten Souveränität Österreichs schien dann genügend Gras über die Sache gewachsen zu sein, sodass nun einer US-Reise der beiden Landeshauptleute Klaus und Gleißner - wie schon beim ersten Anlauf auch diesmal im Rahmen der US-Austauschprogramme - nichts mehr im Wege zu stehen schien. Am 24. September 1956 meldete die US-Presse die Ankunft der beiden österreichischen Politiker im Zusammenhang des „International Educational Exchange Program“: „Heinrich Gleissner, Governor of Upper Austria, and Josef Klaus, Governor of Salzburg, are expected to arrive in New York [... “ “. ${ }^{634}$

res) Mitglied der Deutschen Studentenschaft kurzfristig Vorgänger Heinrich Drimmels als „Sachwalter der Österreichischen Hochschülerschaft". Als pronocierter Deutschnationaler hatte sich Klaus als junger Student und Vertreter des „Katholisch-Deutschen-Hochschulausschusses“ gegen die Ernennung Ernst Peter Picks zum Dekan der Medzinischen Fakultät gestellt und in einem offenen Brief verlautet, „dass Professoren jüdischer Volkszugehörigkeit akademische Würdenstellen nicht bekleiden dürfen. “ Zit. nach: Wagner, Von der Hochschülerschaft Österreichs zur Österreichischen Hochschülerschaft, a.a.O., 116.

$2631 \mathrm{Vgl}$. Schuster, Politische Restauration und Entnazifizierungspolitik in Oberösterreich, a.a.O., 182.

2632 Tweraser, US-Militärregierung Oberösterreich. Bd. 1, a.a.O., 233.

2633 Schuster, Politische Restauration und Entnazifizierungspolitik in Oberösterreich, a.a.O., 181.

2634 United States. Department of State. Press releases, Washington D.C. 1956, viii. 


\section{ÜBERNAHME DURCH DAS STATE DEPARTMENT - \\ INSTRUMENTALISIERUNG DES „EXCHANGE-PROGRAM“ ALS TEIL DER \\ PSYCHOLOGISCHEN KRIEGSFÜHRUNG GEGEN DIE SOWJETUNION}

Die zentrale Bedeutung des akademischen und beruflichen „Exchange-Programs“ gerade im Zusammenhang mit der langfristigen, auf Eigenverantwortung und "selfdemocratization “ hin angelegten US-Reorientierungs-Agenda wurde im Dezember 1949 anlässlich einer Konferenz in Washington D.C. nochmals bekräftigt. Dabei ging es vor dem politischen Hintergrund des Kalten Krieges zunehmend um die Adaptierung zivilgesellschaftlicher Wertvorstellungen und Normen analog zum „American way of life“ und damit sowohl um weltanschaulich-ideologische Hegemonie als auch um ökonomische „Westernization“. Diese Konferenz markiert zugleich den offiziellen Wechsel in der Verantwortung der Re-Demokratisierungs-Angelegenheiten in Deutschland, Österreich und Japan vom US-Verteidigungsministerium zu den Behörden des US-Außenministeriums. Für Deutschland bedeutete das, dass der bisherige Leiter der OMGUS-„Education and Cultural Relations Division“, Alonzo G. Grace, zwar als „former Director" teilnahm, die offiziellen Stellungnahmen aber bereits von Ralph Nicholson, dem Direktor des „Office of Public Affairs, Office of the U.S. High Commissioner for Germany“, verlautbart wurden. OMGUS-Oberbefehlshaber General McCloy selbst ließ sich entschuldigen, wünschte der Konferenz aber viel Erfolg. Für Österreich hatte dieser Zuständigkeitswechsel zunächst noch keine personellen Veränderungen zur Folge: neben Samuel H. Williams als Leiter der USFA Education Division nahmen noch Joseph Z. Schneider als bisheriger Vorsitzender des USACA-, Reorientation Committee“ sowie Ludwig Kleinwächter als österreichischer US-Gesandter an der Konferenz teil. ${ }^{2635}$

Als früherer Leiter der OMGUS-,Education and Cultural Relations Division“ und nunmehriger Präsident der Indiana University sowie Vorsitzender der „Commission on the Occupied Areas of the American Council of Education“ organisierte Hermann B. Wells in Kooperation mit dem U.S. Department of State diese großangelegte Konferenz, die (großteils) öffentlich zugänglich war und im US-Handelsministerium eröffnet wurde. Unter dem Titel „Education in the Occupied Countries - Today and Tomorrow" bekräftigte die Tagung in einer Vielzahl von Vorträgen und Workshops die offizielle „Reorientierungs“Doktrin der US-Regierung in den besetzten Ländern Deutschland, Österreich und Japan. Interessanterweise nahmen sowohl für Deutschland als auch für Japan jeweils ein Universitätsrektor an der Konferenz teil, die österreichischen Universitäten waren hingegen nicht vertreten. $^{2636}$

2635 NARA II, RG 260, EDU-DIV, Box 7, Folder 3. Education in the Occupied Countries - Today and Tomorrow. A Symposion. National Conference on the Occupied Countries, December 9.-.10, 1949, Washington D.C. 1949, Conference Program.

2636 Für Deutschland war dies der Rektor der Freien Universität Berlin, Edwin Redslob, und für Japan der Präsident der Tokyo National University, Shigeru Nambara. Vgl. ebd. 
In einer offiziellen Pressemitteilung der Konferenzleitung bezog sich Ralph Nicholson zu Beginn auf zwei, soeben im Time Magazine erschienene Artikel, worin die bisher unternommenen Anstrengungen der USA, in Deutschland eine demokratische Entwicklung in Gang zu bringen, angesichts der Ausgangslage vorsichtig optimistisch gewertet wurden. Darin hieß es: „Germans who have never shown any talent for democracy are today corroded by 16 years dictatorship, war and defeat. They have probably made greater progress towards democracy than the United States had a right to expect on VEDay. “2637 Nicholson schloss sich dieser Einschätzung an, mahnte angesichts der zunehmenden kommunistischen Bedrohung jedoch zu einer realistischen und pragmatischen Haltung, womit er unterschwellig zum Ausdruck brachte, dass sich die Reorientierungsund Demokratisierungsmaßnahmen nun keineswegs nur gegen ein Wiederaufleben des Nationalsozialismus richteten:

"Democracy with shallow roots must be well and carefully nourished to survive, especially in an area where such high winds blow in from the East. We must remember, too, that traditionally the German people have possed a great capacity for being organized - a willingness to take orders from above. They can only achieve democracy by practicing it. Occasional anti-democratic incidents can be expected, but such incidents must not be allowed to divert us from our mission, nor should they be construed to mean that our progress has been seriously interrupted. Our task there is to help and guide and encourage the Germans of vision and good-will to lead their nation in the right direction." ${ }^{638}$ [Hervorhebung d. Verf.]

Und die „richtige Richtung“ der geistigen Neuorientierung sollte insbesondere bei potenziellen gesellschaftlichen Multiplikatoren verankert werden: eine mentale Demokratisierung, die freilich weniger gelehrt als vielmehr erlebbar gemacht werden sollte, und zwar in Form entsprechend intensivierter Austauschprogramme:

"We are continuing to expose the vital elements, the new leaders of all walks of German life to the operations of democracy on our own society. Democracy cannot be simply explained. It must be seen, lived with, worked with. For that reason, our exchange program is being greatly enlarged. We need impacts that are broad and reach deeply.

And our job goes ever further, deeper. The achievements in political and economic rehabilitation must not be allowed to lead to a new form of adventurous nationalism. You and I need not apologize for the hundreds of millions that we have been spent to sustain life in the German people. What we must resolve is that an effort of no lesser scope be made to achieve healthy, balanced demo-

2637 NARA II, RG 260, EDU-DIV, Box 7, Folder 3. Education in the Occupied Countries - Today and Tomorrow. A Symposion. Ralph Nicholson, Director, Office of Public Affairs, U.S. High Commissioner for Germany, Report From Germany, 2.

2638 Ebd., 3. 
cratic German minds. If it has taken us four years to get the reeducational program into a proper perspective, we must now try, as best as we can, to make up for lost time. This will not be accomplished with exchanges of a few students here and a few teachers there or by similarly unimaginative measures in other fields." ${ }^{2639}$ [Hervorhebung d. Verf.]

Basis dieser öffentlichen Verlautbarung Nicholsons auf der Washingtoner Konferenz war der bereits im Oktober 1949 erfolgte Beschluss der „Commission on Occupied Areas“, worin festgelegt wurde, „to give primary emphasis to the exchange of persons between the United States and these areas“2640 — was freilich auch Österreich inkludierte.

Deutlicher ließ sich es sich im Grunde nicht formulieren: Ab sofort sollten die finanziellen Mittel, die nun nicht mehr primär von privaten Sponsoren, sondern auch von der US-Regierung selbst aufgebracht werden sollten, erheblich aufgestockt werden, um das „Exchange“-Programm der USA wesentlich auszuweiten; dabei bestand das programmatische Ziel dieser US-Kultur-Mission darin, die ausgewählten Personen über einen möglichst langen Besuchszeitraum entsprechend zu „beeinflussen“, damit sie nach ihrer Rückkehr in ihre Heimatländer - quasi als Propagandisten des „American way“ - selbst nachhaltigen ,Einfluss‘ auszuüben imstande wären:

"That the individuals selected for visits to the United States be, within the limits of predictability, those who have key positions or young persons of promise who will be able to exert substantial influence upon their return to their individual countries."2641

Dass sich dabei - analog zu den bereits in der Schublade bereit liegenden weltweiten „Truth-Bomb“-Propagandakampagnen - die ursprünglich erzieherischen und wissenschaftspolitischen Zielsetzungen einer demokratischen Reorientierung mit den geheimdienstlichen Überlegungen zur antikommunistischen Abwehr und Indoktrinierung stark $\mathrm{zu}$ vermischen begannen, ist nicht nur naheliegend, sondern geht auch eindeutig aus einschlägigen Anweisungen und Richtlinien des Department of State hervor. Diese verknüpften die USIE-Austauschprogramme direkt mit den Planungen zur psychologischen Kriegsführung gegen die Sowjetunion, ihre Satellitenstaaten beziehungsweise gegen den Kommunismus allgemein. In einem vertraulichen Memorandum des „Office of Public Affairs“ des State Department, das sich mit der Expansion und Intensivierung der „Cultural Cooperations Abroad“ befasste, wurde direkt auf die „Campaign of Truth“ Bezug genommen und verdeutlicht, dass sich im Kampf gegen den „Leninist-Stalinist-communism“ die Zielrichtung der Reorientierung zwar verschoben, deren Aufgabe und Bedeutung

\section{Ebd.}

2640 Appendix III. Resolutions adopted by the Panels on Public Education and Teacher Education of the Commission on Occupied Areas in their Meeting, 10. Oktober 1948, Washington D.C., 1. Ebd., 3.

2641 Ebd. 
zugleich aber bestätigt habe: „International communism is again proving what the Axis demonstrated during the war, that a totalitarian regime cannot tolerate dissemination of the truth. “2642

In einem weiteren vertraulichen Memorandum, das an alle leitenden Beamten des USAußenamtes sowie an alle US-Diplomaten und verantwortlichen US-Konsulatsbeamten erging, legte U.S. Secretary of State, Dean Acheson, am I3. September I950 fest, dass sämtliche USIE-Programme, also alle Exchange- und Reorientierungs-Aktivitäten, ab sofort als integraler Bestandteil der US-Außenpolitik zu sehen seien und daher in die „psychologische Offensive“ der „Campaign of Truth“ eingebettet werden sollten. ${ }^{2643}$

Die damit verordnete Einebnung der US-Reorientierungs-Politik zu einem - wenn auch schwer durchzuführenden - Teil der Psychologischen Kriegsführung im anti-kommunistischen, politischen Kampf, der immer härtere Züge annahm, ${ }^{2644}$ instrumentalisierte den gesamten Kultur- und Wissensaustausch programmatisch zu einer Art mentalen Waffe im Kalten Krieg. Obwohl sich diese politische Intention im Bereich des akademischen Elitentausches nicht offen bemerkbar machen konnte, ohne gegenteilige Wirkung zu entfalten, sondern intellektuell sublimer Vorgehensweisen und Methoden bedurfte, dokumentierte sich die Militarisierung des geplanten Vorhabens bereits in der getroffenen Wortwahl beziehungsweise in der Semantik. So wurde in dem Memorandum des USAußenministeriums ausdrücklich davon gesprochen, dass die Kulturaustauschprogramme als Form gezielter politischer Informationsverbreitung speziell ausgewählte Operationsziele („targets“) treffen sollten:

2642 NARA II, RG 59, General Records, Department of State. Records of Public Affairs. Information Memorandums, 1948-1951, Lot 52-95, [Entry 1324], 250/49/25/07, Box 1. Department of State [restricted], Office of Public Affairs, Information Memorandum No. 83, 26. Juni 1950, 1.

2643 „1. Propaganda activities of the USSR now border on open psychological warfare against the Free World and are major threat to foreign policy objectives to the United States. 2. The political, economic and military means undertaken by the United States and its allies can obtain maximum results only if the psychological effect of these programs is beneficial to, and in support of, their objectives. 3. A psychological offensive based on truth is essential if the United States is to succeed in its foreign policy objectives." NARA II, RG 59, Box 17, Department of State, Psychological Offensive [Confidential], 13. September $1950,1$.

2644 Um eine finanzielle Aufstockung der Mittel zur erreichen, die in der 81. Kongresssitzung in der Höhe von 79.000.000 US-Dollar debattiert wurde, brachte das Department of State die Gefahr kommunistischer Propaganda entsprechend deutlich zum Ausdruck: „In recent years the Soviet Union has injected into its world-wide propaganda an increasingly bitter and vicious element of hate and slander against the American Government and people. The fact that these charges are a travesty of the truth does not deter the Kremlin. The purpose of these attacks is to convince millions of persons in Europe, Asia, and other parts of the world that the United States is a warmongering, power-hungry national, determined to dominate other nations. This propaganda is designed to poison and to delude the minds of men as a preliminary to their enslavement." NARA II, RG 59, Box 43, International Information Program of U.S. Department of State - „The Campaign of Truth“, 1. 
"The effort must be directed initially towards certain psychological strength and resistance to communism and Soviet imperialism in the areas and countries of most immediate critical concern [...]. The proposed expanded program is thus not just an expansion of normal USIE operations as hitherto conducted. It is a redirection of effort to achieve specific aims. It is founded upon the necessity of hitting designated targets on a priority basis, rather than a mere general dissemination of information. [...] In selecting targets, the Department first specified that twenty-eight countries constitute an 'area of concern'."2645

Diese 28 Länder wurden in dem zitierten Memorandum des State Departments auf vier Zonen aufgeteilt, wobei für jede dieser Zonen ein unterschiedlicher Grad an „domination by or susceptibility to the influence of world communism “2646 angenommen wurde. Innerhalb jedes dieser Länder wurden „priority target groups“ identifiziert, die für die Durchführung der außenpolitischen Zielvorgaben besonders wichtig erschienen. Zur Erreichung der unterschiedlichen Adressatengruppen sollten wie auch schon bisher alle verfügbaren Medien beziehungsweise Formate genützt werden, die als „backbone“ der US-Informationspolitik dienen konnten: neben Radiosendungen, Kinofilmen, Zeitungen und Buchpublikationen auch die zahlreichen U.S. Information Centers sowie akademische Personenaustausch-Programme. Die Aufteilung der Länder erfolgte nach folgendem Szenario:

"The Department intends to direct the full impact of the expanded psychological offensive at four zones of concern. Two of these zones are the satellite or captive countries and the Soviet Union, itself, and in respect to them increased effort will be primarily in the fields of radio activities conducted from outside the countries." ${ }^{2647}$

Den beiden anderen Zonen - die erste umfasste jene Länder, die ein mögliches Angriffsziel kommunistischer Aggression darstellten, die zweite die Länder, in denen die Gefahr großer politischer Unzufriedenheit gegeben war - wurden weltweit insgesamt 2I Länder zugerechnet, ${ }^{2648}$ darunter auch Österreich, für das das State Department ebenfalls „an enlargement at the Mission of discretionary action [...] to carry out a psychological offensive “2649 vorsah.

2645 NARA II, RG 59, Box 43. Department of State, Psychological Offensive [Confidential], 13. September $1950,2$.

2646 Ebd.

2647 Ebd., 2.

2648 Die anderen Länder waren: Afghanistan, Burma, Ceylon, Finland, France, Western Germany, Greece, India, Indo-China, Indonesia, Iran, Italy, Japan, Malaya, Pakistan, Philippines, Triest [sic], Turkey, Thailand und Yugoslavia. Ebd., 3.

2649 NARA II, RG 59, Box 43. Department of State, Psychological Offensive [Confidential], 13. September 1950, $2 \mathrm{f}$. 
Diese globale Ausdehnung und Intensivierung sämtlicher US-Kulturaustauschprogramme hatte freilich immense zusätzliche Kosten zur Folge, die Präsident Truman dem Kongress selbst zur Beschlussfassung übermittelte. ${ }^{2650}$

Vor dem Hintergund dieser großangelegten antikommunistischen Propagandaschlacht, die vom Department of State choreografiert wurde, erfolgte am I6. Oktober 1950 auch in Österreich - wie bereits zuvor in der US-Besatzungszone in Deutschland - ein Wechsel in der Verantwortung für die US-Besatzungsagenden von der Army auf das Department of State. ${ }^{2651}$ Der neue zivile U.S. High Commissioner für Österreich war ab nun Walter J. Donnelly, der direkt dem U.S. Secretary of State unterstellt war und die früheren „civil affairs"-Aufgaben des militärischen Hochkommissars in Österreich, Lieutenant General Geoffrey Keyes, übernahm. Daneben behielt Lieutenant General S. Leroy Irwin, der seinerseits direkt den Joint Chiefs of Staff unterstand, weiterhin den Oberbefehl über die US-Armee in Österreich.

Wie eigens hervorgehoben wurde, bedeutete dieser Wechsel der besatzungspolitischen Verantwortung in Richtung State Department aber keineswegs eine geringere politischstrategische Beschäftigung mit Österreich: „The change to civilian administration does not signify any lessening of our interest in Austria or change in our commitments toward Austria.“" 2652

Doch wie bereits dargelegt, konnte sich Washington nicht zuletzt auch auf Grund der seit 1948/49 laufenden geheimen sicherheitspolitischen sowie wirtschaftlichen Kooperation mit der österreichischen Bundesregierung, die sich als verlässlicher Partner auch ohne formalen Bündnis erwiesen hatte, des Landes als westlicher Verbündeter ziemlich sicher sein. Die politische Westorientierung galt es jedoch, zumal Österreich nach wie vor keinen Staatsvertrag hatte und zum Teil von sowjetischen Truppen besetzt war, aus

2650 Ein interner Bericht hielt diesbezüglich fest: „In April of this year the President directed the Secretary of State to plan a stronger and more effective national effort to mobilize the power of truth in defense of peace and freedom. To that end the President submitted a supplemental estimate in the total amount of $\$ 97.212 .000$ to provide for an intensification of the International Information and Educational Exchange Program in certain areas of the world where the threat of Communist aggression is of critical concern to the national interests of the United States. The President emphasized at that time that he regarded, such an expanded campaign of truth as vital to our national security', and that ,we will never attain real security until people everywhere recognize that the free nations of the world are the true seekers of permanent peace. Of this total amount of 97,3 million, the Department of State estimated that approximately 15,2 million dollars could be expended from available ECA counterpart funds." NARA II, RG 59, Box 43. International Information and Educational Exchange Program. Statement of Facts, 20. September 1950, 1.

2651 NARA II, RG 59, 250/49/25/07, Entry 1324 [Lot File 52-95], Box 2, General Records of the Department of State. Records of the Office of Public Affairs. Information Memorandums, 1948-1952. Department of State. Office of Public Affairs. Information Memorandum No. 102, „United States Policy Toward Austria“, 8. Dezember 1950, 4.

2652 Ebd. 
amerikanischer Sicht weiterhin zu festigen. In diesem Zusammenhang konzentrierten sich die USIE-Planungen ab 1950/5I vor dem Hintergrund der beginnenden wirtschaftlichen Konsolidierung verstärkt auf den Ausbau der „Austrian Youth Activities“ (AYA). ${ }^{2653}$ Daneben bildeten - neben der Informations- und Medienpolitik sowie dem Ausbau der US-Information Center - insbesondere auch Lehrerseminare ${ }^{2654}$ sowie Ausstellungen Schwerpunkte der US-Kulturmission, die sich, im Zusammenhang mit den Hetzkampagnen Senator Joseph McCarthys, aber gänzlich von den ursprünglichen Zielen einer demokratischen Reorientierung zu einer antikommunistischen „Westernisierung“verlagerte.

Die mitunter unglaublich rüde Vorgehensweise bei dieser geistig-mentalen „Rollback“Strategie wurde jedoch auch auf europäischem Boden nicht besonders gut aufgenommen. So provozierte die im Auftrag von McCarthy ausgeführte „Cohn-Shine-Mission“, die während der republikanischen Wahlkampfkampagne Präsident Eisenhowers 1953 einen regelrechten Kreuzzug durch die USIS Information Center in Europa führten und dabei angeblich „kommunistische“ Literatur aus den Regalen entfernen ließen, große Aufregung und wurde quer durch ganz Europa mit „book burnings “2655 assoziert.

Tatsächlich stieß der zweitägige Besuch der beiden McCarthy-Mitarbeiter G. David Shine und Roy Cohn, ${ }^{2656}$ die in zehnminütigen Kurzinterviews quer durch die US-Besatzungszone hetzten und dabei die verantwortlichen Leiter des US-Radiosenders „RotWeiss-Rot", des Wiener Kurier sowie der „Amerika Häuser“ verhörten und dabei ,Säuberungsmaßnahmen' durchführten, ${ }^{2657}$ auch in Österreich auf Ablehnung und Kritik:

"The Austrian have shown that they do not accept American officials in Vienna as really representing present Washington policy, in view of the change of administration. The Cohn and Shine investigations caused many criticisms." ${ }^{2658}$

2653 NARA II, RG 260, EDU-DIV, Youth Activities, Box 2. Needs of Austrian Youth, Oktober 1949. Vgl. auch: Hiller, Amerikanische Medien- und Schulpolitik in Österreich, a.a.O., $310 \mathrm{fff}$

2654 Vgl. Liebl, Die Umerziehung der österreichischen Bevölkerung, a.a. O., $109 \mathrm{ff}$.

2655 Special Report Prepared by the Psychological Strategy Board, „Reported Decline in US Prestige Abroad“, 11. September 1953, 1484. FRUS, 1952-1954, Vol. I. General: Economic and Political Matters (in two parts). Part 2, Washington D.C. 1983.

2656 Vgl. dazu auch:William T. Walker, McCarthyism and the Red Scare. A Reference Guide, Santa Barbara 2011, 79 bzw. $84 \mathrm{ff}$.

2657 Neben 18 „kommunistischen Autoren“, deren Namen auf einer schwarzen Listen verzeichnet waren, befanden die beiden Inquisitoren auch 78 andere hochgefragte Autoren als ,un-amerikanisch“ und setzten diese auf „graue Listen“, was den Bibliothekaren in den US-Informationcenter erhebliche Probleme bescherte. Unter diesen Autoren befanden sich, neben vielen anderen, immerhin auch „Kronzeugen“ der US-Reeducation: so John Dewey [sic], Archibald MacLeish [sic] oder Reinhold Niebuhr [sic]; weiters: u. a. Pearl S. Buck, Theodor Dreiser, Albert Einstein, John Dos Passos, Dashiell Hammet, Ernest Hemmingway, Stefan Heym, Norman Mailer, Thomas Mann, Arthur Miller, Frank Llyod Wright, Jean Paul Sartre, Upton Sinclair oder Henry Wallace. Siehe: Wagnleitner, Coca-Colonization, a.a.O., 171.

2658 „Reported Decline in US Prestige Abroad“, 11. September 1953, a.a.O., 1503. 
Wie die SPÖ-nahe Salzburger Zeitung Demokratisches Volksblatt meldete, kam es bei den Säuberungen im dortigen „Amerika Haus“ im Gefolge der Shine-Cohn-Visitation zur grotesken Situation, dass alle deutschsprachigen Autoren ,including Thomas Mann, Franz Werfel, Stefan Zweig, Erich-Maria Remarque and Friedrich Torberg [sic] had been purged and were no longer available. “2659

In seinem Evaluationsbericht zur Einstellung der Europäer gegenüber Amerika stellte das „Psychological Strategy Board“ fest, dass insbesondere diese Aktion sowie der harsche Antikommunismus McCarthys einen erheblichen Prestigeverlust der Vereinigten Staaten nach sich zogen, Misstrauen in die Seriosität und Integrität der USA schürten und gleichzeitig anti-amerikanische Ressentiments nährten. Die US-Geheimdienstfachleute registrierten auch zunehmend Stimmen, die, angesichts der brutalen politischen Hetzjagd, das demokratische Potenzial der amerikanischen Gesellschaft gerade im historischen Vergleich zu Deutschlands jüngsten Erfahrungen stark in Zweifel zogen:

"Whether or not European reaction to Senator McCarthy is fundamentally the most active cause of current distrust of American leadership, in many European minds 'McCarthyism' is used to justify much of their dislike and distrust of the United States.

Rightly or wrongly, many articulate Europeans point to the possibility that McCarthy philosophy may become dominant in the United States. They profess to see a powerful and prosperous country with an eligible Communist Party showing signs of acute alarm over dangers of internal subversion, and they conclude that this country is either unsure of itself or has no genuine attachment to some of the fundamental values of a democratic society. Recalling that in 1928 , barely four years before becoming Chancellor of Germany, Hitler and his Nazis polled only three percent of the German vote, these European observers note that more than one-third of the US electorate have a favorable view of McCarthy, and that one-fifth hold this opinion intensely. They speculate on what might happen if America should suffer a disaster in foreign affairs coupled with a depression akin to Germany's in 1930-3I." 2660 [Hervorhebung d. Verf.]

Auf das weltweite Auftauchen derartiger anti-amerikanischer Ressentiments, die im $\mathrm{Zu}$ sammenhang mit den fundamentalistischen Überwachungsaktivitäten McCarthys selbst

2659 Günter Bischof, Austrian Anti-Americanism after World War II. In: Draxlbauer/Fellner/Fröschl (Eds.), (Anti-)Americanisms, a.a.O., 148. Allerdings irrt Günter Bischof, wenn er schreibt, dass die Bücher der „kommunistischen“ Autoren Howard Fast, Agnes Smedley sowie diejenigen des afro-amerkanischen Historikers W.E.B. Du Bois in Österreich aus dem Regal genommen wurden bzw. den beiden US,Inquisitoren' in Österreich die Frage gestellt worden wäre, ob sie auch Mark Twain aus den Regalen der US-Information Center entfernen würden - dies bezog sich auf Fragen während einer Diskussion in Schweden. Vgl. „Reported Decline in US Prestige Abroad“, 11. September 1953, a.a. O., 1452.

2660 Special Report Prepared by the Psychological Strategy Board, „Reported Decline in US Prestige Abroad“, 11. September 1953, 1486 f. FRUS, 1952-1954, Vol. I. General: Economic and Political Matters (in two parts). Part 2, Washington D.C. 1983. 
den politischen US-Beobachtern nachvollziehbar schienen, reagierten sowohl Geheimdienstabteilungen wie die CIA als auch die US-Außenpolitik - nicht zuletzt im Hinblick auf die NATO-Planungen - überaus sensibel. ${ }^{2661}$ In der folgenden Detailanalyse des Prestige-Berichtes des „Psychological Strategy Board“ wurde ein „Korrektur-Kurs“ formuliert, der Vorschläge enthielt, wie die derzeitige, quasi selbst induzierte „antipathy to the U.S.“ - die freilich auch historische Wurzeln habe - überwunden werden könnte. Als Ursachen für die aktuellen Aversionen gegen die USA benannte der Bericht unter anderem unmissverständlich folgende Faktoren:

\begin{abstract}
"Revulsion against what many think are manifestations of a dangerous anti-democratic trend in the U.S., particularly attacks on personal liberty and integrity attributed to anti-Communist hysteria; enhanced by bewilderment at the apparent failure of the Administration to clarify its position convincingly. [...] Doubts as to our longe-range determination to 'stick with' Europe - a composite of annoyance at what is considered excessive concern with Far East, drawing far-fetched conclusions from our attempts to persuade European nations to increase their own efforts, and worries as to whether Americans have permanently forsaken isolationism." 2662 [Hervorhebung d. Verf.]
\end{abstract}

Analog zum tabellarischen Überblick über das gesunkene US-Prestige in Europa - im Unterschied zu Deutschland, den Niederlanden, Spanien und der Türkei, wo die Einstellungen gegenüber den USA als "generally satisfactory“ eingestuft wurden, bezeichnete der Bericht die Situation in Österreich, in Großbritannien, Schweden, Belgien, der Schweiz und Griechenland als „verbesserungswürdig““2663 - wurde zur Überwindung der „Yankeephobia“ gleich ein ganzes Bündel an Empfehlungen erteilt. So sollte künftig in allen öffentlichen Reden amerikanischer "high-level governmental officials“ der friedensichernde und auf friedliche Kooperation abzielende Aspekt der US-Wirtschafts- und Sicherheitspolitik betont werden. Darüber hinaus sollten alle Anstrengungen unternommen werden, „to dissociate the Administration from political extremist viewpoint identified in the foreign mind as ,McCarthyism “. ${ }^{2664}$ Des Weiteren wurde empfohlen, künftig in allen außenpolitischen Äußerungen eine tunlichst nicht-aggressive Position einzunehmen und jeden Eindruck „hysterischer“ Unsicherheit zu vermeiden, als wäre die amerikanische Freiheit in

$2661 \mathrm{Vgl}$. Memorandum by Counselor (MacArthur) to the Under Secretary of State (Smith), [Secret], Washington D.C., 2. September 1953, 1526. FRUS, 1952-1954, Vol. I. General: Economic and Political Matters (in two parts). Part 2, Washington D.C. 1983.

2662 Study Prepared by the Operations Coordinating Board, [Secret]. „Reported Decline in U.S. Prestige Abroad“, Washington D.C., 23. September 1953, 1530. FRUS, 1952-1954, Vol. I. General: Economic and Political Matters (in two parts). Part 2, Washington D.C. 1983.

2663 An letzter Stelle rangierten Frankreich, Italien und Dänemark, wo das amerikanische Prestige als ,disturbingly unsatisfactory" eingeschätzt wurde. Ebd., 1529.

2664 Ebd., 1531. 
Gefahr oder die USA wüssten nicht zwischen Kommunismus und anderen „leftist or nonconformist doctrines" $\mathrm{zu}$ unterscheiden:

\begin{abstract}
"Repeatedly stress the peaceful intentions of the U.S. Government and its willingness to 'meet the Soviet bloc half way' in seeking a settlement of international difference and a relaxation of tensions. Avoid outright condemnation of 'neutral countries' or rigid insistence that they must be 'for us' or 'against us'." 2665
\end{abstract}

Obwohl der Bericht sowie die angeschlossenen Empfehlungen von Präsident Truman mit großer Verärgerung aufgenommen wurden - „almost blown his top when he first read this report“ ${ }^{2666}$ - und er außerdem den Verdacht äußerte, dass sich der Bericht („badly overdrawn and colored“) seiner Meinung nach der Existenz von „termites in Washington“ sowie „a lot of disgruntled eggheads“ in den US-Missionen „abroad“ verdanke, konnten der Secretary of State, John Foster Dulles, sowie Allen W. Dulles als neuer Operationschef der CIA,${ }^{2667}$ Truman schließlich doch davon überzeugen, dass die Einschätzungen des Reports korrekt und die Empfehlungen sinnvoll waren. ${ }^{2668}$ Künftig sollte daher insbesondere in Europa jede Form offensiver „pressure tactics“ zurückgenommen werden, und - sofern erforderlich - der nötige politische Druck „,cautiously and confidentially rather than overtly“ ausgeübt werden. ${ }^{2669}$

Wie das in der politischen Realität aussah, zeigte sich zum Beispiel bei den italienischen Parlamentswahlen im Juni I953, wo unter anderem auch die USIS-Dienste im Rahmen der „National Psychological Efforts“ - „extensively ,behind the scenes““ - den antikommunistischen Kräften unter Ausnutzung aller Medien wie Filme, Broschüren, Plakate oder Ausstellungen assistierten. ${ }^{2670}$ Innerhalb der NATO-Länder, aber auch darüber hinaus, sollten - in Kooperation zwischen State Department, US-Verteidigungsministerium und der National Security Agency (NSA) - in allen sicherheitspolitischen Zusammenhängen verstärkt „cultural, spiritual and humanistic aspects of American life“ betont werden, und zwar über lokale beziehungsweise nationale „key government officials“. ${ }^{2671}$

2665 Ebd., 1532.

2666 Memorandum of Discussion at the 164th Meeting of the National Security Council on Thursday, October 1, 1953, [Top Secret, Eyes Only], 1546. FRUS, 1952-1954, Vol. I. General: Economic and Political Matters (in two parts). Part 2, Washington D.C. 1983.

2667 Vgl. James Srodes, Allen Dulles. Master of Spies, Washington D.C. 1999, $419 \mathrm{f}$.

2668 Memorandum of Discussion at the 164th Meeting of the National Security Council on Thursday, October 1, 1953, a.a.O., 1547.

2669 Memorandum by the Operations Coordinating Board [Secret]. Annex B, Washington D.C., undated, 1542.

2670 NARA II, RG 59, General Records Department of State, International Information Administration, Field Program for Austria, Box 3, 150/71/34/07, Henry F. Arnold, Jane Allen, Preparation of IIA Report on the National Psychological Effort, 1. Jänner-30. Juni 1953, 1. Juni 1953, 1.

2671 Ebd. 
In Bezug auf Österreich waren die gezielt psychologisch-strategischen Operationen der US-Propaganda primär von zwei Faktoren bestimmt: einerseits dem Fehlen eines Staatsvertrages und damit verknüpft dem Fehlen der staatlichen Souveränität sowie andererseits der Sowjetischen Militärpräsenz und dem alliierten Besatzungsstatut, dem alle zivilen Behörden unterstanden. ${ }^{2672}$ Dass die Arbeit des „USIS-country teams“ hierbei erfolgreich war, erwies sich beispielsweise bei den vorgezogenen Nationalratswahlen 1953 und dem von den Westalliierten befürchteten Bruch der Großen Koalition. Im Vorfeld hatten die Umfragen einen deutlichen Stimmenzuwachs sowohl bei den Linksparteien als auch beim „Verband der Unabhängigen“ (VdU) und einen Absturz der ÖVP prognostiziert. ${ }^{2673}$ Das Ergebnis fiel dann doch anders als befürchtet aus:

"In line with U.S. policy, USIS media services bolstered the Socialist and People's parties which formed the components of the coalitions government through the use of radio time, newspaper editorials, exhibits, and a special effort in Salzburg (the seat of the resurgent Nazi philosophy). It can be claimed that USIS influence had some bearing on the salutory outcome of the elections which returned the coalition parties to power." 2674 [Hervorhebung d. Verf.]

Im Zusammenhang mit den Nationalratswahlen im Februar I953 kam es übrigens zu einem interessanten Briefwechsel zwischen Samuel H. Williams und dem Department of State. Neben allen darin enthaltenen Seltsamkeiten macht das Schreiben Williams' deutlich, wie eng die erzieherisch-bildungspolitischen Aufgaben - trotz der langjährigen offiziellen "non-interference-policy“ - tendenziell mit machtpolitischen und strategischen Ambitionen der Vereinigten Staaten verwoben waren.

Williams, der mittlerweile längst in die USA zurückgekehrt war, nach wie vor aber gute Kontakte nach Österreich hatte und eigenen Angaben zufolge kurz davor stand, in Washington einen neuen Job als „Director Strategic Intelligence Service“ anzutreten, warnte angesichts des womöglich bevorstehenden Bruches der Großen Koalition vor dem „fall of a government which has been a courageous ally of ours [...] we have poured a billion of

2672 NARA II, RG 59, General Records Department of State, International Information Administration, Field Program for Austria, Box 3, 150/71/34/07, Henry F. Arnold, Jane Allen, Preparation of IIA Report on the National Psychological Effort, 1. Jänner-30. Juni 1953, 1. Juni 1953, 3.

2673 Vgl. Rauchensteiner, Die Zwei. Die Große Koalition in Österreich, a.a. O., 176 ff.

2674 NARA II, RG 59, General Records Department of State, International Information Administration, Field Program for Austria, Box 3, 150/71/34/07, Henry F. Arnold, Jane Allen, Preparation of IIA Report on the National Psychological Effort, 1. Jänner-30. Juni 1953, 1. Juni 1953, 2. Das Wahlergebnis machte die SPÖ (73 Mandate) zwar zur stimmenstärksten Partei, die ÖVP behielt jedoch wahlarithmetisch die Oberhand (74 Mandate), wohingegen der VdU auf 14 Mandate schrumpfte; damit war der Fortbestand der Großen Koalition vorerst garantiert. Vgl. Rauchensteiner, Die Zwei. Die Große Koalition in Österreich, a.a.O., 186. 
dollars into [... “. ${ }^{2675}$ Unter Verweis auf seine guten persönlichen Kontakte zu hochrangigen US-Militärs ${ }^{2676}$ sowie insbesondere zu allen österreichischen „University officials and faculties, scientific and cultural organizations" bot sich Williams kurzerhand dem State Department als Konsulent mit Erfahrung und Expertise an und teilte mit, er sei auch bereit, sich selbst kurzfristig für eine Österreich-Mission zur Verfügung zu stellen. Williams entpuppte sich dabei als ultra-konservativer Hardliner, der angesichts der politischen Krise in Österreich offen seine ,Kritik‘ darüber äußerte, dass unter den für Österreich zuständigen Beamten des State Department „Elemente“ gebe, die keinen Wert auf christliche Werte legen würden: „[...] either unfamiliar with or has abandoned the Christian concepts of altruism, tolerance, honor, decency, and fair play“. Und Williams weiter im Wortlaut:

"There is also an element that is unsympathetic with our present system of government, and which seeks to liberalize it by the establishment of Socialist rule, which in these times is dangerous. As the genuinely democratic Austrian Intelligentsia [sic] insists, Socialism is the 'Vorstufe' for Communism. An aggressive element has attempted to discredit the present Austrian Regime in the eyes of the masses because it supports the Church in its resistance to Communism and Socialism. The political factors in the present Austrian campaign must be understood by you, and the loyalty of American personnel to our democratic ideals must be known, if you are to effect a reorganization and reformation which will enable us to hold the line in one of the most critical spots in the world." ${ }^{2677}$ [Hervorhebung d. Verf.]

Schließlich verstieg sich der frühere USFA-Offizier Williams in seinem, politischen' Kommentar dazu, die österreichische Kirche quasi als einzig zuverlässiges Bollwerk gegenüber der kulturpolitischen Bedrohung durch den Kommunismus darzustellen und glitt dabei in geradezu rassistische Bedrohungsstereotype ab:

"Regardless of the vices and virtues of the present regime in Austria which are not germane to our immediate consideration, the fact remains that the present Austrian government is definitely oriented toward the West, and it has courageously defied threats and pressure from the East. It should

2675 NARA II, RG 59, Department of State, DC/R 763.00/1-3053, CS /H. Samuel H. Williams, to Hon. Carl McCardle, Department of State, Bryn Mawr, Pennsylvania, 30. Jänner 1953, 3. Für die freundliche Zurverfügungstellung einer Kopie des Briefwechsels danke ich an dieser Stelle Herrn Univ.Prof. DDr. Oliver Rathkolb. [Kopie im Besitz d. Verf.]

2676 So nannte Williams namentlich den früheren U.S. High Commissioner USFA, Lt. Gen. Geoffrey H. Keyes, den früheren USACA-Direktor Colonel Charles Dodge (beide nun im Pentagon tätig), Col. Lewis E. Perry, „Commandant at the Strategic Intelligence School“, den stellvertretenden U.S. High Commissioner USFA, weiters den früheren stellvertretenden USFA High Commissioner General J.D. Balmer (nun innerhalb der CIA tätig), General J.A. Elmore (nunmehr ebenfalls im Pentagon tätig) sowie „Dr. Walter Colby“, „Chief of Intelligence for the Atomic Energy Commission“. Ebd. 3.

2677 Ebd., 2. 
be remembered that the seat of the Austrian Government is Io7 miles behind the Iron Curtain, and that it is subject to the whims of four occupation powers, all of which at times create problems of a complex nature. The present Regime has the conservatism characteristic of the Republican Party here, and, like the new administration, it is desirous of preserving characteristic national honorable principles which are identical with our own. Whether we like to admit or not, it must be recognized that the solid Christian resistance of the Church in Austria is the only thing that is holding Asiatic paganism at bay." ${ }^{2678}$ [Hervorhebung d. Verf.]

Die Antwort auf Williams Schreiben, der sich damit wohl doch zu sehr exponiert, wenn nicht gar desavouiert hatte, fiel entsprechend sachlich und deutlich kürzer aus: nach drei Monaten sandte man Williams die zugesandten Unterlagen zurück, dankte ihm für sein Interesse und teilte ihm mit, dass derzeit keine zusätzlichen Ressourcen zur Verfügung stünden. ${ }^{2679}$

Seine Kontakte zu den von ihm geschätzten universitären Kollegen in Österreich pflegte Williams - der auf die ihm verliehenen akademischen Auszeichnungen offenkundig besonders stolz war $^{2680}$ - allerdings weiterhin. Von I955 bis zu seiner Pensionierung im Jahr I964 an der University of Pittsburgh war er wiederholt als Gastprofessor am Zoologischen Institut der Universität Wien, von wo aus er - unter Benützung des Instituts-Briefkopfes zum Beispiel 1955 ein Ansuchen an den „Chief of Staff U.S. Army“ in Washington D.C. richtete, um die Forschungen dreier erfahrener Instituts-Zoologen - „positively politically reliable“ - in Island finanzieren zu helfen, die sich dort mit chemisch-physikalischen Aspekten der Tierpopulation im Umfeld der Geysire beschäftigen wollten. Ohne nähere Erläuterung findet sich der kryptische Zusatz Williams’: „These studies will include topographical and biotic factors of a purely biological nature but which will be of interest in

\section{Ebd. 1.}

2679 NARA II, RG 59, Department of State, DC/R 763.00/1-3053, CS / H. Bradley H. Patterson, Jr., Staff Assistant to the Assistant Secretary, to Sam [sic] Williams, 15. Mai 1953, 1. [Kopie im Besitz d. Verf.]

2680 So listete Williams in seinem Schreiben gleich sämtliche erhaltene Auszeichnungen samt Verabschiedungsfeier im Unterrichtsministerium 1950 auf:

a. Elected Honorary Senator, Technical University in Vienna, 1949.

b. Voted Honorary Member University of Vienna by Faculty in 1949.

c. Elected Honorary Member Oriental Institute in Vienna, 1950.

d. Named Honorary Member Austrian Society for Political Economy (Österreichische Gesellschaft für Wirtschaftspolitik), 1950.

e. Elected Honorary Member Vienna University Society (Universitäts Bund), 1950.

f. Elected Honorary Member Innsbruck University Society, 1951.

g. Awarded degree of Doctors of Philosophy honoris causa by University of Vienna, 1950.

h. Elected Honorary Member Austrian Chapter International Association of University Professors 1950-1951.

i. Received Official recommendation from The City of Vienna, 1952.

j. Guest of honour at an official farewell Reception given by the Austrian Government (Ministry of Education) and given a „Testament of Service to Austria“, 1952. Ebd., 4. 
Strategic Intelligence. “2681 Es ist allerdings stark zu bezweifeln, dass Williams auf diese hanebüchene Weise tatsächlich Mittel für eine geheimdienstliche Operation hatte beantragen können: Vielmehr drängt sich die Vermutung auf, dass er einfach mehr auf die Waage legen wollte, als de facto vorhanden war, um so vielleicht eher finanzielle Unterstützung für das genannte Projekt zu bekommen.

Durch seine vorherige Tätigkeit als Leiter der „USFA-Education Division“ und als nunmehr hochdekorierter Gastprofessor am Zoologischen Institut der Universität Wien offenkundig vollends austrifiziert, meinte Williams, mit barocker Übertreibung und ,Schmäh“ - schließlich berief er sich auf zwei USFA-Veteranen, die längst nicht mehr in Österreich beziehungsweise bereits in Pension (Keyes) waren - gegenüber den verantwortlichen Autoritäten in Washington D.C. auftreten zu müssen:

"As a guest professor in the University here I have been asked to submit this request which I feel sure would be indorsed by Generals Clark and Geoffrey Keyes, both of whom are recipients of Honors here [sic]. Certainly the extension of a limited amount of assistance would engender a lot of goodwill and add much to the morale of this courageous little country which is openly oriented toward 'The West'." 2682

\section{,PHASING OUT ${ }^{`}$ - ZIVILE VERWALTUNG UND BEGINN DER NORMALISIERUNG}

Vor dem Hintergrund der oben skizzierten Entwicklungen der US-Propaganda während dieser ersten Phase des Kalten Krieges liefen in der „target zone Austria“ unter anderem auch die Personenaustausch-Programme kontinuierlich weiter, allerdings bald auf veränderter administrativer Grundlage. Parallel zum Wechsel der besatzungspolitischen Verantwortung vom Verteidigungsministerium ins U.S. Außenministerium wurde der Abbau der USFA Education Division eingeleitet. Deren „Liquidierung“ sollte ursprünglich durch allmähliche Reduzierung des Personalstandes bis zum 30. Juni I950 abgeschlossen sein, wurde aber in Form eines raschen „phasing-out“ schon bis zum 31. März r95o durchgeführt. $\mathrm{Zu}$ diesem Zeitpunkt waren alle Spezialisten sowie alle anderen Mitarbeiter der Education Division, darunter auch 4I Österreicher, abgezogen. Bis Juni verblieben lediglich Williams als Divisions-Leiter und ein Assistent, der für die Supervision der Studentenaustausch-

2681 Samuel H. Williams, to The Chief of Staff U.S. Army, Washington D.C., 5. Februar 1955, 1. Ich danke an dieser Stelle Herrn Dr. Klaus Taschwer für die freundliche Zurverfügungstellung einer Kopie des Schreibens. [Kopie im Besitz d. Verf.].

2682 Von 1955 bis zu seiner Pensionierung im Jahr 1964 an der University of Pittsburgh trug Williams wiederholt als Gastprofessor an der Universität Wien vor. 1968 starb Williams bei einem Bootsunglück im St. Johns River, Florida. Siehe: Obituary - Pittsburgh Post-Gazette, 26. Februar 1968. Ich danke an dieser Stelle Herrn David R. Grinnell von der Bibliothek der University of Pittsburgh für die freundliche Zusendung von Informationsmaterial. 
Programme und der AYA-Jugendaktivitäten in den Büros in Wien, Linz und Salzburg verantwortlich war. Es gab, wie mit Bedauern festgestellt wurde, nicht einmal mehr Büroangestellte. In einem Abschlussbericht der Education Division wurde über die bisherigen bildungspolitischen Aktivitäten in Österreich Bilanz gezogen; und dabei wurden - unter Ausblendung der demokratiepolitischen Kernaufgaben - die Funktionen beziehungsweise Aufgabenbereiche rekapituliert, auf denen die grundsätzliche „non-interference“-Politik der US-Reorientierungs-Abteilung in Österreich ausgerichtet war. ${ }^{2683}$

Die geleistete Arbeit der Education Division resümierte Williams, - seinem Bericht fügte er auch eine detaillierte Statistik der AYA-Faschingsaktivitäten in Wien, Linz und Oberösterreich an -, wie nicht anders zu erwarten, grundsätzlich positiv und meinte lediglich: „There were probably many mistakes of minor nature but which did not injure the Division's operations. Perhaps, the greatest mistake was in initiating new projects for which the staff assistance was not adequate. ${ }^{2684}$

In Bezug auf den bildungspolitischen Status quo - angefangen von der Schulbildung, über die internationalen Wissenschafts- und Forschungskontakte bis hin zum „International Educational Interchange" - attestierte Williams dem österreichischen Unterrichtsministerium, es befinde sich mit den bisher erreichten Ergebnissen „ten years ahead of economic stabilization“, 2685 schließlich lägen die bildungspolitischen Angelegenheiten seiner Ansicht nach auch ,in the hands of a progressive, highly qualified and courageous ministerial staff $[\ldots . . .]^{42686}$ dass die von amerikanischer Seite projektierte Umsetzung einer Gesamtschule in Österreich unrealisiert blieb, fiel hier ebenso wenig ins Gewicht wie der wenig, progressive‘ Realzustand an Österreichs Universitäten. Im Hinblick auf die besatzungspolitischen Auseinandersetzungen auf der Ebene des Alliierten Rates meinte der scheidende Leiter der USFA Education Division unumwunden, dass dieser innerhalb des "Quadripartite Directorates“ mittlerweile vor allem Verteidigungsfunktion zukomme: [Education Division] „has generated largely into a defense of the Austrian Ministry for Education against unfair attacks from an unsympathetic and non-cooperative source" - womit freilich die Sowjets gemeint waren:

"Charges of violations of Article 3 (e) of the Allied Control Agreement, revival of Fascism, employment of Nazi teachers, disregard of Allied Council decrees, by the Ministry for Education, juggling the currencies without permission of the Executive Committee, and demands for the

2683 Hierzu heißt es in dem Bericht u.a.: „The Division promotes the acceptance of the best and most democratizing features of American education and maintains constant liaison with Austrian education in all levels from the nursery schools to the universities. [...] The Division screens technical and research equipment procured for universities through ECA and serves as advisor to Austrian Government and university officials in the restoration of the Research program." NARA II, RG 260, EDU-DIV, Box 5, Folder 28. Education Division. Quarterly Historical Report Covering Period: 1 January-31 March 1950, 7.

2684 Ebd., 9.

2685 Ebd., 4.

2686 Ebd., 5. 
submission of a long-term educational program for Austria, have been introduced unilaterally into the Educational Directorate proceedings without supporting evidence."2687

Seinem Nachfolger aus dem Department of State gab Williams im Schlussbericht der Education Division schließlich noch eine bemerkenswerte politische Botschaft samt einem guten Rat mit auf den Weg, der die bisherige US-Reorientierungs-Politik in Österreich genau auf den Punkt brachte:

"In view of the Austrian Government's commendable acceptance of genuine democratic principles, together with ist demonstrated ability to produce satisfactory textbooks and curricula revisions, the U.S. pursues a policy of non-interference. Its role as advisor and consultant has resulted in a friendly, cooperative and constructive liaison which has accomplished U.S. aims and contributed to the speedy reconstruction and reformation of educational processes by the Federal Ministry. This position of the United States must be maintained, not only because it is effective but also because it is necessary to prevent orientation of educational policies and practices in the wrong direction as the result of antithetic pressure." 2688 [Hevorhebung d. Verf.]

Vor seiner Abreise in die Vereinigten Staaten Mitte September 1950 schrieb der durch einen Autounfall ans Bett gefesselte Williams, der seine Enttäuschung über die vollständige Demontage der Education Division nicht verbergen konnte, noch eine Art Resümee seiner letzten Aktivitäten an Unterrichtsminister Hurdes; darin wird verdeutlicht, dass die Education Division durch punktuelle Hilfeleistungen sicherlich viel zum materiellen Wiederaufbau des Schul- und Universitätswesens in Österreich beigetragen hat:

"My dear Minister Hurdes: As you know, the administration of civil affairs in Austria will be transfered from the Army to the State Department in the very near future. This means the dissolution of the Education Division, USACA, inasmuch as State Department does not plan to carry on many of the activities in which the Division has been engaged.

In the final months of the Division's operations, I have found it possible to expend considerable funds for the purchase of magnetophones, radios, sewing machines, blankets, bed sheets, and sundry other materials for numerous schools and charitable institutions, such as the Institute for the Blind. In addition, I have been able to provide many of Reichert's finest microscopes to Austria's three universities. Organizations such as the Catholic Youth have been recipient of especially designed cabinets, table lamps, radios, and blankets. It appears that this is my final stroke of material assistance as Chief of the Education Division." ${ }^{2689}$

2687 Ebd., 5.

2688 Ebd.

2689 NARA II, RG 260, Youth Activities, Box 5. Samuel H. Williams, Chief, Education Division, USFA, to Dr. Felix Hurdes, Austrian Minister of Education, 8. September 1950, 1. 
Nachdem ab Spätherbst 1950 sämtliche Reorientierungs-Angelegenheiten in den unmittelbaren Verantwortungsbereich des Department of State fielen, übernahm am 15. Februar 1951 Joseph M. Roland als neubestellter Leiter der „Exchange Activities Section of the Division of Public Affairs", die nun innerhalb der US-Gesandtschaft angesiedelt war, offiziell die organisatorische und administrative Leitung der US-PersonenaustauschProgramme in Österreich, die 1952 quantitativ angehoben werden sollten:
"As a part of his duties, he will administer a program under which it is planned to bring 165 Aus- trian leaders, specialists and students to the United States in the current year. The Exchange Activities Section will also support and facilitate educational exchange of persons projects sponsored and financed primarily by private organizations and institutions." ${ }^{2690}$

Obwohl nicht zuletzt mit Abschluss des „Fulbright Abkommens“ am 6. Juni 1950 in Washington ${ }^{2691}$ und der Einrichtung der "United States Education Commission Austria“ (USEC/A) die offizielle Grundlage für einen bilateralen, akademisch-gleichrangigen Wissenschaftstransfer zwischen den USA und Österreich gelegt wurde, waren sowohl die Fulbright-Austauschprogramme als auch alle anderen „Exchange“-Maßnahmen - wenn auch inoffiziell-verdeckt - eindeutig in die politischen Propaganda- und Beeinflussungsstrategien der USA im Kampf gegen den Kommunismus eingebettet.

Dies geht unter anderem aus einer vertraulichen „Security Information“ des Department of State Ende Oktober 1952 hervor, worin in Bezug auf die "crucial Zone Austria“ folgende „Target Groups by Priority“ benannt wurden und dabei auch keineswegs verschwiegen wurde, dass sich nach wie vor gewisse nationalsozialistische Tendenzen feststellen ließen:

“I. Cultural elite (Opinion leaders) which is not only most strongly represented in the Government, but whose value judgements were always widely reflected in public opinion. This group includes artists, educators and journalists. 2. Labor, leadership of which constitutes spearhead of anti-Communist, anti-Soviet efforts in Austria and therefore primary target of Soviet blandishments. 3. Youth, majority organized by political parties or by Catholic Church. Nazi-fostered misconceptions of Western democracy in general and U.S. in particular still prevalent. (Confidential)."2692 [Hervorhebung d. Verf.]

2690 NARA II, RG 59, Box 173. News Notes on Germany - Austria - Japan - The Ryukus, No. 1, Jänner 1951, 3. 2691 Vgl. Walter Seidl, Zwischen Kultur und Culture. Das Austrian Institute in New York und Österreichs kulturelle Repräsentanz in den USA, Wien - Köln - Weimar 2001, 32.

2692 NARA II, RG 59, General Records of the Department of State, Box 1 [150/71/34/07]. Confidential Security Information. Statistical Profile of Exchange Activities for Austria, Denmark, Finland, Germany, Norway and Sweden. Prepared by The Program Planning and Development Staff. International Information Administration, Department of State, 31. Oktober 1952, 3. 
Interessant ist, dass der Bericht des State Department in Bezug auf das „rating of U.S. Educational Exchange programs" nun auch innerhalb der laufenden Austauschprogramme den Fokus klar auf die Jugend legte: „Ist for ,youth“; 3 rd for the ,Cultural Elite‘. (Confidential)“2693

Ohne hier im Detail auf die vom State Department aufgelisteten Empfehlungen für die weitere Durchführung der Personenaustausch-Programme einzugehen - so wurde beispielsweise eine Ausweitung auch auf „influential Austrian personalities“vorgeschlagen, deren berufliches Profil bisher nicht in die regulären Auswahlkriterien der Austausch-Projekte fiel ${ }^{2694}$-, sollen zur Dokumentation doch einige Zahlenangaben zum quantitativen Umfang der US-Austauschprogramme tabellarisch dargestellt werden; und zwar obwohl beziehungsweise eben weil die in der Literatur und in den Quellen oftmals kursierenden Zahlenangaben zum Teil höchst widersprüchlich, in jedem Fall aber nicht kohärent sind. So steht in einen US-Dokument zu lesen, dass bereits 195 / 5 I in Summe 916 ausländische Studierende aus 50 Ländern mit einem US-Stipendium in die Vereinigten Staaten kamen, im selben Zeitraum aber 654 amerikanischen Studierende in 23 Ländern weilten. ${ }^{2695}$ Oliver Schmidt schreibt, es seien nach Abschluss des Fulbright-Abkommens mit Deutschland I952/ 53 im ersten Jahr bereits 253 deutsche Fulbrighter in die USA gekommen. ${ }^{2696}$

Reinhold Wagnleitner konstatiert, dass bis 1955643 Österreicher über das „Exchange of Persons Program“ in die USA kamen, ${ }^{2697}$ deren Zahl bis 1988 allein im Zusammenhang der Fulbright-Programme auf „insgesamt 2654 Stipendiaten“2698 anstieg. Thomas König präsentiert hingegen in seiner Dissertation, in der er im Zusammenhang mit dem FulbrightProgrammen die unterschiedlichen Kategorien österreichischer „Grantees“ anführt, ${ }^{2699}$ eine Tabelle, der zufolge - wie bereits zitiert - zwischen I950/5I und I96o/6r lediglich eine Gesamtzahl von I44 österreichischen,Fulbrightern' zu Studienzwecken in die USA kamen (davon I28 Männer). ${ }^{2700}$ Im Unterschied dazu verlautbarte das Department of State im Juni 1955 im Zusammenhang mit der Vertragsverlängerung des Fulbright-Programmes mit Österreich um weitere fünf Jahre gegenüber der Presse folgende Erfolgsmeldung, die zur gleichen Zeit in Wien und Washington veröffentlicht wurde: „The United States and Austria today renewed for a second five-year period an agreement which already has provided for the exchange of nearly 800 students, so called Fulbright Program. “2701

\section{Ebd.}

2694 Ebd., 3.

2695 Launching the Campaign of Truth. First Phase, a.a.O., 18.

2696 Schmidt, Civil Empire by Co-optation, a.a.O., 153.

2697 Wagnleitner, Coca-Colonisation, a.a.O., 195.

2698 Ebd., 196.

2699 Dies waren v.a.: „Austrian Lecturers“, „Austrian Research Scholars“, „Austrian Teachers“ sowie „Austrian Students“. Siehe: König, Das Fulbright Progamm, a.a.O., 116.

2700 König, Das Fulbright Progamm, a.a.O., $306 \mathrm{ff}$.

2701 NARA II, RG 59, General Records of the Department of State. Bureau of Public Affairs. International Educational Exchange Service. European Country Files, 1951-1956. General Reports Austria [Entry 
Die Pressemeldung beinhaltete im Übrigen auch eine Stellungnahme Außenminister Figls, der bei der offiziellen Vertragsunterzeichnung gegenüber dem US-Vertreter J. Kedzie Penfield die Bedeutung dieses Kulturaustausch-Programmes hervorhob:

"With special pleasure and satisfaction [... we take cognizance of the fact that the majority of the grantees were young students who frequently were given their first opportunity to study in a foreign country and thus broaden their horizons. [...] This fact, I believe is especially significant, because nothing, it would appear to me, is more important in todays world than to strengthen the spirit of international solidarity. How better could this be achieved than through a program which gives the outstanding individuals of our two countries - who tomorrow will bear the political responsibilities - an opportunity to get to know and understand each other." 2702

Interessanterweise finden sich in einem Bericht für das geplante Programm der „United States Educational Commission in Austria“ (USEC/A) für das Jahr 1956 weitaus niedrigere Zahlenangaben: unter den vorgeschlagenen 75 „Grantees“ finden sich 16 „Lecturers/Research Scholars“, sieben „Teachers" und 50 "Students“; für das „Salzburg Seminar“ und das „Bologna Center“ wurden in Summe sechs weitere Stipendien veranschlagt. ${ }^{2703}$ Einer anderen Aufstellung zufolge - diesmal ein „Inspection Report“ von „USIS-Austria“ aus dem Frühjahr I955 - wären die Zahlen des gesamten Exchange-Projektes bis 1955 laufend zurückgegangen: 1951/ 52 kamen noch 249 österreichische „Grantees“ in die USA, 1954/55 wären es nur mehr 64 gewesen. ${ }^{2704} \mathrm{Um}$ dieses einigermaßen verwirrende Zahlenspiel abzurunden, sei abschließend noch der detaillierte statistische Überblick des Departments of State über die Exchange-Aktivitäten aus dem Jahr I952 angeführt: dieser enthält neben einer differenzierten Aufstellung aller unter Fulbright Act und Smith-Mundt Act finanzierten Aufenthalte für „National Leaders“, ,Visiting Lecturers“, WissenschafterInnen und Studierende - wobei allerdings verwirrende Mehrfachzählungen aufscheinen auch eine Aufgliederung aller 255 österreichischen „Grantees“ des Jahres 1951/52 nach Disziplinen.

3020], [250/62/35/0102], Box 1. The Department of State, Washington D.C., to Ambassy, Vienna, 29. November 1955,1 .

2702 Ebd., 2.

2703 NARA II, RG 59, General Records of the Department of State. Bureau of Public Affairs. International Educational Exchange Service. European Country Files, 1951-1956. General Reports Austria [Entry 3020], [250/62/35/0102], Box 1. Annual Program Proposal. United States Educational Commission in Austria (P.L. 584,79th Congress, The Fulbright Act). Program Year 1956. Covering exchanges for the academic year, October 1956-July 1947. Adopted by the Commission, March 22, 1955. Air-pouched to the Department, 30. März 1955, 85.

2704 NARA II, RG 306, Records of the United States Information Agency. Inspection Reports and Related Records, Box 1. Inspection Report. USIS Austria. By Jean-M. Dery, Inspector. February 23-April 26, $1955,27$. 
U.S. Educational Exchange Programs, Grants to Austria, I95I-I952 2705

\begin{tabular}{|c|c|c|c|c|c|c|c|c|c|}
\hline & \multirow{2}{*}{$\begin{array}{c}\text { LSP } \\
\mathrm{PL} \\
402 \\
\end{array}$} & \multicolumn{2}{|c|}{ VL\& RS } & \multicolumn{2}{|c|}{ Teachers } & \multicolumn{2}{|c|}{ Students } & \multirow{2}{*}{$\begin{array}{c}\text { TR } \\
\mathrm{PL} \\
402 \\
\end{array}$} & \multirow[b]{2}{*}{ Total $^{*}$} \\
\hline & & $\begin{array}{c}P L \\
402 \\
\end{array}$ & $\begin{array}{c}P L \\
584 \\
\end{array}$ & $\begin{array}{c}P L \\
402 \\
\end{array}$ & $\begin{array}{c}\mathrm{PL} \\
584 \\
\end{array}$ & $\begin{array}{c}P L \\
402 \\
\end{array}$ & $\begin{array}{c}P L \\
584 \\
\end{array}$ & & \\
\hline 1951 & 50 & 12 & 19 & 3 & 4 & 182 & 115 & & 255 \\
\hline 1952 & 47 & 7 & 15 & 5 & 9 & 80 & 98 & & 169 \\
\hline 1953 & 26 & 10 & 16 & & 8 & 44 & 65 & & 115 \\
\hline
\end{tabular}

*) Die Summe gibt die Zahl der tatsächlich in die USA gekommenen AustauschkandidatInnen wieder - manche wurden sowohl unter Fulbright-Act (PL 584) als auch unter Smith-Mundt-Act (PL 402) gezählt.
LSP $=$ Foreign Leaders
$\mathrm{RS}=$ Research Scholars
PL $402=$ Smith-Mundt-Act
$\mathrm{VL}=\mathrm{Visiting}$ Lecturers
$\mathrm{TR}=$ Trainees
PL 584 = Fulbright - Act

U.S. Educational Exchange Programs, Grants to Americans, I95I-I952 ${ }^{2706}$

\begin{tabular}{|c|c|c|c|c|c|c|c|c|c|c|}
\hline & \multirow{2}{*}{$\begin{array}{c}\text { LSP } \\
\mathrm{PL} \\
402\end{array}$} & \multicolumn{2}{|c|}{ VL } & \multicolumn{2}{|c|}{ RS } & \multicolumn{2}{|c|}{ Teachers } & \multicolumn{2}{|c|}{ Students } & \multirow[b]{2}{*}{ Total } \\
\hline & & $\begin{array}{c}P L \\
402\end{array}$ & $\begin{array}{c}P L \\
584\end{array}$ & $\begin{array}{c}P L \\
402\end{array}$ & $\begin{array}{c}P L \\
584\end{array}$ & $\begin{array}{c}P L \\
402\end{array}$ & $\begin{array}{c}P L \\
584\end{array}$ & $\begin{array}{c}P L \\
402\end{array}$ & $\begin{array}{c}P L \\
584\end{array}$ & \\
\hline 1951 & 4 & 6 & 6 & & 6 & 4 & 4 & & 48 & 68 \\
\hline 1952 & 3 & 4 & 4 & & 9 & 4 & 4 & & 47 & 67 \\
\hline 1953 & 3 & 9 & 9 & & 8 & 8 & 8 & & 48 & 48 \\
\hline
\end{tabular}

U.S. Educational Exchange Programs, Aufstellung nach Disziplinen, I95I-I952

\begin{tabular}{|l|c|c|c|c|c|c|c|c|c|c|c|c|}
\cline { 2 - 11 } \multicolumn{1}{c|}{} & \multicolumn{5}{c|}{ American Grantees } & \multicolumn{5}{c|}{ Austrian Grantees } \\
\hline Disziplinen & LSP & VL & RS & T & S & Total & LSP & VL & RS & T & $S$ & Total \\
\hline NATURAL SCIENCES & & & & & & & & & & & & \\
\hline Astronomy & & & & & & & & & 1 & & 1 & 2 \\
\hline Mathematics & & & & & 2 & 2 & & & & & 1 & 1 \\
\hline Physics & & & & & 2 & 2 & & & 1 & & 3 & 4 \\
\hline Engineering & & & & & & & & & 3 & & 1 & 4 \\
\hline Chemistry & & & & & & & & & & & 3 & 3 \\
\hline
\end{tabular}

2705 Ebd., Table I.

2706 Ebd. 


\begin{tabular}{|c|c|c|c|c|c|c|c|c|c|}
\hline \multirow[b]{2}{*}{ Geology } & \multicolumn{3}{|c|}{ American Grantees } & \multicolumn{6}{|c|}{ Austrian Grantees } \\
\hline & & & & & & & & 1 & 1 \\
\hline Metalurgy & & & & & & & 1 & & 1 \\
\hline Medical Sciences & & & & & 4 & & 2 & 2 & 8 \\
\hline Agriculture & & & & & & & & 2 & 2 \\
\hline Physiology, Pharmacology, Anatomy & 1 & & & 1 & & & 2 & & 2 \\
\hline Plant Sciences (Botany, Forestry) & & 1 & & 1 & & & 1 & 1 & 2 \\
\hline Radiology & & & & & & & & 1 & 1 \\
\hline Psychology & & & & & & 1 & & 2 & 3 \\
\hline Total & 1 & 1 & 4 & 6 & 4 & 1 & 11 & 18 & 34 \\
\hline
\end{tabular}

\begin{tabular}{|c|c|c|c|c|c|c|c|c|c|c|c|c|}
\hline \multirow[b]{2}{*}{ Disziplinen } & \multicolumn{5}{|c|}{ American Grantees } & \multicolumn{7}{|c|}{ Austrian Grantees } \\
\hline & LSP & $V L$ & RS & T & S & Total & LSP & $\mathrm{VL}$ & RS & T & S & Total \\
\hline \multicolumn{13}{|l|}{ POLITICAL SCIENCES } \\
\hline Sociology & & 1 & & & 1 & 2 & & & & & & \\
\hline Business Administration & & & & & & & & & & & 2 & 2 \\
\hline Economics & & & 1 & & 1 & 2 & & & 2 & & 13 & 15 \\
\hline History - American & 1 & & & 1 & 3 & 5 & & & & & 2 & 2 \\
\hline History - European & & & 1 & & & 1 & & & & & & \\
\hline History - Austrian & & & & & 2 & 2 & & & & & & \\
\hline Labor relations & & & & & & & 2 & & & & & 2 \\
\hline Political Science, Intern. Relations & & 1 & & & 4 & 5 & 10 & & 1 & & 8 & 19 \\
\hline Law & & & & & & & 3 & & & & 1 & 4 \\
\hline Total & 1 & 2 & 2 & 1 & 11 & 17 & 15 & & 3 & & 26 & 44 \\
\hline
\end{tabular}

\begin{tabular}{|l|c|c|c|c|c|c|c|c|c|c|c|c|}
\cline { 2 - 11 } \multicolumn{1}{c|}{} & \multicolumn{9}{c|}{ American Grantees } & \multicolumn{7}{c|}{ Austrian Grantees } \\
\hline Disziplinen & LSP & VL & RS & T & S & Total & LSP & VL & RS & T & S & Total \\
\hline HUMANITIES & & & & & & & & & & & & \\
\hline Art \&Architecture Modern & & 1 & & & 2 & 2 & 2 & & & & 1 & 3 \\
\hline $\begin{array}{l}\text { Mass Media } \\
\text { Journalism }\end{array}$ & & & & & & & 4 & & & & 5 & 9 \\
\hline
\end{tabular}




\begin{tabular}{|l|c|c|c|c|c|c|c|c|c|c|c|c|}
\cline { 2 - 12 } \multicolumn{1}{c|}{} & \multicolumn{7}{c|}{ American Grantees } & \multicolumn{7}{c|}{ Austrian Grantees } \\
\hline $\begin{array}{l}\text { Mass Media } \\
\text { Films }\end{array}$ & 1 & 2 & & 2 & 3 & 8 & & & & & 14 & 14 \\
\hline American Lit. & 1 & & & & 15 & 15 & & & & 1 & & 1 \\
\hline Germanic & & & & & 3 & 3 & & & & & 5 & 5 \\
\hline American Civilization or Way of Life & & 1 & 1 & 1 & 7 & 10 & 2 & 1 & 1 & & 1 & 5 \\
\hline Musicology \& History of Music & & & & & 2 & 2 & & & 1 & & & 1 \\
\hline Religion & & & & & & & 3 & & & & 1 & 1 \\
\hline Philosophy & & & 2 & & 1 & 3 & & & & & 3 & 3 \\
\hline Theatre Arts & 2 & 3 & 3 & 3 & 33 & 44 & 9 & 1 & 2 & 1 & 30 & 43 \\
\hline Total
\end{tabular}

\begin{tabular}{|c|c|c|c|c|c|c|c|c|c|c|c|c|}
\hline \multirow[b]{2}{*}{ Disziplinen } & \multicolumn{5}{|c|}{ American Grantees } & \multicolumn{7}{|c|}{ Austrian Grantees } \\
\hline & LSP & $V L$ & RS & T & S & Total & LSP & $V L$ & RS & $\mathrm{T}$ & $S$ & Total \\
\hline EDUCATION & & & & & & & & & & & & \\
\hline Audio Visual & & & & & & & & & & & 7 & 7 \\
\hline Higher & & & & & & & 4 & & & & & 4 \\
\hline Secondary & & & & & & & 2 & & & & & 2 \\
\hline Physical & & & & & & & & & & & & 3 \\
\hline Teacher & & & & & & & 3 & & & & & 3 \\
\hline Educational Administration & & & & & & & 1 & & & & & 1 \\
\hline Educational Psychology & & & & & & & 2 & & & & & 2 \\
\hline Library \& Museum Service & & & & & & & 1 & & 1 & & & 2 \\
\hline Social Work or Welfare & & & & & & & 9 & & & & 2 & 11 \\
\hline Teacher below college level & 1 & & & & & 1 & & & & 3 & & 3 \\
\hline $\begin{array}{l}\text { Foreign Students in schools below } \\
\text { college level (US) }\end{array}$ & & & & & & & & & & & 67 & 67 \\
\hline $\begin{array}{l}\text { General liberal arts - College level } \\
\text { (US) }\end{array}$ & & & & & & & & & & & 29 & 29 \\
\hline Total & 1 & & & & & 1 & 22 & & 1 & 3 & 108 & 134 \\
\hline
\end{tabular}

Dieser tabellarische Überblick über die Statistik der Austauschpersonen nach unterschiedlichen Wissensgebieten beziehungsweise akademischen Disziplinen bietet einen indirekten Einblick in den von den US-Reorientierungs-Stellen im State Department zu 
Grunde gelegten „geheimen“ Lehrplan und dokumentiert gleichzeitig die „politische“ Relevanz der jeweiligen Fachbereiche sowie die stillschweigende Annahme, die AustauschkandidatInnen in diesen Fächern - auch im Sinne der "Campaign of Truth“ - am ehesten „richtig“ beeinflussen zu können.

Was zunächst ins Auge fällt ist, dass die Studierenden mit 8o,8 Prozent die Haupt-

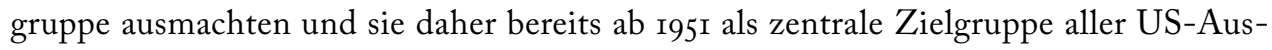
tauschprogramme angesehen werden können.

Darüber hinaus sticht die geringe Zahl naturwissenschaftlicher KandidatInnen, also die eindeutige Dominanz geistes-, sozial- und kulturwissenschaftlicher Fachdisziplinen heraus. In Prozenten ausgedrückt: 88,4 Prozent aller österreichischen „Grantees“ wurden 1951/52 geistes-, sozial- und kulturwissenschaftlichen Bereichen zugeteilt, wobei hier der Bereich der „Erziehungs- und Bildungswissenschaft“ mit 53,6 Prozent eindeutig überwog (Politikwissenschaft 17,6 Prozent; „Humanities“: 17,2 Prozent). Innerhalb des Fachbereiches „Education“ selbst lagen die „Schulbesucher unter College Niveau“ mit 5o Prozent, die „Freien Künste auf College Level“ mit 2I,6 Prozent sowie „Sozial- und Wohlfahrtsarbeit" mit 8,2 Prozent an der Spitze.

Unter den Kulturwissenschaften („Humanities“) dominierte „American Literature“ mit 32,5 Prozent, gefolgt von „Mass Media“ mit 23, 2 Prozent.

Im disziplinären Feld der „Political Sciences“ führte „Internationale Beziehungen“ mit 43,2 Prozent vor „Economics“ (34 Prozent). Wichtigste Disziplinen unter den Naturwissenschaften waren „Medizin“ mit 23,5 Prozent sowie „Physik, Ingenieurswissenschaften und Chemie" mit in Summe 32,3 Prozent.

Obwohl eine klare Dominanz nicht-formalisierter, gewissermaßen „weicher"Wissenschaftsbereiche festzustellen ist (Bildung, Erziehung), fällt doch auf, dass auf jenes Fach mit dem wohl offenkundigsten Bezug zur US-Reorientierung, nämlich „American Civilization or Way of Life“, nur wenige „Grantees“ entfielen, unter den US-Austauschstudenten in Österreich hingegen - darunter immerhin auch zwei, die sich mit österreichischer Geschichte befassten - Studierende des Faches „Germanic“ und Musikwissenschaften den Hauptanteil bildeten. Vortragende Experten aus US-Universitäten finden sich allerdings insgesamt nur I2, wobei auch hier die Fächer „American Literature“ und „Musik- und Theaterwissenschaft" überwiegen.

Auf der Basis der Prozentanteile nach Fächern beziehungsweise akademischen Disziplinen sowie durch einen Vergleich der Zahlen österreichischer und US-amerikanischer "Grantees“ zeigt sich, dass die Auswahl klar auf eher „weiche“ akademische Bereiche gerichtet war und der Wissenstransfer eindeutig asymmetrisch erfolgte.

Der statistisch-tabellarische Überblick weist leider keine Gender-Daten aus, sodass über den Frauenanteil nur Vermutungen angestellt werden können; mit Blick auf die Zahlenangaben anderer Exchange-Statistiken dürfte dieser bei rund zehn Prozent gelegen sein. Damit liegt auf der Hand, dass die Reorientierungs-Programme das Potenzial weiblicher Teilnehmerinnen an den Exchange-Programmen im Großen und Ganzen völlig 
ungenützt ließen, worauf bezeichnenderweise weder in den einschlägigen Berichten der US-Exchange-Stellen noch auf Seiten geheimdienstlicher Analysen eingegangen wurde. Dies ist umso erstaunlicher, als der Frauenanteil in der Bevölkerung Deutschlands und Österreichs infolge der kriegsbedingt hohen Mortalitätsrate bei den Männern nach dem Krieg überproportional hoch war und die Frauengeneration der Nachkriegs-Aufbauära damit zu einem der zentralen ,Träger' auch der geistig-moralischen Reorientierung wurde.

Wie erste Analysen zum Zusammenhang von „Gender and Cold War“ zeigen, erfuhr das heroisch-soldatische Nachkriegs-Narrativ der Siegermacht USA, das in erster Linie männlich konstruiert war, während der Zeit des Kalten Krieges eine spezifisch veränderte Neuauflage. Im Zuge der heroisch aufgeladenen, globalen Abwehr der „Roten Gefahr“ („Red Scare“) durch Politik, Geheimdienste und Militär, wurden maskulin-aggressive Stereotype machtpolitisch aufgewertet und jede Form differenzierter, reflektierter Zurückhaltung und um Ausgleich bemühter politischer „softness“ als subversiv, potenziell homosexuell und damit womöglich auch kommunistisch denunziert und letztlich politisch verfolgt: ${ }^{2707}$

"The full-blown emergence of a national security state dedicated to the production and control of secrets, codified in the National Security Act of 1947 (and the creation of the CIA), contributed to public fears of secret conspiracies fomented by men and women of concealed or unstable political and sexual identities." 2708

Dieses Paradigma mag wohl unter anderem dazu beigetragen haben, dass sich auch im Bereich der US-Reorientierungs-Programme - anders als das analog zu den zivilen sozialwissenschaftlichen Reeducation-Debatten der Kriegsjahre zu vermuten wäre, tendenziell eher traditionelle Rollenbilder erhalten haben, ${ }^{2709}$ Frauen jedenfalls nur in sehr eingeschränkter Form als eigenständige Zielgruppe berücksichtigt wurden.

Mit Einrichtung der „United States Educational Commission in Austria“ (USEC/A) und dem Beginn der Fulbright-Programme in Österreich liefen die existierenden „Exchange“-Schienen zwar zunächst weiter, aber der Fulbright-Austausch ersetzte - ähnlich wie in Deutschland - auch in Österreich weitgehend die anderen, nun zur Gänze vom

2707 Vgl. Robert D. Dean, Imperial Brotherhood. Gender and the Making of Cold War Foreign Policy, Amherst - Massachusetts 2001, $63 \mathrm{f}$.

2708 Ebd., 67.

2709 Die soziokulturellen Beharrungs- und Veränderungsprozesse im Hinblick auf die Rollenbilder der Geschlechter sind freilich vielschichtiger und komplexer Natur und keineswegs auf eine einfache Kausalformel zu bringen. Wie in anderen Bereichen der Gesellschaft unterlagen auch die Rollen- bzw. Frauenbilder Veränderungsprozessen im Kontext technisch-ökonomischer Modernisierung, kultureller Restaurationstendenzen quer durch die politischen Parteien der Nachkriegszeit sowie der transgenerativen Erosion traditioneller Lebensentwürfe und Wertmaßstäbe. Vgl. Ingrid Bauer, Americanizing/Westernizing Austrian Women: Three Scenarios from the 1950s to the 1970s. In: Bischof/Pelinka, The Americanization/Westernization of Austria, a.a.O., $171 \mathrm{ff}$. 
State Department administrierten Personenaustausch-Aktivitäten; die Folge war, dass der Kulturaustausch insgesamt - wohl in beiden Besatzungszonen - „einen erheblichen Teilnehmerrückgang verzeichnete “. ${ }^{2710}$ In Deutschland verlief das gesamte amerikanische Eliten-Austauchprogramm jedoch in einer nicht nur im Vergleich zu Österreich völlig anderen Größenordnung. ${ }^{2711}$ Bis Ende der Fünfzigerjahre kamen insgesamt immerhin über I2.00o deutsche Führungskräfte, Wissenschafter und Studierende über die diversen USIS-Transferschienen in die USA. ${ }^{2712}$

Wie enorm das Austauschprogramm in der US-Besatzungszone in Deutschland vorangetrieben und ausgebaut wurde - womöglich auch, weil das Interesse am transatlantischen Kulturtransfer und die Reisebereitschaft dort größer waren, die Programme liefen ja auf freiwilliger Basis -, zeigt auch eine Vergleichsstatistik, die eine klare Dominanz des deutschen Austausch-Anteils dokumentiert. Wie Ellen Latzin auf der Basis von Primärquellenmaterial zeigen konnte, kamen I950 insgesamt 8I,9 Prozent der TeilnehmerInnen im Bereich der Führungskräfte und Studierenden aus Deutschland, I4,3 Prozent aus Japan und kaum mehr als zwei Prozent aus Österreich. ${ }^{2713}$ So wie in Österreich, wo „das US-Information Coordinating Board“ (ICB) ab 1947 eine zunehmend aggressive antikommunistische Medienpolitik über Rundfunk und Pressemedien betrieb, ${ }^{2714}$ waren die „Exchange“Programme selbstverständlich auch in Deutschland aus Sicht der verantwortlichen Planer als flankierendes „Instrument for smuggeling in democratic bacteria“" ${ }^{\text {"2715 }}$ gedacht - eine Funktion, die die ausgewählten KandidatInnen nach erfolgter Rückkehr und ,erfolgreicher ,Beeinflussung' in überzeugter beziehungsweise überzeugender Weise in Eigenregie selbst ausüben sollten. Das Verzeichnis der gezielt ausgesuchten Austauschkandidaten liest sich jedenfalls, wie Latzin anmerkt, wie „ein Who is Who der deutschen Nachkriegsgeschichte. Die späteren Bundeskanzler Ludwig Erhard, Kurt Georg Kiesinger, Willy Brandt und Helmut Schmidt waren ebenso darunter, wie der spätere Bundespräsident Walter Scheel.“2716

Obwohl sich auch unter den österreichischen „Exchange-Grantees“ bis I955 fallweise einzelne prominente Namen finden - so nahm neben anderen österreichischen Journalisten auch der junge Hugo Portisch im April 1950 an einem Austauschprogramm tei ${ }^{2717}-$,

2710 Latzin, Lernen von Amerika?, a.a.O., 114.

2711 So reisten bspw. in den Jahren 1947-1956 5.568 deutsche Führungskräfte, 1.854 Berufsanfänger, 2.283 Jugendliche sowie 240 Studenten in die USA. Vgl. Latzin, Lernen von Amerika?, a.a.O., 83.

2712 Ebd., 327.

2713 Ebd., 83.

2714 Vgl. Rathkolb, Politische Propaganda der Amerikanischen Besatzungsmacht. Bd. 1, a.a.O., 169 ff.

2715 Latzin, Lernen von Amerika?, a.a.O., 81.

2716 Ebd., 88. Des Weiteren finden sich in den Verzeichnissen auch mehrere Ministerpräsidenten sowie Bundesund Landesminister wie u.a. Franz Josef Strauß, Heinrich von Brentano oder Alois Hundshammer. Ebd.

2717 Siehe: Oliver Rathkolb, US-Medienpolitik und die neue österreichische Journalistenelite. In: Medien und Zeit, Vol. 2, 1987, $10 \mathrm{ff}$. Neben Portisch waren bspw. auch die bereits genannten Franz Cyrus und Inge Sandtner, sowie Walter Hacker und Hans Kronhuber weitere journalistische Austauschkandidaten. 
finden sich doch kaum vergleichbare Namen später herausragender Führungspersönlichkeiten in Politik und Wirtschaft ${ }^{2718}$ beziehungsweise Wissenschaft. ${ }^{2719}$

Ohne hier auf die schwer zu fassenden, komplexen Adaptions- und Transferprozesse eingehen zu können, die sich wohl zwischen positiver Adaptierung und Integration des Erlebten bis hin zu womöglich auch partieller Abwehr und Ablehnung des Erfahrenen bewegt haben - dazu bedürfte es unter anderem eines eigenen Interviewprojekts mit noch lebenden ZeitzeugInnen -, ist nicht nur wegen der zum Teil schriftlich verfassten positiven Rückmeldungen davon auszugehen, dass die Aufenthalte in Amerika das Amerikabild der Kandidaten tendenziell positiv beeinflusst und antikommunistische Positionen eher verfestigt als aufgeweicht haben. Schließlich stand, wie auch die US-Militärs längst wussten, nicht nur die politische Führung längst verlässlich im ,Western Camp،

Die Amerikaner waren in der österreichischen Bevölkerung darüber hinaus vermutlich auch die populärste Besatzungsmacht und der Antikommunismus wohl ebenso konstitutiv für die Nachkriegsidentität des Landes ${ }^{2720}$ wie die zuweilen auch klar dokumentierte Indifferenz gegenüber dem Nationalsozialismus. ${ }^{2721}$ So zitierte Wagnleitner aus dem

2718 Eine Ausnahme ist der Biochemiker und spätere Wissenschaftsminister (1987-1989), Dr. Hans Tuppy (geb. 1924), wie auch der bereits genannte Manfred Mautner Markhof Jr. Siehe S. 597, Anm. 2536.

2719 Beispiele bzw. Zeitzeugen aus dem semi-prominenten Sektor wären hier etwa der deutsch-österreichische Erziehungswissenschafter Wolfgang Brezinka (geb. 1928), der Professor für christliche Philosophie und spätere Rektor der Universität Graz, Johann Fischl (1900-1996), der Botaniker Friedrich Ehrendorfer (geb. 1927) oder der Nationalökonom und Präsident des Verbands Österreichischer Volkshochschulen Richard Kerschagl (1896-1976).

2720 Vgl. Rathkolb, Die paradoxe Republik, a.a.O., 31 f. Vgl. dazu auch: Dieter Stiefel/Ingried Fraberger, Enemy Images. The Meaning of „Anti-Communism“ and Its Importance for the Political and Economic Reconstruction in Austria after 1945. In: Günter Bischof/Anton Pelinka/Dieter Stiefel (Eds.), The Marshall Plan in Austria (=Contemporary Austrian Studies VIII), New Brunswick 2000, 56-97.

2721 Seit dem September 1946 führte die USFA ISB-Survey Section Befragungen der Wiener Bevölkerung (Personen über 18 Jahre) im amerikanischen Sektor zu deren Einstellung zum Nationalsozialismus durch. Zur Abklärung der grundlegenden Haltung wurde folgende Frage gestellt: „War der Nationalsozialismus eine schlechte Idee oder eine gute Idee, nur schlecht ausgeführt?" Wie sich in der Untersuchung herausstellte, wies die Meinungsentwicklung in den fünf Monaten ein negative Tendenz auf, mithin also eine Abwendung von der demokratischen Reorientierung. Wie der Bericht feststellte, hätte sich die Fragestellung als „sehr wertvoll erwiesen“, denjenigen Bevölkerungsteil zu erfassen, der demokratische Ideen ablehnt oder mit der Meinungsäußerung zurückhält. Konkret ergaben die Umfrageergebnisse zwischen August und Dezember 1947 auf die Frage „Der Nationalsozialismus war... “folgendes Ergebnis $(\mathrm{n}=500)$ :

\begin{tabular}{|l|c|c|c|}
\hline & $\begin{array}{c}\text { gute Idee, nur schlecht } \\
\text { ausgeführt }\end{array}$ & keine Meinung & schlechte Idee \\
\hline August 1947 & $38,7 \%$ & $29,7 \%$ & $31,6 \%$ \\
\hline September 1947 & $34,0 \%$ & $28,1 \%$ & $37,9 \%$ \\
\hline Oktober 1947 & $30,4 \%$ & $23,2 \%$ & $46,4 \%$ \\
\hline November 1947 & $40,5 \%$ & $10,6 \%$ & $48,9 \%$ \\
\hline Dezember 1947 & $51,0 \%$ & $10,9 \%$ & $38,1 \%$ \\
\hline
\end{tabular}


Bewerbungsschreiben Hugo Portischs - für den freilich nur Ersteres zutrifft -, der bereits vor seiner Amerikareise zu Protokoll gab, dass es in der Wiener Tageszeitung zu seinen „Hauptaufgaben gehörte [...], die kommunistischen, im weiteren Sinne die marxistischen und die nazistischen Lehren zu bekämpfen [...] und [sich] für die bedingungslose [sic] Zusammenarbeit mit dem Westen einzusetzen. “2722

Inwieweit die akademischen US-Austauschprogramme, von einem möglichen persönlichen Vorteil für die jeweilige Karriere der Teilnehmenden abgesehen, dazu beigetragen haben, dass sich über die folgenden Jahrzehnte Veränderungen und Öffnungsprozesse in der österreichischen Wissenschaftslandschaft ergeben haben, lässt sich schwer abschätzen. Dass sich bereits in den I950er-Jahren, wie es Thomas König als „unbestritten“ ansieht, eine Transformation „hin zur Einbettung und Lokalisierung sozialwissenschaftlicher Praktiken ereignet hat ${ }^{\text {“ }}{ }^{2723}$ ist nicht nur aufgrund der bereits dargestellten restaurativen Tendenzen an den österreichischen Universitäten zu bezweifeln, sondern auch aufgrund der Tatsache, dass sich unter den österreichischen Teilnehmenden des Fulbright-Programmes der Jahre 1951-I96I insgesamt nur 16 Geistes- beziehungsweise KulturwissenschafterInnen befanden, wovon nur eine - nämlich Hedwig Hönigschmied - der Fachdisziplin „Soziologie“ zugeordnet war. ${ }^{2724}$

Die Vereinigten Staaten zählen heute, wie Christian Fleck in einem Aufsatz zur amerikanischen Wissenschaftskultur verdeutlicht hat, zweifellos zu den weltweit führenden Wissenschaftsnationen; eine Entwicklung, die spätestens in der Zwischenkriegszeit einsetzte und sich nach 1945 massiv beschleunigt hat. ${ }^{2725}$ Die wissenschaftspolitischen und wissenschaftsorganisatorischen Entwicklungen innerhalb der stark auf Kooperation und Effizienz hin ausgerichteten amerikanischen Wissenschaftslandschaft haben zweifellos weltweit zu Neuerungen und Innovationen geführt, die mittlerweile auch an österreichischen Universitäten längst zum Standard zählen - Finanzierungsmodi und technisch-materiale Ressourcen ausgenommen.

Dessen ungeachtet blieben sowohl die universitäre Wissenschaftskultur als auch die Binnenstruktur der österreichischen Hochschulen (samt autonomer Dienstposten-

Zit. nach: Headquaters United States Forces in Austria. Information Service Branch, Survey-Section, Ansichten über den Nationalsozialismus. Bericht No. 20, Wien, 13. Jänner 1948, NARA II, RG 407, Box 1426. Administration Services Division. Operations Branch Foreign (Occupied) Area Reports 1945-54. Austrian Reports - Provincial Press Review to Public Opinions.

2722 Wagnleitner, Coca-Colonization, a.a.O., 124.

2723 König, Das Fulbright Programm in Wien, a.a.O., 309.

2724 Vgl. ebd., $306 \mathrm{ff}$.

2725 Als einen zentralen Parameter führt Fleck an, dass die USA nach dem Zweiten Weltkrieg bei der Verleihung der Nobelpreise mit großem Abstand zu führen begannen - so gingen 50,4\% aller Nobelpreise zwischen 1941-1980 an amerikanische Wissenschafter - und dass es darüber hinaus „zu einer Konzentration der Elite des wissenschaftlichen Personals in den USA “ gekommen ist." Christian Fleck, Attraktion und Innovation. Über einige Gründe für den Erfolg der amerikanischen Wissenschaftskultur, Graz o.J., 3 [Kopie des unveröffentl. Manuskriptes im Besitz des Verfassers]. 
planerstellung) lange von jeder Reform verschont. Obwohl der Versuch, die bestehende Autonomie an Österreichs Universitäten formal noch weiter zu stärken, letztlich kein Erfolg beschieden war, gelang es einer Gruppe konservativer Hochschulprofessoren rund um Richard Meister als Vertreter der Rektorenkonferenz, mit dem im Juni I955 erlassenen Hochschulorganisationsgesetz die traditionelle Machtstellung der Professorenkollegien auf den gesamten Wissenschaftsbetrieb zu zementieren und damit die wissenschaftspolitische und gesellschaftliche Abschottung des Universitätssystem zu perpetuieren. ${ }^{2726}$ Das Hochschulorganisationsgesetz 1955 bestätigte, wie Thomas König konzise dargestellt hat, sowohl die „antiquierte Struktur der Fakultäten“ als auch den weitgehend intransparenten Modus der Professoren-Berufungen, bei dem das Ministerium nur in seltenen Fällen intervenierte: „Zumindest weltanschaulich heikle Berufungen dürften in der Regel ohnehin bereits vorab mit Drimmel abgesprochen worden sein. [...] Gerade in der Phase der Hochschulexpansion wurden daher weiterhin vor allem die hauseigenen Dozenten rekrutiert." 2727

Dass in Österreich jedenfalls eine ,weiche“ Form wissenschaftspolitischer „Amerikanisierung“ - hier verstanden als akademische Dominanz und partielle Übernahme amerikanischer Forschungsorganisation und Wissenschaftskultur - im Vergleich zu anderen Staaten erst spät Einzug hielt, dokumentiert unter anderem auch die inhaltliche und formale Gestaltung - Fackelzug und „Damenprogramm“ inklusive - des offiziellen Festberichtes der Universität Wien zur 6oo-Jahr-Feier im Jahr 1965: An ihr nahmen erstaunlicherweise, trotz der geschilderten guten Kontakte zu den leitenden Offizieren der US-Militärverwaltung während der Besatzungsjahre, keine offiziellen Vertreter einer amerikanischen Universität teil. ${ }^{2728}$ Die offizielle Festrede in der Wiener Stadthalle hielt dafür der Altphi-

2726 Siehe: Thomas König, Die Entstehung eines Gesetzes: Österreichische Hochschulpolitik in den 1950erJahren. In: Österreichische Zeitschrift für Geschichtswissenschaften, 23. Jg., November 2012, Heft 2, 70 f.

2727 Ebd., 73.

2728 Persönliche Grußworte überbrachten die Rektoren und Dekane der Universitäten in Paris, Bologna, Oxford, München und Krakau. Wissenschaftliche Vorträge hielten, neben Wiener Wissenschaftern, Vertreter der Universitäten Paris, Göttingen und Innsbruck. Glückwunschadressen langten von folgenden amerikanischen Universitäten ein („L“ steht für Latein, „E“ für in Englisch gehaltene Grußadressen): Ann Arbor (E), Austin (L, E), Baltimore (E), Berkeley (E), Bloomington (E), Boston (L), British-Columbia (E), Harvard (L, E), Charlottesville (L), Chicago (E), Cincinnati (E), Massachusetts (E), Ohio (E), Detroit (E), Ithaca (L), Madison (E), Minneapolis (E), New Orleans (E), New York (L), Pasadena (E), Philadelphia E), Princeton (L), Providence (L), St. Louis (E), Stanford (E). Von den insgesamt 188 Universitäten überbrachten 96 ihre Grußworte ausschließlich in Lateinischer Sprache (51\%), wobei sich nur $13 \%$ der amerikanischen Universitäten für diese traditionelle Gepflogenheit entschieden; die russischen und japanischen Glückwunschadressen wurden aus den Landessprachen übersetzt. Vg1. Die Sechshundertjahrfeier der Universität Wien. Offizieller Festbericht im Selbstverlag der Universität Wien 1965, Wien o.J. [1965]. Eröffnet wurden die Festivitäten am 9. Mai 1965 durch einen Fackelzug der Österreichischen Hochschülerschaft, der in dem Band auch fotografisch dokumentiert ist. 
lologe Albin Lesky ${ }^{2729}$ in seiner Funktion als Prorektor der Universität Wien, wobei er in seiner Standortbestimmung der Institution Universität deren Geschichte im 20. Jahrhunderts vollständig ausklammerte; Lesky war bekannt als Anhänger der Regierungsdikatur Dollfuß-Schuschnigg und war zudem auch NSDAP-Mitglied. ${ }^{2730}$

Die Loslösung von traditionell autoritären Strukturen, die Abschwächung des antimo-

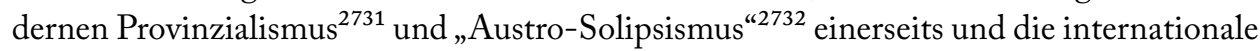
Öffnung der Universitäten Österreichs andererseits war, so lässt sich hier unter Berücksichtigung aller benannten Indikatoren vermuten, ein langwieriger Transformationsprozess über mehrere Generationen hinweg, der sich in der Art der eingangs erwähnten „BlackBox" vollzog: Ein Prozess, der - gemessen an der gesellschaftlichen und politischen Relevanz von Wissenschaft und Intellektualität in Österreich - jedenfalls nach wie vor, und angesichts der Finanzierungssituation vielleicht sogar stärker denn je, durch eklatanten Aufhol- beziehungsweise Nachziehbedarf gekennzeichnet ist.

2729 Albin Lesky (1896-1981), Grazer Altphilologe, war zunächst als Mittelschulprofessor in Marburg und Graz (1921-1932). Nach seiner Habilitation 1924 an der Univ. Graz wurde er 1932 vertretungsweise zum o.a. Professor für Gräzistik an der Universität Wien berufen; 1936 trat er die Nachfolge Ernst Kalinkas an der Univ. Innsbruck an, an der er 1937/38 zum Dekan ernannt wurde. 1938 wurde Lesky allerdings trotz seiner Mitgliedschaft bei der NSDAP des Amtes enthoben. Nach dem Krieg lehrte Lesky als Extraordinarius an der Universität Wien wo er 1963 zum Rektor ernannt wurde. 1963 wurde er zudem Vizepräsident der Österreichischen Akademie der Wissenschaften, 1969/70 schließlich deren Präsident. Siehe: Johannes Feichtinger/Dieter J. Hecht, 1945 und danach. Eine Zäsur und zwei Kontinuitäten. In: Feichtinger/Matis/Sienell/Uhl (Hrsg.), Die Akdemie der Wissenschaften 1938 bis 1945, a.a. O., 197; vgl. auch: Felix Czeike (Hrsg.), Historisches Lexikon Wien (in 5 Bänden). Band 4: Le-Ro, Wien 1995, 44.

2730 Siehe dazu: Peter Goller/Gerhard Oberkofler, Universität Innsbruck. Entnazifizierung und Rehabilitierung von Nazikadern (1945-1950), a.a.O., 27; vgl. dazu auch jüngst: Johanna Holzer, Die Erinnerungskultur der Universität Wien. Gedenken an die Zeit von 1933 bis 1945. In: Österreichische Hochschulen im 20. Jahrhundert. Austrofaschismus, Nationalsozialismus und die Folgen. Hrsg. v. der Österreichischen Hochschülerschaft, Wien 2013, $396 \mathrm{f}$.

$2731 \mathrm{Zu}$ diesem Komplex siehe insbesondere: Gerd Kerschbaumer/Karl Müller, Begnadet für das Schöne. Der rot-weiß-rote Kulturkampf gegen die Moderne (= Beiträge zur Kulturwissenschaft und Kulturpolitik, 2), Wien 1992.

2732 Rathkolb, Die paradoxe Republik, a.a.O., 56. 



\section{Schlussbemerkung}

Wie sich anhand einer Vielzahl konkreter Beispiele zeigen ließ, war der „Reorientierung“, also der grundlegenden Demokratisierung des geistig-kulturellen Lebens, wie dies nach Kriegsende von der amerikanischen Besatzungsmacht beziehungsweise der US-Außenpolitik - neben Deutschland, Italien und Japan - auch für Österreich vorgesehen war, in Bezug auf die akademisch-universitäre Erneuerung letztlich nur wenig Erfolg beschieden.

Ein Hindernis, dass es in diesem Prozess des geistigen Neubeginns zu überwinden galt - geradezu eine tiefsitzende Mental-Blockade -, war zweifellos das tradierte Negativ-Bild von den USA beziehungsweise der amerikanischen Lebensart. Die historische Rekonstruktion der frühen wechselseitigen Wahrnehmungen zeigt die frühe Ausprägung gegenseitiger politisch-kultureller Stereotype, deren Grundlage wenig schmeichelhafte beziehungsweise wenig realistische Ressentiments bildeten. Diese Vorurteile führten spätestens in der 1920er-Jahren zur Verfestigung eines „Anti-Amerikanismus“, der insbesondere in der geistig-kulturellen und politische Elite Europas weit verbreitet war. Zentrale Bestimmungsmerkmale dieses europäischen Stereotyps - gegenüber der amerikanischen Gegen-Wahrnehmung eines zutiefst antidemokratischen sowie völkisch-aggressiven Nationalismus und Militarismus der Deutschen - bildeten die nachhaltigen (hoch)kulturellen Überlegenheitsgefühle gegenüber der ,flachen', ,materialistisch-konsumistischen' amerikanischen Massenkultur, aber auch Überfremdungsängste angesichts einer wirtschaftlich und ökonomisch rasch aufstrebenden transatlantischen Großmacht. Diese Stereotype und Ressentiments wurden mit der Machtübernahme durch die Nationalsozialisten verfestigt, aggressiv aufgeladen und als öffentliches Zerrbild einer barbarischen, von Juden und Freimaurern dominierten großindustriellen Verfallskultur der ,gesunden' deutsch-völkischen ,Lebensart' und rassistischen NS-Gesellschaftspolitik gegenübergestellt.

Der durch die nationalsozialistische Bedrohung ausgelöste Schock einer neuerlichen, in diesem Ausmaß noch nie dagewesenen Aggression und Brutalität des rassentheoretisch verbrämten deutschen Militarismus führte zu einer breiten nationalen Selbstvergewisserung der eigenen geistig-weltanschaulichen und auch demokratiepolitischen Grundlagen. In diesem ersten globalen ,Waffengang“, der auch als „Bildungskrieg“" geführt wurde, kam es im Zuge der parallel geführten Auseinandersetzung mit den Wurzeln und Grundlagen totalitärer Herrschaft - neben konkreten binnenamerikanischen Bildungsreformen im Zuge der „Education for Victory“ - zu einer intensiven kultur- und bildungspolitischen Debatte über die nach Kriegsende als notwendig erachtete „Reeducation“ beziehungsweise „Reorientation“, die eine „Zivilisierung“ und „Demokratisierung“ der indoktrinierten Bevölkerungen der Achsenmächte zum Ziel hatten.

Anders als nach dem Ersten Weltkrieg sollte diesmal nicht nur der Krieg, sondern auch der Frieden gewonnen werden, und zwar durch konkrete Planungen bereits vor Kriegsende 
und nicht erst nach bereits erfolgtem Waffenstillstand - dann wäre es, nach Ansicht der damaligen US-amerikanischen Friedensplaner, womöglich schon zu spät. Mit der Einrichtung des „General Advisory Committee on Post-War-Programs“ der US-Regierung im Jahr 1942 wurden die vielfältigen Aktivitäten des zivilgesellschaftlichen Amerika zur Frage der Reeducation beziehungsweise Reorientation - immerhin waren über 6o große US-Institutionen daran beteiligt - für die Nachkriegsdemokratisierung insbesondere Deutschlands und Österreichs gebündelt und als Weg einer künftigen Friedenssicherung auf europäischer Grundlage ins Auge gefasst.

Die demokratische Umorientierung der indoktrinierten Bevölkerungen der Achsenmächte beinhaltete allerdings bereits von Anfang an eine globale Komponente. Anstelle der bisherigen „westlichen Zivilisation“ sollte, so die Hoffnung Präsident Franklin D. Roosevelts, nach den Erfahrungen des Zweiten Weltkrieges und den begangenen Gräueltaten des NSRegimes, eine „Weltzivilisation“ treten, die künftig auf der Freiheit des Individuums, freien wirtschaftlichen Entfaltungsmöglichkeiten, gegenseitigem kulturellen Austausch, Lernen und auf Bildung beruhen sollte. Anders als jede andere gesellschaftliche Organisationsform, als jede andere Form von „way of life“, bedürfe die Demokratie - darin waren sich alle US-Experten jener Jahre einig - in besonderem Ausmaß einer adäquaten Erziehung und Bildung des Einzelnen, dessen Mündigkeit und Selbstbestimmung der Garant für dauerhaften Frieden und Prosperität wären. Zentrales Element in diesem vielschichtigen und weitverzweigten zivilgesellschaftlichen amerikanischen Demokratie-Diskurs, dessen Konzepte allerdings nur in sehr eingeschränkter Weise auf die nachfolgenden militärischen Planungen für die Besatzungszeit übertragen wurden, bildete die mentale Abrüstung, also die Eliminierung von nazistischem, rassistischem und autoritär-doktrinärem Gedankengut für eine nach haltige Friedenssicherung nach Kriegsende. Als flankierende, langfristige Maßnahme zur Entmilitarisierung und Entnazifizierung sollte dann freilich auch, neben der ökonomischen Rehabilitierung und Stabilisierung, eine grundsätzliche Neuorientierung des gesamten intellektuellen, kulturellen und politischen Lebens an demokratischen Wertmaßstäben, internationaler Kooperation und zivilgesellschaftlicher Partizipation wirksam werden.

Im Unterschied zu den eindimensional-verkürzten Planungen der US-Militärs, die ana$\log$ zur Kriegsdirektive des US-Generalstabs (JCS ro67) in erster Linie auf kurzfristige Negativmaßnahmen nach Kriegsende setzten - dabei wurde der Komplex der Reeducation als reine Nebensache abgehandelt -, dokumentieren die Konzepte der zivilen Experten, dass die „Reorientation“ als progressiver Entwurf einer humanistischen Friedenssicherung durch geistige Abrüstung und als zivilisatorisches Experiment mit globaler Dimension konzipiert war, das sowohl Sieger als auch Besiegte miteinschließen sollte. In heutiger Terminologie handelte es sich bei diesen Plänen um eine Mischung aus kommunitaristischer Verantwortung und „Active Citizenship“2733 entlang den als universal gültig er-

$2733 \mathrm{Zu}$ dieser aktuellen Debatte siehe u.a.: Andrew Lockyer/Bernard R. Crick/John Annette, Education for democratic citizenship. Issues of theory and practice, Aldershot 2003; Kevin McDonough/Walter 
achteten demokratiepolitischen Prinzipien der Freiheit des Individuums und der ,freien“ ökonomisch-wirtschaftlichen Entwicklung. Als idealtypische Richtschnur („role model“) fungierte dabei von Anfang an der „American way of life“.

In Anknüpfung an die erste Grundthese dieser Studie ließ sich zeigen, dass das Kernstück aller US-Reorientierungs-Konzepte, ob diese nun ziviler oder militärischer Natur waren - quasi als conditio sine qua non - die vollständige Entnazifizierung aller Bereiche der Gesellschaft bildete. Aufbauend auf der Grundlage personeller ,Säuberungen“ im gesamten Bereich von Politik, Verwaltung, Medien, Kultur, Bildung und Wissenschaft sollte - unter Meidung der Gefahr jedes „messianischen Komplexes“ (Kandel/Kotschnig) - die langfristige Perspektive der Reorientierung auf (supervidierte) „Selbsterziehung“ und auf Einübung eines demokratischen ,Habitus' abzielen. Von Anfang an setzten die zivilen Reorientierungs-Experten, neben grundsätzlichen bildungspolitischen Maßnahmen, auch auf die erzieherische Wirkung und die soziale Prägekraft eines marktwirtschaftlich organisierten Alltagslebens. Die Herstellung stabiler wirtschaftlicher, ökonomischer und politischer Rahmenbedingungen sowie die Verbesserung der Lebensverhältnisse sollten die Überlegenheit („superiority of the method“) des westlich-kapitalistischen Systems individuell erfahrbar machen und so selbst zu einem nachhaltigen Element der zivilgesellschaftlichen Reorientierung werden.

Obwohl sich für Österreich, initiiert durch die alliierte „Moskauer Erklärung“ über Österreich im November 1943, bald eine Sonderentwicklung abzuzeichnen begann, und damit der Weg für die lange Zeit wirksame beziehungsweise identitätsstiftende „Opfer-Doktrin“ der Zweiten Republik frei wurde, gingen die „Reorientierungs-Konzepte“ für Österreich allerdings nicht nur vom grundsätzlich gleichen Durchdringungsgrad der geistig-mentalen Indoktrinierung durch den Nationalsozialismus aus; sie berücksichtigten darüber hinaus, zumindest anfangs, auch den Umstand, dass in Österreich vor dem „Anschluss“ bereits tiefgreifende politische, kulturelle und bildungspolitische Veränderungen durch das autoritäre System des „Austrofaschismus“ - so der von den US-Militärs verwendete Terminus Platz gegriffen hatten.

Obwohl sich die Alliierten in ihren allgemeinen Deklarationen über die Entmilitarisierung und Entnazifizierung der Achsenmächte grundsätzlich einig waren, existierten weder zu Kriegsende noch danach klare oder gar verbindliche Reglements für ein gemeinsames Vorgehen. Ebenso wie die gesamte Entmilitarisierung blieb dadurch auch der Bereich der Entnazifizierung - von weiterführenden Reorientierungs-Maßnahmen ganz

Feinberg (Eds.), Citizenship and education in liberal-democratic societies. Teaching for cosmopolitan values and collective identities, Oxford 2005; Bernard R. Crick (Ed.), Active Citizenship. What It Could Achieve and How, Edinburgh 2009; Elizabeth Pinnigton, Learning citizenship by practicing democracy. International initiatives and perspectives, Newcastle 2010; zuletzt: Benedikt Wiedmaier/Frank Nonnenmacher, Active citizenship education. Internationale Anstöße für die Politische Bildung, Schwalbach am Taunus 2011. 
zu schweigen - eine von den jeweiligen Besatzungsmächten zonal unterschiedlich gehandhabte Angelegenheit.

Wie sich mit Bezug auf die eingangs formulierte Kernthese - unter Zuhilfenahme statistischen Zahlenmaterials und der Rekonstruktion der gremialen Tätigkeit der zuständigen Sonderkommissionen - zeigen ließ, erfolgte die Entnazifizierung an den österreichischen Universitäten in der Regel als lästige und nur wenig ernsthaft durchgeführte Pflichtübung, der man sich umso leichter entschlagen konnte, als die US-Militärbehörden - an vorderster Stelle die USFA-Education Division - auf eine Kontrolle und Intervention verzichteten und die österreichischen Kollegen gegenüber den in dieser Angelegenheit oft insistierenden Sowjets aus machtpolitisch-strategischen Motiven tendenziell sogar in Schutz nahmen.

Die Politik der Nichteinmischung seitens der US-Besatzungsmacht - die durch den Ausbruch des Kalten Kriegs quasi zementiert wurde - blieb freilich nicht ohne wissenschafts- und bildungspolitische Folgen: anhand einer Reihe von Fallbeispielen sowie anhand der Position der beteiligten Akteure, Behörden und Gremien ließ sich zeigen, dass diese Nichteinmischungs-Politik einem hausgemachten Provinzialismus im akademischuniversitären Bereich Vorschub leistete, dessen politisches Kernproblem in einem personalpolitischen Rückbruch in die Zeit des „Austrofaschismus“ bestand, auch wenn dieser aufgrund des schleichenden Verlaufs als „sanfter Rückbruch“ - freilich ohne Fortschrei-

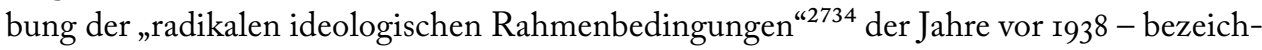
net werden kann; die demokratiepolitischen Folgen für das akademisch-universitäre System Österreich waren, wie Oliver Rathkolb mit Bezug auf die Universität Wien konstatiert, gravierend, blieben dadurch doch ,autoritäre Strukturen und traditionelle inhaltliche Einengungen auf nationale bzw. bilaterale Forschungs- und Lehrräume [...] bestehen. “2735

Frischer Wind in Österreichs Universitätslandschaft - und damit einhergehend ein Aufbrechen autoritär-verkrusteter Strukturen - kam erst Jahrzehnte später. Die über Dekaden hinweg nicht erfolgte Aufarbeitung der jüngeren Vergangenheit Österreichs insgesamt, sowie die bis heute an manchen Universitätsinstituten fortbestehende Tabuisierung beziehungsweise geflissentlich unkritische Darstellung der dunklen Kapitel der jeweils eigenen Disziplin ist - trotz der Fortschritte der letzten Jahre - ebenso ein Indiz dafür, wie die bis in die I97oer-Jahre dominierende konservative Ausrichtung der universitären Pädagogik sowie des gesamten Pflichtschulbereichs - immerhin eine zentrale Reformagenda der US-Reorientierung in Österreich nach $1945 .{ }^{2736}$

Die Überlegungen und Konzepte einer Nachkriegs-Reorientierung, für deren zunächst rudimentäre militärische Umsetzung in Österreich, neben der medien- und informations-

2734 Rathkolb, Die Universität Wien und die „Hohe Politik“ 1945 bis 1955, a.a.O., 53.

2735 Zit nach ebd.

2736 Vgl. Alfred Hiller, US-amerikanische Schulpolitik in Österreich 1945-1950. In: Österreich in Geschichte und Literatur. Hrsg. v. Institut für Österreichkunde, 24. Jg., 1980, Heft 2, 69 f. 
politisch aktiven „U.S. Information Service Branch“ (ISB) analog zur ECR-Abteilung in der Besatzungszone Deutschlands, insbesondere die USACA-,„Education Division“ zuständig war, umfassten den gesamten Bereich von Kultur und Bildung und somit explizit auch den Bereich des wissenschaftlich-akademischen Wiederaufbaus. Nachdem das U.S. Department of State 1946 die Kontrolle über die bisher von den militärischen Besatzungsapparaten nur wenig effizient betriebene und insbesondere in Deutschland primär punitiv durchgeführte „Reeducation“ neu organisierte, griff man auf die früheren zivilen Konzepte (1942-I944) einer langfristigen, auf „Selbsterziehung“ zielenden Demokratisierung zurück. Im Zuge der daraufhin veranschlagten „longe range policy“ bildete insbesondere die Neuorientierung der akademischen, wirtschaftlichen und politischen Eliten einen Schwerpunkt der US-Reorientierung.

Aber trotz präziser Detailinformationen der US-Geheimdienste über den Realzustand der österreichischen Universitäten zu Beginn der Zweiten Republik und der bald zunehmenden öffentlichen Kritik an der unzureichenden autonom durchgeführten Entnazifizierung an den ,Hohen Schulen des Landes', sowie ungeachtet des eigens eingerichteten alliierten Entnazifizierungskomitees Anfang 1946, änderte sich die Situation nicht zuletzt auf Grund der zurückhaltenden beziehungsweise zurückgenommenen Position der USMilitärregierung selbst nach öffentlichen Großkonflikten wie den Hochschulkrawallen im November 1946 kaum merklich. Die dabei mehrfach auftauchenden Konflikte mit übergeordneten Behördenstellen in Washington, welche insbesondere in der Frage der Entnazifizierung Zweifel am Vorgehen an der US-Education Division hegten, führten 1947 kurzfristig beinah zur Aufösung dieser US-Kommandoeinheit auf österreichischem Boden.

Trotz der bereits während der Kriegsjahre im zivilgesellschaftlichen Amerika diskutierten Überlegungen und der differenzierten Konzepte für eine solide demokratische Umorientierung der Achsenmächte nach Kriegsende, deren Kerngehalt vom U.S. Department of State zu einer zentralen Agende der US-Militärbesatzung gemacht wurde, blieb die Vorbedingung der projektierten geistigen und kulturellen Demokratisierung Österreichs, nämlich die grundlegende Entnazifizierung, selbst in dem besonders sensiblen Bereich der Reorientierung des akademisch-universitären Lebens weitgehend unerfüllt. Die „noninterference"-Politik der amerikanischen Besatzungsmacht im Bereich des gesellschaftlichen Elitentransfers sowie die insgesamt nicht-interventionistische Position der westalliierten Mächte haben die konservativen beziehungsweise restaurativen Tendenzen im akademisch-universitären System der Nachkriegszeit - wenn auch sicherlich unbeabsichtigt - insgesamt eher verfestigt als aufgebrochen, jedenfalls nicht verhindert. Resultat war jedenfalls eine österreichische Wissenschaftskultur und Wissenschaftspolitik, die sich, trotz aller grundsätzlich vorhandenen Möglichkeiten für eine vertiefte, internationale Kooperation, eine demokratische Öffnung sowie für eine methodisch-strukturelle Reform und Modernisierung erst Jahrzehnte später allmählich zu wandeln begann.

Die für einen grundlegenden demokratischen Neubeginn in der österreichischen Wissenschaftslandschaft unbedingt notwendigen Entnazifizierungsmaßnahmen wurden 
ebenso wenig verlässlich durchgeführt, wie die Chance zu einer offensiv betriebenen Rückholung der durch den Nationalsozialismus vertriebenen Wissenschaftselite des Landes für einen akademischen Elitentausch aufgegriffen wurde; dieser hätte freilich auch einer klaren und transparenten Personalpolitik samt externer Supervision bedurft hätte. Die nicht weiter in Frage gestellte (personalpolitische) „Autonomie“ der Universitäten ermöglichte die Kontinuität einer rückwärtsgewandten Wissenschaftspolitik, die eine rasche Elitenrestauration beförderte und damit die konservative Orientierung der Universität festigte. Durch die Reetablierung, altvorderer' Kräfte an Österreichs Universitäten wurden reformorientierte, liberale oder gar progressive Positionen an den Rand gedrängt, was letztlich zu einer neuen „Abwanderung junger Intellektueller“ (Christian Fleck) führte.

Lange vor dem Einschwenken der gesamten amerikanischen Reorientierungs-Programme - von der Informations- und Medienpolitik, den U.S. Information Centern („Amerika Häuser"), über Jugendaktivitäten bis zu den kulturpolitischen Austausch-Programmen auf die antikommunistische Propagandastrategie des US-,_Containment“ und „Roll-Back“ gegenüber der Sowjetunion, wodurch sich der Fokus der zuvor antifaschistisch-demokratischen Reorientierung auf antikommunistische „Immunisierung“verschob, hatten die Offiziere der U.S. Education Division in Österreich die Option einer wissenschaftspolitischen Kontrolle und Intervention zugunsten einer paradigmatischen Nichteinmischungs-Politik ersetzt; diese nicht-interventionische Haltung entwickelte sich mehr und mehr in Richtung einer offensiven Entschuldigungspolitik der österreichischen Behördenstellen gegenüber der im Alliierten Rat zumeist von sowjetischer Seite erhobenen Vorwürfe.

Die dabei gepflegten, geradezu amikalen Kontakte zwischen führenden Repräsentanten der USACA-Education Division - tendenziell eher konservative Akademiker ohne größeres historisches Hintergrundwissen über die jüngere österreichische Vergangenheit - und ihren österreichischen Ansprechpartnern auf der Ebene von Universität und Unterrichtsministerium weisen dem Stil und Inhalt nach zuweilen unverkennbare Austrifizierungstendenzen auf, die sich im Fall einzelner Konfliktsituationen gegenüber übergeordneten Behörden in Washington D.C. besonders deutlich zeigten.

Nicht außer Acht zu lassen ist freilich der Umstand, dass die Universität Wien 1945-1955 in der interalliierten Zone lag. Angesichts der zunehmenden Verhärtung der politischen Fronten zwischen Ost und West im Zuge des Kalten Krieges, beständiger sowjetischer Interventionsversuche und einem sich bald abzeichnenden realpolitischen Pragmatismus war die Nivellierung des ursprünglich hohen Ethos der Reorientierungs-Politik - möglicherweise vorgezeichnet.

Freilich erklärt das - siehe das Fallbeispiel der von den USA unterstützten Neugründung der Freien Universität Berlin ${ }^{2737}$ - keineswegs die insgesamt wenig ambitionierten Bemühungen der amerikanischen Besatzungsmacht, die Ausgangssituation nach Kriegsende

2737 Vgl. Paulus, Amerikanisierung von Universität und Wissenschaft in Westdeutschland 1945-1976, a.a.O., $95 \mathrm{ff}$. 
entschieden und konfliktbereit für einen grundsätzlichen Neubeginn des akademischen Lebens und damit für eine grundlegende Neuorientierung der bisherigen restaurativ-autoritären und hochgradig antisemitischen österreichischen Wissenschaftsorganisation und -politik zu nützen. Damit sollen die von amerikanischer Seite gewährten materiellen Hilfestellungen, die von einer Vielzahl privater US-Einrichtungen unterstützt wurden, keineswegs gering geschätzt werden. Gerade darin liegt zweifellos ein großes Verdienst der leitenden Mitarbeiter der USACA Education Division. Ihre Auffassung vom „Struggle for the Austrian Minds“ bezog sich vor allem auf die materiale Unterstützung der österreichischen Universitätskollegen, wobei deren westintegrative Abschirmung vor kommunistischen oder gar sowjetischen Anschuldigungen, Vorhaltungen, Verunglimpfungen oder Ansprüchen als zentrale Aufgabe erachtet wurde.

Langfristig erfolgreich, wenn auch mit wiederkehrenden Rückschlägen bis in die Gegenwart hinein, war die US-Reorientierungs-Politik - und zwar trotz deren fataler propagandistischer ,Militarisierung' als Teil der psychologischen Kriegsführung im Kalten Krieg - sicherlich in jenem Bereich, der bereits in den ursprünglichen zivilen US-Reorientierungs-Konzepten einen integralen Bestandteil bildete: in der Rückdämmung antiamerikanischer Ressentiments beziehungsweise umgekehrt - in der Popularisierung des „American way of life“.

Im Unterschied zu den ursprünglichen Überlegungen zur Demokratisierung nach Kriegsende, in denen es primär um die Verankerung und Festigung friedlicher, zivilgesellschaftlicher Partizipation sowie um die freie individuelle und volkswirtschaftliche Entwicklung im Bereich internationaler Kooperation und Zusammenarbeit ging, vollzogen sich die Prozesse der „Amerikanisierung“ dann doch ganz ohne edukative oder demokratiepolitische Steuerungsimpulse - schließlich entfalteten sich diese nur als Sekundärphänomene der wirtschaftlich-ökonomischen, politischen sowie lebensweltlichen Westintegration.

Mit Bezug auf die zweite eingangs formulierte These ließ sich anhand einer Fülle von Beispielen ziviler Aktivitäten und Planungsüberlegungen darlegen, dass diese von Beginn an auf die (nicht-propagandistische) Popularisierung amerikanischer Lebensart und deren zivilgesellschaftlichen Werte abzielten. In ihrer - zweifellos ideologischen - Gleichsetzung von Demokratie und „American way of life“ fokussierten die zum Teil durchaus komplexen zivilen Reorientierungs-Konzepte also keineswegs auf „Amerikanisierung“, sondern waren ihrem positiven Grundgehalt nach auf die Verankerung und Beförderung friedlicher, zivilgesellschaftlicher Aktivitäten für das Gemeinwohl, auf politische Bildung und Partizipation im Sinne eines funktionierenden Parlamentarismus, auf freie individuelle und volkswirtschaftliche Entwicklung sowie auf Stärkung transnationaler Kooperation und Zusammenarbeit gerichtet - freilich unter der Voraussetzung alliierter Supervision und Kontrolle.

Dass das Vorhaben einer demokratischen, zivilgesellschaftlichen Reorientierung - ursprünglich als historisch einzigartiges Erziehungs-Experiment zur Friedensicherung 
konzipiert -, nach Niederschlagung des nationalsozialistischen Vernichtungskrieges und der Beendigung der fürchterlichen Gräuel des Holocaust durch die Militarisierung der US-Außenpolitik im Kalten Krieg zu weiten Teilen einer antikommunistischen Beeinflussungsdoktrin geopfert wurde, stellt - selbst unter Ausklammerung , moralischer ' Gesichtspunkte - ein demokratiepolitisches Versäumnis und wohl auch Verhängnis ersten Ranges dar. Unter diesen Voraussetzungen reetablierten sich bald personelle und ideologische Strukturen an Österreichs Universitäten, die die bisherige akademische Tradition aus der Zeit von Monarchie und Erster Republik, nämlich einer hochgradig antisemitischen, aliberalen, autoritär-restaurativen, antimodernen und zuweilen deutlich reaktionären deutschnationalen Haltung fortleben ließen.

Ohne die positiven Auswirkungen der politischen Westintegration in Frage stellen zu wollen, konnten im Fahrwasser des rhetorisch-doktrinär zugespitzten radikalen Antikommunismus - und zwar bei allen Beteiligten - wohl letztlich mehr antidemokratische, rassistische oder schlicht bornierte Einstellungsmuster überleben, als selbst unter Anerkennung harscher kommunistischer Feindpropaganda und sicherheitspolitischer Bedrohungsszenarien zu rechtfertigen gewesen wäre.

Dass in der Ära der Regierung George W. Bush jun. als Reaktion auf die katastrophalen Terroranschläge vom Ir. September 200I dann just mit Methoden gekontert wurde, die unter anderem auf nach wie vor im Dunkeln liegende „wissenschaftliche“ US-Geheimexperimente im Zusammenhang nationalsozialistischer Folterexpertisen zurückgehen, ${ }^{2738}$ mag jedenfalls überaus nachdenklich stimmen. Es verweist auf die große bildungspolitische Erfahrungsleerstelle, die durch die baldige Instrumentalisierung der Reorientierungs-Konzepte durch den Kalten Krieg entstanden ist - eine Leerstelle, die heute angesichts der neoliberalen Verknappung der Bildungs- und Wissenschaftsfinanzierung auf kurzfristige ökonomische Nutzen-Kosten-Kalküle besonders deutlich in Erinnerung ruft, wie wenig nachhaltig der kultivierend-zivilisatorische und friedensichernde Aspekt der auf,Humanisierung' gerichteten Bildungsmaßnahmen der Nachkriegsentwicklung in ihrer Wirkung war.

Die Kurve substanzieller bildungspolitischer Debatten seit den Negativbefunden der I96oer-Jahre im Zusammenhang mit der Bildungsexpansion ${ }^{2739}$ weist jedenfalls kontinuierlich nach unten. Angesichts des dominierenden Verwertbarkeitsdenkens unserer Gesellschaft auch in Bildungsfragen scheinen alle zentralen demokratiepolitischen und aufklä-

2738 Siehe dazu: Alfred W. McCoy, Science in Dachau's shadow: Hebb, Beecher, and the Development of CIA Psychological Torture and modern medical ethic. In: Journal of the History of the Behavioral Sciences, Vol. 43, 2007, Nor. 4, 401-417. Hier zit. nach: http://www.uio.no/studier/emner/jus/ikrs/KRIM2950/ h11/undervisningsmateriale/McCoy.pdf. [Zugriff 10.10.2011].

2739 Vgl. Georg Picht, Die deutsche Bildungskatastrophe. Analyse und Dokumentation, Olten-Freiburg im Breisgau 1964; Horst Becker/Liselotte Stürzebecher, Die Westdeutsche Bildungskrise. Ursachen, Wirkungen, Auswege. Hrsg. v. Deutsches Pädagogisches Zentralinstitut (Berlin-Ost), Berlin 1967; Hans Maier, Michael Zöllner, Die andere Bildungskatastrophe: Hochschulgesetze statt Hochschulreform, 1970; Konrad Adam, Die deutsche Bildungsmisere. PISA und die Folgen, München 2004. 
rerischen Aspekte von „Erziehung“ und „Bildung“ verloren zu gehen ${ }^{2740}$ und womöglich bald auch deren bisherige Bildungsträger; selbst in sogenannten politischen „Sonntagsreden“ und gelegentlichen ExpertInnenrunden - für gewöhnlich zu „schulpolitischen“ Debatten und Streitthemen - verschwinden grundlegende emanzipatorische Ideale und Begriffsinhalte, und immer öfter auch die Begriffe selbst, zunehmend aus dem Repertoire vollmundiger Grundsatzrhetorik.

Die zeitgeschichtliche Rekonstruktion und die Rückerinnerung an die ideellen und demokratiepolitischen Wurzeln der US-amerikanischen Reorientierungkonzepte und -planungen, somit an die Bedeutung gezielter und nachhaltiger politischer Bildung in Zeiten einer gesellschaftlicher Krise, scheint vor diesem Hintergrund sowie angesichts des Primats machtpolitisch-militärischer „Friedenslösungen“ auf globaler Ebene von besonderem Interesse und geradezu von, historischer' Aktualität zu sein.

2740 Siehe dazu die Streitschrift von: Konrad Paul Liessmann, Theorie der Unbildung. Die Irrtümer der Wissensgesellschaft, Wien 2006. 



\section{Quellenverzeichnis}

ARCHIVALISCHE PRIMÄRQUELLEN UND MIKROFILM-SAMMLUNGEN

National Archives, Washington D.C., College Park, Maryland, (NARA II)

\section{Record Group (RG) 59}

State Department š Records of the Assistant Secretary of State for Occupied Areas $1946 s ̌ 1949$

[Entry 505 Dš505 E]

Boxen:

1,3š6 [250/46/27/04̌s05 ]

Records of the Department of State š (Lot Files). Records relating to International Information Activities, 1938 š1953

[Entry 1559]

Boxen:

173 š175 [250/50/21/7]

$118 s ̌ 119,123 \quad[250 / 50 / 20 / 6]$

$43 \quad[250 / 50 / 19 / 2]$

$12 s ̌ 17 \quad[250 / 50 / 18 / 5]$

General Records Department of State š Records of Public Affairs; Information

Memorandums, 1948 š195 2 [Lot File: 52 š95 ]

[Entry 1324]

Boxen:

1 š2

[250/49/25/07]

General Records Department of State š Bureau of Public Affairs, International

Educational Exchange Service, European Country Files 1951š1956; General Reports Austria

[Entry 3020]

Box:

$1 \quad[250 / 62 / 35 / 01$ š02 $]$

Records of the Assistant Director of the Office of Public Affairs, 1949š1953 [ Lot File: 54 D7]

[Entry 3020]

Box:

$35 \quad[250 / 62 / 13 / 06]$

General Records of the Department of State š International Information

Administration. Field Programs for Austria, 1949 š1952 
Boxen:

1 š3 [150/71/34/07]

General Records of the Department of State [Lot Files: 56 D/61 D 86] š Gen eral

Records of the Executionary Secretariat, 1948š1956, Office of Jesse Mac Knight

Box:

$9 \quad[150 / 71 / 34 / 07]$

\section{RG 107}

Records of the Office of Secretary of War š A ssistant Secretary of War (formerly classified) correspondence of John McCloy, 1941š1945

[Entry 180]

Boxen:

24š2 $5,44 \quad[390 / 9 / 32 / 06]$

[Entry 180]

$45,55,62 \quad[390 / 9 / 34 / 05]$

\section{RG 165}

War Departement š R ecords of the War Department; General \& Special Staffs: Civil Affairs Division š Gener al Records 1943 š1949

Boxen:

$\begin{array}{ll}10 & {[390 / 38 / 35 / 07]} \\ 86 s ̌ 88 & {[270 / 6 / 35 / 04]} \\ 122 s ̌ 124 & {[390 / 39 / 03 / 2]} \\ 174 & {[390 / 39 / 04 / 02]} \\ 205 \check{s} 206 & {[390 / 39 / 04 / 06 \check{0} 07]} \\ 231 \text { š 232 } & {[390 / 39 / 05 / 3]} \\ 322 \check{s} 326 & {[390 / 39 / 07 / 2 \check{s} 3]} \\ 407 & {[390 / 39 / 08 / 07]} \\ 464 \check{s} 473 & {[390 / 39 / 10 / 1 \check{3} 3]} \\ 504 & {[390 / 39 / 10 / 07]} \\ 525 s ̌ 532 & {[390 / 39 / 11 / 3 s ̌ 4]} \\ 777 & {[390 / 39 / 17 / 05]}\end{array}$

Records of the Civil Affairs Division š G eneral Records 1943 š1949

Box:

$786 \quad[390 / 38 / 35 / 07]$

\section{RG 208}

Office of War Information

Box:

106

[350/73/24/02] 


\section{RG 226}

R\&A Branch Reports 1941 š46

[Entry 8]

Regular Reports [Series 16]

[Entry 16]

Boxen:

$110 s ̌ 113$

COI/OSS Central Files, 1942 š46

[Entry 92]

Boxen:

157, 158, 598

Paris Field Station Files

[Entry 128]

Box:

207

Miscellaneous Washington Files

[Entry 146]

Box:

210

Director of Office \&Filed Station Records

[Entry 190]

Boxen:

$225,282,284$

\section{RG 260}

OMGUS š U SGCC 1944š1945

Boxen:

1 š , 4š6 , 13, 16, 20 [390/40/17/1]

$28,32,33,46 \quad \check{s}$

OMGUS š U SGCC 1944š1945

Boxen:

$14,23,25,23,25[390 / 40 / 18 / 2 s ̌ 4]$

27 š28, 34, 36, 40 š

USFA š E ducation Division š Gen eral Records

Boxen:

1 š8 $\quad[7 / 18 / 5 / 3 \check{4} 4]$

USFA š His torical File

Boxen:

30 š36

$[7 / 20 / 39 s ̌ 41 / 6 s ̌ 2]$ 
OMGUS š E ducation and Cultural Relations Division (ECR), Director`s Office

Boxen:

$11,14 \check{1} 15,18 \check{s} 21,27 \check{2} 28[390 / 46 / 12 / 6 s ̌ 2]$

$31,38,49 \check{5} 50,57 \check{5} 58 \quad \check{s}$

$61,64,67,69,79,87 \check{s} 91$ š

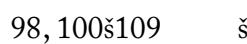

USFA š Youth Activities/Education Division

Boxen:

1 š18 [7/18/5/4š7]

Records of the U.S. Occupation Headquarters World War II.U.S: Allied Command

Austria (USACA). Office of the Director, Files of the Director, 1946 š1951

Boxen:

1 š $20 \quad[390 / 52 / 31 / 5]$

\section{RG 306}

Records of the U.S. Information Agency (USIA) š Office of Research. Miscellaneous

Reports and Studies from various officers of the State Department, 1949 š1953

[Entry 1009A]

Boxen:

1 š2 [250/67/07/04š07]

Records of the Army Staff, Assistant Chief of Staff, G-2 (Intelligence)

[Entry 1009A]

Boxen:

1 š2 [270/6/35/04]

Records of the U.S. Information Agency (USIA) š Office of Research. Special Reports, 1953 š1963

[Entry 1009A]

Boxen:

$2 \quad[250 / 67 / 07 / 04$ š07]

Records of the U.S. Information Agency (USIA) š Office of Research. Country Project Files, 1951š196 4; Austria 1952̌̌ [ff.]

[Entry 1009A]

Boxen:

5 š6 [250/67/09/6]

Records of the U.S. Information Agency (USIA) š Office of Research. Country Project, Correspondence $1952 s ̌ 1963$

[Entry 1009A]

Box:

1

$[250 / 67 / 18 / 3]$ 
U.S. International Communication Agency š Voice of America, Daily Broadcast

Content Reports and Script Translations, 1950 š1 955

[Entry 1037]

Boxen:

76 š78

[250/67/29/1]

Records of the U.S. Information Agency (USIA) š O ffice of Research. Exhibit

Division. Records concerning Exhibits in Foreign Countries. Austria, 1955 š1967

[Entry 1008]

Box:

$2 \quad[250 / 67 / 07 / 04]$

Records of the U.S. Information Agency (USIA) š O ffice of Research and Intelligence, 1955 š1959

[Entry $1007 \mathrm{~A}]$

Box:

1

$[250 / 67 / 5 / 1]$

\section{RG 319}

Records of the Army Staff š A ssistant Chief of Staff (G-2), Reports \&Messages, 1918 š1951

Boxen:

643̌̌645 [270/10/20/06]

$1119 \quad[270 / 10 / 30 / 05]$

Records of the Army Staff š R ecords of the Office of Special Warfare, Secret

Correspondence, 1951 š1958

[Entry 338]

Boxen:

$\begin{array}{ll}5 & {[270 / 18 / 19 / 1]} \\ 6 & {[270 / 18 / 14 / 1]}\end{array}$

Records of the Army Staff š P lans and Operations

[Entry 3338]

Box:

$6 \quad$ [270/15/15/4]

Records of the Army Staff, Assistant Chief of Staff, G-2 (Intelligence)

[Entry 57]

Boxen:

86 š 88

[270/6/35/04]

Records of the Army Staff

[Entry 47C]

Box:

189

$[270 / 5 / 15 / 01]$ 
RG 331

SHAEF š Gener al Staff, G-5 Division, Information Service Branch, Historical Section

[Entry 54]

Boxen:

203,331

$[290 / 7 / 25 / 3]$

RG 407

Administration Services Division Operations; Branch Foreign (Occupied Area)

Reports 1945š54, Austrian Reports, Provincial Press Review š Public Opinion

Boxen:

1424 š1429 [270/69/23/01]

Hoover Institution Archives, Stanford University

Doane Hartigan Papers, I909š 1958

Box 7: Military reports and career of John Doane Hartigan

University of Illinois Archives

Thomas E. Benner Papers, I930š I979

Austrian Materials, Rec. Series No. Io/I/2I

Gottesman Library, Teachers College, Columbia University

„Historical Biographical Files“ š William B. Featherstone

University of Pittsburgh, University Archives

Historical Files š Samuel H. Williams

\section{Universitätsarchiv Wien}

Rektoratsakten, Akademischer Senat, I944š 1947

Dekanatsakten, Philosophische Fakultät, 1945 š 1947

Dekanatsakten der Juridischen Fakultät, 1945 1947

Senatssitzungsprotokolle, 1945 1949

Sonderbestand 9o, Sonderkommission (SK) 1945

Personalakten:

Ernst K. Winter

Erwin Schrödinger

Viktor F. Hess

Hans Kelsen

Felix Ehrenhaft 


\section{Archiv der Bundespolizeidirektion Wien (BPDW)}

Amerikanische Besatzungsmacht I, Akte Juli 45-Sept. 55 (1947-1948)

Russische Besatzung 5 , Akte 1946-I950

Österreichisches Staatsarchiv (ÖSTA), Archiv der Republik (AdR)

Bestand 02, Bundesministerium für Unterricht (BMfU), Präsidium 1946

Bestand o2, BMfU, ${ }_{2} \mathrm{C}_{1}$, Disziplinarkammern, Sonderkommissionen, $1945-1958$

Bestand o4, Bundeskanzleramt (BKA), Sonderkommission $1945^{-46}$

Bestand 02, BMfU, 4716r/IV/Pb/1946, Sonderoberkommission beim BKA

Bestand 04, BKA, Liquidator 1945-1946, Unterricht

\section{Mikrofilm-Sammlung des Instituts für Zeitgeschichte der Universität Wien}

Recordings of the U.S. Department of State relating to the Internal Affairs of Austria I945-I954.

[Mikrofilm-Bestand, Institut für Zeitgeschichte der Universität Wien, Bibliothek]

A Guide to O.S.S./State Department Intelligence and Research Reports. Germany and its Occupied Territories during World War II. Part 4 [A Microfilm Project of University Publications of America, Inc.], Washington D.C. 1977.

[Bestand Institut für Zeitgeschichte, Universität Wien, Bibliothek]

U.S. Office of Strategic Services. Foreign Nationalities Branch Files 1942-1945. Indexes, Bethesda 1998 .

[Mikrofiche-Bestand, Institut für Zeitgeschichte der Universität Wien, Bibliothek]

The U.S. Occupation of Germany: Educational Reform 1945-1949, Microfilm-Collection Congressional Information Service, edited by Gary H. Tsuchimochi, Tokyo r99r. [Bestand Institut für Zeitgeschichte der Universität Wien, Bibliothek].

\section{Mikrofilm-Sammlung der Österreichischen Nationalbibliothek}

Allied Commission for Austria, Allied Council (ALCO), Mikrofilm Österreichische Nationalbibliothek (ÖNB), 1945-1948

Allied Commission for Austria, Executive Committee (EXCO), 1945-1948 



\section{Literaturverzeichnis}

\section{Veröffentlichte unselbstständige und selbstständige Primärliteratur}

Adams, Brooks: America’s Economic Supremacy, London I9oo.

Adler, Friedrich: Die Legende vom glücklichen Österreich. In: Austrian Labor Information, N.Y.C., November/Dezember 1943, I2-I5.

After Defense - what? Edited by National Resources Planning Board, Washington D.C. I94I.

Agar, Herbert, Lewis Mumford, Frank Kingdon: World-wide civil war. Report of Lincoln day meeting, New York 1942.

Alexander, Franz: The Psychiatric Aspects of War and Peace. In: The American Journal of Sociology, Vol. XLVI, Jänner 194I, No. 4, 504-520.

Allied plan for education. The story of the Conference of Allied Ministers of Education, London I945.

American Aid in Foreign-Library Rehabilitation urged by the ALA [American Library Association]. In: School and Society, Vol. 58, August 7, I943, No. I493, 85-86.

American Council on Education. Films for America at War. Supplement, Number I to Selected Educational Motion Pictures. Prepared for the Committee on Motion Pictures in Education, Washington D.C. 1942.

American education and the war in Europe [Educational Policies Commission/National Education Association of the United States and the American Association of School administrators], Washington D.C. I940.

Amerika als Zerrbild europäischer Lebensordnung. Schulungsunterlage Nr. I9. Hrsg. v. Reichsorganisationsleiter der NSDAP, Hauptschulungsamt, o. O., o.J. [1942/43].

Amerika, du hast es besser! In: Das Wissen für Alle, I. Jg., I9or, Bd. 7, I4-15.

Amerikanismus eine Weltgefahr. Reichsführer SS - SS-Hauptamt, Berlin-Grunewald I944.

Amerikanismus. Schriften und Reden von Theodore Roosevelt. Ins Deutsche übertragen und mit einem Vorwort versehen von Paul Rache. 2. Aufl., Leipzig I903.

An Educational „Lend-Lease“ Program Proposed.In: School and Society, Vol. 58, 20. November, I943, No. $1508,403-404$.

Anderson, Eugene N.: The Humanities in the German and Austrian Universities. A Report Submitted to the American Council of Learned Societies, Washington D.C. I950.

Analysis of Reports of Physical Examination: Summary of Data from 19.923 Reports of Physical Examination (Medical Statistics Bulletin No. I, National Headquarters Selective Service System), Washington D.C., ro. November, r94I.

Angell, James Rowland: Radio and National Morale. In: The American Journal of Sociology, Vol. XLVII, November 194I, No. 3, 352-359.

Ashley Montagu, M.F.: Man’s Most Dangerous Myth. The Fallacy of Race, New York 1943.

Austria. Guilt and Virtue. In: Social Research, Jg. 1940, VII, 480-496; Jg. 194I, VIII, I06-I25. 
Austrian Prisoners Harmed - Confinement With Germans Here Viewed as Against Geneva Convention. In: New York Times, 20. Juli I944, I8-I9.

Averill, Lawrence A.: Civilian Moral and Mental Health. In: School and Society, Vol. 57, I3. Februar 1943, No. I469, 169-170.

Ball, Margaret M.: Post-War German-Austrian Relations: The Anschluss Movement, I918-I936, Stanford I937.

Bartlett, John Russell: Dictionary of Americanism. A Glossary of Words and Phrases Usually Regarded as Peculiar to the United States of America. 2. erw. Aufl., Boston I859.

Basler, Otto: Amerikanismus: Geschichte eines Schlagwortes. In: Deutsche Rundschau, 224, August I930, I42-I46.

Bateson, Gregory, Margaret Mead: Principles of Moral Building. In: Journal of Educational Sociology, I5, I94I, 206-220.

Benedict, Ruth, Mildred Ellis: Race and Cultural Relations. Problems in American Life (= National Education Association, Unit No. 5), Washington D.C. 1942.

Benson, George C.S.: American Military Government in Austria May 1945-February 1946. In: American Experiences in Military Government in World War II. Hrsg. v. Carl J. Friedrich, Washington D.C. 1948, 169-194.

Bergel, Kurt: Education for Reconstruction. In: School and Society, Vol. 55, April II, I942, No. I424, $4 \mathrm{I} 7 \mathrm{ff}$.

Bewdley, Earl Baldwin of: The Ideals of Democracy. In: School and Society, Vol. 52, December 21, 1940, No. $1356,266-273$.

Bigelow, Karl W., Bernice Bridges, William E. McManus: The Role of American Voluntary Agencies in Germany and Austria. In: An Experiment in International Cultural Relations. A Report of the Staff of the Commission on the Occupied Areas (= American Council on Education Studies. Ser. I - Reports of Committees and Conferences 49, XV). Hrsg. v. George E. Beauchamp, Washington D.C. I95 I, $5^{8-79}$.

Boltzmann, Ludwig: Reise eines deutschen Professors ins Eldorado. Nach der Ausgabe der Populären Schriften, 1905. Herausgegeben und mit einem Personenregister versehen von Gabriele Dörflinger (= Heidelberger Texte zur Mathematikgeschichte), Heidelberg 2005, I5.

Bondy, Curt: Observation and Reeducation of German Prisoners of War. In: Harvard Educational Review, I944, No. I4, I6.

Boveri, Margret: Amerika-Fibel für erwachsene Deutsche. Ein Versuch Unverstandenes zu erklären, Freiburg i. Br. 1946.

Brailsford, Noel [Henry]: Our settlement with Germany, London I944 [2012].

Brickner, Richard M.: Is Germany Incurable? Philadelphia - New York 1943.

Brigs, Thomas H.: The Ramparts we defend. In: School and Society, Vol. 52, Saturday, September 7 , I940, No. I34I, I47-I48.

Broughton, Philip S.: Government Agencies and the Civilian Morale. In: The Annals of the American Society of Political and Social Science, CCXX, 1942, 168-177. 
Bruner, Jerome S.: The Dimension of Propaganda: German Short-Wave Broadcasts to America. In: The Journal of the Abnormal and Social Psychology, 38. Jg., I943, 3II-337.

Bryan, Alice I.: Equalizing Public Education for Negroes in Tennesse. In: School and Society, Vol. 58, July 3, I943, No. I488, II-I2.

Bryson, Lyman: Which Way America? Communism - Fascism - Democracy, New York 1939.

Bühler, Charlotte: Why do Germans so Easily Forfeit their Freedom? In: The Journal of the Abnormal and Social Psychology, 38. Jg., I943, I49-157.

Caliver, Ambrose: Postwar education of Negroes. Educational implications of army data and experiences of Negro veterans and war workers. Report of a conference sponsored by the U.S. Office of Education, Washington D.C. 1945 .

Canady, Herman G.: The Methodology and Interpretation of Negro-White Mental Testing. In: School and Society, Vol. 55, May 23, 1942, No. 1430, 569-575.

Capt. L.D. Gammas, M.P. Interview in: New York Times, 2. Dezember, 1942.

Carpenter, W.W., A. G. Capps: A total training program for a total war. In: School and Society, Vol. $56,1942,197^{-200}$.

Castle, Eduard: Der große Unbekannte. Das Leben von Ch. Sealsfield - C. Postl. Briefe und Aktenstücke, Wien I955.

Caullery, Maurice M.: Universities and Scientific Life in the United States, Cambridge 1922.

Chronik des Bundesministeriums für Unterricht seit dem Jahre 1948 [bis I953], o. O., o.J.

Colyer, W.T.: Americanism. A World Menace, London 1922.

Comager, Henry Steele (Ed.): Documents of American History, New York 1942.

Conklin, Edwin G.: Education for Democracy. In: School and Society, Vol. 50, Saturday, August 5, I939, No. 1284, I6I-I70.

Corey, Stephen M.: Should we take over their schools? In: School and Society, Vol. 58, October 23, I943, No. 1504, 34 .

Creel, George: How we advertised America. The first telling of the amazing story of the Committing on Public Information that carried the Gospel of Americanism to every corner of the Globe, New York 1920.

Creel, George: Propaganda and Moral. In: The American Journal of Sociology, Vol. XLVII, November I94I, No. 3, 340-35I.

Curti,Merle: The Reputation of America Overseas (1776-I860).In: American Quarterly, No I, 1949, 58-82.

Curtis, Henry S.: Education for Permanent Peace. In: School and Society, Vol. 58, July I7, 1943, No. I $490,34-35$.

Curtis, Henry S.: Wanted: An International Conference on Postwar Education. In: School and Society, Vol. 59, February 19, I944, No. I521, I40-I4I.

Daniell, Raymond: Nazi Virus Thrives in American Zone. In: The New York Times, 22 April 1946, I-2.

Dater, Henry Murray: The Mission of American Liberal Scholarship in the New World Order. In: School and Society, Vol. 58 , October 2, 1943, No. 1501, 251-253.

Davidson, Carter: Has the War doomed Coeducation? In: School and Society, Vol. 59, 1944, No. 1518, 93-94. 
Deutsch, Julius: Echte und falsche Unabhängigkeit. In: Austrian Labor Information, N.Y.C., November/Dezember I943, IO-I2.

Dewey, John: My Pedagogic Creed. In: The School Journal, Vol. LIV, No. 3, January 16, 1897, 77-80.

Dewey, John: Progressive Education and the Science of Education. In: Progressive Education, 5, 1928, 197-204.

Dewey, John: The School and Society, Chicago I942 [1900].

Die Grazer Hochschulen - ein wertvolles Glied unseres Geisteslebens. In: Akademische Rundschau, 2. Jg., 26. Oktober 1946, Nr. 5 .

Die oesterreichische Erziehung nach Hitlers Sturz. Entwurf eines Sofortprogrammes fuer das Schulund Erziehungswesen. In: Austrian Labor Information, Nr. I9, 20. Oktober I943, II-I4.

Die Wehrlosen. Zum Problem der nationalsozialistischen Hochschullehrer. Vereinigung demokratischer Hochschullehrer Österreichs, Wien 1946.

Die Wiener volkstümlichen Universitätskurse. Ansprache anlässlich der Fünfzigjahrfeier im Auditorium Maximum am I3. Oktober 1945 von Rektor Adamovich. In: Akademische Rundschau, I. Jg., Folge 3, 1945, 8-9.

Donick, Emily: Austrian Students „Meet the USA“. In: Institute of International Education News Bulletin, 25. Jg., I950, Heft Juni, 2I-22.

Du Bois-Reymond, Emil H.: Kulturgeschichte und Naturwissenschaft. Rede, i877. In: Estelle Du Bois-Reymond (Hrsg.), Reden von Emil Bois-Reymond, Leipzig I9I2, 54I-566.

Education. Why the Federal Government must Help [Division of Research/National Education Association of the United States], Washington D.C. 1945.

Education after War. In: Nature, Vol. I52, August 21, 1943, No. 3851, 22I-222.

Education and the Defense of American Democracy. Educational Policies Commission/National Education Association of the United States, Washington D.C. I940.

Education and the United Nations. The Report of A Joint Commission of the London International Assembly and Council for Education in World Citizenship, London I943.

Education for war and peace [Sponsored by the School of Education of Stanford University with the co-operation of the Division of Intercourse and Education of the Carnegie Endowment for International Peace], Stanford 1942.

Education in Wartime and After. Hrsg. v. Stanford University, School of Education Faculty, New York - London 1943.

Education under Dictatorships and in Democracies. Education and National Defense Series Pamphlet No. 15. Hrsg. v. Federal Security Agency/U.S. Office of Education, Washington D.C. I94I.

Educational Policies Commission, Learning the Ways of Democracy: A Case Book in Civic Education, Washington D.C. I94I.

Educational Reconstruction in Europe. In: Nature, Vol. I52, August I4, I943, No. 3850, I69-172.

Educational Reconstruction. In: Nature, Vol. I52, July 31, I943, No. 3948, I2O-I2I.

Ehrmann, Henry W.: An Experiment in Political Education. The Prisoners-of-War Schools in the United States. In: Social Research, I947, No. 14, 304-320. 
Ekstein, Rudolf: A refugee teacher looks on democratic and fascist education. In: Education. A monthly magazine. Devoted to science, art, philosophy and literature of education, Vol. 60, 2, Boston/Massachusetts [Oktober] 1939, IOI-IO9.

Entz, Gustav: Denkschrift über das Problem der Entnazifizierung. Gerichtet an die Internal affairs Division USACA, Section De-Nazification, Wien am 27. November 1946.

Eubanks, Leon, Edgar T. Thompson (Eds.): Race Relations and the Race Problem, Durham 1939.

Eubanks, Leon: Negro Education in the South. In: School and Society, Vol. 53, February I, 194I, No. I362, $152-153$.

Events Leading Up To World War II. Chronological History, I93I-I944 (78th Congress, 2d Session, House Document No. 54I), Washington [U.S. Government Printing Service] I944.

Fehling, August Wilhelm: Die Vereinigten Staaten von Amerika. Land und Menschen unter dem Sternenbanner, Berlin I933.

Fischer, Ernst: Für Freiheit und Vernunft. Ansprache an der Universität zur Eröffnung der volkstümlichen Hochschulkurse (= Schriftenreihe „Neues Österreich“, Heft I), Wien I945.

Fleming, Denna Frank: What is it that we fight? In: Representative American Speeches: 1942-I943. Selected by A. Craig Baird, New York 1943, 7I-73.

Frazier, Edward Franklin: Negro Youth at the Crossways. Their Personality Development in the Middle States, Washington D.C. 1940.

Freienfels-Müller, Richard: „Amerikanismus“ und europäische Kultur. In: Der deutsche Gedanke, I927, Heft 4, 30-35.

Fried, Hans Ernest (City College, N.Y.): Separation of Austrian War Prisoners. In: Austro American Tribune. Anti-Nazi Monthly, Vol. II, No. 3, Oktober I943, I.

Fuchs, Martin: Showdown in Vienna. The death of Austria, New York I939.

Fürholzer, Edmund: Menschen wie wir? Ein Amerika-Buch für Europäer, Berlin I943.

Furtmüller, Carl: Progressive Education in the Austrian Republic. In: Austrian Labor Information, No. 23, I2. November 1943 .

Furtmüller, Carl: Staatsbürgerliche Erziehung im neuen Österreich. In: Austrian Labor Information, No. 36, r. April 1945, 8-9.

Furtmüller, Carl: Erziehung - ein zentrales Nachkriegsproblem. In: Austrian Labor Information, No. II, 20. Februar I943, II-I2.

Galloway, George: Post-War Planning in the United States, New York 1942.

Garrison, Winfred Ernest: Intolerance, New York 1934.

Gedye, George E.R.: Betrayal in Central Europe. Austria and Czecho-Slovakia: the fallen bastions, New York - London i939.

Germany After the War, Round Table - 1945. In: American Journal of Orthopsychiatry, Vol. XV, No. 3 July 1945 .

Gollanz, Victor: Shall our Children Live or Die? A Reply to Lord Vansittart in The German Problem, London 1942.

Good, Carter V.: Educational Progress During the Year, 1941. In: School and Society, Vol. 55, Saturday, March 7, I942, No. I4I9, 253-260. 
Graves, E. Boyd: We can learn from Austria. In: Educational Leadership, 8. Jg., I948, Heft I , 37-40. Graz die Stadt der Volkserhebung. Hrsg. v. der Nationalsozialistischen Deutschen Arbeiter-Partei. Gau Steiermark, Graz 1938.

Guidance Problems in Wartime. Education and National Defense Series Pamphlet No. I8. Hrsg. v. Federal Security Agency/U.S. Office of Education, Washington D.C. 1942.

Hacker, Walter: Hochschulen und Demokratie. In: Arbeiterzeitung, Nr. 270, 20. November 1946, 2.

Halfeld, Adolf: Amerika und der Amerikanismus. Kritische Betrachtungen eines Deutschen und Europäers, Jena 1927 .

Harding, Harold F.: Can the Liberal Arts Tradition Survive? In: Representative American Speeches: I943-I944. Selected by A. Craig Baird, New York I944, 306-328.

Hartmann, George W.: Toward a Reasonable Peace. A Little Psychology of the Psychologist. In: The Journal of the Abnormal and Social Psychology, 38. Jg., 1943, 199-210.

Hayes, Edwin J.: Coordination of Military and Civil Affairs Planning. In: Annals of the American Academy of Political and Social Science, 1950, 19-27.

Heiden, Konrad: One man against Europe, London 1939.

Herrmann, K.F.: Schrifttum. In: Friedrich Schönemann/Adolf Halfeld/Friedrich Kegel et al., Kultur in USA. Die Wirklichkeit eines Massenwahns, Berlin I943, 26I-263.

Hertz, Frederick: The Development of the German Mind. A Social History of German Political Sentiments, Aspirations and Ideas. The Middle Ages. The Reformation, London 1957.

Hitler, Adolf: Mein Kampf. Zwei Bände in einem Band, ungekürzte Ausgabe, München 1938.

Hitler, Adolf: Reden, Schriften, Anordnungen. Februar 1925 bis Januar I933. 5 Bde. Hrsg. v. Institut für Zeitgeschichte München, München 1992.

Hitlers Zweites Buch. Ein Dokument aus dem Jahr 1928. Eingeleitet und kommentiert von Gerhard L. Weinberg. Mit einem Geleitwort von Hans Rothfels, Stuttgart I96r.

Hollitscher, Walter: Emergency Problems of Post-war Education in Austria. In: The New Era in Home and School (London), 26. Jg., 1945, Heft 8, 177-178.

How to Read the News. Education and National Defense Series Pamphlet No. 16. Hrsg. v. Federal Security Agency/U.S. Office of Education, Washington D.C. 1942.

Hülsemann, Johann Georg: Geschichte der Democratie in den Vereinigten Staaten von Nord-Amerika, Göttingen 1823 .

Husinsky, Heribert: Vertrieb der ,Akademischen Rundschau' auf Hochschulboden von der Rektorenkonferenz verboten. In: Akademische Rundschau, 2. Jg., Nr. 8, I6. November 1946.

Hutchinson Robert M.: Education and the War. The University in War and Peace. In: Representative American Speeches: 1942-1943, a.a.O., 236-247.

Hylla, Erich: Das Bildungswesen in den Vereinigten Staaten. In: Handbuch der Amerikakunde, Frankfurt a. Main 1931, 245-278.

Ichheiser, Gustav: Some Psychological Obstacles to an Understanding Between the Nations. In: The Journal of the Abnormal and Social Psychology, 36. Jg., 1941, No. 3, 427-432.

Iltis, Hugo: Der Mythos von Blut und Rasse, Wien 1936.

Iltis, Hugo: Die Volkshochschule Brünn: Gründung - Aufbau - Ausgestaltung, Brünn I924. 
Iltis, Hugo: Gregor Johann Mendel: Leben, Werk und Wirkung, Berlin I924.

Iltis, Hugo: Life of Mendel, New York 1932.

Iltis, Hugo: Volkstümliche Rassenkunde (= Buchbeigabe der,Urania - kulturpolitische Monatshefte über Natur und Gesellschaft, 1929/30), Jena 1930.

International Educational Exchange. United States Advisory Commission and The Program of the Department of State. Department of State Publication 3313. International Information and Cultural Series 3, March I951.

Johann A.E. [Alfred Wollschlaeger]: Amerika. Untergang am Überfluss, Berlin 1932.

Johann A.E. [Alfred Wollschlaeger]: Land ohne Herz. Eine Reise ins unbekannte Amerika, Berlin 1942.

Johnson, Charles S.: Growing Up in the Black Belt. Negro Youth in the Rural South, Washington D.C. I94I.

Johnson, William H.: Industrial Education in the War Program. In: School and Society, Vol. 55, May 30, 1942, No. I431, 597-598.

Jung, Edgar Julius: Die Herrschaft der Minderwertigen. Ihr Zerfall und ihre Ablösung, Berlin I927.

Jünger, Ernst: Das Sibirische Tagebuch. In: Ja und Nein, Vol. I, I929, Heft 7/8, 25-27.

Kahrstedt, Ulrich: Pax Americana. Eine historische Betrachtung am Wendepunkte europäischer Geschichte, München I920.

Kandel, I.L., Walter M. Kotschnig: The Messianic Complex. In: School and Society, Vol. 57, February 6, 1943, No. 1467, $156-158$.

Kandel, I.L.: The Vichy Government and Education in France. In: School and Society, Vol. 52, December I4, I940, No. 1355, 619-625.

Kandel, I.L.: The Impact of the War upon American Education, Chapel Hill, N.C. 1948.

Kandel, I.L.: United States Activities in International Cultural Relations (=American Council on Education Studies Studies. Reports of Committees and and Conferences, No. 23). Vol. IX, Washington D.C., September 1945.

Kartzke, Georg: Das Amerikanische Schulwesen, Leipzig 1928.

Keane, Richard (Ed.): Germany what next?, London 1939.

Kefauver, Grayson N.: Proposal for the Reconstruction of Education in the Axis Countries. In: School and Society, Vol. 58, November 6, 1943, No. 1506, 379-38r.

Kelsen, Hans: International Peace - By Court or by Government? In: American Journal of Sociology, Vol. XLVI, January 194I, No. 4, 57I-58I.

Kisch, Egon Erwin: Paradies Amerika, Berlin 1929.

Kleineibst, Richard: Mexiko. Ein Kapitel des amerikanischen Imperialismus. In: Der Kampf. Sozialdemokratische Monatsschrift, I9. Jg., Februar 1926, Nr. 2, III-II2.

Knoickerbocker, H.R.: Is tomorrow Hitler's? II5 Questions on the battle of mankind, London I94I.

Knortz, Karl: Wie in Amerika die allgemeine Volksbildung gefördert wird. In: Ernst Schultze/G. Hamdorff (Hrsg.), Archiv für Volksbildungswesen aller Kulturvölker. Bd. ı, Hamburg 1907, 303-312.

Kohn, Hans: Not by Arms Alone. Essays on our Time, Cambridge I940.

Kollmann, Eric C.: The Nature of this War and American Education. In: School and Society, Vol. 57, Saturday, February 20, 1943, No. 1469, 203. 
Kotschnig, Walter M.: Problems of Education after War. In: International Conciliation, No.379, April 1942, 236-243.

Kotschnig, Walter M.: Slaves Need No Leaders. An Answer to the Facist Challenge to Education, New York 1943.

Kunst, Siegmund: Die Weltlage des demokratischen Sozialismus. In: Der Kampf. Sozialdemokratische Monatsschrift, 2I. Jg., April I928, Nr. 4, I38.

Kürnberger, Ferdinand: Der Amerikamüde, Wien - Köln - Graz I985 [1855].

Lambert, Richard S.: Propaganda, Toronto - New York 1938.

Landis James M. [Office of Civilian Defense]: Moral and Civilian Defense. In: The Journal of the Abnormal and Social Psychology, 38. Jg., I943, 337-349.

Laski, Harold J.: The Rights of Man, London i940.

Lasswell, Harold D.: The Psychology of Hitlerism. In: The Political Quarterly, Vol. IV, July-September 1933 , No. 3, 373-384.

Lasswell, Harold D.: Propaganda Technique in World War I, London 1927.

Lederer, Max: Secondary Education in Austria, I918-38 (= United States Government Printing Office, Bulletin No. 9), Washington D.C. I94I.

Lemkin, Raphael: Axis Rule in Occupied Europe. Laws of Occupation, Analysis of Government, Proposals for Redress, Washington D.C. 1944 .

Lenschau, Thomas: Die Amerikanische Gefahr, Berlin I902.

Levy, David M.: The German Anti-Nazi: A Case Study. In: American Journal of Orthopsychiatry, Juli 1946, Vo. 16, 507-515.

Lewin, Kurt: The Special Case of Germany. In: Public Opinion Quarterly, 7, 1943, 555-566.

Lexikon der deutschen Dichter und Prosaisten des neunzehnten Jahrhunderts. Bearb. v. Franz Brümmer. 5. ergänzte u. vermehrte Aufl., 2. Bd.: Gi-L, Leipzig [1895].

Liddell, Helen: Education in Occupied Germany: A Field Study. In: International Affairs, 1948, 30-62.

Lietzmann, Walter: Unterschiede zwischen amerikanischem und deutschem Schulwesen. In: Die Erziehung, Bd. VI, Leipzig 1930-31, I7-18.

Lindgren, Alina M.: Education in Germany (U.S. Department of the Interior, Office of Education Bulletin, No. 15), Washington D.C. 1939 .

Lippmann, Walter: Public Opinion, New York 1922.

Locke, Alain, Bernhard J. Stern (Eds.): When People Meet. A Study in Race and Cultur Contacts, New York 1942.

Loewenstein, Karl: Political Reconstruction, New York 1946.

Loiseau, H.: L'Education Sociale en Amérique. In: Revue Universitaire, XXXIV, Paris 1925, 228-229.

Losey, Mary: Films for the Community in Wartime (National Board of Review of Motion Pictures), New York 1943.

Löwenthal, Reinhold: Das Schulwesen in den Vereinigten Staaten Amerikas. In: Die Quelle, LXXXIII, Wien 1933, 629-632.

Lüddecke, Theodor: Amerikanismus als Schlagwort und Tatsache. In: Deutsche Rundschau, 224, August 1930, 2I4-22I. 
Machek, Ernst: Verrückte Neue Welt. Ein Panoptikum von Tollheiten, Berlin-Friedenau 1943.

Mackay, Alexander: Western World, London I849.

MacLeish, Archibald: The American Cause, New York 1941.

MacLeish, Archibald. In: The Nation, February I940.

Malinowski, Bronislaw: An Anthropological Analysis of War. In: The American Journal of Sociology, Vol. XLVI, January 194I, No. 4, 52I-559.

Mann, Erika, Klaus Mann: Escape to Life - Deutsche Kultur im Exil, München 1991 [Boston 1939], 364 .

Mann, Erika: School for Barbarians. Education under the Nazis, New York 1938 [deutsch: Die Erziehung der Jugend im Dritten Reich, München I986].

Mann, Tom: Preface. In: W.T. Colyer, Americanism. A World Menace, London 1922.

Marraro, Howard R.: The New Education in Italy, New York 1936.

Master, Ruth D.: Handbook of International Organizations in the Americas [Carnegie Endowment for International Peace], Washington D.C. 1945.

Matejka, Viktor: An die österreichischen Künstler und Wissenschaftler in den U.S.A., Wien, Io. Oktober 1945. In: Austro American Tribune. Anti-Nazi Montbly, Vol. IV, No. 4, 1945, I.

Matthews, Peter: The German people must learn to unlearn. In: Free Europe (Fortnightly Reviev on international Affairs), I94I, No. 46, I25-I26.

McConnell, T.R.: Liberal Education After the War. In: The Annals of the American Academy of Political and Social Science, Vol. 223, January I944, 821-825.

McNeil, Elaine Ogden, Horace R. Cayton: Research on the Urban Negro. In: American Journal of Sociology, Vol. XLVII, September 194I, No. 2, I76-I83.

McNutt, Paul V.: Civilian Morale and the Colleges. In: Education Digest, 6, March 1941, 52-55.

Meiklejohn, Alexander: Education as a Factor in Post-war Reconstruction. In: Free World, January I943.

Meiklejohn, Alexander: The Future of Liberal Education. In: New Republic, 108, January 25, 1943, II3-II5.

Melby, Ernest O. (Ed.): Mobilizing educational resources for winning the war and the peace, New York - London I943.

Merriam, Edward Charles: The New Democracy and the New Despotism, New York 1939.

Military Mobilization Committee of the American Psychiatric Association, Psychiatric Aspects of Civilian Moral, New York 1942.

Miller, Douglas: You Can't Do Business With Hitler, Boston I94I.

Motion Pictures for Postwar Education. Prepared by the Commission on Motion Pictures in Education. American Council on Education Studies (= Reports of Committees and and Conferences No. 2I), Vol. VIII, Washington D.C., October 1944.

Mowrer, Edgar Ansel: Germany puts the clock back, revised edition, London 1938 [1933].

Mowrer, O.H.: Educational Considerations in Making and Keeping the Peace. In: The Journal of the Abnormal and Social Psychology, 38. Jg., 1943, I74-182.

Mumford, Lewis: Faith for Living, New York 1940.

Murray, Henry A.: Analysis of the Personality of Adolph [sic] Hitler, October 1943. 
Neumann, Franz: Behemoth. The Structure and Practice of National Socialism, London 1942.

Neumann, Franz: The Decay of German Democracy. In: The Political Quarterly, 1933, Heft 4, 525-543.

Notter, Harley: Postwar Foreign Policy Preparation, 1939-1945, Washington D.C. 1949.

Odum, Howard W.: Race and Rumors of Race, University of North Carolina 1943.

Our Country's Call to Service. Education and National Defense Series Pamphlet No. r. Hrsg. v. Federal Security Agency/U.S. Office of Education, Washington D.C. 1942.

Our Country's Call to Service. Education and National Defense Series Pamphlet No. r. Hrsg. v. Federal Security Agency/U.S. Office of Education, Washington D.C. 1942.

Overmanns, Jakob: Amerikanisierung des Geistes. In: Stimmen der Zeit, 6o. Jg., 1929/1930, Heft II8, I6I-173.

Park, Robert E.: Morale and the News. In: The American Journal of Sociology, Vol. XLVII, November I94I, No. 3, 360-377.

Park, Robert E.: The Bases of Race Prejudice. In: Annals of the American Academy of Political and Social Science, CXXXX, November 1928, $\mathrm{II}-20$.

Paul, Oscar: Underground Europe, London 1942.

Peez, Alexander: Amerikanische Concurrenz, Wien I88I.

Peiser, Werner: Re-education of the German Youth. In: School and Society, Vol. 59, March II, I944, No. 1524, I77-I80.

Perry, Ralph Barton: Shall Not Perish From the Earth, New York I940.

Perry, Ralph Barton: The Meaning of Morale. In: Educational Record, 22, July I94I, 446-46o.

Peterson, Jan: Germany beneath the Surface. Stories of the Underground Movement, London Melbourne I940.

Picker, Henry: Hitlers Tischgespräche im Führerhauptquartier I94I-42. Hrsg. v. Gerhard Ritter, Bonn I951.

Pirandello, Luigi - in einem Interview mit Corrado Alvaro. In: L'Italia Letteraria, I4. April 1929.

Plank, Robert, Nuschi Plank: Das oesterreichische Erziehungsprogramm. In: Austrian Labor Information, No. 25, I. Mai 1944, 8.

Price, Hoyt, Carl. E. Schorske (Eds.): The Problem of Germany (= Studies in American Foreign Relations. Hrsg. v. Percy W. Bidell, No. 5), New York I947.

Rabovsky, Eduard [sic; recte: Rabofsky]: Die kommunistischen Studenten. In: Akademische Rundschau, I. Jg., I946, Nr. 19, 6-7.

Rache, Paul: Vorwort. In: Amerikanismus. Schriften und Reden von Theodore Roosevelt, Leipzig I903, 4-5.

Rauschnig, Hermann: The Voice of Destruction, New York i940.

Reddick, L.D.: The Negro in the Building of America.In: School and Society, Vol. 53, February 8, I94I, No. $1363,16 \mathrm{I}-\mathrm{I} 64$.

Reichwein, Adolf: Blitzlicht über Amerika (=Vierte Beigabe zu den „Urania“-Kulturpolitischen Monatsheften über Natur und Gesellschaft, Jg. 29/30), Jena I930.

Reports of National Planning Association on Post-War Reconstruction, Washington D.C. 1942.

Representative American Speeches: 1942-1943. Selected by A. Craig Baird, New York 1943. 
Representative American Speeches: 1943-1944. Selected by A. Craig Baird, New York 1944.

Reyer, Eduard: Entwicklung und Organisation der Volksbibliotheken, Leipzig I893.

Röhrs, Hermann: Progressive Education in the United States and its Influence on Related Educational Developments in Germany. In: Paedagocica Historica. International Journal of History of Education, XXXIII, I997, I, 45-68.

Roosevelt, Franklin D.: „To the Patrons, Students, and Teachers of American Schools“, The White House, Washington, October 2, I939. In: School and Society, Vol. 50, Saturday, October 28, I939, No. I296, I.

Roosevelt, Franklin D.: Message to Congress, January II, I944. In: Representative American Speeches: 1943-1944. Selected by A. Craig Baird, New York I944, I5-26.

Roosevelt, Theodore: Der wahre Amerikanismus. In: Amerikanismus. Schriften und Reden von Theodor Roosevelt, Leipzig 1903, II-16.

Rosenman, Samuel I. (Ed.): The Public Papers and Addresses of Franklin Roosevelt. Vol. I: The Genesis of the New Deal, 1928-1932, New York 1938, 742-756.

Ross, Colin: Unser Amerika. Der Deutsche Anteil an den Vereinigten Staaten, Leipzig 1936.

Ross, Colin: USA. Tornisterschrift des Oberkommandos der Wehrmacht. Abt. Inland, Bd. 47, o. O. I94I.

Roucek, Joseph S.: Educational Changes in Slovakia. In: School and Society, Vol. 50, August I9, I939, No. $1286,249^{-250}$.

Rural Youth Program: A Suggested Plan of Action. Recommendations of the Institute for Rural Youth Guidance, Washington D.C. I94I

Russell, John Dale (Ed.): Higher education under war conditions, University of Chicago I943.

Rust, Bernhard: Education and the Third Reich, London 1939.

Schaff, Philip: America. A Sketch of the Political, Social, and Religious Character of the United States, New York 1855 .

Schlegel, Friedrich von: The Philosophy of History, New York i84r.

Schmidt-Phiseldeck, Conrad Friedrich: Europa und Amerika, oder die künftigen Verhältnisse der civilisierten Welt, Copenhagen 1820.

Schönemann, Friedrich: Amerika und der Nationalsozialismus, Berlin I934.

Schönemann, Friedrich: Die aggressive Wirtschaftspolitik der Vereinigten Staaten in Südamerika und die Stellung Deutschlands, Stuttgart 1939.

Schönemann, Friedrich: England gegen Amerika. Eine geschichtlich-kritische Betrachtung, Berlin I940.

Schools at war. A program for action. Handbook of suggestions. Sponsored by the War savings staff of the U.S. Treasury department, the U.S. Office of education and its wartime commission, Washington D.C. 1942 .

Schools of Philanthropy in Amerika. In: Das Wissen für Alle, 7. Jg. 1907, Bd. 30, 476-477.

Schorske Carl E. (mit einem Vorwort von Allen W. Dulles): The Problem of Germany. Part II: Social and Cultural Aspects of the German Problem. In: Hoyt Price/Carl. E. Schorske (Ed.), The Problem of Germany (=Studies in American Foreign Relations, hrsg. v. Percy W. Bidell, No. 5), New York I947. 
Schreier, Fritz: German Aggressiveness - its Reasons and Types. In: The Journal of the Abnormal and Social Psychology, 38. Jg., 1943, 21I-224.

Schuman, Frederick L.: Design for People's Peace. Address before the Institute of Public Affairs, University of Virginia, Charlottesville, July II, I942. In: Representative American Speeches: 19421943. Selected by A. Craig Baird, New York I944, I42-157.

Schuman, Frederick L.: The Nazi Dictatorship. A Study in Social Pathology and the Politics of Fascism. 2. Aufl., New York 1936.

Schwarz, Sebald: Amerika und Wir. In: Die Erziehung, Bd. VI, Leipzig 1930-3I.

Schwerber, Peter: Nationalsozialismus und Technik. Die Geistigkeit der nationalsozialistischen Bewegung, München 1932 [1930].

Sealsfield, Charles [Karl Postl]: Österreich, wie es ist. Oder: Skizzen von Fürstenhöfen des Kontinents. Von einem Augenzeugen [London 1828]. Hrsg. u. bearb. v. Primus-Heinz Kucher, Wien Köln - Weimar 1997.

Serveas, Franz: Wien. Briefe an eine Freundin in Berlin, Leipzig [1908].

Silbermann, Peter A.: Aus New Yorks höheren Schulen, Berlin I927.

Smith, T.V., Glenn Negley, Robert Bush: Democracy versus Dictatorship (Problems in American Life: Unit No. Io), Washington D.C. 1942.

Snavely, Guy E.: The Outlook for Liberal Education. In: School and Society, Vol. 6o, July I, 1944, No. I540, I-2.

Sombart, Werner: Wien. In: Morgen. Wochenzeitschrift für Deutschen Kultur, I, I907, Heft 6, I72-I75.

Soupalt, Philippe: The American Influence in France, Seattle I930.

Speiser, Wolfgang: Unter Adolf Hitlers Sturmfahnen. In: Sozialistisch-Akademische Rundschau, 4. April r93I, 42-44.

Sprock, Benjamin et al.: The Contribution of Development to Morale. In: Progressive Education, I8, May 194I, 240-264.

Sproul, Robert Gordon: Adult Education and the State. In: School and Society, Vol. 50, August I2, I939, No. 1285, 192-I93.

Stagner, Ross: Peace-Planning as a Problem in the Psychology of Learning. In: The Journal of Abnormal and Social Psychology, 38, 1943, I83-192.

Starr, Joseph R.: Fraternization with the Germans in World War II. Occupation Forces in Europe Series, Frankfurt a. Main I947.

Stead, William T.: Die Amerikanisierung der Welt, Berlin 1902.

Steevens, George W.: The Land of the Dollar, London 1898.

Strayer, George D.: Education in a Time of Crisis. In: School and Society, Vol. 58 , August I4, I943, No. I494, 98-99.

Student sein in Graz! In: Akademische Rundschau, I. Jg., März I946, Nr. 20, 4.

Suide, Wilhelm E. (Ed.): Austria. Aspects on Austrian art and music, New York 1944.

Telling America's Story abroad. The State Department's Information and Educational Exchange Program. Department of State Publication 4075. International Information and Cultural Series I4, März I95I. 
The City of Man. A Declaration on World Democracy. 3. Aufl., New York 194I [1940].

The Congress on Education for Democracy. In: School and Society, Vol. 5o, Saturday, October 28, I939, No. I28I, 563 .

The Eclipse of Education under Nazi Rule. In: School and Society, Vol. 53, March 8, 194I, No. 1367, 304-305. The Education Act 1944. With explanatory notes by Alfred E. Ikin, London 1944.

The Education of Free Men in American Democracy. Educational Policies Commission, National Association of the United States, Washington D.C. I94I.

The National Committee on Education and National Defense. In: School and Society, Vol. 53 , February 22, I94I, 237 .

The Nazis and their Subjugated Neighbors. In: School and Society, Vol. 52, December I4, I940, No. I356, 625.

The Negro's War. In: Fortune, XXV, June, 1942, 77.

The Second Nation-Wide Test for the ASTP and the Navy V-I2 Program. In: School and Society, Vol. 58, October 2, 1943, 252.

The Status of Elementary Education in Germany, 1939. In: School and Society, Vol. 52, September I4, I940, No. I342, I92-I93.

The Support of Education in Wartime (Educational Policies Commission, National Education Association of the United States and the American Association of School Administrators), Washington D.C. 1942 .

Thompson, Charles A.: Overseas Information Service of the United States Government, New York I948.

Trading Ideas with the World. International Educational and Technical Exchange. Report of the United States Advisory Commission on the Educational Exchange, Washington D.C. 1949.

Training for Military Government in the Conquered Countries. In: School and Society, Vol. 58, July 3, 1943, No. 1488, 5-6.

Truth Campaign. Counteract Propaganda. In: The Hart County News, 27. Juli I950, Nr. 33, 2.

Tucker, William P.: How Can Libraries Aid Democracy? In: School and Society, Vol. 53, May io, 194I, 23-24.

Turner, Ralph E., Hope Sewell French: Conference of allied ministers of education, Washington D.C. 1944 .

Twain, Mark: Turbulente Tage in Österreich. Aus dem Amerikanischen übertragen und kommentiert von Rudolf Pikal, o. O. (Wien) 2012.

Ueber amerikanische Volkserziehung. In: Das Wissen für Alle, 9. Jg. 1909, Bd. 2, 27-29.

Understanding the war. Suggestions for summer school courses, for extra-curricular programs, and for discussions relating to war information, Washington D.C. 1943.

Universität Wien. Bericht über den Studienbetrieb an der Wiener Universität vom Sommer-Semester 1945 bis zum Sommer-Semester 1947. Erstattet v. Prof. Dr. Ludwig Adamovich, Wien I947, 42.

Usher, Roland G.: Pan-Americanism. A Forecast of the Inevitable Clash between the United States and Europe's Victor, London I9I5.

Vansittart, Lord R.G.: Black Record, London I94I. 
Vickery, William E., Steward G. Cole: Intercultural Education in American Schools, New York 1943. Viktor, Walther: Dichter und Volksbildner [Josef Luitpold Stern]. In: Austro American Tribune, Vol. IV, No. 9, April 1946, ir.

Vocational Rehabilitation and National Defense. Education and National Defense Series Pamphlet No. 19. Hrsg. v. Federal Security Agency/U.S. Office of Education, Washington D.C. 1942

Walters, Raymond: Statistics of Attendance in American Universities and Colleges, 1943. In: School and Society, Vol. 58, December 25, I943, No. II53, $484 \mathrm{ff}$.

Walters, Raymond: The Baltimore Conference on Higher Education and the War. In: School and Society, Vol. 55, January 17, I942, No. I412, 57-62.

Walters, Raymond: The Congress on Education for Democracy. In: School and Society, Vol. 50, Saturday, August 26, 1939, No. 1287, 419-435.

Wanger, Walter: The Role of Movies in Moral. In: The American Journal of Sociology, Vol. XLVII, November 1941, No. 3, 378-383.

War and Defense Courses in Some of the Universities. In: School and Society, Vol. 52, September 7 , I940, No. I34I, I58.

Warner, W. Lloyd, Buford Helmholz Junker, Walter A. Adams: Color and Human Nature. Negro Personality Development in a Northern City, Washington D.C. I94I.

Wartime Guideposts for Rural Youth. Abbreviated proceedings of the Institute of Rural Youth Guidance and 27th Annual Meeting of the Alliance for Guidance of April 23-25, Richmond Washington D.C. 1942.

Wartime Handbook for Education [National Education Association of U.S.], Washington D.C. I943.

Wartime redirection in secondary education; suggested emphases in the secondary school program to meet wartime demands, prepared by members of the staff of the College of education of the State University of Iowa, Iowa City 1942.

Wells, H.G. et al.: Present Views on the Post-War World. In: School and Society, Vol. 52, December 2I, I940, No. 1356, 652-653.

Wesley, Charles H.: Graduates for Negroes in Southern Universities. In: Harvard Educational Review, Vol. X, I940, No. I, 82-94.

What the Schools Can Do. Education and National Defense Series Pamphlet No. 4. Hrsg.v. Federal Security Agency/U.S. Office of Education, Washington D.C. I94I.

When is an „Educational Invasion“ of Conquered Countries „Messianic“? In: School and Society, Vol. 58 , November 6, 1943 , No. $1506,364-365$.

Wilde, William R.: Austria: Its Literary, Scientific and Medical Institutions with Notes upon the Present State of Science and a Guide to the Hospitals and Sanatory Establishments of Vienna, Dublin I843. In: Irene Montjoye (Hrsg.), Oscar Wildes Vater über Metternichs Österreich, Frankfurt a. Main 1989 .

Williams, Samuel H.: Voodoo Roads, Wien 1949.

Willkie, Wendell L.: Economic Freedom for the world. Address on Monday evening, November I6, 1942, before the Eleventh Forum on Current Problems, under the auspices of the New York Herald Tribune. 
Woldt, Richard: Ausbeutungsmethoden im modernen Großbetrieb. In: Der Kampf. Sozialdemokratische Monatsschrift, 3. Jg., I. Oktober 1909, Heft I, 28.

Wright, Herbert: Attitude of the United States towards Austria, New York [1943] 1944.

Youth in Austria. Six Years of Occupation. In: The Times Educational Supplement, No. 1506, 1944, I24.

Ziemer, Gregor: Education for Death. The Making of a Nazi, New York 194I.

Zilsel, Edgar. In: Austrian Labor Information, No. 24, March-April 1943, 9-1o.

\section{Nachschlagwerke, Quelleneditionen}

Annalen des Naturhistorischen Museums Wien, 74, Wien 1970.

Biographic Register of the Department of State, April I, I949. Office of Public Affairs. Department of State (Department of State. Publication 3471), Washington D.C. I949.

The Biographic Register 1957 (Revised as of May I, 1957). Office of Special Services (Department of State 6503), Washington D.C. 1957.

Rot-Weiss-Rot-Buch. Gerechtigkeit für Österreich. Darstellungen, Dokumente und Nachweise zur Vorgeschichte und Geschichte der Okkupation Österreichs. Erster Teil (nach amtlichen Quellen), Wien 1946.

Foreign Relations of the United States (FRUS). Diplomatic Papers, 1944. Vol. I. General. U.S. Government Printing Service 1944. Hrsg. v. Historical Office des Departments of State, Washington D.C. I966. Mr. William Phillips, Political Advisor at the Headquarters of the Supreme Allied Commander, to the Secretary of State, London, I7. Dezember 1944.

FRUS, Diplomatic Papers, I943. Vol. I. General, Washington D.C. I968.

FRUS, Diplomatic Papers. The Conference of Malta and Yalta 1945, Washington D.C. 1955.

Keesings Archiv der Gegenwart, XV.Jg., I945

Protokolle des Kabinettsrats der Provisorischen Regierung Karl Renner 1945. Bd. III: Protokolle des Kabinettsrats I2. September 1945 bis I7. Dezember 1945. Hrsg.v. Gertrude Enderle-Burcel/Rudolf Jerabek, Wien 2003.

USFA Sentinel. For the United States Forces in Austria. (An official military publication for all military and D/A civilian personnel and their dependents assigned to this command), Salzburg 195-1954.

\section{Selbstständige und unselbstständige Sekundärliteratur}

Abrahams, Bradley: The Struggle for the Soul of the Nation. Czech Culture and the Rise of Communism, Lanham 2004.

Adam, Konrad: Die deutsche Bildungsmisere. PISA und die Folgen, München 2004.

Adorno, Theodor W., Else Frenkel-Brunswik, Daniel J. Levinson, R. Nevitt Sanford: The Authoritarian Personality, New York 195 o.

Agard, Oliver, Christian Helmreich, Hélène Vinckel-Roisin (Hrsg.): Das Populäre. Untersuchungen zu Interaktionen und Differenzierungsstragien in Literatur, Kultur und Sprache, Frankfurt. a. Main 20II. 
Aichinger, Manuela: Rot-Weiß-Rot Linz und das Rundfunkwesen in Oberösterreich 1954 bis 1957/58, Diss., Univ. Salzburg 1992.

Aichinger, Wilfried: Sowjetische Österreichpolitik 1943-I945, phil. Diss., Univ. Wien 1977.

Albrich, Thomas: Österreichs jüdisch-nationale und zionistische Emigration. Holocaust und Nachkriegsplanung 1942-1945. In: Zeitgeschichte, 18. Jg., 1990/91, Heft 7-8, I83-197.

Allemann-Ghionda, Cristina: Dewey in Post-War Italy: The Case of Re-Education. In: Jürgen Oelkers/Heinz Rhyn (Eds.), Dewey and European Education, Dordrecht 2000, 53-68.

Altenhuber, Hans: Universitäre Volksbildung in Österreich 1895-1937 (= Nexus. Zur Geschichte der Erwachsenenbildung, Bd. I), Wien 1995.

Amlung, Ullrich: Adolf Reichwein I898-I944. Ein Lebensbild des politischen Pädagogen, Volkskundlers und Widerstandskämpfers. 2 Bde., Diss., Univ. Marburg I99I.

Amlung, Ullrich: Reichwein, Adolf. In: Neue Deutsche Biographie. Bd. 21, Berlin 2003.

Anderle, Michaela: Todesmühlen in Wien. Auf den Spuren eines Films im Dienste der Re-education, Dipl.-Arb., Univ. Wien 2009.

Angetter, Daniela: Erfassung der von der NS-Justiz in Wien in der Zeit von 1938-1945 Hingerichteten, die als Studienleichen dem Anatomischen Institut der Universität Wien zugwiesen wurden. In: Senatsprojekt der Universität Wien. Untersuchungen zur Anatomischen Wissenschaft in Wien. 1938-I945. Hrsg. v. Akademischen Senat der Universität Wien, Wien 1998.

Arias, Ingrid: Die Medizinische Fakultät von 1945 bis 1955: Provinzialisierung oder Anschluss an die westliche Wissenschaft? In: Grandner/Heiß/Rathkolb (Hrsg.), Zukunft mit Altlasten, a.a.O., 68-88.

Arias, Ingrid: Entnazifizierung an derWiener Medizinischen Fakultät: Bruch oder Kontinuität? Das Beispiel des Anatomischen Instituts. In: Zeitgeschichte, 3r. Jg., 2004, Heft 6, 339-369.

Armstrong, Anne: Unconditional surrender. The impact of the Casablanca policy upon World War II., New Brunswick/N.J. r96r.

Armus, Seth D.: French anti-Americanism, 1930-1948. Critical moments in a complex history, Lanham 2007.

Arndt, Richard T.: The First Resort of Kings. American Cultural Diplomacy in the Twentieth Century, Dulles 2005.

Arnu, Titus: „Wir lügen alle“.Margret Boveri I900-I975. In: Hans-Jürgen Jacobs/Wolfgang R. Langenbucher (Hrsg.), Das Gewissen ihrer Zeit. Fünfzig Vorbilder des Journalismus, Wien 2004, 189-203.

Ash, Mitchell G., Wolfram Nieß, Roman Pils (Hrsg.), Geisteswissenschaften im Nationalsozialismus. Das Beispiel der Universität Wien, Göttingen 2 гı。.

Ash, Mitchell G.: Forced Migration and Scientific Change. Steps Towards a New Overview. In: Edward Timms/Jon Hughes (Eds.), Intellectual Migration and Cultural Transformation. Refugees from National Socialism in the English-Speaking World (= Veröffentlichungen des Instituts Wiener Kreis I2), Wien 2003, 24I-263.

Ash, Mitchell G.: Hochschulen und Wissenschaften im Nationalsozialismus und danach - Stand der Forschung und Projekte in Österreich. In: Stadler (Hrsg.), Österreichs Umgang mit dem Nationalsozialismus, a.a.O., 213-227.

Aurenhammer, Hans H.: Das Wiener Kunsthistorische Institut nach I945. In: Margarete Grandner/Gernot Heiß/Oliver Rathkolb (Hrsg.), Zukunft mit Altlasten. Die Universität Wien 1945 
bis 1955 (= Querschnitte I9. Einführungstexte zur Sozial-, Wirtschafts- und Kulturgeschichte), Innsbruck - Wien - München - Bozen 2005, I74-I88.

Aust, Martin, Daniel Schönpflug (Hrsg.): Vom Gegner lernen. Feindschaften und Kulturtransfers im Europa des 19. und 20. Jahrhunderts, Frankfurt a. Main 2007.

Aymard, Maurice: In memoriam: Clemens Heller (1917-2002). In: Social Sciences Information, Vol. 42,2003 , No. 3, 284-287.

Bader, Erwin: Ernst Karl Winter und die Versöhnung der politischen Lager. In: Ulrich E. Zellenberg (Hrsg.), Konservative Profile. Ideen \& Praxis in der Politik zwischen FM Radetzky, Karl Kraus und Alois Mock, Graz - Stuttgart 2003, 363-378.

Balfour, Michael: In retrospect: Britain's Policy of „Re-education“. In: Nicholas Pronay/Keith Wilson (Eds.), The Political Re-Education of Germany and Her Allies After World War II, Kent I985, I39-I50.

Bandhauer, Wolfgang: Niemals vergessen! Elise Richter zum Gedenken. In: Semiotische Berichte, I985, Heft I-2, I65-I79.

Barber, Benjamin: Fears's Empire. War Terrorism and Democracy, New York 2003.

Barclay, David E. (Ed.): Transatlantic images and perceptions. Germany and America since I776, Washington D.C. 1997 .

Barth, Boris, Jürgen Osterhammel (Hrsg.): Zivilisierungsmissionen. Imperiale Weltverbesserung seit dem I8. Jahrhundert, Konstanz 2005.

Bauer, Ingrid: Americanizing/Westernizing Austrian Women: Three Scenarios from the 1950s to the r97os. In: Bischof/Pelinka, The Americanization/Westernization of Austria, a.a. O., I70-I85.

Bauer, Ingrid: Welcome Ami Go Home. Die amerikanische Besatzung in Salzburg 1945-1955. Erinnerungslandschaften aus einem Oral-History-Projekt, Salzburg - München I998.

Bauer, Ingrid: Die „Ami-Braut“- Platzhalterin für das Abgespaltene? Zur (DE-)Konstruktion eines Stereotyps der österreichischen Nachkriegsgeschichte, 1945-1955. In: L'Homme: Zeitschrift für feministische Geschichtswissenschaft, 7, I996, Heft I, I07-I2I.

Bauer, Ingrid: „USA-Bräute“: Österreichisch-Amerikanische Eheschließungen auf den Salzburger Standesamt. In: Erich Marx (Hrsg.), Befreit und Besetzt. Chronik der Stadt Salzburg 1945-1955, Salzburg 1996, I47-151.

Bauer, Kurt: „Kalkulierte Eskalation. Antisemitische Ausschreitungen an den Wiener Universitäten und Hochschulen in den frühen I93oer-Jahren“. Vortrag bei dem Workshop „Alma mater antisemitica“ (I5--I6. Juni I2OI2) an der Österreichischen Akademie der Wissenschaften in Wien. [Unveröffentlichtes Manuskript, im Besitz d. Verfassers].

Bauer, Kurt: Lueger und die Lausbuben. In: Die Presse, 27. April 2012.

Bauerkämper, Arnd, Konrad H. Jarausch, Marcus M. Payk (Hrsg.): Demokratiewunder. Transatlantische Mittler und die kulturelle Öffnung Westdeutschlands 1945-1970, Göttingen 2005.

Bauermeister, Ronald: Pax Americana versus „Krieg der Kulturen“. Studie über die Chancen einer von den USA dominierten Weltordnung für das 2I. Jahrhundert im Kontext historischer Ereignisse und gegenwärtiger Entwicklungen im politischen Europa, Diss., Freie Universität Berlin 2004. 
Baumunk, Bodo-Michael: Ein Pfadfinder der „Geopolitik“- Colin Ross und seine Reisefilme. In: Jörg Schöning (Red.), Triviale Tropen. Exotische Reise- und Abenteuerfilme aus Deutschland 1919-1939, München 1997, 85-94.

Becker, Horst, Liselotte Stürzebecher: Die Westdeutsche Bildungskrise. Ursachen, Wirkungen, Auswege. Hrsg. v. Deutsches Pädagogisches Zentralinstitut (Berlin-Ost), Berlin I967.

Beer, Siegfried: Alliierte Planung, Propaganda und Penetration I943-I945. Die künftigen Besatzungsmächte und das wiederzuerrichtende Österreich, von der Moskauer Deklaration bis zur Befreiung. In: Das Burgenland im Jahr 1945. Beiträge zur Landes-Sonderausstellung 1985. Hrsg. v. Stefan Karner, Eisenstadt 1985, 67-88.

Beer, Siegfried: Die britische Entnazifizierung in Österreich 1945-1948. In: Schuster/Weber (Hrsg.), Entnazifizierung, a.a.O., 399-430.

Beer, Siegfried: Exil und Emigration als Information. Zur Tätigkeit der Foreign Nationalities Branch (FNB) innerhalb des amerikanischen Kriegsgeheimdienstes COI bzw. OSS, I94I-I945. In: Jahrbuch 1989. Dokumentationsarchiv des österreichischen Widerstandes. Redaktion: Siegwald Ganglmair, Wien I989, I32-I43.

Benjamin, Walter: Zur Kritik der Gewalt und andere Aufsätze, Frankfurt a. Main r98I.

Beimrohr, Wilfried: Entnazifizierung in Tirol. In: Schuster/Weber (Hrsg.), Entnazifizierung, a.a.O., 97-Ir6.

Belmonte, Laura A.: Selling the American Way. U.S. Propaganda and the Cold War, Philadelphia 2008.

Benedikt, Michael, Reinhold Knoll, Cornelius Zehetner (Hrsg.): Verdrängter Humanismus - verzögerte Aufklärung. Bd. V: Im Schatten der Totalitarismen. Vom philosophischen Empirismus zur kritischen Anthropologie. Philosophie in Österreich 1920-I95I, Wien 2005.

Benetka, Gerhard: Entnazifizierung und verhinderte Rückkehr. Zur personellen Situation der akademischen Psychologie in Österreich nach 1945. In: Österreichische Zeitschrift für Geschichtswissenschaften, 9. Jg., 1998, Heft 2, 188-217.

Benjamin, Walter: Politisierung der Intelligenz. Zu S. Kracauers ,Die Angestellten‘. In: Siegfried Kracauer, Die Angestellten. Aus dem neuesten Deutschland, Frankfurt a. Main 1971 [1930], ir8.

Berger, Gottfried: Amerika im XIX. Jahrhundert. Die Vereinigten Staaten im Spiegel zeitgenössischer deutschsprachiger Reiseliteratur, Wien 1999.

Berger, Gottfried: Das Bild der Vereinigten Staaten von Nordamerika in der deutschen Reiseliteratur des 19. Jahrhunderts. Unter besonderer Berücksichtigung von Werk und Persönlichkeit des Österreichers Karl Postl, phil. Diss., Univ. Wien 1945.

Berghahn, Volker R.: Awkward Relations. American Perceptions of Europe, European Perceptions of America. In: Alexander Stephan, Americanization and Anti-Americanism. The German encounter with American culture after 1945, New York 2005, 238-252.

Berghahn, Volker R.: Industriegesellschaft und Kulturtransfer. Die deutsch-amerikanischen Beziehungen im 20. Jahrhundert (= Kritische Studien zur Geschichtswissenschaft, Bd. 182), Göttingen 20Io.

Berghahn, Volker: Transatlantische Kulturkriege. Shepard Stone, die Ford-Stiftung und der europäische Antiamerikanismus (=Transatlantische Historische Studien, Bd. 2I), Stuttgart 2004. 
Bergmann, Ingried: Die Kulturpolitik nach 1945 aus Sicht des österreichischen Nationalrates im Vergleich mit dem 3. Reich und im Umfeld des Zeitgeschehens, Dipl.-Arb., Univ. Wien 1989.

Biess, Frank Peter: Zwischen Ford und Hollywood. Amerika und der Amerikanismus in der Weimarer Republik, I924-I930, MA Thesis, Washington University 1992.

Bihl, Wolfdieter: Orientalistik an der Universität Wien. Forschungen zwischen Maghreb und Ostund Südasien. Die Professoren und Dozenten,Wien - Köln - Weimar 2009.

Billinger, Robert D. Jr.: „Austrian“ POWs in America, 1942-1946. In: Zeitgeschichte, 29. Jg., 2002, Heft 3, I23-I32.

Billinger, Robert D. Jr.: Nazi POWs in the Tar Heel State, Gainsville FL 2008.

Billington, Ray Allen: Land of Savagery, Land of Promise. The European Image of the American Frontier, New York - London I98I.

Bischof, Günter: Anglo-amerikanische Planungen und Überlegungen der österreichischen Emigration während des Zweiten Weltkrieges für Nachkriegs-Österreich. In: Manfried Rauchensteiner/Wolfgang Etschmann (Hrsg.), Österreich 1945. Ein Ende und viele Anfänge, Graz - Wien 1997, I5-51.

Bischof, Günter: Austria in the First Cold War, 1945-55. The Leverage of the Weak, London 1999.

Bischof, Günter, Anton Pelinka, Dieter Stiefel (Eds.): The Marshall Plan in Austria (= Contemporary Austrian Studies VIII), New Brunswick 2000.

Bischof, Günter, Anton Pelinka (Eds.): The Americanization, Westernization of Austria, New Brunswick 2004.

Bischof, Günter: Austrian Anti-Americanism after World War II. In: Draxlbauer/Fellner/Fröschl (Eds.), (Anti-)Americanisms, a.a.O., I40-I7I.

Bischof, Günter: Vom Elend der österreichischen Geschichtsschreibung zum Kalten Krieg. In: Reinhard Krammer/Christoph Kühberger/Franz Schausberger (Hrsg.), Der forschende Blick. Beiträge zur Geschichte Österreichs im 20. Jahrhundert. Festschrift für Ernst Hanisch zum 7o. Geburtstag, Wien - Köln - Weimar 2010, 371-390.

Bischof, Günter, Stefan Karner/Barbara Stelzl-Marx (Hrsg.): Kriegsgefangene des Zweiten Weltkriegs. Gefangennahme - Lagerleben - Rückkehr (= Kriegsfolgen-Forschung. Hrsg. v. Stefan Karner, Bd. 4.), Wien - München 2005.

Bischof, Günter: Two Sides of the Coin: The Americanization of Austria and Austrian AntiAmericanism. In: Alexander Stephan (Ed.), The Americanization of Europe. Culture, Diplomacy, and Anti-Americanism after 1945, New York - Oxford 2006, I47-18I.

Bitterli, Urs: God's own country? Einige Überlegungen zum Antiamerikanismus. In: Thomas Beck/Marília dos Santos Lopes/Christian Rödel (Hrsg.), Barrieren und Zugänge. Die Geschichte der europäischen Expansion, Wiesbaden 2004, 232-247.

Black, Edwin: IBM and the Holocaust, The Strategic Alliance between Nazi Germany and America's most Powerful Corporation. 3. Aufl., Washington D.C., 2009.

Blaustein, George Holt Jr.: To the Heart of Europe: Americanism, the Salzburg Seminar, and Cultural Diplomacy, Diss., Harvard University, 2 oro.

Bockhorn, Olaf: „Die Angelegenheit Dr. Wolfram, Wien“. Zur Besetzung der Professur für germanisch-deutsche Volkskunde an der Universität Wien. In: Mitchell G. Ash/Wolfram Nieß/Ro- 
man Pils (Hrsg.), Geisteswissenschaften im Nationalsozialismus. Das Beispiel der Universität Wien, Göttingen 2010, 199-224.

Bostein, Leon: Hollywood und die Geburt des audiovisuellen Amerika. In: Werner Hanak, (Hrsg.), Bigger than Life. roo Jahre Hollywood. Eine jüdische Erfahrung. Anlässlich der Ausstellung „Bigger than Life“. roo Jahre Hollywood. Eine jüdische Erfahrung. Jüdisches Museum Wien, I9. Oktober 20II-I. April 20I2, Berlin 20II, 22-29.

Botz, Gerhard: Nationalsozialismus in Wien. Machtübernahme und Herrschaftssicherung, Radikalisierung 1938/39, überarb. u. erweiterte Aufl., mit einem Nachwort v. Karl R. Stadler, Wien 2008.

Bouvier, Friedrich, Helfried Valentinitsch (Red.): Graz 1945 (= Historisches Jahrbuch der Stadt Graz, Bd. 25), Graz I994.

Baudrillard, Jean: Amerika, München 1987.

Bourdieu, Pierre: Sozialer Sinn. Kritik der theoretischen Vernunft, Frankfurt a. Main 1993.

Braun, Birgit: Umerziehung in der amerikanischen Besatzungszone. Die Schul- und Bildungspolitik in Württemberg-Baden von I945 bis I949 (= Geschichte, Bd. 59), Münster 2004.

Braunbeck, Joseph: Der andere Physiker. Das Leben von Felix Ehrenhaft, Wien - Graz 2003.

Bredella, Lothar, Dietmar Haack (Eds.): Perceptions and Misperceptions. The US and Germany. Studies in Intercultural Understanding, Tübingen 1988.

Brewer, Susan A.: To Win the Peace. British Propaganda in the United States during World War II, Ithaca - London 1997 .

Brint, Steven, Jerome Karabel: The Diverted Dream: Community Colleges on the Promise of the Educational Opportunity in America, 1900-I985, New York 1989.

Broch, Hermann: Die Schlafwandler. Eine Romantrilogie (= Kommentierte Werkausgabe. Hrsg. v. Paul Michael Lützeler, Bd. I), Frankfurt a. Main I994.

Brogi, Alessandro: Confronting America. The Cold War between the United States and Communists in France and Italy, Chapel Hill 20 or.

Bruckmüller, Ernst (Hrsg.): Wiederaufbau in Österreich 1945-I955, Wien 2006.

Bruckschwaiger, Karl: Othmar Spann. Ein österreichischer Vertreter der konservativen Revolution? In: Michael Benedikt/Reinhold Knoll/Cornelius Zehetner (Hrsg.): Verdrängter Humanismus verzögerte Aufklärung. Bd. V: Im Schatten der Totalitarismen. Vom philosophischen Empirismus zur kritischen Anthropologie. Philosophie in Österreich 1920-I95I, Wien 2005, 460-466.

Buchner, Thomas: Alfons Dopsch ( I868-I953). Die „Mannigfaltigkeit der Verhältnisse“. In: Karel Hruza (Hrsg.), Österreichischer Historiker 1900-I945. Lebensläufe und Karrieren in Österreich, Deutschland und der Tschechoslowakei in wissenschaftsgeschichtlichen Porträts, Wien - Köln Weimar 2008, 97-I24.

Bukey, Evan Burr: Hitlers Österreich. „Eine Bewegung und ein Volk“, Hamburg-Wien $200 r$.

Bungenstab, Ernst: Umerziehung zur Demokratie? Re-education-Politik im Bildungswesen der USZone I945-49, Düsseldorf I970.

Bungenstab, Karl: Die Ausbildung der amerikanischen Offiziere für die Militärregierung nach 1945 . In: Jahrbuch für Amerikastudien, I8, 1973, 195-212. 
Bunkert, Heike: Das Nationalkomitee und der Westen. Die Reaktion der Westalliierten auf das NKFD und die Freien Deutschen Bewegungen 1943-I948 (=Transatlantische historische Studien, Bd. 8), Stuttgart 1997.

Bunzl, John: American attitudes toward Austria and Austrian-German relations since 1945. In: David F. Good/Ruth Wodak (Eds.), From World War to Waldheim. Culture and Politics in Austria and the United States, New York - Oxford 1999.

Burschka, Manfred H.: Re-education und Jugendöffentlichkeit. Orientierung und Selbstverständnis der Nachkriegsjugendpresse I945-I948. Ein Beitrag zur politischen Kultur der Nachkriegszeit, Diss., Univ. Göttingen 1991.

Busch, Jürgen, Kamila Maria Staudigl-Ciechowicz: „Ein Kampf ums Recht“? Bruchlinien in Recht, Kultur und Tradition in der Kontroverse zwischen Kelsen und Hold-Ferneck an der Wiener Juristenfakultät. In: Szabolcs Hornyák/Botond Juhász/Krisztina Korsósné Delacasse / Zuszsanna Peres (Eds.), Turning Points and Breaklines (= Jahrbuch Junge Rechtsgeschichte 4), München 2009, IIO-I38.

Busch, Jürgen: Alfred Verdross - Ein Mann des Widerspruchs? Teil 2. Verdross im Gefüge der Wiener Völkerrechtswissenschaft vor und nach 1938. In: Thomas Olechowski/Ilse Reiter et al. (Hrsg.), Vertriebenes Recht - Vertreibendes Recht. Die Wiener Rechtswissenschaftliche Fakultät zwischen 1938 und 1945, Wien 2010, 5. [Unpubliziertes Manuskript im Erscheinen].

Buttinger, Joseph: Das Ende einer Massenpartei. Am Beispiel Österreichs, Frankfurt a. Main 1954.

Cardozier, V.R.: Colleges and Universities in World War II, Westport 1993.

Carruthers, Susan L.: Cold War Captives. Imprisonment, Escape and Brainwashing, Berkely 2009.

Carty, Anthony: Alfred Verdross and Othmar Spann: German Romantic Nationalism, National Socialism and International Law. In: European Journal of International Law, 6, 1995, 78-97.

Caswell, Hollis L.: William B. Featherstone, I900-I95I. In: Teachers College Record, Vol. 52, I95I, No. 8,5 I2-514.

Caute, David: The Dancer Defects. The Struggle for Cultural Diplomacy during Cold War, Oxford New York 2003.

Cheval, Rene: Die Bildungspolitik in der Französischen Besatzungszone. In: Heinemann (Hrsg.), Umerziehung und Wiederaufbau, a.a.O., I90-200.

Chomsky, Noam, Laura Nader, Immanuel Maurice Wallerstein: The Cold War \& the University. Toward an intellectual history of the postwar years, New York 1997.

Clemens Heller - Founder of the „Marshall Plan of the Mind“. In: Austrian Press and Information Service, Washington D.C., Vol. 55, September/October 2002. Zit. nach: http://www.salzburgglobal.org/current/history-b.cfm?goto=heller [Zugriff am 2. Jänner 20I3].

Compton, James V.: Hitler und die USA. Die Amerikapolitik des Dritten Reiches und die Ursprünge des Zweiten Weltkrieges, Oldenbourg 1968.

Conze, Eckart: Wege in die Atlantische Gemeinschaft. Amerikanisierung und Westernisierung in Westeuropa nach 1945. In: Reiner Marcowitz (Hrsg.), Nationale Identität und transnationale Einflüsse. Amerikanisierung, Europäisierung und Globalisierung in Frankreich nach dem Zweiten Weltkrieg, München 2007, 72-86. 
Conze, Vanessa: Das Europa der Deutschen. Ideen von Europa in Deutschland zwischen Reichstradition und Westorientierung (1920-1970), München 2005.

Corke, Sarah-Jane: US Covert Operations and Cold War Strategy. Truman, Secret Warfare and the CIA, 1945-53, New York 2008.

Coser, Lewis: Die österreichische Emigration als Kulturtransfer, Europa - Amerika. In: Friedrich Stadler (Hrsg.), Vertriebene Vernunft. Bd. II, Emigration und Exil österreichischer Wissenschaft, Wien - München 1988.

Crick, Bernard R. (Ed.): Active Citizenship. What It Could Achieve and How, Edinburgh 2009.

Crockatt, Richard: After 9/Ir. Cultural dimension of American global power, London 2007.

Crockatt, Richard: America embattled. September II, anti-Americanism, and the global order, London 2003.

Cull, Nicolas J.: The Cold War and the United States Information Agency. American Propaganda and Public Diplomacy, 1945-1989, Cambridge 2008.

Culver, John C., John Hyde: American Dreamer. The Life and Times of Henry A. Wallace, New York 2000 .

Czaja, Marek: Die USA und ihr Aufstieg zur Weltmacht um die Jahrhundertwende. Die Amerikaperzeption der Parteien im Kaiserreich, Berlin 2006.

Czeike, Felix (Hrsg.): Historisches Lexikon Wien (in 5 Bänden). Band 3: Ha-La, Wien 1994.

Dachs, Herbert: Österreichische Geschichtswissenschaft und „Anschluß“ I918-I938, Wien - Salzburg I974.

Dallek, Robert: Franklin D. Roosevelt and American Foreign Policy, I932-1945, New York 1968.

Daniel, Silvia: A Brief Time to Discuss America. Der Ausbruch des Ersten Weltkriegs im Urteil amerikanischer Politiker und Intellektueller (=Internationale Beziehungen. Theorie und Geschichte, Bd.3), Göttingen 2008.

Daniels, Gordon: The Re-education of Imperial Japan. In: Nicholas Pronay/Keith Wilson (Eds.), The Political Re-Education of Germany and Her Allies After World War II, Kent 1985, 203-2I8.

Danyel, Jürgen: Politische Rituale als Sowjetimporte. In: Konrad Jarausch/Hannes Siegrist (Hrsg.), Amerikanisierung und Sowjetisierung in Deutschland 1945-1970, Frankfurt a. Main 1997.

Darling, Arthur B.: The Central Intelligence Agency. An Instrument of Government, to I950, Pennsylvania State University - London I990.

Dater, Henry Murray: The Mission of American Liberal Scholarship in the New World Order. In: Henry.J. Kellermann, Cultural relations as an Instrument of U.S. Foreign Policy. The Educational Exchange Program between the United States and Germany 1945-1954 (= Department of State Publication 8931), Washington D.C. 1978.

De Tocqueville, Alexis: Über die Demokratie in Amerika, Stuttgart I985.

Dean, Robert D.: Imperial Brotherhood. Gender and the Making of Cold War Foreign Policy, Amherst - Massachusetts 200I.

Defty, Andrew: Britain, America and Anti-Communist Propaganda 1945-53, London 2004.

Deibel, Terry L., John Lewis Gaddis (Eds.): Containing the Soviet Union. A critique of U.S. policy, Washington D.C. 1987 . 
Deicke, Gertrud: Das Amerikabild der deutschen öffentlichen Meinung von I898-I9I4, Diss., Univ. Hamburg 1956.

Delavos, Paul M., Caroline Hefert: „Alltagsgeschäft“ - Daten und Fakten zur Gründung des Zentralinstituts für Theaterwissenschaft. In: Peter/Payr (Hrsg.), „Wissenschaft nach der Mode“, a.a.O., $5^{2-75}$.

Deutsch, Julius: Ein weiter Weg. Lebenserinnerungen, Zürich - Leipzig - Wien I96o.

DeVita, Philip R. (Ed.): Distant mirrors. America as a foreign culture, Belmont/Calif. 1993.

Diamond, Sigmund: Compromised Campus. The Collaboration of Universities with the Intelligence Community, 1945-1955, New York - Oxford 1992.

Diner, Dan: Feindbild Amerika. Über die Beständigkeit eines Ressentiments, München 2002.

Diner. Dan (Hrsg.): Zivilisationsbruch. Denken nach Auschwitz, I988.

Diner, Dan: Gegenläufige Gedächtnisse. Über Geltung und Wirkung des Holocaust, Göttingen 2007.

Dinnerstein, Leonard: Antisemitism in America, New York 1994.

Doering-Manteuffel, Anselm: Wie westlich sind die Deutschen? Amerikanisierung und Westernisierung im 20. Jahrhundert, Göttingen 1999.

Dohle Oskar, Peter Eigelsberger: Camp Marcus W. Orr. „Glasenbach“ als Internierungslager nach I945 (= Mitteilungen des Salzburger Landesarchivs I5), Linz - Salzburg 2009

Donaldson, Scott (in collaboration with R.H.Winnick): Archibald MacLeish. An American Life, Boston - London 1992.

Dorn, Walter L.: Inspektionsreisen in der US-Zone. Notizen, Denkschriften und Erinnerungen aus dem Nachlaß übersetzt und hrsg.v. von Lutz Niethammer (= Schriftenreihe der Vierteljahreshefte für Zeitgeschichte Nr. 26), Stuttgart 1973.

Dostal, Thomas: Das „braune Netzwerk“ in Linz. Die illegalen nationalsozialistischen Aktivitäten zwischen 1933 und 1938. In: Fritz Mayrhofer/Walter Schuster (Hrsg.), Nationalsozialismus in Linz. Bd. I, Linz 200I, 2I-136.

Downs, Robert B.: Images of America. Travelers from abroad in the New World, Urbana/Ill., 1987.

Draxlbauer, Michael, Astrid M. Fellner, Thomas Fröschl (Eds.): (Anti-)Americanisms (=American Studies in Austria. Hrsg. v. Astrid M. Fellner/Klaus Rieser/Hanna Wallinger, Vol. 2), Wien 2004.

Drimmel, Heinrich: Die Antipoden. Die Neue Welt in den USA und das Österreich vor 19I8, Wien München I984.

Dudden, Arthur Power, Russel R. Dynes; The Fulbright experience. Encounters and Transformations. Foreword by J. William Fulbright, New Brunswick 1987.

Durzak, Manfred: Perspektiven des Amerikabildes, historisch, gegenwärtig. Reisen in der Zeitmaschine. In: Sprache im technischen Zeitalter, 56, 1975, 297-310.

Dvořák, Johann: Otto Neurath und die Volksbildung. Einheit der Wissenschaft, Materialismus und umfassende Aufklärung. In: Friedrich Stadler (Hrsg.), Ausstellung Arbeiterbildung in der Zwischenkriegszeit. Otto Neurath und sein Gesellschafts- und Wirtschaftsmuseum, Politische Grafik von Gerd Arntz und den Konstruktivisten, Wien - München I982, I49-156.

Ebner, Paulus: Politik und Hochschule. Die Hochschule für Bodenkultur I9I4-I955 (=Forschungen zur Wiener Stadtgeschichte, Bd. 37), Wien 2002. 
Eckert, Astrid M.: Feindbilder im Wandel: Ein Vergleich des Deutschland- und Japanbildes (= Studien zur Geschichte, Politik und Gesellschaft Nordamerikas, Bd. I3), Münster I999.

Eckert, Hans-Wilhelm: Konservative Revolution in Frankreich? Die Nonkonformisten der Jeune Droite und des Ordre Nouveau in der Krise der zoer Jahre (= Studien zur Zeitgeschichte, Bd. $5^{8}$ ), München 2000.

Ehmer, Josef, Annemarie Steidl, Hermann Zeitloser: Migration Patterns in Late Imperial Vienna (= KMI Working Paper Series: Working Paper Nr. 3), Kommission für Migrations- und Integrationsforschung, Österreichische Akademie der Wissenschaften, Wien 2004.

Ehs, Tamara: Die Entzauberung von Staat und Recht. Hans Kelsen als Vortragender in der Wiener Volksbildung. In: Spurensuche. Zeitschrift für Geschichte der Erwachsenenbildung und Wissenschaftspopularisierung, I7. Jg., 2006, Heft I-4, 6I-92.

Ehs, Tamara: Hans Kelsen und politische Bildung im modernen Staat (=Schriftenreihe des HansKelsen-Instituts, Bd. 29), Wien 2007.

Ehs, Tamara: Vertreibung in drei Schritten. Hans Kelsens Netzwerk und die Anfänge österreichischer Politikwissenschaft. In: Österreichische Zeitschrift für Geschichtswissenschaften [Schwerpunkt: „Vertriebene Wissenschaft“], 2I. Jg., 2010, Bd. 3, I46-I73.

Einwitschläger, Arno: Amerikanische Wirtschaftspolitik in Österreich 1945-1949, Diss., Univ. Wien I984.

Eisterer, Klaus: Französische Besatzungspolitik. Tirol und Vorarlberg I945/46 (=Innsbrucker Forschungen zur Zeitgeschichte, hrsg. v. Rolf Steininger, Bd. 9), Innsbruck 1992.

Elder, Robert E.: The Information Machine. The United States Information Agency and American Foreign Policy, Syracuse/New York 1968.

Ellemauer, Gottfried: Rückkehr unerwünscht. Remigration in Österreich nach 1945, Dipl.-Arb., Univ. Wien 1992.

Ellwod, David: From ,Re-education' to Selling of the Marshall Plan in Italy. In: Nicholas Pronay/Keith Wilson (Eds.), The Political Re-Education of Germany and Her Allies After World War II, Kent 1985, 219-240 ff.

Ellwood, David W.: Comparative Anti-Americanism in Western Europe. In: Heide Fehrenbach/Uta G. Poiger (Eds.), Transaction, Transgressions, Transformations, New York 200o, 26-44. Ellwood, David (Ed.): Hollywood in Europe. Experiences of a Cultural Hegemony, Amsterdam I994. Enderle-Burcel, Gertrude (unter Mitarb. v. Johanns Kraus): Christlich - Ständisch - Autoritär. Mandatare im Ständestaat 1934-I938. Biographisches Handbuch der Mitglieder des Staatsrates, Bundeskulturrates, Bundeswirtschaftsrates und Länderrates sowie des Bundestages. Hrsg. v. Dokumentationsarchiv des österreichischen Widerstandes, Wien r99r.

Engelbrecht, Helmut: Die Eingriffe der Alliierten in das österreichische Schul- und Erziehungswesen nach 1945. In: Heinemann (Hrsg.), Umerziehung und Wiederaufbau, a.a.O., 278-308.

Engelbrecht, Helmut: Geschichte des österreichischen Bildungswesens. Erziehung und Unterricht auf dem Boden Österreichs. Bd. 4. Von I848 bis zum Ende der Monarchie, Wien 1986.

Ensinger, Tami: Linke Projektionen. Zum pädagogischen Umgang mit Antisemitismus unter besonderer Berücksichtigung des Antisemitismus von links, Dipl.-Arb., Techn. Univ. Darmstadt 2006. 
Eppel, Peter: Die Vereinigten Staaten von Amerika. In: Friedrich Stadler (Hrsg.), Vertriebene Vernunft II. Emigration und Exil österreichischer Wissenschaft I930-1940. Teilband 2, unveränderte Neuaufl., Münster 2004, 986-997.

Eppel, Peter: Österreichische Exilpolitik in den USA. In: Österreicher im Exil USA, 1938-1945. Eine Dokumentation. 2 Bde. Hrsg. v. Dokumentationsarchiv des österreichischen Widerstands. [Einleitung, Auswahl und Bearbeitung: Peter Eppel], Wien 1995, 23I-687.

Erd, Rainer (Hrsg.): Reform und Resignation. Gespräche über Franz L. Neumann, Frankfurt a. Main 1985 .

Exenberger, Herbert (Hrsg.): Als stünd' die Welt in Flammen. Eine Anthologie ermordeter sozialistischer SchriftstellerInnen, Wien 2000.

Exenberger, Herbert: Adolf Unger.In: Herbert Exenberger (Hrsg.), Als stünd' die Welt in Flammen. Eine Anthologie ermordeter sozialistischer SchriftstellerInnen, Wien 2000, $280 \mathrm{ff}$.

Falböck, Gaby: Nachrichten aus der Zwischenwelt. Die Austro American Tribune, eine österreichische Exilzeitschrift, erschienen in New York. In: John M. Spalek/Konrad Feilchenfeldt/Sandra H. Hawrylchak (Hrsg.), Deutschsprachige Exilliteratur seit I933. Bd.3: USA, Berlin - New York 2010, 419-439.

Farber, David (Ed.): What they think of us. International perceptions of the United States since 9/II, Princeton 2007.

Faßmann, Heinz: Auswanderung aus der österreichisch-ungarischen Monarchie I869-I9Io. In: Traude Horvath / Gerda Neyer (Hrsg.), Auswanderung aus Österreich: Von der Mitte des I9. Jahrhundert bis zur Gegenwart. Mit einer umfassenden Bibliographie zur österreichischen Migrationsgeschichte, Wien - Köln - Weimar I996, 33-55.

Feichtiger, Johannes: Transatlantische Vernetzungen. Der Weg Hans Kelsens und seines Kreises in der Emigration. In: Walter/Ogris/Olechowski (Hrsg.), Hans Kelsen: Leben - Werk - Wirksamkeit, a.a.O., 315-332.

Feichtiger, Johannes: Wissenschaft zwischen den Kulturen. Österreichische Hochschullehrer in der Emigration 1933-1945, Frankfurt a. Main - New York 200I.

Feichtinger, Johannes: „... fresh nourishment to the arid soil...“. Britische Kulturpolitik in Österreich nach dem 2. Weltkrieg 1945-1948. In: Besatzung in Österreich. Beiträge zur Historischen Sozialkunde, 2, 1995, 57-62.

Feichtinger, Johannes, Eduard G. Staudinger: Aspekte des kulturellen Wiederaufbaus in der Steiermark zwischen Kooperation und Kontrolle. In: Siegfried Beer (Hrsg.), Die „britische“ Steiermark I945-I955 (= Forschungen zur geschichtlichen Landeskunde der Steiermark 38). Unter wiss. Mitarbeit v. Felix Schneider u. Johannes Feichtinger, Graz 1995, 499-527.

Feichtinger Johannes, Herbert Matis, Stefan Sienell, Heidemarie Uhl (Hrsg.), Die Akademie der Wissenschaften in Wien 1938-1945, Wien 2013.

Feichtinger Johannes, Dieter J. Hecht: Die Entnazifizierung an der Akademie der Wissenschaften. In: Feichtinger/Matis/Sienell/Uhl (Hrsg.), Die Akdemie der Wissenschaften 1938 bis 1945 , a.a.O., $\mathrm{I} 7 \mathrm{I}-\mathrm{I} 87$. 
Feichtinger Johannes, Hecht, Dieter J.: 1945 und danach. Eine Zäsur und zwei Kontinuitäten. In: Feichtinger/Matis /Sienell/Uhl (Hrsg.), Die Akdemie der Wissenschaften 1938 bis 1945, a.a.O., I89-I97.

Fellner, Fritz: Die außenpolitische und völkerrechtliche Situation Österreichs 1938. Österreichs Wiederherstellung als Kriegsziel der Alliierten. In: Erika Weinzierl/Kurt Skalnik (Hrsg.), Österreich - Die Zweite Republik. Bd. I, Graz 1972, 53-90.

Fellner, Fritz: Restauration oder Fortschritt. Hochschulprobleme aus der Sicht des Historikers. In: Heinz Fischer (Hrsg.), Versäumnisse und Chancen. Beiträge zur Hochschulfrage in Österreich, Wien - Hannover 1967 , II-28.

Fender, Stephen (Ed.): American and European national identities. Faces in the mirror, Keele 1996.

Fermi, Laura: Illustrious Immigrants. The Intellectual Migration from Europe 1930-I94I, Chicago London 1968.

Ferz, Sascha: Ewige Universitätsreform. Das Organisationsrecht der österreichischen Universitäten von den theresianischen Reformen bis zum UOG 1993 (= Rechts- und Sozialwissenschaftliche Reihe, Bd. 27), Frankfurt a. Main et al. 227.

Fessler, Gudrun: 1945-46 - das erste Schuljahr. Schulalltag, Entnazifizierung, Umerziehung und Wiederaufbau des steirischen Pflichtschulwesens im ersten Schuljahr nach Kriegsende, Dipl.Arb., Univ. Graz 1995 .

Feuerstein-Prasser, Michaela: Von der Besatzungspolitik zur Kulturmission. Französische Schulund Bildungspolitik in Österreich 1945-I955, Diss., Univ. Wien 2002.

Fischer, Heinz (Hrsg.): Einer im Vordergrund: Taras Borodajkewycz. Eine Dokumentation [unter Mitarbeit von Hugo Pepper], Wien - München 1966.

Fischer Heinz (Hrsg.): Versäumnisse und Chancen. Beiträge zur Hochschulfrage in Österreich, Wien - Hannover 1967 .

Fischer, Heinz-Dietrich (Ed.): The Pulitzer Prize Archive. Vol. I. International Reporting 1928-I985, München - London - New York - Oxford - Paris I987.

Fischer, Heinz-Dietrich: Reeducation und Pressepolitik unter britischem Besatzungsstatus. Die Zonenzeitung „Die Welt“ 1946-I950. Konzeption, Artikulation und Rezeption, Düsseldorf 1978. Fischl, Hans: Schulreform, Demokratie und Österreich I9I8-I950, Wien o.J. [I950].

Fleck, Christian: Autochthone Provinzialisierung Universität und Wissenschaftspolitik nach dem Ende der nationalsozialistischen Herrschaft in Österreich. In: Österreichische Zeitschrift für Geschichtswissenschaften, 7. Jg., 1996, Nr. I, 67-92.

Fleck, Christian: Österreichs Universitäten am Beginn der Zweiten Republik: Entnazifizierung und Nicht-Rückkehr der Vertriebenen, 2; zit. nach:

http://www.uni-graz.at/ fleck/pdf/texte/2002c_Zweite_Republil_Unis_scienceexile.pdf

Fleck, Christian: Österreichs Wissenschaften in den Augen amerikanischer Besucher. In: Thomas

Fröschl/Ursula Prutsch (Hrsg.), Österreich und die Amerikas (= Wiener Zeitschrift zur Geschichte der Neuzeit, 5. Jg., 2005, Heft I), II9-I34.

Fleck, Christian: Rückkehr unerwünscht. Der Weg der österreichischen Sozialforschung ins Exil.In: Friedrich Stadler (Hrsg.), Vertriebene Vernunft I. Emigration und Exil österreichischer Wissen- 
schaft 1930-1940 (=Veröffentlichungen des Ludwig Boltzmann-Institutes für Geschichte der Gesellschaftswissenschaften, Sonderband 2), Wien - München 1987, I82-213.

Fleck, Christian:Wie Neues nicht entsteht. Die Gründung des Instituts für Höhere Studien in Wien durch Ex-Österreicher und die Ford-Foundation. In: Österreichische Zeitschrift für Geschichtswissenschaften, II. Jg., 2000, Heft I, I29-I77.

Forster, Christine H.: Die Geschichte der Österreichischen Hochschülerschaft 1945-I955 (= Dissertationen der Universität Wien I66), Wien 1984.

Freeman, Jo: We will be heard. Women's struggles for political power in the United States, Lanham 2008.

Freud, Sigmund: Das Unbehagen in der Kultur. In: Sigmund Freud. Studienausgabe. Bd. IX. Fragen der Gesellschaft - Ursprünge der Religion, Frankfurt a. Main 2000.

Friedenthal-Haase, Martha (Hrsg.): Adolf Reichwein - Widerstandskämpfer und Pädagoge. Gedenkveranstaltung an der Friedrich-Schiller-Universität Jena 15. Oktober 1998, Erlangen - Jena 1999 .

Fromm, Erich, Max Horkheimer et al.: Studien über Autorität und Familie: Forschungsberichte aus dem Institut für Sozialforschung, Paris I936.

Fröschl, Thomas: Antiamerikanismus in Europa und Lateinamerika. Sieben historische Dimensionen. In: Thomas Fröschl (Hrsg.), Atlantische Geschichte (= Wiener Zeitschrift zur Geschichte der Neuzeit, 3.Jg., 2003, Heft 2), 82-97.

Fröschl, Thomas: Historical Roots of the European Anti-Americanism in the 18th and Igth Centuries. In: Michael Draxlbauer/Astrid M. Fellner/Thomas Fröschl (Eds.), (Anti-)Americanisms (=American Studies in Austria. Hrsg. v. Astrid M. Fellner/Klaus Rieser/Hanna Wallinger, Vol. 2), Wien 2004, 59-73.

Funk, Arthur L.: American and Soviet Views on Europe from Yalta to the Marshall Plan. In: Michel Dumoulin (Ed.), Wartime Plans for Postwar Europe 1940-I947 (=European Community Liaison Committee of Historians, Vol. 5), Paris - Baden-Baden 1995, 393-415.

Füssl, Karl-Heinz: Deutsch-Amerikanischer Kulturaustausch im 20. Jahrhundert. Bildung - Wissenschaft - Politik, Frankfurt a. Main 2004.

Füssl, Karl-Heinz: Die Umerziehung der Deutschen Jugend und Schule unter den Siegermächten des Zweiten Weltkriegs 1945-1955, Paderborn 1994.

Füssl, Karl-Heinz: Zwischen NS-Traumatisierung und Demokratie: Die Erziehungspolitik der USA in der deutschen Nachkriegsgeschichte (1945-I952). In: Paedagogocica Historica. International Journal of the History of Education, XXXIII, 1997, Heft I, 22I-246

Füssl, Karl-Heinz: Restauration und Neubeginn. Gesellschaftliche, kulturelle und reformpädagogische Ziele der amerikanischen, Re-education'-Politik nach 1945. In: Aus Politik und Zeitgeschichte. Beilage zur Wochenzeitung ,Das Parlament', B 6, 1997,3-I4.

Gaddis, John L.: Strategies of Containment. A Critical Appraisal of American Security Policy during the Cold War. Revised and Expanded Edition, Oxford 2005.

Gaddis, John L.: The United States and the Origins of Cold War, I94I-1947, New York 2000.

Gaiswinkler, Albrecht: Sprung in die Freiheit, Wien - Salzburg 1947. 
Ganglbauer, Stephan, Christian H. Stifter, Robert Streibel: Kein Ort des Verdrängens. Die Auseinandersetzung mit Austrofaschismus und Nationalsozialismus an Wiener Volkshochschulen. In: Jahrbuch 20II. Schwerpunkt: Vermittlungsarbeit mit Jugendlichen und Erwachsenen. Hrsg. vom Dokumentationsarchiv des österreichischen Widerstandes. Redaktion: Christine Schindler, Wien 2010, I43-185.

Gassert, Philipp: Amerika im Dritten Reich. Ideologie, Propaganda und Volksmeinung 1933-1945, Stuttgart 1997.

Gassert, Philipp: Amerikanismus, Antiamerikanismus, Amerikanisierung. Neue Literatur zur Sozial-, Wirtschafts-, und Kulturgeschichte des amerikanischen Einflusses in Deutschland und Europa. In: Archiv für Sozialgeschichte, Bd. 39, 1999, 53I-66I.

Gatschnegg, Markus: „Amerikabilder“ in der Berichterstattung der „Wiener Zeitung“ I86o bis I867, Dipl.-Arb., Univ. Wien 2004.

Geertz, Clifford: Dichte Beschreibung. Beiträge zum Verstehen kultureller Systeme, Frankfurt a. Main 1987.

Gehler, Michael (Hrsg.): Verschiedene europäische Wege im Vergleich. Österreich und die Bundesrepublik Deutschland I945/49 bis zur Gegenwart. Festschrift für Rolf Steininger zum 65. Geburtstag, Innsbruck - Wien 2007.

Geldmacher, Thomas: Der gute Mensch von Kiel? Marinerichter Otto Tschadek (1904-I969). In: Thomas Geldmacher/Magnus Koch/Hannes Metzler/Peter Priker/Lisa Rettl (Hrsg.), „Da machen wir nicht mehr mit...“. Österreichischer Soldaten und Zivilisten vor Gerichten der Wehrmacht, Wien 2010, 215-226.

Gerhardt, Uta: A Hidden Agenda of Recovery: The Psychiatric Conceptualization of Re-education for Germany in the United States during World War II. In: German History, Vol. I4, I996, No.3, 297-324.

Gerhardt, Uta: Talcott Parsons. An intellectual Biography, Cambridge 2002.

Gerhardt, Uta: The Medical Meaning of Reeducation for Germany: Contemporary Interpretation of Cultural and Institutional Change. In: Paedagogica Historia, XXXIII, I997, I, I35-I55.

Giddens, Anthony: Die Konstitution der Gesellschaft, Frankfurt a. Main - New York 1992.

Gießen, Bernhard: Europäische Identität und transnationale Öffentlichkeit. Eine historische Perspektive. In: Hartmut Kaelble/Martin Kirsch/Alexander Schmid-Gernig (Hrsg.), Transnationale Öffentlichkeit und Identitäten im 20. Jahrhundert, Frankfurt a. Main 2002, 67-84.

Gimbel, John: A German community under American occupation: Marburg, 1945-1952, Stanford I961.

Gimbel, John: Amerikanische Besatzungspolitik in Deutschland I945-1949, Frankfurt a. Main I97I.

Giordano, Gerard: Wartime Schools. How World War II Changed American Education (= History of Schools \& Schooling, Vol.34), New York - Washington D.C. 2004.

Godula, Alexander: Analyse und Diskussion der österreichischen Exilzeitschrift Freiheit für Österreich und ihrer Beilage Jugend und Kampf. Schriftliche Hausarbeit, SE Institut für Publizistik, Universität Wien, Wintersemester 2003/O4.

Goger, Renate: Die Beziehungen der Habsburgermonarchie zu den Vereinigten Staaten von Amerika von 1838 bis 1967, phil. Diss., Univ. Wien 2010. 
Goldner, Franz: Die österreichische Emigration 1938 bis 1945, Wien - München 1972.

Goller, Peter, Gerhard Oberkofler: Universität Innsbruck. Entnazifizierung und Rehabilitierung von Nazikadern (1945-1950), Innsbruck 2003.

Goller, Peter, Georg Tidl: Jubel ohne Ende. Die Universität Innsbruck im März 1938, Wien 20 I2.

Golsan, Richard J.: From French Anti-Americanisms and Americanization to the „American enemy“? In: Alexander Stephan (Ed.), The Americanization of Europe. Culture, Diplomacy, and Anti-Americanism after 1945, New York - Oxford 2006, 44-68.

Good, David F., Ruth Wodak (Eds.): From World War to Waldheim. Culture and Politics in Austria and the United States, New York - Oxford 1999.

Görtemaker, Heike M.: Einleitung. In: Margret Boveri, Amerikafibel für erwachsene Deutsche. Ein Versuch, Unverstandenes zu erklären, Berlin 2006.

Götz, Rainer: Der Wandel des Amerikabildes in der deutschsprachigen Literatur seit 1945. Mythos Amerika und Realität USA, phil. Diss., Univ. Graz 1979.

Graf, Doris: Die Kulturpolitik der Besatzungsmächte 1945-I955 und die Auswirkungen auf das Wiener Konzertleben, Dipl.-Arb., Univ. Wien 1995.

Gramsci, Antonio: Amerikanismus und Fordismus [§§ I-I6]. In: Antonio Gramsci, Gefängnishefte. Hefte 22 bis 29. Bd. 9. Hrsg. v. Peter Jehle/Klaus Bochmann/Wolfgang Fritz Haug, Berlin 1999.

Grandner Margarete, Gernot Heiß, Oliver Rathkolb (Hrsg.): Zukunft mit Altlasten. Die Universität Wien I945 bis I955 (= Querschnitte I9. Einführungstexte zur Sozial-, Wirtschafts- und Kulturgeschichte), Innsbruck - Wien - München - Bozen 2005,

Grandner, Margarete, Brigitta Bader-Zaar: Lehre und Forschung über Nordamerika an österreichischen Universitäten vom Beginn des I9. Jahrhunderts bis I955. In: Thomas Fröschl/Margarete Grandner/Birgitta Bader-Zaar (Hrsg.), Nordamerikastudien. Historische und literaturwissenschaftliche Forschungen aus den österreichischen Universitäten zu den Vereinigten Staaten und Kanada (=Wiener Beiträge zur Geschichte der Neuzeit, Bd. 24), Wien - München 2000, Io8-I73.

Grandner, Margarete: Das Studium an der Rechts- und Staatswissenschaftlichen Fakultät der Universität Wien 1945-1955. In: Grandner/Heiß/Rathkolb (Hrsg.), Zukunft mit Altlasten, a.a. O., 290-312.

Gräser, Marcus: Wohlfahrtsgesellschaft und Wohlfahrtsstaat. Bürgerliche Sozialreform und Welfare State Building in den USA und in Deutschland I880-I940, (= Bürgertum. Neue Folge. Studien zur Zivilgesellschaft, Bd. 6. Hrsg. v. Manfred Hettling/Paul Nolte), Göttingen 2009.

Green, Daniel M.: Constructivism and Comparative Politics, Armonk N.Y. 2002.

Greene, Jack P.: The intellectual construction of America. Exceptionalism and identity from $\mathrm{I}_{492}$ to ı80o, Chapel Hill, N.C. I993.

Greiner, Bernd: „Test the West“. Über die „Amerikanisierung“ der Bundesrepublik Deutschland.In: Mittelweg 36. Zeitschrift des Hamburger Instituts für Sozialforschung, 6, 1997, 16-54.

Grünzweig, Walter: Seeing the World as Others See it: J. William Fulbright, International Exchange, and the Quest for Peace. In: Lonnie Johnson/Karin Riegler (Eds.), Fulbright at Fifty. AustrianAmerican Educational Exchange 1950-2000, Wien [2000], 4-I3.

Guterl, Matthew Pratt: The Color of Race in America, I900-I940, Cambridge 200I. 
Haag, John: Othmar Spann. 1878-1950. In: Research Guide to European Historical Biography. Vol. 8, Washington D.C. $1993,465 \mathrm{I}-4662$.

Habermas, Jürgen: Erkenntnis und Interesse. Mit einem neuen Nachwort. 6. Aufl., Frankfurt a. Main I98I.

Hahn, Brigitte J.: Dokumentarfilme im Dienste der Umerziehung. Amerikanische Filmpolitik I9451953. In: Heiner Roß (Hrsg.), Lernen Sie diskutieren! Re-education durch Film. Strategien der westlichen Alliierten nach 1945, Babelsberg 2005, I9-32.

Hahn, Michael (Hrsg.): Nichts gegen Amerika. Linker Antisemitismus und seine lange Geschichte, Hamburg 2003 .

Hake, Barry J., Tom Steele, Alejandro Tiana (Eds.): Masters, Missionaries and Militants. Studies of Social Movements and Popular Adult Education 1890-I939, Leeds 1996.

Halbritter, Ulrike: Der Einfluss der alliierten Besatzungsmächte auf die österreichische Filmwirtschaft und Spielfilmproduktion in den Jahren 1945-1955, Dipl.-Arb., Univ. Wien 1993.

Hall, Murray G.: Österreichische Verlagsgeschichte 1918-I938. Bd. II: Belletristische Verlage der Ersten Republik, Wien - Köln - Graz i985.

Hall, Murray G., Christina Köstner: „... allerlei für die Nationalbibliothek zu ergattern ...“. Eine österreichische Institution in der NS-Zeit, Wien - Köln - Weimar 2006.

Hall, Stuart (Ed.): Representation. Cultural representations and signifying practices, London $200 \mathrm{I}$.

Hanak, Werner (Hrsg.): Bigger than Life. Ioo Jahre Hollywood. Eine jüdische Erfahrung. Anlässlich der Ausstellung „Bigger than Life“. Ioo Jahre Hollywood. Eine jüdische Erfahrung. Jüdisches Museum Wien, I9. Oktober 20II-I. April 20I2, Berlin 2011.

Hanisch, Ruth: Vom Wienerwald zum Central Park: Wiener Wohnen im New Yorker Exil. In: Eva B. Ottilinger (Hrsg.), Wohnen zwischen den Kriegen. Wiener Möbel zwischen den Kriegen I9I4-I94I, Wien - Köln - Weimar 2009, I3I-I4O.

Hanna, Christian: Das Linzer Landestheater 1945-1980. Ein Beitrag zu einer österreichischen Theatergeschichte. 2 Bde., Diss., Univ. Wien 1987.

Hannerz, Ulf: Cultural Complexity. Studies in the Social organization of meaning, New York 1992.

Hannerz, Ulf: Transnational connections. Culture, people, places, New York et al. 2009.

Hartleb, Florian: Rechts- und Linkspopulismus. Eine Fallstudie anhand von Schill-Partei und PDS, Wiesbaden 2004.

Hartmann, Gerhard: Der CV in Österreich. Seine Entstehung - seine Geschichte - seine Bedeutung (= Schriftenreihe der Bildungsakademie des ÖCV, Bd. 4). 4. überarb. Aufl., Kevelaer $20 I I$.

Hasebein, Heiko: Unerwünscht - toleriert - instrumentalisiert. Jazz und Swing im Nationalsozialismus. In: 1999, I0. Jg., I995, 38-52.

Hauptfeld, Georg, Oliver Rathkolb (Hrsg.), Zwei Leben. Erinnerungen eines sozialistischen Internationalisten zwischen Österreich und den USA [Democracy under fire] (=Böhlaus zeitgeschichtliche Bibliothek, Bd. I2), unter Mitarb. v. Christina Westmann, Wien - Köln I989.

Hegel, Georg Wilhelm Friedrich: Vorlesungen über die Philosophie der Geschichte. Werke Bd. I2, Frankfurt a. Main I970.

Heiber, Helmut: Universität unterm Hakenkreuz. Teil II: Die Kapitulation der Hohen Schulen. Das Jahr I933 und seine Themen. Bd. 2, München - New Providence - London - Paris 1994. 
Heideking Jürgen, Christoph Mauch (Hrsg.): Geheimdienstkrieg gegen Deutschland. Subversion, Propaganda und politische Planungen des amerikanischen Geheimdienstes im Zweiten Weltkrieg, Göttingen 1993.

Heil, Alan L. jr.: Voice of America. A History, Columbia 2003.

Heilingsetzer, Ariane, Maria Mesner, Heinz Rögl, Fritz Weber: Projektendbericht: Zur Geschichte des VSSTÖ I945-I970, unveröffentlichtes Manuskript, Wien I989.

Hein-Kremer, Maritta: Die amerikanische Kulturoffensive. Die Gründung und Entwicklung der amerikanischen Information Centers in Westdeutschland und West-Berlin, I945-I955, Köln 1996.

Heinemann, Manfred (Hrsg.): Umerziehung und Wiederaufbau. Mit einem Vorwort von Manfred Heinemann und einer Einleitung von Wilhelm Roeßler (= Veröffentlichung der Historischen Kommission der Deutschen Gesellschaft für Erziehungswissenschaft, Bd. 5), Stuttgart I98I.

Heinrich, Peter: Der Wiederaufbau des österreichischen Schulwesens nach dem Zweiten Weltkrieg. In: International Review of Education, 2. Jg., I956, Heft 4, 52-65.

Heinz, Karl Hans: Ernst Karl Winter. Ein Katholik zwischen Österreichs Fronten 1933-1938, Wien Köln - Graz I984.

Heiß, Gernot: „... wirkliche Möglichkeiten für eine nationalsozialistische Philosophie“? Die Reorganisation der Philosophie (Psychologie und Pädagogik) in Wien 1938 bis 1940. In: Kurt R. Fischer/Franz M. Wimmer (Hrsg.) Der geistige Anschluß. Philosophie und Politik an der Universität Wien 1930-1950, Wien I993, I30-169.

Heiß, Gernot: Die „Wiener Schule der Geschichtswissenschaft“ im Nationalsozialismus: ,Harmonie kämpfender und Rankescher erkennender Wissenschaft'? In: Ash /Nieß/Pils (Hrsg.), Geisteswissenschaften im Nationalsozialismus, a.a.O., 397-426.

Heiß, Gernot: Von der gesamtdeutschen zur europäischen Perspektive? Die mittlere, neuere und österreichische Geschichte sowie die Wirtschafts- und Sozialgeschichte an der Universität Wien 1945-I955. In: Margarete Grandner/Gernot Heiß/Oliver Rathkolb (Hrsg.), Zukunft mit Altlasten. Die Universität Wien I945 bis I955 (= Querschnitte I9. Einführungstexte zur Sozial-, Wirtschafts- und Kulturgeschichte), Innsbruck - Wien - München - Bozen 2005, I89-210.

Heiß, Gernot: Wendepunkt und Wiederaufbau: Die Arbeit des Senats der Universität Wien in den Jahren nach der Befreiung. In: Margarete Grandner/Gernot Heiß/Oliver Rathkolb (Hrsg.), Zukunft mit Altlasten. Die Universität Wien 1945 bis 1955 (= Querschnitte I9. Einführungstexte zur Sozial-, Wirtschafts- und Kulturgeschichte), Innsbruck - Wien - München - Bozen 2005, 9-37.

Held, Renate: Kriegsgefangenenschaft in Großbritannien. Deutsche Soldaten des Zweiten Weltkriegs in britischem Gewahrsam, München 2008.

Helmer, Oskar: 50 Jahre erlebte Geschichte, Wien 1957.

Hennen, John C.: The Americanization of West Virginia. Creating a Modern Industrial State, r9i6I925, Lexington 1996.

Hentschke, Felicitas: Demokratisierung als Ziel der amerikanischen Besatzungspolitik in Deutschland und Japan 1943-I947 (= Studien zu Geschichte, Politik und Gesellschaft Nordamerikas, Bd. I6), Hamburg $200 \mathrm{I}$. 
Herb Karlfriedrich, Oliver Hidalgo: Alexis de Tocqueville, Frankfurt a. Main 2005.

Herf,Jeffrey: Reactionary Modernism. Technology, Culture and Politics in Weimar and Third Reich, Cambridge I984.

Hilbrand, Rainer: Der Freiheitssender Ausseerland. In: Ausseer Beiträge zur Kultur und Zeitgeschichte (= Schriftenreihe des Heimatmuseums „A“, Bd. 7. Hrsg.v. Hans Michael Roithner), Bad Aussee 1985, 9I-96.

Hiller, Alfred: Amerikanische Medien- und Schulpolitik in Österreich (1945-1950), Diss., Univ. Wien I974.

Hiller, Alfred: US-amerikanische Schulpolitik in Österreich 1945-1950. In: Österreich in Geschichte und Literatur. Hrsg. v. Institut für Österreichkunde, 24. Jg., I980, Heft 2, 65-80.

Hindinger, Gabriele: Das Kriegsende und der Wiederaufbau demokratischer Verhältnisse in Oberösterreich im Jahre 1945 (= Publikationen des österreichischen Instituts für Zeitgeschichte, Bd. 6), Diss., Univ. Wien 1968.

Hiscoks, Richard: The Rebirth of Austria, London - New York - Toronto I953.

Hixson, Walter L.: Propaganda, Culture and the Cold War, New York 1998.

Höbelt, Lothar: Von der Vierten Partei zur Dritten Kraft. Die Geschichte des VdU, Graz 1999.

Hochgeschwender, Michael: Freiheit in der Offensive? Der Kongress für kulturelle Freiheit und die Deutschen, Müchen 1998.

Hochschulen I933-I945. Nachtrag zur Bibliographie sowie Übersichten über Rehabilitationen und Gedenken nach 1945 (= Schriftenreihe des ASTA der Universität Mannheim, Bd. 6), Mannheim 1999. Hoenisch Michael, Klaus Kämpfe, Karl Heinz Pütz: USA und Deutschland. Amerikanische Kulturpolitik in Deutschland, 1942-1949. Bibliographie, Materialien, Dokumente, Berlin I980.

Hofbauer, Hannes: Westwärts. Österreichs Wirtschaft im Wiederaufbau, Wien 1992.

Hoffman, Louise E.: American Psychologists and Wartime Research on Germany, I94I-I945. In: American Psychologist, Vol. 47, February 1992, 264-273.

Hoffmann, Robert: Erzherzog Franz Ferdinand und der Fortschritt. Altstadterhaltung und bürgerlicher Modernisierungswille in Salzburg, Wien - Köln - Weimar 1994.

Hofinger, Johannes: Max Reinhardts Schloss Leopoldskron: Beutegut der Nationalsozialisten. In: David. Jüdische Kulturzeitschrift, I7. Jg., April 2005, Heft 64, 2-6.

Hofinger, Johannes: Die Akte Leopoldskron. Max Reinhardt - Das Schloss - Arisierung \& Restitution, Salzburg 2005 .

Holger, Andreas: Sowjetisierung oder Neutralität? Optionen sowjetischer Besatzungspolitik in Deutschland und Österreich I945-I955. Rekonstruktion oder Neubeginn?, Göttingen 2006.

Höller, Gregor Christian Egon: Feind- und Konfliktbilder des Kalten Krieges in Fernsehen, Film und Literatur, Dipl.-Arb., Univ. Wien 2011.

Holmes, Deborah: Die Schwarzwaldschule und Hans Kelsen. In: Robert Walter/Werner Ogris/Thomas Olechowski (Hrsg.), Hans Kelsen: Leben - Werk - Wirksamkeit. Ergebnisse einer Internationalen Tagung, veranstaltet von der Kommission für Rechtsgeschichte Österreichs und dem Hans Kelsen-Institut (= Schriftenreihe des Hans Kelsen-Instituts, Bd. 32), Wien 2009 , 97-IO9. 
Holzbauer, Robert: Ernst Karl Winter (1895-1959). Materialien zu seiner Biographie und zum konservativ-katholischen politischen Denken in Österreich 1918-1938, Diss., Univ. Wien 1992.

Holzbauer, Robert: Ernst Karl Winter und die Legitimisten. In: „Anschluß“ 1938. Eine Dokumentation. Hrsg. v. Dokumentationsarchiv des österreichischen Widerstands. Ausgewählt, bearbeitet und zusammengestellt von Heinz Arnsberger, Winfried R. Garscha und Christa Mitterutzner, Wien 1938 , 27-36.

Holzbauer, Robert: Ernst Karl Winter. In: Friedrich Stadler (Hrsg.), Vertriebene Vernunft. Bd. II. Emigration und Exil österreichischer Wissenschaft, Wien - München 1988, 458-462.

Holzer, Johanna: Die Erinnerungskultur der Universität Wien. Gedenken an die Zeit von 1933 bis I945. In: Österreichische Hochschulen im 20. Jahrhundert. Austrofaschismus, Nationalsozialismus und die Folgen. Hrsg. v. der Österreichischen Hochschschülerschaft, Wien 2013, 392-402.

Honeck, Mischa: We are the Revolutionists. German-speaking Immigrants and American Abolitionists after 1848 , Athens / Georgia 2011.

Horkheimer, Max: Traditionelle und Kritische Theorie. Vier Aufsätze, Frankfurt a. Main I984.

Horvath, Maria: Die Bildungspolitik des Unterrichtsministeriums Dr. Felix Hurdes unter besonderer Betonung der Schulpolitik und Berücksichtigung der Kulturpolitik, Diss., Univ. Wien 1985.

Horvath Traude, Gerda Neyer (Hrsg.): Auswanderung aus Österreich: Von der Mitte des I9. Jahrhundert bis zur Gegenwart. Mit einer umfassenden Bibliographie zur österreichischen Migrationsgeschichte, Wien - Köln - Weimar 1996.

Hoschek, Maria: Friedrich Wilhelm Foerster (1869-1966). Mit besonderer Berücksichtigung seiner Beziehungen zu Österreich (Europäische Hochschulschriften, 3. Geschichte und ihre Hilfswissenschaften, Bd. 920).3. Auf., Frankfurt a. Main et al., 2006 [2002].

Hruza Karel (Hrsg.): Österreichischer Historiker 1900-1945. Lebensläufe und Karrieren in Österreich, Deutschland und der Tschechoslowakei in wissenschaftsgeschichtlichen Porträts, Wien Köln-Weimar 2008.

Hubenstorf, Michael: Medizinische Fakultät 1938-1945. In: Gernot Heiß/Siegfried Mattl (Hrsg.), Willfährige Wissenschaft. Die Universität Wien 1938-1945, Wien I989, 233-282.

Huber, Andreas: Studenten im Schatten der NS-Zeit. Entnazifizierung und politische Unruhen an der Universität Wien I945-I950, Dipl.-Arb., Univ. Wien 2009.

Huber, Andreas, Katherina Kniefacz, Alexander Krysl, Manès Weisskirchner: Universität und Disziplin. Angehörige der Universität Wien und der Nationalsozialismus, Wien - Berlin 20 II.

Illmayer, Klaus: Ein folgenloser Wechsel. Die Ablösung Heinz Kindermanns durch Eduard Castle. In: Peter/Payr (Hrsg.), „Wissenschaft nach der Mode“, a.a.O., I50-I7I.

International Biographical Dictionary of Central European Emigrés I933-1945. Vol. II/Part I: A-K. The Arts, Sciences, and Literature. Hrsg.v. Hanna Caplan/Belinda Rosenblatt, München - New York - London - Paris 1983 .

Islam, Iyanatul: Anti-Americanism in the Muslim world. A sceptic's guide. In: Brendon O'Connor/Martin Griffiths (Eds.), The Rise of Anti-Americanism, London 2005, 68-90.

Issraelian, Viktor: Die Antihitlerkoalition. Die diplomatische Zusammenarbeit zwischen der UdSSR, den USA und England während des Zweiten Weltkrieges I94I-I945, Moskau I975. 
Jaecker, Tobis: Antisemitische Verschwörungstheorien nach dem Ir. September. Neue Varianten eines alten Deutungsmusters. 2. Aufl., Münster 2005.

Jarausch, Konrad: Missverständnis Amerika. AntiAmerikanismus als Projektion. In: Jan C. Behrends / Árpàd von Klimó/Patrice G. Poutrus, AntiAmerikanismus im 20. Jahrhundert. Studien zur Ost- und Westeuropa, Bonn 2005, 34-49.

Jarausch, Konrad, Hannes Siegrist (Hrsg.): Amerikanisierung und Sowjetisierung in Deutschland I945-1970, Frankfurt a. Main 1997.

Jay, Martin: Dialectical Imagination. A History of the Frankfurt School and the Institute of Social Research 1923-1950, Berkeley - Los Angeles - London 1996.

Jetzlsperger, Florian: Die Umerziehung der Jugend durch die amerikanischen Militärregierungen I945-I949. Bayern und Salzburg im Vergleich, Magisterarbeit LMU München 2007.

Joffe, Josef: Überpower. The imperial temptation of America, New York - London 2006.

Johnson, Lonnie, Karin Riegler (Eds.): Fulbright at Fifty. Austrian-American Educational Exchange 1950-2000, Wien [2000].

Jones, Ernest: The Life and Work of Sigmund Freud. Vol. 2: Years of Maturity, I9OI-I9I9, New York I955.

Jones, Howard:, A new Kind of War'. Americas Global Strategy and the Truman Doctrine in Greece, New York i989.

Jordan, Stefan: Theorien und Methoden der Geschichtswissenschaft. Orientierung Geschichte, Paderborn 2009.

Jung, Hermann: Die deutschen Kriegsgefangenen in amerikanischer Hand - USA (= Zur Geschichte der deutschen Kriegsgefangenen des Zweiten Weltkriegs, Bd. X/I), Bielefeld 1972.

Junker, Detlef: Politics, Security, Economics, Culture, and Society. Dimensions of the Transatlantic Relations. In: Detlef Junker (Ed.), The United States and Germany in the Era of the Cold War. A Handbook. Vol. I2, Cambridge 2004.

Kaelble, Hartmut, Martin Kirsch, Alexander Schmid-Gernig (Hrsg.): Transnationale Öffentlichkeit und Identitäten im 20. Jahrhundert, Frankfurt a. Main 2002.

Kämpfe, Klaus: Educating the Re-educators: Films in the Morale-Program of the U.S. Army. In: Krippendorf (Ed.), The Role of the United States, a.a.O., I58-182.

Karner, Stefan: In Stalin's Custody: The Soviet Camp System for Prisoners of War during and after World War II. In: Günter Bischof/Fritz Plasser/Barbara Stelzl-Marx (Eds.), New Perspektives on Austrians and World War II (= Contemporary Austrian Studies, Vol. 17) New Brunswick London 2009, I2I-I34.

Kasemir, Gerard E.: Die Borodajkewycz-Affäre 1965 . Spätes Ende für „wissenschaftlich“ vorgetragenen Rassismus, Dipl.-Arb., Univ. Wien 1994.

Kastner, Florentine: 373 Camp Wolfsberg. Britische Besatzungslager in Österreich von 1945 bis I948, Dipl.-Arb., Univ. Wien 20or.

Kellermann, Henry J.: Cultural relations as an Instrument of U.S. Foreign Policy. The Educational Exchange Program between the United States and Germany I945-1954 (= Department of State Publication 8931), Washington D.C. 1978. 
Kellermann, Henry J.: Von Re-education zu Re-orientation. Das amerikanische Re-orientierungsprogramm im Nachkriegsdeutschland. In: Heinemann (Hrsg.), Umerziehung und Wiederaufbau, a.a. O., 86-IO2.

Kenner, Clara: Der zerrissene Himmel. Emigration und Exil der Wiener Individualpsychologie, Göttingen 2007.

Kerschhaggl, Winfried: Das Image Österreichs in den Vereinigten Staaten von Amerika. Eine explorative Studie über das Österreich Image (USA, Jänner 1992), Dipl.-Arb., Univ. Wien 1992.

Kerschbauer, Gerd, Karl Müller: Begnadet für das Schöne. Der rot-weiß-rote Kulturkampf gegen die Moderne (= Beiträge zur Kulturwissenschaft und Kulturpolitik, 2), Wien 1992.

Keyserlingk, Robert H.: Austria in World War II. An Anglo-American Dilemma, Kingston - Montreal 1988.

Klautke, Egbert: Unbegrenzte Möglichkeiten. „Amerikanisierung“ in Deutschland und Frankreich (1900-1933) (=Transatlantische Historische Studien, Bd. I4), Stuttgart 2003.

Klee, Ernst: Das Personenlexikon zum Dritten Reich. Wer war was vor und nach 1945, Frankfurt a. Main 2003.

Kleinschmidt, Johannes: Amerikaner und Deutsche in der Besatzungszeit. Vom Fraternisierungsverbot zur deutsch-amerikanischen Freundschaft. Die Regulierung sozialer Beziehungen durch die amerikanische Armee in den Jahren 1944 bis I949, Diss., Univ. Tübingen 1995.

Kleßmann, Christoph: Politische Rahmenbedingungen der Bildungspolitik in der SBZ/DDR I945 bis I952. In: Heinemann (Hrsg.), Umerziehung und Wiederaufbau, a.a. O., 229-244.

Klipphahn, Klaus: Deutsche Propaganda in den Vereinigten Staaten I933-I94I (= Beiheft zum Jahrbuch für Amerikastudien, 3r. Heft), Heidelberg I97I.

Klöckler,Jürgen: Ici l'Autriche - Pays Ami! Frankreich und die Entnazifizierung im besetzten Österreich 1945/46. In: Schuster/Weber (Hrsg.), Entnazifizierung, a.a. O., 455-472.

Klöckner, Thomas: Public Diplomacy - Auswärtige Informations- und Kulturpolitik der USA. Strukturananlyse der Organisation und Strategien der United States Information Agency und des United States Information Service in Deutschland (= Nomos Universitätsschriften. Politik, Bd. 4I), Baden-Baden I993.

Klösch, Christian (Hrsg.): Gegen Rassenhass und Menschennot. Irene Harand, Leben und Wirken einer ungewöhnlichen Widerstandskämpferin, Innsbruck 2004.

Kloyber, Christian, Marcus G. Patka: Österreicher im Exil: Mexiko I938-1947. Eine Dokumentation. Hrsg. v. Dokumentationsarchiv des österreichischen Widerstandes. Mit einem Geleitwort von Friedrich Katz, Wien 2002.

Kloyber, Christian: Mexicos Protest vor dem Völkerbund. In: Informationen des Österreichischen Lateinamerikainstituts, I, I988, 8-12.

Knapp, Marion: Österreichische Kulturpolitik und das Bild der Kulturnation. Kontinuität und Diskontinuität in der Kulturpolitik des Bundes seit I945 (= Politik und Demokratie. Hrsg. v. Helmut Kramer und Eva Kreisky, Bd. 4), Frankfurt a. Main et al. 2005.

Knes, Alexander: Entnazifizierung in der sowjetischen Zone Österreichs von 1945 bis 1948, Dipl.Arb., Univ. Graz 2005. 
Knight, Robert: Britische Entnazifizierungspolitik 1945-1949. In: Zeitgeschichte, I4. Jg., I987, Heft 9-Io, 287-30I.

Knight, Robert (Hrsg.): „Ich bin dafür, die Sache in die Länge zu ziehen“. Die Wortprotokolle der Österreichischen Bundesregierung von 1945 bis 1952 über die Entschädigung der Juden, Wien Köln - Weimar 2000 [1988].

Knight, Robert: Die „Erfindung“ der österreichischen Identität am Beispiel der Erziehungspolitik. In: Rudolf G. Ardelt/Christian Gerbel (Hrsg.), Österreichischer Zeitgeschichtetag 1995. Österreich - 50 Jahre Zweite Republik, Innsbruck - Wien, I997, I59-I63.

Knight, Robert: Kalter Krieg, Entnazifizierung und Österreich. In: Sebastian Meissl/Klaus-Dieter Mulley/Oliver Rathkolb (Hrsg): Verdrängte Schuld, verfehlte Sühne. Entnazifizierung in Österreich 1945-1955. Symposion des Instituts für Wissenschaft und Kunst, Wien 1986, 37-51.

Knoll, Reinhold: Die Entnazifizierung an der Universität Wien. In: Meissl (Hrsg.), Verdrängte Schuld - verfehlte Sühne, a.a.O., 270-280.

Knoll, Reinhold: Die Soziologie in der Geschichte am Beispiel von Ernst Karl Winter. In: Michael Benedikt/Reinhold Knoll/Cornelius Zehetner (Hrsg.), unter Mitarb. v. Endre Kiss, Verdrängter Humanismus - verzögerte Aufklärung. Bd. V: Im Schatten der Totalitarismen. Vom philosophischen Empirismus zur kritischen Anthropologie. Philosophie in Österreich 1920-I95I, Wien 2006, I065-IO78.

Koch, Thomas: Der amerikanische Geheimdienst OSS und die Widerstandsbewegungen. In: Geheimdienste und Widerstandsbewegungen im Zweiten Weltkrieg. Hrsg. v. Gerhard Schulz, Göttingen 1982, 79-I04.

Kochavi, Arieh J.: Confronting captivity. Britain and the United States and their POWs in Nazi Germany, Chapel Hill 2005.

Kofler, Christa: Die Tagespresse der SPÖ und der KPÖ im Land Tirol von 1945 bis 1950 unter besonderer Berücksichtigung ihrer Darstellung des Nationalsozialismus, Diss., Universität Innsbruck I989.

Koller, Christian:, Von Wilden aller Rassen niedergemetzelt'. Die Diskussion um die Verwendung von Kolonialtruppen in Europa zwischen Rassismus, Kolonial- und Militärpolitik (1919-1930), Stuttgart 200I.

Koller, Christian: Die „Schwarze Schmach“- afrikanische Besatzungssoldaten und Rassismus in den zwanziger Jahren. In: Marianne Bechhaus-Gerst/Reinhard Klein-Arendt (Hrsg.), AfrikanerInnen in Deutschland und schwarze Deutsche - Geschichte und Gegenwart, Münster 2004, 155-170.

Köck, Heribert Franz: Leben und Werk des österreichischen Rechtsgelehrten Alfred Verdross. In: Zeitschrift für öffentliches Recht, Bd. 42, 1991, 3-46.

Köstner-Pemsel Christina, Markus Stumpf, „Machen Sie es ordentlich, damit man nachher, wenn wir die Bücher ihren Besitzern zurückgeben, nucht sagt, es hätten Schweine in der Hand gehabt.“ In: Mitteliungen der VÖB 65, 2012, Nr. I, 39-78.

König, Jens Christian: Politische Kultur in den USA und Deutschland: Nationale Identität am Anfang des 2I. Jahrhunderts, Berlin 2010.

König, Thomas: Das Fulbright Program in Wien: Wissenschaftspolitik und Sozialwissenschaften am ,versunkenen Kontinent', Diss., Univ. Wien 2008. 
König, Thomas: Die Frühgeschichte des ,Fulbright Program“ in Österreich. Transatlantische „Fühlungnahme auf dem Gebiet der Erziehung“(=Transatlantica, hrsg. v. Günter Bischof, 6), Innsbruck - Wien - Bozen 2012.

König, Thomas: Die Entstehung eines Gesetzes: Österreichische Hochschulpolitik in den I95oer-Jahren. In: Österreichische Zeitschrift für Geschichtswissenschaften, 23.Jg., November 2012, Heft 2, 57-8I.

Korotin, Ilse: „Keine Rückkehr der weiblichen Vernunft nach dem Nazi-Regime“. In: Der Standard, I5. Juni 2005 .

Korotin, Ilse: Wissenschaftlerinnen und Remigration - die „Austrian University League of America“. In: Frauen im Exil: die weibliche Perspektive. In: Mitteilungen des Instituts für Wissenschaft und Kunst, 6o. Jg., 2005, I-2, 5-I2.

Koß, Siegfried: Vorstellungen der Alliierten von Nachkriegsdeutschland. In: Aus Politik und Zeitgeschichte, B 42-43, 1972, 15-30.

Koszyk, Kurt: „Umerziehung“ der Deutschen aus britischer Sicht. Konzepte und Wirklichkeit der „Reeducation“ in der Kriegs- und Besatzungsära. In: Aus Politik und Zeitgeschichte, I978, Heft 29, 3-12.

Kracauer, Siegfried: Die Angestellten. Aus dem neuesten Deutschland, Frankfurt a. Main 1971 [1930].

Krammer, Arnold: Nazi Prisoners of War in America, Chelsea r991.

Kreimeier, Klaus: The Ufa-story. A history of Germany's greatest film company, 1918-1945, New York 1996.

Kreis, Georg (Hrsg.): Antiamerikanismus. Zum europäisch-amerikanischen Verhältnis zwischen Ablehnung und Faszination, Basel 2007.

Kremp, Werner: In Deutschland liegt unser Amerika. Das sozialdemokratische Amerikabild von den Anfängen der SPD bis zur Weimarer Republik (= Politikwissenschaftliche Perspektiven, Bd. 6, hrsg. v. Manfred Mohs), Hamburg 1993.

Kriechbaumer, Robert: Salzburg 1945-1955: Politische Entwicklungslinien. In: Hans Bayr/Robert Kriechbaumer, Salzburg 1945-1955. Zerstörung und Wiederaufbau. Begleitbuch zur Ausstellung des Salzburger Museums Carolino Augusteum in Zusammenarbeit mit dem Verein „Salzburger Wehrgeschichtliches Museum“, Salzburg 1995, 8I-IIo.

Kriegleder, Wynfried: Amerika-Idyllik und Europa-Skepsis. Zum Verhältnis Amerika-Europa im Werk Charles Sealsfields. In: Alexander Ritter (Hrsg.), Sealsfield-Studien I (= Schriftenreihe der Charles-Sealsfield-Gesellschaft XI), München I998, II-25.

Kriegleder, Wynfried: Vorwärts in die Vergangenheit. Das Bild der USA im deutschsprachigen Roman 1776 bis I855, Tübingen 1999 .

Kriegleder, Wynfried, Gustav-Adolf Pogatschnigg (Hrsg.): Die Geschichten des Charles Sealsfield. Zeitschriftenveröffentlichungen und Vorlagen (= Sealsfield-Bibliothek 7), Wien 2009.

Krienzer, Simone: Strategien der Propaganda im frühen Kalten Krieg. Eine Analyse ausgewählter Plakate zum European Recovery Programm der USA in Österreich 1948-I952, Dipl.-Arb., Univ. Graz 2010.

Krippendorf, Ekkehard (Ed.): The Role of the United States in the Reconstruction of Italy and West Germany, I943-I949. Papers presented at a German-Italian Colloquium held at the John F. Kennedy-Institut für Nordamerikastudien, Berlin, June I980 (= Materialien I6), Berlin I98I. 
Krohn, Claus-Dieter: Der Philosophische Ökonom. Zur intellektuellen Biographie Adolph Lowes, Marburg 1996.

Kroes, Rob (Ed.): High Brow Meets Low Brow. American Culture as an Intellectual Concern, Amsterdam 1988.

Kroes, Rob (Ed.): Cultural Transmissions and Receptions. American mass culture in Europe (= European contributions to American studies, 25), Amsterdam 1993.

Kroes, Rob: Them and us. Questions of citizenship in a globalizing world, Urbana 2000.

Kroes, Rob: If you've seen one, you've seen the mall. Europeans and American mass cultural, Amsterdam 1996.

Krugler, David F.: The Voice of America and the Domestic Propaganda Battles, 1945-1953, Columbia 2000.

Kucher, Primus-Heinz: Polyphone Spiegelungen und Kulturkritik in Charles Sealsfields Amerika-Bericht. Die Vereinigten Staaten von Nordamerika nach ihren politischen, religiösen und gesellschaftlichen Verhältnissen betrachtet (I827). In: Austriaca, Sommaire No. 62, Juni 2006, 29-48.

Kucher, Primus-Heinz: „... dass die Vereinigten Staaten bisher einzig in der Welt dastehen. Ida Pfeiffers Reisebericht über Amerika. In: Ritter (Hrsg.), Amerika im europäischen Roman um 1850. Varianten transatlantischer Erfahrungen, a.a.O., 25I-264.

Kuhnert, Jan: Die Berufsschule im Rahmen der Einheitsschule. Ein Kernproblem der Bildungspolitik in der SBZ. In: Heinemann (Hrsg.), Umerziehung und Wiederaufbau, a.a.O., 245-263.

Kuisel, Richard F.: Seducing the French: The Dilemma of Americanization, Berkeley 1993.

Kuretsidis-Haider, Claudia: „Das Volk sitzt zu Gericht“. Österreichische Justiz und NS-Verbrechen am Beispiel der Engerau-Prozesse 1945-1954 (=Österreichische Justizgeschichte, Bd. 2), Innsbruck 2006.

Kusber Jan, Mechthild Dreyer, Jörg Rogge, Andreas Hütig (Hrsg.): Historische Kulturwissenschaften. Positionen, Praktiken und Perspektiven, Bielefeld 2 oı.

Lammersdorf, Raimund: Zur Perzeption Wilhelm II. in den Vereinigten Staaten, I888-I909. In: Amerikastudien/American Studies, 31. Jg., 1986, Heft 3, 295-302.

Landwehr, Achim: Kulturwissenschaft und Geschichtswissenschaft. In: Klaus Stiersdorfer/Laurenz Volksmann (Hrsg.), Kulturwissenschaft interdisziplinär, Tübingen 2005, 39-57.

Langer, Walter C.: A psychological Analysis of Adolph Hitler. His Life and Legend. With collaboration of Prof. Henry A. Murr (Harvard Psychological Clinic), Dr. Ernst Kris (New School of Social Research), Dr. Bertram D. Lawin (New York Psychoanalytic Institute), Office of Strategic Services, Washington D.C. 1943.

Lange-Quassowski, Jutta-B.: Amerikanische Westintegrationspolitik, Re-education und deutsche Schulpolitik. In: Heinemann (Hrsg.), Umerziehung und Wiederaufbau, a.a.O., 53-67.

Langkau-Alex, Ursula, Thomas M. Ruprecht (Hrsg.): Was soll aus Deutschland werden? Der Council for a Democratic Germany in New York 1944-I945, Frankfurt a. Main I994.

Laqua, Carsten: Wie Mickey unter die Nazis fiel. Walt Disney und Deutschland, Reinbek 1992.

Latzin, Ellen: „Reeducation - , Reorientation': Theorie und Praxis zentraler Leitbegriffe der amerikanischen Besatzungspolitik nach 1945. In: Elisabeth Kraus (Hrsg.), Die Universität München im Dritten Reich. Aufsätze. Teil I, München 2006, 609-635. 
Latzin, Ellen: Lernen von Amerika? Das Kulturaustauschprogramm für Bayern und seine Absolventen (=Transatlantische Historische Studien, Bd. 23), Stuttgart 2005.

Laue, Theodore H.: The World Revolution of Westernization. The 2oth Century in Global Perspective, New York 1987.

Lehmkuhl, Ursula: Pax Anglo-Americana. Machtstrukturelle Grundlagen angloamerikanischer Asien- und Fernostpolitik in den I95oer Jahren, München 1999.

Leidenfrost, Josef: Die Amerikanische Besatzungsmacht und der Wiederbeginn des politischen Lebens in Österreich I944-I947. 2 Bde., Diss., Univ. Wien I986.

Leitner, Irene Maria: ,Bis an die Grenzen des Möglichen‘. Der Dekan Viktor Christian und seine Handlungsspielräume an der philosophischen Fakultät 1938-1943. In: Ash/Nieß/Pils (Hrsg.), Geisteswissenschaften im Nationalsozialismus, a.a.O., 49-77.

Lepsius, Oliver: Hans Kelsen und der Nationalsozialismus. In: Robert Walter/Werner Ogris/Thomas Olechowski (Hrsg.), Hans Kelsen: Leben - Werk - Wirksamkeit. Ergebnisse einer Internationalen Tagung, veranstaltet von der Kommission für Rechtsgeschichte Österreichs und dem Hans Kelsen-Institut (= Schriftenreihe des Hans Kelsen-Instituts, Bd. 32), Wien 2009, 267-282.

Lerg, Charlotte A.: Amerika als Argument. Die deutsche Amerika-Forschung im Vormärz und ihre politische Deutung in der Revolution von I848/49, Bielefeld 20 Ir.

Lichtenberger-Fenz, Brigitte: ,Es läuft alles in geordneten Bahnen‘. Österreichs Hochschulen und Universitäten und das NS-Regime. In: Emmerich Talos et al. (Hrsg.), NS-Herrschaft in Österreich. Ein Handbuch, Wien 2000, 549-569.

Lichtenberger-Fenz, Brigitte: Österreichs Universitäten und Hochschulen - Opfer oder Wegbereiter der nationalsozialistischen Gewaltherrschaft? Am Beispiel der Universität Wien. In: Gernot Heiß et al. (Hrsg.), Willfährige Wissenschaft. Die Universität Wien 1938-1945, Wien 1989, 3-15.

Liebl, Thomas: Die Umerziehung der österreichischen Bevölkerung zu demokratischen Grundsätzen durch die US-amerikanischen Besatzer, Dipl.-Arb., Univ. Salzburg 1997.

Liebner, Petra: Paul Tillich und der Council for a Democratic Germany, 1933-I945 (=Europäische Hochschulschriften, Reihe 3, Bd. 902), Frankfurt a. Main 2001.

Liessmann, Konrad Paul: Theorie der Unbildung. Die Irrtümer der Wissensgesellschaft, Wien 2006.

Locher, Albert: Mit Mark Twain durch Europa. Samuel Langhorne Clemens in der Alten Welt (I89I-I899 und I903/I904). Bd. 2, o. O. 2007.

Lockyer, Andrew, Bernard R. Crick/John Annette: Education for democratic citizenship. Issues of theory and practice, Aldershot 2003.

Louw, Eric P.: Roots of the Pax Americana. Decolonisation, Development, Democratisation and Trade, Manchester 2010 .

Lowe, Roy (Ed.): Education and the Second World War. Studies in schooling and social change, London - Washington D.C. 1992.

Lowen, Rebecca S.: Creating the Cold War University. The Transformation of Stanford, Berkeley 1997; Ron Robin, The Making of the Cold war Enemy. Culture and Politics in the MilitaryIntellectual Complex, Princeton 2oor. 
Lüdtke, Alf, Inge Marßolek, Adelheid von Saldern (Hrsg.): Amerikanisierung. Traum und Alptraum im Deutschland des 20. Jahrhunderts (=Transatlantische Historische Studien, Bd. 6), Stuttgart 1996.

Lukas, Scott: Freedom's War. The US Crusade against the Soviet Union, 1945-1956, Manchester 1999.

Lundestad, Geir: Empire by Invitation? The United States and Western Europe, 1945-1952. In: Journal of Peace Research, Vol. 23, 1986, No. 3, 263-277.

Lutzebäck, Rolf: Die Bildungspolitik der britischen Militärregierung im Spannungsfeld zwischen ,education' und ,reeducation' in ihrer Besatzungszone, insbesondere in Schleswig-Holstein und in Hamburg in den Jahren $1945-47$ (= Europäische Hochschulschriften II), Frankfurt a. Main Bern - New York - Paris I99I.

Mähr, Wilfried: Der Marshallplan in Österreich, Graz - Wien - Köln I989.

Maier, Hans, Michael Zöllner: Die andere Bildungskatastrophe: Hochschulgesetze statt Hochschulreform, I970.

Malina, Peter: Eduard Pernkopf. Versuch einer „Stratigraphischen“ Biographie. In: Senatsprojekt der Universität Wien. Untersuchungen zur Anatomischen Wissenschaft in Wien. 1938-1945. Hrsg. v. Akademischen Senat der Universität Wien, Wien 1998.

Malina, Peter: Eduard Pernkopfs Anatomie oder: Die Fiktion einer „reinen“Wissenschaft. In: Wiener Klinische Wochenschrift. The Middle European Journal of Medicine, I09. Jg., 23. Dezember 1997, H. 24, 935-943.

Manoschek, Walter: ,Aus der Asche dieses Krieges wieder auferstanden'. Skizzen zum Umgang der österreichischen Volkspartei mit dem Nationalsozialismus und Antisemitismus nach 1945. In: Werner Bergmann/Rainer Erb/Albert Lichtblau (Hrsg.), Schwieriges Erbe. Der Umgang mit Nationalsozialismus und Antisemitismus in Österreich, der DDR und der BRD (= Schriftenreihe des Zentrums für Antisemitismusforschung Berlin, Bd.3), Frankfurt a. Main - New York 1995, 49-64.

Marboe,Irmgard: Alfred Verdross - Ein Mann des Widerspruchs? Teil I. Verdross' Völkerrechtstheorie vor dem Hintergrund des Nationalsozialismus. In: Alfred Verdross - Ein Mann des Widerspruchs? Verdross im Gefüge der Wiener Völkerrechtswissenschaft vor und nach 1938. In: Thomas Olechowski/Ilse Reiter et al. (Hrsg.), Vertriebenes Recht - Vertreibendes Recht. Die Wiener Rechtswissenschaftliche Fakultät zwischen 1938 und I945, Wien 20I0, I5 [unveröffentlichtes Manuskript].

Marcowitz, Reiner (Hrsg.): Nationale Identität und transnationale Einflüsse. Amerikanisierung, Europäisierung und Globalisierung in Frankreich nach dem zweiten Weltkrieg, München 2007.

Markovits, Andrei S.: Amerika, dich hasst sich's besser. Antiamerikanismus und Antisemitismus in Europa, Hamburg 2004 .

Markovits, Andrei S.: Uncouth Nation. Why Europe dislikes America, Princeton 2007.

Marrow, Alfred J.: The Practical Theorist. The Life and Work of Kurt Lewin, Univ. of Michigan I969.

Marszolek, Inge: Das Amerikabild im ,Dritten Reich‘. Ambivalenzen und Widersprüche. In: Thadden/Escudier (Hrsg.), Amerika und Europa - Mars und Venus?, a.a.O., 49-64.

Marszolek, Inge: Das Amerikabild im Dritten Reich. In: Daniela Münkel/Jutta Schwarzkopf (Hrsg.), Geschichte als Experiment. Studien zu Politik, Kultur und Alltag im I9. und 20. Jahrhundert. Festschrift für Adelheid von Saldern, Frankfurt a. Main - New York 2004, 25-34. 
Matis, Herbert: Zwischen Anpassung und Widerstand. Die Akademie der Wissenschaften in den Jahren 1938-1945, Wien 1997.

Matsch, Erwin: Wien - Washington. Ein Journal diplomatischer Beziehungen 1838-1917, Wien Köln r99o.

Mausbach Wilfried: Zwischen Morgenthau und Marshall. Das wirtschaftspolitische Deutschlandkonzept der USA I944-I947 (= Forschungen und Quellen zur Zeitgeschichte, Bd.30), Düsseldorf I996.

Mayr, Peter: Ex-Justizminister Tschadek war ein ,Blutrichter‘. In: Der Standard, 4./5. September 2010.

McCoy, Alfred W.: Science in Dachau's shadow: Hebb, Beecher, and the Development of CIA Psychological Torture and modern medical ethic. In: Journal of the History of the Behavioral Sciences, Vol. 43, 2007, No. 4, 40I-4I7.

Medhurst, Martin J.: Cold War rhetoric. Strategy, metaphor, and ideology (=Contributions to the study of mass media and communications, Vol. I9), New York 1990.

Meissl, Sebastian, Klaus-Dieter Mulley, Oliver Rathkolb (Hrsg): Verdrängte Schuld, verfehlte Sühne. Entnazifizierung in Österreich 1945-I955. Symposion des Instituts für Wissenschaft und Kunst, Wien 1986.

Meissl, Sebastian: Der „Fall Nadler“ 1945-1950. In: Meissl (Hrsg.), Verdrängte Schuld - verfehlte Sühne, a.a.O., 28I-30I.

Mesner, Maria (Hrsg.): Entnazifizierung zwischen politischem Anspruch, Parteienkonkurrenz und Kaltem Krieg. Das Beispiel der SPÖ, Wien - München 2005.

Métall, Rudolf Aladár: Hans Kelsen. Leben und Werk, Wien I969.

Mikoletzky, Juliane: „Von jeher ein Hirt starker nationaler Gesinnung“. Die Technische Hochschule in Wien und der Nationalsozialismus, Wien 2003.

Mirel, Jeffrey E.: Patriotic pluralism. Americanization education and European immigrants, Cambridge 2010 .

Missong, Alfred: Ernst Karl Winter - Denker, Bekenner, Kämpfer. In: Ernst Karl Winter - Bahnbrecher des Dialogs. Ausgewählt und eingeleitet von Alfred Missong (= Ernst Karl Winter, Gesammelte Werke, Bd. r. Hrsg. v. Ernst Florian Winter), Wien - Frankfurt - Zürich 1969, r2-2o.

Mitterecker, Gerd-Peter: Der Publizist Ernst Karl Winter. Möglichkeiten und Grenzen oppositioneller Medienarbeit im autoritären Staat, Dipl.-Arb., Univ. Wien 1995.

Möckelmann,Jürgen: Das Deutschlandbild in den USA I9I4-I9I8 und die Kriegszielpolitik Wilsons, phil. Diss., Univ. Hamburg 1965.

Mollin, Gerhard Th.: Amerikanische Spiegelungen - das Deutschlandbild in den USA I870-I9I8. In: Dan Diner (Hrsg.), Deutschlandbilder (=Tel Aviver Jahrbuch für deutsche Geschichte. Bd. XXVI), Tel Aviv 1997, 75-I07.

Moltmann, Günter: Amerikaklischees der deutschen Kriegspropaganda 194I-I945. In: Amerikastudien/American Studies, 3r. Jg., I986, Heft 3, 303-314.

Moore, Bob: Italienische Kriegsgefangene in britischem und amerikanischem Gewahrsam I94I bis 1947. Eine vergleichende Sozialgeschichte. In: Günther Bischof/Stefan Karner/Barbara Stelzl- 
Marx (Hrsg.), Kriegsgefangene des Zweiten Weltkriegs. Gefangennahme - Lagerleben - Rückkehr (= Kriegsfolgen-Forschung. Hrsg. v. Stefan Karner, Bd. 4), Wien - München 2005, 287-302.

Moosberg, Helmut: Reeducation. Umerziehung und Lizenzpresse im Nachkriegsdeutschland, München i991.

Morré, Jörg: Umerziehung in der sowjetischen Kriegsgefangenschaft. Deutsche und Österreicher in der „Antifa“.In: Bischof/Karner/Stelzl-Marx (Hrsg.), Kriegsgefangene des Zweiten Weltkriegs, a.a.O., I52-I66.

Morsi, Gamal: ,Amerika ist immer woanders'. Die Rezeption des American Dream in Italien, Marburg 200I.

Moser, Karin (Hrsg.): Besetzte Bilder. Film, Kultur und Propaganda in Österreich I945-1955, Wien 2005.

Mountjoy, Shane: Manifest Destiny. Westward Expansion, New York 2009.

Mowrer, Edgar Ansel: Triumph and Turmoil. A Personal History of Our Times, London 1970.

Mueller, Wolfgang: Die politische Mission der sowjetischen Besatzungsmacht in Österreich 1945I955, Diss., Univ. Wien 2004.

Mugrauer, Manfred: Die Politik der Kommunistischen Partei Österreichs in der Provisorischen Regierung Renner, Dipl.-Arb., Univ. Wien 2004.

Mühlberger, Kurt: Vertriebene Intelligenz 1938. Der Verlust geistiger und menschlicher Potenz an der Universität Wien von 1938 bis I945, Wien 1990.

Müller, Albert: Dynamische Adaptierung und „Selbstbehauptung“. Die Universität Wien in der NSZeit-Zeit. In: Dieter Langewiesche (Hrsg.), Universitäten im nationalsozialistisch beherrschten Europa. In: Geschichte und Gesellschaft. Zeitschrift für Historische Sozialwissenschaft, 23. Jg., 1997, Heft 4, Göttingen 1997, 592-6r7.

Müller, Emil-Peter: Antiamerikanismus in Deutschland. Zwischen Care-Paket und Cruise Missile, Köln 1986.

Müller, Tim B.: Krieger und Gelehrte. Herbert Marcuse und die Denksysteme im Kalten Krieg, Hamburg 2010.

Müller, Winfried: Schulpolitik in Bayern im Spannungsfeld von Kultusbürokratie und Besatzungsmacht 1945-1949, München - Wien - Oldenbourg 1995.

Müller, Wolfgang: Die sowjetische Besatzung in Österreich $1945^{-1955}$ und ihre politische Mission, Wien 2005.

Müller, Wolfgang: Sowjetische Österreich-Planungen 1938-1945. In: Ernst Bruckmüller (Hrsg.), Wiederaufbau in Österreich 1945-1955, Wien 2006, 27-54.

Müller, Wolfgang: Sowjetische Deutschland- und Österreichpolitik I94I bis I955 im Vergleich: Die Fragen der staatlichen Einheit und des Friedensvertrages. In: Michael Gehler (Hrsg.), Verschiedene europäische Wege im Vergleich. Österreich und die Bundesrepublik Deutschland 1945/49 bis zur Gegenwart. Festschrift für Rolf Steininger zum 65. Geburtstag, Innsbruck - Wien 2007, 60-86.

Nakamura, Kennon H., Matthew C. Weed: U.S. Public Diplomacy: Background and Current Issues (=Congressional Record Service. Report for Congress), [Washington D.C.] December 2009.

Negt, Oskar: Der politische Mensch. Demokratie als Lebensform, Göttingen 2 гı. 
Neitzel, Sönke, Harald Wälzer: Soldaten. Protokolle vom Kämpfen, Töten und Sterben, Frankfurt a. Main 20Ir.

Nemeth Elisabeth, Friedrich Stadler (Eds.): Encyclopedia and Utopia. The Life and Work of Otto Neurath (1882-I945). With the first publication of Otto Neurath's full manuscript of „Visual Education " and the documentation of the Otto Neurath Nachlass (Haarlem, The Netherlands) (=Vienna Circle Institute Yearbook 1996), Dordrecht - Boston - London 1996.

Neubauer, Manuel P.: Rektor und Rektorat im UG. Universitätsrechtliche und universitätspolitische Betrachtungen der operativen Führung österreichischer Universitäten, Dipl.-Arb., Univ. Graz 2009. Neugebauer, Wolfgang, Peter Schwarz: Der Wille zum aufrechten Gang. Offenlegung der Rolle des BSA bei der gesellschaftlichen Reintegration ehemaliger Nationalsozialisten. Hrsg. vom Bund sozialdemokratischer AkademikerInnen, Intellektueller und KünstlerInnen (BSA), Wien 2005.

Nevins, Allan: Herbert H. Lehman and his era, New York 1963.

Nickel, Gunther, Johanna Schrön: Carl Zuckmayers Geheimreport für das ,Office of Strategic Services‘. In: Carl Zuckmayer, Geheimreport. Hrsg. v. Gunther Nickel/Johanna Schrön. 2. Aufl., München 2007, 407-477.

Nieß, Wolfram: Von den Chancen und Grenzen akademischer Selbstbestimmung im Nationalsozialismus: Zur Errichtung des Instituts für Theaterwissenschaft 1914-I943. In: Ash/Nieß/Pils (Hrsg.), Geisteswissenschaften im Nationalsozialismus, a.a.O., 223-259.

Niethammer, Lutz: Entnazifizierung in Bayern. Säuberung und Rehabilitierung unter amerikanischer Besatzung, Frankfurt a. Main 1972.

Nietzsche, Friedrich: Die fröhliche Wissenschaft. Viertes Buch. In: Friedrich Nietzsche. Kritische Studienausgabe. Bd. 3. Hrsg. v. Giorgio Colli/Mazzino Montinari, München 1999.

Nietzsche, Friedrich: Menschliches, Allzumenschliches I (5. Anzeichen höherer und niederer Cultur). In: Friedrich Nietzsche. Kritische Studienausgabe. Bd. 2. Hrsg. v. Giorgio Colli/Mazzino Montinari, München I999.

Ninkovich, Frank A.: The diplomacy of ideas. U.S. foreign policy and cultural relations I938-1950, Cambrige I98I.

Ninkovich, Frank: Kontinentale Expansion, Empire und die Zivilisierungsmission im Amerika des I9. Jahrhunderts. In: Boris Barth/Jürgen Osterhammel (Hrsg.), Zivilisierungsmissionen. Imperiale Weltverbesserung seit dem I8. Jahrhundert, Konstanz 2005, 285-309.

Nitz, Timo: Deutscher Antiamerikanismus. Grundlagen, Entwicklung und Beständigkeit einer Ideologie, Saarbrücken 2006.

Nolan, Mary: „Anti-Americanism and Anti-Europeanism“. In: Lloyd Gardner/Marilyn Young (Eds.), The New American Empire: A 21st-Century Teach-In on U.S. Foreign Policy, New York 2004, II3-I32.

Nolan, Mary: The Infatuation with Fordism: Social Democracy and Economic Rationalization in Weimar Germany. In: Wolfgang Maderthaner/Helmut Gruber, Chance and Illusion. Labor in Retreat, Wien I988, I5I-I84.

Nowell, Elizabeth (Ed.): The Letters of Thomas Wolfe, New York 1956. 
Nußbaumer, Martina: Bauen an der „Musikstadt“. Materialisierungen eines Stadtimages im öffentlichen Raum Wiens. In: Margit Franz et al. (Hrsg.), Mapping contemporary history. Zeitgeschichten im Diskurs. Bd. I, Wien - Köln - Weimar 2008, I07.

Nußbaumer, Martina: Musikstadt Wien. Die Konstruktion eines Images, Freiburg i. Breisgau Wien 2007.

Oberkofler, Gerhard: Die Wahl von Leo Stern in die Deutsche Akademie der Wissenschaften. In: Mitteilungen der Alfred Klahr Gesellschaft, I, 1999, I-20.

O'Connor, Brendon (Ed.): Anti-Americanism. History, Causes, Themes. Volume 3: Comparative Perspectives, Oxford 2007.

Österreichische Hochschulen im 20. Jahrhundert. Austrofaschismus, Nationalsozialismus und die Folgen. Hrsg. v. der Österreichischen Hochschülerschaft, Wien 2013.

Ogris, Werner: 1884-I984. Einhundert Jahre Rechtswissenschaften im Hause am Ring. In: Günther Hamann/Kurt Mühlberger/Franz Skacel (Hrsg), , ıo Jahre Universität am Ring. Wissenschaft und Forschung an der Universität Wien seit 1884 (= Schriftenreihe des Universitätsarchivs, Bd. 3), Wien 1986.

Ohmstedt, Holger: Von der Propaganda zur Public Diplomacy. Die Selbstdarstellung der Vereinigten Staaten von Amerika im Ausland vom Ersten Weltkrieg bis zum Ende des Kalten Krieges, Diss., Ludwig-Maximilians-Universität München 1993.

Olechowski Thomas, Ilse Reiter et al. (Hrsg.): Vertriebenes Recht - Vertreibendes Recht. Die Wiener Rechtswissenschaftliche Fakultät zwischen 1938 und 1945, Wien 2010 [im Erscheinen].

Osten-Sacken, Thomas von der, Andrea Woeldike (Hrsg.): Amerika. Der ,War on Terror und der Aufstand der Alten Welt, Freiburg 2003.

Osterhammel, Jürgen: „The Great Work of Uplifting Mankind“. Zivilisierungsmission und Moderne. In: Boris Barth/Jürgen Osterhammel (Hrsg.), Zivilisierungsmissionen. Imperiale Weltverbesserung seit dem I8. Jahrhundert, Konstanz 2005, 363-425.

Otto, Viktor: Deutsche Amerika-Bilder. Zu den Intellektuellen-Diskursen um die Moderne I9ooI950, München 2006.

Overmans, Rüdiger: „Ostmärker“ oder Österreicher? Nationale Differenzierung zwischen Deutschen und Österreichern in sowjetischem Gewahrsam während des Zweiten Weltkriegs. In: Zeitgeschichte, 29. Jg., 2002, Heft 3, $133-\mathrm{I} 47$.

Overmans, Rüdiger: ,Hunnen“ und ,Untermenschen` - deutsche und russisch / sowjetische Kriegsgefangenenerfahrungen im Zeitalter der Weltkriege. In: Bruno Thoß/Hans Erich Volkmann (Hrsg.), Erster Weltkrieg. Zweiter Weltkrieg. Ein Vergleich. Krieg, Kriegserlebnis, Kriegserfahrung in Deutschland. Hrsg. im Auftrag des militärgeschichtlichen Forschungsamtes, Paderborn - München - Zürich 2002, 335-365.

Paddock, Alfred H. Jr.: US-Army Special Warfare. Its Origins. Psychological and Unconventional Warfare, I94I-I952, Lawrence/Kansas 2002 [1982].

Pakschies, Günter: Re-education und die Vorbereitung der britischen Bildungspolitik in Deutschland während des Zweiten Weltkriegs. In: Heinemann (Hrsg.), Umerziehung und Wiederaufbau, a.a.O., $\mathrm{IO}^{-\mathrm{II} 3}$. 
Pakschies, Günter: Umerziehung in der Britischen Zone. Untersuchungen zur britischen Re-education-Politik (= Studien und Dokumentationen zur deutschen Bildungsgeschichte. Hrsg.v. Christoph Führ und Wolfgang Mitter). 2. Aufl., Köln - Wien I984.

Palm, Kurt: Vom Boykott zur Anerkennung. Brecht und Österreich, Wien 1983.

Parry-Giles, Shawn J.: The Rhetorical Presidency. Propaganda and the Cold War, 1945-1955, Westport 2002.

Patel, Kiran Klaus: „All of this helps us in planning‘. Der New Deal und die NS-Sozialpolitik. In: Aust/Schönpflug (Hrsg.), Vom Gegner lernen. Feindschaften und Kulturtransfers im Europa des I9. und 20. Jahrhunderts, a.a.O., 234-252.

Paterniti, Michael: The Most Dangerous Beauty. In: GQ, September 2002, 468-472.

Paulu, Burton: Factors in the Attention to Establish a Permanent Instrumentality for Administration of the International Broadcasting Services of the United States (Ann Arbor: University Microfilms, I950).

Paulu, Burton: The Smith-Mundt Act: A Legislative History. In: Journalism Quarterly, Summer 1953.

Paulus, Stefan: Amerikanisierung von Universität und Wissenschaft in Westdeutschland 1945-1976 (= Studien zur Zeitgeschichte. Hrsg.v. Institut für Zeitgeschichte, Bd. 8I), München 201 I.

Pepper, Hugo: Ernst Karl Winter und die Sozialdemokratie - im Spiegel von $A Z$ und Kampf. In: Siegwald Ganglmair (Red.), Jahrbuch 1996. Dokumentationsarchiv des österreichischen Widerstandes, Wien I996, I50-I7I.

Peter, Birgit, Martina Payr (Hrsg.): „Wissenschaft nach der Mode“? Die Gründung des Zentralinstituts für Theaterwissenschaften an der Universität Wien 1943.2.Aufl., Berlin 2008.

Peter, Birgit: „Wissenschaft nach der Mode“. Heinz Kindermanns Karriere 19I4-1945. Positionen und Stationen. In: Birgit Peter/Martina Payr (Hrsg.), „Wissenschaft nach der Mode“? Die Gründung des Zentralinstituts für Theaterwissenschaften an der Universität Wien 1943.2.Aufl., Berlin 2008, 15-51.

Peterson, Walter F.: Zwischen Mißtrauen und Interesse. Regierungsstellen in Washington und die deutsche politischen Emigration I939-I945. In: Manfred Briegel/Wolfgang Frühwald (Hrsg.), Die Erfahrung der Fremde. Kolloquium des Schwerpunktprogramms ,Exilforschung' der Deutschen Forschungsgemeinschaft. Forschungsbericht, Weinheim 1988, 45-59.

Petschnig, Edith: Alliierte Entnazifizierung in Österreich. In: Stefan Karner/Gottfried Stangler (Hrsg.), „Österreich ist frei!“ Der Österreichische Staatsvertrag 1955. Beitragsband zur Ausstellung auf Burg Schallaburg 2005. Unter Mitarbeit von Peter Fritz und Walter M. Iber, Horn Wien 2005, I09-II3.

Peukert, Detlev J.K.: Die Weimarer Republik. Krisenjahre der klassischen Moderne, Frankfurt a. Main 1987 .

Pfefferle, Roman, Hans Pfefferle: Glimpflich entnazifiziert. Die Professorenschaft des Sommersemesters 1944 der philosophischen Fakultät der Universität Wien in den Nachkriegsjahren. Endbericht des Forschungsprojekts: Entnazifizierung an der Universität Wien nach 1945 (philosophische Fakultät). Kontinuitäten und Diskontinuitäten universitärer Wissenschaftseliten (Projektleitung: Walter Manoschek), Wien 2 oro. 
Pfoser, Alfred: Literatur und Austromarxismus, Wien 1980.

Picquard, Caroline Joan: The Holocaust Film Source book. Documentary and Propaganda, Westport 2004.

Picht, Georg: Die deutsche Bildungskatastrophe. Analyse und Dokumentation, Olten-Freiburg im Breisgau 1964 .

Pierson, George Wilson: Tocqueville in America, Baltimore - London 1996 [zuvor veröffentlicht unter dem Titel: Tocqueville and Baumont in America, New York 1938].

Pinnigton, Elizabeth: Learning citizenship by practicing democracy. International initiatives and perspectives, Newcastle 2 oro.

Pirker, Peter: „Most difficult to tackle“. Intelligence, Exil und Widerstand am Beispiel der Austrian Section SOE. 2 Bde., phil. Diss., Univ. Wien 2009.

Platzer, Rachel: Entnazifizierung der Studierenden an der Universität Wien unter besonderer Berücksichtigung der medizinischen Fakultät, Dipl.-Arb., Univ. Wien 2005.

Plé, Bernhard: „Social sciences“ in der Ordnungspolitik der USA. Vom Kriegseinsatz zum Medium der amerikanischen Kulturpolitik im Nachkriegsdeutschland, I94I-I957. In: Jabrbuch für Soziologiegeschichte, I997/98, Opladen 200I, 195-213.

Plöchl, Gerhardt: Willibald Plöchl und Otto Habsburg in den USA. Hrsg. v. Dokumentationsarchiv des österreichischen Widerstandes. Ringen um Österreichs „Exilregierung“' 194I/42, Wien 2007 .

Plöckinger, Othmar: Geschichte eines Buches. Adolf Hitlers, Mein Kampf ' 1922-I945.2.aktualisierte Aufl., München 2011 .

Poiger, Uta G.: Jazz, Rock, and Rebels: Cold War Politics and American Culture in a Divided Germany, Berkeley 2000.

Pollack, Erwin: Isaac Leon Kandel (I88I-I965). In: PROSPECTS: the Quarterly Review of Comparative Education, Vol. 23, No. 3/4, 1993, 775-787.

Pool, James E.: Who financed Hitler. The Secret funding of Hitler's rise to power, I919-1933, New York et al. 1997 .

Popp, Valerie: „Aber hier war alles anders ...“. Amerikabilder der deutschsprachigen Exilliteratur nach 1939 in den USA, Würzburg 2008.

Posch, Herbert, Doris Ingrisch, Gert Dressl: ,Anschluss‘ und Ausschluss 1938. Vertriebene und verbliebene Studierende der Universität Wien (= Emigration - Exil - Kontinuität. Schriften zur zeitgeschichtlichen Kultur- und Wissenschaftsforschung. Hrsg. v. Friedrich Stadler, Bd. 8), Wien Berlin 2008.

Posch, Herbert: März 1938. ,Anschluss` und Ausschluss: Vertreibung der Studierenden an der Universität Wien. In: Herbert Posch/Doris Ingrisch/Gert Dressl, ,Anschluss‘ und Ausschluss 1938. Vertriebene und verbliebene Studierende der Universität Wien (= Emigration - Exil - Kontinuität. Schriften zur zeitgeschichtlichen Kultur- und Wissenschaftsforschung. Hrsg. v. Friedrich Stadler, Bd. 8), Wien - Berlin 2008, 99-I40.

Posch, Herbert: Studierende und die Universität Wien in der Dauerkrise 1918 bis 1938. In: Herbert Posch / Doris Ingrisch/Gert Dressl, ,Anschluss‘ und Ausschluss 1938. Vertriebene und ver- 
bliebene Studierende der Universität Wien (= Emigration - Exil - Kontinuität. Schriften zur zeitgeschichtlichen Kultur- und Wissenschaftsforschung, hrsg.v. Friedrich Stadler, Bd. 8), Wien Berlin 2008, 6I-98.

Posselt, Alfred M.: Österreichische Soldaten in den alliierten Streitkräften des Zweiten Weltkriegs. Teil r: Bearbeitung des statistischen Materials. Fakten und Zahlen, Wien 1987.

Prados, John: Safe for democracy. The secret wars of the CIA, Chicago 2006.

Prevots, Naima: Dance for Export. Cultural Diplomacy and the Cold War, Hanover 1998.

Pronay, Nicholas Keith Wilson (Eds.): The Political Re-Education of Germany and Her Allies After World War II, Kent 1985.

Puaca, Brian M.: Missionaries of Goodwill. Deutsche Austauschlehrer und -schüler und die Lehren der amerikanischen Demokratie in den frühen fünfziger Jahren. In: Arnd Bauerkämper/Konrad H. Jarausch/Marcus M. Payk (Hrsg.), Demokratiewunder. Transatlantische Mittler und die kulturelle Öffnung Westdeutschlands I945-1970, Göttingen 2005, 305-332.

Puaca, Brian M.: Learning Democracy. Education Reform in West Germany, I945-1965 (= Monographs in German History, Vol. 27), New York 2009.

Pucher, Michael: Umerziehung im sowjetischen Kriegsgefangenenlager Talicy, Dipl.-Arb., Univ. Graz 1997.

Puddington, Arch: Broadcasting Freedom. The Cold War Triumph of Radio Free Europe and Radio Liberty, Lexington 2000.

Pumhösel, Alois: Ägyptologe, Antisemit, weit mehr als ein Mitläufer (Hermann Junker). In: der Standard, 19. Februar 2013, download unter: http://derstandard.at/1361240485214/AegyptologeAntisemit-weit-mehr-als-ein-Mitlaeufer [Zugriff am 10.5.2013].

Pütter, Conrad: Rundfunk gegen das,Dritte Reich‘. Deutschsprachige Rundfunkaktivitäten im Exil I933-I945. Ein Handbuch (= Rundfunkstudien, Bd.3), München I986.

Pütz, Karl-Heinz: Business or Propaganda? American Films and Germany, 1942-I946. In: Ekkehard Krippendorf (Hrsg.), The Role of the United States in the Reconstruction of Italy and West Germany, 1943-1949. Papers presented at a German-Italian Colloquium held at the John F. KennedyInstitut für Nordamerikastudien, Berlin, June I980 (= Materialien I6), Berlin I981, I83-238.

Radkau, Joachim: Die deutsche Emigration in den USA. Ihr Einfluß auf die amerikanische Europapolitik 1933-I945, Düsseldorf I97ı.

Raeithel, Gert: Wiederkehrende Elemente im deutschen Antiamerikanismus der Nachkriegszeit. In: Amerikastudien/American Studies, 31. Jg. 1986, Heft 4, $336 \mathrm{ff}$.

Raeithel, Gert: Geschichte der nordamerikanischen Kultur. Bd.3: Vom New Deal bis zur Gegenwart. 1930-I995. 3 Aufl., Frankfurt a. Main 1997.

Raeithel, Gert: „Go West“: Ein psychohistorischer Versuch über die Amerikaner. 2. Aufl., Hamburg 1993.

Ranzmaier, Irene: Germanistik - Kontinuitätsstiftende Ansätze der Wissenschaft. In: Mitchell G. Ash/Wolfram Nieß/Roman Pils (Hrsg.), Geisteswissenschaften im Nationalsozialismus. Das Beispiel der Universität Wien, Göttingen 2010, 427-454.

Rathkolb, Oliver (Hrsg.): Gesellschaft und Politik am Beginn der Zweiten Republik. Vertrauliche Berichte der US-Militäradministration aus Österreich 1945, Wien - Köln - Graz 1985. 
Rathkolb, Oliver: Die Entwicklung der US-Besatzungspolitik zum Instrument des Kalten Krieges. In: Kontinuität und Bruch 1938-1945-1955. Beiträge zur österreichischen Kultur- und Wissenschaftsgeschichte. Hrsg. v. Friedrich Stadler, Wien - München 1988, 35-50.

Rathkolb, Oliver: Die paradoxe Republik. Österreich 1945 bis 2005, Wien 2005.

Rathkolb, Oliver: Internationalisierung Österreichs seit 1945 (=Österreich - Zweite Republik. Befund, Kritik, Perspektive, Bd. 15), Innsbruck - Wien - Bozen 2006.

Rathkolb, Oliver: Die Universität Wien und die „Hohe Politik“ 1945 bis I955. In: Grandner/Heiß/ Rathkolb (Hrsg.), Zukunft mit Altlasten. Die Universität Wien 1945 bis 1955, a.a. O., 38-53.

Rathkolb, Oliver: Hans Kelsen und das FBI während des McCarthysmus in den USA. In: Walter/Ogris/Olechowski (Hrsg.), Hans Kelsen: Leben - Werk - Wirksamkeit, a.a.O., 339-348.

Rathkolb, Oliver: Gewalt und Antisemitismus an der Universität Wien seit der Badeni-Krise. Vortrag bei der Tagung: „Der lange Schatten des Antisemitismus. Kritische Auseinandersetzungen mit der Geschichte der Universität Wien im 19. Jahrhundert“, Universitätsarchiv Wien, Ir. Oktober 20I2. [unpubliziertes Manuskript].

Rathkolb, Oliver (Hrsg.): Der lange Schatten des Antisemitismus. Kritische Auseinandersetzungen mit der Geschichte der Universität Wien im I9. und 20. Jahrhundert (=Zeitgeschichte im Kontext Nr. 8), Wien 20I3.

Rathkolb, Oliver: Politische Propaganda der amerikanischen Besatzungsmacht in Österreich 1945 bis 1950. Ein Beitrag zur Geschichte des Kalten Krieges in der Presse-, Kultur und Rundfunkpolitik. 2 Bde., Diss., Univ. Wien r98r.

Rathkolb, Oliver: U.S.-Entnazifizierung in Österreich zwischen kontrollierter Revolution und Elitenrestauration (1945-1949). In: Zeitgeschichte, Ir. Jg., I984, 302-325.

Rathkolb, Oliver: Überlegungen zum Exodus der „Jurisprudenz“. Rechts- und staatswissenschaftliche Emigration aus dem Österreich der Zwischenkriegszeit. In: Friedrich Stadler (Hrsg.), Vertriebene Vernunft. Bd. I. Emigration und Exil österreichischer Wissenschaft 1930-1940, Wien München $1987,276-303$.

Rathkolb, Oliver: Der Kalte Krieg um die österreichische Buchproduktion 1948. In: Medien und Zeit, Vol. I-2, I986, 49-57.

Rathkolb, Oliver: US-Medienpolitik und die neue österreichische Journalistenelite. In: Medien und Zeit, Vol. 2, I987,3-16.

Rathkolb, Oliver: US-Medienpolitik in Österreich 1945-1950. Von antifaschistischer Reorientierung zur ideologischen Westintegration. In: Medienjournal, 8. Jg., I984, Nr. 3, 2-9.

Rathkolb, Oliver: Washington ruft Wien. US-Großmachtpolitik und Österreich 1953-1963. Mit Exkursen zu CIA-Waffenlagern, NATO-Connection, Neutralitätsdebatte, Wien 1997.

Rathkolb, Oliver: Zur Archäologie über österreichische Juristen im Exil. In: Friedrich Stadler (Hrsg.), Vertriebene Vernunft II. Emigration und Exil österreichischer Wissenschaft, Wien München $1988,434-438$.

Rauchensteiner, Manfried, Wolfgang Etschmann (Hrsg.): Österreich 1945. Ein Ende und viele Anfänge, Graz - Wien 1997 .

Rauchensteiner, Manfried: Der Krieg in Österreich ,45, Graz 1995. 
Rauchensteiner, Manfried: Die Zwei. Die Große Koalition in Österreich 1945-1966, Wien 1987.

Raunig, Birgit: The first two years of the Fulbright Commission in Austria. First hand reports by American students - How did they perceive Austria?, Dipl.-Arb., Univ. Wien 2010.

Ravitch, Diane: The Troubled Crusade. American Education, 1945-1980, New York 1983.

Reiling,Johannes: Deutschland: Safe for Democracy? Deutsch-amerikanische Beziehungen aus dem Tätigkeitsbereich Heinrich F. Alberts, kaiserlicher Geheimrat in Amerika, erster Staatssekretär der Reichskanzlei der Weimarer Republik, Reichsminister, Betreuer der Ford-Gesellschaften im Herrschaftsgebiet des Dritten Reiches, 1914 bis 1945, Stuttgart 1997.

Reimüller, Dimitra: Entnazifizierung in Österreich, Dipl.-Arb, Univ. Graz 1988.

Reisch, George A.: How the Cold war Transformed Philosophy of Science. To the Icy Slopes of Logic, New York 2005.

Reisenbauer, Sarah: Die Entnazifizierung des Lehrpersonals der Technischen Hochschule in Wien. In: Österreichische Hochschulen im 20. Jahrhundert. Austrofaschismus, Nationalsozialismus und die Folgen. Hrsg. v. der Österreichischen Hochschülerschaft, Wien 2013, 36I-372.

Reiter, Margit, Helga Embacher (Hrsg.): Europa und der II. September 200I, Wien et al. 201 .

Reiter, Wolfgang L.: 1938 und die Folgen für die Naturwissenschaften an Österreichs Universitäten. In: Stadler (Hrsg.), Vertriebene Vernunft. Bd. II. Emigration und Exil österreichischer Wissenschaft, a.a.O., 664-68o.

Renner, Karin: Hans Kelsen: Der Philanthrop, Dipl.-Arb., Univ. Wien 2oor.

Renner, Gerhard: Entnazifizierung der Literatur. In: Meissl (Hrsg.), Verdrängte Schuld - verfehlte Sühne, a.a.O., 202-229.

Resele, Gertraud: Othmar Spanns Ständestaatkonzeption und politisches Wirken, Dipl.-Arb., Univ. Wien 2001.

Rettenwander, Matthias: Nachwirkung des Josephinimus. In: Helmut Reinalter (Hrsg.), Josephinismus als aufgeklärter Absolutismus, Wien - Köln - Weimar 2008, 317-425.

Riecker, Joachim: ,Das Geheimnis ist Mut'. Antike Vorbilder in der amerikanischen Außenpolitik von Theodore Roosevelt bis Bill Clinton, Paderborn 2006.

Riemer, Rudolf: Die Anti-Hitler-Koalition (=Ost-Kurier. Informationen - Analysen - Berichte. Hrsg. v. Studienzentrum für Ost-West-Probleme), München o.J. [1985].

Riesenfellner, Stefan, Josef Seiter: Der Kuckuck. Die moderne Bild-Illustrierte des Roten Wien, Wien 1995.

Ritter, Gerhard A. (Hrsg.): Friedrich Meinecke. Akademischer Lehrer und emigrierte Schüler. Briefe und Aufzeichnungen I910-1977, München 2006.

Ritter, Alexander: Die USA als Utopie liberaler Staatlichkeit und ethnokulturellen Selbsterhalts. Zum Paradigmenwechsel des Amerikabildes in den Auswandererromanen „Die deutsch-amerikanischen Wahlverwandtschaften“ (I839/40) von Charles Sealsfield und „Ein Deutscher“ (I862) von Otto Rupius. In: Alexander Ritter (Hrsg.), Amerika im europäischen Roman um 1850. Varianten transatlantischer Erfahrung (= SealsfieldBibliothek 8), Wien 20II, 89-II7.

Ritter, Alexander (Hrsg.): Amerika im europäischen Roman um 1850. Varianten transatlantischer Erfahrungen (= SealsfieldBibliothek. Wiener Studien und Texte 8), Wien 20 II. 
Robin, Ron: The Barbed-Wire College. Reeducating German POWs in the United States during World War II, Princeton 1995 .

Roger, Philipp: Aufklärer gegen Amerika. Zur Vorgeschichte des amerikanischen Antiamerikanismus. In: Thadden/Escudier (Hrsg.), Amerika und Europa - Mars und Venus?, a.a.O., I6-34.

Roger, Philipp: L'Ennemi américain. Généalogie de l’antiaméricanisme française, Paris 2002.

Rosar, Wolfgang: Deutsche Gemeinschaft. Seyss-Inquart und der Anschluß, Wien - Frankfurt Zürich I97I.

Rosenzweig, Beate: Erziehung zur Demokratie? Amerikanische Besatzungs- und Schulreformpolitik in Deutschland und Japan, Stuttgart 1995.

Rubin, Barry, Judith C. Rubin: Hating America. A History, Oxford 2004.

Rudy, Willis: Total war and twentieth-century higher learning. Universities of the Western world in the First and Second World Wars, London - New York i991.

Ruggie, John Gerad: Constructing the World Polity. Essays on International Instiutionalization, London 1998.

Rupnow, Dirk: Brüche und Kontinuitäten - Von der NS-Judenverfolgung zur Nachkriegsjustiz. In: Mitchell G. Ash/Wolfram Nieß/Roman Pils (Hrsg.), Geisteswissenschaften im Nationalsozialismus. Das Beispiel der Universität Wien, Göttingen 201о, 79-ıго.

Rust, Val D.: The German Image of American Education through the Weimar Period. In: Paedagocica Historica. International Journal of History of Education, XXXIII, I997, I, $25-44$.

Ruthner, Clemens: „Amerikamüde“,Deutsche“ und ihre „Neger“. Skizze zur Theorie der literarischen Stereotypenforschung (mit einem Seitenblick auf F. Kürnberger). In: Germanistische Mitteilungen. Zeitschrift für deutsche Sprache, Literatur und Kultur, 67, 2008, Heft 67, 82-100.

Ryan, James G., Leonard Schlup (Eds.): Historical Dictionary of the I940s, New York 2006.

Ryback, Timothy W.: „The Salzburg Seminar- A Community of Fellows“. Zit. nach: http://www. salzburgglobal.org/current/history-b.cfm?goto=community [Zugriff am Io. Jänner 2013].

Sadofsky, Wilhelm: Die Geschmacksbildung an den Wiener Theatern von 1945 bis 1949, Diss., Univ. Wien I950.

Sakabe, Yukiko: Die Bibliothek von Guido Adler. In: Mitteilungen der Alfred Klabr Gesellschaft, Nr. I, 2007, IO-I3.

Saldern, Adelheid von: Überfremdungsängste. Gegen die Amerikanisierung der deutschen Kultur in den zwanziger Jahren. In: Amerikanisierung. Traum und Alptraum im Deutschland des 2o. Jahrhunderts (=Transatlantische Historische Studien, Bd. 6). Hrsg.v. Alf Lüdtke/Inge Marßolek/Adelheid von Saldern, Stuttgart 1996, 213-244.

Salomon, Barbara: In the Company of Educated Women. A History of Women and Higher Education in America, New Haven 1985.

Sammons, Jeffrey L.: Ideology, Mimesis, Fantasy: Charles Sealsfield, Friedrich Gerstäcker, Karl May, and Other German Novelists of America, Chapel Hill 1998.

Sanders, Ralph, Fred R. Brown: National Security Management: Global Psychological Conflict, Washington D.C. r96r. 
Sandner, Günther: The German Human Climate and Ist Opposite: Otto Neurath in England, I94045. In: Anthony Grenville/Andrea Reiter (Eds.), Political Exile and Exile Politics in Britain after 1933, New York - Amsterdam 20II, 67-85.

Saunders, Frances Stonor: Who Paid the Piper? The CIA and the Cultural Cold War, London 1999.

Saunders, Frances Stonor: The Cultural Cold War. The CIA and the World of Arts and Letters, New York 2000.

Schäfer-Richter, Uta, Jörg Klein: Die jüdischen Bürger im Kreis Göttingen, I933-I945. Göttingen Hann - Münden - Duderstadt. Ein Gedenkbuch. Hrsg. v. Karl-Heinz Manegold. 2. Aufl., Göttingen 1993 .

Schartner, Irmgard: Die Staatsrechtler der juridischen Fakultät der Universität Wien im „Ansturm“ des Nationalsozialismus. Umbrüche mit Kontinuitäten, Frankfurt a. Main 2oII.

Schausberger, Bernhard: Die Entstehung des Mythos Österreich als Opfer des Nationalsozialismus. Eine Dokumentation, Dipl.-Arb., Univ. Salzburg 199r.

Schembor, Friedrich Wilhelm: Polizeiliche Situationsberichte für die Jahre I945 und I946. In: Studien zur Wiener Geschichte. Jahrbuch des Vereins für Geschichte der Stadt Wien. Hrsg.v. Ferdinand Oppl/Maria Altfahrt/Karl Fischer. Bd. 59, Wien 2003.

Schiller, Herbert I.: Culture. The corporate takeover of public expression, New York et al. I989.

Schlag, Wilhelm: Das Amerika-Institut und der Studentenaustausch zwischen Österreich und den USA. In: Austro-American Institute of Education (Amerika-Institut). 50 Jahre im Dienste des kulturellen Austauschen zwischen Österreich und den U.S.A., 1926-1976, Wien 1976.

Schlander, Otto: Der Einfluß von John Dewey und Hans Morgenthau auf die Formulierung der Re-educationpolitik. In: Manfred Heinemann (Hrsg.), Umerziehung und Wiederaufbau, a.a.O., $40-52$.

Schlegel, Natalie: Die Beurteilung der „US-Kulturmission in Österreich 1945-I955“. Der Bereich der Medien am Beispiel von „Wiener Kurier“, „Salzburger Nachrichten“ und „Radio Rot-Weiß-Rot“, Dipl.-Arb., Univ. Wien 2008.

Schmidt, Alexander: Reisen in die Moderne. Der Amerika-Diskurs des deutschen Bürgertums vor dem Ersten Weltkrieg im europäischen Vergleich, Berlin I997.

Schmidt, Erich: Albrecht Karl Konecny, „Heil Borodajkewycz“. Österreichs Demokraten im Kampf gegen Professor und seine Hintermänner, Wien 1966.

Schmidt, Gabriela: „Schönbauer, Leopold“. In: Neue Deutsche Bibliographie, 23, 2007, 383-384.

Schmidt, Oliver Matthias Arnold: Civil Empire by Co-optation: German-American Exchange Programs as Cultural Diplomacy, I945-I96I, Diss., Harvard University I999.

Schmidt, Ute, Tilman Fichter: Der erzwungene Kapitalismus. Klassenkämpfe in den Westzonen, I945-48, Berlin I97I.

Schneider, Felix: Aspekte britischer Sicherheitspolitik zur Zeit der Besatzung in Österreich $1945^{-}$ 1948. Unter besonderer Berücksichtigung der Steiermark, Dipl.-Arb, Univ. Graz 1993.

Schnell, Hermann: Bildungspolitik in der Zweiten Republik, Wien - Zürich 1993.

Schnitzler, Günter: Nachwort. In: Charles Sealsfield. In der Neuen Welt. Aus: Morton oder die große Tour, München I997, I4I-I74. 
Schoiswohl, Johann: Der US-amerikanische Einfluss im Alltag der Nachkriegszeit. Spuren eines Akkulturationsprozesses. Eine soziokulturelle Analyse im Raum Wels - Oberösterreich, Dipl.Arb., Univ. Salzburg 1990.

Schönberg, Michael: Die amerikanische Medien- und Informationspolitik in Österreich von I9451950. 2 Bde., Diss., Univ. Wien 1975.

Schröder, Hans-Jürgen (Ed.): Confrontation and Cooperation. Germany and the United States in the Era of World War I, 1900-1924, Oxford 1993.

Schubert, Kurt: Die Wiedereröffnung der Universität Wien im Mai I945. Vortrag im Rahmen der Veranstaltungsreihe „625 Jahre Universität Wien“ am ıo. Mai 1990 im Kleinen Festsaal der Universität Wien (=Wiener Universitätsreden, NF, I), Wien I99I.

Schuhmacher, Frank: Kalter Krieg und Propaganda. Die USA, der Kampf um die Weltmeinung und die ideelle Westbindung der Bundesrepublik Deutschland, 1945-I955, Trier 2000.

Schuster, Walter, Wolfgang Weber (Hrsg.): Entnazifizierung im regionalen Vergleich, Linz 2004.

Schuster, Walter: Politische Restauration und Entnazifizierungspolitik in Oberösterreich. In: Walter Schuster/Wolfgang Weber (Hrsg.), Entnazifizierung im regionalen Vergleich, Linz 2004, 157-215. Schwaabe, Christian: Antiamerikanismus. Wandlungen eines Feindbildes, München 2003.

Schwan, Gesine: Antikommunismus und Antiamerikanismus in Deutschland. Kontinuität und Wandel nach 1945 , Baden-Baden 1999.

Schwartz, Lowell H.: Political Warfare against the Kremlin. US and British Propaganda Policy at the Beginning of the Cold War, Basingstoke 2009.

Sciutto, Jim: Against us. The new face of America's enemies in the Muslim world, New York 2008.

Scott-Smith, Giles, Hans Krabbendam (Eds.): The Cultural Cold War in Western Europe, 1945I960, London 2004 .

Sedlmaier, Alexander: Deutschlandbilder und Deutschlandpolitik. Studien zur Wilson-Administration (I913-I92I) (= Historische Mitteilungen im Auftrag der Ranke-Gesellschaft. Hrsg. v. Jürgen Elvert/Michael Salewski, Bd. 5I), Stuttgart 2003.

Seebacher, Felicias: Das Fremde im „deutschen“Tempel der Wissenschaften. Brüche in der Wissenschaftskultur der Medizinischen Fakultät der Universität Wien (= Veröffentlichungen der Kommission für Geschichte der Naturwissenschaften, Mathematik und Medizin), Wien 20 II.

Seidl, Walter: Zwischen Kultur und Culture. Das Austrian Institute in New York und Österreichs kulturelle Repräsentanz in den USA, Wien - Köln - Weimar 200I.

Shappiro, Michael Davis: The Role of Connective Tissue Growth Factor (CTGF) in Fibrosis. Associated With Intestinal Neuroendocrine Tumors, Yale 2005.

Shlapentokh, Vladimir, Joshua Woods, Eric Shiraev (Eds.): America. Sovereign Defender or Cowboy Nation?, Aldershot 2005 .

Sieder, Elfriede: Die Alliierten Zensurmaßnahmen zwischen 1945-1955. Unter besonderer Berücksichtigung der Medienzensur, Diss., Univ. Wien I983.

Siegfried, Klaus-Jörg: Universalismus und Faschismus. Das Gesellschaftsbild Othmar Spanns, Wien I974.

Siemann, Wolfram: Metternich. Staatsmann zwischen Restauration und Moderne, München 2 oro. 
Simon, Joseph T.: Augenzeuge. Erinnerungen eines österreichischen Sozialisten. Eine sehr persönliche Zeitgeschichte. Mit einem Vorwort von Charles Gulick. Hrsg. v. Wolfgang Neugebauer, Wien 1979.

Simpson, Christopher: Der amerikanische Bumerang. NS-Kriegsverbrecher im Sold der USA, New York - Wien 1988.

Simpson, Christopher: Science of Coercion. Communication Research and Psychological Warfare I945-1960, New York - Oxford I994.

Smith, Henry Nash: The Salzburg Seminar. In: American Quarterly, I949, No. I, 30-37.

Smith, Jean, Arnold Toynbee (Eds.): Gilbert Murray. An Unfinished Autobiograhy. With Contributions by his Friends, London I960.

Smith, Richard Harris: OSS. The Secret History of America's First Intelligence Agency, Berkeley 2005 [1972].

Sollbach, Gerhard E.: Amerika 1590. Europas erste Bilder von der Neuen Welt, Kettwig 1992.

Sommerauer, Erich: Wilhelm Czermak - Afrikanistik, Ägyptologe, 2ooro. Download unter http:// www.afrikanistik.at/pdf/personen/czermak_wilhelm.pdf [Zugriff am I0.5.2013].

Spalding, Elizabeth Edward: The First Cold Warrior. Harry Truman, Containment, and the remaking of Liberal Internationalism, Lexington 2006.

Spann, Gustav: Untersuchungen zur anatomischen Wissenschaft in Wien 1938-I945. Senatsprojekt der Universität Wien. Eine Zusammenfassung. In: Dokumentationsarchiv des österreichischen Widerstandes. Jahrbuch 1999 (Red. Siegwald Ganglmair), Wien 1999.

Speiser, Wolfgang: Die sozialistischen Studenten Wiens 1927-I938 (= Materialien zur Geschichte der Arbeiterbewegung, Nr. 40), Wien 1986.

Speiser, Wolfgang: Zeitzeuge. In: Friedrich Stadler (Hrsg.), Vertriebene Vernunft. Bd. II. Emigration und Exil österreichischer Wissenschaft, Wien - München 1988, 907-914.

Srodes, James: Allen Dulles. Master of Spies, Washington D.C. I999.

Stadlen, Hedi: Dauntless Austrian émigrée who campaigned on liberal issues and supported music as the wife of the pianist Peter Stadlen. In: The Sunday Times, 3r. Jänner 2004.

Stadler, Friedrich (Hrsg.): Vertriebene Vernunft. Bd. I. Emigration und Exil österreichischer Wissenschaft 1930-I940, Wien - München 1987.

Stadler, Friedrich (Hrsg.): Vertriebene Vernunft. Bd. II. Emigration und Exil österreichischer Wissenschaft. Internationales Symposion, I9. Bis 23. Oktober 1987 in Wien, Wien - München 1988.

Stadler, Friedrich: Österreich und der Nationalsozialismus - die Folgen für das intellektuelle Leben. In: Friedrich Stadler (Hrsg.), Österreichs Umgang mit dem Nationalsozialismus. Die Folgen für die naturwissenschaftliche und humanistische Lehre. Internationales Symposium 5.-6. Juni 2003, Wien 2004 .

Starlinger, Elisabeth: Aspekte französischer Kulturpolitik in Österreich nach dem Zweiten Weltkrieg (I945-I948), Dipl.-Arb., Univ. Wien I993.

Staudinger, Anton: Austrofaschistische „Österreich“-Ideologie. In: Emmerich Tálos/Wolfgang Neugebauer (Hrsg.), Austrofaschismus. Politik - Ökonomie - Kultur 1933-1938.5.überarb. Aufl. (Red. Christine Schindler), Wien 2005, 28-53. 
Staudinger, Michael: Musikwissenschaft an der Universität Wien I945-1955. In: Grandner/Heiß/ Rathkolb (Hrsg.), Zukunft mit Altlasten, a.a.O., I56-I73.

Steele, Richard W.: Preparing the Public für War: Efforts to Establish a National Propaganda Agency, 1940-4I. In: The American Historical Review, Vol. LXXV, Oct. 1969 to Dec.I 970, 1640-1653.

Steele, Richard W.: Roosevelt, Marshall, and the First Offensive. The Politics of Strategy Making, I94I-I942, Diss., Johns Hopkins University 1969.

Steel, Ronald: Pax Americana. Weltreich des Kalten Krieges, Darmstadt I968.

Steinbach, Günther: Unterrichtwesen zwischen Restauration und Demokratie. In: Jaques Hannak (Hrsg.), Bestandsaufnahme Österreich, 1945-1963, Wien - Hannover - Bern 1963, 287-305.

Steiner, Fritz: „Tiroler Schulpolitik“ im Hauptschulbereich I945-I990, Dipl.-Arb., Univ. Innsbruck I994.

Stelzl-Marx, Barbara: Freier und Befreier. Zum Beziehungsgeflecht zwischen sowjetischen Besatzungssoldaten und österreichischen Frauen.In: Stefan Karner/Barbara Stelzl-Marx (Hrsg.), Die Rote Armee in Österreich. Sowjetische Besatzung, 1945-1955, Graz 2005, 42I-448.

Stephan, Alexander (Ed.): The Americanization of Europe. Culture, Diplomacy, and Anti-Americanism after 1945, New York - Oxford 2006.

Stephan, Alexander (Ed.): Americanization and Anti-Americanism. The German encounter with American culture after 1945, New York 2005.

Stephanson, Anders: Manifest Destiny. American Expansion and the Empire of Right, New York 1995. Stiefel, Dieter: „Hilfe zur Selbsthilfe“. Der Marshall-Plan in Österreich I948-I952. In: Ernst Bruckmüller (Hrsg.), Wiederaufbau in Österreich I945-I955. Rekonstruktion oder Neubeginn? Wien 2006, 90-IOI.

Stiefel, Dieter: Entnazifizierung in Österreich, Wien - München - Zürich r98I.

Stiefel, Dieter: Nazifizierung plus Entnazifizierung = Null ? Bemerkungen zur besonderen Problematik der Entnazifizierung in Österreich. In: Sebastian Meiss1/Klaus-Dieter Mulley/Oliver Rathkolb (Hrsg)., Verdrängte Schuld, verfehlte Sühne. Entnazifizierung in Österreich I945-1955. Symposion des Instituts für Wissenschaft und Kunst, Wien I986, 28-36.

Stiefel, Dieter, Ingried Fraberger: Enemy Images. The Meaning of ,Anti-Communism` and Its Importance for the Political and Economic Reconstruction in Austria after 1945. In: Günter Bischof/Anton Pelinka/Dieter Stiefel (Eds.), The Marshall Plan in Austria (= Contemporary Austrian Studies VIII), New Brunswick 2000, 56-97.

Stifter, Christian H.: Paradigms of U.S. Reorientation and Cultural Exchange Programs in Austria in the Early Stages of Cold War, 1946-I949. In: Zeitgeschichte, 39. Jg., Januar/Februar 20I2, Heft I, 6-I9.

Stifter, Christian H.: „Library work is not philanthropy“. Zur historischen Rolle der Volksbüchereien im Kontext der Volksbildung des i9. und 20. Jahrhunderts. In: Alfred Pfoser/Peter Vodosek (Hrsg.), Zur Geschichte der öffentlichen Bibliotheken in Österreich, Wien 1995, 70-87.

Stifter, Christian H.: „Sehr geehrter Herr Kollege!“ Albert Einstein und die (Wiener) Volksbildung. In: Die Österreichische Volkshochschule. Organ des Verbandes Österreichischer Volkshochschulen, 57.Jg., 2006, Heft 220, 2-II. 
Stifter, Christian H.: Die Erziehung des Kino und die „Mission des Kulturfilms“. Zur sozialen Organisation des „Guten Geschmacks“ in der frühen Volksbildung und Kinoreform in Wien I898-I930. In: Spurensuche, 8. Jg., 1997, Heft 3-4, 54-79.

Stifter, Christian H.: Die Wiederaufrüstung Österreichs. Die geheime Remilitarisierung der westlichen Besatzungszonen 1945-1955 (=Wiener Zeitgeschichte-Studien, Bd. I), Innsbruck 1997.

Stifter, Christian H.: Geistige Stadterweiterung. Eine kurze Geschichte der Wiener Volkshochschulen, I887-2005 (= Enzyklopädie des Wiener Wissens, Bd. III: Volksbildung). Hrsg.v. Wiener Vorlesungen - Dialogforum der Stadt Wien, Weitra [2006].

Stifter, Christian H.: NS-Kriegsverbrecher als ,intelligente Analysten“ der politischen Nachkriegssituation? Anmerkungen zu einem „Experiment britisch-amerikanischer Militärstellen in Österreich I945. In: Zeitgeschichte, 28. Jg., 200I, Heft 6, 32I-330.

Stifter, Christian H. (Hrsg.): „Volksbildung mach ich wo immer ...‘. Viktor Matejka, I9oI-1993“, Schwerpunktausgabe der Zeitschrift Spurensuche. Zeitschrift für Geschichte der Erwachsenenbildung und Wissenschaftspopularsierung, I6. Jg., Heft I-4 I6. Jg., 2005.

Stifter Christian: Kurzcharakteristik der Quellenlage zu Leben und Werk von Wolfgang Speiser. In: Volker Otto/Erhard Schlutz (Hrsg.), Erwachsenenbildung und Emigration. Biographien und Wirkungen von Emigrantinnen und Emigranten (=Tagungsprotokoll der I2. Konferenz des Arbeitskreises zur Aufarbeitung historischer Quellen in der EB, hrsg. v. DVV), Bonn 1999, II7-I33.

Stourzh, Gerald: Geschichte des Staatsvertrages I945-1955. Österreichs Weg zur Neutralität. 3. Aufl., Graz - Wien - Köln r980.

Stöver, Bernd: Die Befreiung vom Kommunismus. Amerikanische Liberation Policy im Kalten Krieg 1947-199I (= Zeithistorische Studien, hrsg.v. Zentrum für Zeithistorische Forschung Potsdam, Bd. 22), Köln - Weimar - Wien 2002.

Stöver, Bernd: Rollback. An Offensive Strategy for the Cold War. In: Detlef Junker (Ed.), The United States and Germany in the Era of the Cold War, 1945-1990. A Handbook. Volume I: 1945-I968, Cambridge 2005, 97-IO2.

Strauss, David: The Rise of Anti-Americanism in France. French Intellectuals and the American Film Industry, 1927-1932. In: Journal of Popular Culture, 10, 1977, 4, 752-759.

Streminger, Gerhard: David Hume. Der Philosoph und seine Zeit, München 201 .

Streßler, Maria: Im Klassenzimmer. Der Wandel des Lehrer-Schüler-Verhältnisses in Österreich, Frankfurt a. Main 2008.

Strobl, Karl: Gruppe Calvarienberg - Wien XVII. In: Siegwald Ganglmair (Red.), Jahrbuch 1995. Dokumentationsarchiv des österreichischen Widerstands, Wien I995, I24-I37.

Strohmeier, Marcus: Lernen um zu kämpfen. Kämpfen um zu siegen. Josef Luitpold Stern (r886I966), Wien 20II.

Stumpf, Robert: „Dieses Mittelstück und die zwei Enden“. Ernst Fischer in der österreichischen Nachkriegspolitik (1945-I948). In: Bernhard Fetz (Hrsg.), Ernst Fischer. Texte und Materialien, Wien 2000, II $35-155$.

Stumpf, Robert: Ernst Fischer als Staatssekretär für „Volksaufklärung, Unterricht und Erziehung und Kultusangelegenheiten“ (1945). Versuch einer politischen Biographie unter struktur- und institutionsgeschichtlichen Gesichtspunkten. 3 Bde., Dipl.-Arb., Univ. Wien 1997. 
Sulzbacher, Cornelia: Adolf Eigl - Landeshauptmann von Oberösterreich. In: Mitteilungen des Oberösterreichischen Landesarchivs, 22. Bd., Linz 20II, 331-349.

Suppan, Franz B.N.: Film und Kino in Graz von 1945 bis zum Beginn der Fünfziger Jahre. In: Friedrich Bouvier/Helfried Valentinitsch (Red.), Graz 1945 (= Historisches Jahrbuch der Stadt Graz, Bd. 25), Graz I994, 6oI-622.

Svoboda, Wilhelm: Die Partei, die Republik und der Mann mit den vielen Gesichtern. Oskar Helmer und Österreich II. Eine Korrektur, Wien 1993.

Svoboda, Wilhelm: „...vorbehaltlos meine Pflicht erfüllt.“ Das Internierungslager Glasenbach. In: Zeitgeschichte, 22. Jg., I995, Heft I-2, 3-29.

Taschwer, Klaus: Das Wissen für Alle. Annäherungen an das populärwissenschaftliche Zeitschriftenwesen um I90o. In: Relation. Medien - Gesellschaft - Geschichte. Sonderdruck. Hrsg. v. Österreichische Akademie der Wissenschaften, Wien 1997, I7-50.

Taschwer, Klaus: Hochburg des Antisemitismus. In: Der Standard, I2. Juni 2012.

Taschwer, Klaus: Die Bärenhöhle und ihr langer Schatten. Über das Wirken und Nachwirken einer geheimen antisemitischen Professorenclique an der Universität Wien nach I9I8. Vortrag bei dem Workshop „Alma mater antisemitica“ (I5.-I6. Juni I2OI2) an der Österreichischen Akademie der Wissenschaften in Wien. (Unveröffentlichtes Manuskript, im Besitz d. Verfassers).

Taschwer, Klaus: Die Vernunft wurde schon früher vertrieben. Auf: http://science.orf.at/stories/I700034/sowie: http://derstandard.at/I342947379780/Antisemitische-Adressen-in-Wien

Taschwer, Klaus: Vertrieben, verbrannt, verkauft, vergessen und verdrängt. Über die nachhaltige Vernichtung der Biologischen Versuchsanstalt und ihres wissenschaftlichen Personals. In: Feichtinger/Matis/Sienell/Uhl (Hrsg.), Die Akademie der Wissenschaften in Wien I938-1945, IO5-II5.

Taschwer, Klaus: Die zwei Karrieren des Fritz Knoll. Wie ein Botaniker nach 1938 die Interessen der NSDAP wahrnahm - und das nach 1945 erfolgreich vergessen machte. In: Feichtinger/Matis/Sienell/Uhl (Hrsg.), Die Akademie der Wissenschaften in Wien I938-I945, a.a. O., 47-54.

Taylor, Frederick: Zwischen Krieg und Frieden. Die Besetzung und Entnazifizierung Deutschlands I944-I946, Berlin 2011.

Tent, James F.: Education and Religious Affairs Branch, OMGUS und die Entwicklung amerikanischer Bildungspolitik 1944 bis I949. In: Heinemann (Hrsg.), Umerziehung und Wiederaufbau, a.a.O., 68.

Tent, James F.: Mission on the Rhine. Reeducation and Denazification in American-Occupied Germany, Chicago - London 1982.

Teschler-Nicola, Maria, Margit Berner: Die Anthropologische Abteilung des Naturhistorischen Museums in der NS-Zeit. Berichte und Dokumentation von Forschungs- und Sammlungsaktivitäten I938-I945. In: Untersuchungen zur Anatomischen Wissenschaft in Wien 1938-1945. Akademischer Senat der Universität Wien, Wien 1998, 333-358.

Thadden, Rudolf von, Alexandre Escudier (Hrsg.): Amerika und Europa - Mars und Venus? Das Bild Amerikas in Europa, Göttingen 2004.

Thaller, Manfred: Studien zum europäischen Amerikabild. Darstellung und Beurteilung der Politik und inneren Entwicklung der Vereinigten Staaten von Amerika in Großbritannien, Deutschland und Österreich im Vergleich zwischen 1840 und I94I. 2 Bde., Diss., Univ. Graz, 1975. 
Theimer, Gerald: Die Wiener Staatspolizei in den Jahren I945-1947, Diss., Univ. Wien 1995.

Theuermann, Gerda: Umerziehung und Amerikabild: „Der Ruf. Zeitung der deutschen Kriegsgefangenen in den USA“, Dipl.-Arb., Univ. Graz 1992.

Tidl, Marie: Die Roten Studenten. Dokumente und Erinnerungen I938-1945. Mit einem Vorwort v. Karl R. Stadler (= Ludwig Boltzmann Institut für Geschichte der Arbeiterbewegung. Materialien zur Arbeiterbewegung Nr.3), Wien 1976.

Tode, Thomas: KZ-Filme in Wiener Kinos. Überlegungen zu zwei „Atrocity-Filmen“.In: Karin Moser (Hrsg.), Besetzte Bilder. Film, Kultur und Propaganda in Österreich I945-I955, Wien 2005, 357-373.

Todorov, Tzvetan: Die Eroberung Amerikas. Das Problem des Anderen, Frankfurt a. Main 1985.

Tolzmann, Don H. (Ed.): German-Americans in the World Wars. Bd.r: The Anti-German Hysteria of World War One, München - New Providence 1995.

Totten, Christine M.: Deutschland - Soll und Haben. Amerikas Deutschlandbild, München I964.

Toynbee, Arnold, Michael Balfour, John Mair: Four-Power-Control in Germany and Austria 1945I946, Oxford 1972 [Reprint der Ausgabe von 1956].

Tragl, Karl Heinz: Chronik der Wiener Krankenanstalten, Wien - Köln - Weimar 2007.

Tschögl, Rudolf: Tagespresse, Parteien und alliierte Besatzung. Grundzüge der Presseentwicklung in der unmittelbaren Nachkriegszeit I945-I950, Diss., Univ. Wien 1979.

Tweraser, Kurt: Die „unpolitische“ Periode der amerikanischen Besatzung in Linz und Oberösterreich. Sommer und Herbst 1945. In: Prinzip Hoffnung. Linz zwischen Befreiung und Freiheit. Ausstellungskatalog. Red.v. Willibald Katzinger und Fritz Mayrhofer, Linz 1995, 27-56.

Tweraser, Kurt: US-Militärregierung Oberösterreich. Bd. I: Sicherheitspolitische Aspekte der amerikanischen Besatzung in Oberösterreich-Süd 1945-1950 (= Beiträge zur Zeitgeschichte Oberösterreichs, Bd. r4. Hrsg. v. Oberösterreichisches Landesarchiv), Linz 1995.

Tweraser, Kurt: The „Operational Code“ of Senator Fulbright and International Education: Belief System, National Missions, Political Contexts. In: Österreichische Zeitschrift für Politikwissenschaft, 4I. Jg., 20I2, Heft I, $26 \mathrm{f}$.

Tweraser, Felix W.: Paris Calling Vienna: The Congress for Cultural Freedom and Friedrich Torberg's Editorship of Forum. In: Austrian Studies, Vol. I3, Austria and France, 2005, 158-I72.

Tweraser, Felix W.: „Our Man in Vienna“: Friedrich Torberg's Journal Forum and the Popularization of American Letters in Austria. In: TRANS. Internet-Zeitschrift für Kulturwissenschaften, Nr. I7, Februar 20IO: http://www.inst.at/trans/I7Nr/I-II/I-II_tweraserI7.htm [Zugriff 28.3.20I3]

Ucakar, Karl: Demokratie und Wahlrecht in Österreich. Zur Entwicklung von politischer Partizipation und staatlicher Legitimationspolitik, Wien 1985.

Ulrich, Rudolf: Österreicher in Hollywood, Wien 2004.

Urban, Otto H.: Die Ur- und Frühgeschichte an der Universität Wien vor, während und nach der NSZeit.In: Ash/Nieß/Pils (Hrsg.), Geisteswissenschaften im Nationalsozialismus, a.a.O., 37I-396.

Vaillant, Jerome: Was tun mit Deutschland? Die französische Kulturpolitik im besetzten Deutschland von 1945 bis I949. In: Heinemann (Hrsg.), Umerziehung und Wiederaufbau, a.a.O., 20I-2IO. Velma Hastings Cassidy (Ed.), Germany 1947-I949 (= Department of State Publication 3556. European and British Commonwealth Series 9), Washington D.C. 1950. 
Verosta, Stephan: Die internationale Stellung Österreichs, Wien I947.

Vickers, Sarah Pauline:The Life of Ruth Bryan Owen. Florida's First Congresswoman and America's First Woman Diplomat, Diss., Florida State University 1994.

Vodosek, Peter: Eduard Reyer I849-1914. Biobibliographie, Berlin 1976

Vogel, Bernd: NS-Registrierung in Wien. In: Walter Schuster/Wolfgang Weber (Hrsg.), Entnazifizierung im regionalen Vergleich, Linz 2004, 337-36r.

Vogel, Norbert: Grundtvigs Bedeutung für die deutsche Erwachsenenbildung. Ein Beitrag zur Bildungsgeschichte, Bad Heilbrunn/Obb. I994.

Vogel, Stefan: Der französische Sektor in Wien 1945-1955. In: Studien zur Wiener Geschichte. Jahrbuch des Vereins für Geschichte der Stadt Wien. Hrsg. v. Karl Fischer. Bd. 6I, Wien 2005.

Wagner, Gerhard: Von der Hochschülerschaft Österreichs zur Österreichischen Hochschülerschaft. Kontinuitäten und Brüche, Dipl.-Arb., Univ. Wien 2010.

Wagnleitner, Reinhold (Ed.): Understanding Austria. The Political Reports and Analyses of Martin F. Herz, Political Officer of the US Legation in Vienna 1945-1948, Salzburg 1984.

Wagnleitner, Reinhold: Coca-Colonisation und Kalter Krieg. Die Kulturmission der USA in Österreich nach dem Zweiten Weltkrieg (=Österreichische Texte zur Gesellschaftskritik, Bd. 52), Wien I99I.

Wagnleitner, Reinhold: Die Kinder von Schmal(t)z und Coca-Cola: Der kulturelle Einfluß der USA im Österreich der 5oer Jahre. In: Die „wilden“ fünfziger Jahre. Gesellschaft, Formen und Gefühle eines Jahrzehnts in Österreich. Hrsg. v. Gerhard Jagschitz/Klaus-Dieter Mulley, St. Pölten - Wien I985, I44-I73.

Wagnleitner, Reinhold: The Irony of American Culture Abroad. Austria and the Cold War. In: Recasting America: Culture and Politics in the Age of Cold War. Hrsg. v. Lary May. In: American Studies International, XXIV, I989, Heft I, 285-30I.

Waibl-Stockner, Jasmin: „Die Juden sind unser Unglück“. Antisemitische Verschwörungstheorien und ihre Verankerung in Politik und Gesellschaft, Wien 2009.

Walker, William T.: McCarthyism and the Red Scare. A Reference Guide, Santa Barbara $20 I r$.

Waller, J. Michael: Fighting the War of Ideas like a Real War, Washington D.C. 2007.

Walter, Robert, Werner Ogris, Thomas Olechowski (Hrsg.): Hans Kelsen: Leben - Werk - Wirksamkeit. Ergebnisse einer Internationalen Tagung, veranstaltet von der Kommission für Rechtsgeschichte Österreichs und dem Hans Kelsen-Institut (= Schriftenreihe des Hans Kelsen-Instituts, Bd. 32), Wien 2009.

Walter, Robert: Hans Kelsens Emigration aus Österreich im Jahre I930. In: Stadler (Hrsg.), Vertriebene Vernunft. Bd. II, a.a.O., 463-473.

Weber, Elisabeth: Österreichische Kulturzeitschriften der Nachkriegszeit 1945-1950, Frankfurt a. Main 1988.

Weber, Wolfgang: Großbritannien, Österreich - und ein NS-Erbe. Österreichische Soldaten der deutschen Streitkräfte in britischer Kriegsgefangenenschaft 1943 bis 1947. In: Bischof/Karner/Stelzl-Marx (Hrsg.), Kriegsgefangene des Zweiten Weltkriegs, a.a.O., 303-328.

Weckel, Ulrike: Beschämende Bilder. Deutsche Reaktionen auf alliierte Dokumentarfilme über befreite Konzentrationslager (=Transatlantische Historische Studien - Bd. 45), Stuttgart 2012. 
Wehler, Hans-Ulrich: Historische Sozialwissenschaft und Geschichtsschreibung. Studien zu Aufgaben und Traditionen deutscher Geschichtswissenschaft, Göttingen I980.

Wehner, Jens: Kulturpolitik und Volksfront. Ein Beitrag zur Geschichte der sowjetischen Besatzungszone Deutschlands 1945-1949 (=Europäische Hochschulschriften, Reihe 3: Geschichte und ihre Hilfswissenschaften, ${ }_{518} 8$, Frankfurt a. Main 1990.

Weidenholzer, Josef: Auf dem Weg zum „Neuen Menschen“. Bildungs- und Kulturarbeit der österreichischen Sozialdemokratie in der Ersten Republik (= Schriftenreihe des Ludwig Boltzmann Instituts für Geschichte der Arbeiterbewegung). Mit einem Vorw. v. Karl R. Stadler, Wien München - Zürich r98r.

Weidenholzer, Josef: Austromarxismus und Massenkultur. Bildungs- und Kulturarbeit der SDAP in der Ersten Republik. In: Gerhard Botz/Hans Hautmann/Helmut Konrad/Josef Weidenholzer (Hrsg.), Bewegung und Klasse. Studien zur österreichischen Arbeitergeschichte. Mit einem Vorw. v. BM Hertha Firnberg, Wien - München - Zürich 1978, 48I-499.

Weinert, Willi: Die Entnazifizierung an den österreichischen Hochschulen. In: Meissl (Hrsg.), Verdrängte Schuld - verfehlte Sühne, a.a.O., 254-269.

Weinzierl, Erika: Friedrich Engel-Jánosi. In: Stadler (Hrsg.), Vertriebene Vernunft. Bd. II. Emigration und Exil österreichischer Wissenschaft, a.a. O., 515-519.

Weisbord, Marvin R.: Productive Workplaces Revisited. Dignity, Meaning and Community in the 2Ist Century, San Francisco 2004.

Weiß, Brigitte: Re-education. Der Umerziehungsversuch von Kriegsgefangenen in Großbritannien während und nach dem Zweiten Weltkrieg, Dipl.-Arb., Univ. Graz 2002.

Wells, Herman B.: Being Lucky. Reminiscences \& Reflections, Bloomington 1980.

Wember, Heiner: Umerziehung im Lager. Internierung und Bestrafung von Nationalsozialisten in der britischen Besatzungszone, Essen 1992.

Wenninger, Florian, Lucile Dreidemy (Hrsg.): Das Dollfuß/Schuschnigg-Regime 1933-1938. Vermessung eines Forschungsfeldes, Wien - Köln - Weimar 20I3.

White, Graham, John Maze: Henry A. Wallace. His Search for a New World Order, Chapel Hill I995.

Whitnah, Donald R., Edgar L. Erickson: The American Occupation of Austria. Planning and Early Years (=Contributions in Military Studies, No. 46), Westport - London 1985.

Wiedmaier, Benedikt, Frank Nonnenmacher: Active citizenship education. Internationale Anstöße für die Politische Bildung, Schwalbach am Taunus $201 r$.

Wielinger, Gerhart Klaus: Hans Kelsen. In: Wolfgang Mantl (Hrsg.), Politik in Österreich. Die Zweite Republik - Bestand und Wandel (= Studien zu Politik und Verfassung ro), Wien - Graz I992, 766-784.

Wiggerhaus, Rolf: Die Frankfurter Schule. Geschichte, theoretische Entwicklung, politische Bedeutung, München 1987 .

Wiggerhaus, Rolf: Theodor W. Adorno. 3. überab. u. erweiterte Aufl., München 2006.

Wilder E. Spaulding, The Quiet Invaders. The Story of the Austrian Impact upon America, Vienna I968. 
Will, Wilfried van der: The Agenda of Re-education and the Contributors of Der Ruf I946-47. In: Stuart Parkes (Ed.), The Gruppe 47. Fifty years on a reappraisal of its literary and political significance, Amsterdam et al. 1999, I-I4.

Willet, Ralph: The Americanization of Germany, I945-I949.2. Aufl., London - New York 1992.

William, David J.: The History of Eduard Pernkopf's Topographische Anatomie des Menschen. In:Journal of Biocommunication, Vol. $15,1988, \mathrm{Nr} .2$.

Winkler, Allan M.: The Politics of Propaganda. The Office of War Information, I942-1945.2.Aufl., New Haven - London I979.

Winkler, Günther: Die Rechtspersönlichkeit der Universitäten. Rechtshistorische, rechtspolitische und rechtstheoretische Untersuchungen zur wissenschaftlichen Selbstverwaltung, Wien - New York 1988.

Wirth, Maria: Christian Broda. Eine politische Biografie (=Zeitgeschichte im Kontext 5), Göttingen 201 .

Wistrich, Robert S.: Die Juden Wiens im Zeitalter Franz Josephs (=Anton-Gindely-Reihe zur Geschichte der Donaumonarchie und Mitteleuropa 4), Wien - Köln - Weimar 1999.

Wlach, Gudrun: Klassische Archäologie in politischen Umbruchszeiten. Wien 1938-1945. In: Ash/Nieß/Pils (Hrsg.), Geisteswissenschaften im Nationalsozialismus, a.a.O., 343-370.

Wohofsky, Elisabeth: »Mickey Mouse trübt den Blick«. Antiamerikanismus in der österreichischen Linken im Übergang der I98oer zu den 9oer Jahren am Beispiel der Volksstimme und Salto, Dipl.-Arb., Univ. Wien 1996.

Wollenberg,Jörg (Hrsg.): „Völkerversöhnung“ oder „Volksversöhnung“. Volksbildung und politische Bildung in Thüringen 1918-1933. Eine kommentierte Dokumentation, Bremen 1998.

Wolper, Gregg: The Origins of Public Diplomacy: Woodrow Wilson, George Creel, and the Committee on Public Information, Diss., University of Chicago r99r.

Woods, Randall Bennet: J. William Fulbright, Vietnam and the Search for a Cold War Foreign Policy, Cambridge - New York 1998.

Wylie, Neville: Barbed Wire Diplomacy. Britain, Germany, and the politics of Prisoners of War, 1939-1945, Oxford 2010.

Zacharasiewicz, Waldemar: Das Deutschlandbild in der amerikanischen Literatur, Darmstadt 1998. Zagovec, Rafael A.: „The Mind of the Enemy“. Kriegsgefangenenverhöre und die Moralanalysen der westalliierten Aufklärung. In: Günther Bischof/Stefan Karner/Barbara Stelzl-Marx (Hrsg.), Kriegsgefangene des Zweiten Weltkriegs. Gefangennahme - Lagerleben - Rückkehr (= Kriegsfolgen-Forschung. Hrsg. v. Stefan Karner, Bd. 4.), Wien - München 2005, 267-287.

Zagovec, Rafael A.: Islands of Faith: National Identity and Ideology in German POW Camps in the United States, I943-I946. In: Zeitgeschichte, 29. Jg., 2002, Heft 3, II3-I22.

Zangl, Veronika: „Ich empfinde diese Maßnahme persönlich als ungerecht.“ Heinz Kindermanns Entlastungsstrategien I945-I954. In: Peter/Payr (Hrsg.), „Wissenschaft nach der Mode“, a.a.O., I72-206.

Ziemke, Earl F.: The U.S. Army in the Occupation of Germany 1944-1946 (=Army Historical Series. Center of Military History, United States Army), Washington D.C. I99o [1975]. 
Zilsel, Paul: Über Edgar Zilsel. In: Friedrich Stadler (Hrsg.), Vertriebene Vernunft II. Emigration und Exil österreichischer Wissenschaft 1930-I940, Wien - München I988, 929-934.

Zimmermann, Maria: Die Affäre Borodajkewycz. Höhe- und Wendepunkt eines antisemitischen und antidemokratischen Hochschulskandals im Jahr 1965 - inhaltsanalytisch untersucht am Beispiel von sechs österreichischen Tageszeitungen, Dipl.-Arb., Univ. Wien 200 .

Zink, Harold: The United States in Germany, I944-1955, Toronto - New York - London 1957.

Zöchling, Christa: Die gefälschte Biografie. In: Profil, 6. September 2oro, Heft 36, 30-33.

Zöllner, Erich: Zur Geschichte des Klischees von Wien und den Wienern. In: Michael John/Albert Lichtblau, Schmelztiegel Wien - einst und jetzt. Zur Geschichte und Gegenwart von Zuwanderung und Minderheiten. 2. verb. Aufl., Wien - Köln - Weimar 1993.

Zuckmayer, Carl: Deutschlandbericht für das Kriegsministerium der Vereinigten Staaten von Amerika. Hrsg. v. Gunther Nickel et al., Frankfurt a. Main 2007.

Zuckmayer, Carl: Geheimreport. Hrsg. v. Gunther Nickel/Johanna Schrön. 2. Aufl., München 2007.

Zuckmayer, Carl: Zusammenfassender Bericht über einen Auftrag in Deutschland und Österreich, November 1946 bis 3r. März 1947. In: Carl Zuckmayer, Deutschlandbericht für das Kriegsministerium der Vereinigten Staaten von Amerika. Hrsg. v. Gunther Nickel et al., Frankfurt a. Main 2007, 72-155.

Zuckmayer, Carl: Amerika ist anders. In: Alfred Gong (Hrsg.), Interview mit Amerika. 5o deutschsprachige Autoren in der neuen Welt, München I962, 38I-4I2.

Zwerin, Mike: La tristesse de Saint Louis: Jazz Under the Nazis, New York 1987.

Zwer, Nepthys: Otto Neurath und das Rote Wien. Der Beitrag des GWMs zur Schul- und Bildungspolitik der sozialdemokratischen Stadtregierung Wiens zwischen 1925 und 1934, Dipl.-Arb., Univ. Wien 201 . 



\section{Verzeichnis der Abkürzungen}

\begin{tabular}{|c|c|}
\hline $\mathrm{AAO}$ & Am angegebenen Ort \\
\hline $\mathrm{AC}$ & Allied Commission \\
\hline ACA & Allied Council Austria \\
\hline $\mathrm{ACE}$ & American Council on Education \\
\hline ACLS & American Council of Learned Societies \\
\hline ADR & Archiv der Republik \\
\hline AFHQ & Allied Forces Headquarters \\
\hline $\mathrm{AKH}$ & Allgemeines Krankenhaus, Wien \\
\hline ALC & Austrian Labor Committee \\
\hline ALCO & Allied Commission for Austria, Allied Council \\
\hline ANM & Anmerkung \\
\hline $\mathrm{AO}$ & Außerordentlich \\
\hline APO & American Forces Post Office \\
\hline APU & Austria Planning Unit \\
\hline AUFL & Auflage \\
\hline AYA & American Youth Activities \\
\hline $\mathrm{BBC}$ & British Broadcasting Corporation \\
\hline $\mathrm{BD}$ & Band \\
\hline $\mathrm{BDE}$ & Bände \\
\hline $\mathrm{BDM}$ & Bund Deutscher Mädel \\
\hline BGBL & Bundesgesetzblatt \\
\hline BIS & British Information Service \\
\hline BKA & Bundeskanzleramt \\
\hline BMFU & Bundesministerium für Unterricht \\
\hline BMI & Bundesministerium für Inneres \\
\hline BRIG & Brigade \\
\hline BSA & Bund Sozialistischer Akademiker \\
\hline $\mathrm{BSC}$ & British Security Coordination \\
\hline $\mathrm{BZW}$ & Beziehungsweise \\
\hline $\mathrm{CAD}$ & Civil Affairs Division \\
\hline CAME & Conference of Allied Ministers of Education \\
\hline CAPT & Captain \\
\hline CATS & Civilian Affairs Training Schools \\
\hline CBS & Columbia Broadcasting System \\
\hline $\mathrm{CCC}$ & Civilian Conservation Corps \\
\hline CCAC & Combined Civil Affairs Committees \\
\hline $\mathrm{CCS}$ & Combined Chiefs of Staff \\
\hline
\end{tabular}


CIA

CIAA

CIC

COI

COL

COSSAC

CSCAD

CSDIC

CV

DAAD

DC

DDSG

DIPL ARB

DISS

DJ

DÖW

DRK

EAC

EAM

EBD

ECR

ED

EDS

EDU DIV

ERA

ERP

ERW

ETO

ETOUSA

EXCO

F

FAM

FBI

FEA

FF

FIAT

FM

FNB

FÖJ

FÖST
Central Intelligence Agency

Coordinator of Inter-American Affairs

Counterintelligence Corps

Coordinator of Information

Colonel

Chief of Staff to the Supreme Allied Commander

Combined Staff Civil Affairs Division

Combined Services Detailed Interrogation Center

Cartell Verband

Deutscher Akademischer Austauschdienst

District Columbia

Donau-Dampfschifffahrts-Gesellschaft

Diplomarbeit

Dissertation

Deutsche Jugend

Dokumentationsarchiv des Österreichischen Widerstands

(Nationalsozialistisches) Deutsches Rotes Kreuz

European Advisory Commission

Ethnikón Apeleftherotikón Métopon (Griechische Nationale Befreiungsfront)

Ebenda

Education, Cultural, Religious Affairs Branch, OMGUS

Editor

Editors

Education Division

Educational and Religious Affairs

European Recovery Program

Erweitert

European Theater of Operations

European Theater of Operations, U.S. Army

Executive Committee

Folgende Seite

Free Austrian Movement

Federal Bureau of Investigation

The Foreign Economic Administration

Folgende Seiten

Field Information Agency Technical

Feldmarschall

Foreign Nationalities Branch

Freie Österreichische Jugend

Freie Österreichische Studentenschaft 
FR

FRUS

G-2

G-5

GARIOA

GCU

GPU

GZ

HICOM

$\mathrm{HJ}$

HRSG

ISB

JCS

JG

KPÖ

KTN

$\mathrm{KZ}$

LT COL

MAJ

$\mathrm{MF}$

MG

MIT

MOI

NYC

NARA

NATO

NBC

NEA

NKFD

NO

NR

NRC

NS

NSA

NSC

NSDSTB

NSFK

NSKK

NSV

OCD
Frankreich

Foreign Relations of the United States

„Intelligence“-Abteilungen der US-Armee (Nachrichtendienst)

Civil affairs-military government section, U.S. Army

Government and Relief in Occupied Areas

German Country Unit

Gossudarstwennoje Polititscheskoje Uprawlenije, sowjet. Geheimdienst

Geschäftszahl

High Commissioner

Hitler Jugend

Herausgeber

Information Service Branch

Joint Chiefs of Staff

Jahrgang

Kommunistische Partei Österreichs

Karton

Konzentrationslager

Lieutenant Colonel

Major

Mikrofilm

Military Government

Massachusetts Institute of Technology

British Ministry of Information

New York City

National Archives Records Administration

North Atlantic Treaty Organization

National Broadcasting Company

National Education Association of the United States

Nationalkomitee Freies Deutschland

Number

Nummer

National Research Council

Nationalsozialismus, nationalsozialistisch

National Security Agency

National Security Council

Nationalsozialistischer Studentenbund

Nationalsozialistischer Fliegerkorps

Nationalsozialistischer Kraftfahrkorps

Nationalsozialistische Volkswohlfahrt

Office of Civilian Defense 
OEX

OFF

ÖH

OIC

OII

OMGUS

ÖNB

OPC

OPMG

ORIG

OSS

ÖSTA

ÖVA

ÖVP

OWI

PFC

PG

PHIL

POLAD

POW

PROF

PWB

PWD

$\mathrm{R} \& \mathrm{~A}$

RAD

RAVAG

RFE

RIAS

RL

RLB

RWB

SA

SACMED

SANACC

SBZ

SCAEF

SEKT CHEF

SHAEF

SK

SPD
Office of Educational Exchange

Office of Facts and Figures

Österreichische Hochschülerschaft

Office of International Information and Cultural Affairs

Office of International Information

Office of Military Government (US)

Österreichische Nationalbibliothek

Office of Policy Coordination

Provost Marshall General

Original

Office of Strategic Services

Österreichisches Staatsarchiv

Österreichisches Volkshochschularchiv

Österreichische Volkspartei

Office of War Information

Private First Class

Parteimitglied

Philosophische

Political Advisor

Prisoner(s) of War

Professor

Psychological Warfare Branch

Psychological Warfare Division

Research and Analysis Branch

Reichsarbeitsdienst

Radio-Verkehrs-Aktiengesellschaft, Österreich

Radio Free Europe

Rundfunk im Amerikanischen Sektor

Radio Liberty

Nationalsozialistischer Rechtslehrerbund

Nationalsozialistischer Rechtswahrerbund

Sturm Abteilung

Supreme Commander Mediterranean Theater

State, Army, Navy, Airforce Coordinating Committee

Sowjetische Besatzungszone

Supreme Commander, Allied Expeditionary Forces

Sektionschef

Supreme Headquarters, Allied Expeditionary Force

Sonderkommission

Special Projects Division 
SPÖ Sozialistische Partei Österreichs

SS

SSD

SWNCC

UAW

UK

UN

UNESCO

UNIV

UNRRA

US

USA

USACA

USCOA

USEC/A

USFA

USFET

USGCC

USIE

USIS

USSR

VERF

VG

VGL

VIAC

VOA

VOL

VORW

VSSTÖ

WARCAD

WHOM

WLTH

WLWO

WNRC

WRUL

ZB

ZIT
Schutzstaffel

Special Services Division

State-War-Navy Coordinating Committee

Universitätsarchiv Wien

United Kingdom

United Nations

United Nations, Educational, Scientific and Cultural Organization

Universität

United Nations Relief and Rehabilitation Administration

United States

United States of America

United States Allied Council Austria

United States Commissioned Officers Association

United States Education Commission Austria

United States Forces Austria

United States Forces European Theater

United States Group Control Council

Information and Educational Exchange

United States Information Service

Union of Soviet Socialist Republics

Verfasser

Verbotsgesetz

Vergleiche

Vienna Interallied Command

Voice of America

Volume

Vorwort

Verband Sozialistischer Studenten Österreichs

War Department, Civil Affairs Division

Kurzwellensender in New Jersey

Kurzwellensender in New York

Kurzwellensender in Cincinnati/Ohio

Washington National Records Center

Kurzwellenstation in Boston/Massachusetts

Zum Beispiel

Zitiert 



\section{Personenverzeichnis}

\author{
Abel, Othenio 34I \\ Acheson, Dean III, 578, 58I, 590, 628 \\ Ackermann, Manfred I86 \\ Adamovich, Ludwig 308, 309, 314, 316, 317, 34I, \\ $344,346,347,348,352,353,365,366,367,368$, \\ $4 \mathrm{I} 3,4 \mathrm{I} 8,426,449,450,45 \mathrm{I}, 456,462,466,467$, \\ $468,469,472,475,479,48 \mathrm{I}, 482,483,602,605$ \\ Adams, Charles Francis 74 \\ Addams, Jane 59 \\ Adler, Friedrich I82, I86 \\ Adler, Guido 429 \\ Adler, Max 393 \\ Adorno, Theodor W. I6o \\ Aiken [US-Major] 194 \\ Alexander, Thomas R. 552 \\ Allen, George V. 570, 6r6 \\ Andersch, Alfred 235 \\ Anderson, Eugene N. 526, 537, 538, 539, 540, \\ $54 \mathrm{I}, 546,547,586$ \\ Anderson, Harold I37 \\ Antoine, Tassilo 604, 605 \\ Arias, Ingrid 3II \\ Arndt, Richard T. III \\ Aron, Robert 426 \\ Arzt, Leopold 604, 605, 62I \\ Astor, Johann Jacob 67 \\ Attlee, Clement R. 176 \\ Aubela, Franz 44I \\ Baeck, Paul L. 400 \\ Baker, Josephine 55 \\ Baldwin, Stanley 104 \\ Balmer, J. D. 636 \\ Bamberger, Richard 478 \\ Barnes, Russell II2 \\ Bateson, Gregory 170, 202 \\ Batke, Franz $4 \mathrm{I} 5$
}

\author{
Bauer, Franz 478 \\ Bauer, Ingrid 94 \\ Bauer, Kurt 294 \\ Bäuerle, Theodor 599 \\ Bauer, Robert II3, II7, 194 \\ Bayer, Hans 62I \\ Beam, Jacob D. 389 \\ Beethoven, Ludwig van 58,70 \\ Benda, Oskar 357, $35^{8}$ \\ Benedict, Ruth 525 \\ Benesch, Thomas 4I9 \\ Benét, Stephen Vincent 233 \\ Benjamin, Walter 50 \\ Benner, Thomas E. 27I, 369, 406, 407, 408, 416, \\ $4 \mathrm{I} 8,449,450,466,467,468,469,470,482$, \\ 6o1, 602, 605
}

Benton, William 556, 563, 564, 570

Berle, Adolf A. I77

Berner, George 6I2

Bevin, Ernest 103

Bianchi, Leonhard J. 6I2

Bischof, Günter 45, 74, 575, 632

Bismarck, Otto 52I

Bissell, Richard M. $57^{8}$

Blaustein Jr., George Holt 6o9, 6I5

Bleichsteiner, Robert 477

Bloom, Sol 563, 564

Boas, Franz 528

Bock-Bordy, Friedrich II4

Boettinger, [Maj.] 220

Bondy, Curt 233

Bondy, Emilie 367

Boris, Leopold 478

Borodajkewycz, Taras 402

Boveri, Magret 238

Bowles, Gordon T. 526, 537

Bragg, William 404 
Brandt, Willy 649

Branscomb, Harvie 572

Braudel, Fernand 609

Brecht, Bertolt 582

Brecht, Bertolt 39

Brecker, Richard L. 58I

Breitner, Burghart 605

Breitner, Hugo I9o

Brewster, William E. 6r9

Brezinka, Wolfgang 650

Brickner, Richard M. I70, I7I

Broda, Christian 402, 403, 440

Broda, Engelbert 367

Bronner, Augusta 426

Brown, Stanley N. 6r9

Bruckner, Anton 70,600

Brunner, Karl 335, 44I

Brunner, Otto 355, 356, 360

Bryan, William Jennings 523

Bryson, Lyman 6II

Buchanan, Norman S. 543

Buck, Pearl S. 63I

Bühler, Charlotte I6I, 370, 5II

Bühler, Karl 367,370

Bungenstab, Karl-Ernst 20, I74

Burckhardt, Frederick H. 54I

Burckher, Oskar v. 478

Burgert, Norbert 466

Burnet, [Col.] 219

Bush, George W. 662

Butler, Frances 586

Butler, Harold 178

Butler, Nicholas Murray 77, I03

Buttinger, Joseph 182

Byrnes, James F. $55^{2}, 5_{63}$

Campbell, Richard D. 61о, 6r3

Carey, George R. 25I

Carnegie, Andrew 77

Carr, William G. I4I
Castle, Eduard $35^{8}, 426$

Chameides, Maximilian 367

Cherrière, Paul D. R. 328

Chiari, Hermann 605, 62I

Churchill, Winston 88, I77, I78, I80, 2II, 240

Cicin, Rea Sylvia 6I2

Ciechanowski, John M. I03, IO4

Clark, Mark W. 255, 265, 4I8, 424, 513, 638

Clark, Thomas D. 6II

Clay, Lucius D. 536, 537, 552, 557, 575

Clayton, John M. 73

Cohn, Roy 63I

Colby, Walter 636

Columbus, Christoph 35

Compton, Wilson M. 591, 592

Conant, James Bryant I4I, 394, 6I2

Cook, B. B. 487

Cooper, Gary 83

Corey, Stephen M. I49

Cormack, John W. 566

Coser, Lewis 199

Crawford, Joan 83

Creel, George 79

Cyrus, Franz C. 621, 622, 649

Czermak, Wilhelm 339, 341, 342, 346

Czernetz, Karl 394

Czernin, Ferdinand I80, I84

Czernin, Franz 394

Czerwenka, Fritz 6I2

Daim, Wilfried 478, 490

Dalbosco, Lilly 478

Damian, Heinz 432

Daniel, Silvia 47, 48

Dantine, Walter 597

Danzinger-Schenk, Lotte 620

D'Arms, Edward 586

Dater, Henry Murray 145

Davies, Elspeth 6II

Davis, Elmer II2 
Davison, Edward 231, 236

Day, Edmund E. I4I, 525

de Buffon, Comte Georges-Louis Leclerc 36

Debussy, Claude 600

Degenfeld-Schonburg, Ferdinand 478

Del Negro, Walter 44I

Dempf, Alois 605

Dengler, Paul Leo 426

Denk, Wolfgang 605

Deuel, Wallace I3I

Deutsch, Julius II4, 394, 452

Deutsch, Maria II4, 190

Dewey, John 76, 77, 80, 100, 199, 63I

Dickens, Charles 39

Dietz, Wilhelm 4I5

Diner, Dan I5

Disney, Walt 83

Döblin, Alfred 520

Dobretsberger, Josef 402, 605

Dodds, Harold Willis 572

Dodge, Charles G. 265, 605, 618, 636

Dollfuß, Engelbert I84, 188, 254, 281, 283, 296, 345,35 I, 510, 653

Donald Duck 83

Donnelly, Walter J. 624, 630

Donovan, William J. I09, I65, I66

Doppler, Günther 478

Dopsch, Alfons 343, 344

Dörfl, Josef 447

Doris Graf i9

Dorn, Walter L. $536,537,53^{8}$

Dos Passos, John 54, 63I

Draper, William H. 555

Dreiser, Theodor 63I

Drimmel, Heinrich 39I, 624, 652

Du Bois-Reymond, Emil 40

Du Bois, W. E. E. 632

Duda, Herbert W. 42I, 477, 620

Duggan, Laurence I4I

Dulles, Allen W. 634
Dulles, Eleanor 386

Dulles, John Foster 634

Dunn, James C. 217

Dunn, L.C. 528

Durig, Arnold 605

Dürmayer, Heinrich 460, 466, 47I

Duschek, Adalbert 337

Dwight, Henry Edwin 69

Echols, J. P. 556

Eden, Anthony I6I

Edney, A.J. 501

Eerden, Albert van $42 \mathrm{I}$

Ehrendorfer, Friedrich 650

Ehrenhaft, Felix 367, 403, 404, 405, 406, 407, 408, 409

Ehrmann, Henry 586

Eigl, Adolf 260, 261, 262, 263

Einstein, Albert 403, 405, 409, 528, 63I

Eisenhower, Dwight D. 2I3, 218, 254, 58I, 63I

Eisler, Armand 400

Eitner, Lorenz 166

Ekstein, Rudolf I87

Elledge, Scott 6ro

Elsner, Hans 478

Elßler, Fanny 70

Emerson, Ralph Waldo 45, 67

Endtresser, Karl 4I5

Engelhardt, Nataly 6I2

Engelhardt, N. L. $5^{25}$

Engel-Jánosi, Friedrich 188, 367, 420

Englander, Alois 192

Entz, Gustav 347, 483, 491, 507, 508

Erhard, Ludwig 649

Erhardt, John G. 190, 290, 291, 422, 452, 46I, $466,468,503,504$

Erhardt, Karl 443

Erikson, Erik 169, 202

Ernst, Erna 478

Exinger, Walter 478 
Faltis, Ernst 478

Farcas, Edith 6I2

Fast, Howard 632

Faustmann, Karl 478

Featherstone, William B. 250, 252, 256, 266, 267, 269, 271, 272, 282, 309, 316, 318, 34I, 368, $406,407,418,482,514,601,602$

Febvre, Lucien 609

Feigl, Friedrich (Fritz) 367

Feldhammer, Karl 497

Feldl, Peter 427

Felix Pronay 6r2

Fellinger, Karl 605

Fernbach, Johann 478

Feuchtwanger, Lion 520

Fexner, Fritz 478

Feyerabend, Paul 544

Feyrter, Friedrich 443

Ficker, Heinrich 605

Fig1, Leopold 264, 326, 328, 387, 424, 436, 437, $438,446,453,473,474,475,485,486,487,488$, 489,643

Finch, John 6II

Finsterer, Hans 605

Fischer, Ernst 319, 320, 321, 322, 348, 364, 365, $425,428,430,434,460,477$

Fischer, Eugen 530

Fischer, [Ltn.] 269

Fischer, Rudolf 308, 447

Fischl, Hans II4, I9o

Fischl, Johann 650

Fleck, Christian 37I, 543, 544, 65I, 66o

Fleischmann, Kornelius 478

Flory, Lester D. 251, 252, 255, 266

Foerster, Friedrich Wilhelm I75, 202, 205, 52I, 523

Foerster, Heinz 544

Ford II., Henry 577, 578

Forrestal, James 557

Foucault, Michel 26
Fox, E. W. 526

Franck, César 600

Frank, Bruno 520

Frank, Philipp 372

Franz Ferdinand 44

Franz I.69

Franz Joseph I.388

Fred, Edwin B. 572

Frederick Hertz $3 \mathrm{I}$

Freud, Sigmund 45

Fried, Hans Ernst 202

Friedrich der Große $52 \mathrm{I}$

Frisch, Karl 605

Frisch, Kurt 466

Fröbel, Friedrich $5^{8}$

Fromm, Erich 159, I60, 202

Fuchs, L. 478

Fuchs, Martin II3

Fulbright, William J. 548, 553, 562, 568, 572

Fuller, Leon W. 526, 537

Fürnberg, Friedl 460

Furtmüller, Carl II4, I88, I89, I9o

Füssl, Karl-Heinz 65

Gable, Clark 83

Gaiswinkler, Albrecht 497, 498, 499

Galen, [Maj.] 6r8

Gallup, George Horst 238

Ganner, Hans 44I

Gassert, Philipp 83,89

Gelbard, Rudolf 46I

Geyer, George 218

Gibisch, Wilhelm 478

Gimbel, John 20

Ginsberg, Vida 6II

Giordano, Gerard 122

Glaser, Ernst 479

Gleispach, Wenzel 294, 375

Gleißner, Heinrich 263, 264, 498, 623, 624

Glöckel, Otto I9I 
Gödel, Kurt 372

Goebbels, Joseph 86, 87, 89, 108

Goerdeler, Benigna 599

Goerdeler, Carl Friederich 599

Goethe, Johann Wolfgang 36, 58, 89

Goldingers, Walter 356

Goldmann, Emil 366

Goldner, Franz I80

Gollanz, Victor 139

Goller, Peter 345

Gombrich, Ernst 367

Goodykoontz, Bess 547

Goofy 83

Grace, Alonzo G. 557, 625

Graf, Ferdinand 468

Graff, Kasimir 605

Graf, Max 600

Graham, Frank P. 526

Gramsci, Antonio 50,5I

Grave, Boyd E. 416

Gray, Cecil W. 25I

Gregg, Catherine 27I

Grillparzer, Franz 36

Grinnell, David R. ${ }_{3} 8$

Groves, Joseph R. 502

Gruber, Heimo 428

Gruber, Karl 290, 29I, 407, 475

Grünberg, Emile 396

Gründorfer, Wilhelm I82

Gschnitzer, Franz 605

Guardia, Fiorello La IIo

Guggenheim, Solomon R. 596

Guha, Willhelm 478

Gullion, Allen W. 232

Günther, Hans F. 530

Günther, Herbert 478

Günther, Otto 404

Gutfreund, Herbert 478
Haas, Edith 478

Habe, Hans II5, I94, 200

Habsburg, Otto 183,383

Hacker, Walter 476, 649

Haertl, Karl 478

Haeuserman, Ernst 194

Haindl, Otto 6I2

Halberg, France 6I2

Halfeld, Adolf 5I, 52, 53

Halifax, Lord I76

Hamann, Günther 478

Hamdorff, Gustav 63

Hammer, Hilde 393

Hammerschmid, Hans 46I

Hammet, David 63I

Händel, Georg Friedrich 70

Hanslick, Eduard 600

Hantsch, Hugo 367, 500

Harand, Irene 380

Harris, David 396, 526

Harrison, Geoffrey W. 240

Hartigan, John D. 260, 26I, 262, 267

Hartmann, Gerhard 439

Hartmann, Heinz 202

Hartmann, Ludo Moritz 425

Hassinger, Hugo 605

Hauptmann, Gerhard 39

Hauptmann, Walter 478

Haushofer, Karl 530

Havers, Wilhelm 605

Havighurst, Robert J. 543

Haydn, Joseph 70

Hayek, Friedrich 4OI, 544

Hayer, Raimund 478

Haynes, Lloyd A. 4I8, 598

Hechtl, Leonhardt 447

Hefel, Ernst $4 \mathrm{I} 2$

Hegel, Georg Wilhelm Friedrich 37

Heger, Franz 620, 622

Heidler, Hans 479 
Heine-Geldern, Robert 38I

Heine, Heinrich 89

Hein, Wilhelm 6I2

Heiß, Gernot 347, 356

Helbok, Adolf 44I

Heller, Clemens 609, 610, 612, 614, 615

Heller, Hugo 609

Heller, Viktor 433,447

Helmer, Oskar 46o, 464, 466, 467, 575

Hemmingway, Ernest 63I

Hendrickson, Robert C. 261, 262

Herriot, Edouard Io3

Hertz, Friedrich 394

Hertz, John Daniel 67

Herz, Martin F. 351, 558, 583, 613

Hesse, Kurt 287

Hess, Victor F. 367, 368, 406, 47I

Heydte, Friedrich August Freiherr von 285, 286, 287, 288

Heym, Stefan 631

Hietsch, Otto 6I2

Hilker, Franz 547

Hilldring, John H. 216, 218, 219, 220, 224, 225, $25 \mathrm{I}, 253,527$

Hiller, Alfred I9

Himmler, Heinrich 263

Hindel, Robert 6I2

Hirschmann, Karl 237

Hirst, Eric A. $27 \mathrm{I}$

Hirt, Peter 612

Hitler, Adolf 84, 85, 86, 88, I33, I59, I69, 388 , $393,404,440,448,453,483,484,508,521,529$, $530,531,533,590,595,632$

Höbelt, Lothar 604

Hofe, Harold van 420

Hoffman, Gray Paul 590

Hoffmann-Ostenhof, Otto 427

Hofmann, Louise $\mathrm{I}_{5}$

Hold-Ferneck, Alexander 375, 377, 393

Höllering, Franz II4
Holman, Rodger V. 268

Holzbauer, Robert 373

Holzmann, Josef 479

Hönigschmied, Hedwig 65I

Hoover, Calvin 525

Horkheimer, Max 394

Horne, [Col.] 224

Horn, Robert 6II

Hovde, Bryn J. 525, 526

Howard, Charles P. 249, 254

Howard, Harry N. 396

Howland, Harold E. 608

Hubell, Jay H. 619

Huber, Andreas 432, 448, 456, 46I, 465

Huber, Paul 479

Hugelmann, Karl G. 285, 375

Hughes, Stuart H. 509

Hula, Erich 38I

Hull, Cordell I77, I79, 2I4, 215, 232, 526

Hülsemann, Johann Georg 73

Humboldt, Alexander von 40

Hume, David 70

Hume, Edgar Erskine 4OI, 595, 599

Hupka, Josef 366

Hurdes, Felix 319, 320, 329, 338, 399, 404, 408, 409, 4I8, 427, 438, 439, 450, 456, 457, 459, 47I, $475,477,640$

Husinsky, Heribert $45^{\circ}$

Hylla, Erich 547

Ichheiser, Gustav 367

Ickes, Harold I59

Ilitchev, Ivan I.493

Iltis, Hugo 527, 528, 529, 530, 531, 532, 533

Irvin, L. P. 607

Irwin, Leroy S. 630

Isenbarth, Hans-Heiriek 6I2

Jackling, [Col.] 254

Jagenbrein, Reinhard 479 
Jagic, Nikolaus 605

Jahoda, Marie 372

Jantz, Howard 420, 42I

Jarrell, Randall 6iI

Jefferson, Thomas 68, 100

Jiresch, Hans 479

Jodl, Alfred 399

Johann, A. E. 86

John, Ernst 62I

Johnson, Alvin 378, 394

Johnson, Walter 6II

Jonas, Franz 463

Josselson, Michael 58I

Jung, Edgar Julius 53

Junker, Hermann 605

Jus, Ursula 478

Kaes, Hans 447

Kafka, Franz 39

Kaftan, Johann 324

Kahl, Magnus 479

Kahr, Heinrich 312,605

Kaiser, Marius 605

Kallir, Otto I8I, 382

Kaltenbrunner, Ernst 263, 498

Kandel, Isaac L. 98, 150, 657

Kant, Immanuel 77

Kattan, Oskar 425

Kauders, Otto 424, 479, 605, 62I

Kauer, Friedrich 478

Kautsky, Karl 56

Kazin, Alfred 6II

Kefauver, Grayson N. I4I, I5O, I54, 219, 220

Keil, Josef 605

Keindl, Adolf 479

Kellermann, Henry J. 20, I74, 210, 558, 586, 595

Kelsen, Hans 285, 364, 375, 378, 392, 393, 394, 395, 396, 397, 398, 399, 400, 401, 402, 403

Kempel, B. 6I4

Kenda, Hans 323, 350, 412, 479
Kennan, George F. 227, $5^{82}$

Kerschagl, Richard 620,650

Kerschensteiner, Georg 60

Keyes, Geoffrey H. 265, 422, 615, 624, 630, 636, 638

Keyserlingk, Robert H. 215

Kiesinger, Kurt Georg 649

Kindermann, Heinz 357, 358, 440

Kinzl, Hans 44I

Kirsch, Gerhard 404

Kirste, Leo A. 620

Kisch, Egon Erwin 54, 86

Klauser, Artur 466

Klaus, Josef 623, 624

Kleinwächter, Ludwig 407, 625

Klimpfinger, Sylvia 37I

Kloimstein, Lothar $45^{2}$

Knappen, Marshall 218

Knoll, August Maria 388,39I, 4II, 425, 478

Knoll, Fritz 360

Knoll, Reinhold 4II

Knortz, Karl 63

Knosp, Engelbert 6I2

Koestler, Arthur I3I, 58I

Köhler, Fritz 447

König, Thomas 569, 642, 651, 652

Koplenig, Johann 475

Koppers, Wilhelm 478

Köppner, Ambros 478

Körner, Theodor 339, 397

Korotin, Ilse 372

Kossuth, Lajos 73

Köstler, Rudolf 466,605

Kotschnig, Walter M. I4I, I5O, I5I, I54, 202, 657

Kourasov, Vladimir V. 327

Kracauer, Siegfried 50

Kraft, Rudolf 620

Kragora, Alexander 434

Kralik, Dietrich 34I

Kraus, Herbert 62I 
Kreller, Hans 604

Kretschmer, Paul 605

Kretzman, [Maj.] 254

Kris, Ernst W. I69, 202

Kris, Marianne 202

Kroes, Rob 24

Kronhuber, Hans 649

Krünes, Justine 6I2

Kudlacek, Otto 496

Kürnberger, Ferdinand 38

Kurz, Johannes 478

Labouisse, Henry R. 224

Lamaestre, Espiau de 337

Langer, Robert 400

Langer, Walter C. 169

Lang, Franz Josef 44I, 442

Langhammer, Günther 454

Lareiter, Matthias 620,62I

Lasky, Melvin J. 58I

Latzin, Ellen 649

Lauda, Ernst 605

Lazarsfeld, Paul F. 372, 597

Lebedenko, Nikolaj 339, 465, 466, 469

Lehman, Herbert H. 216

Leidenfrost, Josef I9, I33

Leitmeier, Hans 478

Leitner, Maria 54

Lenau, Nikolaus 39

Leontieff, Vasilly 6II

Lepier, Erich $4 \mathrm{I} 5$

Lesky, Albin 653

Leutgeb, Karl 430, 443, 453, 479

Lewin, Kurt I37, I70, 202

Lhotzky, Alphons 477

Liebeswar, Konrad 409

Liebl, Thomas I9

Lightner, Allan K. 390

Limbert, Paul M. 547

Lincoln, Abraham 73
Lindemann, Eduard 525

Lindner, Karl D. 312, 605

Lippmann, Walter 566

Loftsgordon, Wallace J. 269

Lorenz, Karl 62I

Lorenz, Reinhold 374

Lott, Charlotte $4 \mathrm{I} 8$

Lott, Leigh M. 269, 308, 309, 310, 312, 313, 314, $315,316,417$

Löwe, Adolf 207, 210

Ludwig, Emil 520

Lugmayer, Karl 304, 319, 333, 34I, 425, 427

Lukacs, Judith 6I2

Machatschki, Felix 605

Machlup, Fritz 372

Mackay, Alexander 40

Mack, Harold 250

MacLeish, Archibald III, II2, I3I, I4I, I45, I54, $252,525,526,527,529,533,535,537,56$ I, 562 , $564,590,63 \mathrm{I}$

Mader, Gerald 447

Maestre, de la [Capitaine[ $43^{8}$

Magruder, C. B. 616

Mahler, Gustav 70,600

Mailer, Norman 63I

Malina, Peter $4 \mathrm{I} 5$

Malisoff, William Marias 396

Maller, Theodor 462

Mann, Ambrose Dudly 73

Mann, Erika 199, 200

Mannheim, Karl 394

Mann, Horace 76, Ioo

Mann, Klaus I99, 20I

Mann, Thomas 520, 631, 632

Mann, Werner 478

March, Arthur 605

Marchet, Arthur 4II

Maresch, Gertrud 6I2

Maritain, Jacques 523 
Marsch, Fritz 480

Marshall, George C. 215, 216, 251, 28I, 504, 507, $559,565,566,573$

Marx, Karl 50

März, Eduard II4

Masaryk, Jan 6I2

Matejka, Viktor $185,338,365,374,519$

Mattauch, Josef 406

Matthiessen, Francis O. 6IO, 6II, 6I2, 6I5

Mautner Markhof, Manfred 597, 650

May, Arthur J. 420, 421, 422

Mayer, Christiane $4 \mathrm{I} 6$

Mayer, Franz 620

Mayer, Hans 350

Mays, Karl 43

McCaffrey, George H. 249, 25I, 254, 268

McCarthy, Joseph 396, 631, 632

McChrystal, Arthur J. 338, 339

McCloy, John I59, I65, 527, 625

McClure, Robert ${ }^{6} 65$

McDonald, Neil 6II

McGrath, Earl J. 547

McGuire, Martin R. P. 526, 572

McNutt, Paul I26

McRae, Robert B. 513

McSherry, [Gen.] 25I

Mead, Margaret I70, I7I, 202, 6II

Meister, Richard 308, 339, 34I, 342, 344, 42I, 425, 426, 43I, 436, 456, 48I, 604, 605, 652

Meitner, Lise 372

Melichar Irwin 62I

Mellner, Josef 605

Menger, Karl 367

Merth, Karl 237

Meschieri, Luigi 6r3

Métall, Rudolf Aladár 395, 403

Metternich, Klemens Wenzel Lothar von 68, 69,71

Meyer, Stefan 605

Michaela, Anderle I9
Mickey Mouse 83

Miller, Arthur 63I

Miller, Douglas I3I

Miltner, Franz 44I

Moeckel, Wolfram 6I2

Molden, Fritz 6I2, 6I4

Montel, Heinrich 325

Morgenthau, Henry 87, 9I, I63, I72, I74, 213, 527,533

Morse, Samuel F. B. 68

Mosely, Philip E. 396, 543

Moser, Johann 478, 497

Motley, John Lothrop 69

Moulton, F. R. 602

Mowrer, Edgar Ansel 8I, I7I

Mozart, Wolfgang Amadeus 70

Mras, Karl 478

Müller, Paul 477

Mundt, Karl 566, 567

Murphy, Joseph M. 269, 4I8, 425

Murphy, Robert D. 4I7, 537, $55^{8}$

Murray, Henry I69

Nadler, Josef 360, 440

Nambara, Shigeru 625

Napoleon III. 68

Needham, [Maj.] 367, 438, 483, 490

Neitzel, Sönke 230

Neugebauer, Wolfgang 315

Neurath, Otto I62, I63

Neureiter, Max 6I2

Nicholson, Ralph 625, 626, 627

Niebuhr, Reinhold 199, 525, 526, 547, 63I

Nietzsche, Friedrich 44

Ninkovich, Frank A. 564, 565

Nobel, Alfred 200

Noce, Daniel 509

Novotny, Fritz 440, 478

Novy, Franz 394

Nowotny, Franz 479 
Oberhammer, Hans 478

Oberkofler, Gerhard 345

Oberparleiter, Karl 492

Oettinger, Karl 440

Oppenheimer, Robert 599

Oppenheim, F. 528

Otruba, Gustav 6I2

Palmers, Paul I3I

Papanek, Ernst I86, I90

Papanek, Jan 38I

Papen, Franz von 53

Parkman, Henry 249

Parsons, Talcott 202,6II

Partsch, Margarete 478

Pasvolsky, Leo 217

Patton Jun., Smith 536

Pauli, Hertha 200

Peez, Alexander 42

Peiser, Werner ${ }^{172}$

Penfield, J. Kedzie 643

Perchter, Otto 478

Pernkopf, Eduard 4I4, 4I5, 4I6

Pernter, Hans I68, 338, 35 I

Petkovic, Benita 6I2

Pfeiffer, Ida 40

Pfliegler, Michael 425

Pick, Ernst (Ernest) Peter 406, 624

Piff, Friedrich Gustav 375

Pirandello, Luigi 49

Pisk, Paul Amadeus 528

Pittermann, Bruno 478

Pitt, Felix N. 547

Planck, Max 404

Planitz, Hans 349, 447, 603, 604, 605

Platzer, Werner $4 \mathrm{I} 5$

Plesch, Janos 404

Plöchl, Willibald M. I84, I87, I88

Pollack, Oskar 394

Pollock, Friedrich 207, 210
Pollock, T. C. 205

Pomeroy, Harold E. 249

Ponger, Kurt 182

Ponger, Vera 182

Poole, DeWitt C. 198

Portisch, Hugo 649, 65I

Pötsch, Leopold 529

Potter, John Milton 526

Pound, Roscoe 394

Praschniker, Camillo 36o, 605

Prochnik, Edgar L. G. 177

Proksch, Anton 479

Przibram, Karl 367, 478

Puchinger, Rudolf 478

Putscher, Friedrich 478

Raab, Julius 498

Rabofsky, Eduard 447, 453, 454, $45^{8}$

Radon, Hans 605

Rager, Fritz 182, 192

Rainer, Anton 6I2

Rassl, Karl 478

Rathkolb, Oliver I9, 27, 29, 371, 398, 60I

Rauchegger, Bruno I68

Rauch, Karl 445

Ray, Hardy M. 337, 4I3 , 438, 490, 508

Raynal, Guillaume Thomas François 36

Redslob, Edwin 625

Reichel, Ferdinand 6I2

Reichwein, Adolf 6I

Reid, Ogden 262

Reinhardt, Max 6ro

Reininger, Robert 605

Remarque, Erich-Maria 632

Renner, Hans 497

Renner, Karl 348, 400, 489

Reyer, Eduard 6o

Rhomberg, Rudolf 6I2

Rice, William G. 6II

Richardson, Owen 404 
Richter, Elise 367

Richter, Hans Werner 235

Rich, Thair C. $4 \mathrm{I} 8$

Riddleberger, James W. I16, 379, 387, 388, 389

Riddy, Donald Chales 218

Riedl, Ludwig 168

Riedl, Otto 478

Riesel, Elise 426

Rilke, Rainer Maria 39

Ringel, Erwin 243

Rittler, Theodor 605

Robin, Ron 235

Rockefeller, John D. 67

Rockefeller, Nelson D. Iо9

Rogin, Lawrence 547

Rohde, Ruth Bryan Owen 523

Rohracher, Andreas 168, 453, 498

Rohracher, Hubert 605

Roithner, Franz 168

Roland, Joseph M. 586,64I

Rollet, Edwin 440

Roosevelt, Franklin D. 16, 86, 87, 88, 102, 103, IO5, I09, IIO, I2I, I25, I30, I33, I35, I36, I65, I66, I72, I74, I79, I80, 188, 2II, 213, 2I4, 215, $217,218,222,240,246,25 \mathrm{I}, 526,529,656$

Roosevelt, Theodore 46,523

Rose, [Col.] 493

Rosenberg, Alfred 86

Rosenmayr, Leopold 6I2

Rosenzweig, Wilhelm 479

Rösner, Hermann 478

Rosner, Robert 465

Ross, Colin 85

Rostow, Walt 6II

Rotha, Paul 163

Rott, Eduard 478

Rott, Hans I8I

Rubel, Peter 427

Ruche, L. 34I

Ruppertsberger, Franz 620
Rupprich, Hans 34I

Ruske, Robert C. $25 \mathrm{I}$

Russel, William F. Io3

Saar, Claudius v. 478

Sander, Bruno 605

Sander, Fritz 393

Sandker, Gregory J. 268, 27I, 4I6, 6I3, 6I4

Sandtner, Inge 62I, 649

Sanford, Nevitt R. I6o

Santayana, George 76

Sartre, Jean Paul 63I

Sas-Zaloziecky, Vladimir 477

Saunders, Frances Stonor 578

Savel, Daniela 5 I9

Sayoka, Tatiana 6I2

Schaff, Philip 4I

Schairer, Reinhold 205, 523

Schärf, Adolf 3II, 393

Scharf, Erwin 438

Schaumann, Otto 62I

Scheel, Walter 649

Scheidl, L. G. 6I2

Schenk-Danziger, Lotte 62I

Schenk, Erich 429

Schiller, Friedrich $5^{8}$

Schlander, Emil 605

Schlatter, Richard 6II

Schlegel, Friedrich 36

Schmidt, Helmut 649

Schmidt, Oliver M. 549, 595, 615, 623, 642

Schmiedek, Raoul 453, 472, 473

Schneeweiß, Josef 427, 452, 453, 462

Schneider, Franz 394

Schneider, Joseph Z. 618, 625

Schoiswohl, Johann I9

Schönbauer, Ernst 375, 399, 603, 604, 605

Schönbauer, Leopold 310, 3I2, 3I4, 603, 604, 605

Schönberg, Arnold 600 
Schönberg, Michael I9

Schönigh, Franz Joseph 556

Schorske, Carl E. 531, 532, 533

Schrödinger, Erwin $367,47 \mathrm{I}$

Schrott, Ludwig 415

Schubert, Franz 70

Schubert, Kurt 346

Schueller, Richard 394

Schuhmann, Frederick L. I25

Schultze, Ernst 63

Schultze-Soelde, Walter 44I

Schuman, Frederick L. 159

Schuschnigg, Kurt I84, 254, 28I, 283, 296, 345, 35 I, 5 IO, 653

Schuster, Walter 624

Schwager, Zalel 466

Schwarzacher, Walter 479

Schwarz, Hans-Peter 174

Schwarz, Peter 315

Schwarz, Walter 479

Schwind, Ernst 375, 393

Sealsfield, Charles [Karl Postl] 37,38, 69,71

Sedlmaier, Alexander 78

Sedlmayr, Hans 34I, 360, 440

Seghers, Anna I3I

Seidel, Kurt 6I2

Seiffert, Herbert 599

Selke, George A. 267, 4I7, 4I8

Shaw, Howland G. 219

Sherwood, Robert E. Io9

Shine, David G. 63I

Shirer, William L. I3I

Shuster, George N. 526

Siegelbauer, F. 44I

Siegel, Margarete 478

Siepen, Karl 62I

Silber, Elfie von $4 \mathrm{I} 5$

Silone, Ignacio 58I

Simmons, Kenneth L. 269

Simon, Ernest David 154
Simon, Hans 195, 196, 197, 198

Simon, Joseph T. 399

Sinclair, Upton 54, 63I

Skrbensky, Otto 295, 296, 323, 337, 343, 346, 350, 35 I, 352, 353, 356, 358, 369, 370, 400, 405, 406, 407, 4I2, 4I5, 429, 43I, 450, 473, 478, 543, 544, 600, 601

Slavik, Felix 473

Smedley, Agnes 632

Smirnova, [Fr.] 438

Smital, Otto H. 6I2

Smith, Henry Nash 6ro, 6II

Smyth, Howard M. 396

Snook, Russel A. 260

Snyder, Harold E. 6I7

Sobek, Franz 473

Sölch, Johann 4I6, 426, 478

Sollmann, William F. 52I

Spalding, Elizabeth $56 \mathrm{I}$

Spann, Othmar 374, 375, 377

Spaulding, Wilder E. 69

Speier, Hans 538, 551, 586, 599

Sperber, Manès $58 \mathrm{I}$

Spranger, Otto 192

Srbik, Heinrich 360, 604

Sreck, Ingeborg 6I2

Stalin, Josef 9I, 236, 240, 590

Starnbacher, Otto 478

Starr, Mark 572

Stead, William T. 47

Steinacker, Harold 44I

Steinmetz, Martha 599

Steinwenter, Artur 605

Stemmer, Wilhelm 479

Stern, Josef Luitpold I90, 528

Stern, Leo 425, 439

Stettinius, Edward R. 245, 251, 526

Stiefel, Dieter 299, 345

Stimson, Henry L. IIO, 232, 379

Stoehr, Richard 62I 
Stolz, Otto 44I

Stone, Donald C. 573

Storch, Otto 478,605

Straub, Richard 479

Strauss, Hans 192

Strauß (Sohn), Johann 70

Stripling, Robert E. 564

Strojteleva, [Mles.] 438

Studebaker, John W. II9, I23, I4I, I5I, 599

Stuhr, Eduard 478

Stumpfl, Friedrich 44I

Stumpf, Robert 36I

Sturmthal, Adolf 615

Suetter, Reuff 620

Sundquist, James L. 552, 573

Sweeny, James Johnson 6II

Sweet, Paul R. I66, 498, 5 OI

Tarra, Valentin 497

Tarzan 99

Taschwer, Klaus 638

Tate, E. H. 486

Taylor, John W. 157, 218, 504, 526, 552

Tent, James F. 20, I42, I73, 212

Teufenstein, Wilhelm 62I

Theuermann, Gerda I9

Thiel, Ladislaus 479

Thimig, Helene 6ro

Thirring, Hans 405, 436, 472

Thompson, Dorothy 199

Tietze, Hans 6I

Tillich, Paul I99, 207, 210

Tilroe, Dexter G. 27I

Tirpitz, Alfred 75

Tocqueville, Alexis de 49,63

Tod, Johannes 478

Toman, Walter 597

Torberg, Friedrich 582, 632

Truman, Harry S. ${ }_{117}, 526,529,559,560,561$, $566,578,579,580,5^{81}, 634$
Trummer, August 290

Tryon, Robert C. 166

Tschadek, Otto $363,364,479$

Tsinov, G. K. 486

Tuppy, Hans 650

Tuppy, Johann 478

Twain, Mark 72, 632

Tweraser, Kurt 245, 246, 263, 5II, 562, 624

Ustinow, Istvan V. 34I

Vansittart, Robert ${ }_{13} 8$

Verdross-(Droßberg), Alfred 285, 349, 397, 398, 399, 401, 403, 605

Voegelin,(Eric) Erich I84, 40I

Voltaire, François Marie Arouet 36

Voltelini, Hans 375

Wagner, Gertrud 367

Wagner, Richard $5^{8}$

Wagnleitner, Reinhold I9, 20, 27, 642

Waismann, Friederich 367

Walker, Herbert Walker 218

Walk, Josef 262

Wallace, Henry A. IIo, I4I, I49, I89, 396, 529, 583,63 I

Wandruzka, Adam 6I2

Wastl, Josef 334

Weckel, Ulrike 5 I 9

Wedekind, Franz 39

Weinberger, Otto 482

Weinzierl, Erika 478,490

Weisner, Robert 478

Wellesz, Egon 367

Wells, Hermann B. $157,537,55^{2}, 553,557,573$, 625

Wells, H. G. IO4

Welzer, Harald 230

Wenger, Leopold 605

Wengraf, Rudolf 430 
Weninger, Josef 478

Wense, Theodor 44I

Werfel, Franz 89, 632

Werner, Erich 479

Westinghouse, George 67

White, Helen C. 547

White, Ralph 588, 589

Whiting, J. H. 606

Wickersham, Cornelius W. 25I, 253

Wiethe, Camillo 605,620

Wilde, Oscar $7 \mathrm{I}$

Wilder, Billy $5^{\mathrm{I} 8}$

Wilde, William Robert Willis 71, 72

Wiley, John C. 168

Wilhelm, Adolf 605

Wilhelm II.75, 77, 52I

Williams, Samuel H. 408, 4I4, 4I5, 420, 42I, 422, 423, 514, 515, 576, 599, 600, 6ог, 6I 2, 6r 3 , 6I4, 615, 617, 625, 635, 636, 637, 638, 639, 640

Willkie, Wendell L. 97, I35, I45, 233

Wilson, Woodrow 48, 78, 79, 80, 81, 84, I46, 2II, $56 \mathrm{I}$

Winant, John Gilbert 245

Windisch-Graetz, Alfred 73

Winkler, Harold 396

Winter, Ernst Karl 180, 185, 373, 374, 376, 377, $378,379,380,38 \mathrm{I}, 382,383,384,385,386,387$ 388, 391, 397
Winter, Florian Ernst 390

Winter, Ilse 6I2

Winter, Michael 466

Wirth, Maria 440

Wisner, Frank G. 553, 554

Wolff, Hugo 600

Wolff, Karl 349

Wolfram, Richard 357

Wollschlaeger, Johann 86

Woodcook, [Mr.] 34I

Wright, Benjamin 6iI

Wright, Frank Lloyd 63I

Yarborough, W. P. 469

Zagovec, Rafael A. 23I, 237

Zaring, Joseph L. 5II, 623, 624

Zdansky, Erich 62I

Zechner, Leopold 4r6, 434

Zellwecker, Edwin 320

Zernatto, Guido 184

Zheltov, Aleksej S. 483, 484, 485, 487

Zöllner, Erich 38, 6I2

Zook, George F. II9, I4I, I57, 547, 548

Zuckmayer, Carl 94, I0I, I99, 532

Zweig, Stefan 632 
Mag. Dr. Christian H. Stifter, geboren i962, Studium der Geschichte und Philosophie an der Universität Wien, Zeithistoriker.

Direktor des Österreichischen Volkshochschularchivs. Herausgeber der Fachzeitschrift Spurensuche, Redaktionsmitglied der Zeitschrift zeitgeschichte sowie Beiratsmitglied der Wissenschaftsjury des Theodor Körner-Fonds.

Mitarbeit an historischen Fernsehproduktionen sowie zahlreiche Buchpublikationen und Fachartikel zur Zeitgeschichte und Geschichte der Wissenschaftspopularisierung und Erwachsenenbildung. Organisationsleitung und Vorträge bei rund 30 internationalen Konferenzen und Seminaren zur Zeitgeschichte, Politischen Bildung und Erwachsenenbildung in Österreich, Deutschland und der Schweiz.

Ausgezeichnet mit dem Förderungspreis der Stadt Wien für Volksbildung (200I), dem Innovationspreis des Deutschen Instituts für Erwachsenenbildung (Bonn) und der Leibniz-Gesellschaft für die Online-Historiografie Erwachsenenbildung (2008) sowie dem Ludo Moritz Hartmann-Preis des Verbandes Österreichischer Volkshochschulen (2008).

Forschungsschwerpunkte: Kalter Krieg in Österreich; Kultur-, Bildungs- und Wissenschaftspolitik in Österreich im 20. Jahrhundert; Geschichte der Wissenschaftspopularisierung, Volks- und Erwachsenenbildung im 19./20. Jahrhundert. 


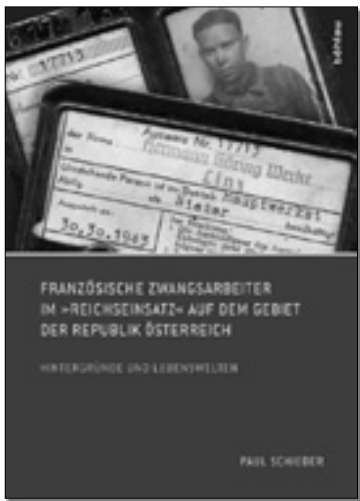

PAUL SCHIEDER

\section{FRANZÖSISCHE ZWANGS- ARBEITER IM „REICHSEINSATZ“ AUF DEM GEBIET DER REPUBLIK ÖSTERREICH}

HINTERGRÜNDE UND LEBENSWELTEN

Etwa 70.000 Franzosen - zum überwiegenden Teil Männer - wurden zwischen 1942 und 1944 zum „Reichseinsatz“ in der „Ostmark“ herangezogen, hauptsächlich in den Gauen Wien und Niederdonau, meist in Industrie- und Handwerksbetrieben. Diese Studie spürt den Erfahrungswelten dieser lange von der Forschung vernachlässigten Gruppe nach: anhand der in Frankreich veröffentlichten Erinnerungsliteratur, aber auch mithilfe von acht narrativbiografischen Interviews. Deren Dekodierung zeigt typische Entscheidungssituationen und Handlungsspielräume, von den Hermann Göring Werken bis zu Schoeller-Bleckmann. Schwierig war für viele der „STO“ genannten Zwangsarbeiter aber auch die Rückkehr nach Frankreich, da sie lange Zeit wegen eines latenten Kollaborationsvorwurfs nicht als Opfer Anerkennung fanden.

2012. 218 S. 24 S/W-ABB. UND TAB. FRANZ. BR. $170 \times 240$ MM.

ISBN 978-3-205-78672-6

BÖHLAU VERLAG, WIESINGERSTRASSE I, A-IOIO WIEN, T: + 43 I 33024 27-O INFO@BOEHLAU-VERLAG.COM, WWW.BOEHLAU-VERLAG.COM | WIEN KÖLN WEIMAR 

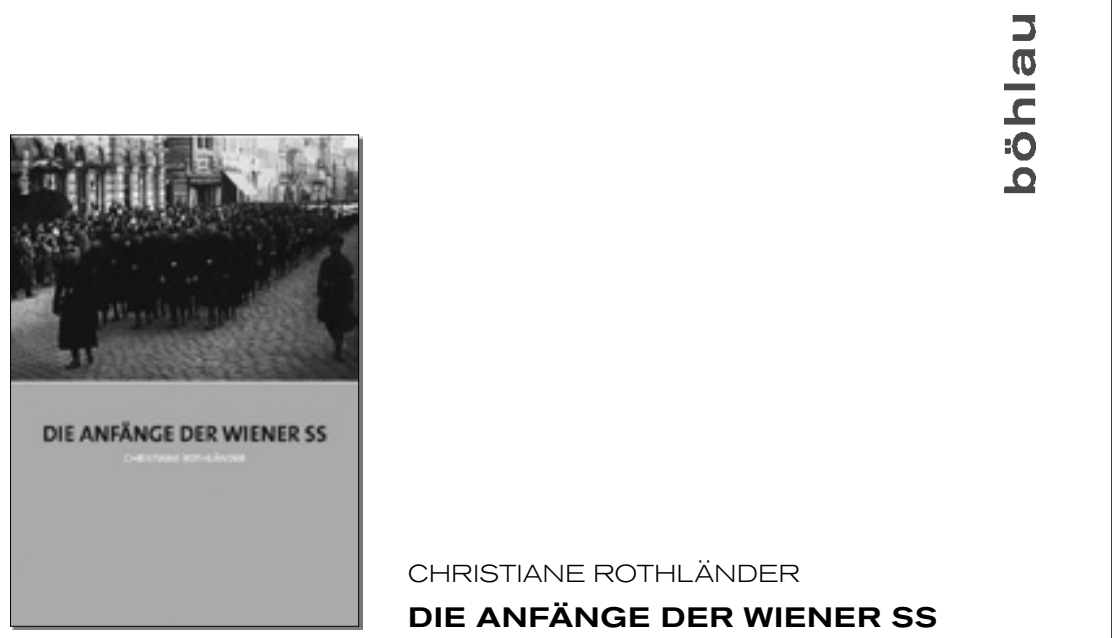

Das Buch behandelt die Gründung der ersten österreichischen SS-Einheit, des SS-Sturms 77 in Wien, und ihres Ausbaus zur 11. SS-Standarte. Erstmals wird damit die Frühzeit der Schutzstaffel aus dem Blickwinkel der Geschichte einer Standarte analysiert. Führerkorps, soziale Zusammensetzung, Aufbau, interne Organisation und Finanzierung der Wiener SS werden ebenso untersucht wie ihre Stellung zur Politischen Führung und SA sowie ihre Entwicklung zur Terrortruppe. Einen ersten Höhepunkt erreichte der Terrorismus der SS mit dem Juliputsch 1934, an dem beide Wiener SS-Standarten in unterschiedlicher Form beteiligt waren und dessen Scheitern auch dem Versagen Heinrich Himmlers zuzuschreiben ist. Beleuchtet werden weiters die Flucht der Wiener SS-Angehörigen aus Österreich nach dem Parteiverbot und der Aufbau der „SS-Legion“ in Deutschland. Die Autorin stützt sich dabei insbesondere auch auf bisher unveröffentlichtes Bildund Quellenmaterial, wie z.B. die Akten des Verwaltungsamtes des österreichischen SS-Abschnittes, das Trupp-Tagebuch eines Wiener SS-Mannes und zahlreiche Personalakten aus österreichischen und deutschen Archiven.

2012. 653 S. 86 S/W-ABB. UND 26 TAB. GB. $170 \times 240$ MM

ISBN 978-3-205-78468-5

BÖHLAU VERLAG, WIESINGERSTRASSE I, A-IOIO WIEN, T: + 43 I 33024 27-O INFO@BOEHLAU-VERLAG.COM, WWW.BOEHLAU-VERLAG.COM | WIEN KÖLN WEIMAR 

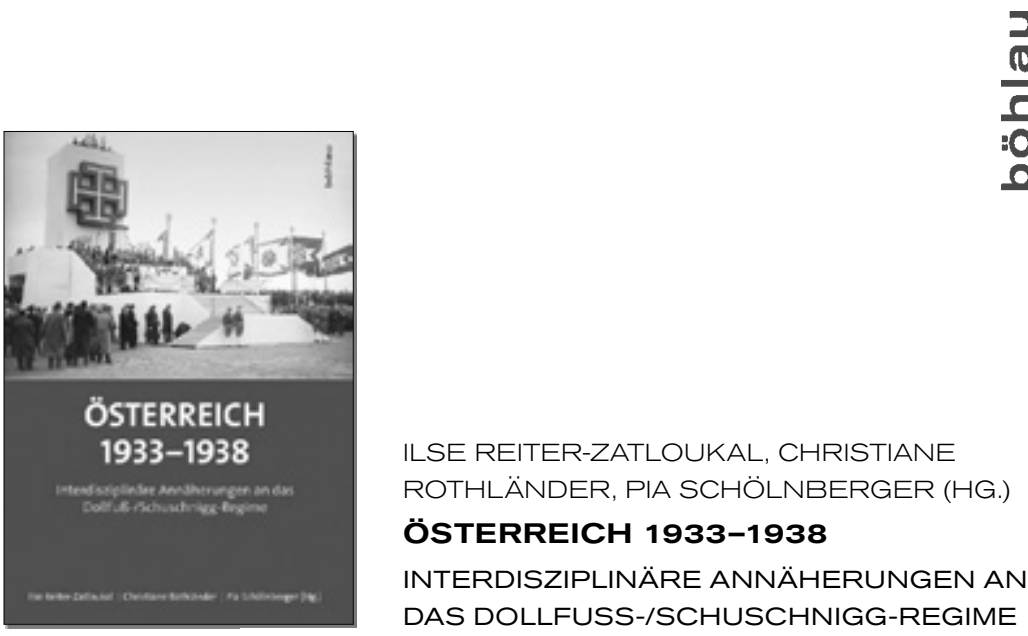

Die Publikation bietet den aktuellen Forschungsstand sowie neue Perspektiven der wissenschaftlichen Auseinandersetzung über das politische System der Jahre 1933 bis 1938 in Österreich. Für eine breite Diskussion dieser bis heute umstrittenen Epoche innerhalb der österreichischen Zeitgeschichte werden unterschiedliche Themenbereiche interdisziplinär - geschichtswissenschaftlich, rechtshistorisch, politologisch - beleuchtet. Die Themenschwerpunkte umfassen die Etablierung des austrofaschistischen Systems, politische Gewalt und Justiz, unterschiedliche Arten der Verfolgung von RegimegegnerInnen, eine eingehende Diskussion der Maiverfassung 1934, wirtschaftliche/soziale sowie Genderaspekte des Dollfuß-SchuschniggRegimes sowie die Frage der Rückgabe in dieser Zeit entzogenen Vermögens nach 1945.

2012. 400 S. GB. $240 \times 170 \mathrm{MM} \mid$ ISBN 978-3-205-78787-7

BÖHLAU VERLAG, WIESINGERSTRASSE I, A-IOIO WIEN, T: + 43 I 33024 27-O INFO@BOEHLAU-VERLAG.COM, WWW.BOEHLAU-VERLAG.COM | WIEN KÖLN WEIMAR 


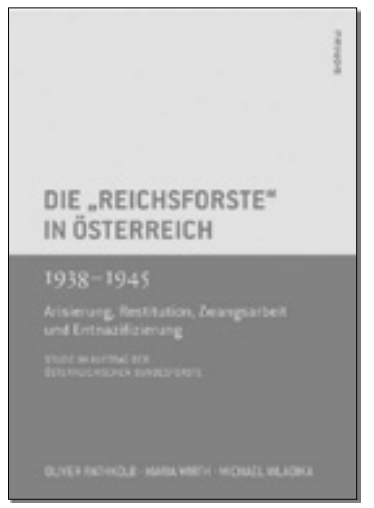

OLIVER RATHKOLB, MARIA WIRTH,

MICHAEL WLADIKA

\section{DIE „REICHSFORSTE“ IN ÖSTERREICH 1938-1945}

ARISIERUNG, RESTITUTION, ZWANGSARBEIT UND ENTNAZIFIZIERUNGSTUDIE IM AUFTRAG DER ÖSTERREICHISCHEN BUNDESFORSTE

Im Zentrum stehen Forschungen mit umfangreichen neuen Quellen zur Geschichte der „Reichsforste“ während der NS-Zeit in Österreich: Erstens die internen Karriereverläufe der leitenden und mittleren Ebene der Reichsforstverwaltung unter Berücksichtigung von Widerstand und politischer Maßregelung bzw. der Entnazifizierung nach 1945. Schwergewicht wird auf die Interpretation der personellen (Dis-) Kontinuitäten 1938-1945 ff gelegt.

Im Kapitel „Arisierung“ und Restitution von Liegenschaften konnten sowohl Umfang als auch Einzelfälle des Entzugs von Grundstücken und Immobilien durch die Reichsforste rekonstruiert und eine Bestandsaufnahme der Restitutionspolitik vorgelegt werden.

Im dritten Teil erfolgt eine Bewertung des Einsatzes von Zwangsarbeiterinnen und Zwangsarbeitern in Betrieben der Reichsforste.

2010. 407 S. 21 S/W-ABB. UND 14 TAB. GB. MIT SU. $170 \times 240$ MM.

ISBN 978-3-205-78482-1

„Die VerfasserInnen legen hier eine bemerkenswerte und wichtige Studie zu einem wesentlichen Teil der österreichischen Wirtschaftsstruktur vor.“

Vierteljahresschrift für Sozial- und Wirtschaftsgeschichte

BÖHLAU VERLAG, WIESINGERSTRASSE I, A-IOIO WIEN, T: + 43 I 33024 27-O INFO@BOEHLAU-VERLAG.COM, wWw.BOEHLAU-VERLAG.COM | WIEN KÖLN WEIMAR 

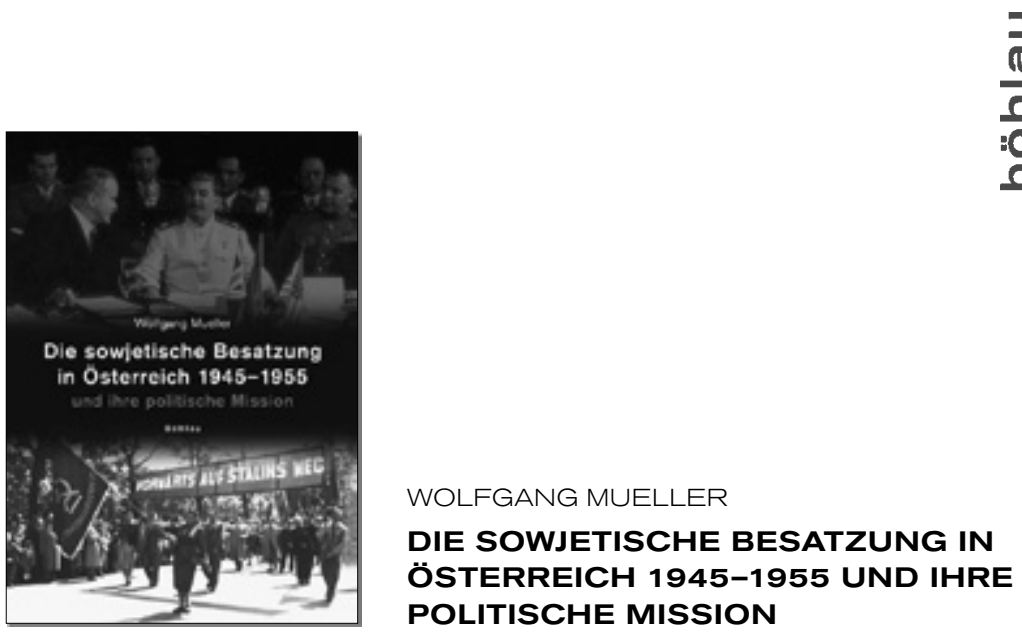

Welche Vorstellungen besaß die Sowjetunion von Nachkriegsösterreich, welche Rolle spielte sie beim Aufbau der Zweiten Republik, welche politischen Ziele verfolgte sie in den Besatzungsjahren 1945-1955? Wollte Stalin Österreich „sowjetisieren“?

Die erstmalige Auswertung bislang streng geheimer Moskauer Archivdokumente, Politbürobeschlüsse und der Korrespondenz Stalins mit der KPÖ führt zu einer neuen Sicht der sowjetischen Österreichpolitik. Darüber hinaus gibt der Autor Einblicke in die Geschichte und Struktur des sowjetischen Besatzungsapparates in Österreich von seinen Anfängen bis zum Abschluss des Staatsvertrages.

2005. 300 S. 14 S/W-ABB. GB. $170 \times 240$ MM | ISBN 978-3-205-77399-3

„[...] ein Standardwerk für die Zeit der Besatzung. Über die sowjetische Besatzung in Österreich auch nur ein Wort zu verlieren, ohne Mueller gelesen zu haben, wird nicht möglich sein.“

Wirtschaft und Gesellschaft

BÖHLAU VERLAG, WIESINGERSTRASSE I, A-IOIO WIEN, T: + 43 I 33024 27-O INFO@BOEHLAU-VERLAG.COM, WWW.BOEHLAU-VERLAG.COM | WIEN KÖLN WEIMAR 
Die Studie beschreibt die US-amerikanischen Planungen für eine Nachkriegsdemokratisierung Österreichs und deren Umsetzung nach 1945. Christian H. Stifter stellt dies anhand von Fallbeispielen im Bereich des universitär-akademischen Wiederaufbaus 19451955 dar. Das ursprünglich zivilgesellschaftliche Experiment einer "geistigen Abrüstung" und Umorientierung wurde allerdings selbst in seinem Kernbereich, der vollständigen Entnazifizierung, nur sehr eingeschränkt wirksam. 